\title{
1
}

(4-2) 
Med

K6525 



\section{BUTTERFLY-HUNTING IN MANY LANDS}



Digitized by the Internet Archive in 2016

https://archive.org/details/b28083842 


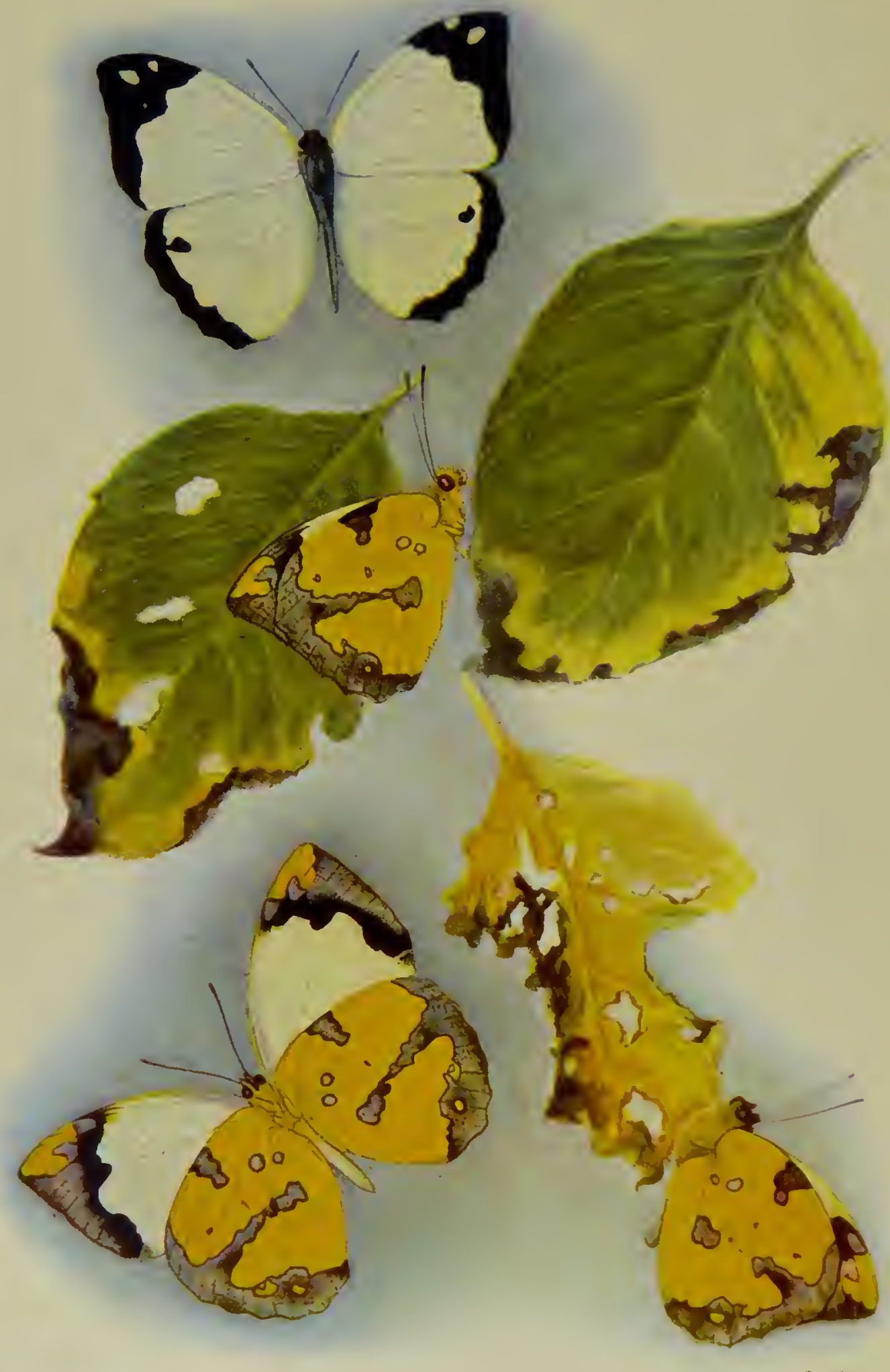

Horace Knight, del.

W'itherby \& Co., imp.

ERONIA CLEODORA, HÜBN.

ON THE WING AND AT REST. 


\section{BUTTERFLY-HUNTING IN MANY LANDS}

NOTES OF A FIELD NATURALIST BY

GEORGE B. LONGSTAFF

M.A., M.D., OXON.; F.R.C.P., F.S.A., F.G.S. LATE VICE-PRES, ROY. STAT. SOC. LATE VICE-PRES. ENTOM. SOC., LOND. HON. MEMB. ENT. SOC. LANC. AND CHES. AUTHOR OF "STUDIES IN STATISTICS"

TO WHICII ARE ADDED TRANSLATIONS OF PAPERS BY FRITZ MÜLLER ON THE SCENT. ORGANS OF BUTTERFLIES AND MOTHS: WITH A NOTE BY E. B. POULTON, D.Sc., F.R.S.

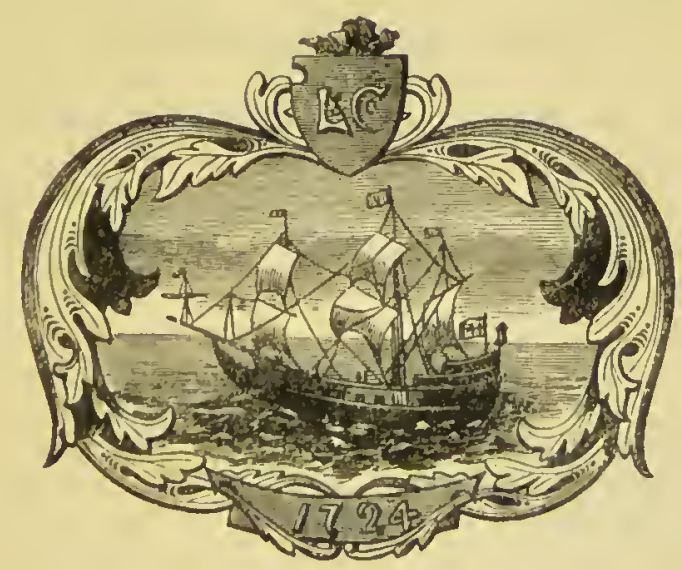

WITI SIXTEEN PIATES, SEVEN COLOURED

\section{LONGMANS, GREEN, AND CO.}

39 PATERNOSTER ROW, I.ONDON NEW YOKK, BOMBAY, AND CALCUTTA 
12894

$$
371234
$$

First Published, February, 1912. Reissued in October, 1912, with a Revised Index.

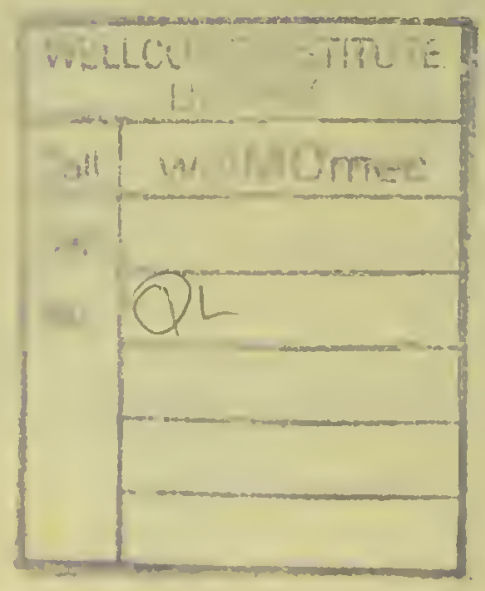


To mu old jfiello $\&$ jfellow Fureliat

\section{Eclwen fllage}

Flade Mrofessor of ffille $\mathcal{E}$ it at ortord

these tales of the llet

are affectionately dedicated 



\section{PREFACE}

SucH a book as this needs an apology. It is an attempt, possibly a foolish one, to put into a readable form the technical diaries of a wandering entomologist, and to entomologists alone it appeals. The basis of the work is a pile of note-books containing long lists of specimens taken from day to day. Nothing but the favourable reception by brother naturalists of papers dealing in like fashion with some of my earlier voyages would have induced me to undertake the heavy task. Yet, even in these days of easy travel, it has not beell the lot of many to have collected insects in every continent.

I have to thank the President and Council of the Entomological Society of Loudon for kind permission to reprint papers which have been read before that Society, and to reproduce the frontispiece and some of the figures in the text. My thanks are also due to the Editors of the Entomologist's Monthly Magazine for allowing me to make full use of my contributions to that Journal, now extending over many years.

The original paper's have been revised, and in wany places rnatter has been added that is not entomological, nor even scientific, in the hope of lightening an otherwise monotonous narrative.

'The chief results of my observations have been gathered together and classified in the last chapter, and it is my fond hope that from the details there set in serried array some inferences of enduring value may be drawn.

The constant clianges of nomenclature are a source of trouble to the collector no less than to the systematist. I lay no claim to consistency of treatment. In the first chapter tho names that I was familial with in school-boy and undergraduate days are used, but to facilitate identification tho name given in $\mathrm{Mr}$. $\mathrm{R}$. 
South's list is in some instanees added in braekets. The author's name is in that ehapter given only in cases of diffieult synonymy.

All authors' names, of genera as well as species, are given in the Index, but in the text the name of the author of species only is given, and that but once in each chapter.

Generic names in braekets are sometimes those of sub-genera, sometimes synonyms: they are given solely to facilitate the identifieation of speeies figured or described in mueh used works.

Ineonsisteneies of nomenelature no doubt occur; they are partly due to the fact that, e.g., Bingham's "Butterflies of India" appeared after my eaptures of 1903-4 had been determined, partly to the fact that I have not felt equal to harmonizing the oecasionally discordant determinations of specialists.

The names of insects alluded to merely by way of illustration or eomparison are not indexed. Names of plants are indexed by genera only, and the natural order is given in brackets. The Appendix is not indexed.

My knowledge of systematie entomology is very slight and almost confined to the Butterflies, henee as a colleetor of Inseets of all Orders, in diverse parts of the world, I have been more than usually dependent upon specialists. My thanks are due in the first place to the Entomologieal Staff of the British Museum, without whose kindness the large majority of my eaptures would be still unnamed. Valuable help has also been reeeived from Mr. G. T. Bethune-Baker, Dr. Malcolm Burr, Mr. J. E. Collin, Mr. H. Druee, Mr. H. H. Druee (who has devoted much time to my Blues and Skippers), Prof. Selwyn Image, Mr. W. J. Kaye, Mr. G. A. K. Marshall, the Rev. F. D. Morice (who named my Egyptian and Sudanese Hymenoptera), Mr. L. B. Prout, Mr. R. Trimen, F.R.S., Commander J. J. Walker, and Col. J. W. Yerbury. Other kind helpers are mentioned in the text.

Some to whom I owe much have been lost to entomology since this book was begun: C. T. Bingham, Martin Jacoby, Edward Saunders, and G. H. Verrall have truly left gaps that it will be hard to fill.

To the skill of Mr. Hornee Kuight and his son, Mr. Edgar S. Knight, my book owes any attruetiveness that it nay possess. 
Mr. F. R. D. Onslow and Mr. R. Shelford have spent unuch labour on my proofs, and I am decply indebted to them; Mr. Shelford's acquaintance with the East and extensive knowledge of Oriental insects of all orders has been of especial value. $\mathrm{He}$ had previously named many of my Orthoptera.

At Professor Poulton's suggestion I have printed in an Appendix translations by Mr. Ernest A. Elliott, F.Z.S., F.E.S., of a series of papers by Dr. Fritz Müller, dealing with the Scent-organs of Lepidoptera. These valuable papers, written in German or Portuguese, were difficult of access, and hence too little known. I am grcatly indebted to Mr. Elliott and Professor Poulton for their laborious assistance in this matter. The original illustrations have been reproduced.

I have rescrved to the last those to whom I am most deeply indebted. Dr. Dixey, F.R.S., has for many year's been one of my most intimate friends, and he alone knows how much, and in how many ways I am his debtor. The Hope Professor of Zoology at Oxford, Dr. E. B. Poulton, F.R.S., has for the past seven years placed the resources of the department under his charge-and his able staff of assistants-at my disposal, and ever welcomes me on my frequent visits to Oxford, helping me in all sorts of ways.

\section{G. B. LONGSTAFE.}

MORTEhOE, 1911. 


\section{NOTE}

The late Col. Bingham's descriptions of the new species of South African Hymenoptera collected by Dr. Dixey and the author, are unfortunately still unpublished. When the proofs of Col. Bingham's paper were received, it was discovered that only a part of the manuscript had been printed. It is hoped that the missing pages, containing the above descriptions, will soon be traced and published. as a supplementary paper. 


\section{CONTENTS}

Introduction: The Use of Metaphor in Natural History-Protection, partial

PAGE

1

\section{CHAPTER I}

SOME EARLY REMINISCENCES

William Spence-Trovey Blackmore-Stainton-Diaries-Wimbledon-Rugby - Natural History Society-Rannoch-Oxford-Canada-Peak of Tenerife - Spectre of the Brocken

\section{CHAPTER II \\ INDIA AND CEYLON, 1903-4}

Equipment-Simla-Foothills of the Himálaya-Butterflies at rest-Attacks of foes-Kháibar Pass-Malakand-Lahore-Delhi-Kamáon-The Mutiny -False heads of Butterflies-Suburbs of Calcutta--Darjiling-BuddhistsThe Plains-Southern India-The Nilgiris-Butterflies drinking-Decoys -Ceylon-Mimicry-Adam's Peak . . . . . . . . . . .

\section{CHAPTER IIT}

CHINA, JAPAN, CANADA, 1904

Penang-Pidgin English-Singapore-Hongkong-Flowers-Macao-Piratos -Canton-Nagasaki-Russian War-A Country Inu-Mixed Fauna-Kyōtō -The Nakascndō-Nikko-Yokohama-Japanese refloctions-Occan yarns -British Columbia-Tho Rockies-Montroal . . . . . . . . .

\section{CHAPTER IV}

ALGERIA, 1905

Guyotville-Biskra-Oases-Suleiman bin Arbi-Lifc in the Desert-Severity of the Struggle for Existence-Hammam Meskutine-Hammam R'IhraSccnt in male Cleopatra-Becs and Wasps-Blidah-Apos . . . . . 154 


\title{
CHAPTER V \\ SOUTI AFRICA, 1905
}

British Assoeiation-Port Elizabeth-Strange Vegetation-East LondonGlimpse iuto a Butterfly Paradise-Durban-Teraeolus and AoraeaMimiery-Attitudes of Skippers-Yellow Butterflies seeking concealmentDay-flying Moths-Colenso and Ladysmith-Battlefields-Vitality of tails of Lizards-A protected Grasshopper-Johannesburg-Geology of the Veldt -Kimberley-Bulawayo-The Matopos-Chamaeleons-Victoria FallsHippopotami-Visitors to Eleetrie Lights-Rain Frorest-Loeusts-Back to East London-Weevils-Legs used as jaws-Table Mountain .

\section{CHAPTER VI}

\section{WEST INDIES AND SOUTH AMERICA, 1906-7}

Barbados-Yellow Butterflies and yellow leaves-Suails' eggs-TrinidadWealth of Butterflies-La Guaira-Savanilla-Iguana-Puerto BelloColon-Windbound-Cemetery-Jamaiea-Vegetation-Humming BirdsThe Great Earthquake-Personal experiences-Psyehologieal results-The Negro-Butterflies-Their relation to those of the Spanish Main-MothsBeetles-Fireflies-Other Inseets-Waiter hands a Locust new to Scienee -Land Mollusea-Panama-Caráeas-Number and beauty of ButterfliesClouds of Ithomiiues-Butterfly Seents-Abuudanee of Skippers-Moths at Light-Easter Monday at Port of Spain-Yellow Fever-TobagoParasol Ants-A new Hairstreak-Gulf-weed . . . . . . . . .

\section{CHAPTER VII}

\author{
CEYLON, 1908
}

Nount Lavinia-Crows-Coast and Inland Butterfies eompared-Tenaeity of Life-Kandy-Snakes, Lizards, and Geekos-Rattan Palm-Snails-Seents in Danaines-Big Butterflies-Brilliant Blues-Scents as diaguostiesSpecies of Terias-Moths-Whip-Seorpions-Haragama-Numbers of White Buttorflies-"Follow my Leader"-Butterflies driuking-DambullaAnuradhapura-Firoflies-Triukomali-Doubtful Nnral policy-Laud Leeches-India : Natherún-Wouderful mimiery of Wasps by Flies .

\section{CHAPTER VIII}

IGYPT AND TIE SUDAN, 1909

Dynastic Butternies-The Nile-Scareity of Inseets-Tihartum-Mirnge-Bees aud Wasps-The Whito Nile-Cranes, Crocodiles, and Hippopotami-The persisteneo of the Woodon Pillow-Peeulinr Fauna-Arnbie-Cairo-Great Pyramid-P'clrified Forest-Effoets of nu Earthqunke . . . . . . . 


\section{CHAPTER IX}

NEW ZEALAND AND AUS'TRALI , 1910

Albatross - Hobart - Wellington - Immigrants - Hot Lakes - Eruption of Pohoto-Wanganui River-The Land of Ferns - Peripatus - Sugaring -Christ Church-A startling Likeness-Dunedin-Lake Wakatipu-A Perilous Ford-Paradise-New Species-Sydney-Successful MimicryIclbourne-Adelaide-Halley's Comet

\section{CHAPTER X}

BUTTERFLY BIONOMICS

$\S 1$, Scents- - 2, Coloured Juices- $-\S 3$, Tonacity of Life- $\$ 4$, Mutilations by Foes-§ 5. Experiments on Palatability- $\$ 6$, Successful Mimicry- $\$ 7$, Peculiarities of Flight- $\S 8$, Heliotropism- $\$ 9$, List and Shadow- $\$ 10$, Inverted Attitude- $\S 11,4$ titudes at Rest- $\$ 12$, Some Cosmopolitan Lepidoptera- $\S 13$, Seasonal Forms- $\$ 14$, Solection of Coloured Resting Places

\section{APPENDIX}

l'APERS BY FRITZ MIÜLLER, TRANSLATED BY MR. E. A. ELLIOTT, F.Z.S., F.E.S.

Introductory Note by Professor E. B. Poulton, D.Sc., F.R.S. .

601

§ I. On Hair-tufts, Feltcd Patches, and similar Structures on the Wings of Male Lepidoptera. [From the German] . . . . . . . . .

§II. On the Sexual Spots of the Males of Danais erippus and D. gilippures. (Plate A.) [From the Portanguese].

$\$$ III. On the Scent-organs of the Butterflios, Epicalia acontius, Linn., and Myscelia orsis, Drury. (Plate B.) [From the Portuguesc] . . . .

§ IV. On Sccnt-organs on the Legs of certain Lepidoptera. (Plato C.) [trom the Portuguese]

$\S$ V. On Scent-Organs on the Legs of certain Lopidoptera. (Supploment.) (Plato D.) [From the Portuguese] . . . . . . . . .

$\$$ VI. On the Scent-organs of Antirrhaca arehaca, Hübn. (Plato E.) [From the Portuguese]

§ VII. On the Costal Fold of the IIcsperidac. (Plates F and G.) [From the Portruguese]

§VIII. Where is the Scat of the Musky Suent in Hawk-Mothts? [I'rom the Gicrman] 
§IX. The "Maracujá [or Passion-flower] Butterflies." [F'rom the German] . 651

$\S \mathrm{X}$. The Scent-scales of the Male "Maracujá Butterflies." (Ilate H, Figø.

1, 2.) [Erom the German] . . . . . . . . . . . . 655

$\S \mathrm{XI}$. The Scent-scales of the Male of Dione vanillae. (Plate H, Figs. 3-9.) [From the German] . . . . . . . . . . . . . . (6)

$\S$ XII. The Stink-clubs of the Female "Maracuja Butterfles." (Plate J.j [From the German] . . . . . . . . . . . . . . . 664

$\operatorname{INDEX}$. . . . . . . . . . . . . . 663 


\section{LIST OF ILLUSTRATIONS}

BVE I'AGL

Frontrsplece.-Eronia cleodora, Hiibn., on the wing and at rest on diseoloured leaves of "u-Bomaan," Isoglossa woodii, Clarke. The Bluff, Durban, Natal, August, 1905 . . . . . . . . . . . . . . . . 19

PLATE I . . . . . to face 112

ASIA

FIG. 1.-Epinephele davcndra, Moore, ․ Kháibar Pass, Oetobor, 1903 . . 51

Fig. 2.-Pantana droa, Swinhoe, sp. nov. §. Hongkong, April, 1904 . . . . 128

FIG. 3.-Teracolus protraetus, Butler. Lahore, November, 1903 . . . . . 57

Frg. 4.-Parnassius hardwickii, Gray. Mt. Huttú, noar Simla, Ootober, 1903 . 45

Fig. 5.-Papilio naaeki, Ménétriés. Wada, Hondo, Japan, 10th May, 1905 . 140

PLATE II . . . . . . to face

192

SOUTH AFRICA

Fig. 1.-Myorrhinus longstaffi, Marshall, sp. nov. Second Croek of the Buffalo River, Last London, Cape Colony, 28th Septembor, 1905 . . . . . .

Frg. 2.-Nemopistha lancearia, Navís. Victoria Falls, Rhodosia, Septomber, 1905 .

FIG. 3.-Ellimenistes eallosicollis, Marshall, sp. nov. Second Creek of tho Buffalo River, East London, Capo Colony, 28th September, 1905 . . . .

FIG. 4.-Notogonia dixcyi, Bingham, sp. nov. Tho Bluff, Durban, Natal, August, 1905

FIG. 5.-Diopsis affiris, Adams. Gwaai, 11th Soptomber, 1905 . . . . .

Fig. 6.-Odyncrus longstafi, Bingham, sp. nov. Second Croek of tho Buffalo River, East London, Capo Colony, 28th Septombor, 1905 . . . . . .

Fig. 7.-Phymateus leprosus, Sorville. Sandhills, East London, Capo Colony, 29th Septomber, 1905

Fir. 8.-Parthenodes scotalis, Hampson, sp. nov. Victoria Falls of tho Zambesi, Rhodesia, September, 1905 . . . . . . . . . . . . .

Fig. 9.-Stcmmatophora chloralis, Hampson, sp. nov. Victoria Falls of tho Zambesi, Rhodesia, Soptombor, 1905 . . . . . . . . . . .

Fia. 10.-Ischnoptcra longstaffi, Shelford, sp. nov. Rain Forost, Viotoria Falls of tho Zambesi, Rhodesia, Soptembor, 1905 . . . . . . . . . .

Fic. 11.-Platytes, sp. nov. Victoria Falls of tho Zambosi, Rhodesia, Soptomber, 1905 
FIG. 1.-Pieris (Perrhybris), ? sp. nov. .

FIG. 2.-The same, underside. Above La Guaira, Venczuela, 29th March, 1307

FIG. 3.-Theela nubes, sp. nov. $\delta$.

FIG. 4.-The same, underside

FIG. 5.-The same, o. Tobago, April, 1907

FIG. 6.-Gryllacris longstaffi, Griffini, sp. nov. Walderston, and Port Antonio, Jamaica, February, 1907

FIG. 7.-Hoplotarache viridifera, Hampson, sp. nov. Puerto Bollo, Panama, 27th December, 1906 .

FIG. 8.-Myelobia paleacca, H.-Schäffer. Carácas, Venezuela, MIarch, 1907 .

INDIA, CEYLON

FIG. 1.-Tearia ferruginea, Fabricius

FIG. 2.-The same at rest. Mimicked by 5 and 6 .

FIG. 3.-Polistes narginalis, var. stigma, Fabricius. Mimicked by 5 and 6 . . 392

FIG. 4.-Enmenes edwardsii, Saussure. Nimicked by 5 and 6 . . . . . 392

FIG. 5.-Cerioides cumenoides, Saunders . . . . . . . . . . . . 392

FIG. 6.-The same at rest. Mimic of 1, 2, 3, 4 . . . . . . . . . . 392

FIG. 7.-Cerioides, sp. nov. . . . . . . . . . . . . . . . . 392

EIG. 8.-The same at rest. Mimic of 9 and 10 . . . . . . . . . 392

Fig. 9.-Eıınenes flavopieta, Blanchard . . . . . . . . . . . . 392

FIG. 10.-The same at rest. Mimicked by 7 and 8 . . . . . . . . . 392

All the above were taken close together at Mathcrán, Western Gháts, March, 1908

FIG. 11.-Seelimena logani, Hancock. A swimming Grasshopper. Dambulla and Peradeniya, Coylon, March and April, 1908 . . . . . . . . 375

FIG. 12.-Derispia interrumpens, Walk . . . . . . . . . . . . . 36?

FIG. 13.-Derispia coceinelloides, Wostwood. Two Heleromorous bectles, extraordinarily like small Lady-birds. Kaudy and Peradouiya, Coylou, Fcbruary, 1908

FIG. 1.-Calopicris enlimene, Kilug

F1G. 2.-Tho samc, undorside. Bluo Nilo, ucar Khartùm, F'cbruary, 1909 . 
FIG. 4.-Euproctis xanthosoma, Hampson, sp. nov. Near Kosti, White Nile, 17 th February, 1909

FIG. 5.-Hypoglaucitis, sp. nov. Kasr Ibrîm, Nubia, and Khartt̂m, January and Fobruary, 1909

F1G. 6.-Laelia scminuda, Hampson, sp. nov. Roseires, White Nile, 19th February, 1909

F1G. 7.-Porthesic erythrosticta, Hampson, sp. nov. Khartûm, 15th Fobruary, 1909.

Fig. S.-Julodis fimbriata, Klug. Burri, Khartûm, 11th Febru民ry, 1909

F1G. 9.-Copicucullia sublutea, Graes. Khartûm, 12th February, 1909 .

Fig. 10.-Enchloë belemia, Espor. Attitude of Rest. Biskra, Algeria, February, 1905 .

Fig, 1.-Morrisonia sequens, Howes, $s p$. nov. Rotorua, North Island, New Zealand, February, 1910

FIG. 2.-Morrisonia chlorodonta, Hampson, sp. nov. North Island, Now Zealand, February, 1910.

F1G. 3.-Morrisonia longstaff, Howes, sp. nov. Lake Wakatipu, South Island, New Zealand, March, 1910 .

Fig. 4.-Rhadinosomus acuminatus, Fabricius. Pipiriki, North Island, New Zealand, 22nd February, 1910 .

Fig. 5.-Teramocerns barbicornis, Fabricius. Pipiriki, North Island, Now Zealand, February, 1910.

FiG. 6.-Scolopterus tetracanthus, Walk. Tikitapu Bush, North Island, Now Zealand, 14th February, 1910 . . . . . . . . . . . . . .

FIG. 7.-The same, side view

FIG. 8.-Esthesis variegatus, Fabricius, Longicorn beetle mimicking Fig. 9. Como, near Sydney, New South Wales, 2nd April, 1910

F1G. 9.-Rynchinm abispoides, Moade.Waldo. A New South Wales Wasp, mimicked by 8

\section{ILLUSTPATIONS IN TEXT}

FiG. 1.-Butterfly envelope, creased but open

FIG. 2.-Butterfly envolope, foldod .

F1G. 3.--Butterflies injured by birds.

(a) Mylothris trimenin, Butler.

(b)

Colias marnoana, Rogenh. 
Fig. 11.-Sematura acgistus, Fabricius, at rest - PAGr

FIG. 12.-Thecla linus, Sulzer, at rest . . . . . . . . . . . . . 320

FIG. 13.-Leg of water Grasshopper . . . . . . . . . . . . . 375

FIG. 14.-Shillúk wooden pillow . . . . . . . . . . . . . 416

FIG. 15.-Jointing of granite . . . . . . . . . . . . . . . . 437

FIG. 16.-Shadow of upright Butterfly . . . . . . . . . . . . . 560

FIG. 17.-Shadow of Butterfly listing towards the sun . . . . . . . . 560

FIG. 18.-Shadow of Butterfly listing from the sun . . . . . . . . . 561

FIG. 19.-Calisto zangis, Fabricius, at rest . . . . . . . . . . . . 570

ON Cover.-Eudamus catillus, Cramer.

\section{FRITZ MÜLLER'S PLATES ILLUSTRATING THE APPENDIX}

Prate A. Scent-organs of Male Danais crippus and D. gilippus . . . . . 620

.. B. Scent-patches and Scales of Male Myscelia orsis, etc. . . . . . 625

, C. Scent-organs on the Legs of Male Moths . . . . . . . . . 630

, D. Scent-organs on the Legs of Male Erebid Moths . . . . . . 633

" E. Scent-organ of the Male Satyrinc Butterfly Antirnaca archaea . . 639

" F. Scent-organs and Scales of Male Hesperidae . . . . . . . . 647

"G. Scent-organs and Scales of Male Hespcridae . . . . . . . 648

"H. Scent-scales of Male "Maracujá Butterflies," etc. . . . . . . 660

" J. Stink-glands and Clubs of Female "Maracujá Butterflies" . . . 


\section{ERRATA.}

Note ou p. x. The missing MS. has been found, and Col. Bingham's paper will appear in Part II. of the Transactions of the Entomological Society of London, about October, 1912.

Page xvi., Plate IV., Fig. 12, see p. 364.

$$
\text { " } \quad \text { Fig. 13, sec p. } 362 .
$$

Page 25, last line, read "(plexippus, auct. nec Linn)."

11 65, 1. 12, read Zizera maha.

"68, footnote, the reference is to Trans. Ent. Soc. Lond., 1902, pp. 451-458.

"76, 1. 15, read "(plexippus, anct. nec Linn)."

" 104, 1. 18, read ransonnetii.

" 116, 1. 9, read drypctis.

, 170, 1. 13 from bottom, read Thalpomena.

Plate II., read "Nemopistha."

Page 194, to footnote add, "pp. 593, 594."

„209, 1. 4, read Spartecerus; also p. 210, 1. 5, and 1. 13; also p. 211, 1. 6.

"213, 1.6 from bottom, read Polyrrhachis.

,221, 1. 1, read Fig. 11.

"221, 1. 9, read "also Oestropsis."

"224, 1. 13 from bottom, read Polyrrhachis.

1) 230, 1. 20, read Fig. 10.

"239, 1. 20, read Bantia.

"245, 1. 5 from bottom, read Polyrrinachis.

1, 247, last line, read Eurynotus.

"260,1. 12, read sulphureus.

"263, 1. 5, read Fig. 7.

Plate III., read "GryLlacris."

Page 289, 1. 21, read phylaea.

"290, 1. 12 from bottom, read Ammalo.

„290, 1. 10 from bottom, read Halisidota.

,292, 1. 7, read Anceryx.

"295, 1. 16, read Lagocheirns ananiformis.

". $304,1.14$, read Hcliopetes laviana.

"304, 1. 10 from bottom, read Anartia jatrophae.

"306, 1. 3 from bottom, read Papilio arcas arcas.

"310, 1. 15, road Hymenitis andromica.

" $316,1.5$, read ittona.

Figs. 1, 2)."

320, 1. 10 from bottom, aftor " $P$. sincera, Fold," road "(seo Plate III,

Pago 324, 1. 19, after Synchloe' insort "(Coatlantona, Kirby)."

" 327, 1. 13 from bottom, read Melissodes rufodentata.

". 329, 1. 10, for Anosia read Danaida.

"333, 1.7 from bottom, after " brilliant " road "—almost "old gold '-."

" 362, 1. 13 from bottom, read Fig. 13. 
Plato IV., Fig. 9, road flavopicta.

Page 372, 1. 17, read Plirynichus.

" $374,1.10$ from bottom, read Omplua.

" 375, 1. 21, read Platc IV., Fig. 11.

"384, 1. 14 from bottom, read Uloma.

"392, 1. 8, rcad petiolata.

" $\quad 393,1.17$, read asiaticus.

Page 399, 1. 16 from bottom; also p. 401, 1. 19; also p. 413, 1. 6 from bottom, read Sceleodis.

Page 402, 1. 19 from bottom, also p. 408, lino 7 from bottom, also Plate V., Fig. 5, Sir George Hampson has named this insect Crypsotidia nuesosema.

Page 402, 1. 9 from bottom, read militaris.

"407, 1. 9, also p. 414, line 5 from bottom, read eutimene. The violet glance is confined to the male.

Page 407, 1. 3 from bottom, the plant here, and on p. 410, referred to Arnetio, probably belongs to the allied genus Heliotropium (Boragineac).

Pagc 408, 1. 22, read epunctifera.

" 416, 1. 9, The beads are worn round the neck; neither sex wears anything round the waist.

Page 420,1.5 from bottom, also on pp. 421,424,425, and 426, the place therc termed Fachi Shoya, is "The Mahdi's Place" on Abba Island, opposite to the village properly so named.

Page 421, 1. 12 from bottom, read Arenipses.

"422, 1. 3, read eulimene. It is, however, incorrect to describe Calopieris eulimene and Teracolus ephyia as Ethiopian species from Uganda, they aro rather Northern Sûdân insects.

Page 425, 1. 4, read unilyriata.

$" \quad 425,1.3$ from bottom, read mystica.

"428, 1. 9, read Zizera lysimon.

" 460, 1. 21, read "H.M.S. "Penguin." "

" 463, last line but one, read impatiens.

" 467, 1. 16 from bottom, read Oncacontias.

" 473, 1. 14 from bottom, read badius.

" 474, 1. 16, refer to Plate VI., Fig. 3.

, 477, 1. 6, read huttoni.

477, 1. 18, read Monomorium.

504, 1. 11 from bottom, end of line, insert " I."

$522,1.4$ from bottom, read drypetis.

$526,1.6$, add "or were still alive."

529, 1.6 from bottom, read ceylanica.

$568,1.16$, delete the second "during."

$572,1.17$, and p. $573,1.18$, read ransonmetii.

$588,1.13$, read bolanica. 


\section{INTRODUCTION}

IF the stay-at-home naturalist should suppose that everywhere within the Tropics insects are more plentiful than in the Palaearctic Region he would make a great mistake. More varied they may beand this is especially true of South America-but not necessarily more numerous. The veteran naturalist Dr. A. R. Wallace, in his "World of Life," 1 emphasizes the fact that gregarious plants are far" more prevalent in Temperate latitudes than they are in the Tropics. Plants such as heather, gorse and the like cover immense tracts of country; while extensive woods are often composed of oaks, beeches, or pines almost to the exclusion of other trees. A tropical forest contains many more species of trees to the square mile than would be found in Europe, Siberia or Canada. Masses of vegetation consisting of few species do not favour a very varied insect fauna, but may be quite compatible with a large insect population. In the more favoured parts of England butterflies make up in numbers for what they lack in variety. At the same time while it must be admitted that within the Tropics butterflies are more familiar objects than in Great Britain, it is certainly the case that insects need looking for in all countries alike; over large areas they may be comparatively scarce, whereas in favoured spots they will be found in great abundance. Such spots are open spaces in woods, whether natural or the work of man, exposed to the morning sun and well supplied with a variety of flowers; they are likely to be especially productive if water be also at hand. For some reason as yet unexplained the tops of hills, more particularly somewhat isolated knolls surrounded by woods, have a great attraction to many insects, notably swallow-tailed butterflies. On the other hand woods of a uniform character, especially if dense, may be quite poor as hunting grounds. Least productive of all are lands which have been long and well cultivated to the extermination of the aboriginal flora; nor must it be forgotten that tillage is not the only agricultural operation that displaces the native plants, for the constant and systematic grazing of land by cattle, sheep, camels and still more by goats, is

$$
1 \text { p. } 56 .
$$


only a degree less effectual. In an area of this kind the few insect inhabitants are such as have adapted themselves, like so-called "weeds of cultivation," to the very special conditions superimposed by the sustained operations of the patient husbandman. Such insects, "our garden friends and foes," to use the apt title of one of the works of the late Rev. J. G. Wood, are often found, like the aforesaid weeds of cultivation, to enjoy a wide distribution. ${ }^{1}$ Yet even in well cultivated areas one may happen on oases, so to say, patches of land too wet, or perchance too dry, for profitable cultivation, where many of the indigenous plants survive, and with them some at any rate of the indigenous insects.

Since it would appear that, in spite of all that has been written on the subject during the last fifty years, there is still a good deal of misapprehension as to the sense in which certain expressions are used by naturalists, it seems desirable to say a few words on the Use of Metaphor in Natural History.

We may perhaps assume that now-a-days no one thinks that by the term Natural Selection it is suggested that Dame Nature walks about pulling up the weaker seedlings, or stamping on worms that are slow to get out of the way. Probably the use of the happier term "Survival of the Fittest" has abolished such crude ideas, but the habit of literal interpretation dies hard.

Flies are for the most part very defenceless creatures and have little save the swiftness of their movements to protect them from their enemies. On the contrary bees and wasps are formidable animals well armed for attack or defence. It is common knowledge that many flies are so like bees or wasps as to be readily mistaken for them. Such a fly is said to "mimic" the bee or wasp that it resembles. The bee or wasp is termed the "model." There is good reason to believe that the resemblance is a real protection to the fly, since of its various enemies some, at all events occasionally, mistake the defenceless " mimic" for the well armed "model." "

Again certain butterflies, which we have reason to believe afford palatable food to birds and other creatures, are so like certain other butterflies (belonging to widely different groups) which in their turn are believed on good evidence to be distasteful to birds, etc., that, especially during life, the one may be readily mistaken for the other. In such a case the palatable butterfly is said to "mimic" the distasteful, and the two are spoken of as "mimic" and "model " respectively.

1 For notos on somo widoly distributed Lepidoptera, see Chapter X., $\$ 12$.

2 For recent experiments soe R.I. Pocock, F.L.S., in Proc.. Zoolog. Soc., I,ond., 1911, pp. 853-855. 
Yet again very many insects of various orders bear such a striking resemblance in form, or colour, or both, to the substances, vegetable or mineral, upon which they habitually repose as to be difficult of detection when at rest. They appear moreover in numerous instances to seek out as resting places objects like themselves with a view to concealment, and not infrequently they adopt an attitude which increases their resemblance to their surroundings.

Now in the preceding paragraphs the words "mimic," "model," and the phrase "seeking out ... with a view to concealment," are used in a metaphorical and not in a literal sense.

The form of mimicry sketched out above will always be associated with the name of Bates, but Fritz Müller has familiarized us with the fact that distasteful insects in many cases appear to mimic one another. They are said to "form," or "be drawn into associations" which "exhibit common warning colours," thereby sharing the risks involved in the education of young birds, which it would appear do not instinctively distinguish between the palatable and unpalatable. Here again many of the expressions used are metaphorical.

So far as the writer knows, there is no naturalist of repute who for one moment imagines that in any literal sense the fly mimics the wasp, or the palatable butterfly mimics the distasteful. There are probably very few naturalists who believe that, for example, a yellow butterfly hunting about for a yellow leaf on which to settle, does so with the conscious idea of getting thereby protection from its foes.

That an insect should consciously assume a certain attitude with a view to concealment is of course conceivable, that it should choose a special background for the same purpose is also conceivable. That an insect by any conscious effort on its part could assume the form, or even the colour of another insect is utterly inconceivable.

Of course what is really meant is, that such and such an insect has been successful in the struggle for cxistcnce owing to its resemblance in form, or colour, or habits to such and such another insect which started better equipped for the contest, and that the constant elimination of the less protected individuals has gradually perfected the "mimicry." For brevity's sake the words "inimic," "model" and the like will be used throughout this work-the metaphor is too convenient to be laid aside.

That the Struggle for Existence is severe and does actually result in the Survival of the Fittcst is a belief which I share with nearly all field naturalists of experience. But if this be truc, this processconveniently if inaccurately termed Natural Selection-must be a 
very potent factor in Evolution. Whether Natural Selection-even with such limited aid as it may have received from Sexual Selection and the little understood direct Influence of the Environment ${ }^{2}$-has been the sole cause at work throughout past ages in the production of the almost infinite variety of animals and plants, living and extinct-whether we can adequately explain by Natural Selection the first steps in the evolution of the eye, the ear, the organs of flight, or even of so-called Mimicry-these are questions far too large for discussion in these pages.

As regards Mimicry there is just one point that should be emphasized. Even although it may be demonstrated that some creature or creatures readily feed upon a certain insect, it may nevertheless be quite allowable to describe that insect as relatively unpalatable, if it can be shown that other insectivorous animals habitually, or even frequently, reject it. Similarly to demonstrate that butterfly A really is protected by its resemblance to butterfly $B$, it is by no means necessary to prove that A deceives all its enemies, or even always deceives one enemy in particular. The protection to the species may be very real if its enemies (or any of them) are occasionally deceived by the resemblance.

1 The reality of the influence of the environment in the production of colour has been clearly proved by Prof. E. B. Poulton, F.R.S., but he explains his results as brought about through the nervous system, and not by the direct action of light on the skin-the susceptible nervous system being itself a product of natural selection. See Colours of Animals, Chapters viii, ix. Also Trans. Ent. Soc. Lond. 1903, p. 311 et seq. Also Essays on Evolution, pp. 152-4. 


\section{CHAPTER I}

\section{SOME EARLY REMINISCENCES}

Perhaps it was because William Spence was the husband of a greataunt, or possibly because I was a strange studious child left much to my own devices, but whatever the reason may have been I began to notice insects at an early age.

A copy of J. W. Douglas" "World of Insects" bears the inscription- "To a young Entomologist from an old one. William Spence, Oct. 7, 1858."

I was then under ten. A saying of my uncle remains impressed upon my memory:--" George, never throw away a bad specimen until you get a better." I can see the speaker now, a benevolent looking white-haired old gentleman, sitting in an armchair in the dismal house in Lower Seymour Street. I was barely eleven when he died.

The entomologist to whom I was most indebted as a boy was Mr. Trovey Blackmore, of the Waterside, Wandsworth, a very shy man of delicate health, who died in early middle life. ${ }^{1}$ Besides butterflies and moths he collected Roman pottery and copper tokens, of which last he had a large number. A family "Nonsense Rhyme" celebrated him thus :-

\footnotetext{
"There was an old buffcr called Trovey

'To such a point madness drove he,

Hc collectcd old mugs,

Bad half-pence and bugrs,

'This silly old fcllow called 'Trovey."
}

Blackmore introduced me to Biston hispidaria in Richmond Park with the words: "That is the best insect in your collection, I will take it home and set it for you" (1862). He also told mo how to get an order of admission into Coombe Wood, and took me to Micklelam and Darenth. It was as his guest that I attended a meeting of the Entomological Society of London in September, 1866, during the first presidency of Sir John Lubbock. 'This was the first meeting of

1 In 1876 , aged 41. 
a scientific society that I attended. Curiously enough, when forty years afterwards I was admitted as a fellow of the Society of Antiquaries, the chair was occupied by Lord Avebury. It is still more curious that on that occasion I found on the table a volume of the newly published "Victoria History of the County of Warwick," and therein came across many quotations from my list of the Rugby Lepidoptera, printed in 1868 !

In August, 1858, though not ten years old, I went up the Rhine with my parents, and still remember my excitement on seeing a Scarce Swallow-tail swoop round our party when sitting on the top of the Drachenfels. I have also a lively recollection of pursuing red- and blue-winged grasshoppers among the Robinia bushes on Rolandseck. In those early days, however, it would have seemed to me almost criminal to bring a Continental specimen into England, moreover for several years I kept to a stern resolve to admit to my collection none save insects captured by my own hands. Both principles are perhaps good for beginners, but, be that as it maj, I can to this day realize my feeling of moral degradation, when, yielding to persuasion in the cause of science, I first consented to exchange specimens (Christmas, 1867). Naturally the new policy increased my knowledge, widened my circle of entomological acquaintances and tended to the filling of my cabinet.

It was in that same summer of 1858 that, in the hotel garden at Koblenz, my brother showed me Donati's comet, then insignificant enough, but the first of those weird bodies that I had set eyes upon. The wine-growers of the Rhine-land were full of hope and told grandfathers' stories of the famous vintage of 1811 -the last great comet year. My father joined in the conversation, relating his boyish memories of the great comet, which appeared when he was twelve years old. About a month later, at Wandsworth, on the memorable 5 th of October, I saw Arcturus gleaming through the then mighty comet's wide sweeping, gracefully curved tail. It was truly a sight to be remembered, and it was duly drawn upon the pages of many a school book.

But 1858 produced something more than a great comet and a famous vintage; it was a famous year in entomological anuals, for all kinds of rarities were recorded in the journals. My own captures were, indeed, not very remarkable, but there is a note that in that summer I saw in my father's garden at Wandsworth a Painted Lady and a Humming-bird moth, both rare visitors to that locality. It was probably in that same year that the Large Tortoise-shell was taken in the aforesaid garden-I remember the turn of the path 
where I netted it. Though I have seen literally thousands of Painted Ladies since, I doubt much whether a score of Large Tortoise-shells have crossed my path.

In the earliest of my collecting days that I can recall to mind all orders of insects interested me alike. At one time I was especially keen on water creatures and remember dredging up the strange stick-like insect Ranatra linearis from a pond on Wandsworth Common.

When my kind friend Blackmore first showed me Stainton's "Manual"-perhaps the best book on the British Lepidoptera ever published-it was still coming out in $3 d$. parts. It was indeed a privilege to be started with such a book in one's hands, and many and many a time have I thanked my stars that I was brought up on Stainton, rather than on the spoon-food of Newman. From the first I learned the Latin names of insects-and found no difficulty in it-and, what is more, learned to name my captures from descriptions, instead of from figures. I have never ceased to regret that "The Manual" did not reach a second edition. A few years later, but still as a small school-boy, it was my privilege to attend some of Mr. Stainton's Wednesday evening "at homes," and I shall never forget his kindly bird-like face, his charm of manner, and, above all, his unfailing kindness to me. Some delightful letters in his lady-like hand-writing are still among my treasures. Later I spent somewhat similar evenings with Edward Newman, Robert McLachlan, and H. G. Knaggs.

I was a collector in the good old days of the Entomologist's Weekly Intelligencer, a delightful little paper which told many a tale of the wonderful things caught by the then comparatively new method of "sugar." Thus, for example, Agrotis saucia, ${ }^{1}$ till then a great rarity, visited the tempting sweets in all parts of the country. A leading article, in 1858, urged the importance of keeping diaries and ended with the refrain: "Let diaries therefore be made." This was followed up by a letter from the pen of S. J. Wilkinson (who was then writing "The British Tortrices") setting forth the best form of diary. The reading of article and letter a year or so later roused my youthful ardour, and I opened the season of 1860 with my earliest diary. This, which lies before me as I write, is inscribed in a farthing blue and white washing-book, and solemnly records in a child's round hand the capture of a "Twenty-plume moth" and of a "Small White." It further describes some larvae found drawing together the twigs of Broom, which must have been those of

\footnotetext{
1 Now, alas! neitber Agrotis nor sancia, but Lycophotia margaritosa.
} 
Depressaria assimilella - but with this effort, alas! it eoncludes, saying nothing of visits, which (as I know from other sources) were paid that year to St. Leonard's-on-Sea, Weymouth, and Bonchureh, Isle of Wight.

In the summer of 1861 I again went to Bonchureh, and vastly enjoyed ehasing Colicus cdusa (as it was then ealled), and also took Pyrameis cardui, and, on the downs, Aspilates eitraria (ochrearia), and Botys flavalis. There is no diary of this visit extant, but I have a small book of pressed flowers from the Isle of Wight eollected in that summer. However, in the autumn the diary was resumed in a somewhat less infantile form; the Latin names (specific only) being made use of, even in the ease of such a small inseet as Fabriciana. This diary proves that the larvae of Caja were then much commoner in the southern suburbs than they are now.

The next year I spent part of April and May at St. Leonards, and there made the aequaintanee in the field of Mr. Edward Cooper; it was his fiftieth birthday when we met, whereas I was but thirteen. However, we both served under the same colours, and at once struck up a friendship whieh lasted several years. Our chief colleeting ground was Hollington Chureh Wood, a lovely spot, redolent of spring flowers. Well do I remember my delight at seeing Euphrosyne for the first time and in great abundanee, and with it plenty of that most decorative butterfly the Orange-tip, as well as the eheery little Grizzled Skipper. Perhaps the best thing we got was the conspieuous black and white Pyrale, Ennychia octomaculalis, which was, however, not to be had for the asking. In the summer a short time was spent at Deal, whence I walked to St. Margaret's Bay, where in those days there were but three or four cottages. Aloug the undereliff, by the rifle range of the Royal Marines, an extraordinary profusion of inseet life, and that in gorgeous forms, delighted the eye. Every head of Knapweed, and there were innumerable heads, bore a fair burden of at least three or four Six-spot Burnets, and two or three Rose-beetles. Though I have seen Zygaena fulipendulae commonly enough since then, I have never beheld it in anything like such numbers, still less have I come across such a profusion of Cetonia aurata. There is unfortumately no record of the Plumes and Geometers eaptured on the same ground. Later in the year I went to Tumbridge Wells, and made the acquaintanee of Lycaena aegon, and the handsome pulpy green and yellow larva of Hadena pisi-so eonspieuous when removed from its surroundings, but often harmonizing well with its food plant. A short visit to Folkestone is associated with sweet memories of Lyeacna adonis and Acidalia 
ornata. It was a favourite amusement of ours (my companion was one Frank Conigrave, then leading treble in the choir of St. Paul's Cathedral) to slide down the steepest grassy slopes that the Warren afforded. Once while so engaged I was fearfully startled to find myself unexpectedly in mid-air-having shot over a small unseen chalk-pit! It fortunately was but a very little one, and my small body landed on the luxuriant herbage beyond practically unhurt.

The diary shows that in the autumn I occupied myself with larva collecting, and in October waade my first experiments with a sugar-trap. These were not very successful, for though a lot of Anchocelis pistacina and one Agriopis aprilina were ensnared, most of the moths were drowned miserably in a soup-plate originally containing nearly dry sugar, which heavy rain had dissolved.

By 1863 a form of diary had been adopted almost identical with that employed in my foreign travels of recent years. In its columns even Tortrices and Tineae appear with their Latin names in full. It was one of the advantages of Stainton over Newman, that the former made no sharp distinction between Micros and Macros-a distinction the futility of which has been amply proved by modern views on classification. My chief hunting grounds in those days were Wimbledon Common and Coombe Wood, though one expedition reached to Weybridge; it was probably in this year that Blackmore first took me to Mickleham and Darenth. A visit to the English Lakes, and to Durham in the autumn, yielded but trifling results from an entomological point of view. At this time I paid much attention to larvae, and actually wrote descriptions of 43 species, besides those of a few pupae.

The following year was also largely devoted to describing and rearing larvae. It was my ambition to remove the reproach attached to the description of so many species-" larva unknown." Another' visit to St. Leonard's in the early spring produced Brephos notha, and, what interested me much more, a "bracelet" of the eggs of Eriogaster lanestris, from which ultimately a fine series of the perfect insect was reared. At about this time my most intimatc entomological chum was my school-fellow Mr. (now the Rev.) C. J. Buckmaster; our chief hunting grounds were Wimbledon Common and Park, and Coombc Wood, with occasional long days at Mickleham or Darenth. In the autumn I went to Ben Rhydding with my parcnts, but got little on the inoors.

It was carly in that summer of 1864 that the Entomologist's Monthly Magazine emerged. Though but a boy of fiftecn, I scnt a contribution to the first volume recounting, among other items, 
the capture of Eupisteria heparata in the alder groves of Coombe Wood, and the finding of eighteen larvae of Orgyia gonostigma on Wimbledon Common. ${ }^{1}$ These beautiful caterpillars were wont proudly to stretch themselves out on the oak bushes in the hollow below the Windmill, usually on the topmost leaf. In those days I was a very small boy for my age, and yet they were well within my reach. Is the creature really extinct there? or are the larvae, protected by their many brushes, ${ }^{2}$ still wont to sun themselves on the tops of the trees far above the heads of the tallest man? For be it known that since the reign of the Conservators began, in 1872, the whole aspect of the common has greatly changed, as they very promptly put a stop to the old practice of "lopping and topping," with the result that in a few years what had been scrub grew into the present beautiful woods. In the old days that I am writing of -full forty years ago-there was a clear view from Tibbett's Corner to the Windmill, nothing intervening save a wide expanse of heather, and a few small birch bushes. That, however, was before the Volunteers and the numerous camp-followers had had time to crush the life out of the heather. But if we have lost much heath we have gained many trees, so that if Jerry Abershaw still swung in chains on Jerry's Hill, as he did in Jacob Faithful's boyhood, he would not be visible to the motorists on the Portsmouth Road hard by. Sad to relate in the course of modern improvements even the stump of the gibbet has disappeared, and if Captain Marryat were to-day to start to walk from his father's house at Wimbledon to Roehampton ${ }^{3}$ he would miss one of his chief "leading marks." Another landmark, the yet more prominent Admiralty semaphore, is now remembered by the "Telegraph Arms," erected almost on the site.

The next year, 1865, found me at Rugby, and my collecting was restricted to the then long midsummer holidays. This was not, however, altogether a loss, for at Rugby I was well grounded in Botany, Geology, and Chemistry. The first two sciences at any rate have intimate relations with other branches of Natural History, and so long as life lasts I shall be grateful to $\mathrm{Mr}$. F. E. Kitchener and

1 Entomologist's Monthly Magazine, Vol. i. p. 72.

- For the protection afforded to the caterpillars of this group by their tussocks of hair, see Poulton's "The Colours of Animals," p. 196-8.

"Joseph MIarryat, M.P., purchased "Wimbledou House" in 1815, and died there in 1824. Jerry Abershaw was hanged at Kennington on August 3rd, 1795. The Rev. Bloomfield Jackson says that the post of the gibbot was long preserred as a portion of Mrr. Bull's shop at 27, High St., Putney. I owe tbis information to Mr. C. T. Davis, the accomplished Wandsworth Librarian. 
Mr. (now The Venerable) J. M. Wilson for the substantial addition to my happiness that their instruction provided. Unable to collect insects I took to flowers instead, and spent my half-holidays in working for the prize collection. Here again, as with moths, I had the advantage of a book without pictures, Bentham's "British Flora." In the holidays I again worked the Common (getting Nemeophila russula and Anticlea rubidata), as well as Coombe Wood and Darenth. A July visit to Lyndhurst, my first considerable purely entomological expedition, afforded new experiences. What a glorious sight it was to see Argynnis adippe and paphia flying about the bramble blossoms! The last named was in profusion. Then there were in denser parts Leucophasia sinapis weakly flitting over the herbage, and, even more beautiful, old Haworth's favourite, that "elegant fly," Limenitis sibylla, tastefully coloured and with gliding flight of grace incomparable. A later visit to Tunbridge Wells, where I again met Mr. Cooper, is best remembered by a few nights spent at Hever Castle. This appealed strongly to my boyish imagination, and I did not perhaps entirely disbelieve the legend of the hapless Anne Boleyn's headless apparition. Sleeping at one end of the "long gallery," my mother at the other, it happened that late at night I had to go to her room to get something or other. I started somewhat nervously to traverse the long gallery by the dim light of a chamber candle; when half way along an owl swooped down upon me and almost extinguished my light. For the moment poor Anne's ghost was a reality. But, in spite of owls and ghosts, how I did enjoy catching perch in old Sir Thomas Boleyn's moat!

After I had been at Rugby rather over a year I screwed up courage to face the jibes of the boys, and began to collect insects. To elude observation as far as possible, my net was carried in my pocket, the ring thereof round my waist, and its stick, in three joints, carried in a purpose-made pocket, for a Median statute forbade any boy below the Sixth Form to carry a walking-stick. With these precautions I did fairly well, getting such insects as Macroglossa fuciformis, common at flowers of Bugle and Ragged Robin, Emmelesia albulata, Eupithccia lariciata, Asthena sylvata, Boarmia abietaria and Hydrocampa stagnalis. That June the only specimen of Ino statices that I ever saw alive fell to my net. ${ }^{1}$ An interesting incident of quite different character appears in my diary. 'The local magistrates had furbished up the parish stocks and naturally itched to make use of them. A worthless fellow got drunk and

1 Entomologist's Monthly IIagazinc, Vol. III., p. 138. 
created a disturbance one Sunday, so thcy clapped him into the stocks, and kept him there for six hours [Junc 7th, 1866 !]. All the school went to see the man in his durance vile, but the effect was rather spoilt by his brother taking round a hat, into which sorne bystanders were foolish enough to put sundry coins.

The summer holidays found me again at Lyndhurst, this time with Buckmaster, but perhaps it was too latc in the season, for we did not do as well as I had done on my previous visit. Amongst a lot of Amphipyra pyramidea we got a solitary Catocala promissa at sugar. I remember that we were both much struck by the partiality of Phycis fusca (carbonariella), a coal black moth, for the blackened places where the heather had been burnt the year before, whereas we found Crambus warringtonellus and C. selasellus anywhere on heathy ground. We had a glorious time, but: "Don't forget before you pack up a lantern to empty it of oil." So say the stains upon my treasured interleaved copy of the "Manual " every time that it is consulted.

Mr. Wilson once took a party of young geologists from Rugby to see the museum at Warwick. In the train, Fison (now Sir Fred Wm. Fison, Bart.), a "big fellow" in the Sixth, and much venerated as our most promising "stinks man," remarking on the beauty of the country, said: "How much jollier it is nowadays with hedges and green fields than it was in geological times, all striped with red and blue and green, with nasty great slimy beasts crawling about!"

On the cold night of November 13th-14th, 1866, all in our house were roused at 1.30 A.M. by Mr. Wilson, and told to put on some clothes and great-coats and go into the garden to see the meteors. We were, it is to be hoped, both at the time and afterwards, duly grateful to him. Just as I reached the door some six or seven fine meteors were streaming together across the sky. Thcse were quichly followed by others, singly or in groups, and for the twenty minutes or so that we werc in the garden the sky was never clear of meteors for more than a few moments at a time. It was a quite marvellous sight, and although the learned said that the showcr was not equal to that of 1833 , certainly nothing since has come near to it. So great was the cffect on the school that the new paper which appearcd shortly afterwards was called The Mctcor. If not always as brilliant as its namesake, its carcer was not so flecting.

During 1866 there are many refcrences in the diary to Trovey Blackmore, and onc to a mutual fricnd and neighbour the late Mr. N. Tuely; moreover, the correspondence with Mr. Ed. Cooper 
was still kept up. It was, however, in Jannary, 1867, that I discovered two vcry near entomological neighbours, the Messrs. Blackburn. We soon became intimate friends, and their proximity and ardolir as collectors caused them to dominate entirely my entomological life for several years. At about the same time Trovey Blackmore's health began to fail seriously.

Under the influence of Thomas Blackburn I began to collcct beetles enthusiastically, but after a very few weeks found that it was not compatible with the ordinary school work, supplemented as this was by special preparation for Oxford. At about this time a letter appeared in The Meteor purporting to come from the pen of a neglected specimen in a small collection of insects in the Arnold Library, and signed "Mouldy Bug." My school-fellows at once decided that $I$ was the author, and for the next year or so I was generally called "Mouldy Bug," or simply "Mouldy." The true author was, I believe, Mr. Arthur Sidgwick, one of the masters, and doubtless he thoroughly enjoyed the wrongly imputed authorship.

The Marlborough College Natural History Society (founded April 9th, 1864, by the Rev. T. A. Preston) had proved a great success, and was followed little more than a year later by the Harrow School Natural History Society. Mr. Wilson one day asked me to breakfast to meet the Rev. F. W. Farrar, then a Harrow master, the founder and life and soul of the latter society. As a result, the Rugby School Natural History Society was founded on March 23rd, 1867. Mr. F. E. Kitchener was the first President, the writer the first Honorary Secretary, and of the seven original ordinary members the most notable is the great hunter, Mr. F. C. Selous. At the first ordinary meeting the Honorary Secretary read a paper on "Insects: their Collection and Preservation," causing some amusement by producing from various pockets, like a conjuror, a complete entomological armamentarium. About a year later he compiled for the first volumc of the Transactions a "List of the Lepidoptera (Butterflies and Moths) which have bcen observed within 8 miles of Pugby." It was a merc list of Latin names, without comments, and included Micros. A posthumous paper "On Caterpillars" was read after the author had entered the ranks of the Old Rugbcians. In the Society's "Entomological Album" will be found a notc by the same hand on the larvao of four species of Eupithecia, which, while very similar in shape and markings, strikingly rescmble in colour their vcry different food-plants, Heather, Ragwort, Angelica, and Wild Carrot. The larvac of this genus had at this time a great fascination for me. 
My Rugby captures in 1867 included Emmelesia decolorata, Scotosia vetulata, Anticlea rubidata, Macaria liturata, Eupitheria lariciata, Avcntia flcxula, and Hcdya scrvillana.

In the holidays I took Adela cuprella on Wimbledon Common, and Macaria notata in Coombe Wood, as well as Biston hirtaria in Hyde Park. Expeditions to Epping and West Wickham do not seem to have produced much result, but the appearance of Pyrameis cardui at Putney is notable.

An expedition to the Isle of Wight was chiefly devoted to thatchbeating for Depressariae. Later I went with my parents to Devonshire, my first visit to a county which has since become a second home. Among my captures were Agrotis saucia at sugar at Ilfracombe and Lynton; Camptogramma fluviata ${ }^{1}$ at lamps at Exmouth, where I also met with Sterrha sacraria; thatch yielded Depressaria ciliella, yeatiella, albipunctella, and badiclla. Among the insects that I did not take in Devonshire was "a large butterfly, dark brown, almost chocolate-coloured, with a broad white edge to all its wings," which my mother saw at Hele, near Ilfracombe, about the flowers of Pied Valerian. Unlike its congeners, it did not revisit the same spot when I was there with my net. ${ }^{2}$

In this year, 1867, Mr. Blackmore had a serious illness, and it is my impression that from this time forward he did but little collecting in this country. Newman's "Moths" was now coming out; I viewed it with mingled feelings.

It is indicative of the impulsive enthusiasms of youth that whereas the diaries state that in the spring I had resolved to work at the Tineina especially, a similar resolution as to the Tortrices was made in the autumn. However, second thoughts were the more enduring and I remained faithful for the three years or so until I ceased to collect altogether. Indeed Buckmaster and I entertained the ambitious idea of writing a book to supersede Wilkinson's work, but this never took definite shape.

At Easter, 1868, I left Rugby and divided the next six months between working for Oxford and collecting. On Wimbledon Common I found Adela cuprclla ${ }^{3}$ common though very local, and also took there Chorcutes scintillulana as well as Anchylopcra. subarcuana (inornatana). Regent's Park was visited for Biston hirtaria. Once again West Wickham was not very productive; but Coombe Wood yielded Notodonta dromcdarius, which I had not

1 In those days common at lamps in the Wandsworth district.

2 Sec Entomologist's Monthly Manazine, Vol. IV., p. 36.

3 Ibid., Vol. V., p. 77. 
taken there before; moreover Buckmaster pointed out to me a larva of Acronycta alni on a hazel just outside the rood. At Darenth I took Hadena contigua at rest on a tree-trunk, also Tortrix sorbiana and two specimens of the local T. semialbana. Box Hill produced Ellopia dolabraria, Lithosia rubricollis (abundant among yews) and Crambus chrysonuchellus. To this day I have scarcely got over my disappointment at missing two of the lovely little Lcptogramma literana beaten from oaks on Ashstead Common; it has a bad habit of darting to the ground when disturbed, and is almost as cryptic on the wing as at rest.

Several of these boyish expeditions remain with me as vivid impressions, but it was in July, 1868, that, to quote an old diary, "I spent the most glorious month of my life," with that perfect travelling companion, the late John B. Blackburn, in a peasant's cot at Camghouran on the shore of Loch Rannoch. To give my fellow collector's account: " "At the somewhat gloomy close of a fine day early in July, we left the road which borders Loch Rannoch, and crossed the rough fields which lead to Camghouran. We had reached the end of a somewhat harassing journey, and it was with feelings of intense satisfaction that we saw the collecting-cases and portmanteaux, containing all necessaries for a Scotch campaign, laid on the stone floor of our little abode. Our kind hostesses very soon put before us a meal, such as all who have visited Camghouran will vividly remember; and the sight of the newest of milk and the freshest of eggs ${ }^{2}$ urged us to recruit before we turned out, as we had resolved to do, for a few hours' collecting on our first night.

"To one of us the scenery, and, better still, the insects, of the district were quite new; and, as we passed down the long barleyfield beyond which lies the great sugaring-ground of Rannoch, the other set himself to combat the slightly gloomy impression conveyed to the mind by the grand mountain solitudes and sloping moors veiled partially, as we saw them now, by uncomfortable looking masses of cloud. Turning to the left, we reached two very different tracts of land separated by the high road: that next the loch being grass-grown, and covered with fine birch trees, while the other produces a mingled mass of heather, rushes, and fern, amongst which grow, singly or in clumps, birch, fir, and alder trees. Here, at nine o'clock, sunset had scarce faded from the sky: dark banks of cloud were still shot with vivid lines of light; the air was soft

1 Entomologist's Monthly Magazine, Vol. V., p. 221.

2 (Editorial note to original papor.) "Milch-cows and productive bens appoar to bave boen imported since our experience in 1865.-R. McL.(mchlan) ; E. C. R.(yo)." 
and warm, and the loch lay motionless, almost at our feet. Some eighty trees, near the loch's edge, received an application of the sugar, and we retired among the heather and woods in the background to "moth" until the charm should have exerted its sway. Here a fine $G$. papilionaria crossed our path and was safely boxed, and somewhat peculiar forms of $B$. repandata occurred commonly.

"Darkness had come on by about a quarter to eleven sufficiently to warrant a first visit to the sugar; anxiously, and with darkened lamps we drew near to the first tree. Former experience told us that sugaring at Rannoch was not quite profitless. One held the net below the sweet track of bark, the other flashed a stream of light upon it; both peered with eyes as greedy as the most ravenous polyodon. A Carabus drew back, and politely stopped eating; two "daddies" buzzed off, and banged against the lamp; and a great snail seemed to be regarding contemplatively the shiny traces of his own ascent; but there were no moths.

"Tree No. 2 surprised us with a goodly sight. The brothers tincta and occulta absorbed sugar side by side, both in the loveliest of condition; $N$. conflua, C. cubicularis, and $X$. rurea dropped in to complete the party. At the next "spread" we found tincta and nebulosa, a lovely $H$. contigua, $R$. tenebrosa, and $T$. pronuba. This first night was, indeed, undeniably good. Tincta was common; occulta, of the deepest shade of blackness, and without a rub, not by any means rare; and a fair sprinkling of duplaris, contigua, tcnebrosa, festiva, conflua, cubicularis, rurea (and var. combusta), polyodon, adusta, and augur. ...

"Our sugaring continued to be good throughout the whole four weeks of our stay. For some time A. tincta and occulta were of frequent occurrence, and few insects, when in faultless condition, present a more striking appearance than the latter [but it is a somewhat ticklish moth to box]. H. contigua and adusta were not rare; viminalis came out in some numbers [towards the end of our stay]; of each of $N$. ncglccta, M. furva, C. haworthii, C. duplaris, and $O$. suspecta [at end of the month], we secured a few specimens; and $S$. anomala, with the last traces of respectability rubbed out of him, one night surprised us by a visit. $R$. tcncbrosa was common (and, as usual, far from fine), and $N$. conflua not scarce.

"The 'vulgar herd,' most of them constant attendants, comprised $N$. augur, baja, C-nigrum, brunnea, xanthographa, plecta and festiva; $X$. polyodon and rurca (both species represented by very fine varieties); T. orbona [remarkable forms] janthina, and pronuba; C. cubicularis; A. porphyrca; H. pisi. 
"The following trespassers came to sugar:- $-L$. cccesicuta, $C$. russata, M. Aluctuata, B. repandata, M. margaritata, R. eratuegata, $L$. peetinitaria, C. populata, $\dot{L}$. olivata, and $H$. elutata."

To Blackburn's list of "trespassers" I may add the following micros:- Tortrix fosterana, T. ribeana, Endrosis fenestrella, Grapholitha pentileriana and abundance of Paedisea solandriana. My friend never alluded to the mammalia that were attracted, by our lamps rather than our sweets; possibly he thought they would be out of place in a journal devoted to Entomology, but I suspect wounded pride had something to do with it. The solitude of such a place as Tiannoch may be a bit skeerie at midnight, and when one hear's a large animal night after night gallop up and down in the long heather close by, one is disposed to draw near one's companion for security. The loud barking of the foxes in the mountains behind was scarcely reassuring. We christened the great unknown "the mad stag." Once, as Blackburn was squatting down to secure an insect in his net, he heard, as he thought, my step behind him, and looked up to discover the deer (for such indeed it was) looking over his shoulder! With a bound it disappeared into the darkness, and haunted us no more. But worse was to come. One night we were fairly driven off the sugaring-ground by a solid phalanx of big-horned black highland cattle! What could wo do save retire in good order, walking backwards with lamps directed into the great beasts' glaring eyes?

Camghouran ${ }^{1}$ (as it is spelled in the Ordnance Map) consists of a group of huts irregularly scattered over the hill-side, but the Robertsons who dwell therein call it "the toon." As a rule house and stable are under one roof, and that not too well adapted to keep out the weather, of which one usually gets so much in those parts. When the wind blew we felt the pattern of the stones in the walls by the narrow vertical and horizontal draughts which seemed to cut us into cubes. We slept in bunks, where a sheet stretched over some hay promised well, but if restless one was apt to get a good deal mixed up before morning. Our full postal address was :-

$$
\begin{gathered}
\text { c/o Mis. Robertson, No. } 5, \\
\text { Camghouian, } \\
\text { by Kinloch Rannoch, } \\
\text { Pitlochry, }
\end{gathered}
$$

Perthshire, N.B.

1 Blackburn spolled the namo Camachghouran, but the Ordnanco Nap gives Camghouran; it is pronounced Cam-a-ghouran-tbe gh a guttural aspirato. Tho natives call the district Ranach. 
but a letter inscribed simply "T'o the flyman in Kanach" was delivered by the first post.

We did not give "light" much chance as an attracting agency, since we spent most of the short hours of darkness outside, nevertheless a specimen of Agrotis lucernea (which we suspected of designs upon our treacle store) once gave us a quarter of an hour's chase round the tiny room. The small window-panes were examined daily for the local Oecophora similella, Linn. (stipella, Doubl.) which associated with Tinea pellionella, T. (?) fuscipunetella, and T. rusticella, as well as remarkably fine Endrosis fenestrclla, and an occasional Aglossa pinguinalis; however, we found the Oeeophora more common in a neighbouring shed.

Our fare was simple, our appetites comprehensive. We brought a ham and a bag of oatmeal along with us, and had arranged for a periodical supply of mutton by the "machine," as the carrier's cart was not inaptly named. However the thirty miles jolting proved quite too much for the second joint, so we gave up mutton. Luckily there were plenty of eggs, and accordingly when we left for the South the chief item in our bill was " 19 dozen eggs at $3 \mathrm{~d}$. the dozen."

One day we were honoured by a call from Capt. Robertson, of (I think it was) the Highland Light Infantry, a son or nephew of the Struaness of Struan-the great Lady of the place, who lired in "the beg hoose." As a result he was good enough to grace our humble board, and in honour of the great man our hostess provided three poached eggs each, instead of the usual ration of two. At this we fly-men greatly rejoiced, but the gallant officer, whose appetite was on the peace establishment, was amply satisfied with two eggs, and great was his amusement when Blackburn and I, having easily demolished our three eggs apiece, greedily tossed for a fourth, since we had no notion of letting his odd one go out.

For some time we were at,a loss to make out what was the staple food of our Robertsons. Oatmeal, to our surprise, they had none; certainly they did not fare on mutton, for "braxy sheep" is a luxury rarely to be had, and they could not periodically feast upou the one small porker. Careful observation showed us that the chickens and the dog were both fed on potato peel, and that the said porker lived on potatoes. In fact our hosts were potato feeders, being too poor for oatmeal porridge or oat cake.

One day that same porker's screams rent the mountain air, and made ne leave pins and setting boards to rush to his sty. There I saw Maggie, our cook, parlour-miaid and house-maid, seated in the 
sty upon a milking stool with the pig between her knees, the little animal squealing loudly as she scrubbed it with soap and water!

On grassy knolls within the precincts of "the toon," Aphelia pratana was as common as it is upon the South Downs. Among the frequenters of the patches of wood on the lower ground were many insects that are familiar to London collectors:-e.g. beating sallows by day drove out a few Hypermecic angustana, Hübn. (erueiana, Zett.), and Enpithecia tenuiata, while Depressaria conterminella flew over the same bushes at dusk; strongly marked varieties of Grapholitha pentileriana were to be found among alders; birches produced Tortrix ribeana, Antithesia corticana and praclongana, together with Grapholitha paykulliana, Fabr. (ramella, Linn.), and campolitiana, Treit (subocellana, Don.), these Tortrices were chiefly found on the birch trunks, but upon the twigs, Argyresthia goedartella and retinella fairly swarmed.

Stilbia anomala occurred freely on the moors and remained for three days in exquisite condition, after which it was almost over. It was best taken at dusk just beyond the houses. At the same time and place we searched ant-hills for Tinea ochraceella till our eyes watered with the emanations of formic acid: the moths crawl up the grass stems on the nests, but they were very scarce.

Erebia blandina (aethiops) was common enough in the open parts of woods, a male was taken with the fulvous patch on one forewing devoid of the usual spots; in the same places, especially on the slopes of Crois Craig, Plusia interrogationis, very variable and in exquisite condition, was to be found on dull days on stones and birch stumps. It was in searching for this lovely Noctua that I first seriously felt the disadvantages of my short and bad sight; Blackburn found many more than I did, and also picked up a fine Hadena rectilinea at rest upon a stump.

The Black Wood of Dâll was somewhat of a disappointment; its mighty pines, over twelve feet in girth, and dense growth of various species of Vacinium and heath suggested all sorts of things. Among the pines we took Ellopia fasciaria (prosapiaria) and a few Cedestis yysselinella and Gelechia galbanella, while small dark varieties of Tortrix fosterana were not uncommon; Fidonia brunneata (pinctaria) was common enough but exceedingly local; Sericoris dalcana (alternana) was also to be had. Towards the end of the month Grapholitha geminana flew in clouds over the Vaccinium in the sunshine, in fact I have rarely, if ever, seen an insect so abundant; sometimes eight or ten were in my net at once. We spent some hours walking up and down a piece of lush herbarge near the road where Blackburn 
had taken three superb specimens of Stcrrha sacraria in the previous summer, but without result; we picked up, however, a few of the Rannoch Cetoniid Trichius fasciatus for Mr. (now the Rev.) Thomas Blackburn, and I fancy it was here, or in some other marshy land near the loch, that we found Schrantic turfosalis. It was certainly not far from this spot that, on and around two splendid Aspens (Populus trcmula), we came across swarms of Grapholitho, cinerana, variable, but without any trace of fuscous or ferruginous; I boxed 40 in a quarter of an hour!

Emmelesia ericetata (minorata) was very common in all directions, but for $\boldsymbol{E}$. blandiata (adacquata) we had to make a pilgrimage to Kinloch Rannoch, but were rewarded, at any rate, with a few specimens; there we also found Eupithecia succcnturiata; while on the way we came across a young Aspen which had many of its leaves spun together two and two, with a somewhat disgusting looking larva of Cymatophorce or between them; we found about a hundred on that one small tree.

But all said and done the great expedition at Rannoch is that to Mount Grayvel. ${ }^{1}$ The ascent begins at the cottage door, and the views gain in beauty and variety as one climbs up. As soon as the moor is reached Acidalia fumata and Larentia caesiata start from one's feet; both might well be said to swarm, but the number of the latter, mostly in perfect condition, was almost incredible; they rose in dozens from each rock as one drew near. Among heath Eupoccilia angustana was everywhere plentiful, with them we found a solitary Eupoecilia of which Mr. McLachlan said after'wards "it comes nearest to my degrcyana, but the wings seem too short; I think I saw a specimen from Mr. Burney identical with yours." Among heath and fern we found also many small dark specimens of Scricoris lacunana, together with Plutella cruciferarum, ${ }^{2}$ and very large examples of Plcurota bicostclla. Now and again Ncmcophila russula flew wildly past, while Blackburn found Scodiona bolgiaria at rest among the heather. Larvae of Lasiocampa callunac were in some numbers, and those of Saturnia carpini not uncommon. Sweeping the heath yielded Acronycta monyanthidis. On such ground the lovely Crambus margaritcllus was generally common, but C. cricallus was only picked up occasionally. Phycis fusca (carbonariclla), as

1 So Blackburn spelled it: the local pronunciation was Garra-rcl. No such namc occurs on the Ordnance Map, lut where it should bc found there stands Mcall-NanSac. Qucry, is one name Scottish, the other Gaelie?

2 Mr. J. H. Durrant informs me that this familiar insect was described by Curtis as maculipennis, 凤 name that has priority over Zoller's. 
usual, was found among burnt heather, which reminds me that, on returning from one of our expeditions to the mountain, wc came upon a small cup-shaped hollow near the burn overlooked by a group of grand old pines, it was filled with ling which had evidently escaped all fires during the lifetime of the oldest inhabitant; we plunged into it, when to our surprise the ling closed over our heads! We did not catch much in that hollow, indeed it was no easy matter to penetrate the dense growth.

Where Vaccinium prevailed over Erica and Calluna we found a few Mixodia palustrana, and many Coccyx ustomaculana, together with a few of a Lithocolletis which we attributed to vacciniella, although Mr. Stainton said in a letter that the determination was "not free from doubt."

In the wetter parts of the higher moorland the Large Heath, Coenonympha davus (typhon), was abundant, and on the same ground (even up to $2000 \mathrm{ft}$.) Nemeophila plantaginis gave us many a headlong chase, in one case leaving the writer stretched prone upon the bog with great clatter of pill-boxes. In such places Bactra (?) lanceolana simply swarmed, but they were so small and highly coloured as to suggest that they could scarcely be conspecific with the large pale obscurely marked form that was to be found in the meadows by the loch side.

Near a burn below Grayvel we took a solitary Coccyx tacdana (fnitimana), and not far off a few Coremia munitata, which seemingly preferred stony ground. On the actual slopes of the mountain Tortrix viburnana was common, as indeed it was on the higher moors generally; on the same slopes at our first visit Mixodia schulziana was abundant, to be replaced later on by swarms of the pretty little Pamplusia monticolana (mercuriana).

The rugged summit itself seems to owe its virtues to the fact that its stony head is but sparsely clothed with grass and moss, in place of the denser growth of heath and bilberry with which its neighbours are covered. Hard work stumbling about on this rough terrain yielded a few spccimens of Psodos trepidaria (coracina), an insect hard to see and harder still to catch. Small and dark specimens of Sericoris daleana (altcrnana) were to be had in plenty, and a very fincly marked Amphisa gcrningiana was secured. Crambus fur'catcllus was tolerably common, and we were fortunate in securing a fair number of Scoparia alpince (paralis), a distinctly "good thing." A few Mixodice schulzicona also reached the summit, as well as the tiny lithocolletis (?) vacciniella. Among the bilbcrrics half-way up Cidaria populate was very abundant and Scopula alpinalis not uncommon. 
"Descending, we visited a hollow on which the sun just then shed warm and friendly rays, and here Erebia cassiope (epiphron) sported to and fro in considerable numbers, its little black form being very conspicuous against the bright green grass."

With one of the "good things" of this classical locality, Dasydia obfuscata, we were somewhat disappointed, but managed to secure a few fine specimens. Mr. Blackburn obtained eggs and succeeded in getting a few of the larvae through the winter. It was somewhat tantalizing to cut out from one of the old birches on the sugaring ground the empty pupa-case of Trochilium scoliaeforme. Exactly where we got Botys fuscalis has escaped my memory, and the same is true of Peronea caledoniana, but Ellopia fasciaria flew rather freely at night in the neighbourhood of fir-trees, and Larentia olivata was found at rest as well as flying by the loch side at night.

As for larvae we got several of Hadena adusta, while sallows gave nourishment to a few Notodonta ziczac, and a fair number of Clostera rechusa and Cerura furcula. Certain larvae beaten from alder we took to be those of Selenia illustraria, but they presented a most curious variety of colouring: whether or no Mr. Blackburn reared them I cannot remember. He found a fine brood of Dasychira fascelina just emerging from the egg. I beat a larva from Rowan (Pyrus aucuparia) from which I ultimately bred a most lovely specimen of Cidaria psittacata.

During the last few days of our stay we spent some time collecting Tortrix larvae from birch and sallow, but more especially from Myrica galc, Vaccinium vitis-idaca and $V$. myrtillus. Those found on the two last-named plants would seem to have been terribly infested with ichneumons, whose larvae and pupae were common, together with Tortrix larvae, but most of the latter were hor's-de-combat, healthy ones being very scarce. From such of the latter as we did find we reared during the next two months a number of Peronca forrugana, nine $P$. maccana (off $V$ accinium), one $P$. lipsiana (off $M$ yrica), several $P$. hastiana and one Phlaeodes crenana.

Profiting by the melancholy experience of a "fly-man," who, on a previous occasion, had unwisely confided his store boxes to the tender mercies of the "macline," we trudged on foot, boxcs in hand, all the weary miles from Camghouran to Kinloch Rannoch.

On our way North we had jourmeyed from London to Dundee by sea, and after thoroughly enjoying a good lunch in the Thames, were induced by the chief steward to compound for our food for the whole voyage. However, when we got well into the North Sea it began to blow pretty stiffly from the nortli-cast, and contimued to do 
so. It was the longest voyage that I had made, and was, perhaps, the worst in my experience. Any way the mention or mere thought of food was but an intensification of a misery that was scarcely endurable. For my part, I reached Punch's second stage, when one fears that the ship will not go to the bottom, yet somehow Dundee was reached at last. Now we had taken very little money with us, and on the return journey a portmanteau went astray which necessitated posting in a dog-cart some twenty miles, a heavy tax on the slender balance in our pockets. The train from the North just missed the Dundee train at Perth-we saw our train moving out of the station, but were told that if we ran we could catch it at the next station! Accordingly run we did, cumbered as we were with precious store-boxes and setting-houses. It was a very hot Angust day, and the permanent way did not afford a good running ground. At first the train receded hopelessly, but we held on; anon we seemed to keep our distance, then to be gaining slowly. How hot, but how thankful, we were when the half mile or so was covered, and we found ourselves panting and exhausted in our thirdclass compartment! When we got on board our steamer at Dundee the head steward again suggested that we should compound for our meals, but with proud wisdom after our painful experience, we more or less politely declined. We cast off in perfect weather, which endured to the end of our voyage over a glassy sea. Naturally a month's hard work collecting day and night with truly simple fare had got us into splendid health, and given us the appetite of two young wolves. Meal followed meal with the usual nautical frequency, and we ate oft and gaily. Alas! the question of payment inevitably came up, and to our chagrin we found that the lost portmanteau had more than absorbed our surplus cash. Accordingly we had a long and sad discussion as to the relative expediency of having dinner or breakfast, for we could not afford both. What the decision was I forget, but whichever way the lot fell, the event entailed more self-denial than we found pleasant. At the docks we got into a cab having but a few coppers in our exchequer, and had to call at a friendly office in the city to borrow money to pay the fare.

Soon after our return from Scotland the Blackburns introduced me to the National Collection, then in the gloomy cellar at Bloomsbury, and my diary refers to the T'ortricina therein as "in a most wretched state ; aceriana, dealbana, and ocellana all muddled up."

I was extremely desirous to capture something new to Britain, and my chagrin was great indeed when Dr. Knaggs, after expressing 
a strong opinion that one of my Rannoch Tortrices was "new" finally decided that it was nothing but an extreme varicty of Graphslitha payjiulliana, Fabr. (ramclla, Linn.).

Mr. Stainton wrote me in refcrence to some Rannoch Tineina: "The insects in your box which have interested me most are Nos. 3 and 4, of which you say: "Bred and beaten from ash. Larva olive colour, with brown dorsal stripe.' They are the dark variety of Prays eurtiscllus, which I have never bred, though I have often bred the ordinary white form. Many entomologists think the dark specimeus ought to be a distinct species."

In England the heat of the summer of 1868 was unprecedentcd. It had the effect of greatly reducing the numbers of heath-feeding larvae on Wimbledon Common: another result, perhaps, was the occurrence of several specimens of Pyrameis cardui at Wandsworth, though it had also occurred there in the previous year. At the blossoms of Petunia in my father's garden in September, I saw Sphinx convolvuli, as well as another large Hawk-moth, which I thought at the time to be Acherontia atropos. That autumn I bred two specimens of Peronea rufana, Schiff. (autumnana, Hübn.) of the variety bistriana, from larvae taken on White-Poplar in Southfield, Wandsworth, between one and two miles from the old Wimbledon Common locality. ${ }^{I}$

In 1869 I had some very pleasant collecting at Forres, in Morajshire, with the late $\mathrm{Mr}$. George Norman, of which an account appeared in the Entomologist's Monthly Magazine (Vol. VI., p. 214). Again my almost wild desire to capture a species new to Britain was disappointed. Some very distinct Dcprcssariac attached to Broom, in which all the veins were marked with fuscous, and in some cases the thorax striped with the same colour, turned out to be merely a variety of the common $D$. costosa. However in this, perhaps at that time my favourite genus, I shortly afterwards had the pleasure of identifying as $D$. cnicella, Treit., some specimens taken on Hayling Island by Mr. Moncreaff among Sea Holly (Erynginum maritimum), the insect bcing then, so far as I kwow, unrecorded as British.

At Forres I found a larva on the Sweet Gale (Myrica galc) which I felt sure at the time must be that of Acronycta myricae, Guen. (euphorbiac, Schiff.), then undcscribed. Accordingly I described it with great care, and hopefully watched it pupate, but alas! the imago never emerged. A description published a few years later proved that my conjecture was a sound one. While at Forres I

Entomologist's Monthly MIagazine, Vol. VI., November, 1869, p. 143. 
busied myself with getting eggs of Erebia blandina (aethiops) for the late Mr. Win. Buckler. After some fruitless attempts I was successful. A few butterflies were confined in a band-box covered with gauze containing also some of the food-plant (the grass, Molinia coerulea). The point was to keep the butterflies alive, and this I succeeded in doing by the simple expedient of inserting into their cage a damp sponge, at which they drank frequently. Water seemed to suit them better than syrup.

Earlier in the same year (1869) I again travelled on the continent, and it was in the Franconian Switzerland that I first saw Lycaenids drinking at a puddle in the road, many species together, including, I believe, among others Lyeaena ninima, Fues., and L. arion, Linn., the two extremes. The next year, in the Tyrol, I got near enough to a Purple Emperor when drinking to catch it in my hat! At Maidenhead, in the middle of an August afternoon during a heavy shower, I pill-boxed two Humming Bird moths sitting within a few yards of one another on a fence. I have always looked upon these as among my most remarkable feats of legerdemain.

At Oxford I joined the then moribund Oxford University Entomological Society, and the minute-book shows that I attended several of the meetings and took part in the discussions.

In my second term an accident cost me the sight of my right eye. It was not a great while after my recovery that I found the setting of some Hydrelia unea, taken in Headington Wick Copse, very trying to my eyes, the trouble being much increased by monocular vision. Ultimately with great reluctance I decided to give up collecting altogether.

At that time I had a considerable number of entomological correspondents, including Messrs Stainton, Knaggs, BuchananWhite, Buckler, Hellins, Moncreaff, Harper-Crewe, Porritt, Norman, McLachlan, and Mrs. Hutchinson of Leominster. Few of these, alas! are still living, but some of their letters still remain in my possession. In later years, towards the end of his life, I had much interesting correspondence with Barrett, chiefly about the larvae of Eupithecia jasioneata, with which I supplied him.

My first long voyage was in 1884, when I wont to Canada with the British Association. I did no collecting but saw a number of $V$ anessa antiopa among willows near the Devil's Lake in the Rocky Mountains, also a specimen of Pyrameis virginiensis, Drury (huntera, Fabr.) busy at a flower bed near the Parliament Buildings at Ottawn; moreover I made my first acquaintance with Danaida archippus, Fabr. (plexippus, Linn.) on Hanlan Island near Toronto. When in the 
Indian Camp at Blackfoot-Crossing as I was starting for a walk over the prairie with my friend $\mathrm{Mr}$. William Barnard, a young brave, "Yellow Horse," ran up and excitedly tried to stop us. He was eloquent in the sonorous Blackfoot tongue, but for some time failed to make himself understood. At first I thought he was anxious to tell us not to go near the burial place of his tribe-if exposure of the dead may be termed burial. At last a sudden thought struck me; there were some ominous black clouds in the sky, nevertheless I thought it would not rain. Accordingly I made the sign for rain commonly used by the deaf and dumb in England followed by the Blackfoot negative sign, which I happened to know. Our friend Yellow Horse at once understood, smiled, indicated his disagreement, and let us pass on. We were right, the untutored savage wrong, it did not rain. The signs used were (1) pointing to the sky with fore-finger = weather, $(2)$ a quick double shake of the fingers = rain, (3) the action of tossing a thing away with the right hand, as if worthless = negative.

A visit to Tenerife in 1887, and subsequent visits to Madeira and to Vesuvius, called my attention to volcanic phenomena. I reprint here an account of a winter ascent of the celebrated Peak, written at the request of Mr. Latimer (of the Western Daily Mercury), who was in the island at the same time as our party. On the lower parts of the island I saw for the first time alive Pyrameis indiea, Herbst, and Deiopeia pulchella, Linn.-insects I was destined to see again far, far away. A note published at the time is placed at the end of this chapter. On the slopes of the Peak I saw many large beetles, sluggish black apterous creatures (T'enebrionidae; ? Blaps, or? Pimelia). These, old Dr. Crotch told me, were benefited by the absence of wings, since it saved them from the risk of being blown away to sea. From the parochial point of view of a Canarian naturalist the theory was plausible enough, but how does it apply to closely allied insects on the Sahara, or on the Libyan desert?

Meanwhile, in 1879, I had bought a house at Mortehoe, North Devon, and from that time spent some portion of every year there. It was but natural that moving into a new locality aroused entomological thoughts, and I took to noting in my interlenved copy of "The Manual," such species as I from time to time came across. Yet I did no collecting on my own account, though usually carrying a net and a few pill-boxes. When, however, a Buckmaster, an Image, an Onslow, or more frequently a Dixey favoured me with his society, I rejoiced to have an excuse to sally forth at night with lantern and sugar-pot. Occasionally the Red Valerian (Centranthus 
$m b c r)$, or the treacle-bedaubed gorse bushes yielded such things as Agrotis ditrapezium, A. lunigera, Leucania unipuncta, or Polia xanthomista. This led naturally enough to the printing of a local list in 1901, followed by new editions in 1903 and 1907 .

It was in 1903, just before I sailed for India, that Dr. Dixey called my attention to certain bionomic questions, and the consequent value of observations on some of the very commonest insects. This proved to be a turning point in my life, for which I cannot be too thankful to him. Shortly afterwards I found that the distinguished entomologist, who succeeded Westwood as Hope Professor, was willing not merely to house in the great collection under his charge almost anything that I might catch, but what was in my case especially important, to get my captures set and so save any strain on my surviving eye. Thus it was that after an interval of over thirty years, at the mature age of fifty-four, I returned with renewed ardour to my boyish love. From this it results that the Hope Collection in the Oxford University Museum is now cumbered with over twelve thousand specimens of all orders of insects collected by me under the circumstances related in the following pages.

\section{A SPRING ASCENT OF THE PEAK OF TENERIFE. ${ }^{1}$}

Before leaving Fngland we had deeided to aseend the Peak, but on our arrival at Orotava we heard on all hands that it was impossible to go up on aceount of the snow. However, a preliminary reconnaissanee from the Cañndas, or old erater, more than half way up, confirmed our impression that the diffeulties werc greatly over-estimated, and Dr. Croteh, the one Englishman in the plnee who knew the monntain well, reassured us. The aseent in winter is so rarely essayed that it is diffieult to get an outfit. Alpenstoeks could not be bouglit, but fortunately were to be borrowed from goatherds; nails to repair the gaps in shooting boots had to be specially made by the blacksmith (N.B.- They were sueh as were loeally used for shoeing asses !); snch a thing as a bluo gauze veil eould not be supplied by all the drapers and milliners in the town. Finally it was with difieulty that guides could be induced to attcmpt "El Pico."

At length, soon after 6 A.M., on March 12, we started, the thrce baggage mules laden with food, water, and wraps for the eold, and after a substantial menl we followed on horseback. Our party eonsisted of Mrs. Longstaff, her sister, Miss C. A. Dixon, Mr. R. $\Lambda$. Read, and myself, with two guiles, two muletecrs, and sundry boys in charge of tho horses.

The route lay at first through small ficlds and terrneed gnrdens, whicre flourished nnder a broiling sun vines and figs, guavas and bananns, the priekly pcar (lome of the cochineal insect), aloes, palms, tho castor oil plant-here grown for a erop and not for ornament-and, suggestive of consolation for the same, oranges and sugn:

' Reprinted from the Western Daily Mercury, 1887. 
cane. The potatoes secmed as far advaneed as those in England in June, and the young eorn, more than a foot high, was cnlivened with a pink Gladiolus growing in profusion.

Amidst these benutiful surroundings it was impossible to forget for one mornent that Tenerife is but a volcano and nothing more. At starting, the pebbles by the shore, were seen to consist of lava; the road is always a lava stream, the innumerable terrace-walls are built of lava; lava, basalt, scoria, pumiee-the whole island is made up of these in various proportions. Seetions displayed in rarines in many cases show the lower surfaee of a lava stream to have burnt to a bright red the aneient soil over whieh it flowed. Immense labour is required to produee agrieultural land from sueh unpromising materials. The lava, from $4 \mathrm{ft}$. to $8 \mathrm{ft}$. thick, has to be broken up and removed, then the aneient soil thus exposed is eleared off, the lava put into its place and the soil on the top of it. Finally all this would be in vain, and no "Saek" or "Canary" eould be produeed without eostly irrigation works. The one animal eommonly seen is a large sombre-coloured lizard.

The gardens are soon left behind, and for hours we ride or walk orer the endless lava streams which in bygone ages left the old erater through the Portillo del Taoro, and poured into the vale of Orotava; to our right rise the lofty erags of Tigayga, the Egyptian Vulture grandly soaring above them. The peeuliar vegetation of the Peak is seen to advantage. There are seareely any grasses or small plants; at first nothing but the tree heath, here from $4 \mathrm{ft}$. to $8 \mathrm{ft}$. high, though in the patehes of the aneient forest still remaining it reaches a height of at least $40 \mathrm{ft}$.; then the Adenocarpus, a serubby leguminous shrub of green bue; lastly a plant which is found nowhere in the world but on the Peak of Tenerife, betreen the heights of about 5000 and $9000 \mathrm{ft}$. above the level of the sea. This, the Ilountain Broom (Retama canariensis), is a striking objeet; it is leafless, but in May produces a profusion of white flowers which are the delight of bees; to travellers it is invaluable, as it affords shelter, bedding, and firing, and we get soon to look on its grey-green elumps with affeetion. We hear, but do not see, the real "Canary" bird (Serinus canariensis) singing among its branehes.

Soon after noon, at a height of $7000 \mathrm{ft}$., far above the white elouds that eoncenl our starting plaee, we pass through the Portillo into the ancient erater called the Cañadas. This is eight miles in diameter, and on the north-east, south, and southwest, is enelosed by precipitous erags, varying in height, but in one place reaching $2000 \mathrm{ft}$. above the plain. The boundary wall is broken here and there, as at the point we entered, but especially on the nortl-west, where devastating streams of lava have issued from time to time.

The guides want us to eneamp in a bleak place where the wind sweeps round the eliffs of the aneient erater, but we decide to leave the riding horses there and push on on foot aeeompanied only by two baggage mules, the two guides, and a muleteer. After a trudge of two or three miles aeross the pumiee-eovered plain, the guides who followed us strike, and hitel up the mules to two bushes. So Mr. Read and myself have to go baek and lcad on the mulcs ourselves, wishing the guicles "good-night." On this they skulk after us in a whipped-dog sort of fashion. At lengtli we reael a spot towards the foot of the mountain, where some lava bloeks on the side of a hilloek and a few friendly Retana bushes afford a little shelter from the wind, while a patch of snow at a convenient distance ensures a water supply.

The guides, astonished at our energy, now appeared disposed to sit down and bewail their fate. Bnt Mr. Read and I began immedintely to build up with blocks 
of lava a low wall to windward, the guides grudging such assistance as they rendered; the Alpenstocks were built into it, and a very tolerable tent madc by stretching rugs over them. The ladics meanwhile busied themselves with cutting largc quantities of Retama twigs for bedding, while the guides in a leisurely manncr collected dead Retama, of which there was abundance at hand for firing. In two hours wc had a really comfortable bivouac and a blazing firc. Without our assistance the guides and their beasts would lave been miserable; the mulcteer would not eveu melt snow for his animals, and was in truth a surly, lazy fellow. We supped at sundown and at once made ourselves snug for the night, and with sucl success that instead of being cold as we had expectod we were all too warm.

A bivouac $8000 \mathrm{ft}$. up a mountain is too cxciting a situation for sleep, and we soon found ourselves sitting up in a row looking at the stars and waiting for the moon to rise. The guides made no attcmpt to keep the fire going; this was left to their employcrs, who had, moreover, late in the night, to sally forth to replenish the scanty store of wood that their lazy improvidence had supplied. At midnight we roused the camp-the guides grumbling bitterly-and, after some food, were soon on the move in the brilliant moonlight. Easy gradients over pumice and small patches of snow took us in an hour and a half over the Montaña Blanca to the foot of the Pico del Teyde itself, and we began thc ascent. A slight path led by zigzags up a steep slope of loose cinders, ${ }^{1}$ at the top of which somc huge blocks of lava constitute a resting place, where in summer the night is often spent, but which is now inhospitable owing to snow drifts. This spot, $9700 \mathrm{ft}$. above the sea, bears a name which shows the enterprise of our countrymen-Estancia de los Ingleses. Here the guides again rebelled; they said it was impossible to go further in eonsequence of the snow. Accordingly we took the furs and other wraps they werc earrying, and again bid them good-night.

By this timc the great rarity of the atmosphere at such an elcvation told severcly on one of the ladies, who was attacked with "mountain sickness." After every 200 yards or so she was compelled to lie down on the rocks; finally, both ladies werc ovcreome with the cold of tho strong north-west wind that nearly cut onc's ears off, and produccd an effect on the nose that no quantity of pocket-handkerchiefs sufficed to assuage. Further progress was impossible under the circumstances, and the four of us liad to scek an apology for shelter on the lee side of a crag that might lave afforded a perch for a pair of ravens, but gave most inadequate and angular aceommodation for four human beings. However, we had to huddle together under such wraps as we had, and economise heat as much as possible.

In about an hour and a half the sun rosc magnificently, and we rejoiced in all those glories of cloud and light which aro peculiar to a mountain sunrise and defy description. Herc and there the sea was visible through a sheet of elouds, and far, far bclow lay the Villa and the Puorto de Orotava. Tho heavy surf breaking on thirty miles of coast showed that the wind was not eonfincd to the top of the mountain. To the south-east, among the clouds and scarccly distinguishable from them, appcarcd tho mountains of Grand Canary.

On looking about us after sunrise we found that we wero closo to Aita Vista

1 Though the coarser volcanic ojectamenta are commonly, and conveniontly, termed "cindors," and the finer "ashes," it should not be forgotten that, since but little true combustion occurs in volcanoes, those terms are not strictly correct. Like slag, which some forms of lava and scoria olosoly resomble, most of the solids poured forth by volcanoes partako rather of the nature of glass, or porcolain. Lava is in generic term; basalt and obsidian (" volcanic glass") are species. 
$(10,700 \mathrm{ft}$.$) , the place where somc five-and-thirty years ago l'rofessor C. P'iazzi$ Smyth lived with his teleseopes for sereral months. $\Lambda$ small wooden hut, belonging to a sulphur company, was snowed up and wc failed to force tlic door, but a comparatively warm place was found for Mrs. Longstaft wherc she could at least lie down on the cinder's in the sun, and the guides, who by this time had come up to look for us, wcre told to take care of her. Our party was now reduced to three - myself, faint with the cold and panting for breath; Miss Dixon, panting but othcrwise well; and Mr. Read, fit for anything.

There still remained to vanquish $1,500 \mathrm{ft}$., and that the hardest part. We found as a rule the snow was the best going, but we had bcen warned by Dr. Crotch that the only real danger was that of falling into snow pitfalls and damaging onc's legs among the blocks of lava or obsidian, the latter as sharp as glass. The truth of this danger we soon realized, and therefore as far as possible kept either on the snow or on the lava, avoiding the places wherc they were mixcd. In a few places the snow slopes approached the consistcnce of icc, but, as a rule, they afforded good foothold. At 11,700 ft. we rcached the Rambleta, an elevated crater, from which the terminal cone rises. Here Miss Dixon had to succumb, and was left on the sunny sidc of a roek, where she tried to imagine berself warm.

Mr. Read and I now tackled the final cone, El Piton, a pile of ashes ${ }^{1}$ varying in height from $400 \mathrm{ft}$. on one side to $600 \mathrm{ft}$. on the other. At first we attempted to climb a snow slope, but the surface, unlikc that of most of the snow, was of almost icy hardness, probably owing to the internal heat of the mountain melting the snow every day, while the intensc radiation causcd it to freeze again at night. The goat-hcrd's stout staff proved a vcry imperfect substitute for an ice-axe, and, a step giving way, Mr. Read had an involuntary glissade which might easily harc been attcnded with disastrous results. We then abandoncd that side of the cone and by making a short circuit ascended with the greatcst ease a lava strearn or dyke on the southern faee, which afforded almost a natural flight of steps.

The excrtion of climbing, the rarity of the air at $12,000 \mathrm{ft}$., and perhaps the exhaustion duc to cold when sitting on the rock before dawn, ncarly overcame me, and I only did the last few hundred feet with dificulty-but it was worth it all. We stood on a narrow ridge of light colourcd rock, partly white, partly pink, forming a wall around the crater; this was shaped like a bowl hold sloping, the western side being but twenty feet above the bottom, the eastcrn perhaps eighty feet, and on that side cnding in a vcritablc peak, the extremity of the crag, whicl was fringed with icc, being no larger than the seat of a chair, but a chair that the keen N.W. wind made it hard to sit upon.

This was, then, actually "El Pico del Tcydc," the "Pcak of Hell," as the Guanches (aborigines of 'Tencrife) called it, and no bad name. I sat down to adjust my veil, and at once leaped to my feet-the ground was too lot to sit upon! On all sides hot vapour, charged with sulphur, issucd from numcrous small aperturcs like rat or rabbit-holes, their mouths fringed with beautiful crystals of sulphur. The air as it issued from thesc was as hot as that of a Turkish bath, and the next day when I showed somc of these crystals to a lady she smelt them and said, "Does it not remind you of the Dcvil?" We saw a stone of some pounds weight which liad, to all appearancc, becn blown out of its plnee tliat very morning by a new "fumerolc" or blowhole.

It was at once evident that the volcano on which we stood could only be called extinct by a great stretch of terms. In 1705 it surrounded the town of Guimar

1 Sec note above. 
with lava streams; in $\mathbf{1 7 0 6}$ it destroyed the flourishing town of Garachico, and filled up its harbour; and in 1788 there was a lava flow on its S.W. spurs; it has been emitting stcam and sulphur continuously, at least since Humboldt climbed it in the last century, and is doing so now-some say more frcely of late than formerly. Vesuvius was believed to be quite extinct until it burst forth and overwhelmed Pompeii. Who ean say when El Pico will again resume aetive habits? I Within the crater are some abandoned works of a company formed in defiance of prudence and common sense to extract the sulphur and turn it to commercial purposes. Wc at any rate were rejoieed to hear that the ireverent company had eollapsed. In spite of its intcrnal heat there was snow in the erater, or rather ice, having the tcxture of white poreelain.

Of course, the view from the summit was very grand. The greatcr part of the island was visible, while over a sea of eloud we saw the sister islands of Palma and Grand Canary-Gomera, the nearest, was covered in a bank of cloud. To the west one looked right into the fine erater of Cliajorra, $2,000 \mathrm{ft}$. below us, secmingly quite extinet, while in the einder-covered plain bejond were seattercd at least a score of small volcanic cones-one of them of a bright red colour.

The downward journey presented no diffieulty beyond the inevitable jarring, shaking, and jolting involved in a continuous descent for several hours. Miss Dixon was found behind her roek quite refreshed, while Mrs. Longstaff, after several hours' sleep on her cinder bed, awoke to find the mountain siekness liad left her. As in going up, the snow afforded the easiest path, but the guides, who in spite of our advice had no nails in their boots, were compelled to keep to the rocks. We found our eamp, that had been so warm and comfortable at night, was not as well suited for a hot afternoon; the heat on the bare pumice was almost intolerable, while to make matters worse, the good-for-nothing muleteer had left all our food in the broiling sun, so that much of it was bad. He had melted no snow to renew our water supply, nor even made a fire against our return. 'The monotony of the long ride down the slopes of Mount Tigayga was relieved by a fine display of the phenomenon known as the "Speetre of the Brocken." Soon after dark the weary ride came to an end, and we got baek to eivilization and the comfortable fonda kept by the wortlyy Justo and Carolina, old servants of the Marquez de Candia.

The next day, to our surprise, we woke to find ourselves heroes, and werc congratulated on all hands. The truth is there is no difficulty whatever in ascending the Peak in winter, but it is better to go without guides. T'hese men arc cxeellent fellows under thcir own conditions, but they do not understand snow, and they bear eold badly. It is only neeessary to exereisc common sense; to sound the snow eonstantly with the Alpenstoek so as to avoid the firozen plaees; and be on the look-out for the one real danger, namcly, falling through the small snow caves between the blocks of lava-these latter are very hard and sharp and casily injure knee and ankle-they almost destroyed our boots. It is thereforo wise to keep as much as possible either on the open snowfields or on the lava ridges, and not to ehange from one to the other oftencr than can be avoided. In summer it is possible to ride up to an elevation of $10,000 \mathrm{ft}$., but in winter only to about $8,000 \mathrm{ft}$., although it is difficult to imagine that there could be any pleasurc

1 In 1896 a small lava stream issucd from some part of the mountuin. Again at the end of 1908 a more considerable outflow took place between Chajorra and the sea. It is stated that the last great cruption of the prineipal cone was witnessed by Columbus whon waiting for promised financial support from Spain provious to starting on his zreat voyage. 
in riding (or rather in being driven by the guides) to the greater altitude. The animals are poor creatures, badly saddled and harnessed, overworked, and not ton well looked after. It should be mentioned that none of the party werc experienced mountaineers.

\section{NOTE ON "THE SPECTRE OF THE BROCKEI" 1}

The Val de Taoro is bounded on the west by the erags of Mount Tigaygra. which rise about $3000 \mathrm{ft}$. above it. This mountain is a spur of the Peak of Tenerife runniug down from the lip of the Cañadas, or old crater, towards the sea. For a considerable distanee its northern slope forms a table-land, perhaps lialf a mile or more wide, sloping evenly and gradually towards the sea, and limited on the east by a cliff, whieh falls by a sueeession of crags to the valley or rather plain below. Along the top of this wall of rock, one of the paths to the Peak runs for several miles. On March 8th, 1887, again on the 13th, and also on April 5th, I passed along this path in the afternoon, an hour or two before sunset. The Val del Taoro was on each occasion covered with thin white mist, which did not extend appreciably above the top of the cliff, being probably so limited by currents of air. As we stood near the edge of the precipice looking orer the valley, with the setting sun behind us, we saw our shadows projected on the thin mist; each shadow of course followed every movement of its owner (keeping for example excellent time to a reel), and on one occasion (Mareh 8th) it was so sharp. that when I went through some euts and guards of the sword exereise the shadow of my walking stick was perfectly clearly defined. I should say that the speetre varied in distinctness on different occasions and at different spots on the same das, the variations being evidently due to the varying density and changing form of the surface of the mist. A lady friend saw it again on April 12th, under similar circumstances in the same place, but it was then far less elear. When seen at its best the spectre was surrounded by a halo eonsisting of three eomplete sets of faintly eoloured rings, the head of the figure being in the centre of the system. A blue haze surrounded the head and reached about to the shoulders; the colours followed in the reversed order of the speetrum, green, yellow, orange and red; the first red ring crossed the figure at its middle, then came blue again, and so on, the second red ring reaching about to the feet; outside this again a third reversed spectrum, the outside red ring extending about once and a half the height of the figure. Beyond this triple system of eoloured rings, at a distanee of perhaps $15^{\circ}$ from the line connecting the speetator's eye with the head of the shadow, was an arch of white light, broad and faint, like a lunar rainbow, but suffieieutly distinct. Each person could see the rings around his own spectre only, or that of a persou standing very close to him. ${ }^{2}$ It was extremely difficult to judge the apparcnt height of the spectre, or its distance from the spectator. It was certainly larger than life, perhaps three times as large; its distauce night have been two hundred yards; but I regret that I did not pay especial attention to these points.

1 Quarterly Journal of the Royal Metcorological Society, Vol. NIII., No. 64, October, 1887.

2 In company with a scientific elergyman I was oue day complaceutly contemplating uny Spoctre and chaffingly romarked: "I am a holicr man than you, Padro, I havo a uimbus." His prompt reply was: "My dear fellow, no one cau sec it but yoursolf." 
The best account of the phenonienon that I liave seen is in Glaisher's translation of Flammarion's "The Atmosphere;" but there is some confusion in the description of the order of the colours.

\section{NOTE ON GUANCHE SKULLS.}

A young Swedish doctor, demonstrator of Anatomy in the University of Uppsala, effectch an entrance into a cave on the face of a cliff, which had served the Aborigines as a burial place. From this cave, which I revisited with him the next day, he removed about twenty-five skulls, which we carefully examined. Something like two-thirds of them afforded indubitable evidence that their owners had suffered from depressed fractures which had healed during life. Surely it is very remarkable that such a large proportion should have gone through such an ordeal. [The exact numbers I forget, but am eonfident that the proportion is not exaggerated.] It so happens, however, that the Jesuit history of the conquest of the Canaries, states that the fair-haired inhabitants of the Western Isles had a strange pastime. They would go out, it is said, in opposing armies, and have mimic (?) combats, hurling stones at one another !

It is probable that the cave in which these skulls were found had not been disturbed by man for ccnturies. From its roof, across the entrance, hung a veil of Maidenhair, Adiantum (?) capillus-veneris whose fronds measured a full yard.

\section{ENTOMOLOGICAL NOTES.1}

Mr. Jenner's statement that "partial migration ... explains the occasional presence of grcat numbers (of insects) on the sea coast, as every movement in that direction is stopped, and the species becomes as it were heaped up there," was curiously illustrated by an occurrence that I witnessed in April, in the island of Tenerife. Behind the town of Santa Cruz, towards Taganana, stands a range of mountains with a strangely sharp crest. Near the summit the southern slopes are carpeted with a small Bugloss (Echium sp.) with brilliant purple flowers; on the north side of the ridgc the ground falls suddenly away in precipitous crags, densely wooded with Laurels and Laurustinus trees, under the shade of which is the most exquisite fernery ever imagined. A strong wind was blowing from the north, which struck against the cliff, and was turned upwards by it; a large number of white butterflies, Pieris daplidice, I think, impolled either by curiosity, a love of adventure, or of the beautiful, or what-not, kept flitting up these purple mountrinmeadows, and making for the wooded crags. Each as it reached the edge, all unsuspecting, was cruclly swept up into the air, to a lieiglit of thirty fect or more; after a bricf struggle it succumbed to force majeure, came down agail and paticntly began anew the ascent of the slope. Here the "herping up "was literally effected; $P$. daplidice, though common thronghout the island, was nowhere so abundant as on this spot.

On a rubbish-heap outside the town of Puerto Cruz, and also in a stubble-field (cf. Stainton's "Manual," vol. i., pp. 143 and 150), I morc than once observer the gently-fluttering, Crambus-like, flight of Deiopeia pulchella; on a tall, shrub-like spnrge (Euphorbia (?) piscatoria) the grandly conspicuous larvao of Deilephila

1 Entomologist's Monthly Magazine, 1887, Vol. xxiv., p. 158. The allusions are to communications from Mossrs. Barrett and Jenner in the previous number. 
euphorbiae were abundant in some plaees; on the snow-elad (in April) lava streams of the Pico del Teyde Mr. Wainwright took a specimen of Colius edusre at a height of nearly $10,000 \mathrm{ft}$.

I have scen Sphinx convolvuli several times in my garden at Mortehoe; it would not look at Verbenas or Petunias, but showed a great partiality to the more gorgeous flowers of Gladiolus. I can confirm all that Mr. Barrett says about its noble flight, and the ease with which it may be observed. [By standing perfeetly still, the insects will visit flowers quite elose to one, even sipping honey from a spray of White Tobaeco held in the hand-nay, more, on one oceasion a moth so cmployed was rudely thrust aside by a yet bolder individual!] 


\section{CHAPTER II ${ }^{1}$}

\section{INdiA ANd CEYLON, 1903-4}

WHAT follows is an account of the entomological experiences of a "globe-trotter," that is, of a traveller whose main object was to take an all too rapid glance at the scenery, the peoples, and the architecture of the places visited, and whose route was planned with that object. That I was able to give so much time to collecting was due to the fact that, whereas my daughter and her companion felt the heat so much that they usually kept within doors from about 10 a.m. to 3 p.m., I, for my part, protected by a "sola topi" of the "pigsticker" type, and a spinal pad to my coat, suffered no serious inconvenience from the sun's rays so long as $I$ took active exercise. Indeed there can be little doubt that I must have been intended for a Salamander. Thus in the Red Sea at the end of September it had been very hot; the air had the hot smell of a Turkish bath; it was one continuous drip and trickle. Nevertheless I thoroughly enjoyed it, though most people complained greatly. An American, who appeared to be much distressed, when asked how he was getting on, replied: "Wa-all, I'm just thinking what a fool I have been not to be contented with reading about Shadrach, Meshech, and Abed-nego instead of coming here to see what it was like!"

I sailed from England in September, 1903, without the slightest intention of collecting, and started accordingly with no entomological outfit save half-a-dozen pill-boxes. Not only was I without net and killing-bottle, I was without books, and worse still, was in woeful ignorance of the Lepidoptera of the Oriental Region.

Finding it very hot at Bombay we took train for Simla the day after landing, and a little south of Jhánsi I was struck by the large numbers of bright yellow butterflies flying along the railway bankscertainly a Terias, in all probability hecabe. October 5th found us at Kálka, at the foot of "The Hills." Fortunately the new railway was not yet open, so we had to be driven up the 58 miles to Simla

1 The greator part of this chaptor first appenrod in tho Transactions of the Entomological Socicty of London, 1905, p. 61. 
in a "tonga," or post-cart, by a wild-looking hillman who handled the ponies magnificently. To one fresh from Europe the sights on the road were truly marvellous: natives in divers strange costumes, or lack of costume, long trains of wagons drawn by handsome humped oxen, or by buffaloes, surely the most uncouth of all domesticated beasts; flocks of goats and herds of cattle; strings of pack-mules bedecked with red wool tassels, often with necklaces of turquoise-blue beads, but always tinkling with many bells, and, to crown all, long lines of solemn camels, always hideous, yet always picturesque and strangely fascinating. However, amid all these strange sights there was one other which interested me, if possible, even more; I mean the multitude, the variety, and above all the beauty of the Butterflies. The first sight of such a thing as the big Hypolimnas bolina, Linn., black, flashing with violet-blue, excited an emotion better imagined than described. At all events, the creatures took me fairly by storm : collect I must!

The resources of the bazár at Simla only produced a child's butterfly-net, a mere toy, scarce twelve inches in diameter and of a vile, pale yellow colour. Armed with this and a tin cigarette-box filled with triangular envelopes I took the field. To this scanty equipment was shortly added a cyanide bottle. It was two long months before the toy-net was superseded by an umbrella-net from Watkins and Doncaster. This last is a very convenient weapon for use in towns, or when travelling or sight-seeing. It is inconspicuous when rolled up, but can be quickly brought into action; it is, however, inadequate for serious tropical work. In Calcutta I purchased a large $\mathrm{Y}$-net with jointed canes, and had it fitted to the end of a landing-net stick made in two pieces that were six feet long when joined. A fair-sized net is required for large and swift butterflies, while for the many that habitually tly high and settle far from the ground, six feet is none too long for a stick, though in narrow woodland paths it will be fonnd unwieldy.

Subsequent experience in many lands has taught me that the strain caused by a sudden swoop with a large net is quite too much for the sticks usually supplied by the shops. Messrs. Hardy Brothers, of Alnwick, and 61. Pall Mall, have fixed for me a specinlly strengthened $Y$ upon the middle joint of one of their steel-centred, cane-built, salmon-rods. For general purposes this has done me excellent service; the butt end may be attached when required, giving a stick of six feet, which I find to be as long as I can mannge. Mosquito netting, dyed green, ${ }^{1}$ is far more serviceable than leno,

1 This can be obtained at the Army nud Nary Stores. 
owing to its superior power of resistance to thorns. It is well to have in one's portmanteau, several spare bags, and I always travel with two sticks, and have an umbrella-net as well, for use in city gardens and on like occasions. A collector going to a remote place should be thoroughly provided, or grievous disappointment may result at a critical moment.

In common with most collectors I pinch all butterflies except Blues and Skippers, which I prefer to box, or bottle. Mr. Otto Möller, of Darjiling, told me that he found it best to pinch all butterflies, even the smallest. Chloroform I find the most convenient death agent, but ihere is something to be said for ammonia, and much for cyanide. ${ }^{1}$ All butterflies, except the larger Skippers, travel

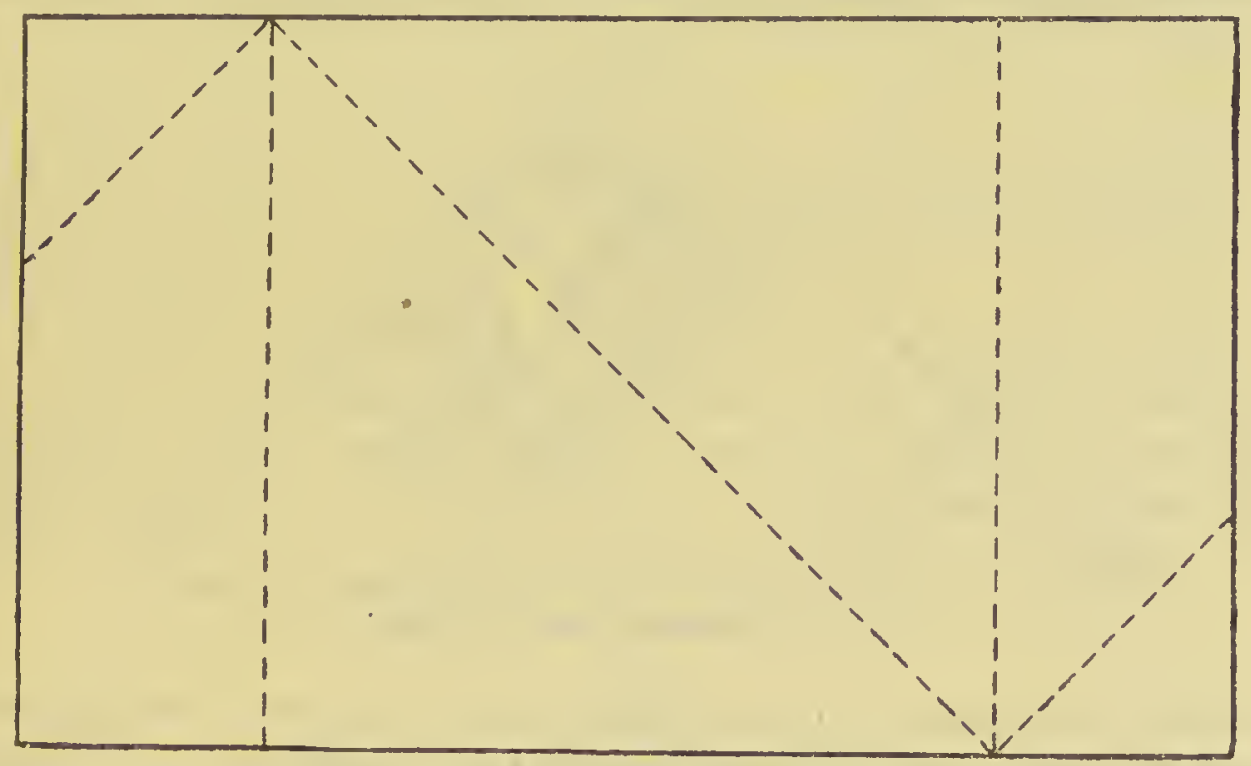

Frg. 1.-Butterfly envelopo, creased but open.

best in three-cornered envelopes. The diagrams [Figs. 1 and 2] show the method of folding, and if increased by one-fourth would be a useful size. Larger envelopes are requisite for Papilios, while smaller suffice for Lycaenids. The number, date, locality and remarks may be written neatly on the envelope; when the insect is set these data may be cut out, folded if necessary, and placed on the pin beneath the specimen as a permanent record. The data should be copied daily into a quarto note-book ruled in convenient columns, with index-numbers corresponding to the specimens. Note-books should be strongly bound, but must open well; the paper should be of the best quality so as not to "dog's-ear." They can be made and ruled to order by a

' If grasshoppers aro killed by chloroform thoir hind-legs are apt to eome off as the result of spasm. 
good stationer; I get about half-a-dozen books at a time; it is convenient to have 25 lines to a page, and each book should give space for 2000 specimens. I usually prepare my note-books, cntering the index-numbers, on the voyage out. A wholesale stationer will cut the papers of required sizes for a very small charge. It is well to order some thousands at once, of three or four sizes-the largest number of the size mentioned above. The paper should be of medium stiffness, unglazed, slightly absorbent, yet suitable for writing upon. I make it a practice to fold, each day, those that will be wanted for the morrow, so that nothing should delay the desirable early start. Skippers, stout-bodied moths, Micros, and flies are best pinned, but in travelling make a point of always carrying boxes containing pinned specimens yourself. Smaller beetles and Aculeates

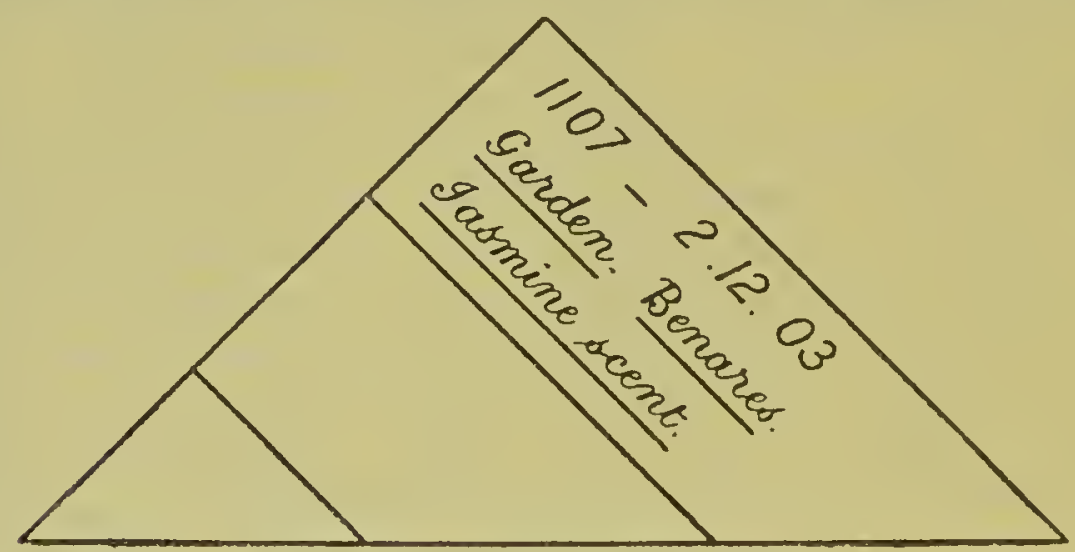

Fig. 2,-Butterfly envelope, folded.

may be put in screws of tissue paper, bearing the data. Orthoptera may be made into rolls like cigarettes: it is easier to tie up such rolls with Berlin-wool than with cotton or string, as it does not slip. Remember always that good data are almost as valuable as the specimens to which they are attached, some think even more so.

The cnvelopes containing butterflies are best packed in cigar boxes (wooden, never tin ${ }^{1}$ ); such as hold fifty cigars are of a convenient size. They should be packed just tightly enough not to shake about, and a small quantity of maphthalene crystals put in each box. The boxes should be wrapped in brown paper, with label tied on; moreover the labels should have some ootton or linen basis so as not to tcar casily when wet. I eithor register or insure (for 5 s. cach parcel)

I Insects sont homo in tin-boxes are very linblo to mould. Some collectors, in especially damp localitics, have found it necossary before packing insects to dry them artificinlly (over a lamp). 
according to the postal regulations of the country; that is well worth the small extra charge. It is as well to carry with you from England labels, good string, brown paper and sealing wax, since it is often difficult to get these things, especially brown paper. By adopting these precautions I have never lost a consignment, and have had but one box seriously damaged in the post. Surely when the cost of a long voyage is considered, it is unwise in the extreme to be in any way mean in the after treatment of one's captures. By sending home frequent small consignments the risk of loss or damage is divided. The brass dropping-bottles for chloroform supplied by Messrs. Watkins and Doncaster are very convenient. A reserve of chloroform ${ }^{1}$ should be carried in larger metal bottles, but care should be taken not to fill them too full, or the expansion of the fluid in the tropics is apt to burst the bottles. Forceps and other special apparatus should be carried in duplicate.

Very nearly all the insects taken in the voyages herein described have been added to the Hope Collection in the University Museum at Oxford, and the note-books relating to them will ultimately go into the Hope Library.

Naturally in a rapid tour of this kind, much of the time spent in towns, there was small probability of turning up anything new, but it is hoped that some of the observations made (even on the commonest species) may throw a glimmer of light on some of those questions of Bionomics which are now attracting the attention of naturalists.

\section{INDIA.}

\section{Simla, lat. $31^{\circ}$ N., alt. $7200 \mathrm{ft}$.}

In refercnce to the seasonal variation of many species it may bc remarked that at Bombay on October 2nd and 3rd there was heavy rain, the tail-end of the monsoon. It was held to be a very latc season, the rain had lingerce and the cold weather was delayed.

My collecting at SIMLA was confincd to a riding expedition along the old Hindustan-Tibet road. This is an exccllent riding-path, patted down as it is by the barc feet of the natives and the great pads of the camels so as to afford a smooth surfacc such as is scldom seen in mountain roads. The track follows the watershed of the Sutlej and Jumna, cut at one time on the hot and dusty, almost trceless, southern sidc of the mighty ridgc, where the terraced slopes

1 Chloroform bought at the best druggist in Caricas would scarcoly kill large moths; apparently it had bcen diluted with alcohol. 
are covcred with crops of maizc, or ruddy millct; anon crossing to the coolcr northern side which is mostly clothed with fine forest of Spruce, Deodar, Holm-oak and Rhododendron-thus winding in and out, but for the fifty miles that we traversed always maintaining an altitude of from 7000 to $9000 \mathrm{ft}$. Yet so deep arc the valleys, so steep the hill-sides, that wc scarcely got a glimpse of either of the mighty rivers between which we marched.

From an entomological point of view the most important flowers were a brilliant but small Ragwort, several kinds of Golden-rod, a pale mauve Cineraria, and two straw-coloured Thistles : one of them, tall and slender, was especially attractive to butterflies; the other was a very decorative plant with Acanthus-like leaves and large globular heads. From the gardener's point of view, howcver, the most striking plant that we saw was the crimson-flowered Potentilla atrosanguinea, which was especially common under the shade of the Deodars, as on Jakko Hill; some secd sent home proved fertile and has stocked several gardens. Some of the Rhododendrons formcd huge trees with trunks over twelve feet in girth.

We went by way of Fágu, Theog, Matiána and Narkanda to Bághi, returning by the samc route, except that from Bághi to Narkanda we walked over Mt. Huttú, 11,000 ft. ${ }^{{ }^{2}}$ The expedition occupied eight days, but for simplicity of description I shall not distinguish between outward and return journeys.

The general aspect of the country was decidedly autumnal; the nights were chilly and most flowering plants had gone to seed. There was more cloud than usual, and there were occasional slight thundershowers. Most of the butterflies seen appeared to have been out some time, and were much battered. Two circumstances (besides the embryonic net) tended to restrict the bag: one, the fact that collecting was for the most part confined to a narrow mountain road, bounded by a precipice on the lowcr, and a cliff upon the higher side; the other, a limitation of wide application, that a tropical sun is not conducive to rapid pursuit.

\section{SIMLA, alt. $7200 \mathrm{ft}$., to FíGU, alt. $\$ 200 \mathrm{ft}$.}

October 10 th and 17 th.

Gonepteryx rhamni, Linn., var, nipalcnsis, Doubl., was abundant throughout the journcy, and so was Auloccra swaha, Koll., though in very poor condition; both occurred in Simla itsclf. The latter is

"In Indian names "a" is pronouuced as " $a$ " in father, " $n$ " as "oo" in boot "a" or" "u" as " u" iu but. 
a Satyrid, having on the upper sidc a resemblance to our White Admiral, flying also with much of the grace of that favourite buttcrfly. It loves open spaces in woods, returning to the same spot when disturbed. When it settles on the ground, a rock, a flower, or a trcetrunk, it often leans over on oue side as much as $45^{\circ}$ or even $50^{\circ}$. I saw one of thcse butterflies makc three successive efforts, getting further over cach time. On two distinct occasions I watched a butterfly settle twice, turning the first time over to the right, the second time to the left. I think there is no doubt that this "list" makes the insect less conspicuous when settled.

Pararge schakr', ${ }^{1}$ Koll., is another common roadside butterfly in the Simla district; it closely resembles our $P$. megaera, Linn., but is larger. Chrysophanus phlaeas, Linn., var. timeus, Cram., was also commou; Colias fieldii, Ménét., is sufficiently like our C.edusa to pass readily for that species; Polyommatus baeticus, Linn., is also suggestive of our South Downs, where it has been seen occasionally; the same may be said of Argynnis lathonia, Linn., var. isscea, Moore. Again, Pyramcis indica, Herbst, is very like our $P$. atalanta, Linn., though not so handsome and scarcely as graceful in its movements. So far there was plcnty to bring to mind the fact that we were still within the Palaearctic Region. There were, however, a few insects to suggest the close proximity of the great Oriental Region, for if Atella phalantha, Drury, is very like a Fritillary (at least as seen from above), and Rerda sena, Koll., closely resembles a Hairstreak, on the other hand the under-side of Belenois mesentina, Cram., is decidedly more brilliant than our Whites, while there is no denying that Precis (Junonia) orithyia, Linn., is quite Oriental in its aspect. This insect had struck me with admiration at Solon on the way up to Simla, and is called by the school-boys of India's summer capital, "The Ladies' Fancy." With the habits of a Vancssa or Pyrameis, there is something about the shape of the wings, the prominent ocelli, the brilliant blue of the hind-wings, and the lcaf-like colouring of the under-sidc which gives this butterfly a very tropical appearance. Howevcr, I soon learned to look upon it as amongst the most familiar butterflies of Northern India. At Fágu it was common, but like most butterflies which have a proclivity for scttling on the ground, not too casy to catch.

At FíG another buttcrfly of quite European aspcct was common, Vanessa lashmirensis, Koll.; this is no credit to its nannc, looking likic an urticue that had becn born and bred in the "Black country." 
But the Chalcosine ${ }^{1}$ day-flying moth Agalope hyatina, Koll., elegant in shape and quiet in colour, its wings white, shaded with grey towards the tips, ochreous at the base, was quite a stranger.

\section{FÁGU, alt. $8200 \mathrm{ft}$., to Theog, alt. $7400 \mathrm{ft}$.}

October 11 th and 16th.

Before our start in the morning I found abundance of Chrysophanus pavana, Koll., in dry weedy corners of cultivated ground; this is sufficiently distinct from C.phlaeas, but has no especial oriental glamour.

From the ground by the roadside I picked up a large newlyemerged Bombyx with the awe-striking name of Trabala vishnu, Lefevre; it proved extremely tenacious of life and got a good deal damaged in the killing, as there was no oxalic acid available. Two Blues, Cyaniris vardhana, Moore, and Zizera maha, Koll., var. diluta, Feld., together with the Hairstreak, Merda sena, completed the bag for this stage.

\section{Theog, alt. $7400 \mathrm{ft}$. to Matiána, alt. $7700 \mathrm{ft}$.}

October 11 th and 16 th.

At TheoG, our first halting-place, Goneptcryx nipalensis was especially common, and here I took my first Athyma opalina, Koll., a Nymphaline resembling on both upper and lower surfaces Limenitis sibylla, Linn., an insect to which it is closely allied both in structure and habits.

On the road, besides Mcrda sena, Chrysophanus pavana, Precis orithyia, and Argynnis issaea, several things turned up. Of Pyrameis cardui, Linn., a fresh brood appeared to have emerged on the 15th or 16th October, and was common at the flowers of a straw-coloured thistle. I saw a few more Athyma opalina, and secured one. In their elegant floating flight one seems to see through the white markings of the butterflies of this genus. The Simla school-boys call them "Sailors," but to me the name "Ghosts" would seem more appropriate. They settle on the leaves of trees or shrubs, rarely affecting flowers. Here I got my first Precis lemonias, Linn., an insect with the habits and structure of a Vanessid, but with much the appearance of Pararge acgeria, Linn. A specimen of Tcrias libythca, Fabr., taken on the return journey, bears the note "casy to catch," which

- Sir George F. Frmpson regards the Chalcosinae as a sub-family of the \%ygacnidac. 
is true, but at the time I do not think that $\mathrm{I}$ distinguished it from the much commoner $T$. heeabe, Linn., which it closely resembles.

At Matrína the only new insect found was Huphina nerissa, Fabr., of which I took two specimens, both males. This is a somewhat glorified Ganoris napi, Linn.; one of the specimens appeared to have a slight scent which I could not describe, but certainly it was not that of the male napi.

Perhaps the most abundant butterfly at Matiana, and indeed throughout the woods of the district, was Cyaniris singalensis, Moore (very like our argiolus); it was in poor condition, flying about the tops of tall shrubs, but not seeming to affect either ivy or holly, although both were there.

Pararge schakra was especially abundant at Matiana and on the road thence to Narkanda. It differs from our $P$. megaera in being larger and having more conspicuous ocelli, though these are variable; one of my specimens, a female, having the ocellus near the tip of the fore-wing far larger than the rest. In its habits this insect sometimes reminded me of $P$. megcera, sometimes of Satyrus semele, Linn. It abounds along roads and in bare places, alighting almost always on the earth or on rocks, with its wings expanded like megaera, but when it settles down to rest the wings are raised, the fore-wings drawn back within the hind-wings, and all that remains visible is the colour of dust. In no case did I see it turn on one side as S. semele does, but three times observed it settle with its back to the sun, so as to reduce its shadow to a mere line; unfortunately I made this observation towards the end of my acquaintance with the butterfly, so was unable to make sure whether this was a mere chance or a definite habit. At any rate, I did not observe any instances to the contrary. I suspected in $P$. sehakr a the existence of a very slight sweet scent, that appeared to be unlike that of any other species.

At Matiána a number of Geometers were beaten out of alders, three Philereme variegata, Warr., and one Cidaria niphonica, Butl.; they had a jerky flight, which saved many of them from capture. One night a Deltoid, Hypena tristalis, Leder., caine to light.

Matińna, alt. $7700 \mathrm{ft}$., to NArkanda, alt. $8800 \mathrm{ft}$.

Octobcr 12th and 15th.

Many of the same insects were met with as on the previous stage, but the following may specially be noted; Terias heeabe, my first specimen of the commonest species of a very characteristic Indian 
genus; Ganoris canidia, Sparrm., a White like I. rapae, Linn., but with bigger black spots; and Belenois mescntina, flying fast and going straight ahead in a purposeful manner. Here I may remark that the swift flight of the Whites generally has much impressed me; it is evidently closely related to the fact that they are quite the most conspicuous of all butterflies, especially at a distance. Argynnis issaca was again well to the front; another Athyma opalina was securely "papered," and a specimen of Precis lemonias was taken, in which the anal angle of both hind-wings had been bitten off nearly symmetrically. ${ }^{1}$ Amongst many of the argiolus-like Cyaniris singalcnsis, one C. vardhanc was taken. Three Geometers, Philereme variegata, Docirava aequilineata, Walk., and the familiar widely-

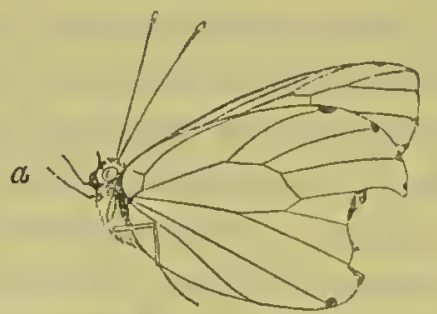

FIG. 3.-Mutilated butterflies:- $(a)$

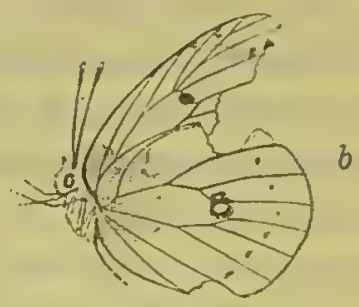

(b) Colias marnoana.

distributed Polyphasia truncata, Hufn. (Cidaria immanata, Haw.), complete the list.

The dák bungalow at Narkanda is delightfully situated, nestling in the woods it looks right upon "The Snows." The cawing of rooks in early morning brought to our minds thoughts of home, soon to be dispelled by seeing birds near as large as thrushes, some bright green, others of the brightest crimson, as well as blue magpies (?) with two very long tail feathers.

At NARIKANDA Argynnis issaca was in great numbers in the woods, so was the Chalcosiine moth Agalope hyalina; this flies fast and always in the same direction, this afternoon it was up-hill and against the wind, more especially up certain gorges in the mountain side. It was hard to catch, and on the wing looked much larger than it

1 Not long before this observation was made, Prof. E. B. Poulton, F.R.S., had called the attention of entomologists to the indirect evidenec of attacks by birds and lizards afforded by mutilated survivors. Ho referred to Fritz Müller's obserrations on the subject as far baek as 1863 , which were supplemented and confirmed by Mr. G. A. K. Marshall's very numerous later observations in South Africa. When both forc-wings, or both hind-wings, bear similar and symmetrical injuries, still more in those rare cases where all four wings are symmetrically mutilated, it is practically certain that the insect must have been at rest with its wings orer its back when the injuries were inflieted. Trans. Fint. Soc. Lond., 1902, 1. 366. [Sec Fig. 3.] 
is, but on settling vanished suddenly, burying itself in the herbage. Colias fieldii was common, but was not remarkable for swift tlight.

NARKANDA, $8800 \mathrm{ft}$., to BÁGHI, $8900 \mathrm{ft}$.

October 13th.

The road traverses a magnificent forest made up for the most part of grand Spruces, their boles often 6 feet in diameter, with few and short branches. Many of them supported a species of Ampelopsis, (very similar to the familiar Virginian Creeper), now just beginning to turn red, but so lofty were the trees-at the very least 100 feet -that none of the creepers could get morc than half way up their towering stems. Under the trees was a profusion of ferns, but at this season of the year the road was too dark and chill to be the haunt of butterflies, so I had to content myself with the grand vegetation, and the occasional inspiring glimpses of "The Snows," lying far away beyond the deep valley of the Sutlej, over which onc might occasionally see, among many Kites, the lordly Eagle.

BÁGHi, $8900 \mathrm{ft}$, over MT. HuTtú, $11,000 \mathrm{ft}$., to NARKANDA, $8800 \mathrm{ft}$. October 14th.

BígHI, our furthest point, is but 26 miles W.N.W. of Simla, though by the winding mountain road it is fifty. Here I met with Neptis astola, Moore, thus making my first acquaintance with that beautiful but difficult genus. The steep footpath up Mt. Huttú, when it has attained an elevation of a little more than 10,000 ft., emerges from the forest on to a flowery clearing that bore evidence of former cultivation. Here I saw Colias fieldii, Atella phalantha, and Argynnis issaca, and here also I took two specimens of Parnassius harchickii, Gray, ${ }^{1}$ one worn, the other in beautiful condition; above it is a lovely creature, but the underside has a curious resemblance to oilcd paper. Delicate looking though it be, it is strangely tenacious of life. The concurrcnce of a Clonded Yellow, a Queen of Spain, and an Apollo was very suggestive of the Alps. All too soon the path plunged again into the now somewhat scrubby forest to come out finally, at near $11,000 \mathrm{ft}$., on to the grassy, flower-bedccked plateau in which the mountain culminates.

The highest peak was of course crowned by a Lhí To, or "Spirit-of-evil pillar," a cubical structure of stone which brought to

I Sec Plate I, Fig. 4. 
mind the High Places of Baal. Such are to be found on any easily accessible peak, and more especially at the top of every pass, or Kótal. From a pole stuck into a chink in the stoncs there usually flies a small flag, on which prayers may be inscribed, though more often it is a mere rag. The pions-or it may be conscious-strickenmountaineer here offers, with muttered prayer, a handful of flour or rice, and adds a rag to those adorning the neighbouring bush; in rare cases he goes so far as to offer a brass pot, or "lota." This was indeed a fitting place to appease the unseen powers of nature! There, far away to the North, and extending for scores of miles to East and West, lie the everlasting "Snows." But between us and those white-crested mountains lies a mighty sea of ever-changing blue and purple; a sea in which the hollows of the waves are valleys through which run mighty rivers, the crests are mountain ranges the equals of the Alps-for the snow we see is all above the 16,000 $\mathrm{ft}$. level, and some of yon peaks touch $23,000 \mathrm{ft}$. Truly it is well described by one word, Himálaya, "The Abode of Snow."

The troops of butterflies seemed to rejoice in the glorious panorama. The brilliant Argynnis issaea was common, and the dingy $V$ anessa kashmirensis quite abundant-possibly some of the more distant white peaks to the left arise from its name-place, Kashmir. Colias fieldii was also in large numbers, a female exhibiting a symmetrical injury to the hind-wings very suggestive of a peck by a bird. Precis orithyia was there too, but Aulocera swaha was conspicuous by its absence, though we had seen it at Bághi, down below. Of a Humming-bird moth, Rhopalopsyche nyctcris, Koll., much smaller than ours, I netted three specimens, one at the flowers of a Dclphinium. The little Herbula cespitalis, Schiff., reminded me of home. The Blues were represented by Cyaniris singalcnsis. A male Tcrias hccabc was of the wet-season form. I noted that this species is very easy to catch, and is brilliant on the wing; also that when settled on a shrub or flower it is usually extremely conspicuous, but not so when it chooses as its resting-place a certain low plant with oval leaves fading to a yellow tint; then the rounded form of the wings greatly aids its concealment. An old English fricnd, Enxoc corticca, Schiff., was taken flying in the sunshine. I had several exciting chases after a big yellow Swallow-tail, and eventually secured one-my first Papitio! It proved to be our machaon, Linn., var. asiatica, Ménét. Here, as in Japan, it scorns fens and dykes, glorying in mountain tops. On the way down to Narkanda several Pyramcis indica. disputed the path with our party.

The great resemblance to European forms presented by the bulk 
of the butterflies seen in this expedition cannot fail to strike the reader.

During this expedition I met a very interesting man, a German Moravian Missionary, who was taking his little boy of seven to Delhi, on his way to school in Europe. He had been living for eight years at the foot of the glaciers, just on our side of the Tibetan frontier. Before that he had spent five years at a mission station where it was so cold, that he was cut off from all letters and newspapers for four or five months every winter. At his present station he occasionally meets an English official, but with that exception and the members of his own family, we were the first Europeans that he had seen for months. He greeted us eagerly in broken English and was quite delighted to find that I understood a little German. $\mathrm{He}$ was accompanied by a party of about a dozen natives of the mountains whose long black hair gave them a wild look. The Moravians, it would appear, have several stations in these frontier states where they have been at work for some fifty years, during which time they have made 100 converts. What marvellous perseverance, what invincible faith! My friend told me that these mountaineers, in their own homes, showed no trace of caste customs, but as soon as ever they came in contact with Hindus, his Buddhist servants fell into groups which would not take water the one from the other.

\section{SOLON, eirca $5000 \mathrm{ft}$., to KálKA, $2184 \mathrm{ft}$.}

October 20th, 1903.

Starting from Simla by starlight, soon after 5 a.m., before the kites were up and stirring, we got to Solon by breakfast-time, and I there caught at 9 a.m. my first butterflies, two alsus-like Blues, Zizera lysimon, Hübn., f. karsandra, Moore, and Z. maha. Also two flies, a Musca of the domestica, Linn., group, and an Anthomyid.

On the drive from Solon to Kálka, by making the most of stoppages to change horses, and by occasionally jumping out of the carriage, I managed to secure quite a lot of things. Among the commonest was the beautiful Precis oenone, Linn., and with it $P$. orithyia and $P$. lemonias. Of Atella phalantha, Belenois mesentina, and Merda sena, I took single examples. T'erias laeta, Boisd., was rather common. There were also Catopsitia pyranthc, Linn., the gnoma-form, Terias hecabe, and Huphina nerissa. About two miles above Kálka, say at about $2700 \mathrm{ft}$., I got a single Precis iphita, Cram. At about the same place the great catch of the morning was male, 
lor I took my first Hypolimnas bolina, three males and a ferrale, believing then at the time to be two species. Why does not this glorious insect retain its far more poetical and more appropriate name, Diadema jacintha? Surely a black butterfly $3 \frac{1}{2}$ inches in expanse with four large glancing-blue spots, one on either wing, deserves to be ealled after a gem. Anyway, I shall never forget the iropression produced by my first sight of its truly oriental splendour; it was like Kingsley's "At last!"

On my way down I also saw Pyrameis inclica, and missed two Papilios, probably P. maehaon.

Two Buddhist Pilgrims in yellow robes, shading their shaved heads by an umbrella, brought Kim vividly to mind, while that common sight in India, a man carrying a bed upon his head, explained and illustrated a familiar text.

At KáLKA I got nearly two hours' collecting late in the afternoon; it was partly on waste ground about the station, but mainly in a field bearing a crop of some kind of pulse with thin pods $4-5$ inches long.

A black and brown Cantharid beetle, Mylabris sidac, Fabr., was flying about flowers in the sunshine in large numbers. The genus Preeis was represented by orithyia and oenone; the genus Terias by heeabe, laeta, and quite a number of libythea. The inevitable Atella phalcuntha, never very common, and Belenois mesentina were to the front again. Ganoris eanidia was fairly common; I noted that a male had a "snuffy scent." Single specimens of Ixias marianne, Cram., and Huphina nerissa, both males, were taken. Of Catopsitia pyranthe I took two females, one of which had suffered a symmetrical injury to both hind wings. Three or four Hypolimnas bolina, both sexes, were disturbed in their first sleep, and being drowsy fell an easy prey. The Blues were represented by several spceies-Zi:era maha, Z. otis, Fabr., var. indiea, Murray; Catochrysops encjus, Fabr; and Ncceaduba arclates, Moore. Two Pyrales, Zinctienia fascialis, Cram. (reeurvalis, Fabr.), and Bradina admixtalis, Walk., and a morn Acidaliid were picked up. A Sphinx, Nephele hespere, Fabr., was taken during the afternoon at the flowers of a Bryonia. A little later on, a Lymantriid moth, Euproctis lunata, Walk., came to the lamp of the railway carriage, to which a Sphinx, probably another $N$. hespera, also paid a momentary visit. 
Pesháwali, lat. $34^{\circ} \mathrm{N}$., alt. $1165 \mathrm{ft}$.

October 22nd-25th, 1903.

This city is finely situated in the extremc north-west of the great plain of the Panjáb, or Five Rivers ; the mountains of the Sufid Koh and the foot-hills of the Hindú Kúsh bounding the view to the west and north respectively.

In its ancient mud fort, with wall within wall and elaboratc flanking defences which make it quite impregnable to infantry and field-guns, we saw a large number of partially manufactured cannon belonging to the Amir, which had been impounded by the British Government when on their road to Kábul. He had tricd to smuggle them through without permission, but calculated without his host.

In the bazár our ladies were greatly impressed by the magnificent appearance of the men, Punjábis and Afridis, cspecially by the fieryred beards of those who had been to Mecca [Hajji]. Lime produces a fine colour, but there is an intermediate green stage which is decidedly not imposing. An old grey-haired man, whose beard has not bcen dyed for scveral weeks, presents a most strange appearance.

Owing to the kind offices of a magistrate friend we had an opportunity of seeing the house of the chief carpet-merchant of the city. It was vcry sad to find that the drawing-room of a man who dealt in all the beautiful fabrics of Kashmir, Kábul, Bokhára and Pcrsia was filled with the tawdry rubbish of Paris and Berlin.

In the hotcl garden I took a few things; Terias heeabe was common, two of them lacked "the dog's head mark." 1 Belenois mesentina was represented by a solitary male. One of three males of Ganoris canidia yielded a decided scent, hard to describe but certainly not that of $G$. napi. That dingy Skipper Parnarce mathias, Fabr., was abundant at the flowers of Duranta. I missed sevcral specimens of a yellow Papilio, probably demoleus, Linn., and possibly also $P$. aleibiades, Fabr., or one of that group. Of the Blucs a Polyommatus baeticus, and threc Zizera liarsandra were taken.

Two moths came to light, Oligochroa akbarella, Rag., and Earias insulana, Boisd. (tristrigosa, Butl.).

Near the waterworks at BńRA, amidst a wilderness of stones, I nctted a female Belenois mcscntina, three Blues, T'arucus theophrastus, l'abr. (two males and one female), and my first T'eracolus, a female etrida, Boisd. Dr. Dixey tells me that he had no idea that this

${ }^{1}$ In a typical specimen the black horder of the fore-wing is so scalloped as to make tho outline of the yellow ground-colour: resomble a dog's head. Whon tho border is narrow this appearanoc is lost. 
species ranged so far north. A strange-looking long-uosed Grasshopper, Tryxalis nasuta, Linn., seemcd well adapted to its stony desert surroundings.

From Pesháwar my most interesting cxpedition, from cvery point of view, was to Ali Musjid in the Kháibar Pass. This tiny white building, said to be the first Musjid (Mosque) ercetcd in India by the invading hordes of Mohammcdan conqucrors, stands in the middle of the valley about $2400 \mathrm{ft}$. above sea level.

On either side are the forbidding crags which Pollock's infantry sumounted in 1842, and so forced the pass, making the relief of the gallant Salc a comparatively easy matter. In front, pcrched high aloft on a hill that seems to close the valley, is the fort which Sam Browne reduced with his 40-pounders in 1878. Naturally wc longed to go further, to see what there might bc beyond that turu of the road where the valley narrows to a gorge. However I had not gowe ten yards when the ringing voice of a sentry on the rocks to the right made me hesitate; the next moment an orderly ran domn and exhibited a board whereon were written in diverse tongues the most peremptory orders against moving one step beyond the Musjid. It was hot and glaring. My daughter sat down to sketch. A few yards on the other side of the sacred cnclosure was a green patch of vegetation beside the small stream which, clear as crystal, was full of frogs and tiny fish, and its banks fringed with a profusion of a species of Mint over which many butterflies were sporting. It was with difficulty that I persuaded the soldier to let me traverse those few yards; however, by letting him see me catch a butterfly, and letting him smcll the cyanide bottle, he was somewhat pacified. I could not speak Pushtú, nor even Hindustáni, so was probably a Russian spy. Soon other sipáhis came down: each one insisted on smelling the bottle in turn: each saw a butterfly succumb to the fumes, and to each I tried to cxplain that the bottlc would hill anything, even a Russki! To each the process of papering was demoulstrated. The result was that I was permitted to move on perhaps 100 yards, and then they got quite excited at the chase. Soon a number of them indicated by signs a desire to be photographed. They stood in a row, and when all was ready I gave the word "'tcll-shun!" Thcy instantly sprang up. I pressed the button, and then said, "Staud at-ease. Stand easy." They were obviously delighted-saying "Achchha" (good). Then the word was passed round that I knew the words of command and was therefore a pakka Sáhib, and no Russki. Presently I had to photograpl another group, and they finally insisted on my writing down all their names and 
lauks. Never have I met with more jovial aud good-natured barbariaus than these men of the Kháibar Rifles, who twice a week guard our side of the pass as far as Lundi Kótal. Yet I was assured that any of these men, Afridis, would have thought nothing of shooting me!

And now for the Butterflies. Danaida chrysippus, Linn., was fairly common. I took two males and two females, one of the latter with pale ground-colour of an umbreous tint and much shading along the costa. Pyrameis cardui was the commonest butterfly, mostly in fine condition. I took one Ganoris brassicac, Linn., of the form nipalensis, Gray, a female, and saw several G. canidia, all of which had possibly strayed from a patch of cultivated ground hard by. The Clouded Yellows were represented by several Colias hyale, auct., form cratc, Esp. The beautiful Precis orithyia was quite abundant; $P$. almana, Linn., also occurred, but was not common. I saw several Terias hecabe. The Satyrids were the most interesting of all. A specimen of Yphthima bolanica, Marshall, was my first acquaintance in that elegant and delicately-made genus. Hipparchia (Nytha) parisatis, Koll., a handsome insect suggestive of Vanessa antiopa, was rather common, but unfortunately much worn. Very conspicuous on the wing, it did not appear to be attracted by the Mint, but usually settled on the ground, and was then very difficult to see. I also secured two specimens (both females) of a very distinct pale Satyrid, much the colour of $C$. pamphilus, but far larger and with dentate hind-wings, Epincphele davendr'a, Moore, a species that proved to be new to the Hope Collection [Plate I., Fig. 1]; I caught two Polyommatus baeticus, but saw no Skippers.

Three of that widely-distributed beauty, Utetheisa (Deiopeia) pulchella, Linn., were seen flying in the sun, and with them a brilliant little Burnet, Zygaena kashmirensis, Koll.

Among the outsiders were a Grasshopper, Poecilocerus pictus, Fabr.; a Beetle, Clinteria confinis, Hope ; two Bees, Bombus simillimus, Smith, one of each sex, and a Wasp, Vespa auraria, Smith, a worker.

After about two hours the caravan from Kábul came down-long strings of camels together with mules, asses, and a few horsesbringing all sorts of produce from Afghanistán and Bokhára. With the animals were many weird men, women, and children, some clad in sheepskins (with the wool inside), other's in some stuff of a light greenish blue that was most picturesque. A very little later and the northward-bound caravan made its appearance: again long strings of heavily laden camels, both the common sort and the two-humped Bactrian species-all alike bearing large packs of 
Indian or Luropean goods. The men aceornpanying the beasts werc all armed, for the northern part of the pass, in eharge of the Amir, was felt to be less seeure, and an uncle or a eousin inight be lurking behind any rock bent on doing his part in the hereditary family feud. Hardly had the last eamel turned the eorner when the piekets of the Kháibar Rifles eame streaming down from their sángars (or little stone shelters) on every side, and we were given peremptory ordel's to retire. The troops marehed baek to their quarters and we drove rapidly towards the rich plains of India down the road that so many eonquerors have followed since the days of Alexander the Great.

In the early morning of the day on which we left Pesháwar one of the ladies of our party was awakened by a report. The watchman, or cháukídar, of a bungalow elose by had been shot while endeavouring to stop a thief!

These watehmen who guard every house, are said to bc recruited from a easte of thieves. In India one does not pay a thief to catch a thief, but to keep thieves away. It is related that once upon a time an officer fresh from England, when engaging his servants declined to have a cháukídar. More experienced offieers told him that he would be robbed if he did not. He said that he slept with a loaded revolver under his pillow, and he would like to see the thief that would dare to toueh his things. This pleasure he was denied, for when he woke in the morning, he missed his watch, his money and his revolver. Nay further, he found that his wardrobe was limited to the pyjamas he had on! Under these distressing eircumstanees there was but one thing to be done, so he scnt his servant with a note to the C.O. explaining that it ras not possiblc for him to appear at early morning parade. Later in the day, a sadder and a wiser man, he engaged a eháukídar.

The Gházis, or Mohammedan fanatics, are a constant source of danger along the frontier, for from time to timc onc of them, impatient for the joys of Paradisc, will "run amuck" and kill the first European that he chanees to meet. One such ineident was not without a grimly humorous sidc. The wife of a Sergeant-Major late one winter aftermoon was walling in the outskirts of the Pesháwar eantonment, when a Glúzi rushed up and stabbed hcr. The assassin was caught and in due course tried and hanged, but he was a disappointed man. In the gloaming he had mistaken the sex of his vietim who was elothed in an ulster aud wore a "bowler" hat of the manly ent then in vogue among women. But, look you, to ensure prompt admission to Paralise it is requisite that you 
should have killed a Christian man, for women, having no souls, do not count!

Malakand, lat. $34^{\circ} 30^{\prime}$ N., alt. circa $3000 \mathrm{ft}$.

October 28th and 29th, 1903.

By the kind hospitality of the Assistant Political Officer, Capt. R. W. E. Knollys, I was enabled to get two days' collecting at this remote frontier post.

MaLakand is approached by a narrow-gauge military railway which leaves the main line at the important Cantonment of Nowshera and passes Mardán the head-quarters of the famous Guides. Where this railway crosses a river the railway station and fortified bridge-head are one, the tickets being served out through a gun embrasure. On reaching the terminus at Dargai (not to be confounded with Dárgai where the desperate fight took place) we were met by Capt. Knollys who, though politeness itself, struck me as being just a little stiff. Accordingly I addressed him thus: "I am afraid, Sir, that I must plead guilty to being a globe-trotter, but venture to urge two extenuating circumstances." He replied, "Indeed, Sir, and what may they be?" To this I answered, "I am not a Member of Parliament, and I am not going to write a book to set you all right." From that moment he was cordiality itself. Evidently this explanation had taken a load off his mind, for he led me to understand that not very long before he had suffered many things at the hands of a travelling M.P. We found out afterwards that he actually had vacated his house for us and was sleeping in a tent in his own compound. If our host took me for a Member of Parliament, the native troops took me for a Bara Sáhib ${ }^{1}$ of some sort, probably a judge, for the sentries always presented arms to me, and once the guard turned out. Of course this was highly gratifying to one who had never reached a higher military rank than Captain of Volunteers.

Perched on a saddle, about $3500 \mathrm{ft}$. above the sea where the old Buddhist road crosses the foot-hills, looking forward over the Swát valley, and back over the dusty plain of the Panjíb, this isolated fortress affords a picture of rocky desolation. It has been the scene of much fierce fighting. We stormed it in 1895; in 1897 it was so suddenly attacked by swarms of tribesmen that our officers, hastily summoned from their game by the bugles sounding the alarm, fought all night in their polo kits, and indeed the situation was 
barely saved by the prompt arrival of the Guides from Mardan, who had started within the hour of getting the news and marched throughout the night. Even now the Pass is closed every night by ehevaux de frise, and the garrison is always prepared for an attack. Moreover, when scrambling over the hillsides, in addition to the usual Indian thorns in all their varieties, wire entanglements have to be negotiated.

When we drove with our host through the peaceful looking Swát valley to the outlying fort at Chakdurra we had as an escort a sowar (trooper) of the Swát Levies, armed with both lance and sabre, and when I went collecting it was deemed prudent that I should be accompanied by a gigantic chaprássi, a Pathan of the tribe of the Jusufsai, or Sons of Joseph-for they claim to be one of the lost Tribes. My cicerone had fought against us in 1895, since which time he had served in our native army, and was now a Commissionaire or Official Messenger. I fear it tried his loyalty sorely to have to wait upon a mad catcher of flies.

The rocky hills seemed too dry and burnt up to harbour many Butterflies, but on the parched slopes of the fortified crag, nicknamed Gibraltar, the pretty little Melitaea trivia, Schiff., was almost abundant; on a glaucous shrub at the foot of the same hill were numbers of the glaucous green and yellow Grasshopper, Poccilocerus pictus, which though conspicuous enough on the wing was decidedly cryptic when at rest. Other Orthoptera were Quiroguesia blanehardiana, Sauss., and Tryxalis nasuta. I took also three Wasps, two Vespa velutina, Lepel. (var. "des Indes," Sauss.) hebraeus, Fabr., ㅇ.

In addition to the above a long and hot walk only jielded one Ganoris canidia, of; two Terias hecabe, a female of the variety without the "dog's head," and a large but otherwise normal female; tro Blues, a Zizera Karsandra, and a Z. maha, var. diluta, Feld.; one Precis orithyia; a dingy Skipper, Gegenes nostrodamus, Fabr., and a Micro, which Lord Walsingham says is Eretmocera impactella, Walk., the variety with smaller spots; it belongs to the Hyponomcutidac. Some puddles of water at the baggage-mules' drinking-place proved very attractive, yielding a female Argynnis hypcrbius, Johanss. (niphe, Linn.), a male Tarucus thcophrastus, and the conspicuous Hipparehia parisatis.

The next day (Oct. 29th) I liglited upou an oasis in the desert in the shape of the staff-sergeant's garden, where irrigation had produced a brilliant mass of flowers, some vegetables, and a small ficld of Lucerne. Here butterflies abounded: Tcrias hecabe, without the 
"dog's head mark," was in plenty among the Lucerne as well as at the Marigolds; the Lucerne also yielded both Colias fieldii and $C$. erate, the eastern form of hyale. Among the Danaines Danaida chrysippus was common, and D. plexippus, Linn. (genutia, Cram.), abundant at the Marigold flowers, at which also one Tirumala limniace, Cram., was taken. Athyma perius, Linn., was rather common, but preferred the wet mud left in the irrigation channels to any flowers. Argynnis hyperbius was also common, but had more refined taste, and was usually taken on the Marigold beds; its female was observed during life to resemble D. plexippus. Precis almanc was common, $P$. orithyia very abundant at the same flowers, together with a few $P$. oenone, one of them very fine and large. As usual in India Atella phalantha and Belenois mesentina put in an appearance, the first at Marigold, the second, a male, among the Lucerne. The Hairstreak Ilerda senc occurred alike at Marigold and high up on the mountain-side. The flowers of Gaillardia proved more attractive than the coarser Marigolds to the smaller fry; the brown Skipper, Parnara mathias, was in abundance, so were the dingy Blues, Zizera karsandra, and Z. maha, but the latter and its variety dilutc, preferred mud to any flowers.

Other small things were Polyommatus baetieus, and the Skipper Gegenes nostrodamus, which was common at the flowers of Gaillardia and Marigold; unfortunately I secured but two specimens, probably because it is a dull and unattractive insect. Two or three Melitaea trivia also turned up at these favourite flowers. Not far from the garden I took two more Hipparchia parisatis; this as before did not appear to be much attracted by flowers, but settled on the ground where it was very inconspicuous. I observed it lean over from $20^{\circ}$ to $30^{\circ}$, and even saw it walking about with a "list" of $20^{\circ}$.

At Malakand we had the good luck to be just in time to see the fag end of the ticklish and much dreaded operation for the annual relief of the Chîtrál garrison. Indeed at Simla I had heard the Adjutant General say that some day the whole column would be cut up. This year the risk was considered greater than usual, and to support the relief marching up and the old garrison marching down, two battalions of infantry, a battery, a few cavalry, and many sappers with a train had been moved up to Chakdurra, 10 miles beyond Malakand, and the last post on the road to Chîtrál, which stands in splendid isolation 100 miles further. The troops we saw were a regiment of Panjáb infantry (either the 24tll, or 25th), Bengal Sappers and Miners, an immense mule train of baggage and ammunition, and the 2nd battalion of the 4th Gurkas. The North-West men 
were fine, tall, mostly handsome and comparatively fair, but the swarthy little Gurkas interested me most. In striking contrast with the Hindus they are a merry race. Very like Japanese, but darker, a trifle bigger and a trifle better looking. Undeniably very, very smart. I was introduced to some of the native officers, to whorn a few complimentary phrases were interpreted. All wanted to be photographed. The dread kúkri, the special weapon of the Nipálese, was exhibited and to the great gratification of the owner handed round to the ladies. "Battalion!-'ten-shun!" They fall in and march off, played out by the very creditable band of the Sikh regiment which forms the garrison of Malakand. Each company came to attention with remarkable smartness as they passed the group of officers standing near us.

\section{LAIIORF, lat. $31^{\circ} 35^{\prime} \mathrm{N}$, alt. circa $700 \mathrm{ft}$.}

October 31st-November 4th.

At the capital of the Panjáb which, though a city of the plains, was perhaps as picturesque as any of the Indian cities visited by us, my chief collecting ground was the extensive Lawrence Garden. This though full of flowers is so wild in parts, that, not to mention a Mongoose, I even came across a Jackal at midday; it skulked guiltily away like a whipped hound. On days when the band plays it is a great sight to see the police in their handsome uniforms mounted upon camels high above the crowd. Unfortunately, however, we missed the great sight of the place, the wife of the Lát Sáhib ${ }^{1}$ driving camels tandem!

The class of Butterflies found at LAHOre differed widely fiom those met with at Simla and further north, the predominant forms being Oriental. Here I first captured Papilio demoleus, Linn. (erithonius, Cram.), the "tailless swallow-tail," which $I$ had perhaps seen at Pesháwar; this butterfly has a wide range in India and might almost be termed abundant, frequenting especially the flowers of Zinnia, Lantana, and Bougainvillea. When feeding it settles for a few moments only, fluttering with its wings the while; then it is not hard to catch, but when rushing from place to place it is quite otherwise. In colouring it is very like $P$. machaon, but far less handsome; the yellow ground-colour is often quite pale and bright when the insect is fresh, but it usually turns much darker and duller; cyanide very possibly hastens this process. It was at

1 Jiterally Inord Mrater ; the title hy which the natives designate the Tientenant Govornor. 
Lahore also that I first came across another very common Indian butterfly, Papilio pammon, Linn.; its graceful form and flight and rich velvety-black coat at first excited me so much that I had great difficulty in catching it. ${ }^{1}$ Naturally enough I followed Linnæus in taking the sexes for different species: he called the male pammon, and the very different female polytes. At Lahore it especially affected the flowers of Bougainvillca speciosa and a shrub with blossoms similar in colour and scent to, but much larger than, those of White Jasmine. Like $P$. demoleus it flew rapidly from flower to florrer and fluttered while feeding. The female taken here was of Wallace's Form II. (polytes); among the males was a sombre variety with scarcely any orange on the under-side of the hind-wings.

Danaida chrysippus was abundant, more especially at the flowers of Asclepics (the food-plant); amongst them was a dwarf female. Timumala limniace was scarcely common.

Of the Brimstone-like Catopsitia pomona, Fabr., I only netted one female, but believe I saw others; it visits flowers high up on trees. C. pyranthe was abundant; it flies fast and high and is hard to catch ; it was fond of settling on the flowers of Durcunta plumieri, Jacq. on the tops of high hedges, forming a pretty contrast with the lilac-blue racemes. This is one of the many plants belonging to the Natural Order Verbenaceae which I have noticed to be especially attractive to insects.

Tericus heeabe, both sexes, was fairly common; it flew slowly and near the ground. The black and white Terccolus pucllaris, Butl., was also fairly common; perhaps it owes its name to the child-like simplicity of its dress. It flies near the ground, but so jerkily as to be somewhat hard to catch, and, moreover, has the habit of flying into bushes, by preference those well provided with thor'us, and not coming out again. Of the dainty T. protraetus, Butl., I could only get two specimens; its salmon-pink colour with broad black margins dusted with blue-grey make it one of the most beautiful little butterflies that I came across; its dress is all in exquisite taste, the under-side being a quiet greenish-yellow that must greatly protect it when at rest. [See Plate I., Fig. 3.]

White butterflies were not much in evidence; I took a somewhat worn female of Appias libythea, Fabr., also two Bclcnois mescntina, both females. This last is another common Indian butterfly; its upper surface reminds one of $P$. daplidicc, Linn., but the underside of the hind-wings and tips of the fore-wings are bright orange with

${ }^{\prime}$ Sec, howover, Chapter X., $\$ 7$, for my subsequent experioneo of tho swift flight of this buttorfly. 
brownish veins. Experience at Lahore confirmed me in the opinion that Whites of all sorts are most difficult to catch; they are shy, and fly rapidly with a jerky vertical movement. But then Whites are by far the most conspicuous butterflies, especially when at a distance, and doubtless they need their swift wings. Tho Catopsilias are nearly as conspicuous as the true Whites, and they fly even inore swiftly.

Among the Nymphalines the widespread Atella phalantha was represented by a few specimens at Marigold flowers. Precis orithyia (an insect that is apt to suffer much loss of beauty from grease) was not common, and the same is true of $P$. almana; a few of each were taken at flowers. At Zinnia flowers I got my first Hypolimnas misippus, Linn., a male; it impressed me as a most tropical-looking insect, though not so gorgeous as $H$. boline; it had both hind-wings clipped, possibly by a bird.

The Blues were represented by two species - the neatly-marked Tarucus telicanus, Lang, common at the blue flowers of Plumbago capensis, and the little greyish-blue Zizera maha, abundant at the flowers of a species of Millet and some herbs of the Labiate family; amongst them was a specimen of the var. diluta. Blues swarm in India; many of the species are small and dusky, so that they are hard to follow on the wing, and their flight is even more jerky than that of Whites. They are often found on grassy banks as at home, but are especially addicted to water-drinking and are constantly present in irrigated fields and gardens. It must be confessed that the abundance of bigger game often led me to pass them by. Again, Blues when killed are apt to fold their wings the wrong way, and it is difficult to set them right again; but if kept in the bottle a short time only with a view to preventing this untorrard result, they are apt to recover and fly away when the paper is opened while examining one's captures after the day's work.

The dull-coloured Skipper Gcgenes nostrodamus, was common in the gardens, but I only took one female. Small moths, mostly Pyrales, were abundant in a patch of long grass and herbage iu a damp spot. One of these was Pyrausta incoloralis, Guen., another the very widely-distributed Marasmia trapczalis, Guon.; but by far the commonest was the pretty little black-aud-white Zinckcnia , fascialis, very suggestive of our Ennychia cingulalis, Liun. Among the Pyrales was the tiny Gold-tail, Porthcsia xanthorrhoca, Koll. (marginalis, Walk.), which was flying in the suu.

Two things, besides the numerous green Parrots, especially impressed me about the Shah Dara, Jehangir's mansoleum. One 
was the dignified figure of the Sheik, who is the official guide, and the way in which he proudly rolled off the sonorous Persian of the inscriptions. In the North-West to know Persian is pretty much what it is to know Sanscrit further East, or to know Greek in Europe.

The other thing was to see the workmen of the British Ráj repairing a Moslem tomb, and using for the purpose red sand-stone from the distant and far-famed quarries of Futtipúr Sikri.

In the gardens of the mausoleum I saw at dusk a number of Hawk-moths at the yellow tubular flowers of a small tree; probably a species of Allamanda, but possibly Tecoma stans, Juss. My shorthandled net only allowed me to catch two, which proved to be beautiful specimens of Nephele hespera, and Choerocampa celcrio, Linn.

In writing to Dr. Dixey from Lahore, I made the suggestive remark: "It is evident that being late in the autumn many of the butterflies are old and much worn. Curiously enough they are more often tattered and torn than actually rubbed." It is difficult to apportion rightly the breaking of the wings between the work of thorns and insectivorous foes. Certainly Indian butterflies fly into and through bushes in a way that is not seen at home.

To my mind the greatest glory, of the many glories of Lahore, is the seventeenth century Musjid of Wazir Khán, which is covered with Nakashi work, a mosaic of shaped pieces of glazed pottery, a sort of out-door marqueterie. The patterns, floral and geometrical, are excellent, and on a scale exactly suited to their positions, a thing not very often seen in architectural ornament; the colouring is a harmonious blending of blue and yellow with green and purple, constituting the most successful ont-door decoration for a hot climate that I have come across; seen against a bright blue sky it is simply perfcct. A less beautiful thing in the city is the sheep, with a tail as fat as a leg of mutton. The printed cottons, which in general effect so much resemble those of Northern Italy, are made in Lahore.

In this city we rcalized how little effect a century of our occupation has had upon the changeless East. We have introduced kerosene oil and aniline dyes-voilà tout!

In the Ajaib Ghar, or Wonder House of Lahorc, Anglicé Museum, well known to readers of "Kim," is a small collection of insects. This was useful to me, but the destruction wrought by Dermestes, etc., both among the insects and the textile fabrics of the Industrial Collection, is most sad. I trust Mr. Kipling will see to it. 
Amits $\Lambda$, lat. $31^{\circ} 40^{\prime} \mathrm{N}$, alt. circe $750 \mathrm{ft}$.

November 5th and 6th, 1903.

At the sacred eity of the Sikhs my eollecting was practieally confined to two gardens elose to the hotcl. Here a large dull brown butterfly, with somewhat of the Vanessa habit, spread itself perfeetly flat upon the surface of the earth and more especially of the damp mud of the little irrigation channels, lying so close to the surfaee as to be with diffieulty discerned, so exaetly did it resemble the tint of the mud. I seeured three which proved to be Euthatia garuda, Moore, all females.

Papitio pammon was eommon; besides males I took one female of Wallace's Form I, whieh differs but slightly from the male and henee is now termed pammon pammon. Of Precis almana I took one, of the ubiquitous Belenois mesentina likewise one, a female, but I was somewhat surprised to net a female Colias fieldii, since the great plain of the Panjáb seemed an unlikely loeality for the genus.

Yphthima nareda, Koll., also oceurred in the hotel garden, but was searcely eommon; it flew elose to the ground.

What struck me most about the famous Golden Temple of the Sikhs, next to the general picturesqueness of its surroundings (and the filthiness of the water in its tank), was the tablet just within the great silver gates, erected by the British Ráj to the memory of that famous party of the 15th Sikhs who defended their post on the frontier until every man had been killed.

The famous carpct faetory was at a standstill because the Moslem workmen were keeping the great Sikh festival!

Delin, lat. $28^{\circ} 30^{\prime} \mathrm{N}$, alt. circa $700 \mathrm{ft}$.

November 7 th-12th, 1903.

When collecting in the fair Kudsia Gardens outside DeLHI it was impossible not to be stirred by the historie associations of the ground. Between the northern walls of the eity, the famous Ridge, and the mighty Jumna, seareely morc than a furlong from John Nicholson's grave, there stands, ncarly lidden by trecs and flowering shrubs, all that is left of the Summer Palace of the kings of Delhi. Its erumbling walls, where not covered by Bougainvilleas or other ereepers, bcar testimony by many a bullet-mark and round-shot hole how fire-swept the place was during the long swcltering days of 1857. Concrete blocks with suitable inseriptions mark the sitcs of the breaching batteries of the last stages of the sicge-batteries 
placed strangely near the walls when measured by the range of modern guns, for yon unrepaired breach in the Water Bastion is scarce two hundred yards from the most advanced battery!

Here in a beautiful garden, the very ideal of quiet and peace, where the numerous grey-striped Squirrels are quite tame, and the greenest of Parrots and the crested Hoopoes look as if war were unknown upon earth-here I watched many gorgeous Papilio aristolochiae, Fabr., fluttering upon the flowers, or sailing over the trees; at one moment they looked like black crêpe against the light, at another they displayed a circlet of brilliant rubies beneath. Once I had three of these beauties together in my net. With them were a few $P$. demoleus and $P$. pammon, the lattcr being females of Form II.

Danaida chrysipprus was also common; one, a male, was unusually small. Crastia corc, Cram., was common in shady places under mango trees, but was rarely seen at flowers. The pretty little black and salmon-coloured Tercaeolus calcis, Cram., was abundant alike in the Kudsia Gardens and close to the hotel, flying near the ground, yet not so easy to catch. One of them was very small. Of $T$. prellaris I saw two only. The wet-season form of Tcrias hecabe was abundant, flying low and about bushes.

Of the brilliant yellow and orange Ixias pyrenc, Linn., I took but one; the less gaudy Orange-tip, I. mariannc, Cram., was rather common, but some of them were worn and none very easy to catch. Here I took my first Delias eucharis, Drury, a very worn fcmale. The common Whites were Huphinc nerissa, all males, and Belenois mesentina, which was abundant at flowers. The slender little Nychitona xiphia, Fabr., flitted weakly along close to the ground, reminding me irresistibly of Leucophasia sinapis, Linn., in spite of all structural differences. One of these ghostly crcatures was taken flying over a tablet that marked the site of "Battery No. IV. Left attack; mortars." One wondered whether therc were any butterflics in that place during the terrible summer of 1857 .

Have the natives forgotten those days? We have not. $\Lambda t$ Mcerut -where the old women in cocked hats did nothing, while the mutineers were busy murdcring Christians in Delhi-we saw British troops groing to church with rifles and ball cartridge! In May, 1857, the mutineers tried to catch our men in church, unarmed, but the hour of parade was altered, so that their crafty scherne was happily frustrated.

Three or four Precis lcmonius appeared to be rather fond of shade; they settled upon the ground in preference to flower's, and then were 
hard to see. Of the gorgeous Hypolimnas bolinc I saw one of each sex; it needed an effort to believe that they were one species.

The Blues included Catochyrsops cnejus; I'arucus theophrastus; Chilades varunana, Moore; and C. Laius, Cram., this last was common. The only Skipper taken was Telicota augias, Linn.

A little Geometer, Semiothisa fidoniata, Guen., like a Macaria, was common among herbage, and one specimen of Tephrino, disputaria, Guen., was taken in like situation. The first-named also came to light, along with Oligochroa akbarclla, Rag. Can M. Ragonot have intended a deliberate insult to the memory of the great Emperor when he named this lowly and insignificant little Phycid after him?

Other moths taken in the Kudsia Gardens were the tiny Noctuids Metachrostis badia, Swinhoe, and Earias insulana, Boisd., the latter being common among bushes mear a back-water of the Jumna.

In the verandah of the hotel I took a fine Sphinx orientalis, Butl., the eastern form of convolvuli, Linn.; it had probably been attracted by the lights the night before.

\section{LíLIKót. November 10 th.}

Eleven miles south of Delhi lies this glorious city of ruins, and there, under the shadow of the Kutab Minar, flying over the stones and amidst the thorny vegetation were many Whites and Orange-tips. The butterflies appeared especially to delight in flying about inside the thorniest bushes, or even flying through and through them, so that torn wings were almost the rule. Prominent in the countless crowd of Belenois mesentina so employed were Ixias marianne and I. pyrene; a female of the former was distinguished by the substitution of cream-colour for white in the ground-tint of the wings. The delicate-looking Teracolus etrida, lover of ruins, was in abundance, flying close to the ground.

The great mosque of the Kutab presents several points of architectural interest, but one thing especially impressed me. It was erected by Kutab-ud-din Aibak, after the capture of Delhi, in 1191 A.D. The Mohammedan soldier had to carry out his designs through the instrumentality of Hindn workmen, who were ignorant of the principle of the arch. Accordingly we see in place of voussoirs, or redge-shaped stones fitting together and coustituting the arch, successive horizontal layers of stone, each "sailing over" or projecting beyond the other, while two flat slabs at the top take the place of the keystone. [lig. 4.] 
This is not the placc to descant upon the wouderful pillar of wrought iron nearly 24 feet loug, and of an average diameter of 14 inches. A truly marvellous piece of forging for the fifth century A.D. And what a testimonial for the climate that the inscription is still quite sharp after being exposed to the weather for fourteen centuries!

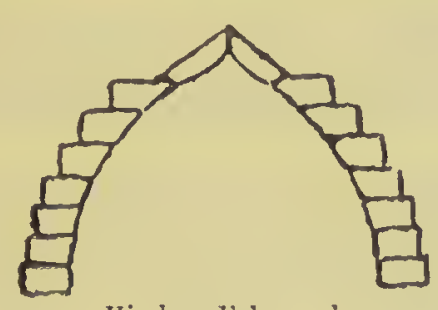

Hindu. False arch.

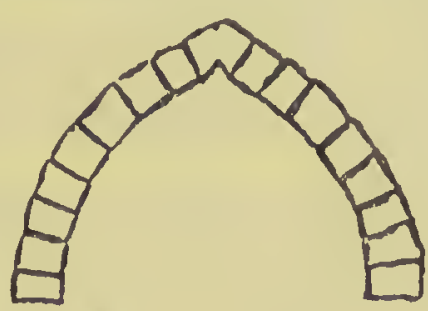

Moslem. 'T'rue arch.

FIG. 4.

Delhi has been called the Romc of India, but whereas Romans speak of the Eternal City, Delhi has changed its site at least seven times in its history, and magnificent remains of some of its prcdecessors survive at Lálkót and Indrapat.

\section{NÁini Tíl, lat. $29^{\circ} 30^{\prime}$ N., alt. $6500 \mathrm{ft}$.}

November 16th-23rd, 1903.

Unlike Simla and Darjiling, which stand astride lofty ridges, NÁINI TÁL lies in a basin by a lake, a situation which, however plcasant it may be in summer, gives it in late autumn a dank feel. In summer it affords good collecting, I am told, but in November I found but few insects, and those mostly battered and forlorn-looking. The fauna, though more Oriental than at Simla, a degree and a half to the north, is much more Palaearctic than at Lahore, which is yct half a degree north of Simla, but of coursc upon the plain.

A very clear picture rcmains with me of a bright sunny aftcrnoon, with a raw chill in the air very suggestive of homc. On the one hand are Phododendrons and Thujas growing as forest trees, and hard by cactus-like Euphorbias somc 15 fcet in height; on the other, Poplars are shedding their golden leaves in bright contrast to the crimson of the wild Ampelopsis (I cannot call it "Virginian" creepcr); a Brimstone $^{1}$ butterfly dashes wildly past, then a belated Tortoise-shell" or Red Admiral ${ }^{3}$ darts up from the path only to return again to the same stone, while several Small Coppers ${ }^{1}$ disport themsclves

\footnotetext{
1 Probably Gonepteryx nipalensis, but possibly a Catopsitia.

"Vanessa liashmirensis.

- Chrysophanus pavana. 
about the autumu flowers on the bank. Quite a l'alacarctic picture surely.

In addition to the above I found at Náini Terias hecube; the Hairstreak Merda sena, and the Blue Zizera maha; also the Fossor, Pompilus analis, Fabr., a female, while Agrotis flammatra, Guen., a British rarity, eame to light.

A climb to the top of China Peak (pronounced Cheena), $8568 \mathrm{ft}$., produced two more Palaearctic forms, Argynnis issaea, and Polyommatus baeticus.

Five days were spent on horsebaek in an expedition into Kamcion as far as Ranikhet and Cháubattia, some twenty-four miles north of Náini as the crow flies. The road, at first so slippery with ice as to eompel us to dismount, falls rapidly to Kháirna (Kháirana, or Khyrna, for the spelling seems uncertain). At about $6000 \mathrm{ft}$. Merda, sen $x$ was again met with, at about $4000 \mathrm{ft}$. Neptis astola, Moore, and Terias hecabe. When near the bottom our eye was eaught by the fluttering down of shells from a large pod-bearing tree. On glancing up we saw about a dozen eharming-looking greenish Monkeys, their little black faces set off with most becoming white frills. It did not take them long to strip that tree of every pod.

At Kháirna, $3200 \mathrm{ft}$., a tiny village in a deep and narrow valley; I had a little further time for eollecting, but it was limited by the steady mareh across the valley of the great chill mountain shadow, which sent all butterflies quiekly off to bed. Precis orithyia was eommon, but the specimens were very small; $P$. ocnone, $P$. lemonias, and $P$. iphita were also seen, the latter at flowers, not a usual habit of the species. Several Athyma perius were seen, also several Catopsilia pyranthe; of those taken one was of the gnoma, the other of the pyranthe form. Of Ganoris canidic and Tarucus tclicanus I took one eaeh, but Zizer a maha was in abundanee. In addition to these were Utcthcisc pulchclla, flying for short distances about low herbage according to its wont, also a Fly which hovered at flowers just like a Sphinx-a Bombylius not in the National Collection. The widely-distributed Grasshopper, Thisoicetrus littoralis, Ramb., whieh was very common, had the eurious habit after its short flight of settling so brusquely upon a shrub as to make its branches shake, but then quickly making its way to the ground. I missed a Macroglossa twice at the same flowering bush. Late in the afternoon I took a P'apilio panmon (a female of Wallaee's Form II., polytcs), which was flying about and into bushes, apparently seeking for a restingplaee for the niglit, but possibly for a plant whereon to lay its eggs.

Close to the village of Khíima 1 saw upon the cliffs by the 
roadside several beautiful Lizards, grey-spotted, with bright blue legs,

During the loug and hot pull up again from Kháirna to the ridge on which stand Ranikhet and Cháubattia, a dwarf Prccis orithyia and a Noptis astola were taken at about $3500 \mathrm{ft}$., and at about $4000 \mathrm{ft}$. Belcnois mesentina, Pyrameis indica, and Ilcrda sena.

At Ranikhet, $6000 \mathrm{ft}$. (where, by the way, the cooking at the Dák bungalow was the best that we came across in India), Monkeys were not uncommon in the woods, but unlike our legumen-loving friends of Kháirna, of a revoltingly ugly type; Butterflies, however, were scarce, and were represented by Pyrameis cardui, Vanessa kashmirensis, Ilcrda sena, and Lycaena maha, var. diluta.

At Cháubattia, four miles to the east of Ranikhet, and at a height of about $6200 \mathrm{ft}$., the officers' quarters command a most glorious panorama of Nanda Devi, 25,749 ft., Nanda Kót, 22,491 ft., and Trisúl, 23,581 ft., mountains of unsurpassed grandeur of form, and held most sacred by pious Hindus as sources of Holy Ganges. These stand between fifty and sixty miles away, yet shine forth as clear and bright as if quite close. As we gazed in rapt admiration at these giants among giants, we little thought that within four years my nephew, Dr. Tom G. Longstaff, would earn a world-wide fame by struggling to the top of Trisúl, not indeed the highest but quite the most striking of the three.

On the road to Chábattia we met with rather more butterflies, viz. our old friends Terias hecabe, Precis oenone and P. lemonias, Pyramcis cardui, and Chrysophanus pavana, and in addition something quite fresh, the Erycinid Dodona durga, Koll., of which I got three specimens; though a small insect it proved tenacious of life. A little beetle, Oides sp., was taken flying over the road.

On descending again from Náini to the plains I found, as at Simla, that butterflies got more numerous and more Oriental in charncter. At the top of the road the Hairstreak, Ilerda scna, was common; at $5000 \mathrm{ft}$. Y phthima philomcla, Johanss., was met with; at the Brewery, circa $4500 \mathrm{ft}$, butterflies were very common at a flowery turn of the road, and I took Pyramcis inclica, several Prccis iphita, P. lemonias, and a male Hypolimnas bolina, while I missed a brown and white Neptis-like butterfly which may have been Rahinda hordonia, Stoll, or, possibly, Symbrenthia lncina, Cram. 
LuCKNow, lat. $27^{\circ} \mathrm{N}$, alt. circa $500 \mathrm{ft}$.

November 24th and 25th, 1903.

LuckNow possesses a museum containing a fair collection of insects, which would have been more instructive if the majority of the species had been named.

In the beautiful garden of the Dilkusha Palace, where Havelock fell sick of the illness that was to prove fatal in the very hour of triumph, there was a great wealth of flowers and consequently a great assemblage of butterflies. Besides such things as Papilio dernoleus; Argynnis hyperbius, a female; Hypolimnas misippus, several males; Crastia core, both typical and the variety vermiculata, Butl.; and a Catopsilia which evaded capture, I took there my first Rapala. melampus, Cram. This is a small copper-coloured butterfly belonging to a genus which, with its robust body, sharp-cut wings, and curious anal lobe to the hind-wing, looks very different from our Hairstreaks or Coppers. It is neither easy to see on the small flowers which it frequents, nor to catch.

Other butterfies taken in the same garden were the Blues, Catochrysops strabo, Fabr., Tarucus telicanus, and Zizera (?) argia, Moore, var. similis, the last two in abundance; Mycalesis perseus, Fabr., and the brilliant tawny Skipper, Telicota augias. A beautiful little Noctua with yellow under-wings, Hyblaea puera, Cram., was taken at flowers in full sunlight. I also took a Grasshopper, Gastrimargus marmoratus, Thunb., a species of wide distribution.

By the roadside between Dilkusha and La Martinière a few Chiladcs putli, Koll., a tiny brown Lycaenid, were obtained.

At the Alam Bagh, ever to be remembered in connection with Colin Campbell, the dry-season form of Tcrias hccabe was flitting quietly about, and I netted Ixias marianne (not so vulgar-looking as its name might lead one to expect), also a variety of the female of I. pyrcnc without the orange-tip. A male of the wet-scason form of Huphina nerissa was also taken, while Dclias cucharis was common -one was fecding on Zinnia flowers close to Havelock's grare. Utetheisa pulchella was flying commonly in the sun amongst the grass, and with it a specimen of its near ally Argina cribraria, Clerck. The Coleoptera were represented by Mylabris sidac, and the Micros by a Pyrale, Pyrausta phocnicealis, Hübn. (juncturalis, Walk.).

Pcel's naval guns at the Residency rominded us that the sailorinen were as handy in the relicf of Lucknow as in the defence of Ladysmith. But there were no butterflies to be secu in the well-kept garden on the afternoon of our visit, and perhaps that was as well 
since our minds were filled with deeper thoughts. I stood bareheaded in the little cemetery beside the plain slab of stone that bears the majestic inscription, dictated by the hero himself:

HERE LIES

\section{HENRY LAWRENCE}

\section{WHO TRIED TO DO HIS DUTY}

When the mutiny broke out, our obliging guide, then a boy of cighteen, was in the great Martinière school. He sang in the choir of the Residency Church, and one Sunday afternoon as they were practising the Magnificat some one burst in crying out that martial law had been proclaimed, and that they were to get back to their school with all haste. What did they do, think you? They finished the Magnificat!. . . You may imagine the quiet pride with which the now elderly man, who as a big boy had carried a musket throughout the defence, told us that he still sang in that choir.

Benares, lat. $25^{\circ} \mathrm{N}$., alt. $270 \mathrm{ft}$.

November 28th-December 2nd, 1903.

The sacred city of the Hindus, as a city, was a great disappointment: the temples are all small, mostly mean, and those that are not filthy are at any rate dirty. But the view of the Gháts from the Ganges is the most interesting in India. The buildings of the Gháts themselves, modern as they are, rival some of the works of ancient Egypt, while the groups of the bathers in the holy river form a constantly moving picture. Many of the worshippers at their morning prayers seemed truly devout, yet as a whole they did not impress one as Moslems do.

BENARES proved more remarkable for the number and variety of its pilgrims than for its Butterflies. In the hotcl gardens, wherc Jackals howled loudly by night, a few battered spccimens of Papilio dcmolcus were seen by day, and the males of both spccics of Hypolimnas were fairly common. Of $H$. bolina I took a fine femalc, while of misippus I also sent home a female marked "common." It is, howcver, ccrtain that at the time I did not know this inscet to be a Hypolimnas, sincc I only learned from the Calcutta Mnscum Collcction that the fcmale of misippus was brown. 'Thcre is therefore little doubt that it passcd for a variety of Danairla chrysipmes which it mimics in such a surprising manncr, and which ccrtainly was common cnough in the 
same garden. It is one of the inconveniences of the method of "enveloping" one's captures that so much is left to memory, and the chances of comparing insects are so very few. Dwarfed specimens of Prccis orithyia were now very common; $P$.oenone and $P$. lemonias were less common but almost as small; several $P$. almana occurred. But in spite of the excessive drought and the consequent occurrence of dwarfs, ${ }^{1}$ one of my specimens of Terias hecabe, taken at Benares, was quite of wet-season type. Catopsilia pomona was represented by a very large male of the typical form and a smaller female in fine condition, exhibiting the transition to the catilla, Cram., or extreme dry-season form. Similarly, C. pyranthe was represented by a male of the typical and a female of the gnoma form.

Together with the above were several smaller things: among the Blues Polyommatus baeticus occurred, while Catochrysops strabo, and the tiny Chilades putli, were both common. The Skipper Parnara mathias was also common, and I took one Telicota augias. The little Pyrale, Zinckenia fascialis, was in some numbers in one small flowerbed. Of the long-waisted Wasp, Eumenes esuriens, Fabr., I saw but one, a female.

But among the frequenters of the small garden adjoining the hotel those that interested me most were the "lobed " and "tailed" Lycaenids, of which there were no less than four species. Of Aphnacus ictis, Hew., I took a solitary male; of $A$. elima, Moore (which, however, de Nicéville considered to be only a dry-season form of ictis), I secured two, also males. Of the third species, Pratapa deva, Moore, but one turned up, and that had lost the anal angles, with their appendages, and a large part of both hind-wings, which had apparently been bitten off, absolutely symmetrically, by a lizard. The fourth species, Rapala mclampus, was common, and I secured seven specimens, all, however, males.

Concerning $R$. melampus I wrote to Dr. Dixey at the time: "The Tailed Copper (or Hairstreak), first seen at Dilkusha, Lucknow, and found commonly here [Benares] to-day, greatly interests me. Not only is it very beautiful, but it is surprisingly hard to see, especially when at rest. Then the structure of the hind-wing is most strange; posterior to the tail (the next interspace but one) a portion of the

1 This appears to contradict Prof. Poulton's observation that the dry-soason form of tho seasonally dimorphic Precis sesames, Trim., is in S. Africa larger than the wet-soason form. But the sesamus that he woighed had passed tho larra and pupa stages during tho wot season, whoreas my small Indian Precis were of the second dryseason brood at least, so that their larvao and pupao had been submitted to dry. sorson conditions. 
wing, nearly circular, with a very obvious fringe of large scales, is set at right angles to the plane of the wing and to the direction of the veins." [See Fig. 5.]

According to Schatz and Röber, this "anal lobe" occupies the space between the sub-median and inner marginal veins; the second anal and third anal of Comstock; $1 b$ and $1 c$ of Meyrick; but I have not found in these authors any allusion to the striking fact that this lobe is quite out of the plane of the wing. This omission may be due to the fact that the process of setting usually flattens the lobe out

APHNAEUS ELIMA, Moore.

Enlarged from sketches from the living butterfly.

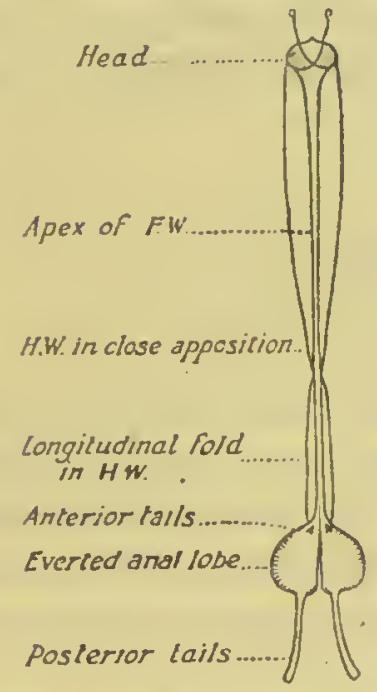

Diagrammatic view from above.

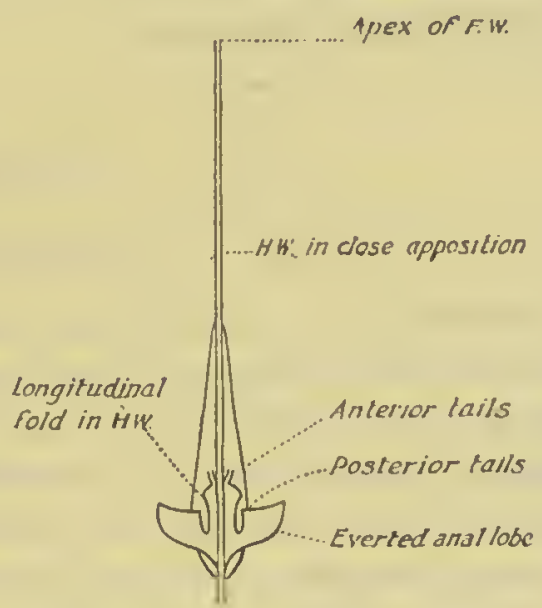

Diagrammatic view from behind.

Drawn at Benares, November 30, 1903, by G. B. LoNGSTAFE.

Frg. 5.

so that its natural form is hardly seen in cabinet specimens. It did not occur to me at the time (and the suggestion arrived by letter too late) that the object of this structure is possibly to produce the appearance of a head in a non-vital part, the tails representing the antennae. However, drawings made at the time strongly bear out the suggestion. The resemblance would be still more striking if these Lycaenids, like so many of the family, habitually rest with the head downwards. ${ }^{2}$

In another letter from Benares I said: "Thorns are not specially bad here, only that one does not know the look of many thorny

1 Exotische Schmetterlinge: II. Theil. F'amilien und Gattungen der Tagfalter, 1892, pp. 268-9, Plate 47.

? Soo Chapter X., $\$ 10$. 
plants until too late. But, on the other hand, burrs of every sort and kind abound to an incredible degree and tangle up the net; much of one's time is spent in freeing net and breeches therefrom."

It might have been added that at Benares I first made acquaintance (somewhat intimate) with "Spear-grass," which is yet more provocative of bad language than either thorn or burr. Indeed, I am disposed to conjecture that Spear-grass, and not the Darnel or Ryegrass of commentators, was the "Tares" which the devil sowed amongst the wheat.

Some three miles from Benares, on the way back from Sarnath, where Buddha first taught, Delias eucharis was flying in extreme abundance in a small field of the tall Marigold which is so much cultivated for the service of the temples. A truly gaudy sight it was to see crowds of these white, yellow, and scarlet butterflies upon the orange-coloured blossoms.

\section{Calcutta, lat. $22^{\circ} 30^{\prime} \mathrm{N}$. Near sea-level.}

December 4th-12th, 1903.

Naturally one could not expect to turn up anything new at Calcutta, the capital of India, and long the home of de Nicéville, that martyr to science who met his death in the deadly Terai when officially investigating the life-history of an insect pest. However, I determined in the few days at my disposal to get at any rate a sample of the fauna of Lower Bengal.

The Eden Gardens, abutting on the Máidán and elose to Government House, bear much the same relation to Calcutta as Kensington Gardens to London, and from their proximity to the hotel afforded a eonvenient eollecting ground for odd hours.

The Duranta was nearly over, and the most attractive featurc proved to be a hedge of Lantana in full bloom. These dissimilar plants both bclong to the Verbenaccae and are both natives of the West Indies, although the latter appears to have run wild in many parts of the East. On that hedge Danaida chrysippus ras in abundance, accompanicd by D. plexippus (genutia), which I had not secn since I was at Malakand, while numerous Tirumala limniace and Crastia core completed the company of the Dauaines. I was able to confirm my Benares observation that the male of $D$. chrysippus had a slight but decided odour suggestive of cockroaches, which was perhaps stronger when the "scent sacs" on the hind-rings werc opened, though of this I was not sure. On the other hand, the male 
of $C$. core had a faint scent that suggested to me rancid oil, or old lamps. So far as I could judge, this scent was connected with the hind-wings, but not with the very conspicuous genital tufts.

At the Lantana flowers along with the Danaines were abundance of Suastus gremius, Fabr, a somewhat dingy Skipper, also a few of the brilliant and conspicuous Delias eucharis. The upper-side of the female of this species faintly mimics Tirumala; the male yielded, on rubbing the wings, a sweet flowery scent, which I was not at first able to describe, but later it struck me as resembling that of our domesticated Ganoris rapae and suggestive of sweet-briar. Dr. Dixey informs me that scent-scales are very numerous in Delias.

In the shadier parts of the garden together with numerous Terias hecabe, one at least of markedly wet-season type, and many $Y$ phthima hübneri, Kirby, several Nychitona xiphia were found, which, as ever, reminded me of Leucophasia sinapis, a slender form and fragile appearance being in each species associated with a weak flight elose to the ground. One of the $Y$. hübneri had the whole hind margin of both hind-wings bitten off nearly symmetrically.

Catopsilia pyranthe and C. pomona were both met with, the former the more frequently. No Papilio turned up although I was told that $P$. pammon occurs in the garden. Amongst young Palms the males of Elymnias undularis, Drury, were occasionally disturbed, and a very striking thing it is. Then Nepheronia hippia, Fabr., came along, flying strongly, the male looking on the wing, or more especially when settled on a flower with wings expanded, much bluer than its cabinet appearance might lead one to suppose. Three Limcnitis procris, Cram., proved difficult to cateh, preferring the leaves of tall shrubs to flowers; but it is scarcely as graceful on the wing as our White Admiral.

I took two specimens of Catochrysops pandava, Horsf., var. bengalia, de Nicév. (being the dry-season form); the female is a demure creature, but the male is of an iridescent blue, bordered with black. Hypolimnas misippus, a nale, Precis almana and $P$. lcmonias completed the list of twenty species taken in four visits to the gardens. With them was a Fossor, Elis thoracica, Fabr., a female.

The walk from the hotel to the museum went far towards solving the problem of the disproportion between the garrison of Calcutta and the size of the city. The pavement of the road alongside of the Máidan (the first green one that we had seen in India) is of quite unusual breadth. It is usually occupied by throngs of people, mostly Bengális. Presently three Pathín sipáhis come swaggeringr along the middle of the path arm-in-arm. Instantly the crowd 
divide and leave the pavement barc. It is cvident cnough that the respective fcelings of Bengali and Pathán are those of fear and contempt.

\section{BÁLIGANJ.}

At the truly splendid muscum (where, by the way, I saw a native artist at work producing some of the very best coloured figures of beetles and butterflies that I have seen), Mr. S. E. Peal, besides helping me in other ways, put me on the track of one of the late Mr. de Nicéville's favourite collecting-grounds, a rus in urbc, at BÁLIGANJ, a suburb only three miles from the hotel. I visited this place twicc, on December 5th and 9th. It consists of a large deserted garden long run wild; weedy meadows and jungly woods are all that is left of onee trim lawns and ordered shrubberies, while a palm avenue and several tanks covered with a floating flower of the Convolvulus order, harbouring countless dragon-flies, eomplete the tale of departed greatness. Altogether it is full of sad beauty. Palms and Crotons with an unclergrowth of ferns were the charaeteristic plants, flowers were few, yet in eertain favoured spots butterflies were in quite bewildering swarms. The quiet eharm of this old garden was greatly enhaneed by the absenee of eurious natives and the (comparative) absenee of burrs, that curse of "up-country" collecting, though eertainly the unsuspeeted prickles of innocentlooking Palms to some extcnt took their plaee.

Some of the species seen near the eentre of the city, in the Eden Gardens, were here eonspieuous by their absenee, e.g. Limenitis procris, Precis lemonias and Hypolimnas misippres.

The four eommon Danaines, Tirumala limniace, Crastia corc, Danaida plexippus and $D$. chrysippus, were not so eommon as might have been expected, probably owing to the searcity of the flowers they love. In the last-named speeies I was able once more to confirm the presenee of a distinet, but not strong, odour suggestive of eoekroaches. A few Papitio pammon of both sexes gave to the assemblage that air of distinetion which the genus always has. Among the more sombre things, most frequent under the shade of groves, were a number of Mycalesis indistans, Moore, together with one $M$. perseus, which two spccies, so far as obscrved, have no "list" when at rest. In the shade also were two or three Mclanitis ismene, Cram. Close down amoug the herbage together with Yphthima. hübneri there werc flying large numbers of $Y$. philomcla, Johanss., (baldus, Fabr.) ecrtainly a gregarious speeies. 
Preeis almana, was noted, and $P$. atlites, Johauss., here came under my observation for the first time, but in poor condition; it is then a rather ghostly-looking butterfly though a somewhat strong flier; this last is also true of Atella phalantha. A singlc specimen of my old Amritsar friend Euthalia garuda was observcd, as before, to settle with its wings fully expanded and closely appressed to the the ground. Elymnias undularis was in abundance; it is especially addicted to the characteristically Indian butterfly habit of flying into or through bushes, and even of flying about inside them. It is clearly gregarious, several specimens flying in and about one bushy Palm, its food-plant. The male is very striking on the wing, and when settled, even though the under-side is somewhat leaf-like, it is yet quite conspicuous. The female, on the other hand, is on the wing a very fair mimic of Danaida plexippus, but its flight is weaker.

Catopsilia pyranthe and $C$. pomona were both rather common; Terias heeabe was abundant, and, as usual, gregarious, or, at least, sociable.

In half-shaded spots an occasional Nychitona xiphia flitted slowly along close to the ground. Ergolis ariadne, Linn., was abundant; of $E$. merione, Cram., two specimens were secured. The butterflies of this genus settle with the wings three-fourths expanded.

Nepheronia hippia was rather common; though its female somewhat mimics Timumala limniaee, the male, when on the wing, looks much bluer than that insect.

A brilliant fulvous Skipper, Telieota bambusae, Moorc, was the only representative of the group, but there were several Blues, to wit: Catochrysops strabo, which was common ; Lampides eclcno, Cram., larger than usual, one bcing of the form alexis, Stoll; and a lot of Neopitheeops zalmora, Butl. A single cxample of Curetis thetis, Drury, apparently bitten by some enemy, fell to my nct; its silvery-white under-side is very striking. But perhaps the strangest-looking butterfly of the lot was Loxura atymnus, Cram., of which I got two. Its wings are much plaited longitudinally, and when at rest its extremely long tails, crumpled look, and brown colour give it quite the appearance of a dead leaf. A closer examination shows that the portion of the hind-wing near the anal angle is bent down, or back, nearly to a right angle; this bent portion is, howcver, relatively smaller, more oval and less sharply bent than the rounder anal lobes of Rapala and Aphnaens; moreover it is not furnished with the very large marginal scales which are so conspicuous in those genera. 
Toliganj. December 7th, 1903.

About two miles from Báliganj, and due south of Calcutta (about half a mile beyoud the Sports (lub), is the locality referred to as Toliganj. Here, too, is an old abandoned garden, but lacking the elements of departed grandeur that give a poetic colouring to de Nicéville's old hunting-ground. The prominent features are a great profusion of Lantana in full bloom, a Bamboo grove and a good deal of thorny jungle. The day that I was there the Lantana was the chosen haunt of great numbers of the bigger butterflies such as Delias eucharis, Tinumala limniace, Danaida plexippus, Papilio pammon, mostly worn, $P$. aristolochiae, and a few $P$.demoleus, together with an occasional Nepheronia hippia, with his broad wings proudly expanded to view. The sight of these big fellows, expanding from three to four inches, quietly settled on the flowers, or fluttering after the manner of Papilio, or grandly sailing around-gorgeous in their white, yellow and scarlet, black and grey blue, mahogany-brown and black, black and cream colour, black and coral-red, black and yellow, or sky-blue and black-afforded indeed a glorious sight not soon to be forgotten. Alas! such a tropical glory takes much colour out of the most vivid mental pictures of butterfly life at home.

In a shady grove not far from these flowers Danaida plexippus was simply swarming, as many as ten or even twenty being in sight at once, for it is one of the most gregarious butterflies that I have met with. A few observations on this species and Tirumala limniace failed to detect any odour, but it was far otherwise with Dclias eucharis, of which several specimens had a distinct sweet scent, very like that of $G$. rapae. My strong impression is that this scent is confined to the male, but I cannot, unfortunately, speak with certainty on the point. The male of Huphina ncrissa has a distinct scent, also like that of $G$. rapae, although the butterfly itself more resembles $G$. napi. The scent of these two butterflies is neither so strong nor so unmistakably characteristic as that of $G$. napi, but its existence is quite beyond question.

These scents are not easy to deal with. The human nasal organ is but a poor affair at best, moreover scents are very hard to describe, and these butterfly odours are only suggestive of, certainly not identical with, those to which I have, for want of any better standard, compared them. Then the scents are trausicnt and may easily be scattered by the wind or overpowered by neighbouring flowers. Again the scales, independently of any scent, are irritating to the mucous 
membrane, and any one who has tried to use the sense of smell for diagnostic purposes must know how even the most volatile perfume is apt to linger on, lurking as it would appear in the cavernous recesses of the nose. Of course it is much easier to determine in the field whether or no a scent is sexual in the case of those species in which the sexes are distinguishable by very obvious characters. Lastly, it should never be forgotten that in all probability the scents described are far more obvious to the insects themselves than to human observers. ${ }^{1}$

Only a solitary representative of the Euploea group appears among the Toliganj specimens, but its envelope bears the note: "Common, has a slight peculiar scent, rather disagreeable." Most probably I believed this at the time to be the common Calcutta species Crastia core, but it turns out to be Pademma kollari, Feld., and it is now impossible to say what those wcre that I passed over or missed.

In variety the Toliganj butterflies were disappointing, but, besides the above named, they included a very fine female Ixias pyrene, the sole Orange-tip seen at Calcutta; a few Catopsilia pyranthe; several Ergolis ariadne; Elymnias undularis, not common; plenty of that very distinct Blue, Neopithecops zalmora; a single specimen of Loxura atymnus, and plenty of Yphthima hübneri, Y.marshalli, Y.philomela and $N y$ chitona xiphia.

The list is closed by "Melanitis ismene, lover of darkness, as its name seems to say. It flitted about everywhere dressed in all the tints of fallen leaves, or, alighting among them, fell partly on one side and was one of them." ${ }_{2}$ I quote the words of E. H. A(itkin), that keen observer and telling writer. The few specimens that I saw that day were very dark and of the dry-season form. A note made at the time says: "This shade-loving species, which only flies for a very short distance and settles on the ground, has a 'list' to the right of $20-30^{\circ}$, making it very like a dead leaf."

A pretty blue and black parasitic bee, Crocisa histrio, Fabr., was caught feeding on the wing like a Sphinx.

On December 8th, I visited the grand Botanic Gardens at HowraH, but it was too late in the day for many butterflies to be about. Very late in the afternoon, just before lcaving the gardens, I noticed a few Danaicla ploxippus (genutia) fluttering about a Palm-tree prior to settling down for the night. On looking carefully I saw on one of the huge leaf-stalks, some twelve or fourteen feet from the ground, a cluster of the butterflies hanging together like swarning bees. By pelting with sticks and stones the cluster was broken up and proved

\footnotetext{
' See Chapter X., $\$ 1$.
}

"A Naturalist on the Prowl, p. 203. 
to consist of at least seven or cight individuals. Altogether there were perhaps twenty in and about that trec. This certainly estahlishes the fact that D. plexippus is gregarious. Both Mr. S. E. Peal and Mr. F. Möller told me that thcy had ncver scen such a thing. However, somc years aftcrwards I came across a lettcr from Prof. Vernon L. Kellog to Prof. E. B. Poulton, in which he says :-

"The Monarch Butterfly, Anosia plexippus, gathers each winter in thousands in a small forest of Pine trees on Point Pinos peninsula on the bay of Monterey. Sometimes these butterflies will gather in a single tree in great clusters and festoons; other winters they will not be so completely massed, but will be spread over a few acres of forest... our winter here is very mild; there are bright warm days all through it, and these butterflies do not by any means remain immovable during their hibernation." 1 The butterfly here alluded to is the American Danaida archippus, Fabr. (plexippus, Linn.), and is very closely allied to D. plexippus, Linn. (genutia, Cram.) There is no doubt an error in the original record of locality, since Linnaeus' description of plexippus applies to the Oriental insect.

Just outside the garden gates is a populous village through which the road to Calcutta passes. A Calcutta merchant driving a friend home from the gardens one Sunday at night-fall found the bazár as usual crowded with men, women and children, all over the roadway. As ill luck would have it he knocked down and ran over a native. At the time Lord Curzon had been preaching a crusade against ill treatment of natives, and horrible thoughts passed through the driver's mind of leading articles in the native Press. He stopped of course and got out to find a woman who was evidently dead! All his fears were redoubled when a man ran up and said, "Only old woman, Sáhib; my mother, Sáhib." The merchant begnn to pour out his regrets and his willingness to do anything in his power, when to his surprise the native said he would be quite satisfied witl the payment of fifty rupees (abont three guineas). His relief was immense, for he would gladly have paid ten timcs as much to get out of his difficulty, so he said that he was rvilling to give him that sum but that he had not so much money about him; however, if the man would call at ... (a well-known commercial address) at ninc o'clock the ncxt morning he would be paid. Accordingly he drore back to Calcutta with a load off lis mind. On Monday morning, after he had been sitting in his counting-house for some hours, a clerk camc in and said: "By the way, sir, there is a native here who

' Proc, Ent. Soc. Lond., 1904, p. xxiii. 
has been waiting to see you since 6 o'clock." "What on earth does he waut?" "I don't know, sir, but he says he wants to see you himself." "Very well, show him up." Thereupon a native entered, made a low salaam, and presented a "chit" (account):-

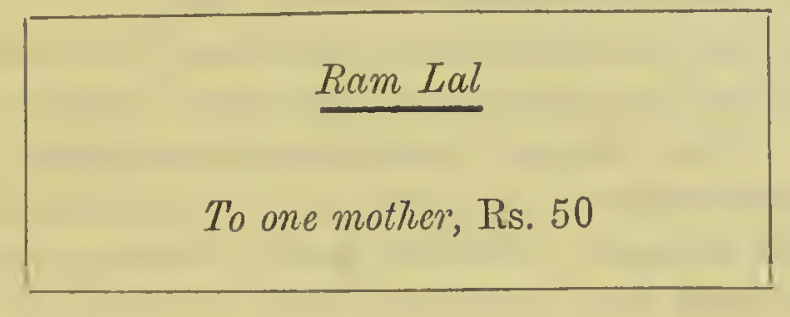

DarJiling, $27^{\circ} \mathrm{N}$, alt. $7000 \mathrm{ft}$.

December 13th-22nd, 1903.

I set off to this celebrated hunting-ground with great misgivings as to season, but still full of wild hopes. The ascent by the cogwheel railway took us through a most interesting forest, where amongst other things we saw our first Tree-fern, as well as the far more beautiful wild Banana (Musa sp.). Near TINDARIA, at about $3000 \mathrm{ft} .$, I saw several Ixias pyrene and succeeded in catching one from the train while it was going at full speed-about seven miles an hour! This was a male of the large form evippe, Drury.

Before reaching KURSEONG, nearly $5000 \mathrm{ft}$., where I had arranged to stop with a view to a little collecting, we got into the clouds, and at our destination it was very cold, with an atmosphere only too like that of the West of Scotland. During a gleam of sunshine I took a Vanessa kashmirensis, a poor dull thing compared to our urticae. At night two moths, an Acidaliid Erythrolophus (S!ynegiodes) hyriarius, Walk., and Caradrina albosignata, Oberth. (thought by Sir G. Hampson to be probably identical with lineosa, Moore), came to light.

The following morning was brighter and we started early to walk up to the next station, Toosk, but though the weather was more benignant, the railway ran through a district devoted to tea-growing which did not promise well for collecting. A few Vancssa kashmirensis, a Pyrameis inclica and a $P$. cardui flew along the road, the latter with both apices of the fore-wings and one hind-wing nenr the anal angle apparently bitten. Near Toong station, $5500 \mathrm{ft}$., in a sheltered and flowery spot I took single specimens of the Hairstreaks Merda epiclcs, Godart, a female, and Camena clcobis, Godart; the latter on the upper surface is like Thecla qucreus, but bluer, on the 
underside almost white with a practically black spot on the anal lobe. Here also I took a male Hiposcritia lalage, Doubl., and a native caught in his fingers a Dodona eugenes, Bates, an Erycinid, and the same man brought me a fine Saturniid moth Loepa nevsarra, Moore, $6 \frac{1}{2}$ inches in expanse, apparently not long dead.

Meanwhile all trace of cloud had disappeared and when the train rounded the last corner our eyes met a sight to take one's breath away. There in grand array stood seven snowy peaks-each over 20,000 ft. in height-and overtopping all the mighty three-peaked Kangchinjanga himself, full four miles above us and seeming to look straight down upon us from the sky, though in reality some 45 miles away. And this was not all, for we could see down into the blue valley at least a mile below the train. A vertical range of 5 miles! We had the great and unwonted good fortune to see both the after-glow of sunset and the fore-glow of sunrise on those majestic snowy heights every day of our stay. There was, however, one phase as strange as it was beautiful, when the horizon appeared to be bounded by a range. of lesser mountains, distant perhaps 30 miles, beyond which there seemed to be unbroken blue sky. Where was Kangchinjanga? Raising the eyes a little its triple peak was seen, floating as it were in mid air, like the Island of Laputa! The explanation I take to be that 20 or 30 miles of atmosphere is enough to make "blue sky," just as sometimes on an apparently clear day the cliffs of Cap Gris-Nez are not visible from Dover. From the top of Tiger Hill one morning we saw the conical top of Everest, 120 miles off, peeping over the intermediate ranges from his commanding height of $29,002 \mathrm{ft}$. (Note the accuracy of the trigonometrical survey of India.) Unfortunately we were prevented from going to Phallút, and so making a somewhat less distant acquaintance with Everest, because the rest-houses were all in the possession of Government agents buying yáks for the Tibetan mission.

Entomologically speaking, our visit to DARJILING was the saddest of disappointments, for it was as cold as England in Norember, and the local entomologists-Messrs. Möller and Lingren-assured me that Kallima was hopelessly over, as indeed were most things. They, and every one we met, spoke of the astonishing multitudes of butterflies in the rainy season; the harder it rained, they said, the more insects there were in the short interludes between the showers.

On the high ground I got little; Vancssa lishmircnsis, Pyramcis indica and cardui, none of them common, also a brilliantly-coloured beetle, a species of Cassina. I saw a school-hoy catch Colias ficlnii 
and a tailed Blue. At Jalaparar, $7500 \mathrm{ft}$., I got a female Huphina nadina, Luc. (remba, Moore).

The only chance was to go down into the valleys, but it takes long to descend, and as the butterflies are for the most part only "at home" from 10 a.m. to 2 p.m., one does not get many hours' collecting; moreover, from those precious hours there are deductions to be made for sunless intervals due to clouds, the shadows of woods, and the still deeper shadows of lofty mountains.

My first expedition, lasting three days on horseback, was to the Tista valley, lying to the east of Darjiling. On December 17th, we went to PAsHok, about 17 miles, sleeping at the Public Works Department rest-house, about $2300 \mathrm{ft}$. above the river, and about $3000 \mathrm{ft}$. above the sea, a delightfully situated lonely bungalow in the woods, where the air was filled with the chirrupping of cicadas, a sound that hugely delighted my daughter's ayah.

When we got down to about $4000 \mathrm{ft}$. above sea-level insects began to be fairly numerous, although it was late in the day for butterflies. Vanessa kashmirensis was common, and with them were several Pyrameis indiea. I secured two of the handsome White Hiposcritia lalage (argyridana, Butl.), both females. Several Neptis astola were seen, mostly worn. At a shady turn of the road I got Lethe rohria, Fabr., an aegeria-like Satyrid butterfly; close by Arrhopala areste, Hew., flashed azure in the sunlight, but a specimen of another beautiful Lycaenid, Spindasis vuleanus, Fabr., was badly battered. Of Zemeros flegyas, Cram., and Abisara fylla, Doubl., I netted one each, and a large bee, Bombus (?) funerarius, Smith, a male, tempted me to catch him.

In the wood in which the rest-house stands Myealesis indistans was in abundance; this is a typical shade-lover; when kicked up from the herbage it flaps about three yards like our Epinephele janira, and then settles on dead leaves or on the earth. Some of them had a slight "list," but this did not seem to be a marked habit, possibly because this position is not so advantageous in shade as in sunlight, though the habit was first noticed in Melanitis, a typical shade-loving genus. The existence of shade-loving butterflies might seem to be correlated to a tropical sun, but even in England Pararge aegeria and Epinephele hyperanthus, still more Leneophasia sinapis, are what I should term partial shade-lovers.

In the same wood, also in the shade, Terias laeta and $T$. heeabe were both plentiful, and in sunnier glades the common Indian Blue, Lampicles eeleno, was both abundant and gregarious. In a young Cinchona plantation close by I found Ganoris eanidia; a Blue, 
Cyaniris puspa, Horsf.; and a very large handsome Skipper, Celuenorrhinus lencocera, Koll. In the rest-house there was a dead Pyrale, Lepyrodes geometralis, Guen.

The next day, December 18th, I sent my pony on ahcad, and walked down to the river collecting on the way. In the Cinchona plantation close to the rest-house I found Zemoros fleyyas; lower down were Euthalia appiades, Ménét., of which I saw several worn specimens; a Hairstreak, Arrhopala bazclus, Hew., like a glorified Thecla quercus; Lethe verma, Koll.; and Melanitis ismene, the last as usual in the shade.

A path leading off through the wood brought me to a tea-garden, perhaps $1500 \mathrm{ft}$. above sea-level, where I lingered all too long. Tea-gardens are not as a rule good places for butterflies, and the pretty flower of the Tea-plant, then just coming out, does not appear to have great attractions for them, but this particular garden, just at the edge of the forest, and especially that corner of it where a little stream runs in, was certainly very prolific.

Athyma ranga, Moore, was in abundance, though worn; likewise its relatives of the genus Neptis, but the three specimens that I sent home belonged to as many so-called species: $N$. aceris, Cram., $N$. astola, and $N$. varmona, Moore; the closely allied, but brown and black, Symbrenthia lucina, Cram. (hippoclus, de Nicév.), was almost as common among the Tea-bushes. Of the satin-winged Hiposcritia indra, Moore, I took two females. Of the following I got single examples only:-Caduga melanerus, Cram., and Parantica melanoides, Moore, two very similar black and white Danaines; Athyma selcnophora, Koll.; Yphthima philomela ; Arrhopala centaurus, Fabr.; and Castalius anaura, de Nicév., a female, while another Blue, Lampides elpis, Godart, pale and beautifully sheeny, was common. I also nissed what was, I believe, Libythea rama, Moore. There were in addition two moths, an Arctiid, Lcucoma submarginata, Walk., and a Hypsid, the fuscous and white Zonosoma eenis, Cram. (interlectum, Walk.), the former possibly, the latter certainly, a day-flycr. The great number of fresh species showed that I had cutcred a distinct geographical sub-region.

At last I dragged myself away and an hour later reached a most attractive flowcry bank immediately above the river. This was evidently a great place, for in a very short time I sccured two sadly battered Papitio momnon, Linn., of the form agenor, Linn.; a large male Ixias pyrenc with the fore-wings almost symmetrically bitten near the tip of the costa; also an insect that I had greatly desired to take, the lovely and delicatc-looking Map-butterfly, Cyrestis 
thyodamas, Boisd., in splendid eondition. This, a Nymphalid, by the posscssion of a well-marked anal lobe to the hind-wing suggested the Rapala group of Lyeaenids, but a close examination of the veins shows that neither lobe nor tail is homologous in the two widcly separated genera. In addition to the above a sccond Caduga tytia, Gray, was secured, the first having been netted $1000 \mathrm{ft}$. higher. This blue and black Danaine is distinguished by having brown hind-wings. Time was, however, getting on, and my sais was waiting with the pony by the little bridge, so I reluetantly mounted. I had not riddcu far when I caught a glimpse of Kallima inachis, Boisd., flying by the roadside ; flinging myself out of the saddle I was fortunate in netting the butterfly of all othcrs that I had wished to see alive. It proved to be a fine female; to wait to see in what attitude she would settle would have involved too great a risk, and alas! no more were seen. A few minutes later my sais brought me a damaged Enploed with a lovely purple gloss; seeing many about (in spite of my unele's adviee ${ }^{1}$ ) I foolishly did not keep it.

These things happened close to the Tísta bridge, by whieh the road to Lhasa crosses the river, here only some $650 \mathrm{ft}$. above the sea, so deeply are these Himalayan valleys cut down. Sad to say in a few minutes the winding of the road took me under the deep ehill shadow of the mountain and the purple-glossed Euplocac and nearly all the other butterflies vanished for that day. A solitary Neptis aceris, together with a few Ixias pyrcne, Huphina nerissa and Lampides clpis, were all that I saw; with them was a Hypsid day-flying moth, Trypheromera plagifera, Walk.

The rest-house at RIANG was reaehed too late for any more eollecting, so I had to eontent myself with watehing the long trains of Colonel Younghusband's bulloeks painfully dragging wagon-loads of eompressed hay for the Tibetan expedition. Alas! for the onee fair road, now a foot deep in white dust.

December 19th. It was such a long march from Riang by way of Mongpu and Sareil baek to Darjiling that little time could be given to eollecting, moreover many hours werc spent passing along a beautiful forest track in the deep afternoon shadow of the mountain. At the start, elose to the river, the silvery-whitc Aeropteris vagata, Moore, the only Uraniid that I eame across, was eouspicuously spread out upon a leaf. Near MongPu, at about $3000 \mathrm{ft}$., Ergolis merione was very common about the Castor-oil plant, Ricinus communis, upou which its larva feeds. A little higher up I came across Iiehcrra actc, Moorc, a Lyeaenid with very loug tails that wave with the wind;

\footnotetext{
1 Seo above, p. 5.
} 
it has a swift jerky flight. 'The hind-wing of this species is much plaited, but the anal lobe is rudimentary.

Other captures were Huphina nerissa, a male; Ganoris canidia, a female with all the hind margin of the hind-wing gonc; Tachyris hippo, Cram., a male; Arrhopala rama, Koll.; Neptis astola; Ilerda, epicles, with all the hinder part of the hind-wing apparently bitten off by a lizard; Cirrhochroa aoris, Doubl., whieh I had seen at Pashók on the previous day; Lethe rohria, very like Pararge aegeria in its habits and liking for shade; and Argynnis hyperbius, this last in the Cinehona plantation at about $3600 \mathrm{ft}$. A large white butterfly, bright yellow underneath, fluttering at the sweet white flower of the Cinehona, led me to dismount, and it was well that I did so, for it turned out to be Prioneris thestylis, Doubl, and fortunately a female; this must be very much the less common sex, at any rate the Hope Colleetion contained no female of the genus.

All the afternoon was spent in a somewhat weary ride along a very bad traek through the forest. Many of the trees were immense, and up their huge boles erawled large-leaved crecpers such as I had never set eyes upon before. It was chill and dark with scarce a butterfly to be seen, but I eaught sight of a mammal which I took to be a Civet Cat.

The next day, Deeember 20th, I rode down to the Ranjit River, the boundary of Sikkim, the great Papilio country. Unfortunately the distance to be traversed redueed my actual collecting to less than four hours.

At about $3000 \mathrm{ft}$. I took two of the Eryeinid Zeneros flegyas, also Symbrcnthia lucina. The chief colleeting-ground was near the suspension bridge leading into Independent Sikkim, closed this year (1903) to all Europeans, including entomologists, on account of the Tibetan difficulty. It was trying to a European temper to be stopped by a coloured policeman, while natives passed freely over.

Here, some $800 \mathrm{ft}$. above the sea, the first thing that I happened upon was Danaida chrysippus in extreme abundance in a very limited loeality, it was in fact decidedly gregarious. By the way; pinching and eyanide are both but very imperfeet ways of slaying thesc toughskinned Danaines.

Elymnias undularis, both sexes, was eommon, but I did not sec any $D$. plexippus for its female to mimic; although the under-side of this butterfly is leaf-like, it is, as a fact, usually conspicuous when settled. I caught distant glimpses of two Papilios and missed my first Hcbomoia, in faet the things that I missed that day would hare mado quitc a good eollection. 
The following were all common: Huphina nadince and H. nerissa, both males; Ixias pyrene, large; Neptis aceris; Precis iphita, spreading itself out like a Eupithceia when settled; Symbrenthia lucina, and Lampides celeno, while Terias hecabe was both abundant and large.

Other things taken were Yphthima marshalli, Butl., and Or'sotriaena mcda, Fabr. (mueka, Moore), a very dull butterfly. In marked contrast was Jamides bochus, Cram., the male iridescent dark-blue above, quite gem-like, beneath dull grey with a metallic ocellus at the anal angle of the hind-wing; the female is comparatively dull in colour.

That day for some reason I missed a larger proportion of the good things than usual, but managed to catch the following:Prioneris thestylis, a male; Cirrhochroa aoris, looking on the wing like a big Argynnis, but settling with wings half-expanded, several seen, but only one netted; a Charaxes (Eulepis) athamas, Drury, taken on a flower, was the only individual of the genus that I got in all my travels. Another specimen of this very distinct and beautiful species was seen feeding upon human ordure. Fear of fouling my net prevented me from striking down upon it, and it suddenly darted up, went twice round with a swift jerky flight and then disappeared. Mr. Möller had indeed told me that Charaxes was a very foul feeder.

The elegant day-flying Moth Trypheromera plagifera must be added to my list, as well as the little Geometer Psilocambogia memorata, Walk., which I found dead, caught and set out upon a burr of some Composite flower; lastly a Beetle, Mimcla horsfieldi, Hope, of brilliant green with coppery tinge.

The extraordinary abundance of Dragon-flies of many kinds at the Ranjit River was remarkable, yet I did not once see a butterfiy attacked by any of them.

I left Darjiling on December 22nd, with much regret, and a strong desire to return at a better time of the year. On the way down, at about $4000 \mathrm{ft}$., Ixias pyrene was common, while close to Tindaria station, at about $2900 \mathrm{ft}$., I netted from the train Cyanir is dilectus, Moore, a pale Blue with a whitish patch on each wing, as well as another Blue, C.ladon, Cram., f. pseudargiolus, Boisd., and an Acidaliid, Idaea remotata, Guen.

At Tindaris I left the train and walked down to Sukna. The following things were met with: (1) At altitudes of from $2800 \mathrm{ft}$. to $2000 \mathrm{ft}$.:-The Erycinid, Zemcros flegyas, almost abundant, but rather worn; Mycalesis indistans; Prceis lemonias, a small specimen in fine condition, also large ones worn (this and $P$. iphita were the 
only species of the genus captured in the Darjiling district); single examples of Ncptis accris, $N$. astola and $N$. varmona; Symbrenthia lucina, common; Lampidcs celcno form alcxis, also common; Ganoris canidia, a femalc; Huphina nadina, a malc, about $3000 \mathrm{ft} . ; H$. ncrissa, a male, about $2500 \mathrm{ft}$.; Tachyris hippo, a very finc femalc; Tcrias hccabe, abundant, two males, one of them dwarfed, were of the variety without the "dog's head."

(2) At altitudes of $2000 \mathrm{ft}$. to $1500 \mathrm{ft}$.:-Here I took Catopsilia, myranthe, a male; Yphthima marshalli, two; Huphina nerissa, worn males, common; Precis lemonias, several; Tcrias libythea, common; and the Blue, Zizcra otis.

At about 3.30 p.m., I watched a fine specimen of Papilio aristolochiac flying very slowly about herbage, apparently seeking for a resting-place for the night, just as $I$ had seen $P$. pammon doing at Kháirna on November 18th; near the same place I missed two specimens of a black and white Danaine.

(3) A little way above Sukna, perhaps at about $700 \mathrm{ft}$. above sea-level, Orsotriacna meda was in the greatest abundance in a deeplyshaded wood; this typical shade-lover is sluggish, yet it was on the move later than most things (for it was just before sundown), but when kicked up from ferns or other low herbage it did not fly morc than two or three yards. It varies greatly in the pale streak on the under-side, which may be white and very conspicuous or almost obsolete; this is quite independent of season, for my specimens were all distinctly "dry." One specimen exhibits a well-marked bite out of the hind margin of both hind-wings above the anal angle, the injuries on both sides corresponding closely.

It was dark when I reached Sukna station, $500 \mathrm{ft}$. abovc sea-level, and fireflies, Luciola sp., were flitting about on all sides. A flare, lighted just before the arrival of the train, attracted many moths, of which I secured a large sharp-winged transparcnt Pyralc, Cydalima conchylalis, Guen.; and the wide-ranging Noctua, Prodcnia littoralis Boisd. In the train, immediately after starting I bottled a malc winged ant, Dorylus juvenculus, Shuck., one of the most strange-looking inscets that I have met with.

Thus closed my short Darjiling campaign, and leaving behind with much regret the Buddhist priests and their praycr-whecls, the cheery but dirty Lcpchas and Bhutias, with thcir turquoisc-bcdecked women folk, and above all the awc-inspiring Himálaya, we steamed away into the darkness over the monotonous plain of Bengal. 
BuNKáPúr, lat. $25^{\circ} 30^{\prime} \mathrm{N}$, alt. cir'ca $250 \mathrm{ft}$.

December 22nd, 1903-January 3rd, 1904.

In absolute contrast to Darjiling, BANKáPúR, the civil station of the great city of Patna, is situated on the level, monotonous, and highly-cultivated plain of the Ganges, affording little harbour for butterflies, so that a fortnight's stay with old friends at the hospitable par'sonage yielded small entomological results.

In spite of these unpromising surroundings, Danaida chrysippus was common, and in company with it Hypolimnas misippus, of which I saw several males and secured one female, the latter such a close mimic of chrysippus that even the small white spots on the thorax and head are reproduced.

Of Tirumala limniace I saw a solitary example, of Crastia core, two; but the other very common Danaine, Danaida plexippus, was abundant in a mango orchard, and distinctly gregarious in its habits. It has rather an unpleasant scent, but whether or no it is confined to one sex I unfortunately did not notice.

The Satyrids were represented by a solitary Mycalesis perserus; the Swallow-tails by Papilio pammon, worn, P. aristolochice, and P. demoleus, the last a specially flower-loving species. Prccis was represented by four species: almana, one of them with large pieces, in part corresponding, bitten out of each hind-wing; oenone, one; lemonias, several; and orithyia, several, the latter all small. Single specimens of the common and generally distributed Atella phalantha and Ergolis morione were seen in gardens. A fine Limonitis procis was taken sipping toddy from a palm; the first shot missed him, but he foolishly returned to his fatal liquor.

Of Catopsilia pyranthe I took two malcs and a female. One of the former when held fluttering beneath my nostrils gave out a strong scent that instantly brought greenhouses to my mind, then my own greenhouse, then Polianthes tubcrosa (barbarously termed by nurserymen "Tuber Rose"), and lastly Jasmine. I do not think that I ever smelt so distinct a scent in a butterfly, always excepting the male of Ganoris napi. The other male pyranthe I held under my nose while I stroked the "feather-tufts" of the hind-wing; this at once elicited the odour of jasmine, further confirming the observation of Wood-Mason.

Two males of Huphina ncrissa bear the following notcs: "Sccnted, not like napi, more like rapac;" and "this specimen had a scent like $P$. rapac, i.c. of the sweet-briar type." Again a fomale of Dclias 
"ucharis (which was common) bears the note, "has a scent much like rapae," and the spccimen appear's to have becn wilfully rubbed. My observations on butterflies in England show that in some cases femalcs have a scent, but not like, or as strong as the males. My strong impression is that the male of $D$. eucharis has the rapae, or sweet-briar scent.

The three species of Terias, viz. hecabe, libythea, and laeta, were all common; one of the laeta appeared to have been bitten by a bird.

Nychitona xiphia was not uncommon, and several Ixias marianne were seen. Chilades varunana (according to de Nicéville the wetseason form of $C$. laius) was common about irrigated flower-beds, indeed Blues are wonderfully fond of water. The only butterfly seen at Bankápúr that was at all out of the common, besides Limenitis procris, was the large grey Lycaenid Virachola isocrates, Fabr., of which I took one at flowers in the Commissioner's garden. I noted that its hind-wings were much folded posterior to the tails, the convexities of the folds being towards the upper surface. These foldings of the wings are not well seen in set specimens.

Although Bankápúr is far from being a good locality, it will give some idea of the abundance of butterflies in India when I say that in mid-winter, December 24th, I took in a suburban garden within three-quarters of an hour no less than ten species, some of them represented by numerous individuals.

BUDDha GáYA, lat. $24^{\circ} 42^{\prime}$ N., alt. circa 500 ft.

December 30th and 31st, 1903.

Though the revived cult of Buddha has no attractions for me, it was impossible not to be stirred at visiting another of the places especially consecrated to his memory.

The temple marks the spot where Gautama sat in meditation under the Pípal, or Bo-tree, until he became Buddha, the Enlightened One, something like 2500 years ago. The present Bo-tree (Ficus religiosa) does not appear to be very old, but that at Anuradhapúra, in Ceylon, which is stated to have been a slip of the original tree, is very much older. Some portions of the stone "rail" placed round the tree by the Emperor Asoka, about 250 B.c., still remain. The low reliefs carved thcrcon arc very Greok in charncter (like most of the early Buddhist sculptures of Northern India), and the Hindu guide showed us what appcared to be a representation of Apollo with four horses driving the Sun. This guide, a babu of the Public 
Works Department, kindly patronized Christianity, Buddhism and Brahnanism alike, and displayed his superiority to all three religions by quoting Auguste Comte and Herbert Spcucer.

The vicinity of the shrine and its sacred Bo-tree was by no means productive, but the next day, on a steep hill of red trap rock, overlooking the town, I saw for the first time the Acraeine Telehinia violae, Fabr., on the wing it reminded me of Argynnis cuphrosync; it was locally abundant and gregarious, its tone of colouring harmonizing with the red igneous rock. On the same hill were two or three Precis oenone and several small $P$. orithyia, while Zizerce otis was abundant.

In the course of this walk I noticed a Fakir, or religious mendicant ascetic, watching my operations with evident suspicion, probably owing to the reverence in which some of these folk hold all animal life. Presently a small native boy threw a stone at a squirrcl. I thought better of the Fakir when he cursed the boy so fiercely that he fled in terror as fast as the squirrel, while I rolled up my umbrella-net and passed on, trying to elude observatiou!

Mozuffarpúr, lat. $28^{\circ} 8^{\prime} \mathrm{N}$., alt. cirea $300 \mathrm{ft}$.

On a flying visit, January 2nd, 1904, to this place, nearly north of Bankípúr, I took in the Judge's garden two Zizera otis, and one 2. maha. It was at the gate of this very compound that a few years afterwards a bomb, intended for my host's successor, killed two ladies.

JHÁNSI, lat. $25^{\circ} 30^{\prime}$ N., alt. circa 750 ft.

January 5th-13th, also 21st, 1904.

Situated on a sandy plain, broken by precipitous ridges of igueons rock, JHínsi, something like $750 \mathrm{ft}$. above the sea, is characterized by dryness, heat, and sparseness of cover.

As in other Indian stations the Kite and the Vulture are most important officials of the Sanitary Department. More friendly arc the chattering black Máinas in every gnrden; bnt, after all, the characteristic bird of India is the grey-headed Crow, which, always consequential, hops solemnly about as if everything in city and country alike belonged to him, and he was responsible for it.

Among the butterflies a couple of Papilio uristolochiae taken at flowers near the lake were the sole representatives of their family. Several Belenois mesentinc werc captured, but it was scarcely common; the male harl a distinct, but faint, sweet scent; on the 
ridge of Retribution Hill (where Sir Hugh Rose in 1858 slew 2000) mutineers), I took a female $B$. mescntina in which the hind-margins of the hind-wings had been symmetrically broken off, probably by the bite of a lizard. Of three specimens of Trias hecube, one, a small female, was of the variety without the "dog's head" notch. Of T. libythca a single specimen was taken, but T. laetce was plentiful and of gregarious habits. Teracolus ctricla was loeally rather comrnon, especially the female. On the other hand, the male of Ixius murianne was rather eommon.

Two Atclla phalantha were taken; the only Precis noted was orithyia, and that very dwarfed, one individual measuring only 1.4 inches across the wings.

I'clchinia violac was abundant at the foot of Retribution Hill, and scattered specimens occurred elsewhere. This insect, like the Danaines, has a tough skin whieh enables it to resist pinehing, and doubtless makes it indigestible. When injured a yellow juice exudes; a minute drop of this placed on the tongue tasted somewhat bitter and disagreeable, but the flavour was by no means strong.

The Jhánsi Lycaenids were fairly numerous, but not very brilliant, the most remarkable was Chiladcs putli, for it is actually smaller and darker than our alsus; other species were $C$. lainu, whieh appears to have been eommon, but of whieh I unfortunately took but one specimen, and Catochrysops contracta, Butl., of which I took two; T'arucus theophrastus was eommon, the two sexes are, on the upper surfaee at least, very different, and $T$. tclicanus was also noted as common, though I secured only one of each sex. Blues are very abundant in India, but they are very much alike, so that being ignorant of the distinctions between allied species, one was but too apt to negleet them while in the eager pursuit of larger game. For these reasons too much weight should not be attached to the observation that such and sueh a speeies was common or abundant, but the qualification, "or something superficially like it," should be added.

Two moths came to light, the Agrotid Euxoa spinifora, Hiibn., and the Macaria-like Scmiothisa frugaliata, Guen. Besides these I took a brown beetle, Bolboccras quadvidens, Fabr.

After prolonged drought there was a heavy rainstorm at Jhánsi, on January 14th, and there was slight rain at Gwílior on the 16th and 17 th. With the exception of a very few days with elouds and oeeasionally a few drops of rain, there had been almost uninterrupted sunshine for three months, i.c. sinee Oetober Sth. On January 20th, writing to Dr. Dixey, I said, "There has been a very cold 'wave' in 
Northern India with a few showers of rain, but scarcely enough of the latter to aftect either vegetation or insects." On January 23rd there was gentle rain at Jhánsi lasting several hours.

At Gwálior, on January 15th, an untoward circumstance was near bringing the author to an untimely end. The splcndid resthouse erected by the hospitable Máharájah Scindia for the accommodation of European visitors was full, but His Highness soon set up and placed at our disposal one of his own luxurious tents which had been made for the Delhi Durbar. Moreover, we went for a drive round the foot of the rock on which the fortress stands, in a carriage from His Highness's stables, a Victoria drawn by a pair of sturdy transport horses. This carriage had no brake, the military harness no breeching. At one place a very steep road was carried on a low embankment; at the critical point one of the horses refused to pull back, the carriagc "took charge" and, after a swerve or two, went over, and we were all pitched out on to a stony bank the other side of the deep ditch-the Victoria across my back!

All, myself included, thought my last moment was at hand: a dull aching suggested a severe internal injury. We had fancied that we were in a lonely spot, but, as always happens in India, coolies seemed to spring up from the ground, and they lifted the burden from my shoulders. A polite Hindu, a pleader of the High Court, came up and said: "By the mcrey of God, you are not killed!" This gentleman most kindly sent for a pálki, or palanquin, that he knew of, and despatched other messengers for the Civil Surgeon, who lived some miles away. I was carried back to my tent to await the amival of Capt. Battye, I.M.S., an old acquaintance, as it turned out, for $I$ had acted as his dresser in a tobogganing accident at Grindelwald some years before. This surgeon, and subsequently two others, failed to find any broken bone, a fact that spoke well for my scapulae, since the other party to the impact-the Victoria-suffcred from a comminuted fracture. One of the horses had been injured; the Máharajah, in true Oriental fashion, sent the driver to prison!

So it befell that I was denied the undoubted dignity, but questionable joy, of visiting, on the back of onc of the Máharájah's elcphants, the intcrior of the historic stronghold. As I wrote home at the time: "Imagine an island exactly half the length of Lundy, and nearly its height, rising shecr from the dusty plain; along the top of its beetling cliffs a vast wall, nowhere less than 30 fect high, often morc, its monotony broken by bold round bastions; carve on the cliffs colossal statucs, scatter at intervals palaccs, tombs, and tcmples of the threc great $\Lambda$ siatic faiths, and-you have Gwálior." 
Strong as it unquestionably is, it has been captured six timesthrice by us. In 1886 it was ceded to Scindia, a I'rince always loyal to us, in exchange for Jhánsi, a fort requiring fewer men to hold, and occupying a strategic position of great importance at a railway junction.

During my convalescence I greatly appreciated the skill of my native servant as a mosseur.

By January 21st, though still suffering, I was just equal to another day's collecting at Jhánsi, but the species taken were not such as to show any change of type due to rain, cven if such change had been possible. The insects met with were $B$. mcsentina, $I$. marianne, T. etrida, A. phalantha, and T. theophrastus.

\section{ORCHHA.}

On January 9 th we visited this fine deserted city, some eight miles to the east of Jhánsi; it was once the capital of the native state of Orchha, and its bridge and castle are among the finest in India. During an hour's collecting I took or saw Danaida plexippus, Precis lemonicus, $P$. oenone, and $P$. orithyia (this last in abundance); Atella phalantha, an Ixias, Teracolus etrida, a Terias, and several female Belenois mescntina. Monkeys were almost as common as butterflies among the ruined tombs.

\section{BARWA SÁGAR.}

On January 14th, I got a couple of hours' unproductive collecting in the neighbourhood of the interesting and romantically-situated old castle of this name, which lies some twelve miles to the east of Jhánsi. BARWA SÁGAR, like Orchha, is somewhat off the ordinary route of globe-trotter's. The castle stands high, and is approached by a winding road between fine old trees that strangely recalled an English park. We were put up in what had been in the good old days the Zenana, now tumed into a Dák bungalow. The whole place suggested rest, and the look-ont over the pretty lake with its countless thousands of Cormorants was a pleasant change after dusty Jhánsi.

Here I observed in two specimens of Danaida chrysippus (of which certainly one was a male) a distinct cockroach-like odour, sufficicntly strong to be perceptible when the insect was fluttering in the net. Of Catopsilia pyranthe I took a female of the gnome form; of Tcrias hecabe a male, the variety withont the "dog's head" mark; 
T. lacta was quite abundant. Two specimens of Huphina nerissa wcre taken, one worn, the other a dwarf. The male of Belenois mesentina was common; in two specimens I detected a sweet scent like that of $P$. rapae, but more or less faint. A Polyommatus baetieus completes the list.

AGRA, lat. $27^{\circ} \mathrm{N}$., alt. $550 \mathrm{ft.}$

Janunry 25th and 26th, 1904.

The sight-seeing centre of India afforded neither time nor place for entomological research, and the few butterflies noted were of the most familiar Indian forms. While at AGRA one lived in imagination with Akbar and Shah Jehan, and tried to imagine the charms of the fair lady who, one of many, the "Chosen of the Palace," inspired her husband to erect over her mortal remains by far the most beautiful tomb that has ever been built. Surely the Táj Mahál is an enduring proof that true love is compatible with polygamy. In discussing the beauty of the Táj two things are needful. In the first place the monument must be considered as a whole, with its walls and mighty gateway, its garden, its pavilions and mosques, as well as the tomb itself.

Secondly, to an Englishman who from his youth up has associated white marble with vulgar mantelpieces, and still more vulgar tombstones, it takes time, repeated visits in the morning, at sunset, and by moonlight, before he grasps what a lovely material white marble really is, and what a glorious result it may produce when, as at Agra, Italian beauty of detail is grafted upon Moghal grandeur of conception. In short, disappointing at first, the beauty of the Trij grows upon the visitor till it becomes almost overpowering.

Parts of the great fort are as beautiful as the Táj, "but," as the guide said to the writer, "your honour is experienced old man, you know everything."

\section{Fathipur Sikri.}

January 28th and 29th, 1904.

The reign of Akbar the Great practically coincided with that of our Elizabeth. During his long reign he conccived and carried out the idea of this wonderful city, but almost as soon as it was built he abandoned it, as the water supply was defcctive. Conscquently it romains to this day, as it were, a vast red-sandstono fossil city, the Pompeii of India. Akbar was the most tolerant of sovereigns, his 
wives-Christian and Hindu as well as Moslem-were allowed freedon of worship, and he even built temples for them. His tolerance is shown to this day by his architecture, a strange but beatifiul mixture of Hindu with Mohammedan. Incidentally it affords evidenee that in India, as in Japan, the art of the earpenter preceded that of the mason, whereas in Europe the reverse was the case. In Akbar's great tomb near Agra the general design is obviously based on timber eonstruetion, while at FATHIPÚR SIKRI some of the most beautiful of the smaller buildings, entirely constructed of the eelebrated sandstone of the place, exhibit undoubted imitation of wood construction in the eaves, while the stone slabs covering the roofs are carved so as to resemble tiles.

Here I found, most appropriately, that those ruin-frequenting butterflies, Belenois mosentina and Teracolus etrida, were both common, but all appeared to be males. The Belenois had a faint, sweet, flowery scent, which did not appear to me to be quite like that of any other inseet. I took also one Teracolus puellaris, a female, and a most feroeious wasp, Eumencs dimidiatipcnnis, Sauss., a female.

There were no Monkeys among the ruins, but I saw a Hare. Countless Doves eoo-ed continually, and from time to time a Jay was seen, brilliantly eoloured in two shades of blue, like a pieee of Múltán pottery.

I asked the earetaker of Akbar's tomb what was the purpose of a certain pavilion, and he answered, "Band-stand, music-hall, tomtoms!"

AJMIr, lat. $26^{\circ} 30^{\prime} \mathrm{N}$, alt. circa $1800 \mathrm{ft}$.

February 4 th and 5 th, 1904.

The erowds in the streets of AJMIR and JúTPÚR, the only eities of Rájpútána that I visited, afforded a wonderful display of colour, such as I did not see elsewhere.

The most notable capture here was Tcracolus fausta, Oliv., of which I only got one male, a poor specimen, missing two others; it has a very distinet orange look on the wing, and I feel sure that I saw one on January 22nd at Pálipahári, the artillery praetice-camp near Jhánsi. Of $T$. ctrida I took two males, one of whieh had lost the apex of the left fore-wing and all its hind-margin, as well as the apex of the left hind-wing. This is notable as possibly being an attack on a "direction mark."

I saw several battered Precis oenonc. The smaller fry were 
represented by a neat little chequered Skipper, Hesperia galba, Fabr. The emerald-like Stilbum splendidum, Fabr., turned up both here and at Jacipure, and did its best to gratify the Rájpúts' love of brilliant colour, for the little Cuckoo-wasp is as brilliant, though of course not so effective, as the numerous wild Peacocks that sat in twos and threes upon the railway fences.

On Táragarh, the precipitous hill that overtops the city by perhaps $500 \mathrm{ft}$., I got only Belenois mesentina, Terias laeta, and a long-waisted female wasp, Eumones dimidiatipennis.

\section{MT. ABu, lat. $24^{\circ} 30^{\prime} \mathrm{N}$., alt. of civil and military station circa $4100 \mathrm{ft}$.}

February 6th-8th, 1904.

Insects were extremely scarce upon the sacred Jaina mountain. The commonest butterfly was Terias laeta; it was abundant up to $4500 \mathrm{ft}$., and the only representative of the genus seen. These, together with Belenois mesentina, Huphina nerissa, a few Precis lemonicus, and a couple of tages-like Skippers (which I missed upon rocks at about $4400 \mathrm{ft}$.), were the only butterflies that $\mathrm{I}$ saw on the elevated plateau. One moth, the very widely-distributed Crambus, Eromene ocellecc, Haw., came to light.

At lower elevations, on the fine road up from the plain, tho following were met with: at about $3000 \mathrm{ft}$., Belenois mesentina, Tarucus telicanus, and Polyommatus baeticus, the last as usual in poor condition. From $3500 \mathrm{ft}$. down to $2500 \mathrm{ft}$. a few Yphthima inica, Hew., were seen, and at about the last-named elevation, among the rocks of a nearly dry water-course, I saw two specimens of the beautiful Nymphalid, Symphaedra thyclia, Fabr., but only secured one; unfortunately time was pressing, or I might probably have taken more; it has the habits of a Vanessa.

The temple of Vimála Sah, built wholly of white marble which must have been transported 300 miles, and then carried $4000 \mathrm{ft}$. up the granite mountain, is a marvel of beautiful work. Its spccial characteristic is the delicately wrought pendant under the dome, built, mind you, in the cleventh century, anticipating our Gothic builders' efforts in the same direction by close upon five ccnturies. The hundreds of figures of Buddha, all exactly alike, show low far a religion can depart from the ideas of its foundcr. 
Bомвау, lat. $19^{\circ} \mathrm{N}$, near sea-lcvel.

February 10th, 1904.

In an hour's visit to the Victoria Gardens, where insects werc fairly numerous, I got Papilio demoleus, P. aristolochice, Noptis varmona, and Nepheronia hippia, a female, the last-named mimicking Tivumala.

On February 15th I was much interested in watching the movements of a solitary butterfly in the small public garden of the University, in the heart of the city. It appeared to be a large Catopsitia, possibly the catilla form of pomona, but at any rate of a general greenish-yellow colour; when disturbed it invariably settled in one or other of several small shrubs with yellow leaves, when it would vanish quite suddenly. It was only after several attempts that I succeeded in getting a glimpse of it when settled, so strong was the protective resemblance. ${ }^{1}$

BIJÁPÚR, lat. $17^{\circ}$ N., alt. cirea $1500 \mathrm{ft}$.

February 16th and 17th, 1904.

This was further south than I had yet collected, but the scanty vegetation among the ruins seemed too parched to yield very much. The most prevalent genera here, as at so many places where thor'us, burrs, rocks, and ruins predominated, were Belenois and Teracolus, the last a genus which, though beautiful in the cabinet, is not effective on the wing.

Teracolus etrida was abundant, the males appearing to be about twice as numerous as the females; they varied greatly in size, so much so that among the males the largest had nearly double the alar expansion of the smallest. Of $T$. duleis, Butl., I took one female, and of $T$. amatus, Fabr., var. modestus, Butl., two males.

The only Terias seen was lacta. Belenois mesentina was abuudant; a slight sweet scent was detected in one specimen.

Catochrysops strabo was common, also Polyommatus bacticus, one specimen having lost two-thirds of each hind-wing, presumably the work of some enemy; of Zizera karsandra, I took onc.

At night scveral moths camc to light, viz., Lymantria incerta, Walk. (Enome detersa, Walk.), the Geometcrs, Tephrina disputaria,

1 In April, 1908, I walked through this sanc garden and watched $\Omega$ Catopsilia. settle twice, each time on a yellowish lcaf, apparently sclecting the jellowest available. 
Gruen., and Idcea (?) fibulata Guen. (worn), and the very widely-distributed Fitiella zinckencllct, Treit.

A feroeious-looking Araehnid, a Solpuga, shared the Dák Bungalow with us.

Among the many marvels of BIJÁṔ̛r are the monster cannon : one of these "The Lord of the Battle Plain," east during the reign of our Elizabeth, has a calibre of 2 feet 4 inches. It was a curious proof of the superstitious reverenee which the natives show to anything big, that grains of rice inside the gun gave evilence of recent púja (worship) offered to it.

Another gun, of 12-inch ealibre, I take it of mueh later date, was a forerunner of our "wire" guns, being built up of longitudinal iron bars, round which other bars were spirally wound and the whole forged together. A smaller gun of similar strueture in the fort at Jhánsi defied the efforts of our sappers to destroy it.

ANANTḰ́PÚR, lat. $14^{\circ} 30^{\prime}$ N., alt. circa $1500 \mathrm{ft}$.

February 18th-23rd, 1904.

This small civil station, situated on an irrigated though elevated plain devoted to the growing of cotton and riee, is typical of Southern India.

A very hot walk to some small granite hills on the other side of the lake produced little beside two males of Ixias mariannc, and a solitary Teracolus eucharis; the hills seemed actually too hot, dry, and parched to harbour butterflies.

About the trees along the dam, or "bándh," were a few Hypolimnas misippus, males, and abundance of Papilio aristolochiae.

In the eotton fields by the river Byblic (Hypanis) ilithyia, Drury, was to be got, but not plentifully.

The best eollecting-ground was a very weedy nursery-garden and orehard. Here I one day had the advantage of the assistance of my host, Mr. Edwin Seott, I.C.S., whose keen appreciation of scents helped me greatly. Danaida chrysippus was abundant; of its seent Mr. Seott's first impression was "some sort of dung," then "a zoo"; later he said "possibly like a coekroach, but more like a musk-rat." The scent is, I think, general, but is perhaps stronger when the sacs on the hind-wings are opened: a faet that I also observed at Calcutta.

Crastia corc was common and gregarious, frequenting a special Mango-trec. When he sunlt this inseet Mr. Seott at onee cried out 
"acetylene," adding that he would like to put a lighted saatch to it to see whether it would burn! Subsequent observations on the butterfly and the gas eonvinced me of the accuracy of his comparison. The genital organs appear to exude the scent, probably the longr tufts appended to them. ${ }^{1}$

At this place I confirmed in two specimens of C'atopsitia pyranths, the jasmine odour eounected with the "scent tufts" of the male, but did not find it as strong as in specimens of the same species examined at Bankápúr six weeks before. Mr. Scott agreed to the comparison with jasmine, but thought the scent was perhaps even more like that of Polianthes tuberosa.

I also examined two males of Tirumala limniace for scent, but was unablc to elicit any from the prominent sacs on the under-side of the hind-wings, although I suspected some to be emitted by the genital tufts.

Pupilio demoleus was frequently met with, and $P$. aristolochiae was common, but I only took a single $P$. pammon. Although the male of Hypolimnas misippus was fairly common, I saw only one worn female; this was of the very marked variety inaria, Cram., in which the white marks near the apex of the fore-wing are entirely wanting, and the black tip is reduced to a narrow border, so that it closely mimics D. chrysippus, var. dorippus, Klug, a form which is very rare in India. Several times I saw the male $H$. misippus reconnoitring $D$. chrysippus as if in doubt as to its identity.

Of Precis oenone I took but one, of $P$. almana two, but $P$. lemonias was eommon. Of the following species I took mostly single examples:-Danaida plexippus; Ergolis ariadne; N'optis eurynome, Westw.; Polyommatus bactious; Lampides ecleno, f. conferanda, Butl.; Catochrysops hapalina, Butl., two; C. strabo; Zizcra otis, f. indica, two; and the Skipper, Suastus gremius.

Of Melanitis ismene I took but a small fraction, for one seldom sees a butterfly so battered, yet even this fraction was found in the shade. In marked contrast are the habits of Telchinia violac, since it haunts the most sun-scorched places; it was not uncommon at Anantápúr, but if gregarious, as elsewhere, then I did not hit upon its headquarter's.

I took one Terias libythea, and saw several $T$. hccabe, though it was but moderately common.

Cephonodes hylas, Linn, an insect very like Sesia bombyliformis, Esp., was two or thrce times seen, and once caught, hovering at flowers. There were also flying in the sun Utctheisa melchclla and

'Scc, horrorer, Chapter X., § I. 
Trigonodes hyppasia, Cram., a Noctua very like Hydrclia unca, Linn., which reminded me of Headington and old Oxford days.

Out of the grass I kicked up Tephrina catalaunaria, Guen., a pretty little Macariid Geometer Scmiothisa subalbitaria, Swinh., and Sterrha paullula, Swinh. The common dragon-fly, Orthetrum sabina, Drury, and a bug, Eysarcoris guttigera, Thunb., completed the tenants of the garden.

A number of things came to light, viz.:-Utetheisa pulchella; Lymantria incerta, Walk.; a Noctua, Ericeia inangulata, Guen.; a Pyrale, Schoenobius bipunctifer, Walk.; and a tiny Quadrifid Noctua, Raparna digramma, Walk. (lactea, Swinh.), as well as two Bugs, Acanthaspis apicata, Dist., and Dieuchcs uniguttatus, Thunb., the former apparently a scarce insect since the National Collection contains the type only. There was in addition to these a small ochreous narrow-winged Geometer to which $I$ have not been able to assign a name, and an Ichneumon-fly, Henicospilus sp. One evening insects came to light in swarms, among them were many Mosquitos, but from their attitude these appeared to be all Culex, fortunately none of the ague-carrying Anopheles.

BANGAlứ, lat. $13^{\circ} \mathrm{N}$., alt. $3100 \mathrm{ft}$.

February 23rd, 1904.

The change of trains at this large military station gave me a couple of hours collecting in the extensive public gardens. A high wind was against a good day, but the afternoon proved interesting since it gave me the first glimpse at that fauna which is, to a great extent, common to Ceylon and Southern India. Here I saw for the first time that very striking black, white, and orange Lycaenid, Talicada nyseus, Guér., as well as the huge and magnificent Papilio polymnestor, Cram., $5 \frac{1}{2}$ inches in expanse, a truly gorgeous monster in which pale lilac is the prevailing colour, trimmed with black.

The only other things noted were more ordinary, to wit Catopsitia pomona, a female; Crastia core; several Telchinia violae; Nychitona siphia; and an abundance of Ncptis curynomc, accompanied by one $N$. jumba, Moore, quite a distinct species.

\section{Tile Nilgiris, lat. $11^{\circ} \mathrm{N}$.}

February 24th-March 3rd, 1904.

ThF Nilgiris, or Blue Mountains, rising abruptly from the plain, itself nearly $2000 \mathrm{ft}$., above the sea, form a rolling table-land with 
an average altitude of from 6500 to $7500 \mathrm{ft}$. This plateau consists for the most part of grassy downs with here and there "sholas," or thickets of mixed growth, vcry beautiful at this time of the year owing to the red colour of the young lcaves of the preponderant tree. Unfortunately, alike for the entomologist and the artist, these "sholas" have been largely cut down to make way for the extensive Government plantations of Eucalyptus, which are by comparison dull, dreary and monotonous.

On the way up the cog-wheel railway I saw on the side of the cutting two beautiful blue-green Papilios, which may have been either P. telephus, Feld., or P. teredon, Feld. At about $4500 \mathrm{ft}$. I netted a Neptis eurynome from the train in motion.

It was evidently too early in the year to get many butterflies at Utakamand, the elevation making the nights cool, so it was necessary to seek out sheltered flowery banks facing south, or preferably southeast. In two such spots within a very circumscribed area Talicada nyseus was common; a single example also occurred (along with the inevitable Pyrameis cardui) on the grassy top of an isolated and exposed peak of about $8000 \mathrm{ft}$. This Lycaenid is quite typical of South India and Ceylon; it is a conspicuous insect on the wing, its tricolour of black, white and orange-red (which should delight German entomologists), making it look larger than it really is.

Terias hecabe was rather common, but worn. A female Polyommatus baeticus and several Pyrameis indica were also old friends, and the same applies to two or three Papilio aristolochiae, which were a good deal the worse for wear, seen at flowers in the hotel garden.

A few Yphthima chcnui, Guér., occurred at about $7800 \mathrm{ft}$., the only Satyrine I met with at Útakamand. Ganoris canidia flew up to $8000 \mathrm{ft}$.; a male had a distinct smell like that of our G. rapac. I submitted the living butterfly to my daughter and her lady friend, who both noticed the scent, though unable to describe it. When mignonette was suggested for comparison they both said "No"; but when sweet-briar was mentioned they said it was like that, my daughter speaking the more confidently of the two.

At about $7400 \mathrm{ft}$. I took a female Catophaga paulina, Cram., and also a fine female of Hiposcritia narcndra, Moorc, quite a Ceylon species. The specimen is labelled "flies fast: rathcr common from $7400 \mathrm{ft}$. to $8400 \mathrm{ft}$." It is but too evident that I had not recognized that I was catching anything out of the common, and it is more than probable that I confounded the females of Catophaga and Tachyris with Hiposcritia, so that I am not by any means disposed to trust the statcment that H. narcndra was common then and therc. One 
necessary consequence of my complete ignorance of the Indian fauna was that I did not know what was most worth catching. These white butterflies are, as a rule, by no means easy to catch, and were often in bad condition, but in each locality I used to endeavour to secure one or two good samples. Doubtless the Hiposcritia passed for a very fine Tachyris.

Amongst herbage Mecyna polygonalis, Hübn. (a rarity in Britain), was often kicked up, having much the habits and appearance of my old Bermuda and Mortehoe friend Nomophila noctuella, Schiff. (Stenopteryx hybridalis, Hübn.), which too was fairly common in exposed situations at about $8000 \mathrm{ft}$; ; a similar elevation a single example of the Danaine Badacara nilgiriensis, Moore, was taken.

Above the Botanic Garden on the road to Dodabetta, at about $8000 \mathrm{ft}$., I several times saw, but missed, Vancssa canace, Johanss. (haronica, Moore), a butterfly that looks dingy in the cabinet, but on the wing looks much brighter and bluer than would be expected. It is sometimes called the Blue Admiral (completing the trio), though in truth it is much more like a Tortoise-shell. Argynnis hyperbines was common at the higher elevations, and in exposed situations up to $8500 \mathrm{ft}$., reminding me of $A$. aglaia. It flew up and down the roads, returning again and again to the same spot.

The commonest and most characteristic butterfly of Útakamand was the pretty little Colias nilgiviensis, Feld., which was seen coursing over the grassy downs from 7300 to $8600 \mathrm{ft}$. Its flight is moderately fast, but quite close to the ground. It was somewhat startling, but in a way refreshing, to come across this Arctic survival so far within the tropics, associated, moreover, with species characteristic of Ceylon. The late Col. Bingham considered nilgiriensis to be a local race of hyale, auct. As it was especially abundant in the hotel garden I took the opportunity of examining five males for scent; in two of them I suspected the existence of a slight scent, but in the remaining three the result was negative.

From Útakamand I moved to KoNUr, which stands on the southern edge of the plateau, overlooking the plain. It is at about $6500 \mathrm{ft}$. above sea-level, or 1000 feet lower than Útakamand. At this elevation Colias nilgiricnsis was not nearly so common as at the higher levels.

Worn Pyrameis indica, a few Neptis curynome and Prccis iphita turned up here and there. Of a pair of Tcrias hecabc taken in copulâ, the male proved to be of "intermediate dry," the fomale of "pronounced dry" type. Opportunities of noting the pairing of the several forms occurred very rarely. Here I securcd one specimen of 
I phthima ceylonica, Hew., another foretaste of the great southern island. $Y$. inica, turned up at about $5800 \mathrm{ft}$, but at about $6500 \mathrm{ft}$., in a clearing in a wood, I found $Y$. hübncri, together with $Y$. chenui, and $Y$.philomela. There were swarms of thcse Iphthimas on that sunny bank, but as I did not distinguish the spccies at the time I cannot now say of what the bulk of them consisted. Bingham considered ceylonica to be a race of hïbneri, but the other species he held to be distinct. Some of the specimens have injuries to the wings, which from their shapes may have been inflicted by birds, but I attach little importance to this, especially as the injuries are unilateral, since the wings of Yphthima (and to a somewhat less degree of Mycalesis also) are so fragile that quite unbroken specimens are exceptional.

The genus Papilio was represented by a couple of demoleus. As usual Argynnis hyperbius showed a preference for lofty and bare places. On one occasion I watched a female of this species for some time under the impression that it was Danaida chrysippus! The resemblance on the wing is greater than might be supposed. Vanessa haronica, which had before eluded me so often, fell a victim at last; I secured two specimens on a shady road through a wood. It settles on rocks or walls, a habit that makes it hard to net, moreover it is shy and easily disturbed, though usually coming back again to its resting-place.

True to its generic name, Nomophila noctuclla was common in grassy places, and I took Boarmia inccptaria, Walk., flying in the hotel garden at dusk.

It was tantalizing to be told by the hotel manager at Konúr of the immense number and variety of butterflies there in the summer. I was, however, fortunate in making the acquaintance of a dealer, named Solomon, a coloured man, who told me that at that time of the year it was no good collecting on the high ground, but for a consideration he agreed to show me a very good place near the foot of the hills. Accordingly I went with him on March 2 nd, and again alone on the following day. This involved travelling by an early goods-train down to KALLÁR, the first station on the mountain railway above Mettupalaiyam, about $2000 \mathrm{ft}$. above the sea, but only $200 \mathrm{ft}$. to $300 \mathrm{ft}$. above the plain. Hcre, as in other parts of India, the best placcs for insects, at any ratc in the winter season, are to be found in the bclt of jungle at the foot of the hills, or in the woods on their lower slopes. But it is just in thesc places where the drcaded Anophcles is as abuudant as the Rhopaloccra, and the stationmaster at Kallár told me that entomologists always slept at Konúr 
and went up and down by train to avoid the nocturnal tcriors of the deadly malaria-carrier-the tiny, innocent-looking Anopheles.

The collecting-ground was various, and included, besides bushy jungle with plenty of flowers near the station, large irrigated Banana and Betel-nut (Areca catcchu) plantations as well as the bed of the river with its bordering woods.

The first thing to catch the eye was Papilio hcctor, Linn., and very magnificent he looked fluttering at the flowers of Lantana in his crimson and black suit set off with white. This is indeed one of the most striking butterflies that I met with in my travels, with its wings expanding four inches and upwards. It proved to be distinctly common, but the collector does not get within reach of every Papilio that he sees, nor indeed does he succeed in netting all that are struck at. P. hector was accompanied by plenty of $P$. pammon and a few $P$. aristolochiac. One of the $P$. hector brought home is remarkable for the fact that the whole of the tips and half the hind-margins of both hind-wings have apparently been bitten off, almost absolutely symmetrically, by some foe. If the red spots on the under-side be really "warning marks" this is the more noteworthy.

A boggy, but sunny, corner of an irrigated banana-garden produced single specimens of the fine Skippers Tagiades atticus, Fabr., and Tagiades obscurus, Mabille (distans, Moore).

This same garden and the adjoining plantations of betel-palm yielded a few Melanitis ismenc, a fair number of Mycalesis per'seus as well as Yphthima marshalli and $Y$. philomela; there was also abundance of the pretty and very distinct Yphthima ceylonica, with its silvery-white hind-wings, which tried, not without occasional success, to pass itself off as a Blue. A few hasty observations on this species when at rest failed to detect any such "list" as is common in many members of the family.

From Kallár I sent home two specimens of Mycalcsis pcrscus, one an ordinary example of the dry-season form in which the ocelli are indicated by faint dark dots, the other (unfortunately very tattered) in which the full complement of ocelli on the under-surface is indicated by the conspicuous chalky-white spots of varying sizes, to wit, two large and one small on the fore-wings and two large and five small on the hind-wings. Three of these spots aro faintly visible on the upper-surface. There are no rings and no pupils to the spots. It would appear to be a inique aberration of the dry-season form. In the shade along with the dusky Satyrs was the inevitable Nychitona xiphice. Solomon caught a solitary aberrant male of Elymnias caudata, Butl., approximating in colouring and rarkings 
to the female; on the forc-wing, bclow the median vcin, is a longitudinal tawny stripe, whilc the hind-wing is a lighter tawny colour than usual. Neither Sir Gcorge F. Hampson, nor the late Colonel Bingham remembered having scen anything quite like it.

A wcedy neglected ficld near the river yielded, besides Danaida chrysippus and Atella phalantha, plenty of the Orange-tip Ixias marianne, as well as a smaller number of the more gaudy Isias pyrens. One of the latter proved to be a worn specimen of the female lacking the orange tip, a distinct and well-marked variety; another was of the racial form cingalensis, Moore. The Whites Huphina nerissa, and Catophaga paulina were in plenty. A single Catopsilia pomona was netted, a somewhat papery-looking insect, especially on the under-side; also several C. pyranthe of the transitional gnoma, form. In one of the latter, a male, I detected a faint scent, but less like that of jasmine than in the Catopsilia examined at Anantápúr. In the same field Telchinia violae was abundant, while Ergolis ariadne was, as usual, common among Castor-oil plants.

But all this time Solomon was most anxious to get me down to the river. This is a rapidly-flowing stream, occupying perhaps half its bed, and having on either bank sloping woods of mixed growth. Solomon sought out a place wherc a tiny tributary emerging from a rushy swamp trickled over the damp sand. He forthwith stuck into the wet sand a foot or so from the rill and well clear of the herbage, three or four large butterflies of which he had netted woru or broken specimens; then he stood by to watch. Nothing much happened, for unfortunately clouds had come up and the afternoon was only partly sunny, whereas to get many things at water, whether decoys be used or not, it needs, as Solomon put it, to be "plenty hot." It was indeed hot cnough for most Europeans, but not up to the exacting butterfly standard. However, next day the conditions were more favourable, and I found near what was left of Solomon's decoys a number of Whites and Orange-tips. Accordingly I put down a few more decoys and walked away. After spending some time in vain endeavours to catch the conspicuous Hcbomoia glaucippe, Linu.--giant of Orange-tips-which was carecring wildly about in all directions, I returned to the decoy-place and sat dorm just within the reach of my six-fect net-stick. Catophaga paulina werc there in abundance, but all males, mostly sitting quite close together, almost touching, with wings erect so that the "hook-tip" of the fore-wing was very conspicuous; in another cluster close by were from six to eight Ixias marianne.

It will perhaps give some idea of the numbers when I say that 
I quite easily notted five C. paulina in one swoop, and seven in another.

Then Hebonoia glaucippe came along, reconnoitred the position with great circumspection, and settled warily for a socond or two, but darted swiftly off at the least movement on my part. Nevertheless, with care and patience, I managed to secure a couple of specimens. My old friend Papitio demoleus came next and soon settled down a short distance away from the Whites; he was shortly followed by another of his own kind, and yet another: they all settled close together, within a hand's-breadth, forming an exclusive community, and continued to drink steadily. All at once a blue-green flash, and Papilio telephus sailed close past me; again and again he came, and finally, looking askance at the vulgar assemblage of Whites and Orange-tips, settled quite close to the $P$. demoleus, evidently preferring their more select company. This occurred several times. $P$. telephus, when settled with wings erect, displayed an unexpected beauty, for, in place of the ebony and emeralds on the upper-surface, it showed beneath nothing but sheeny mother-of-pearl picked out with tiny rubies. By patient watching and judicious swooping I secured three specimens, and, be it recorded, these were all I saw that day. So much for water; what share the decoys had in my success it is hard to say, but Mr. E. E. Green, of Peradeniya, told me that decoys were efficacious, and Mr. Denton, of Regent Street, says that he has used even paper decoys with success.

The congregation of butterflies at damp sand was observed by Bates on the banks of the Amazon in 1849. He noted that they were all males, mostly of the genus Callidryas. ${ }^{1}$ Indeed Sir J. D. Hooker had the year before noted butterflies sitting on damp sand "in thousands" in the Ranjit valley, Sikkim."

Mr. E. André noted a similar thing in Venezuela in 1897, where the attraction was the foul mud of a farmyard: the butterflies were chiefly Callidryas, with some Heliconius, Papilio, Metamorpha and Caerois. He adds: "Each species tried to herd with its own kind," but he says nothing as to sexes. There is a capital photograph in his book of a group of Callidryas. ${ }^{3}$

Doubtless this habit of butterflies is well known to all tropical collectors. I had myself in Germany, some thirty-four years before, noted swarms of Blues drinking at small puddles in the roadseveral species together." At Mortehoe, on the 1st of August, 1905,

1 "Naturalist on the Amazons," Ist edn., p. 249.

2 "Himalayan Journals," Vol. I., p. 152 (1854).

3 "Naturalist in the Guianas," p. 142.

+ Seo p. 25, supra. 
in the early aftermoon, I saw fourteen or fiftcen Ganoris napi sitting close together on wet mud; thcy were all males.

Adjoining the plantation of the singularly graccful $A$ reca palns was a piece of wastc ground covered with Lantana in full bloom, this was crowded with butterflies such as Crastia core and Narmoda. coreoides, Moore, one or both of which (for I did not distinguish them when alive) was abundant; with them were several Neptis eurynome, and two or three Nepheronia ceylanica, Feld., another southern species. But more striking than all these were the swarms of Tirumala limniace, a big and handsome black and bluish-white Danaine, which I found all over India but never saw elsewhere in anything likc such numbers as on that mass of Lantana.

Other things that turned up in the course of the two days' collecting were Tachyris hippo, two; Teracolus etrida, one; Hypolimnas bolina, two males; H. misipprus, one male; Precis iphita, common; Castalius rosimon, Fabr., plenty of Lampides celeno, including the form conferanda; and one Parnara mathicas.

A specimen of the fine Skipper, Caprona ransonnettii, Feld., was seen to settle, in full sunshine, on the under-side of a leaf, with its wings fully expanded like a Geometer. I do not ever remember seeing a butterfly do this before, but then we are perhaps wrong in calling Skippers butterflies. One of the Lampides, a female(?), was found settled close to the ground, with all its wings erect as usual and close together; it was, however, moving its hind-wings alternately, in a rhythmical manner, in the plane of the wing, about $10-15^{\circ}$ forward and then back. No other specimen of the species was near it.

On the occasion of my first visit to Kallár, as we were walking back to the station, Solomon suddenly darted off like the wind, and I found that he was after a very large Papilio which he had caught sight of flying about a puddle in the road, some hundred and fifty yards off. He waited long and patiently until it settled to drink and then popped his net over it. It was a male Papilio polymnestor in splendid condition, familiarly called by Solomon a Blue-bottle. This haughty beauty was not kind to me at Kallár; many a time I caught a glimpse of her flying about in a supercilious sort of way, but she never gave mc a chance of closer acquaintance. Solomon had the advantage of me in many ways, first and forcmost in years, next in his keen sight, but he was also wily and skilful with his net. During the day he took among other things a specimen of Papitio agamomnon, Linn., a fine black-and-green fellow that I too had seen; also one of that grand diamond-beotle-grcen buttcrfly Papitio crino, Fabr., which 
I missed the next day at Lantana flowers, as I believe, through sheer excitement.

Tricinnśpali, lat. $10^{\circ} 50^{\prime} \mathrm{N}$, alt. circa $400 \mathrm{ft}$. or less.

March 4th and 5th, 1904.

The famous Rock is a mass of granite consisting of enormous blocks-perhaps $100 \times 50 \times 50 \mathrm{ft}$. The rocks of Southern India struck me as unusual in this respect-the fewness of the joints. Whether this be due to the absence of frost, or to the stability of the hills and absence of earth-movements, I cannot say. ${ }^{1}$

My collecting here was almost confined to the banks of an irrigation canal, where the genus Papilio was represented by $P$. hector, $P$. pammon, and $P$. aristolochiae, of each of which I saw several.

Danaida ehrysippus was common; in the male of Tirumala limniace I detected a very faint scent, suggesting old cigar-boxes.

Catopsilia pyranthe was rather common, the specimen preserved was of the intermediate form; a scent was noted in the male, but it was not so strong as in some of the Bankápúr specimens. Of Delias eucharis I took two females, by far the less common sex, at all events in collections. Both sexes of Huphina nerissa occurred. Terias heeabe was abundant.

The most striking fact about the butterflies of Trichinápali was the predominance of the genus Teraeolus; of these I met with three species: T. eucharis, Fabr., was in abundance, but my specimens comprise eight males to two females; of T. etrida I took two males; and I was greatly delighted to see here for the first time that truly exquisite little gem the crimson-tipped T. danä̈, Fabr., which proved to be rather common, and two of each sex were secured. It is one of the most "elegant flies" that I have ever seen alive.

Precis orithyia was common, the specimens small and brilliant; $P$. lemonias was in larger numbers than I met with anywhere else, in fact quite abundant; Ergolis ariadne was common; I netted a pair of Byblia ilithyia, Drury, in copulâ, one was of the wetseason form, the other intermediate tending to wet. As usual Telchinia violae was common.

I took here one specimen of that beautiful Lycaenid with the under-side striped like a tiger, Spindasis vulcanus. This is one of the butterflies with an anal lobe to the hind-wings, but unfortunately there was no opportunity of observing it at rest. Lampides ccleno

${ }^{2}$ Dr. John W. Evans tells mo that in the tropics eruptive rocks weather by a process of scaling, by which concentric layers are split off. 
was common; some smaller and dingier Blues werc abundant: Zizera otis, var. indica, and Chilades varunana. I also took one specirnen of a small bright golden Skipper, Ampittia maro, Fabr.

\section{TANJÚR, lat. $10^{\circ} 47^{\prime} \mathrm{N}$, alt. $350 \mathrm{ft}$. or less.}

Narch 6th, 1904.

The predominant genus of the plains of Southern Madras would appear to be Teracolus, which was represented in my envelopes from TANJÚR by a male $T$. etrida, a pair of $T$. cucharis, as well as five males and two females of my favourite Crimson-tip, T. danaë, which was quite common.

Of Catopsilia pyranthe I took a dwarf male of the intermediate form. Tcrias hecabe was common, and I took a very large female, over 1.8 inches in expanse, of the dry-season form. Single specimens of the following were sent home: Nychitona xiphia; Papilio pammon, male; Danaida chrysippus, female; Castalius rosimon and Lampides celeno, of the form conferanda. Telchinia violae was common, one being of a fine red colour.

\section{Mádura, lat. $9^{\circ} 55^{\prime} \mathrm{N}$., alt. $600 \mathrm{ft}$.}

\section{March 7th, 1904.}

The imposing Dravidian architecture of the South culminates in the truly magnificent temple at MÁDuRA. The traveller who confines his attention to the Northern cities will come away with the idea that the architecture of India is that associated with Islam. Indeed the sole Hindu religious work of the North which really impressed me was the colossal sitting statue of Siva in the celebrated cave on the island of Elephanta, near Bombay. That figurc, with its three faces representing the god in his three aspects of creator, preserver, and destroyer, did to my mind suggest something super-humau. All other sculptures that I had seen were rudc, coarsc, even repulsive.

The ancient Hindu temples of the North were destroyed by the Moslem invaders and the materials, as at Lalkót and Ajmir, used in the construction of mosques. Here, however, in the extremc south of the continent, stands a group of temples that for impressireness rccall those of Egypt. They are, howevcr, much lcss aucient, having been for the most part erectcd bctween the 13th and 18th centurics.

In the grcat temple near Trichinápali it was intcresting to sce "the tablcs of the money changers, and the seats of them that sold 
doves," doubtless pretty much the same as those that stood in another temple nearly nineteen centuries ago.

Mádura was about the least productive place that I visited. Danaida chrysippus was scar'cely common. A male Huphina nerissa, gave out the sweet-briar scent quite strongly. I saw several Telchinia violae upon a railway bank. Prceis ocnonc was fairly common; on the other hand $P$.almana was commoner here, about the irrigation ditches bordering meadows, than at any place I visited; they were of the "intermediate dry" form. P. lemonias was also abundant, some of them being very brightly coloured.

In a grove of young palms near the river a singular dragon-fly, Rhyothemis variegata, Linn., was tolerably common; the tips of its wings are transparent and colourless, but the basal three-fifths of the fore-wings, and the basal five-sixths of the hind-wings, are lightbrown with a bold dark-brown pattern somewhat suggestive of tortoise-shell. I saw what was probably the same creature in the Kudsia Gardens at Delhi, flying near the tops of trees, and then, as now, took it for a Heliconius-like butterfly, which it somewhat resembles on the wing. Not knowing that any butterfly of that shape was found in India I was greatly excited at seeing it, and proportionately disappointed when at last its capture was effected. ${ }^{1}$

Mádura was the last place in India at which I collected.

On the royage from Tuticorin to Colombo I met the wife of a missionary from Travancore. She had assisted her husband by working in the zenanas, and two results of her experiences greatly interested me. Strongly prejudiced as she was against the whole system, she told us that it had been a great surprise to her to find "so much beautiful family life within the zenana." It had been another surprise to discover that the women had such great influence on the conduct of public affairs.

This last fact seemed to offer some explanation of the existence of such a capable woman-ruler as the Begúm of Bhopál, and of such a heroine as the Máharání of Jhánsi, who was cut down by one of our men when charging at the head of her troops in 1858.

"Compare Prof. R. C. Punnett's experioneo, "Spolia Zeylanica," Vol. VII., Part XXV., p. 22 (1910). 
CEYLON.

Lat. $7^{\circ} \mathrm{N}$.

All the places that I visited in this beautiful island were within twenty miles north or south of the seventh parallel of latitude. The luxuriance of the vegetation was an immense relief after the parched plains of India. At the lower elevations it was more distinctly tropical than anything that $\mathrm{J}$. had yet seen, but this character was lost at greater altitudes. On the beautiful journey up from Colombo, we saw a magnificent specimen of the great Talipot Palm (Corypha umbraculifera, Linn.) in full flower, it is one of the glories of Ceylon.

\section{Peradeniya, alt. circa $1200 \mathrm{ft}$.}

\section{March 10th, 1904.}

The justly celebrated gardens lie about four miles south of Kandy near the centre of the island. Their situation, in a bend of the river, is beautiful, and all our familiar hot-house plants grow luxuriantly in the open air:- splendid Palms of many kinds, some planted in solemn avenues, huge Bamboos almost as tall, various species of Dracacna, Croton, Acalypha, Maranta ; Nutmeg, Cinnamon, Camphor ; huge trees of Ficus clastica with roots spreading far over the surface of the ground. Grass has been largely ousted by the Sensitive-plant, Mimosa pudica, which, introduced from South America, has run wild it grows about a foot and half high, and when one walks through it a broad path is left owing to the collapse of the leaves. One of the most strikingly beautiful things in the gardens is the Giant Bamboo from Malaya, Dendrocalamus gigantcus, growing in clumps $100 \mathrm{ft}$. in height, which bend gracefully over the waters of the Mahaweli-ganga.

Here, well out of reach, I saw my first Ornithoptcra; truly it is well named! ${ }^{1}$ A second specimen came down to earth, but I missed it through sheer excitement. Several Catopsilia pomona were netted; one was a female verging on the catilla form, the others were typical males, one of which had a slight scent. Of three male Terias hecabe two were wet-season, the other" of "intermediate wet" form. A male $T$. libythca was also of wet-season type, a female was also taken. The only Nymphalids noted were two Ncptis curynome and several Prccis iphita. Here also I took my first Parantica aglca, Cram. (ccylanica, Feld.), a Danaine found in abundance later.

1 Tho namo Troides has priority. 
Of Orsotriciena mandata, Moore, I saw only one, but the pretty little Yphthima ceylonica was swarming amongst the sensitive-plants. Mr. E. E. Green, the entomologist to the Ceylon Government, suggested that its colouring might be indirectly protective, since on the wing it looks much smaller than it is, only the white posterior twothirds of the hind-wings being conspicuous, and these the least vitally important to the insect. The only Blue seen was Zizera karsandra.

A second visit to the gardens, rather late one afternoon, produced no insects, but gave me my only sight of a wild Cobra (Naia tripudians), about $2 \frac{1}{2}$ feet long, with a very large hood. I found myself for the first time in the near presence of a dangerously poisonous serpent without any plate-glass intervening. For a moment there was a struggle between the impulse to compass its destruetion, and the fear of breaking my net stick in the endeavour, meanwhile the laidly beast crawled quickly away into the roots of a so-called Travellers' Palm, Urania speciosa, and I saw it no more.

Unfortunately for me, Mr. Green was on the point of going to England on leave, but though busy with his preparations for departure, he was good enough to show me several very interesting things, such as young snakes, larvae of the leaf-insect, etc.; above all he gave me some very useful advice. Peradeniya, he said, was not as rich a locality as Kandy; and, as regarded the highlands of Ceylon, he told me that, at any rate at that time of the year, Lepidoptera were for the most part confined to certain favoured spots, which it was unlikely that I should hit upon. He therefore strongly recommended me to concentrate my attention on Lady Horton's Drive at Kandy, advice that proved to be sound.

KANDY, alt. $1500 \mathrm{ft}$.

March 11th-15th, 1904.

On the eastern side of the artificial lake at Kandy stand some low hills, covered for the most part with natural forests, througl which have been cut a number of roads named after the wives of former governors. Lady Horton's Drive is one of these, it rums about half-way up the hill, winding around its southern and eastern slopes. A wide road, bounded on either side with forest of rich and varied tropical growth, lying fully open to the morning sun, cominanding, moreover, a glorious view over groves of palms to the bluest of distant hills, it affords an almost ideal collecting-ground. The climate of Kandy, so far as I experienced it, is delightful; tropical heat tempered by elevation, and with a pleasant softness in the air, 
yet free from the excessive damp of many places within the tropics. Its vegetation is by far the richest that I had seen. My pleasure in collecting in this earthly paradise was enhanced by the companionship of Mr. W. G. Freedley, junr., of Pliladelphia, who had been collecting butterflies in Borneo, Celebes, Japan, Macao, etc.

In such a locality it was perhaps to be expected that Pierines would not be dominant, at any rate so it was. By far the cornmonest of the family was Catopsitia pomona, of which the males were very abundant, but strong fliers and by no means easy to catch. We remarked that usually they all flew in the same direction, and that uphill. As the females were comparatively scarce one was not surprised to see more than once signs of jealousy on the part of the males. On stroking the "scent tufts" on the hind-wings of the male, I detected a slight jasmine-like scent. A female Terias hecabe had apparently been bitten in both hind-wings when at rest, the injuries being more or less symmetrical. Delias eucharis was scarce, Catophaga paulina more common. In one case I saw a bird try to catch a specimen of the latter on the wing; the bird missed its quarry, but I was more successful; it proved to be a male.

The Danaines were well to the front, the commonest species being Parantica aglca; this is smaller and greyer than Tirumala limniace and varies considerably in size, a small male measuring only 2.5 in., a large female as much as 3.4 in. across the wings. It was curious that this species appeared in abundance late in the afternoons, as other things were retiring. I was surprised to find that a male when fluttering in the net gave out a strong scent like that of Crastia core, i.e. resembling acetylene. This was noted in two or three specimens, and was quite unmistakable. Tirumala septentrionis, Butl., appeared to be rather common; a female has the hind-wings much broken, perhaps from the bite of a lizard, but the breakage is only in part symmetrical. Danaida plexippus, of which I took a very small one, was very scarce, and I did not see $D$. chrysippus at all. The genus Crastia was represented by many individuals. I took five C. asela, Moore; of one of them I noted at the time, "has a scent as in core."

But the most prominent group of butterllies at Kandy was assuredly the Papilioninae; I met with six species. The most remarkable was Ornithoptcra darsius, Gray, whicl is peculiar to Ceylon, an insect that I had greatly wanted to take; it appears to be fairly common, as two were seen at Peradeniya, seven or eight at Kandy, and two at Haragáma. It sails about somewhat slowly and 
majestically, looking very distinguished in its rich yellow and black livery, and very impressive by its size, five and a half to six inches in expanse of wings! When it comes within reach it is not hard to catch, and I secured two males and a female, but it is a formidable-looking creature in the net, with a thorax suggestive of a Bombyx. Mr. Freedley told me that the males have a scent like sassafras, but I learned this too late for confirmation. The male Papilio pammon was common enough, one specimen was unusually small, measuring nuder three inches. Two specimens of $P$. aristolochice (a distasteful butterfly) were brought homc; one of them has the tips of the hind-wings up to the tails bitten off quite symmetrically, thus much resembling the mutilated specimen of $P$. hector taken at Kallár. Of the tailless $P$. dissimilis, Linn., I took three, but probably saw more, since it so very closely mimics Tirumala limniace or a large Parantica aglca, as readily to pass for one of those insects; it is indeed most easily distinguished from them by its habit of fluttering while feeding on a flower. One of my specimens has the anal angle and a great portion of both hind-wings bitten off in an almost symmetrical manner, suggesting the bite of a lizard. Prof. E. B. Poulton, in the paper alluded to above (p. 44), noted that whatever the cause may be, it is in the great majority of cases the hind-wings that suffer these injuries; doubtless the framework of the fore-wings is the stronger, but that does not seem to be a sufficient explanation, since owing to their greater length they must be more exposed to chance injuries from thorns and the like. One is therefore driven to the explanation that their enemies must usually attack butterflies from behind. Mr. Freedley took a Papilio dissimilis that mimicked Euploea, for the species is dimorphic, one form mimicking each Danaine genus. Indeed it would appear that the name dissimilis implies that its bcarer is like anything rather than a Papilio. ${ }^{1}$

In a shaded glen down which a tiny stream and a footpath strove for the possession of the ground, I took closc to the water a faded specimen of my Kallár acquaintance Papilio telephus, and missed another that was drinking at the mud. But far more exciting than all the before-mentioned species was Papilio parinda, a truly magnificent fly that dashed about in all directions. ${ }^{2}$ It measures

1 The nomenclature of this butterfly is very puzzling. Of Linnoeus' two names clytia and dissimilis, it would appcar that tho formor has priority; lankeswara, Moore, is a Ceylon race of the dark form. My dark specimens might thoroforo be called $P$. clytia lankeswara, my light spccimons $P$. clytia dissimilis.

2 The male of the Coylon butterfly is almost identical with that of the mainland; the fomale is distinct. Mr. Rothschild considers parinda, Mooro, to be a local race 
about $5 \frac{1}{2}$ inehes aeross the wings and is rendered most eonspicuous by its eolouring-French grey and blaek. It rarely settled and was very hard to eateh; Mr. Freedley and I were eonstantly striking at it, but it almost always eluded us. After many fruitless attempts I sueceeded in netting two, one so battered that its powers of flight were seriously impaired; Mr. Freedley was even less fortunate, probably beeause he had a very small net.

There was yet another Papilio which eluded me altogether. It was black-and-green, and I feel pretty sure $P$. agamemnon, a butterfly that I missed at Kallár in the Nilgiris. It had the extraordinary and most aggravating habit of flying up and down, or rather baekwards and forwards, just like a sentry, over some small trees below the road. Its path, if one may so call it, was about a dozen yards in length, and it always turned round at the same plaee, moving by a sueeession of jerks. I once actually watched it for twenty minutes so oeeupied, it then settled for a moment on a Lantana flower; I struek at it and missed, and the performance began again. Another day it was at its post as before. Of all the Papilios that I saw this speeies was by far the wariest.

In striking eontrast to the Papilios in every way are the Satyrines. A solitary Mycalesis perseus was a very unattraetive shade-lover. The bright little Yphthima ceylonica was abundant; so far as observed it sits upright. Nissanga patnia, Moore, a very distinet species, with leaden metallic lines on the under-surface, was fairly common at the edges of woods, but I did not meet with it on the "patnas" or grassy plains of the highlands of Ceylon.

The Nymphalines met with ineluded several interesting speeies, notably Cynthia asela, Moore, of which I saw a very fine example, but eaught only a very tattered fellow. It seems to like sailing about over the trees. With Cethosia nietneri, Feld., I had similar ill-luek. Of Cupha placida, Moore, again I have but a very morn speeimen annotated thus: "Has the swift flight and to some extent the habits of Precis, but is fond of resting on the lenves of trees." These remarks are probably intended for, or at least inelude, the allied Cirrhochroa cognata, Moore, whieh was eertainly eommon, though very local; one of my five specimens, otherwise in good condition, has two snips taken out of each hind-wing, symmetrically, but it appears to be an insect readily chipped. Both these species have fulvous wings with black tips, so they are readily confounded in the field.

of polymnestor, Cram. ; the late Col. Bingluam suggosted that parinda might be looked upon as a dimorphic female of polymnestor peculiar to Ceylon. 


\section{ASIA.}
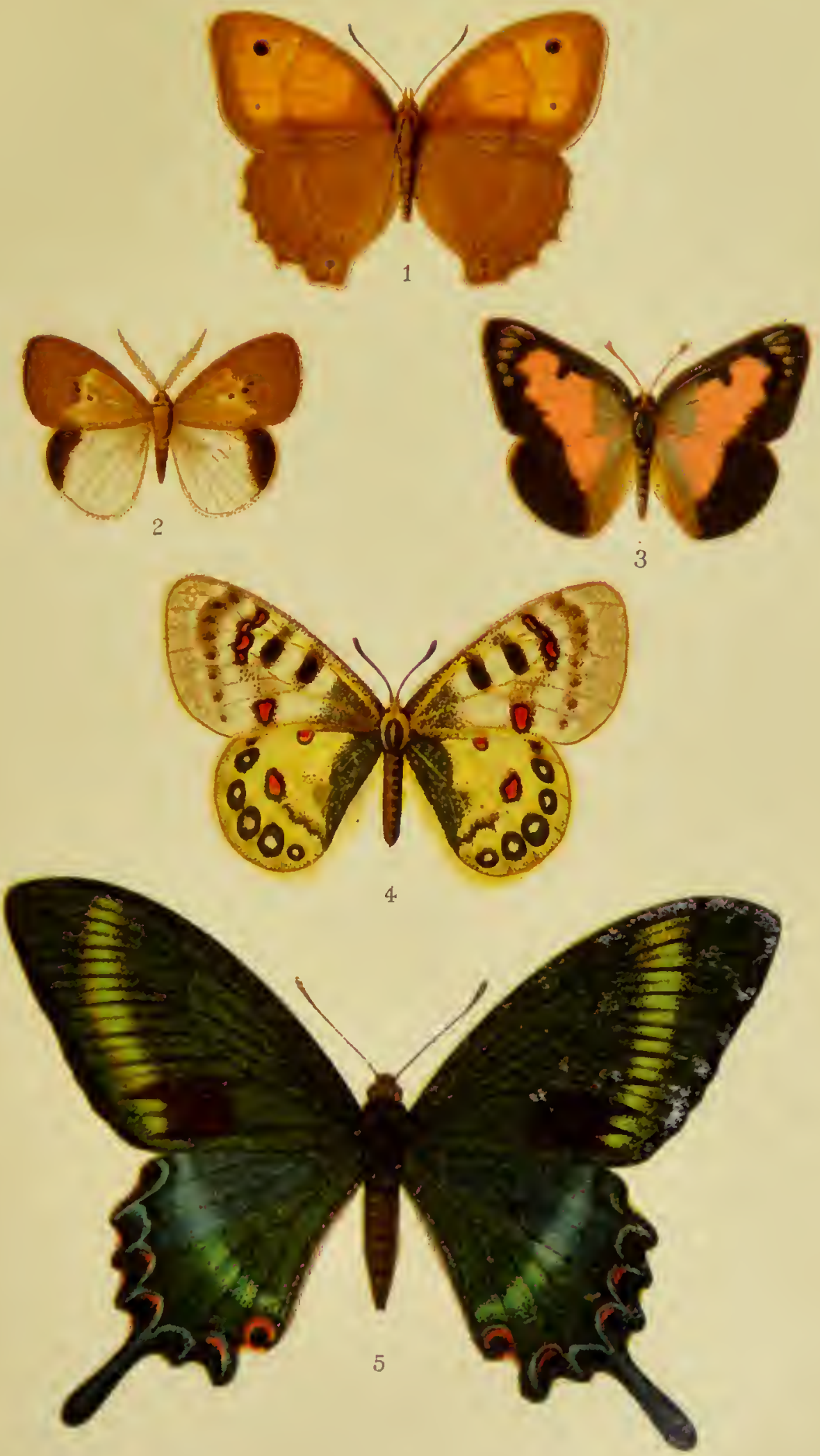

H. and Edgar S. Knught del.

Wase, Vewman Chrumo.

I. EPINEPHELE DAVENDRA.
2. PANTANA AROA.

3. TERACOLUS PROTRACTUS. 

Neptis curynome might be said to have been abundaut, while its ally, the brown-aud-black Rahinda simuata, Moore, was decidedly commou. Of the Frycinid Libythea rama, which appears to mimic Kahinda, I sceured one specimen at Kandy, and believe that I missed another in the Pashók tea-garden near Darjiling.

I saw no females of Hypolimnas bolina at Kandy, but took three males, one of which had lost both the anal angles of the hind-wings, the injury being in part symmetrical. Preeis iphita was common, so was $P$. atlitcs, looking on the wing like a dingy Neptis; a new brood appeared on March 14th. Ergolis merione was common.

The Lycaenids were not well represented, but I saw several Loxura atymnus, Cram, var. areuata, Moore; as usual Lampides celeno was common, almost spangling in the sunlight, among them was a single specimen of the yet more beautiful $L$. laeteata, de Nicév. (pscudelpis, Moore, nee Butl.). It is a somewhat rare butterfly reminding me of the British adonis (bellargus). Talicada nyseus and the dingy Spalgis epius, Westw., brought up the rear.

The Skippers were represented by single examples of the dull Parnara mathias, and the dark fulvous Iambrix salsala, Moore.

At rest on a fence outside the "Queen's Bath" I found one morning a fine Sphinx, Meganotum melanomera, Butl. A very distinct-looking Arctiid, having a crimson body and light pink forewings, with a longitudinal fuscous streak, Creatonotus interruptus, Linn., came to light, as also did Eupterote diffusa, Walk.

A few insects of other orders forced themselves upon me, busily occupied as I was, c.g. a gigantic, black female Carpenter-bee, Xylocopa tenuiseapa, Westw., with peacock-green wings; a very large, evil-smelling, brown Bug, I'essaratoma javaniea, Thunb., covered beneath with a waxy substance that during life glistened like silver. Another bug, Chrysocoris stockcrus, Linn., was an intense metallic green with black spots; yet more conspicuous than any of these was the large Fulgorid Hotimus maculatus, Oliv., a so-called Lantern-fly, expanding three inches across the wings. Its fore-wings are black and white, the hind-wings light blue with a very broad black border. This was fairly common, flying high and settling on tree-triuks out of reach, but easily disturbed, whon it flies off to a similar restingplace not many yards away. 
Haragína, 11 miles S.J. of Kandy.

March 12th, 1904.

This appears to be locally recognized as a great place for butterflies; the collecting-ground is along the course of a rapidly-flowing stream with wooded banks, perhaps $500 \mathrm{ft}$. below Kandy, or say $1000 \mathrm{ft}$. above sea-level.

Again I had the advantage of Mr. Freedley's company on the occasion of my expedition. The first thing to catch our attention was Hebomoia glaueippe, careering about in considerablc numbers, but most unwilling to be caught.

The pretty little Talicada nyscus was literally swarming. Indeed I cannot remember ever having seen a Lycaenid in such numbers. It was repeatedly observed to settle with its head upwards and immediately turn round. This habit of resting with the head down is common, if not general, in the family, and has an obvious bearing on the protective use of tails, anal lobes, and directive marks. ${ }^{1}$ Zizerc otis was also in abundance, and Lampides celeno was common.

Tirumala septentrionis was not common, and the specimens netted werc tattered males; one had a symmetrical injury near the anal angle of the hind-wings, possibly due to the bite of a bird. I saw a few specimens of Crastica ascla, and secured two males, which exhibited the acetylene odour.

Neptis eurynome was common, and I took a specimen of the elegant Hypsid day-flying moth Dcilemera nigrovcnosa, Moore, which seems to mimic it. Of the beautiful Nepheronia ceylanica, I took one male. Cirrhochroa cognata was noted flying about a particular tree and did not appear to be attracted by flowers; I only saw it in that one spot, and the two taken were in poor condition. It is very like Cupha placida (Messaras crymanthis, Stgr.), of which I took a fine specimen close by, at wet sand. I again confounded the two species as at Lady Horton's Drive. A few Ergolis ariadne and several Nychitona xiphia were seen. A male Huphina ncrissa had the sweet-briar scent; a fcmale was in fine condition.

At the furthest point reached in our walk, by a little bridge, two or thrce spots in the damp sand appeared to be vcry attractive. Besides the Cupha already mentioned there was Ixias pyrcnc, var. cingalensis, and Papilio pammon, the male, which was also seen flying about bushcs, but not at flowers, was rather common. My Kallár friend Catophaga paulina was literally in crowds; thcy were all apparently malcs, sitting in dense clustcrs, their pointed white wings

${ }^{1}$ Sec Chap. X. $\$ 10$. 
suggestiug to me toy eucampments. I easily netted ten at one swoop, whilc Mr. Freedley by a more cunning movement succeeded in getting as many as thirty-four into his net! In the same place I saw six or seven of the beautiful Papilio telephus, settled quite close together, and managed to secure three of them. It is a black-andgreen species not easy to distinguish from $P$. jason, Linn.

The females of Catophaga paulina were common at flowers. One of the males, by the way, had a symmetrical injury to the tips of the hind-wings, but I can hardly see how it could have been inflicted by an enemy without simultaneous injury to the fore-wings.

This day I saw two Ornithoptera darsius, one quite out of reach, the other I missed badly.

\section{Hatton, alt. $4200 \mathrm{ft.}$}

March 16th-18th, 1904.

In going up-country from Kandy, when near Ullapáne station [alt. circa $2500 \mathrm{ft}$.] I caught, from the train, Narmada montana, and a little further on, circa $3000 \mathrm{ft}$., a male Catophaga pautina, a species that is very abundant in the Ceylon highlands.

Before Hatron is reached the line enters the tea country, whence the glorious primaeval forests have disappeared, having been ruthlessly and completely cleared out to make way first for coffee and later for tea. Though doubtless "grateful and comforting," the teaplant is most unpicturesque, only by a little surpassing the potato in that quality. The Australian Grevillea trees [Nat. Ord. Proteaceae] with their light feathery foliage, planted in regular rows to shelter slightly the tea from sun and wind, do but little to relieve its stiffness, and are a miserable substitute for the departed woodland glories, indeed they almost deserve to be classed as "undesirable aliens." About Hatton there are but scraps of the forest left on the tops of the highest hills, and we were told that the tea-planters are constantly urging the Forest Department to allow these to be improved away.

Here for the first time I examined Catophaga paulina for sccnt, and was surprised to find that the three males tested had a scent nearly as strong as that of $G$. napi, but different; it was described at the time as "like swect-briar, but sweeter and more luscious," and I wrote to Dr. Dixey the same evening, adding that I had no doubt whatever.

About the hotel garden Argynnis hyperbius was common; a male harl the fore-wings notably shorter and broader than usual.

A stroll in what is left of the old forest, towards the top of 
a high hill, say at about $4500 \mathrm{ft}$., produced sevcral specinens of Lethe daretis, Hew., a regular sylvan Satyrine, rcpeatedly settliugr ru the path, apparently always erect. 'I'wo of them liad lost large portions of the hind-wings near the anal angle, onc symmetrically and in a way to suggest the bite of a lizard. On the under-surface of this butterfly the unusually large light-coloured scales set on a black ground near the hind margin of the hind-wings are strikingly conspicuous. In the same scrap of forest I took a single specimcn of another species of the same genus, L. drypetes, Hew. (embolina, Butl.); also a Limenitis ealidasa, Moore, settled on a leaf of a tree far from the ground, as is usual with the genus. Several Atella phalantha, a few Neptis eurynome and Terias hecabe were also scen, a female of the last-named being of the "completely wet" form.

My only specimen of Cyaniris singalensis is very like our argiolus. With some difficulty I secured a specimen of the large black and white Skipper, Celaenorrhinus spilothyrus, Feld. This was the second Skipper [the other being Caprona ransonnettii, at Kallár] that I had seen settle on the under-side of a leaf during full sunshine, the wings being expanded like a Geometer's. Another example was settled on a rock with its wings expanded in like manner.

In the hotel I found at rest on a wall what at the time I took to be a fine Burnet, but it was the Syntomid, Euehromia polymena, Linn., ${ }^{1}$ it has narrow black wings bearing orange spots, the body is blue, ringed and collared with scarlet; in my bedroom I took a beautiful little Tortrix-like Noctua, Metachrostis ineondita, Butl., measuring only $17 \mathrm{~mm}$. across the wings: also Pomasia psylaria, Guen., a pretty little yellow Geometer with metallic markings, evidently attracted by light; with the moths was a most formidablelooking, long-waisted wasp, Eumenes petiolata, Fabr., a female.

We visited Hatton in order to ascend Adam's Peak, driving thence to a small hotel near the mountain. We were called at midnight, and started soon after by the dim light of lanterns. The last $1000 \mathrm{ft}$. or more is a remarkably steep conc of granite, sparsely covered with scrub. The ascent presents no mountaineering difficulties, but is remarkably fatigning as it cousists of excessively irregular steps, some natural, others hewn out of the rock, or built up, some formcd by roots. It took nearly two hours, and to go up steps continuously for that length of time by lantern light, with eyes glued to the ground, is trying alike to eyes and limbs, nerves and

1 The Syntomids have for the most part a strong resemblance to the Zjgacnids, and Sir Georgo F. Hampson, in his "Moths of India," placed the trro families next to one another, but he has nore recontly soparaled them widely. 
temper. So steep is it that the descent took nearly as long as the ascent. There is another way up, on the other side, where it is said the pilgrims help themselves up the worst parts by very ancient chains. On the summit, $7252 \mathrm{ft}$., live the priests who show pilgrims the Footmark, said by the Buddhists to be that of Buddha, by the Hindus that of Vishnu, by the Mohammedans that of Adam, and by the native Christiaus that of St. Thomas. Under all the circumstances it is scarcely surprising that the footmark is nearly six feet long!

Having visited Gaya where Gautama meditated under the Bo-tree, Sarnáth where he first taught, the Temple of the Tooth at Kandy, and finally having made the great pilgrimage to the top of the Peak, we all felt that we had " acquired much merit."

When coming down from Adam's Peak on March 18th, at the height of about $6000 \mathrm{ft}$., I saw several of the Lithosiid, Asura uniformis, Hmpsn., but in the rongh scramble of the descent could only secure one; at about $4800 \mathrm{ft}$. were several Talicada nyscus, and a few hundred feet lower down I bottled two green beetles, Coryphocera elegans, Fabr., somewhat resembling our Rose-beetles, but much more shiny.

\section{Nuwára Eliya, alt. $6200 \mathrm{ft}$.}

March 18th-21st, 1904.

This Sanatarium is like Útakamund in that it is situated on a grassy plateau forming a basin among mountains. The "patnas," or grassy areas, are bounded by woods, which in their turn are fringed by somewhat stunted scarlet Rhododendrons. At the best season it doubtless affords excellent collecting, but I found Mr. Green's statement, that I should be unlikely to light upon the good localities, amply confirmed.

I saw several Papilio teredon flying about, and secured two that were drinking at wet mud. A female Terias hecabe proved to be of the wet-season form. Of Neptis eurynome I took two. In a sedgy place I took the Skipper Baracus vittatus, Feld., curiously enough the only butterfly that I had taken in a swamp up to that date. The streaky markings of the under-side, following the veins, appeared when the insect was settled on sedge to be strongly protective. Of Talicada nyseus I saw several; the only other Blue seen was the argiolus-like Cyaniris lanka, Moore, much battered.

Among moths I found one of the yellow Geometer Corymica specularia, Noore, at rest on a tree-trunk, and an Acidaliid, Idaea costata, Moore. Also on Mt. Pederutalagalla, at abont $8000 \mathrm{ft}$., the 
Skipper Baracus vittatus, again among sedgy grass, and Aurusas sordida, Hmpsn., flying at dusk. This last, a nearly uniformly dark fuscous insect, is presumably scarce, since the British IIuseum possesses the type only.

\section{HAKGÁLA, alt. $4800 \mathrm{ft}$.}

On March 19th and 21st I visited the beautifully situated and well-kept Botanical Garden at HAKGÁLA, some five miles south of Nuwára Eliya and at a considerably lower elevation. Nestling under beetling crags, which form a grand background, it is a glorious blaze of flowers.

Along the road Catophaga paulina was swarming, males with their sweet-briar-like scent appeared to predominate largely. They flew rapidly and always in the same direction-roughly speaking, from south-east to north-west. They frequently flew in strings, just as if they were tied together, and reminded me strongly of the strings of floating stars that are dropped by a certain kind of rocket; I often saw three, four, or five, and once even seven, so following their leader's every movement.

At a turn of the road close by the garden there was a small patch of a tall, but small-flowered Composite plant (Vernonia sp.); this plant did not appear to be common in the district, but it was especially attractive to a black Danaine, which was quite abundant within the limits of the plant's distribution. Chittira fumata, Butl. (peculiar to Ceylon), is very distinct and handsome on the wing, its flight is slow and it is easy to catch, but like all Danaines it has a tough integument and is very tenacious of life. The favoured flower was so attractive to the butterfly that it would even go into deep shade to visit it. Chittira fumata may be said to be gregarious; it has the acetylene odour of Crastia core, but not so strong and with a difference. I made no observation as to the relation of scent to sex in this species, which, by the way, was almost certainly seen at Hatton.

Near this same spot I took one Tirumala septentrionis as well as two Crastia asela, and saw others.

The inevitable Lycaenids were worn Talicada nyseus; Lampides bochus, one; and Polyommatus bacticus, which was common.

It was interesting to watch the pretty little Honey-birds (Dicaeum sp.) feeding at some tall spikes of flowers. 


\section{Horton Plains, alt. $7000 \mathrm{ft}$.}

March 23rd, 1904.

This beautiful district gives some idea of what Ceylon must have been before the era of tea-planting. Situated about $2500 \mathrm{ft}$. above the railway, and approached by steep zigzag paths through rather poor woods, are extensive rolling plains of coarse grass; these patnas are surrounded by woods having a general temperate zone character, but with here and there an epiphytal orchid to remind one that the latitude is but $7^{\circ} \mathrm{N}$. In the more swampy parts of the patnas the devastating work of Wild Pigs was evident enough; we also saw tracks of the so-called Elk, the Sambhur (Cervus unicolor), while paths through woods, and unmistakable droppings, proved that wild Elephants had passed that way not many days before. It was, however, not the season for Butterflies, the air being too exhilarating for their luxurious ways.

About half a dozen Chittirc fumata were seen at elevations of 6000 to $7000 \mathrm{ft}$., mostly at their favourite Vernonia. On the patnas and among sedges in the woods were a few of the Skipper Baracus vittatus; they were not easy to see. I was surprised to come across no other butterflies on these patnas, which seemed the very place for a Marsh Fritillary, a Small Heath, or at least for a Blue; but no, even the eponymous Nissanga patnia was not to be found.

In the woods I took two specimens of the beautiful Lethe daretis, and saw two or three others. They frequented shady paths and flew but a short distance, settling upon a trunk or branch, reminding me strongly of $P$. aegeria in my own garden at Mortehoe. The only Argynnis seen here (or indeed in Ceylon) was A. hyperbius; it was rather common in open spots in woods, the female looking on the wing very like Danaida ehrysippus; a female had the apices of both hind-wings and the anal angle of both fore-wings symmetrically bitten.

Of Terias hecabe I found in a wood a few of the intcrmediatc "dry" form. Neptis curynome ${ }^{1}$ was not uncommon in the woods, flying in its usual ghostly manner, and settling upon leaves of trces. In the same woods Cyaniris lanka was common, but yet it was astonishing to see so few insects in such a locality.

"Col. Bingham, the latest authority, in his "Butterflies of British India," reckoned astola, varmona, and some others of Moore's species as mero forms of eurynome, Westw. 


\section{HAPUTÁLE, alt. $4500 \mathrm{ft}$.}

March 23rd, 1904.

When we got baek at night after our long day on the plains, we found two diseoncerting things: my native servant was drunk, and a hen had laid an egg in my daughter's bed! The latter event was said to portend unusually good luck, but my daughter perversely viewed it otherwise.

At the beautifully situated Rest-house, overlooking the plain and the old eamp of the Boer prisoners, a great many moths came to light. Prominent among these visitors, owing to its numbers, was the small Noctuid, Plotheia decrescens (frontalis), Walk., an extraordinarily variable species; another Noctuid was Cosmophila xanthindyma, Boisd.; there were two Deltoids, Olybana lentalis, Guen., and Rivula basalis, Hmpsn.; the Lymantriid Dasychira inclusa, Walk., and the extremely widely distributed Plemyria (Camptogramma) fluviata, Hübn., which I used to take at Wandsworth many years ago.

The formidable looking beetle, Xylotrupes gideon, Linn., was an uninvited visitor to my bath-room.

On the same day an Acidaliid, Idaea costata, flew into my face in a tunnel near Ohiya station, alt. $5000 \mathrm{ft}$. The railway journey back to Colombo is perhaps the most beautiful that it has been my lot to make.

Colombo, at sea-level.

March 25th and 26th, 1904.

Following Mr. Green's advice, I went to the MIuseum and was well rewarded, though too pressed for time to reap all that I might have gained by a more deliberate examination of the loeal eollection of butterflies.

My colleeting grounds at CoLomBo were the Victoria Park, mueh exposed to the sea-wind; the old Cinnamon Garden, said to be mueh worked for insects by the Museum "boys"; and the old Duteh Cemetery. None of these were very promising or very produetive.

However, I saw here for the first time in Ceylon Danaida chrysippus; I also netted one Parantica aglca, and missed what I thought at the time was Hestia jasonia, Westw.

Precis atlites was common in the Dutch Cemetery, but worn, so was $P$. almana, nearly all of the wet-season form, $P$. astcrie, Linu. ; one speeimen, however, was dwarfed, and another was of the "dry" 
form with the ocelli rudimentary. $P$. almana would appear to be the more prevalent species in Ceylon and Southern India, where it replaces $P$. orithyia, so universal in the North.

I saw several Delias eucharis in the Victoria Park, and once more noticed their fondness for lofty flowering trees; those taken were males. In the same place, what I think must have been the eatilla form of Catopsitia pomona eluded my net; its congener pyranthe was common, and I took two males. Once more Telchinia violcue was common, but of Papilio aristolochicue I have only one to record, of Yphthima ccylonica two.

Of the Blues there were several species. Nacaduba ardates was very abundant and decidedly gregarious, it positively swarmed in Victoria Park, though good specimens were scarce. Everes argiades, Butl., var. parrhasius, Fabr., and Zizera karsandra were also both of them abundant. I took also a single worn specimen of Castalius rosimon.

An immature example of my Pesháwar friend Tryxalis nasuta, taken in Victoria Park, completes the list of my captures in Ceylon, an island that I was truly sorry to leave and that will always occupy a treasured place in my memory.

English is more spoken in Ceylon than in most parts of India, but the Sinhalese appear more noted for fluency than accuracy. The inner meaning of the following apparently strange request of a lad is easy to fathom: "Master, buy some butterflies, ready-made." On getting back to the hotel from an entomological expedition, one of the messengers came up to me and said: "Missie told you to told me they had gone in." 


\title{
CHAPTER III
}

\author{
CHINA，JAPAN, CANADA， 1904
}

\section{STRAITS SETTLEMENTS}

Penang, lat. $4^{\circ} 22^{\prime} \mathrm{N}$.

Good Friday, April 1st, 1904.

After a pleasant voyage across the Indian Ocean, affording the rare experience of a calm so absolute that the glassy sea reflected not only a brig with all sail set, but the clouds above it, the "Malta" called at Penang. In this island port, which owes its marvellous prosperity chiefly to tin, the Chinese are to be seen at their very best. The combination of a British Government with a population mainly Chinese would seem to be a conspicuous success. Whether it be as coolie, as merchant, or even as magistrate, John Chinaman prospers, ousting the native Malay.

It was early in the morning when we arrived, and our stay was very brief, merely giving time for a rapid run round the tomn. Though I caught sight of two large butterflies I made no attempt at pursuit.

We were struck with the artistic merit of the common saucers or bowls out of which, with the aid of chop-sticks, the dock-side coolies ate their frngal breakfast. The Herculean frames of the Chinese 'rikisha coolies were most impressive, especially their huge calves, contrasting with the familiar spindle-shanks of India. How much of Bible phraseology is simply Oriental, c.g. if the Psalmist had lived in a trowser-wearing land he never would have used the words, "Neither delighteth $\mathrm{He}$ in any man's legs"; again in showery Europe one scarcely sees the point of "shaking the dust from of" one's feet."

Naturally enough the local cab-driver has little love for the 'rikisha coolie. A Jehu said to us deprecatingly, "Rikisha man no savez; no speak English." It is pcrhaps as well to explain what Pidgin English is. It may be regarded as essentially Chincse translated directly into English : a few simple English words being strung 
together with Chinese construction. The word "Pidgin," literally "business," has, in combination, come to mean pretty much what "ology" does in modern English.

A traveller on his return home told a friend that Pidgin English was a most flexible language, capable of expressing any idea however complex. His friend said, "I bet you it could not express the idea Archbishop."

"The simplest thing in the world," replied the traveller; "number-one topside Joss-pidgin man."

Joss being God, joss-pidgin is equivalent to Theology or Religion, and the sequence is obvious. Savez, now cosmopolitan, is possibly the only French word in the language. Neither Pidgin French nor Pidgin German is spoken in commercial circles.

\section{Singapore, lat. $1^{\circ} 17^{\prime} \mathrm{N}$.}

April 3rd, 1904.

As the "Malta" was slowly going to her berth in the inner harbour a vulgar "tramp" actually presumed to "take her water," so that to avoid a collision the proud P. \& O. mail steamer was forced to port her helm and in so doing ran down an unfortunate coal lighter. This sank with a gurgle, its crew of two men climbed up our cable unhurt, while the proverbial rat was seen to rise in the patch of black scum which marked the position of the sunken craft, to look round, taking stock of the situation, and swim ashore. The captain's wrath at the disrespectful conduct of the pilot in charge of the trading steamer may be imagined.

We had on board a number of chests of new dollars from the mint, and a smart armed party of Sikh police marched up to take charge of the Government treasure. To avoid the horrors of coaling we went ashore and spent a very hot night at a crowded hotel, but the next morning managed to snatch an hour or two for a visit to the beautiful Botanical Gardens. It might have been expected that the great profusion of flowers would have attracted a proportionate crowd of butterflies, but gardens, especially when so well kept, afford but poor collecting grounds. Moreover, hot though it was, the sun was scarcely bright enough for my fastidious clients. Nevertheless to a naturalist visiting an Equatorial locality for the first time everything is of interest.

The commonest butterflies were Prccis atlites, Johanss., and $P$. almana, Linn., but I did not waste much time in pursuit of them. The single almana brought away was of the "wet" form asteric, Linn.; 
two atlites were a worn "wet," and a fine intermediate " dry " specimen. A female of the crocale form of Catopsilia pomona, Fabr., wass secured. Catochrysops pandava, Horsf., the wet-season form, was in some numbers, as was also Tcrius hccabc, Linn., of which wide-ranging species two males and a female were taken, all of the wet-season form. All these were disappointingly familiar friends, but somewhat more striking (because new to $\mathrm{me}$ ) were Danais aylecides, Feld., and Danaida (Salatura) hcgcsippus, Cram. Of the former I saw but one, of the latter several in the outskirts of the garden. Perhaps the most lovely sight in this lovely garden was a pond filled with the sacred Lotus (Nclumbium speciosum, Willd.) in full flower; but those of the party who were not on entomology intent were hard to please; they complained (most unreasonably as I thought) of the excessive heat, and were glad to leave a place but 77 miles north of the Equator.

\section{HoNGKONG, lat. $22^{\circ} 20^{\prime} \mathrm{N}$.}

$$
\text { April 8th-19th, } 1904 .
$$

Hongkong is well known to be one of the most frequented ports in the world, but surely it is more than this, it is one of the most beautiful. The blue water of its extensive harbour hemmed in by mountains and dotted with rocky islets affords anchorage to countless craft sailing under every flag and varying in build from the clumsy but picturesque junk, and the snake-like destroyer, to the latest type of ocean liner and most modern battle-ship-the whole forming a picture not easily erased from the memory. Among the larger craft are countless row-boats, or sampans, navigated by women, who often have a baby strapped upon their backs, an arrangement apparently equally agreeable to both parties. The city of Victoris is divided into a European and a native quarter. The latter, in spite of the buildings being in great part of Europenn type, is quite picturesque, its streets going up and down steps like Clovelly.

The men's hats are at least as wide as their shoulders, nearly flat with pointed crowns; but porters, the Chinese police, and other minor officials wear hemispherical hats bearing an ideograph with an English number. The men all wear pigtails, women who pretend to be at all above the ruck go in for "golden lilies" and hobble about in the most pitiful way on their little stumps of feet, often helped by women of a lower class, but with more natural organs of locomotion. Bluejackets of several nations hugely enjoy 'rikisha riding. Soon after S.M.S. "Hansa" came into the port an 
enterprising German bar-keeper hoisted a German flag, aud in a very short time had nearly all her liberty-mon drinking inside-like moths at sugar. But superior to every one in the middle of the crowded streets stands the Sikh policeman; very tall and proud, with tightly curled beard and big pagri of many colours, looking down with undisguised contempt upon the motley throng of all races and nationalities.

Hongkong is a strongly fortified naval station, and approach to the fortifications is guarded with commendable jealousy, but the military authorities are not consistently wise. For example, on a prominent building, which must be conspicuous alike from the harbour and from the sea outside, is written up in large letters, "Magazine Road." This unfortunate name quite gratuitously calls the attention of the passer-by, and doubtless of the foreign naval officer, to the well-hidden magazine not far off, to which this house can but serve as a leading mark. Again, on the wall of a wellconcealed modern battery, just below a public footpath, is written up the calibre and description of the armament, with its exact height above the sea-data which would have been equally available to the garrison if painted on the reverse wall of the battery, and so out of sight of the road.

Perched some $1200 \mathrm{ft}$. above the busy city of Victoria, and often enveloped in damp clouds, stands the Peak Hotel, which was our comfortable resting-place, memorable alike for its panoramic view over the harbour to the mountains beyond Kowloon, its excellent " bird's-nest soup," and the luxuriant growth of mould upon our boots and shoes. Even Devonshire had not prepared me for such dampness, indeed the drying-room was one of the most important and best managed departments of the hostel. Communication with the city was by a somewhat alarming funicular railway, which one is forced to use, for otherwise, as a 'rikisha coolie said to me with much truth, "Topside no can."

Convenient paths cut on the sides of the hill afford capital collecting giound, butterflies being most plentiful on the wooded slopes to the east of the city above the Happy Valley. Coming so recently from India, where the results of persistent drought were so painfully in evidence, it was a delightful relief to see the shrubs and trecs all bursting into fresh spring verdure. The first plant to catch the eyc was the small orange-red Azalca (?) sincnsis, then in full bloorn; it constanlly reminded us that this was ueither the coast of Cornwall, nor the Channel Islands, not even the Riviora di P'onente, nor the Bay of Naples. I was yct more pleased to happen upon 
several tall spikes of the handsome ground-orchid, Phuius grandifolius, Lour., which I had long grown in my hot-housc at Putney. ${ }^{1}$

Now for our butterflies. The only Danaincs met with were Radena similis, Linn., of which onc cxample was captured on a Composite flower, and the gorgcous purple-glossed Euploeine, Trepsichrois midamus, Linn. (superba, Herbst). This very striking insect was not uncommon at the flowers of Lantana camara, Linn., indeed what Oriental butterflies did before this Ncotropical Verbeno, was introduced into the East I know not. Be that as it may, I secured two males and four females of midamus. As is so often the case witl members of this group, this butterfly is hard to kill; again, when it is pinched, a yellow juice exudes, which appeared to have no marked taste, but one of the females had such a powerful acetylene-like odour as to be clearly perceptible when in the net.

The Satyrines were represented by Lethe confusa, Auriv., of which two were secured, two Yphthimas, and a Mycalesis. The latter, $M$. mineus, Cram., f. ehinensis, Leech, was rather common; two of the specimens taken were "dry," three "intermediate tending to dry," and one "intermediate tending to wet." Of Yphthima hïbneri, Kirby, which was quite common, four wet-season specimens were taken, two of, two $q$, also two of that were "intermediate wet." Of $Y$. avanta, Moore, two "wet" examples were taken; it was only moderately common; specimens observed at rest did not exhibit the Satyrine habit of "listing."

A little below the Peak, near the funicular railway, I saw three or four Clerome cumeus, Drury - the only Morphine butterfly that I came across during my long journey-it appeared to be a somewhat solitary fly and rather fond of shade; somehow it mas not easy to net and I secured only one specimen.

Curiously enough the only Nymphalines among my Hongkong captures are two Cupha erymanthis, Drury, and two species of N'ptis, though it is possible I may have seen some Precis. Both Ncptis ophiana, Moore, and N. eurynome, Westw. (but ? leucothö̈, Cram.), were fairly common; of the first I brought home two, of the latter five specimens.

In January, 1907, it was my singular good fortnne to come across two plants of this same orchid in the Mahogany Wood, Rockalva estate, Ramble, Jamaica. This extraordinary instance of wide distribution oxcited the admiration of P. H. Gosse ["A Natnralist's Sojourn in Jamaica, 1851," p. 137, where the plant is giren its synonym $P$. tankervilliae, Dryand.]. I lave, however, been informed since by Mr. W. Fawcett that this plant was introdueed into Jamaica about 120 years ago, and is now common all ovor tho islaud. See Fawcett and Rendle, "Flora of Jamaica," Vol. I., pp. 108-109. 
Five Abisara ccherius, Stoll, and a single Zcmcros flcgyas, Cram., represent the Erycinidac; the former was locally common.

As a family the Lycaenidae were by no means numerous, though Zizera argia, Ménét., f. similis, Moore, was certainly abundant: it did not object to flying when the sun was obscured, or even when rain was falling. The other Blues were Iraota timolcon, Stoll, looking like large Thccla qucrcus, Linn., of which I took two; and Lcherca eryx, Linn,, a Hair-streak with a green underside like our T. rubi, Linn., of this I secured but a single worn specimen.

The Pierines appeared to be neither numerous nor remarkable. The Common White of the island was Ganoris canidia, Sparrm.; a $f$ yielded a most distinct scent of the sweet-briar type. Huphina ncrissa, Fabr., f. coronis, Cram., was not common; the two taken, $\delta$ and $q$, were of the wet-season form. On the other hand, there were plenty of Tcrias hecabc, but the ot and two of brought home were all "dry." I secured but a single example of Catopsitia pyranthe, linn., a of of the form gnoma, Fabr.; this yielded a distinct, but not strong, jasmine-like scent.

But if the Hongkong Pierines are insignificant the same complaint cannot be made of the Papilionines, which were very much in evidence, being both numerous and varied. Of the widely distributed Papitio pammon, linn., which was common enough, I took two males. Of $P$. helenus, Linn., I got four specimens, one of them decidedly small; the creamy patch on the hind-wing of this butterfly is very conspicuous as it flies. Then again there was the handsome P. paris, Linn., swift and hard to catch; of the four specimens that I managed to secure one had large pieces (apparently) bitten out of all four wings almost symmetrically. Less common than the three preceding were $P$. telephus, Feld., and $P$. bianor, Cram., both taken at Lantana flowers, and lastly the handsome long-tailed yellow and black $P$. untiphates, Cram. (alcibiadcs, Fabr.), which, though not scarce, proved to be wary and hard to catch.

The Skippers were also represented by six species: the dingy Parnara bromus, Leech, three; $P$. pellucidus, Murray, four ; Iambrix salsala, Moore, two; Suastus gremius, Fabr., one; the nearly black Astictopterus henrici, Holland, which was common; while of the bright tawny Telicota augias, linn., I took two males.

One circumstance struck ine as remarkable: in the "Happy Valley," beyond the cemetery, the ground was so foulcd with human excrement as to make collecting difficult, yet clouds of butterflics (Papilio, of inore than one species, Trepsichrois, and Ganoris) fluttered about the Lantana bushes growing around. There was no evidence 
that the insects were attracted by the ordure, but of a certainty they were not repelled by its stench. ${ }^{1}$ Yet experience of collecting in England (especially of sugaring) has convinced me that moths avoid the neighbourhood of dung-hills, ashpits, and refuse heaps.

Another circumstance worth noting is that close by the Lantans. was a quantity of another Verbenaceous plant with blue flowers (probably a Stachytarphcta) which appeared to be scentless. This attracted swarms of the common Ganoris, but not a Papilio or Trepsichrois; perhaps the tube of this flower was too small for the proboscis of the larger butterflies.

Day-flying moths are quite a feature of Hongkong, and several notable sorts turned up. Of Chalcosice thallo, Linn., only one was taken, but of another moth belonging to the same group, the black and white, red-headed Pidorus glaucopis, Drury, I got six; a single individual of Euschema (Dysphania) militaris, Linn., a big gaudy slow-flying Geometer with black and yellow colouring, brought vividly to mind our own Arctia villica, though it is even more like the Chalcosiine Canerkes cuschemoidcs, Moore. Another Geometer that made itself obvious was the large yellow and fuscous Magpie, Obeidia tigrata, Guen.; this has a somewhat slow flight, and on the wing often looks like a yellow butterfly; it was abundant and decidedly gregarious, many flying about one tree in the afternoon. When pinched it exudes a yellow juice having a bitter taste. I do not appear to have examined it for scent, but whether or no it possesses an evil odour, it has other characteristics of a protected species. At flowers I took single specimens of the fuscous and white Lcptosoma celsum, Walk., and the orange-headed, black and white Macrobrochis gigas, Walk., both belonging to the Hypsidae. At flower's there was also a yellow-under-winged Agaristid, Zalissa albifaseia, Walk. (var.).

Another day-flying moth belonging to quite a different group, the Lymantriidae, was a smoky-grey and white Pantana not represented in the British Museum. Mr. Druce told me that it agreed with a species described by him from a specimen taken on the Chinese mainland under the name of curygania. I gave Sir George Hampson a specimen which stood in the collection at Cromwcll Road for some time as Pantana eurygania, Druce. Subsequently, however, Col. C. Swinhoe examined it, and satisfied Sir George that it was distinct firom Druce's species, and described it as $P$. droa, sp.nov. ${ }^{2}$ I found the males flying freely among pine trees above the Happy Valley,

I Sec above, p. 83 ; compare Trans. Ent. Soc. Jond., 1906, p. 315.

= Amm. Mag. Nat. Hist., 7 th Ser, vol. 17, p.513 (1206). "Nearest to P. Icrminata, Walk., from Burma." 
they did not seem to mind a certain amount of rain. It is surprising that so conspicuous an insect should not have been recorded before. (See Plate I., Fig. 2.)

At rest upon a rock, looking just like a piece of lichen, was the Lithosiid Parasiccia punctatissima, Pouj., while one afternoon I happened upon a fine freshly emerged specimen of Actias selene, Hübn., sitting on a plant; a day or two later another came to the hotel lights during dinner.

The handsome blue Cicada, Geana maculate, Fabr., was in abundance, flying slowly from tree to tree.

On some nights the gas-lamps outside the Peak Hotel proved very attractive. The Arctiids were represented by one Utethcisa pulchella, Linn., and two males of the very variable Ermine, Diacrisia obliqua, Walk.; the Lymantriids by one Euproctis varians, Walk., and a female Aroa socrus, Geyer (substrigosa, Walk.); the Limacods supplied a single Thosec sinensis, Walk.; there was also a solitary Nolid, Celama mumila, Snell. The Geometers on the other hand were somewhat more numerous, including Craspedia propinquaria, Leech, a small species resembling Eois bisetatc, which came freely, and was also taken by day at rest on a leaf, and a single example of a somewhat larger insect with curiously formed hind-wings, Krananda latimarginaria, ${ }^{1}$ Leech.

Besides the larger insects there were two of the delicate creamy, black-dotted Pyrale, Entephria cudicalis, Walk., and one of the Crambid, Charltona kala, Swinh.; together with these were a number of females of a Phycid which does not seem to be the same as any in the British Museum, but which Sir George Hampson is unable to determine in the absence of any male specimen.

An English lady, the wife of an officer of marines, who had spent some time in Hongkong, told us that somewhat remarkable theological results may follow from the too common practice of leaving English children under the charge of Chinese nurses.

SCENe.-A Hongkong drawing-room. A precocious little girl discovered playing with toys in the centre of the stage, around arc Papa, Mamma, and other ladies and gentlemen drinking tea.

(A loud clap of thunder is hcard without.)

Child, looking up from its play: "Big Topside man makee muchee tumtum; welly angly."

1 At first I described this as a now spocies in the Entomologist's Monthly Magazine $(1905$, p. 184) as Orsonoba orthogrammaria. There wero extenuating circumstances tending to condone the error, but it is not neccssary to detail them. 
Papa: "Who is Big Topside man?"

Child: "He live in Church, has black whiskers and black boots." (Sensation.)

$$
\begin{gathered}
\text { Macao, lat. } 22^{\circ} 21^{\prime} \mathrm{N} . \\
\text { April 12th, } 1904 .
\end{gathered}
$$

The small steamer that plies between Hongkong, Macao, and Canton afforded a new experience. Soon after starting I was much surprised on going below to see a stalwart quarter-master marching up and down with a Winchester repeating rifle over his shoulder. On asking this formidable individual for an explanation I found that the Chinese third-class passengers were coufined to the lower deck, being kept there by steel grids covering the hatchways and padlocked down! It would appear that the natives of the country about the Chu Kiang, mostly pirates by descent, have not yet entirely abandoned that profession,

"And it is, it is a glorious thing

To be a Pirate King!"

More than once in comparatively recent times the rascally passengers have risen and seized the vessels employed in this trade, so that the owners have found it necessary to supply sufficient stands of arms for the European members of the crew.

On this voyage fortunately no rising was attempted, and we reached the typically Portuguese town of MACAO in due course. This tiny settlement looks for all the world like a bit of Funchal, but that its streets are full of Chinamen, its harbour of junks and sampans. The forenoon of the next day was devoted to entomology, but un fortunately most of the available time was spent in looking for a good collecting ground. The country beyond the Portuguese boundary produced little besides the big Dragon-flies, which coursed up and down the innumerable ditches-appropriate enough to China. A visit to the very interesting garden of a wealthy Chinese produced nought but Terias hecabe; subsequent examination proved my three specimens to be respectively a fine large male of the wet-season form, a female of the dry-season form, which lacked the "dog's-head mark," and a similar female of extreme "dry" type.

A scrap of rough ground at the north-eastern corner of the settlement seemed the most promising spot, but by the time that I discovered it the day was far advanced. Here Ganoris canidia, the only White seen, was in abundance; a $q$ was very dark, a of had a fairly strong sweet-briar sceut. The little Blue, Zizcra argia, f. 
similis, was also abundant. Somewhat less numcrous were Neptis eurynome and Papilio pammon, of the latter two males and a female of Wallace's Form I. (cyrus, Fabr.) were taken. In addition to these were a fair number of the handsome purple-glossed Crastia amymone, Godart, f. Kinbergi, Wllgrn.; a female was observed to be hard to kill, while several males exhibited the acetylene odour, in one instance strong enough to be obvious when the butterfly was fluttering in the net. A single example of Mycalesis minens, f. chincnsis, together with the day-flying Chalcosiine moth Pintia ferrea, Walk., complete the short list. It would seem that I failed to hit upon the collecting ground of which Mr. Freedley had spoken to me so enthusiastically at Kandy. This day I tried my hand at Pidgin English, and found that I was quite understood when I said of the butterflies to an onlooker : "Fly muchee ${ }^{1}$ fast : I old man no catchee can."

\section{Canton, lat. $23^{\circ} 8^{\prime} \mathrm{N}$. \\ April 14th, 1904.}

On the way up the Chu Kiang the most prominent object is Tiger Hill, standing opposite the famous Bogue Forts. This would appear to be one mass of rock, unbroken by either joint or bedding, and must weigh millions of tons, exceeding in size even the rocks $I$ had seen in Southern India.

As we neared the landing-place the pack of sampans reminded me of Henley, especially as the propulsive power was mainly obtained from other boats, rowing being out of the question. Our boat-woman proved more than a match for all comers, alike in skilful navigation and in the readiness of her glib tongue. One felt instinctively that she boldly said what a man at Henley would scarce have dared to thint.

We were carried in chairs, three men to each, through the streets of CANTON, the most interesting city that it has been my lot to visit, so full is it of strange life and vivid colour. The architecture is disappointing, but the streets, 7 feet wide, and their yellow, squinnyeyed, flat-faced occupants are most fascinating. We had some difficulty in diagnosing the comestibles exposed for sale, but believe that we did make out strings of dried rats, and possibly bêches-demer and birds' nests for soup. When I asked our excellent guidc, Ah Sing, whether it was true that his countrymen ate dogs, he replied: "My countrymen, sir, are poor, they cat everything." The Chinese shopkeepers advertise their wares in such a way as to adorn,

"A Pidgin English scholar says "plenty" is the correct word. 
not to disfigure the city. As you look up or down a street hanging boards a foot or so wide and 5 to 10 feet long call attention to the names of the tradesmen and the nature of their wares, set forth in ideographs of white, black, or gold "upon a ground of blue, vermilion, or emerald green. The characters are picturesque in themselves, and the Chinese are unrivalled in their successful use of the boldest colour contrasts. There are no models or paintings of the goods for sale, such as were quite general in Prague forty years ago, so that it is fair to surmise that a large proportion of the population can read the difficult writing-writing, remember, in which each character (ideograph) represents not a letter, but a thing or idea. It is said to be necessary to learn 3000 to 4000 ideographs before one can read fairly fluently. One consequence is that a Japanese or a Chinaman can read the ideographs written by a man speaking a language quite foreign to him, a fact that proved of great advantage to the Japanese in their recent wars. Colour may be said to culminate in the Chinese pawnshop. There is no prejudice against pawning, and it has such obvious advantages that men in temporary straits think nothing of pledging their lovely embroidered garments.

Yet the native town of Canton is not the place that any one would choose to live in; it appeals strongly to other senses than those of sight. ${ }^{1}$

As in duty bound we were introduced to the executioner, but found that official somewhat depressed by slackness of trade. My late friend, Mr. E. A. Bonner, some two or three years previously had a great stroke of luck, for he looked in just in time to see seventeen heathen Chinese decapitated! It was said that in the fifties, in the days of Governor $\mathrm{Yeh}$, the executioner was chosen by competitive examination of a highly practical character. The fortunate successful candidate was he who never failed to strike off a head at one blow. Such an ordeal required both skill and endurance.

Somewhat less practical were the examinations which have been conducted by the Civil Service Commissioners of China-or their equivalents-from time immemorial. The so-called Examination Hall is an area of several acres enclosed by lofty fortified walls, within which stand countless tiny houses or stalls, 6 feet $\times 4$ feet. It is said there are 11,600 of these torture chambers, within which as many unhappy candidates toiled nervously at their old-time papers on the doctrines of Confucius, under the glaring eyes of the examiners, who invigilated on lofty towers in the midst. Three ordeals of

1 It may, howevor, well bo doubted whether in the matter of evil odours Canton excels some parts of Marseillo. 
24 hours each reduced the applicants to 88 , who then had to go to far Pekin for a further process of elimination. The happy survivors, sooner or later, obtained appointments in the public service. And so it befell that this, the oldest and most elaborate Examination System that the world has seen, resulted in-perhaps the most incompetent body of officials in the world. I use the past tense, for we were told that the examination held the year before our visit was the last of the old régime-for in these days even China moves, or at any rate talks of moving.

Though the Canton Examination Hall is not much like the Schools of my own University, yet it seemed appropriate to take from such a spot some few specimens to enrich the cabinets of the Hope Department of the Oxford Museum. The courtyard was weedy enough to harbour such a domestic-looking butterfly as Ganoris canidia, one of them a dwarf, as well as the more interesting Grapta aureum, Linn., the Oriental Comma, which was flying about in some numbers. I also secured a single example of the Acraeine, Parebc vestc, Fabr., the only one that I have seen alive.

In the somewhat dreary and prison-like British Concession the insignificant Zizerce argia, f. similis, was to be seen in abundance.

The voyage northwards along the China Coast is remarkable for the number of stacks, or isolated rocks, most of them bearing lonely lighthouses. We wondered much how the fishermen dared go so far out in the picturesque, but cumbrous and ill-sailing junks, and heard tales of the frightful losses in typhoons. But were the ships of our own navy between the days of Alfred and the Great Harry so very different?

On the night of April 23rd, after lcaving Shanghai, when ncar the mouth of the Yang-tse-Kiang, a Cirphis (Leucania) unipuncta, Haw., came to the lights of the "Empress of India." It is a farranging species.

Whenever I have secn the Red Sea it has bcen blue, but we found the Yellow Sea true to its name. A Londoner like myself may venture to think that he knows something about fog; if, also like myself, he has becn up the St. Lawrence and on the Banks of Newfoundland, he is apt to think he knows all about fog. Imagine, then, my surprise on learning from the captain that in the southern part of the Yellow Sea fog is so prevalent that it is often difficult to "make" Japan. 


\title{
JAPAN.
}

\author{
NAGASAKI, lat. $32^{\circ} 45^{\prime} \mathrm{N}$. \\ April 25th, 1904.
}

Japan! The land of incongruities.

We were guided into the harbour by a Government launch, for the Russian war was in full swing, and we had to thread our way through a mine field! A nation until recently one of the most conservative in the world, does not neglect any modern invention likely to be of service in its mighty struggle with the Colossus of the North.

The recurring necessity of eoaling gave us the opportunity of landing, so we left the merry little Japanese women to their grimy task, and crossed over the hill to MOGI, a small fishing village on the other side of the peninsula. The country was pretty and all arrayed in bright spring colours. The crops were trim and tidy, the woods every shade of emerald and bronze, the wild flowers mostly of English type, e.g. two sorts of scentless Violet, a Potentilla, and the good old Dandelion. A prominent plant new to me was like Lucerne, but smaller, and with flowers the eolour of Thrift; being used for fodder it gave much brilliance to the landscape both here and in other parts of the eountry. On the way to and fro (all too short) I got some delightful collecting. The Fauna even more than the Flora afforded illustrations of the strange mixture of the Oriental with the Palaearetic which is so charaeteristic of the Japanese arehipelago, and which is, presumably, most marked in the southern island Kiusiu. Thus both Zizera maha, Koll., f. diluta, Feld., and Cyaniris ladonides, de l'Orza, had a very Palaearctic look, and the same may be said of the handsome Satyr with the terrible name, Blanaida (Neope) goschlevitschii, Ménét., of which several were seen, reminding me of large Pararge megaera, Linn. Moreover, even the fine Papilio xuthulus, Brem, is a good deal like $P$. machaon, Linn. On the other hand, the brown Papilio alcinous, Klug, has a distinctly Eastern look, while true Oriental magnificenee was reached by the splcndid blue-green Papilio (probably maacki, Ménét.) that I saw in the road and missed in spite of the polite assistance of a Japanese gentleman who was passing by and marked it for me. $P$. alcinous was quite eommon, and I secured two $\delta$ and one $q$. Unfortunately I did not examine this species for scent; Leech, quoting Pryer, says: "The of emits a pcculiarly sweet, musky odour 
when alive. The $q$ also emits a fainter odour, but to me this is as unpleasant as that of the of is pleasant." 1

Continued rain spoiled the voyage through the Inland Sea. Its picturesqueness cannot be what it once was, for the junks have disappeared and all the fishing craft are schooner-rigged and more or less European (or perhaps American) in build. For did not the Mikado, after receiving the report of an Imperial Commission, issue an edict that "On and after such a date, every fishing boat should ..."? Surely nothing less imperious could have changed the immemorial practice of such conservatives as fisher-folk are all the world over.

We duly reached KoBÉ, and after an inspection by the most polite of Medical officers landed and took train to Куо̆то. Two things impressed us on this journey: (1) the extraordinary noise made by the numerous passengers walking about the stations in wooden clogs of simple construction; they are held on by straps from a pin which passes between the big toe and the next. (2) The advertisements in the fields,

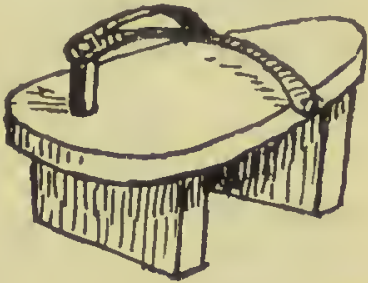

FIG. 6.-Japanese Clog. more especially near the stations. England and America seemed to be outdone. Some of the signs were grotesque, a few artistic, but all insolent in their aggressiveness.

\section{Куо̄то, lat. $35^{\circ} 3^{\prime} \mathrm{N}$.}

April 28th-May 4th, 1904.

On coming out of the station we received a rude shock-everywhere telegraph poles and telephone wires, electric lights and electric trams! And this in the old capital of Japan; truly we had come too late.

However, a further acquaintance with the city reassured us somewhat, for we found all the women wearing the traditional national costume. Most of the men also wear native garments but in their case the effect was too often spoiled by the addition of a European hat or cap. The upper garments of adults of both sexes are usually of quite sombre colours, and give to the crowd a monotonous appearance that we had not anticipated. It is true that the under kimono (corresponding to the European petticoat) is commonly red, or of

'J. H. Leech, "Buttorflies of China and Japan," p. 511, quoting H. Pryer, "Rhopalocera Niphonica," 1886, p. 4. 
other bright tint, but this is rarely visible. The universal dark grey roof-tiles largely contribute to the dinginess of a Japancse town-a dinginess that was relieved mainly by the Wistarias now in full flower, and the quantity of red and white bunting displayed on all sides, for it was war time. There is one other pleasant piece of colour in a Japanese city, all jinrikisha men, licensed porters, street orderlies and such-like folk wear a very picturesque blue drcss, in cut somewhat suggestive of that of a knavc in an old-fashioned pack of cards, and adorned with large white ideographs.

The great war with Russia then in progress showed itsclf in various other ways. For instance, picture post-cards and other representations of incidents in the war, real or imaginary, were much in evidence, affording a strange combination of modern realism of the most sensational type with the traditional Japanese art. One night we went to the theatre, where we saw a patriotic war play. It was the high melodrama of old in an Eastern setting, quite outdoing the glories of Astley's. Men died several times over with the most vigorous contortions, and there was no lack of smoke and redfire. The drama culminated in a Russian railway troop-train, which entered thc house from behind the audience and passed by an elcvated track above the heads of the spectators in pit and stalls on to the stage. Of course it was blown up, but that was not enough to gratify patriotism, and somehow it finished its wild career by going to the bottom of Lake Baikal, to the huge delight of the audience.

More sober and far morc interesting was the procession of 1500 studcnts with red paper lanterus through the streets of KirōTo in commemoration of the recent victory on the Yalu. The crowd was cnthusiastic, but I thought tempered by a realization of the costfor the Japanese seemed to feel greatly the loss of life. I was with a party of ladies - suddenly the passing students realized that we were English and rushed at us to shake hands. For some minutes I was shaking hands (both) with as many as could get at me! There is no doubt that at the time of our visit the English were very popular.

Such time as could bc suatched from sight-seeing and curio hunting was utilized in short excursions to the woodcd hills around, with, as will be seen, but vcry moderate results.

The large Satyr Blanaida goschlicvitschii was common. The hindwing of this butterfly is markedly fluted, like that of Pararge acgeria. ${ }^{1}$ A specimen at rest on a rock at Chüdó had no list, but the sum

1 Longstaff, Ent. Month. Mag., and Scr., Vol. siv., 1903, p. 255. 
was not shiming at the time, and another specimen found nearer the city listed some $15^{\circ}$ to either side. The only other Satyrine butterfly met with was Yphthima philomela, Johanss., f. zodia, Butl., being the extrcme wet-season form; five specimens were taken close to the town. The hind-wing is fluted as in the preceding species.

The commonest Nymphaline seen was Ncptis eurynome, thc spring form, called by Moorc sangaica. Of the familiar Palaearctic Grapta C-album, Linn., I took a single specimen.

The Blues were represented by five species, but only one of them, Curctis paracuta, de Nicév., with underside gleaming silver-white, was of distinctly Oriental character; of this a single individual was captured in a wood near Kyōto. The insignificant Zizera maha, f. cilutc, as well as Everes argiades, Pallas, f. hellotia, Ménét., would seem to be widely distributed in Japan, but the commonest Blue in the Kyōto district was Cyaniris ladonides. The Small Copper, Chrysophanus phlaeas, Linn., f. turcicus, Gerh., naturally reminded one of home; it was common at Kyoto, and also occurred at Arashiyama, some five miles to the westward.

At most places that I have visited there is a Common White; at the old Japanese capital, and in the neighbourhood, e.g. at Kami Sakomoto, and Arashiyama, this was Ganoris melete. ${ }^{1}$ The of has a distinct, fairly strong, lemon-verbena scent, a fact confirmed by Major H. A. Pratt, R.A.; this butterfly is very nearly related to our G. napi, which is well known to have the same scent.

Terias hecabe, f. anenome, Feld. (? mandarina, de l'Orza), without black markings, was common in the woods at the foot of Mt. Hieizan and also at Arashiyama; those taken were of the wet-season form. Of the singularly shaped Orange-tip Euchlö̈ scolymus, Butl., three specimens were secured.

The three Swallow-tails, Papilio demetrius, Cram., P. machann, Linn., and $P$. xuthulus (the spring form of xuthus, Linn.), were all common, indeed one or other of the yellow spccies was not infrequently seen in the principal streets, where it seemed quitc in keeping with its artistic surroundings.

Two specimens of the black Halpe varia, Murray, occurrcd on Mt. Hieizan-rising about $2700 \mathrm{ft}$. some four miles to the north-east of the city; with them were several of the commoncr Japanese

${ }^{1}$ Dr. F. A. Dixey says that my specimons do not agroe with Múnćtriés' deseription, but do agree with Lcoch's figure. They are the G. aglaope, Motsehulsky, whieh is idontical with megamera, Butl, and is, according to Lcoch, tho Japanoso spring form of melete, Ménétriés. 
Skipper Tagiadcs montanus, Brcm., an insect that rcminded me of Euclidia glyphica, Linn.

I took but few moths at Kyōto: Anagoga indictinaria, Brem., was common in pine-woods; of Abraxas miranda, Butl., I got two; but of the curious day-flier, Pterodecta gloriosa, Butl. (felderi, Brem.), I only secured one, while Zettienia albonotaria, Brem., came to light.

The Dragon-fly Mnais costalis, Selys, was to be had in abundance, but of the Caddis-fly Perissoneura paradoxa, McLachl., I rot but one. On Mt. Hieizan I captured one of the pretty Cicindela japonica, Guér., while the allied Calochroa chinensis, Cram., was rather common; on the same mountain one Carabus eccopterus, $\mathrm{K} z$., was secured.

\section{The Nakasendō.}

May 7th-May 10th, 1904.

Our best view of Japanese scenery, and incomparably our best insight into the ways and manners of a most interesting people, was gained on our four days' journey, partly on foot, partly by jinrikisha, along so much of the old high road from Kyōto to Tōkyō (known as the Nakasendo,, or Central Mountain Road), as extends from Nakatsugawa to Oya, 109 miles.

The road lies entirely within the inland province of Shinshu; probably no part of it is less than $1000 \mathrm{ft}$. above the sea, the greater part between 2000 and $3000 \mathrm{ft}$. It is rough and in parts barely passable for jinrikishas, especially where it crosses the three passes:-Torii-tōge, $3150 \mathrm{ft}$; Shiojiri-tōge, $3340 \mathrm{ft}$; and Wadatōge, $5300 \mathrm{ft}$.

Our first acquaintance with a native iun was made at NAkATSUGAWA; on approaching the door I was not a little disconcerted by the landlady and her daugliter prostrating themselves on either hand and touching the ground with thcir foreheads! No English guide to ctiquette tclls one what to do under such trying circumstances; which should be picked up first, mother or daughter?

Again, what was one to do when shown to onc's room? This was a box of wooden frame-work, at least three sides consisting of sliding shutters with paper pancls; the floor covered with exquisite matting spotlessly clean. On the one immovable side, in an alcove, hung the onc kakemono; on a shelf stood the one curio and the one flowerspray in water. In the centre of the room stood a table some ten 
inches high for tea, and by it an iron, or bronze, brazier for kettle, pipe, and the warming of hands. Voilà tout! Anything more absolutely unlike the busy fussiness of an English lady's boudoir $\grave{a}$ la Japonais could scarcely be conceived. What, I repeat, was one to do? As a fact I sat down on the floor and felt like a new doll plumped down in a strange doll's house. While thus engaged, or it might be while dressing or undressing, a panel in the wall would noiselessly open, and a woman enter, cross the room, and disappear ghost-like through the opposite wall (for it is possible to walk right through a Japanese house in any direction). As the intruding lady manifested neither surprise nor abashment at my presence, why should I object to hers?

In these country inns the bedding consists of a number of very thick cotton quilts laid upon the floor, the guest insinuates himself at any desired level, under one, two, or three quilts according to the temperature-an excellent arrangement. Washing is done in a copper basin at a sink in the public passage, where soap is allowed; not so in the hot bath, the great Japanese institution. Out of deference to our prejudices we were taken one by one to the bathroom, and as a very special attention the hand-maiden closed the door. The natives sit in rows in the bath, usually with the door open. A clergyman who has spent many years in the country told me that when the Mikado not long ago issued an edict stopping mixed bathing, the police in some cases, as a transition measure, were satisfied if a string was stretched across the bath with notices on either side: "for ladies," and, "for gentlemen!"

Mais, revenons à nos moutons: several butterflies were taken the first day, May 7th, along the lower part of the road, ${ }^{1}$ i.e. below $2000 \mathrm{ft}$; s such were the big before-mentioned Satyr Blanaida gosctulievitschii, of which but one was captured, though others were seen ; Argynnis anadyomene, Feld., a Fritillary recalling paphia, of which two were taken on mud in the road; Dichorrhagia nesimachus, Boisd., a nearly black Nymphaline butterfly with a weak fluttering flight, of which a single specimen was taken on a white dusty road, whcre, with its wings fully expanded and appressed to the surface, it was very conspicuous; our old friend Pyrameis cardui turned up, a worn specimen; of Libythca lepita, Moore, one was taken and another seen, both by the road on the first day of the expedition; three Swallow-tails come into the same category-Papilio maeilcutus,

1 This was written four yoars aftor tho journey, and as my notos do not in all cases give tho dotails it is quito possible that some of these spocies may have been seen at greater olevations. 
Janson, and $P$.demetrius, which were common, and $P$. bianor (dehaani, Feld.), of which several were seen.

Some species, on the other hand, were not met with (or at any rate not captured) below $2000 \mathrm{ft}$., and were mostly seen between that altitude and $3000 \mathrm{ft}$. Such were Vanessa io, Linn., of which I took a somewhat small and dull coloured specimen, and Major Pratt saw another; $V$. antiopa, Linn., a specimen was seen by Mrs. Pratt; of the common Blues, Cyaniris ladonides and Everes argiades, var. hollotia, two each were taken, on the Shiojiri-tōge, ${ }^{1}$ at about $3100 \mathrm{ft}$. I secured two of the very distinct Satsuma ferrea, Butl., which is steely-blue above, black beneath, with gimped wing marginsvery Japanese-looking. Pierines were fairly numerous; females of Gonepteryx rhamni, Linn., were abundant up to $3000 \mathrm{ft}$., especially above Fukushima; one specimen had been so pecked by a bird as to make a notch on all four wings in the part where they overlap when the butterfly is at rest; only a single female was netted, and this was faded and worn as if it had hibernated. Of Leptosia amurensis, Ménét., the Eastern form of our Wood-White, several were taken on the Shiojiri-tōge; flying with it was the even more familiar Ganoris rapac, linn. The males of the last-named had the characteristic sweet-briar scent; a female was very dark. At about $2000 \mathrm{ft}$. I was much interested in taking a specimen of Parnassius citrinarius, Motsch.; possibly others were seen, but it was not practicable to stop to pursue them. Near Wada, circa $3500 \mathrm{ft}$., at about 3 p.m. ou May 10th, a gorgeous peacock-blue Swallow-tail was seen quietly flitting to and fro over a small flooded paddy-field; at first it looked as if wet feet and muddy legs would be needed for its capture, but patience was rewarded, the sacrifice proved unnecessary, and a magnificent specimen of Papilio maackii, Ménét. (tutanus, Fenton) was secured. It is possible that a butterfly seen on May 7th, on lower ground, belonged to the same species. [Plate I., Fig. 5.]

To this list of Highland forms may be added Hespcria maculata, Brem. \& Grey, like our Syrichthus malvae, Linn., but handsomer; it was common above $2300 \mathrm{ft}$. Another Skipper, Tagiadcs montanus, which was common throughout the journey, occurred at the summit of the Torii-tōge, at a height of $4000 \mathrm{ft}$.

Other butterflies that were found indifferently on higher and lower ground were Neptis sangaica (this was, however, distiuctly commoner the first day, on the lower part of the road); Euchloë scolymus, whieh was not common; Ganoris mclctc, in some numbers,

$$
\text { ' N.B.-Tògo = pass, } \left.\left.\begin{array}{l}
\text { San, Zan } \\
\text { Yama }
\end{array}\right\}=\text { mountain, } \begin{array}{l}
\text { Kawa } \\
\text { Gawa }
\end{array}\right\}=\text { rirer, Shima = island. }
$$


the male with a strong lemon-verbena scent; and Colias poliographus, Motsch. (the Far-Eastern form of hyalc, auct.). This last, the Japancse Pale Clouded Yellow, occurred on each day of the expedition, but between Niegawa and Shimono-suwa, at from 2000 to $3000 \mathrm{ft}$., was quite abundant-indeed I even succeeded in netting a specimen from my jinrikisha! Papilio machaon (several of the specimens very pale) and $P$. xuthulus were both common throughout, the latter extending up to our highest point, $5500 \mathrm{ft}$., above the summit of the Wada-tōge.

I only brought away two moths from this expedition, both Geometers. Abraxas miranda occurred at about $2000 \mathrm{ft}$., while Panagra petraria, Hübn., was found in a wood at about $3500 \mathrm{ft}$.

The Caddis-fly Stenopsyche griseipennis, McLachl., came to light at Oya, circa $2000 \mathrm{ft}$., on May 10th. The next morning I took at the same place Chrysophanus turcicus.

At Karuizawa, $3300 \mathrm{ft}$., on May 11th, I met with Pyrameis indica, Herbst, as well as the large Notodonta-like Geometer, Pachyligia dolosa, Butl., while the small black Arctiid Diacrisia caesurea, Goeze (Chelonia luctifcra, Esp.), came to light.

On May 12 th we ascended Asama-Yama, $8280 \mathrm{ft}$., the highest of the active volcanoes of Japan. The ascent is quite easy, being for the most part over small scoria, but we were unfortunate in our weather. The strong smell of sulphur declared our proximity to the crater, but the cloud was so dense that we literally could not see more than five yards; moreover, the wind was so strong that it drove the rain horizontally, while every now and then a stronger gust than usual sent us staggering. Any idea of a view was out of the question, and common prudence suggested that our position was not without danger, so we had to beat a rapid retreat. The next morning it was tantalizing to see from the train the summit of Asama-Yama far above the clouds, with a wreath of steam slowly rising from the crater-the very ideal of peaceful repose.

\section{N'IKko, lat. $36^{\circ} 45^{\prime} \mathrm{N}$. alt. circa $2000 \mathrm{ft}$.}

$$
\text { May } 15 \text { th }-17 \text { th, } 1904 .
$$

Quite apart from the wonderful temples, the great Cryptomcria avenue, and the curio-shops, Nikкo left a most vivid entomological impression on my mind.

Together with the now familiar Blanaida goschkevitschii was the wet-season form of the comparatively insignificant Yphthima zodia. In a wood at the foot of Toyama, at an altitude of some $2100 \mathrm{ft}$, the 
pretty Araschnia burejana, Brem., was not uncommon; Neptis sangaica was in larger numbers, while but two Grapta C'album were taken. The Blues were represented by two Everes argiades, f. Tellotia, but at the summit of the small wooded hill Toyama Cyanirisladonides was in abundance though worn. This pretty knoll culminates in a tiny ruined temple of very remarkable construction. It is of wood to which thin slabs of lava are cramped vertically, just as weatherboarding is fixed on old river-side cottages in England. Near Kyōto, on Mt. Hieizan, we had seen a granite bridge of essentially timber construction, with mortices and tenons, and even wedges, all of granite. At Fathipur Sikri we had seen the famous local red-sandstone used so as to imitate roof tiles and wooden beams. This precedence of the joiner's craft in the East is a curious contrast to the history of the building arts in mediaeval Europe, for our cathedrals and churches clearly show that joinery in the West developed from masonry.

Around that tiny fane, quite indifferent to its structural peculiarities, coursed innumerable Swallow-tails of four species. Of these, Papilio demetrius is represented by but one specimen in my collection. but $P$. bianor, and the magnificent $P$. maacliir, were both in abundance, while with them, in even greater numbers, was $P$.' machaon, often flying in threes and fours together. Machaon would occasionally settle on an Azalea flower; not so the others. None of these Papilios were common on the sides, or at the foot of the hill. Why did they behave in this manner? I wish I could tell whether both sexes were so occupied.

Other common Nikko butterflies were Colias poliographus and Papilio macilentus. Late in the afternoon I was able to catch the latter in my fingers; the Papilios take a long time selecting their night quarters, and are then very leisurely in their movements. Of Ganoris melete I took but one at Nikko, a female; of the Skipper Tagiades montanus I captured two, one on Toyama, the other at Chuzengi at a height of $4000 \mathrm{ft}$. Another Skipper, the pretty black and white Daimio tethys, Ménét., was abundant, especially on the slopes of Toyama; though conspicuous when settled, it was hard to follow on the wing.

At Nikko a fair number of moths were secured; conspicuous among them was the singular Ptcrodecta gloriosa, a day-flyer which I had previously met with at Kami Sakamoto, near Kyōto. Another day-flyer was the Ermine Diacrisia punctaria, Stoll; I believe (but am not sure) that the black and white Geometer Odczia atcrima, Butl., var. mocroraria, Frr., had similar habits, but the majority of the Geometers noticed were kicked up from the herbage as one 
walked along: viz. Zcttienia albonotaria, Z. rufcscentaria, Motsch., and Hygrochroa subspcrsata, Feld., these three all among Cryptomerias; Epione advenaria, Hiibn., which I have never seen alive in England; Epirrhoë supcrgressa, Butl., which is very like our Melanippe unangulata, Haw.; a very worn Scotosia sp.; the Argent-and-Sable, Mclanippe hccatc, Butl.; Phibalapteryx tcrsata, Schiff., which I have also taken in my garden at Mortehoe; Abraxas miranda, and Microstega (Botys) pandalis, Hübn., another British species; on the other hand, Anagoga indictinaria came to light. Another familiar Palaearctic species, Ectropis (Tephrosia) consonaria, Hübn., was taken at rest on a beech-trunk at Chūzengi, above Nikko. At that altitude, $4370 \mathrm{ft}$., the trees were leafless, and in some parts the woods suggested England in March-but this was only on one side, on the other the prevalent underwood consisted of Azalea, now in full bloom, white, orange-red, purple-crimson, and salmon-pink. A hill on the way up, perhaps 300 to $400 \mathrm{ft}$. high, was a glowing mass of red.

Nikko looked like a good place for Neuroptera, but I had not time to pay attention to the group. A solitary Dragon-fly, Gomphidia sp., is represented in the British Museum by unnamed Japanese specimens. I brought home also two Caddis-flies, Stenopsyche griseipennis, which came to light, and Sciops (?) octomaculata, McLachl.

\section{Yokohama.}

May 19th, 1904.

About the racecourse several insects now reckoned as old friends were met with, such were Papilio machaon, of which a tattered specimen was taken; Colias poliographus, a male; and Zizcra maha, var. diluta. The wet-season form of Yphthima zodia was abundant, but of the black Skipper Halpe varia I took but a single specimen. The only moth was a small Pyrale, Pyrausta varialis, Brem. The last butterfly that I saw in Japan was the same species as the first, Blanaida goschkevitschii; this was in abundance; late in the afternoon it was constantly seen to settle on the sunny side of pine trunks, when it would list to port or starboard indifferently, often as mucl as $40^{\circ}$. While watching these butterflies a Dragon-fly, almost certainly Orthetrum japonicum, Uhler, of which there were plenty hawking about, was seen to carry off one of these big Satyrs high into the air; they both went far out of reach, but as far as I could see the butterfly showed no signs of struggling. 


\section{The Pacific Ocean.}

$$
\text { May 20th-31st, } 1904 .
$$

Japan was left under a sense of great depression. To the natural feeling of regret at leaving such an interesting country after an all too short visit was added a very real sympathy with our kindly hosts in the loss of a battle-ship and a cruiser announced in that morning's papers.

It is impossible to omit some account of my impressions of that wonderful country. Of these the first, and the last, relates to their "wee winsome women." The daughters of the Empire of the Rising Sun are not, according to our canons, either beautiful ${ }^{3}$ or graceful; their wondrous dress gives them figures decidedly suggestive of pillows, and yet they are beyond all women charming! Of course this apparent paradox is to be explained by their unequalled, unapproached manners. Not merely do they lay themselves out to please, but their every act is performed as if it gave themselves the greatest possible pleasure in the performance. Cynics may say that it is all artificial, all a matter of education, so be it: the Japanese system of the education of women is thereby proved to be the most successful in the world, and the sooner that our Newnham, Girton, and Somerville girls go to Japan to learn manners the better for us Englishmen-only one hopes that they will not spoil their Japanese sisters.

As before said, Japan is by no means remarkable for bright colouring, yet, strange to say, when it rains it bursts out as it were into bloom, for then the transparent (? oiled, or waxed) umbrellas display their yellow and orange tints, while the women lift up their kimonos and expose a scarlet, or otherwise brightly coloured garment which corresponds to an English woman's petticont.

No observant traveller can fail to note the influence of Nature on Japanese art. The weird growth of stunted pines upon the mountains, distorted by the prevalent winds; the aspiring fluted trunks of the lofty and solemn Cryptomeria japonica; the graceful curves of the bamboo; the peculiar growth of the maple, are all reflected in Japanese pictures and lacquers. Again, not to speak of the familiar chrysanthemum and the cherry blossom, there is the common wayside Pyrus japonica with its eminently decorative red flowers.

1 An oxception must be made in farour of tho complexions of the country girls: brunotto with a bright scarlot flush in tho chceks-a touch of colour as beautiful as unlooked for. 
We were lucky in seeing that grand climber, the Wistaric, in pcrfection. In its wild state it frequently fails to hold its own, but when it has succeeded-when it has climbed 80 to 100 feet up a suitable tree, and its flowers hang in a very waterfall of lavendercoloured blossom, it is truly a glorious sight. The white species, whose countless racemes are often seen hanging from light bamboo frameworks about houses and gardens, is equally beautiful. Then there are the Azaleas on the mountains, white, or every shade of red, so that the very woods glow with the warm colour. A shrubby Potentilla is as common as it is decorative; the Japanese Bramble is as bcautiful as it is singular. To these may be added the Solomon'sSeal, a magenta-coloured Lucerne, sevcral ferns allied to Osmunda, a fine wild Strawberry which is unfortunately quite tasteless, and the now quite familiar Ampelopsis veitchii. Lastly, while there are white roses the size of sixpences, there are other's as big as teacups.

The Japanese artists conventionalize in such a masterful manner that it is always possible to tell the genus of a decorative insect, often (especially with the Swallow-tails) even the actual species, so well are the essential characters caught and fixed.

Lastly, while the form of Fuji-no-yama is now almost as familiar in Europe as in Japan, it is probably not so well known that the fantastic outlines of other mountains in their pictures are largely based on the weird, almost grotesque forms of the crags of Myoggi-san, between Karuizawa and Tōkyō. Indeed the Japanese have an almost child-like love of anything approaching the grotesque in Nature.

Japanese poetical feeling was well shown by the congratulatory telegram sent by the Mikado to Edward VII. on his coronation :-

"The Emperor of the Land of the Rising Sun congratulates the Emperor of the Realm on which the Sun never sets."

The Japanese are the most polite people that I have as yet come across; they are also by far the cleanest, and constantly put one to shame in that respect. Japanese crowds have justly been described as the sweetest in the world. This reminds me of a piecc of advice that I would give to any European travelling in Japan. At the port of debarkation supply yourself with socks constructed to accommodate the great toc by itself, and have a pair of house sandals made to your own size (which, whatever your stature, will probably be far bigger than any kept in stock). Thesc may be carried in a small cotton bag and worn whenever a house, or shop, or temple is entered. It is cold to walk with only stockinged feet, boots are out of the question, and the best form of sandil, with a 
pin to go between the big toe and the second, can only be worn with the special socks. The writer suffered much inconvenience from having to make the best of sandals of the other pattern that constantly slipped, and were most uncomfortably small.

The Japanese with all their politeness are, at all events in country places, very full of fun and would laugh heartily at our party, while they had not the slightest objection to us in our turn laughing at them. The first time that we essayed chop-sticks the landlady and her daughter were literally convulsed with laughter-they bent double and rolled from side to side! It may here be remarked that they bid fair to rival the Swiss as hotel-keepers.

The lower orders, though very short, are almost grotesquely muscular. The upper classes are said to be less strong, but judging by the officers, their stature seems equally small. So far as I could see, the people, and especially the children, looked wonderfully healthy and robust. The only ailment that obtruded itself Tas an eruption on the scalp, and that did not appear to impair the general health of the children afflicted with it.

The "Empress of Japan," though not large, has, like her sisters, beautiful limes, looking more like a very large private yacht than a mail steamer. Of all the steamers that I have sailed on I know none to equal those of the "C.P.R." The discipline is splendid; ${ }^{1}$ the service (all the stewards are Chinese) excellent, the table equally good. On Sundays we had strawberries and cream, while there was a very fresh-looking rose on every lady's plate.

Our voyage was scarcely a pleasant one owing to fog and met. We were once six days without "sights" and found ourselves some 35 miles north of our proper course. This, however, is considered, under such circumstances, not to be a very great discrepancy between ascertained position and dead reckoning. When the weather would permit, hockey on deck was a great institution, especially as it. was distinctly cold. For my part I had not played the game for forty years, and enjoyed it immensely.

A curious feature of this voyage was the outbreak of what can best be described as an epidemic of Patience-playing. For days there was played scarcely a game of bridge or a rubber of whist; even more surprising, not a game of poker or map. Morning, noon, and night every available table in drawing-room and smoking-room alike was occupied by Patience! Young and old, men and women, all played "The Demon." Even the sporting fraternity, when not

${ }^{1}$ At drill all the boats were lowered a fathom or so from the davits rithin vine minutes. 
itself engaged in the prevailing pastime, stood around absorbed in watching the players, quick to see a slip, for had they not heavy bets on the result?

But accounts of voyages are as dreary as the voyages themselves. There was, however, an even larger crop of stories than usual, of which I recall the following.

A Japanese gentleman, who had been poring over an English phrase-book, was anxious to air his newly acquired knowledge. Accordingly, on meeting an Englishman at a railway station he politely raised his hat and said: "Good evening, Sir or" Madam, as the case may be."

Two Scotsmen and a Frenchman shared a cabin one night on a Channel steamer' the vessel pitched and rolled heavily, and two of the three were not happy. One of the Scots had the irritating habit of snoring in a crescendo till he would wake with a start. His fellow passengers resented this, more especially the Frenchman. Once again the stalwart Scot began his crescendo, and as he was working up to his loudest the vessel gave a heavier lurch than usual. Accordingly he gave vent to a louder snort than ever, after which he subsided into absolute quiet. "Grâce à Dieu!" said the Frenchman, "il est mort."

An American bishop from Shanghai told us that the only means of communication between the Italian nuns, who do the nursing in a hospital there, and the foreign sailors who make up a large part of their patients, is Pidgin English. Some English seamen came one day to inquire after a ship-mate who had met with a serious accident. The sister-in-charge said: "He topside walkee last night." They accordingly went upstairs, but failed to find him in the upper ward, and only gradually realized that he was dead.

The same bishop gave us the substance of an Euglish essay on "The Cat," written by a Chinese pupil in a mission school:-

"The cat is one of God's best gifts to man, therefore $\mathrm{He}$, in His mercy, endowed bim with nine lives. These, however, are not so useful in China now as formerly, since the introduction of Christianity."

As a piece of English literature this effort of the Yellow-boy may be well considered to attain the high level of the classic treatise of the Bengáli babu on "The Horse":-

"The horse is a noble animal, but does not always do so." 
We had on board a vulgar girl, who hailed from Chicargo: slet was the possessor of a particularly unpleasant voice, and one afternoon at tea she bchaved in a noisier way than usual. A very taciturn man at my side said: "If I had that voice I would hire myself out as a fog-horn on the Banks of Newfoundland." It is said to have been the misanthrope's only remark at meal times during the whole voyage.

Another of our first-class passengers, an Englishman, paid a visit one day to an Austrian gentleman in the second-class, when the following convcrsation took place :-

Austrian: "Dere is one Professor von Mcsmerism on board; I would take some lessons, but he says I must pay $£ 5 . "$

Englishman: "Of course you won't do that."

Austrian: "Ach! no, two or dree will join togedder and make one class. How much do you tink we should pay?"

Englishman: "I wouldn't pay a d-n."

Austrian: "How much is a d-n ?

Englishman: "Two shillings and fourpence."

[Exit Englishman to first-class, leaving Austrian considering ways and means, and the diffeulties of the English coinagc.]

We reached Victoria, Vancouver Island, on May 31st, 1904.

\section{CANADA.}

Victoria, VANCOUVER Island, lat. $48^{\circ} 25^{\prime} \mathrm{N}$.

June 1st, 1904.

Notwithstanding the many excellent points of the good ship "Empress of Japan," we wcre none of us sorry when the cold, wet, weary voyage came to an end, and we got our first sight of British Columbia.

The park of Victoria was one glorious blaze of gold, such Broom I never saw. Introduccd not very long ago, I am told, it now bids fair to oust many of the native shrubs. Here I saw a number of Whites of very ordinary appcarance, but flying among the grass were many of a Heath now to me, Cocnonympha elho, f. ampelos, W. H. Edw., like a large pale pamphilus.

In the afternoon an old friend, Dr. Georgc Hewlett, R.N., of H.M.S. "Bonaventure," then lying at Esquimalt, took me for a 
delightful drive into the forest. We had a pleasant ramble under the sombre spruees, talking of past times in Bermuda, Nova Seotia, and Newfoundland, but unfortunately it clouded over and drove most of the butterflies to roost; we saw only Grapta faunus, Edw., of which I managed to seeure one out of several seen, and Papilio glaucus turnus, Linn., of which I saw a single example. Of the last I took a broken one the next day at Vancouver City.

At VANCOUVER I had an experience which was as fortunate as it was eurious. Though provided with through tiekets to London, I had landed at Victoria with my supply of ready money almost exhausted. Vain endeavours to find a lost piece of baggage occupied most of my few hours in the eity, so that the visit to the Bank of Montreal was postponed until uneomfortably near the hour of the departure of the train. The question arose in my mind how I was to give the bank proof of my identity. It was true that I had a letter of introduction to an old lady living somewhere in the place, but she might think it strange if I ealled with a eab and asked her to accompany me to the bank. Accordingly I kept her in reserve, and, resolving to try to bluff it through, walked boldly into the bank. As I entered, the teller in his wire thief-proof eage addressed me by name, and said he knew me well and my father too! "That's a good thing," said I, produeing my letter of eredit, "for I want to raise the wind." He glanced at the doeument saying, "And I know your signature too; it is thirteen years since $I$ have seen it, but it has not ehanged." This gentleman had been a junior elerk in a bank with which both my father and I had aceounts. I had not the slightest difficulty in getting money forthwith, and was passed on to other branches of the bank along the line of route.

\section{North Bend, B.C. $425 \mathrm{ft}$.}

June 3rd, 1904.

Our journey across the Nearetic eontinent was a mere rush, affording few entomological opportunities; it would indeed not be worth recording save as my first, and only, experience of eollecting in North Ameriea. It is true that on the oceasion of the visit of the British Assoeiation to Canada in 1884, I had got as far West as Laggan, but on that journey I did not collect. When I visited Bermuda, Nova Seotia, Newfoundland, Quebec, and Niagara in 1901, my only entomologieal notes were of the abundance of Nomophila noctuella at Bermuda; a single specimen of Papilio (probably) glancus turnus, seen on a hill above the Codroy River, Newfoundland, and 
the very large number of white butterflies seen just outside Toronto Station.

NorTH BEND, in the gorge of the Fraser River, once famous as a gold-washing station, consists of a charmingly situated hotel, under the excellent management of the C.P.R. A walk along the track down as far as China Bar, possibly seven miles, was thoroughly enjoyable and gave one an insight into the fauna and flora.

Two plants stamped themselves upon my memory, the longstalked Western Daisy (Bellis integrifolia, Michx.), and the very graceful orange-and-scarlet Columbine (Aquilcgia canadensis, Linn.), which were both in profusion. There was also a bright-red Tigerlily.

Butterflies were fairly numerous. The most abundant was a dingy little Skipper, Thanaos persizu, Scudder (very like our tages), with these were a fair number of the much larger T. jucenalis, Fabr. Other Skippers were the small black Amblyscirtes vialis, Edw., and the more cheery-looking Hesperia cespitalis, Boisd., of each of which three were captured. The little brown, almost tailless Hairstreak, Incisalia irus, Godart, was common, and if dull, at least distinct. The purple-glossed Copper, Chrysophanus (Heodes) helloidcs, Boisd., was fairly common. The Blues were represented by the tiny, tailed Everes comyntas, Godart. A more decidedly American insect was Phyciodes tharos, Drury, of which the spring form was to be seen in plenty. This genus, confined to the New World, consists of pretty little butterflies allied to and resembling Melitaea. More striking Nymphalines, but yet of a more Old World look, were Tanessa californica, Boisd., of which I saw but one battered individual, and Grapta faunus, which has similar habits to our Small Tortoiseshell, but is more fond of settling on the leaves of trees and shrubs; the specimens taken were worn. I did not see any Satyrs.

Of the Pierines I met with three species. Ganoris olcracce, Harr., is a geographical race of napi, and accordingly the only specimen netted, a male, had a distinct lemon-verbena scent. Ganoris rapac was introduced into the New World early in the second half of the nineteenth century, having appeared near Quebec in 1S60. Prof. Comstock says that it reached New York in 1S6S, and since then has greatly reduced the numbers of the native olcracca, driving that species from the gardens into the woods. In England rapac is unquestionably a garden butterfly, napi being commoner in woods, fields, and lanes. It is most interesting to learn that prior to the invasion of rapac, the American form of napi frequented gardens. Anyway I saw several rapac that day at North Bend, where gardens 
are few and far between; it had brought its sweet-briar scent with it from Europe. The other Pierine was Colias ehrysotheme, Steph., f. philodiee, Godart, of which I saw several, and took onc of each sex.

The Swallow-tails were represented by the fine yellow Papilio glaueus turnus, which was rather common.

Moths were not at all prominent, a worn-ont Acidaliid could not be named; of the Quadrifid Yellow Under-wing, Syneda divergens, Behr., which seemed to be a day-flier, I took two; I also got two, one of each sex, of the handsome day-flying Saturniid, Pseudohazis eglanterina, Boisd.

A week divided between Glacier House, in the Selkirks, and Lake Louise, in the Rockies, was devoted to mountaineering of a mild kind, though rain sadly curtailed our operations. At that time of the year (beginning of June) the snow-line was so low at Glacier as almost to reach the railway track, so that the ascent of Mt. Abbott (8500 ft.), in August a "grass mountain," had to be made with a Swiss guide over snow all the way. The usual path was broken by a somewhat menacing snow cornice, so that we had to make a wide detour and traverse a slope where we would have been glad of a rope. However, our descent was much accelerated by glissading.

On our way to the Asulkan (wild goat) Glacier we crossed the track of a considerable avalanche, under which the river made its way, and were surprised at the force of the Lawine Luft, or blast of wind caused by the avalanche, many quite large trees having been broken in half. Had not the guide Feuz assured me that this was the cause, I could never have believed it. We saw several marmots on the snow, and tracks of mountain goats and foxcs.

The views were everywhere superb, and indecd much morc imposing than they can possibly be after the molting of the snow. I had secn a fow of the peaks in 1884 , but they were for the most part strangers, nevertheless I seemed among old friends since I had met many of the mon after whom the mountains had becn named, e.g. Sir John Abbott, Douglas Freshfield, George Dawson, W. F. Donkin, Prof. Macoun, Sir Richard Temple, and Sir Charlcs Tupper.

From the Great Divide of the Rockies to the mighty St. Lawrence the routc was not new to mc, for I had traversed it just twenty years before. Many of the changes I was unable to sce, since the train passed in the night some of the places of which I saw most in 1884. At Banff, for instance, in 1.884, Mr. William Barnard and I slept on the not very clean floor of the section housc. On a cold September morning we went out to draw our washing water from the wcll, and 
while drying ourselves the sponges froze as stiff as boards. After breakfast we had sallied forth, crossing the deep, dark, swift Belly River on three logs lashed together, then, traversing a swamp (where I found a fine skull of a Caribou), made our way to the hot sulphur springs, enjoying a warm bath therein, though the vegetation around was glistening with hoar frost. Now Banff boasts a large hotel and is a tourists' centre. In parts of the prairie the extension of settlement was considerable, in other parts the change was not so marked.

At Winnipeg, in 1884, we had seen several teams ploughing Main St., to reduce the stiff clay mud to a moderately even surface with a view to paving it. This had in the interval been fairly successfully aecomplished, but it was very sad to find that the City Fathers had pulled down the one historic building of Winnipegold Fort Garry-rather than suffer the continuation of Main St. to deviate a few yards from the straight line!

At Winnipeg Station a young porter came up to me and said: "I expect you knew my grandmother." I did not wish to appear surprised, but it was natural to ask, "Who may your grandmother have been?" To this the porter readily answered, "Mrs. Pinneger, pew opener of Holy Trinity Church, West Hill." It appears that he had read the name upon my luggage and made a good shot at my identity. As a result I had to deliver a message to the Vicar of Wandsworth, as well as to the Bank Manager.

\section{Rat Portage, Ontario What.}

\section{June 13th, 1904.}

This spot, onee a busy gold-mining centre, lies almost equidistant between the two occans. A stroll on the shores of the Lake of the Woods gave me another glimpse of the Canadian butterfly fauna. Several species seen at North Bend, more than a thousand miles to the westward, were met with again here, to wit: Ganoris olcracca, both sexes; Colias chrysotheme, a small male and two females; and Everes comyntas, one; as well as Phyciodes tharos. This last, which might almost have been called abundant, is fond of settling with halfexpanded wings in moist, grassy places in woods. In addition to these, several species that were new acquaintances turned up. Of Euchloë ereusa, Dbl., \& H., I saw but one. Two Blues were in abundance, Cyanivis ladon, Cram., f. lucia, Kirby (being the northern spring form), and Plcbcins (Cupido) coupcri, Grote \& R. The company was completed by the sylvanus-like Skipper, Atrytonc hobomok, Harr., of which several were seen settling on mud where 
it was hard to catch them. It is not at first quite apparent why American entomologists, having given this innocent looking fly a picturesque Indian name, familiarly speak of it as "The Mormon"; for the dimorphism of its female is as nothing compared with the polymorphism of some Papilios. Flying freely in the sun among the butterflies was Euclidia cuspidca, Hübn., a near relative of our E. $m i$, Clerck. Many bushes were infested with a larva having an interrupted pale dorsal line, which I took to be a Clisiocampa.

\section{Chalk River Station, Ontario East.}

June 15th, 1904.

A rapid raid from the train yielded booty in the shape of two Brenthis bellona, Fabr., a small Fritillary resembling selenc, but without silver spots beneath.

\section{The Mountain, Montreal.}

June 16th, 1904.

A short afternoon in Montreal's beautiful park was my last chance of studying Canadian butterflies in the field. The most obvious was Colias chrysotheme, but it was swift of flight and very wild, so that it was only at the cost of much exertion that I secured a male. A worn Brenthis myrina, Cram., was even more like selene than is bellona, since the resemblance extends to the under-side. The little bright fulvous Atrytone hobomol was the commonest butterfly, sitting on flowers in the same attitude as our two Common Skippers, and with it I took two Euclidia cuspidea.

When the fine SS. "Bavarian" reached the landing-stage at Liverpool I had girdled the top of the world.

Using round numbers, I was five months in India, three weeks in Ceylon, a fortnight in China, a month in Japan, and a fortnight in Canada-say eight months in all. During that time, in spite of inany distractions, I managed to collect 2164 specimens, of which no less than 1867 were butterflies of 268 different species. 


\section{CHAPTER IV}

ALGERIA. FEBRUARY 6TH-APRIL 3RD, 1905

ALGER

February 6th-14th.

TuE "Général Chanzy" was not a comfortable steamer: her Clyde builders would appear to have given her lines that facilitated rolling on the very slightest provocation, and her French owners by no means exemplified the whilom adage, "they manage these things better in France." 1 However, in spite of discomfort we duly reached the old pirate stronghold, which, up to the time of its bombardment by English and Dutch ships under Lord Exmouth in 1816, was wont to defy Europe. Algiers still retains much of its former picturesqueness and Oriental character, though these are fast disappearing before French "improvements" ; indeed Mustapha, the European residential quarter, might well be on the Riviera.

Butterflies were by no means common, it was evidently too early. On the slopes at the back of the hotel, at about $300 \mathrm{ft}$. above the sea, several Whites were seen, also a Gonepteryx and a Colias, but the only butterfly netted was a male Ganoris rapae. Flying against a sandy cliff close by was Macroglossa stellatarum, which I found afterwards to be one of the commonest Algerine moths. The butterfly that was commonest around Mustapha was the fulvous form of Pararge aegeria, Linn. (meone, Cram.). This was especially numerous near Koubba, and taking it at the time to be a species new to me especially noted its habits. It flies slowly, and, as a rule, for a short distance, settling on the ground, or on stones, with its wings from three-fourtibs to four-fifths expanded, and turns round so that its back is to the sun. I never saw one of these butterflies settled more than $45^{\circ}$ out of this adjustment. 'T'wo specimens had had their rings snipped, perhaps by a would-be captor: It was a source of some

"Shortly after this was writton-early in 1910-the "Geneiral Chanzy" Was wrecked on Minorca, with the loss of all on board. 
satisfaetion to my insularity that British speeimens of aegeric are unquestionably more beautiful than Algerine meone.

Owing to the scarcity of Lepidoptera I was driven to pay more attention to other orders of inseets than is my wont, and of these the Hymenoptera claimed the first plaee. On or about a sandy cliff by the roadside, some $300 \mathrm{ft}$. above the sea, I secured two of the solitary wasp Odynerus (Hoplopus) eonsobrinus, Duf., and with them a female Fossor, Salius sp., that the latc Mr. Ed. Saunders was unable to name; also a male of the fine Podalirius dispar, Lepel. This last I found more commonly at somewhat higher levels, e.g. near Birmandreis, eirea $550 \mathrm{ft}$., where both male and female were caught hovering. In the same locality a male of Pararge megaerca turned up.

Beetles were not numerous, they eomprised a specimen of the familiar Chrysomela banksii, Fabr., near the Colonne Voirol ; and an example of Brachyeerus sinuatus, Oliv., taken by Miss Kennedy on a wall. This weevil has extremely hard integuments so that it must be difficult to masticate and well-nigh impossible to digest. A Carabus found crawling on some steps in Mustapha, about $150 \mathrm{ft}$. above sea-level, does not appear to be represented in the South Kensington collection.

At Birmandreis I took an Aeridian, Epaeromia strepens, Latr., and my daughter took another, Tryxalis giganters, Fuessly. At the same place I found the bug Enoplops seapha, Fabr.; also two of the black and yellow Syrphid fly Chrysotoxum italieum, Rond. (intermedium, Lio. \& S.), an obvious mimie of a small wasp.

\section{GuyotviLLe.}

February 8th.

I spent a very plcasant day on the sand-dunes of GuYotviLLe, nine miles to the west of Alger, near the terminus of the tramway, but it was too early for very profitable eolleeting. With Pararge meone were several Gunoris rapae, and another old friend, Chrysophanus phlaeas. A solitary grasshopper put in an appearaneePachylylus danieus, Linn. An ant-lion, Palpures libelluloides, Linn., intcrested me greatly. This inseet runs backwards, and burics itsclf with startling rapidity in the sand whieh it so closely resembles.

Among the Aeuleata were single specimens of two British Fossors - Ihilanthus triangulum, Fabr., and Pompilus plumbeus, Fabr., together with a number of Odynerns eonsobrinus, and a small female bee S'phecodles sp., while the Iittle Notogoniu nigrilu, Kohl, was taken 
flying about sandy banks, and was more than once seen to enter holes therein.

The only beetles that I came across were two Blaps coynuta, Sol., a female found dead and a male crawling on the sand.

Biskra, lat. $34^{\circ} 50^{\prime} \mathrm{N}$, altitude $400 \mathrm{ft}$.

February 16th-March 8th.

Disappointed in the chilliness of Alger, and the lateness of vegetation and insect life, we determined to make without delay for the southernmost hotel in the land. The journey was cold, and at a station on the high central plateau of the Atlas range, which was passed in the night, we were told that the fresh fallen snow was a metre deep. This was, however, quickly forgotten as we passed through the gorge of El Kantara (The Bridge), and the opening view disclosed a grove of date-palms marking the oasis of the same name, and then for the first time we felt the fascination of the desert.

BISKRA, now the terminus of the railway, was once an important military outpost connected with civilization by a semaphore telegraph, the towers of which still stand upon prominent heights far above the railway. Set just where the main caravan route across the portion of the Sahara known as the Ziban emerges from the foothills of the Atlas on its way to Tuggurt and Wagla, and ultimately to Timbuktu, it guards the gate of the desert, and the place is interesting in many ways. The old fort, with enceinte sufficiently extensive to contain all the white population, told of the troubled times not long ago (if indeed even now quite of the past), and reminded some of us of the mud fort of Pesháwar, though entirely devoid of its picturesqueness. The market is an important one, and here may be studied to advantage the man-child of the desert in his native dress, a costume that for grace and dignity is probably unequalled. I say "manchild" advisedly, for the women are strictly secluded from the profane gaze of the tourist. Camels seen innumerable; indescribably fascinating in the middle distance as they slowly rend their swinging way across the desert plain, they are at close quarters indescribably hideous and provokingly supercilious. I had the good fortune to see a caravan from Timbuktu the morning after its arrival. Three days before the end of the three months' journey a foal, seemingly the first of the season, had been born, and, being unable to keep up with the caravan, had been strapped upon its mother's back! This foal, longer as to its legs than any foal 
of horse or ass, had a surprisingly small body and a quite charming head. When carried in my arms and petted it gave vent to all the grunts and gurglings of its native langrage, but in a childish treble, and was altogether a most fascinating little beast. Perhaps it differed most from its hideous mother in that it had a new coat of its own, whereas nearly all other camels whose acquaintance I have made seem to wear second-hand clothes, and bad at that.

The spurs of the Aures mountains, themselves a part of the great Atlas range, which shut in the view towards the north with a wall of from 1000 to $2000 \mathrm{ft}$. in height, backed by higher ridges and peaks ranging to 6700 and even $7700 \mathrm{ft}$., are for the most part bare and devoid of obvious vegetation, and though brilliant with varied colour-especially under the glow of sunset-suggest the extreme of desolation. A closer inspection, however, reveals a greater number and variety of plants than would have been expected; these are mainly to be found in the small Wâdîs or watercourses (now dry) that score the hillsides. This vegetation spreads to a greater or less extent over the higher portions of the desert, but the year of my visit was an exceptionally dry one, and stretches of land in more favourable seasons carpeted with flowers were then so barren that the Bedawin expected to lose many camels from starvation.

The spring of 1905 was unusually cold throughout the Mediterranean basin, and patches of snow which during the greater part of our stay were to be seen on the higher mountains, naturally cooled down the prevalent north-westerly wind. One morning is firmly impressed on my memory; I left the hotel before 8 a.m. to walk to Fontaine Chaude with the keen blast full in my face; my hands were visibly blue, while I felt assured that nose and ears were of a tint to match, yet at the same time the morning sun beat full upon my back, so that I was grateful for my light sun-helmet. Under such circumstances the strain on the vaso-motor system in its endeavours to maintain the normal temperature of the body must be excessive, its anterior and posterior portions respectively having inconsistent demands made upon them.

The bed of the river was for the most part dry when I saw it. Along its banks runs the Oasis of Biskra, while other oases are visible to the east and south as dark patches on the desert, like islands on a sea. As the sun rises and warms the desert, and the laycrs of air in contact with it, these dark patches are seen to rise from the earth, and appear to float on the further side of nonexistent lakes. 'Ihis phenomenon, due to refraction, is well knowu 
as miragc; it is, perhaps, not as wcll known that, if looked for, it may be secn as far from the Great Sahara as the Southarnpton Water and the Gulf of the St. Lawrcncc. It may even be seen on any hot, still day on Woolacombe Sands.

These oases, which point to water at no great depth below the surfacc, are, and have for ages been, completely cultivated, so that their vegetation is practically confined to date-palms, corn, and other crops with a few weeds of cultivation; the indigenous flora no longer exists to afford pabulum for insects, which are consequently confined to a very limited number of species. The cosmopolitan Pyrameis cardui was fairly common; Chrysophanus phlacus was seen once; Ganoris rapae and Colicas cdusa, auct, put in an occasional appearance, the last-named the more frequently; our Mustapha friend Pararge meonc was occasionally to be met with. A small aromatic Umbellate in a vegetable garden attracted Odyncrus consobrinus, Osmia kohlii, Ducke, an unnamed Andrcna, and the vulgar fly Eristalis tcncx, Fabr. In fields of broad-bean both sexes of Psithyrus fulvitarsis, Brullé, were common; this bee was also found buzzing about mud walls, together with Polistes gallicus, Linn., and a number of Odynerus consobrinus; the same bee haunted an earth bank which evidently contained its nests.

Turning over stones in the river-bed not far off brought to light a Scorpion, the apterous Heteromeron Adesmia farcmonti, Lucas, as well as abundance of the gregarious Pachychila impressifrons, Sol., a beetle with an extremely hard exo-skeleton.

In the Chetma Oasis, about five miles to the eastward, a field of cultivated vetch yielded, besides Apis mellifica, several specimens of Podalivius (?) ambiguns, Per. The widely-distributed moths Nomophila noctuella, Schiff., and Plutella maculiponnis, Curtis (crucifcrarum, Zell.), looked homelike enough, but the beetles on the sand close by-Pimelia arcnaria, Sol., and ATis spinosa, Fabr. (dead)-gave a more exotic tonc to the place. The flowers of Clcomc arabica, Linn., yielded nothing but honey-becs.

In the famous Jardin Landon but very few additional species occurred. The common Cricket Gryllus domcsticus, Linn., was found upon a path where the Ant Myrmccocystus viaticus, Fabr., was busily at work. The lawns provided food and shelter for a few Acridians, such as Acrotylus patruclis, Sturm., Stcnobothrus bicolor, Charp., Epacromia strcpons, E. thalassina, Fabr., and the Tryxalid, Euprepocnemis plorans, Charp.

In or about the hotel I came across the Ladybird Bulace lichatschovii, Hummel, var. pallida, Muls., the Bug Lygacus pandurus, 
Lepel., the huge Grasshopper Acridium aegyptiaeum, Linn., and a Fly of the genus Sareophaga.

In the north-western outskirts of the town a rough grassy place adjoining the "Tir-à-pigeons," in the Beni Mora Oasis, was (when the mountain wind was not too strong) somewhat more productive. Here the eharacteristie Butterfly was Euchlö̈ belemia, Esp., whieh on Mareh 8th was not uncommon though not easy to eateh. An odd speeimen had oceurred in the Jardin Landon four days before. Two Aeuleates were eaptured, Colletcs coriandri, Per., and Notogonia nigrita; a Fly very near to Taehina marklini, Zett.; the Acridian Stenobothrus bieolor, and the Bug Lygaeus pandurus, the latter taken on the wing. Close by I disturbed what I feel sure must have been Macroglossa stellatarum.

As regards the desert itself, as might have been expected, the mole stony and wind-swept portions proved the least productive; thus the foothills to the north-east yielded no Lepidoptera at all, though I have a hazy recollection of having on one oecasion seen what was probably $P$. eardui. But even in the parts that were comparatively prolifie, Lepidoptera were so searee at the time of my visit that I was driven to eolleeting Hymenoptera and Coleoptera to occupy my time. Yet even with these it was not always easy to fill my boxes.

The long-legged, apterous Heteromeron Adcsmic biskarensis, Lueas, was rather common, looking not unlike a spider as it ran rapidly over the sand. On my first walk the only ereature on the wing appeared to be Podalirius crinipes, Smith, of which the female might often be heard as it hovered over the flowers of the "Qedad," or Camel-grass (Aeanthyllis tragaeanthoides, Pom.). It proved, however, hard to localize the sound, and therefore not easy to see the bee; moreover, it was decidedly diffieult to eatch, so that it took some time to secure four specimens. The same day I eaught upon my coat that strange fly Hippobosea camelina, Leach; possibly in the desert, where food is scaree, man may be almost as great a delieacy as eamel. These same foothills yielded a week later a eouple of Adesmia aeervata, Klug, running on the ground; also Eristalis tenax, though assuredly there are no drains on those arid slopes.

Hammam-ES-Salainin, called by the Freneh "Fontaine Chaude," lies some four miles to the north-east of Biskra, nestling elose under the mountains at the head of, as it were, a bay of desert. It is known to entomologists as the place where Lord Walsingham stayed for several inonths, engaged for the most part, in studying the Tineina of the loeality. His lordship's fame as a colleetor, a skilfu] 
shooter of dueks, but, above all, a mighty walker, seemed to haunt the place, and I had the advantage of visiting it with his Bedawin assistant, who seemed to be a born naturalist. Suleiman bin Arrji (if I have his name aright) is tall, distinguished-looking, of soft and gentle voice, speaking French, if not with fluency, at least with an elegance that I could not but envy. He seemed to know wherc every ereature lived, and what it fed upon; in many cases he knew its Latin name. To see him turn over a stone, pluck a grass-stem, thrust it into a hole in the ground and presently extract a large spider, was an education. He told me proudly that the Bedawin knew where to find water in the desert, adding with contempt in his voiee that the Frenchman did not.

There was a certain amount of vegetation about the stream leading from the sulphur spring, there was also vegetation of a sort in the dry gullies on the mountain-sides, gullies which had all the appearance of occasionally functioning as watercourses. Here I found, at the end of February or beginning of March, an Umbelliferous plant bearing small lumps of a gummy exudation; these proved to be the abode of larvae from which I bred on April 12th and May 3rd two speeimens of Agonopteryx (Dcpressaria) thapsiella, Zell.

Stone turning was not as profitable as might have been expected, perhaps because there were too many stones. I had got into the habit of catching beetles with my fingers, but was rebuked by Suleiman who said that it was not safe to dispense with forecps. Pondering over this remark I turned three stones in succession with this result:-(1) A most formidable looking Spider, alleged to bc deadly; (2) A large Scorpion; (3) A small horned Viper, or Asp (Ccrastes cornutus)! After the last I took to my foreeps and used them assiduously. The danger, such as it is, consists in the way that animals lurk in the loose sand or vegetable debris under the stones. Of less deadly seekers after shade I found Opatrum rusticum, Oliv.; Microtclus cariniccps, Reichs.; Aphodius granarius, Linn.; Nephodes sp.; Micipsa sp.; Hclops sp.; none of the three last bcing represented in the National Collection. Other Colcoptera met with were Blaps prodigiosa, Erichs.; Pimclia simplex, Sol.; and $P$. latrcillci, Sol.; this last again being umrepresented at South Kensington; Adesmia farcmonti, one; $A$. accrvata, one; A. biskiarcnsis, commonly. Of Scarabacus puncticollis, Latr., two were picked up off the sand, and one taken on the wing. On one occasion my daughter heard a slight rustling noise procecding from a clump of Zaïta (Limoniustrum guyonianum, Coss.), she watched earcfully and soon saw the pretty beetle Graphiptcrus multiguttatus, Oliv., 
run out on to the open and heard it make the stridulating noise characteristic of the genus, she then saw the handsome big Carabid Anthice scx-maculata, Fabr., running about in the middle of the little bush. Query, was the big Carnivore in pursuit of the lesser? The Graphipterus, which is fairly common about Biskra, has quite soft integuments. It courses over the sand with surprising rapidity, and its broken coloration, a neat pattern of black and white, makes it remarkably inconspicuous; it is apterous; when pursued it often conceals itself under stones, or among the roots of plants or buries itself (like Zophosis) rapidly in the sand. The big Anthia, a much less common insect, is also exceedingly swift of foot; it too is black and white, but of such ferocious aspect that I nicknamed it the Hyaena beetle. Presumably it is the master beast of all insects in those parts, as perhaps it is the swiftest of foot.

I learned from Suleiman that the flowers of the fine Orobanchid parasite, Phclypaea violacca, Desf., are infested with a small Weevil, a species of Baridius. The same keen-eyed collector pointed out the fine large Mantid Blcpharopsis mendica, Fabr., which was quite inconspicuous as it sat upon a glaucous green desert plant. Its elytra are decorated with a grey-green pattern strangely like certain cheap wall-papers. Only two other members of the Orthoptera were met with, viz. Euprepocnemis plorans, and Pamphagus algericus, Brunn., the latter some little height up the mountain, where also, in an absolutely waterless ravine the Dragon-fly Lestes sponsa, Hansem., seemed somervat out of place, but it had probably gone there ahunting, since others of the same species, together with Micronympha elegans, Lind., were taken by Suleiman along the stream which flows from the hot sulphur spring. Gonia capitata, De Geer, was the only fly that I brought away, but the Aculeata were represented by a couple of female Podalirius crinipes, and a male Osmia latreillei, Spin., as well as several Apis mellifica. In addition to these were two species of ant, one, Myrmecocystus viaticus, of which a worker was seen carrying with the greatest ease an apparently impossible load; the other, the glistening $M$. bombycinus, Rog., with its thorax and abdomen seemingly electro-plated. My daughter and I were interested in watching the workers of this very agile ant engaged in excavating, or at least in removing, sand from the mouth of the nest; the sand was shifted but a very short distance by an excessively rapid movernent of the hind-legs. While this was going on a "soldier" appeared, thrust out his head, as if to reconmoitre, and then withdrew, perhaps to report our presence.

I visited Hammam-es-Salahin three times; on the last occasion 
(March 3rd) the weather was unfavourable and no butterflies were seen. Suleiman showed me the locality for 'Teracolus nounu, Lucas, but said it was too early for it. On Feb. 27 th and 28th I was more fortunate and took a specimen of Euchloë belledice, Hübn. (belia, Cram.), three of $E$. belemia and five of $E$. charlonia, Donz. The last-named, Dr. Dixey says, is probably identical with $E$. lavaillanti, Lucas. My specimens were all males. With the Pierines was a very small, worn Painted Lady. All these butterflies were taken on sandy hillocks near the baths, with the exception of one E. belemia which I came across in one of the mountain gullies. The Euchlo: all flew swiftly and were by no means conspicuous as they coursed over the light-coloured sand. Both charlonia and belemia sat in their pill-boxes in a remarkable attitude, their fore-wings drawn back so far within the hind-wings that the costa of the hindwing actually projected beyond the costa of the fore-wing. As a consequence every scrap of white or yellow on the underside of the fore-wings was concealed by the highly cryptic hind-wings, which are of an almost uniform green in charlonia, of a striped green and white in belemia. But in addition to this the abdomen is much raised so as to be held almost erect between the hind-wings, which in turn are held far from the object on which the butterfly sits, thus greatly increasing the resemblance in form as well as colour of the whole butterfly to a leaf. [See Plate V. Fig. 10.] Unfortunately I did not see either butterfly resting in natural conditions. On one of my visits Suleiman brought me an example of the cosmopolitan Nomophila noctuella.

Another favourite collecting ground of mine lay some three miles to the west of the town, just north of the Route des Zibans, where a low ridge of hills has led to considerable accumulations of sand. The scanty vegetation of these slopes, and the ground betreen them and the road, was prolific in typically desert insects.

The first creatures to catch the eye were the heavy black Heteromerous Beetles of the genus Pimelia, whose curious tracks made a sort of embroidery over the smooth sand. Here and there the insects themselves might be seen journeying at a fair pace orer the ground, succeeding in a surprising manner in ascending even steep slopes of dry running sand. Among many $P$. consobrina, lucas, some of which were seen to bury themselves, was one of another species which Mr. Arrow considers to be near to, but not identical with, $P$. senegalensis, Oliv. The beetles of this geus are phytoplagous in habit and several times I saw them climbing up and eating the petals of Rctama retam, Webb. Sulciman told me 
that they eat the Euphorbia guyoniana, Bois. Reut., down to the ground; on the same plant he said that later in the year might be found "dcs chenilles avec eorncs et des tâches rougâtres"evidently Dcilephila euphorbiac, Linn. I did indeed dig out of the sand two brown Sphinx pupae, but unfortunately they dried up and the moths never emerged.

A smaller Heteromeron, Erodius bicostatus, Sol., might be scen occasionally crawling on the sand, whereas Zophosis approximata, Deyr., ran with great rapidity. Both these species were to be obtained in greater numbers by scratching the sand away from the roots of the Zaita. The Zophosis is covered with a (?) waxy substance, exactly the colour of the sand, easily rubbed off by the fingers, or in the killing bottle, leaving the beetle black and shining. Any one familiar with cabinet specimens only would be surprised to hear that it is a very cryptic insect. Among my specimens of Erodius Mr. Arrow found one, if not two, species unrepresented in the National Collection. Another beetle found on the sand, or at the roots of Zaita, was a black Tentyria. Single specimens of the pretty Graphipterus multiguttatus and the formidable Anthia sexmaculata were secured. Other beetles found were Sepidium requieni, Sol., and Cleonus sp., the latter a Weevil just the colour of the sand and further protected by its stony-hard integuments. Once I followed some tracks over the sand for several yards, and where they ceased found Scarabaeus puncticollis, buried about an inch and a half below the surface. On the Spurge, Enphorbia guyoniana, our garden friend Coccinella 7-punctata, Linn., was conspicuous.

Of Bugs I found but two species, a Menaccarns allied to hirticornis, Puton, on the sand under a Retama bush, and Lygaeus pandurus on Euphorbia.

I took but few Diptera, those mostly at the Spurge flowers, viz. Rhyneomyiu sp., two males of a species not in the British Museum; one Musca vitripennis, Meig. ; and a male Tuchina allicd to marklini. Lastly a specimen of Hippobosca camelince was, after scttling threc times on my coat, finally secured.

The Aculeata were somewhat more plentiful. Ants werc reprcsented by the silvered Myrmecocystus bombyeinus running with quite rcmarkable swiftness over the sand, together with the less distinguished-looking Camponotus maculatus, Fabr. The flowers of the Spurge yielded males of Andrcna lepclctieri, Lucas, and A. cphippinem, Spin., as well as several Apis mellificc. The sweet-smelling white flowers of the desert Broom, Retama retam, were more productive, the honey-gatherers including Andrence albofasciata, Thunb., a femalc ; 
A. nigroacnca, Kirby; several specimens of Colletes coriandri; three Chalicodoma nasidens, Latr.; four C. sicula, Possi, and two of another Chalicodoma to which the late Mr. Ed. Saunders failed to assign a name. Besides these there were on the Retama blossoms solitary males of Dioxys chalicoda, Lucas, and Podalivius calcaratus, Lepel., and I found, settled on the sand, a male of the Fossor Notogonic argyropyga, Kohl.

It was at the foot of these sandhills that I took a single Melituca didyma, Esp., f. deserticola, Oberth., flying rapidly yet suggesting a small Acraca. Here also a thin whip-like, sand-coloured Snake some two feet long came towards me with a darting motion. It is the only time that I have seen a snake approach me, perhaps, however, I got between the reptile and its abode. After a hot chase it disappeared down a hole under a large plant of Limoniastrum. A Biskra dealer in curiosities, who seemed to be somewhat of a naturalist, declared that these snakes fly through the air "comme une fleche," and certainly my animal gave quite that impression.

Another sandy region, locally known as The Dunes, affords a good collecting ground. It lies about five miles south-south-west of Biskra on the Oumache road. Here, where sheets and ridges of loose sand alternate with tufts of vegetation, the following Beetles turned up: Graphipterus multiguttatus, three captured by Mr. R. T. Ussher, also two by myself at the roots of Limoniastrum, together with a specimen of Erodius clcgans, Kra.; Adesmia faremonti, one taken by Mr. Ussher; Zophosis approximata; Erodius bicostatus, three; Cleonus hieroglyphicus, Oliv., and Sepidium requieni, the last three all found at the foot of slopes of running sand which they were unable to climb. The exo-skeleton of the Clconus turned the points of several pins! The Cetoniid Oxythyrea stictica, Linn., together with Tontyria sp., occurred on the flowers of the Spurge. Suleiman found on the bare sand two Scarabaeus puncticollis and one Anthic ser-maculata.

At the foot of a clump of rushes growing on the sand I found a. populous nest of the electro-plated Myrmccocystus bombycinus. The most attractive flowers were those of the Euphorbia guyoniana which yielded, besides Honey-bees and numerous 7-spot Ladybirds, the Bugs, Lygaens pandurus and Brachypclta atcrima, Forster; the Flies, Syrphus corollac, Fabr., and Catabomba albomaculata, Macq. With these were the following Bees: Andrcna ephippium, two females; $A$. nigroacnca, with its var. nigroscricea; a stylopized specimen of A. rosac, Panz., var. trimmerana, Kirby ; Colletes coriandri, and Halictus (?) malachurus, Kirby, a female.

On March 1st I went by rail to Li OuTA1A, some ten miles north 
of Biskia, and collected in the dry valleys, locally termed Oueds, or Wâdîs. Here I saw Pyrameis cardui, four specimens of Colias edusa, and a single example of the neat little Melitaea didyma. On the earthy cliffs of the Oued the Tiger-beetle, Cicindela flexuosa, Fabr., and the Ant Myrmecocystus, viaticus were hawking about, while the brilliant Chrysis ignita, Linn., was searching, I suppose, for nests of Eumenes. A Pimelia simplex was picked up from the ground and when killed exuded much fluid by the mouth. There wcre also found on the ground Adesmia faremonti, and a female $A$. biskarensis, as well as the evil-smelling Bug Lygaeus fulvipes, Dallas, the last-named found by my daughter. The best collecting, however, was furnished by a large plant, almost a bush, of a species of Spergula. On or about its flowers were numbers of Bees, to wit: Colletes coriandri, in abundance; C. braccatus, Per., two; C. acutus, Per., one; Andrcna lepeletieri, a male; A.nigro-cenca, two; also two other male Andrcnac, to which Mr. Saunders could not assign names; Osmia submicans, Mor., a male; Eucera algira, Lepel., a male ; Podalirius atriceps, Pel., and $P$. (?) ambiguus, one of each. Together with these was the Dipteron Catabomba albomaculata. There were also some very wary Wasps which I thought might be mimicked by this Syrphid, but I failed to secure any of them.

It was at Biskra that I made my first acquaintance with the Desert, and was much impressed, as no naturalist can fail to be, with the severity of the struggle for existence thereon. To begin with, plants live under most adverse conditions, more especially as the prevailing lack of moisture is from time to time intensified by periods of exceptional drought. It was during such a period that I visited Biskra; as an obvious result of the drought extensive regions near the town, which gave evidence of having been cultivatcd in more favourable seasons, were then absolutely barc. My Bedawin assistant told me as we gazed over the desert from a lofty sandhill near the sulphur spring, that in ordinary ycars, where we then saw little save sand and stones, the prospect was "all flowers." Such vegetation as did meet the eyc was much of it strange, often succulent, often protected by thorns or spines, notably the Qcdad or Camel-grass, a plant that no European marnmal would attempt to cat. There was an Umbellifer with all the appearancc of a Rush, another was possibly protected by its odour, but the milky-juice of the prevalent Euphorbia seemed to give it alone among plants an immunity from the attacks of camels and goats, though not from Deilcplitia. Perhaps the most showy plant on the desert was the parasitic Phclypaea violacea, Desf. (Orobanchacece). 
My seientifie Bedawin pointed out to me the tracks on the sand of the Hare, the Jaekal, the Jcrboa, and the fine Indian Houbara Bustard ${ }^{1}$ (Otis macquccni, E. Gray). But it was mueh easier to track smaller gamc, sueh as the Pimclia and other beetles, (?) Ayrotis larvae, and above all Lizards. The latter usually let their tails drag alon: the ground leaving a eontinuous line on the sand betwcen the footprints, but when alarmed the ereatures raise their tails aloft, seemin'r thereby to get greater freedom of movement. Thus a lizard trail consisting of foot-marks only is clear proof of "full speed ahead," which in the ease of a desert lizard means a very notable paee. I have spoken previously of the rapid gait of Adesmia, Graphiptcrus and Anthia. In marked eontrast to these are the heavy movements of Pimclice and Erodius, though they are very eonspieuous. The big blaek Pimelias are often found with dents on their elytra; do these indieate attaeks by birds? That they are somewhat protected is suggested as well by their habits as by the fact that dead speeimens, cntire, but eleaned out by ants, are frequently met with; such are usually of a brown tint. The beetles of the genera Pachychila and Cleonus must be well proteeted by their hard integuments, but the latter are in addition eryptieally coloured.

Dr. G. R. Crotch's opinion that the large wingless Heteromera so abundant in the Canary Islands are actually protected by their inability to fly has been already mentioned. ${ }^{2}$ Here I found allied beetles very numerous on the outskirts of the Sahara. Could a like line of argument be reasonably followed here? Could it be maintained that if endowed with wings these beetles would have rum serious risks of being lost in the desert? I should be sorry to have to maintain that view. It would, however, seem to be a fact that the loss of wings by restricting locomotion has favoured the derelopment of a great number of closely allied species inhabiting very restricted localities.

But Bectles are not the only swift-footed desert inseets; the Ant Myrmecocystus bombycinus is remarkably quiek in its morements, even for an ant. Indeed the state of habitual terror in which the denizens of the desert seeur to live, sometimes quite "got on my nerves," as the saying is.

Among Birds the Desert Wheatcar-Saxicola descrti, Temm., is a well-known instanee of cryptie coloration. Scen from the side, as when, sitting on the ground, one looks at the bird perched on a

1 By the kinduess of Mr. R.T. Ussher I was enabled to try my first experiment in bird-skinning on a specimon of this bird.

2 Soo above, p. 26. 
small sandhill or bush, it appears to be somewhat brilliantly coloured, having its neck and side of the head, as well as the lower edge of the folded wing, black, with a red-brown head and pale belly. But, on the other hand, when seen from above, as a hovering hawk would look at it, its reddish head and back are scarcely distinguishable from the sand.

The cryptic habits of the two Butterflies Euchloë belemia and E. charlonia have been already described [see p. 162].

Lastly, the Mantid Blepharopsis, referred to above, is one of the most striking examples of protective resemblance that $I$ have come across.

Hamam Meskutine, lat. $36^{\circ} 25^{\prime}$ N. circa $1000 \mathrm{ft}$. above sea-level.

$$
\text { March 11th-16th, } 1905 .
$$

Our stay at Constantine was so short as to allow but a hurried walk through its fearsome gorge-where, by the way, Colias edusa was coursing up and down the slopes. It was almost heart-rending to see how far French "improvements" have marred the beauty of perhaps the most picturesquely situated city in Africa. From Constantiue we went to the wonderful hot springs of Meskutine. The hotel people were charming, so was Mdlle. Antoinette, the tame Wild-Boar, though she was somewhat addicted to gnawing portmanteaux until driven away by a ridiculously small terrier.

Here, by the way, Wild-Boars are very common, and work much destruction, so that one realized the meaning of the Psalmist's words: "The wild-boar out of the wood doth root it up." Doubtless their abundance is owing to the Moslem religion forbidding the native inhabitants to eat their flesh.

My collecting ground on the hillside above the sulphur springs differed in almost every respect from that at Biskra, accordingly nearly every insect taken was different, and of almost European aspect. Butterflies were fairly common, most of them-Ganoris rapac, Colias edusa, Pararge megaera, Cocnonympha pamphilus, and even Vanessa polychloros, were homelike enough, but far more conspicuous than any of these was that grand insect Goncptcryx cleopatra, Linu., which was quite common. Then there was Euchloë bcllcdicc, and another butterfly quite new to me, Thestor ballus, Fabr., was fairly common. This last with its green underside was hard to see on the wing, still harder to see when settled, the black spots on the fore-wing being completely concealed in the attitude of rest. 
Among Moths the biggest was a male Saturnia atlantica, Lucas, found in the hotel; the smallest was an old friend, Plutella maculipennis. Another old friend, Caradrina quadripunetata, Fabr. (cubieularis, Bork.) came to light. Chesias oranaria, Lucas, was found among low plants, and Scoparia angustea, Steph., was beaten out of a hedge of Pistacia lentiseus, Linn.

Near the interesting ruined Roman city of Avrouna my daughter found the apterous female of Oenogyna gandolphei, Oberth.

Diptera were represented by Bombylius boghariensis, Macq., taken on the hillside hovering near the ground, Eristalis tenax and Calliphora erythroeephala, Meig., together with Syrphus sp., which was found in some numbers in company with Apis mellifica, at the green flowers of a Buckthorn, Rhamnus alaternus, Linn.

A community of the Ant, Camponotus sichelii, Mayr, was found under a stone, and one of Aphaenogaster sardoa, Mayr, under another, while $A$. barbara, Linn., took the place of the latter at Announa. Sweeping yielded Andrena minutata, Kirby, Halictus (?) malachurus, and a Fly Spilogaster sp. The leaves of some large Agaves near the hotel appeared to be attractive, and among other insects I took on them a male of Osmia latreillei. There is, I think, little doubt that insects, more especially Diptera, are fond of sitting on large leaves, probably to sun themselves. Thus I have often noticed Syrphids sitting on the leaves of Rhododendrons and Hydrangeas in my garden at Mortehoe.

The most conspicuous Aculeates were the large Carpenter-bees, of which by far the commonest was Xylocopa violacea, Linn., occurring on the flowers of Prunus sp., of Cineraria sp., and on Agare leares, but of $X$. cyanea, Smith, one example only was secured. Of Andrena viridata, Per., I took a single male, but $A$. lucens, Imh., was rather common. At the flowers of Horehound, Cynoglossum cheirifolium, Linn., I took a male of Podalirius pitipes, Fabr., var., while $P$. dispar, was to be had on the same flowers as well as on those of Asphodel. A female of $P$. dispar had two, a $X$. violacea had four pollinia on its head, but whether of Orehis or Aselepias I cannot now say. A female of Bombus terrestris, Limn., taken at Cynoglossum flower's, was the first of the genus that I met with in Algeria. The Fossors Notogonia nigrita, and a female Salines, were secn about cliffs of alluvium and tufa respectively.

Here I may remark that I have often noticed that Xylocoprae and Bonbi are more quickly knocked down and killed by cyanide than are Noctuae, or even quite small beetles.

I met with very few Orthoptera at Hammam Meskutine, only the 
Cockroach, Loboptera (?) decipiens, Germ., and the Grasshopper, ${ }^{1}$ Acridium aegyptiacum, which flew from tree to tree. Very few Beetles turned up; Copris hispanus, Linn., a female; Geotrupes hypocrita, Serv.; Asida elevata, Chev.; and Scaurus atratus, Fabr., the last two found under stones together with two larvae of a Lampyris. ${ }^{2}$

Here for the first time in Algeria I came across Tortoises; two specimens measured $4 \frac{3}{4}$ and $5 \frac{1}{2}$ inches respectively. Here also I found a small Crab under a stone near a stream, but over 30 miles from the sea.

During the beautiful drive from Sétif to Bougie through the mountains of Kabylia, by way of the Gorge de Chabet, I saw but few insects. In the higher parts of the road, 1800 - $2700 \mathrm{ft}$., I netted Pyrameis cardui, and a couple of Vanessa polychloros. In the dismal gorge itself the flowers of a shrub of Laurustinus (Viburnum tinus, Linn.), apparently wild, attracted several Cyaniris argiolus, Linn., as well as the Drone-fly, Eristalis tcnax. At Rosemary I was disappointed in seeing nothing but Honey-bees.

Strange; at this point I laid aside my pen and took up that delightful book, "The Household of Sir Thomas More," where presently I came across this passage: "As for Rofemarie, I lett it run alle over my Garden Walls, not onlie because my Bees love it, but becaufe 'tis the Herb facred to Remembrance. . . ."

Below the gorge, at about $500 \mathrm{ft}$. above sea-level, there were more insects, but no great variety; Colias edusa, males only; Coenonympha pamphilus; Coccinella 7-punctata; Aphodius prodromus, Brahm.; a stylopized Andrena sp.; a Tipulid fly, Pachyrrhina sp.; Bombylius variabilis, Loew, and the Ant Aphaenogaster barbara.

Near Cape Oras insects were more numerous. Goneptcryx cleopatru was lairly abundant, and a couple of $G$. rhamni were netted; the only other butterflies were a pair of Ganoris rapae, and a solitary Pararge aegeria, var. meonc. This last was twice seen to settle with its wings up and tail to the sun; it was thus very inconspicuous, casting no shadow. A specimen of Acridium aegyptiacum was secured, not 丸lways an casy matter.

"This large crasshopper would cortainly by most travollers bo callcd a "Locust"; so with the typical migratory locusts, Schislocerca peregrina and Acridium pardalinum, but, by 2 most unhappy confusion of nomenclaturc, none of them are Locuslidac, but al bolong to the Acridiidac.

${ }^{2}$ This is not L. noctiluca, Linn.. but thore aro unnamed spocimons of tho same larva in the Britis' Museum. 
One of the most obvious insects was the small Chafer, Tropinote hirtclla, Linn., of which number's were flying about, or settled on, flowers, especially favouring those of Fedia decipiens, Pomel. They greatly resembled bees on the wing. There was also a fair number of Wasps and Bees. Among the former Polistes gallicus was prominent. I here took two males of Podalirius dispar, also four males of a species of Eucera to which Mr. Saunders failed to assign a name. The vast genus Andrena was represented by nigrocienea, and two unnamed males, while Apis mellifica put in an appearance as usual. There was in addition an unnamed Sawfly, while Diptera were represented by Bombylius boghariensis and Melanostoma (?) mellinum, Linn.

BOUGLE we thought the prettiest place that we visited in Algeria; the view over the blue waters of the bay towards the snow-clad peaks of Kabylia reminded us of a Swiss or Italian lake. Unfortunately we were able to stop but one night. A short walk the next morning gave the impression that the entomological attractions of Bougie might prove equal to its artistic merits. The following were met with: Lycaena icarus, Rott., a male; Ganoris brassicac; Synchlö̈ daplidice, Linn., one; Euchloë bclemia, one; and E. belia, Linn. (cupheno, Linn.), four males. Naturally I was much excited on taking such a pretty butterfly as belia for the first time; it was evidently just emerging and promised to be abundant.

The Bee Anthidium siculum, Spin., had a strangely red look upon the wing; with it were Podalivius dispar, a male; Osmia cocrulescons, Latr., a female; and Odynerus (Ancestrocerus) parietum, Linn.; while Tropinota hirtella was again successful in passing itself off as a Bee. I also took Bombylius variabilis, and the Grasshopper Thelpomence. algeriana, Lucas.

\section{Hammam R'ihra, oR Righa, $1850 \mathrm{ft}$. above sea-level.}

March 20th-31st, 1905.

Going by rail from Alger I took during a short stoppage at Blidah a male of Psithyrus fulvitarsis and a Nomada near to furva, Panz., also, on flowers of Rescda, the Chafer Tropinota hirtclla. At Bou Medfa station ( $800 \mathrm{ft}$.), whence I walked to the hotel, I took several Aculeates-Eucera nigrilabris, Per., with pollinia on its head, Polistes gallicus, and Apis mollifica, as well as the Fly Bombylius

1 Tho apparcnt discrepnucy is due to tho Arnbic lctter "Ghain," which is usually translitoratod "Gh," but sometimos "Kh" ; it is a guttural colsonant somewhat liko the Northumbrian " $R$," or the French "R-grassayc." 
bogharicnsis. Close to the station, and indeed all the way up, I found Enchloë belemic plentiful. At about $1000 \mathrm{ft}$. I took single examples of Euccre trivittata, Brullé, Andrena albofasciatce, a male, and Nomada, cirtana, Per. (? var.), also a male. At about $1200 \mathrm{ft}$. I took my first Thais mina, Linn., and was greatly delighted thereat. A little higher was Thestor ballus.

Hamman R'mira stands on a hillside looking aeross a valley; below and to the left are vineyards, to the right a piece of rough ground (good for botanizing) leading to the Forêt de Chaïba (chiefly pines), which culminates in the peak of Mont Samsam, $2800 \mathrm{ft}$.

The dead, bleaehed spires of the Land-shell Bulimus (Rumina) decollatus, Linn., were eonspieuous on every side.

Butterflies were fairly plentiful, quite plentiful during the latter days of my stay. Satyrines were scarcely eommon. Of Parargc meone I saw a fair number, but only one of $P$. megaera, and that on March 30th-it was perhaps only just coming out at that elevation; of Coenonympha pamphilus I got but two. There were several Pyrameis cardui about, the first fresh speeimen being seen on Mareh 25th. The Lycacnidae were somewhat poorly represented by a solitary male Cyaniris argiolus, and by the two species of Thestor; of these T. ballus was eommon enough, and I took eight males and five females, whereas of $T$. mauretanicus, Lueas, I seeured but one male and three females; it appeared to be local, frequenting the edge of the forest, moreover it was hard to see. The dominant group was unquestionably the Pierines. The only Common White was Ganoris brassicae. Two of these were in no way remarkable, but the third was unique in my experience-fluttering about flowers near the ground, quite unable to fly away; I found that it had been almost done to death by a bird, nearly the whole of the hind-wings and three-fourths of the fore-wings were gone. Of Colias edusa I took but one of eaeh sex. If the Picrinae were the dominant group, assuredly Euchloë was the dominant genus; $l \lambda$. bclcmia and L. belledice were both common enough, but towards the end of my stay E. betia (eupheno) was far commoner than either, indeed quite abundant, so that I seeured a benutiful fresh series of this brilliant Orange-tip, comprising ten males and eight fomales; the females emerged from four to six days later than the males. In one specimen, a female, there was a sharply-eut noteh in the hind-wings, larger in one than in the other; this I took to be the work of a bird.

The gorgeous Gonepteryx clcopatra was quite common, the less gaudy $G$. rhamni scarcely less so. I satisfied myself of the very remarkable fact that all the nales of clcopatra examined (15) had 
a distinct, or fairly strong, rich, sweet scent, which I compared to that of Freesia-some lady friends compared it to that of Gorse, Syringa, or Primrose; on the other hand, in ten males of rhamni examined there was either no scent to be detected, or something very faint and unlike Freesia. Such a marked physiological difference between two forms by many regarded as conspecific is very rernarkable and needs further investigation.

Thais rumina was common just before I left, it appeared to be but little attracted by flowers. No two were quite alike, the scarlet markings being especially variable.

I saw two or three Papilio podalirius, Linn., before March 26th, but by the 29 th it was fairly common. This magnificent butterfly was most easily secured at the flowers of Hawthorn or Pear, the latter proving to be especially attractive to it.

On some evenings the electric lights at the hotel entrance attracted a considerable number and variety of moths. Of Zygaena ludicre, Lucas, and Lymantria atlantiea, Ramb., I got but one each; of Hemerophila abruptaria, Thunb., three; Idaca virgularia, Hübn, two ; 1. marginepunetata, Göze, one; Melanippe fluetuata, Linn., one; fire specimens of a Larentiid, (?) Cidaria sp., which does not appear to be represented at South Kensington; Eupithecia pumilata, Hübn., one; $E$. innotata, Huibn., three; a specimen of a Boarmiid not in the National Collection; Cirphis albipuneta, Fabr., one; Caradrina quadripunctata, two; Agrotis puta, Huibn., one; Euxoa (?) nigricans, Linn., one; Laphygma exigua, Hübn., one ; Noctua C-nigrum, Linn., one ; Cloantha polyodon, Clerck (perspicillaris, Tinn.), one ; Calophasia platyptera, Esp., one; Cueullia ehamomillac, Denis, three; Xylocampa areola, Esp. (lithorrhiza, Bork.), one; Thalpocharcs (MFiera) ostrina, Hübn., one; Plusia gamma, Linn., four; the Quadrifid, Apopcstcs cataphanes, Hübn., two; Seoparia angustca, two; the Phycid, Acrobasis obliqua, Zell., three; and the Tineid, Ancsychia bipunctella, Fabr., two.

The following moths were found by day:-Aspilates ochrearia, Rossi (citraria, Hïbn.), one kicked up; Plusia gamma at flowers; Scopula ferrugalis, Schiff., one disturbed; Zygaena ludiera at flowers of Asphodel ; Ncmophora pilella, Schiff. \& D. in the pine wood.

Along the winding roads through the Foret de Chaïba the webs of the larvae of Cnethocampa processionea, Limn., were mnch in evidence, and the larvae themselves were often seen marching across the track. One such procession was carefully observed. The column consisted of 121 larvae marching in Indian file; they formed a waving line across the road, the small deviations from the straight 
line being apparently determined by obstacles encountered. There were about ten caterpillars to the foot, so that the column covered twelve feet of ground. Three times I moved the leader from the van to the rear, but this seemed to make no difference, the column went on unperturbed. If a larva were taken out of the middle the ranks very soon closed up. Larvae taken from the ranks and placed near the tail of the column failed to find it, unless placed very close to it. They travelled with the head of one touching the tail of the next ahead, and they appear to march along a thread of silk. Presumably this thread is laid down by the leader, but I failed to assure myself of this.

Next to the Lepidoptera in importance, so far as my collection was concerned, stood the Hymenoptera. To begin with the humble but industrious ants: of these five species occurred-Aphaenogaster' testaceo-pilosa, Lucas, of which a colony was found under a stone in the fir-wood; they were remarkably shy of light; and $A$.barbara, big black fellows which were also very shy, and in that respect contrasted with the small yellow Tetramorium caespitum, Linn., which had a colony under the same stone. At the summit of Mont Samsam (2800 ft.) I found under stones communities of Monomorium salomonis, Linn., and Camponotus cruentatus, Latr., the last-named being remarkably sluggish in its movements.

The only Scoliid was Dielis ciliata, Fabr., which was very abundant in two spots, a bank between the hotels, and a vineyard south of the hotel, towards Vesoul, at an altitude of about $1600 \mathrm{ft}$. This insect has tough integuments; it flies close to the ground among the Calendula algeriensis, Bois. Reut., and C. arvensis, Linn. The bright orangeblossoms of these small Marigolds are quite a feature of Algeria-till the evil season when the vineyards are hoed. D. ciliata was also taken at the yellow flowers of the wild Jasminum fruticans, Linn. It is curious that I came across no Pompilus nor Eumenes at Hammam P'ihra, but of Odynerus I got two: 0 . (Hoplopus) consobrinus and one o. (Ancestroccrus) parietum, the last at Hawthorn blossom. The true Wasps were two Polistes gallicus and a femalc Vcspa germanica, Fabr., the latter found in the forest. Of Halictus I took several:-H. ochraceo-vittatus, Dours., one; H. (?) malachurus, two fomales; Halictus sp., one; $I$. (?) costulatus, Kriech, onc (though Mr. Saunders thought this might possibly be new); also Halictus near to villosulus, Smith, ne. Naturally cnough thcre were several species of Andrena; of A. minutula, Kirby, which thoroughly deserves its name, I got seven; of $A$. surdoa, Lepel., one; of Andrena sp., one; of $A$. flavipcs, Panz., as many as thirteen, of thesc one was taken by Miss M. J. Donald on 
Asphodel, but the majority, in eompany with a number of males of A. lucens, were taken in the Forêt de Chaïba at $2000 \mathrm{ft}$. elevation, flying near the ground about a Genista that was not in bloorn. Of Yylocopa cyanesccns, Brullé, I took but one, whereas $X$. violacru was fairly eommon, frequenting Asphodel among other flowers; a solitary Nomada agrestis, Fabr., turned up. Other bees met with were: C'eratina cucurbitina, Rossi, one; Chalicodoma sicula, Rossi, one; Chalicodoma (?) sp. nov., one; Osmia kohlii, one o, two o; O. (?) notata, Fabr.; Anthidium siculum, three; Eucera trivittata, one ; Eucera sp., three; E. numida, Lepel., a of; Podalivius pilipes, seven at flowers of Vinco sp., also a variety of the male flying along the road in the Forest: $P$. dissimilis, Friese, one at flowers of Jasminum fruticans; $P$. nigrocincta, Lepel., $q$ var. ; $F$. dispar, four speeimens, one of them, $\delta$, at flowers of the Boraginaeeous plant Solenanthus lanatus, D.C.; Bombus terrestris, two $\not$ visiting flowers of Solcnanthus, two ot at flowers of Coronilla valentina, Linn., in the fir-wood on a dull day when there was little moving; Psithyrus vestalis, Lepel., a of; Apis mellifica; also an unnamed bee whieh had five pollinia, probably of the Orehid Ophrys lutea, Cav., on its head.

Flies are far more delieate in strueture than Bees and Wasps, so that they are more diffieult to preserve, moreover, they are far less well known, so that it is hard to get them named. Henee the following list does not inelude all the speeies that I brought home. The genus Bombylius is eertainly represented by more individuals in Algeria than in England; of $B$. medius, Linn., I took three males and two females; I also took another speeies to whieh Mr. Verrall eould not assign a name. Of the familiar Empis tesscllata, Fabr., I brought home two, and a like number of another Empis not jet named; there are a male and a female of Lucilia sp.; a female of Pollenia rudis, Fabr.; a speeimen of Oligodranes (?) fumipcnnis, Loew ; also two of Usia (?) atrata, Meig.

Hammam R'ihra yielded but a solitary Dragon-fly-Orthetrum chrysostigma, Burm. ; and only three kinds of Grasshoppers-Thatpomena algeriana, Acridium acgyptiacum, and Epacromia strcpons, of which last I got three speeimens.

My Bugs included a Centrocarenus (Centrocoris) varicgatus, Kolen.; Camptopus lateralis, Germ. ; Carpocoris purpurcopennis, De Geer, a fetid inseet of which I took three, one of them on Asphodel; and several larvae of a Iygaeid, (?) Aptcrola pcdestris, Stâl, a gregarious ereature, a luundred or so being found under one stone.

My named Beetles eomprised Copris hispanus, of whieh one of ench sex eame to light; Scarabacus cicatricosus, Lueas, found on the 
road; Rhizotrogus, two of a species not in the National Collection; Tropinota hirtella, abundant ou Asphodel and other flowers; Dasytes cyancus, Oliv., abundant on the flowers of Ccntaurea pullata, Linn., and on the yellow flowers of a Hawkweed-like Composite; Drypta dentata, Rossi, one under a stone; Pachychila imprcssifrons, several under stones; P. kunzii, Sol., one under a stone on the top of Samsam; Agapanthia asphodcli, Latr., a small Longicorn which bears a strong cryptic resemblance to the unopened buds of the flower from which it takes its name; it was not uncommon but was difficult to see, for not only were its general shape and colour like the buds, but its antennae closely resembled the narrow bracts of the inflorescence; Canthanis viridissimus, Lucas, three on the yellow flowers of the somewhat mustard-like Crucifer, Hirschfeldia geniculata, Batt.; Epilachna sp., not in the British Museum, two; Apion sp., one.

At Hammam R'ihra I was greatly struck by the strangely close superficial resemblance between the perianth of Aristolochia longa, Linn., and the spathe of the Aroid, Arisarum vulgarc, Targ.-Toz., a resemblance which I cannot attempt to explain as other than purely accidental.

Attracted by the glowing accounts of the flowers of the lower plains we went by rail on March 27th to AFFreviLLe, but the results were disappointing alike as regards flora and fauna. At Bou Medfa station I took a new Bee, Melecta luctuosa, Scop., a female. At Lavaranche the widely-distributed Pyrale, Scopula ferruyalis turned up, and Miss Donald found an immature Mantid, Empusa fasciata, Brullé, on a Palmetto (Chamaerops humilis, Linn.). At Affreville station I got the Grasshopper Acrotylus insubricus, Scop., and a singlc example of Synchloë daplidicc. At Affreville itself the now familiar Fuchloë belledice and E. belia were met with, as well as Chrysopluanus phlaeas. The only other captures were the Aculeates Podalirius dispar, a male, and Dielis ciliata, together with the Bug Camptopus lateralis.

Chiffa Gorge, Blidali, circa $1200 \mathrm{ft}$.

April 1st, 1905.

A visit to the celebrated Gorge was successful in so far as we got an excellent view of the Apos at quitc close quartcrs. The only Butterflies that I actually captured were a malc of Ganoris napi, the only one seen, and two males and one femalc of Thestor ballus. My note-book, however, tells me that in addition I saw Ganoris brassicae, 
Goncptcryx clcopatra, Euchloë belemia, Pyrameis cardui, Purarge mconc, and Cocnonympha pamphilus, as wcll as Macroglossa stellutarum, a very common Moth in Algeria.

The two Cetoniids, Tropinota hirtella and Oxythyrea stictica, werc obtained on flowers. The common Polistes gullicus, Apris mellifica, Xylocopa violacea, Dielis ciliata and Andrena flavipes, wero accompanied by the less common Eucera numida, a female, E. longicornis, Scop. (a British species), a male, and Podalirius atro-albus, Lepel. Of Acridium aegyptiacum, I took a pair; the female had but one hind-leg when caught.

On March 31st I saw in a public garden at Blidah two specimens of Grapta sp., but had no net with me ; on the following afternoon, at about the same hour, I went again in search of them, but it was cloudy and they were not to be found. It is interesting that Mr. H. J. Elwes, F.R.S., commenting upon Mr. E. G. B. Meade-Waldo's statement that he had seen Grapta C-album, Linn., high upon Tizi Gourzá in Morocco, stated, "I am not aware that this has been taken in North Africa before." 1

\section{Mustapha.}

April 1st-3rd.

A number of moths came to the hotel lights:-Cucullia chamomillae, one; Agrotis puta, seven; Cirphis albipuncta, three: Hadena oleracea, Linn., one; Xylophasia solieri, Boisd., one; Chloridca (Heliothis) peltigera, Schiff., one; Eupithccia centaurcata, Fabr., one; and the pretty little Phtheochroa rugosana, Hübn., one.

\section{Guyotville.}

$$
\text { April 3rd. }
$$

My visit earlier in the year had impressed me so farourably that I decided to spend my last day in Algeria on the dunes. Naturally on my sccond visit insect life was morc obvious and more varied, and it seems probable that even later in the season still bettcr results would be obtained. The wild arca is, however, not what it once was, having been grcatly reduced by cultivation, and at the time of $\mathrm{my}$ visit the proccss of "improvement" was still in full swing.

The Butterflies were somewhat disappointing. A big Papilio podalirius fniled to producc the thrill of excitement that it once did.

$$
1 \text { Trans. Ent. Soc., Lond., 1905, p. } 373 .
$$


'There were two or three of a Gonepteryx, also a Ganoris of sorts, as well as three or four each of Euchloëbelemia, and E. bclia; I also saw several Pararge meone, a lot of Pyrameis cardui, two Chrysophcunes phlacas, as well as a Blue that evaded capture.

Neither were Beetles very numerous or striking. $\Lambda$ few Pimclia subquadrata, Sol., crawled upon the sand, and one $P$. platynota, Fairm., was found on the road. In the flowers of Marigold (Calendules monardi, Bois. Reut.), Acmoeodera discoidca, Fabr., was common enough. Two species of Erodius might be seen rumning on the sand, a solitary specimen of $E$. vitrei, Sol., and half a dozen of a species allied to Ii. carinatus, Sol., which does not appear to be represented at South Kensington; this remark applics also to an Onitis caught flying along the road. The abundant Tropinota hirtella was there of course.

The Grasshopper, Acrotylus insubricus, was the sole member of its order taken. Two Coreid bugs, Verlusia sulcicornis, Fabr., were the only Hemiptera. Of Flies I brought home Sarcophaga sp.; Anthrax sp.; Bombylius sp.; a large red Myopa ; Bibio (?) hortulanus Linn.; Usia acnea, Latr., three ; and Rhyncomyia petalus, Wlk., three.

The commonest Aculeate was certainly Dielis collaris, Fabr., of which I brought away seventeen; while of its congener, E. ciliata, I took three only; but by far the most striking of the group was Scolia bidcns, Linn. It was the first time that I had seen this fearsome insect alive, and I spent much time in securing seven males and three females, all taken close to high-water mark at Mignonette (Resecda propinqua, R.Br.). Its exo-skeleton has notable pin-resisting power. Of the common Wasp, Polistes gallicus, I took five; of Colletes acutus, one; of Prosopis fertoni, Vach., five; and of a variety of Sphecodes fuscipennis, Germ., one. Of other Bees I took a female Halictus that is probably malachurus; a female of Dioxys tincta, Jur'; a male Nomada agrestis; nine Osmia ferruginea, Latr.; three $O$. rufigastra, Lepel.; three 0 . spinolac, Lepel.; two Anthidium siculum; three Podalirius atro-albus; seven of the Mason-bee, Chalicodoma sicula. Of Eucera algirce, I took but one female, but of another Euecra (Macrocera) which Mr. Ed. Saunders thought might be a new species, I was fortunate enough to get three specimens. The Ant, Myrmceocystus viaticus, brought up the rear.

Altogether it was a delightiul day, the blue Mediterranean and the golden sands making a picture that lingers in the nnemory. 


\section{CHAPTER V \\ SOU'LH AFRICA, $1905^{1}$ \\ CAPE Town, lat. $34^{\circ} \mathrm{S}$. Sea-level. \\ August 8th, 1905.}

Surely no one who was on deck when the "Kildonan Castle" anchored in Table Bay will forget the impressive scene. Behind the town-lights which gleamed along the front the grand mass of Table Mountain, clear cut against a streak of dawn, lay under the Southern Cross and Magellanic Clouds: in the opposite quarter Jupiter and Venus shone brilliant beyond our experience, the latter reflected in the sea, while Orion standing on his head demonstrated that we were indeed in a Southern land. These astronomical facts had a bearing on our entomological operations, since we had to grow accustomed to the fact that the most promising hunting grounds were slopes with a north-east aspect.

Faithful to our own science rather than to the Association of which we were members, Dr. Dixey and I had decided to go on to Durban by the same steamer, and put in as many days collecting as possible on the Natal Coast. This left but a day and a half at CAPE Town, in which to get a glimpse of its fauna and flora, and we were truly fortunate in that the Southern spring smiled upon us and provided, if indeed few insects, at any rate what Mr. Boswell would have termed "some fine prospects." The drive under the imposing line of crags termed the Twelve Apostles is very finc, as is the view from the highest point of the road towards the northcast. Spread out at one's feet between Table Mountain and Table Bay lies the city, while in the far distance a range of mountains, at this season capped with snow, completes the picture.

1 This chapter originally appeared in the Transactions of the Entomological Society of Jondon for Soptembor, 1907, p. 309, as a joint papor by Dr. F. A. Dixcy, F.R.S., and mysolf, cutitled: "Intomological Observations and Captures during tho Visit of the British Association to Soutb Africa in 1905." My companion is not responsiblo for any points in which this account may differ from the original. 
We were aware of the poverty in Rhopalocera of the Cape Peninsula, and Mr. L. Péringucy, the obliging director of the South African Museum, impressed the fact upon our minds, yet we werc hardly prepared to find butterflies so scarce as in fact we did.

The best scheme seemed to be to drive to Camps Bay, stopping on the way to collect on the slopes of the Lion's Head, above Sea Point. While waiting for the carriage we took in the garden of the Mount Nelson Hotel, on Narcissus flowers, a few Honey-bees, Apis mellifica, of the somewhat brighter race adansoni, Latr., that is prevalent throughout South Africa, and with them their familiar mimic Eristalis tenax. An Empis was also common in the garden.

The country had all the appearance of early spring, and it was evident enough that we were much too early for good sport. Below the Lion's Head, by a little stream perhaps $200 \mathrm{ft}$. above sea-level, we took two specimens of the brownish Lycaenid Cacyreus palemon, Cram., quite unlike any Blue that either of us had previously seen alive; these and a Skipper that eluded capture at Camps Bay werc the only butterflies we saw that day.

Turning over stones proved disappointing; besides sundry Scorpions and Myriapods the chief tenants were Ants, a larger yellowish species, Camponotus maculatus, Fabr., and a smaller black species, Acantholepis capensis, Mayr. With the ants werc a few Beetles, such as two specimens of Formicomus coeruleus, Thunb.; an Anthiid, Microlestia tabida, Fabr.; another beetle not yet determined, and two larvae of a Lampyris.

Along with the beetles were sundry Cockroaches, creatures we were afterwards to find numerous; among them were two Pseudodcropeltis juncea, Sauss., and immature examples of possibly the same species. ${ }^{1}$

The best harbour for insects appeared to be a species of Solanum, a medium-sized, prickly shrub bearing numerous seed capsulcs. On this plant the red Lady-bird Chilomencs lunata, Fabr., was abundant, and a black species, Chilocorus sp., unrepresented in the National Collection, was fairly common. Several other Ladybird-like beetlcs, as yet undctermincd, were found on the same plant, as well as one specimen of Epilachna hirta, Thunb. (the sole phytophagous genus in a family otherwise carnivorous). On the lcaves were also two cxamples of the tiny Abacetus minutus, Dej.

A dark-green, scarlet-striped Bug, Lygacus festivus, Thunb., accompanied the Lady-birds, while immature specimens of the same

'Mr. Shelford says that it is not possible to determino with ecrtainty the speeies, or in somo cases oven the genus, of immature cockroaches 
were common inside the sced-vessels together with nunbers of is fetid browu bug not yet named, and what we took to be beetle larvase. A third bug, of a pale searlet eolour when alive, frequented the same Solanum.

The few flowers that were out yielded nothing but a Honey-bee and an Empis.

At Clifton, Camps Bay, on the undercliff above the dazzling white beaeh, upon the flowers of a shrubby Senecio-like Composite, we took the small green Longicorn, Promeccs lincaris, Linn., the small bronzy Bce, Halictus jucundus, Smith, o, and Apis mellifica,

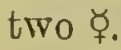

A small Carabid, Platynus rufipes, Dej., found under a stonc, eompleted our small bag. As we often expericnecd afterwards, the South-east Trade brought up clouds and gave us a dull aftcrnoon, so that eollecting was practically over at an early hour.

On a shrub in the Botanieal Gardens, at about 4 feet ahove the ground I foumd a green Chamaeleon (C. pumilus., Daudin) coneerning which I shall have more to say later.

Port Elizabetil, Algod Bay, Cape Colony, lat. $34^{\circ} \mathrm{S}$. Ser-level. August 11th.

The steamer did not give us a very long time at this place. After an early breakfast we took the train to ZwAARTKOPS, some seven miles to the northward.

The coast here is flat and fringed with sandhills; by the railway thc country is sandy and hcathy; on the south side of the river its delta forms a level plain perhaps a mile wide between the saudhills and the railway, this is diversified by brackish swamps and intersected by streams. On the drier portions of this saline plain Termitaria are numerous, from 1 foot to $2 \frac{1}{2}$ feet high, and 2 to 3 feet aeross; on the surface they are smooth and hard as if "rendered" with cement, many-ehambered within. One long ridge of sand was eovered with thorny shrubs. The most eouspicuous plant was a tall $A$ lö̈ (?) arboresccns, (?) fcrox, ${ }^{1} 6$ or $S$ feet high in full flower, but there were also at least two species of Cotylcdon (Echcveria), and several species of Mescmbryanthcmum, one with large pink flowcrs, another with still larger yellow flowcrs, a third salmon-coloured, and a fourth shrubby, with small pink llowers. In such a locality

1 The truo Aloc, of the Nat. Ord. Liliaceac: the plant most commonly so named is the Agave, an Amoriean genus of tho Nat. Ord. Amaryllideac. 
it scemed quite natural to put up a comple of Hares. Low growing Euphorbias were many and varied, one appeared to be absolutcly stemless, the involucres springing directly from the ground. There was also an ivy-lcaved Pelargonium.

A fresh easterly breeze swept over the open ground and added to the difficulty of catching butterflies. The males of Synchlö hellica, Linn., were common, flying fast, and rarely settling; four specimens were secured. Of Leuceronia buquetii, Boisd., at least three were seen, two were secured, both males, but a third managed to get out of the net; they flew strongly. The proboscis of this butterfly when fresh is of a bright green colour like its eyes. Colias electra, Linn., was more restrained in its movements, and two males were taken. Of Pinacopteryx charina, Boisd., several were seen, also two or three individuals of an orange-tipped Teracolus (probably omphale, Godart), but it eluded all our efforts to effect its capture. ${ }^{1}$

On the lee side of bushes which afforded a slight shelter, the Lycaenid, Leptomyrina lara, Linn., was common, taking short flights and settling on the ground or on low plants. Nearer the sea on a sunny bank under the lee of the sandhills, the very beautiful and singular Lycaenid Phasis thysbe, Linn. (osbecki, Auriv.), was not uncommon, though apparently very local; it has a quick skipping flight and time allowed the capture of but two males and a female. In the same locality a pretty little rose-coloured Geometer, Sterrha plecturia, Guen., was fairly common, but unfortunately only two specimens were brought away. On the open plain the familiar and cosmopolitan Nomophila noctuella was often disturbed and two were taken, as well as a specimen of the scarcely less widely distributed Scopula ferrngalis, Hübn.

A piece of rough heathy ground near the railway station yielded two Satyrids, Pseudonympha sabacus, Trim., and others were seen near the same spot; the genus is characteristic of South Africa. Close by a small Blue, Zizera lysimon, Hübn., was netted, as well as a fine variety of Sterrha sacraria, Linn.

Under some planks lying on the sand of the river bank we found among smaller Bugs, our first specimens of Physorhynchus crux, Thunb. This large Reduviid, whose wings are so closely appressed to the abdomen that we for some time took it to be apterous, is very conspicuous when alive, the pale testaceous thorax and margins of the abdomen showing up the black cross upon its back, but the pale portions soon darken and the insect is dingy in the cabinet. The same planks afforderl cover to a Slow-worm. 'This was a pale

\footnotetext{
'Dr. Dixoy's ecstatic cry, "Teracolus l" still scoms to ring in my oarn.
} 
yellowish fawn-colour above, with eight brown lines along the back; beneath it was white with a pink tinge of blood showing through its anterior half, giving it a very worm-like appearance. Under chloroform the animal was extremely violent and was some time in dying.

Turning over stones produced a few Beetles: single examples of Lycanthropa synoecoides, Ques., Harpalus exiguus, Dej., and Blenosia (Blacodes) sp., as well as two Trigonopus sp., the last two both represented at South Kensington, but unnamed. With the beetles were several Blattidae, to wit Deropeltis erythroeephala, Fabr., + , an immature Pseudoderopeltis sp., and three specimens of another Cockroach which stands unnamed in the National Collection.

An old Termitarium, long abandoned by its builders, afforded asylum to a number of insects, among which the most numerous and most conspicuous was the large Carabid Mierolestia rugosopunetata, Thunb.; there was also a solitary Weevil, Hipporrhinus appendiculatus, Gyll.

The great spikes of Aloe proved attractive to Flies and a Bee, Prosopis sandaraeata, Bingh. At the same flowers a Bird with a long thin tail was very busy, but whether catching bees or eating honey could not be determined.

The Hopliine beetle Gymnoloma atomaria, Fabr., was taken on a flower. Among Flies the cosmopolitan genus Sarcophaga was represented, and an Asilid, apparently a Dysmachus, was noticed to settle on the ground

While searching for beetles it was impossible to orerlook the numerous empty spires of the large and handsome Snail, Aehatina zebra, Chem. (fulgurata, Pfr.); one of them was tenanted by a stump-tailed Lizard which was purplish-grey spotted with olivebrown. A couple of Tortoises added to the picture, the carapace of one was about 5 inches, of the other nearly a foot long.

Among the Bees that we brought home was a little one (unfortunately not labelled) that was in all probability taken at Zwaartkops, though possibly at Cape Town, which turns out to be a novelty; the late Col. Bingham described it as Halictus inornatus, sp. nov. ${ }^{2}$

1 Its description, with those of other Aculeata taken by us in Soutb Africa, will be published in the Trans. Int. Soc. Lond., at about the same time as this rolume. The prper was read May 3, 1911. See below, pp. 196, 207, 212, 236, 245. 
East London, Cape Colony, lat. $33^{\circ} \mathrm{S}$. Sea-level.

August 12th.

An eager reconnaissance from the deck before breakfast revealed a tempting spot a mile or two to the north-east of the town where hills of blown sand capped by scrub suggested many possibilities. Accordingly we landed at the earliest opportunity and took a carriage. The road from the quay alongside the inner harbour brought us in a very few minutes into the QueEN's Park, throngh which we were to drive. Our attention was at first caught by the weird forms of gigantic tree-Euphorbias,- - strangely contrasting with the stemless form seen at Port Elizabeth-but these were soon forgotten, for as we passed the park gates we seemed to enter a very preserve of Butterflies. To one of us the sight was new as it was beantiful, to the other it brought back vivid recollections of India and Ceylon; both agreed to dismiss forthwith the Kaffir driver, who, while he pocketed his easily-earned fare, doubtless pondered on the strange developments of European civilization and the increase of lunacy consequent thereon.

The park is formed ont of a piece of the primaeval scrub of varied growth, filling a horseshoe-shaped hollow between the town and a tributary of the Buffalo. It is intersected with roads, footpaths, and streams; in parts are artificial shrubberies and flower-beds, which are gradually ousting the natural scrub. In the varied scene of insect life the most obvious characters were clouds of Mylothris arathina, Cram., of both sexes, their brilliant white and orange colouring showing clearly as they fluttered slowly and fearlessly over the large bushes of Poinsettia, Euphorbia puleherrima, glowing with their scarlet bracts. The males give out quite a strong scent very closely resembling that of sweet-briar. Amongst the agathina we took three specimens of the nearly allied rüppellii, Koch, of both sexes, and in another part of the park a single male of the delicate trimenia, Butl., with its pale yellow hind-wings.

Less showy, but almost equally common, was Belenois severina, Cram., the Common White of this part of the world. Both sexes were well represented, the male having a distinct scent. All were of the dry-season form; some were very small. Of $B$. gidien, Godart, a single male was taken, also strongly scented. Of the more gaudily coloured $B$. zoehcalia, Boisd., two males and a lemale turned up.

T'ericus was represented by a single brigittu, Cram., a male; Colices by two electrc, also males; and T'ercucolus by two ompluale, one of 
each sex. Last, but not least beautiful of the Picrines was Eroniu, cleodora, 'Hübn., of which five specimens were taken, while a male E. leda, Doubl., was netted, but managed to get away.

The widely-ranging Danaida chrysippus, of the typical African colouring, which, as is well known, is darker than in the Indian form, was flying slowly about in some numbers; two females that were taken yielded the musk-rat odour.

Another butterfly that was very common was the Nymphaline, Eurytela hiarbas, Drury. It has a curious slow flight, gliding backwards and forwards about bushes, for flowers seem to have no attraction for it; but if the flight of this butterfly, and its coloration, brown with a transverse white band, remind one of the Neptis group, its general appearance and shade-loving habits suggest a Satyrine. $E$. hiarbas usually settled on the ground with wings more or less expanded and from time to time slowly closed and opened them again; it oriented itself with tail to the sun, but not very accurately. Conspicuous amongst the Nymphalines was our old friend Pyrameis cardui, mostly in poor condition, but one was very fine. The large genus $P$ recis was represented by three species, sesamus, Trim., archesia, Cram., and cebrenc, Trim., the latter not uncommon. One specimen of each was secured, but we had our first lesson in the elementary fact that to see a Precis is not always the same thing as to catch it.

A sunny bank cleared of scrub was grown over with a Senecio not unlike the Oxford squalidus, Linn. Amongst these flowers Byblia goetzius, Herbst, was rather common, often settling on the ground; they were all females, one of intermediate character, the rest "dry." A single B. ilithyia, Drury, was "very dry." This and a specimen taken at Ladysmith were all of this species that we saw in South Africa.

One of the spots in the park where butterflies were especially numerous was a sunny bank close to an open drain whose black stream evolved so much sulphuretted hydrogen as to suggest pollution by a laundry. Some Poinsettia bushes (inclinding one with the bracts pale yellowish instead of the more usual scarlet), growing where the smell was most sickening, proved quite as attractive to butterflies as others in sweeter situations. ${ }^{2}$

A few fine blue and black Papilios dashed abont to tantalize us (they were almost certainly $P$. niveus, Crnm., f. lyacus, Doubl.), but

It is well known that the loeal races of $F$. clcodora show great differenees in the amount of black bordering to the wings. This in the East London specimens is redneed to a minimum. Seo Dixoy, Proc. Ent. Soc. Lond., 1905, p. Ixri.

2 Compare my exporicuce near Darjiling (p. 83), and at Hongkong (pp. 127, 128). 
the common South African P. demodocus, Esp., proved much easicr to capture, and bctween the park and the town two specimens fell victims to our nets; one of then seemed to have been injured by a bird.

Satyrines were conspicuous by their absence. A single female specimen of the common, dingy, South African Skipper, Gegenes letterstedti, Wallgr. (hottentota, Latr.) was the sole Hesperid seen, but the Lycaenids were better represented by a solitary male of the far-ranging Tarucus telicanus, Lang, and several specimens of the "amphisbaenoid" 1 tailed and lobed Blue, Argiolans silas, Westw. This has a rapid and jerky flight and is fond of settling high up, so that the observation of its false head and its attitude at rest was attended with difficulty, but a male and four females were easily taken off the red blossoms of a tall shrub.

The only Moth captured was a male Lymantriid, Euproctis mesozonc, Hmpsn., which flew fast in full sunshine; this is a species represented in the National Collection solely by the type.

Among other orders the Diptera were represented by an Idica and another fly; we did not take a single beetle, being indeed too busy with the butterflies. There were many small Grasshoppers in the coarse grass by the foul stream, the most striking being the common South African Catcintops melanostictus, Schaum, whose red tibiae and striped femora render it conspicuous. The only Aculeate taken was a worker Belonoguster praunsi, Kohl, one of two seen on the same plant. This genus, very characteristic of the country, has an extremely long peduncle to the abdomen. We took a specimen of the Sawfly Athalic himantopus, Klug, a species that Colonel Bingham said was widely spread over the African continent. The Bug Ateloccrce stictita, Westw., was caught flying: during life its underside is covered with a white waxy substance.

Among the things that we saw that morning, but did not catch, were a Charaxcs, an Amauris (probably) and Atella phalantha, Drury.

\section{Dutiban, Natal, lat. $22^{\circ} 50^{\prime} \mathrm{S}$. Sen-level.}

$$
\text { August 13th-21st. }
$$

At DURban we had the great advantage of an introduction to Mr. A. D. Millar. This gentleman and the members of his family are enthusiastic entomologists. It had been our intention to go northwards and explore the country about the mouth of the Tugela, but, acting on Mr. Millar's advice, we decided to stay in Durban and 1 The Amphisbaena is a legless Lizard which, it has been alleged, can move
either backwards or forwards. 
so make the best use of our time, which was here, as elsewhere, all too short.

The Ocean View Hotel in the residential suburb called THE BEREA is perhaps $200 \mathrm{ft}$. above the sea; its garden yielded a few of the commoner butterflies-Papilio dardanus, Brown, f. cenea, Stoll, a male, Preeis clelia, Cram., Myealesis safitza, Hew., both sexes, and Zizera lucida, Trim., a male.

Lanes and bits of open ground near the hotel, still retaining much of the character of the primaeval scrub, afforded fair collecting. It was in such a place that wc were much excited at bcating out our first Sclamis anaeardii, Linn., a large greenish Nymphalinc very leaflike on the underside and with a peculiar satiny sheen that gives it a very tropical aspect. There we found late in the aftermoon both sexes of Danaida chrysippus, with them were less familiar butterflies, Aeraec terpsichore, Linn. (buxtoni, Butl.), several feigning death in the net; A. cabira, Hopff., one; a pair of Precis sesamus; an example of Eurytela hiarbas, also several specimens of Byblia goetzius, of both sexes, all more or less "dry" in character; this butterfly flies low down rather quickly, settling usually on the ground under a bush, but is easily disturbed. We also took at the Berea two males of Belenois severina, two males and a female of Mylothris agathina, and one of each sex of Terias regularis, Butl. Of smaller things we took one each of Zizerce lysimon, and Gegenes lettersterti, while beating produced a Geometer, not yet identified.

The glow-lights of the hotel only yielded the Boarmiid Tephrina arenosa, Butl., and two Noctuae:-Ophiusa mejanesi Guen. (a moth that occurs in India, coming very near to Walker's type of crpedita, a species sunk by Sir George Hampson), and Ethiopica (Caradrina) miera, Hmpsn. A humble Fly, Homalomyia canicularis, Lim., was an inmate of the hotel.

Sandy banks by the roadside were haunted by various Fossors, two of which, Liris haemorrhoidalis, Fabr., a male, and Pompilus cliversus, Smith, a female, exhibit Lycoid coloration, the last-named more especially, with its yellow-brown wings tipped with black. It may be explained that it is well known that in Africa a great many insects of various orders are coloured like the distastcful Malacodermatous beetles of the family Lyeidae, orange-brown tipped with black posteriorly. ${ }^{1}$ With thesc were two of the slcuder ycllow and black Dielis fasciatella, Hübn., both males. The Syrphid fly, Eristalis tecriops, Wied., was too handsome to be passed by.

I Seo G. A. K. Marshall, Trans. Ent. Soc., Isond., 1902, pp. 340, 344, 380, 515-51S, and Plato XVIII. 
The first of lis favourite localities to which Mr. Millar directed us was the Old Cemetery at Sydenham. About three miles to the north of Durban, it lies on the north (sunny) side of a hill sloping very gradually towards the Umgeni River, and may be some $400 \mathrm{ft}$. above sea-level. The Cemetery itself is small, neglected and overgrown with coarse grass and herbage, which doubtless nourishes many larvae, while there are enough flowers to attract butterflies. The grassy lanes on either side afford excellent collecting ground, and, although most of the land around is cultivated, there is some scrub to the south.

Here we found, beside our familiar friend Danaida chrysippus, our first specimens of Amauris culbimaculata, ${ }^{1}$ Butl., both males. Single specimens of the beautiful dark red Acrcea petraea, Boisd., and of $A$. natulica, Boisd., a male, were taken. The fore-wings of the last-named are, when the insect is fresh, of a fine rose-crimson, the hind part of the abdomen (in the male) being banded above with pale rose-pink and white, but white beneath. Males of $A$. terpsichore were fairly common, especially among dead grass. A. encedon, Linn., of which two examples were taken, was so successful in its mimicry of $D$. chrysippus as at first to make the writer believe it to be that species.

In the Cemetery a few males of Hypolimnas misippus, Linu., were sailing around, flying high and seldom flapping their wings, lout no females wcre observed. In an open space within the enclosure, as well as in a cleared mealy-field adjoining, the "blueeycd" Precis clelia was locally common, settling on the bare eartli and on the grave-stones; with them were a couple of $P$. ccbrcne, but that species was commoner in the dry bed of a spruit half a mile to the north; some of the specimens were very small. Three examples of $P$. natalica, Feld., were taken; $P$. scscumus was not uncommon. Only two Precis (Catacroptera) cloant7ı, Cram., were seen, one of them in the dry spruit. Eurytela hiarbas was very common about hedgerows. Single specimens of Pyramcis cardui and Salamis anacardii turncd up. Several male specimens of Byblia goctzius wcre taken, but it was hardly common. To effect the capture of Charaxes varanes, Cram., required considerable negotiations, as its flight is both high and strong, but it has a habit of settling at the encl of a prominent twig, and is then fairly ensily detected in spite of the resemblance of its under-surface to a leaf.

Of Mycalesis safitra, two fomales were taken, one ncar the

' For the specific distinctness of this form from A. ccheria, Stoll, sec Rothschild and Jordan, Novit. Zool, x. 1903, p. 501. 
Cemetery, the other in the village of Sydenham (a mile nearer Durban), they were flying in full sunshine in the early afternoon. Of $M$. pcrspicua, Trim., three males were taken among dry grass, etc., near the before-mentioned spruit; they were rather common there, but of restless habits, so that it was very difficult to see them settle. It was interesting to find that on separation of the wings and stroking the patch near the costa of the hind-wings they gave out a very strong scent quite distinct in character from that of $M$. saftzia, which has one of the strongest scents known to me.

Of Belenois severina, a male was taken, but $B$. gidica appears to have been commoner, since three males and a female were brought home. Three Pinacopteryx pigea, Boisd., two males and a female (near Sydenham village), and one $P$. eharina, were taken. We met with but one Mylothris agathina, a male, but Eronia leda, Doubl., was not uncommon, flying rapidly along a lane near the Cemetery, often in company with Teracolus auxo, Lucas; it was hard to eatch, but three males and a female were secured. The genus Teracolus was more dominant at Sydenham than at any other locality which we visited, the most abundant species, especially in fields, was $T$. auso (the dry-season form called by Wallengren topha); the males of this species appeared to outnumber the females by two to one. On one occasion a specimen of auxo and one of Eronia leda, both males, were in the net together, they were duly pinched, and as the net was lying open on the ground another auxo (sex not known) came and settled on it close to the dead butterflies. The next commonest species was T. annae, Wallgr. [dry-season phase = wallengrenii, Butl.], of which thirteen males and one female were taken. On the other hand, of $T$. omphale we took but three males and one female, and of T. achine, Cram., a like number, while of the lovely T. phlegyas, Butl. [according to Trimen = ione, Godart], we secured but a single male, of which it was noted that the purple tip was not apparent in flight. Butterflies of the genus Terias were in abundance locally, the specimens brought home proved to be T. regularis, four males (one of them intermediate in character, the rest "dry"), and $T$. senegalensis, Boisd., one male, "dry." The only other Pierine taken was Colias clectra, on the road about a mile on the Durban side of the Cemetery; the species was not common.

One Papilio dardanus was taken at Sydenham, but $P$. dcmodocus was common; it flew fast but generally not very high, twice at least it was observed to flutter its wings when feeding, as its congener $P$. demolens, Linn, had been observed to do in India. A specimen taken in Sydenham village was very small. 
A considerable variety of Lyeaenids was taken, though they cannot be said to have been abundant: Virachola antalrss, Hopff., a male; Hypolycaena philippus, Fabr., a female; Axiocerces harpax, Fabr., a male settled on a rose-bush in the Cemetery; Polyommatus baeticus, one ; Zizera lucida, two females; Z. lysimon, one on the way; Lachnocncmonea bibulus, Fabr., four, in the Cemetery. This speeies sits with the abdomen turned up at an angle of $45^{\circ}$ (like Euchlö̈); I never saw this butterfly drinking, but it is fair to assume that the collector who sent the specimens to Fabricius reported its habits as he had observed them: its specific name would well describe many a Blue. In addition Catochrysops malathana, Boisd. (asopus, Hopff.) turned up; while on the slopes of the spruit before mentioned I met with a single example of Alcena amazoula, Boisd., a female, which was very cryptie among the grass where it was found. In general appearance this species so closely resembles a tiny Acraca that at first it was placed next to that genus.

The Skippers again were varied rather than numerous, single specimens being taken of eaeh of the following:-Sarangesa motozioidcs, Holland, almost invisible as it sat on a rock in the spruit with its wings spread out flat; Netrobalane canopus, Trim., resting with expanded wings on the upper side of a Solanum leaf; Parnara fatuellus, Hopff.; Gomalia albofasciata, Moore; the large species Rhopalocampta pisistratus, Fabr., and R. forestan, Cram.; lastly Caprona adclica, Kirsch, a prettily marbled butterfly with a scaleless pateh on the fore-wing, of which there are but two specimens in the British Museum.

The Syntomids Pseudonaclia puella, Boisd.; Syntomis simplcx, Walk. (two), a metallic-blue thing easily caught; and Euchromic formosa, Guér., were taken flying, the latter near the spruit. A crippled specimen of the singular Geometer, Caenina poecilaria, H.-Schäff, was taken in the Cemetery, a better one missed in the spruit, both among long grass.

The following Hymenoptera were taken: Xylocopa divisa, Klug, a male; a grey Wasp, Icaric cincta, Lepel., $\not$; the Ant Camponotus maculatus, eight specimens under a stone; and an undetermined Ichneumon-fly.

The great order Coleoptera was very poorly represented by two Lady-birds, Ortalia sp., beaten out of a Composite ereeper (apparently a Senecio), the specics is represented in the British Muscum, but runnamed; thrce Haplolycus, apparently of two species (onc possibly conyener, Gerst.), were either beaten out of, or taken flying about the same creeper; Acantholycus constrictus, Fabr., was caught flying slowly; 
two specimens of Anomalipus porcatus, Sol., were found under a stone; and four specimens of a Heteromeron, Opatrum sp., apparently in the National Colleetion, but unnamed, were also found under stones.

Stone-turning also yielded an extremely flat Slug; it was of a pale greenish-grey, obseurely retieulated with darker, whitish beneath - probably Vaginula sp.

The Bugs, at least as regards individuals, were somewhat more plentiful; beating the elimbing Composites (one with yellow, another with lavender flowers) revealed a number of the fetid Pentatomid Antestia varicgata, Thunb., blaek, with orange spots, and pale yellow markings, these were at first taken by both of us to be Lady-birds; two other fetid Pentatomids, Holeostethus goniodes, Dall., and $H$. scapularis, Thunb., were also taken.

There were two as yet undetermined Aeridians among our captures as well as the common Catantops melanostictus. Also a Dragonfly, Orthetrum fasciolatum, Ramb.

The Botantcal Garden lies on the slope of the hill between the Berea and the Racecourse, and eomprises portions of the original serub, so that it naturally harbours many butterflies. Amongst these was a small female of Danaida chrysippus, whieh was actually mistaken by the author for its mimie Acraea cncedon (of which three specimens were captured), while pcr contra the Acraea was mistaken for the Danaine! A single speeimen of Plancma escbria, Hew., and two of Acraea cabira were netted; one of the latter settled on a leaf with wings closed was ineonspieuous. Of Amauris albimaculata, a male and two females were taken.

Eurytela hiarbas was common in the wooded parts of the garden, where also three Precis elgiva, Hew., were secured, together with two $P$. natalica, of the dark, or intermediate form (one very tattered), sitting on leaves with wings fully spread. The same bit of surviving serub yielded two of the Satyr-like Crcnis boisduvalii, Wallgr., one of each sex. Ncptis agatha, Cram., was not uneommon, but as the garden is a good deal exposed to the prevalent south-east wind many of the specimens were worn. Salamis anacardii was beaten out at 4.45 p.m. : it had a very slow flight. Of Byblia goctzius we took a male of the dry-season form. In a shady spot were two Mclanitis lcda, Cram., the only specimens that we met with in South Africa. Mycalesis safitza, with its janira-like flight, was not uncommon in the shade; the four speeimens taken in the gardens were all females of the dry-seasoul form (var. cvenus, Hopff.).

Bclcnois scvcrina was common; though the large majority were 
"dry," amongst them was found a "semi-wet" male. It was noted of a pair in cop. that the male supported the female in flight. Only one $B$. gidica, a male of the dry-season form, was taken. But if not quite the commonest White of the gardens, certainly Pinacopteryx pigea was the most characteristic; a dozen specimens, both sexes about equally balanced, were secured, they were all of the "dry" form (alba, Trim.); it appeared to be an earlier riser than many butterflies. A pair were observed in cop., the male supporting the female, and when settled enclosing the female between his wings. Of $P$. charina, two of each sex were taken, one of the females was less "dr'y" than the rest. Mylothris agathina was scarcely common, males prcvailing. In the more open grassy parts a few Tcracoli were to be got: of $T$. spcciosus, Wallgr., we took two males; $T$. omphale was commoner, and we took five males and two females; of $T$. achine, one of each sex. Of Eronic cleodora we took but one; Terias regularis was common enough; six specimens taken proved to be all females, of the dry-season form. We did not meet with this species ontside Natal.

Just outside the hedge of the Botanical Garden a fine Papilio morania, Ang., was taken flying low and settling on wayside plants, along with Belenois severina; others of the genus were $P$. demodocus, a male; $P$. dardanus, two males, a species that does not fly as fast as many of its congeners; $P$. nireus, f. lyaeus, a male and two fcmales.

The Lycaenidae were conspicuous by their scarcity, only two being met with-Hypolycaena philippus, a male taken as late as 5 p.m., and Zizera lysimon, two, one of them beaten out but little carlier (together with two $P$. pigea and two $B$. severina).

But if Blues were scarce it was far otherwise with Skippers: of our old friend Gegenes letterstedti, seven were taken, five being males, two females; this sits in the familiar Skipper attitude, but the posterior third of the hind-wing is plaited; Parnara fatuellus, onc ; Acleros mackenii, Trim., seemed to be common but was hard to catch, a malc only was netted; of Pterygospidca flesus, Fabr. (ophion, Drury), five spccimens were sccured; it has a rapid darting flight, dashing wildly up and down the glades like a flash of silver, and suddenly settling with wings widely spread like a Boarmia, usually (so far as our experience wont) on the upper side of a leaf, though it was on at least one occasion seen to settle on the undcr side, which Mr. Trinen givcs as its habit. The finc large Skipper Rihopalocampte keithloa, Wallg1., rests in a siugular attitude, the wings are raised above the back but do not meet, since both primaries 
and seeondarics are eurved outwards somewhat spirally, uloreover the posterior half of the secondaries is euriously plaited over the abdomen; a specimen of $R$. forcstan was beaten out as late as

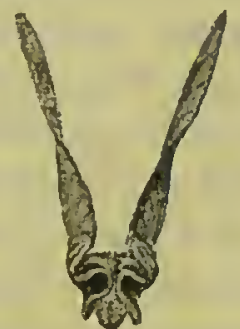

Fig. 7.-Rhopalocampta lieithloa. Position of wings in resting attitude, seen from be. hind.

4.45 p.m., darting away with a whirligig flight. On the other hand, it was noted that Skippers were very active one morning before 9 a.m.

The Lymantriid moths Euproctis punctiferc, Walk., three males, and E. stellata, Dist., two males, were beaten out one afternoon, together with the Larentiid Geometer, Epirrhö subspissata, Warr., and the Aeidaliids, Craspedia pulverosaria, Walk., and Idaea spoliata, Walk., one of each; the Deltoid Hypena thcrmesialis, Walk. (Ophiuche masurialis, Guen.) three; the Pyrales Bradina admixtalis, Walk, one; $B$. atopalis, Walk., two; and some others not yet determined.

Only two Beetles were captured, one the Weevil Strophosomus ancorifrons; the other, Cardiophorus sp., was found under an old tarpaulin.

The sole Aeuleate brought away was a beautiful light blue Bee, Crocisa picta, Smith, $\not{q}$, which with its rapid flight suggested a small diagon-fly.

Three speeies of Diptera were met with: Eristalis tacniops; Syrphus aegyptius, Wied.; and Sarcophaga sp.

A solitary Pentatomid bug, Agonoscelis vcrsicolor, Fabr., was taken.

Of Dragon-flies we took one of a speeies not yet determined, and two that would appear to be Orthetrum fasciolatum.

From the gardener's point of view perhaps the most striking thing about the Botanieal Gardens is the free use of the thorny Euphorbia splendens as an edging to beds; when we were there its brilliant red braets were most effeetive. Those who have only secn small plants in the stove can form but little idea of its beauty.

In approaehing Durban from the sea one first sights THE BLUFF, a ridge of high ground separating the harbour from the Indian Ocean. Aeeess is obtained on the landward side by a steep path, which, protected from the sea winds and lying fully open to the sum, is the resort of many butterflies. At first it is hard to realize that south of the Equator hillsides with northern aspeets are the entomologist's most likely hunting gromnds. At the eastern cxtremity, near the lighthouse, the Bluff is more or less bare; but the path towards the west soon leads into the serub, or natural forest, of mixed growth with a scareely penetrable rank undergrowth of the coarse 
Plate II.

SOUTH AFRICA.
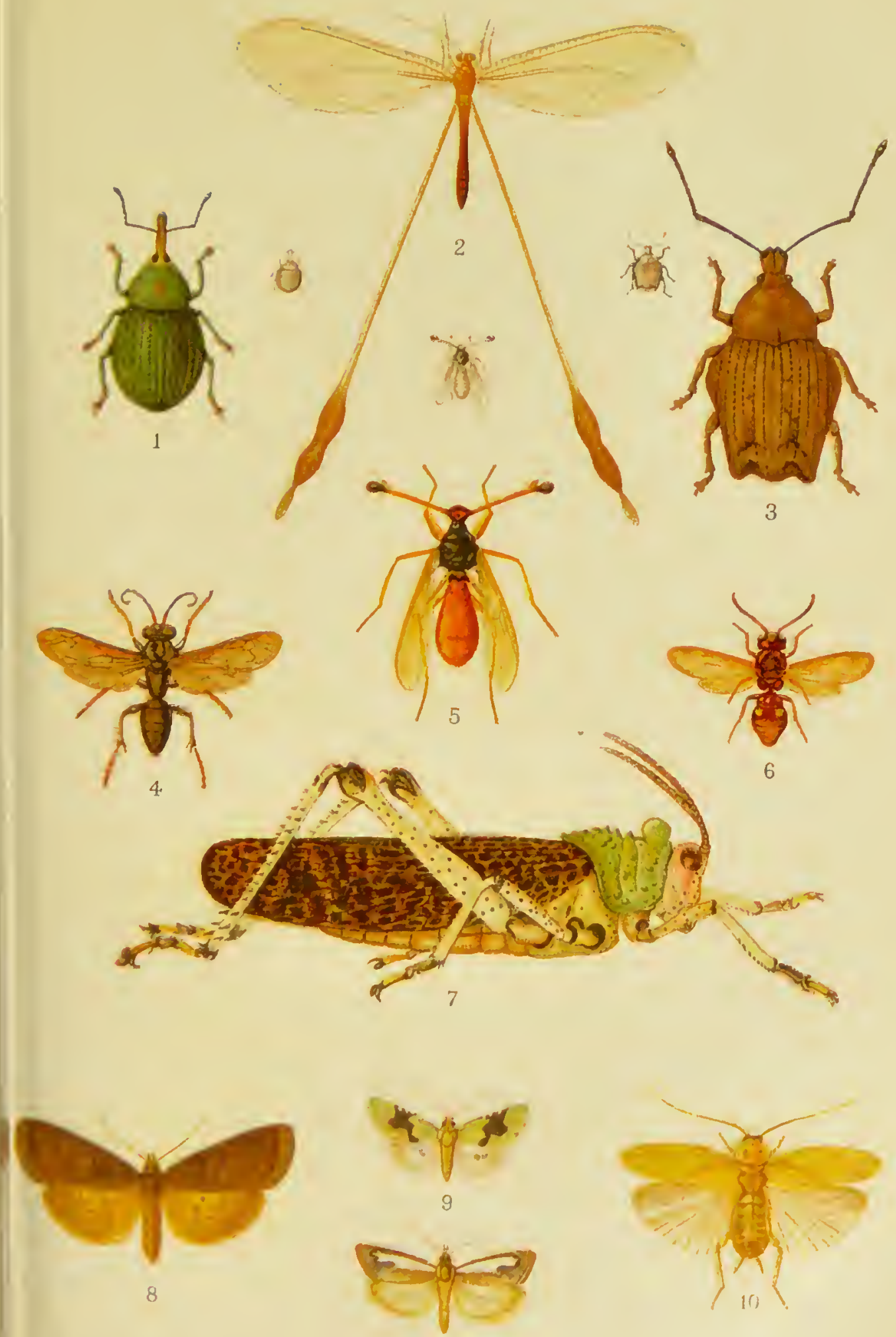

H. and Edgar S Knignt it.

11

Viust, Nowman Chromo.
1. MYORRHINUS LONGSTAFFI.
2. MEMOPISTHA LANCEARIA.
3. ELLIMENISTES CALLOSICOLLIS.
4. NOTOGONIA DIXEYI.
5. DIOPSIS AFFINIS.

6. ODYNERUS LONGSTAFF!

7. PHYMATEUS LEPROSUS.

8. PARTHENODES SCOTALIS

9. STEMMATOPHORA CHLORALIS.

10. ISCHNOPTERA LONGSTAFFI. 

Acanthaceous plant called by the natives "u-Bomaan." Through the scrub there has been cut a very wide, grass-covered road, which keeping parallel to the coast, runs up hill and down dale for at least a couple of miles, how much further we had not time to investigate. This road with its occasional glimpses of the sea, perhaps 150 or $200 \mathrm{ft}$. below, afforded the most delightful collecting ground imaginable. One was constantly reminded of ridings through woods in Southern England, but rudely brought back to reality, once by catching the net in the well-concealed thorns of the familial "fernasparagus" (Asparagus plumosus) of our dinner-tables, another time by a glimpse of the dusky form of a cryptically-coloured Kaffir in the gloomy shadow of the forest. But everything has its drawbacks; that of the Bluff was climatic, for all too soon after midday, on both our visits, the south-east Trade-wind freshened and great clouds rolling up from the Indian Ocean sent all well-regulated butterflies to bed.

Danaida chrysippus was very common, especially towards the more civilized end of the road. Planema esebria, curiously enough the only species of the Acraeine group that we saw there, has a flight of moderate rapidity, but two were easily caught. Several Atella phalantha were seen and a few netted. Precis was represented by a single clelia.

Eurytela hiarbas was present but not common; of Byblia goetzius, two were taken, one of them less "dry" than usual. Salamis anacardii, with its slow flight, looked strangely smaller than it is; it soon settled on a leaf and appears to be a very sluggish insect. Two females of Mycalesis safitza are recorded from the Bluff.

By far the predominant butterfly was Belenois severina, which was very abundant; the males largely exceeded the females in numbers, but a good many of the latter were seen. Though the very large majority were of the dry-season type, intermediate examples were also present. They appeared to be markedly gregarious, ${ }^{1}$ though this may have been due to the distribution of their favourite flowers. Two pairs were observed in cop., the females, hanging down impassive, were carried by the males. Of $B$. gidica, which was far less common, we took two males and three females. Most of this species were seen near the bottom of the path leading flom the harbour up to the lighthouse. Of $B$. thysa, Hopff,, we took two males; when on the wing they closely resembled the male of Mylothris agathina, in

"Perhaps I apply the word "gregarious" to buttorflios whon "sociablo" might be more correct. Certain it is that while many buttorflies are solitary in their babits, othors are found in companies. 
flight and general aspect. Indeed, even as seen in the net the Belenois so closely mimics the Mylothris that though specially on the look-out I was deceived, and this even when the two insects were taken the same morning.

Pinacopteryx eharina was decidedly common, but the sexes were very unequally distributed; we took seventeen males to two females. One male specimen had lost the anal angles of the hind-rings, probably from the bite of a lizard. Of Glutophrissa saba, Fabr., a male was taken. The beautiful Eronia eleodora, Hübn., was quite common; we took eighteen specimens which appear to be mostly males; it flies fast. The Plate forming the frontispiece of this volume gives a fair idea of the brilliance of the butterfly and the conspicuous arrangement of its strongly contrasted colours, but it shows even more satisfactorily its cryptic coloration when resting, as it was several times observed by us, upon or close by yellow, blotched and perforated leaves of the "u-Bomaan." This plant, now known as Isoglossa woodii, Clarke, belongs to the Natural Order Acanthaceae, and is not the food plant of the larva. ${ }^{1}$ The underside of the hindwing of the butterfly varies almost as much as the discoloured leares, and the resemblance is general, that is to say, it is not a definite case of leaf-imitation. It should be noted that a coloured sketch of the leaves was made at the time, but in the absence of the butterfly, to avoid any tendency to exaggerate the resemblance. Mr. H. Knight's drawing is quite admirable.

Of Teracolus achine we took a male; of $T$. omphale, two of each sex; but we naturally paid more attention to the beautiful Purpletip, Teracolus speciosus. This was not uncommon, and we secured six males and two females; during its flight, which is rapid, it looks like an ordinary White, the purple not showing on the wing. Butler named the "dry" form of this butterfly jobina, and considered the "wet" form to be the ione of Godart.

Of Terias regularis we took a male, and of $T$. sencgalensis a female, both of the dry-season form.

We managed to get two specimens of Papilio policenes, Cram., but one of them was sadly battered; also one 'male of $P$. dardanus, f. cenea; a specimen of $P$. nireus, f. lyaeus, was easily secured flyiug low down when a cloud passed over the sun.

Curiously enough we took but a solitary Blue, Firachola antalus.

1 It was a triumph of the Botanieal Department at Crommoll Road to name this plant from three prossed leaves. It is figured in J. Medley Wood's "Natal Plants," vol. i., Plate XXII., under tho namo of Ectcinanthus origanoides, T. For further particulars, sce Chapter $\mathrm{X}$., $\S 14$. 
Single specimens of the Skippers, Gcgencs lettcrstcdti, a female; Gomalia albofasciata and Parnara fatucllus were taken, the lastnamed settled on a leaf in the sun, with the wings fully expanded; we also obtained two Kcdestes macoma, Trim.

We kicked up from grass, etc., two specimens of the exceedingly variable Noctua Optivusa lienardi, Boisd., one of them settled upon the ground; in like manner we turned up a battered example of the restless moth belonging to the same group, Rcmigia repanda, Fabr., and found another at rest upon a leaf in the full sun. Here also we took our first specimen of that beautiful Catocaline, the steel-blue and orange-yellow Egybolia vaillantina, Stoll, known to the Colonists as the Peach Moth, together with the Quadrifid Noctua R7tanidopteora cinctigutta, Walk., pale fawn with large, neatly outlined, cream-coloured spots on the fore-wing; and the curious Geometer Cartaletis libyssa, Hopff, of which several were seen, but only one taken. This moth, orange, with a black white-spotted border to all the wings, looks like anything rather than the Boarmiid that it is. It flies rather high with feeble fluttering action, and when on the wing somewhat recalls Danaida chrysippus, or an Acraece; it also resembles Acraec by exuding a yellowish juice when pinched, but the juice in C'artaletis is odourless. These are three very striking and characteristic moths. Another Geometer, allied to our Magpie Moth, was Zerenopsis geometrina, Feld.

The Hyponomeutid, Erctmoccr'a scatospila, Zell., and the familiar Scopula ferrugalis, complete the list of moths, so far as I have been able to assign them names.

The yellow and chocolate-coloured Lamellicorn Macroma cognata, Schönh., was very conspicuous on the wing; the Clavicorn Episcapt,ula aulacochiloides, Crotch, was taken under a log, associated with ants and fungi. Asida bicostata, Fåhr., and Hister subsulcatus, Mass., were also found under logs; a specimen was obtained of the phytophagous Lady-bird, Epilachna infirma, Muls. The Weevil Sciobius pullus, Sparm., a female, was beaten out of a Clematis-like creeper [? really a Senccio]. The Carabid Arsinoë quadriguttata, Casteln., was taken on low herbage.

Two Crickets were captured, also the Acridian Monachidium viridipennc, Burm., and others of the group still unnamed, including one which made a loud snapping noise in leaping, whereas the very spiny-legged Acridium ruficorne, Fabr, sat on a bush and made no attempt to escape. From under a log was unearthed an immature female Cockroach, which Mr. Shelford thinks may possibly be a new species. 
A blue Wasp was taken, and several others scen; it turns out to be a new species and has been named by Colonel. C. T. Bingham after the captor, Notogonia dixeyi [sec Platc II., Fig. 4, also footnote, p. 182, supra]. Under a log wcre found numbers of the big-headed soldiers and thin workers of Camponotus maeulatus.

The conspicuous Reduviid bug, Physorrhynchus erux, was common under logs of wood, corrugated iron, etc., near the lighthouse; it has a peculiar pungent odour.

The solitary Fly brought home was apparently the cosmopolitan Sareophaga carnaria, Linn.

On the sandhills near the lighthouse were plenty of the widely distributed Snail, Helix (Euparypha) pisana, Müll., probably introduced.

Dr. Dixey found a horrible Worm in a surprising place, it was on a dry sandy path at about 3.30 p.m., on a dull afternoon. I call it horrible for it was nearly as thick as the finger and from 11 to 16 inches in length according as it was fully extended or otherwise. Its colour was of the olive-brown that one associates with seaweed, but it had a black ring, an inch wide, behind its head.

CONGELLA, some three miles to the west of Durban, is another very pleasant locality. The ground rises gradually from near the level of the harbour for perhaps a mile to the large banana plantations from 200 to $300 \mathrm{ft}$. above sea-level, the slopes being covered with wild scrub traversed by a woodland track, while through the lower portions are cut wide grass-covered roadways foreshadowing the development of an eligible building estate.

As usual, Danaida chrysippus was to be had; we took five males and a female. We took a female of Amauris ccheria, and three females of $A$. albimaculata, the latter flew slowly and were easily caught. Aeraea was well represented, the commonest species being the black, yellow-spotted $A$. cabira; one specimen of this was taken on Lantana flowers (for this Neotropical shrub has spread even to Natal), but as a rule it was scen flying about the tops of trces, in which situation it looked a much larger insect than it really is; thirteen specimens were taken, one of these which reached the hotel alive, having survived pinching as Acracac so often do, proved rery resistant to chloroform. A. terpsichore looks on the wing like a small British Argynnis; wc took five. Of $A$. petraca, which when alive is very rosy, both above and below, we took two. Of $A$. natalica, wc got one among grass; its hind-wings have a lovely rosy flush in life, indeed the beauty of many of these Acracac cannot be appreciated from cabinet specimens; $A$. encedon, of which we took three, is a 
feeble insect, with slow Hight, and it again succeeded in passing itself off momentarily as chrysippus. The yellow juice expressed from A. ratalica proved to be slightly acrid. A single male Planema agaricc, Hew., completed the group.

Byblia goetzius flew over the grass like a "Pearl-bordered"; one settled on a red path, another on dead grass, both with wings erect, both incouspicuous; we took a male and four females, one of the latter was "quite dry." Two Neptis agatica were taken flying slowly. Precis clgiva, a retiring insect, was found in the track through the wood, of four specimens one was much battered; of $P$. clelia several were seen; of $P$. natalica two, of the dry-season form, one worn; of $P$. sesamus one settled closely appressed to the ground; also at the edge of the banana garden, on very red soil a Precis was seen three times quite clearly, but unfortmnately missed; this was either $P$. octavia, Cram. (the wet-season form of sesamus), or something uncommonly like it; it nearly matched the red soil in colour, but was somewhat more orange in tint. Of Salamis anacardii, one of each sex was obtained; of Atella phalantha, a single example; of Charaxes varanes, usually a high Hier, a female was luckily netted off a shrub. Mycalcsis safitza was common; four males and nine females were taken.

No specimens of Bclcnois severince appear to have been brought back from Congella, but it was certainly common there; of $B$. gidica we took three of each sex, one had the hind-wings chipped symmetrically, apparently by a bird; of two specimens taken in cop. the male was "dry," the female "very dry." Of $B$. thysa we took six males, but we have no record of its model Mylothris agatlina from that locality. Both these butterflies have strong scents, which are quite distinct. Of Glutophrissa saba and Nychitona alcesta, Cram., single examples were taken, the latter has a slow, flapping flight. Of Eronia clcodora we took two; of $E$. leda a single female; of Pinacoptcryx pigea nine, four males and five females; of $P$. charina a solitary male. Congella is not the sort of locality that Teracolus especially delights in, and the genus was represented by but single male specimens of T. actiric and T. omphale, and three males of T. spcciosus. Of Tcrias regularis we took four males and two females.

Of Papilio demodocus, which frequents high and open ground, wo took one in the cultivated region above the woods, but of $P$. nircus, f. lyaeus, we got four males by taking advantage of its habit of not infrequently flying low and even settling on the ground.

Of Zizera lysimon we took two; of Tarucus tclicanus five, of which at least four were females, one with the fore-wings injured 
apparently by a bird; of Polyommatus bacticus two; of Castalius calice, Hopff, one, a tattered specimen, and of Virachola antalus one female, boxed off a plant close to the ground; it was sitting hear downward, but the false head had been bitten off, so that it could not deceive again. ${ }^{1}$

Among the Skippers were the now familiar Gegcnes letterstedti, two; Parnara fatuellus, one; Sarangesa motozi, Wallgr. (pato, Trim.), onc ; Aeleros mackenii, one male and two females, this and other Skippers were more active on dull days than most butterflies; Eretis djaclaelae, Wallgr., one settled with wings outspread; and Pterygospidea flcsus, seven. Of the last species several were seen to settle on the upper sides of leaves, with wings spread out like a Boarmiid.

The beautiful Egybolia vaillantina was rather common, it is a slow feeble flier, the wings flapping much, so it was easy to catch six specimens. The Lymantriid Enproetis punctifera, of which we took three males and a female, was very common, it is one of those insects which look on the wing far larger than they are, an appearance that may be due either to bright colour (in this case orange) or to the mode of flight. Of the small Syntomid Psevidonactia puclla, and the Chalcosiine Anomoeotes levis, Feld., we took two each, the latter looks surprisingly large on the wing. ${ }^{2}$ Other moths taken were the Geometer Graeillodes caffra, Guen., one; the Pyrale Antigastra morysalis, Walk., one; the Hyponomeutid, Eretmoeera lunifcra, Zell., one, and several other unnamed Micros.

The Odonata were represented by two Orthctrum faseiolatum, of and one Brachybasis rhomboidalis, Beauv.; the Orthoptera by a Cockroach found under a log, (?) Deropcltis autraniana, Sauss., immature; and an Acridian, Tryxalis stiali, Boliv., which was very hard to see, being shaped and coloured like a piece of dend grass or straw.

Near the reservoir, on a shrubby lavender-flowered Composite, were taken together the South African form of Honey-bee, Apis adansoni, and the Syrphid Eristalis tacniops, which was noticed to be a fairly close mimic of the bee, at all events when alive. Both insects are brighter than their British representatives.

The Beetles found at Congella were the Clavicorn Megalodacne grandis, Fabr., and the Heteromeron, Anthracias taurus, Fabr., both found under logs; also Endema nobitis, Klug, and the very distinct Carabid, Thyreoptcrus flavosignatus, Dej., found under the bark of a dead stump among numerous ants.

Sce p. 69, supra. Also Chapter $\mathbb{X}$., $\$ 10$.

"Compare my observations on the Indian Chalcosine, Agalope hyalina, Fioll.. near Simla, p. 44, supra. 


\section{From Durban to Johannesburg.}

August 22nd, 1905.

The first point of the journey over the Highlands of Natal at which we had a few minutes' time to leave the luxurious carriages of the Government Railway was INCHANGA, $2470 \mathrm{ft}$. above sealevel. Here on some sandy ground near a stream bordered by rushes and coarse grass or on a bank with a few flowers (Senecio sp.) we took a dry-season specimen of the Satyrid Pseudonympha cassius, Godart; a Wasp prettily marked with rich brown, black and white, Polistes fastidiosus, Sauss., $\Varangle ;$ a handsome Braconid, Iphiaulax whitei, Cam.; and an apple-green Mantid larva; also by sweeping the Scnecio, etc., two Apis mellifica, race adansoni, $\not{q} ;$ an Asilid (?) Dysmachus sp., and the Grasshopper Catantops melanostictus.

We spent the night at the Falls of the Umgeni, at Howlck, lat. $29^{\circ} 28^{\prime} \mathrm{S}$., $3400 \mathrm{ft}$. above sea-level, and before dark turned over a few basalt stones, taking a number of Ants, Pheidole irritans, Smith; two Blattae with a very strong, sweet, really rather pleasant scent, suggesting pear-drops, or amyl acetate ; they were immature and Mr. Shelford thinks they may possibly be a new species; a small Beetle, Euleptus caffer, Boh., and an Acridian, at present unnamed. It was cold at night here.

At Estcourt, lat. $29^{\circ} 2^{\prime}$ S., alt. $3800 \mathrm{ft}$., on an open grassy place near the Station we were rather more successful. Two males of Synchlö̈ hellica were secured; they were noticed when at rest to withdraw the fore-wings completely between the hind-wings, and to raise the abdomen, just as Euchlö̈ was observed to do in Algeria. ${ }^{1}$ We also took a small Syntomid (as yet unnamed), a Lady-bird, Epilachna similis, Thunb.; two Ants, Camponotus cosmicus, Smith, and a Grasshopper, I'rilophidia sp.; this last was originally discovered by Mr. G. A. K. Marshall, and declared by Señor Bolivar to be a new species, but it has not yet been named.

Colenso, lat. $28^{\circ} 46^{\prime}$ S., alt. $3200 \mathrm{ft}$. The late afternoon was spent on the low ground south of the Tugela, between the river where the Boers were so securely posted, and the spot where Colonel Long's guns were abandoned. The immense value of cover in modern war was made evident when one stood in the very shallow spruit which served for shelter to our men after the loss of the guns. The only butterflies seen were Pyramcis cardui and Danaida chrysippus. Several moths were kicked up, the Boarmiid Geometers Ostcodes

\footnotetext{
${ }^{1}$ Sec p. 162, suma; also Plate V., Fig. 10.
} 
turbulenta, Guen., Lwo ; Zamarada pulverosa, Warr., onc; and Nassunic petavia, Stoll, a male; also two tiny Noctuae with yellow hind-wings, Eublemma sperans, Feld.; a Crambus and two Mieros, none of them yet named. Two immature Acridians of the colour of dry grass were taken, also a Beetlc, Scaptobius natalensis, Boh., one, and the Heteromeron Opatrum (!) arcnarium, Fabr., six. Sevcral speeimens of the Ant Phcidolc irritans were taken, also somc Termites, two workers and two soldiers of the same eommunity. The former when taken were earrying bits of grass and leaves; when brought baek to the hotel they were dead and partly mutilated, apparently by the soldiers in the same pill-box. The soldiers, on the eontrary, reaehed home alive and pugnaeious, for they would grasp the point of the forceps and allow themselves to be lifted off the ground without letting go.

August 24, 1905.-The next forenoon we aseended Hlangwane; the hill commanding the whole position, which unfortunately Buller did not oeeupy on December 15th, 1899.

Some of the Boer trenehes on the crest are so ingeniously constructed as to be invisible from the front, all exeavated material being deposited to the rear on the reverse slope. But it must be remembered that these trenehes were erected after our disastrous repulse, and that there was then no serious obstaele to an attack upon the Boer left and left-rear.

Again we saw no butterflies, and that moruing we did not even get a moth. Under cow-dung on the plain two speeimens of a new Dung-Beetle were found, (?) Eratognathus natalcnsis, Péring., and under stones, ehiefly on the hill, we found an Omostropus, whieh Mr. Péringuey says is also new; an immature Bug and sundry Ants, to wit, the small Pheidole irritans, of which the workers are very tiny; $P$. megaccphala, Fabr., well deserving its name, and the big black Mesoponera caffraria, Smith; also a Blatta sp., and an Ant-lion. Near the top of the hill a large family of the Coekroach, Dcropcltis crythroeephala, was found under a stone.

Under stones in and among the Boer trenches a number of large Seorpions were found, olive-coloured, with testaeeous rings, the large joint of the ehelae and tip of the tail pale testaeeous, paler bcneath. Other dwellers under stoncs werc very young Snakes, a nearly globular Toad which squeaked piteously when taken up, and a Gecko. The last (Pachydaetylus maculatus, A. Smith) was a sluggish animal with large eyes, doubtless correlated with nocturual habits. Its body was dull pale brown, with a eomspicuous row of dark brown spots on either sido of the baek, outlined with blaek and ontside that with 
pale ashy; belly flesh-colour. When chloroformed, the short stumpy tail was cast off (causing slight haemorrhage), and took much longer to die than the body, wriggling with an apparently spiral movement. Professor Poulton believes that the vitality and activity of the tails of lizards after they have been cast off are an adaptation for the purpose of distracting the attention of a pursuing enemy. Professor: W. A. Herdman, F.R.S., suggested that the persistence of the movements of the tail in this instance was due to the fact that the amputated part had lost its connection with the respiratory and circulatory organs, by means of which the chloroform is conveyed to the tissues. Professor Herdman's explanation is doubtless the correct one and tallies with the fact that active insects, such as Humble-bees, succumb much more rapidly to volatile poisons than do more sluggish beetles of the same size. At the time, however, I connected the greater activity of the tail in the killing-bottle with the absence of a brain. ${ }^{1}$

A drive to Hart's Hill in the afternoon made us realize completely what is meant by "carriage exercise," for the road is probably the worst that we ever traversed. It proved more interesting from the point of view of Military History than that of Entomology, nevertheless at the bottom of the hill we kicked up Sterrha lineata, Warr., a brownish Geometer; on the slopes, we took under stones Harpalus capicola, Dej., ơ; Paederus crassus, Boh.; a Staphylinid represented in the General Collection at South Kensington and in the Sharp Collection, but in both unnamed; the big Ant Acantholepis vestitc, Smith; the tiny Pheidole irritans, and Tetramorium solidum, Emery.

Here I got a couple of Snails, the handsome, shiny, yellow-green and brown Achatina simplex, Smith.

On the summit of the hill, in an old Boer trench, looking down over the slopes on which many a brave soldier breathed his last, was Pyrcemeis cardui, the only butterfly that we saw that day. It may be remarked that it was bitterly cold when we reached Ladysmith a little before midnight.

Ladysmith, lat. $28^{\circ} 38^{\prime}, 3300 \mathrm{ft}$., August 25, 1905.-The next day was devoted to Spion Kop, and naturally enough disputed questions of strategy and tactics diverted our attention from insect hunting. We had a perfect day for the enjoyment of the glorious view, we had also the advantage of the company of a Sapper Captain to assist in the interpretation of the Times' IIstory map of the battle. We realized low the hill was the key to the position, and

' Journal of the Limnean Society, "Yoology, vol. xxx., 1907, p. 48. 
looked upon the wide and open road to Ladysmith by which we had driven to the foot of the reverse slope of the famous hill. On Aloe Knoll we saw the pit made by one of the shells from the naval six-inch guns just before the sailors were ordered to cease fire.

A specimen of Precis sesamus was taken close to a Boer's grave near the farmhouse below the Aloe Knoll, while a conspicuous Larentiid, Ortholitha pudicata, Walk., with reddish fore-wings and orange hind-wings, was netted on the top of the Knoll. The Beetle Zophosis caffer, Deyr., was found just below, running on the path. A small Grasshopper was brought from the summit of Spion Kop, and a larger species from the lower slopes on the north side; this last was coloured like dead grass on the exposed portions, but the lower surface of the abdomen and the lower edges of the femora were of a deep bright red. On the road back to Ladysmith, near the halfway house, the conspicuous Graphipterus cordiger, Klug, was taken under a stone, as well as the obscure Zophosis caffer.

August 26, 1905.-On our walk out to Waggon Hill and Caesar's Camp we found under a stone on the open veldt a Carabid, Polyhirmi notata, Perond.; when touched it emitted from its mouth a quantity of dark brown fluid having no perceptible odour. Under another stone were two somewhat remarkable Toads; their olive-green colour being relieved by dull vermilion markings on the top of the head, sides of the back and upper surface of the legs. They were also adorned with a dark $Y$-shaped mark on the back of the head, and a dark spot on either side of the middle of the back. The dingr Boarmiid Semiothisa brongusaria, Walk., was common on rough bushy ground.

The famous work at the western end of Waggon Hill was garrisoned by Precis sesamus, while the variable Geometer Tcphrina catalaunaria, Guen., was taken close to the Earl of Ava's grave. Within the trenches of Caesar's Camp we took the Geometer, Tcphrina arcnosa, as well as two Acridians.

Returning to Ladysmith we found on the northern (reverse) slope of Caesar's Camp, under large stones near the head of the then dry spruit, the curious Cockroach, Dcrocalymma porccllio, Gerst. (intcrmcdia, Kirby). It is remarkably flat and sits closely appressed to the stones; it appeared to be extremely local. Between this point and the bridge over the Klip River just outside the town we found insects much commoner. The scrub is intersected with deep gullies, for the most part dry, but evidently conveying at some time much water to the Klip; in these gullies Precis ccbrcnc and $P$. sesamus were not uncommon, also Synchloë hcllica, of which a male and four females 
were taken. $P$. sesamus was fond of collecting into little companies of three to five in narrow and somewhat dark dongas, apparently secking shelter from the high wind; it oriented fairly accurately; and when settled with expanded wings closely appressed to the very dark coloured shale, it was by no means conspicuous. A male of Colias clectra, and a female of 'Tcracolus eris, Klug, were taken near' the river. Single cxamples of Yphthima astcrope, Klug, Zizcra lysimon, and Tarucus sybaris, Hopff., $q$, were secured, whilc other Lycaenids were seen, as also Pyramcis cardui and Danaida chrysippus.

A specimen of the handsome Quadrifid Noctua, Acanthonya praetoriae, Dist., was taken resting in the dry bed of a spruit; the nebulous Boarmiid, Osteodcs turbulcnta and other Geometers were kicked up, including a beautiful green one (with somewhat the look of Euchloris vernaria, Hübn.) which got away into the undergrowth. An Ichneumon-fly and a common Honey-bee were also taken. A small Bug, Pododus sp. (not in the National Collection), was seen running on the sand; on being pinned it exhaled a strong odour of acetate of amyl. The Beetle Zophosis caffor while running swiftly on the sand was occasionally blown over by the wind.

The electric lights about the town and railway-station attracted a fair number of insects, the commonest being the large flying Ant, Dorylus helvolus, Linn., o, a yellowish-brown insect with very flexible abclomen; its position in the insect world was at the time a puzzle to us. When pinned the thorax cracked and emitted a puff of whitc powder. The largest insect at light was the Lamellicorn, Oryctcs boa:, Fabr., a rotten-wood feeder, of which two were taken. With these were the Noctuids Audea variegata, Hmpsn., Leucania (Borolia) mclicunoides, Möschl., Homoptera canescens, Walk.; the Syntomid, T'hyretes caffrce, Wallg1., of; three Phycids: Microthrix inconspicuella, Rag., one, and $M$. insulsella, Rag., two, and several other moths not yet named.

Two moths, Plusia limbircna, Guen., and a Micro, were taken in the bedroom of the hotel.

August 27, 1905.-An afternoon was spent on the north-eastern defences, The King's Post, and 'I'he Devons' Post, which wcrc on low rocky liills with a little small scrub. At the latter, which rums out towards Lombard's Kop, exposed to the cross-fire of two "Long Toms," the works were more solid and better built than any that we eame across, whether built by Boers or Britons, and slowed pretty plainly that there must have been skilful wallers anong the Men of Devon. Single specimens of P'rccis arehesia, the semi-transparent 
Acraca neobule, Dbl. \& H., and Byblia itithyia, were taken at the King's Post, but the commonest butterfly there was Pyrameis cardui, for the most part small and rather worn specimens; flying with it was Utcthcisa pulchclla. Lizards were numerous, but although Dr. Dixey spent some time in watehing them, they were not seen to make any attaeks on butterflies.

At the Devons' Post Synchloë hcllica, Pyrameis cardvi, P'reciti cebrene, and Zizera lysimon were taken. Alongside a stream separating the two hills Yphthima asterope was rather common, looking not unlike a Blue on the wing; futile attempts were made to see the butterfly settle, but it was restless. At the flowers of Aloe (?) ferox were Xylocopa hottentota, Smith, o, the Wasps Belonogaster distinguendus, Kohl, 3 , , and Eumencs dimidiatipennis, Sauss., $q$, a large red and black, brown-winged insect; the Phytophagid Ortalia pallens, Muls., was taken flying near the same flowers.

Anywhere along the ridge that strange Grasshopper, Phymatcus leprosus, Serv., might be seen. This is of a grey- or yellowish-green, tinted with yellow, orange, and pink; its hard thorax, though strongly tubereulate, shines with an enamel-like texture. It is very sluggish, and unlike most of its tribe does not readily take flight, but when it does so makes a rattling noise. When touehed it emits eopiously a dark olive-green, very fetid fluid, which dries up as a stieky varnish readily soluble in water; this, accidentally tasted, was found to be bitter and extremely unpleasant. [See Plate II., Fig. 7.]

I suppose there never were battlefields where so few relics are to be found. An occasional shrapnel bullet, or fragment of shell, is all that is to be seen. The Kaffirs have made a clean sweep of the country. I onee happened on a water-bottle. Owing to the marvellous climate in some places preserved-ment tins (where not scratehed) were still, after three years, as brilliant as silver.

August 28, 1905.-At Ingagane Station, lat. $27^{\circ} 56^{\prime}$ S., alt. $3900 \mathrm{ft}$., a specimen of the Geodephagous beetle, Acupalpus natalicus, Péring., was found under a lump of hard earth.

At NewCastle, lat. $27^{\circ} 48^{\prime}$ S., alt. 3900 ft., a specimen of Precis sesamus was found in a tiny dark kloof; its love of darkness was also noted on subsequent oceasions. Several Acridians, whose determination is postponed, were taken. An immature Coekroach was found under a flat pieee of iron, together with a eommunity of the Ant, Acuntholepis vestita. The Heteromerous beetle Zophosis caffer was caught running swiftly over sand.

At INkivelo, under the shadow of Amajuba (lat. $27^{\circ} 32^{\prime} \mathrm{S}$., about $4500 \mathrm{ft}$. above the sea), a Fly, Sarcophaga sp., was taken, but on this 
diny at these altitudes the conditions were decidedly wintry, and the night of August 28th was cold.

Johannesburg, Transvaal, lat. $26^{\circ} 10^{\prime}$ S., alt. $5700 \mathrm{ft}$.

$$
\text { Ang. 30th-Sept. 2nd. }
$$

The weather during our short stay was chilly and almost sunless, while the time available only permitted of two short afternoon walks in the outskirts just beyond West Cliff.

But three butterflies were seen, Pyrameis cardui; Papilio dcmoclocus; and the Skipper Parnara ayresii, Trim., a species that does not appear to be widely spread. Moths were about as poorly represented by the cosmopolitan Nomophila noctuella, by Sterrha sacraria, of the dingy South African form, lacking the crimson colour, and by that obscure Phycid, the almost cosmopolitan Etiella zinckenella, Treit. Thus four out of the six Lepidoptera were denizens of Europe as well as South Africa.

The most promising mode of collecting appeared to be turning over stones, old tins, etc., on the veldt; this back-aching process yielded Ants in great plenty, the commonest species being the bigheaded Camponotus marginatus, Latr., which turned up in this locality only; it is a very shiny insect, intensely black, but with red legs and antennae. Close by, the more generally distributed $C$. maculatus was found, while the long black Plectroetena eaffra, Spin., the smaller Pheidole megacephala, and two Cremastogaster sordidula, Nyl., var., were also met with. There were in addition to the Ants plenty of Termites. Indeed the great abundance of both Ants and Termites is the most striking point in the South African insect fauna. Whon I asked local pcople what was the food of the ants the reply was, Termites. What, then, did the Termites eat? My conjecture was that they lived upon the roots of plants which did not show above ground during the dry season.

The bectles included several Carabids, viz.: Chlaenius scllatus, Dej., two; another Chlaenius that may possibly be new; Harpalus deceptor, Péring., nine spccimens ; H. angustipennis, Boh., two; Macrochcilus dorsalis, Klug, one; Trcchus rufipes, Boh., one; then there were two of a Trigonopus that may possibly be new; the very distinctly marked Graphipterus cordiger; an Opatrum that is probably arcnarium, six specimens; an unnamed Psaryphis; a Lamellicorn of the genus Aphodius that is not represented in the National Collcction; two Weevils, Mipporhinus cornieulatus, Fảhr.; and Brachycerus scverus, 
Fåhr.; also a Lady-bird, Exochomus nigromaculatus, Göze, which is occasionally found in Britain.

Under stones were two Pentatomid bugs, Dalsira modesta, Fabr., and the lance-head-shaped Gonopsis angularis, Dall., also Lygueus rivularis, Germ.; there were also several other bugs that are not yet named. Along with the bugs were several Cockroaches and a black and red Scorpion. Two specimens of Aeridium pardulinum, Walk., and a number of as yet undetermined Acridians were also taken.

The most interesting insect met with at Johannesburg was a Homopteron, Gyaria walkeri, Stål, allied to Flata, a genus well known from its alleged resemblance when at rest to a spike of flowers. It is of a creamy-white colour with eyes of a beautiful pinkish hue, that is unfortunately soon lost after death by cyanide. The insects are gregarious, and sit in rows of from three to five each near the base of the stems of a shrubby herb which attains the height of about two feet. Sitting for the most part with their heads up, they cannot be said to look in the least like flowers; immature specimens look more like a Coceus, or even a lixuriant growth of Penieillium. When a plant harbouring the Gyariae is approached the insects jump off and fly away a short distance much like moths. They were only found within a very circumscribed area. ${ }^{1}$

Settled on rocks basking in what little sun was to be had several Flies were captured, all males, of a species of Dichactometopia allied to tessellata, Macq., but probably new to science.

Pretoria, Transvaal, lat. $25^{\circ} 53^{\prime}$, alt. $4500 \mathrm{ft}$.

August 31st.

The British Association paid a mere flying visit to the political capital, but this jnst permitted a carriage-drive to the Wonderboom, a singular tree of wide-spreading growth, which stands at the foot of the northern slope of a range of hills about $3 \frac{1}{2}$ miles to the north of the city. So far as results were concerned the time and trouble, and more particularly the dust, might as well have been spared. Insects were very scarce save at the sweet-scented white flowers of Dombeya densiflora [Nat. Ord. Stereuliaceac] which proved very attractive. There was, however, an incommensurability between the height of the trees and the length of the net-stick which was tantalizing in the extreme. A few Whites as well as Donaida chrysippus and a Lycaenid were seen out of reach. The pedunculated

1 This paragraph refors to Prof. J. W. Gregory's description and figure in "The Groat Rift Valloy," London, 1896, pp. 273-5, and Frontispiocc. Also to S. L. Hinde in Trans. Ent. Soc., Jond., 1902, p. 695, and Platc xxri. 
Wasp Belonogaster griseus, Fabr., was abundant, and four males were with difficulty secured; the South African form of Apis mellifica was also busily at work together with two smaller Bees (q). These last Colonel C. T. Bingham described as a new species under the name of Ceratina vittata, ${ }^{1} s p$. nov., so an otherwise disappointing day was redeemed. A specimen of the Chafer Oxyt7yrea marginalis, Schönh., was taken on the lavender flowers of a Buddleia [Nat. Ord. Loganiaceae] near the river, and close by a single example of the Lycaenid, Spindasis mozanibica, Bert. On the veldt below the big tree, the common but pretty Grasshopper, Catantops melanostictus, was very active and difficult to secure; in the same place we netted two specimens of Terias brigitta, a species we had not met with in Natal.

\section{RAILWAY JOURNEY FROM JOHANNESBURG TO KIMBERLEY.}

September 4th, 1905.

GLFN Siding, lat. $28^{\circ} 55^{\prime}$ S.-On the flowers of a low-growing Senecio (not unlike the Oxford S. squalidus, Linn.) a Wasp was taken, Ammophila (?) argentca, Brullé, f, which Colonel C. T. Bingham said was not typical, but possibly a local form of the species; with this was a Honey-bee, Apis adansoni, $\Varangle$. At this place Pyrameis cardui and Colias electra were noted.

Blommfontein, lat. $29^{\circ} 7^{\prime}$, alt. $4500 \mathrm{ft}$.-In the station-yard the last-named two butterflies were again seen, and a female Sync7ulö̈ hellica was taken.

Norval's Pont, Cape Colony, lat. $30^{\circ} 38^{\prime}$, alt. $4000 \mathrm{ft}$. The cosmopolitan Plutella maculipcnnis, Curt. (cruciforarum, Zell.), camc to our lights.

Colesberg Junction, lat. $30^{\circ} 44^{\prime}$; alt. $4370 \mathrm{ft}$.-At this station, naturally associated with the exploits of General French, several moths visited the lights of the train. They were the pretty silverstriped Geometer, Conchia nitidula, Cram.; an unnamed Noctua; our old friend of many lands, Nomophila noctuella; and three Phycids, two of them being the dingy Microthrix insulsclla.

During the long railway journcys over the clevated tablelands of the interior, and more especially between the Orange River and Vryburg far north of the Vaal, the train travels for hour after hour over plains at one time rolling, at another level, but the view is almost always broken by the characteristic flat-topped hills or "kopjes" which played such a conspicuous part in the war. They

\footnotetext{
' See footnote, p. 182, supra.
} 
are cvidently capped by horizontal strata of harder material, I believe in many instances the igneous rock called dolerite. Thesc kopjes are numerous, sornetimes forming more or less broken ranges, sometimes groups, but often quite isolated. The impression given to the geologic eye is that their flat tops must once have been united by a continuous sheet of the capping material. The scene at once recalled to my mind the flat-topped hills of the Saxon Switzerland, but the African scene is on a vastly larger scale. A very moderate exercise of the geological imagination serves to explain by the action of existing agencies the excavation of a sinuous cañon such as those of Western North America; or of a "baranco," or "ribeira," cut through the basalts and tuffs of Tenerife or Madeira. Here, however, the flat-topped kopjes differ from the examples quoted, by the distances which separate them ; for miles, often many miles, of veldt must be traversed in journeying from one kopje to the next. It is, indeed, the difference between "intaglio" and "relievo." To effect the result the work of denudation must have been on such a vast scale as to baffle the imagination. The existing rivers are few and far between, and all too puny for the task; moreover, the present rainfall does not exceed 25 inches in the year. Can ice conceivably have been the transporting agent? Or are the kopjes the ruins of ancient islands? The plains are now elevated from 2000 to $4000 \mathrm{ft}$. above sea-level and the distance from the coast is from 200 to 300 miles. Lastly, where has the prodigious amount of material removed been deposited ? It is certainly a problem of the first magnitude.

\section{Kimberley, Griqualand West, lat. $28^{\circ} 43^{\prime}$ S., alt. $4010 \mathrm{ft}$.}

September 5 th -7 th, 1905.

The Diamond City with its white dust (in striking contrast to the red of the Golden City) did not impress us as a good locality; moreover, we had but little spare time, and the weathcr, for the most part cloudy, was unfavourable.

At KenIlwortil the Weevil Cleonus mucidus, Gerst., was beatcn from Senecio, and two dead Heteromera, Psammodes (Moluris) vialis, Burch. (pierreti, Sauss.), and P. scabricollis, Gerst., as wcll as an Earwig were taken under stones. Under one stone a large dark, short-legged Spider with globular abdomen was found in the midst of copious remains of bectles, cte.

On the veldt in the outskirts of the town, beyond the Old Kimberley Minc, the following were found by turning over stones, 
old tius, otc. :-The Lamellicorn, Trox denticulatus, Oliv.; the Heteromeron, Psammodes vialis, two dead specimens; the Weevils, Brachycerus globosus, Fabr., one; Episus bohemani, Auriv., one; Sparticerus sp., four; and $S$. rudis, Fåhr., nine. None of the last three species were represented in the British Museum; for weevils their integuments are but moderately hard, but, on the other hand, in the red sandy soil under the old tins, or among the roots of Composite plants, their rough surface as well as their colour make them difficult to see. Eight specimens of the Carabid, Bacoglossa melanaria, Boh., were found in holes in the ground under stones or tins; they ran fast when disturbed. It was noted that under the South African sun even large stones, not to speak of the omnipresent rusty tins, afford so little protection from his rays that frequently insects were found lurking in holes in the earth beneath, so that they were doubtless often passed over. Besides the above beetles the stones and tins harboured a number of the Ant Monomorium subopacum, Smith, race australe, Emery.

Under a decaying calf's foot and pastern were three specimens of Nccrobia rufipes, Fabr., a British insect; two of the cosmopolitan Dermestes vulpinus, Fabr., and another beetle not yet named. The Fly, Agria nuba, Wied, was captured in the same locality.

At the Dutoitspan Mine we saw Pyrameis cardui, and took two Synchloë hellica, one of each sex, as well as the Grasshopper Acrotylus sp. A Longicorn, Tetradia lophoptera, Guér., was seen on the wing, it settled on the light grey road of the compound and disappeared, being so exactly the colour of the dust that it was most easily found by feeling with the hand !

A warty, stump-tailed, but active Lizard was found under a stone, when caught it uttered a sound between a squeak and a hiss.

It may seem a somewhat wild statement, but I was much struck by the fact that a Burchell's Zebra in an enclosure near. Kenilworth was not nearly as conspicuous on bare ground as the same beast would have been in England, its lighter parts seemed to harmonize wonderfully with the reddish brown soil.

At the Wesselton Mine, on a weedy piece of waste ground, two specimens of a Lycacnid, so worn as to be scarcely recognizable, were netted; also two of a very elegant Bombyliid, Systocchus sp., which was only to be discerned on the wing as the light caught its long white pubescence.

$\Lambda$ dull, cheerless morning was spent on the golf links in sight of the Meinorial to the Honoured Dead. There secmed to be nothing to do but turn over stones, which, though doubtless an annoyance 
to the golfers, afforded shelter to a number of Arthoprodid. The most interesting beetle was Graphipterus cordiger, a quite soft insect of a drab colour bearing upon its elytra a black mark which has been variously compared to a heart, a fiddle, and a tennis-racquet; of this we secured eight examples. Of the Weevil Sparticerus rudis, which was very common, we took seven specimens, again noticing its resemblance to the red soil of the veldt. It may be here mentioned that the general colour of the soil at Kimberley, as at Johannesburg, Pretoria, Durban, and indeed most of the places that we visited, is red; the white dust that is so disagreeable in the town is derived from the mining refuse, and a very similar dust is met with near the gold mines of the Rand. Among the common S. rudis was found another Sparticerus which shammed death, this specimen is not represented in the British Museum collection; we also took two Episus bohemani. The Carabidae were represented by one Bacoglossa melanaria, three Harpalus hybridus, Boh., all females, and five H. affinis, Péring. Dead examples of the Heteromera, Psammodes scabricollis and $P$. vialis, with other remains showed that it was not the season for that genus, and the unearthing of a large beetle-larva pointed to the same conclusion.

With the beetles were several Bugs and an Ant, Aphacnogaster barbara, Linn., var. capcnsis, Mayr, accompanied by a number of "silver fish" (Thysanura).

\section{TAILWAY JOURNEY FROM KIMBERLEY TO BULAWAYO.}

September 7 th and 8th, 1905.

Taungs, British Bechuanaland, lat. $27^{\circ} 33^{\prime}$ S., alt. $3590 \mathrm{ft.}$ The very distinct Catocaline Noctua Chalciope rivulata, Hmpsu., and a Tinea, not as yet determined, came to light in the train.

Mochudi, Bechuanaland, lat. $24^{\circ} 22^{\prime}$ S., alt. $3100 \mathrm{ft}$.-Two flies which would appear to be the too familiar MIusca domestica, were taken near the station, as well as an obscure beetle found under a stone. It was somewhere near this place that we entered the forest characteristic of this part of Africa, an open or easily penetrable growth, with deciduous trees of moderate size having a curious tendency to be flat-topped, affording a striking contrast to a Canadian forest of pointed firs. An English wood with its round-topped, or dome-shaped trees, is more beantiful than either.

ArTesia, lat. circa $24^{\circ} \mathrm{S}$., alt. $3100 \mathrm{ft}$-A female of the rery African-looking Jycaenid, Zeritis damarensis, Trim., as well as a 
specimen of the wide-ranging Polyommatus bacticus, also a female, were netted. The liasty turning over of a few stones yielded the Pentatomid bug Diploxys acanthura, Westw. ; four Ants, Camponotus maculatus; also a dead Beetle with a very hard carapace, Anomalipus sp., represented in the British Museum collection, but without a name; as well as a Weevil, Sparticerns sp.

Mahalapye, lat. $23^{\circ} 3^{\prime} \mathrm{S}$., alt. $3300 \mathrm{ft}$.-Here we entered the tropics, an event that was signalized by the capture of a male Catopsitia florella, Fabr., and the determination of its sweet scent.

Palapye Road Station, lat. $22^{\circ} 44^{\prime}$ S., alt. $3010 \mathrm{ft}$.- The beetle Xenitenus dilucidus, Péring., was taken in the train.

SERUI, lat. $22^{\circ} 27^{\prime}$ S.-While stopping at this station the electric lights of the train attracted a number of insects, among those that were secured were the very small drab Noctua Eublemma sp. (near foedosa, Guen.); a Quadrifid Noctua, Homoptera sp. (which may be new); an Acontiid Noctua, Arcyophora rhoda, Hmpsn.; a flying Aut, Mesoponerc caffraria, a female; and several moths not yet determined.

It was during this journey (? at Francistown) that we were startled by a huge cock Ostrich belonging to the station master which stalked along the train thrusting its hideous head, with those unsympathetic eyes, into the carriage windows, presumably in search of food.

Bulawayo, South Rhodesia, lat. $20^{\circ} 9^{\prime}$ S., alt. $4470 \mathrm{ft}$. September 9th-11th, 1905.

The most promising spot near the Matabili Capital was, we were told, the Waterworks situated a few miles to the westward, at an altitude of perhaps $4600 \mathrm{ft}$. Here we came across two shrubs in full flower, which proved very attractive to insects: one with white sweet-scented flowers, Dombcya (?) rotundifolia, Har'v., was frequented by Acraea doubledayi, Guér., though these butterflies seemed shy of actually settling upon the flowers. Altogether we took seven specimens, three of them about the Dombeya. On these flowers wc also took the slender Scoliid Myzinc capitata, Smith, of, and the long-bodied wasp Belonoguster griscus, $\not$; there were also two beetles of the genus Mylabris (or perhaps Ceroctis), a Cantharid of very similar colouring to the Longicorn Hylomela scxpunctata, Fabr., a species that we met with at Ladysmith and East London, but not nearer. Two of the Cetoniid, Rhabdotis (Puchnoda) sobrina, Gory \& P., werc also taken on the Dombeyc; it is an active insect easily alarmer 
and taking flight. This dark olive-brown bectle is less conspicuous on the whitc flower than might be expected owing to the small white spots, with which it is relieved, breaking up the mass of its groundcolour. I should be quite prepared to learn that Macroma cognata, a beautiful ehocolate-brown and eanary-ycllow C'ctoniid, that we took on the wing at Durban and East London-where in truth it was obvious enough-finds concealment when on an appropriate baekground, by the broken pattern on its baek. Another entomologist had discovered the attractive powers of the Dombeya before we did -the yellowish-grey, yellow-marked Chamaeleon dilepis, Leaeh, $q$; it was surprising that so large an animal could be so inconspieuous.

The other flowering shrub was a species of Combretum [Nat. Ord. Combretaceae], with spikes of yellowish-green flowers having the superficial appearanee of catkins. This was especially attractive; it was frequented by Aeraea doubledayi, but the Lycaenid Axioccrces harpax scttled on it in large numbers, and seven specimens, five of them males, were secured; they elosely resembled when so settled the curiously formed dry seed-vessels of the Combretum, of which many remained on the bush.

Other Lyeaenids at the same flowers were Crudaria leroma, Wallgr., of which only two were obtained, together with single specimens of Tarucus telicanus, of, and Aloeides (?) taitiosama, Wallgr., f. With these butterflies were numbers of other inseets, eonspieuous among them the bright coral-red Braeonid, Iphiaulax vchitci, its smoky-blaek wings bearing a scarlet (or yellowish) triangle on the eosta, and the large blue-winged peduneulated Wasp Eumencs dyschcra, Sauss., var. o. Here Dr. Dixey took with the common Icaria cincta, $\Varangle$, a male of the new species Myzinc "ufo-nigra, Bingh. ${ }^{1}$ The Mason-bee Chalicodoma coelocera, Smith, t, was takcn at a flowering shrub, whether Combretum or some other is uneertain, but be that as it may, the Combretum eertainly produced an unnamed Bug and sundry Flies: Rhynehomyia sp., Exoprosopa sp., and $E$. (?) lar, Fabr.

Apart from those found on or about flowers, inseets were scarce, and it took a good deal of work to sceure the following butterflies:Teracolus topha, a femalc; T. antigone, Boisd., a female whieh flew slowly near the ground without settling; $T$. annac, a female; $T$. achine, two males, and Terias brigitta, a malc and two females, the former less "dry" than the latter. Ccrtain dark, yellow-striped Grasshopper larvae wcre scen on the stems of Combretum and other shrubs; they wcre truly gregarious, and wcre obserred to advance and halt together as if drilled.

\footnotetext{
1 Soc lootnotc, p. 182, supra.
} 
On a stretch of somewhat lower flat country covered with coarse dead grass we saw many individual specimens of the Red Migratory Locust, Schistocerca peregrina, Oliv., but no swarms; we spent much time in vainly endeavouring to catch them, for they are extremely wary and took to flight in an exasperating manner when approached within four or five yards. The general colour of the living insect is dark mahogany-red, with some greenish-brown shading, but the wings shine brightly in the sunlight, so that the insects resemble small flying-fish.

On September 10 th we had a delightful excursion to The Matopos, a wild group of granitic hills about forty miles to the southsouth-west of Bulawayo. The veldt may be from 4500 to $5000 \mathrm{ft}$. above sea-level, the kopjes rising from 100 to $800 \mathrm{ft}$. higher. In the wider valleys are stretches of coarse grass, but for the most part the country is covered by somewhat open scrub and forest, not especially tropical in aspect. Some of the hills are wooded, others mere bosies of almost smooth granite. Such a country was most attractive, but the length of the drive to and from the terminus left little time for collecting.

The coach-road passes close by the Zoological Garden, a piece of forest four square miles in area, enclosed by a lofty iron fence. It was most interesting to see a Giraffe browsing on the leaves of a tree, under almost natural conditions.

The commonest butterfly was Aeraca doubledayi, which was to be seen flying among long grass as well as at the flowers of Combretum and Dombeya, altogether eight specimens were taken; a single example of $A$. calderena, Hew., was taken among long grass, together with Yphthima asterope, var. norma, Westw., and the Blue, Everes eissus, Godart.

The catkin-like racemes of the shrub Selerocarya eaffra, Sond. [Nat. Ord. Anacarcliaceae], were also very attractive, yielding the Lycaenids Hypolycacna caeculus, Hopff, a female, and the very beautiful and distinct Stugeta bowkcri, Trim., a male, also the now familiar Apis adansoni, $\not{q}$; but far more startling than auy of these was the beautiful long-beaked Sun-bird with blue throat surmounting a breast of crimson shot with violet (Nectarinia (?) metalliea).

On the branches of the Selerocarya were a number of Polyrachis schistacea, Gerst., a dull, black Ant with nearly globular abdomen.

A small tree with sweet-scented, viscid, yellow-green flowers, a species of Gardenia ${ }^{1}$ [Nat. Ord. Rubicaccac], was extremely attractive to insects, and it was interesting to watch the Sphinx Cephonorles

1 Or possibly Tricalysia jasminiflora, Hook., of tho same Natural Order. 
hylas, Linn., hovering amidst the numerous Carpenter-bees, the commonest of which, Xylocopa caffra, Linn., o, var. mossambica, Grib. (with two white rings on the abdomen), it appeared to mimic; of the other species $X$. olivacea, Fabr., and $X$. divisa, var., single examples only were secured, females; the former species is very handsome, its thorax being of a beautiful "old gold" colour. A Bombyliid fly, Systoechus sp., as well as a male of Catopsitia florella (by no means the only one seen), were taken on the same tree.

The Combretum attracted besides Acraea doubledayi, the Lycaenid Axiocerces harpax, a male, and the fine Wasp Belonogaster griseus, $\xi$, which has a conspicuous yellow spot on the side of the abdomen, also a number of the brilliantly-coloured Braconid Iphiaulax whitci. On the same plant was found a Lady-bird, Chilomencs sp., which is in the National Collection, but without a name.

On Dombeya flowers, besides Ants, three specimens of the Cetoniid Rhabdotis sobrina were taken.

Certain Aculeates were taken at flowers of one sort or another, which it is not now possible to distinguish:-Bclonogastor guerini, Sauss., $\not$, var. dubius, Kohl, Elis (Diclis) fasciatella, ơ; also the long-waisted, black, red and yellow wasp, Eumenes lucasia, Sauss., o. This last was the third specimen known to Colonel C. T. Bingham, the type being at Paris and the co-type in the British Museum, from Bab-el-Mandeb (2500 miles away). Lastly, a small slender, black, white-ringed solitary wasp, a female of a new species of Labus, said by the late Colonel Bingham to come very near the Javan species that is the type of the genus. It would appear to be the first notice of this genus in Africa. Colonel Bingham described this as Labus ravus, sp. nov. in MS.; but before his paper was published Mr. Geoffrey Meade-Waldo described a specimen from Natal as L. annulatus, sp. nov. ${ }^{1}$

Other things that were picked up on that memorable day were a worn specimen of the pale fawn-coloured Mycalesis simonsi, Butl., one of two or three that were seen at one partially shady spot; a large "dry" Terias brigitta, o; a Tryxalis sp.; a fly, Anthrar sp.; and a beetle, Zophosis angusticollis, Deyr., found running rapidly over the ground at the World's View, close to the grave of Cecil Rhodes.

The account of the expedition would not be complete without mention of the swarms of the Red Locust, Schistoccrea peregrina, which during the drive back to the train rose in glittering clouds on every side. It was, however, not withont repeated efforts that a fer specimens were netted out of the many thousands seen.

\footnotetext{
1 Am. Mag. Nat. Iist., (5), viii. p. 36, 1910.
} 
In the town of Bulawayo, Zophosis eaffer was taken running over the ground, while by turning over stones many things were obtained, including the curious hairy beetle, a Heteromeron, Usagaria australis, Péring., four specimens; Psaryphis sp., which was not represented in the British Museum; the Geodephagid, Omostropus eonsanguineus, Péring., three; the Staphylinid, Myrmedonia procax, Péring.; a Weevil; and the obscure little Bug, Pododus depressus, Walk.

About the filter-beds near the railway station the Lycaenids Zizera lysimon, one, and Aloëides taikosama, two males, were taken.

The two beetles, Meligethes sp. and Pseudo-eolaspis sp. (the last is represented in the National Collection but unnamed), and the small dingy bug Agonoseelis puberula, Stål, were taken either at or near Bulawayo, or at the Matopos; the beetle Pogonobasis sp. (unnamed in the British Museum) was taken somewhere in South Rhodesia prior to our arrival at the Falls, but the locality cannot be now designated, for the notes concerning these insects are unfortunately defective.

I have mentioned the finding of two Chamaeleons. This place will be as convenient as any to describe my observations on the living animals.

Chamafleon pumilus, Daudin. My specimen, a female, was taken on a shrub, about 4 feet from the ground, in the Botanical Gardens, Cape Town, August 9th, 1905.

Deseription.-Apple-green; at the back of the eye two patches of greyish-pink placed vertically; a lateral stripe of the same colour extending from shoulder to pelvis, widest in middle, where are two dark grey spots. Several orange tubercles on the back. Belly striped with greenish white; underside of head striped blue-green and pink. The ground colour varies to dusky green.

It was kept in confinement and the following observations were made at Durban, August 16th, 1905. After it had been kept for some time in the dark it became of the brightest apple-green. On exposure to light it forthwith darkened. Placed on a dark tin case near the window in bright light it darkened along the dorsal "rea.

It was taken out into the garden and placed alternately on a black pair of trousers and on a white towel. It darkened in both cases, but therc was no noticeable difference. When put on a twig of a shrub with bright grcen leaves it became paler. The side away from the sun was of the brightest apple-green, the side exposed to the sun became clarker along the baek. The bright green harmonized wonderfully with the young leaves, the creature appeared flat, and was scarcoly 
distinguishable. The neck and belly did not appear to change colour.

It was then killed, being rapidly overcome by chloroform, then becoming more dusky than I had seen it previously: that is to say it assumed its darkest coloration.

Chamaeleon DILePIS, Leach. The animal, a female, was taken near the Waterworks, Bulawayo, September 9 th, 1905 (about 3 to 4 feet from the ground), on a shrub of Dombeya (?) rotundifolia, the white flowers of which were attracting a number of insects of various orders. I was startled on detecting the animal, which at first escaped my notice.

Description.-Pale ycllowish-grey, legs and tail darker; streaked and blotched with greenish-grey. Throat with six cadmiun-yellow stripes. A yellow spot behind the shoulder, another over the ribs, and a yellow lateral line.

It gave vent to a gurgling hiss when disturbed, and once bit me, but not hard enough to hurt.

It was kept alive and observed at Victoria Falls, September 16th, 1905. Placed on a plant of young Acacia, the animal soon lost all its darker bands and became almost uniform grey-green, with the above yellow markings. In the sun it became strongly mottled, with some tendency to be paler on the shady side, but this was not very marked. Its excrement consisted of elytra and other insect-fragments.

When chloroformed, it became a uniform pale yellowish colour, a little paler than my khaki coat; that is to say, assumed its palcst coloration.

The moment that I saw the green Chamaeleon turn dark on the side towards the sun (a quite unexpected phenomenon) Mr. Abbott H. Thayer's model of the Wild-duck in the Oxford Museum came to my mind. Here, I thought, was a striking instance of the principle of counter-shading, whereby shadow is amihilated and with it the conception of solidity.

The dissimilar action of chloroform on the two reptiles is remarkable. If it be assumed (as seems likely) that the darkening of the green chamaeleon was paralytic, then the blanching of the grey chamaelcon must have been the result of stimulation, or vice vcrsá. ${ }^{1}$

1 These observations, together with others of his own, genorally concordant mith mino, were communicated to the Linnonu Socioty by Professor E. B. Poulton, F.R.S. Journal Tinncan Society, Zoology, vol. xxx., 1907. pp. 45-4S. 
THE RAILWAY JOURNEY FRON BULAWAYO TO THE VICTORIA FAILS.

September 11th, 1905.

Red Bank Station (19 miles from Bulawayo).-We took alongside the train Teracolus achinc, Cram., a male; T. antigone, a male; and two fine specimens of Papilio angolanus, Göze (? corinncus, Bert.), which had probably been disturbed from the drippings of the water-tank.

Satw-Mrlils Station, near Umguzi (57 miles from Bulawayo).A male of Belenois mesentina, Cram., was netted, also a Noctua flying in the sun. The Red Locust, Schistoccrca peregrina, was abundant; by great exertions we succeeded in catching two.

GWaAI (89 miles from Bulawayo), lat. $19^{\circ} 7^{\prime}$ S., alt. $3240 \mathrm{ft}$ Towards evening the train stopped in a stretch of flat, bare country beside a reedy pond to take in water. A fine specimen of Charaxcs saturnus, Butl. (the only one we saw in our travels), was taken flying about a low tree by Dr. Dixey. We also took the brilliant cardinal-red Dragon-fly, Crocothemis erythraea, Brullé. Sweeping the rank vegetation by the pond yielded a multitude of small insects, amongst them a number of the singular Fly, Diopsis affinis, Adams, which carries its eyes and antennae upon long rigid stalks or horns projecting on either side of the head. [See Plate II., Fig. 5.] The appearance of these little black and red flies forcibly suggests a Watkin Range Finder in miniature, the eyes being so far separated as to afford an appreciable base-line; if the insect were resting on the underside of a stalk it would be able to see its cnemies or prey above it without exposing itself. With the Diopsis were Musca (?) domestica, Scpcdon sp. and other small flies; two small Scoliids, Myzine sp., in too bad condition to name; and other insects, including the Phytophaga, Haltica pyritosa, Erichs.; Hispa spinulosa, Boh. nec Schönh.; Chactocnema sp.; two specimens of the Acridian, Paratctix scaber, Thunb., and a small moth, Eretmocera derogatella, Walk.

An unnamed Gcometer, the cosmopolitan Tineid, Plutclla maculipennis, and the Cockroach, Paraplccta pallipes, Still, all camc to light in the train on the night of Scptember 11th between Gwaai and Wankie. Mr. Shclford says that the Paraplccta was first received from Damaraland, but is very rare in collections. 
The Victoria Faliss of the Zambesi, lat. $18^{\circ} \mathrm{S}$., alt. $3000 \mathrm{ft}$.

September 12 th-19th.

This, oul furthest point, was the locality from which $\nabla c$ expected most. Apart altogether from the magnificence of the Falls thernselves and the geological puzzles that they afford, the locality presents certain peculiarities to the botanist and entomologist.

Picture a rolling sandy plateau a little over $3000 \mathrm{ft}$. above sealevel. Low distant hills bound the view, though the characteristic South African flat-topped kopje is for once absent. Above the Falls the banks of the Zambesi are low and almost flat, the country on cither side of the river resembling much of that passed through in the railway journey from Bulawayo. The forests of South Phodesia are chiefly composed of deciduous trees of moderate size, for the most part tending to be flat-topped and so harmonizing with the horizontal strata and giving the landscape a character of its own. The undergrowth of scrub is, as a rule, scanty and easily traversed, while the coarse grass and other herbage is so sparse as to leave much burning sand bare; though it must be borne in mind that our visit was towards the end of a very dry season. Doubtless during the rains much of this sand would be covered with vegetation and gay witl flowers, but as it was we found loose dry sand extending to within a very few feet of the Papyrus growing at the water's edge. The banks above the Falls are fringed with a narrow belt of shady wood in which (especially on the right bank) the small date-palm, Phocni $x$ reclinata, is the prevailing tree, and a shrubby Ipomoea was at the time of our visit the most striking flower. Here and there towered the monstrous Baobab tree, Adansonia digitata, with stem like an inverted carrot. 'The first leaves on the commoner forest trees spread an emerald tint suggestive of spring and affording a refreshing contrast to the parched herbage and scorching sand.

Opposite to the Falls is the Rain Forcst, poctically called by the Barotse, "The place where the rain is born." This stretches along the clcft for three-quarters of a milc, not counting the similar growths on the Knife-Edge. Between the Rain Forest proper and tilc cdge of the chasm, whorc the spray is most drenching, is a strip of coarse boggy grass and hcrbage looking for all the rorld like a bit of Exmoor into which the bright bluc flowers of Lobclia crinus have escaped from some parterre. The forcst proper, from 50 to pcrhaps 300 yards wide, is of varicd growth, in which large specimeus of Ficrs with their characteristic fluted stems arc a promiuent feature; 
but towards the Falls it is bounded by a dense hedge of very bright green trees, Eugenia cordata, an evergreen of the myrtle tribe. ${ }^{1}$ The amolnt of spray, or "Rain," naturally varies with the height of the water and the force and direction of the wind. A sound that one soon learns to associate with the ceaseless roar of the cataract and the pattering of the spray-drops on the forest leaves is the musical cry of the Emerald-spotted Dove (Chalcopelia afra).

We saw the Falls at a period of low water, this of course detracts from their grandeur, and, what is more, from their characteristic mystery, for the shrinking of the spray columns enables one to see the chasm better and so better comprehend its weird topography. But thongh the most absorbed collector cannot fail to be impressed by such unwonted surroundings, this is not the place to dwell upon the majesty of the Falls themselves, or the airy beauty of the brilliant rainbows that attend them by day or their more ghostly representatives in the moonlight.

Two pre-eminent impressions remain graven upon the memory:a vast river over a mile in width, dotted with wooded islets, glides noiselessly through the burning sand, coming one knows not whence; and again the same mighty river, with scarce a warning rapid or cven swirl upon its peaceful waters, suddenly draws a veil of spray over its face as with a mighty roar it flings itself down 350 feet into a chasm athwart its channel, and emerging thence, one can scarce see how, pursues its long mysterious course between grim basaltic crags through the incredible zigzags of the Batoka.

The hotel is situated close to the railway station, in the open forest, about a milc from the Falls, and perhaps $100 \mathrm{ft}$. above them, though geographically speaking below. The first insect to attract notice was a large Acrcece flying about the tops of the trees, occasionally as many as a dozen together. After the exercise of somc patience a fair scries of specimens and a stiff neck were secured. These butterflies proved to be very beautiful, with pinkish fore-wings and white hind-wings; they were new to Mr. Marshall, but previously known to Mr. Trimen hy two specimens only, and then considered by him to be a variety of $A$. anemosa, Hew., to which Aurivillius gave the name of alborcudicata. A long series amply proves this form to bc a new specics, which should consequently bear the name given to the supposerl varicty by $\Lambda$ urivillins. If, tired of gazing $1 p$ at these beanties, the eyes were turned with relief to the ground, Ants might

1 For an exeollent account of the botany of Southern Rhodesia, with a good description of the Matopo Hills and the country about the Falls, sco a paper by Miss L. S. Gibbs, F.L.S., Joum. Timean Soc., Botany, vol. xxxvii., 1906, pp. 425-494. 
be seen running swiftly over the sand with their abdomina borne high in the air. They were Camponotus fulvopilosus, De Geer, dull grey-black with pale brown hairy abdomen, very cryptic in their sandy home. The "soldiers" have such disproportionately big heads as to suggest drummer-boys in bear-skins. The species was common about the hotel and on the way to the Falls. Also running swiftly over the sand a small Beetle was taken, a Zophosis not in the National Collection. A flowering tree close to the hotel produced the widely spread Apis mellifica, race adansoni, as well as two other Bees not yet determined.

The irrigated kitchen-garden of the hotel attracted numerous insects, the most striking being Aeraea atolmis, Westw., of which about a dozen, all males, were secured; it is a beautiful insect looking blood-red when alive; with them were taken three $A$. atergatis, Westw. (both this and the last-named were, until quite recently, rare insects in collections); three male $A$. anemosa, one of them a dwarf, and two $A$. alboradiata, of and . . With the Acraeae were two females of Terias brigitta, of the "dry" form, also one Aphnaens eritissoni, Trim. In the same garden were taken the steely-blue-winged Wasp, Diseolia ebenina, Sauss., four males and a female; also another somewhat fly-like Wasp, the handsome black and yellow Bembex capicola, Handl., a male-only the second specimen known to the late Colonel C. T. Bingham, the type being at Vienna.

The electric lights of the hotel attracted a considerable number of insects, but they were for the most part small and insignificant in appearance:-

Noctuina.-Eustrotia (Xanthoptera) opella, Swinh., three, a common Indian species. Homoptera scandatula, Feld., one, a Catocalid. Homoptera (?) sp. nov., one. Paromphale chionephra, Hmpsn., sp. nov., two. ${ }^{1}$ Areyophora (?) sp. nov., one, an Acontiid not in the British Museum. Entelia polyehorda, Hmpsn., one, a variablc Quadrifid. Eublemma snelleni, Wallgrn., a very small Quadrifid.

Geometrina. - Comibaena leueospilata, Walk., one: a pretty Emerald.

Pyralina.-Argyractis sp., two. Stcmmatophora chloralis, Hmpsn. in MS., sp. nov., five: a very distinct and pretty little insect, whitishgrecn with black central band; its description will shortly be publishcd. [Sce Plate II., Fig. 9.] Parthenodes seotalis, Hmpsn., sp. nor., five: a somewhat dingy Hydrocampid. ${ }^{2}$ [Plate II., Fig. 8.] Platylcs $s p$. nov., five: a beautiful Crambid which Sir Georgc F. Hampson has

1 Hampson, Ann. Mag. Nat. Hist. (8) riii. p. 439 (1911).

2 Hampson, Tbid. (7) xviii. p. 470 (1906). 
kindly promised to describe. [Plate II., Fig. 10.] Microthrix insulsclla, two: a dingy Phyeid. Ittiella zinckenella, one: an almost eosmopolitan Phycid. Also several other small moths not yet determined.

Neuroptera. - Nomopistha (Halter) lanccaria, Navás. Threc speeimens of this very singular inseet came to the lamps; its very long, slender and spirally twisted hind-wings seem to suggest a flying machine rather than an insect. ${ }^{1} \quad$ Father L. Navás has reeently described this from a fragmentary speeimen in the British Museum. ${ }^{2}$ [See Plate II., Fig. 2.] (?) Oestropis sp., and (?) Blymorphanismus sp., two green Trichoptera, together with other Caddis-flies morc like European forms.

OrTHOPTERA.-A Cricket.

HEMiptera.-Acanthaspis nugax, Stål, a Reduviid bug with a peculiar fetor.

Coleoptera.-Apate monacha, Fabr., two o. Himatismus sp., three: not in the British Museum. Trochalus sp., one: in the National Collection, unnamed. Xylopertha sp., one. Two Longicorns, Plocederus melancholicus, Gahan, and Tetradia lophoptera, Guér. (fasciaticollis, Thomps.), also came to light; the latter was captured by one of us on his bed, clinging closely to the sheet, and making a curious creaking noise when disturbed. ${ }^{3}$

Lastly a male Acraea alboradiata was taken fluttering on the floor below an electrie light at 9 p.m.!

While onc of us was busy with the electric lights a waitcr excitedly called out that there was a "Tarantula" under the stocp. He was most anxious that it should be secured, but declared that its bite was deadly. It proved very fleet of foot and doubled like a hare; other waiters joincd in the ehase, which proved most exciting, especially when the spider ran over the neck of the ardent entomologist. When the fierce creature yielded at last to the soothing influence of cyanide it was scen to be of a pale reddish-brown, with pale grey abdomen, but armed with most formidablc-looking redbrown mandibles, tipped with blaek. Black cyes added to its feroeious aspect. Ultimatcly a sceond specimen was bottledtogether with one of another species.

Above the Falls the RigirT Bank of the river (here the southwestern) was the most readily accessible collecting ground, and perhaps for that reason received an undue amount of attention. 'There

1 This was writton long bofore Monoplanos became common objects; but the comparison still secms to me to hold good.

"Wytsmann, Genera Insectorum, Nenopteridac, by tho Rov. L. Navás, S.J., 1910.

3 "The voicc no doubt procecds from tho mesonotum."-G. J. Arrow, in litl. 
our familiar friend Danaida chrysippus, a female somewhat small and dark, was busy with the flowers of Combretum. The genus Acraea was well represented: A. alboradiuta, though not so cornmon as elose to the hotel, was frequently seen, especially near the cascade at the western extremity of the Falls, loeally known as the Leaping Waters; with this were several $A$. anemosa, all males, one very small; we also took three $A$. encedon; a single speeimen of $A$. caldarena, a male; $A$. rahira, Boisd.; a stunted $A$. atergatis, and elose to the Falls a female $A$. atolmis. In a way the most striking butterfly was Hamanumida dacdalus, Fabr., for it was the first time that either of us had seen it alive. It was very common, flying close to the ground, and settling on the grey sand or dust with wings spread out flat, in which position it was curiously inconspieuous, the white dots on the butterfly's wings producing much the same effect as prominent grains of sand glistening in the sunshine. Precis clelia and $P$. cebrenc were both fairly common, but of $P$. natalica and $P$. archesia we took but one apiece, the former of the "dry," the latter of the moderately dark, or intermediate form. $P$. sesamus was seen though not taken. Neptis agatha, graeeful as alrays, was not uneommon; Atella phalantha was there also, with its fearless sailing flight, returning again and again to the same spot. Tro male Byblia goetzius were taken playing together, but Charaxes varanes was more often seen than netted. The Satyrids were represented by the restless little butterflies of the genus Iphthima; of these $Y$. asteropc was common enough in the half-shade, and with them were taken a couple of the var. norma, also two Y. itonia, Hew.

The Common White of the Zambesi appeared to be Bclcnois gidica, and very "dry" they were; the dry-season form of B. scrcrina ras also quite common. Of the Tcracoli we took five species, by far the commonest being $T$. omphale, the males predominating; of T. achine we took four males, of T. antigone, one. Near the Leaping Waters we got a single female specimen of $T$. phlcgyas, and tro T. cris, both males. Many of the genus fly quiekly, but the fiight of 1 . cris is specially rapid and erratic, so that in all probability more were seen than taken. Terias brigitta, both sexcs, was fairly common, it was cspeeially attracted by a small low-growing, larenderflowered Labiate, four or five of the little bright ycllow butterflics flying together over a patch of it formed a fine contrast in colour. This butterfly lhas a jerky flight, so that it proved to be not so very casy to cateh as one at first imagined. Of $T$. scnegalensis, two males were taken. The T'erius were by 110 means so markedly "dry" as the T'cracoli. A single P'apilio angolanus (? corinneus) was secured. 
The Lyjacnidac were not very prevalent, and no speeies was abundant. Of the handsome Stugeta bowkcri, and of Axioccrccs amanga, Westw., we took single examples, but $A$. harpax was eommoner, espeeially among reeds and sedges at the water's edge. Of Hypolycaence cacculus, Zizera lysimon, and Liptena (Durbania) pallida, Trim., we took but one eaeh, the latter at flowers of Ipomoea.

The Skippers were represented by solitary male individuals of Gcgenes occulta, and Parnare mathicas, Fabr. (mahopaani, Trim., inconspicua, Boisd.).

In addition to the butterflies already named the following may be mentioned as being taken while drinking at the mud of small inlets and baekwaters of the right bank of the river:-

Both sexes of Acrcuea alboradiata and A. atolmis; Belenois gidica and $B$. mescntiva, both males; of Terias brigitta a female was taken, eontrary to the usual rule with Pierines, viz. that speeimens found drinking are males; but this speeies, though eertainly attraeted by water, is of a restless habit like Yphthima, and seldom settles; Papilio leonidas, Fabr., three speeimens were taken at mud and others seen; lastly a speeimen of Axioccrces amanga.

So mueh for the butterflies found on the right bank. The moths were far less numerous, and the only things brought home were a Geometer, Gracillodes caffra, a Crambus sp. and another small, and as yet unnamed Pyrale, Argyractis sp.

As might have been expeeted Dragon-flies were fairly numerous, espeeially a speeies with a deep eardinal-red body, Crocothemis erythraea, whieh has a very wide range in Afriea. Some of these were taken at mud puddles in the baek-waters, others about the roeks whieh extend far into the river above the Falls, roeks on whieh one often saw the Snake-bird, Plotus lcvaillanti, sitting absolutely still and giving an appropriate finish to the peaeeful landseape. Another large and handsome Dragon-fly, Pscudo-macromia torrida, Kirby, with a pair of sapphire-like spots behind the eyes, was enmmon, as was also the smaller Pscudagrion dcckeni, Gerst. Besides these wore others not yet named.

A Myrmeleon sp. was noted as being the eolour of dried grass. Sorne White-ants were taken but, so far as our observations went, Termites are not as eommon at the Falls as in other parts of South Afriea that we visited.

Very little attention was paid to Diptera, perhaps beeause they did not pay the usual arnount of attention to us; only two tvere brought home, Sarcophaga sp. and Haematopota sp., the latter taken 
on the topi of the captor, and bottled before it pushed the attack home.

Of the Aculeates the most striking were the Carpenter-bees, of which the commonest was Xylocopa divisa, found at Combretum, or other flowers, though one, a male, was noted as hovering persistently about a trec overhanging the river. The male of this bee is of a beautiful old-gold colour; of this sex only two were taken, but females, of the variety with the band on the back of the thorax white in place of old-gold, were commoner, and four or five specimens were secured. Of $X$. caffra, we took two specimens, botli females of the variety mossambica, with a white ring in place of the usual two yellow rings. Of $X$. olivacea, we got but a single female. We met with three species of the very slender-waisted Wasps of the genus Ammophila, viz.: A. ludovica, Smith, a female, and $A$. beninicnsis, Beauv., a male, both at wet mud, while a femalc of A.fcringineipes, Lcpel., was taken at flowers. Of the large and handsome black and yellow Sccliphron spirifcx, Linn., we only secured a single female, also at flowers. Of the long-waisted grey wasp Bclonogaster gucrini, var. dubius, a single worker was taken at mud. We also took single examples of Salius (Hcmipepsis) vindex, Smith, a male; the Scoliid Myzine capitata, a male, and the small red wasp Odynerus carinulatus, Sauss, a female, the last-named at wet mud. The integuments of two males of Rhynchium rupeum, Sauss., proved of a truly rocky hardness. Running over damp mud three specimens of a notable Ant were taken, Paltothyrcus tarsatus, Fabr., notable for its powerful bite, but still more for its evil odour, which is extremely strong and pungent, suggesting a mixture of formic acid and bisulphide of carbon. ${ }^{1}$ Running along the branches of the tree-Ipomoea, near the Leaping Waters, were a number of another ant, Polyrachis schistacce, which we had seen at the Matopos on Sclcrocan'ya caffra.

The Coleoptera met with were not very numerous, but comprised Pogonobasis sp. (in the National Collection, but without a name), which was taken on the ground by Miss L. S. Gibbs; two specimens of Scymnus sp.; threc Weevils, Bayous cacnosus, Gyll., which Mr. G. A. K. Marshall had previously seen from Uitenhage, Capc Colony, only; Rhabdinoccrus brachystcgiac, Mrshll. (in litt.) and . Ycnorrhinus incultus, Faust, the first specimen of the latter that Mr. Marshall had

1 For Dr. S. Schönland's observations on the odome of this insect iu Bechuanaland, seo Proc. Ent. Soc., Lond., 1904, p. xl. Ho speaks of it as " a stonch which comos near that awful stench of the woll-snowu Caralluma lutea (an Asclepiad plant) found in the same ncighbourbood." The plant, il appoars, attracts flies. 
seen; also a Eumolpid, Pseudo-colaspis chrysitis, Gerst.; and two Heteromera of the gen us Opatrum, under dead wood. Two specimens of Adesmia intricuta, Klug, a Heteromeron only represented in the National Collection by specimens from Mozambique, were found crawling on the ground near the Leaping Waters.

The Red Locust, Schistocerca peregrina, was by far the most common and most conspicuous of the Orthoptera; as usual it was chiefly found among coarse grass, but could not be said to be gregarious.

In shallows in the river just above the Falls, a small banded Water-snail, Cleopatra morrelli, Preston, was to be found, together with abundance of a spotted species with sinuated lip, Melanic victoriae, Dohrn. The former had been first found in the same locality not long before by Mr. Morrell and described as recently as April, 1905, by Mr. H. B. Preston. ${ }^{1}$

The LEFT BANK of the river differs in character from the right. The ground lies somewhat higher, there is more wood and scrub but less grass and fewer palms. A female Danaida chrysippus was seen at water; of the Acraeae the commonest was $A$. encedon, males predominating, while single female specimens of $A$. atolmis and $A$. anemosa turned up. Prccis clclia was fairly common, and $P$. sesamus was seen, as is its wont, fluttering about and settling under the shade of a dark bank.

The Whites were represented among our captures by two male Bclenois gidica. Teracoli were far less common than on the right bank, probably because there was less of the open grassy country in which they delight; single specimens only of $T$. omphale, a male, and $T$. eris, a female, the latter at Combretum flowers, were secured. Terias was represented by a female senegalensis, Boisd., of the usual dry-season form, but also by a male brigitta, of distinctly "wet" character-a notable exception among so many very markedly "dry" butterflies. $^{2}$ A male and two females of Catopsilia florella were secured while feeding on the large-flowered species of Combretum that grows in the Zambesi scrub; this butterfly was almost certainly seen more than once on the right bank, but eluded capture, for Catopsilia is very swift of flight and hard to net save when busy honeygathering. Papilio demodocus was taken on the Knife Edge near the eastern extremity of the Falls.

Axiocerces amanga, at Combretum flowers, Zizera lysimon, and

' Proc. Malacological Society of London, 1905, p. 300.

2 Seo Dixey, Proc. Ent. Soc. Lond., 1905, pp. Ixi-lxii, and ibid. pp. Ixvi-lxvii. Compare Chapter X., $\$ 13$, infra. 
Liptena pallida, were the only Lycaenids brought home, the last taken near the top of the Palm Kloof. Between the last-named place and the railway bridge large Libellulid Dragon-flies were especially common and comparatively easy to catch as they hovered over the path head to wind, like hawks. The commonest would appear to be Pseudo-macromia torrida, but there was also a species of Macromia as well as the slender Pseudagrion (?) deckeni.

Speaking of the railway bridge, perhaps one may be allowed to congratulate the engineer who designed it (Mr. G. A. Hobson, of the firm of Sir Douglas Fox and Partners) on a structure which seems as well fitted to its position alike in form and colour as such a thing can be; one shudders to think what might have been placed there by less sympathetic hands.

The only Hymenoptera taken on the left bank were two small Bees, one, unnamed, at Ipomoea, the other Poclatirius rapidus, Smith, o, hovering at Combrctum flowers, also the Braconid Iphiaulax whitci, and a long-waisted Wasp, Belonogaster guerini, var. dubius, ఫ̧.

Beetles were few and far between: a Mylabris sp. (? Ceroctis sp.), found here, as well as on the other bank, in the flowers of Ipomoea, appears to mimic the Longicorn Hylomela sexpunctata, a beetle that we met with only at East London. In the same flowers was another beetle, a long narrow purple fellow, not yet named.

A Fly, Haematopota sp., that attracted my attention by biting my hand, was the only Dipteron taken.

If the left bank yielded us but a small bag it was some considerable consolation, at all events to the fortunate observer, to have had the opportunity of contemplating from a distance of not more than 100 yards a family of Hippopotami disporting themselves in the water.

By the kindness of the Chartered Company's Forester, Mr. C. E. F. Allen, I was enabled to visit with him two of the wooded islands some miles above the Falls. Entomologically the results were disappointing, but here again Hippopotami came to the rescue, for the thicket on one of the islands was traversed in all directions by their paths, while in an open space lay the bleaching bones of one of the uncouth monsters. The ubiquitous Danaida chrysippus was represented by a male, but no Acraca was taken, and the only Nymphalines werc Prccis natalica, with ocellated underside, and a Neptis which eluded capturc.

The Common White of these islands was Bclcnois scverina, of which five "dry" malcs wcre taken; but $B$. gidica was nearly as common, and two of each sex werc brought homc. All the gidica 
from the Zambesi were of extreme "dry" type, drier than their congener. No Tcrias werc taken and but three Teraeoli, all males, two of T. antigone, one of evenina, Wallg1. Of Eronia leda, a female of "dry" type was taken. The only Satyrids were four Yphthima asterope, var. norma. The Lycaenids were even scarcer, as a solitary Zizera lysimon was the only Blue.

A Geometer, an Emerald with red chequered fringes, Comibaena lencospilata, was the only moth taken, while unfortunately "other orders" would appear to have been even more than ordinarily neglected, as the captures were limited to a single individual of the evil-smelling Ant, Paltothyreus tarsatus, and a pretty black and white two-winged Fly, Tabanus sp.

Mr. Allen was good enough to give us four insects taken in a druggist's shop at Livingstone, five miles above the Falls; they were two Flies, one of them a large, fierce-looking fellow, Tabanus sp., a red-bodied Wasp Odynerus carinatulus, ${ }_{\text {, }}$, and a Malacoderm beetle, Melyris nobilis, Gerst.

The easiest way down to the river at its lower level, below the Falls, is by the gorge known as the PALM KLOOF, which is separated by the Knife Edge from the eastern portion of the chasm. The path loads rapidly down into a wood of singularly tropical aspect, bounded on either hand by walls of basalt, and thence to the water's edge. The collecting ground is very restricted and difficult, being almost co-extensive with the steep path, so that the ratio of things taken to things seen was a low one.

The butterfly that was most characteristic of the Kloof was Neptis marpessa, Hopff.; it was distinctly common, and we took it nowhere else. It has the graceful, sailing, sibylla-like flight of the genus, but is smaller than the more generally distributed agatha. Several males of Leuceronia thalcussina, Boisd., were seen, all out of reach. They flew rather high, among the tops of the trees, and seemed to avoid the path. Bclenois gidiea, $B$. severina, and the wide-spread $P$. mesentina, were all taken in the Kloof; the latter, a male, flew fast. The path through the dark wood looked thc very place for Satyrids, but only three were mct with, two Yphthima asterope, one typical, the other of the var. norma, and a shade-loving Myealesis, of which Mr. Trimen says: "ncar eampina, Auriv., also like anynana, Butl., but the underside very red." Our old friend Papilio demodocus put in an appearance. A small, worn Lycaenid, probably Cacyreus lingeus, Cram., a male; a tailed Blue, (?) Deudorix sp., \&, which may possibly be new, and a male Tarueus telieanus, represented that group. Three large Geometers, two of them 
Conolophia conscitaria, Walk., the third a Thorn not yet determined, were disturbed from the herbage.

The phytophagous Beetle Monolepta vincta, Gerst., was abundant by a spring near the bottom of the Kloof, flying in the sun, but might also be taken by sweeping shrubs.

Of all the collecting grounds at the Victoria Falls, we naturally anticipated most from the PaIN FOREST; it was accordingly the first, as it was the last place that we visited. One caution is necessary in limine : the area of the forest is so small, and the driest of sandy areas are so near, that it cannot reasonably be expected to yield valuable evidence as to seasonal forms, for a butterfly captured within its ambit may well have gone through all its early stages outside and have merely entered the spray-bedewed area to quench its thirst. Human experience points in this direction; for it is difficult to imagine anything more refreshing than after some hours' collecting in the drouth to get wetted through by the spray, which was truly grateful and comforting-especially in a thirsty land where beer is two shillings a small bottle. Repeated carefullytimed experiments showed that ten minutes in the hot sun and parching wind sufficed to dry one's garments thoroughly. The chief drawback to these natural Rain Baths was the difficulty of manœuvring a sopping net, and the condition of some of the "very dry" Belcnois gidica, when taken out of the net under such circumstances was deplorable.

One butterfly did not appear to appreciate the delicious smell of the damp vegetation, at all events our old friend Danaida chrysipprs failed to put in an appearance. The Acracae too were surprisingly scarce, only single examples of $A$. alboradiata,,$+ A$. ancmosa, $\delta$, and A. atolmis, + , were taken. Only one Precis is recorded, a ragged natalica, but Neptis agatha was frequently seen sailing about the Eugenia trees. Yphthima itonia was common enough, a specimen of $Y$. asterope, var. norma, was also taken. Another specimen was obtained of the Mycalcsis (as yet unnamed), taken in the Palm Kloof, also one Mr. safitza. Bclcnois scrcrina was the commonest White; all taken were males; but extremely "dry" specimens of $B$. gidiea (males predominating), were fairly common, especially where the spray was heaviest. Three females of Lcuccronia thalassina were taken, also a female Glutophrissa saba, which was so extremely "dry" as to have lost all trace of mimicry of Dcilcmera. Of Terias sencgalensis,,$+ T$. brigitta, of, and Teracolus antigone, $q$, single examples werc secured. That only one Tcracolus was taken is not surprising, since the genus especially haunts open arid places. 
Papilio leonidas flew slowly about the Eugcnia, with the manner of a Danaid, but the model, if such there be, was not seen ${ }^{1}$ four specimens were secured.

One might naturally have expected to find many of the preeminently thirsty Blues in the Rain Forest. Accordingly, Zizera lysimon, met with occasionally in all the Zambesi hunting grounds, was really common in the Rain Forest only, probably the other places were too dry for it. But of other Lycaenids single examples only were taken, to wit, Tarucus telicanus, d, Everes cissus, and Catochrysops malathana, the last-named sitting head downwards.

Somewhat unexpectedly we found Skippers commoner within the range of the spray than outside, the following presenting themselves : Parnara mathias, a male and two females; Gegenes letterstedti, three; Parosmodes morantii, Trim., one, a species represented in the National Collection by a single specimen from Mashonaland presented by Mr. G. A. K. Marshall; and one Parnara fatuellus.

It is curious that two Humming-bird Moths of different species were taken close together, and within a minute or two, Macroglossa trochilus, Hübn., and Aellopus commassiac, Walk. It is also curious that no smaller moths were brought from the Rain Forest. On the other hand Diptera were numerous; of these the most striking were trro species of the strange stalk-eyed genus Diopsis; one, near to dubia, Bigot, was to be got in abundance by sweeping in the drier parts of the Forest, the other Mr. G. H. Verrall ${ }^{2}$ thought might be ichneumonea, Linnaeus' long-lost type of the genus. Of another fly, distinguished by its apple-green abdomen, Odontomyia sp., several were obtained by sweeping in moister places. The same method produced other flies, among them a specimen which $\mathrm{Mr}_{1}$. Verrall thought might be a local race of Syrphus baltectus, De Geer, also four Sepedon sp.

A species of Plecia, with a reddish thorax, was flying lazily about the Eugenia trees in large numbers, with its legs trailing behind just as Bibio marci, Linn., does in English woods in April. Then thero was a pretty black and white Tabanus sp.; a pair in cop. of another Plecia; two specimens, a of and a $\%$, of an Asilid that is perhaps Promachus rïppclli, Liv., but may be new, unfortunately it was taken

1 Note by Dr. Dixey : In North-East Rhodesia, on the Chambezi, some 700 milos away, it flics with and appears to mimic Tirumala petiverana, Dbl. \& H. Compare Trimen, "South-African Butterfies," vol. iii., 1889, p. 213. See, however, Papilio.

${ }^{2}$ This genial entomologist died whilo this was in the press; a great loss to science, a great personal loss to all who knew him. 
without prey; a Syrphid, Helophilus sp., near to but not identical with africanus, Verrall; lastly, something extremely like Musca domestica.

As might have been expeeted Dragon-flies were fairly numerous, prominent amongst them the large and handsome Pseudo-macromio, torrida flying in the open swampy spaee between the belt of Ergenia trees and the edge of the chasm; other speeies were Phyllomacromio, trifasciata, Ramb., and (by sweeping) the Demoiselle, Brachybasis rhomboidalis, Beauv., which appears to have a wide distribution in Afriea.

Two Wasps were taken, Eumenes tinctor, Chrst., and Ammophila beniniensis, both females, while sweeping produced an Iehneumon-fly. Ants were represented by a solitary Camponotus sp., of which Colonel C. T. Bingham wrote, "New, but as a single speeimen I cannot venture to deseribe it; allied to C. sericeus, Fabr."

The Orthoptera if not numerous were variously lepresented by a Mantis larva obtained by sweeping; four Cockroaehes of the genus Ischnoptera, sp. nov. (near to bimaculata, Gerst.), found under stones and running very rapidly away when disturbed; Mr. Shelford has been good enough to deseribe this as I. longstaffi. [Plate II., Fig. 11.] Sweeping yielded also many Grasshoppers, one of whieh had its head and thorax eonspieuously marked by two lateral yellow stripes. Prototettix impressus, Stål, was taken on a tree.

When looking for beetles two very aetive little Bugs were found under stones or leaves, another was adorned with a red abdomen. Sweeping as usual yielded sundry Homoptera. The same operation produeed a few Beetles: a Lagria, in the colleetion at South Kensington, but unnamed, of whieh five specimens were obtained; a single Cryptoccphalus callias, Suff.; two of the Phytophagid Lcma chalcoptera, Lae.; six Haltica indigacea, Illig.; two Hispa sp.; also one $H$. bellicosa, Guér., of which the National Collection has specimens from the Gold Coast only. Lastly, three Staphylinids, Osorius rugiceps, Boh., were found under dead wood.

In sueh a spot it was but seemly to find an Amplibian, aecordingly we may note that a toad-like Frog was abundant among the marshy spray-drenched grass between the Rain Forest and the Chasm. Many of them were extremely small, hardly larger than blue-bottles. A large specimon evacuated a mass of elytra, etc., of small beetles, apparently mostly geodephagous but some perhaps phytophagous; this was interesting, in so far as it bore out our experience that the Coleoptera of the Forest were very small.

Three speeies of Land Snails were found in the Rain Forest; two 
turreted forms, Opeas octona, Chem., and the transparent O. mamillata, Craven, both under stones, both gregarious. Sweeping grass yielded the delicate, transparent, horny Succinea (?) badia, Mor., very near to the British S. putris, Linn. A Barotse boy, a servant to Mr. Allen, collected for me a number of the dull-looking Paludina capillata, Frauen., but exactly where he found them is not on record.

\section{INSECTS TAKEN ON THE RAILWAY JOURNEY FROM THE VICTORIA FALLS TO EAST LONDON.}

September 20, 1905.-Matetsi Station, 230 miles from Bulawayo. Precis cebrene, seen. Castalius hintza, Trim., a male. Pseudagrion (?) deckeni, a small Dragon-fly, the colour of dead grass.

Katuna Station. Precis cebrene, one female.

North of DeKa Station. Glyphodes (Dysallacta) negatalis, Walk., a Pyrale of very wide distribution, taken in the train by Mr. D. Gunn.

Deka Station. Danaida chrysippus, a female. Lycacna osiris, Hopff, a male at water. Catochrysops asopus, a male, also at water. Eumenes lepeletieri, Sauss., a female at water; this is a yellow Wasp with a conspicuous black cross on the abdomen.

Wankie Station, 212 miles from Bulawayo, alt. $2450 \mathrm{ft}$. Teracolus antigone, a male.

Lukosi Station, 196 miles from Bulawayo. A Carabid beetle, Anisodactylus nitens, Péring., under a stone.

Inyantue Station, 177 miles from Bulawayo. Sphingomorpha chlorea, Cram., a Quadrifid Noctua that truly deserves its generic name, caught at light in the train by Mr. D. Gunn. It is widely distributed in India and Africa.

S. of Inyantue. A Dipteron, Argyramoeba sp., in the British Museum, unnamed.

Malindi S'ration, 147 miles from Bulawayo. An Ant-lion, Myrmeleon sp., at light in the train.

September 21, 1905.-Bulawayo, lat. $20^{\circ} 9^{\prime}$ S., alt. $4470 \mathrm{ft}$., near the railway station. Acraea doubledayi; also the widely-distributed Lady-bird, Exochomus nigromaculatus, a Bug, and some unnamed Orthoptera, all taken by sweeping.

Plumtree Station, S. Rhodesia, alt. $4560 \mathrm{ft}$., 65 miles S. of Bulawayo. Acraea doubledayi, a female, fluttering close to the ground. Axiocerces harpax, one on the flowers of a yellow Composite.

September 22, 1905.-Tsessebe Station (Tati District), 94 miles 
S. of Bulawayo, alt. $3900 \mathrm{ft}$. The Ant, Camponotus fulvopilosus, running on the ground.

Shoshong Road Station, near the tropic, alt. $3250 \mathrm{ft}$. A number of the Ant, Camponotus maculatus, under the bark of a log.

Artesia Station, Bechuanaland, lat. circa $24^{\circ}$ S., alt. $3100 \mathrm{ft}$. I'cracolus antigonc, a male. Zeritis simplex, Trim., a male. Spindasis clla, Hew. Castalius calicc. Syrichthus (Pyrgus) sataspes, Trim. Gomalia albofasciata, a dwarf. The two Skippers were taken at water, as well as the Wasp Eumenes lepclctieri, o, and the Honeybee Apis mellifica, of the usual S. African form.

Mochudi Station, Bechuanaland, lat. $24^{\circ} 22^{\prime}$ S., alt. $3100 \mathrm{ft}$. Acraea anemosa, a female, drinking at the drip of a tap. Zcritis molomo, Trim., a female. Hesperia spio, Linn. (vindex, Cram.), at the flowers of a small yellow Hibiscus.

Crocodile Pools Station, about lat. $24^{\circ} 40^{\prime}$ S., alt. $3300 \mathrm{ft} . \quad$ A Beetle, Zophosis sp., not in the British Museum Collection, was taken running rapidly over the sand, which when alive it exactly matched in colour.

Ootsi Station, lat. $25^{\circ}$ S., alt. $3620 \mathrm{ft}$. Axiocerces harpax, a female taken, and another seen at a shrub with flowers forming yellow tails. A Bug and a small Lady-bird, Scymnus sp., taken at Combretum flowers.

Pitsani Station, lat. $25^{\circ} 26^{\prime}$ S., alt. $4420 \mathrm{ft}$. Scmiothisa brongusaria, a Boarmiid, came to light in the train. The two Beetles, Lyctus sp. and Bostrychus brunneus, Murray, were taken this day somewhere in British Bechuanaland, but the exact locality was not recorded.

Along the line at frequent intervals we passed the remains of the celebrated block-houses, sometimes elaborately fortified, sometimes decorated with stones, after the manner of small railway stations at home. Of course the Kaffirs had carried off everything of conceivable or inconceivable value, and often nothing was left but a heap of stones and a few old meat-tins. This day we had the pleasure of travelling in the same compartment with Professor A. Penck, of Berlin, and very good company he was. As we passed one of these accumulations of stones and tins, an Englisl geologist called out, "See, Penck, is that a kitchen-midden ?" He promptly replied, "No, that is a Kitchener-midden." It would have been a clever jest for an Englishman.

Mafeiking, lat. $25^{\circ} 56^{\prime}$ S., alt. $4190 \mathrm{ft}$. Single specimens of Sterrha

1 Many blnok bootles cover thomsolves with fine particles of the sand on which thoy dwoll, and so casily escapo observation.-See above, p. 163. 
sacraric, Linn., and Crambus tenuistriga, Hmpsn., and two other moths were taken at lamps in the town. The S. African specimens of the Stcrrha are far less beautiful than European, as they lack the crimson.

September 23, 1905.-W -Wrenton Station, 28¹1' S., alt. $3930 \mathrm{ft}$. Hesperia spio, one at water.

Pokwant, $28^{\circ} 43^{\prime}$ S., alt. $3650 \mathrm{ft}$. The ubiquitous Utethcisa pulchella.

September 24, 1905.-Shanks STATion (E. of Steynsburg Junction), alt. circa $5000 \mathrm{ft}$. A Cricket was found under a stone, and in like situations six beetles, Trigonopus sp., not in the National Collection; the Carabids, Harpalus xanthographus, Wied., and H. subaëneus, Dej.; and the Chrysomelid, Polysticta 24-signata, Thunb., three specimens; as well as a number of the pungent Ant, Acantholepis vestita.

Hannington Station, alt. $5170 \mathrm{ft}$. The same Trigonopus, another Polysticta 24-signata, and Harpalus fusco-acneus, Dej., were found under stones.

Contal Station, a few miles east of Hannington, alt. circa $5200 \mathrm{ft}$. Under an old sleeper, three beetles were taken : the same Trigonopus that had been met with earlier in the day, Harpalus rufocinctus, Chaud. (rufo-marginatus, Boh.), and a Carabid near to Pcrcus, not in the British Museum.

STORMBERG Junction, lat. $31^{\circ} 28^{\prime}$ S., alt. $5300 \mathrm{ft}$. A few hundred yards from the station we saw swarms of a purplish-grey migratory Locust with yellowish-drab wings and yellow hind tibiae, Acridium pardalinum. We had seen several flights shortly before reaching the station, but now we got amongst them. They did not fly very far, and the swarms were many rather than excessively large. The wings of those captured were much frayed, presumably by long flight and knocking against obstacles, though it is possible that individuals with damaged wings were more easily caught than sounder specimens.

Turning over stones was fairly productive, as it yielded Harpalus rufo-cinctus, seven; H. natalensis, Boh., four ; H. clavipes, Boh., two; II. subaëncus, two; $H$. fusco-aëncus, three; two other Carabids not yet named; the red and black Hister crucntus, Erichs., four under one stone; Polyhirma gracilis, Dej., one ; the two Weevils, Rhytirrhinus lituratus, Fåhr., and Stramia (?) führaei, Fst., one ench, as well as an immature female of (?) Blatta oricntalis, and two very large Ants, Acantholepis vestita. A specimen of Pyramcis cardui was taken on the hillside, but the day was scarcely fitted for butterflies. 
Lower Incline Station, circa $4500 \mathrm{ft}$. Five or six specimons of Polysticta 24-signata were found close together under a stone.

Queenstown, Cape Colony, lat. $31^{\circ} 50^{\prime}$ S., alt. $3500 \mathrm{ft}$. In the Public Gardens just before dark a large (?) Plusia, or small (?) Sphins, was seen at Verbena flowers, but missed. Shortly after leaving the station two of the widely distributed Crambid, Eromene ocellea, Haw., flew to the lights of the train.

\section{EAst London, lat. $33^{\circ} \mathrm{S}$. Sea-level.}

SECOND VISIT. September 25th-29th.

Six weeks had elapsed since our first flying visit to this place. After an unusual drought it had rained the day before our arrival, and it was blowing a violent gale when early in the morning we came to the end of our long railway journey of six days and six nights. The gale terminated with heavy rain that greatly damaged the condition of the butterflies. One victim of the flood, a female Saturniid, Arina forda, Westw., was rescued from drowning.

A good deal of our time was spent on our old ground in the Queen's Park. The Poinsettia flowers were over: energetic sanitary reformers had nearly completed the covering in of the unsavoury stream, but the operations of the Kaffir workmen had wrought sad havoc in some of the best collecting ground.

Mylothris agathina did not appear to be nearly so common as before, but perhaps this was owing to the absence of Poinsettia flowers to assemble them. There was, however, no doubt that the closely allied $M$. rïppellii was common enough. The males of both these species have a strong and seemingly identical sweetbriarlike scent. The very local and singularly elegant $M$. trimenia was quite common, both sexes being well represented. Its fore-mings are white, its hind-wings a beautiful yellow. I compared its scent to that of clover.

Belenois severina and $B$. zochalia were both very common; of the latter the females seemed to be more numerous than the males, but perhaps this was because they are more distinctly coloured.

The beautiful Eronia clcodora was quite common. A few Pinacopteryx charina were taken, all "dry"; a male Byblia goctzius, significantly a very fresh specimen, was distinctly of the "wet" form, but, with this possible exception, there was no evidence that the recent rains had produced any change of type, probably there had not been sufficient time. The only Tcracoli noticed in the Park were 
a male achinc and several omphalc of both sexes. These Teracoli, with one exception that was intermediate, were decidedly "dry," but not so extremely "dry" as our Rhodesian specimens." Colias electra was seen but not taken.

Of Papilio nireus, f. lyacus, we secured two males, but we met with both sexes of $P$. demodocus. Of $P$. dardanus, perhaps the commonest of the three Papilios, two males and one female were taken, the latter of the form cenea, which mimics Amauris ccheria. Of the last-named species four specimens were taken, also three of the closely allied $A$. albimaculata; the latter at any rate has a strong disagreeable odour like musty straw; both forms are very hard to kill. Danaida chrysippus was fairly common.

Lycaenids were not so numerous as might have been expected in the Park, either as regards species or individuals. Of Zizera lysimon and Cacyreus palemon single specimens were taken; females of Argiolaus silas were fairly common, they flew high and settled on the tops of trees, but also visited flowers. A few of the widcly ranging Tarucus telicanus were to be seen, two of them whilst at rest were observed to move the hind-wings alternately backwards and forwards in their own planc.

On the occasion of our former visit we saw no Satyrids, but this time two specimens of Pseudonympha cassius turned up, as well as two females and a male of Mycalesis safitza.

With the exception of Charaxes varanes, which was fairly common, though worn, the Nymphalines were not very prominent. Eurytela hiarbas was less plentiful and in less good condition than on our first visit; of Byblia goetzius only a single male was seen, while a Precis archcsia was taken scttled on the ground. Several fine Pyrameis cardui were observed.

Among the flowers introduced into the garden portion of the Park, and tending to run wild, was the Pride of Madeira, Echium fastuosum, a rcmarkable plant of the Natural Order Boraginaceac, whose small flowers form solid spikes, oftcn 6 fcet high or more, the apparently simple spikes being made up of innumcrable, densely packed, scorpioidal cymes. The flowers, which havc prominent stamens, may be blue, or creamy white, thosc in the Queen's Park being all of the latter variety. This plant proved very attractive to insects of several orders; among the numerous butterflies that fed upon the flowers was a singlc example of the pretty Vanessid, Hypanartia hippomenc, Hübn. The following insects were also taken on the spikes:-Apis adansoni, as was only to bc expected; the very

' Soo Dixey, Proc. Ent. Soc. Lond., 1905, pp. 1xi., lxvi. 
small Bee Prosopis sandaracata, Bingh., with black and yellow thorax and red abdomen, was abundant, as was also the prettily marked P. 5-lincata, Cameron; but of Prosopis simples, Bingh., sp. nov., unfortunately only a uniquc example was secured; ${ }^{1}$ there was also a Sawfly, Athalia himantopus, a female.

In addition there were on the same flowers a Fly of the genus Catabomba, three of the genus Idia, and another fly; the latter was found to be held in the clutches of a green Spider with red-brown markings, which, owing to its coloration, was practicably invisible among the crowded flowers, and would never have been detected but for its prey. But this does not exhaust the list, which includes the small Longicorn Syessita vestigialis, Pascoe, and a number of small Cetoniids. The most abundant of these was the little Oxythyrea marginalis; I noticed at the time that this beetle was rendered strangely inconspicuous by the creamy white specks on thorax and elytra breaking up the dark ground-colour and simulating the general look of the anthers of the flower. Another small Cetouiid, Stringophorus flavipennis, Gory \& P., occurred on the same flowers and its elytra bear similar spots. Together with these were two specimens of a third and still smaller Cetoniid, Comythoralgus fasciculatus, Schönh., which were quite difficult to distinguish, but in this species the means of concealment are different, for the thorax and elytra bear numerous conical, horny projections, while there are two conical tufts of scales near the apex of the abdomen. ${ }^{2}$

Two specimens of Gegenes lcttcrstedti were the only Hesperids noted; this species settles with the fore-wings raised, the hind-rings nearly horizontal, like several of our English Skippers.

The following Moths were taken, but doubtless the list might easily have been lengthened, especially if we had workcd at night; Macroglossa trochilus, at flowers in the late afternoon; Syntomis kuhlweini, Lefebre; the day-flying Lymantriids Laclia punctulata, Butl., and Aroa discalis, Walk., males of the latter specics being very common on the outskirts of the Park; the Geometers Zcronopsis leopardina, Fcld., fluttering near the ground; Craspcdia intcrnata, Guen. (strigulifcra, Walk.), and the variable Scmiothisa brongusaria; we also kicked up a Pyrale, Pyrausta incoloralis, Gucn., and two spccimens of the Boarmiid Obolcola inconclusaria, Walk., one of cach sex.

$\Lambda$ s usual the most obvious represcntatives of the Hymenoptera were the handsome Carpenter-becs, Xylocopa caffra, $q$; $X$. fratcrna,

1 Sco footnote, p. 182, supra.

= Soo Longstaf, Trans. Ent. Soc. Lond., 1906, pp. 91-93. 
Vachal, a male said by Colonel Bingham to be not typical ; X.divisa,, ; and $X$. flavo-rufa, De Geer, four females; the last two species were practically confined to the purple flowers of a Leguminous shrub; flaro-rufa has a strong odour like that of our English Bumble-bees. Other Aculeates taken were the long-pedunculated Wasps Belonogaster praunsi (said by Colonel C. T. Bingham to be not typical); the slender dark-blue-winged Enuncnes tinctor, of both sexes, one male specimen, of Saussure's variety, very starved examples; the dull grey Icaria cincta, ఫ̛; Pompilus ruficeps, Smith, a female; a male Pompilus which is possibly new; Polistes marginalis, Fabr., ఫ̧; Larra agilis, Smith, a female, taken on a bank of dry earth; a Mason-bee, Chalicodoma coelocera, male, taken at the purple flowers along with the Xylocopae. To these must be added Ants from a community of Camponotus maculatus, and a fine specimen of the common coral-red Braconid Iphiaulax whitci.

The handsome Eristalis taeniops was conspicuous among the Flies, which were not very numerously represented; another fly to which Colonel Yerbury has been able to assign a name is Chaetolyga dasyops, Wied. Other flies were (?) Syrphus sp., Idia sp., and two Bibio-like Plecia sp., which floated in the air almost stationary with their long legs hanging down; sweeping yielded a Diopsis, a solitary example which Mr. Verrall thought distinct from the others that we brought home.

The wide-ranging Grasshopper Catantops melanostictus was abundant. On the leaves of Pride of Madeira were marshalled a number of immature specimens of a gregarious dark orange-striped Acridian, the same species that was seen at Bulawayo.

Although Beetles were not numerous in the Park, we took, in addition to the Cetoniids previously mentioned, some interesting species: Macroma cognata, a handsome dark olive and yellow Cetoniil, flying at flowers; Gametis balteata, De Geer, another of the same group, also a conspicuous species though much smaller than the last. This beetle is black and red, or perhaps orange-brown more correctly describes its decoration. On the Second Creek of the Buffalo River, there grows a profusion of a climbing Composite with greenish-white flowers (? Senecio sp.), a plant nevertheless in general habit and appearance very suggestive of Clematis vitalba, Linn. On one of these plants I took a number of specimens of two species of Haplolycus, which are represented in the National Collection but as yet unnamed. These Malacodorms have the usual Lycus coloration, viz. orange-brown with the apical two-fifths of the elytra black, and a black stripe down the middle of the thorax. On the same day, on 
another bush of the same climbing Composite growing a hundred yards higher up the stream, I took an example of Gametis bulteatu, and was at once struck by the striking resemblance of the two insects. I may remind any entomologists who may not be familiar with living specimens of beetles of the Lycus group, that during life the orange-brown colour is much redder than might be supposed from cabinet specimens, whereas the Cetoniid preserves its colour well. The very next day Dr. Dixey saw both these beetles in some numbers (3 Haplolycus and 8 Gametis) in the Queen's Park on and about a flowering tree and noted their similarity. With them were two specimens of a Lycoid-coloured Braconid (Zombrus sp.). The Gametis resembles the Haplolycus the other way on, the head of the one being coloured like the tail of the other, but probably that fact does not detract from any benefit that it may derive from the likeness. Mr. G. A. K. Marshall has proved experimentally that Lycid beetles are very distasteful to Kestrels and Baboons. Gametis balteata may now be added to the wonderful synaposematic Lycoid group figured in Mr. Marshall's valuable paper. ${ }^{1}$

Other beetles taken in the Park were the Longicorns, Promeces iris, Pascoe, and Alphitopola maculosa, Pascoe, var., by beating; Trigonopus marginatus, Wied., several under stones; also under a stone the Staphylinid Xantholinus hottentotus, Sachse; a Phytophagid not in the National Collection, Atechna inenaerabilis, Vogel, var.; Apoderus nigripennis, Fabr. ; the metallic groen Colasposoma flavipcs, Har.; the Cassid Aspidomorpha silacea, Boh. (tecta, var., Boh.); and a Weevil, Balaninus apicalis, Fåhr., var. B., which was obtained by beating.

Two Bugs complete the list of insects taken in the Queen's Park: a black Pentatomid with red-tipped antennae, Aspongopus lividus, Dist., and a large Coreid, Carlisis wahlbergi, Stål, dark brown with red-ringed antennae, a very striking thing on the wing, very stinking in the net.

I may remark that throughout South Africa large Millipedes (Julus) are very common. Many of these are of a foxy-brown colour; a black one with red-brown legs found under a stone in the Queen's Park measured $5 \frac{1}{2}$ inches in length.

On September 27 th, by the kindness of Mr. John Wood, who was accompanied by Mr. Rattray, wo spent a very pleasant afternoon on the NAHOON Piver, a few miles to the north-east of the town.

1 Trans. Ent. Soc. THond., 1902, pp. 340, 344, 380, 515-518, and Plate XVIII. "A synaposematic group" is a group exhibiling the samo "warning colours,"-Müllerian Mimicry. 
We were somewhat late in the day and a strong wind was another adverse condition, so that we got very few butterflies.

On the island where we lunched, Belenois severina was abundant and Mylothris riuppellii, the only representative of the genus, was common; Pinacopteryx charina, Eronia cleodora, and Atella phalantha also occurred. A Geometer, Ectropis spoliataria, Walk., a small Noctua, Ozarba (Erastria) corniculans, Wallgr., and a very handsome Agaristid, Xanthospilopteryx africana, Butl., taken off a tree-trunk, completed the Lepidoptera on the island. Sumning itself on another tree-trunk close by was a brilliant green Hymenopteron, Ampulex mutilloides, Kohl, o. Mr. Rattray caught a specimen of the scarlet Braconid, Iphiaulax whitei, which appears to be very common in South Africa.

Mr. Wood set a stalwart Kaffir to work with an axe to hack dead trees to pieces. This did not prove a very productive operation; moreover of the creatures found but a small proportion have yet been named. Among the beetles were single specimens of the Longicorn, Promecidus chalybeatus, White; the Sternoxid Alaus moerens, Germ., and a species of Notiophygus. Blattae were numerous, Mr. Shelford has named for us Hyposphaeria stylifera, Burm., immature; Bantuce (?) brunneriana, Costa, several ; also Pseudo-deropeltis albilatera, Stål, two specimens, and $P$. wahlbergi, Stål, a male. Bugs were represented by a singularly flat form, well adapted to its life under bark. It goes without saying that Woodlice were plentiful.

Taking a boat the Kaffir pulled us a mile or two down the river and we landed on the eastern bank, where rich flowery meadows promised great things, but the rising of the wind and the lateness of the hour led to disappointment. A single Teracolus achine, of, a Boarmiid moth, Osteodes turbulenta, and a Pyrale, Antigastra morysalis were the only Lepidoptera that we brought away from a spot which under more favourable conditions should swarm with them. Beetles are somewhat less susceptible, and we took on flowers the gem-like Cetoniid Oxythyrea haemorrhoidalis, Fabr. (which surely deserves a better name) together with the commoner 0 . marginalis, also the Longicorn Hylomela sexpunctata, which closely mimics a species of Mylabris (or? Ceroctis) that we met with in South Rhodesia. The Acridian Cyrtacanthacaris ruficornis, Fabr., of which two were takcn, is remarkably coloured: brown, with a paler stripe down the back, the blue tibiae are furnished with conspicuous white spines tipped with reddish.

Sweeping added to the list the Lady-birds Atcchna hebc, Clk. and Cryptocephalus flavago, Suff., the Weevil Ellimcnistes squamifcr, 
Boh.; also the Phytophaga, Ootheca laevipennis, Jac., Gynundroptethalma malvernensis, Jac., var., and Lupcrus inconspicuus, Jac., as well as a rather pretty Bug Veterna sanguincirostris, Thunb., the cornmon Grasshopper Catantops mclanostictus, and the Tettigid Prototettiss impressus.

We took two pedunculated Wasps, Belonogaster praunsi, and Ammophila ferrugineipes, a male; also an Ichneumon-fly, and a number of Ants, Cremastogaster sordidula, var., and Pheidole irrituns, of which last the soldiers alone have big red heads.

Turning over stones yielded the Beetles Trigonopus marginatus, and Lissogcnius conspersus, Burm., as well as the common South African Reduviid Physorrhynchus crux, and two Scorpions.

A specimen of the Scarab Syrichthus spurius, Burm., was picked off the ground, while Mr. Rattray found a specimen of the large thick-legged Coreid bug Rhyticoris terminalis, Burm., also a large Weevil with very hard integuments, Mecorrhynchus loripes, Schönh., and two Millipedes whose integuments turned the point of No. 16 pins. Mr. Wood found lying dead on the left bank of the Nahoon a Carabid beetle, Haplotrachelus sp., which is not in the National Collection.

The Kaffir boatman caught several of a Psammodes unrepresented at South Kensington, they were crawling over the rocks by the lower landing-place, nearly opposite the Boat Club House.

A few Snails were picked up, viz. a young specimen of Pachnodus natalensis, Krauss; a variety of the Helix-like Tropidophorc insulare, Pfr., and a number of the very long, finely sculptured spires of Coeliaxis layardi, Ad. \& Aug.

Lastly, on the west bank whon it was quite evcning a Hesperid was netted, Sarangcsa motozi.

An old termitarium on the ligh ground above the Club House yielded, besides sundry ants (Crcmastogastor weitzechcri, Emcry), a Night Adder, a small serpent said to be very poisonous.

Since our return to England, wc have been much concerned at hearing of a disastrous flood at East London, which seems to hare devastated the island in the River Nahoon wherc some of our collecting was done, and to have cansed the death by drowning of scveral natives, including our Kaffir boatman and his family. Much damagc has been done on the banks of the Nahoon and Buffalo rivers, and part even of the Queen's Park is reported to have been washcd away.

Acting on the advice of Messrs. Wood and Rattray, we spent the next day, September 28th, on the SECOND CrEkK of the Buffalo 
River, a delightful locality. It is approached by a pleasant walk over open downs where we met our old friends Synchlö̈ helliea, Colias cleetra, and Teraeolus omphale; after a mile or so the path enters a wood, and descends rapidly to a brawling stream, which follows an impetuous course to a fall into a tidal pool, beyond which is a flowery meadow forming the delta of the ereek. The wider tracks through the upper part of the wood had a home-like feeling, and we almost expeeted to see Pearl-bordered Fritillaries disporting themselves about the flowers, but instead of these we found in moist plaees the pretty Satyrid, Pseudonympha eassius. These butterflies were of less "dry" form than most that we had met with, the majority of them might be better deseribed as intermediate. The more generally distributed and homely Myealesis safitza. was also common; a female exhibited a supplementary ocellus on the fore-wing.

The commonest White was Pincueopteryx eharina, but Eronia cleodora, Belcnois zoehalia and Mylothris agathina were all present in some numbers, and one M. trimenia was taken. Teraeolus omphale and $T$. achine occurred in the more open places.

The Acraeinae were conspicuous by their absenec, but the Danainae were represented by Amauris eehericu and albimaeulata, as well as by Danaida chrysippus.

The only Nymphalines taken were Byblia goetzius, Atclla phalantha, and a solitary Precis archesia, a species which aecording to $\mathrm{Mr}$. Brooking of East London frequents dark holes in roeks.

Lycaenids were not common, a solitary Tarucus tclieanus, and a couple each of Axioeerces harpax and Phasis chrysaor, Trim., one settled head downwards, were taken.

We took four Hesperids, viz. one each of Hesperic spio, Eretis djaelaelae, Gegenes letterstedti, and Pterygospidea flesus. The lastnamed after dashing about wildly settled on the upper side of a leaf.

But ferw moths were seen, and two specimens of Osteodes turbulenta, and the Syntomid mentioned below were all that we eaught.

The greenish-white flowers of a elimbing Composite (? Scneeio sp.) that spread in dense mats over some of the bushes by the stream were very attraetive to insects of more than one order. Two Aculeates, Xylocopa divisa, $q$, and Eumenes tinctor, + , two, one of them a starved dwarf; the moth Syntomis leuhlweini (one found to be in the tender embraees of a spider); the Fly Eristalis taeniops, the Reduviid bug Harpactor erythroencmis, Germ.; two Lycoid beetles, Acuntholycus sp. and Haplolycus sp. (the latter numerous), and their nimic the Cetoniid Gametis balteata (referied to above) were all 
taken off this plant, together with a Mantis that was presumably attracted by the insects rather than the flowers.

Dr. Dixey found on a tree another small Mantis, bright leaf-green in colour, which he kept alive for over a week. It was seen to catch a fly by a motion of lightning-like quickness and eat it, rejecting the wings and abdomen. When approached it would smartly assume the "praying" attitude, sometimes also turning its head in the direction of the visitor. It used to clean its eyes by passing its forelegs over them, with an action like that of a cat cleaning its face. It also cleaned its antennae in its mouth, bringing them down by its fore-legs.

A soft-skinned Cantharid, Decatoma lunata, Pallas, looked conspicuous enough on a pale straw-yellow liliaceous flower.

It was at the Second Creek that the finding of two species of Heterochelus, allied to vulpinus, Burm., buried in yellow Composite flowers, first drew my attention to the little Lamellicorn beetles of the sub-family Hopliinae. They are numerous in Cape Colony, and we came across no less than thirteen species. The most obvious characteristic of the group is the great length of their posterior legs. The development of these varies greatly in different species, but as a general rule is much greater in the males than in the females; indeed in some species the male femora and tibiae are grotesquely disproportioned to the animals; moreover both femora and tibiae are provided on their inner sides with strong spurs or spines (perbaps better described as teeth). These strange limbs evidently attracted the attention of the older writers, since Fabricius named one species dentipes, and Burmeister another forcipatus. The explanation of these hypertrophied legs that is usually received is that they are used by the males to grasp the females. Mr. Trimen, accepting this explanation, tells me that he thinks copulation is attended with especial difficulty in these beetles.

The latest writer on the subject, Mr. Péringuey, rejects the ordinary explanation in the following words:-

"The great development of the hind-legs is not intended for sccuring a better hold of the female. Therc is nothing morc ridiculous than to sce half a dozen males with their long hind-legs emcrging from the pistils of a Compositc flower whcre they are mobbing a fcmale which is almost entirely buried head foremost in the pistils, the sub-horizontal pygidium alone being exposed to view. But it is when discntangling themsclves that the use of the long hind-legs becomcs apparcnt; by mcans of his long, hinged claw the male hooks himsclf out 'of the corolla. It is not only amongst the flower- 
frequenting kinds that this extraordinary development of the hindlegs with their curiously serrate, dentate and mucronate tibiae is met with, because the species of Hoplocnemis, in whieh the development has beeome almost a monstrosity, do not feed on flowers, or at least have not been observed doing so. The habits seem to be more those of certain Dynastinae, and I suspeet them to live, while in the larval state, in the exerement deposits of the subterranean white ant, Hodotermes viator, Latr." 1

Mr. Péringuey, I am bound to say, fails to convince me, and I venture upon yet another explanation.

Many of the species of Dichelus and Heterochelus burrow into the disks of Composite flowers, eating out the ovaries. When so engaged

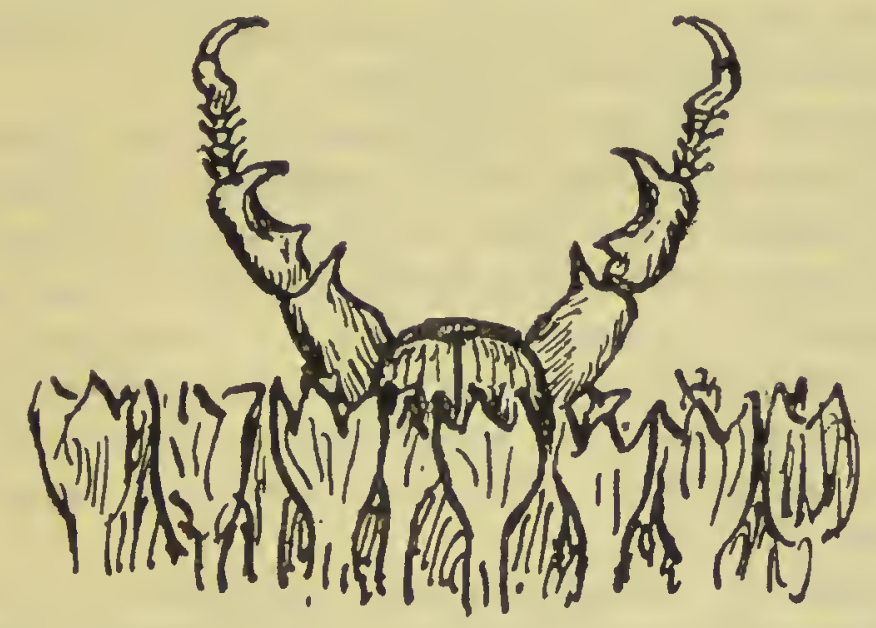

FIG. 8.-Diagram of posterior legs of Heterochelus, $\delta$ ( $\times 5$ diam.).

The body of the beetle is buried in the florets of a Composite flower.

the whole of the body of the insect may disappear from view, or the extremity of the abdomen may alone protrude, but in either casc the hind-legs extend beyond the florcts, widcly scparated and closely resembling the open jaws of an ant-lion. Whilc pieking onc out of a flower I was startled by receiving a very respcctable pinch, or bitc, inflieted by the formidable teeth mentioned above.

Now the suggestion that I have to offer is this: while probably in the first instance adapted to assist the male insect in grasping its mate, thcse huge hind-legs are now of grcat advantage to the otherwise helpless beetle when burrowing into flowers in search of food. The wiclcly gaping "jaws" may probably terrify some encmies, but thcy

1 Transactions of the South African Philosophical Society, vol. xii., pp. 625, 626. "Descriptive Catalogue of the Coleoptera of South Africa. Hopliinac." 1902. By L. Péringuey, F.E.S. 
eertainly afford by no means despieable weapons of defence against such foes as may presume to eome to elose quarters.

This suggestion meets with support from the faet that Lepitriss lineata, Fabr., a pretty speeies that I found abundant on the flowers of Mesembryanthemum at Simon's Town, has long thin hindlegs not provided with teeth, but, unlike Heteroehelus and Dichelus, this insect is very active, taking to its wings almost as readily as a bee. Dr. Dixey did not notice this beetle on Mesembryanthemum, but not far off found five speeimens inside the spathes of the Cape Lily, or eommon white Arum, Calla aethiopica (Riehardia africana), three in one spathe and two in another. He says that they did not attempt to fly. Possibly the faet that they were to some extent enelosed in the arum, whereas those on Mesembryanthemum were quite exposed, making no attempt to burrow like Heterochelus, may explain this notable difference of habit.

Mr. Trimen in the introduetory ehapter of his "South African Butterflies," after remarking on the poverty of the Rhopalocera of the Cape Peninsula as eompared with the richness of its Flora, and stating that in that part of the world butterfies eannot perform a very promineut part in the fertilization of flowers, goes on to say: "The great number of densely-hairy flower-frequenting Coleoptera in South Afriea must also play a large part in plant fertilization." 1 The beetles referred to are chiefly Lamellicornia of the sub-families Cetoniinae and Hopliinae.

The meadows by the estuary yielded a different lot of things, especially Phytophaga and Weevils. Thus Malacosoma polita, Jac., was abundant in the flowers of an Iris, while sweeping yielded Ootheea laevipennis, Cryptoeephalus polyhistor, Suff., Trochalus sp., two, and the Cetoniid Oxythyrea hacmorrhoidalis, as well as the following small Weevils :-Eremnus gyrosicollis, Boh., Sciobius o'nciti, MIrshll., \%, S. pullus, Strophosomus sp., and two new species which Mír. G. A. K. Marshall has deseribed ${ }^{2}$ under the names Ellimenistes eallosicollis, sp. nov., and Myorrhinus longstaffi, sp. nov. [see Plate II., Figs. 1, 3]. Both these insects are blaek: the first (of whieh I obtained four examples) covered with brownish grey seales, Mr. Marshall says, is somewhat intermediate between E. pulvinaticollis, Boh., and F. bidentatus, Boh.; the seeond, which was to be had in abundanee, is a much smaller iuseet, eovered with liglıt-green scaling, and is said by Mr. Marshall to be nearly allied to Mr. setarius, Fåhr., but witl mueh more obvious setne. With the beetles in the sweeping

I Op. cit., vol. i., p. 42, note.

2 MIarshall, Proc. Zool. Soc. Lond., 1906, pp. 922 and 932. 
net were two Bugs, a black, yellow-spotted Stenozygum that is possibly new, and the large pale ochreous, fetid Pentatomid, Busicryptus distinctus, Sign.

Other beetles taken in the same locality were the Lady-birds Chilomenes lunata, and Polysticta macularis, Dej.; Melyris ciliatus, Oliv.; the Halticid, Physodactyla africana, Chap.; a Trochalus apparently undescribed; a Telephorus; a Lagria; and a Scarabaeid, Syrichthus spurius, Burm., the last found in rotten wood.

Among Orthoptera were the big Phymateus leprosus, the common Catantops melanostictus, Prototettix impressus, the handsome Acridium meficornc, and two unnamed Grasshoppers, one grass-green, the other a curiously soft species, black with scarlet rings and spots.

The only Flies taken were two Bombyliids of the genus Systoechus, one at flowers, the other by sweeping.

A few Aculeates complete the list, viz.: Xylocopa flavo-rufa, a male; $X$. divisa, a female; the prettily variegated Polistes fastidiosus, a female; the grey Icaria cincta, a worker; two small black Bees, Halictus deceptus, Smith, females; lastly a fine distinct red, yellow and black wasp, which the late Colonel C. T. Bingham described as Odynerus longstaffi, sp. nov., from a specimen in the National Collection from Natal, hitherto unnamed, making our specimen a co-type. [Plate II., Fig. 6; see footnote p. 182, supra.] Lastly an example of the blue-green Chrysid Hexachrysis simillimus, Grib., was taken settled on a bare rock, gleaming like a piece of copper-glance.

On our return walk we kicked up a Noctua in the wood, and as we reached its upper edge at about 3 p.m., we found Termites on the wing in swarms; five specimens were brought home alive in separate pill-boxes, but on reaching the hotel it was found that one had cast off a wing, another all four wings. Later in the afternoon Syntomis lahlwocini was found in some numbers flying about, or settled upon a particular species of tree. The large Reduviid bug Physorrhynchus crux was also taken on the wing.

On the morning of sailing, September 29th, I paid a somewhat hurried visit to the scrub-crowned sandhills seen from the ship that August morning when we first anchored at East London, but this expedition did not add much to our list.

Two Ants turned up, Camponotus cosmicus, also taken at Estcourt, and Polyrhachis gagates, Smith, of which but a single specimen was met with in this land of ants; there were also the following Aculeates: Polistes maryinalis, worker, Bclonogaster gucrini, var. dubius, worker (a very large specimen), liumencs tinctor, female, Icaria cincta, worker, the big Carpenter-bee Xylocoysa flavo-rufa, male, and 
two of the pretty little Bees Prosopis 5-lineata, taken at a red flowering shrub. The only other Hymenopteron was an Ichneumonfly with Lyeoid eolouring.

A Fly that seemed to mimie a peduneulated Wasp Colonel Yerbury says may be the male of Baccha picta, Wied., of whieh that author described the female only from the Congo and Guinea. Another fly taken would appear to be Sarcophaga carnaria.

Beetles proved less numerous than might have been expected: two Tiger-beetles, the first we had seen in South Africa, Cicindela candida, Dej., and C. capensis, Fabr., were eommon close to the sea on the bare sand, which they so closely resembled in colour as to be seareely visible save when on the wing. Also running on the sand was a nameless Zophosis and an equally nameless Anoplochilus. The flowers of a species of Iris produced Camptolenes fastuos $\alpha$, Lac., besides abundanee of Malacosoma polita.

Lissogenius conspersus was taken flying in the sun, as was also Scarabaeus convexus, Hausm., and the Cassid Aspidomorpha tecta, Boh., the latter looking like a golden spangle floating in a sunbeam. The Hopliine Khoina bilateralis, Thunb., was found on flowers, and Eurynotus muricatus, Kirby, under bark.

The Coreid Serinetha amista, Germ., seems to mimic a Lycus. Another bug taken was the Reduviid Harpactor segmcntarius, Germ.

Orthoptera were rather common, eonspicuous among them was a very fine speeimen of the large, heavy and sluggish Phymatcus (?) leprosus, more glaueous than those taken at Ladysmith, so that they match more elosely the light-coloured sand. Mr. Kirby thinks that it may possibly be a new species [Plate II., Fig. 7]. The beautifu? apple-green Tryxalis stali, darker above, paler beneath as is so often the ease, was found at the verge of vegetation, while an abundant Grasshopper found on the bare sand was highly cryptie. A curiously formed small Hemerobiid Neuropteron, Mantispa (?) tcnclla, Erichs., was taken on the wing; seen for the first time its resemblanee to a Mantis was startling.

Perhaps the locality was too mueh exposed for butterflies, at all events they were neither numerous nor remarkable:-Amauris albimaculata, a female ; Eurytela hiarbas, within 100 yards of the sea ; Byblia goetzius, a female, "dry"; Pscudonympha cassius; Argiolaus silas, a female; Mylothris riippcllii, a female; Pinacoptcryx charina; Colias clcctra; Tcracolus omphalc, a female, and the Skipper Erctis djaclaclac. A Geometer, Obolcola inconclusaria, a male, and the Lymantriid Aroa discalis, whieh was eommon flying about the serub, were the only moths. 
The lights at the hotel yielded only Dorylus helvolus, all males, the very widely distributed Acidaliid Idaea fibulata, and one or two other moths not yet named.

The cosmopolitan Dermestes vulpinus shared the hotel accommodation with us, while Cimex lectularius, Linn., was even more intimate.

Thus ended our delightful collecting at East London, a place less known entomologically than many others in South Africa.

\section{Port Elizabeth, Cape Colony, lat. $34^{\circ} \mathrm{S}$.}

SECOND VISIT. September 30th, 1905.

The stoppage on the return voyage gave us a long morning's collecting; but an accident separated us, so that while I visited Humewoon, about a mile and a half to the south-east, Dr. Dixey spent his time, more profitably as it turned out, on the more sheltered slopes of the left bank of Baaken's River, just north of Fort Frederick. At this spot butterflies were plentiful. The males of Colias electra were common, as were both sexes of Synchloë hellica, while Pyrameis eardui was in abundance, some worn, but many in fine condition. The Skipper Cyclopides metis, Linn., was fairly common, but only two were taken, together with one Gegenes letterstedti, a female; but out of many Lycaenids seen flying about only a single specimen of Zizera lysimon was secured. This Blue was found by us over a wide range of country, but nowhere in any numbers except in the Rain Forest at Victoria Falls.

A yellowish-brown Grasshopper, Epacromia thalassina, Fabr., with head, thorax and jumping legs green, was also taken.

On the north wall of the Fort itself, or on the ground close by, considerable numbers of the red and brown Bug Scantius forsteri, Fabr., were found, for the most part paired. Many of them exuded a drop of clear liquid when pinned, and in one or two a slight, somewhat offensive odour was detected.

The swampy heath-like waste beyond Humewood and the woods at the back of it proved very barren of insect life, partly perhaps from the uniformity of the vegetation, partly from exposure to the sea-winds. A fow Synchlö hellica of both sexes and three or four Pyrameis eardui were the only butterflies seen.

Stone-turning yielded a small Beetle which Mr. L. Péringuey believes to be a new species of Anaulacus, but possibly a Mierous; four Linunnolus muricatus, also another species of the same genus 
that may be new ; one larva of Luciola sp.; the Cockroach Deropeltis erythrocephala, as is so common with the group, was very local and markedly gregarious.

Two Snakes found under a log warned me to be discreet in prying into secluded dwelling-places. I was fairly accustomed to Scorpions.

Five specimens of an undetermined beetle were found on Cornposite flowers. Sweeping produced a red-winged Homopteron. Two Dragon-flies, Sympetrum sanguineum, Müll., a common species, and the large and beautifully coloured Anax mauricanus, Ramb., were neither of them easy to catch. A common-looking Greenbottle, Lucilia sp., was taken, but the species, or others like it, was abundant throughout our journey.

The flowers of a yellow Chrysanthemum in the garden of the Humewood Hotel attracted a certain number of insects: Apis adansoni; the active green Longicorn Promeces linearis; and the Hopliine Dicranocnemus squamosus, Burm., the last-named in abundance buried in the flowers (and in other Compositae); but it was noted that their hind-legs did not mimic jaws.

\section{CAPE Town, lat. $34^{\circ} \mathrm{S}$.}

\section{SECOND VISIT. October 2nd and 3rd.}

The first day was devoted by the author to the ascent of Table Mountain by way of The Gorge.

Most of the collecting was along the road at about $1200 \mathrm{ft}$. above the sea. Butterflies were scarce; a few specimens of Pyrameis cardui, Psendonympha vigilans, Trim., and the Lycaenid Cacyreus palemon, were all that I saw.

The fine black and white Carabid, Anthia 10-guttata, Fabr., was not uncommon running on the path; when handled it emitted a very pungent odour; one specimen of this beetle was taken in a pinc wood just above the outskirts of the town. It was noted that this beetle was not so swift in its movements as the Biskra species $A$. sex-maculata, Fabr.; probably the struggle for existence is not so severe on the Cape Peninsula as on the Sahara. Under stones five specimens of Microlestia tabida were taken. But the greatest numbers of beetles were found on, or actually in. Composite fowers, especially those of a species of Scnecio. The most abundant species was the Hopliine IIetcrochclus forcipatus, a species in which the posterior legs are enormously developed in the male sex; no females were seen. With these were a fer $(3 \delta, 1$ \%) of the allied Dichclus dentipes, of which also the males have large postcrior legs. There were also a 
number of Encyophancs sp. (unnamed in Brit. Mus.) of both sexes. All these were buried in the disks of the flower with only the hindlegs protruding. ${ }^{1}$ A specimen of the hairy Hopliine Anisonyx lynx, Fabr., was taken in another Composite flower, Gazania sp.

By shaking the flowers of a Senccio into the net the following were obtained: Ootheca tricolor, Fabr., two; (?) Hedybius sp., six; a very small Weevil, an Erirrhinid of uncertain genus, one; Oosomus sp., seven; several Telephori, and a Cricket.

At the flowers of a yellow leguminous shrub two workers of Apis adansoni were taken, together with three Bees of the genus Megaehile, all males, all distinct species, and all apparently new! However, Colonel C. T. Bingham said that it was useless in that genus to describe males without females. It was noted with surprise that the beautiful strong-scented, golden-yellow blossoms of the Protea, an endemic shrub highly characteristic of the Cape Peninsula, attracted nothing but a few flies. At about $1400 \mathrm{ft}$. Bombylius lateralis, Fabr., was met with, and the Satyrid Pscudonympha vigilans up to $1500 \mathrm{ft}$.

The summit, $3600 \mathrm{ft}$., was in dense cloud, for the "table-cloth" was spread, and the only insects taken at that altitude were hairy Hopliines; two Anisonyx lynx, and one A. ursus, Fabr.; two were on flowers, one on the wing.

Turning over stones at the foot of the Lion Hill, circa $300 \mathrm{ft}$., yielded two Ants, Acantholepis capensis; the Beetle Oncotus tardus, Sol. ; a larva of Luciola sp., and the Cockroach Temnoptcryx phalcrata, Sauss.

The next day we took train to Simon's Town, which lies about fifteen miles to the south of Cape Town. Here our collecting was confined to a strip of sandy ground with eastern aspect, close to the shore and at the foot of the line of hills, perhaps $3000 \mathrm{ft}$. in height, capped with sandstone crags, which overlook Simon's Bay.

As we came out of the station a large blue-black Carpenter-bee, Xylocopa eapensis, Lepel., dashed at Dr. Dixey's head; forthwith I made violent efforts to catch the bee, and for some time the bewildered entoinologist was in considerable peril betwoen the swoops of the net and the assaults of the Aculeate.

The Heteromerous beetle, Opatrum (?) arcnarium, was common in a very sandy place under stones, and in like situation were single specimens of Harpalus fuscipennis, Wied., and the black and red Reduviid bug Acanthaspis lythrodes, Germ., of which the British Museum possesses but a solitary example.

\footnotetext{
1 Sec above, p. 243, Fig. 8.
} 
The dry sandy soil, scorched by the sun and exposed to the sea winds, is thoroughly suited to the taste of a Mesembryanthemurn, which grew luxuriantly, its handsome flowers attracting many insects. Among these was the Hopliine beetle, Lepitrix lineata, referred to above, which was abundant at one spot close to the railway station. Unlike the Dicheli and Heterocheli, they did not bury themselves among the stamens of the flowers, but were as active as bees. On the other hand, some small black Bees with white-ringed abdomen, Halictus albofasciatus, Smith, of, did bury themselves in the Mesembryanthemum, but nevertheless were so active as to be difficult to catch; associated with them, closely mimicking them, and almost equally hard to catch, were some Flies (?) Ploas sp. and (?) Prorachthes sp. The mimicry, especially in habits, was very marked during life, yet in the cabinet the insects look distinct enough.

On other flowers were such small things as six green beetles, (?) Hcdybius sp., the tiny Eumolpid Eurysthenes balyi, Chap., a Eutrapela sp., which stands without a name at South Kensington; Attagenus sp.; Harpalus xanthographus, Wied.; Telephorus sp.; the Hopliine Pachycnema obscurepurpuria, De Geer, a $q$; also one of each sex of a small Bee, Dasypoda sp., which according to Colonel Bingham is near to, but distinct from discincta, Ill., and the little Halictus tcrminalis. Smith, o. A yellow Liliaceous flower was tenanted by a small beetle, Notoxus inconstans, Lafert.

The black and yellow Croctis capensis, Linn., was found in the yellow flower of a prickly Composite, while in the flowers of Senccio (?) concolor (a species with purple ray-florets) were numbers of a small Heteromeron, Notoxus sp.

Close to the beach, running swiftly over the sand and taking the short flights so characteristic of the genus, were several Cicindela brevicollis, Wied. An Asilid, (?) Dysmachus sp., was fond of settling on the bare sand. The Elater Ocdisternon cuprcum, Linn., was also taken on the sand; during life it was of an iridescent bronze colour, which proved very fugitive.

On a tuft of grass, above the ground, a semi-papyraceous nest was found to be tenanted by a numerous community of ants, Cremastogaster stadelmanni, Mayr.

Lastly, on the heathy scrub on the lillside at Glencairn two Lycaenids were taken, Phasis thero, Linn., and Cacyrcus thespis, Linn. With them was a Fly, Hacmatopota sp.

Just before embarking we drove down to The Flats, near Claremont, but the weather conditions were unfavourable and the results wholly disappointing. Pyramcis cardui and Pscudonympha cassius 
were the only butterflies obtained; the latter was worn, and appeared to be of the wet-season form. An as yet undetermined Moth (? Pseudosterrha sp.), a Grasshopper and a few very ordinary Flies, Eristalis tenax, Catabomba sp., and Calliphora vomitoria, Linn., were the only other things taken.

Thus ended our eight weeks in Africa, resulting in the capture of some 2500 specimens of all orders. So extensive is the fauna and so far from being exhausted, that even in this scamper (for our journey may well be so designated) several new species were taken, while there remain a number of insects not yet worked out which almost certainly include several other novelties.

During the voyage home, on the tenth day out from Cape Town, at about 10 a.m. on October 14th, I saw a small Pyrale on the hurricane deck; it looked like a species that I had seen in South Africa. It was in good condition, and appeared to be a feeble flier. Not having a box handy it was blown away before I could secure it. The "Walmer Castle" was at the time about $2^{\circ}$ north of Cape Verde, and the land distant about fifty miles. The wind was westerly, squally with much rain. It is of course quite probable that the moth might have been disturbed from among the cargo or the ship's provisions.

At Madeira on October 17th, at 10.15 a.m., in bright sunshine I watched a Convolvulus Hawk at the blue flowers of Plumbago. When feeding there were at least 2 inches of proboscis between moth and flowers. 


\section{CHAPTER VI.}

WEST INDIES AND SOUTH AMERICA, 1906-7.

Barbados, lat. $13^{\circ} 5^{\prime} \mathrm{N}$.

December 18th, 1906.

THere is nothing specially impressive or romantic about the appearance of BARBADOs itself as seen from the sea. But the way in which the lusty negro boatmen urged the coal-lighters against the Trade-wind was a sight to be seen, as they are fine specimens of humanity, and showed to advantage in bending to the great sweeps. The Barbadian negro is the best of his kind, and boating seems to bring out his best qualities. I had some years before seen something of the Bermuda boatmen, and to see was to admire. The negro will not put forth his strength without a spur, and such a spur is supplied by wind and waves.

Having breakfasted on flying-fish in the approved fashion, we resolved to devote the very short time at our disposal to visiting the Belle Estate. It was the end of the rainy season; a shorrer had fallen early that morning. We were told that there had been a great deal of rain in November; the Trade-wind was blowing strongly, the usual "Christmas winds" as the Barbadiaus call them. A drive of $2 \frac{1}{2}$ miles to the north-east of Bridgetown, through cultirated country, where we saw on every hand little save sugar-cane, brought us to a small wood and a winding gorge or gully near the cstate buildings, which could not have bcen more than 150 or $200 \mathrm{ft}$. above the sea.

Here I saw my first Neotropical butterflies, but Precis lavinia, Cram., and Callidryas eubule, Linn., f. scnnae, Limn., might have bcen Oriental forms, lavinia bcing a charactcristic Preeis, and Callidryas bcing cxtremely closcly allied to Catopsilia. Of the former I managed to secure two examples, both males, one "wet," the other "dry." The species appcarcd to be rather common, settling on the ground, or very near it, with wings spread out but oftcn flapped. It was too windy to judge of orientation. The Brimstonc was also 
common, and I secured two of cach sex; the males had a strong scent, which both my wife and I compared to Stephanotis. The males were "wet," but the females were partly "dry" in character, thus conforming to the Old World rule that the dry-season coloration is more persistent in the female, possibly because the female life being the more valuable stands more in need of protective colouring. The females had a fainter sweet smell, certainly disagreeable and suggesting pomade. When a cloud passed over the sun, a female Callidryas was seen, after some looking about, to settle upon a yellow leaf of the Life Plant (Bryophyllum calyeinum, Salisb.).

But if the Nymphaline and the Pierine presented no conspicuous new features, it was not so with the Skippers. Eudamus protcus, Linn., is a robust insect, nearly black with whitish markings, glossed over with a curious brassy-green, but even more remarkable are its long broad tails. It was quite common in the little wood, resting on the Lantana flowers with its wings up and half open. ${ }^{1}$ It was here, by the way, that I first saw Lantana camara in its native province, less luxuriant than in the East, curiously enough, and with smaller flowers. Amongst the proteus I found two specimens of $E$. santiago, Lucas, making in all four species of butterflies, which I am told may be regarded as a goodly number for an island with such a poor fauna.

I kicked up a very worn example of the common West Indian Noctuid Poaphila immunis, Guen.

The flowers of a species of Ipomoea attracted a few Honey-bees, Apis mellifica, Linn., f. ligustica, Spin., as well as the small grey Centris nitida, Smith.

Sweeping grass and mixcd herbage yielded the Bugs Nezarca marginata, Beauv., a green insect, and the brown and green Edessa meditabunda, Fabr., together with some unnamed Acridians, and a Spider with a beantiful silvery pubescence. A rotten calabash fruit was swarming with a little Nitidulid beetle of the genus Stelidotc. Sevcral Dragon-flies are still unnamed.

Mrs. Longstaff was much interested by finding in the gully several eggs of the big Bulimus oblongus, Mïll. They wcre white, calcarcous, and almost as large as sparrows' cggs. Dead spircs werc present on all sides, but the only live Molluse secn was about half-grown. Whilo poking about in the gully, I came across two large Toads and a beautiful blue and green Lizard.

It was most satisfactory on returning to the ship to rcalize that in such a flying visit I had proved the scent-bearing properties of

1 See bolow, p. 288, Fig. 10. 
Callidryas to resemble those of Catopsitia, and had seen the yellow butterfly choose out a yellow leaf as a resting-place.

SECOND VISIT. April 16th.

When homeward bound we got part of another day ashore at Barbados.

This time, after again going through the necessary ceremony of eating flying-fish, we drove over to Oistin Bay on the south coast, passing through country that reminded me of the Sussex downs about Rottingdean-the paucity of trees, the bare wind-swept downs, the white (coral) roads, the churches nestling here and there in sheltering hollows, drawing round themselves a screen of stunted trees-all recalled our own South Coast. It is needless to say that the cultivated open Barbados of the twentieth century bears little resemblance to the island which we occupied in the seventeenth-an island clothed with dense tropical forest. Following the instructions of Mr. H. F. D. Bartlett, F.E.S., we left the carriage at a point on the shore between two houses named "Dover" and "Calais." There, as he had told me, the small Tiger-beetle, Cicindela hebraea, Klug (? saturalis, Fabr.), coursed rapidly over the ground; it was very wary, and hard to follow over the glaring white sand, so that it took some time to collect four.

A neighbouring Sea-grape (Coccoloba uvifcra, Jacq.) harboured various Aculeates: Apis ligustica, an Odynerus, and the long, paleyellow Scoliid Dielis dorsalis, Fabr., of which I got males only. A few Flies are still unnamed; the same remark applies to some Dragon-flies.

We did not see a single butterfly that day-our last in the West Indies.

\section{Trinid 4 , lat. $10^{\circ} 45^{\prime} \mathrm{N}$.}

December 19 th, 1906.

If Barbados is somewhat commonplace, mobody could say that of TRINIDAD. The steep mountain-sides, draped with rich vegetation to the very water's edge, seem to suggest a new world, and the romantic feeling is increased as the ship passes between the islets which almost close the Bocas, and the Gulf of Paria opens to our gaze. Neither a Spanish galleon nor a Carib canoe would seem ont of place round yonder rock.

'The Harbour Master, himself an entomologist, was good enough 
to take us ashore in his launch. The temperature and the general look of things were tropical without question, in every garden stately palms rose above a wealth of flowers. After a glorious breakfast at the Queen's Hotel, we drove to the Maraval Waterworks, making acquaintance on the way with the large orange pods of Cacao growing ont of the trunks of the trees in a surprising manner.

Near the reservoir was a flowery bank so rich in butterflies that in a very short time I captured eighteen specics. Perhaps I got hotter than I had ever been in my life, but the sense of hurry, the desire to make the best of the flying hours, was far more trying than the heat. Here I saw my first Humming-birds, two species, one of them of a beautiful metallic green.

The somewhat dull and uninteresting Euptyehia hermes, Fabr. (camerta, Cram.), is recorded in my note-book as common in partial shade, but I had time to take one only, and the same may be said of the white-striped $E$. hesione, Sulz. Far more interesting to me were my first Heliconiines. Of Eueides aliphera alipherc, Godart, I took a female, and noted that it had a slow flight, also a peculiar scent, which was strong, and compared at the time to that of acetylene; moreover, it was tenacious of life. Of the far more exciting scarlet and black Heliconius amaryllis euryades, Riff., I took a male, which also had a peculiar but rather pleasant scent. Another long-winged butterfly, after being duly pinched, got up and flew a long distance, giving me a hot and exciting ehase. I brought it safely back to the hotel, and noted that it had no scent, but by some misadventure it was lost afterwards. From recollections I am disposed to think that it was Tithorea megara, Godart, a well-known Trinidad Ithomiine.

The best represented group was the Nymphalinae, and among them the commonest was Anartia jatrophae, Linn., a member of a Neotropical genus allied to Preeis; jatrophae is a grey-brown buttcrfly with a somewhat ghostly flight, it settles on the ground, and was seen to orient with tail to the sun; $A$. amalthea, Linn., is much morc showy, being black, scarlct, and white; it flew near the ground, frcquenting damp ditches, and settled with wings three-quarters expanded, orienting somewhat indecisively. Adclpha eythcrea, Linn., with similar habits to the latter, seemed to have a slight pleasant scent, though I was not sure of this. Phyciodes leucodesma, Fcld., a smaller insect, was also rather common, it has a gliding flight like that of the Old World Ncptis, which it somewhat resembles also in its black and white colour-scheme. 
Callidryas eubulc was not cominon, but I took a wet-season raale, which had a strong scent, suggesting Stephanotis, though less agreeable. Tcrias (Eurema) was represented by one albula, Cram., and two nise, Cram. One of the latter, an intermediate male, possibly had a slight scent, the other, a large wet-season female, certainly had a slight sweet scent, which my wife eonfirmed. Of Daptonoura lycimnia, Cram., which appeared to be rather eommon, I secured two males, both with a strong, sweet, flowery scent, perhaps like that of Freesic. I managed to get one example, a male, of the very eharacteristie Enantia (Dismorphia) licinia, Cram., of the Trinidad form acutipennis.

A female Papitio cymochles, Doubl., was the sole representative of the group; it had a somewhat musty odour.

The Skippers were represented by single individuals of Cecropterus aunus, Fabr., Hesperia syrichthus, Fabr., and Prenes nyctclius, Latr., as well as a pair of Vehilius venosus, Plötz.

Naturally enough in the enthusiasm eaused by my first introduction to the South Ameriean butterfly fauna I had no time to devote to other orders, yet two or three things that obtruded themselves were taken, such as the Honey-bee, Apisligustica; the variable Bug, Hypsclonotus fulvus, De Geer; an Ant, and a bright, yellow-green Acridian of very cryptic habit found sitting on the underside of a leaf of one of the Mclastomaceae, when it was touched, much dark liquid, soluble in water, exuded from its mouth. ${ }^{1}$

So ended an all too brief glimpse of Trinidad, an island which, whether looked at from the point of view of geography, geology, or natural history, clearly forms part of Venezuela, and eannot be considered as one of the Antilles.

\section{La Guaira, Venezuela, lat. $10^{\circ} 45^{\prime} \mathrm{N}$.}

Decomber 20th, 1906.

The R.M.S. "Tagus" entered the small harbour of LA GUAIRA about midday. La Guaira is a name that gets into the papers now and again when the tortuous polities of Venezuela try the temper of Europe or America more than usually, but in the minds of most people it is associated with Kingsley's great romance. We had heard it spoken of as the Aden of the Caribbean Sen, but we found it much less hot than we had expected.

The elaborate formalities of the officials kept us from lauding

1 Compare Phymalcus in Soutb Africa, p. 204, supra. 
until the afternoon was far advanced, and a mantle of heavy clouds had descended from the mountains, which seem to overhang the town. There was nothing for it but to watch the grey Pelicans fishing, or to look up at the mouldering fort above, and then down again to the equally mouldering gunboat in the harbour, and moralize over the fall of the Spanish power and the unlimited capacity of the Spanish-American for bad govelnment.

When at last we set foot upon the Spanish Main we found the streets were muddy, and that there were all the signs of much recent rain. A push was made to the most promising spur, a little to the west, where a fair number of butterflies were seen, though few were taken. The extremely steep and slippery slopes appeared to consist of bright red clay scantily clothed with small bushes, amongst which a species of Cistus predominated. Pursuit was almost out of the question, and operations were not facilitated by the well-meant attentions of some small Indian boys.

On examination at home my captures proved to be Ithomia iphianassa, Dbl. \& H., an insect of thoroughly South Aınerican type; Ageronia ferentina, Godart, and Tmolus cambes, Godm. \& S., one of each. Of the last-named Mr. H. H. Druce informs me that the type came from Mexico, and that it has not previously been recorded south of Guatemala. It had a scent which my wife described as that of coarse brown sugar, while I compared it to treacle. There were also a worn specimen of Sphaenogona gratiosa, Dbl. \& H., two of Terias albula (one of them having the black border of the hindwing unusually pronounced), and two of the Slipper Heliopetes laviana.

With thcse butterflies wcre a very few insects of other orders. Of several Grasshopper's there was one so coloured as to resemble the red soil. A large but dingy Bug, Acanthocephala affinis, Walk., made up for deficiencies in colour by its remarkably enlarged tibiae. A Lady-bird, Hypcraspis connectens, Thunb., was obtained by sweeping close to the sea. A large white, black-barred Pyrale, Lcdercria nilckenialis, Snell., was also taken.

A bare muddy slope fully exposed to the sea-winds could not in reason be expccted to yield a vcry rich cxample of the Ncotropical fauna, more especially late in the afternoon; ncverthelcss, I returned to the ship with some fecling of disappointment. 
Savanilis, Colombin, lat. $11^{\circ} 10^{\prime} \mathrm{N}$.

December 22nd, 1906.

Having a few hours to wait at this miserable port, we determined to investigate some low wooded hills a little to the west of the pier. This pier is rather a poor affair, a mile in length, and the wind was so high as to make walking along it somewhat nervous work. The eaptain told me that a German steamer had gone right through it not long before. On reaehing the land we struek off to the right along the shore for a mile or so, and then turned inland into a serubby forest. A high wind was mueh against eolleeting, and the sunshine was intermittent. We found the forest dry in the extreme, all vegetation parehed and run-to-seed. The seed-vessels seemed to be endowed with every provision of nature to ensure their distribution; burrs of every sort and kind tangled up the net into a hopeless mass, and when I got back to the ship my flannel trousers were plastered over, so that it took half an hour to remove the adherent vegetable matter; the most troublesome foe was a small pod which adhered by invisible hooks, and on trying to remove it broke up into several seetions. Never again will I wear flannels in sueh a place.

The most exciting beast that we came aeross was an Iguana, a lizard nearly four feet long, which ran off like a rabbit. Mrs. Longstaff also saw a large Snake.

Butterflies were comparatively searee, and I seeured but twelve speeies. The commonest by far was the black and white Skipper, Heliopetes laviana, and next in point of numbers eame its white eongener, $H$. arsalte, Linn.; with them I took two of the pretty little $H$. domicella, Eriehs. Other Skippers, though less taking in appearanee, were of better quality, viz. Thymcle grenadcnsis, Schaus, of whieh I saw several, but only captured one in very poor condition; and Vetilius illudens, Mabille, of which the speeimen brought home was the only example seen during the whole tour; it was taken on the seashore.

The only Nymphalines were one Cystincura eana, Erichs., and three of the little Phyciodes frisia, Poey.

The Eryeinid Hamearis crostratus, Hew., not unlike our Ncmcobius lucina, but with the habits of Chrysophanus phlacas, was not uneommon. Catochrysops hanno, Stoll, was the only Blue seen.

Two large males of Callidryas sennae, both "wet," had a strong scent like that of Frecsia. I took a very worn speeimen of what would appear to be Sphacnogona gratiose. Terias was represented 
by Lwo delia, Cram., f. lydia, Feld., having the longitudinal black stripe very broad. One of them, a male, was "wet"; the other, of the oppositc sex, intermediate, inclining to "dry."

A solitary Geometer perhaps should be referred to Flavinia.

A Dung-beetle, Onthophagus marginicollis, Harold, taken on the wing, was all that I saw of the great order Coleoptera.

A Podalirius that I took was not to be found in the National Collection, and remains in Mr. Meade-Waldo's hands. There werc several Wasps, for it is never quite too dry for them: Polybia nigra, Sauss., and a pale-red species of the same genus; the handsomc orange Polistes versicolor; Oliv.; while on the sand near high-water mark two Monedula signata, Linn., were found.

We tried to work our way round a small hill, and so back to the pier by another route, but lost ourselves among the winding tracks, and finally had to try back about a inile to an Indian's hut. The mistress thereof was very imperfcctly arrayed in a single skimpy garment, much the worse for wear, which declined to cover the whole of her person at one and the same time. A long conversation, partly conducted in bad Spanish, partly in Portuguese, took place, and it was at last arranged that a little girl of eight should be our guide. This child, as a rule, it would seem, dispensed with clothing cntirely, but this was a very special occasion. Accordingly she retired with hcl mother into the recesses of the hut, from which she presently emerged resplendent in a smart white muslin frock, though othcrwise her attire was simplicity itself. This up-to-date young lady put us back on the road by which we had come, and we had to retracc our steps.

At Savanilla we parted from pleasant travellors, English and Spanish, who had sat at our table. They wcre bound for Bogoté by way of the Magdalcna River, and said that Savanilla was exactly halfway in time betwecn London and Bogotá. How I should have liked to have accompanied them to that justly celebrated buttcrfly hunting ground!

I may hcre remark that I was grcatly struck by the cxtremc softness of Spanish as spoken by South American gontlemen.

\section{SAVANILLA.}

SECOND VISIT. March 15th, 1907.

On our return journcy we again landed at Savanilla for a short time, and on this occasion turned to the left, and collected about the mouth of a small river. The ehief' attraction was the Black Mangrove 
(Aviccnnia nitida, Jacq.); at its flowcr's werc scveral Blucs, Catochrygops hanno being the commoncst; of Callieista bubastus, Cram. (salono, Hew.), the tail-less form, and of Chilades exilis, Boisd., two each were taken, but of Thecla hazia, Hcw., onc only. A Precis lavinia and a Terias delia, a dry-season female, complete the list.

But those same insignificant-looking Mangrove flowcrs attracted a number of insects of other orders, many of which still await determination. As might have been expected, Hymenoptera predominated : a tiny Megaehile, near peruviana, Smith; a number of an unnamed Mclipona; a green Augochlora; Polybia occidentalis, Oliv., and $P$. nigra, Sauss. ; the grey, red-tailed Sphex, Harpactopus thomac, Fabr.; Tachytes amazonum, Smith, var.; and Mierobembex sulphurca, Spin. Conspicuous, however, among all these was Pepsis equestris, Erichs., a magnificent insect nearly 2 inches in expanse, of a blueblack colour, all except the basal third of the fore-wing, which is a dead white. They were easily frightened off the flowers, and were swift of flight, but I managed to net a couple.

It may be remarked that the Mangrove belongs to the Natural Order Verbenaceae, of which so many members are especially attractive to insects.

From the river were obtained a Ranatra unidentata, Stål, and a water-beetle, Cybister laevigatus, Brullé. On the sand just above high-water mark were a number of highly cryptic Acridians.

Living in Colombia is not so expensive as the sight of the first bill might suggest: the paper dollar is so depreciated as to pass for a cent; a fact not easy to realize.

\section{Cartagena, Colombia, lat. $10^{\circ} 25^{\prime} \mathrm{N}$.}

December 23rd, 1906.

We entered the beautiful land-locked harbour of CARTAGENA DE LAS INDIAS in the early morning. How different must have been the whole look of the place in 1585 when it was sacked by Drake! and yet again how different when the muddling and quarrelling of Vcrnon and Wentworth led to the disaster of 1741 !

The finc situation remains, but the city itself bears to-day a forlorn and abandoned look. The chief merit of the cathedral is its size, both within and without it suggests povcrty and neglect. One cannot but rejoice that the famons-or rather infamous-Inquisition is no morc, but it is a pity that the building was not suffered to stand as a mollument. I have seen no volunteers so ill-drilled and unserviceablc in appcarance as the sorry soldiers of Colombia. The 
guardship has been run into the shallows to prevent it from sinking at its moorings.

It was very hot that morning, and everything had a dry, burntup look as I tramped through the dust to La Popa, a wooded fortcrowned hill about $400 \mathrm{ft}$. in hoight, whence is a magnificent view, showing as on a chart, the singular distribution of land and water, with the city standing on a spit, washed on the one side by the ceaseless surf of the Caribbean Sea, on the other by the placid, mangrove-fringed waters of the lake-like harbour.

I netted two of the many Callidryas sennae that were coursing about, one of each sex; the male had the usual strong Freesia scent, the female a disagreeable, but somewhat sweet odour. The male was large and decidedly "wet," the female might better be described as intermediate, inclining to "wet." Sphaenogona (?) gratiosa was rather common, flying through bushes close to the ground, but in my hurry I secured one female only; Cystincura cana, with its slow gliding flight near the ground was also somewhat common, showing a partiality for shady spots. Of the Erycinid, Hamearis erostratus, several were seen, again reminding me of a Small Copper in its ways; another Erycinid was also met with, Nymphidium molpe, Hübn., of which I took a female.

Only two Blues were captured, Leptotes eassius, Cram., and a female Theela that would appear to be vibidia, Hew., though $\mathrm{Mr}$. H. H. Druce says it is impossible to speak with certainty.

The only Papilio was a worn specimen of the somewhat dull $P$. (?) serapis, Boisd., others were seen in shady places.

Two males of Danaida (Tasitia) eresimus, Cram., and a solitary Skipper, Hesperia notata, Blanch., make up the ten species brought home from that hot and hurried walk. Two Dragon-flies found among the Mangroves have not yet been determined. It was hard to tear one's self away, and very hot and very dusty was the last passenger to go on board, where he found that he had somewhat tried the feelings of his wife and the temper of the captain.

Colon, Panama, lat. $9^{\circ} 20^{\prime} \mathrm{N}$.

We arrived off Colos on the morning of December 24th, but could not go in as a pretty stiff "Norther" was blowing, and the quay is quite open to that quarter. The miserable alternative was to stand off and on all day, going dead slow in a somewhat rough sea.

On Christmas-day there was no change, and our monotonous occupation was unbroken. Annong the passenger's was a young 
Trinidad lady, accompanied by her marricd sister. She was to have landed the day before in order to be married at noon to a young fellow employed on the canal works, who had been granted two days' leave of absence for this very special purpose. Fortunately the bride-elect took chaff well, for she got plenty of it. Fancy the would-be bridegroom returning to his work without a wife!

At dinner we did our level best to be merry, but the attempt was only partially successful.

Boxing-day found us anchored off Colon. The wind had not abated, and after watching the big waves breaking on the quay for some hours we weighed anchor and set off for the old harbour of Puerto Bello, some 20 miles to the northward. The entrance is narrow, with rocks on either hand, and thrice we essayed to enter, but each time as we drew near a heavy rain-squall obscured everything, and we had to sheer off, finally putting out to sea again for the night.

December 27th. After a very rough night outside, we woke to find ourselves just off the entrance, and got in before breakfast, passing between cruel-looking rocks on which the waves were lashing themselves in a fury of rage.

Puerto Bello, which gave its name to Portobello near Leith, is a tiny port like a tropical Dartmouth; quite land-locked, its steep shores covered with forest which overhangs the water, it looks like the most peaceful and secluded of lakes. The town has almost disappeared, the fortifications that Vernon destroyed in 1739 have been long dismantled, and are in great part draped with creepcrs. I would much have liked to land, but no boats put off, moreorer it rained steadily most of the day. We shared the anchorage witl three vessels wind-bound like ourselves.

As the wooded shores were only half a mile away on either hand, and the wind was but trifling in the sheltered harbour, it is not surprising that a number of insects came to the ship's lights, and a very interesting lot they wcre. The creature which interested me most at the time was a Neuropteron with conspicuously clubbed antennae, presumably a spccics of Ascalaphus, a curious genns that I have not come across alive cither before or since.

The sole Gcometer, Anisodes placidaria, Gnen., is in cffcet a tiny Ephyra [near pendularia]; Selcnis sucro, Cram., and S. lanipes, Guen., are Quadrifid Noctuae [of which the former has a wing pattern like our Hemcrophila abruptaria]; Aluaca loxca, Cram., a chocolatecolourcd moth with a round pale spot on the fore-wing belongs to the same group, and all threc are very distinct from anything 
Palaearctic. Another Noctuid-they were all single specimenswas a most distinct and beautiful insect, in superb condition, white with blue-grey and dark-green markings. Sir George Hampson has described it as Hoplotarache viridifera, sp. nov. ; the type is a female, it belongs to the sub-family Erastrinae ${ }^{1}$ [Plate III., Fig. 5]. Then there was a Limacodid, Eulimacodes distincta, Möschl., presumably scarce, since the National Collection has to be content with a drawing of it, and a Sphinx, Aellopus fadus, Cram. Another specimen of the last-named had come to the ship's lights the night before, soon after we had left the Colon anchorage, and this in spite of the strong wind blowing on to the land.

At last, after knocking about outside for four days and nights, we tied up alongside the wharf. Such an experience, only too common in the old days of sailing vessels, is now quite exceptional. The most curious circumstance was that in spite of a persistent northerly gale and heavy sea, the temperature in our cabin throughout the whole time ranged from $80^{\circ}$ to $85^{\circ} \mathrm{F}$. It was especially trying at night, for when we steamed slowly with the wind aft for an hour or two, the air would be perfectly stagnant in the cabin as one lay close under the open port, with no covering save pyjamas, yet naturally in a profuse perspiration. At last one would fall asleep, to awake shivering in a gale of wind, for the ship having changed her course was now steaming on her own wake against the wind. This process was repeated again and again.

On landing, every one was presented with a circular, setting forth in English and Spanish the danger of mosquito bites, signed by that famous sanitary reformer, Colonel Gorgas, of the United States Army.

Colon is quite the most wretched place that it has been my fortune to visit. The houses of the Negroes stand on piles in the swamp; and in onc place I saw a notice-board setting forth the eligibility of a building site, morc than half of which was covered with several inches of water. The more rccently erected houses for Europcans, and the barracks for canal labourers, are all cnclosed with wire netting, and look like gigantic meat-safes. Originally the town bore the name of the railway promoter Aspinwall, but he had to give place to the great Genoese navigator. At Colon Lesseps buried a great reputation.

A short mile from the town is some rising ground, not $100 \mathrm{ft}$. high, known as Monkey Hill, otherwise Mount Hope. This, the sole

I "Lepidoptora Phalacnae," vol, x., 1910, p. 716 (No. 6083), P1. CLXX. Fig. 32. 
really eligible site anywhere about, is for the most part devoted to the famous cemetery which the Americans are now getting into order. On asking an official how many had been buried there, I was told, "Anywheres between 300,000 and 500,000." No one will ever know the number of lives laid down in the making of the railway, and in Lesseps' futile work on the canal. It used to be said of the former that every sleeper cost a life. It is distinctly gruesome to see graves waiting for occupants, and a shed full of coffins by the gateway kept in readiness !

The Americans have done marvels, and their praiseworthy efforts have met with a quite astonishing measure of success. Nevertheless as a student of vital statistics I must protest against the unfairness of comparing the death-rates of a selected population of labourers in the prime of life, with the mixed population of the old city of Panama. Some of the official reports of the health of the Canal Zone savour too much of the quack advertisement.

The tragic ground of Mount Hope was a great resort for butterflies. Danaida archippus, Fabr., ${ }^{1}$ spread its big wings in leisurely flight; both sexes had a scent, that of the male being scarcely disagreeable, but that of the female was compared at the time to rabbit-hutches, or musty dry dung.

The prevalent Nymphalines were the grey Anartia jatrophae, and the more showy black, cream-colour and crimson $A$. fatima, Fabr., which glides about quite close to the ground, passing through and under the vegetation; Precis lavinia, the wet-season form, could scarcely be described as common. A few of the fine, pale grey Peridromia feronia, Linn., were seen to settle head downwards on the silvery trunks of palm trees; though very cryptic they were shy and easily disturbed, flying strongly but returning again and again to the same trunk. This butterfly is interesting as having attracted the special attention of Darwin, but I regret greatly that I had forgotten the passage, ${ }^{2}$ otherwise I might have listened for the noise which it makes during flight, and seen it run upon the tree trunks. Quite unlike any of the preceding, Euptychia hermes flitted gently about, never going more than a few yards at a time. Callidryas sennac was to be seen flying strongly as usnal; a male of the

1 American entomologists call this insect D. plexippus, Linn., but the type, though stated to havo come from Amcrica, has a white transverse bar, and is unquestionably $D$. genutia, Crnm. Throughout this book the Oriental species, with the white bar, is called $D$. plexippus, Linn., and the Amerioan (and widely spread) spccies without the whito bar, $D$. archippus, Fabr.

2 "Journal of Researches," ctc., cd. 1860, p. 33. Comparc my obscrrations at Trinidad, pp. 324, 325, infra. 
wet-season phase had a very strong, rich, Freesia-like scent, both when alive, and at home dead ; but the prevalent Pierines were Tcrias delia, wet-season specimens of the form lydia (4 0,1 \%) and T. nise $(1 \mathrm{f}, 3$ q), all, save one female which was "dry," of the wet-season form. One of the T. Iydia appeared to have suffered a symmetrical injury to the hind wings.

Catochrysops hanno, the only Blue met with, was tolerably common. Skippers, however, were much to the fore-the longtailed Eudamus catillus, Cram.; ${ }^{1}$ Megistias labdacus, Godm., and Hylephila phylaca, Drury, looking very golden on the wing; commoner than these was the white Heliopetes arsalte, dashing about in all directions ; and still commoner was Hesperia syrichthus.

A Labiate plant (Hyptis capitata, Jacq.) was attractive to Aculeates and Flies; among these were the grey-black, purple-winged Social Wasp Synoeca cyanea, Linn., var. ultramarina, Sauss., Melipona amalthea, Fabr., and Apis ligustica, together with some Syrphids. Two other wasps-Monedula signata, Linn., and a Crabro-were taken on the wing. Sweeping produced a few Beetles-Euryscopa cingulata, Latr., Oedionychis 10-guttata, Fabr., Homophoeta aequinoctialis, Linn., and Ceratoma mificornis, Oliv. With these was a neat black and cream-coloured Bug, Hypselonotus concinnus, Dall., which is white underneath.

It surprised me greatly that the only insects visiting the ship's lights at the quay were a number of Muscid flies of the blue-bottle type.

There was a heavy shower on the morning that we landed, and very heavy rain was reported for November and December.

\section{Jamaica, lat. $17^{\circ} 45^{\prime} \mathrm{N}$. to $18^{\circ} 35^{\prime} \mathrm{N}$.}

December 31st, 1906-March 8th, 1907.

My first view of JAMAICA was in this wise. It was the last day of the year, and I went on deck at 5 a.m. To the west the moon shone brilliantly over a smooth sea, just above her was Jupiter. To the east Venus positively blazed out, as yet undimmed by the dawn. To the south $a$ and $\beta$ Centauri pointed to the Southern Cross. To the north the outline of the Blue Mountains was faintly traceable. .... As I gazed on the wondrous scene it all gradually changed, everything seemed to dissolve until the rising sun proved Jamaica to be quite close to the ship.

1 See the cover of this volume. 
Right ahead, lying abreast of the slore and well in the breakerrs, almost alongside the light-house, was the wreck of the huge Norddeutseher Lloyd "Königin Luisc," a handsome new ship painted white. Her skipper ingloriously blew out his brains within a quarter of an hour of striking, and before he had landed his passengers !

As we passed the reef at Port Royal we were told of the great earthquake of 1692, when it is said that Port Poyal, for its sins, was engulfed and 3000 persons perished. We were also told of houses and churehes that might be seen deep down in the harbour.

When walking in Kingston the poor quality of the buildings struck me, and reeolleetions of my chairmanship of the Building Act Committee of the L.C.C. made me say to myself that Kingston greatly needed a Building Act; but this was only a passing thought, for was I not on entomology intent?

It is needful to bear in mind that the aboriginal forest in Jamaica has in most places disappeared long ago, and that in the palmy days of the island the land was covered with sugar estates. The area under cultivation has, however, greatly shrunken since then, and mueh of the land is now eovered with forest of seeond growth, termed in Spanish rastrajo; but land that has gone out of cultivation is in Jamaica officially described as ruinate-a sufficiently expressire term. As in other quarters of the world, this second growth is, for the most part, of poor quality and consequently little worth; moreover, it is often smothered with a pall of ereepers, chiefly species of Convolvulus and Ipomoea. Two of these Bind-weeds, with bright yellow flowers, are most effeetive, but at the time of my visit all, or nearly all, were dead and gone-to-seed, and the general appearanee of the rastrajo was most untidy, and even depressing. If Jamaien has given to the East two vegctable plagues in the shape of Lantana camara and Mimosa pudica, Afriea has in retaliation given to Jamaica Thunbergia alata, a well-known green-house creeper, of whieh the eommonest variety is orange with a dark eye, though another varicty is paler, with a green eye. This ereeper now eovers the hedges in Jamaiea, and invades the ruinate lands, making a strong fight of it with the indigenous bind-weeds.

Though there are many Coco-nnts in some distriets, it eannot be said that Palms are a striking feature of the regetation. Speaking generally, trees of any size are loaded with Epiphytes of many kinds, chicfly members of the Natural Order Bromcliaccac (whieh inclndes the Pine-apple), but also many Orchids. The trecs which we most admired were a marked contrast to one another-the Bread-fruit 
(Artocarpus), with its large, rich dark-green shining leaves, and the stately Erythrina, or Coral-tree, whose scarlet flowers contrasted exquisitely with its leafless, silvery-grey stems against the background of bright blue sky. Ferns of all sorts and sizes, from tree-ferns downwards, are met with in the greatest variety and profusion. Oranges were but a penny a dozen, and at one place we had a quite distinct sort at dessert every day for a week. The Sweet-bitter orange is most refreshing, and makes excellent orangeade. Tangerine oranges are comparatively dear, only six going to the penny, but they are the best that I have ever tasted. The Star-apple is good, but covers the lips with india-rubber. The Sour-sop is unrivalled as a constituent of ice-creams. A wide extent of country is devoted to the growth of Bananas, largely the result of American enterprise and the patient labour of Indian coolies.

I do not remember seeing any snakes in Jamaica, but the fierce little Mongoose which was imported to destroy them was not infrequently seen. It is said that the mongoose soon found it easier to eat the eggs of ground-nesting birds than to hunt snakes. To this change of diet is attributed the extraordinary increase in the number of Ticks, since the said ground-nesting birds are believed to have preyed upon the ticks at some period of their life. Whether these statements give a correct account of the matter I know not; but, be that as it may, the ticks are a perfect nightmare, and the fear of them often prevented me from going into likely places in search of Lepidoptera.

It is impossible to write of Jamaica without mentioning the Humming-birds. They were especially common in the gardens of the King's House outside Kingston. Their tameness surprised me; by standing quite still you might see a humming-bird visit several flowers on a bush, and then perch on a twig but two yards off, looking at you just as a robin might; after resting for a few seconds, the tiny creature would visit three or four more flowers, to return again to its perch, and this would be repeated indefinitely. Doubtless the exertion of feeding on the wing is considerable.

Once I caught a humming-bird in my net, and ran perhaps fifty yards to show it to my wife, but it had knocked out so many of its feathers during that short time that I did not repeat the experiment. Among the flowers that I saw them visit were species of Hibiscus and Convolvulus. A different species, green in colour, visited the tiny Composite flowers of the Distreptus spicatus, Cass., while yet another species was seen to enter the gigantic white flowers of the Bcaumontice grandiflora and sit down in thern. The Distreptus is very attractive 
to insects (especially to Blue butterflies), and the humming-birds might visit the flowers to catch them, but it is scarcely conceivable that they could extract honey from such minute flowers. At Mandeville, however, I saw my sole specimen of the sornewhat scarce "Doctor" (Trochilus polytmus), which has two long battledore-like tail feathers, and watched it feeding at the flowers of the Life Plant (Bryophyllum calycinum, Salisb.). These flowers are tubular, but the mouth is much contracted, and the birds bored holes near the base of the corolla just as bumble-bees do; many of the flowers were found to be pierced. This operation, I take it, must have been associated with honey-gathering, but Dr. A. P. Wallace seems to think that humming-birds are almost exclusively insectivorous. Another day I saw the common green species visit the Life Plant, but have no note of its mode of feeding. A black species was seen at Lantana flowers. In the garden at Walderston a small humming-bird visited a Tropacolum flower within a yard of $\mathrm{my}$ elbow. At Port Antonio a tiny species was seen at the small Labiate flowers of a species of Coleus, also at those of Vervain (Stachytarpheta).

\section{The Great Earthquake.}

The morning of January 14th, 1907, was passing fair, in a land where fine mornings are the rule. I went out collecting a little to the east of the Constant Spring Hotel, and remember well, after digging a number of beetles, Scalmus interstitialis, out of a rotting $\log$, coming across several of the beautiful green and black butterfy, Victorina stelenes, sunning themselves on mango leaves, but I had to hurry back to lunch, having arranged to go into Kingston with my wife. We went by the electric tramway and noticed that it was exceptionally hot, though, perhaps, scarcely as hot as on the previous day. When we reached Harbour Street the clock was almost on the stroke of three, and, having arranged to meet Mrs. Longstaff in the museum at four o'clock, I ran to the Colonial Bank, and was just in time to get in before the doors closed for the day. By the courtesy of the teller I drew the money that I required - -it was the last cheque cashed in that building. From the bank I went to one of the principal stores with two new white drill coats that fitted badly; they assured me that I should have them back the next day-but the store was burned down in the course of that fateful afternoon.

From Harbour Street I repaired to the old Mico building in 
Hanover Street, in which the meetings of the Agricultural Conference were held. This was an old brick building, formerly a college, better built than most in Kingston. It was roofed with tiles, and approached from the street by over a dozen rough brick steps, unusually steep, and not provided with a hand-rail. Within that building were sitting the Governor of Jamaica with his chief officers; representatives, official and other, from all the Antilles; the Archbishop of the West Indies, and other local celebrities; Sir Alfred Jones and representatives of the Colonial Office. It is not too much to say that a great part of the brains of the British West Indies was debating under that roof and was, I believe, in a fairly optimistic frame of mind as to the prospects of the colonies.

Wishing to speak to an old friend, Mr. A. A. Pearson, C.M.G., who, as a representative of the Colonial Office, had arrived from England but a couple of days before, I went up the steps and stood in the lobby looking through the open door, and waiting until the gentleman then addressing the meeting should sit down.

Suddenly, without one moment's warning, the building shook, and there was a sound as of tiles falling from the roof, though I did not see any fall. At once I said to myself, "The earthquake I have so often wished to experience! What a pity it is such a slight one!"

Calling to mind the proverbial advice to get out of a building as quickly as possible, and especially fearing that I might be hurt if a stampede took place, I made my way to the door. Not relishing the look of the steep steps, I stood for a moment to one side, but quickly realizing that if anything came down it would probably be the portico under which I was, I thought the steep steps the lesser evil of the two, and rushed for thern, expecting every moment to be pushed down by those behind. I was barely half-way down when the anticipated occurred, for I seemed to be pushed from behind in such a way as to be turned round in the air, going down the rest of the steps on my back and landing in the street on the top of my head! To my great surprise I was not seriously damaged, for a slight scalp wound was of trifling consequenee. When I regained my feet the members of the Conference were leaving the building "in good order," and I did not see that the building itself was seriously affected. Up to that time I did not in the least realize that anything very terrible had happened. I said to a gentleman near me, "You have been down too; I will dust your back and you can dust mine." Mr. Pearson came up, and it was arranged that Mrs. Pearson should dine with us-"barring more earthquakes," he called out after me, as I was setting off to look after my wife. 
I may here remark that on mature reflection I came to the eonelusion that I had not been pushed from behind, but had beess thrown down by the final effort of the shoek, whieh it was generally agreed eombined an upward thrust with a rotatory movement. Unfortunately I did not hear the Arehbishop's celebrated speeeh: "Now, gentlemen, let us keep our seats"-a remark whieh appeared unkind to Mr. Pearson who had been thrown out of his.

The museum is perhaps half a mile from the Mico building, and it was quiekly evident that the shock had been far more severe than my first impression led me to believe. There were ruins on every side; in plaees masses of fallen brickwork had to be elambered over. Everywhere panie-strieken blaeks were making for the eountry as fast as their legs could earry them; they screamed and called loudly on eaeh Person of the Trinity in turn: it was as if all the inmates of a large lunatic asylum had been turned into the streets.

Hurrying on as quiekly as the obstacles would permit, I was soon relieved to see my wife unharmed standing in the street surrounded with fallen buildings. She described her experiences in these words :-

"I was in the museum, and, having seen the objects on the ground floor, started to go upstairs. The staircase was built against the outer wall in which there was a window overlooking the street, and as I passed this window the brilliance of the sunshine espeeially struek me. Suddenly there seemed to be a terrific blow upwards from beneath my feet, aceompanied by an awful noise and shaking. I at once realized that it was an earthquake, and a bad one. Turning round immediately, I ran down the stairs and out of the front door. To my horror it had beeome suddenly dark, for the air was filled with the dust of falling buildings so that I eould but dimly see my way. The air was full of falling things, and the fore-court wall to my right hand swayed like reeds in the wind. I found the gate with difficulty, and deseending two or three steps made my way into the middle of the street. Though my hat was eovered with dust not a fragment of brick had tonehed me! When the air eleared somewhat a man called out to me: "You had better get out of those wires." Looking down I found there were broken and twisted eleetrie wires round me. Some of the houses opposite had eollapsed entirely, others were more or less wreeked. A womau whose head and shoulders appeared out of a heap of ruins could not release herself; in vain I called to one black after another to help her; in one ease I offered to hold a man's horse white he did so, but in vain. At last a white man appenred and at once set her free." 
Seven weeks latcr I re-visited the nuseum. The only specimens remaining were the skeletons of a whale and a crocodilc, which, hanging from the ceiling of the lower room, gazed as with a gruesome grin upon the ruins. The upper walls had disappeared and the roof was standing just above the joists of the first floor, having apparently experienced the same rotatory movement as the statue of Her late Majesty Queen Victoria and the writer of this account. Practically the whole of the walls of the upper storcy had fallen outwards-many tons of brickwork. That my wife escaped with her life is surprising, that she was unscathed is simply marvellous.

There were other remarkable escapes in the precincts of the unuseum. A carpenter had just come down a ladder, when the wall against which the ladder was leaning fell ontwards. A wall fell upon a cradle which it crushed without hurting the baby within. Another wall fell where a child was feeding some rabbits; the hutch was crushed and the rabbits wcre killed, but the child escaped.

Mr. Abell, a visitor at the Constant Spring Hotel, who some years before had suffered a sunstroke in India, was watching a gamc of tennis, when suddenly the lawn appeared to move up and down in waves, like a carpct blown up by the wind. He said to himself: "Gracious me! I have got it again!" Then he saw a huge crack opcn at the bottom ${ }^{1}$ of the hotel building and extend upwards to the top, at which he remarked: "Well, that is not a sunstroke anyhow." This occurred about six miles from Harbour Strect where the damage was greatest.

The earthquake occurrcd at 3.25 p.m., and lasted about 26 scconds, its effects bcing aggravated by a destructive firc which greatly added to the horror of the situation. As far as could bc ascertained somewhere about 1000 lives were lost. Mrs. Longstali" and I betook ourselves to a surgery to render such help as mighti be possible, but the first two surgeries we came across were wrccked and deserted. Scalp wounds from falling bricks were vcry numerous, in somc cases extensive and positivcly appalling to look at, though the ncgro's head is proverbially hard ; thcre were also many fracturcs. Shingles from the fallen roofs made better splints than palings, but bandages were a greater difficulty; for the most part onc had to inake the best of torn-up women's garments, the trimmings scrving (with dead grass) for padding. Mrs. Longstaff begged for bandage inaterial from the women, but did not succed in getting hold of a shcet till latc in the day. It was impossible to attend to the cases

'I have not been able to think out the nature of tho strain which eaused this huge erack to run upwards from bolow. 
as fast as they came in, and some very sad ones were altogether past help. There was no laudanum to be had, as every bottle was broken. The doetor's forecourt garden, filled with the injured, was a sad sight. As dusk came on the increasing glare in the sky showed that the fire was approaching, and naturally enough this caused a panic among the poor ereatures who eould not run away. However, I went out to reconmoitre, and comforted the patients by telling them that the house was eut off from the fire by large gardens. When darkness elosed in, and there was but one lamp-by the light of which an amputation was being performed-we had to go: my wife tired out, and myself quite ready for food and drink and rest. I had just secured a eab, by the offer of a sovereign, when we got the use of a private earriage on the eondition of taking a patient home and then visiting another.

That night the guests of the Constant Spring Hotel slept on mattresses on the lawn, not daring to stay in the shattered building. It was a lovely night, and the Southern Cross shone out peacefully over the glare of the still burning city. The sensation of feeling mother-earth from time to time shake under one's head, as the numerous after-tremors passed aeross the island, was as new as it was strange.

The earthquake did not consider people's eonvenience in any way; thus, a lady at the Constant Spring Hotel was in her bath at the time. This lady's sister was ill in bed, but her husband carried her into the garden wrapped in a blanket. In a private house another lady, the wife of a high official, was taking her siesta; she saw the wall at the foot of her bed waving towards her, so she, rery disereetly, pulled the pillow over her head. Then the wall felloutwards-and the roof followed, but the bed was quietly launehed into the drawing-room, the roof falling in such a way that the lady slid down under its cover, and escaped serious injury. It is stated that the front of a house fell out, then the first floor gently subsided to the ground lcvel, and the occupants, two elderly ladies, quietly walked into the strcet.

I myself saw a housc in one of the prineipal streets looking like a doll's house with the front open. Nothing seemed damaged sare the front wall, but that had fallen out. On the first floor was a tablc set out for a meal, with bottles and glasses untouched. It was more like a scene at a thcatre than real life.

These terrifying natural phenomena may, however, be viewed from quite another aspect. Farthquakes may be considered as 
AMERICA

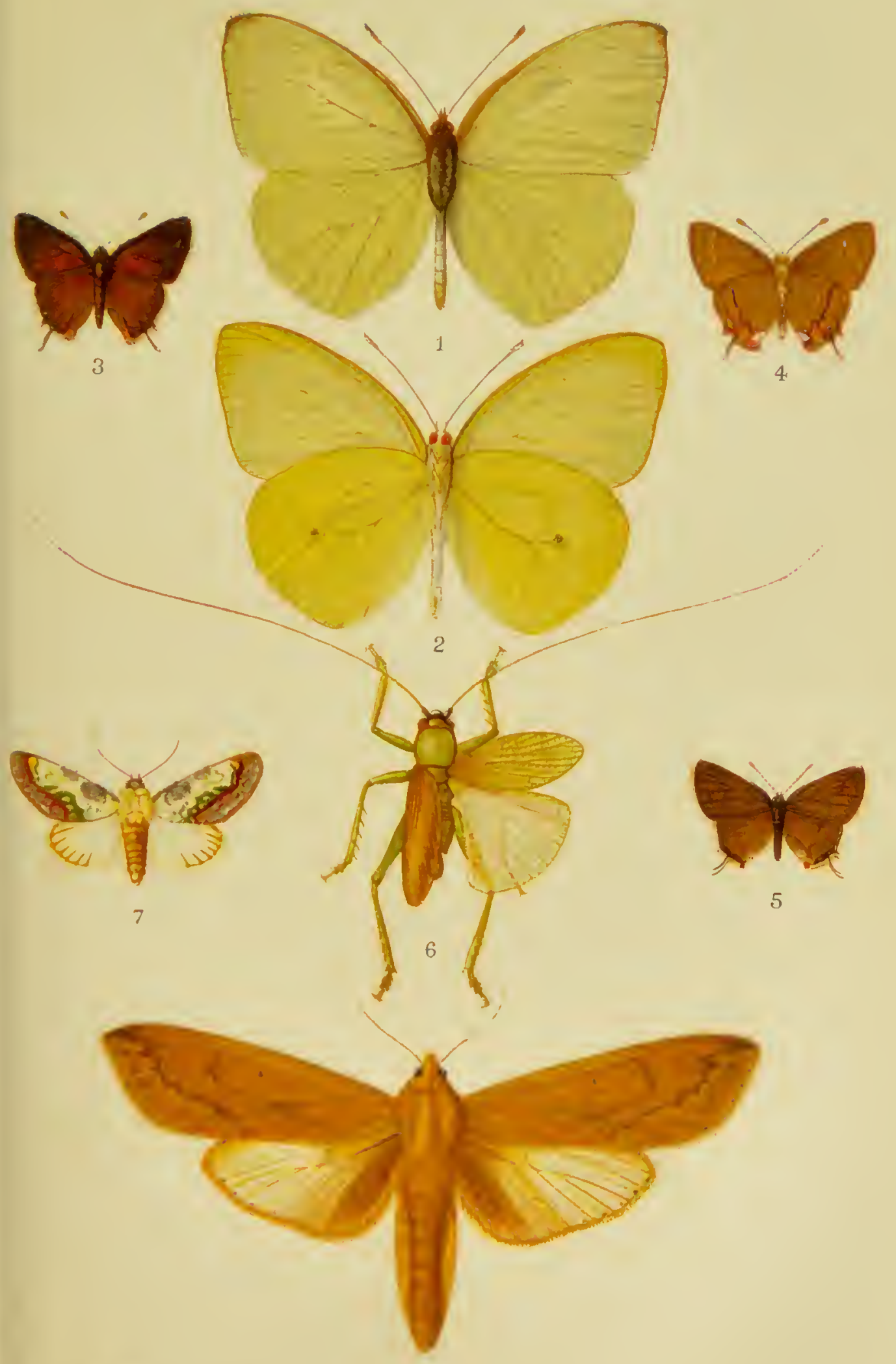

$H$. and $E$, L S limblon, 

curative agencies. It is stated on very high authority that more than one bedridden white lady, having been shaken out of her bed, found again the use of her legs.

On landing in Jamaica, Mrs. Longstaff had despatched a postcard to her sister, saying that it was pleasant to be once again on terra firma, after such a long voyage: by the irony of events, the card reached its destination at the same time as the news of the earthquake.

A little over two centuries before, on June 7th, 1692, Port Royal, the then capital of the island, over against Kingston on the opposite side of the harbour, was overwhelmed by an earthquake, many of its buildings sinking into what is now part of the harbour, with the loss, it is said, of some 3000 lives. In the interval no shock of any importance had been felt.

Again, in 1907, the permanent disturbance of the ground was far greater at Port Royal than at Kingston. The massive concrete foundations of the batteries subsided, so that some of the guns sank in the sea up to their trunnions. The harbour-master reported notable alterations in the soundings, and when I left several palm-trees near the point were to be seen rising out of the sea. It is, however, noteworthy that the Government buildings at Port Royal withstood the shock wonderfully well; probably they were built in cement. The submarine cable was fractured some 16 miles away.

A sad circumstance connected with the earthquake was the loss to this country of the services of one of its best officials. Sir Alexander Swettenham, K.C.M.G., was compelled to resign, not because he failed to rise to a great emergency, but simply because an injudiciously worded letter, written under peculiarly trying circumstances, was in some unaccountable manner made public, whereas the letter to which he replied has never seen the light. He was practically condemned unheard, to the lasting discouragement of our Colonial service.

About two months after the earthquake, Bishop Joscelyne told me that he had been studying a report of the Diocesan Architect, who had been instructed to examine all the churches in the island, and that it would appear that the greatest destruction had been wrought along a line extending from Kingston in a north-northwesterly direction across the island to Port Maria. Now this is just the line where an extensive earth movement might be expected, where contorted metamorphic strata are found, and frequent intrusions of syenite and porphyry occur.

Though by nature the reverse of courageous, I was, like many 
others, not in the least frightened, but was surprised at my own coolness. Also, like many others, I found that the succeeding trifling vibrations disturbed my equanimity more than the initial severe shock. Indeed, a slight but somewhat sustained shock, which I experienced at Mandeville eight days after the great eartliquake, produced sensations unpleasantly akin to fear. I seemed to see passing before me in a ghastly procession all the injured persons that I had helped to tend on that memorable afternoon, and involuntarily I ejaculated: "Good God! when will it stop?"

The wooden houses of Jamaica are easily shaken by the morement of luggage or furniture, or even by a heavy footstep; but curiously enough one never had the slightest doubt as to the cause of a vibration. As I lay awake in bed after one of the numerous slight shocks, I pondered much, seeking an explanation of this curious fact, and believe that I found one. The vibration caused, for instance, by dropping a heavy weight on the floor of a room above, or by the banging of a door, is of a diminuendo character, whereas that of an earthquake is either sostenuto or actually crescendo. Now, the human nervous system has much experience of vibrations of the first description, so that none but exceptionally nervous individuals are put out by them; but, on the other hand, our organism is not sufficiently familiar with vibrations of the second class to regard them with equanimity. I was confirmed in the truth of this theory many months afterwards when seeing a lady off for the Continent. Before the Victoria Station was rebuilt I fancy that the wooden platforms had got somewhat rickety, and as I was standing by the carriage door, the platform began to shake so violently that I seriously considered which was the safest place to stand in, but before moving I realized that a porter was rapidly pushing towards me a truck piled up with heavy baggage. The vibration was crescendo, and my diaphragmatic region was correspondingly uncomfortable.

The earthquake emphasized in a remarkable manner the distinction between the Black and White races. In the case of the Blacks terror seemed to be unreasoning and umrestrained; they gare way to their emotions and yielded to a sauve qui peut. Of course a few Whites were little better, but they were quite the exception, and as a rule White men turned at once to help, their idea being to do something. It would scarcely be fair to say that the Blacks were more selfish than the Whites, still less that they were deficient in kindness; it seemed to me rather that the difference was like that between children and grown men. Nothing could hare exceeded 
the courage, the thoughtfulness, and the devotion to duty of the Rev. S. R. Brathwaite ( $\mathrm{W}$ Wesleyan minister), a fine specimen of a fullblooded negro; he was as cool, as quiet, and as resourceful as any European, devoting himself to encouraging the timid, comforting the afflicted, and aiding the injured. Another notable fact was the excellent behaviour of the men of the West Indian Regiment, who showed the good effect of discipline, alike in the terrible scenes of the fire in the camp (when a score of officers and men were burnt), and in the trying picket duty in the city afterwards.

It is quite likely that a contributory cause of the panie was the fact that the Seventh Day Adventists had quite recently held a mission in Jamaica, preaching their favourite doctrine of the speedy coming of the end of the world. Naturally enough, emotional negroes who had heard their teaching would take the earthquake to be the fulfilment of their prophecies.

The negro is a cheery, good-natured fellow, who takes life very easily. His ideal occupation is said to be to lie on his back under his own coco-nut tree, chewing a piece of "cane" from his own estate, and meditating upon the hardness of the Christian religion in forbidding a man to have more than one wife, seeing that one woman can do so little work.

Admitting the negro to be indolent and unenterprising and vain withal, he is at the same time intensely religious. Nowhere have I seen such universal church-going, nowhere have I heard such congregational singing. It must, however, be admitted that the negro's religion does not have as much effect upon his morals as it should; moreover, it is reported that he is, as a consequence of his highly emotional disposition, easily wrought upon by Revivalists.

The powerfully made African is largely displaced by the slim coolie from India. The coolie, though relatively weak and unquestionably slow, can be trusted to go on working, and so gets through more in a day. It takes a constant stimulus to make the negro work, and this is entirely lacking under the easy conditions of his life. An experienced official told me that he was convinced that to double his taxation would be an act of kindness! The required stimulus is given by the sea. Accordingly we find the negro boatmen of Bermuda are famous; an officer of the Royal Mail Steam Packet Company spoke to me in the highest terms of the way in which the boating connected with their coasting work is carried out. I have said above what a grand sight it is to see the Herculean boatmen of Barbados bending to the big sweeps as they urge the heavy coal lighters against the ceaseless "Trade." But in the last-named island over-population 
gives the necled stimulus, and sends some of the best labourers tr the Panama Canal.

When the negro women are seen on the high road going to Kingston market with piles of produce upon their heads, one almost forgets their coarse features in their proud carriage as they swing along with their stalwart limbs. When clad in white, or better still in red or yellow, one feels that there is much to be said for a black skin, but blue (of which they are fond) is not becoming to their peculiar style of beauty, making them look pale.

I met a centenarian black, who seemed proud of having been a slave, and did not remember anything to complain of in his former life. When Queen Victoria died the negroes got the idea into their heads that Edward VII. would re-enslave them. I asked the lady who told me this, whether they anticipated cruelties, etc., but she said, "Oh dear, no! They seemed to fear the indignity of the condition; at any rate, that is what they complained of."

And now, after these long digressions, some account must be given of my entomological experiences. ${ }^{1}$

The Island of JAMAICA is 144 miles long by 49 miles wide, and comprises an area of 4207 square miles, so that it is about equal in size to the counties of Devon and Somerset taken together. It lies well within the tropics, being between the latitudes $17^{\circ} 45^{\prime}$ and $18^{\circ} 35^{\prime} \mathrm{N}$.

Rather more than half the total area of the island is below the $1000 \mathrm{ft}$. contour line, but some 60 square miles have an altitude of $4000 \mathrm{ft}$. and upwards, the Blue Mountain Peak attaining $7360 \mathrm{ft}$.

My most remote points were separated by 120 miles of longitude, and 40 miles of latitude, but though threc weeks were spent at an elevation of $2000 \mathrm{ft}$. and upwards my highest point was but $2900 \mathrm{ft}$.

As regards geological formations, I collected upon almost all those of which the island is made up, with one important exception-I did not explore the Blue Mountains, indeed there seemed to be little inducement to do so at that time of the year.

My remarks naturally enough apply to the places visited, and to the times of my visits, limitations which should not be forgotten. My collecting was confined to ten weeks (Dccember 31 to March 8) of the dry season, the tropical winter. Howcver, the general aspect of the country towards the end of the dry season docs not suggest to

1 The form of the account which follows differs from tho oarlier part of the work, and appears (so far as Butterflies aro concorned) vearly as it was first published in the Transactions of the Entomological Socicty of London, 1908, pp. 37-51. 


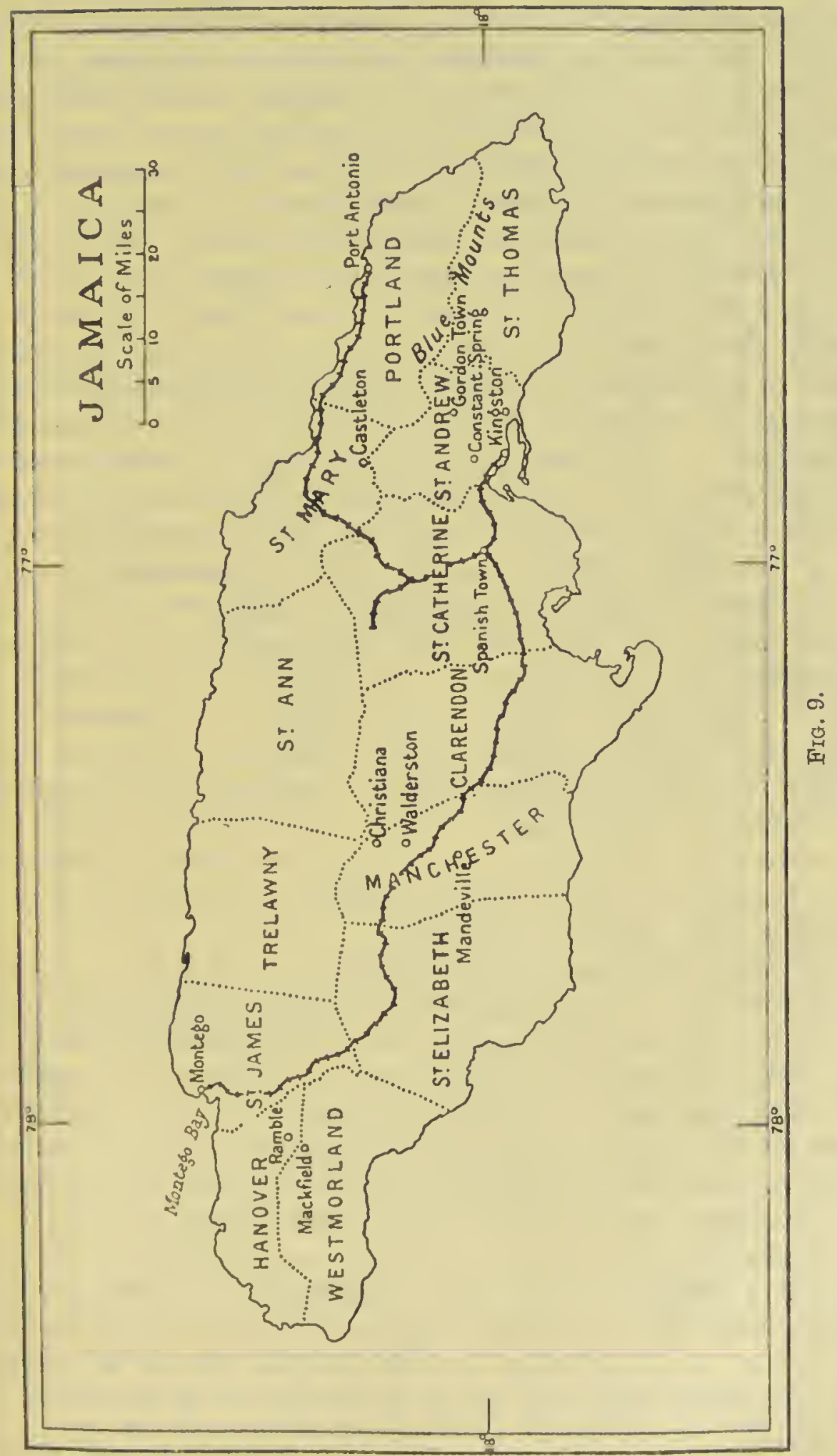


the English visitol either winter or early spring, but rather a fine, hot, late autumn, with burnt-up, gone-to-seed herbage, and falling leaves. The quiet and solitude of the woods was surprising, so that the falling of a big leaf, such as are common in the tropics, would make clatter enough upon the path to give one a start. Often where trees and varied undergrowth littlc disturbed by cultivation suggested a profusion of insects, scarcely any were found. Not only were butterflies scarce, but beetles, bees, wasps, and especially' flies. There is a note in my diary for February 16th: "Christiana. Caught a wasp, the first seen since Constant Spring" (January 14). During that month I took but some half a dozen flies. Mr. P. H. Gosse, in his altogether admirable "Naturalist's Sojourn in Jamaica," expresses his surprise at the scarcity of insects, in words that merit quotation. "I had left England with high expectations of the richness of the West Indian entomology: large and gaily-coloured beetles, I supposed, would be crawling on almost every shrub, gorgeous butterflies be filling the air, moths be swarming about the forest-edges at night, and caterpillars be beaten from every bush. These expectations were far from being realized:... in general butterflies are to be obtained only casually. Moths are still more rare ... in general beetles and the other orders are extremely scarce, and especially Diptera: I have often been astonished at the paucity of these, as compared with their abundance in Canada and the Southern United States. . . . One may often walk a mile,-I do not mean in the depth of the forest, but in situations comparatively open, beneath an unclouded sun,- - and not see more than a dozen specimens of all orders" (pp. 94, 95).

Between sixty and seventy species of butterflies ${ }^{1}$ occur in Jamaica, and it is a surprising fact that such a large tropical island should not produce more species than Great Britain. During my ten weeks' collecting I obtained forty-seven spccies, as compared with thirty-six species that are to be found in the one Deronshire parish of Mortehoe. Indeed for the most part I found Jamaica poorer in butterflies than Mortehoe in the summer. There wcre but two occasions on which the numbers were comparable.

On the afternoon of February 25 th I was ferricd over from Port Antonio to Navy Island. The Trade-wind was blowing rather strongly, and the only sheltered spot was some swampy ground to the leeward of a bluff; here Anartia jatrophae was in the greatest profusion, many being busy about the flowers of the Logwood-trces

"The nogroes always call buttorflies "bats," a torm that for some time greally" puzzled me. 
(Haematoxylon campeachianum, Linn.), with them werc a ferw Dione vanillac, and one Prccis lavinia.

The other time was on March 3rd, near the top of Shotover, to the west of Port Antonio. Here, about $1000 \mathrm{ft}$. above sea-level, on a spur of a somewhat higher hill, commanding a glorious view of sea and coast, was a steep slope with an aspect a little south of east. An acre or two of this slope, partly sheltered by trees, displayed a greater wealth of flowers than I saw anywhere else in Jamaica, the dominant and most attractive being a species of Vervain (probably Stachytarpheta jamaicensis, U.). It was a very hot day, with less wind than usual, and I was there from 11.15 a.m. to 12.30 noon. The beautiful, but ill-smelling Fritillary, Dione vanillcue, was fairly swarming, while Euptoieta hegesia was scarcely less abundant, and among them were numerous Precis lavinia, and a few Skippers, Prenes nyctelius, $P$. ares, and Morys valerius. The Brimstone, Callidryas cubule, was coursing about in all directions, often stopping to take a sip from the Vervain, but not a single White was seen. Colacnis was conspicuous by its absence, while Anartia jatrophac, if present, did not obtrude itself on my notice. A hasty glimpse of a Papilio was obtained, also of a butterfly (? Actinote sp.), that suggested my South African acquaintance, Planema esebria, Hew. Among the butterflies were a few of the beautiful Arctiid, Utetheisa bella (speciosa). Altogether it was such a sight as seldom gladdens the eye, but which happily lingers long in the memory.

A few words on the localities visited:-

Constant Spring (Dec. 31-Jan. 14); the hotel stands near the northern edge of the Liguanean plain, about $500 \mathrm{ft}$. above the sea. There is good collecting in the woods at the foot of the mountains up to Stoney Hill, say $1000 \mathrm{ft}$.

Gordon Town (Jan. 9); the bed of the Hope River bclow the town, which I visited once, is about $800 \mathrm{ft}$.

Chancery Hall (Jan. 8, also March 7), on the plain, is beside the dry bed of a strcam, to the west of Constant Spring.

Temple Hall ( $J a n .11,12$ ), eirca $850 \mathrm{ft}$., is on the road to Castleton, Jamaica.

All these places are in St. Andrew Parish. Parishes in Jamaica take somewhat the place of counties in England, and as the names are in constant usc it seems well to give them.

Castleton, St. Mary Parisl (Jan. 11, 12), is just beyond the height of land; the Botanic Garden is $500 \mathrm{ft}$. above the sea. It proved a disappointing locality. 
Mandeville, Manchester Parish (Jan. 16-22), ranges from $2000 \mathrm{ft}$. to about $2200 \mathrm{ft}$. It proved very poor in inscet lifc.

Mackfield and Ramble, close together, the former in Westmorland, the latter in Hanover (Jan. 24 - Feb. 2). A delightful rolling country of pasture intermixed with woods. About 800-1000 ft. Unfortunately the very headquarters of the collector's greatest foe in Jamaica - that tiny horror, the Tick.

Montego Bay, St. James (Feb. 2-5); the collecting ground ranges from the sandy shore to the top of a wooded hill of about $300 \mathrm{ft}$., and was fairly productive.

Walderston, Manchester (Feb. 6-20); the collecting ground ranged from about $2500 \mathrm{ft}$. to $2900 \mathrm{ft}$. (Mile Gully Mountain). An almost waterless district, but the tops of the hills are covered with woods. One day (Feb. 16) was spent at Christiana in a gorge cut through Trappean Conglomerate, about seven miles to the north of Walderston. Height about $2000 \mathrm{ft}$. in a well-watered country.

Spanish Town, St. Catherine (Feb. 20-23); near the edge of an extensive plain, its elevation above the sea must be inconsiderable.

Port Antonio, Portland (Feb. 24-March 5) ; from the coast my collecting ground extended to the summits of Park Mount on the east and Shotover on the west, both about $1000 \mathrm{ft}$. One wonders what son of Oxford gave the green hill its honoured name.

Speaking generally, insects were commonest near the sea and on the slopes of the hills up to $1000 \mathrm{ft}$. Flies, bees, and wasps were especially scarce at $2000 \mathrm{ft}$. and over.

\section{JAMAICAN BUT'IERELIES.}

Danainat.-Danaida archippus, Fabr., 4 of. Only seen at Port Antonio. Found about Asclcpias, also at Rose and other flowers; it is hard to kill. The Jamaican specimens of this butterfly differ from those from South America in the following particulars. They are brighter; they have less black along the veins; there is more fulvous at the tip of the fore-wing; the white spots beyond the cell are outlincd and sometimes suffused with fulvous.

Danaida (Tasitia) jamaiccnsis, Bates. 2 q near the stream which the Kingston-Castleton road crosses close by Temple Hall; a of ncar Ramble Post Office, another of ncar Walderston. Like the preceding, this is hard to kill. The form met with on the mainland, $D$. cresimus, Cram., which appcars to be distinct, bas much more black about it, c.g. along the costa and the vcins.

Satyrina E.-Calisto zangis, Fabr. 26 spccimens. Tery generally 
distributed in woods, but seldom abundant. Constant Spring, Castleton, Mandeville, Mackfield (common), Walderston (common), Port Antonio (abundant). The sexcs about equally divided. It flies amongst herbage so close to the ground as to be difficult to catch, yet seldom moves many yards. It is distinctly a shade-lover. On 27th February, 1907, near Port Antonio, I saw it flying freely on a rainy day.

Heliconinae.-Heliconius charithonius, Linn. 21 specimens. Generally distributed throughout the island and not uncommon. Constant Spring, Castleton (common), Mackfield, Walderston, Christiana, Montego Bay, Port Antonio (common). This butterfly has usually a slow flapping flight, often in half-shade. It is distinctly local, in the sense that it is confined to a very small area in each locality; sometimes it may be seen flying up and down a very short beat. It settles on leaves or flowers with wings fully expanded. Mr. P. W. Jarvis, of the Colonial Bank, told me that the butterfly was very common later in the year, and that it "clustered" on going to rest for the night, a number of specimens sitting close together, but not actually clinging to one another. On 5th March, 1905, at Shotover, near Port Antonio, close upon $1000 \mathrm{ft}$. above the sea, at about noon on a dull day, eight or ten were scen flying about under the shelter of a hedge. As many as seven of thesc settled on dead sticks, etc., within a space of 2 feet by 1 foot. ${ }^{1}$ This butterfly is somewhat hard to kill. As compared with Venezuelan specimens, those from Jamaica have all the yellow marks a little larger; and the red spot near the base of the cell of the hind-wing is smaller, or even absent.

Nymphalinae. - Colaenis cillene, Cram. (should not the name be cyllone?), 12 \&, 4 \%. Gencrally distributed and not uncommon. Constant Spring (common), Castleton (common), Mackfield, Montego Bay, Walderston, Port Antonio. A grand insect on the wing, sailing about like a piece of rich gold. The imperfect condition of many of the specimens is not apparent during its strong flight. It is most easily taken at flowers such as Lantana camara and Eupatorium odoratum. One of my specimens appears to have been bitten by $\Omega$ lizard. The male is distinguished from that of the South Amcrican C. delila, Fabr., by its more orange tint and the comparative absence of black; but cillone is perhaps only a local race of delila.

Dione vanillae, Linn. 16 \$, 7 \%. Gcnerally distributcd and in some places very abundant. Constant Spring (common), shore of Port Royal harbour, Mandeville (abundant), Ramble (abundant), 'Compare Miss M. E. Fountaine's note in Entomologist, vol. xliv.,pp. 403, 104 (1911). 
Montego Bay, Walderston, Spanish Town, Port Antonio (swarning on Shotover). A brilliant insect appearing very red upon the wing, and reminding me of an Acraea. Although it could fly about wildly enough, several males wcre seen one afternoon fluttering among dead leaves close to the ground. I do not detect any differcnce between Jamaican and South American specimens, save that the former are usually smaller and often brighter.

Euptoieta hegesia, Cram. 12 specimens. Widely distributed but in most places scarce. Constant Spring, Temple Hall, Montego Bay (common near the hotel, also found on the sandy shore), Walderston, Port Antonio (common in a swampy meadow near the shore to the east, but in swarms on the top of Shotover). Jamaican specimens have the orbicular and reniform stigmata less clearly outlined than those from the Spanish Main; moreover the ground-colour is a brighter tawny. This insect reminded me of Atella phalantha, Drury.

Phyciodes frisia, Poey. 5 specimens. This little butterfly was confined to the Liguanean plain and the hills bounding it on the north, and was not common. Constant Spring, Stoney Hill, near Gordon Town, Spanish Town.

Precis lavinia, Cram. 8 specimens, all males. Constant Spring, Chancery Hall, Mandeville, Port Antonio. It usually settles on or near the ground, frequenting hot, dry, exposed places. Is wary and not easy to catch.

The nomenclature of this very variable and wide-ranging species (from the Southern United States to the Argentine) has long been in great confusion, but has been cleared up by Mr. G. A. K. Marshall, who has recently re-arranged the genus in the National Collection. Cramer named three forms, all from Surinam, lavinia, cvavetc, and genoveva. It appears to me that Mr. Marshall is quite correct in uniting these under the first name, together with the Northern form coenia, Hübn. (the name adopted by Messrs. Godman and Salvin in the "Biologia Centrali-Americana").

Jamaican specimens, usually known by local collectors as Junonia gcnoveva, Cram., are, as a rulc, brightcr than thosc from South America, with the transverse whitc band ncar the tip of the forewing fairly conspicuous, being of the form zonalis, Feld. ${ }^{1}$ They are somewhat intermcdiate in character, between the South American and North Amcrican forms, to the latter of which specimens in the Hope Collcction from the Bahamas approach more ncarly.

1 H. Fruhstorfer (Stelt. Ent. Zcit., 1907, p. 224) comes to tho same conclusion as Marshall as to Cramor's threo forms, but makes the Cuban form (zonalis according to Marshall) a now sub-specios michaclisi. 
Anartia jatrophac, Linn., var. jamaicensis, Möschl. 8 f, 7 q. Widely distributed and abundaut. Constant Spring, Castleton, Mandeville, Mackfield, Montego Bay, Walderston (searce), Christiana, Port Antonio. This, which is par excellence the common road-side butterfly of Jamaica, constantly reminded me of the Indian Precis atlites. A somewhat ghostly looking insect on the wing; when settled among whitish dead grass, with wings closed, it is very cryptic. It usually settles on the ground or close to it and does not frequent flowers much. Janiaican specimens are all very readily distinguished from those from South America by the broad bright fulvous, or orange brown, margin to the wings. There is a mere trace of this colour in specimens from the mainland, which moreover appear to be less densely scaled.

Cystineura dorcas, Fabr. (mardania, Cram.). 22 specimens. Local. Constant Spring, Gordon Town, Mackfield (abundant), Williamsfield Cave, Montego Bay, Port Antonio (common).

This delicate and very distinct butterfly, which somewhat resembles a Satyr, frequents moist, shady places with long grass. There is sometimes much fluttering in its very slow flight, but at other times it glides. Though not such a flower-lover as many Nymphalines, it often visits the Spanish Needle, Bidens leucanthus, W. It usually settles with its wings wide open, and if it close them up re-opens them quickly. On February 1st, 1907, near Chichester Rectory, Ramble, two were beaten out after sundown; both settled almost at once, one on the top of a grass stem with its wings up, the other towards the top of a long green fern. The second very delibcrately set up its wings, then after an interval it retracted its forewings so as to conceal the large white patch. I failed to find any naturally at rest. It may be noted that $C$. cana, Erichs., the representative of $C$. dorcas on the mainland, lacks the conspicuous orange brown of the latter species.

Victorina stclcnes, Linn. (So spelled by Linné; Mr. Kirby has it steneles; probably Linné meant to call it after either Sthenclus or Sthenele: the other names are meaningless.) 11 specimens. Widely distributed, but not common. Constant Spring, Mackficld, Walderston, Christiana, Spanish Town, Port Antonio. On the banks of the Piio Grande, on March 2nd, I saw four or five flying together about a bush of what I took to be the Rose Apple (Jambosa vulgaris, D.C. = Eugcnia jambos, Linn.).

Cabinet specimens give littlo idea of the beauty of this butterfly during life, since its lovely green fades rapidly. Bold, like many of its family, it will return again and again to the same perclı, often 
a dark-green leaf at or above the level of the eye. Sitting there with its wings three-quarters open it is a truly beautiful object, yet not nearly so conspicuous as might be thought, and this is true whether its wings be open or closed, whether at rest or in its rather slow flight. One courageous specimen settled first at my feet and then upon my net. In Jamaican specimens the fulvous spot at the anal angle of the hind-wing is larger and brighter than in South American; there is also somewhat more fulvous on the underside, the bands being broader.

Aganisthos orion, Fabr. (odius, Fabr.). 5 specimens. This very fine and robust Butterfly was only met with to the west of Port Antonio near the sea-level. ${ }^{1}$ A strong flier frequenting the tops of trees, especially the Star Apple, Chrysophyllum cainito, Linn., on the leaves and fruit of which it occasionally settles. More frequently it is seen to rest on tree-trunks (in particular the Logwood), on posts or buildings within a few feet of the ground, always with its head downwards and wings closed over its back. When thus settled it may be detected, if seen in profile, at a considerable distance in spite of its cryptic coloration. It is not easy to catch even when settled, and I spent much time over it. One of my specimens seems to show a bird-bite at the usual corner of the hind-wings. In the Jamaican specimens the fulvous band across the fore-wing is much broader than in those from the mainland; there is also a tendency for the fulvous on the hind-wing to be more extended. It is quite probable that sundry large brown butterflies seen at Ramble and Walderston may have belonged to this species or the next. At the suggestion of the late Col. Bingham, I tried to attract this butterfly by over-ripe bananas, scenting some with alcohol, other's with ammonia. I strolled off a short distance, returning from time to time, to find indeed no butterflies, but on each occasion fewer and fewer fragments of the fruit. On the last visit I found-an ass eating with much gusto the last piece.

Coea achcronta, Fabr. (cadmus, Cram.). A broken fore-wing of this species was picked up off the ground in a wood above Constant Spring, January 5th, 1907. The Haiti specimens in the Hope Collection are more fulvous than those from the mainland, and this fragment appears to be of Haitian type.

LyCAENIDAE.-Leptotcs (Tarucus) thconus, Lefebvie, 1856 (Plebcius

1 Messrs. Godman and Salvin ("Butterflies of St. Vincont, Gronada, etc.," Proc. Zool. Soc. Lond. 1896, p. 515) say: "Gronada. Two specimens of this common species, whioh is also found in Hispaniola, but in no other West Indian island that wo know of." It is, howovor, ono of the fow butterflies named by Gosse ("A Naturnlist's Sojourn in Jamaica" (1851), p. 99). 
cassius, Cram., var. a, floridensis, Morrison, 1874), 8 đ, 19 ․ Taken in every locality that I visited: common at Mackfield; abundant at Constant Spring, Gordon Town, and Port Antonio. The excess of females taken may be attributed to their superior size and attractiveness, but possibly they are easier to capture. It is most often seen flying over shrubs or near woods; it has a quick jerky flight, and, especially the female, appears larger than it is. After rain it is about the first butterfly to come out.

All my specimens taken in Jamaica are distinguishable at a glance from those taken in South America, Trinidad or Tobago. They are smaller and darker; the hind-wing of the male is violet-blue instead of white; the fore-wing of the female is shot with blue over at least two-thirds of the fore-wing, and there is much less white in the hindwing. On the underside the metallic-centred ocellus is larger, and there are differences in the dark markings of the fore-wing.

In my opinion it is specifically distinct from $P$. cassins, Cram., but if not distinct it is a very well-marked local race. The earliest description of the form that I can find is that by Lefebvre, and it should, I think, bear his name. ${ }^{1}$

Catochrysops hanno, Stoll (? monops, Zeller). 11 specimens. Abundant at Constant Spring, also met with at Mackfield, Walderston, and Port Antonio. Its small size and insignificant appearance probably cause it to be often passed over. It frequents small Composites by the roadside, especially Distreptus spicatus, Cass.

Callipsyche thius, Hübn. A single very fine male near the Jam Factory at the foot of the hills, Constant Spring. On the wing I took it for a Skipper. This and the specimens from Jamaica in the National Collection lack the white mark at the tip of the fore-wing of the male seen in Venezuelan examples.

Calycopis pan, Drury. Three specimens, taken in the garden at Walderston by my Portuguese servant. The lobes of the hind-wings are everted as in the Indian Aphnacus and the South African Argiolaus.

Pigrinae.-Callidryas eubule, Linn. (f. scnnac, Linn.). 17 d, 14 \%. Constant Spring (common), Gordon Town (abundant), Castleton, Temple Hall (abundant), Mandeville, Mackfield (common), Montego Bay (common), Walderston, Christiana, Spanish Town (abundant), Port Antonio (abundant).

If not actually the most abundant, it is at all events the

"Ramon de la Sagra, "Historia fisica, etc., de la Isla do Cuba," vii., p. 611, 1857. Edited by H. Lucas. In “The Buttorfly Book," 1899, ․ 270, Dr. W. J. Holland calls it Lycaena theonus, Tucas. 
most conspicuous butterfly on the island; brilliant in colour, brald in flight, and numerous in individuals, it was always much in evidence. The dry-season form prevailed, more especially as the spring advanced.

Mr. E. André ${ }^{1}$ speaks of Callidryas as a great drinker. The only time when I have seen any proof of this was when going down the beautiful Rio Grande on a raft. At about 3 p.m. five yellowisli butterflies, which I took to be $C$. eubule, were seen drinking close together on the bank.

Kricogonia lyside, Godart, 6 o, 2 q. Ramble, Montego Bay, Spanish Town, Port Antonio; not uncommon along the coast to the eastward.

Glutophrissa (?) drusilla, Cram. Common at Constant Spring, also taken at Montego Bay. This species usually flies fast and high, frequenting flowering trees and so keeping out of reach. I took a female at the flower of Eupatorium odoratum. My specimens are small, especially the females, which are quite devoid of black markings. Somewhat similar specimens from Jamaica and other islands were named ilair'c, Godart, by Mr. Butler, but the type of Godart's insect came from Brazil. In the museum at Kingston this bears, or rather bore, ${ }^{2}$ the name Appias poeyi, Butl. It is perhaps the $M y$ lothris margarita of Hübner. It would be interesting to see Jamaican specimens taken in the wet season, for the presumption is that mine are of the "dry" form.

Sphaenogona adamsi, Lathy. Of this butterfly, so rare in collections, I was fortunate enough to secure a male and three females. One of the latter was taken near Constant Spring, the other three specimens on the Manchester Mountains, viz. one at Contrivance, about $2700 \mathrm{ft}$., the other two on Mile Gully Mountain at nearly the same elevation. The solitary specimen in the National Collection is labelled "Kingston, Jamaica."

Terias (Eurema) cuterpe, Ménét., 39 đo, 21 o. The commonest species of the genus in Jamaica: Collstant Spring (abuudaut), Gordon Town (not common), Castleton, Mandeville, Rauble (abumdant), Montego Bay, Walderston (not common), Port Autonio (common). As this little butterfly flits along close to the ground it looks easy to catcli; however, it goes faster than one would think; its flight is jerky, and when struck at it almost always goes down into the herbage and so escapes the net again and again. This

1 Seo abovo, p. 103.

I I have altered the tonso from present to past, sinee the enrthquake destrojed all tho types and somo others of the Lopidoptera in tho museum. 
remark must be held to apply to several species of Terias, for they were not always distinguished in the field.

A male was taken at Mackfield with a small symmetrical injury to each hind-wing.

Terias westwoodii, Boisd. (The Jamaican form, (?) dina, Poey.) Three males, two females. Only met with at Montego Bay. It flies more freely and more strongly than the last. The Jamaican specimens are small and pale: the black on the hind-margin (especially in the female) is limited to the tip of the fore-wing.

Terices messalina, Fabr., 10 \&, 10 \%. Constant Spring, hotel grounds and wood to N.E., Mackfield (common), Montego Bay, Spanish Town, Port Antonio. It looks larger than euterpe when on the wing.

Terias delia, Cram., 16 of, 14 \%. Widely distributed, but not so common as euterpe. Constant Spring (common), Castleton, Mandeville, Mackfield, Montego Bay, Walderston, Port Antonio.

A male taken above Constant Spring at about $1000 \mathrm{ft}$. elevation on January 1st; and another male taken near Chancery Hall, $500 \mathrm{ft}$., on January 8th, approached the form lydia, Feld., in having the longitudinal black streak broader than usual. On the other hand, another male taken somewhat below the first-named and on the same day has no black streak at all, merely the streak of orange.

Terias elathea, Cram., 3 \&, 1 ‥ Scarce. Constant Spring, Montego Bay, Port Antonio (Shotover Hill).

This butterfly appears to be specifically distinct from delia, Cram., but is certainly very closely allied to it. The females are difficult to distinguish, and some specimens of the male sex not easy. In two males from Venezuela one has the black streak obsolescent, in the other entirely absent with indeed very little orange.

Pieris (Perrhybris) phileta, Fabr. (monuste, Hübn. et auct., nec Linn.), 4 o, 1 \%. Only seen at Montego Bay, and at Contrivance, Walderston. The flight of this butterfly is sometimes extremely swift, and it exercised my active Portuguese servant and myself very severely to secure three specimens near the shore of Montego Bay. ${ }^{1}$ Sometimes it may be taken at the flowers of Eupatorium odoratum, Linn. During life the clubs of the antennae are of a beautiful turquoise blne.

'Mr. P. A. Buxton found P. phileta in groat profusion about Kingston and IIandeville, April 19th-23rd, 1909, but found it easy to catch, as its flight was thon not much fastor than that of Ganoris napi in England. Ho noticed tho olubs of its antennae, but says that they wore bright green with a tinge of bluo. If $I$ was corroct in describing thom as turquoiso-bluo thoy must have fadod-just as tho stono doos. See Reports of Rugby School Natural IIistory Society, 43rd, 1909, p. 40; and 44th, 1910 , p. 26. 
Papllioninae,-Papilio polyclamas, Linn., f. polycrales, Hopfi. 7 specimens. Constant Spring (common), below Gordon 'Towu, Spanish Town; not seen on the high land. Fond of flowers, especially Bougainvillea, fluttering as it fceds, as many of the family do. A male observed flying in deep shade about 5 p.m., settled on a dead leaf and closed its wings; the underside was distinctly cryptic.

All my specimens are of the insular form in which the marginal spots of the fore-wing are paler, those of the hind-wing greener, than in South American examples: the marginal pattern on the underside of the hind-wing is coarser, with more brick-red and more white in it.

Hesperidae.-Euclamus proteus, Linn. 9 specimens. Constant Spring, below Gordon Town, Port Antonio (common). Has a quiet
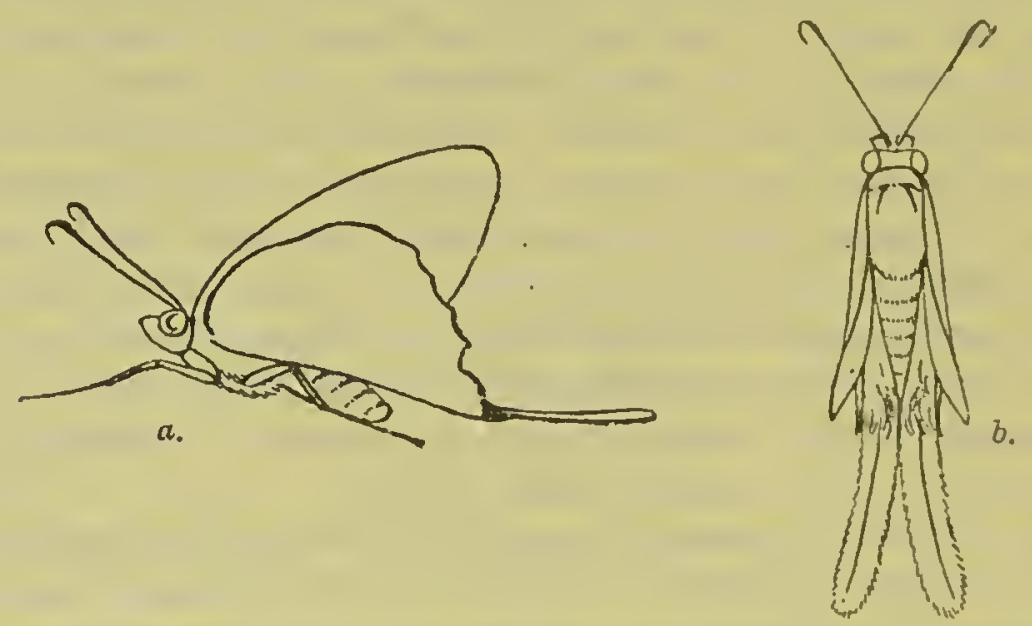

FIG. 10.-Eudamus proterus at rest. (a) Side view; (b) from abore.

flapping flight; at rest all its wings are nearly upright, but the forewings much sloped back, the tails at right angles to the plane of the hind-wings. Frequents Bougainvillea flowers. (See Fig. 10.) ${ }^{1}$

Eudamus catillus, Cram. Two specimens, taken late in the afternoon in a wood at Montego Bay; flight not very swift. (See cover of this book.)

Thymele grenadensis, Schaus. A very worn specimen on the bank of the Rio Cobre, Spanish Town; it scttled repeatedly on the same spot.

T'elegonus hurga, Schaus. A worn specimen, in the Mahogany Wood, Rockalva, Ramble. It was very bold, returning again and again to rest on the same fallen tree.

Perichares corydon, Fabr. Two. Mackfield, Montego Bay. 
Prenes nyctelius, Latr. Three. Mandeville, Shotover, East Harbour, Port Antonio.

Prenes ares, Feld. One. Shotover, Port Antonio.

Anastrus simplicior, Möschl. One. Cold Harbour, Port Antonio. Rests with the wings fully expanded.

Acolastus amyntas, Linn. One, taken by Mrs. Longstaff in the Botanic Garden, Castleton.

Serdis insolita, Butl. (aurinia, Plötz). One of each sex taken at the foot of Park Mount, Port Antonio, about 2.30 p.m. A very distinct insect identified by Mr. H. H. Druce with Plötz's excellent figure of the male from a Jamaican specimen. Mr. Godman ${ }^{1}$ says of the figure that it probably belongs to Limochores or Serdis. Mabille places it in his genus Serdis under the heading "Species non visae." 2

Ephyriades otrcus, Cram. One specimen, near Chancery Hall, Constant Spring; settled on a projecting grass stem with wings fully expanded.

Hesperia syrichthus, Fabr. Twelve. Generally distributed over the Island, especially common at Mandeville and Port Antonio. A somewhat variable species within limits. It rests with the wings fully expanded.

Hylephila phylaeus, Drury. Five. This brilliant little golden Skipper was common near the shore, Port Antonio.

Catia drurii, Latr. Two. Below Gordon Town, circa $800 \mathrm{ft}$., and on the Park Mount Road, Port Antonio, circa $600 \mathrm{ft}$. It is very hard to see. It rests with all the wings up, the fore-wings much sloped back.

Catia vesuria, Plötz. One, taken by my Portuguese servant in the garden at Walderston. There was but one specimen of this species in the National Collection and that was unnamed.

Morys valerius, Möschl. Four. Two above Constant Spring, circa $700 \mathrm{ft}$; two on Shotover, Port Antonio.

Thymelicus vibex, Hübn. (The yellowest form: T. combinata, Plötz, testc H. H. Druce.) A female came to light at Montego Bay.

Cymacnes silius, Latr. One, in the wood above the Jam Factory, Constant Spring.

1 Ann. Mag. Nat. Hist. (7), xx., p. 152 (1907).

: Genera Insectorum, Hosporidao, p. 144 . On April 5th, 1908, Mr. H. H. Druco wrote saying that among somo oddments in the British Museum he had come across the typo of Butler's Pamphila insolata. Tho specimen is from Jamnicn (labelled insolita), and appcars to be idcntical with my insects. Butlor's namo has priority since Plötz published his description in 1883. (See Proc. Zool. Soc. Lond., 1878, p. 483.) 
I call especial attention to the number of species in which Jamaican examples differ from Venczuclan in the rcplacement of black or grey by fulvous, or orange-brown. [Compare the Arctiid moth, Ammelo insulata.] It is true that the soil of Jamaica, even where the formation is white coralline limestonc, is often of an orange-brown colour, but it scarcely seems possible to connect the two as cause and effect. It is just such differences as these, occurring in different families, and not complicated by any possibility of mimicry, which seem to me to afford good evidence of the effect of environment, ${ }^{1}$ although we may at present be quite unable to explain it.

Many facts as to the scents of Jamaican butterflies, and other Bionomic points will be found in Chapter X.

\section{JAMAICAN MO'THS.}

I did not come across many moths by day, though a fair number visited the hotel lights at night, when it was noticed that they often sat quietly on brilliantly illuminated walls or blinds, in preference to going near the lamps themselves. Unless otherwise specially stated it may be assumed that all the moths in the following list were victims of the fatal attraction of light.

Syntomidae.-Cosmosoma achemon, Fabr. Two: Mackfield, Montego Bay. A common West Indian species.-Empyreuma pugione, Linn. One: Walderston. A very Zygaena-like form.

ArctindaE.-Utetheisa bella, Limn., sub sp. venusta, Dalm. (spcciosa, Walk.). Common: Constant Spring, Montego Bay, Spanish Town (at light), Port Antonio. As its several names imply this is an eren more beautiful moth than the European species; it was usually seen flying by day, both in the sun and at dusk, or was kicked up from long grass, like a Crambus.-Ammelo insulata, Walk. Common: Constant Spring, Montego Bay, Walderston. Jamaican specimens arc yellower than Venezuelan; A. helops, Cram. (Halosidota chrysogastcr, Walk.). Two: Mandeville, Montego Bay.-Arc marginata, Drury. Two males and onc female: Mandeville, Ramble, Mackfield.-Automolis delicata, Möschl. A single specimen of this very beantiful insect came to light at Constant Spring; it well descrves its namc; as the British Museum posscsses but three spccimcns, all from Jamaica, it is presumably not common.-Ecpantheria nigriplaga:

1 The insects roforred to aro still kept together just as they wcre exhibited at the Darwin Colcbration at the Limuean Society, and may be secu in the Hope Department of the Oxford University Museum. 
Walk. A male taken at Mackfield.-Opharus bimaculatus, Dewitz. One at Montego Bay. The British Museum has but three specimens, all from Central America.-Euglyphia hicroglyphica, Cram. One at Constant Spring. [A specimen of this lovely moth was captured in the West India Docks, London, in 1867.]—Theages strigosa, Walk. Two: Montego Bay, Walderston. The latter specimen was taken by a new method: a black hand-maiden of the household saw it enter the huge white corolla of the Beaumontia; she deftly tied up the mouth of the flower, plucked it with the insect imprisoned, and brought it to me in triumph! In that climate this glorious creeper has been known to grow 18 feet in one season. More than once I saw a humming bird enter one of its capacious white tubes and sit down to feed, but whether on honey or on insects was not determined.

Noctuidae.-Agrotis ypsilon, Rott. A specimen of this cosmopolitan species came to light at Spanish Town.-Pcrigea subaurea, Guen. Common: Mandeville, Mackfield, Walderston, Spanish Town. A neatly marked species, recalling Hydroecia nictitans.Prodenia signifera, Walk. One at Mandeville; $P$. cupentia, Cram. Two at Walderston. A pretty chocolate and grey species.-Cirphis latiuscula, H.-Schäff. Three : Constant Spring, Montego Bay; C. numidicolc, Guen. Four : Mackfield, Montego Bay, Walderston.Cydosia histrio, Fabr. Three: Constant Spring, Montego Bay. A spotted red and black insect with white hind-wings, which I took to be an Arctiid.-Monodes nucicolora, Guen. Three: Spanish Town.Poaphila immunis, Guen. Four: Constant Spring, Montego Bay. A common West Indian species.-Remigia repanda, Fabr. Abundant: Constant Spring, Mandeville, Montego Bay, Walderston. A variable insect, some specimens coming very near to the Oriental $R$. archesia, Cram.; R. megas, Guen. One at Walderston.-Erebus odorus, Fabr. One specimen of this large, broad-winged moth came to light at Constant Spring; another was either disturbed, or flew by day of its own accord at Spanish Town.-Homoptera lunata, Drury. Two: Mandeville, Montego Bay.-Melipotis bistriga, Walk. One at Montego Bay; M.manipularis, Guen. 'Two at Spanish Town; M.parens, Walk. Two at Spanish Town; not a common species._Elousa albicans, Walk. One at Spanish Town; a small grey and white insect.

Deltoidak.-Ethnistis munitalis, Ledr. Threc: Constant Spring, Mandcrille.

Hypsidak,-Tauron crgolis, Walk. One at Constant Spring; a good mimic of Ithomia.

DAlceridat.-Acrage ciliata, Walk. A malc at Coustaut. 
Spring. This species is represented in the British Museum by Walker's type only, a female. ${ }^{1}$

Cossidat-Duomitus jamaicensis, Schaus. Two at Constant Spring. This may be described as a Leopard-moth with the wingpattern of a Goat-moth.

SpHingidae.--Theretra nechus, Cram. Two: Mandeville, Walderston.-Ancyryx alope, Druce. One at Montego Bay.-Calliomma pluto, Fabr. One at Montego Bay. - Cocytius (?) medon, Stoll (?.duponchelii, Poey). One at the flowers of Beaumontia, Walderston. - Pachylia ficus, Linn. One at Spanish Town.

URANidDaE.-Sematura aegistus, Fabr. Six: Mandeville, Walderston. One taken on the wing just before dusk, the others at light.

The clever drawing made by $\mathrm{Mr}$. $\mathrm{H}$. Knight (from my sketch and specially set specimens) illustrates the very peculiar attitude adopted by this common Jamaican moth. The hind-wings are somewhat fluted, as in Pararge acgeria, the anal angle of the hind-wings is inverted, not everted as in the Lycaenids. A procryptic resemblance to a dead leaf might be naturally suggested as a possible explanation,

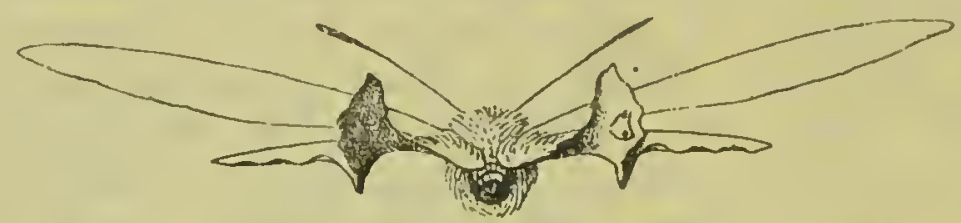

FIG. 11.-Semalura aegistus at rest, viewed from behind.

but the only specimens that I have seen at rest were inside houses whither they had been attracted by light.

Geometridae.-Ourapteryx flavifimbria, Walk. A white moth, of which I took one specimen at Mackfield.-Orthogramma coppryi, Guen. One at Constant Spring; it somewhat resembles Ennomos fuscantaria.-Sabulodes subopalaria, Walk. One at Mandeville.Nepheloleuca politia, Cram. Two: Mandeville, Montego Bay.Oenothalia alexonaria, Walk. One at Walderston; the British Museum possesses two only, paler than mine.-Biston arnabia, Cram. A male at Spanish Town: a whitish-grey moth.-Oxydia vesulia, Cram. Three: Mandeville, Walderston; a variable species--Hyria rubripictata, Himpsn. A single specimen of this very pretty little purple and gold moth came to light at Walderston.-Racheospila (?) undulosa, Kaye (? rufilineata, Warr.). Two woru specimens at Constant Spring; R. sigillaria, Guen. (congruata, Walk.) One at

1 Tho Dalceridac are a small group near the Lasiocampidac, but rescmbling the Lymantriidac. 
Montego Bay. This is a small Emerald with pink margins to the wings.-Tachyphylc (Diehorda) iris, Butl. Two at Montego Bay; a small bright green Emerald.--Anisodes ordinata, Walk. One at Mandeville [like Ephyıa pendularia, but larger]; A. conspicillaria, Snell. One at Mandeville, a little thing; $A$. coxaria, Guen. One at Mackfield.-Bapta tributaria, Walk., f. argentea, Warr. (type from Jamaica). One worn specimen of this glistening white moth came to light at Walderston.-Hammaptera tcnera, Warr. Six at Montego Bay.-Craspedica compensata, Walk. One at Constant Spring.-Triphosa stellata, Gueu. Two: Constant Spring, Montego Bay. [Like a small Scotosia.]-Pterocypha defensata, Walk. Four: Montego Bay, Spanish Town; an extremely variable Larentiid.-Drepanodes sp. A moth came to light, at Montego Bay, which may be a dark form of $D$. falcularia, Sepp., otherwise it is not represented in the British Museum. Mr. L. B. Prout thinks it is probably a new species.

Pyralidae.-Pyrausta insignitalis, Guen. A single specimen was taken in the wood behind "The Retreat," Constant Spring, flying very low down among the herbage; it looks golden-yellow on the wing; $P$. meninalis, Hübu. One at Constant Spring; P. carclinalalis, Guen. A tiny scarlet and black moth; one was taken flying in the sun at Castleton; another came to light at Constant Spring; it is curious that these sun-loving Pyrales are often taken at light; $P$. agathalis, Walk. One at Mackfield. This is another little Purple and Gold, that one would have expected to take in sunshine rather than at the electric light; $P$. signatalis, Walk. One at Montego Bay.-Zinckenia perspcctalis, Hübn. One at Walderston. This would appear to be a common species, it is black. - Nacoleic indicata, Fabr. Three: Constant Spring, Castleton, Mackfield; $N$. annulalis, Hübn. One at Montego Bay.-Argyractis jalapalis, Schaus. Two at Constant Spring; a China-mark.-Crocidophor'a huronalis, Guen. Two: Constant Spring, Walderston; a goldenbrown moth with neat laced pattern.-Dcsmia tages, Cram. One at Mandeville.-Salobrena rubiginea, Hmpsn. Seven: Maudeville, Walderston, Constant Spring; a very distinct looking thing, brick-red with truncate fore-wings. - Syngamia florclla, Cram. Four specimens of this purple, gold-spotted moth came to light at Mandeville, but it was also met with by day at Christiana and the Bog Walk, Spanish Town; S. tytiusulis, Walk. One at Mackfield; a tiny light grey creature-Samia ecclesialis, Guen. Four: Mandeville, Walderston. A moth with lace-like pattern.-Pachyzancla phocopteralis, Guen. One at Montego Bay, at light; one at Port Antonio, by day. This is a dingy, widely distributed species.-Glyphodes inciclatis, Hübn. Two: 
Mandeville, Montego Bay; G. hyalinata, Limn. One at Montego Bay; a pearly dark-bordered moth; G. aurocostalis, Guen. Three: Montego Bay, Spanish Town; white with fawn-coloured costa.-Leucinodes orbonalis, Guen. Three at Contant Spring.-Nomophila noctuellu, Schiff. Two: Constant Spring, Castleton. This is one of the most generally distributed of moths.-Platytes opposita, Zell. Cominon : Constant Spring, Mackfield; a tiny silver-white Crambid.

Tineidae.-Autoceras mixta, Möschl. Four : Castleton, Montego Bay, Walderston; a Hyponomeutid.

For the entomologist who, in consequence of age, infirmity; fatigue, or mere lack of enterprise, does not venture into the wilds by night, the lamp is an excellent means of collecting, and one by which some insight may be obtained into the moth fauna of a locality of which the traveller might otherwise have no idea. It has, however, two grave disadvantages: (1) a great number of odd specimens are obtained, and (2) it gives no information as to the place of abode, or mode of life of the insects captured.' Boxing moths off lamps is much like cutting stamps off envelopes, it does not tell you anything about the countries from which they come. "Light" is admirable from the point of view of the systematists and of the "mere collector," but not very profitable to the naturalist.

\section{JAMAICAN BEETLES.}

I did not spend much time in looking for Beetles, and what little work I did in that way was disappointing. As a group the Lamellicorns were the most obvious. Rotten wood produced fair numbers of Scalmus (Ninus) interstitialis, Esch., a large beetle which I found at Constant Spring, Mackfield, and Port Antonio. When landled, especially when first handled, they emitted a creaking sound, caused by an evident up-and-down movement of the abdomen, but whether or no this rubs against the elytra, I was not able to satisfy myself. The rufous colour of young individuals presents a fine contrast to the black of adults. At Stoney Hill, near Coustant Spring, a dead specimen of Macraspis tetradactyla, Linn., was found in a rotten log; my servant took another at Walderston flying in the garden. A Gymnetis lanius, Linn., locally known as the "News-bug "-being the supposed bringer of news-was found in a house at Walderston; it is a creature with very hard integuments. Ligyrustumulosus, Burm.,

' Mr. F. R. D. Onslow says that light attracts far moro males than fomales. 
ventured even on to the Governor's dining-table in the King's House, but that was after the earthquake had shaken all institutions to their very foundations. The Scarab, Phanaens sulcatus, Drury (belzebul, Fabr.), Mandeville, Walderston, was abundant flying about dung at dusk, it also came to light and one was "found drowned." The small Chafer, Cyclocephala signata, Drury, came freely to light at Constant Spring and Spanish Town. These beetles are locally known as "Hard-backs," though they are in reality somewhat soft, as beetles go. Democrates croesus, Newm. Four came to light at Walderston, and one was found in a hole in the earth under a stone. Of Lachnosterna sp. a specimen came to light at Spanish Town; the British Museum possesses a single, unnamed, specimen from Jamaica.

The Longicorns were somewhat insignificant; Achryson surinamum, Linn., turned up in our bedroom at Constant Spring. Lagochirus ananeformis, Linn., came to light at Montego Bay. Chlorida festiva, Linn., came to light at Port Antonio. Elaphidion spinicorne, Drury, did the same at Constant Spring.

At Mackfield on February 1st my servant brought me a specimen of the Elaterid Fire-fly, Pyrophorus noctilucus, Linn., which exhibited a pair of constant green lights from points near either angle of the prothorax. It "clicked" violently when held in the fingers, but I failed to make it display a red light as described by Gosse. ${ }^{1}$ When the green lights were dying out they seemed to pulsate. Unfortunately I had no further opportunity of observing this interesting insect, but the smaller Fire-fly, Photuris jamaicensis, Ernst Oliv., was a frequent visitor to the hotel lights at Constant Spring, Mandeville, Walderston, and especially Castleton. This Firefly, which belongs to quite a different group, the Malacodermata, exhibited on irritation an intermittent bright green light on the under-side of the last two segments of the abdomen. The scintillations appeared to be about 20 to 25 per minute. Four of the beetles werc put into the cyanide-bottle with the result that their lights at once became continuous and remained so; the insects themselves appeared to become insensible almost immediately. After the expiration of 15 minutes the light of two of the insects was rather faint; after] 25 minutes one was very nearly extinct; after 35 minutes all the lights were faint, one was scarcely visible; after 50 minutes three of the insects were still distinctly, though faintly, luminous; at 64 minutes three of the lights were nearly out, the fourth was faint. Bed-time terminated the experiment. Another beetle of the same species ' "A Naturalist's Sojourn in Jamaica," p. 102 (1851). 
experimented upon five weeks later was still faintly luminous after being 75 minutes in the cyanide-bottle. ${ }^{1}$

The Lycid Thonaimus militaris, Dalm., was taken by day on the wing at Mandeville and Walderston. Lady-birds were fairly numerous, by far the commonest being Neda sanguinea, Linn., which I met with at almost every place I visited, it was taken by sweeping, at rest on various plants, etc. Brachyacantha erythrocephala, Fabr., occurred somewhat commonly at Walderston, Christiana, and to the east of Port Antonio. Of Hyperaspis connectens, Thunb., I took a single example at Christiana. At Port Antonio, close by the sea, I captured a single specimen of another Lady-bird which is not represented at South Kensington.

Of the Hydrophilidae I took at Walderston under bark of rotten wood two specimens of a Cyclonotum, and Mrs. Longstaff found another in a snail shell at Mackfield. At Spanish Town among dead leaves near the Rio Cobre I obtained four specimens of another species of the same genus. In company with them were two of a Histerid of the genus Epierus.

Other miscellaneous beetles were a Diabrotica which came to light at Walderston; the British Museum has the species, but it is nameless. Of Haltica jamaicensis, Fabr., two turned up at Christiana sitting on a plant which looked very like Willow Herb, Epilobium hirsutum, Linn. Sweeping at Port Antonio yielded three Ccratoma ruficornis, Oliv. At the top of Park Mount, Port Antonio, circa $1000 \mathrm{ft}$., three specimens of a distinct, prettily marked Weevil, a Cholus of a species not in the British Museum, were taken; two of them were obtained by sweeping, the third was found on the underside of a stem, apparently seeking shelter from the rain. Of another Weevil, a glaucous green insect, which Mr. Gahan assured me was not represented in the National Collection, one was taken at Constant Spring on a leaf of a species of (?) Acacia, where it mas strangely conspicuous; two others were found by Miss Walders on Tropaeolum in her garden at Walderston. A fungus (? Polyporus) on a $\log$ by the Rio Cobre at Spanish Town was full of a species of Arrhcnoplitis, of which there are unnamed Jamaican representatives at South Kensington.

\section{JAMAICAN BUGS.}

The Pentatomid Loxa flavicollis, Drury, a large green fetid beast, with a long spine on each shoulder, came to light at Constant Spring

' Compare pp. 327, 333, infra. For Fire-flies of Ceylon, see below, pp. 378, 379. 
and Montego Bay. Nezara marginata, Beauv., a smaller but also offensive insect occurred at the same localities, falling to the beating stick. The fetid brown Piezodorus guildingi, Westw., was swept up at Constant Spring and Ramble.

The Lygaeids were represented by the brilliant scarlet and black Dysdercus jamaicensis, Walk., of which two came to light at Walderston, together with the similarly coloured $D$. andreae, Linn., and $D$. mimus, Say. Of these $D$. andreae was very abundant on some cotton plants in the cemetery at Montego Bay, and D. mimus might be obtained in any numbers by sweeping at Constant Spring, Ramble, Walderston, or Port Antonio.

The Coreid Jadera aeola, Dall., came somewhat freely to light at Montego Bay and Walderston.

Other bugs were Euchistus bigibbulus, Beauv., a small dark brown insect with spiny shoulders, which was swept at Constant Spring, but came to light at Port Antonio; Lycambis triangulus, Spin., which I beat out in the cemetery at Montego Bay, is a bug with highly developed femora; a black Phthia with brilliant orange markings, found crawling on the ground by my servant on the slopes of Mile Gully Mountain, at an elevation of about $2400 \mathrm{ft}$.; it was unrepresented in the National Collection; a Charicsterus, also unrepresented at South Kensington, was swept up near the shore to the east of Port Antonio; while sweeping on Shotover yielded three of the red and black Oncopeltus fasciatus, Dall.

A concrete reservoir in the Castleton Gardens yielded half a dozen of a Ranatra allied to, if not identical with, fusca, Beauv.

However, my greatest triumph in the bug line occurred in this fashion:-After retiring to bed at Constant Spring I was aroused by a knocking at the door and a man's voice calling to me eagerly to bring my net as he had a very big bug. As the entomological language of the "Pearl of the Antilles" takes a strong colour from the Great Republic, I expected to find a Sphinx or a big Noctuid, and sallied forth in my pyjamas. It was somewhat disconcerting to find quite a party on the landing, including a lady. A gentleman held in a folded handkerchief a huge water-bug called by Americans the Electric Bug on account of its frequenting the electric lights. I was myself somewhat awed, not having seen such an animal before, it is three inches long and over an inch wide! Judging from a neverforgotten boyish experience of our little British Naucoris cimicoides, Linn., the American insect, Bclostoma colossicum, Stål, might inflict a most painful wound. 


\section{JAMAICAN ACULEATES.}

Two forms of Honey-bee were met with, Apis mellifica, f. ligustica, and $A$. mellifica, f. mellifica, the latter being somewhat the commoner. I do not appear to have come across more than two Carpenter-bees, Xylocopa aeneipennis, De Geer, both at the flowers of Bougainvillea in the garden of the Constant Spring hotel. Perhaps the commonest bee in the island was Exomolopsis rufitarsis, Smith, which was to be found at Constant Spring at the flowers of a blue Labiate, and was swept up at dusk; it was also obtained near Port Antonio, by sweeping. The same method of collecting at both the last-named place and Ramble frequently yielded a species of Augochlora, which at Port Antonio was in company with a Halictus and a Ceratina.

The only Wasp found in any numbers was Polistes crinita, Fell, which occurred at Spanish Town, Christiana and Port Antonio, but was abundant at Constant Spring where its pedunculated nests stood in rows in one of the bath-rooms, a somewhat fearsome sight; it was also to be seen at the flowers of Eupatorium odoratum, and Polygonum (?) acre, Kth. Sweeping at dusk at Constant Spring yielded several Odynerus simplicicornis, Sauss.; of O. grenadcnsis, Ashmd., a female was captured at Port Antonio. At Chancery Hall, not a great way from Constant Spring, I took both sexes of the Scoliid Dielis plumipes, Drury, on Eupatorium odoratum; the female is a large handsome dark-yellow and black insect, the male is smaller, more slender and paler. Sweeping at Port Antonio produced a single specimen of Plesia (Elis) nitida, Smith, together with an unnamed Notogonia.

The most obvious Ants were Camponotus conspicuus, Smith, and Odontomachus (?) haematodes, Linn. The former is of a yellow-red colour; its female camc to light at Constant Spring, and amputated its own wings shortly after capture. A large community was found at Mackfield in a dying Banana-tree, which was in a wet pulpy condition, seemingly in consequence of the operations of some internalfeeding larva. At Walderston a number of the same ants were found in a hollow dead stick, as well as under a stone; it was also met with at Montpelier station and at Port Antonio. They were extremely active and swift in thcir movements, but thcir bite was quite trifling; on the other hand, they were protected by very hard integuments; and exhaled a strong odour of formic acid, nevertheless cocks and hens fed on them grecdily. The Odontomachus is a much more formidable insect of a blackish colour; less active in its morements 
than the other kind, it goes about with its jaws widely extended, evidently seeking whom it may devour. Its bite is severe, decidedly painful at the time though not producing any lasting effect; doubtless its more powerful armament permitted it to indulge in more leisurely movements. It was common at Mackfield, and a female came to light at Montego Bay. A nest was found in a rotten log of rrood.

\section{JAMAICAN ORTHOPTERA.}

None of my Neuroptera, and very few of my Orthoptera, havc as yet been named, but nevertheless the latter are not without interest. One day at Walderston when hunting among vegetable débris for Land Shells, I saw, as I thought, a dead leaf move, and assume a position like a Satyrine butterfly sitting up with closed wings, but it proved to be Phyllotettix rhombeum, Felton, an Acridian with a leaflike expansion of the pronotum. Mr. Shelford tells me that this curious insect was originally described, from a Jamaican specimen, in a letter from Samuel Felton, F.R.S., to Henry Baker, dated December 2nd, 1763, as Cicada rhombea. ${ }^{1}$

At Castleton a servant caught in his bedroom a big Acridian which bit like a bull-dog, actually drawing blood. When treated with chloroform it bit yet harder.

On February 6th, at Walderston, a Locustid came to light. Its head, the upper part of its face and base of the antennae were black; the elytra and greater part of the antennae were pale brown; the rest of the animal of a light yellow-green. On February 26th, during dinner at Port Antonio, one of the black waiters brought me another specimen on a salver-my wife said "like John the Baptist's head in a charger" - with the question, "Is this any good, sah?" To the great amusement of the company I produced a box from my pocket ${ }^{2}$ and secured it, saying sotto voce to my wife: "I don't care much about these things and I already have one, but it will please the waiter." Three years afterwards I was startled to come across a description by Dr. Achillc Griffini of Gryllacris longstaffi, sp. nov. ${ }^{3}$ This travelled specirnen had been sent by Mr. Shclford to Genoa,

1 Phil. Trans. Roy. Soc., 1765, vol, liv., Tab. vi., p. 55. Also Linnacus, Syst. Nat., Ed, xii. 1767. Tom. i. Pars ii. pp. 704, 705, where Linnaeus erroneously attributes the insect to- "Backer, auct. Angl."

2 Why is it that the production of a pill-box from a collector's pocket affords such amusement to tho looker-on? It is a strange and as jet unexplained psychological fact.

3 Ann. Mag. Nat. Mist. (8), iii., p. 366 (1909). 
where it was reported to present such unusual structural characteristics as to make it possible that it should be referred to a new genus, but the point could not be settled as both my specimens are males. [Plate III., Fig. 6.]

One day during a meal at Constant Spring I saw a curious spider (? Gasteracantha sp.) spinning a web on a rose in a flower-vase; its abdomen was protected with a hard spine-bearing carapace.

\section{NOTES ON THE LAND MOLLUSCA OF JAMATCA.}

By Mrs. G. B. Longstaft; F.L.S.

Jamaica is well known to be one of the richest regions in the world for land shells. Unfortunately we were there in the dry season, so it was more or less difficult to procure living specimens, nevertheless we managed to get a fairly representative series. Dead shells were found in great numbers and often in a remarkably good state of preservation. The wide extent of limestone is probably one reason for the richness of the molluscan fauna. Shells were observed to be most numerous on the limestones of Tertiary age, especially on the "White Limestone" of Oligocene age." There were nothing like as many specimens on the limestone of Pleistocene age; this was very noticeable in the neighbourhood of Port Antonio, where both formations occur.

Shells were met with in great numbers in recesses or cavities of the limestone, also under loose stones in the so-called sinks. They were not only found thus in the wild uncultivated parts, but also in banana and yam plantations, where they were living both under stones and under leaves, and also attached to the stems of trees. Their frequency in cultivated ground stands in marked contrast to their absence from such habitats in other countries. In New Zealand, for instance, it was rare to find any but introduced species in gardens, quarries, \&c., endemic forms being confined to the bush and other uncultivated land. This was also more or less the case in Ceylon.

None of the land shells of Jamaica attain a very great size, the largest being decidedly smaller than the well-known Bulimus oblongus, Müll., of Barbados and Tobago. Many, however, are characterized by great beauty of form and colour, and some are remarkable for the development of numerous teeth which in certain instances almost close the aperture, so that it is a matter of wonder

1 "Gool, and Phys. Geogr. of Jamaica," by R. T. Hill, 1899. 
how the animal protrudes itself or retires again. Some of the sinaller speeies of Pleurodonte, Fischer, are instances of this latter charaeteristic. The genus is endemic to Jamaica, and we met with one or more speeies at every plaee we visited, in all twenty-three distinet forms being taken. The speeies with the exeeption of $P$. aeuta, Lam., and $P$. sinuatce, Müll., have a limited range. I found the former or one of its varieties wherever we went, except at Montego Bay, but the latter I only happened to meet with at Walderston, though Mr. Jarvis states that its distribution is general. Very fine examples of $P$. acuta were obtained near Walderston by turning over a heap of big stones by the roadside; these varied in the colour of the inside of the lip from deep manve to light brown, the teeth also varied both in size and number, there being either one or two, or else they might be absent altogether. The small var. sublucernc, Pils., was taken abundantly among dead leaves near the Rio Cobre at Spanish Town, and small forms which come very near this variety were found at Mandeville. There oceurred near Maekfield, as well as the typieal form, a large variety which was remarkably flat and thin. In the distriet of Mackfield - whieh was partieularly rieh in shellsmany of the smaller speeies with numerous teeth oceurring there, such as $P$. sehroeteriana, Pfr., P. pieturcta, Ads., P. tridentina, Fer., and $P$. olieniana, Pfr. The first-named was especially abundant under the sheaths of the leaves forming the stems of banana trees. ${ }^{1}$ Two dead representatives only of $P$. bronni, Pfr., were found at Montego Bay. No speeies taken were eommon to both Montego Bay and Mackfield, but $P$. sloaneana, Shuttl., was found at the former place, and also at Montpelier. $P$. invalida, Ads., was met with both in the neighbourhood of Spanish Town and Constant Spring. P. sinuosc, Fer., was found at the latter, but appeared only to be represented by its var. simson, Pfr., at the former loeality. Besides $P$. aeuta, only two species were seen common to Mandeville and Walderston, viz. P. bainbridgei, Pfr., and P. peraeutissima, Ads., the speeimens of the former were dead. $P$. ear $a$, Ads., was taken at Walderston alone. At this locality a small variety of $P$. peracutissima was found resembling $P$. earce in size and $P$. sehrocteriana in the lighter colour of the kecl. There arc also two speeimens of this peculiar form in the British Museum (Nat. Hist.). 'The commonest species at Port Antonio was $P$. valida, Ads.

1 Mr. William Fawcott, F.L.S., whose knowledgo of the plant is unrivalled, tclls me that the Banana has no true stem. The flower bud is formed at the lovel of the ground and grows up through the lcaf-sheaths until it makes its appearance where tho loaf.stalks separate. 
Other characteristic members of the Helicidae found were Thelidomus aspera, Fcr., and Eurycratera jamaicensis, Gmel., both occurring in Manchester and Westmorland and the latter at Stoney Hill, near Kingston, as well; two species of Dialeuca, Albcrs, $D$. conspcrsula, var. fuscocincta, Ads., at Walderston, and D. subcanica, Ads, at Constant Spring and Port Antonio; four species of Zaplyyscmo, Pils., all of which were taken in Manchester, two also in Westmorland, and one, Z. tencrima, Ads., had a still wider distribution occurring also in the Bog Walk; Hemitrochus grammicala, Ads., at Mandeville and Constant Spring. Six species of the curious bee-hive shaped Sagda, Beck, were found, and probably more were seen and passed over on account of the strong resemblance of the different species to one another. The largest form found, S. magna, was only taken at Mackfield, and the small transparent S. pila, Ads., was tolerably frequent at Walderston. The handsome Zebra undata, Müll., was abundant at Spanish Town, adhering to trees so firmly as to be removed with difficulty.

Several species of the graceful Cylindrella were taken, the white shells when hanging from limestone rocks looking like delicate stalactites, while the small, slender, dark brown specimens resembled cigars in miniature. Examples of Lia, Albers, and Hacroceramus, Guilding, were also found. Specimens of the carnivorous Glandina, and of the ugly coriaceous slug Vaginula, were met with. Among the freshwater forms Semisinus lineolata, Ads., was perhaps the most characteristic; it was found both in the Rio Cobre, and also near Mackfield. Species of Neritina occurred at the latter locnlity as wcll as near Port Antonio.

A fairly good series of the Hclicinidae was obtained. Besides the type Helieina ncritclla, Lam., which was widely distributed, occurring at Mackfield, Mandeville, Walderston and Port Antonio, there were found species of the subgenera Pocnia, Ads., Alcadia, Gray, Eutrochatclla, Fischer, and Lucidclla, Swainson. E. joscphinac, Ads., var. pulchra, Ads., taken at Mackfield, may be mentioned as an espccially beautiful form with its delicate plaited frill romd the periphery; when attached to the limestone rock its ycllowish grcy colouring renders it cryptic. The dark reddish-brown, hirsute cpidermis of A. palliata, Ads., and allied specics makes them cryptic also when fornd in the soil under pieces of rock or dead learcs.

Two species of the bcautifully coloured and polished Proscrpina, Gray, wcre taken: 1'. niticla, Sow., occurred in great numbers near Mandcville, it was also found at Walderston, and its rariety, planulata, Ads., at Mackfield; this is larger and varics from canary 
yellow to rich orange brown; $P$. pisum, Ads., seemed more unconmon, and two specimens only were met with at Mackfield.

Many other species were obtained, but spacc only admits of some of the most characteristic being noticed here.

I am greatly indebted to Mr. P. W. Jarvis for some of the names, and to Mr. E. Smith for access to the Chitty, as well as the fine general, collection in the British Museum (Natural History), with the aid of which I named the Helicidae and Helicinidae.

\section{PANAMA.}

March 11th and 12th, 1907.

On our return voyage the elements offercd no obstacle to our entrance into Colon, and we at once took the train across the isthmus. The energy of our American cousins showed itself on every side. They have double-tracked the railway: on every eminence rise meat-safe-like barracks to accommodate the 80,000 labourers upon the pay-rolls. The French plant, being thought not quite up to date, has been replaced by machinery of the newest type and scores of locomotives, "steam-shovels," and the like, just stripped of their brass, are rusting by the roadside, a sad monument of wasted money and labour. Everywhere new lines are being laid, new roads are being formed, and the primaeval forest is being cleared away. Much vegetation has becn destroyed by pouring paraffin oil on to the swamps to kill mosquitos. In short everything is being burmed, blasted, and dammed.

Mrs. Longstaff caught sight of a Caiman in the Rio Chagrcs. How turbulent that treacherous stream may on occasion be, was shown by a large dredger that lay stranded many feet above the ordinary level of the river.

The huge American hotel at Ancon is pretentious, structurally bad, and ill-managed. Wire screens intended to exclude mosquitos make the rooms insufferably hot, but are so badly fitted that bluebottles-not to say bumble-bces-could casily pass through thc gaping cracks between the window linings and the screens.

When driving into the old Spanish city of Panama late in the afternoon a large buttcrfly settled in our buggy and was sccured by Major Elton; it proved to be the Brassolinc, Opsiphancs cassiac, Linn.

At the hottest hour of the afternoon I climbcd the conical hill of 
Ancon, about $500 \mathrm{ft}$. It was so steep that it was quite difficult to make one's way up over the short dry grass, and the heat was intense. Under such circumstances it was not possible to get very much, especially as the most productive part of the day had passed. Of two Papilio polydamas, Linn., and several Euptychic oreba, Butl, seen, one of each was captured. A Phoebis was seen but missed. A black and red Heliconius in dense scrub was quite inaccessible. The Erycinid Mesene silaris, Godm. \& S. (which, by the way, was not represented in the British Museum) was observed to have a moth-like flight. Two females of Terias delia, Cram., were both of the dry-season form; certainly everything on that hot hill was dry enough! The Skippers, which always contributed so largely to the bag, were Eudamus simplicius, Stoll ; Megistias labdaeus, Godm.; Morys valerius, Möschl. : Hesperia syriehthus, Fabr., and H. laviana, Hew. Several of the beautiful Utetheisa ornatrix, Linn., were seen among grass. A Wasp, Montezumia coerulea, Sauss., was taken as well as Sphex (Isodontia) costipennis, Spin., and S. nigrocoeruleus, Tasch., which last Mr. Rowland Turner says is not a common insect.

Close to the top of the hill, in a somewhat scrubby wood, a procession of "Parasol-ants," Atta sexdens, Linn., was seen on the march across the path. I could follow them forwards for about two yards only where the column was lost in the dense undergrowth, but was able to trace thcm back about 8 yards to a tall tree from which they were bringing their "parasols," or pieces of leaf much bigger than themselves, a fact that may be verified by reference to the Hope Collection at Oxford.

A walk the next morning on lower ground near the railway was most disappointing in its results. Danaida archippus put in an appearance. I took three females of Preeis lavinia, one of them the ocellated form, but two were very "dry," one of the latter being an aberration with very dark hind-wings, almost destitute of any fulrous colour; there were also a few P. jatrophae about. Of Tcrias dctia I secured two intermediate males, and one dry-season female; as is so often found the "dry" character's were more marked in the latter sex. A pale Hamearis erostratus, Hew., was the sole Erycinid, a Catochrysops hanno the sole Lycaenid. There wcre but two Skippcrs, the common Hesperia syrichthus, and a male Thymelicus athenion, Hübn. The bug Hypselonotus fulvus, De Geer, was obtained by swecping.

On our way back at night the Sphinx, Dilophonota oenotrus, Stoll, came to the lights of the train at Christobal station. 


\section{VENEZUELA. \\ March 17th-March 31st, 1907.}

I landed on the Venezuelan shore for the second time March 17th, 1907 , but on this occasion the whole afternoon was spent ill struggling with the authorities of the port, so that it was necessary to spend a night at La Guaira. The next day a few minutes' halt at Zigzag Station, about $1500 \mathrm{ft}$. up the railway to the capital, enabled me to sample the insect fauna. Butterflies were very plentiful, and I ran back to the railway carriage with specimens of Actinote antaeas, Dbl. \& H.; Euptychia phares, Godart, a species that I did not see again; Phyciodes leucodesma, Terias albula, and Hesperia syrichthus; together with sundry Wasps, Bugs, and Grasshoppers. These included a large Polistes with dark wings and pale tarsi; the Bee, Melipona capitata, Smith, and the conspicuous greyish-black, purple-winged social wasp, Synoeca cyanea, var. ultramarina. The Bugs, narrow brown fellows, were Catorrhintha guttula, Fabr.

The railway, after many terror-inspiring twists, which made us glad that it was under British administration, gains access to the capital by a gap in the mountains on its western side.

CARÁCAS stands at a mean altitude of $3200 \mathrm{ft}$. above the sea in North Lat. $10^{\circ} 30^{\prime}$. The city is beautifully situated on a plateau sloping southwards to the Rio Guaire; this plateau is open to the East towards Petare, closed to the West by the Observatory Hill some $300 \mathrm{ft}$. above the plain; on the South it is bounded by two low ridges that separate Carácas from El Valle, but on the North it is dominated by a lofty range of mountains, which, rising abruptly from the valley, culminate to the North-West in Silla, $8760 \mathrm{ft}$., and Naiguata, $9300 \mathrm{ft}$.

The Observatory commands a grand prospect, but the path leading to it was far from productive, yielding only Phyciodes anicta, Hew.; Synchloë lacinia, Hübn., the dark form; Leptotcs cassius, botl工 sexes; Terias elathca, a male, an aberration of the "moderately dry" form in which there was no tracc of the usually conspicuous longitudinal black streak, and scarcely any of the orange border thereto; also Hesperia notata, Blanch., the only example taken.

The village of EL VALLE stands at about the same level as Carácas, some four miles to the south, and as it is conveniently placed at the terminus of a tramway I visited it three times, but my first

3 This section is reprinted almost as it first appeared in the Entornologist's Monthly Magazine, 2nd Series, vol. xix., 1908, pp. 69-76, 118-123. 
visit was spoilt by heavy rain. A bluff on the outskirts of the village displayed sufficient flowers to attract a fair number of insects, the best of which was the large Skipper, Prenes cvadnes, Cram., the only one that I met with, but a lane leading from the village southwards to a ford proved a better collecting ground. This lane, bounded on either side by a wet ditch and a flowery hedge, had an English look that was delightfully refreshing. Here were a number of the commoner butterflies, conspicuous among them the Brimstone, Callidryas cubule, f. sennae, of both sexes, though it was not as common as in Barbados or Jamaica; Danaida archippus (plexippus); Actinote antaeas, the beautiful yellow and black Heliconius charithonius charithonius; the brilliant red, black and white Anartia amalthea, flying, as usual, close to the water, but unfortunately in poor condition; the dingy Satyrine, Euptychia hermes (camerta, Cram.), together with its more attractive white-striped congener, $E$. hesione; there were also several males of the Common White of those parts, Leptophobia aripa, Boisd., and a male of the common Terias albula, a white member of a yellow genus. But besides these familiar forms there were several of greater interest, at all events to one new to South America. The small Nymphalines, Phyciodes lelex, Bates, and P. liriope, Cram.; a female of T'erias nisc, tro male Sphaenogona arbela, Hübn., of an unusually pale form; a female of the fine Daptonoura lycimnia; a specimen of the large Ithomiine, Mechanitis veritabilis, Butl. ; the black and white Lycaenid, Polyniphe dumenilii, Godart, and the Skipper, Chiomara gesta, H.-Schäff. But there were in addition several butterflies in that narrow lane which I did not meet with elsewhere in Venezuela; conspicuous among them, on the flowers of Lantana camara, was a specimen of the longwinged, richly silver-plated Dionc juno, Cram., strikingly resembling Colaenis julia, Fabr. (which flew alongside of it), as regards its upper surface, but with a silvery underside that at once recalled the European Argynnis lathonia, Linn. Evell more attractire was the essentially Neotropical Nymphaline, Myscclia cyaniris, Hew., grey with white stripes, shot with brilliant violet; conspicuous as this looks in the cabinet it is by no means so conspicuous when resting, as it is fond of doing, on light grey bark; one of them had suffered a symmetrical injury to both hind-wings suggestive of the attack of a bird. A black, white, and red butterfly seen fluttering at the bottom of a ditch turned out to be a small male of the truly exquisite Papilio cercas ecrcas, Cram., perfect in shape and fiuish, and with a marvellous blue gleam in certain lights; like many of its aristocratic genus it had an odour like musty straw. Loss striking than the last 
was an unusually small fermale of its soberly coloured congener, $P$. polydamas. Lastly, there were two Skippers peculiar to that lane, viz. : Xenophanes tristis, Boisd., and Paches geometrinus, Feld., both well meriting the specific name of the latter.

Near the village the Bug, Oncopeltus cingulifer, Stal, was taken on the wing, and the pale, prettily banded Wasp, Polybia fasciata, Sauss., was common. I noticed the close resemblance between the wasp and a small Syrphid which was flying about the same plants.

I tried another and very different collecting ground at El Vallea combe on the southern side of the ridge lying immediately to the north of the village. A narrow path led through low scrub up to the crest, perhaps some $500 \mathrm{ft}$. above the river; most of my collecting was done, however, a couple of hundred ft. or so lower. A short distance up, near a lime kiln, several Heliconius charithonius, were seen, and close by the small black and white Lycaenid, Polyniphe dumenilii, was to be had in abundance; it is strange, but true, that this very small butterfly is the proud possessor of one of the strongest scents (?) very suggestive of pigsties, or at any rate of pigs! Several other Lycaenids were taken in this combe: Leptotes cassius, a male; Catochrysops hanno, two males, one of them with a faint, the other with a very strong sweet, Freesia-like scent; Thecla rufofusca, Hew., two ; Callipsyche thizcs, Hübn., ${ }^{1}$ six ; but the most interesting Lycaenid was a single rather sorry individual, of which Mr. H. H. Druce writes: "This is an interesting specimen. I cannot distinguish it from the well-known Eastern and African Zizera gaika, Trimen (pygmaea, Snell.), which has a wide range-India, Ceylon, Malaya, Australia, Solomon Is., South Africa (Rhodesia), \&c.--but I have never seen it from America, and do not know that it has been recorded. Can it have been recently introduced?" This insect was certainly taken at El Valle, March 26th, 1907, but unfortunately my record leaves it in doubt whether it was taken near the river or up the combe.

The only Satyrines found were a few Euptychia hermes, but the Nymphalines were as usual well represented, conspicuous amongst them being the bright little Cybdelis mnasylus, Dbl. \& H., looking for all the world like a miniature Hypolimnas misippus; this is the only place that I came across it, but here it was quite common, fluttering about low plants, and never settling for long. Phyciodcs

1 Mr. H. H. Druce says: "This is tho same as Thecla agra, How.; my males from Venezuela have a white tip to the fore-wing, which is not prosent in Jamaica specimons." 
was represented by one anieta, and Dynamine by postrerta, Cram., thescus, Feld., and sara, Bates; one of the last-named was drinking at mud. A fine Hypna elytemnestra, Cram., caused me much tribulation; I saw it on both my visits to the combe, missing it three times, then, as I was returning to its haunt full of good resolutions to keep cool and so ensure success, a wretched boy brought it to me in triumph, having caught it with his hat! It had been a good specimen of the very distinct form rufescens, Butl. The Vanessa-like Anaea ryphea, Cram., was rather commoner, and I secured four; one of these was captured on the very windy crest of the ridge together with Danaida cresimus, a female, easy to catch, but hard to kill; Synchloë lacinia, f. saundersii, Dbl. \& H., and two males of the common Precis lavinia, of the dry-season form corresponding to zonalis, Feld., but duller than Jamaican specimens. ${ }^{1}$

My delight was great at taking Callicore marchalii, Guér., a butterfly more interesting to Venezuelan politicians from its bearing the mystic figure " 88 " upon the underside of its hind-wings, than for its singular beauty. I also took here my first Didonis biblis, Fabr., a handsome black and scarlet butterfly with which I was soon to become familiar in Trinidad; it returns again and again to the same place, as do our Vanessae.

Pierines were not common up that combe. Of Meganostoma cerbera, Feld., I took a female; of Sphaenogona gratiosa, a male, and of $S$. arbela, three males of an unusual pale form. The now very familiar Callidryas eubule was represented by a small, somewhat "dry" male. I captured one of each sex of Pseudopicris (Lcptalis, Dismorphia) nehemia, Boisd. That hillside did not produce a single Papilio.

Skippers, as is often the case in the New World, were more remarkable for the number of species than of individuals; those met with were: Heliopetes alana, Reak. (adusta, Plötz), a species unrepresented in the National Collectiou, one; $B$. arsalte, one, a creamy white insect with a swift, dashing flight; the large long-tailed Eudamus eatillus, one; E. curyeles, Latr., one; Arteurotia tractipennis, Butl. \& Druce, one; the pretty Larentia-like Chiomara asychis, Cram., one; one of an unnamed small black species, and one of the very widely distributed Hesperia syrichthus.

To the Lepidoptera taken must be added a specimen of the dayflying Heterusia atalantata, Guen,, an orange-yellow, black-edged Geometer (like a glorified Bupalus piniaria, Linn.); also a solitary

1 This is the P. michaclisi of Frubstorfer (Stett. Entom. Zeit., 1907, p. 224). See remarks on this species in Jamaica, p. 282, supra; also Chap. X., § 13. 
Phaeochlaena punctata, Druce, of which the British Museum possesses nothing but a drawing; it is a small blaek moth with yellow veins on the fore-wings, and yellow black-bordered hindwings; formerly placed among the Oenochromiidae, it is now put in the Diopsidac.

"Other orders" were not much in evidence, but I took a couple of the common Wasps, Polistes annularis, Linn., and a single Polybia sericea, Oliv., as well as the little Eumenes parvula, Sauss., and a very few Beetles: Gallerucella sp., was found by Mrs. Longstaff in a water-course; Odontota sanguinicollis, Fabr., oceurred near the river; a beautiful Weevil, Platyomus sp., of a pinkish-white with turquoise spots, was found in the eombe, I suspected it to be connected with Castor-oil plants near which it was taken; Mr. Arrow says it is not in the National Collection. Mrs. Longstaff, on the way baek to the city, when hunting for Water Snails, eame aeross Tropisternus mexicanus, Castel., apparently an abundant speeies, as well as an unnamed Gyrinus.

An attempt to reach the primaeval forest high on the mountains to the north of Carácas proved a disastrous failure. We elimbed on horseback up the once fine road to La Guaira; its cobble paving is fast disappearing, and the road itself much cut away by impetuous water-courses now left free to work their wild will, since the railway built by English engineers has given the Venezuelans an excuse for not repairing the old Royal Road. We went up and up, but no signs of forest appcared. Meanwhile threatening elouds eame down the mountain, as if to meet us; the guide took us a turning towards the West and proudly showed, what he thought much better than any forest - a somewhat miserable nursery garden. We lunehed in gloom at about $5000 \mathrm{ft}$., and then the rain began. There was nothing for it but to hurry down again, and we reached Caráeas to find the streets in the suburbs rushing rivers and ourselves like drowned rats. Bag :- Phyciodes anieta, one ; Euptychia pharella, Butl., one ; E. hermes, one; Terias phialc, Cram., a male; Sphaenogona arbela, a female of the usual yellow form, and five specimens of the elegant Oressinoma typhla, Dbl. \& H., a delicate Satyrid with a broad white stripc across both wings. It was not much eonsolation to eome across a colony of the inoffensive Ant Camponotus rufipes, Fabr.

When climbing up the old La Guaira road I had notieed a wooded gorge far below on my right hand and took an early opportunity to investigate it. It proved to be a waterworks conservation and was partly enelosed. The eollecting ground may be said to be from 3500 to $3700 \mathrm{ft}$. above sea-level. The shaded path was just the 
place for Satyrines, which were fairly numerous, being represented by Euptychia saturnus, Butl,, three, a species that I did not find elsewhere; $E$.hermes, five; E. pharella, three; and Oressinoma typhlo, three, one of them very small, this is a butterfly that is by no means fastidious, often flying when the sun is not shining.

Nymphalines were quite unusually scarce, the only species captured were Phyciodes lelex, and P. anicta. The sole Lycaenid was Polyniphe dumenilii. No Papilio was taken.

Of the Pierines, those taken were Pseudopieris nehemia, six males (with a slight, or moderate, flowery scent), and a female; Sphacnogona arbela, a male of the usual yellow form; also three males of Terias phiale, one of them an aberration having more black than usual on the hind-wing and but little yellow.

Heliconius was poorly represented by a single charithonius, but the Ithomiines were more numerous, and included Ithomia andromica, Hew., two; Aëria eurymedia, Cram., one ; Hypoleria ocalea, Dbl. \& H., one; and Athesis clearista, Dbl. \& H., a female.

Actinotc antacas was of course present, and there were a few Skippers, to wit, Hesperia syrichthus, one; Eudamus curycles, one; Hesperia uniformis, Plötz, one (a species recorded by Plötz from Brazil) and a worn insect that is probably Chiomara gesta, H.-Schäff.

I also secured specimens of the pretty orange, black-bordered, day-flying Geometer, Devarodcs hypocritaria, Guen. (simulans, Walk.), and of the smoky, black and white Oenochromiid, Phaeochlacna circumfumata, Warr.; together with these was a Uraniid, Epiplemea obliviaria, Walk., of which there are but two worn examples in the British Museum. A beetle, Euphoria (?) morosa, Jaus., was taken on the wing.

But I reserve to the last my favourite hunting ground at Carácas, which I visited altogether four times during my short stay. A few minutes' walk beyond the Puente 9 de Febrero brings one to the closed Cementerio Hijos de Dios, to the right of which the path crosses a deep "barranco" (ravine) where there are usually a number of Actinote anteas: this is an unmistakable Acraeine; it has a slow flight, and when at rest the fore-wings are always drawn back completely within the hind-wings, so as to give the insect a very long, drawn-out look. It is tenacious of life, but I did not detect any scent. An aberrant specimen had no ferruginous at the base of the fore-wing and very little ochreous about it.

Beyond the barranco the path leads across a field past a cottage and round the head of another smaller barranco-where the effects of denudation with fairly well-formed earth-pillars may be studied 
-it then strikes a small water-course, or leat, ${ }^{1}$ cut along the mountain side. The path may be followed eastwards, beside the channel, along the contour at a height of about $3600 \mathrm{ft}$. above the sea. A more delightful walk can scarcely be imagined: to the left high mountains, to the right and at one's feet the city, yet for all practical purposes miles away, since the numerous barrancos keep all but a few farmers well out of reach. There are plenty of flowers along the watercourse and plenty of insects. A walk of about a mile brings one to the source, a small mountain torrent rising in the cloud regions far above, but compelled by the patient farmers to water their lands below. It is easy to scramble down the bed of the stream, but I found it better to take a path to the right leading through a picturesque farmyard, below which another water-course is reached, about $120 \mathrm{ft}$. lower down the mountain. Here Leptophobia aripa was usually in abundance, together with the beautiful day-flying Arctiid, Utetheisa ornatrix. The male White has a sweet scent suggesting orange blossom; in an aberrant Arctiid the spots on the underside showed through the wings, making the moth look very different from the usual form. Turning again to the left along the channel the source was soon reached. A strip of forest on either bank (presumably retained to preserve the water) hid the torrent from view. Here was all that a tropical collector could desire-trees, flowers, shelter from wind, sunshine (in the forenoon), and above all moisture. It was a little before 4 p.m. on the rather dull afternoon of March 20th, 1907, that I first scrambled up this gully. I had met with a few Ithomiines previously, but only odd ones, here and there; now it was my pleasure to see what I had read about.

Bates, in his classical paper on the Heliconiidae, writing of the grenus Ithomia, ${ }^{2}$ says:- "They are prolific insects, and gregarious in thcir habits, flocks of many different species associating together. Their flight is low and weak; and they affect only certain parts of the forest, generally shady hollows, where many hundreds may often be seen sporting together, though not an individual is found in any other part of the neighbourhood."-Trans. Linn. Soc., vol. xxiii., p. $539,1862$.

Again:- "The flocks of Butterflies, all of the same colour, and undistinguishable from one another when on the wing, which fly together in the same dry hollows of the forest. ..."-Ibid., p. 541.

1 This is just what a Madoiran Portuguese would call a levada; I have had much difficulty in learning tho Spanish oquivalont, porhaps toma or acucducto.

2 The Ithomiinac are now hold to bo quito distinct from the Heliconiinae. 
Alongside the right bank of the mountain stream was a comparatively level strip of ground, some six or eight yards wide, darnp, and in places swampy, covercd for the most part with the Lifeplant (Bryophyllum calycinum, Salisb.). The place was overshadowed by what appeared to be a species of Coral-tree, or "Bois immortel," as it is called in Trinidad (Erythrina sp.), and therc was an undergrowth of Wild Coffee and a few Bamboos. As I pushed along, my movements suddenly disturbed a number of butterflies, which fluttered about in clouds, looking with their transparent wings almost like Tipulae, only more ghost-like. Sometimes their wings would catch the light with an iridescent gleam, but more usually little could be seen save the opaque white marks upon their wings. Of course the more thickly scaled forms were more conspicuous, but as a rule all the black portions of the insects were invisible. It was a wonderful sight, but quite bewildering. Two or three sweeps of the net entrapped a dozen or so. I took back that afternoon thirtyfive specimens, which I imagined included three or four, possibly five or six species. In truth, there were eleven species belonging to eight genera!

A visit to the same spot the next day produced a similar result, the hour was earlier and the Ithomiines were not so closely packed, yet I took home thirty specimens, which proved to belong to nine species, three of which I had not taken on the first day. A third visit failed to add further to the list, which stands as follows:-

\begin{tabular}{|c|c|}
\hline Athesis clearista, Dbl. \& $\mathrm{H}$. & 3 \\
\hline Ceratinia coeno, Dbl. \& $\mathrm{H}$. & 17 (abundant). \\
\hline Ceratinia dionaea, Hew. . & 2 \\
\hline Ptcronymia latilla, Hew. & 16 (very common). \\
\hline Pteronymia asopo, Feld. & 3 \\
\hline Pteronymia victorina, $\mathrm{Hew}$. & 2 \\
\hline Ithomia agnosia, Hew. & 6 \\
\hline Ithomia cymothoë, Klug. & $S$ \\
\hline Ithomia iplianassa, Dbl. \& H & 6 \\
\hline Ithomia sylvclla, Hew. . & 1 \\
\hline Hymcnitis andromica, Hew. & 19 (abundant). \\
\hline Leucothyris phcmonoë, Dbl. & 3 \\
\hline Hypolcria ocalca, Dbl. \& H. & 1 \\
\hline Aëria agna, Godm. \& S. . & 1 \\
\hline
\end{tabular}

The last of these flew higher than the rest, or possibly more might have becn takcn.

A total of cighty-cight specimens, belonging to fourtecn species 
divided amongst eight genera of one group of butterflies, is a sufficiently remarkable record for three visits to a strip of ground which certainly did not exceed 50 yards in length by 10 yards in width. While fully bearing out Bates' account, it forms a striking exception to Darwin's rule that nearly allied species are seldom found in close competition on the same ground.

On another occasion I met with a similar experience. On March 28th, 1907, a hot sunny morning, as I was walking along the upper water-course where it runs through the wood almost clinging to the face of the cliff (perhaps a quarter of a mile from the previously described locality), passing under the shade of a large tree I disturbed a crowd of butterflies so dense that fourteen were easily netted in two or three swoops. Ten of these, which all proved to be Ithomia sylvella, were pinched; four of them got away. In this instance the butterflies were confined to some 4 or 5 yards of the narrow path, and it was almost a "pure culture" of that singularly delicate little species, indeed, the only other butterflies of the genus taken at that spot were two specimens of Athesis clcarista, and single specimens of Pteronymia latilla, and Dircenna jemina, Hübn. (iambe, Dbl. \& H.). I may add that I have no reason in either case to think that the Ithomines were drinking at the stream.

Judging from the British Museum series, $P$. victorina and $L$. phemonö are not very common insects. In four or five of the above species I found more or less scent of a disagreeable character, recalling stables or pig-sties. In some examples I thought the scent was connected with the brushes, or fringes, near the costa of the hind-wings, but unfortunately my observations did not yield very definite results.

But besides Ithomiines there were plenty of other butterflies along the banks of that stream and the water-courses leading from it. 'To begin with the less exciting Satyrines. There were Euptychia hermes, and the smaller $E$. pharclla, the latter very common amoug grass and less chary of sunlight than many of the family; one had a small symmetrical injury to the tips of the fore-wings, possibly inflicted by a bird; but the more attractive Oressinoma typhla was, on the contrary, always found in the shade.

The commonest Nymphaline was the tiny fulvous Phyciodes anieta. It was in this favoured spot that I first made acquaintance with the beautiful genus Dynaminc, capturing three thescus, Feld., and one geta, Godm.; the insects of this genus fly much like Blues; Anartic amalthea flew over the water of the levadas, and Prccis lavinia was as usual easier to see thau to catch. A single specinen 
of Pyramcis myrinna, Doubl., was captured at the flowers of a Coinposite crecper near the farmhouse, while the shades of the wood yielded the larger game, Victorina stelenes and Amphirene epaphus, Latr.; one of the last-named was drinking in the bed of the strearn, where I had the bad luck to miss a Callicore. But of all the beautiful butterflies seen there by far the most startling was my first Mlorpho. A huge bird-like creature sailing down the gully, now giving an azure flash, now almost disappearing as the upper surface turns away -flash, flash, flash, and it is out of sight! Shortly afterwards I had the pleasure of beating out of a bush a male Morpho peleides, Koll., and netting it as it flapped away.

The sole Danaine was a male Danaida archippus, but the Acraeines were represented by a number of Actinote antaeas, though that species was commoner in the outskirts of the city; of its congener A. hylonomc, Doubl., I secured but a single specimen. The only Erycinids taken were a couple of Charis argyrodines, Bates, and one of the conspicuous black, yellow, and scarlet Lymnas jarbus, Fabr.

Heliconiines were not common, but I took Hcliconius charithonius, and two of the beautiful black and red $H$. hydarus, Hew. (one of the species into which the beautiful $H$. melpomenc, Linu., has been split up); the latter were both males, one only of which had a very strong odour, like acetylene, or, better, as Mr. G. H. Sworder of Tobago (who was familiar with the insect and its scent) suggested, hazeline, a preparation of the Witch-hazel (Hamamclis virginica). This insect is tenacious of life.

I got but one Papilio, but its beauty was striking even among so many fine insects, for a male $P$. cymochles, Doubl. (crithalion zcuxis, Lucas), feeding on the flowers of Lantana is a sight worth going far to see. Its handsome black, scarlet, and eream-coloured livery is in itself a feast of colour, but when that marvellous violet-blue gloss is seen, words altogether fail one.

Among the Lycaenids the wide ranging Lcptotes cassius was by far the commoncst, the scxes occurring in about cqual numbers; next in order of abundanec camc the chocolate-scented I'molus palcgon, Cram., which frequented the flowers of a Composite shrub (? Vernonia scorpioidcs, Pers.); of Thccla rufof usca, Hew., I captured two, but of the following only one each: T. crolus, Cram.; T. togarna, Her.; Thcclopsis tephraca, Hübn. (this had a peculiar, strong, rather disagrecablc odour); Callipsyche thius, and Catochrysops hanno, this last sitting head downwards and opening its hind-wings at intervals.

The Pierines were represented by a fair number of species, but few of them werc common, indeed, of the following single specimens 
only were taken: Terias nise, a male with a strong scent like Pink Bindweed; T. leuee, Boisd., a female, the only specimen met with; T. elathea, a male, an aberration with the black streak obsolescent; a male of the mis-shapen Enantia (Dismorphia) melite, Clerck, had a scent like mignonette, two were netted, but unfortunately the female got away; and the "Black-White" Euterpe critics, Feld., a male; as regards the last-named I fear I did not notice at the time how closely it mimics some of the black and red Papilios, notably $P$. serapis, Boisd. (? iphidamas, Fabr.), a species that I took at Cartagena. The genus Terias was much to the fore; in addition to those already mentioned several $T$. albula were taken, some of them remarkably small; also of $T$. phiale four males, some of them having a slight flowery scent; and of T. delia three females, all of dry-season type, and one of the extreme "dry" form named by Butler persistens. Three females of Meganostoma cerbera, Feld., were captured; this species, of which Felder called the dry-season form therapis, appears to me to be quite distinct from $M$. caesonia, Stoll, but whether distinct or not, the delicate combination of pink and yellow on its under surface makes it a very beautiful butterfly; one example, in spite of its sex, had a slight, very sweet scent, suggesting clover. Of Daptonoura lycimnia, Cram., I took one of each sex, the male had a strong, very sweet scent of the Freesia type. Altogether I took six specimens of Sphaenogona arbela, four males of the ordinary yellow form, one of the form santhochlora, Koll., and a female of the unusual pale form, with hind-wing nearly white; two of the males had a slight scent which might, perhaps, be compared to that of mignonette. Of S. gratiosa I took a female. Undoubtedly the most conspicuous Pierinc was the large and handsome Brimstone Amynthia macrula, Fabr. This was only seen on one especially hot morning (March 21st) when several of both sexes were observed close by the Ithomiine locality flying strongly; I only secured one male, and as the day wore on the species disappeared.

There was more than the usual crowd of Skippers; but in the Neotropical Region Skippers are so common, often so inconspicuous in colour, and the allied species so difficult to distinguish that the collector is apt to neglect them in the presence of more attractive game; for truly the most scientific entomologist is but human! Nevertheless of Prcnes nyctclius I took two; of Heliopetcs laviana three; of Hesperia syrichthus two. Of the long-tailed Eudamus protcus and the white-striped $E$. eurycles but one each was secured, though there were plenty about; of Gorgythion bcyga, Prittw., three. Of all the following there were but single examples in my bag: Cycloglypha 
thrasybulus, Fabr:; Chiomara gesta (the three species last named all curve the forc-wings downwards like our Thanaos tages, Linn.); the conspicuous black and red Pyrrhopyge charybdis, Dbl. \& H.; the large grey Larentia-like Mylon zephus, Butl.; the black Cogia calchas, H.-Schäff.; Epeus veleda, Godm. \& S.; Mnestheus itona, Butl.; Pellicia sp. (prop. bromio, Mabille, teste, H. H. Druce); P. dimidiata, Plötz (didia, Möschl.); Metron leueogaster, Butl.; Mergistias telata, H.-Schäff. ; Methionopsis ina, Plötz (modestus, Godm. \& S.), with a curiously long proboscis; Thymelieus dares, Plötz; and Niconiades merenda, Mabille. But the most attractive of the group was the black Carystus coryna, Hew., with its brilliant silver-washed underside; the only specimen seen-just where the upper water-course leaves the stream-was settled upon a mass of silvery-white micaceous shale, which shone in the sunlight with the same metallic lustre as the butterfly. Possibly the result of mere chance, this is certainly the most remarkable instance of cryptic colouring that I have happened upon.

A few day-flying Moths taken in the same locality must be mentioned; single specimens of each occurred. The Arctia-like Syntomid Ctenucha venosa, Walk., at the flowers of a white Composite; another Syntomid, more Zygaena-like, was Macrocneme maja, Fabr., found in the bed of the stream, apparently drinking; the black Geometer with a creamy-white transverse bar across the forewings, Ephialtias tryma, Schaus; Heterusia atalantata, Guen.; the black, orange-striped Geometer, Josiomorpha eruciata, Butl., which proved tenacious of life; and the transparent, sea-green Pyrale, Theages vestalis, Schaus.

The most attractive flowers were two shrubs of the Natural Order Compositae; one of these, with racemes of white flotrers, was especially attractive to bees, another, with purple flowers, I take to have been Vernonia scorpioides. Then there was a Hyptis of sorts, and of course Lantana.

The commonest Bee was Melipona capitata, Smith; I also met with $M$. amalthea, Fabr., and another species of the genus not yet named; then there was an Augoehlora and a Nectarina; I took two specimens of a Megaehile represented in the National Collection, but namclcss. The only Honey-bees were of the mellifica form, and were captured on the small white flowcrs of a Papilionaceous shrub. The Bumble-bees had a handsome representative in Bombus violaccus, Lepel., which almost rivals $X y$ locopa in size and colour; it was quite common. The only Carpentcr-bee was Xylocopa acncipennis, De Geer, and I took but onc of that. In the big barranco near the cemetery I took at flowers a singlc examplc of the brilliant metallic-green Pec, 
Euglossa cordata, Linn. Mr. G. W. Sworder told me that in Tobago Euglossa specially frequents the flowers of the Orchid, Coryanthes maculata punctata, Lindl. The structure of the Orchid is remarkable, and so is the length of the proboscis of the Bee, and doubtless there is a relation between them. ${ }^{1}$

The commonest Wasp was the large Polistes annularis, a distinctly formidable-looking animal with a pale cream-coloured band, but dusky-winged; of $P$. subsericeus, Sauss., I got but one; there was also an unnamed Polistes, a large insect with dark wings and pale tarsi. Of Polybia there were several species; $P$. nigra, Sauss., $P$. angusticollis, Spin., and $P$. occidcntalis, Oliv., the latter obtained by sweeping, but none of them were common. Of Odynerus I took a single specimen, a female. The Social Wasps of the genus Zethus were represented by the greyish-black, purple-winged chalybeus, Sauss., and by another species unnamed, of which the British Museum possesses an example from Nicaragua; it is allied to $Z$. hilarianus, Sauss. There were also two of another social wasp, Synoeca cyanca, var. ultramarina. I captured three of the somewhat dingy, long-waisted Mischocyttarns labiatus, Fabr., var. drewscni, Sauss., and one of a Sphex of the genus Oxybelus. The harmless Ant, Camponotus rufipes, Fabr., was frequently seen.

I had little time to give to Bugs or Beetles, and therefore naturally only took such as obtruded themselves on my notice. A Lygaeus nearly allied to circumlatus, Stål, had no representative in the National Collection. Another bug of the same family, Dysdercus ruficollis, Linn., was taken on the wing. Euchistus bigibbulus was a Jamaican acquaintance.

Curiously enough only one solitary Beetle came in my way. 'This was a Dung-beetle, a species of Canthon, which Mrs. Longstaff found in the water of a tank near the above-mentioned farm; it was of a species not represented in the British Museum. This, with a very elegant Demoiselle Dragon-fly having carmine patches at the base of the wings (near to Agrion brightwelli, Kirby, and caja, Drury), completes my list of captures in the best locality that it has been my good fortune to visit.

Close by the Ithomiine swamp was a small cavo which I entered in the hope of finding Lepidoptera at rest, but did not see any living creatures save crowds of bullet-bodied, long-legged Harvestmen (Phalanginm). I have never before or since seen any approach to such a number of these animals together.

There is a difference in the meaning of the word "grand" in

"See Darwin, "Fertilization of Orchids," p. 175. 
Spanish and in English. In the former languagc it maintains its primitive meaning of "large," as in Rio Grandc. That is probably why it occurs in the phrase "Grand Hotel," a building of which the grandeur is not obvious. To a visitor to that hostel I would give three pieces of advice: (1) Walk delicately across your bedroorn until you are quite sure that the floor will bear your weight; (2) in communicating with the Chinese washerman, use Pidgin English in preference to Spanish; (3) don't refuse Venezuelan black beans, they are much better than they look. But whatever criticisms might be passed on the Grand Hotel from the point of view of mere human guests, there can be no doubt that to Moths and Locustids the arc-light in its patio was extremely attractive. It is indeed somewhat remarkable that a light in a courtyard enclosed on all four sides, and that near the middle of the city, should attract so many insects, but two things may possibly contribute to this result: (1) the light is nearly as high as the lowest side of the buildings enclosing the patio, and (2) the ground on two sides is higher than the city.

The Visitors' List is as follows :-

SyntomidaE.-Cosmosoma teuthras, Walk., one; the Arctiid-like Eucereon setosum, Sepp., two.

ARctimde.-Bertholdia specularis, H.-Schäff., one, a beautiful grey and scarlet insect, with much of the fore-wing transparent; Ammalo insulata, Walk., two, paler and not so yellow ${ }^{1}$ as the Jamaican specimens, a remark which also applies to the British Museum series; Utetheisa ornatrix, two; the striking; but I believe common, Ecpantheria muzina, Oberth., one; the transparent-ringed Pyraloid, Psychophasma crosa, H.-Schäff., one.

NoctUIDAE.-Cirphis latiuscula, H.-Schäff., one ; the cosmopolitan Chloridea (Heliothis) armiger, Hübn., one; the Boarmiid-like, purpletinged Synia hypnois, Hübn., one; the huge and variable Ercbus odorns, Linn. (which was quite common), ten; $E$. zcnobia, Fabr., one; the large handsome Ophinesa tropicalis, Guen., one in fine condition; the Yellow-underwing Hypocala filicornis, Guen., one; the White-underwing Mclipotis fasciolaris, Hübn., one, which Sir George Hampson says is an uncommon variety of a common species; another Mclipotis Sir George says is identical with the specimen marked by Butler, surinamcnsis, Möschl.

DeLTOIDAE.-Tortricodes ${ }^{2}$ orncodalis, Guen., an insect with long palpi and curiously incised fore-wings, two.

1 For tho greator provalenco of fulvous or yellow in Jamaicau butterflies, as comparod with thoso from the mainland, soo p. 290, supra.

" Cuonco gare this namo to the Deltoid gonus in 1854, but he had himself used 
Sphingidae,-Dilophonota ello, Linn., three.

Notodontidae.-Dicentria (Phya) laciniosa, H. Edw., one.

GeometridaE.-The large and variable Boarmiid Oxydia vesulia, two, a Jamaican acquaintance; Alcis syrniaria, Guen., a female [not very unlike our B. betularia]; Semiothisa enotata, Guen., one [a moth very like our "Peacock"]; Eucosmia affinitata, Guen., one [obviously allied to our Scotosia llubitata].

Pyralidae.-By far the most remarkable was the huge ochreous, very Sphinx $x$-like ${ }^{1}$ Galleriid, Myelobia paleacea, H.-Schäff., four inches in expanse. I got two specimens, whereas the British Museum has but one [Plate III., Fig. 8]. Hardly less remarkable is Terastia meticulosalis, Guen., which appeared to be rather common, at all events I got four specimens; though not quite so large, its resemblance to our Angle-shades is striking, there are prominent tufts of scales along the sides of the abdomen; Glyphodes quadristigmalis, Guen., one; $G$. nitidalis, Cram., one; Maruca testutalis, Guen., one.

The large Skipper, Perichares corydon, Fabr., turned up in one of the court-yards by day, and a recently dead specimen of the Nymphaline, Catonephele nyctimus, Westw., a male, was found on the floor.

With the moths were numerous big Locustids, a green Phaneropterine, allied to the Katydid, and a brown Conocephaline, as well as the beetle, Phileurus valgus, Linn.

On March 29th, proceeding to La Guaira to join the homewardbound steamer, we got out at Zigzag station, $1500 \mathrm{ft}$. above the sea, and completed the journey on foot, a walk that I should much like to repeat. The road, right down to the coast, presented all the appearance of very heavy rain within a few days previously. Insects were most numerous between the station and about $1000 \mathrm{ft}$; below this vegetation became sparse, and later on clouds overspread the sky. Zinckenia perspectalis, Hübn., occurred close to the station. The most abundant butterfly was Phyciodes lcucodesma, with its somewhat gliding flight, but $P$. anieta and Tcrias albula were also common, as was the handsome scarlet and black Hcliconins hydarus. A much smaller, but lovely black and red butterfly, Hacmatera pyramus, Fabr., was taken on the railway track, Other Nymphalines captured were Colaenis julia, two; Nica canthara, Doubl., one; Anartia amalthea, two; Dynamine sara, three; Synchloë lacinia, two of the dark form, another of f. saundersi, and Cystineura cana, two, a

the same name, in 1845, for the well-known Tortrix, Cheimatophila hyemana, Hübn. -Teste J. H. Durrant.

1 Another of the genus is called smerinthoides. 
ghostly looking thing with gliding flight somewhat like that of a Neptis.

The only Ithomiines met with were the musty-smelling Tithorca, furia, Stdgr., of which I took a female at about $1300 \mathrm{ft}$., and Pteronymia victorina, of which I took one, and possibly saw others, at about $1000 \mathrm{ft}$. Of Eueides isabella, Cram., f. hübneri, Ménét., I got but a single example which seemed to be most unwilling to die. The Erycinids were limited to Nymphidium molpe, and Charis argyrodines, one of each.

Satyrines were notable for quality rather than quantity, single specimens were taken of Euptychia hermes, of the wet-season, or ocellated form; $E$. hesione, and $E$. mollina, Hübn., the last-named a whitish species not taken elsewhere.

Skippers were but moderately numerous: those taken were: Chiomara gesta, one; the very neat little Heliopetes domicella, three; Zophyrion satyrina, Feld., one, a species well named, since the ocelli on its under surface are very suggestive of a Satyr; and Staphylus mazans, Reak. (ascalaphus, Stdgr.), one.

If Skippers were comparatively uncommon, Blues were decidedly scarce, for my bag included only Thccla mufofusca, one, taken at about $750 \mathrm{ft}$., and T. togarna, two, one taken just below Zigzag, the other as low as $500 \mathrm{ft}$.

Pierines were fairly plentiful but not so easy to catch, conspicuous among them, though not really common, was Callidryas eubule; the specimens were large, and tending to the wet-season form. Of Sphacnogona gratiosa, a female was taken, but others were seen; a female Daptonoura lycimnia, f. polyhymnia, Feld., contrary to precedents, had a rich sweet scent. I Of Pieris (Perrhybris) calydonia, Boisd., I brought home two males, both scented like our $G$. brassicae, but more distinctly, also a male of another Picris, of which Dr. Dixey says:- "It is near to P. scvata, Feld., and appears to be identical with three specimens from Venezuela placed in the National Collection under $P$. sincera, Weymer, but which might well be considered as a distinct species, or at any rate local race." This was taken at an altitude of about $1300 \mathrm{ft}$. close to the track. There were several good-sized Whites about that declined to be caught, it is possible that among them there may have been others of this interesting species. It had a faint, sweet, flowery scent; Dr. Dixey says that its scent-scales are both numerous and large.

Between 2 and 4 p.m., from about $1000 \mathrm{ft}$. down to about $500 \mathrm{ft}$., the Hypsid day-flying moth, Phaloë lorza, Boisd., was in 
abundance. Its flight is slow and heavy, suggesting a pale, dingy Heliconius; nine specimens were taken, eight of them proved to be females. Among the last butterflies taken were Phyciodes liriope, Cram., and a tattered Hypanartia lethe, Fabr., both at about $750 \mathrm{ft}$. The Pyrale, Conchylodes platinalis, Guen., occurred near the same contour-line. The only insects of "other orders" taken were Synoeca cyanea, var. ultramarina, and a Canthon found by Mrs. Longstaff.

At the decidedly dirty Hotel Neptuno, a fine specimen of the large Brassoline, Caligo memnon, Feld., was awaiting my arrival; it had been pinned upon the wall two days before by the obliging interpreter who knew my fancies. Another redeeming feature was the excellent coffee.

The next morning was devoted to a stroll along the coast towards the east, anxiety as to the arrival of the steamer preventing any lengthy expedition. The best spot reached was a neglected cemetery by the sea-side, where we found Phyciodes loucodcsma, common; $P$. liriope; Anartia amalthea, tattered; Tcrias albula, common, one very large; Pieris phileta (monuste), two males of the wet-season formthis species I have always met with close to the shore; $P$. calydonia, a male; Nica canthara, two; Mcchanitis veritabilis, one; Heliopetes arsalte, one; another Skipper was Bolla sp., of which three specimens were obtained (Mr. H. H. Druce says that there is one specimen of this species in the Godman-Salvin Collection unnamed); and Ageronia ferentina, settled on the pale grey trunk of a palm, which it closely matched in colour. Danaida archippus was seen a little way beyond the cemetery on a purple-flowered Asclepias.

The Aculeata found in the graveyard were the Carpenter-bee Xylocopa aeneipennis, well protected in its hard integuments; the formidable dusky-winged Polistes annularis, and the tiny Social Wasps, Nectarina augusti, Sauss., whose brown oval nest, about 4 inches by $2 \frac{1}{2}$ inches, was on a shrub about 3 feet from the ground.

Near the cemetery at La Guaira (as well as on the way down from Zigzag) Mrs. Longstaff took a species of Canthon, a beetle of which the British Museum has a plentiful supply but unnamed.

While walking down to the ship I picked up from the pavement a fine Water-beetle, Hydrophilus insularis, Casteln.

So ended my fortnight in Venezuela, yielding in butterflies alone 492 specimens, of 124 species, of which 53 were represented by single examples. Tet me add that I found the Venezuelans, more especially the country folk, civility itself, and my operntions were in no wise interfered with. 


\section{Trinidad. 1}

SECOND VISIT: April 1st and 2nd; April 11th-14th, 1907.

We reaehed TRINIDAD on our homeward voyage, on the morning of Easter Monday. The Queen's Park, or Savannah as it is usually ealled, reminded me irresistibly of Clapham Common, the more so as it was eovered with crowds of ehildren and young people disporting themselves at football (T. $80^{\circ} \mathrm{F}$.), crieket, and kiss-in-the-ring. It is true that the Savannah presented points of difference from the surburban Common, as, for instance, a erescent of mountains from 1500 to $2000 \mathrm{ft}$. high made a better baekground than rows of villas, and a fine eabbage-palm here and there took the plaee of the somewhat pudding-shaped horse-ehestnuts, while, lastly, nearly all the players at the varied forms of pastime were of cbony hue ;-nevertheless the Clapham-like impression stieks in my mind. The present ideal of the young West Indian negro is to be taken for a erieketer, and he dresses aceordingly.

The following story whieh was told me by an eye-witness amply eonfirms the popular opinion as to the harduess of the negro's cranium. The occasion was a cricket match, whether in Barbados or Trinidad I eannot remember, the players ineluding both whites and blacks. A certain white boy was a local terror, owing to the unusual swiftness of his underhand bowling. A lusty negro lad was at the wieket, the ground was hard, and one of the dreaded balls rose and struek the batsman full on the forehead with considerable foree. The spectators expeeted to see him fall stunned; but he simply rubbed his head, saying, "You must be careful, Mr. Arthur; just think, that might have hit me on the leg!"

Most of my collecting was done on the Ariapeta Road (or rather path, for it is little more) above St. Ann's, where I worked up to perhaps $1500 \mathrm{ft}$. I did not revisit Maraval, but one day we took train to San Juan, and another day visited the Pitch Lakc at $\mathrm{La}$ Brea. We were execptionally fortunate in having a cool breezy day for La Brea, as it is famous for its heat, and viscid piteh is not a matcrial that any one would choose to stroll upou under a sultry sun. Nevertheless it was quite hot cnough to make us thoroughly enjoy the most delicious green pinc-apple that I ever happened upon. Some negresses annoyed my wife by staring at lier, but one of thcm, when rebuked for her rudeness, said: "If you were the Blesscd Virgin herself eome to the earth, I should look at you."

1 It is convenient to deal with $\Lambda$ pril 1 st $-14 t h$, as one risit, breken by a trip to the neighbouring island of Tobago. 
On the short voyage from Port of Spain to Scarborough we had been disagreeably impressed by the odour pervading our cabin, but did not learn till some days afterwards that it had been subjected to disinfection after the removal of a man suspected to be suffering from yellow fever! When the small steamer reached Port of Spain on its return from Tobago, the porter of the excellent Queen's Hotel was there to meet us with the cheery message that the best hotel in the West Indies had been closed by order of the Governor, in consequence of two deaths from yellow fever. The obliging porter took us to hunt for quarters, since there was no possibility of getting away for four days, when the "Orinoco" would be due homeward bound. The second-best hotel was, as might have been expected, absolutely full. The best boarding house in the town had also been closed in consequence of a case of fever, but we ultimately found quarters at the Colonial Hotel, of which all that I need say is that it was distinctly better than the Neptuno at La Guaira, although my wife did have to sit up half the night in active pursuit of Arthropoda belonging to orders in which, greatly to Mrs. Longstaff's annoyance, I declined to take any interest, possibly because they took but little interest in me.

A male Danaida archippus, the only insect of its group, was taken at La Brea. Near San Juan, I took four specimens of Tithorca megara, Godart, three males and a female, they were flying slowly in a shady wood; the males had a strong, sweet, flowery scent, like that of Stephanotis, but with a spicy element; I thought it was associated with the tufts. A single specimen of Ithomia pcllucida, Weymer, occurred in a wet place on the Ariapeta path at an elevation of about $500 \mathrm{ft}$.

The Satyrines, though confined to one genus, were somewhat numerous. Euptychia hormes was extremely abundant ; of E.renata, Cram., several, and of $Z$. hesione many were met with on the Ariapeta Road, the latter did not seem to mind rain; one example had suffered a symmetrical injury to both hind-wings; again, at about 500 ft., I came across two E. penelope, Fabr., also two of the delicately beautiful E. ebusa, Cram., which is almost black, with violet lind-wings.

At San Juan an aberrant specimen of Actinote contaeas was secured; the wings were all paler than usual, and the intermediate black lines on the hind-wings wanting.

The two very similar, and almost equally handsome scarlet and black Heliconii-hydarus hydarus and curyades, Rifi., were both captured. The former was rather common above St. Ann's, at about 
$1000 \mathrm{ft}$., and olle was taken at La Brca. A ficmale hydarus had such a strong Witch-hazel odour that it was quite perceptible through the net; two males, in which little or no scent could be detected during life, had a dccided scent when their papers were opened at Oxford three weeks later. Two euryades were taken above St. Ann's, and another in a wood at San Juan, but this species did not appear to have a strong scent. The rich golden-brown Eueides aliphera aliphera, Godart, was rather common on the Ariapeta path at about $100 \mathrm{ft}$, and appeared to be more or less gregarious in its habits; both sexes had a strong smell like stables. It is curious that the Nymphalines of the genus Dione have the same odoor; they are also very similar in general appearance to Eueides. ${ }^{1}$

The Nymphalinac are very well represented in the New World, and therefore in Trinidad, but the genus Colaenis, which I had found so prominent in Jamaica, was during my flying visits to Trinidad met with but once, in the person of a single femalc, C. julia, Fabr. ; while the nearly allied Dione was represented by a single male, vanillae. On the other hand, the more humble-looking Phyeiodes levcodesma was abundant. Of Synchlö̈ laeinia, f. saundersi, I captured one at San Juan. A male Precis lavinia was intermediate in character; at San Juan, on April 2nd, Anartia amalthea was common about a small swamp, but it had lost its beauty, the specimens being mostly tattered : on April 14th it was seen above St. Ann's, at an eleration of $1000 \mathrm{ft}$., in much better condition, but in that locality also it showed a partiality for water. A. jatrophae, common enough at the time of my first visit in January, was evidently over, a tattered male being all that I saw of it. A single specimen of Adelphia eytherca, Linn., occurred high up the path. The pretty little Dynamine theseus, Feld., was locally common at about 800 to $1000 \mathrm{ft}$; onc cxample had the black borders to the hind-wings broader than usual. At La Brea a specimen of D. postverta, Cram. (mylitta, Cram.), was picked up and another missed; it has a beautiful undersidc. The two large grey butterflies, Peridromia fcronia, Linn., and Ageronia ferentina, Godart, which are as much alike as thcir names are confusing, both occurred in the same open flowery part of the rood on the Ariapeta path, at about $1000 \mathrm{ft}$. above sea-level-one of my favourite spots. They are alike hard to catch. The first-named scttled on grey tree-trunks, looking like a large Boarmiid moth, and almost as cryptic, but always head downwards; thcy were, however, very shy and casily disturbed, though returning again and again to the same tree. I have already referred to Darwin's observations on this

1 For Fritz Miullor's vicws soo below, Appendix, $\S$ IA.-XII. 
butterfly. ${ }^{1}$ It is some small consolation to me that although the great naturalist observed points that escaped my notice, he did not observe that the male has a treacly scent. The beautiful scarlet and black Didonis biblis was common enough above $300 \mathrm{ft}$. elevation, fluttering about the bushes, but many of the specimens were worn. Here, again, my deficiencies as an observer are painfully evident, for I did not detect any scent in a butterfly in which Fritz Muiller found no less than three $!^{2}$ While the light grey Cystineura cana, Erichs., occurred nearer the sea-level (e.g. at La Brea), it was extremely abundant up the Ariapeta path from 400 to $1200 \mathrm{ft}$. With the colouring of a Satyrine it has almost the flight of a Neptis. Butler's name cowiana would appear to have been given to a melanic specimen, but with a long series before me I quite satisfied myself that it is no "good species." The handsome green and black Victorina stelenes was fairly common.

In England one is apt to forget that the Erycinidae are an extensive family, but short as my experience in Trinidad was, I made the acquaintance of six species: of Lemonicas pseudo-crispus, Westw., I took but one; of the small, elegant, delicate, Satyr-like creature Mesosemia tenera, Westw., I took two specimens in a swamp just above the reservoir at St. Ann's; at San Juan I saw four or five little butterflies dancing together in the sun, perhaps courting, but only managed to secure one of them, which proved to be Charis argyrodines, Bates; of $C$. avius, Cram., I saw two or three in the same swamp as the $M$. tenera. From the Pitch Lake I bronght home two Nymphidium molpe, Huibn,, both females, while near the favourite spot up the Ariapeta path I found a male of $N$. lamis, Cram., at rest on a leaf with its wings fully expanded.

The Blues were interesting: the elegant Leptotes cassius occurred both at St. Ann's and La Brea, being identical with spccimens taken in Venezuela, but quite unlike the Jamaican $L$. thconus $;^{3}$ Catochrysops hanno was also met with both at $\mathrm{La}$ Brea and St. Ann's, but appeared to be confined to circumscribcd spots; of Polyniphe dumenilii, three were taken at St. Ann's; two of them rejoiced in the pig-sty odour, though it was comparatively faint. One of them was a very large female, of which $\mathrm{Mr}_{\mathrm{r}}$. H. H. Druce says that the upper side of the fore-wings is more suffuscd than in continental specimens. It is curious that Mr. Kaye with his grcat experience in Trinidad, has met with only three specimens of this

1 See above, p 264.

: See below, p. 501 ; also Appondix, §§ I., IV.

3 See above, p. 285. 
black and white Blue. Thecla politus, H. H. Druce, ${ }^{1}$ was to be had in some numbers on a flowering shrub in the Botanic Garden, close to the Governor's house; of T. badaca, Hew., one occurred at St. Ann's; the same may be said of $T$. spurius, Feld., but in this instanee the butterfly was seen sitting head downwards: the hind-wing is folded and furnished with a large lobe; T. syncellus, Cram., one example of this very brilliant, dark purple-blue butterfly was taken on the Ariapeta path at about $1000 \mathrm{ft}$.; T. albata, Feld. (sedecia, Hew.), one at La Brea; T. linus, Sulz., was rather common about the swamp near St. Ann's reservoir, also far up the path at 1000 to $1400 \mathrm{ft}$. This is a very distinet species, having a striped underside; the lobes are everted, though not quite to a right angle, and when the ereature is at rest the tails are erossed representing the

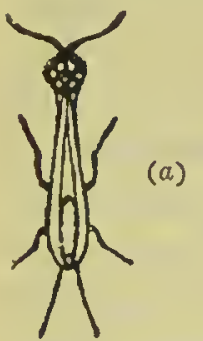

(b)

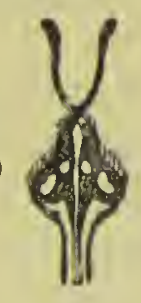

Fig. 12.-Thecla linus at rest.

(a) Nat. size ; ( $)$ Lobe enlarged. antennae of the false head, which indeed looks more like a head than does the real organ. [See Fig. 12.]

Papilio polydamas, with its odour of musty straw, oeeurred in the Botanie Garden, and also at La Brea. I took a fine female of the beautiful $P$. cymochles (zeuxis) in a swamp at San Juan and a male high up the Ariapeta path, and at the latter locality got one $P$. acncides, Esp. (gargav'us, Hübn.); it had a musty straw odour.

Pierines were distinctly searce, Callidryas appeared to be over; of Sphaenogona gratiosa I caught a male, also one of the same sex of Aphrissa statira, Cram., but this speeies was shy, restless, and wild, so that others escaped my clutehes. Terias albula alone was common, and its light colour made it conspicuous; it oceurred both at St. Ann's and at St. Juan.

Skippers were more numerous than Pierines, or at any rate more varied; Thymelicus vibex, Hiibn., of the yellowest form ealled by Plötz combinata, two males at St. Ann's; Hcliopctes arsaltc, with its swift dashing flight was rather eommon; a small blnek Skipper was plentiful at San Juan, but probably I was too intent on larger game to pay much attention to it, for I eaught only one, which proved to be Staphylus mazans, Reak. (ascalaphus, Stdgr.); Cogia calchas, H.- Seliäff., turned up in the Botanic Garden, as did the handsome Fire-tail, Pyrrhopygc venczuclae, Scudd. Single speeimens of Eudamus catillns at Lantana, another seen ; Megistias tclata, H.-Selüff.; Cymaenes silius, Latr., and Perimeles remus, Fabr., were found upon the Ariapeta Road.

\footnotetext{
1 Soo bolow, p. 330.
} 
The Pyrale Mapeta xanthomelas, Walk., took its place among the butterflies, and very conspicuous it was, being especially common among Cacao-trees just above St. Ann's Reservoir. Another Pyrale, the silver-grey Glyphodes ausonia, Cram., of which two occurred at the lighest point attained on the Ariapeta Road, close to the spot where I took Euptyehia cbusa, was so like that butterfly upon the wing, that the two were confounded; yet any one seeing the insects side by side in a cabinet would have said that such a thing was quite impossible.

The only other Heterocera met with in Trinidad were the Hawkmoths, Pserdosphinx tetrio, Linn., and Dilophonota ello, Linn., taken beneath arc-lights in the streets of Port of Spain.

I took but very few Beetles : the Longicorn, Stirastoma depressum, Linn., distinguished by the hardness of its exo-skeleton, was found on a tree-trunk at the good butterfly locality up the Ariapeta path, at about $1000 \mathrm{ft}$. The large orange and black Cantharid, Horic maeulata, Sweder., and Ligyrus tumulosus, Burm., sought the electric lights. Asphaerca nobilitata, Fabr., was captured when flying over the swamp near St. Ann's Reservoir. The Elaterid Pyrophorus pellucens, Esch., captured at night in the Belmont Circular Road, exhibited two constant green lights, powerful enough for me to read by their aid the smallest print. Under the thorax, in the crack between it and the abdomen, was a triangular area which was faintly luminous, the light having a slight reddish tinge. Chloroform at first increased the brilliance of the green lights, but they were soon eclipsẹ. ${ }^{1}$

The flowers in the Botanic Garden attracted quite a number of Bees, mostly small species: Melipona capitata, Smith; M. rufieans, Latr.; M. amalthea, Fabr., and $M$. rufiventris, Lepel., a foxy-coloured neatly banded species; Melissod esrufodentata, Smith; Melissoptila sp.; the common Honey-bee of the mellifica form. With these was the large Bombus-like, yellow-banded, Centris flavifrons, Fabr., and a large blue-black Pompilid.

The Wasps were represented by a very few individuals: Polistes annularis; Polybia oceidentalis, Oliv., var. oeeodoma, Sauss. At San Juan I took Larra gastrica, Tasch., and the very elegant black and yellow Secliphron fugulum, Dahl., as well as two Pompilids.

At the last-named locality I took a Bug, a species of Zieea, which

1 Compare P. H. Gosso's account of Pyrophorus noctilucus, Linn., "A Naturalist's Sojourn in Jamaica," p. $106 \mathrm{ct}$ seq. By tho kindnoss of Dr. F. L. J. M. de Vortouil, R.N., I vas able to exhibit at the Entomological Society a number of living spocimons of P. noctilucus from Trinidad. Proc. Ent. Soc. I,ond., May 1st, 1907, p. xxxii. 
Mr. W. L. Distant says is structurally distinct from any species represented in the British Museum. Oncopeltus cingulifer, Stall, which I had also taken near Carácas, was netted flying high above St. Ann's. Lastly, the brown fetid Dinocoris picens, Beauv.-a creature with an awe-inspiring name ${ }^{1}$ - was attractcd by the electric light. I have not permission to publish the details of Mrs. Longstaff's researches at the Colonial Hotel into the habits of insects of this order (alluded to above), but I have no reason to suppose that she found the dim light of candles in any way attractive, if anything the reverse.

\section{ToBAgO. ${ }^{2}$}

$$
\text { April 3rd-10th, } 1907 .
$$

A glance at the map shows that this island stands outside the crescent of the Lesser Antilles, or Windward Islands, about 20 miles to the north-east of Trinidad in lat. $11^{\circ} 15^{\prime} \mathrm{N}$. The southernmost of the Windward Islands proper, Grenada, is about 70 miles W.N.T. of ToBago. It is therefore pretty obvious that, geographically speaking, Tobago belongs to South America rather than to the West Indies. The mountains of the north-east coast of Venezuela, consisting for the most part of clay slates and schists believed to be of Silurian age, run by way of the peninsula of Paria and the islets of the Bocas, along the northern coast of Trinidad, and would appear to be prolonged to the eastern half of Tobago.

In area Tobago is about equal to the county of London, comprising but 114 square miles, and therefore only about three-fourths of the size of the Isle of Wight, and only one-fifteenth of that of its neighbour. (Trinidad, area 1754 square miles = Lancashire.) The south-rrestern portion of the island, which is low and more or less flat, is formed of coralline limestone, and is completely cultivated. The central and north-eastern portions are hilly, rising to $2000 \mathrm{ft}$., and in large part covered with forest, some of it virgin, but much of it of second growth, or "rastrajo." The destruction of thc forest is proceeding apace.

My stay was limited to eight days, thrce of which, thanks to the hospitality of the Hon. H. L. Thornton and Mr. G. H. Sworder werc spent at their cstate, "Cocon Wattie," the remainder near the coast.

Wc found the neighbourhood of Scarborough, the capital, for some milcs on either side of the town very dry and parched, though

1 Pitch-black torriblo bug.

2 The greator part of this section appened in tho Transactions of the Entomological Socicty of London, 1908, pp. 53-57. 
we were told that there had been some nice showers at night during March. The Trade-wind blows very strongly along the coast, a dry, hot blast which greatly increases the difficulties of the collector.

Cocoa Wattie is a plantation near the middle of the island towards the confines of cultivation, lying about $550 \mathrm{ft}$. above sea-level. The wooded banks of a small river and some swampy hollows clothed with coarse grass and thin scrub afforded the best collecting grounds, and yielded, as might have been expected, a somewhat different fauna from that of the coast. It rained heavily on April 8th.

Anosica archippus, Fabr. (plexippus, auct. nec Linn.). Three o, one $q$. Rather common in the outskirts of Scarborough; one specimen at Cocoa Wattie. My specimens resemble those from the mainland, though one Tobagan, a of, approached Jamaican specimens in colouring.

Euptychia hermes, Fabr. (camerta, Cram.). Five. Abundant at Cocoa Wattie.

Euptychia hesione, Sulz. Six. Common at Cocoa Wattie.

I have taken this species and the following flying during rain.

Heliconius hydarus hydarus, Hew. Three of, two q. Rather common on the river bank at Cocoa Wattie. All the specimens are small, three extremely so; four of them have the bluish gloss (as in the form guarica, Reak., though that is a larger insect) which Mr. W. J. Kaye associates with wet conditions. ${ }^{1}$

Precis lavinia, Cram., f. zonalis, Feld. Two o. An example taken near the coast of the "dry" form, but with the anterior ocellus on the hind-wing very small. (Mr. W. J. Kaye has two very dark specimens from Mexico in which this ocellus is altogether wanting; in the National Collection there is a specimen from Colombia in which there are no ocelli on the upper surface, and only faint indications of them beneath.) The Cocoa Wattie example is intermediate, approaching the wet-season form. Both the specimens would probably be called by Mr. Godman coenia, Hübn., and by West Indian entomologists genoveva, Cram.; but I follow Mr. G. A. K. Marshall. ${ }^{2}$

Anartia jatrophae, Linn. Three. On the coast, not common. 'Those taken are pale in colour and semi-transparent, of the mainland form.

Anartia amalthec, Linn. One at Cocoa Wattie. Messrs. Godman and Salvin ${ }^{3}$ say of this spccics: "Barbados, a single specimen - not previously noted from any West Indian island."

' Comparo Col. Manders and T. do Nicévillo on bluo-glossod Euploca, Trans. Ent. Soc. Lond., 1911, pp. 420, 421.

"See above, p. 282 ; also Chap. X., § 13.

"Godman and Salvin, "Butterflies of St. Vincont, Gronadn, otc.," Proc. Zool. Soc. Lond., 1896, p. 515. 
Dynamine thescus, Feld. This pretty little butterfly was common both on the coast and inland. It has a rapid gliding flight, but otherwise has some of the habits of a Lycaenid; thus, it often settles with its head downwards, and more than once I saw it immediately after settling move its hind-wings rapidly; the insect was, however, too shy to enable me to make out the exact nature of this movement.

Cystineura cana, Erichs. Two specimens on the coast, and two at Cocoa Wattie. It has a gliding flight.

Leptotes cassius, Cram. Two of, two o. Of the mainland form, in which white prevails over blue. Rather common along the coast; three specimens were small, but one female was larger than usual.

Catochrysops hanno, Stoll. One specimen to the east of Scarborough.

Thecla beon, Cram. Four. One specimen on the shore to the south-west of the town at the flowers of the Seaside Grape; rather common at Cocoa Wattie, frequenting the flowers of a purple Papilionaceous shrub.

Thecla politus, H. H. Druce. A $q$ at Cocoa Wattie.

Mr. H. H. Druce says that hitherto this species has been wrongly identified with T. beon, Cram. ${ }^{1}$ To one of my specimens in the Hope Collection he has appended a note: "Some of of T. politus have blue scales on the hind-wings above, which I have not noticed on the only of I have from Santarem."

Thecla nubes, $s p . n o v{ }^{2}$ One specimen at the Seaside Grape, near Hillsborough; four at Cocoa Wattie at the pink flowers of a creeper. [Plate III., Figs. 3, 4, 5.]

Callicista bubastus, Cram. (salona, Hübn.). One taken in Fort George, another at the flowers of the Seaside Grape, near Hillsborough on the coast.

Terias nise, Cram. Three of, three $q$, all of the wet-season form. Common near the coast. The male had a very strong scent like Convolvulus arvensis.

Terias albula, Cram. Three. Near the coast, less common than the last; one taken two miles inland on the road to Cocoa Wattie.

Picris phileta, Fabr. (monustc, auct. ncc Linn.). Two males under the coco-nut palms to the west of the town; one "wet" the other intermediate in phase.

Callidryas cubulc, Linn., f. scnnae, Linn. Abundant alike in

1 Proc. Zool. Soc. T,ond., 1907, pp. 625, 626.

2 Described by H. H. Druce, Proc. '/ool. Soc. Lond., 1907, p. 625. Mrr. Druce recoived the specimcus too lato for figuring. 
Scarborough and along the coast towards the east, tearing about in all directions, but not at all common at Cocoa Wattie. Six $\delta$ and four $q$ taken, of these three were of the wet-season form, seven intermediate, but all were very small. I noted that the males were attracted in numbers by the flowers of the Pineapple in the Government Botanic Station.

Phoebis agarithe, Boisd. Three ${ }^{*}$, one $q$. Common to the east of Scarborough; very showy on the wing, though very difficult to catch, being not merely a strong flier, but also wary and seldom remaining on a flower for more than a few seconds, moreover it seems to like exposed places in the full blast of the Trade-wind. Those taken were all small, one male remarkably so; they are moreover much paler than specimens in the Hope Collection from Barbados and Venezuela.

Eludamus catillus, Cram. One small specimen on the shore to the west of the town.

Pyrrhopyge venezuelae, Scudder. One at Cocoa Wattie.

Hesperic syrichthus, Fabr. Common on the coast; one example at Cocoa Wattie.

Callimormus corades, Feld. Three at Cocoa Wattie.

Systasea erosa, Huibn. One at Cocoa Wattie. In this species the fore-wings are remarkably convex.

Epeus veleda, Godm. \& S. One at Cocoa Wattie.

Megistias cortica, Plötz (epiberus, Mabille). One at Cocoa Wattie.

Cymaenes silius, Latr. One at Cocoa Wattie. This species rests with the wings in the same position as our Pamphila thaumas and P. sylvanus.

Of the twenty-eight species in this list, twenty-four ${ }^{1}$ arc known to Mr. Kaye as occurring in Trinidad; those not met with in both islands being Phocbis agarithe, Thecla nubcs, Epeus veleda and Callimormus corades. None of these is recorded by Messrs. Godman and Salvin from the Lesser Antilles.

As regards the general abundance of Butterflies, Tobago occupies a position between Jamaica and Trinidad. Whercas cight days' collecting in Tobago yiclded 28 spccics, seven days' in Trinidad yielded 61 ; but it took ten weeks to get together 47 specics in Jamaica. On the other hand, Venezucla proved much richer than any of these islands, for 135 specics wcre collected in fiftcen days.

In addition to the above I saw on the wing, about a milc from Cocoa Wattie, Caligo sp.; also Mr. Sworder gave me spccimens of

1 Of these twenty-four at least nineteen also occur in Vonezucla. 
Ithomia pellucida, Weym., and Pteronymia asopo, Feld., which he had taken at Cocoa Wattie, and he showed me specimens of other butterflies which I did not happen upon alive, including Morpho s]. The Hope Collection has Terias westwoodii, Poisd., from Tobago. Neither the last-named nor $P$. asopo have as yet been recorded from Trinidad.

The following moths were taken :-

Utetheisa ornatrix, Linn., locally abundant about Scarborough, more especially in what remains of Fort George; some of the specimens had a peculiar somewhat musty odour during life. Except a single Pionea taeniolatis, Guen., which was kicked up from herbage, all my other moths were victims of the fatal attractions of light. These included the Syntomid, Eueereon maia, Druce; an Arctiid, a species of Virbia; a specimen of Poaphila immunis, Guen., resembled British Museum specimens from Venezuela, rather than the familiar West Indian Noctuid; the lines are different, and, if it is not a distinct species, it would appear to form a well-marked local race; our pretty Jamaican friend, Cydosia histrio, turned up again; the Quadrifid Pleoneetyptera paueula, Walk., is a small reddish-grey Geometerlike moth; then the Deltoid, Tortricodes orneodalis, was an old acquaintance. The Geometers were represented by the reddish $A n i$ sodes metaspilata, Walk., and the bright green Tachyphyle (Dichorda) iris, Butl.

The commonest Pyrale was perhaps the ochreous, dark-bordered Nacoleia cbulealis, Guen.; then there were Diatraca saccharalis, Fabr., Azochis gripusalis, Walk., and the Chrysaugine, Tosale oriplagalis, Walk.

Parasol-ants were extremely destructive to Mr. Thoruton's young cacao plants, attacking them when they had but few leaves and none to spare. Vigorous efforts to destroy the mests met with but indifferent success. M. Forel has detcrmined the species to be Atta eephalotes, Limn., var. polita, Smith. The black Odontomachus haematodes, which was to be found under dead leaves, etc., both bites and stings severely, but the cffect fortunately passes off in a few minutes.

Near the shore to the east of Scarborough the blossoms of the Seaside Grape (Coccoloba uvifcra, Jacq., Nat. Ord. Polygoneae) were very attractive to Bees and Lycacnids, the most numerous visitors being several species of Mclipona, among which M. amalthca, Fabr., and $M$. favosa, Fabr., contended on almost equal terms for the first place, but another unnamed Mclipona is surcly the tiuiest of all bees. Lastly there was an undetermined Angoehlora. With the bees were 
a Sphex, and a Wasp, Notogonia sp., and Polybia occidentalis, Oliv. The big Xylocopa aeneipennis, De Geer, as might have been expected, preferred a larger and more gaudy flower, and accordingly haunted the purple blossom of a Papilionaceous shrub. At Cocoa Wattie I captured a small black Pompilid, Salius (Hemisalius) opacifrons, Fox.

In a ditch some two miles to the east of Scarborough I found a specimen of Uroxys which is not to be matched by any in the British Museum. At Cocoa Wattie I took a Photinus, to which Mr. Gahan cannot assign a name, and a Diabrotica, which he considers new. Mr. Sworder found in a tank a male Phengodes pulchellus, Gerht., which exhibited a green light from the under surface of the middle of the abdomen; the light was constant, but appeared to be under the control of the insect. He also, when out with me, dug out of rotten wood the abundant New World beetle, Scalmus (Ninus) interstitialis; the specimens were small, one of them remarkably so. In contrast with the last he took in the same surroundings Passalus interruptus, Linn., a very large insect of which I afterwards found a dead specimen at the foot of the lighthouse in Fort George. A Dynastid beetle came to light at Cocoa Wattie, which may be a form of Aegopsis trinidadcnsis, Sternb., but does not agree exactly either with that species or with $A$. curvicornis, Westw. Several Coreid bugs, Jadera aeolc, Dall., came to the lamp. That evening Mr. Sworder easily convinced me of the advantage of placing the attracting lamp on a white sheet; many insects that would otherwise probably escape are quite conspicuous on the sheet.

When homeward bound we made our first acquaintance with the Sargasso, or Gulf-weed. Like many other things of which much has been heard, it hardly came up to expectations. For a day or two we saw quite small patehes at long intervals, then larger masses, but at its best there was nothing that the inost scientific, or evell the most unscientific imagination could picture as affording lurking places for such fearsome monsters as we know by the old charts were commonplace to the Elizabethan sea-dogs. Yet its colour is brilliant and looks all the more so by eontrast with the blue sea. A quarter-master constructed for me a small grapnel out of stout wire, with which I proceeded to fish. I made many and many a cast, and was surprised at the difficulty of catching any weed, and the still greater difficulty of bringing it to deck. When a ship is going at even such a moderate pace as 13 or 14 knots, fishing is by no means easy, and the sea seems at the last inoment to snatch from the 
orapuel anything that it may have hooked. However, I secured a piece on April 21st in Lat. $29^{\circ} \mathrm{N}$., Long. $40^{\circ} \mathrm{W}$., and a second sample some 22 hours later, say about 300 miles from the first. The weed when in the hand is pretty, and quite unlike any Alga found in British seas. Kingsley's figure gives a good idea of it. ${ }^{1}$ This is what he says of the results of his examination: "A tiny curled Spirorbis, a Lepraria with its thousand-fold cells, and a tiny polype belonging to the Campanularias, with a creeping stem, which sends up here and there a yellow-stalked bell, were all the parasites we saw." So wrote Charles Kingsley of the results of his fishing on December 17th, 1869. Careful examination with a pocket lens of the fronds at my disposal revealed three organisms, and three only; these three organisms were present in both my samples, and moreover would appear to be the same that Kingsley found. It surely indicates a very remarkable similarity of conditions extending far in both time and space.

1 "At Last!" 1882, pp. 8-11, with figure 


\section{CHAPTER VII.}

CEYLON, 1908.

Latitude of the extreme points visited, $9^{\circ} 27^{\prime} \mathrm{N}$. and $7^{\circ} 24^{\prime} \mathrm{N}$.

January 7 th-March 16th.

My fortnight in the great Crown Colony in '1904 was so delightful that I was glad to seize an opportunity for making its more intimate acquaintance.

Among the passengers on the R.M.S. "Orotava" was Mr. Seth Smith, F.Z.S., who was on his way to Australia to obtain living specimens of mammals and birds for the Zoological Gardens. At Port Said we had a pleasant walk for some distance along the SweetWater canal, where Mr. Seth Smith saw many more birds than I did insects. Three days afterwards (December 29th), the sea being smooth, the wind light and variable, the captain brought me a large Locust which had just settled upon the bridge. The ship was about 70 miles from land, off Mecca. The captain told me, and I am disposed to agree with him, that the white paint on the upper works of the ship appeared to attract insects. Mr. Seth Smith saw a Red Locust the next day. ${ }^{1}$

On Sunday, January 5th, we passed close to Minikoi Island, an outlying atoll of the Laccadives. It is the only specimen of the class that I have seen and the dcsire to land upon it was naturally strong. Two little boys on the ship who had just been reading the charming book of that name thought that Minikoi was "T'he Coral Island." We tried to think that we could smell Ccylou from an immensc distance: the aroma is supposed to be that of ciunamon, but the element of imagination loomed large.

'Schislocerca peregrina, Oliv. Owing to tho unfortunate confusion of nomonclature the "locusts" of ordinary parlanco, having short antennac, aro included in the Acridiidac, or Grasshoppers, and havo nothing to do with tho loug-horned Locustidae. 


\section{Mount Lavinia.}

January 7 th-12th, 1908.

Mount Lavinia, a mass of rock breaking the even line of the sandy shore a few miles south of Colombo, has a charm all its own. Far away to north and south the waving coco-nut palms fringe the golden sands which are the resort of fishermen innumerable. These are an amphibious race who boldly face the roaring surf in their catamarans, strange "dug-out" craft with picturesque brown sails, craft that are the very embodiment of safety till the fatal moment when the out-rigger giving way causes disaster as promptly as when the engine of an aeroplane strikes work, with, however, the important difference that the amphibious fisherman has no fall but simply rolls over into his other element.

The Crow ${ }^{1}$ throughout the east is familiar, but nowhere more so than at Colombo, where the hotel-keepers find it advisable to put up notices warning their guests of its habit of stealing such trifles as rings, eyeglasses, or even necklaces. At Mount Lavinia crows used to come into our room at the hour of chhota háziri ${ }^{2}$ and we were told that not long before one had succeeded in carrying off an egg-cup! A lady, a Colombo resident, told us the following story of her personal experience. She was the owner of a tiny fat puppy that could hardly stand. Once, when lapping milk from a saucer it was attacked by two crows front and rear. One seized the puppy by the tail and dragged it backwards, holding it while its mate tackled the milk. When, however, the latter had drunk its fill the selfish bird went off, declining to take its turn at tail-pulling.

The few days spent on the coast, though not very profitable as regards the collection of butterflies made, were of interest as a basis for comparison. Thus, in five days' work on the coast I took 104 specimens, whereas a like time at Kandy produced 106 specimens, no great difference truly, but the coast collection included only 26 species, the inland collection 43 ; of these, 16 species were common to both lists. There was but one butterfly taken by me on the West Coast, which I did not, sooner or later, meet with at Kandy, viz. :Zizera lysimon, Hübn. f. kar'sandra, ${ }^{B}$ Moore, of which I took two at

1 The Indian Grey-neeked Crow, Corvus splendens; an amusing account of its familiaritios is given in "Cassell's Naturn History," rol, iv. pp. 11-13.

2 Litorally "Littlo brenkfast." Early tea.

3 In this chapter I linvo endenvoured to follow the nomonclature of later authorities (Bingham and Hampson), but have usually givon in brackets tho name under which the species will bo found in Moore's "Lepidoptera of Coylon." 
Mount Lavinia and one at Fort Frederick, Trinkomali, on the East Coast; it would appear to be a lowland species.

The actual coast was too exposed to the prevailing wind to be of much good as a collecting ground, and the Cinnamon Garden proved somewhat disappointing. Naturally enough my attention was first drawn to the Papilios which were obvious and not uncommon. The yellow tail-less $P$. demoleus, Esp. (erithonius, Cram.), which had been such a familiar object in Northern India, was to be seen flying swiftly about in exposed spots close to the sea, as well as in the Cinnamon Garden. When feeding on flowers it flutters its wings, not stopping long on any one flower. A female exhibited a slight peculiar scent in the field, which was stronger in the house. Then there was another old friend, Papilio aristolochiae, Fabr., curiously shaped out of crêpe and studded with rubies; it had a hay-like scent, sometimes musty, sometimes sweeter, and it was hard to kill. Two or three P. pammon, Linn., were seen. The gorgeous red, black, and white, $P$. hector, Linn., than which I have seen few handsomer butterflies, occurred somewhat commonly in the Cinnamon Gardens; my specimens were netted in the near neighbourhood of Lantana bushes, though not actually taken on the flowers. Like the last-named species this was tenacious of life, and its male had a musty odour. Hector flies straight along, sometimes high, but not very swiftly. The movement of its wings, rendered more obvious by the strong contrast of colours, appears to be rotatory. My friend Commander J. J. Walker, I.N., M.A., has recently called my attention to the flight of our little black and white Pyrale Ennychia octomaculalis, Fabr., as appearing to "spin" on the wing. Something of the same sort struck me in the flight of the beautiful Peach Moth of South Africa, Egybolia vaillantina, Stoll, a steel-blue and orange-yellow Catocaline Noctua. ${ }^{1}$ In all these cases I think that the apparently excessive movement of the wings in a rotatory manner is due to an optical illusion caused by the sharply contrasted colours of the insects.

It was at Mount Lavinia that I first had the pleasure of catching the black and grcen $P$. agamemnon, Linn., a butterfly that I had seen twice before. They were in poor condition, flying rapidly, often quite close to the sea, where the only flower under the palms was the Periwinkle of the tropics, Vinca rosea, Linn., a plant but little attractive to insects. One specimen appcared to have a very slight sweet sccnt. Besides these I saw scveral of the magnificcnt, great black and yellow Ornithoptera darsius, Gray, and one afternoon

\footnotetext{
Soe above, p. 195.
} 
seeured a fine speeimen of eaeh sex fluttering on the flowers of Clerodendron infortunatum, Linn., a plant called by the sinhalese Gas-pinna. This most aristoeratic butterfly, whieh has all the magnifical air of a Kandyan Chief, is peculiar to Ceylon. The male had a slight spiey scent, the female a slight disagreeable one.

The little brilliant yellow Terias hecabe, Linn., was by far the eommonest Pierine, being especially numerous near the sea. It has a jerky flight, close to the ground; when disturbed after 4 p.m. it settles again almost at onee. Of the twenty specimens taken on the West Coast no less than fifteen $(11 \delta, 4 q)$ were of the wet-season form, as against two (one of each sex) that were of the dry-season form; three $(2 \delta, 1$ ) were intermediate in charaeter. Next in order of abundanee was Catopsilia pyranthe, Linn., of whieh indeed I saw far more here than in any plaee. The males undoubtedly have a sweet seent, whieh may be compared to that of Stephanotis. In one female a similar seent was noted, but in two others it is described simply as "sweet," with the qualifieation (when submitted to Mrs. Longstaff) "a little bit hair-oily." Of C. pomona, Fabr., I took but one at Mt. Lavinia, a very large female of the typieal form, and noted of it: "flies faster than pyranthe; had a very slight sweet scent, both alive and after death."

From the imperfectly expressed statements of several natives I gathered that we had just missed one of those butterfly flights for whieh Ceylon is famous; it had oceurred at about Christmas, but would seem not to have been of the first order of magnitude.

The somewhat gaudy Delias cucharis, Drury, was not eommon. The only other Pierine observed was a solitary Nychitona wiphia, Fabr.

Of the Blues I saw several kinds, the prevailing genus was Castalius, the commonest species rosimon, Fabr., which was, however, confined to the Cinnamon Garden; two specimens were observed at rest, with their wings elosed and their tail towards the sun. Of C. ettion, Dbl. \& H., an insect that I had not taken before, I secured one example. Of Lampides celcno, Cram., so abundant at Kandy, I took but one; of Zizera lysimoni I got two. Of Evcres parrhasius, Fabr., I took two females in the Cinmamon Gardens; both were settled with their heads downwards, and both were moving their hind-wings in the manner peeuliar to Lycaenids. ${ }^{1}$ Talicada nyscus, Guér., was common near the railway station; a speeimen was watched moving its hind-wings.

Of the Satyrines I met with but one speeies on the eoast, the pretty Yphthima ecylonica, Mow. Bingham considered this to be a See above, p. 104, also Chap. X., \$10. 
racc of $Y$. hübneri, Kirby. Its white hind-wings make it, superficially at any rate, the most distinct species in the genus. So far as my authorities tell me, the typical hïbneri is not found in Ceylon. At Kallár, in the Nilgiris, in 1904, I took both forms. At Mt. Lavinia ceylonica was abundant, especially in the Cinnamon Garden, flying close to the ground, its white hind-wings being very conspicuous; it settled with wings half opened and with tail to the sun.

It was rather a surprise to find Nymphalines so scarce, there were not many species, and none of them were common. A few Preeis atlites, Linn., represented a genus that is generally much in evidence. Two or three Atella phalantha, Drury, occurred near the hotel, a few Neptis varmona, Moore, in the Cinnamon Garden. Elymnias fraterna, Butl. (which Bingham considered to be an insular race of $E$. undularis, Drury), was rather common; it often flies in bushes, or, if not, close to the ground. I noted that at 4 p.m. it was hard to make the insect fly clear of cover, so that it was aggravatingly difficult to catch. The male has a decided odour of vanilla-scented chocolate, but my wife compared it to "very strong honey, or coarse brown sugar." Two Telehinia violae, Fabr., one of each sex, were captured.

The commonest of the Danaines was Crastia asela, Moore, which was regarded by Bingham, I think rightly, as a race of core, Cram. Its slow heavy flight was noted. Both sexes had the strong acetylenelike odour, especially perceptible in the field, sometimes marked when fluttering in the net. The impression produced was that the scent was associated with the protruded caudal tufts; the yellow juice expressed on pinching was tastelcss. Parantica aglea, Cram. (ceylaniea, Feld.), was almost as common as the last; both had a quitc feline tenacity of life, and both had a similar scent-a scent common to both sexes; both species have a heavy flight.

Considering that Skippers were so numerous at Kandy it is remarkable that at Mt. Lavinia I took but one example of the group, a female Parnara mathias, Fabr.

An expedition by rail to Kalutara (also on the coast, but some 20 miles south of Mt. Lavinia) produced many of the above-named insects, but only one fresh spccies, Tirumala septentrionis, Butl., which seemed to takc the place of Parantica aglea. Like the other Danaines, septentrionis appeared to have many lives, but, unlike then, the male had a rather pleasant scent, a scent which appeared to have no connection with the pouches on the hind-wings. Subsequent observations at Haragama confirmed the existence of this sccnt in the male, which I sometimes compared with that of Clover. But in one instance it is noted of a female: "Slight Stephanotis scent in the 
field, very slight at home." Speaking of the same individual Mrs. Longstaff said: "Slight (?) ginger."

The lights of the hotel attracted the following moths: the Geometer Dirades theclata, Guen., and the Crambids Schoenobius adjurellus, Walk., and bipunctifer, Walk.; also the Chafer Schizonycha ruficollis, Fabr., and another beetle, Coptodera sp.

Two specimens of the Arctiid, Amsacta lineola, ${ }^{1}$ Fabr. (one of them crippled) were found by Mrs. Longstaff on rocks close to the sea.

The pale-banded Vespa cincta, Fabr., made its début at Mt. Lavinia. It is an insect with which I became very familiar later on; the Ceylon specimens are smaller and paler than those found in India.

A female of the Carpenter-bee, Xylocop a fonestrata, Fabr., occurred on the shore, as well as the very large, violet-black $X$. tenuiscapa, Westw.; the Honey-bee of the country appeared to be Apis indica, Fabr. A spotted-winged Dacus was the only Fly that interested me sufficiently to involve its capture.

The red, black-spotted, Lygaeid bug, Dysdercus cingulatus, Fabr., was netted when flying along a road; another Lygaeid, large, black with scarlet margins, Melamphaeus fulvo-marginatus, Dohrn, ${ }^{2}$ occurred in the Cinnamon Gardens; a less brilliant member of the same family, Aphanus sordidus, Fabr., was found under bricks. The phytophagous Beetle, Hoplosoma ceylonensis, Jac., might be taken either on the wing or by sweeping. Idaethina orientalis, Nietn., was to be found in the flowers of a species of Convolvulus in the Cinnamon Gardens, also at Kalutara in the enormous yellow and maroon-coloured flowers of a Thespesia. A number of the dull Opatrum contrahons, Walk., were found under a $\log$ on the shore. At Kalutara I also took the cosmopolitan Pyrale Zinckcnia fascialis, Cram., and the Lamellicorn beetle Singhala hindu, Heller.

A few as yet unnamed Dragon-flies and Acridians close the list.

KANDY, $1500 \mathrm{ft}$.

January 14th-March 2nd, 1908.

The train in its beautiful climb from Colombo to KAxDY certainly takes the traveller into a more agreeable climate; though sometimes, may be, a bit steamy, the temperature was but $75^{\circ} \mathrm{F}$., as against $82^{\circ} \mathrm{F}$.

1 Mooro calls this Creatonotus emittens, Walk.. so does Hampson in his "Moths of India," but in his "Lepidoptera Phalncnac," rol. iii., p. 324, he gires it the Fabrician name. My specimens wore of the southern form, Aloa flora, Swinhoe.

2 Probably named from a specimon in which scarlet bad fadod to fulrous. 


\section{INDIA - CEYLON.}

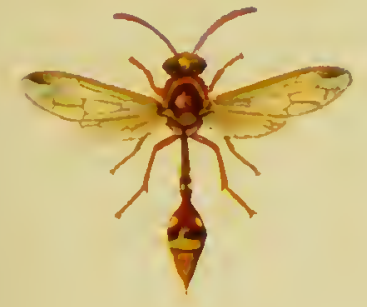

4

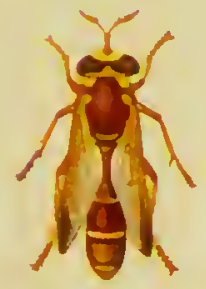

6

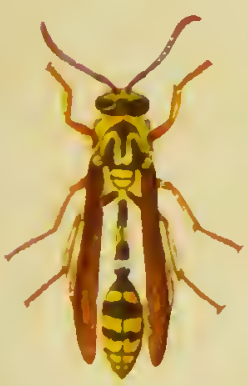

10

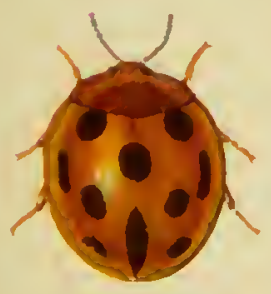

13
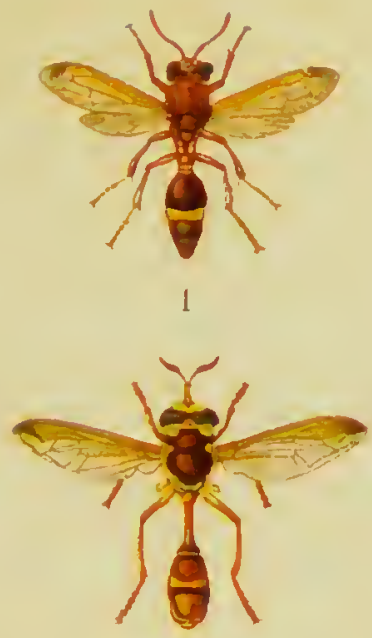

5
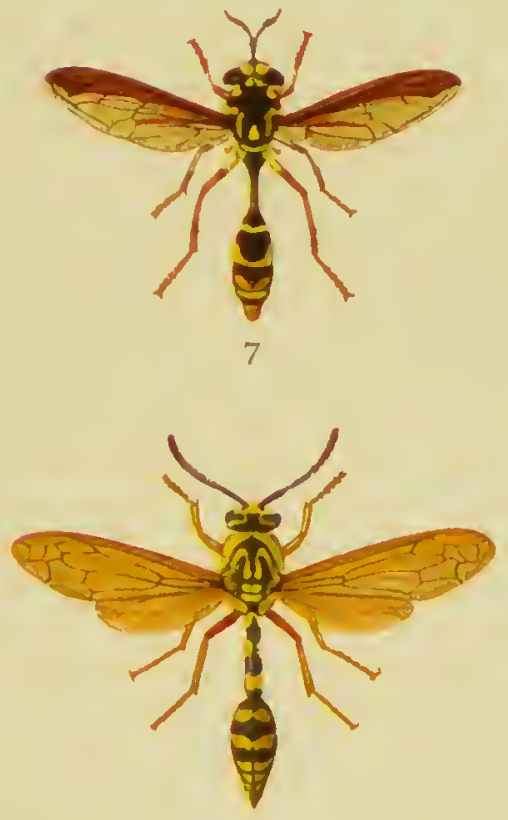

9

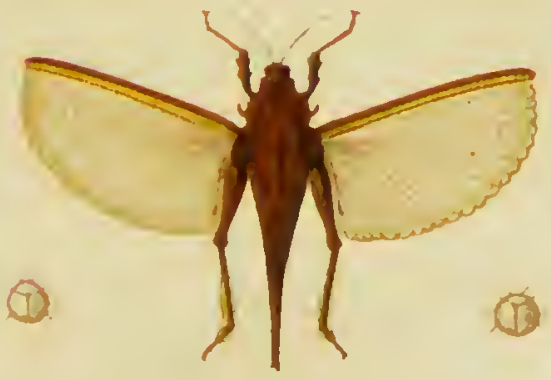

11

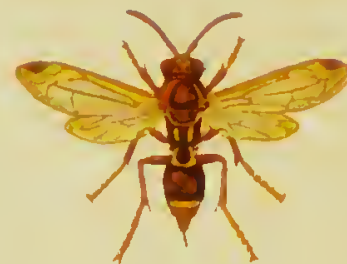

3

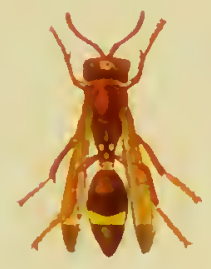

2

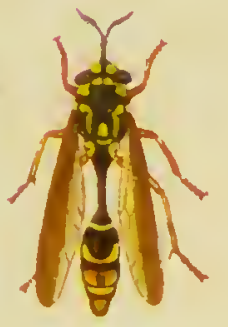

8

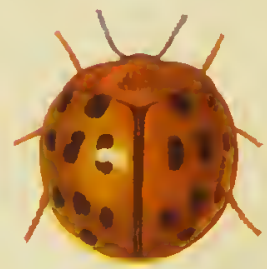

12

$H$ and Edgar S. Knight dut.

1. ICARIA FERRUGINEA

2. THE SAME AT REST.

3. POLISTES STIGMA.

4. EUMENES EDWARDSII.

5. CERIOIDES EUMENOIDES

6. THE SAME AT REST. 

on the coast; after a "cold" night the early morning temperature several times fell to $65^{\circ} \mathrm{F}$., once even to $62^{\circ} \mathrm{F}$.

Our hotel stood in its own garden over-shadowed by palms of various kinds. The air was filled with the ceaseless chirrupping of grasshoppers, crickets, and cicadas. The Barbets, commonly called Copper-smiths, plied their trade assiduously, and though sometimes their "tonk, tonk, tonk," rather got upon the nerves, it was withal a cheerful note.

In the dead of night now and again the Jackals' cry was heard, but they never came very near. We did not see many Mammals. Once indeed a Mongoose and once a Hare crossed my path, while three-striped Squirrels were fairly common. Once at dusk I saw a large flock of Flying-foxes coming up from the direction of Peradeniya, where they are especially common; evidently they were journeying forth in search of their evening meal, just at the time that in England Rooks would have been seen returning home. The Flying-fox is a gregarious animal, large numbers may be seen by day hanging up together in one tree. One Sunday a large Bat flew about the chancel during Matins.

Snakes were fairly common, though I saw no Cobras. One evening in the garden, close to our room, I nearly stepped upon a small thin species, but it was too dark to distinguish its markings. Some boys killed a thin whip-like Snake in Lady Macarthy's Drive; it was at least 4 feet long, destitute of any special markings; though it had a suspicious-looking triangular head placed upon a slender neck, I failed to find any fangs. That same day I saw some other boys stoning a Snake which was swimming in a shallow part of the lake. This one was about 3 feet long, somewhat thickly made, and had a line of very sharply marked diamonds down its back. As it got away through a sluice I was unable to examine it more closely, but it was decidedly a handsorne beast. Mr. E. E. Green writes that judging from my description this was almost certainly Tropidonotus piscator, which has a very Viperine appearance, and is so pugnacious that it will deliberately strike at a stick held near it. Twice I came across Rat-snakes, rather slender, some 6 feet long, of a reddishbrown colour. They are harmless, and are said to enter houses in pursuit of rats.

Lizards were very numerous both at Mt. Lavinia and Kandy. The most notable is a species of Calotes, which has the power of changing colour far more rapidly than a Chamaeleon. For instance, I saw one lying in the road at Kalutara, it was then of a grey-brown tint: I succeeded in popping my green net over it, lo! it was 
forthwith grecn. Unfortunately, however, it was too active for me and got away. A much less active, less timid, and indeed almost domesticated reptile is the Gecko; a pale, anaemic, uncanny-looking creature which clings to walls by the suckers on its feet. The Gecko is wont to take up its position behind a picture hanging near a lamp, issuing forth as soon as the house is lighted up to make its late dinner off the unsuspecting visitors to the light. In our hotel at Kandy the head of a Gecko might be seen nightly just projecting from behind a time-table that was pinned upon the wall. The only insect that I actually ever saw one of these animals eat was a small Homopteron, but I would not like to trust a rare moth to their powers of self-restraint. ${ }^{1}$

This reminds me that one night crowds of winged Termites camc to the lights, and I noticed the hotel dog devouring them eagerly. A resident told me that both dogs and cats are extremely fond of Termites.

Once only did I see a Chamaeleon in Ceylon, a large one which surprised me by its activity.

The exterior of the Temple of the Tooth is undoubtedly very picturesque; it would be hard to say the same of the interior, which is disappointing. The so-called Tooth would defy the classificatory powers of a Cuvier or an Owen, and it would be a full size for the biggest effigy of Buddha at Dambulla. As for the yellow-robed priests, they, like their temple, are unquestionably picturesque, and many of the younger men are distinctly good-looking, but the older men-with one or two notable exceptions-have a most sinister cast of countenance. The Buddhism of the "Light of Asia," and Buddhism as actually practised in Ceylon are two very different things; it is strange to be told that Mrs. Besant, Colonel Olcott, and the other Esoteric Buddhists, whose message has fallen upon deaf ears in the West, have caused quitc a revival of Buddlism in Ceylon. If this had had a purifying or ennobling influcnce it uight hare been well, but the most obvious result is an increased bitter opposition to Christianity on the part of the priests.

Some of the Kandyan Cliiefs, as the native landed gentry are

1 An interesting British parallol to this appoared recently:-"Two onthusiastic entomologieal friends, Mossrs. A. Gravoson and T. Smith . . . one night (in August, 1910) reperted soeing quite a number of toads sitting boldly on the hoathor-tops, obviously waiting for tho supper which the winged risitors should proride-no wonder some spocies aro becoming searcor." This would appear to haro boen in the Kondal distriet, and is reeorded by Mr. Frank Littlewood in the Entomologist, 1911, 1. 73. 
called, are strikingly handsome. They have long pedigrees, but it is suggested that their undoubted European features may be due to Portuguese or Dutch blood. Some of their boys whom I saw at Trinity College were simply beantiful; they are mostly brown, but one almost black boy might have been a model to Murillo for the youthful St. John.

Kandy is the scene of an interesting experiment. All the sons of the Kandyan Chiefs go to Trinity College, which is said to be the best secondary school in the island. Here for some time the aristocracy of the Sinhalese youth has been subjected to European influences. Hitherto, however, it has been found that when the boys left school they married girls brought up under the old régime, so that much of the good that had been gained was lost. Of late years a girls' school has been started-like Trinity College under the auspices of the Church Missionary Society-and now all the daughters of the Chiefs are brought up under similar conditions to their brothers. As there is no one else for the boys to marry than these girls great results are naturally expected. At both schools the idea is to train the children in Sinhalese, and to preserve all manners and customs which are not actually vicious. It may interest my readers to know that Sinhalese boys have much greater aptitude for crickct than English boys, though it is difficult to make them take much troublc about it. A pure Sinhalese Anglican priest at Kandy is a master of English, a good reader, and an excellent preacher, short, precise, and knowing when to stop. They say that when he gives a Shakespeare reading the room is crammed.

There may be more deadly things in the forest at Kandy, but the most deadly thing that I came across was the Rattan-palm (Calamus sp.); it lets fall long graceful trailers, which Dr. Willis of Peradeniya will tell you are used by the plant for climbing, You arc of course at liberty to believe him if you likc, but I assure you that these trailing stems are perfcctly adapted for quite another purpose, to wit, to catch the topi, clothes, and more especially the net of any unwary entomologist who may venturc within their reach. These pliant, whip-like, fishing lines are beset with recurved prickles placed in scts of thrce at every inch throughout their lcngth. You will see at the Temple of the Tooth how, in accordance with a latter-day development of doctrine, the Buddhist priests have improved upon mediaeval representations of the inferno by ghastly pictures of naked sinners stuck upon Rattan-palms.

The fine Snail, Acavus grevillei, Pfr., was common on the trunks of various palms behind the hotel. The native lads soon grasped 
the idea of hunting for snails for Mrs. Longstaff, and one morning early whell we first opencd our eyes we saw, a few paces from our open window, a native lad in the lightcst of clothing, who had probably been squatting there for hours waiting for us to wake. The moment that we showed signs of life he rosc to his feet, salaamed, and proceeded to exhibit his shells.

On the leaves of Palmyra Palms (Borassus flabelliformis) in the hotel garden Mrs. Longstaff found a number of minute Snails, which Col. H. H. Godwin-Austen, F.R.S., has described as Pupisoma longstaffi, sp. nov.1 The same mollusc occurred at Anuradhapura in like situation.

It is one of the recognized sights of the place to see the Elephants of onc of the Kandyan Chiefs bathe at Katugastota. The water of the river is shallow and the animals lie dorn in it, but if one of them should roll over on its side there is sufficient depth of water to cover its mouth, and the nostrils of any other animal; this, however, causes the elephant no inconvenience, for it kceps the end of its trunk above the surface, suggesting the periscope of a submarine, though not homologous with that organ. It is not necessary, it is not even advisable, to give the mahout a Rs. 5 note for putting his elephant through its tricks, as I actually saw an American tourist do.

There is no question that Kandy is a very fine entomological locality, but it has the disadvantage of being very well known. Of Tirumala septentrionis but two specimens turned up, and it must be assumed that it is not common, at all events at that time of year. It is even more remarkable that no Danaida chrysippus were taken, although I have a note of having seen one out of reach ou January 25th. Neither was $D$. plexippus taken, though I saw two or three in Peradeniya gardens on Jauuary 18th. In marked contrast with these, Parantica aglea was abundant at Kandy. There is not the slightest doubt that in this species the sccnt is common to both sexes, but in most cases it was not to be detccted in the house, although many of the specimens were still alive. In onc spccimen the sccnt was noted as "acctylene + cockroach," in anothcr as "in the field, acetylene + cockroach; at home, cockroach only"; in yet another the scent was notcd as "not so puugent as in C. ascla." The flight of aglea is rcmarkably slow, and often has a peculiar daucing charactcr, cspccially in the afternoon. ${ }^{2}$

1 "Land and Frosh-wator Mollusca of India, ctc.," rol. ii., Part xi., March, 1910, pp. 303, 304, and Platc cxxxii, Figs. 3, 3a, $3 b$.

? Soo above, p. 110. 
Crastia asela was quite one of the commonest species, and I devoted some little time to the study of its scent. The results of my observations are not all quite concordant, but one thing is proved beyond a doubt, viz. that the scent is not peculiar to either sex, though it was not observed in every individual examined. My general impression is that the scent was strongest in the female. The scent is usually described in my notes as resembling that of acetylene, but in some specimens, mostly females, it had a very pungent charaeter compared to that of acetic acid as in the Whip Scorpion, Thelyphonus. In one instance the pungent odour adhered to the fingers after pinching the insect. It is notable that in the same specimen the yellow juice was found to be tasteless, or nearly so. I appear to have examined the juice in five specimens; in two males it is noted as tasteless; in one male as "? slightly bitter"; in two females as nearly tasteless. Though these butterflies were tenacious of life and were often found to be alive when the papers were opened for examination in the house, a large proportion proved to be scentless, whence I infer that the scent is more volatile than in Pierines. At first I was under the impression that the scent was evolved by the peculiar anal tufts of the male, but I was able to negative this idea entirely. (1) The scent is even stronger in the female than in the male. (2) The tufts were often protruded without any emission of scent. (3) In eight specimens the abdomen was amputated, but in no instance could any scent be connected with the severed body; on the other hand, the scent seemed to come from the base of the wings, or possibly from the thorax. Though in no instance resembling that of Pademma, the brand of the male varies much in size, in one specimen it was obsolescent. This, be it remembered, is not a mere colour variation, for the brand is a definite structure.

Authorities seem to be agreed that Pademma sinhala, Moore, is the Ceylon race of the Indian kollari, Feld. It is extremely like Crastia asela, differing chiefly in the brand of the male; both my specimens, males, appear to have been captured under the impression that they were the commoner species. Both specimens were tenacious of life, both had the acetylene odour in the field; one of them had no scent in the house, but on pinching it a second time, the tufts were protruded and there was a momentary strong acetylene scent. I found the yellow juice tasteless.

Of Narmada montana, Feld, which is perhaps the Ceylon race of coreta, Godart (coreoides, Moore), I took four males at Kandy. One or two of these were recognized during flight, ${ }^{1}$ though very like ${ }^{1}$ Sc also Col. N. Manders, Proc. Zool. Soc. Loond., 1911, p. 703. 
Crastia asela. This species also proved tenacious of life; its scent resembled that of $C$. asela, but was perhaps sweeter.

It is noteworthy of these Danaines that an individual of $\mathbb{N}$. montana had suffered a symmetrical injury to the fore-wings, while a specimen of $C$. asela had lost nearly all the hind-margin of one forewing and the adjoining portion of the hind-wing-an injury suggestive of a Lizard's bite.

Of the Satyrines Orsotricuence mandata, Moore (regarded by Bingham as a race of $O$. meda, Fabr.), was very local and only found commonly along the edge of a paddy field beyond Lewelle Ford. Those taken were of the wet-season form.

Of Myealesis mineus, Linn., f. polydeeta, Cram., I got a solitary male. The pretty little Nissanga patnia, Moore, a butterfly peculiar to Ceylon, was abundant, especially about Lady Horton's Drive. Twice I suspected that it had a scent, though it cannot have been strong. This butterfly sometimes settled with its wings expanded, but more usually they were closed though, so far as I saw, the eye-spots werc always exposed to view. It was somewhat careless as to orientation.

Yphthima ceylonica was very abundant, the males appeared to have a very slight scent suggestive of chocolate. It usually settled with its wings half open and with its tail to the sun, and was once seen to adjust itself to that position. A female had the underside of a yellowish colour, in place of the usual grey; a (?) male had a small symmetrical injury to both fore-wings, which might have been inflicted by a bird.

Of Melanitis ismene, Cram. (leda, Drury, nee Linn.), I took but four at Kandy; two of these, one of each sex, both dry-season specimens, were taken flying at 9 a.m. ; a male, intermediate, inclining to "wet," was, on the other hand, taken at dusk; others were seen when it was so nearly dark that I could not catch them. One evening when strolling in the garden in search of this species a leaf of a Coco-nut Palm fell close to me with a positive crash; when one considers that it measured between 11 and 12 feet it can be understood that I was not a little startled. Of Elymnias fraterna I saw but two, one of which-a worn female-I took for a battered Danaida chrysippus.

The great sub-family of the Nymphalines is very much to the forc at Kandy. On my second day out I came across a male of Apatura (Rohana) camiba, Moore, settled on the upper side of a leaf with wings expanded, but never saw another; this Col. Bingham considered to be a sou thern race of parisatis, Westw. Of Enthatia (Adolias) vasanta, Moore, I also found a single example, it was resting on the ground in a damp ditch with wings fully expanded. I had not the good fortune 
to capture Particnos cyaneus, Moore, one of Ceylon's finest butterflies, but more than once was grievously tantalized by watching its remarkable flight. It is a large and very striking insect of a beautiful greyish-blue colour: in marked contrast with Papilio parinda, which flies with much seemingly laborious flapping, though its wings do not appear to be depressed below the horizontal position, the Partienos glides about, at every two or three yards strongly depressing its wings with a jerk, but seldom appearing to raise them much above the horizontal. One day I had the misery of studying this movement for the best part of an hour as the lordly insects sailed about far above me. That accurate observer Mr. E. E. Green agrees with my description of its movements. After I left Kandy Mr. E. F. S. Tylecote succeeded in capturing one or two specimens of cyaneus; but I had previously had ample opportunity of observing how an entomologist might be helped on occasion by much practice in dealing with swift bowling.

The commonest Neptis at Kandy is the species generally known as varmona, Moore, which however Bingham regarded as indistinguishable from eurynome, Westw. It has the floating flight so characteristic of the group; when it settles the wings usually remain expanded, but not always; it appears to be for the most part indifferent to its position with regard to the sun. Neptis jumba, Moore, was comparatively scarce, it is quite a distinct species in which, when alive, the whitc markings have a distinctly blue tinge. In two males I thought I detected a faint scent, like chocolate, or perhaps vanilla. Rahinda sinuata, Moore, regarded by Bingham as a race of hordonia, Stoll, was rather common, its resting habits are similar to those of Neptis.

The great tropical and sub-tropical genus Precis, called by many authors Junonia, was well represented by five out of the six Indian species, but of P.lemonias, Linn., one only, of P. orithyia, Linn., two only, of $P$. atlites, Linn, three only, and of $P$. almana, Linn., threc only were seen, the latter being of the "wet" form, asteric, Linn. On the other hand, $P$. iphita, Cram., was often abundant. Out of twenty-one specimens brought home, mostly in poor condition, thrce only, all males, had the sub-costal whitc spots on the under-side of the hindwing; of thesc two were "wet," the other was intcrmediate, tending to "wet," but I cannot say that these spots are characteristic of either sex or season. These butterflies often settled with the wings closed, but almost cqually often with them widcly opened; they seemed to sit either with head or tail to the sun. In two malcs a slight treacly odour was detected. 
Here it must again ${ }^{1}$ be admitted that in the field I was constantly confusing Cupha and Cirrhochroa, as the supcrficial resemblance is striking enough. Cirrhochroa cognata, Moore, is the commoner; Bingham held this to be indistinguishable from thais, Fabr., but de Nicéville appeared to consider it a local race. It is a strong flier and conspicuous on the wing, looking yellower than it is; it is also conspicuous when settled, usually upon a leaf, and often far out of reach. Cupha (Messaras) placida, Moore, which Bingham was inclined to regard as distinct from erymanthis, Drury, was reckoned by de Nicéville as " a good local race" of that species.

Among the fine butterflies peculiar to Ceylon is Cethosia nietneri, Feld., its engrailed hind-wings and somewhat Persian pattern seem to place it by itself. Its flight is extremely feeble, sometimes near the ground, but occasionally high; it sits on leaves with expanded wings, but occasionally visits Lantana flowers. Out of nine specimens taken two had suffered symmetrical injuries, one to the tips of the forc-wings, the other to the middle of the hind-margin of the hindwings. Cynthia asela, Moore, is another large butterfly peculiar to Ceylon, it is remarkable for its sexual dimorphism, the male being tawny, the female French grey. It was common at Kandy, especially at the top of the hill above Lady Horton's Drive, but hard to get in good condition. There is no doubt that the male has a scent, faint, it is true; I compared it to sassafras and to French polish. The female varies in the width of the transverse white band. Two specimens had suffered symmetrical injuries to the hind-wings, which I attributed to a bird and a lizard respectively.

That glorious, though common, butterfly, Hypolimnas bolina, Linn. (jacintha, Drury), turned up from time to time. When spread ont upon a leaf it looked particularly beautiful. Two specimens had symmetrical injuries to the forc-wings. Four specimens of the Blue Admiral, Vanessa haronica, Moore, were taken, all of them males, one at rest upon a stack of cord-wood sat with its head downwards. Both Bingham and de Nicéville regarded this as a geographical race of canace, Johanns., but it docs not appear to me that Bingham's descriptions of either larva, pupa, or imago are consistent with that riew, nor are the figures given by Moore and Bingham.

Curiously enough I met with but two Atclla phalantha at Kandy. I see that Messirs. de Nicévillc and Manders say of it: "Cominon cverywhere in Ceylon, but not abundant." 2

1 For provious experience, seo above, pp. 112, 114.

" "A List of tho Butterflies of Ceylon," Joum. Asiatic Soc., Bengal, N.S., vol. Ixviii., Part II., No. 3, 1899, pp. 170-233. An nduirable papor. 
E'rgolis taprobana, Westw., which Bingham regarded as a race of merionc, Cram., was abundant. It might be at once distinguished from Cirrhochroa by its skimming or gliding flight, which was hardly checked by a modcrate amount of rain. It settles on leaves, or on the ground, with wings fully expanded, but frequently closes them for a moment and opens them again; on at least one occasion it was seen to orient itself. The allied E. ariadne, Linn. (minorata, Moore), was not quite so plentiful.

Telchinia violae was seen from time to time. It is tenacious of life; its yellow juice proved to be slightly bitter.

Three specimens of Abisara echerius, Stoll (prunosa, Moore), were all that the family of the Erycinidae could produce. On the other hand, Blues, more especially the smaller forms, were very plentiful whether measured by species or individuals.

Two examples of each of the somewhat dingy Neopitheeops zalmora, Butl. (dharma, Moore), and Spalgis epius, Westw., were brought home, doubtless more were seen. Chilades laius, Cram. (varunana, Moore), was also apparently scarce, and the same was true of Cyaniris puspa, Horsf. (lavendularis, Moore). Of the tiny Zizera gaika, Trimen (pygmaea, Snellen), one of the most widely distributed of the Blues, Kandy produced but one; $Z$. otis, Fabr., of the form indica, Murray, was abundant enough, it flies very close to the ground; a specimen was noted to settle head downwards.

Talieada nyseus was common in one spot, wherc a quantity of its food-plant grew. The neat little Everes parrhasius was quite common; though not so tied to the soil as Zizera, it was not often seen far above it.

The genus Nacaduba is very puzzling, the more so as good specimens are not easy to obtain. So far as I can make out (following Bingham), I met with two species, both common, viz. $N$. ardates, Moore, and N. atrata, Horsf. (prominens, Moore, pars.). Three specimens of the latter were seen to settle head downwards. In two males a scent was detected; in one I dcscribed this as "sweet flowery," and my wifc at once said, "That's a sweet smell"; in the other I gave a similar description, and my wife said, "very, very faint jasmine."

Unlike most of the other small Blues that I have mentioncd, those of the genus Lampides are species of notable bcruty, some indecd of almost dazzling brilliancy. Frequenting the leavcs of shrubs and the lower branches of trees they formed a notable feature of the Kandyan fauna. The most abundant of them was the milkylooking L. celeno, Cram. (aelianus, Fabr.), an insect of quict beauty. 
I had many opportunities of watching it, and many times saw it settle head downwards, and certainly on at least three occasions observed that peculiar movement of the hind-wings which has been noted in so many of the Lycaenidae. Taking all my observations together it may be asserted that its male has a sweet scent, though this must be much fainter than in many Blues. In one specimen only did I note the scent as "decided," my wife then comparing it to hair-oil. The exquisite $L$. lacteata, de Nicév., has the reputation of being a rare species, but I took one specimen during my flying visit to Kandy in 1904, while on my second visit I was fortunate enough to secure twelve specimens, though four of them were in poor condition; all save one were males, while of the allied $L$. elpis, Godart, usually considered a commoner insect, I took but six, all males. At the time of capture all were examined for scent alike; the diagnosis of the species being made for the most part in England. It is therefore the more interesting to find that nine of the lacteatc are noted as having a scent suggestive of chocolate or vanilla, whereas in five of the elpis a scent described as "street," but once as "? clover" was noted; seemingly it was not nearly so obvious as in the other species. Elpis is a wide-ranging species, but laeteata is confined to Ceylon. To me the difference between the two scents found in two forms, the distinctness of which has been doubted, is a matter of great interest. Two specimens of $L$. elpis were seen settled head downwards; one of them first settled with its head up, but forthwith turned round. One example of $L$. celeno had suffered a severe injury, apparently at the mouth of a lizard, the whole hind margin of one hind-wing together with an angular, adjoining portion of the fore-wing being absent.

There was yet another member of the genus, Lampides bochns, Cram., which in numbers did not fall far short of eeleno. The males darting about in the brilliant sun reminded me of floating spangles in a pantomime. One example was seen settled head downwards.

I did not see a single Catochrysops at Kandy, but Tarucus was represented by two plinius, Fabr. Of Castalius I got two rosinon, both females, several cthion, and several decidia, Hew.

Of course Polyommalus baetiens was well to the fore, it frequents the flowers of low plants, seldom rising far from the ground. It was especially abundant on Lady Blake's Drive by the banks of the Mahaweli-ganga. Sevcral were watched as they sat head dormwards moving their hind-wings. The male has a moderntcly strong scent like that of Mendow-sweet.

Of the Thecloid groups of the Lycaenids I was not fortunate 
cuough to catch any of the more striking sorts. The somewhat dull Surendra qucrectorum, Moore (discalis), occurred very sparingly. The slightly more attractive Liapala lazulina, Moore, was not common. I thought its male had a scent like chocolate, but my wife compared it to vanilla biscuits, a distinctly closer comparison. Chocolate is so frequently flavoured (and therefore scented) with vanilla that one's imperfect sense-organ often fails to distinguish the true smell of the chocolate (as for instance in cacao-butter) from that of the vanilla. I believe both scents are found among butterflies. In R. lazulina, I specially noted that the lobes on the hind-wings are everted, as in Aphnaeus. ${ }^{1}$ A single Virachola isocrates, Fabr., a female, occurred on the top of the hill above Lady Horton's Drive.

The long-tailed Loxur a arcuata, Moore, was quite common in the " half-mile gallop." It is a singular insect with a darting flight, and it rests in a peculiar attitude. The head is usually directed downwards, the wings closed above the insect's back, with the lobes of the hind-wings three-quarter everted, showing an eye-spot when viewed from above. The inner margin of the hind-wing is bent inwards. The long tails are crossed with their tips turned upwards in a curve, and they appear to be somewhat twisted. ${ }^{2}$

So much for the Lycaenids. The Pierines made a more goodly show but were not really as numerous. Of the ghostly little Leptosia xiphia I saw but one at Kandy. Delias eucharis is as interesting a butterfly as it is beautiful. Though believed to be distasteful I took two specimens with well-marked symmetrical injuries, involving in one case both fore-, in the other both hind-wings. It appeared to be somewhat tenacious of life, though not nearly so hard to kill as the Danaines. In the course of my Indian tour ${ }^{3} \mathrm{I}$ had detected a scent in this butterfly, but was in some doubt as to whether it existed in the female as well as in the male; accordingly, the butterfly being common at Kandy I examined a number of specimens. Dr. Dixey had informed me that the scent-scales are very numerous in the male Delias. As a result of my investigations I can state with confidence that the male $D$. cucharis has a strong scent, sometimes very strong (so as to be perceptible when the insect is fluttering in the net), which may, I think, be well described as like that of sweet-briar. As regards the female I speak with less assurance: nevertheless a majority of those examined had a vcry faint scent, which I described as "sweet" (twice), "dusty or musty," "flowery," "sweet-briar"

1 See above, p. 68, and Fig. 5.

2 For tho resting attitude of tho elosely allicd $I$. alymnus, Cram., sco above, p. 79.

3 See abovo, pp. 85,86 . 
(twice). Mrs. Longstaff onee called it "sweet," twice failed to detect any sceut: onee said, "very slight lemon-vcrbena; yes, perhaps more like sweet-briar," but onec she said, " a little gentle sort of seent ; query ginger, or eoarse brown sugrar."

Though Catopsilia pyranthe seemed to be eommon in the lowcr eountry, I came across but a single male at Kandy; it is interesting that the ordinary way of testing for seent gave a negative result, but that when the tufts or fringes were disturbed a strong Freesia-like scent was evolved. In contrast to this $C$. pomona was plentiful; they varied very mueh in size; some speeimens appeared to have been out a long time, one being stained. The great majority were of the pomona form, but four were decidedly of the form crocale, Cram., while two were transitional between these forms. On the other hand, there were three of the catilla, Cram., form, while two approaehed catilla in eharacter. As regards time-while crocale oeeurred from January 17 to February 11, no eatilla were seen before February 2, and the last (transitional) was taken on March 2. I several times beat this butterfly out of Tithonia diversifolia, a rank Mexican Composite that has been reeently introduced; onee this oceurred after rain when everything was very wet; it seemed to be fond of resting among the leaves of the topmost shoots. C. pomona is a flower-frequenting butterfly, being especially fond of the Vervain, Stachytarpheta jamaicensis (another introduced plant). It looked partieularly handsome, feeding on its purple flowers, its greenish yellow eolour forming a fine eontrast, and reminding me of Callidryas eubule seen the year before at the same flowers at Port Antonio, Jamaiea. There was some slight evidence of unusual tenacity of life in Catopsilia, but I do not lay stress on this. The scent of the male varied in intensity in different individuals, but though usually distinct was seldom very strong. I compared it often to Frecsia, once to Stephanotis. In several females a very faint sweet or flowery scent was deteeted, but it was of different quality to that of the malc. Injuries were observed in several speeimens: a $\delta$, hind-mings, symmetrical; a $q$, hind-wings, symmetrieal, (?) due to a bird; a $\hat{o}$, a small injury involving all four wings, (?) due to a bird; a $q$, anal angles of fore-wings, symmctrieal; a $q$, tips of fore-wings, symmetrical; a $q$, tips of hind-wings and anal anglc of fore-wings, symmetrical; a $q$, apiees of hind-wings, symmetrical; a $q$, apiees of hind-wings, symmetrieal. This is a strongly built butterfly and not liable to a.eeidental ehipping as are many dclicatc Satyrines: in no other speeies were so many mutilated individuals met with.

I do not know anything that is morc closely associnted in my 
mind with hot countries than the merry gambols of the little ycllow butterflies of the genus Terias. There is still considerable doubt as to the number of species belonging to the hecabe group. It will be seen that the question is by no means a simple one when it is borne in mind that not only do the sexes differ, but that both sexes are influenced by season so as to exhibit a wet-season and a dry-season form, the latter being commonly more marked in the female. Moreover there are intermediate forms of all grades. Lastly, at least one of the species, or sub-species, or races, into which the insects of the hecabe group may be divided is extremely variable in respect to the width of the black marginal borders to both wings. While Messrs. Butler, Moore, and Swinhoe have described about thirty specics, on the other hand Dr. Dixey at present includes them all under hecube-provisionally at all events.

Looking at the matter from a Ceylon point of view, one fact is prominent. Mr. E. E. Green and other experienced local collectors are familiar with two forms of larva, the one more or less solitary in its habits, having a green head and turning to a green pupa; the other gregarious, with a black head and producing a dark brown or black pupa. The latter we are told always produce butterflies with the character said by the late Capt. E. Y. Watson ${ }^{1}$ to distinguish $T$. silhetana, Wallace, viz. a dark spot at the extreme base of the cell on the underside of the fore-wing, a character which he declared to be absolutely constant. The late Col. C. T. Bingham stated that the dry-season specimens of hecabe might be distinguished from sithetana (as well as from sari) by the reddish-brown season-mark near the apex of the fore-wing on the underside, forming a line or bar, sharply dcfined externally, whereas in the other forms it extends more or less towards the apex, forming a patch rather than a bar; in silhetana this patch is especially developed in the female.

Now, in 1908 I brought home from Ceylon 136 Terias of the hecabe group. Rejecting four specimens (believed to be three hecabc and one silhetana) which were in such poor condition that no certain determination was possible, there remain 132. The large majority of these-eighty-four specimens (53 of, 31 \&)-had, besides the reniform mark on the disco-cellular veins, two brown marks in the cell. Thesc I call hecabe. In thirty-scven spccimens (26 o, 11 q) there wcre threc brown marks in the cell, the additional mark being a small dot at its extreme base. These I call silhetana. There romain eleven specimens $(5$ o, 6 o) having a distinct facies: they have but one dark mark in the cell, a transverse line. These seem to me to bc rotundalis,

1 He was "sniped" in camp during the Tirab campaign, Nov. 8th, 1897. 
as figured by Moore. Now Bingham made rotundalis a synonym of silhetana, but to me it seems rather to be allied to sari, Horsf. Seven of my rotundalis $(4 \delta, 3$ ) are decidedly "wet" ; the remainin" four $(1 \neq, 3$ q) are "intermediate, tending to wet." All have the dog's head profile quite distinct. My eighty-four specimens of hecabe, all-20 o, 19 \%, "dry"; 21 o, 7 q, "wet"; 12 f, 5 \%, intermediatehave the black border of the fore-wing sufficiently wide to show the dog's head profile clearly. In all of them there are two marks in the cell, and two only. In all the dry-season specimens the season-mark is a transverse bar clearly defined on the side towards the apex. In the thirty-seven silhetana, on the contrary, the narrowness of the black margin makes the dog's head profile shallow, indistinct, or obsolete, in no less than twenty-one out of the twenty-six males, though it is distinct enough in ten out of the eleven females.

Captured specimens are extremely difficult to deal with, but Mr. Green has been good enough to send to the Hope Department a number of butterflies reared from the gregarious, black-headed larvae; they are all clearly referable to silhctana. At present we seem to lack material to decide the limits of variability of $T$. hecabc, though Mr. Pryer's results in Japan seem to show that they must be very wide. ${ }^{1}$

As already stated the Terias taken on the West Coast were all heeabe as above characterized. The sixty specimens taken at Kandy included all three forms : T. hecabe was represented by twenty "dry" specimens (10 $\delta, 10$ \%) as against three "wet" (all males), and four intermediate (all males). T. silhetana was represented by serenteen "dry" specimens (7 o, 10 q) as against two "wet" (both males), and six intermediate (all males). Of $T$. rotundalis, on the other hand, there were no "dry" examples among the eight taken, but there were four "wet" (2 $f, 2$ $\%$ ) and four intermediate $(1 \hat{\delta}, 3 q)$. It is possibly significant that no rotundalis were taken at Kandy until I had been there ten days, although both silhetana and hecabe were common on my arrival. Is rotundalis perhaps a wet-season form of silhetana?

Not one single Ixias or Teracolus was seen during my stay at Kandy; moreover I seem to have taken but five specimens of Catophaga (Appias) paulina, Cram., 3 \$., 2 \%.

The magnificent Hebomoia glaucippe, Linn., f. australis, Butler, was very rarely seen at Kandy, the few noticed (and it mas scarcely. possible not to notice them if present) were attracted by a Lantana hedge. Huphina nerissa, Fabr. f. phryne, Fabr., was seen trice only.

1 H. Pryer, "Rhopalocera Niphovica," 1886, pp. 8, 9. 
The glorious sub-family of the Papilionines, Linnaeus' ideal butterflies, forms quite a feature of the Ceylon landscape; they do not require looking for, since they force themselves on the attention. On the occasion of my first visit to Ceylon, in the middle of March, 1904, I met with but one specimen of the black and green Papilio agamemnon (see above, p. 112), but in 1908 it was certainly the commonest of the genus, being in fact abundant in the latter half of January. Though nearly all the specimens were more or less tattered and torn, in one the injuries affected both hind-wings symmetrically, and I deemed them to be probably the result of an attack by a vertebrate enemy. This butterfly especially favoured the hill-top, where it might be seen fluttering its wings-from time to time momentarily closing them-as it sipped honey from Lantana, Stachytarpheta or Vernonia. When on flowers it was easily taken, but it is surprising how inconspicuous it is, as well during its swift darting flight as when settled. In marked contrast with agamemnon is the truly magnificent $P$. crino, Fabr., its brilliant green which when in the hand gleams like a diamond beetle, seeming almost luminous in the sunlight. The first sight of it caused a never-to-be-forgotten thrill of delight. It is not easy to catch, moreover it frequently breaks off its tails by violent fluttering in the net. I saw scarcely a dozen specimens in all, mostly attracted by Lantana bloom, though chary of settling on the flowers. The form taken in Ceylon is $P$. montanus, Felder, but this is not peculiar to the Island.

Papilio pammon was fairly common at Kandy. This butterfly is far more difficult to catch than either $P$. aristolochiac (which is undoubtedly a distasteful species) or $P$. hector. Unfortunately I secured but two females, one of the form cyrus, Fabr. (that resembling the male, being Wallace's form I.), the other of the interesting form romulus, Cram. (Wallace's form III.), a good mimic of $P$. hector, a species which could scarcely be called common. The latter is nuquestionably tenacious of life, a point that I have not noted in pammon. Again, hector has a somewhat musty odour; whereas in the only specimen of pammon in which I detected any scent it was somewhat agreeable.

$P$. aristolochiae, f. ceylonica, Moore, is almost as difficult to kill as hector; it flies slowly, going straight on, and has a scent that I once compared to that of new black net, but more usually to that of musty hay. It was quite common at Kandy. Of $P$. dcmoleus I saw but one or two. Of P. lanlecswara, Moore, f. dissimilis, Liun., and of $P$. scurpedon, Linn., race teredon, Feld., one each. On the other hand the Ceylon race of $P^{\prime}$. polymnestor, Crim., which Mr. Rothschild 
ranks as a sub-species (parinda, Moore), was almost common. It is a grand insect on the wing, but not easy to catch.

It may be remembered (see above, p. 111) that on my first visit to Kandy I was told that the male of the big Ornithoptera darsives had a scent like that of sassafras. At Kandy I was unable to procure that drug, but the Apothecaries' Company of Colomio were good enough to send me some blotting paper that had been moistened with oil of sassafras, and I was thus enabled to make a direct comparison, with the result that the two odours appeared to be almost identical. This butterfly, certainly the most distinguished of those peculiar to Ceylon, was frequently to be seen, and when within reach it was not hard to catch.

The Skippers are so very pnzzling that it is almost out of the question to diagnose them in the field; the best way therefore is to box all that you come across and examine them at home; they usually travel well so, whereas pinching is especially destructive to members of the family since their large scales seem to be very easily rubbed off. At first I remarked that Skippers were very scarce at Kandy, but they got commoner as the season advanced. I had noticed in South Africa that insects of this group are early risers, and I took one of the dingy little Sarangesa albicilia, Moore (peculiar to Ceylon), rather early one morning. Of the handsome Tagiades obscurus, Mabille (distans, Moore), I took one off Tervain flowers, on which it sat with wings fully expanded. Near the hilltop I took two of the striking black and white Tagiades atticus, Fabr., settled on the upper surface of leaves. A solitary specimen of the small greyish Hesperia galba, Fabr., was all that I saw of the species.

Iambrix salsala, Moore (Astictopterns stellifer, Butl.), was rather common. The tiny grey Taractrocera macvines, Fabr., was occasionally met with among low herbage, but as it looks quite like a fly when on the wing, it might well have been overlooked. Of the brilliant little Ampittia dioseorides (maro), Fabr., the females-which are very different from the males-predominated. Telicota bambusac, Moore, a very wide-ranging species, has a more European appearance than most of the preceding; I took but one, a male, and noted that its hind-wing was folded when the creature was at rest. The neat, black and white Notocrypta feisthamelii, Boisd. (Plesioncura alysos, Moore), and the tawny Padraona gola, Moore, were botll unique, but of Halpe ecylonica, Moore, I secured two specimens.

Next I must mention three species which belong to a rery difficult group and may be quite ensily confounded, though really distinct enough. Parnara mathias, P. guttatus, Brem. \& Grey (bada, 
Moore), and $P$. colaca (eingala), Moore. Of the first I got five, of the second one, and of the third eleven specimens at Kandy. It is curious that of the last Messrs. de Nicéville and Mander's say: "We have no exact locality for this species from Ceylon, and Moore gives none." I cannot be more "exact" than to state that ten of mine came from Lady Horton's Drive, sensu largiori; one from the road above the Reservoir, while I got yet another from near the Abhayagiriya Dágoba at Anuradhapura.

$P$. mathias rests with all the wings up; $P$. colaca with fore-wings quite, hind-wings nearly up, but both sloped back.

High above the reservoir which supplies Kandy with water, one sunless afternoon I took a specimen of the large but dull Parata butleri, Auriv. (alexis, Moore, nee Fabr.), it was on a Vernonia flower. A single specimen of the rarc Bibasis sena, Moore, an insect much like the last, but larger, was taken on the hill-top above Lady Horton's Drive; it is very inconspicuous for its size, and when at rest folds its hind-wings. Another species of similar general look, Badamia exclamationis, Fabr., was a little commoner; it was taken on Vernonia flowers, sitting with all its wings up and much sloped back, the hind-wings being folded. One specimen was seen to settle under a leaf. It is not easy to get these large Skippers in good condition as they are violent in their ways, and moreover their scales, especially those of the thorax, are but loosely attached.

So much for the Butterflies. I scarcely worked for Moths, save to box such as came to the lights of the hotel. These included two species of Syntomid: the dingy Syntomis passalis, Fabr. (two), my wife also found under a stonc near the hotel a pupa from which the moth emerged in four days; and the black and white S. cyssea, Stoll, (four), two of f. georgina, Butl., and two of f. eysseoides, Butl. The tiny Eressa subaurata, Walk., occurred on a wall in the hotel garden.

Though small in size the Lithosiines were amongst the most characteristic of the visitors to the lights. Of these the commonest was the littlc spcckled grey and black Siecia (Aemene) taprobanis, Walk., but of the ncat cream-colour and black S. guttulosanc, Walk., there came but one. Several species of Asura (Setina), buff-coloured insects suggestive of, but smaller than, our irrorella, Linn., were taken; A. solita, Walk., five; $A$. curcucta, Moorc, two; and A. semifascia, Walk, one. Gampola fuseialu, Moore, and Mema (Katha) brevipennis, Walk., are both obscure species which occurred singly; so also did Chamaita (Homopsyche) nympha, Moore (a close ally of our Nudaria). More distinctive was Chioncema (Bizone) peregrina, 
Walk. (puella, Moorc, nce Drury), a pretty whitc and scarlet rooth, which was also beaten out in Lady Horton's Drive.

It was somewhat surprising that only one Arctiid turned up, the handsome ermine Creatonotus gangis (intcrruptus), Liun., which was, however, common; it is pinkish-grcy with a longitudinal dark stripe, and has a crimson abdomen. Onc spccimen was noted as having a strong musty smell.

The tiny Acontiid Noctucue were sometimes thought to be Tortrices, so small are they. The pinkish-grey Enispa (Micraeschus) oblataria, Walk., for example, is but $13 \mathrm{~mm}$.- say half an inch-in expanse; one occurred in the hotel at Colombo, one at Kandy. Again the little pink, yellow-fringed $E$. croeeicineta, Hmpsn., might well be taken for a Geometrid allicd to Hyria, or even for a relative of Pyralis costalis. Then there were the pretty little Tarachs tropica, Guen., of which a specimen was also met with at Peradeniya by day; Lithacodia (Acontia) signifera, Walk.; Rivula simulatrix, Hmpsn., and the larger orange and chocolate-colourcd Cosmophila crosa, Hübn., a very widely distributed insect.

The Quadrifinac that came to light were the variable Erchcia (Melipotis) cyllaria, Cram., its dark hind-wings curiously marked with three white spots; the patchy Chrysopera (Achaca) combinans, Walk., its purplish fore-wings bearing a pale costal patch, its hindwings with yellow apices; the huge Nyctipao macrops, Linn., for all the world like a large Old Maid decorated with big ocelli. Added to these one of the hotel servants brought me Ophidcres fullonica, Limm., a large Yellow Underwing.

Threc Deltoids also came to light, Khynchina anyulata, Walk. (plusioides, Butl.), two spccimens; Hypcna varialis, Walk, and Progonia patronalis, Walk., one of cach.

Though the Lymantriids are day-flying moths the following camc to light: Euproctis scmisignata, Walk. (citrina, Moore), a fcuralc; E. scintillans, Walk., a female; E. corvina, Moorc, a malc, and Aroo subnotata, Walk., a femalc.

A solitary Limacod, the small spcckled Narosa conspersa, Walk. was a marked contrast to Eupterote mollifera, Walk., a handsome ycllow-brown moth suggcstive of a glorificd malc Drinker; it is variable, the two males that camc to the lights being rery different in colouring. Then there was a white Uraniid very delicately lined with grey, Pseudo-micronia coclata (fratcrna), Moorc, suggestive of Ouraptcryx. The Geometcrs at light were few and comparatively insignificant, pcrhaps the most noteworthy was Hyposidra talaca, Walk., a pretty purplc-brown, hook-tipped moth, and the dull 
Emerald, Hemithea tritonaria, Walk., but Craspedia (Idaea) fibulata, Guen., and Idaea actnaria, Walk., were of very ordinary Acidaliid type. The usual crowd of Pyrales turned up: Nacoleia diemenatis, Guen., a widely distributed species (like our purpuralis), of which a specimen was found by day close to the hotel ; $N$. tampiusalis, Walk. ; Endotricha mescnterialis, Walk. (like a bright flammectis); the universally distributed Diasemia ramburialis, Dup., and Zinckenia fascialis, Cram.; the pretty white, pink-tipped Noorda fessalis, Swinh., also wide-ranging; Glyphodes celsalis, Walk.; Sylepta adductalis, Walk.; a finely marked S. iopasalis, Walk., which my servant brought me, had probably also been attracted by the hotel lights; the pretty Leucinodes orbonalis, Guen.; the creamy Pyrausta incoloralis, Guen., a wide ranging insect; Pachyzancla phoeopteralis, Guen., which was commoner than any of the preceding; Hellula undalis, Fabr.; and the brick-red Bostra pallidicosta, Hmpsn., which passed muster as a Noctuid. The Crambids were represented by two or three Schoenobius bipunctifer, and quite a number of the more attractive Ancylolomia chrysographella, Koll. (taprobanensis, Moore); the Phycids I may say of course included Etiella zinckenella, Treits., but only one specimen; with it were Epicrocis aegnusalis, Walk., and E. lateritialis, Walk. Not the least interesting of the visitors was the fine Tineid, Hapsifcra seclusella, Walk., of which three females turned up. Less striking was the Gelechiid, Timyra irrorella, Wlsm. The tiny black and ochreous Zygaenid, Dendrocera quadripunctata, Hmpsn., was found in the hotel, but whether it had been attracted by light I cannot sily.

But besides Lepidoptera other insects, amongst which Beetles were the commonest, came to the hotel lights:-The tiny Lamellicorn Orphinns mysorensis, Westw. ; Copris repertus, Walk., and C. signatus, Walk.; the formidable-looking Oryctes rhinoceros, Linn.; Onthophagus turbatus, Walk.; 0. dama, Fabr. ; Macrocheilus tripustulatus, Fabr.; the black Elater, Melanotus hirticornis, Herbst; Apogonia rauca, Fabr.; A. solida, Walk.; and a Coelolophus, represented in the British Museum from Ceylon, but unnamed.

A Mole-cricket, Gryllotalpa sp., was among the less common visitors, also a male Dorylus orientalis, Westw. The black and yellow Wasp, Odyncrus fistulosus, Sauss., had perhaps lost its way. There were two Bugrs, the common green, very fetid Pentatomid, Plautia fimbriata, Fabr., and the black, orange-spotted Reduviid, Acanthaspis angularis, Stål, bearing a formidable recurved spine on its shoulders. One night a great number of Termites came; one of thern confined in a pill-box was observed to have shed its wings within an hour and a half of its capture. 
I did not come across very many noths by day, but this may woll be because littlc time was devotcd to hunting for them. However, the handsome Agaristid, Eusemia nigripennis, Butl., did not need much looking for; it is a largc black moth with primrose-yellow markings. I saw but one example, which flew very slowly in the full sunshine and settlcd on a leaf with wings fully expanded. The pretty white and bronze-green Chalcosia thallo, Linn. (venosa, Walk.), also compelled attention by its slow, weak, vapouring flight. This moth is much given to fluttering about trees and bushes, and one afternoon was seen in considerable numbers about the trunk of a tall tree (Litsaea zeylanica); it is very tenacious of life, resisting chloroform as well as pinching, and has a peculiar, disagreeable, musty odour, not at all strong and seemingly present in botl sexes; on pinching much yellow juice is expressed, which appeared to have a slightly bitter taste. Though not at all related to Chalcosia, one cannot help mentally associating Deilemera (Nyctemera) with it; of D. coleta, Cram. (nigrovenosa, Moore), a delicately marked insect with weak flight, three specimens were taken flying in more or less bright sunshine. This insect also is tenacious of life, but scarcely so markedly as Chalcosia; it also yields a yellow juice, which seemed to be very slightly bitter. A specimen of D. lacticinia, Cram., surprised me by coming to light at the hotel.

Associated in my recollection with both Chalcosia and Dcilcmera is the fine Geometer, Euschema palmyra, Stoll (transversa, Walk.), a large grey-blue, black-spotted, Tiger-like moth, a very slow day-flyer, of which I took two specimens; and by the kindness of Mr. Tylecote brought home a third, taken by him at Peradeniya. This moth is cxtremcly hard to kill. The little two-tailed Epiplema conflictaria, Walk. (lilacina, Moore), was seen spread out very flat upon a leaf.

One drizzling day I made a dash at a swiftly flying Lycaenid, as I thought, but found in my net a smoky Psychid, Hcylacrtsia griseata, Hmpsn., of course a male. Several Lymantriids also wcre taken on the wing, some in full sun, c.g. Lymantria ampla, Walk., and Aroa subnotata, Walk., both with quick darting flight, also the prctty pink, yellow-spotted Euproctis scintillans, Walk.

Onc of the hotel servants brought me on three occasions living specimens of Acherontia lachcsis, Fabr., which he had found on the trunks of Palms in the garden; two of them squeaked loudly whon touched; it is closely allied to our Death's Hend moth. One windy day I picked up Daphnis hypothous, Cram., on a path by the lake; it is very likc the European ncrii.

Day-flying Noctuids do not scem to be in any way charactcristic 
of Kandy, but on my second visit to Lady Horton's Drive at about noon on a dull day the triangular form of the large pale fawn-coloured Yellow Underwing, Ophiusa indiscriminata, Hmpsn. (discriminans, Moore, nec Walk.), caught my eye as it rested on a fern; later on I took two of the obscure Amyna punctum, Fabr. (selenampha, Guen.). On the hill above the Reservoir, at about $2000 \mathrm{ft}$., I took a speeimen of the striking yellow-underwinged Deltoid, Dichromia erosa, Guen.

A specimen of the delicate green Glyphodes pomonalis, Guen., was unfortunately in poor condition. Close to the Reservoir I kicked up out of rank wet grass the well-named Phryganodes obscurata, Moore, and higher up the hill the singular Filodcs fulvidorsalis, Hülon., with long antennae and long yellow body. A male of the Tineid, Timyra machlas, Meyrk., turned up in Lady Horton's Drive.

My solitary Plume, Mr. Bainbrigge Fleteher tells me, is Alucita canclidalis, Walk. (leucodactyla).

One hot day, on a bank above Lady Anderson's Road, I saw an inseet, which I took for a Bombylizes, hovering at a flower; in the net it positively hummed, but on closer inspeetion I thought it might be a Skipper. However, it ultimately proved to be a Clear-wing, Melittia chalciformis, Fabr., a strange-looking creature with very hairy hind legs.

The following were met with in various places in the immediate neighbourhood of Kandy, chiefly on Lady Horton's Drive or thereabouts.

Hymenoptera: Salius flavus, Fabr., a large black Wasp with legs, wings and antennae ferruginous; the tough-skinned Discolia leviceps, Smith; the formidable Hornet, Vespa cincta, Fabr., occurred in many places, but most commonly about a large patch of Vcrnonia above the Reservoir; it was not seen to catch anything, nor to feed on the flowers; it has a very faint hum, a pure low-pitched note free from any buzz. The Bees included a single specimen of Ccratina sp.; the brilliant Podalirius zonatus, Linn., conspieuous by the metallic sky-blue bands on its abdomen, often to be scen hovering at the flowers of Vervain (Stachytarpheta); the Honey-bee of the country was evidently Apis indica, it was abundant; $A$. dorsata, Fabr., of which I took but one specimen, is a large bee with an orange waistband; Nomia cllioti, I. Smith, var., occurred at Vervain, with apparently another member of the genus; of the Carpenter-bees I Inet with three spceies, Xylocopa tcnuiscapa, Westw., two females, $X$. nigro-cocrulea, Smith, two, and $X$. collaris, Lepel., one; T also took 
a single Cuckoo-wasp, the brilliant green Stilbum splendidium, Fabr. ${ }^{1}$

Coleoptera were not so numerous as might have been expected, but it must be remembered that I paid but little attention to the order. The Tenebrionid Ceropria induta, Wied., was abundant under rotting logs on Lady Anderson's Road, it is swift in its morements and brilliant in the sunshine with its violet-pink iridescence; in like situation I took one of the horned Anthracias (Toxicum, Latr.) opprignans, Walk., together with two of the Endomychid, Eumorphus pulchripes, Gerst., a pretty orange and black fungus-eater, and several of the Passalid, Tiberius waterhousei, Kaup; also under logs in the same place the almost uniformly red Lycostomus similis, Hope, together with the excessively hard-impossible to pin-Xylinades westermanni, Schönl. (possibly the same as sobrinulus, Dohrn in MSS.), and two Carabids of the genus Coptodera. Several Carabids of the genus Omphra were taken higher up above the Reservoir, together with a number of Pseudo-blaps javanus, Wied. At rest on a Palw leaf $I$ found the red and black Telephorus dimidiatus, Fabr.

In Lady Horton's Drive I took on the wing the undescribed Longicorn Oberea cylindrica, Gahan in MS., a small, slender, pale red insect with black-tipped elytra. A native child standing close to me picked a specimen of the large Longicorn Xylorrhiza adusta, Wied., off the stem of a woolly-leaved shrub; it was extremely cryptic, looking like a piece of dead wood. A Weevil of the genus Alcides was taken in the hotel garden by beating. In and about the buildings of the hotel, I took several specimens of the Heteromerous beetle Derispia coccinelloidcs, Westw.; since the great Hope Professor gave it that name perhaps I, a humble Lepidopterist, may be forgiren for having taken it to be a Lady-bird [see Plate IV., Fig. 11].

Hemiptera were quite numerous, by far the most conspicuous being the black-spotted, metallic, golden-green Pentatomid, Chrysocoris stockerus, Linn., which was commonly to be seen flying in the sum; it was almost as offensive as beautiful. Shortly after death the golden tint is to a great extent replaced by blue. Is this due to the fading of a yellow pigment, the interference colours remaining constant? The only other Pentatomid was the widely distributed, very fetid, green Plautia fimbriata, Fabr. The pale red Coreid, Serinctha abdominalis, Fabr., was taken on the wing. The Lygreids were represented by abundance of the little Nysius ccylanicus, Motsch., which swarmed upon the flowers of the intruduced Erigcron cunadense, a wandering plant which finds a home alike in the valleys

1 Somo reeent writers call this woll-known iusect S. cyanurum, Forst. 
of the Thames and the Mahaweli-ganga; also by Dysdercus cingulatus, Fabr., a bug that varies mueh in size and eolour, as its black spots may be placed on either a pale red or a grey ground; Graptostethus argentutus, Fabr., was found above the Reservoir; and the pale red Dindymus sita, Kirby, lurked under a stone; the dingy Brachyrrhynchus mcmbranaceus, Fabr., is well adapted by its extreme flatness to its habitat under loose bark. Reduviids were to be had in some variety, the blaek and red Lophocephala guerini, Castel., was found on the road, it had apparently been injured and was unable to fly; Sphedanolestes nigro-ruber, Dobrn, which was netted on the wing, is evidently a scarce species, sinee Mr. Distant had never seen it before I showed it to him; Coranus obscurus, Kirby, is featureless as its name implies; Conorrhinus rubrofasciatus, De Geer, is black with reddish marks; the dull coloured Petalochirus brachialis, Stål, being armed with spines on its shoulders and along the abdomen, ought to be treated with cireumspeetion, for owing to the lack of it I pricked myself smartly. The black Sycanus collaris, Fabr., which has long thin antennae, flew briskly in the sunshine, making a sort of hum or buzz.

Diptera were not very prominent, at all events I did not take many: an undetermined Musca; a species of Idia; Rhinia discolor, Fabr., the two last about the flowers of Wendlandia notoniana, Wall.; an undescribed species of Blepharipoda; S'arcophaga sericea, Walk., and an undeseribed Chaetodyga, which has a singularly raucous buzz.

Two remarkable Whip-scorpions, Thelyphonus sp., must not be forgotten; I took them, one a little below, the other somewhat above the Reservoir, both under stones. They emit an extremely pungent odoul of acetie aeid (which however soon passes off in the eyanide-bottle), and the name Oxypoei is well applied to the group.

The Royal Botanic Gardens at Peradeniya were by no means produetive of inseets, as regards either speeies or individuals, being, probably, too well kept; but I suspeet that the well-known poverty of gardens as entomological hunting grounds is in the main due to the paucity of indigenous plants therein. One, all too small, portion of the garden is purposely kept in a more or less wild state, and this was the only place in the island in which I saw Danaida plexippus, Linn. (genutic, Cram.). Close to Mr. Green's laboratory I took Precis orithyia; my only other Ceylon speeimen of this common Indian butterfly was found on the road above the Reservoir at Kandy. Cyanivis puspa is another capture worth mentioning. The pretty 
little Yphtlima ceylonice was the one really common butterfly at Peradeniya.

In the Gangaruwa Jungle close by I captured a male Melanitis ismene of the dry-season form, also, at rest upon a rock, the tiny Burnet-moth, Dendrocera quadripunctata, Hmpsn.

In Lady Blake's Drive along the opposite bank of the Mahaweliganga, Terias libythea, Fabr., was not uncommon, but it did not occur at Kandy, the specimens of both sexes were of the wet-season form. Of T. venata, Moore, I met with but two individuals in Ceylon, both wet-season males, one in the gardens, the other in Lady Blake's Drive, not far away. Of the $T$. hecabe group I got in the Peradeniya district sixteen specimens altogether; of these I referred a single "wet" male to rotundalis, two males-one "wet," the other intermediate-to silhetana, the remaining thirteen to hecabe, six of them "dry" ( 1 f, 5 q), three "wet" ( 2 f, 1 q), and four intermediate $(3 f, 1$ ) .

It was on Lady Blake's Drive that a large butterfly prored almost too much for both Mr. Green and myself; a Tirumala septentrionis, as we thought, eluded us over and over again, though it is usually an easy thing to net. At last, after repeated efforts, Mr. Green's superior skill conquered, and to our surprise there was in his net Pepilio lankeswara, f. dissimilis. Yet I should underestimate the power of Mr. Green's vision if I said that it equalled that of the average hawk. This will give some idea of the occasional perfection of mimicry.

A few insects of other orders were taken in what I may call the Peradeniya district, but they were neither numerous nor important. When I was out with Mr. Green he found a Carabid of the genus Coptodera and the Heteromeron, Psendo-blaps javanus, under stones ; the small Lamellicorn, Singluala hindu, was to be got in abundance in the flowers of a (?) Cistus; along with it were Haptoncus pubcscens, Murray, and the tiny Idaethina oricntalis. The Lycid, Lycostomus similis, looked very red as it flew to a Mango leaf on which it settled. On damp rocks in the shade, near the river, I found several Derispia interrumpens, Walk. ${ }^{1}$ it is notable that while Westwood called amother species of this genus coceinclloidcs, Walker described his species as actually belonging to the genus Coceinclla, so like are these Hetromerce to Lady-hirds. ${ }^{2}$ The tiny Pentatomids, Coptosoma

Scc Plato IV., Fig. 12.

: It must be admitted that I did not sec any Coccinellac for the Derispiac to 
siamica, Walk., a very variable species which is common in the flower's of the introduced Tithonia diversifolia, are almost as much like Lady-birds. A very grey Dysdercus cingulatus was netted on the wing.

It was on Lady Blake's Drive also that I took the huge Discolia indica, Sauss., a fearsome black creature with bands of red bristly hairs on its abdomen, while, as is nsual, a Mango-tree in full bloom attracted a number of Bees, chiefly Apis indica and a species of Melipona, but among them were a couple of the large Apis dorsata, Fabr. The only Fly that I brought home was Rhinia discolor, Fabr.

A day expedition to Sanda Polla Forest, a large plantation about 28 miles N.W. of Kandy and about $400 \mathrm{ft}$. above sea level was in several respects a disappointment. I chartered a small motor and set forth gaily, ever and anon driving the terrified natives, their children, and their beasts, to right and left as we sped along the beautiful road with much tooting. Of course there was not time to stop at the most promising part. An excellent lunch at the best rest-house that I have seen in the East, Kurunegala, consumed more valuable time; however I got to the forest at last, having picked up a very civil native officer of the Forest Department. I had scarcely realized to what an extent the forest was artificial and was consequently surprised that the only insect other than such as I saw daily in Lady Horton's Drive, was a single Chilades laius, Cram., f. varunanc, Moore, the wet-season form. A wet-season male and an intermediate female Tericus hecabe were taken, as well as an intermediate male T. silhetana. Even Beetles were very rare, although the forest-officer gave grand accounts of the Longicorns that he was in the habit of sending away. One log, a rotten one, yielded the Dung-beetle Catharsius molossus, Linn., and five specimens of Tiberius waterhousei, Kaup.

Presently the chauffeur said it was time to be off, and somewhat reluctantly I folded up my net. It was just as wcll that we did start then, for when we were about halfway home the car fell sick, it seemed to have a paralytic strokc. I was not sorry to get out and walk, leaving the car to follow, as I hoped to pick up some insects. The nearly dry bed of a small river looked promising, so I went down to explore it and look for butterflies drinking. On turning a sharp corner I found myself confronted by a huge Eleplant which secmed to block the way with his widespread cars. There was a ncrvous moment until his mahout returned, for it is said that clcphants are

mimic, and there does not appear to be any Coylon Ladybird at all similar to thom in the National Colloction. 
rarely safe with white men. Resuming my walk along the road, little was seen save a few Precis almuna of the wet-season form. I walked and walked, with many a glance back in vain hopes of seeing the car. Reaching at last the Galagedara Rest House I ordered food; while this was being prepared-consisting of tea, and nauseous bread, made, as is usual, with sugar instead of salt-the car arrived, but the chauffeur said it could go no further that night. There being no telegraph along that road the only thing to be done was to order a bullock hackery. After delays that seemed interminable the strange vehicle appeared. It may be described as a pair of wheels connected by a plank on which one has to balance one's self behind a diminutive bullock. It was eleven miles to Kandy, the first three up a hill that seemed unending, but the rest of the road was better, so that the little beast trotted intermittently, and, with liberal use of the goad and torrents of Sinhalese expletives, we made perhaps 3 miles an hour.

In this wise I returned, slowly, painfully, ingloriously, like a chhota raíyat, ${ }^{1}$ where twelve hours earlier, I had dashed along a very bara sáhib. ${ }^{2}$ In spite of the tropical moon and the fire-flies it was very dark under the palms. Late as it was--for it had taken the best part of four hours to cover eleven miles-we made a small detour to the garage. The proprietor forthwith sent out a sleepy chauffeur with a more powerful machine to go and tow back home the lame duck-made in Germany, be it said.

\section{Haragama.}

Four times I made the fatiguing pilgrimage to HaraGand, twice alone, once with Mr. Green, once with Mr. Tylecote. It is a tenmiles drive and Kandy horses are not swift. Certainly, when seen under favourable circumstances, it is a wonderful place. My first visit was on January 20 th; at 7 a.m. that morning at Kandy the thermometer had fallen to $65^{\circ} \mathrm{F}$. Having had a small second breakfast I left the carriage at $9.30 \mathrm{a.m}$; ; at that hour very few butterflies were on the move, but as I walked up the valley it got warmer and they gradually made their appearance. It was 3.30 p.m. before the carriage was regained, and with it food, and above all drink. For six hours I had walked under a tropical sun, a very task of Tantalus, to be for all that time within hearing of the brawling river the water of which I dared not so much as taste. A great part of the time I was walking under coco-palus, but could not persuade any 
of the few natives that were abont to give me a green nut wherefrom to drink withal. No, the palms were all the property of a great native landowner, and they dared not pick a single nut.

It is strange that in a locality where the Lantana covered acres, I did not so much as see either Danaida chrysippus or plexippus. However, Tirumala septentrionis was not uncommon. Parantica aglea was comparatively scarce, at any rate only two specimens were brought home. Crastia asela was commoner than either of the other Danaines; a female specimen had suffered a remarkable unilateral injury whereby it had lost nearly all the hind margin of the fore-wing, and part of that of the hind-wing adjoining.

Neither did the Satyrines figure very largely in the living picture: Nissanga patnia, so abundant at Kandy, was quite scarce; of Orsotriaena mandata one female was taken; I have no note of I phthima ceylonica, but can hardly believe that it was entirely absent.

A female Euthalia vasanta, Moore, found fluttering on the ground, had probably been trodden upon, a fate to which its habits may well lay it open. A worn male of $E$. garuda, Moore, was also taken. A tattered male of Charaxes fabius, Fabr., was drinking on damp sand, as was a male of Charaxes (Eulepis) athamas, Drury. The latter is a handsome species that apparently varies with the season; by a perverse ingenuity Moore concocted anagrams of the type name, and gave them to the different forms-samatha and hamasta! Of Rahinda sinuata I saw several; Neptis jumba was rather common, N. varmona abundant. Precis iphita was plentiful, but I saw no more than two $P$. lemonias, one of them, a male, was settled with half-opened wings. Cupha placida was common, it flies fast, looking on the wing much yellower than it is; it was once seen to orient with its wings half-open, but on another occasion to settle in the shade with its wings up. The bizarre Cethosia nietneri was almost common, one day I took three males within a few minutes, all at the same spot. I saw the female of Cynthice asela, and took scveral males. Wet sand attracted the male, Lantana blossoms the fcmale of Hypolimnas bolina, she doubtless finding the latter swecter and more fruity; the male of Atella phalantha was also thirsty. Both sexes of Ergolis taprobana were taken. On February 13th, I saw a Limenitis procris, Cram., race calidasa, Moore, at wet sand, and missed another at Lady Macarthy's Drive, Kandy, thrcc days later.

Though a number of specics of Blues were taken at Haragama, they could not be said to be very plentiful. Of many kinds but single examples were met with, vi\%. Nacaduba atrata and Castalius decirlia; Neopithecops zalmora; Megisba malaya, Horsf.; Cyaniris puspa. 
and Polyommatus baeticus; the last four were all drinking at wet sand. In contradistinction to this very select assemblage, Talicuda nyseus was present in great abundanee. Mr. Green demonstrated to me the larva of this speeies feeding on the parenchyma between the upper and the nether epidermis of the fleshy-leaved Bryophyllum calycinum, Salisb. This plant is well known to those who are familiar with the forests of East or West under the name of the "Life Plant" from the faet that the leaves will produce roots. It is a member of the Crassulaceae and apparently of uncertain origin. Griesbach ("Flora of the West Indies") speaks of it as " an Asiatic Weed, ranging now from Mexico to Guiana" " ; but Thwaites (Enumeratio Plantarum Zeylandiae) wrote: "Said to have been introduced." It is somewhat diffieult to believe this latter statement, sinee we find the larva of a butterfly highly eharacteristie of Southern India and Ceylon living as a miner in its leaves. What did that larva feed upon before the plant was introduced? And how is it that the plant has two native names? If it were not so eommon where it oceurs 7 . nyseus would be prized for its beauty and its singularity. A nember of a family in whieh it is often most difficult to distinguish the elosely allied speeies, it stands out by itself, unlike any other. It was twice observed to settle with elosed wings and head up, but at onee to turn round, ${ }^{2}$ and was several times seen to move its hind-wings in the characteristic Lycaenid manner.

Other Blues met with were Zizera indica, of whieh one was seen sitting head down; Everes parrhasius; Lampides bochus, and $L$. celeno; none of these were common. Castalius ethion was, however, somewhat more plentiful, especially about wet sand. Several females of Surendra quercetorum were taken off Lantana; one of them was sitting head downwards.

There is no question that the striking feature of the Haragama butterfly fauna is the abundance of Pierines, an abundance that is quite remarkable. Before going into details it may be of interest to quote my notes as to the hour of appearanee of different kinds of butterflies. "On February 13th I reached the bridge at $10 \mathrm{a.m}$., and found few butterflies about; the first Hcbomoic put in an appearance at 10.30 , it was abundant later; the first $P$ apilio parinda was seen at 11 a.m., it was very eommon later, the first Catophaga was also seen at 11, but it remained comparatively searce all day" (probably it was getting over, as there were still fewer on February 18th). Unfortumately I have no note of the weather, but have a note that

\footnotetext{
1 I mysolf saw it in tho Bermudas, in 1902, growing luxuriantly.

Soe nbove, p. 114.
} 
on that day very few insects were seen drinking. Wilh this experience may be compared another" "Lady Horton's Drive, January 15 th. liained most of the day morc or less, no true sunshine. Yphthima ceylonica moving about frecly; they sat with wings fully expanded, but owing to lack of sun the question of orientation did not arisc. Nissanga patnia abundant. It was hard to make Orsotriacna mandata come out into the open, but Ergolis taprobana was skimming about bushes, in spite of the rain. Several Papilio aristolochiae and onc or two $P$. pammon seen. Three or four Whites were beaten out. There was heavy rain in the afternoon." Also a third day may be compared:- "February 5th, Lady Horton's Drive, 3.0-3.30 p.m. Many Lycaenids about, especially settlcd on the leaves of trees and shrubs. 3.30-4 p.m. Many Crastia asela and Parantica aglea flying slowly about."

Catopsilia pomona was fairly common. The brilliant Ixias pyrcne, Linn., f. cingalensis, Moore, was only found at Haragama, where it was common almost to the point of abundance, but it flies swiftly and is by no means easy to catch. I brought home nine males and four females; all the former, but none of the latter, had a fairly distinct scent, which seemed to me to resemble closely that of Meadow-sweet (Spiraea ulmaria). A female was watched for some time and seen to settlc thrice on yellowish leaves of Bryophyllum.

A still finer butterfly, Hebonoia glaueippe, race australis, though more than once seen by me at Kandy, is always associated in my mind with Haragama from its great abundance about the Lantana. When in fine condition it is a grand insect, but one that is hard to catcl, moreover, worn spccimens are common. On the wing the most conspicuous of butterflies, when settled with its wings closed the underside is remarkably cryptic, no orange is then exposed, but the gencral colour is suggestive of a faded leaf, an appearancc greatly heightened by a "mid-rib" which is actually raised. This remarkable structure is no optical illusion, no mere effect of colour, but is due to a fold in the wing which is visible on the upper side; a similar dark raised linc may be seen in the space below the median vein. The fact that this line is raised is noted by Moorc, but was apparently overlooked by Bingham. Both sexes of this fine butterfly are endowed with a strong heavy scent which recalled that of the flower of the Mango. I took altogether ten males and three femalcs.

Huphina nerisse, like its morc gorgcous rclative, though not confined to Haragama, was distinguished by its grcat abundance there. I took in all twonty-five males and four females, but could easily have got many more. The males had a decided scent, suggesting 
that of our Small White, which-following Professor Inage-I have all along compared to that of sweet-briar. Nychitona siplia was rather common; I suspected a slight sweet scent in one specimen, but lay no stress on this observation.

The most numerous of all the butterflies was unquestionably Catophaga paulina; males greatly predominated over females, my takings being thirty-nine and six respectively, though the actual disproportion of the sexes seen must have been far greater. In phase they were all "clry," or at least "moderately dry." The males had a persistent sweet scent of the Stephanotis type; in one individual it was recorded as "extremely sweet." My note-book contains the following:-- " Haragama, January 20th, about 1 p.m., saw numbers of males of Catophaga, all flying down the river, by ones or twos, but often three, four, or five together in strings. In the old spot by the bridge, where $I$ had seen them four years before, were some twenty-five on the damp sand. With them were a male Hypolimnus bolina, a Hebomoia, a very few Blues, and some other things. When disturbed they would fly off and eircle round, coming back to the faroured spots often five, six, or seven together, in strings, conforming to the movements of the leader, like wild geese." [See above, p. 118.] Again on January 30th I saw a dense eluster of butterflies sitting together on the sand, and popped my net over them; about half of them got away, but $I$ found in my net thirty-eight Catophaga, four Huphina, and one Hebomoia! At a moderate computation there must have been altogether eighty butterflies. The same day I disturbed another cluster of perhaps about the same number, and with three sweeps of my net caught about a quarter of them, to wit, ten Huphina, seven Catophaga, and two Ixias.

Another Haragama Pierine, whieh if not so gorgeous as some others, is to my mind more exquisitely beautiful, is the pale blue, black-bordered Nepheronia ceylanica, Feld. This lovely ereature, which should be seen alive to be properly appreeiated, has the underside of a delieate bluish white with a silvery or shell-like lustre. During life its eyes gleam like olivines. It is rather common in the forest, is somewhat partial to shade, and has an aggravating way of flying right into bushes, indeed, save when on Lantana blossom, it is a hard butterfly to net. A female so seen was aetually taken for Parantica aglea, of which it is a very fair mimic. The lovely male is far more often seen than its comparatively dull partner, my number's are 14:2. Apparently both sexes have a deeided, but not very stroug seent, like that of lircesia. Mrs. Longstaff described the seent of a female as "slight frangipani." 
The Terias taken at Haragama consisted of one hecabe (an intermediate male), seven silhetana (tro "wet" males, two intermediate and two "dry"; as well as one dry-season female), and one rotundalis (a wet-season female).

But Blues and Pierines were not the only insects seen drinking at damp sand. Once I saw four Papilio pammon sitting all in a row; $P$. telephus was seen, but got away, then the glorious $P$. crino twice put in an appearance; though $P$. aristolochiae was fairly common, it did not seem to be thirsty; $P$. agamemnon, again, though common, preferred Lantana honey to water; a female $P$. lankeswara, f. clytic was mistaken on the wing for Crastia asela. A female Ornithoptera darsius, which had suffered a symmetrical injury to both hind-wings very suggestive of a bird's beak, had a decided musty straw odour, very different from that of a male, which suggested to my wife Rosemary, or rose-scented hair-oil, but to me it seemed more aromatic, suggesting Canada-balsam, or Sassafras. However, the Papilio most characteristic of Haragama is certainly parinda, a grand insect; the male was quite common, though the female was scarce. Thcy are easier to catch in the afternoon than in the morning, though fewer may be seen. I feel sure that Mr. Millar of Durban was right in saying that, in the afternoon, though fewer butterfies are seen than in the morning, the proportion of females to males is much greater.

Skippers were conspicuous, if not exactly by their absence, at any rate by their rarity. A female Parnarce mathias, a female Iambrix salsala, and a male of the neat black and white Notocrypta feisthamelii were all things that I had met with elsewhere that season, but not so the tawny brown and grey Capronce ransonnetii, Feld., which looked very pretty as it sat with widely spread wings; of this I took four specimens, all on February 18th.

One morning a native collector arrived on the ground just before me, and later in the day I happened upon his decoys, a parinda and a glaucippe pinned on to plants, as well as two parinda stuck into mud. I also got some evidcnce of the attractiveness of urine.

It is difficult to believe that Moths are as scarce at Haragama as snakes in Ircland, it is morc likely that I was too much occupied with butterflies to look after them, but, be that as it may, four visits scem to havc produced but two nothis; a Syntomis passalis, Fabr., f. montana, Putl., and an Aroa subnotata, a male, taken flying quickly at about 3.30 p.m.

For similar reasons I found Beetles few and far between; single 
specintens of Mylabris oricntalis, Dcj., Telephorus dimidivinus, and Ichthyurus inermis, Fairm., were netted on the wing, the latter has short yellow elytra; some Carabids of the genus Omphra, which were found under a stone, Mr. Arrow thinks may be ovipennis, Reiehe (in $M S$.).

Hymenopterous society was almost equally select, being made up of single individuals of Iearia ferruginea, Fabr., the large steel-blue-winged Salius iridipennis, Smith, the black, yellow-lerged Sceliphron intrudens, Smith, and the brilliant green Cuckoo-wasp Hexaehrysis oculata, Fabr.

Two specimens of the Bombyliid, Hypercalonia tantalus, Fabr., represcnted the great order Diptera, while two Plautic fimbriata did the same for the Hemiptera.

Though Dragon-flies were abundant enough at Haragama, I never saw one catch, or even chase, a butterfly.

One day a native brought me a fine specimen of that strange creature, a Phrynieus sp. It is allied to the Scorpions, but its chelae, or pincers, are so long and slender that they might easily pass for the first pair of legs, whereas in reality the first pair of legs are extremely long, attenuated, and flexible, and would appear to function as antennae.

It was at Haragama that Mr. E. E. Green showed me the smallest of Snakes (one of the Uropeltidae), scarcely as thick as the pen-holder with which I write, and little if at all longer. The snake curled itself up in the palm of my hand, raised its head, and put out its tiny tongue. It lives in dead wood, pursuing in their burrors the beetle-larvae upon which it feeds. Truly, as Mr. Green said, the Tropics produce alike the largest and the smallcst creatures. Another day, when splitting a rotten log with my hands, I disclosed another small snake (though somewhat larger than the first), but it got away: Again, the turning over of a sawn log exposed to view a Toad and a pretty little Mouse with a thin face and large ears.

After my first expericnce of motoring in Ceylon I had many misgivings about undertaking a longer expedition to Anuradhapura and Trinkomali. However, I was assured that a somcwhat disreputable-looking Wolseley car was the most enduring of any in the island. It was not preciscly silcnt; it had evidently had no paint or varnish wasted upon it since it left the manufactory, and evcrything that need not shine was dull. Neverthcless, haudsome is that handsome does, and that car took me, my wife, and Miss Poole, the wholc journey successfully. It was a non-stop run, for a faulty electrical connection that was put right in two mivutes could scarcely 
be called a break-down. Certainly motoring is the mode of progression for the Tropics. The car was of course covered, that is a necessity, and the rapid motion through the air made it difficult to rcalize the heat of the low country through which we passed. The entomological results, however, might have been better had we travelled in a bullock-waggon.

I have always urged that the irritation caused by the bites of insects is greatly increased by scratching, and that a little self-control will often lead to its rapid subsidence. But still more serious results may follow. We were going through a straggling native village when a small calf chose that occasion for strolling across the road; the car would have easily cleared it, but at the critical moment the calf stopped and leisurely licked the small of its back! The car gave a jump, and when I last saw that calf it was on its back in the middle of the road, with its legs straight up in the air as stiff as those of a Noah's ark beast that had been knocked over by a child.

Dambulia, 45 miles due $\mathrm{N}$. of Kandy, $334 \mathrm{ft}$. above sea-level.

February 24th and 29th.

The huge, almost smooth, isolated black rock rises about $700 \mathrm{ft}$. above the plain. On one side it overhangs considerably, and this portion, enclosed by walls, forms the celebrated Rock Temple, now something over 2000 years old. In the dim light of the temple, beneath the painted ceiling we saw rows of solemn Buddhas of stone, wood, or plaster, sitting in cross-legged meditation. They were usually dignified, often impressive, as was certainly the colossal recumbent figure, 47 feet long, carved out of the solid rock.

We got an afternoon here for collecting on the outward journey, a morning on our return. The gorgeous Papilio hector was seen in larger numbers here than at any place, but $P$. aristoloehiae was scarcc. Nychitona xiphia was common, T'alieada nysers abundant. Here I found for the first timc Azanus jesous, Guér, one of each sex, also Catochrysops strabo, Fabr., which was common, but all I took were of the male scx. It is sufficient merely to incntion Catopsilice pyranthe (one), Terias tieeabe (one), T. rotundalis (a male), Lampides celeno (onc), Tirumala septentrionis (two), Chilades laius (two), Zizera incliea (two), Polyommatus baetiens (one), and Atella plualantha (one); none of them were common.

Wet sand in the river bed and some tributary streams attracted a fair number of butterflies. Catopsilice pomona and Catophaga paulina 
were in abundance, and among the others were a male Churuses fabius, several Tarucus plinius, all males, as well as a male of the beautiful and very distinct Curetis thetis, Drury. In the bed of a small stream two or three miles north of Dambulla, I saw a Papitio jason, Esp. (telephus, Feld.) on the wet sand, struck at it, netted it, but with the same swoop netted also three Catopsilia pomona, one Huphina nerissa, and eleven Catophaga paulina! Numbers of the little Nacaduba ardates were about a tiny puddle in the path.

The only moths met with at Dambulla were the day-flying Deilemera coleta and the Geometers, Alana capitata, Walk., and the purplish-grey Timandra mundissima, Walk., the latter in the resthouse at night, where it was accompanied by the Chafer Phyllognathus dionysius, Fabr. The Elater Melanotus hirticornis was clinging to the mosquito-curtain of my bed, having been in all probability attracted by light the night before. Inside the same curtains I found the Pentatomid bug Megymenum brevicorne, Fabr., a tuberculated brown creature with short flat antennae; whether this insect had merely taken advantage of a convenient resting-place, or whether he had an evil design upon the writer, I am unaware, but if the latter, all I can say is that he was anticipated. A few other bugs whose actions were less open to suspicion were the brilliant scarlet and black Reduviid, Sphedanolestes nigro-ruber, a rare insect; another Reduviid, the handsome, large, shining, blue-black Physorrhynchus linnaei, Stål, which has the underside and the margins of the abdomen brilliant scarlet, the antennae of the male are hairy; it exhales a pungent acetic odour, quite unlike that so commonly met with in Pentatomids. I found my specimen under a log. Yet another Reduviid, Velitra rubro-picta, Am. \& Serv., was found under the bark of a $\log$ in the compound of the Rest-house; it is a somewhat variable bug, my specimen lacking the usual red pigmentation.

A few beetles were turned up from under logs: the Tenebrionids, Pseudoblaps clavipes, Walk, and two specimens of another species of the genus; a Carabid of the genus Omphria; Platysoma desinens, Walk., and Tacniolobus sp. Mrs. Longstaff found a specimen of Trachypholis hispidus, Web., near the Rock Temple. I also came across the Phytophagid, Apophylice pallipes, Jac., ${ }^{3}$ and the planteating Ladybird, Epilachna indica, Muls. A native child brought me a living specimen of the large, brilliant, metallic, emerald-green Stcrnoccra stcrnicornis, Linn.; it is a well-known Buprestid which I feel sure that I had seen more than once in Lady Horton's Drive;

1 I bad heard of Martin Jacoby's death from Mr. Green but a fer days preriously. Shortly before sailing I had promiscd to get bim some Phytoplaga. 
it was very conspicuous on the wing, but never came within reach.

Of the Hymenoptera the most conspicuous was Xylocopa tenuiscapa. A flowering shrub was especially attractive to Bees, including plenty of Apis florec, Fabr., var. andreniformis, Smith, a Ceratina, and a Prosopis; I took also one of the blue bee Podalirius zonatus.

The most interesting Dambulla insect was Scelimena logani, Hancock, of which my wife caught the first specimen when fishing for IVater Snails in a swift but shallow stream. This is a genuine Water Grasshopper, or rather amphibious grasshopper. It flies in the sun readily enough for two or three yards, and, when it alights on rock or sand at the water's edge, is by no means easy to see, being exactly the colour of its surroundings; it is, however, easily caught when detected. When it takes to the water it swims beneath the surface with a series of jerks, each stroke carrying it but a short distance, recalling a Water-boatman (Notonecta), though it does not swim on its back as they do. Examination proves the hind tibiae and tarsi to be flattened out so as to form jointed oars. [See Fig. 13; also Plate IV., Fig. 13.] Mr. H. Knight pointed out that the blade of the oar strikes the water with a concave surface as the insect kicks out, whereas in recovering a convex surface is presented to the water. Mr. Shelford informs

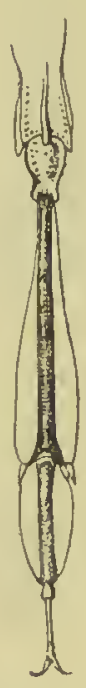
me that the nearly allied Gavialidium crocodilus, Sauss., has hind legs of the usual structure. I subsequently came across $S$. logani in a small stream close by the Rock Temple at Hindugala, two miles south of Peradeniya, but not in such numbers as at Dambulla.

\section{Avuradhapura, 86 miles (by road) N. of Kandy, $278 \mathrm{ft}$. above sca-level.}

February 25th and 26th, 1908.

The road from DambulLA to ANURADHAPURA lcads through a very sparsely inhabited jungle. In ancient times the land was irrigated and under cultivation, but the irrigation works were allowed to fall into decay, and Nature resumed possession, as a consequence it is now covered with a forest of secondary growth. The trees are of very moderate sizc, there are practically no palms, and there is littlc save a general untidiness to suggest the tropics. Houses are milcs apart and very few people are met with, the only vehicles bcing the picturesque covered bullock-carts. 
Flowers are but little more obvious than human beinors, and a large part of those seen are wecds introduced from Ancrica. Such of the aneient tanks as still hold water are ervered with Watcr-lilies. From time to time one gets a glimpse of long-tailcd Monkeys, and one of them in its terror almost fell into the motor. The Golden Oriole, and other brightly eoloured birds, blue or green, now and again fly across the road, but the bird that interested me most was the Jungle Fowl (Gallus bantivus, or possibly a closely allied speeies), the reputed ancestor of our various breeds of domesticated fowls. The cock is in general eolouring very like a game-eock.

The most remarkable thing about Anuradhapura is the vast extent of the ruins. They reach for miles into the forest. The great bell-shaped Dágobas, about as big as St. Paul's, rank first in magnitude, but I admired more the countless granite monoliths, of whieh there must be many thousands. These monoliths are for the most part square, often ornamented in the upper portions and usually bearing capitals; of somewhat slender proportions they range from 8 feet or 10 feet to upwards of 25 feet in height. Many of them lean in a manner whieh is surprising until one learns that they are pushed out of the vertical, and held in the oblique position by masses of treeroots, for Anuradhapura has been a deserted city for over a thousand years during which the forest has reigned supreme. Its most important buildings are upwards of 2000 years old. Apart from the main show-places, it is strange to see in all direetions these monoliths standing in the tangled forest, and oecasionally a solemn figure of Buddha, still meditating, teaehing, or "renouneing the rorld." The priests in their flowing yellow robes of almost classic fashion, as they move quietly about the ruins serve to conneet the remote past with the present, for to Buddhists this is very holy ground. Dr. J. C. Willis, the Director of the Royal Botanic Gardens at Peradeniya, seems to think that the much venerated Bo-tree may quite possibly be the original trce, whieh in its turn grew from a branch of that under which Gautama attained Buddha-hood, at Bodh Gaya in Northern India. That braneh was brought to Ceylon in 288 B.C. Even so it would not be the oldest known tree in the world, for the Tree of Confueins dates back to 500 B.C.

The part of the ruincd city that found most farour with butterflies was the pavcment round the Ablayagiriya Daigoba. In India I had learned to associate ruins and the genus Tcracolus; it was the same here, the species in eharge, which was quite common, being T. amatus, Fabr. (modestus, Butl.). Thesc pretty butterflies were deeidedly of the "wet" phase, the females were almost equally 
divided between the pale form and the reddish form. I have often found Ixias associated with Tcracolus, but her'c found but a single male mariunne, Cram., of intermediate "dry" phase, though Huphina nerissa was distinctly "wet." Other buttcrflies were a male Catopsilia crocale, a male Dclias cucharis, a few Danaida chrysippus, Zizcra indica, and Catochrysops strabo, with single specimens of Prccis lemonias (dry-season form) and Parnara colaca.

Two species of Podalivius, hovering as usual, werc also as usual hard to catch, viz. the blue $P$. zonatus, and the violet-black, $X$ ylocopo-like $P$. violaceus, Lepel.; the only wasp was the small yellow Eumenes csuriens, Fabr. On the flowers of Vervain were two black and red Mylabris, the large M. pustulata, Thunb., and the small M. thunbergi, Billb. A few Carabids of the genus Omphra were found among the ruins. Among some dead snail-shells Mrs. Longstaff found a specimen of Ethas carbonarium, Pascoe.

The Ricst-house lights were not so attractive as might have been expected, the neat but solitary Pyrale Samcodes canccllalis, Zell., having as its only companions the Scarabs, Copris repertus, and Catharsius pithecius, Fabr., f. crassicollis, Walk., three, and a species of Encyalesthus, not in the British Museum, which was actually too hard to pin.

I went one morning about four miles along the Trinkomali Road which goes through the forest. Speaking generally butterflies were not common or remarkable: Danaida chrysippus, Precis iphita and lemonias, Hypolimnas misippus (a species that I did not see elsewhere in Ceylon), Yphthima ceylonica, Mycalesis mineus, f. polydecta, the "dry" phase; Papilio pammon, and P.tclcphus; Zizerce indica and Z. gaika; Catochrysops cncjus, Fabr.; and Tcrias hccabe, two males, one "wet" and one "dry." A male Lithosiid, Nishada flabiferca, Moore, was seen to settle upon a lcaf.

When I say that butterflies wcre not common I must make an exception in favour of Catophaga paulina. Mr. John Pole had told me that if I could find a dainp place where bullocks had halted I should be sure to find numbers of buttcrflies there; he said the butterflies werc attracted by the ammonia. I dicl find such a place, and surc chough there was a patch of white butterflies about five feet long! Sweeping my net along them filted it with a rusting crowd of at least $50 \mathrm{C}$.panlina. Aloug with the Whites werc odd specimens of Crastia ascla and Narmada montana.

The old flight of moss-grown steps through the forest $1 p$ to the temple at Mihintale had quitc a romantic charm that grcatly affecterl us. Though there was little tine or opportunity for collecting, I 
took, or at least saw, Pupilio hector, Nepheronia coylanicu, Culopsitio. pomona, Nissanga patnia, Zizera gailea and Lampides celeno, as viell as the metallic-green Bug, Chrysocoris stockerus. MIrs. Longstaff, while hunting for snails at the bottom of the steps, found among dead leaves a dark metallic-blue phytophagous Bicetle, Coryncides dohrni, Baly, as well as a luminous beetle-larva (? apterous female). This insect used the last segment of the abdomen in walking as a "clasper," somewhat like a Geometer larva, or a leech. On the underside of the penultimate segments it exhibited two constant green lights. In the centre of each was a black non-luminous spot. When put iuto the cyanide-bottle the lights were almost instantly extinguished.

Fire-flies always interest me, and although out of the order of the narrative it may be convenient to record here some observations made at Kandy.

January 21st, 1908. Luciola (?) vespertina, Fabr., ${ }^{1}$ a female, taken at light in the hotel. When first captured it was flashing at the rate of about 120 to the minute. On being chloroformed the light at once became constant, but in a minute or two was extinct.

January 24th, 1908. A fire-fly, Luciola vespertina, Fabr., came to light. When disturbed it gave forth an intermittent light at the rate of from 60 to 90 flashes to the minute, possibly sometimes even more rapidly, but it declined to flash for many seconds together, so that it was not easy to measure the rate. It was put into the cyanide-bottle, and as soon as it appeared to come under the influence of the poisonous vapour, and before it ceased to move its legs, the flashes gave place to a continuous light. This was fairly bright after fifteen minutes, but when looked at after the beetle had been thirty minutes in the bottle the light was found to be extinct.

January 25th. A fire-fly, Luciola vespertina, flashed very irregularly. When running about in the box the flaslies followed at fairly regular intervals, but when the insect stopped the light ras cxtinguished. I actually connted 29 flashes in one minute, but the rates measured for shorter periods (quarter to half a minute) worked ont at $36,36,44,24,28,32,36$ per minute. It occurred to me that possibly the rapidity of the flashes might be proportional to the rapidity of movement of the legs or wings. When put into the cyanide-bottle the light was cxtinguished almost inmediately.

January 28th. Two fire-flics, Luciola vespertina, camc to light.

Fire-fly A was very active; four counts gave the rate of pulsation

1 This lacks the black spot on the elytra, and Mr. C. J. Gahau thinks that it may possibly be distinct. 
of the light as $100,104,90,86$ per minute. It was then put into the cyanide-bottlc; in about lalf a ininute, beforc the death of the insect, its light becamc constant; in four minutes the light was very faint, in five minutes it was extinct.

Fire-fly $B$ was also very active; four counts gave the rate of flashing as $116,122,106,102$ pcr minute. It was then chloroformed; within about twenty seconds the light had become almost constant, in three minutes it was faint, in four minutes extinct.

A short halt some 25 miles short of Trinkomalí, in a delightful part of the forest, where the trees were much finer than usual and the roadside grass of more interesting character, yielded only Crastica asela, Tirumala septentrionis, a male with a pleasant scent, and a "wet" Terias hecabe. Grubbing among dead leaves unearthed the brilliantly shining Phytophagid beetle, Corynodes dohrni, and a second specimen, an apterous female, of the fine scarlet and black shining Bug Physorrhynehus linnaei; it has remarkably thickened fore femora, and a fetor of its own.

\section{Trinkomalí.}

February 27 th, 1910.

Trinkonali is very beautiful, and we saw it under the best of weather conditions, alike during an afternoon walk round Fort Frederick and an evening row in the lovely harbour; but the whole place is wrapped in an air of gloom the impression of which has not yet worn off.

Fort Frederick is entcred by a fine gateway forming part of the old Dutch works; just inside will be seen the date 1676 , but it was not captured by us till September 1795, and the Royal Arms must have been set up later still. As I entered a native policeman saluted mc; he and one other native seemed to make up the garrison. The fine ranges of barracks looked forlorn in the extreme; a notice, "this water to be used for washing only," seemed to grin mockingly nt the visitor. In a singularly beautiful retired corner under the shade of a group of trees stood a row of tomb-stones marking the last resting-place of some of the Dutch officers of the quite old days. In an ancient battery close by wcre a couple of 32 -pounders bcaring the monogram "G.R." A 9-inch muzzle-loading rifle-gun, an obsolete weapon of the mid-Victorian epoch, set on end in the ground formed a scat. On cvery hand the remains of turn-tables and rotting 
gum-carriages were to be seen. At the highest point was a nava] signalling station still rigged with yards, blocks, and halyards, lut there was no flag, no one in charge; one missed the neatly dressed man with a telescope, the respectful salute, the cheery gossip, and wondered listlessly how long it might be before the halyards would rot and the yard would fall. A few paces further, at the point, lay the latest instrument of destruction, a " $9 \cdot 2$." But it had no breechpiece and no elevating gear; each end was plugged with wood, its muzzle propped up by a baulk of timber. I suppose it had cost the British tax-payers over $£ 10,000$ to make that gun and place it there.

An exceptionally fine Palmyra Palm must have seen many changes since it first raised its proud head, at least a century ago. Two half-tame Deer wandered about in peaceful possession, waiting for the time when the rapidly invading jungle should have driven away all recollection of their old masters, from whose hands they had doubtless often taken food.

A solitary Dove was an appropriate living symbol of the changed times, and the only warlike thing still in commission was the Speargrass.

Doubtless ere long Fort Frederick may afford quite good collecting, as it was I found Papilio hector where I should have seen a signal-man, and Catopsitia pyranthe appropriately enough fast asleep close by; several Blues - a female Tarucus theophrastus, Fabr. (the only one seen in Ceylon), a male Azanus jesous, a female Zizera lysimon, a male Catochrysops strabo, and a female C.cnejus. Then there were Telchinia violae (it was just the sort of place it likes), Yphthima ceylonica and quite a number of Teracolus amatus. On a wall of a deserted building was a delicate greeny-blue Wasp: Seeliphron bengalense, Dahl.

To me there is always something inexpressibly sad about abandoned military works, especially if they be in a remote part of the world. One thinks of the brave men of old who attacked or defended them, performing deeds of heroism now totally forgotten. Certainly the makers of treaties and framers of policies never think of those men.

Exceedingly sorrowful and depressed I walked across the Maidan to the Rest-house, distinguished from all others by a llagstaff smartly rigged in man-o'-war fashion. Its large dining-hall is covered with photographs of Naval Officers and ships-of-war, with heads of deer interposed here and there. The wizened old Rest-honse keeper, "Tamby" by name, and his still older waiter, who had both attended 
to the wants of geuerations of sailors, looked woe-begonc to the last degrce, for had not their glory altogether departed? Tamby said to me wistfully, "You know, master, when they come back?" Alas! I did not know. So far as I am aware the only other guest of Tamby's that night was a male Hyperlophce cristifera, Walk., a Noctuid in whieh the sexes greatly differ.

Soon after our arrival the Rest-house was invaded by an army of Box-wallahs, who at once besieged us with shells, sharks' jaws, skins of leopards and pythons-with all the things, in fact, which had found a ready markct in the squadron; the men were sorrowful and looked really hungry. After some trifling purchases I said to them, "You had better go away and pray to Muhammad for the sailor's to come baek." They quite understood and smiled sadly.

Then there are the trim Admiralty buildings in tidy rows along the shore of the harbour, a harbour alike beautiful, safc, eommodious, and easily defended.

That part of Admiral Fisher's poliey of coneentration whieh led to the abandonment of "Trinko," among other outlying stations, may have been wise, but I incline to agree with those who, realizing that modem ships are far more dependent upon dockyards in war time than were the "wooden walls," look upon the abandonment of this place-the only good harbour in Ceylon-as an aet of madness which may in the future eost the nation dear.

\section{HABARANE.}

On our return journey to Kandy wc made a mid-day halt at Habaranc, a very English-looking placc in the heart of the forest, in hopes of finding something new, a hope that was not justified. $\Lambda$ number of butterflics were observed but they wcre members of the Old Guard. Crastice ascla, I'irumala septentrionis, 'i I'arantica aglea; Precis iphita, Ergolis taprobana and ariadne, Cethosia nictneri, a Neptis; Zizera otis, Lampides celeno; Catopsilia pomona and pyranthe, Terias hecabe, C'atophaga paulina, Huphina ncrissa; Papilio tclephus, $P$. hector, $P$. aristolochiae, $P$. parinda, Ornithoptera darsius; and Iambrix salsala. With these were the common Chrysocoris stockerus, and the wasps Secliphron bongalense and Eumenes flavopieta, Blanch., the last having a U-like mark on its thorax. 


\section{HATTON.}

March $3 r d-10$ th, 1908.

Hatton, lying just below Kotagala, or The Duke's Nose, a prominent mountain which forms a conspicuous object from many points on the railway, is a chief town of the tea-country. Kotagala is capped with a surviving patch of forest: it was in its dampest glades that I made my first intimate acquaintance with the dread Land Leech: a restlessly active, pushing, over-familiar, blood-thirsty animal that I never wish to see again.

A few things came to the lights of the hotel; the Boarmiid, Tephrina parallelaria, Walk.; the Pyrale, Bostra castanoptera, Moore; the Crambite, Poujadia inficita, Walk.; the tiny white Hydrocampid, Mixophila renatusalis, Walk. (Crambus ermineus, Moore) and the Chafer, Anomala walkeri, Arrow.

Xylocopa tenuiscapa, a female, turned up in our bedroom, but that I presume was an accident.

In or about the hotel garden I took Terias hecabe and T. libythea, also a female of Pademma sinhala, Moore, which had an acetic odour. A very old friend was also there, Pyrameis cardui, an insect that I had not met with in Ceylon previously. The two-tailed Geometer, Epiblema obseuraria, Moore, spread out upon a dark stone closely resembled in colour a piece of lichen.

In the tea-gardens between the hotel and the forest Catopsitia pomona, Catophaga paulina and Argynnis hypcrbius, Johanns. (niphe, Linn.) were occasionally to be seen. It was noted at the time that though the male hyperbius looked on the wing like the Fritillary that it is, its female was actually netted for Danaida chrysippus. In the drying-house a Hister was found under wood. A fly, Rhinia sp., frequented the flowers of the tea plant.

Naturally enough I spent most of my time in the forest, and this in spite of the haunting terror of leeches. The summit of Kotagalla is perhaps $1000 \mathrm{ft}$. above the hotel; one day I climbed up for some distance, but as insccts got less and less common with the altitude, was not cncouraged to persevere. The only Danaines met with werc Crastia ascla and Chittira fumata, Butl. (taprobana, Feld.), neither of them in any numbers, but the latter interested me inasmuch as I thought I saw it in the same place in 1904. ${ }^{1}$

The only Satyrs were single examples (both females) of Lethe drypetis, Hew., and L. daretis, Hew. (though at least one other of 
the latter was seen), both of them speeies whieh I had taken in the same place previously. It is somewhat remarkable that on neither visit did I see Yphthima ceylonica. A few Neptis varmona, Atella phalantha, and Preeis iphita were observed and one Hypolimnas bolina, while Limenitis calidasa sat on a leaf high out of reach. The Blue Admiral, Vanessa haronica, was very decidedly eryptic when settled on the bare mottled, purplish-grey rocks, and by no means easy to eapture, but after some manœurring up and down the bed of the stream I at length secured a speeimen.

The eommonest Blue, especially near water, was Cyaniris singalensis, Feld. (which Bingham regarded as a race of huegeli, Moore); they were all males, and several of them had a sweet scent, but not of the ehocolate-vanilla type, common to so many Blues. Of $\mathrm{C}$. limbata, Moore, I took but one, not distinguishing it at the time from the preceding. Curiously enough I do not seem to have met with any Lyeaenids other than these two.

Catopsilia pomona was deeidedly common, once more showing a partiality for the bluc flowers of Vervain (Stachytarpheta); the only other Pierines were Terias hecabe and silhetana, which oecurred in about equal numbers.

Several examples of Papilio teredon, Feld. (regarded by Bingham as a race of sarpedon, Linn.), were seen; it was noticed that they did not flutter when settled on damp sand; a single $P$. parinda and one or two $P$. agamemnon also put in an appearance. But the Papilio eharacteristic of Hatton was unquestionably $P$. helenus, Linn., f. mooreanus, Rothsch., which was almost common along the stream. Its seheme of colour, black with a squarish cream-coloured patch, is chaste and effective; its flight was somewhat wild, but near the Tamils' drinking-place a couple were netted sitting quite close together. On another oecasion threc were scen drinking together, their wings but three-quartcrs open, so that the ereamcoloured spot on the hind-wings was entirely concealed and they appeared to be blaek uniformly. This species flutters when drinking.

But though this Papilio was the biggest thing I took at Hatton, it was not the best, for the very dark, almost blaek Skipper, Hantana infernus, Feld., is distinetly rare; it is (for a Skipper) a slow flyer, and I secured three specimens which were all scen to settle on the underside of leaves with wings fully expanded. The only other Skippers actually eaptured were Notoerypta feisthamelii, which settled with its wings up, and a female Celaenorrhinus spilothyrus, Feld. 'The latter is a conspienous inseet with a moderately quiek flight; it 
settled under a leaf; there can be no doubt that this habit is an elicetive mode of protection. Another largc black Skippcr, sinnilarly concealed, was netted, but managed to get away. The same day the handsome Tagiades obscurus (distans, Moore) was seen settled on the upper surface of a leaf with wings expanded; on a previous occasion a Hantana settlcd on the nppcr surface of a leaf of a Bramble, Rubus rugosus, Smith, the prickles of which made the butterfly's position unassailable.

The Pyrale, Pachyzancla phocopteralis, was locally abundant by the stream. The handsomc Tineid, Timy ra crassclla, Fcld. \& Rog., camc to light; it resembles our Phibaloccra qucrcana. The Oecophorid, Psaltica monochorda, Meyrk, was taken in the forest and in a tca garden.

The only Aculeate was an undetermined Ccrccris. On the other hand, Flies were comparatively numerous : Rhinia discolor; a rubbed Anthrax; a brilliant green Psilophus, with a coppery spot on its abdomen, not represented at South Kensington; the Syrphid, Asarkina ericetorum, Fabr.; and a Tabanid Haematopota unizonata, Ricarde, which attacked me one dull afternoon just before rain.

Turning over stones and logs in the forest, more especially in damp places, proved a perilous employment, which indeed the Leeches finally forced me to abandon. These things are difficult to explain, but it is a fact that I am more frightened of ticks and leeches, insignificant though they appear, than I am of venomous serpcuts. The latter can be put to flight, but the smaller and morc insidious foes know no fear.

The Beetles found were a Tenebrionid, a species of Ulma, togethor with the Passalids, Chilomazus comptoni, Kaup., and an ummamed species of the same gcnus. I found upon my net a slender red and black Longicorn, an Oberca, represented in the British Museum, but undescribcd. The Cetoniids, Clintcria plcuronota, Blanch., and Popillia complanata, Newm., wcre taken flying about flowers or shrubs. Somewhcre and somehow at Hatton, for I canuot speak precisely, I got a specimen of the Melolonthid, Lachnostcrna cingalcnsis, Brenskc. The brilliant Chrysocoris stockcrns turued up again.

At the Devon Falis, circa $4000 \mathrm{ft}$ above sea-level, and 10 miles west of Nuwára Eliya, I took nothing remarkablc: Ncptis varmona, Talicada nyscres, Dctias cucharis, Tcrias Teccabc, and Tclicota bambusae.

At NANU OYa station, $5300 \mathrm{ft}$., a pale yellowish-brown phytophagous bectle, Lema ycrburyi, Jac., flcw into the train. 
BANDARAWELA, circa $4000 \mathrm{ft}$. above sea-level.

March 11th-14th, 1908.

The railway journey from Hatton to this place is one of marvellons beanty. The train, after running for many miles through tea-gardens, enters the primaeval forest near the Horton Plains, a most fascinating region but little disturbed by man, where the Rhododendrons catch the traveller's eye, not lofty trees as in the Himálaya, but rather having the character of big shrubs. The train then enters a short tunnel under the ridge of the mountain, to emerge in quite a startling manner: there is a complete transformation scene. One finds one's self high on the side of a steep mountain range, with a rich plain spread out at least $3000 \mathrm{ft}$. below. This plain is almost enclosed by hills which are highest on the side taken by the train.

At BANDARAwELA there are tea-gardens on the higher ground, but between them and the river is a wide stretch of grass land having a down-like character. There is but little wood, though there is a swamp not far from the town.

As at Hatton so here Yphthima ceylonica was conspicuous by its absence, but I was pleased to catch a specimen of the very distinct $Y$. singala, Feld., an endemic species. I also took one Mycalcsis perseus, Fabr., an "intermediate tending to dry" female, and saw others; I did not meet with this species elsewhere in Ceylon. Several M. polydecta were seen, but they were difficult to catch, owing to their habit of keeping closc down among the vegetation, whence they are dislodged with difficulty. I secured one of each sex, both more or less "dry"; when the pencils of hairs on the wings of the male were exposed a strong burnt-sugar odour was clearly perceptible. A female of Lethe rohria, Fabr., race nilgivicnsis, Guér., a butterfly of slow flight, was seen settled on the ground in an open place near water.

Neptis varmona was rather common, and a few Prccis iphita and orithyic were noted. Late one windy afternoon on a barc and exposed hill-top a solitary malc Pyramcis cardui was found haunting the cairn that crowncd the summit; it was just the sort of spot that the species loves all the world over, and, as usual, when disturbed it returned to its post again and again; both its hind-wings had suffered loss, apparently by the mouth of a lizard. I was somcwhat surprised to take a female Cethosia nictncri halfway betwecn Bandarawela and the river on the Welimada path. 
Danaines were not numcrous, single specimens of four specics were met with : Danaida chrysippus, a small female; Narmarla montanu, a female, on the top of a grassy hill rising from the plain, not at all the locale that suggests that insect; also Parantica aglea and Crastia asela.

Some of the Blues which were abundant at Kandy wcre scarce at Bandarawcla, such for instance as Lampides celeno and bochus; some were common enough at both places, such as Polyommatus bacticus, Zizcra otis, and Everes parrhasius. On the other hand, this was the first place in which I came across Spindasis vulcanus, Fabr., and elima, Moore (? ietis, Hew.), the former not uncommonly; it has a curious rapid curvetting flight close to the ground.

The Pierines were not numerous: Catopsitia just put in an appearance, as did several Dclias eucharis, but Terias was in abundance including both typical heeabe and libythea; the last was commoner here than elsewhere, being indeed the dominant Pierine of the locality. It was a matter of great interest to me to detect a sweet scent in the male of this species, all previous observations on Oriental Terias having yielded negative results; the interest was increased by the fact that the scent was definite and distinctive, being compared at the time to that of Pink Bindweed (Convolvulus arvensis), and indistinguishable from that found by me in several West Indian species of the genus. ${ }^{1}$

A few Papilio parinda were seen, and I think also one P. pammon.

The small grey, fly-like Skipper, Taractroccra macvins, which I had also taken at Kandy was commoner hcre, but Baracus vittatus, Feld., a swamp-loving species also common at Bandarawela, did not occur at Kandy, being confined to the higher ground.

The finest Moth met with was unquestionably Choerocampa theylia, Linn., which came to light together with Siccia taprobanis, and Tcphrina parallclaria. The last-named was also kicked up by day, being very common in the afore-mentioned swamp which also yielded the Gelechiid, Timyra irrorclla, Wlsm. The Noctuid Amyna natalis, Walk., was found under a stone when looking for beetles.

Two males of Xylocopa temiscapa wcre secured by watching a hole abont two fcet from the ground, in a dead portion of a solitary trec.

Two examples of a Chlacnins not in the British Museum werc found under stones; Mylabris pustulata was taken on the wing, as was Anthrax sp. A Bug with long spines on its shoulders that would appcar to be Clctus clongatus, Dohrn, was taken in the swamp, it is a species hitherto unknown to Mr. Distant.

1 Seo below, pp. 509, 510. 
Ella, $3250 \mathrm{ft}$. above sea-level ( 8 miles from Bandarawela).

March 13th, 1908.

If the view from the World's End is positively awe-inspiring, and that from the mouth of the railway tunnel so startling as almost to take away one's breath, that from the Rest-house at Ella is picturesque in the highest degree.

A gap between two mountains affords an outlook over the palmgroves on the plain, which loses itself in the soft blue distance where lies the sea some fifty miles away. A waterfall in a wooded gorge that cleaves the rugged mountains on the right gives an alınost theatrical completeness to the scene. It is altogether a place at which we would gladly have stayed for days instead of hours.

Yphthima ccylonica, not to be found in any of the higher conntry, was here fairly common, it was accompanied by Mycalesis polydecta. One Precis orithyic and one $P$. iphita, a male, were all that I saw of the genus; Neptis varmona, Atella phalantha, and a solitary Ergolis taprobana were the only other Nymphalines, as Crastia asela was the only Danaine.

The common Blues of the place appeared to be Everes parrhasius and Zizera otis, while on the scarlet flowers of Woodfordia floribunda Salisb., I took a second specimen of Spindasis elima, from which some foe had symmetrically removed the anal angles of the hindwings together with their appendages.

Terias libythea and hecabe were both common. There were a few Papilios about, the only one that came within reach being aristolochiae.

Aroa subnotata flew swiftly along the road at 2 p.m. The Dungbeetle, Copris sodalis, Walk., and some Ants were found under stones.

\section{NuWARA EliYa, $6210 \mathrm{ft}$. above sea-level.}

March 14th and 15th, 1908.

As in all properly constituted "Hill Stations" in the East, Nuwara Eliya ccntres in a racecourse. There is no doubt about the Briton carrying his civilization with him in an open, not to say assertive, way. The whole district constitutes ono vast park, but this has not checked the introduction of the Eucalyptris, Wattle, and other Australian trees, as well as the Californian Cupressus macrocarpus and the morc humble Gorse--all of which seomed to me singnlarly out of place, jarring notes in the landscapo. It must, however, be 
admitted that the anglicizing process has been very complete in Nuwara Eliya. Even the well-kept church with its trim flower beds has quite an English look, inside and out. The seven windows in the apse, filled by a fine series of designs by James Powell, ${ }^{1}$ give a cool, soothing, green tone to the interior, constituting one of the most successful pieces of modern decoration that I know.

Nuwara Eliya has perhaps a Scottish rather than an English look, and this was intensified by the little monsoon which brought deluges of rain each afternoon.

At the times of my two visits, in 1904 and 1908, this locality struck me as an entomological desert, but I feel convinced that at other times of the year it must be more productive.

The top of One-tree Hill, a few hundred feet above the botel, was the most productive spot I reached. This was the only place in Ceylon where I met with Pyrameis indiea, Herbst, of which I saw several, one much battered. Its flight is quicker than that of our Red Admiral, but less graceful. Argynnis hyperbius was common on the same ground. Cyaniris lanka and Polyommatus baeticus helped to keep the place lively, as did Baraeus vittatus, though the grass had no claim to that swampy quality which that Skipper seems to love. A few Chittira fumata and Terias hecabe turned up, as well as a pretty Gelechiid, Tipha brochias, Meyrk. I spent some time over a large Fly, a species of Dexia, a noisy creature which was hard to see flying in the sunshine, but easy to capture when settled on "Nelus" (the general native name of the rank undergrowth), whenever the sun was covered by a cloud. I secured 4 of and $1 \%$, and found that the National Collection had $2 q$ only, from Ceylon, unnamed. Three Passalid beetles of the genus Chilomazus were found under a log. The Heteromeron, Apogonia coriacea, Waterh., and a large specimen of the Lithosiid, Asura solita, visited the hotel lights.

A visit to lovely HAKGíLA was spoiled by deluges of rain; the slow-flying Chittira fumata was dancing about round the Vernonia at the old spot a little above the entrance to the Botanic Garden. ${ }^{2}$ Cyaniris lanka and Chilades laius occurred close by. An Anomala. (Lamellicorm) was taken flying in the sun, and Mrs. Longstafi found at the roots of grass a very striking Chrysomelid, Sphacrolina templetoni, Baly; it has a metallic blue thorax and elytra like new mahogany.

We steamed up the Malabar Coast in perfect weather in the

1 I recognized the hand of this artist at the first glance.

: Seo above, p. 118. 
P. \& O. ship "Delta," the most commodious and by far the cleanest vessel in which I have sailed. Commander Daniell (an old shipmate in the "Malta") is a fine example of the merchant seaman, moreover a jovial fellow, and a good performer in the music-room.

When in lat. $14^{\circ} 20^{\prime} \mathrm{N}$., Long. $73^{\circ} 50^{\prime} \mathrm{E}$., off the coast of Goa, the ship passed through a sort of scum; it was in patches from a dozen yards to a furlong or more across. It was evidently very light, floating on the surface, varying in colour from sulphuryellow, through greenish, to a dirty brown. There was much discussion on board as to its nature. When some of the surface water was fished up, the unknown substance was seen to rise to the surface very quickly. The strongest pocket lens available showed it to consist of particles all nearly the same size and somewhat resembling saw-dust. A very confident opinion was that it was chopped up, or pulped bamboo. My own view inclined to a lowly vegetable organism, some kind of Alga, and I suggested that the sulphur yellow was alive and growing, the brown dead or dying. This scum must have extended, with intervals of clear blue water, for several miles.

A specimen was ultimately submitted to Prof. Sydney H. Vines, F.R.S., who reported: "It is one of the blue-green Algae (Cyanophyeea,, or Phycochromacecue, or Myxophyceae), belonging to the family of the Oscillariae, though I have not been able to determine it specifically." He added that it was allied to the organism which sometimes covers small lakes in England and Ireland with a dense scum: this after a time breaks up and disappears - a phenomenon known as the "breaking of the meres."

Darwin observed a similar appearance, but reddish brown in colour, off the coast of Brazil, and a different species off Cape Leeuwin, W. Australia. ${ }^{1}$ An organism of this family gave its name to the Red Sca. Captain Cook's sailors called this scum "sea saw-dust."

\section{INDIA.}

Matherán, Whisteris Ghíts, $2250 \mathrm{ft}$. above sea-level.

$$
\text { MIarch 23rd- } \Lambda \text { pril 1st, } 1908 .
$$

Matherín, a spur, or rather an outlier of the Sahyadri Range, lying 28 milcs due east of Bombay, is unlike any place that I have visited. Approximately flat upon the top, the ground falls sheer on three sides to the dusty plain below. The steep sides are surmounterl by cliffs

\footnotetext{
1 " Journal of Researches, ctc.," pp. 14-18.
} 
of basaltic rock hundreds of feet in height, so that butterflies must be pursued with circumspection, for in many places a false step would be fatal. The ascent is made on what may be called the landward side by a toy-railway. This is a novel structure, and we stopped twice in what appeared to be most perilous places on the face of a cliff. The second time flames came out of the funnel, and they had to rake the fires out!

The plateau (as well as such portions of the scarps as are not too steep) is clothed with jungle of medium size, which, in the absence of palms and dominant creepers, has little of the tropical aspect, though Monkeys (and, it was alleged, Panthers) range therein. On emerging from this forest and going out on to one of the Points, it is difficult to believe that one is not on an island, and that the sea is not at one's feet, in place of being 28 miles away. On these Western Gháts the rainfall is measured by feet instead of by inches, and at the end of the rainy season many of the roads have to be reconstructed to make them passable. Again, gardens are so liable to be washed away bodily, that the gardener's art is almost confined to pot-culture. It was difficult to realize these things, as we laboriously tramped through the deep red dust, for at the time of our visit the drought was extreme, the trees were in great part leafless, and I compared the colour of the grass to the very pale drab of the eover of my Letts' Diary, No. 36. There was water in Charlotte Lake certainly, but the other drinking places were reduced to puddles, or even patches of damp mud.

My captures in nine days' work were sufficiently numerous to give an idea of what the locality might be expected to producc under less arid conditions:-

Solitary males of Danaida plexippuss and D. chrysippus, together with abundance of Crastia core, Cram. (one of the latter with a well-marked symmetrical injury to the hind-wings), represented their sub-family.

Satyrines were few and far between, comprising Iphthima hucbneri-one so exceptionally "dry" as to lack occlli on the underside of the hind-wing-and one rcmarkable example of Arycalcsis pcrsens, approaching in character that taken on the Nilgiris in 1904 (scc above, p. 101).

Atella phalantha was fairly numcrous, odd specimens of Precis almana aud lemonias, of vcry "dry" character, occurred; several Ncptis were seen, the only one netted proving to bc curynomc.

Blues were more notable for varicty than numbers, Ncopithecops zalmora being the commonest. The others taken were Catochrysops 
strabo, Nacaduba dana, de Nicév., N. urdates, and N. hcrmus, Feld., Polyommatus baeticus, Castalius decidia, Mcgisba malaya, Zezius chrysomallus, Hübn., and a sadly tattered Ircotce timoleon, Stoll, a glorious insect of fine gleaming blue with a black border. The great majority of the Blues were taken at water, as was also the solitary Erycinid, Abiscra echerius.

The Common White of Matherán was unquestionably Huphina nerissa, though curiously enough it did not frequent the wet mud as at Haragama; a single Nychitona xiphia was taken, one also of Terias libythea, but of T. laeta, Boisd., I took several, although my notebook says "not common." Of Catopsilia pomona I took two; of the beautiful Nepheronic hippia, Fabr., a solitary male, which had a very slight scent like that of burnt sugar.

A male Papilio demolens had a scent like fresh straw, while $P$. aristolochiae smelled distinctly fusty. $P$. polymnestor was rather common.

Three species of Skipper were met with, all of them new to me. Sarangesa dasaharce, Moore, appeared to be not uneommon in a most perilous spot at the very edge of a high cliff, and I only secured one; this settled on the ground, with wings fully expanded, and so sitting was quite inconspicuous. Of Sarangesa purendra, Moore, I took two. Celaenorrhinus ambareesa, Moore, is a large Skipper of peculiar habits. I first saw it, on March 25th, at Poreupine Point, a prominent headland of the mountain. The hour was that of sunset, 6.50 p.m., and the Skippers were flying wildly about in some numbers. Three days later, in a similar spot, locally known as Louisa Point, at 7 p.m., I took another, this time at rest, with wings expanded, on the sweet yellowish flowers of Ghela (Randic dumetomum). At the lastnamed place, between 6 and 6.30 p.m., there were many large Dragon-flies hawking about, but I failed to catch any of them.

The one notable Moth was the large blue-grey, black-spotted Geometer, Euschema palmyra, with its very slow fluttering flight; it was not uncommon flying in the afternoon; several were "found drowned" in and about Charlotte Lake. The Matherán specimens differ somewhat from those taken in Ceylon. Another of the same family, Luxiaria hypaphancs, Hmpsn., has a strongly marked underside. A good specimen of the pretty Antigastra calalcunalis, Dup., was kicked up; it is a Pyrale widely distributed in the Old World. Noorda fessalis came to light. Plhycodes radiata, Ochs. (hirudinicornis, Guen.), a large, robust, yellow-underwinged Hyponomeutid was taken near water.

The excessive drought and eonsequent great scareity of water 
brought insects of several orders to the little puddles that were all that was left of several of the watering places. Among these the Hymenoptera were in great force.

The steely-blue Sceliphron bengalense, the black, yellow-legged S. intrudens, and the smaller S. coromandelicum, Lepel., were all more or less common, the latter was also taken by my wife in the Rugby Hotel. Eumenes flavopicta, the small black and yellow $E$. punctata, Sauss., the large yellow E. pctiolala, Fabr., and E. edwardsii, Sauss., were only met with by ones or twos. Two Vespa cineta, larger and darker than Ceylon specimens, were taken at Charlotte Lake. Several Icaria ferruginea, a fine example of Sphcx splendidum, Fabr., with its big head, yellow wings, and metallic violet abdomen; Pseudagenia blanda, Guér., blue with red hind femora $;^{1}$ a Notogonia that may be new, since it is not to be found in the National Collection, nor in Col. Bingham's book; a Nomia and a Crabro also occurred. Then there were Apis dorsata and A. indica, and in addition to all these the distinct grey Pompilus reflexus, Smith, with its red abdomen, as well as the two small Fossors, Trypoxylon intrudens, Smith, and pileatum, Smith.

But Aculeates were not entirely confined to muddy puddles; the blue, white-banded Podalirius fallax, Smith, preferred Labiate flowers, as did Anthidium ordinatum, Smith, and A. ardens, Smith. Again the brilliant Podalirius zonatus was found on the white flowers of a shrub at Porcupine Point; Crocisa histrio, Fabr., black with bluish-white markings, was buzzing about the ground. I do not seem to have any note of the exact conditions under which I captured Polistes sagittarius, Sauss., and P. marginalis, var. stigma, Fabr., or the metallic blue-green Cuckoo-wasp, Hcxachrysis oculata, Fabr., with its almost superfluous adornment of a ruby on its abdomen.

But while I was catching these Wasps I had not the slightest idea that along with them I had been taking two species of Ccria-a genus of Syrphid Flies bearing a strong resemblance to Conops. Of Ccria cumenoidcs, Saunders, I took seven specimens, it is a good mimic of more than one of the wasps with which it was associated, viz. Icaria ferruginca, Eumcncs cdwardsii and Polistes marginalis, var. stigma. Col. Yerbury tells me that his friend Col. C. G. Nurse noticed this striking instance of mimicry at the same placeMatherín-in 1899. [See Plate IV., Figs. 1-6.]

I also took a male and two females of a yellow and black Ccria, which Mr. Austen believes to be a new species. As will be seen

1 Mr. Shelford writos that this wasp, which also occurs in Bornco, provisions its nost with Crickots. 
from the figures [Plate IV., Figs. 7, 8], this Fly is a quite extraordinary mimic of the Wasp, Eumenes flavopieta [Plate IV., Figs. 9, 10]. It is a well-known rule in cases of Batesian mimicry that the mimic is scarcer than the model. This seems to be borne out by three closely allied black and yellow Ceria. From a single specimen, a male taken at Darjiling, de Meijere described $C$. trinotata; of another as yet undescribed species, the British Museum has a single specimen from Assam, while 1 took but three of my species, ${ }^{1}$ so that presumably all are scarce.

It scarcely seems likely that Tabanus albimedius, Walk., was really attracted by water, though taken close to it, but several specimens of a species of Oehromyia were captured about foul mud at the head of Charlotte Lake; the long-winged Bombyliid, Exoprosopa sp., was taken about water, but not the allied Argyramoeba distigma, Wied.

In Charlotte Lake itself I took half a dozen specimens of Hydatieus sp., one Cybister asiaticum, Sharp, and one of another species of the same genus. On the top of the water there were Whirligigs in abundance, viz., Dineutes indiens, Aubé, and a species of Oreetochilus. A Heterotarsus invited capture by walking over my store-boxes.

It was both hot and cold at Matherin: it would rise to $80^{\circ}-84^{\circ}$ or even $86^{\circ}$ at midday, and the sun penetrated the corrugated iron roof of the hotel, which was very imperfectly protected by straw outside, yet in the morning it might fall as low as $71^{\circ}$. Moreover in the afternoon a high wind would sometimes rise suddenly, and one would shiver when the temperature fell to $73^{\circ}$. This is no laughing matter, and I got such a severe chill that I had to call in the services of the Civil Surgeon, Captain Superintendent McPhelson, as well as make use of my bearer's talent as a masseur.

1 Mr. Austen informs mo that tho namo Ceria is preoccupiod in another Order, but that there is an old name Cerioides, formorly belonging to the genus which should be reinstatcd. Tho latter name seoms somewhat unfortunate. 


\section{CHAPTER VIII}

\section{EGYPT AND THE SÛDÂN}

January 1st-April 18th, 1909

THE land of the Pharaohs has much to recommend it; but though historically of surpassing interest, as a hunting ground for butterflies it holds an extremely low place. So far as our positive knowledge goes it would be manifestly unfair to accuse the long lines of despots who ruled at Memphis or Thebes of having caught all the butterflies, but it would not be so unreasonable to attribute their present scarcity to the ancestors of the present fellahîn, who through all the dynasties so assiduously cultivated the valley of the Nilefor one soon learns that Egypt is the Nile, and that the Nile is Egypt.

The Great Pyramid stands at the apex of the Delta, and from that point southwards, right away to the Sûdân, there extends on either bank of the river-unbroken by any tributary-a strip of land, varying in width from a few yards to a few miles, blessed with a soil of almost unequalled fertility. Each of these strips is bounded on one side by the Nile, on the other by the barren Libyan and Arabian deserts respectively. Thus for all practical purposes Egypt may be said to approximate closely to Euclid's definition of a linelength without brcadth. All the available land has becn cultivated for centuries, most of it for millemnia, so that the indigenous flora of the Nile valley, save such hardy fragments of it as could adapt themsclves to the artificial life of "weeds of cultivation," has long since disappeared, and what it may have bcen like no man knows. With this flora has departed a famn, probably nevcr very cxtensive, but doubtless very interesting.

In spite of the Badâwîn, and their countless camels and goatsanimals that find a sustenance whero others would soon pcrish-the Descrt has to a grcat extent held its own, and its flora and famn retain much of their original character. The inscct fauma of the 
desert will always be associated with the name of Klug, and his monumental work. ${ }^{1}$

The wonderful paintings, still so marvellously preserved in many a temple and tomb, tell us that three thousand years ago, as to-day, the wheat cultivated by the Egyptians was of the bearded variety, which, as seen at a distance, makes the ripe cornfields look "white to harvest," in place of golden, as in other lands. From these same paintings it may safely be inferred that many plants and animals, now to be found only in the far Sûdân, were then familiar objects in both Lower and Upper Egypt. Even a butterfly caught the observant eye of those old-time artists, and portraits of it have been handed down. One of these entomological illustrations adorns a tomb at Beni-Hasân; this tomb bears a date showing that it belongs to the Twelfth Dynasty, earlier, that is, than 2000 B.c. Other insects are represented on the painted pavements of the Eighteenth Dynasty at Tell al-Amarna, say 1500 B.c., but perhaps the most perfect representation, from a tomb at Thebes, is now in the British Museum at Bloomsbury. This tomb is said to be that of a Scribe of the Royal Granaries of the time of Seti I., say 1400 B.c. Besides a celebrated cat and many birds, no less than seven butterflies are figured, all evidently belonging to one species. ${ }^{2}$ Unfortunately these paintings are not sufficiently well executed, or, it may be, not sufficiently well preserved, for it to be possible to dogmatize as to the specific identity of the insect represented, but it would, I think, be safe to hazard the conjecture that it is Danaida chrysippus (or possibly its variety dorippus) -indeed it would appear to be mid-way in colouring between the type and the variety. It may be confidently asserted that the model before the painter was not $D$. alcippus, sincc the whitc hind-wings of that form must have riveted the attention of a far less careful draughtsman. The body bears conspicuous white spots, but the transverse white bar seems to be broken up into spots; the black marks on the hind-wing are clcarly indicated. One of the butterflies appears to have six functional legs, but the artist might have allowed his knowledge of the general hexapod character of the Insecta to direct his brush.

A visitor to Egypt will soon notice that the wind usually blows from the north, and this is a circuinstance of the wcightiest economical and cven political importance, since it is thercby possible

1 "Symbolae Physicae Insoctorum," Klug and Ehronberg, 1830-1845.

"A good "process" reproduction of this painting will bo found in "A History of Egypt," by J. H. Breastcd, Fig. 156. 
for sailing vessels to make their way up against the strcam during some part of most days. If it had not been for this prevalent wind it is safe to say that Egypt could never have enjoyed its long prosperity, not to speak of the faet that its elimate would have been insufferably hot.

The Pyramids of Gîza, lat. $30^{\circ} \mathrm{N}$.

January 1st-4th.

For me Egypt began and ended at the Great Pyramid. At its very base, surely quite indifferent alike to the ambitions of Cheops, and the speculations of the Pyramidologists, I found two worker ants, Myrmecocystus viaticus, Fabr., one of which ran rapidly over the sand, earrying the smaller of the two in its mandibles. On the surrounding desert another ant, Aphaenogastcr arenaria, Fabr., was to be found under stones, or sometimes running over the sand, while Monomorium salononis, Linn., oecurred on and about the Umbellate, Deverra tortuosa, Desf., a plant also frequented by the Lady-bird, Coccinella 11-punctata, Linn.; doubtless they were both in pursuit of Aphides, but I made no note of the presenee of the latter. A stone on the very edge of the desert gave shelter to three specimens of the Mutillid, Ephutomma continua, Fabr.

Turning stones also produeed the Weevil, Dicranotropis (Cleonus) hieroglyphicus, Oliv.; the Heteromera, Ocneva hispida, Forsk., and Mcsostena laevicollis, Sol., as well as the Dung-beetle, Onthophagus (?) marmoratus, Faldm., and immature individuals of the Earmig, Labidura riparia, Pall. About the roots of such plants as might be found upon the desert in mid-winter were several Tentyria glabra, Sol. The black, clean-looking Pimelia angulata, Fabr., was oecasionally to be seen erawling: over the sand, but was more eommon among rubbish in the hotel garden.

In the last-named locality the big Carpenter-bee, Xylocopa acstuans, Linn., a female, the yellow Philanthus triangulum, Fabr., with its waxy-looking abdomen, also a female; and two females of the Fossor, Ammophila tydci, Guill., were taken. The common Beetle, Aulacophora fovcicollis, Küst., was to be found in any numbers upon vegctable-marrow. Among mixed herbagc in the garden I took an immature Chrotogonus lugubris, Blaneh.; this is an Acridian of the sub-family Pyrgomorphinac, which I met with frequently in Egypt. On the golf-links I took, muder stones, an undetermined Ocnere.

At Tamarisk flowers on the Nile bank at Gîza, I caught in my 
hand two Stilbum splendidum, Fabr., of the blue form, amcthystinum, while Myrmecocystus viaticus was rushing about at my feet.

During my very short stay under the shadow of the Pyramid, I saw but two species of Butterflies and two of Moths. Several Pyramcis cardui, Linn., and a couple of very dark but otherwise typical Danaida chrysippus, Linn., were observed in the hotel garden. Cirphis loreyi, Dup., a great rarity in Britain, came to light, and the pretty Crambid Eromene ocellca, Haw., another British rarity, was found by Mrs. Longstaff in our sitting-room and also seen by myself on the desert.

A voyage up the Nile in one of Cook's luxurious steamers does not give the entomologist much scope, especially as, rightly enough, almost every moment on shore is devoted to the all too hurried study of the wondrous ruins which make Egypt unique among countries.

January 5th. At Sakkâra, near the tomb of Ptah-hetep, Pimelia angulate was found crawling on the sand.

At Badrashên (lat. $29^{\circ} 48^{\prime} \mathrm{N}$.), a number of Moths visited the glow-lights of the "Rameses the Great": Agrotis ypsilon, Rott." (suffusa, Fabr.); Euxoa spinifera, Hübn.; the Boarmiid, Tcphrina disputaria, Guen., and abundance of Eromenc ocellea, certainly the commonest moth of the Nile valley.

January 8 th. The thermometer on deck at 8 a.m. was as low as $50^{\circ} \mathrm{F}$, but it was much warmer when we reached Asyût (lat. $27^{\circ}$ $12^{\prime}$ N.) where about a dozen worn and broken specimens of Danaida chrysippus were seen, all appeared to be typical. Several Stilbum splendidum glistened in the sun, and the Bee Eucera nigrilabris, Lepel., a female, was taken with them. In the suburbs workers of Myrmccocystus viaticus were seen running swiftly about in the neighbourhood of their nest.

January 9th. At 8 a.m. the thermometer on deck fell to $46^{\circ} \mathrm{F}$. and it was very cold in the wind. At Sohâg (lat. $26^{\circ} 35^{\prime} \mathrm{N}$.), Agrotis ypsilon again came to the lights of the steamer, accompanied by a few Eromene occllca and our old familiar friend, Nomophila noctuella, Schiff.

January 10th. On the Nile bank at Dendera (lat. $25^{\circ} 38^{\prime} \mathrm{N}$.) the black somewhat fetid Bug, Aspongopus vidualis, Fabr., was to

${ }^{1}$ The larva of this Noctuid-the Cotton Cut-worm-is a sorious pest to the Fellahin, greatly damaging the young cotton crop. 
be found in large numbers under the leaves of Vegetablc-marrow. The walls of the beautiful temple of Hathor were literally plastered with nests of the Mason-bee, Chalicodoma sicula, Possi; all that I captured were females. The Noctuid, Spodoptera mauritia, Boisd., came to light at this place.

January 11th to 14th. Luxor, lat. $25^{\circ} 38^{\prime} \mathrm{N}$. Here Vespa orientalis, Linn., put in its first appearance: Miss Wurtz caught one on board, the only male that I came across, but specimens of the other sex were met with in the Ramesseum and in the Temple of Amen, where Myrmecocystus viaticus and Monomorium subopacum, Smith, were also to be found. Stilbum splendidum, var. amethystinum was taken at Tamarisk flowers near the Ramesseum, and upon the same plant I found two of the handsome green Buprestid, Steraspis spcciosa, Klug. Stone turning brought to light Mesostena laevicollis. At Medînet Habu Chaticodoma sicula was common, but not in such large numbers as at Dendera. A female of Eumenes tinctor, Chrst., was taken in the hotel garden; I had knocked one down with my hat on the deck of the steamer the day before, when about a dozen miles north of Luxor. In the garden I took also a solitary female of Tarucus telicanus, Lang, a butterffy that I had previously met with both in South Africa and in India. After dark a specimen of Caradvina (Laphygma) exigua, Hübn., came to light, the larva of this moth (a rarity in England) does much damage to the young cotton plants and to barsîm (White clover).

January 15th. The well-known Red Locust, Schistocerca percgrina, Oliv., was captured in the Temple of Horus at Edfut, and on the same day the Fly, Agria nuba, Wied., came on to the steamer.

January 16th. At Kôm Ombo (lat. $24^{\circ} 30^{\prime}$ N.) several Danaida chrysippus were seen, all typical but very dark; a male is noted to have had the day after capture (dead) a very strong musk-rat, or mousy, odour.

Aswîn, lat. $24^{\circ} 5^{\prime} \mathrm{N}$.

$$
\text { January } 17 \text { th-27th. }
$$

As a butterfly locality I expected more of Aswinn (situated as it is just north of the Tropic of Cancer) than subsequent experience justified, but it is of course quite likely that morc things night be found later in the year. The parts of the desert that I visited appeared to be quite devoid of vegetation-often thcre was not even a 
blade of dead grass to be seen, nothing but sand, rocks, and sky. I say "appeared," for I came across the trails of Lizards, and where there are lizards there must be insects, and where there are insects in all probability vegetation of some kind, though it is conceivable that lizards might subsist on insects dependent in their turn on the dung of passing animals. It was hard to remember that it was mid-winter.

Such insects as I did come across were mostly seen in the small oasis near the golf-links, especially on a small patch of a lilacflowered Crucifer that I took to be Radish (Raphanus sativus, Linn.). Here Pyrameis cardui was in abundance, but faded and worn; many were seen to orient; among the Painted Ladies were a few Danaida chrysippus, dark but otherwise typical. The same patch of flowers attracted many insects of other orders, conspicuous amongst them being Eumenes tinctor and $E$. dimidiatipennis, Sauss.; there also Elis senilis, Fabr., was in abundance, its sexes so unlike that it did not occur to me that they were conspecific. Of all the insects on those flowers the Cetoniid, Epicometis squalidus, Linn., was the most abundant, and I could easily have collected a pint of them, whereas a Stilbum splendidum was alone in its glory.

In the same oasis that long-legged, black, spider-like Heteromeron, Adesmia cothurnata, Forsk. (? bicostata, Klug), was to be seen running about in all directions, occasionally accompanied by his big relative, Ocncra hispida, more often by the common ant, Myrmecocystus viaticus. A Steraspis speciosa was found on an Acacia, and a dead one on the ground. A potsherd gave shelter to the Noctuid Sesamia (Nonagria) cretica, Leder.; sundry stones on the desert round about concealed Sceliodis castanerus, Eschsch., Mesostena laevicollis and Pimelia grandis, Klug.

On the right (eastcrn) bank of the Nile, close to the river, Polyommatus baticus, Linn., was occasionally to be seen together with a Danaida chrysippus and two or three Pyramcis cardui. Here Mustard flowcrs (Sinapis sp.) proved to be specially attractive, yielding a Halictus; Andrcna ephippium, Spin.; Megachile albocincta, Rad.; Eumenes tinctor and Elis senilis. The samc flowcrs attracted the handsome well-named Fly Eristalis tacniops, Wied., and the Beetles, Himatismus villosus, Hang, and Coccinclla 11-punctata, Liun. Stone turning produced Ocncra hispida, a number of Thriptcra crinita, Klug, and a Scorpion.

In the Garden of the Cataract Hotcl on Janunry 26th, 1909, at about 5.30 in the afternoon, Miss Stracey called iny attention to a number of Stilbum splendidum upon a Parkinsonice (an Australian tree with yellow flowers); they formed two clusters, one on a branch, 
the other on pods, consisting of 14 and 34 individuals respectively; they were sitting close together, quite still, and appeared to be stupid. Mr. Morice was much interested in my account of this observation, which he is not able to account for, and cannot exactly match by any other recorded case among the Hymenoptera. I mentioned the matter to Mr. F. C. Willcocks, F.E.S., of Cairo, but he said that he had never noticed anything of the kind, though he interests himself in insects of all orders. Mr. Morice informs me that Stilbum infests the larvae of the larger species of Eumenes (especially dimidiatipennis) exactly as Ichneumons do those of Lepidoptera.

On the island of Elephantine, in the hotel garden, I captured a specimen of Tarucus telicanus at Duranta flowers, where it was accompanied by the following Bees and Wasps:-a male Podalirius near to albigena, Lepel.; a male Ceratina tarsata, Moraw.; Elis senilis in abundance; a male Odyncrus (?) bellatulus, Sauss., and three specimens, all males, of an Odynerus (Lionotus) of the minutus group, which Mr. Morice thinks may be new; a male Philanthus coarctatus, Spin., and Eumenes tinctor. There were in addition several Stilbum splcndidum, and the Flies, Eristalis tacniops and Syrphus aegyptius, Wied. (? scutellaris, Fabr.). The common Egyptian Sarcophagid, Agria nuba, sunned itself on the leaves of Canna. It was in this garden also that I took a male Gegcnes nostradamus, Fabr., the only Skipper that I saw in Egypt.

In cultivated fields, about the flowers of lupins and beans, females of the big Xylocopa acstuans were not uncommon; grassy places harboured Chrotogonus lugubris, while Pimelia spinulosa, Klug, ran over the sand near high-water mark or lurked under the leares of marrow. At the south end of the island I came across a large pot-hole in the granite, perhaps four feet across by three feet in depth; it was high above the water, and partly filled with sand on which were about 100 specimens of the Pimclia, a few still alive, but mostly dead, and many of them bleached from black to a rich brown. On the open sand I found a single Blaps gages, Fabr., and two small, dead Dung-beetles, Catharsins scsostris, Waterh. (pylades, Péring.), a creature that ranges over to Sierra Lcone in one direction, and down to South Africa in another.

Mrs. Longstaff found three moths in the hotel:-Eromcnc occllca; a Nolid, which Sir George Hampson thinks is new; and a dead Enxoa spinifcra.

On the left (western) bank there is but the narrorrest strip of cultivation, a very fer yards wide, squeezed in between the rirer 
and the cliffs of rich golden sand, beyond which lies the desert. Here, as at Mena, it is sometimes literally possible to stand with one foot on cultivated land, the other on the desert. Along the line of demarcation, at the foot of the talus of blown sand, some traces of the indigenous flora persist, I noticed specially a small pinkflowered Papilionaceous plant (probably Lotus arabicus, Linn.), a coarse grass and a few Acacia bushes. The last bore evident traces of Lasiocampid larvae in the shape of untidy webs and defoliated branches. On and about the Lotus a neatly marked, but not very brilliant Blue was quite abundant; this turned out to be Catochrysops eleusis, Dem., a butterfly that is not common in collections ; its range would appear to be limited to Upper Egypt and the Sûdân. ${ }^{1}$ There were among the more numerous Catochrysops, a few Polyommatus baeticus, and a solitary little Chilades trochilus, Frey., the latter was sitting head down moving its hind-wings in the characteristic Lycaenid fashion. A few Eromene ocellea were disturbed from the patches of bean and lupin. There were a few of the commoner Aculeates among the flowers. At the roots of grass the Beetle Sceliodis castaneus was in abundance. I found my first specimen of Scarabaens sacer, Linn., lying on the ground dead. This beetle takes us back to the beginnings of history, for, as is well known, it was an object of worship to the ancient Egyptians. To how many has it occurred that its very name is a connecting link between Egypt, Germany, and England? Kheper ${ }^{2}$ is surely the same word as the German Käfer, and the English Chafer, and according to the Egyptian mythology, the Scarab God, Kheperâ, was the creator of the world.

Here again Chrotogonus lugubris was well protected by its cryptic colouring, but Ocnerce hispida and Thriptera crinita sought concealment under a $\log$ of wood, whereas Adcsmia cothurnata, as usual, ran merrily over the ground, scorning any subterfuge. The Bug, Asponyopus vidualis, rejoicing in a fetor peculiarly its own, might be found in plenty under the leaves of Colocynth, Citrullus colocynthis, Schr. (Nat. Ord. Cucurbitaceac), that scductive gourd which thirsty travellers have too often bcen tempted to taste.

A visit by boat to Aisanarti Island, just below the Cataract, yielded a male $I$. bacticus, a female $C$. cleusis, also two females of the yellow, brown, and black Eumencs esuriens, Linn., a Blaps gagcs, and some cven commoncr things.

January 28th. At DAKKFH (lat. $23^{\circ} 15^{\prime} \mathrm{N}$.), just within the Tropics, a somewhat greater variety of moths than usual visited the

' Sce bolow, p. 569.

" The $k h$ is a hard guttural. 
ship's lights: prominent among them was Deilephila livornica, Esp.; then there were two of the Lasiocampid, Trichiura obsolete, Klug, a moth whieh oeeurs at Cairo; an Acidaliid, Craspedio, consentanso, Walk., and several of the now familiar Crambid, Eromenc ocellea.

January 29th. At Amâda (lat. $22^{\circ} 45^{\prime}$ N.) I took my first speeimen of that curiously "watered," or perhaps it should be "damasked," Blue, Azanus ubaldus, Cram., a female; also two of the Leaf-eutter, Mcgachilc albocincta. From a diminutive native I aequired a relatively large Chamaeleon and took it on board. My preliminary observations eonfirmed the phenomenon that the side of the ereature turned towards the sun darkened, but, before my observations were eomplete, an officious fellow-passenger liberated the animal during my temporary absence.

The same evening near Kâsr Ibrîm (lat. $22^{\circ} 35^{\prime}$ N.) Eromcne ocellea, which I had found in plenty among the eoarse grass at the landing-place, came in great numbers to light, but many more interesting things came also: Trichiura obsoleta; six Euxoa spinifera; a female of the more familiar $E$. segetis, Schiff.; Agrotis ypsilon; Chloridca (Hcliothis) peltigera; Plusia ni, Huibn., was new to me; the little Noetuid, Eublemma brachygonia, Hmpsn., four specimens, also new to me, and the Phycid, Ancylodes pallens, Rag. The National Collection eontains but three of the Eublcmma from widely separated loealities, and of the Ancylodes only Persian and Arabian examples. Lastly there was a Catocaline, Hypoglaucitis sp., which Sir George Hampson says is probably new to scienee [see Plate $V$., Fig. 5].

January 30th. At Abû Simbel (lat. $22^{\circ} 18^{\prime}$ N.) I was surprised to see no Danaida, though there was abundance of the Asclepiad plant, Culotropis procera, Willd., neither did I eome across a Painted Lady; however, both Polyommatus bacticus and Catochrysops clcusis were to be had, as well as both sexes of the common Iylocopa acstuans. The only Beetles taken at Abû Simbel were Pimelia spinulosa, Thriptcra crinita, and Himatismus villosus; the Bug Iygaeus miliaris, Fabr., was eommon about the Calotropis. The lights bronght nothing save Euxoa spinifcra and Eromcne occllca.

Although the magnifieent colossal statnes of Rameses II., hewn out of the eliff, have to be freed at eomparatively short intervals from the sand which comes down from above and aecumulates about their feet, I was told by a gentleman who had elimbed the cliffs that to his surprise he found no sand on the table-land abore. This quite tallies with my own observations; in such deserts as I have seen, rock predominates over sand. A comparatively small 
quantity of sand, blown about by the winds, finds a resting plaec here and therc, at the foot of a eliff or against the walls of a building.

January 31st. Wâdî Halfa (lat. $21^{\circ} 55^{\prime}$ N.) is really the first town in the Sûdân, but from a naturalist's point of view might be better looked upon as the last town in Egypt. In the short timc at my disposal I got next to nothing. Andrena bipartita, Brullé, was abundant in the eultivated land to the north of the town, and in the same distriet I caught a couple of Colletes braccatus, Perez, and one Megachilc albocincta, for although Leaf-cutters were eominon enough they are sometimes exceedingly hard to catch, and here I was successful once only.

\section{THE ANGLO-EGYPTIAN SÛDÂN.}

February 1st-22nd, 1909.

On looking out of the train in the morning after the stifling night on the Nubian desert-somewhere between Berber and the River Atbara-a ehange in the appearance of the eountry is observed. A thin thorn-serub, varied by oeeasional groups of Dûm Palms, Hyphacne thebaica, Del., throws a slight veil over the nakedness of the desert. Oceasionally a few Gazelles create a flutter of excitement among the passengers, and when the sun gets up the mirage slowly develops, as if the horizon were first softened and then evaporated by the heat. From time to time stray butterflies are seen; these I took to be Catopsilia florella, Fabr., though it is just possible that among them may have becn 'Teracolus protomedia, Klug. During a short halt at Wâd Ben Naga Station (lat. $16^{\circ} 32^{\prime}$ N.) I tricd to solve this problem, but the sense of anxious hurry lest the train should start, the swift flight of the butterflies, the strong wind, the blinding glarc, and the great heat combined to frustrate iny efforts; and I only suecceded in netting a male of Tarucus thcoplurastus, Fabr., a Blue that I met with from Luxor to my southcrnmost point at Gebel Ein-a range of ncarly $16^{\circ}$ of latitude.

Khartúm (lat. $15^{\circ} 35 \mathrm{~N}$; $1200 \mathrm{ft}$. above sea-level).

Khartûm is unlike any plaec that I have scon. Situated on the southern bank of the Blue Nile, just above its junetion with the White Nile, it is a new eity; it is, noreover, a Ituropean eity, for the native population lives almost exchusively in mud villages on the outskirts. The palace in which Gordon lived and died is its oldest 
edifice, though built by Ismail Pasha; on either side of this, stretched along the river bank, is a long line of Government Offices and barracks interspersed with the comfortable houses of officials set each in its pleasant garden. Since every one, naturally enough, wished to have a bit of river frontage the length of the town is considerable, but its breadth insignificant, and its cross-streets starting from the river run vaguely into the desert.

At the end of one of these cross-streets, hard by the rising walls of the Anglican Cathedral, stands Hamo Thorneycroft's fine statue of Gordon, who, sitting his camel with the grace for which he was famous, seems to gaze wistfully over the boundless desert. In Khartûm one feels always in the hushed presence of Gordon, just as in Omdurmân one is haunted by the evil genius of the Khalifa. The familiar figure of Sir Rudolph von Slatin Pâshâ, seen daily in the streets, reminds one how very recent are the terrible events of January, 1885, when every man, every child, and every old woman was ruthlessly put to the sword. In a place whose tragic history is but of yesterday, a place 1000 miles from Cairo, it seemed wonderful to find people living not only in peace and security but even in luxury. Perhaps the incongruity seemed greatest when listening to the stringband of the Sudanese regiment playing dance-music after dinner.

The following story reached my ears, of which it may be said, se non é vero é ben trovato: A man who knew Khartûm well, and the officials resident there, found himself one day at Omdurmân while Cook's dragoman was holding forth as to the objects of interest. Standing on the top of the Khalîfa's house he pointed to a neighbouring building and said: "That is where von Slatin Pâshâ lived with his eleven wives." He at once rebuked the dragoman, saying that of course his statement was-at least as to the wives-entirely without foundation; moreover that Slatin was a great man and powerful, and that if he heard of it the dragoman's stay in Khartûm would be short. A week later a friend came to Khartûm, and the first man said to him: "Have you been Cook's excursion to Omdurmân?" On receiving an affirmative reply he said: "By the way, what did the dragoman show you?. Did he mention vou Slatin?" "Oh yes," was the answer. "As we stood on the top of the Khalifa's house he pointed to a neighbouring building and said: "That is where von Slatin Pâshâ did not live with his eleven wives.'"

The day after my arrival I was walking over the desert to the eastward, beyond the rifle ranges. To my left and left front lay the Blue Nile, its course being marked by a row of acacia trees, distant perhaps two miles. The desert was so flat and monotonous that one 
seemed to make no progress, and a tree more prominent than the rest seemed as far off as ever. As I gazed at the distant trees somewhat wistfully they seemed to rise slowly into the air, and the river itself came into view. Slowly and impereeptibly the water spread itself out over the sand, until I seemed to be walking towards a lake whose surfaee was strangely unruffled, in spite of the strong north wind sweeping over the desert. I glanced to the left and was confronted by the same appearanee of a vast inundation. Turning round I found that the same sheet of water had eut me off from the domes and palms of Khartûm. The rising river seemed both to bar my advanee and to have eut off my retreat-there appeared to be water on three sides of me! Had I not seen many a mirage before, I feel sure that I should have turned and fled in terror towards the desert, and even as it was, I found it diffieult to overeome a eertain nervousness as I pursued my way. However, gradually as the aeaeia trees drew nearer and nearer, the inundation began to retreat, so that when I at last stood upon the bank, there was the Blue Nile flowing steadily many feet below the level of the arid desert.

Any description of Khartûm would be inadequate if it did not allude to the prevailing northerly wind, which is not only healthgiving, but entomologically speaking most important. Mr. A. L. Butler, the Curator of the Zoologieal Gardens, informed me that there is no eontinuous rainy season, but that heavy tropieal downfalls are frequent in June, July, and August.

Khartûm is not altogether a pleasant plaee for the eollector. To the south is a speeially barren ${ }^{1}$ and wind-swept desert; the northern bank of the river is abandoned to barracks, railway works and dockyard-for Khartûm is a naval port with a fleet of gunboats-hence my operations were praetically eonfined to the neighbourhood of the river bank above and below the eity. Of the two loealities, the best, though the most distant, was beyond the water-works, near tlie terminus of the tramway in the village of Burri. Here, among Calotropis procera, the wide-ranging Danaida chrysippus was common, and I was delighted to see alive for the first time the form alcippus, Cram. The white hind-wings of these beautiful butterflies are conspicuous in flight, and at onee reminded me of the yet morc beautiful Acraea alboradiata, Auriv., which I had seen in such numbers at the Victoria Falls four years before. From Cairo ot Aswân I had eome across a fair number of chrysippus, but all of tho typieal form. At Abû Simbel, in Nubia, I was surprised not to mcet

1 Actually barren: potentially it is said to be fortile, a thin coating of sand covering a deep deposit of silt. 
with it, sinee the Calotropis was in plenty; it would be interesting to know what form oeeurs there. The twenty-eight specimens brought home from Khartûm may be elassified as follows:-

Typical chrysippus, 3 t.

chrysippus, but with the veins of the hind-wing dusted with white, 6 o , 2 ㅇ.

f. alcippoides, Moore, $4 \delta, 2$.

f. alcippus, Cram., 5 ot, 2 ㅇ.

f. dorippus, Klug, var. albinus, Lanzkneeht, 1 t (i.e. fore-mings lacking the transverse white bar, hind wings white).

Of the total specimens seen, I estimated at the time that at least three-fourths were either alcippus or alcippoides.

The musk-rat odour was evident enough in many examples, about equally strong in both sexes, but in one of the scent was eompared to that of tobaceo.

The next most conspicuous butterfly was Papilio dcmodocus, Esp., I believe the only one of the sub-family that oceurs there. During my stay it was not at all eommon, and I took but two (one very large and fine) and saw one or two others.

The Pierince were unquestionably the dominant group. The first of them to attract attention was Catopsilia florella, of which I took 5 to and $10 \%$; it was quite abundant along the river bank above Burri. One female was so unusually pale in eolour as to resemble a male. Of the five males taken all had a sweet or luscious scent, in some faint, in others decided.

Belenois mesentina, Cram., was also abundant, especially on cultivated ground; 10 t and 19 o were taken; some of the speeimens of both sexes were very small. One $q$ resembled a of in appearance. In some of the males I detected a slight scent, once deseribed in my note as Iuscious, in others as musky; in two female specimens a slight musky scent seems to have been suspected. A male had lost a large pieee out of each of its four wings.

In the bean fields near the junction of the Blue and White Niles Colias marnoana, Rogenl. (a miniature edition of our C. hyalc), was common. Fifteen in all were taken, including tro white females. Two examples had symmetrieal injuries affeeting all four wings. A slight scent was noted in some specimens, described as peculiar, ehocolate-like, or clove-like. The observations were, however, not very definite, and the scent was noted in one fomale specimen.

The prevalence of the genus T'eracolus at Khartim was in itself sufficient indicatiou that we were within the limits of the Ethiopian fauna. None of the species were really common during iny stay, but 
of $T$. eptyyia, Klug, I secured four males (two of them veritable dwarfs) and a female, missing several others-for an orange-tipped Teracolus flying swiftly over the sand in the glaring sumlight is more difficult to follow with the eye than might be supposed. I also took a single dwarf male of $T$. daira, Klug. To the west of the town I took the only $T$. chrysonome, Klug, o , that fell in my way. Lastly, I caught near the tennis-ground a female of $T$. protomedia, which seemed to me to have a faint scent like opium. At Burri I secured a specimen of the very beautiful Calopicris culimine, Klug.

I did not come across a single Satyrid or Skipper in the Sûdân. There was but one Nymphaline-the ubiquitous Pyrameis cardui, which was met with in the largest numbers on an exposed piece of ground at the very point of junction of the two rivers, exactly where one would have expected to see it. A fresh brood made its appearance on February 7th; one of these, a rnale, had an unusual underside, very grey in tone, with but little dark shading, and without any black in the ocelli. Even slight variations are rare in this remarkably constant species.

Blues were fairly numerous though of few species; Polyommatus baeticus and Tarucus theophrastus were both abundant, the first especially in bean fields, the second about Acacia bushes, or at flowers of Aerva (?) javaniea, Juss., a plant belonging to the Natural Order Amarantcceae. I fancied that a male of the former butterfly had a slight scent like Meadow-sweet, while one of the latter had a moderately strong, sweet, luscious odour. Of Azanus ubaldus, I took half a dozen, having previously come across a fernale at Amâda in Nubia. Of the little Chilades trochilus (a species also met with at Aswân), I took only one. Zizera lysimon, Hübn., was commonest on weeds in fields from which a crop had bcen removed, especially frequenting Aerva and a species of Arnebia (Nat. Ord. Borayineae). On the other hand, Catoelurysops cleusis was common about small, low-growing, whitc-prickled Acacia bushes on the edge of the desert. The Khartûm males were markedly bluer, less violet, than the Aswân specimens.

Moths were not very numerous, but many of those taken were interesting. 'The almost cosmopolitan Utetheisa pulchella, Linn., was fairly common on both sides of the town. The little Pyrale, Noctuclia foralis, Huibn., which is likc an "improved" Herbula eespitalis, Schiff, occurred at the flowers of Arnebia, and the handsome Deileplita livornica was taken at about 11 a.m. one hot, sunny morning, hovering at the flowers of Eehium sp., both Hawk-moth and flower being 
quite Palaearctic. All my other moths were victims of the serluctive attractions of the clcctric lights. On some evenings, when the north wind was not too strong, these were much frequented, but while boxing moths on such occasions crowds of small flies entangled themselves in my scanty hair in a most irritating way. Amongst the moths $D$. livornica turned up again, with it was a singular pale grey Syntomid, Apisa canescens, Walk. ; also scveral Geometrids, including Craspedia conscntanea, which I had taken at Dakkeh, and even as far north as Luxor; a very worn Tephrina, probably disputaria, var.; four specimens of Peridela sudanata, Warr. \& Rothsch. ${ }^{1}$ also an "Emerald," new to science, which Mr. L. B. Prout has described for the next part of his contribution to Wytsmann's Genera Insectorum, under the name Prasinocyma sanguinicosta, sp. nov.; as so often happens with novelties, a unique example. There was in addition a malc specimen of a Lymantriid which Sir George Hampson has described? as Porthesia crythrosticta, sp. nov. [Plate V., Fig. 7]. He says it resembles Euproctis rufopunctata, Walk. The Noctuac were more remarkable than numerous; several specimens of Caradrina cxigua, whose larva feeding on cotton, barsîm (a kind of clover), and Hibiscus, is quite a plague to the farmers of modern Egypt; a female of Euxoa spinifcra, another common Egyptian moth; four specimens of Sesamia cretica; onc of $S$. cupunctifera, Hmpsn., the latter very distinctly marked, more so than any in the National Collection. Another cotton pest of Egypt, Prodenia litura, Fabr. (littoralis, Boisd.), was represented by a single example. One of the most unexpected visitors was Copicucullia sublutca, Graes. [Plate V., Fig. 9]; the type of this species came from Eastern Turkestan, and the British Museum possesses but a single example, and that from the desert of Gobi in Northern China, no less than $30^{\circ} \mathrm{N}$. and $70^{\circ} \mathrm{E}$. of Khartûm! Sir George Hampson thinks that desert insects probably have an unusually wide range, since desert conditions are similar over very large areas (a remark that applies with almost equal truth to arcas long under cultivation). Of Spodoptcra mauritia, two specimens turned up; of the common and very active Quadrifid, Acantholipcs affinis, Butl., only onc. Of a Catocaline, which is probably a new species of Mypoglaucitis, I took two, and Mrs. Longstaff amother; a specimen of the samc moth came to the lights of the steamer at Kasr Ibrim, in Nubia, on January 29th. ${ }^{3}$ As might have been expected, there were plenty of Pyralcs among the frequenters of the lamps: two Galleriids,

1 Novitalcs Zoologicae, vol. xii., 1905, p. 28, Fig. 26.

2 Ann. Mag. Nat. Hist., Scr. 8, vol, v., 1910, p. 435.

3 Sec above, p. 402, also Plate V., Fig. 5. 
one the unattractive Lamoria imbclla, Walk., four specimens, this is a widely distributed African species, ranging from Natal to the Nyanza; the other Arenipses sabella, Hmpsn., a species found in Arabia and on the Persian Gulf, of which I also got four. Other Pyrales were the almost cosmopolitan Hellula hydralis, Guen., one; Noctuelia florculis, two ; Polyocha ancrastiodes, Warr. \& Rothsch., one ; the ubiquitous Nomophila noctuella, three; Noorda blitealis, Walk., a species that ranges from Ceylon over India to Aden was in abundance; Eromene occllea, two, small and pale when compared with the large numbers seen in Egypt; and Eticlla sp. nov., still in Sir George Hampson's liands. Also a Tortrix which Lord Walsingham says is the cosmopolitan Bactra lanceolana, Hübn.

For the determinations of the Hymenoptera brought home I an greatly indebted to my old friend the Rev. F. D. Morice (now President of the Entomologieal Society of London), who spent much time over them.

Ants did not make themselves very obvious. On the battlefield of Kerreri, during an extremely hurried visit, I managed to secure a worker of Camponotus scriceus, Fabr. In the hotel at Khartûm my first capture was a worker of C. sylvaticus, Oliv., var. maculatus, Fabr. In the Zoological Gardens close by I took on the trunk of a Parkinsonia three worker ants of which Mr. Morice writes: "This C'amponotus is unknown to me, unless it be a form of pubeseens, Fabr.; the pilosity is very curious." I did not meet with either of these three ants in Egypt. In the western suburbs, toward Mogran, I found a worker of Myrmecocystus viaticus running rapidly over the ground; in the same neighbourhood, under a stone, I found an ant which, with the general appearance of a Formicid, has a long and powerful sting; Professor C. Emery has been good cnough to name it for me as Euponera (Brachyponera) scnnaarensis, Mayr, a well-known Ethiopiall form, but unlike the other ants named not extending into the Palaearctic Region.

Another ant, Prenolcpis longicornis, Latr., hunted on the luncheon tablc; while Aphaenogaster barbara, Linn., was common in the garden; a malc of tho red and black Mutillid, Apterogyna savignyi, Klug, was also taken in the hotel.

Of the diffieult genus Myzinc I met with threo species on the Mogran hunting ground. The commonest appears to bo fasciculata, which the late Mr. Ed. Saunders described from Biskra; of this I took scven specimens, all males; of rousselii, Guér. (also a Biskra insect), I took four males; lastly, there were two males which Mr. Morice thinks may be either acgyptiaca, Guér., or guevini, Lucas 
(latifusciata, Palm.); perhaps it is the insect represented in Fig. 27 of Savigny's Plate xv.

On the river bank to the east of the town, beyond the waterworks, I took a male of Scolia erythroccphala, Fabr., a handsome insect, black with yellow-ringed abdomen, and purple-tipped wings, with base and costa ferruginous. On the other side of the town I took a female Scolit very similar, though lacking ferruginous on the wings, which Mr. Morice thinks may be a variety of the last, but possibly a new species. In the same locality as the last I got a small female Scolic, a greyish insect with a yellow abdornen, which Mr. Morice says is quite unlike any species known to him. Of Elis senilis I brought home five males, varying greatly in size, some were taken on Tecoma stans, a yellow-flowered tree of the Natural Order Bignoniaceae, others on Calotropis near the rifle ranges.

The Sphegidae were numerously represented. The only Ammophila that I met with at Khartûm was a solitary female of gracillima, Tasch. Of the handsome black, yellow-legged, long-waisted Sceliphron spirifex, Linn., I took one at Khartûm, and Mrs. Longstaff another in the train at Mut Mîr Station on the Sûdân Railway; it also occurred at Luxor; my specimens are all females. Philanthus coarctatus and variegatus, Spin., were both abundant towards Mogran, males greatly predominating. Other abundant small Sphegids mere Cerceris albicincta, Klug, $2 S \stackrel{0}{0} 2$, and C. subimpressa, Schlett., $2 \pm \vec{o}$, 2 ; $C$. annexa, Kohl, was not so common, only 4 f and 1 o being taken. The great majority of these small Sphegids (as well as of Chrysids and Flies) was obtained by sweeping the white fluffy Amarantaceous Aerva, but a few were obtained from the Boragimeous Arnebic. The large Bees and Wasps, on the other hand, frequented Tecoma stans, Acacia, and Parkinsonia, though a few occurred at Calotropis.

Of Bembcx lusca, Spin., I secured one of each sex, of B. mcitcrranea, Handl., three males, one was taken on Acrva, one near Burri, where, so far as I know, that plant did not grow. Of the fine large Sphcx umbrosus, Chrst., a black-bodied insect with clear wings (sare at the base), a male specimen was taken to the west of the town. In the same locality, on a small umbellate weed, I took a male Tachytcs, a striking insect with a testaceous abdomen and dark borders to the wings. Mr. Morice thinks this may be the male of supcrbicns, Morice, the description of which will shortly appear in the Transactions of the Entomological Society; he compares it with monctaria, Smitl, from India. $\Lambda$ male Oxybclus taken at Tccoma flowers bears the label: "A very fine species unknown to me.-F.D.M."; of 
O. lamcllatus, Oliv., one of each sex was brought home; a female Diodontus ninutus, Fabr:, quite justifies its name.

The difficult genus Pompilus was represented by ten males of a species of the Aporus group.

No Social Wasps were met with; on the other hand, the solitary Eumenes was much to the fore, by far the commonest species being the Egyptian blue-black $E$. tinctor, of which I took ten malcs and four females; of $E$. dimidiatipennis and $E$. lepelletieri, Sauss., I took one male each; of $E$. esuriens, a truly hungry-looking, long-waisted beast, I took one of each sex. Of the large black, purple-winged Phynchium (?) synagrioides, Sauss., with its orange-tipped tail, I took two of each sex; it frequented the flowers of Teeoma; of $R$. cyanoptcrum, Sauss., I found a solitary male at Aeaeic flowers; of $R$. niloticum, Sauss., I took two males at Khartûm, another at Atbara junction 200 miles to the northward. A female Odynerus (Lionotus) belonging to the parvulus group may possibly prove to be a new species.

The handsome and conspicuous Carpenter-bees were as common in the Sûdân as in Egypt, but in addition to the strikingly dimorphic $X y l o c o p a$ aestuans, with its very different males and females, five males of $X$. tasehenbergi, Vachal, turned up at Khartûm.

Of the Leaf-cutters several species were met with. Two Megactile favipes, Spin., were taken in the western suburbs, also at Calotropis, near the rifle ranges; this is a small species which I afterwards found quite common in Egypt; but $M$. albocineta, also an Egyptian species, was the commoner at Khartûm, frequenting the flowers of Calotropis and Tecoma, it is not, however, by any means easy to catch, still I secured three males and five females; of $M$. argentata, Fabr., I took two males and a female, it also frequented Tecoma; lastly at Culotropis and other flowers I took three specimens of $M$. (?) patellimana, Spin. (or possibly a new specics).

There were but two specics of Ant7idium among my captures, viz. tessellatum, Klug, of which I took two fcmales; and (?) 7karschi, Fricse, of which I took a male, at least a bce which Mr. Morice says is probably the undescribed male of that specics. I also got several specimens of both sexcs of a Podalirius which Mr. Morice says is near bimaeulatus, Panz., possibly byssinus, Klug, but that there perhaps may be more than one species among them. Thrce males of Coratina tarsata turned up at Khartûm.

Among the most notable of the Bees was the large, handsome, black and white Crocisc nubica, Lcpel. It was most often scen at the flowers of T'coma or Acacic, especially near the tenuis courts, but it was extremcly hard to catch; in all I sccured five malcs and two 
females. At the same flowers, both near the tennis ground and in the public garden, there was a number of a nuch smaller Crocisa, of which I took six males and a female, this is very probably undescribed. Then there were quite a number of little Bees, including Colletes nanus, Friese, a Biskra insect of which two of each sex were taken, some of them at Aerva near Burri, others towards Mogran; a single male of Coelioxys decipiens, Spin., was captured; it also occurs at Biskra. I also sent home four males and two females of an Osmia, allied to lativentris, Friese, but apparently distinct. Of Nomia I took but a solitary male edentata, Moraw., but found Nomioides more plentiful, securing besides four females of the tiny black, yellow-banded $N$. rotundiceps, Handl., a male of $N$. excellens, Saunders (originally described from Biskra specimens); this was taken at flowers of Calotropis on the desert near the rifle ranges; there occurred also a solitary female of what is either $N$. turanica, Moraw., or an undescribed form.

Among those gem-like creatures, the Chrysididae, I was successful in getting some interesting insects, although I did not find them numerous. The brilliant but widely distributed Stilbum splendidum was the commonest, and I brought home twelve, some of them of the var. amethystinum. Unfortunately, however, Chrysis nasuta, Mocsary, is so similar to Stilbum in size and general appearance that I doubtless confused the two, and brought home but two males and two females. I call this unfortunate, since it appears that Mocsary in 1902 described the male only, from Salisbury, Rhodesia; he has seen my specimens and believes them to be the two sexes of nasuta. Chrysis pallidicornis, Spin., was the commonest of the genus, and I secured seven specimens. It is variable in the colour of its tail, which may be red, reddish, or green (var. chloris, Mocs.). Of C. fasciolata, Klug, I took two; of the rainbow-coloured $C$. aurifascic, Brullé, one; the last-named is, I am informed, a rarity, but it extends as far as the Cape. Of the common Egyptian Hcdychridium ahcnerm, Dahlb., I took but one. The genus Parnopes was represented by a male and two females of a green and red species which both Mr. Morice and M. du Buysson are agreed is new; it has been described as Parnopes nilotica, Morice in MS., sp. nov. Nearly all these Chrysids, but not the Stilbum, were obtained by sweeping Acrva. The occurrence of intensely brilliant, blue-green metallic colouring in such widely separated genera as Chrysis, Ampulcx, and Euglossa is a remarkable fact which appears to be quite unexplained.

Insects of other Orders were few in number, thus but a single species of Bug was met with, Lygacus militaris, Fabr., taken among 
Calotropis: it appears a very bright red on the wing. Mr. Distant tells me that it is a common species.

A servant at the hotel brought me a large Mantid in spirit, Hierodula bioculata, Burm., she said that it had come to light at the beginning of February. Of the common North African Locust, Acridium argyptiacum, Linn., I took one. A specimen of the Locustid Phancroptera minima. Brunn., came to light. Numbers of large Earwigs, Labidura riparia, were found under a stone near the junction of the two rivers at Mogran; I had met with the same species near the Great Pyramid.

It is to be feared that but little attention was paid to Flies, and those that I brought home were not remarkable. Of Agria nuba, a pair were captured. Among Calotropis, on the desert near the rifle ranges, I took two males and a female of Dacus longistylus, Wied., a wasp-like fly which Becker, in his work on Egyptian Diptera, attaches to the same plant. The brilliantly coloured Blue-bottle, Pycnosoma marginale, Weid., was also common on Calotropis, but I suspected that a dead camel close by was even more attractive to it. A solitary Anthrax has not yet been provided with a name. Two specimens of Phinia (Idia) aenea, Walk., complete a somewhat commonplace list.

Quite the most obvious Khartûm Beetle was the dark brown and gold Cetoniid, Pachnoda savignyi, Gory \& P., which was very commonly to be seen flying around, or settled upon the flowers of Acacia or Tecoma. When settled on a flower it was easily alarmed, and readily took to its wings. Many specimens in the British Museum have the brown replaced by yellow, but I saw none so coloured. At Burri I took flying about Acacia flower's two of the large green Stcraspis speciosa, a species common in Upper Egypt, also at the same florvers a very finely coloured example of the magnificent Julodis fimbriata, Klug-blue, green, yellow, and orange-red. [Plate V., Fig. 8.] The electric lights of the hotel attracted the small Chafers, Adoretus clypeatus, Burm., and Schizonycha sp., as well as two specimens of the small Dung-beetle, Catharsius sesostris. Amongst the odds and ends attracted by the light was an Opatrum, as usual obscure and nameless. Of Himatismus villosus I found one on the Cathedral site, whilc three others came to light. Débris under bushes of Calotropis gave shclter to a Sccliodes castancus, and a number of the abundant Ocnera hispida; of the latter Mrs. Duckett took one in the hotel. Zophosis plana, Fabr., crawled upon the sand near the rifle ranges. Other beetles met with were Coccinclla 11-punctata, and five specimens of Bulaca lichatschovii, Hummel, var. pallida, Muls.

Unfortunately, when we reached Khartum the dry season was so 
far advanced that with the water at such a low level it was not possible to make the usual excursion up the Blue Nile. However, after a good deal of difficulty I managed on February 15 th to hire a small oil-fed steam-launch, in which we got to Sôba, fiftcen miles uY stream, where mounds and brick-bats are all that remain of the evidently once considerable capital of the Christian kingdom of Aloa. We landed on the north side of the river at about noon, and had to climb up a steep bank sheltered from the north wind, with the sun's rays pouring down upon our backs with a power that I have seldom experienced, so that I fully expected to be struck down. At the top we found ourselves in a somewhat scanty thornscrub.

The Sûdânese keeper of the ruined shanty, by courtesy called the Rest-house, with the aid of two female slaves, prepared some coffee for me. A few beans were roasted in the ashes of a wood fire, they were then ground with a stone in a rough mortar. The operation of boiling was effected in a narrow-necked pot of the local red earthenware, and the liquid was strained through a tuft of grass thrust into the mouth of the pot. After boiling up three times and straining as often, the red pot was served up in its own elegant cosy of plaited straw of many colours. The resultant fluid was eafé noir of the finest flavour that it has ever been my lot to taste, a result probably attributable to the fact that less than half an hour had elapsed since the roasting of the beans.

The cruel prickles, the great heat, and the strong wind, contributed to make collecting difficult. With the exception of a female of the common Eumenes tinetor, found in the Rest-house, and two Sphegids, Bembex mediterranea and Tachysphex fuctuatus, Gerst., both females, all my captures were butterflies. Of the orange-tipped Teracolus ephyia, I took four males, in one of which I detected a sweet scent; a male Belenois meséntina also had a sweet scent, which was lacking in two females. Tarucus theophrastus was in abundance about bushes; one at rest was seen to move its wings after the manner common among Lycaenids. The talie of the day was a nice little series of seven males of Calopieris eutimine, four of them in fine condition. This is not only a scarce, but a most beantiful insect; the orange tips to its fore-wings are delicately shot with violet, while the veins on the underside of the hind-wings are brilliant orange. [Plate V., Figs. 1, 2.] 


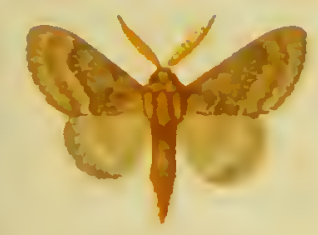

3

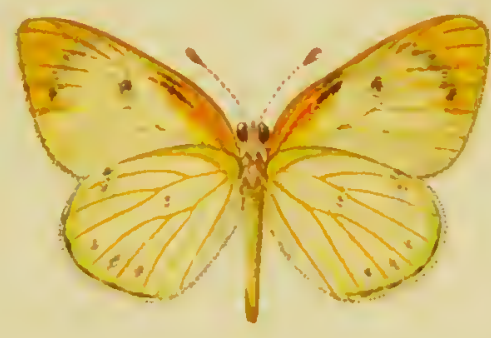

2

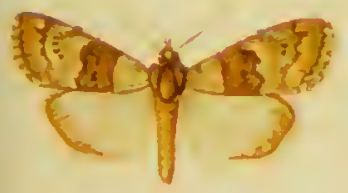

5

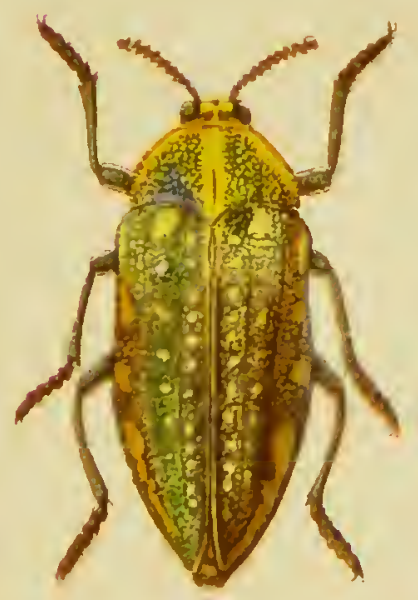

8

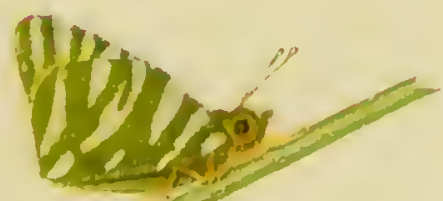

10
H. and Edgar S. Knight del.
1. CALOPIERIS EULIMENE.
3. TRICHIURA DEFINITA. UNDER SIDE.
4. EUPROCTIS XANTHOSO
5. HYPOGLAUCITIS, ST, NOV
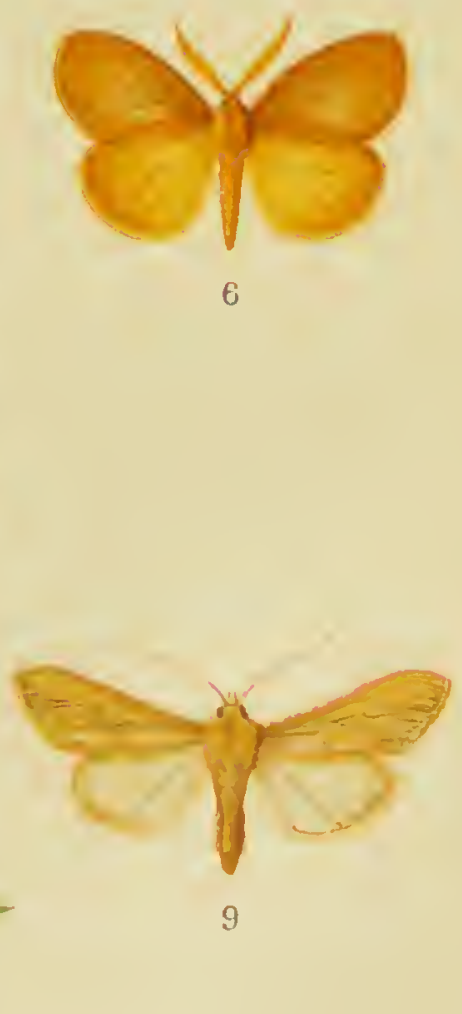

Wnst, Newman Chromo.

6. LAELIA SEMINUDA.

7. PORTHESIA ERYTHROSTICTA.

8. JULODES FIMBRIATA

9. COPICUCULLIA SUBLUTEA.

10. EUCHLOË BELEMIA. 



\section{The White Nile.}

February 16th-20th, 1909.

Unfortunately a projected journey as far as the Bahr-el-Ghazâl fell through, and I was able to carry out but a very short expedition, whieh, nevertheless, was the most interesting part of the whole tour.

The steamer was very comfortable and the manager civility itself : indeed so luxurious is travelling nowadays that we were somewhat disposed to grumble when the supply of iee failed. Yet one might well plead extenuating cireumstanees, for aërated water without iee is apt to taste flat at $114^{\circ} \mathrm{F}$. in the shade. It was, however, really tantalizing to be five days in a eountry of such possibilities, and yet to get in all less than twelve hours' colleeting. An entomologist ought, if possible, not to be pressed for time, and he ought to travel in a private steamer.

On February 16th, when about 40 miles above Khartûm, at 4.50 p.m., there being a gentle breeze from the wcstward, numerous Ladybirds coming from the eastward settled upon the ship. All those examined proved to be Coccinella 11-punctata, a eommon Egyptian speeies. The flight lasted a little over an hour, and there must have been hundreds of the beetles. ${ }^{1}$

During the greater part of the way the steamer passed through absolutely flat country elevated but little above the river. At this stage interest centred on the number and variety of large birds. Wc soon came to Cranes-grey, demoiselle, and others-Storks, Ibis, Herons, Geese of several sorts; Dueks and Teal innumerable. On low muddy islands the Cranes stood in rows like soldiers, eaeh kind by itself, in scores or even hundreds. Of Pelicans we saw but few, of Flamingoes possibly one or two. Then there was the Marabout, whieh is a very handsome bird; so is the less common Irish Eagle. There were also Kingfishers and other small fowl.

Crocodiles were frequently seen asleep upon the banks, for the most part very eryptie, but onc or two were more brightly colourcd. One big fcllow quite deceived the experts who declared it to be a logr, a diagnosis that was upset by a rifle shot. My wife eomplained that her usual afternoon siesta was mueh disturbed owing to the fact that "the gentlemen would shoot eroeodiles." A more eorrect phrase would have been "shoot at crocodiles," for the huge ereatures were hard to hit and harder still to kill. Hit or missed thcy invariably

1 Proc. Ent. Soc. Lond., 1909, p. xxxii. 
got away so that none were measured, but I should guess that several must have been from 6 to 8 feet in length.

We soon reached Papyrus, at first a plant or two, but later plenty. With the Papyrus appeared the Hippopotamus; of these ungainly monsters we saw perhaps eight, or at least the tops of their heads and backs.

The Shilluks are among the savage races that rise superior to clothing. On state occasions they wear feathers in their hair, and sometimes, I believe, a string of beads round the waist, but two

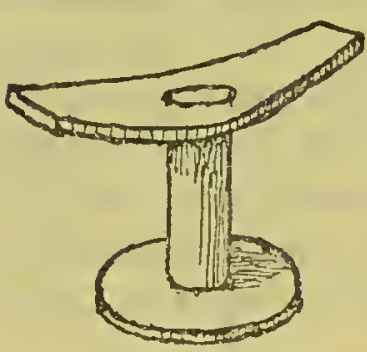

FIG. 14.-Shillûk Wooden Pillow. gentlemen that we saw fishing from a canoe had left all such vanities at home, doubtless to avoid the chance of damage by immersion. It is a strange fact that the wooden pillow used to-day by the Shillûks is practically identical with those upon which the heads of mummies rest. [See Fig. 14.] Altogether it was a most delightful trip, though all too short.

At one stopping place we were brought what we were told was Lotus-it was, however, not the sacred Nelumbium, but a white water-lily somewhat larger than our English Nymphaea alba, Linn.

Later we entered a very scanty forest which appeared to consist chiefly of Acacias and other prickly trees.

The first night, at Getêna (63 miles), three Noctruae came to the steamer's lights, all Egyptian species: Agrotis segetum, Caradrina exigua, and Sesamia eretiea.

The following day, Feb. 17th, I got a short two hours' collecting in the middle of the day at Ad Duwêm (125 miles, lat. $14^{\circ} 10^{\prime} \mathrm{N}$.), but unfortunately much of this precious time was wasted in looking for good collecting ground. A female Polyommatus bacticus, two males of Tarueus theophrastus, and a male of Azanus ubaldus, were all Khartûm friends, as were Belenois mesentina, a male, Teracolus daira, one of each sex, and T. protomedia, also one of each sex. The last is a strong flyer, and some got away in consequence. I did, however, add one species to my list in the shape of Tcracolus halimede, Klug, var. leo, Butl., of which a male was secured, but unfortunately I damaged its hind-wing in pinching it. Other captures were:-the common wasp, Eumencs tinctor, a female, as wcll as Icaria cineto, Lepel., also a fcmale, quito a tropical form; the small Bee, Osmia sp.; the Chrysid Parnopes viridis, Brulle; the Fly Agria muba; Coceinella 11-punetata, and the widely distributed Utethcisa pulchella, of which scveral were seon. That aftornoon, further up the river, a 
femalc Xylocopa aestuans came on to the steamer and was captured by Miss Marriage.

On the retum voyage three days later (Feb. 20th), I got another two hours ashorc at Ad Duwêm, from 8.45 to 10.45 a.m. Butterflies were fairly common in and near some gardens a short way upstream, but there was a strong wind and many of them were much torn. On this occasion Danaida chrysippus put in an appearance and I took a male, a fine specimen of the alcippus form with hardly any fulvous upon the hind-wing; it had the characteristic odour of the species strongly developed. The most conspicuous insect however was Teracolus protomedia, which was common enough, but not very easy to catch in the high wind, though I managed somehow to secure nine, all males. This butterfly seemed to be cspecially attracted by the red flowers of a Cacsalpinia (Nat. Ord. Leguminosae) in one of the gardens; in three of the specimens I detected a scent, slight but distinct, which was noted at the time as "a somewhat unpleasant, stuffy smell," "a slight scent, scarcely agreeable," "distinct, dusty, hard to describe." The commonest butterfly would appear to have been Teracolus daira, of which I brought away five males and three females, one of the former being a dwarf, a female is recorded as having had a clove-pink scent, both in the field and at home. Of $T$. halimcde I got one female; of $T$. (?) liagore, Klug, a male. This last must be a very rare spccies. Dr. Dixey told me that he had never seen a specimen, but he thought that my insect must be Klug's liagore. ${ }^{1}$ I also took five males of Belenois mescntina, three of which had a slight, somewhat hay-like scent.

The flowers of Parlinsonic (Nat. Ord. Leguminosac) attracted, besides the common Xylocopa aestuans, and Eumencs tinctor, the large handsome grey, black and white Bee, Podalirius nubricus, Lepel., of which I secured one of cach sex; in company with these was a Podalirius that Mr. Morice thinks likely to be the undescribed male of $P$. incanus, Klug, of which I seem to have taken the femalc in the suburbs of Khartûm at the same flowers.

Late at night we reached Kosti, 192 milcs from Khartûm. This is the place that is oficn called after the name of the district, Gôz Abú Gûma. Quite a number of insects camc to the lights of the steamer during the cvening. Among them was Cirphis loreyi, a rarity in England, but common enough in Egypt. There were also two specimens (? males) of a Trichiurce placed by Sir George

1 Miss Sharp, " Monograph of Teracolus," 1901, p. 127, considors T. liagore, Klug, to be the dry-season form of ' $I$ '. daira, Klug, and MIr. Walter Rothschild scems to concur. 
Hampson with obsolcta, Klug. My Egyptian specinens quite agree with those in the British Museum from Cairo, but the two from Kosti are identical with three from the Blue Nile, and differ from the others in being smaller, darker, and of a blue-grey instcad of a reddish tint. Mr. G. T. Bethune Baker has since described this form as Trichiura definita, sp. nov. ${ }^{1}$ [See Plate V., Fig. 3.] Then there was a little ochreous Noctuid, a species of Antarchaea, which is not in the British Museum, also a very distinct Lymantriid, a tiny moth nearly black, with an orange, black-spotted abdomen, which Sir George Hampson has described as Euproctis xanthosoma, sp. nov., adding "very distinct from all other species known to me" " [See Plate V., Fig. 4]; also a Setoenobius and a Chilo, both of which appear to be new. With these novelties were the less remarkable Endotricha consobrinalis, Zell., and the very generally distributed Hypsopygia nuaritialis, Guen., a species near the British Pyralis costalis, Fabr.

It is curious in how many places and under what different circumstances I have taken single specimens of Acridium argyptiacum; here it came to light, accompanied by other Acridians and Crickets (not yet named), as well as by the Mantid, Enıpusa egcna, Charp., and the Cockroach, Derocalymma porcellio, Gerst.

The huge, but dingy Water-bug, Limnogeton fiebcri, Mayr, was accompanied by a number of Beetles, many of them obscure species that I have been unable to identify :-Opatrum subsulcatum, Reich., in some numbers; Opatrum sp.; Tanymecus sp.; Taeniolobus sp.; Chlaenius sp.; Paederus sp. ; Luciola sp., not in the British Musenm; and lastly a male of the common Ant, Myrmecocystus viaticus.

At our most southerly point, Gebel t̂n (lat. $12^{\circ} 40^{\prime} \mathrm{N}$.), $20 \mathrm{~S}$ miles from Khartûm, I had a very short time for collecting. The thin scrub was extremely dry, there was scarcely any lierbage, and but one or two shrubs were still in flower. The heat was intense, $114^{\circ} \mathrm{F}$. in the shade, at the same time the sense of hurry was most disconcerting. Under these adverse conditions all that I succeeded in taking back to the ship wcre two Dragon-flies and six Bntterflies. A male Danaida chrysippus, with the usual sccnt, differed from the type only in having the veins of the hind-wings margined with white; of two Tcracolus halincde onc had a large piece missing from a hind-wing; there were two T'. eupompe, Klug; and, lastly, a $T$. cvarnc, Klug, the only specimen that I met with. All these I'cracoli were males, and the two last-named species decidedly of dry-season type. 
That night we slept at Roseires (not to be confounded with the place of the same name on the Blue Nile). Here again insects came to light, viz.: Cirphis loreyi, as before; the ubiquitous Nomophila noctuclla; a yellowish Arctiid, superficially rather like a Nonagria, not known to Sir George Hampson; another specimen of the new Antarehaec previously taken at Kosti; a Lymantriid which Sir George Hampson considers to be the male of an undescribed female from British East Africa, and has described as Laelia seminuda, sp. nov. ${ }^{1}$ [Plate V., Fig. 6.] With the moths came the Acridian Oxyeoryphus compressicornis, Latr. The next morning a Mantid, Calidomantis savignyi, Sauss., was found on a water-lily on the breakfast table; doubtless it had been attracted by the lights the night before. Several Beetles also visited the lights-which, by the way, were acetylene, and not very brilliant:-Coceinella rufescens, Muls.; Brachinus sp.; Ora sp.; Tanymeeus sp. (the same as at Kosti); Paederus sp. ; and Chlaenius sp.

The next morning we left Hillet Abbas at $10.30 \mathrm{a.m}$.; it is a bare, miserable place, not improved entomologically by a tearing wind. However, besides three Dragon-flies, I managed to get hold of one Azcnus ubaldus, a female; a female Tercuealus dcira; and two males of T.halimede. This last is a delicate insect, white with a cadmium-yellow flush; it appears to have a slight, somewhat disagreeable scent. Here I missed a Blue, probably Polyommatus bcceticus.

On our way down stream again I got a short hour's collecting at Kosti in a small vegetable garden close to the landing place. Only two butterflies rewarded my efforts, a male Zizera lysimon, and a male Dunaida ehrysippus; the last, taken at Onion flowers, was almost typical, with merely a little white along the veins of the hind-wings. It proved tenacious of life and had the usual characteristic scent.

'The flowers of Carrot yielded a female of the Scoliid Elis senilis, of which I had taken several males at Khartûm. When I first met with this in Egypt I had no notion that the sexes were conspecific. The male, very variable in size, is smaller', its abdomen orange-red, ringed with black, its head and thorax clothed with grey pubescence (whence the name), its wings are nearly transparent. 'The female is larger and stouter: the pubescence orange, abdomen blue-black, and about two-fifths of the wings purple. On the same flowers I took the beautiful Eumenes lepelletieri, Sauss., one of each sex, a fine yellow insect with a black cross on its abdomen; a pair of the yellow-eyed

\footnotetext{
1 Ann. Mag. Nut. Hist. (8), vol, v., p. 141 (1910).
} 
I'achysphex fluctualus, Gerst.; a malc of Odynerus (?) bellalulus, Sauss.; also a Pompilid, whieh puzzles Mr. Moriee, but which he thinks may be Salius brctonii, Guér. There were also several Pecs: a female Nomia cdentata, Moraw., and four Megachile (?) venustu, Smith. With these was the Egyptian Grasshopper, Chrotogonus lugubris.

We stopped at Tawila (185 miles above Khartûm) to fill up with fuel. Fortunately, the proeess of "wood-ing" was a slow one, and I got ashore from 1.0 to 4.30 p.m. The terrain was eovcred with a scanty serub just above the level of the river; the small trees wcre mostly Aeaeias, but all were exasperatingly thorny. Collecting was good, in spite of the wind, nearly all my eaptures being made at one or two late Acacias that were still in flower. The sense of hurry and the desire to eatch as many things as the time permitted interfered with observation. In the midst of my work I tore my net very badly, but fortunately the steamer was not far off, and I ran back to get a new one; euriously enough, two of my bost spccimens were taken with the damaged net, in spite of a hole quite a foot across! Most of my captures werc by this time old friends, c.y. Tarucus theophrastus, two males and a female; Belcnois mescntina, a solitary male; Teracolus protomedia, a male with a sweet seent; $T$. daira, three males and two females, one of each sex was unusually large, but on the other hand one female was a veritable dwarf; $T$. cupompc, seven males and one female; $T$. halimede, var. lco, two males and one female.

But besides these old friends I made some new aequaintances, to wit, Tcracolus phisadia, Godart, six of caeh sex. The male is very pretty and delicately coloured, being pink with a blaek border to the wings, one of them was noted as having a sweet, luseious scent; the fcmale is sulphur yellow. I also got two T. calais, Cram., a Delhi acquaintanee, one of them small. Of Horpacnia criphia, Godart, I took one of each sex, both quitc remarkably small spceimens. Two old South Afriean fricnds also turned up, Lenceronia buquetii, Boisd., a female, and three Virachola antalus, Hopff.

The only moth that I saw was Stcriha sacraria, Linn., whicl I kicked up. There were but two Aenleates in uny bag: a male Eumenes tinetor, and a femalc E. lepelleticri.

Late that afternoon we stopped at Faehi Shoya, on Abba Island (176 miles above Khartum), where the Mahdi used to live. I landed and collceted from 5.15 p.m. till dusk. The following were for the most part disturbed from grass, ete. :-a ncarly typical male Danaida chrysippus, only slightly dusted with white; it was tenacious of life 
and had the characteristic scent; five females of Teracolus halimede; also a female of $T$. eupompe, lacking the red tip. It is notable that at Tawila, earlier in the day, males prevailed over females. The female of halimede is variable, the ground colour is usually white, but in a specimen from Ad Duwêm it was yellow; sometimes there is a mere trace of the yellow flush, but occasionally it approaches that of the male; moreover, the black markings vary in intensity.

At Fachi Shoya I got a single moth, a Lithosiid, which is almost certainly a new species. A native sailor brought me two beetles, Rhyticlonota scabrinscula, Esch., and Mrs. Longstaff found a beetle in our cabin, Phcropsophns (?) lafertei, Arrow. That night there was a violent gale from the north, which blew out of my cabin two of my precious Tawila butterflies in their papers. What they were I shall never know, but have an impression that they were Teracoli of which I had others. In spite of the gale a Catocaline Noctuid came to light, Pandesma quenavadi, Guen., a common Indian form.

On my last night on the White Nile, Feb. 20th, above Geteina, Blattella (Phyllodromia) treitliana, Wern., an uncommon Cockroach, came to light, and Herr Schwabacher gave me a Cirphis loreyi.

The fauna of the Sûdân is extremely interesting from the point of vicw of geographical distribution. The Sûdân may indced be compared to Switzerland, in which country French, Germans and Italians meet. The insect fauna of Egypt is essentially Palaearctic in character; the great majority of its insects are also to be found in Southern Europe. As examples of Palaearctic species extending through Egypt to the Sûdân the following may be mentioned:Cirphis loreyi, Euxon spinifera, Caradrina exigua, Deilephila livornica, Xylocopa cestuans, Eumenes tinctor, and Coccinella 11-punctata.

Another element is the Oriental, which would appear to have reached the Sûdân through Persia by way of Arabia. Such inscets are Teracolus calais, Pandesma quenavadi, Noorda blitealis, Arnipscs sabella, and Copicucullia sublntea (though perhaps this last may be reckoned as Palaearctic rather than Oriental).

Other Sûdân inscets have a far wider distribution, such as Danaida chrysippus, Polyommatus bacticus, Zizern lysimon, Utetheisa pulchella, Eromene ocellea, and Sterrha sacraria. Together with thesc are the almost cosmopolitan Pyrameis cardui, Agrotis ypsilon, and Nomophila noctreella.

Though doubtless many, if not all, of these common insects are to be found in Uganda, yet the fauna of that country may well be considered as characteristically Ethiopian. From Uganda not a few Ethiopian species have passed to the Sûdôn, where they mect the 
Palaearctic and Oriental insects previously named. Such are Papilio demodoeus, Catopsitia florella, Leuccronia buquctii, Herpaenia eriphir, Calopieris eulimine, Teraeolus protomedia, T. daira, T. chrysonome, T. cphyia, T. halimede, T. phisadia, T. eupompe, T. liagore, and T. evarne, Virachola antalus, and Lamoria imbella.

So far as my slight opportunities enabled me to hazard an opinion, the Palaearctic fauna of Egypt extends almost unchanged as far south as Wâdî Halfa. It would, of course, require much study on the spot to define the line, if such there be, north of which Ethiopian species do not range. The line of demarcation may safely be assumed to be different for different species. For instance, the African butterfly, Catochrysops clcusis, is as abundant at Abu Simbel in Nubia, and even at Aswân, as it is at Khartûm; one or two Sudanese moths also, as I have mentioned, extend into Nubia; nevertheless I was distinctly impressed with the idea that it was south of the Nubian desert, roughly speaking at the river Atbara (say $17^{\circ} 30^{\prime} \mathrm{N}$.), that I first came in contact with the Ethiopian fauna, though, on the other hand, forms which occur in the Palaearctic Province were common enough at Khartûm and even south of it, but these were for the most part wide-ranging, if not actually cosmopolitan species.

The Hon. N. C. Rothschild stayed for some time at Nakheiln, on the Atbara, in 1904, where he and his companions, the Hon. F. R. Henley and Mr. A. F. N. Wollaston, took several species of Tcracolus and other insects that I met with at Khartûm or south of it. ${ }^{1}$ Mr. Rothschild informs me that he thinks the Tcracoli probably extend as far northwards as the thin Acacia scrub, that is to say, to some point north of the Atbara, but south of Wâdî Halfa.

It is interesting to compare with my captures those of Mr. Wr. L. S. Loat, F.Z.S., ${ }^{2}$ in 1901 and 1902. Many species are common to the two lists, but not only had he somewhat more time than was at my disposal, but a large number of his insects wcre taken as far south as lat. $5^{\circ} \mathrm{N}$., whereas I did not get beyond $12^{\circ} 40^{\prime} \mathrm{N}$.; it was therefore only to be expected that, as compared with my captures, his were more strongly Ethiopian, including, c.q., a $N^{\prime} e p t$ tis and two species of Acraea. Mr. Loat took 11 species of Tcracolus, I took 10; sir species are common to the two lists.

As regards the Hymenoptera Mr. Morice writes me: "I may say that the only insects I had previously examined from Khartim and the White Nile, wcre those taken by the Swedish expedition five

1 Novitates Zoologicae, 1905, rol. xii., pp. 21, 22.

" "On Lopidoptern from tho White Nile," by F. A. Dixey, M.D., F.R.S., Trans Fint. Soc. Lond., 1903, p. 141. 
or six years ago, and you have certainly got much more material than they did-though, strange to say, hardly any of the same species!"

February 22nd.-On my return journey, at Atbara Junction (lat. $17^{\circ} 35^{\prime} \mathrm{N}$.), I took a male of Rhynchium niloticum, a red and black Wasp whose acquaintance I had made at Khartîm.

At Abû Hamed (lat. $19^{\circ} 30^{\prime}$ N.) I made a raid upon the stationmaster's garden and picked up a female Philanthus variegatus, a common Khartîm insect which I did not meet with north of this, although $\mathrm{I}$ am told that it is a North African species; also two females of Nomia latipcs, Moraw., a Bee that I did not come across elsewhere; and a fcmale of $N$. eclentata. A Dragon-fly and a Grasshopper are still unnamed.

February 23rd.-The common Enxoc spinifcre came to light at Wâdî Halfa. ${ }^{1}$

\section{NOTE ON THE LAND AND FRESHWATER MOLLUSOA OF THE SÛDÂN.}

By Mrs. G. B. Longstaff.

The dearth of land Mollusca in Egypt and the Sûdân offers a marked contrast to their abundance in Jamaica. This is to a certain extent atoned for by the numbers of freshwater Mollusca occurring in the Nile, numbers, however, of individuals rather than of species, for many species range with but slight variation over considerable distances. Possibly, indeed, if individuals from districts still more remote could all be brought together, it might be found that some now regarded as distinct species would prove to be but several links in a chain of the varieties of one form.

The Mollusca here recorded were collected at the mouth of the White Nile near Mogran, as well as at various ipoints where the steamer stopped during a five days' trip from Khartûm to Gebcl hin and back. The month of February seemed a most favourable time, since the river was subsiding and many specimens were found at its margins either alive or quite recently deceased. The only land shell taken was Limicolaria flammea, Müll. The largest specimen, which is of the variety scnnaariensis, Parreyss, was found by the obliging manager of the steamer, Mr. Macdonald, on a hill at Gebel în. It agrees very nearly with Fig. 5 on Pl. vi. of "Fauna der Land und Süsswasser Mollusken Nord-Ost-Afrika," by C. F. Jickeli. Three shorter shells were met with which greatly resemble the val.

\footnotetext{
' This account of the Sindin appeared in the Entom. Month. Mag.
} 
numidica, Reeve, as represented in Fig. 7 on the same plate. Two of these occurred at Hillet Abbas and the other at Fachi Shoya. All the specimens were dead with only portions of the epidermis preserved.

Two living examples of Suecinea rugulosa, Morelet, were found on water plants ("umm Sûf") at the edge of the White Nile at Gebel En. The Swedish zoologists in 1901,- - and they were the first to record it from this district,-also took but two specimens, at Gebel Ahmed Agha, a little further south. Theirs, however, are much smaller than mine, which come nearer to the type in dimensions, one of them being $8 \mathrm{~mm}$. in length and $4.5 \mathrm{~mm}$. in width. They were likewise the first to take at the same locality Isidora sericina, Jickeli, which had previously only been recorded from districts north-east of Abyssinia. They, however, got but one small specimen, whereas I took six, one at Gebel Ên and five at Hillet Abbas, four of which were alive, and the first if not alive when taken was quite recently dead. Again my largest is nearer the type in size than theirs as it measures $9.5 \mathrm{~mm}$. in length and $6.5 \mathrm{~mm}$. in width. All were on water-plants. Another species which the Swedes were the first to record from the White Nile, Planorbis boissyi, Pot. \& Mich., was taken by me at Gebel Ên (six), Hillet Abbas (four) and Fachi Shoya (two); they were on the mud and were mostly in good condition, but only one was alive. I found eight living specimens of Melania tuberculata, Müll., near Mogran, and kept them alive for a time to observe their movements: the animal advances slowly and then brings its shell forward with a jerk. R. Hägg only mentions one of this species, which was met with at Mahmudia some forty miles further south.

The largest example of Ampullaria kordofana, Parreyss, was taken at Kosti. It was dead but the epidermis was well preserved; the length measures $66 \mathrm{~mm}$. and the width equals $56.5 \mathrm{~mm}$. Three smaller shells were found at Gebel $\hat{\mathrm{E} n}$, two of which were alive; three at Tawila, two of which also were alive; and one at Hillet Abbas.

A muddy creek among water-plants at the latter place was especially productive, and here I took my finest specimen of A. wernei, Phil., its length equals $93 \mathrm{~mm}$. , and its width, 95; another is nearly as large; these and several of smaller dimensions were alive. This species was also taken at Gebel $\hat{F} n$, Fachi Shoya and Tawila.

Lanistes bolteni, Chem., occurred at Gebel En, Hillet Abbas, Fachi Shoya, and Tawila, altogether about thirty examples were found, of which only seven were living.

Numerous specimens of the variable species Cleopatra bulimoides, Oliv., were taken. Those from Mogran were the largest and had the 
most convex whorls; out of one hundred and ten only five, and these immature, had a keel on the spire, this was observed on very few adults and on one only was it continued on the body whorl (var. uniliata, Germain). They were nearly all of a uniform yellowish horn-colour, with the exception of nine which had dark brown spiral bands, these included the five keeled young shells. At Gebcl En about forty individuals were found which were greatly decollated, whereas those at Mogran were only slightly so. The southern specimens are less robust and have a smaller spiral angle. Thirtythree are spirally striped with dark brown, only eight are selfcoloured similar to those found near the mouth of the river, and three of these have a keel on the whorls of the spire. Fourteen of the striped shells have two keels on the spire, which are not continued on the body whorl (var. bicarinata). Ten individuals were met with at Hillet Abbas, which are also decollated, five are unicolorous, the rest have dark stripes. Four have keels on the spire.

Vivipara unicolor, Olivier, which is equally variable, was found at all the stopping places and also near Mogran. Those from the latter locality have almost convex whorls with but little trace of angularity, whereas one taken at Gebel $\hat{\mathrm{E}} \mathrm{n}$, as well as those met with at intermediate places, are distinctly biangular (var. biangulata, Küst.). Some have in addition several spiral moniliform threads, these are especially clearly exhibited on a shell from Hillet Abbas, which thus approaches the var. robcrtsoni, Frauenf.

I did not find specimens of Corbiculc so numerous in the White Nile as lower down at Aswân, nevertheless I met with individuals characteristic of two of the thrce groups into which M. Pallary divides the species. At Gebel Ên were found three good specimens of the triangular form, C. artini, Pallary, and at Hillet Abbas three much worn single adult valves, and two young living examples. C'. consobrina, Caill., occurred at these two localities as woll as ncar Mogran. A single valve taken at Hillet Abbas is the largest, measuring $31 \mathrm{~mm}$. in height, and $34 \mathrm{~mm}$. in width.

Numerous specimens of Sphaerium sp. indct., were obtained at Gebel F̂n, Hillet Abbas, Fachi Shoya, and Tawila.

Both an adult and a young example of Nodularia (?) parreyssi, v.d. Busch, were found at Fachi Shoya. Eight individuals in different stages of growth, though none quite mature, were also takcn at Mocran. At Sobâ on the Blue Nile there occurred five spccimens which closely agree with Pallary's figures of $N$. mysticus, Bourg. A very good example of $N$. aegypticuca, Fér., was found at Hillet Abbas, and two larger, thinner, and more orbicular specimens were met 
with at Tawila and near Mogran respectivcly. N. teretiuscula, Phil., var. lithophaga, Zieg., was fairly abundant, occurring at Hillet Abbas, Fachi Shoya, Tawila, and near Mogran. Specimens of a species resembling the last but higher in proportion to the width and less attenuated posteriorly were taken at Tawila, Ad Duwêm, and near Mogran, these last were greenish and not so dark in colour as the others, which were nearly black.

Seven examples of Mutcla nilotica, Fér., var. angustata, Sow., were found near Mogran. The largest has a width of $120 \mathrm{~mm}$, height at the umbo $42 \mathrm{~mm}$, greatest height $48 \mathrm{~mm}$. There were also met with here three immature individuals of the var. elongata, Sow., agreeing with Germain's figure of M. moineti, Bourg. Eight specimens of Mutelina rostrata, Rang., were taken at the same locality. A recently killed example of Spatha rubens, Lam., var. cailliaudi, von Martens, was obtained from a fishing boat at Kosti, as well as a single valve of a larger specimen. At Fachi Shoya I found the right valve of a species which seems to agree with Spatha marnoi, Jickeli.

Three fine specimens of Aethoria elliptica, Lam., of the typical form, were taken at Tawila. They were adhering to one another and contained the animals, they are devoid of tubular spines and are more or less oval in contour. A valve with the broken hinge of the other attached, similar to the preceding, was found at Gebel En. At Fachi Shoya I met with a smooth valve fixed to two spiny ones (var. tubifera, Sow.). This large bivalve is so like the common Oyster that one was astonished to find it in a river at such a great distance from the sea. Likc the Oyster it is not only variable but extremely irregular in form; it is gregarious, occasionally forming, we were told, such rocky masses as to be an impediment to navigation.

I am greatly indebted to Mr. Edgar Smith for hclp in comparing my spccimens with those in the Natural History Museum. The works of M. Pallary have becn of considerable service, and I have in the main followed his classification.

\section{EGYPT.}

February 24th-April 18th, 1909.

The return voyage down the Nilc was a come-down in other senses, and it was difficult to keep up much cntomological enthusiasm. Morcover, as I began to despair of finding inscets of much interest, the marvellons history of the comntry as depicted in tomb and temple 
became more and more absorbing, till I felt-as so many have done-that to linger in the country or to return to it would mean to become a " digger:"

\section{AswÂN.}

February 25th.

Most of my time was spent in revisiting the oasis near the golflinks. It was a cold morning, $62^{\circ} \mathrm{F}$., with a strong wind. In sheltered places, especially about Crucifer's, Pyrameis cardui was abundant, many of the specimens were fresh though chipped, several - practically all that were settled on the ground-werc seen to orient. Polyommatus bacticus was common; Tarucus theophrastus was not uncommon at orange-blossom. This same bridal flower, growing near a Sâkyeh or water-wheel, also attracted Eumencs tinctor and Elis senilis-although the name of the latter would have suggested that it should be beyond such romantic food. A male Podalirius near to albigena, and a female Megachile flavipes, were satisfied with such less overpowering sweets as Raphanus affords, and though I found the Chafers less common than before, our old friends Myrmecocystus viaticus and Adesmia (?) cothurnata were still coursing over the sand, and Mesostena laevieollis and Pimelia spinulosa still hid under stones.

That night the vessel's lights were visited by Agrotis ypsilon, Euroa spinifera, and Sesamia cretica.

\section{LUXOR.}

February 26th-March 9th.

One day a severe sandstorm made everything impossible, and I varicd my entertainment by spending three days in bed: a very rare cxperience. My time in the neighbourhood of the ancient capital, Thebes, was mainly devoted to the engrossing study of Egyptology. The following story, told me by a German fellow-travellor of his quite recent personal experience, shows how ill-equipped some persons are for such a journcy. Herr S. noticed that a certain lady (at least a first-class passenger) did not seem to take in the words of the rlragoman expounding Dr. Budge at second-hand. Out of kindness he essayed to help her by explaining the general principles of the ancient picture writing, and pointing out some of the commoner lieroglyphs. He quite thought that he had made some progress, and 
that the lady was getting really intercstcd, when she suddenly broke out with, "Yes, I suppose they are all quotations from the Koran."

Such entomological efforts as I did make at Luxor werc but poorly requited, and I can recall few distriets less productive than the Theban plain. The hotel garden harboured a very few Tarucus theophrastus, and they were in bad eondition. From time to time a White gave me a desperate chase, and after many efforts I secured one-a female Ganoris rapac, Linn. To the south of the town I pieked up odd examples of Catochrysops lysimon and Tarucus telicanus, and saw Pyrameis cardui.

The Aculeates met with were Xylocopa acstuans; Collctcs braccatus, a Bee that was abundant at mignonette flowers; Megachile flaripes; the Wasps, Sceliphron spirifcx, Eumencs tinctor, and Vespa orientalis at flowers of carrot; with these was a Myzine (?) aegyptiaca, which I had also taken at Khartûm.

The large garden of the hotel also yielded the big red Locust, Schistocerca percgrina, Coccinella 11-punctata, Ocnera hispida and the Syrphid fly, Eristalis tacniops.

But if the days were unproductive it must be admitted that the nights were less so, and the moths about the electric lights kept me busy on the terrace of the hotel. Most of the Noctuids were by this time old friends: Agrotis ypsilon, A. scgctum, Enxoa spinifcra, Cirphis loreyi, Caradrina cxigua (in some numbers), Scsamia cretica and Spodoptera manritia; the same is true of Craspcdia consentanea, Tephrina dispntaria, Deilephila livornica, Trichiura obsoleta, Nomophila noctuella, and Eromenc occllca. There were, however, a few neweomers, of which the most eonspieuous, or at least the most numerously represented, was Plusia circumflcxa, Linn. (a near ally of our P.gamma, which it elosely resembles), an inseet which ranges over Southern Europe and a great part of Africa. The Catocaline, Psendophice haifac, Habditeh, is an inseet that has been but reecutly described from Alexandria, and the National Colleetion possesses but one specimen; unfortunately only one visited my hotel. A muel more conspieuous thing was the handsome Taragama acaciac, Klug: I have little doubt that the stripped branehes and unsightly webs which I. saw on the Acacias at Aswann and elscwhere were the work of the larva of this Lasiocampid.

Other inscets found about the lights were the Carabid, Chlacnins brahminus, Laf., the onee revered Scarabacus sacer, and a Molc-criehet, Gryllotalpa africana, Pallas.

Mareh 11th.-At Baliana (lat. $26^{\circ} 15^{\prime}$ N.), on the $A$ bydos rond, a number of Ganoris rapae were seen in and about the fields; an obseure 
Heteromcron crawled in the Temple of Seti, quite unconscious of the superiority of the earlier carvings to the later which so sadly deface them. At night Sescumia erctica and Plusia circumflexa came to the steamer's lights, accompanied by Endotricha consobrinalis.

March 12th.-At Asyût I did not see a single butterfly, and sweeping produced nothing more exciting than Coccinella 11-punctata, Mcgachile flavipes, and Apis mellifiea; while Vespa orientalis occurred in the little public garden.

Abû Fêdah (lat. $27^{\circ} 30^{\prime}$ N.). The steamer's lights brought together a number of Cirphis loreyi and a Lamellicorn beetle, a species of Pentodon, represented at South Kensington, but not named.

March 13th.-At Tel-al-Amarna (lat. $27^{\circ} 37^{\prime} \mathrm{N}$.) the insects met with-Tarucus tclicanus, Xylocopa acstuans, and Chalicodoma siculafell far short of the wall paintings in interest. It may, however, be noted that this was my northernmost locality for the Blue, at least in Africa, for in $1903 \mathrm{I}$ took it at Lahore (lat. $31^{\circ} 35^{\prime} \mathrm{N}$.).

Near Matâi (lat. $28^{\circ} 26^{\prime} \mathrm{N}$.) the steamer ran aground at a very narrow place where the difficulty of navigation was considerable and the stream strong. The current striking the stern of the vessel on the port side swung it right round, and, there not being room enough, literally brushed off the rudder against the bank. The turning movement had liberated the bows and the Râiz (pilot) managed to anchor in a convenient bay a little lower down where there was less current. To these river steamers the loss of a rudder is such an ordinary occurrence that they carry a spare one, and it did not take the engineers many hours to clear away the wreckage and ship another.

A few insects came to the lights of the disabled ship: Inany Agrotis ypsilon, several Luxoa spinifera and Cirphis loreyi, a few Nomophila noetuclla. A couple of Scarabaeus sacer turned up, but I was more surprised to see Schistocerca percgrina. While in pursuit of moths I boxed a specimen of the blood-sucking fly, Hippobosca francilloni, Leach, off the face of a fellow-passenger.

Arabic is a difficult language: I am told that it is related to Hebrew, but it has little or nothing in common with Aryan tongues. A puzzled student once waggishly said that in Arabic every noumsubstantive had three meanings:-

1. Its own proper primary signification.

2. A secondary signification the exact opposite of the first.

3. Some sort of camel.

A clergyman coming down the Nile told ine that he was greatly 
intcrested in the religious stories and traditions of the Arabs, and his eloth must be my exeuse for quoting two of them.

(a) When the Creator had made the Camel, he looked at it-aud laughed. Then he looked at it a seeond time-and laughed again.

(b) The reason why the Camel is the most supereilious of all creatures is this-

Man knows the ninety-nine attributes of God, but one thing he does not know-the Ineffable Name, that graven upon the seal of Solomon-but thc Camel docs.

\section{Calio and District, lat. $30^{\circ} \mathrm{N}$.}

March 16th-April 18th, 1909.

CAIRo is of course a eity of extraordinary interest, and it is interesting from many points of view, but as regards insects it cannot be termed a great loeality, while as far as Lepidoptera are concerned my efforts were almost fruitless.

Danaida chrysippus appeared to be over, at all events for the time, but, on the other hand, Ganoris rapac had come out sinee my first visit and was fairly common about the fields of Barsîm, the Egyptian white clover; it was also to be seen in the beautiful gardens at the Barrage, gardens so highly cultivated as to produce nothing but the Small White and the ordinary form of the Honey-bee. On Mareh 30th, I saw a male of Colicus cdusa, in the garden of the Gezira Palace Hotel, where Mrs. Longstaff found a spceimen of Spodoptcra mauritia sitting on her parasol, and where Plutclla maculiponnis condeseended to eome to light.

One day I took train to Matarîya, about seven miles to the north-east of Cairo. Near the station a solitary Polyommatus bacticus was netted, and sueh eommon things as Polistes gallicus, Linn. (which also oecurred on Gezîra Island), Myrmccocystus viaticus, Coccinclla 11-punctata, and Epicomctis squalidus, the last on Raphanus. However, my objective was the Rev. F. D. Moriee's old collecting ground, the banks of the abandoned railway to Suez; so I struek out to the right across the desert, but, owing to the early date, March 24th, and the exceptional dryness of the seison, did not find either flowers or inseets very plentiful, moreover the wind blew as it nsually does in Egypt.

A few Synchloë glauconome, Klng, eoursed swiftly along close to the ground; a Painted Lady was the only other butterfly, and I saw no moths. The blaek spider-like Heteromeron, Adesmia dilatata, 
Klug, was to be seen running at a moderatc pace in all directious; Tentyria glabra, on the other hand, is a comparatively sluggish insect found under stones. The little Zophosis complanata, Sol., is cxceptionally swift in its movements, curvetting about so as to give much trouble to its would-be captor. It frequented desert plants, from which, when disturbed, it would make short excursions on to the open sand, returning again to its shelter. The integuments of this beetle are hard and brittle ; in the cabinet it appears as a uniformly black insect, but on the desert closely approximates in colour to the sand, being dust-coloured, with a tendency to rcd, but sometimes appearing almost white in the bright sunlight. This colour is due to a coating easily rubbed off by the fingers, disappearing entirely in the cyanide-bottle; it seems to consist of an excretion, perhaps waxy in its nature, to which probably the finer dust of the desert adheres and gives the last touch to its cryptic colouring. ${ }^{1}$ Under stones an Ocncra hispida turned up, as well as another species of the same genus. The Ant of the place was an Aphaenogaster, which Mr. Morice thinks may be a race of barbara.

On the Mukattam Hills, above the Citadel, hills of white limestone built up mainly of Nummulites and other fossils, I found under stones the common Ocncra hispida, Mieipsa grandis, Kraatz, and three specimens of a species of Adesmic. Inside the Citadel itself I found a worker Myrmecocystus viaticus carrying a brother in his mandibles.

The most promising locality that I visited was the Wâdî Hof, a few miles to the East of Helwân. This is a winding gorge cutting through the limcstone hills, bounded on either side by steep cliffs, but without any stream at the bottom. These gorges are one of the puzzles of Egypt, and seem to point to a time when rain was much more abundant than now, for it seems very difficult to suppose that such rain-storms as undoubtedly occur from time to timc can have performed such extensive works of excavation. At the bottom of the Wâdî there is little sand, but many stones. Small slender Lizards, exactly the colour of the ground, were to be seen in abundance running swiftly along with their heads held high. Vegctation was more varied and more abundant than one at first imagined; it would have been delightful to have had more time there, and especially to have visited it later in the year or in a less dry spring. However, I succeeded in netting that regular desert insect, MLlitaca didyma, Lsp., f. deserticola, Oberth., which I had previously taken in a somewhat similar locality near Biskir. Another specinen was unfortunately

\footnotetext{
'Soo above, p. 163.
} 
missed, as was a White whieh, so far as I could see, was probably Synchloë glauconome. Hovering at the flowers of the Labiate, Stachys acgyptiaca, Pers., and by no means easy to net, were two Bees, Podalivius suworzevii, Moraw., and another larger speeies of the same genus; and yet another Podalirius eoming very near to albigena. The only other bee was a female Mcgaehite argentata.

At the flowers of Zygophyllum coccineum, Linn. (Nat. Ord. Zygophyllaceac), and also on the wing, I took several of the Buprestid, Psiloptera argentata, Mann, while the Heteromeron, MIicipsa grandis, was found under a stone.

The Fly, Agria nuba, was not uneommon. On the flowers of Ochradcmus baccatus, D.C. (Nat. Ord. Resedaccae), I took a couple of what Mr. E. E. Austen says is probably a new species of Urellia-a tiny fly with green eyes, its wings beautifully netted with a sharp black pattern. At the same flower was an undetermined bee.

Two Acridians, Poeciloeerus bufonius, Klug (of the sub-family Pyrgomorphinae), eomplete my list.

Somewhat similar to the Wâdî Hof is the Wâdî Abû Roâsh on the western side of the Nile, about six miles north of Mena, but its vegetation seemed less varied. My first visit was interfered with by a sandstorm, an interesting sight but a disagreeable one. When the wind is strong enough and blows in a suitable direction, the sand is swept up into the air, so that the sky is darkened, and may even beeome as opaque as in a London fog, putting a stop to all navigation on the Nile.

At Abû Roâsh I saw but one butterfly, almost certainly a Painted Lady, neither did I capture a single moth; it is, however, only fair to the locality to mention that it was a windy day. Perhaps the insects that interested me most were the lovely little Chrysis fasciolata, of which I seeured a dozen, some of the blue, but the majority of the green form. Then there was the blaek, grey-banded Nutilla (Dasylabris) arabica, Oliv., as well as the nearly allicd Aptcrogyna olivieri, Klug. The only ant brought home was Myrmecoeystus bombycinus, Rog. A malc of the elegant slender Splucx nivertus, Dufour; a Cclonites mongoliens, Moraw, a female Miscophus ctcnopns, Kohl, and several Pompilids were among my captures; the Miseophus and the Pompilids frequently settled on the sand, but were often driven off for a yard or two by the strong wind. A male Éncmcnes nigra, Brullé, was a more powerful iusect, as was also Vespa oricntalis, of which two females appeared to be feeding on the hollow reeeptacle of the Coinposite lichinops spinosus, Liun. 
An unnamed species of Larinus, a Weevil, was found on the lastnamed plant; it is somewhat cryptic, but its yellow pubescence is apt to come off upon the fingers. The common Ladybird, Coccinella 11-punctata also haunted the Echinops, so it may reasonably be assumed that the plant harboured an Aphis, which may have attracted the Wasp also.

The large, conspicuous Nemestrina lateralis, Wied., occurred on flowers of Centaurea aegyptiaca, Linn. (This fly was also taken on Gezîrn Island at Lantana flowers.) I also took another Bombylius, as yet undetermined.

Leaf-cutter-bees were fairly numerous at the flowers of Centaurea and Echinops, especially the former. The little Megachile flavipes was quite common, but I took only one $M$. mucorea, Friese. I also got a Podalirius that comes near to albigena.

A couple of the swift dust-coated Zophosis complanata were all that I saw. The odoriferous carcass of a Jackal gave shelter to a Saprinus which is not represented in the British Museum.

At Abû Gurâb, about six miles south of the Great Pyramid, in a part of the ruined brick-work known as "The Boat of the Sun," there was an evidently urinous spot in the sand, and the rain of the day before caused it to emit a strong ammoniacal odour. This proved very attractive to Hymenoptera, and in a very short time I captured three Chrysis fasciolata, a Megachile flavipes, and a number of $M$. mucorea, all females. With these was a Bee with a conspicuously red abdomen, Paracoelioxys rufiventris, Spin., of which Mr. Morice wrote to me (December 9th, 1909):- "P. rufiventris, I believe, since Spinola described it, has only been found once (by myself and Schmiedeknecht) - sitting on the Great Sphinx! You have also its host, Megachilc mucorea, which we discovered on the same occasion, both host and parasite in considerable numbers."

Late one lovely noonlight night I explored the interior of the Pyramid of Chephren, and at the bottom of the descending passage, 105 feet from the entrance, found an Ocncrca hispida crawling on the floor. One day at Oxford, Dr. Dixey, talking to a group of entomologists in my hearing said, "Cardui, oh! that is the sort of thing that you would expect to find on the top of the Pyramid, and if anyone ever does discover the North Pole he will probably find a worn specimen of cardui hybernating upon it." I liave not yet visited the North Pole, and should scarcely hope to find cardui there if I were foolish enough to direct my steps in that direction, but not very long before the conversation in question, I did go up the Great Pyramid, and as I reached the top a butterfly flew off. With some difficulty I 
induced the numerous Arab guides and hangers-on to sit still and make 110 attempt to catch it. The butterfly returned, as I had expected, more than once, and at length settled; there was no longer any question as to its identity-Pyramcis cardui!

The sole butterfly that I saw on the desert round the Pyramids was a Polyommatus baeticus, netted near the Sphinx.

At the Mena House the wire gratings erected to exclude mosquitos, excluded also moths, so that they were a mitigated blessing like the Irishman's well-meant remark to his friend :- "Faith! Pat, it's a good bhoy that ye are, and may ye be long in your grave before the Divil finds out that ye're dead!"

As a result of the "blessed" netting the only moth that reached the lights was a common Agrotid.

In the cultivated land just below the hotel garden Ganoris rapae was common, there were also a few Aculeates; the little Philanthus triangulum, the yellow and black Eumenes coarctata, Linn., var. mediter'ranca, Podalirius atro-albus, Lepel., and another species near to senescens, Lepel. Moreover Coccinella 11-punctata was again in evidence. Mrs. Longstaff, when hunting for Mollusca, found a Chrotogonus lugubris on the canal bank alongside the Gîza Road.

The garden itself, though frequently visited, did not afford much variety: a Harpalus was found under a stone; Erodius puncticollis, Sol., crawling upon the ground; a Saprinus; several Mryrmecocystus bombycinus; the Mantis, Hierodula bioculata, was taken running on the ground under a Eucalyptus tree by day, while Scarabacus sacer was picked up at night. Among the things taken on the wing the only species yet named are Elis scnilis and a Clerid, of a carnirorous genus, Trichodes angustifrons, Abeille (? crabroniformis, Fabr.).

In the hotel itself Mrs. Longstaff found Opatrum subsulcatum, and the Syrphid fly, Catabomba albomaculata, Meig.

On the Nubian Desert ants are nothing like as numerous, either as regards species or individuals, as they are at Biskra, or in South Africa, indeed I saw none near Mena save a few Aphacnogastor arcnaria.

A female Pompilid was taken at Wild Mignonette (Rescia sp.) a little to the soutli of the Pyramids; the small Scolia interstincta, Klug, was found in the desert; Philanthus triangulum occurred in the Granite Temple; of Ammoplita crminca, Kohl, three females were taken settled on the sand with the abdomen held high in the air; of Odyncrus (?) dautici, Rossi, a female was found on the higher resert, and Eumenes nigra near $A$ bû Roâsh. On the desert near the Sphinx I saw a long pale insect flying swiftly close to the sand on 
which it often settled, it was only after several attempts that I succeeded in catching it, when it proved to be Bembcx chlorotica, Spin. A female Vespa orientalis was taken in the recently excavated Temple of the Pyramid of Mykerinos.

Xylocopa aestuans occurred on the desert near the Sphinx as well as on Gezîra Island. A stylopized female of Andrena ephippium was taken settled on the sand; Apis mellifica, for some reason best known to itself, haunted the Granite Temple of the Sphinx. The large and handsome Podalirius fulvitarsis, Brullé, was met with near Mena; while $P$. suworzevii was taken at flowers of Hyocyamus (?) muticus, Linn. (Nat. Ord. Solanaceae), a little to the south of the Sphinx.

Prominent among the desert beetles was Ocnera hispida, though it generally concealed its hard body under a stone, whereas Pimelia spinulosa often ran boldly in the open. An allied beetle, Prionotheca coronata, Oliv., found under stones just above the hotel, is distinguished not only by its coronet of curved spines-like bramblethorns-round the sides of its abdomen, but by a copious brown pubescence. Other Heteromera were Tentyria glabra and Mesostena laevicollis, beetles that hide themselves, whereas Zophosis plana has the habits of its congener, $Z$. complanata. Some specimens of the Mesostena were found ten or twelve miles into the desert.

The handsome Carabid, Anthia marginata, Dej., was not uncommon under stones on the higher desert, above the Pyramids; this species occurred also at the foot of Gebel Dixon twelve miles to the west; but the pretty Graphipterus variegatus, Fabr., a beetle with soft integuments, ran freely over the sand in the sunshine: it is swift in its movements, doubling smartly. It can make a creaking or rustling sound, which seemed to me to be produced by rubbing the femora against the edge of the elytra, or possibly the edge of the abdomen. ${ }^{1}$ I also saw this species at Sakkâra.

The very hard Weevil, Pychnodactylus (Cleonus) tomentosus, Fåhr., was found near the Sphinx in a hole in a limestone rock covered by a stone. Scarabaeus sacer was to be found about dung, or under stones, among them was a specimen of $S$. compressicornis, Klug, an Arabian specics of which the British Museum has one specimen from the Fayyûm, but it would appear to be scarce in Egypt. I may now record, with not a little pride, that, about a mile south of the Great Pyramid (in such a case one should be precise) I found a dead donkey! It is disappointing to have to add that associated with it I found nothing more remarkable than an obscure Saprinns;

\footnotetext{
' See R. I. Pocock, Ann. Mag. Nat. Hist. (i), x., pp. 154-158 (1902).
} 
however, Mr. Arrow says that the species is not represented at South Kensington.

Orthoptera were less common than might have been expected, but Truxalis nasuta, Linn., was among the denizens of the desert. One afternoon, when walking near the Third Pyramid with an unscientific acquaintance, he followed my example by turning over a stone, and forthwith, in accordance with the well-known law regulating such matters, unearthed something that I had myself not come across even in turning many stones, viz. two Cockroaches, Polyphaga africana, Linn., which (when alive) were of a pale sandy colour. A few minutes later this gentleman's wife called Mrs. Longstaff's attention to something running very swiftly in a straight line over the smooth sand. Greatly to our friends' amusement my wife pursued the creature at high speed, ultimately effecting its capture. It turned out to be the Mantid, Eremiaphila hralili, Lefebvre, new to the Hope Collection. During the whole of my time in Egypt I had been, at Mr. W. F. Kirby's special request, on the look-out for examples of that little-known genus. Apart from its swiftness of foot, the insect is almost white when alive and in the highest degree cryptic.

A good many fossils might easily be obtained in the Cairo district. The Mukattam Hills above the Citadel are of Eocene limestone, full of fossils, and, as is well known, Nummulites may be picked up off the sand at the foot of the Great Pyramid (which is indeed to a great extent built of those Foraminifera), while a couple of miles to the south a valley cutting into the escarpment exposes Miocene beds that are extremely rich in fossil remains. Amongst these are numerous large, somewhat flattened Echinids, Clypcaster aegyptiacus, Mich., which may be found on the surface, weathered-out, and in a remarkable state of preservation. One day I rode a dozen miles to the westward to Gebel Dixon, at the foot of which is an exteusive "petrified forest," said to have been discovered by my kinsman, Mr. Waynman Dixon, civil engineer and Egyptologist; at anj rate, it would appear that he first brought it to notice. I do not happen to havc come across any explanation of these "petrified forests." The general appearance is that of a wood which had been destroyed by fire-the only remains being an accumulation of trunks and branches lying on the surface fully exposed. This exposture I takc to be the result of sub-aerial denudation. The blowing sand has, by attrition, disintegrated all softcr material which has been removed by the wind, leaving behind the hard silicified wood as we see it to-day. There is plenty of evidence in the descrt of the porrer of blowing sand to effect such a work. 
On my way back from Gebel Dixon three Gazelles galloped across the track-a beautiful sight; they appeared to me darker in colour than the animals that I had seen on the Libyan Desert, and my dragoman, Hajji Alî Gâbri, himself a child of the desert, or at least a Badâwîn, assured me that they were not the common Gazelle, and that it was a very unusual circumstance to see them so near to Cairo. ${ }^{1}$

At the foot of Gebel Dixon, at least ten miles from any water, I saw a big Dragon-fly (Anax sp.); I have often seen dragon-flies far from water, but never so far as on this occasion.

Near Gebel Dixon, and in other places on the desert, some search was made for the probable food-plant of Helix desertorum, Forst., the

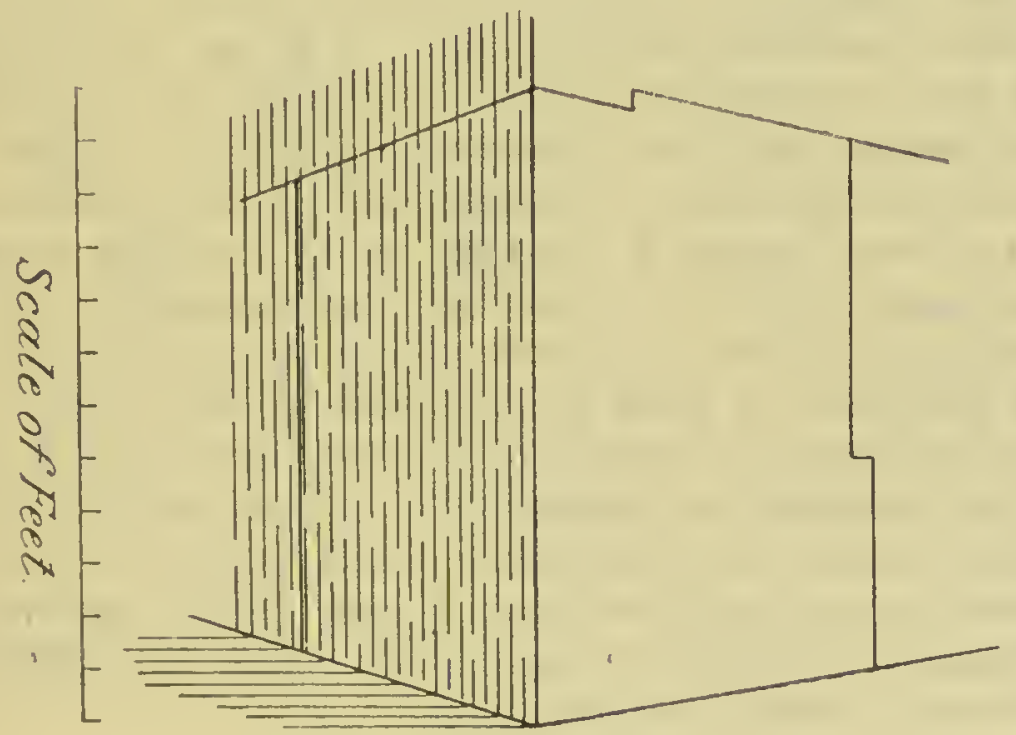

FIG. 15.-Jointing of Granite.

common Snail of those parts. It has been stated that these Molluscs, unlike their congencrs, live upon a species of Alga that grows in dewdrops. All I can say is that I never found a living animal sealed up (as they all were) but what a careful search would reveal some traces of larger vegetation, such as dead stalks, within a very few yards. It is well known that these animals can live for several years without food, and I expect that it is quite common for thcm to remain thus sealed up for months, or even a year or more, until such time as rain restores the desert flora to its fitful life.

Absolutely devoid of ornament, the simple majesty of the Granite Temple, or Temple of the Sphinx, inspircs a fecling akin to awe.

${ }^{1}$ Mr. Pocock informs me that in all probability these animals were Dorcas Gazelles (Gazella dorcas), a species of which many local races have been described. 
Onc of the huge blocks of granite measured roughly $12 \mathrm{ft}$. by $7 \mathrm{ft}$. by $5 \mathrm{ft}$. The size of these blocks is in itself wonderful, but yet more wondcrful the skill with which the fine joints and smooth surfaces have been wrought. The curious shape of many of the blocks adds another marvel. On the right-hand side of the diagram (Fig. 15) will be seen two "scts-off" cach of about six inches. Why was this done? Was it to sccure a special locking-bond, such as engineers use in lighthousc towers? Or was it to save costly material by the expeuse of cheap labour? Remember that those granite blocks had been transported by land and water close upon 600 miles. Or lastly, was it a mere tour de force? Similar sets-off may be seen in other parts of the building.

But the Granite Templc has yet another story to tell, to which my attention was drawn by Mr. Newton, of Mena. It has suffered severcly from an carthquake-probably the same as that which so seriously damaged the King's Chamber in the Great Pyramid. An examination of the massive granitc pillars, and especially the lintels (or stone beams) in the light of my Jamaican experience convinced me that the shock had come from the north or north-east. The crushing at the joints had been confined to the north side.

The Temple of the Third Pyramid, that of Mykerinos, has been excavated recently, and many stone hammers were found as well as granite blocks placed in position but in various stages of dressing. Thesc give some idea of the immense labour involved in such work. Just inside the entrance was found a stone bearing an inscription to this cffect: "This is the Temple of the deified King Mykerinos. and must not be used as a stone quarry." 


\section{CHAPTER IX}

\section{AUSTRALASTA, 1910}

Is when we were still some distance off the land numerous Seals had come out to bid us welcome to Cape Town, so when we left, the Mollymauks saw us off, handing over the R.M.S. "Arawa" to the charge of the numerous Petrels and stately Albatrosses, which were to conduct her personally across the Southern Ocean. Soon after losing sight of Africa we crossed the Mozambique current which brings warm water from the shores of Madagascar and Zanzibar down the eastern coast of Africa. The temperature of the water, which the Captain told me had been $60^{\circ}$ Fahr. at 4 a.m., rose by breakfast time to $72^{\circ}$, but the south-west breeze coming up from the Antarctic was as low as $57^{\circ}$, though it was midsummer, and as a consequence the ship was wrapped in fog. The fog, however, in no wise disconcerted the Whales, which rolled and spouted in the warm water. Ten days later the temperature of the sea fell to $39^{\circ} \mathrm{Fahr}$ - - midsummer, mind you!-but possibly that meant that ice was not far off. Although the "roaring forties" treated us cxceptionally well, roaring for but one day and night, the voyage from the Cape to Hobart was cold, cheerless, and tedious. We saw ncither land, nor ship, nor even an iceberg, and one wearied of watching the quite mysterious flight of the Albatrosses. 'Those grand birds seemed simply to will, and then to glide in an incxplicable manner without the least exertion. The moving ship was to them as a motionless $\log$, and, calm or storm, it seemed no trouble to overtake her, if by chance they had lagged behind to catch a fish or to squabble over some refuse cast overboard by the ship's cooks.

\section{Hobart, Tasmania, lat. $43^{\circ} \mathrm{S}$. January 20th, 1910.}

As we steamed along the Tasmanian Coast, when about 5 miles off South East Cape, the nearest land to windward being 23 miles off, I caught on the ship a Muscid fly, Pollenia stygia, Fabr., and two or 
three others werc seen on board; the species is confined to Australasia. It was dark when we entered the fine harbour, and I was gratified to see the skill with which the ship's officers workcd the signal lamps-a ncw accomplishment in the mercantile marine-the blinking light of a man-of-war at anchor being at once answered in the Morse code by our own. One of the junior officers presently brought zee word that my son's ship, H.M.S. "Challenger," was at Wellington.

It was pleasant the next morning to land for a day ashore. We chartered a carriage for Mt. Wellington, though the cloud on its summit looked anything but promising. There is naturally great interest attaching to the capture of the first Butterfly in a new continent; accordingly on catching sight of one in a promising wild spot on the hillside some way above the town we called a halt. A fine golden-brown Satyr appeared to be not uncommon flying about quickly among tall bushes of a heath-like shrub, and from time to time settling upon the ground. They proved to be males of Hetcronympha merope, Fabr., common to Tasmania and Australia. After many a chase four were secured; they yielded a faint scent of a sweet treacly character. The only other Lepidopterous insect was the large handsome Crambid, adorned with silver streaks, Talis argyroncurus, Zell., also peculiar to Australia and Tasmania, of which three specimens were taken. On the flowers of what I took to be a shrubby Antennaria were two Lycid beetles, Porrostoma rufipcnnis, Fabr., and Calochromus scutellaris, Erich., and a Lady-bird Coccinclla conformis, Boisd., together with abundance of the small brown and black Chafers, Phyllotocus rufipcnnis, Boisd. We then pushed on to the Fern Tree Hotel, but meanwhile the clouds lad come down to meet us, bringing rain of a hopeless character. The small Boarmiid, Emmiltis rubraria, Doubl., was kicked up, and scarching the trunks of the gum-trecs, while seeking shelter from the rain, yielded Scoparia syntaracta, Meyrk., Scoparia gomphota, Meyrk. (nI insect of which the British Museum possesses but two specimens, from Tasmania), also a Nudaria-like moth, Thallarcha sp.; this mas originally in fine condition, but the pill-box in which it was confined had been previously tenanted by a slug, and the little moth spoiled its wings with some of the slime left behind by the mollusc. This was the morc unfortunate since it turned out that there was but a singlc worn individual (also from Tasmania) in the National Collection, and Sir George Hampson does not consider either' specimen good enough to describe.

Of Beetles there was no great variety, but Adclinm abbreviatum, 
Boisd., was common under pieces of dead Eucalyptus wood, whilc in momentary glimpses of sunshine numbers of the velvety-black, red-tailed Lycid, Metriorrhynchus haemorrhoidalis, C. Waterhouse, flew slowly about bushy small-flowered Composites. The common Earwig, Forficula auricularia, Linn., also turned up, presumably an introduced species.

The only Molluscs that Mrs. Longstaff met with were introduced Slugs, viz. Limax maximus, Linn., and Agriolimax agrestis, Linn.

After we had refreshed the inner man there was nothing left for it but to descend. We found the town bathed in sunshine and paid a short visit to the Botanical Garden. Here I saw fresh specimens of the southern form of Pyrameis cardui, Linn., named by McCoy, kershawi, after Mr. Kershaw of Sydney, N.S.W. It oriented as I had seen the typical form do in many remoto places. Precis velleda, Fabr., looked quite familiar, though I had never seen that species alive before : it was rather common but much worn and of extremely "dry" type. The only other butterfly was the widcly spread Zizera labradus, Godart, a very uninteresting Blue, none the more attractive for being in poor condition. Out of a pine-tree I beat the Lithosiid Scoliacma orthotoma, Meyrk., it has a curiously truncated hind-wing.

The Ant Camponotus novae-hollandiae, Mayr, was very busy on the paths, and some as yet undetermined Acridians were to be found upon the lawns. There were several links with the Old Country; the Honey-bee, Apis mellifica, Linn., var. unicolor, Latr., and Eristalis tencex, Linn.; while Mrs. Longstaff found two living specimens and Inany dead spircs of our common garden Snail, Hclix aspersa, Müll., vir. undulata, Moq. Tand.

From Hobart to Wellington the sca was unusually benevolent to us, drizzly wcather, however, for three days made obscrvations impossible; on the fourth a more broken sky allowed a noon-tide "sight," which proved us to be about 25 miles south of our reckoning. In really bad wcather this might havo becn awkward since the lights on the Western Coast of the South Island are few and none too good. In the afternoon we sightcd far, far away the New Zcaland Alps, but could not make out any snow.

The next day we steamed up the fine harbour of Wellington, a harbour whose main fault is that though complctely land-lockcd, it is too large to afford much shclter from an easterly wind. When we got alongside we were greeted by a not too clean Naval Lieutenant, who had come away from his ship in the midst of coaling. Grimy 
though he was, he was none the less weleome, for hard we not journeyed from the top of the world round to the bottom in order to see him?

\section{EIGH'L' WEELS IN NEW ZEALAND.}

\section{Weliington (North Island), lat. $41^{\circ} 15^{\prime} \mathrm{S}$.}

January 20th, 1910.

It is difficult for any one who has read Commander J. J. Walker's "Antipodean Field Notes" 1 to make any general remarks about New Zealand, for that observant traveller's aecount of the aspect of the country is quite excellent. Indeed, my only excuse for writing at all is that he says nothing about the moths that he came across.

Wellington gave me the impression of solid prosperity and active business life. This impression is enhaneed by the neeessities of its situation, for the business quarter of the city lies along the foot of lofty hills, the main streets being laid out on land reclaimed from the harbour, hemee the chief traffie is eompressed within narrow limits, while the inhabitants live scattered over the steep hillsides. The suburbs are made readily aeeessible by electrie tramways, which seale the hills in all direetions. The author of "New Zealand Moths and Butterflies" lives at about the highest point, eommanding a grand view over the lake-like harbour. We were fortunate in the oeeasions of our short visits, for we found "Windy Wellington" quite ealm and peaeeful, and suffered from neither gales nor earthquakes.

On my first visit I had an afternoon's eolleeting in the Botanieal Garden. A part of this is eultivated, but a considerable portion consists of a hill eovered with the Manuka, or Tea-tree (Jeptospcrmum seoparium, Forst.), a gregarious plant highly eharacteristie of Australasia. From 6 feet to 20 feet high, often covering immeuse traets of country, it has somewhat the appearanee of a large Heath, but belongs to the Natural Order Myrtacece. Its pretty little white flowers were nearly over at the time of my visit. Manuka bush is usually the resort of Crambi; here the speeies were ${ }^{*} C$. ramosellus, Zell., ${ }^{2}$ and the abundant, but pretty, ${ }^{*} C$. flexuosellus, Walk. Upon the paths, in the wilder and less frequented parts of the garden, two small species

1 Entomologist's Monthly Magazine, Second Series, rol. xp., 1904, p. 24.

2 To give an idea of the singularity of the Now Zcaland fauna, but at the same timo to avoid repetition, I bave in this chapter marked with a * species sucb as, to the best of my knowledge and belicf, are confined to Now Zealand. 
of Tiger-beetle besported themselves, *Cicindela tubcrculata, Fabr., and ${ }^{*} C$. parryi, White. Concerning the latter I have the following note: "On the ground; easier to catch than the British species; does not fly so readily; somewhat cryptic," whieh quite bears out Commander" Walker's remarks (loc. cit., p. 152).

But on that afternoon most of the inseets in the garden seemed to be holding high festival at the blooms of a native shrub, the White Rata (*Metrosideros scandens, Sol.). Here I secured several females of the pretty little *Clurysophanus sallustius, Fabr., one of the cornmonest of the few indigenous New Zealand butterflies, which, in general appearance, is much more suggestive of Nemeobius lucina, Linn., than of an English Copper.

At the same flowers were a number of the black and white dayflying moth, *Deilemera annulata, Boisd. ${ }^{1}$ This, the first moth that I saw in New Zealand, soon became an even more familiar friend than the little butterfly. It is interesting in several respects. In the first place, it is peeuliar to New Zealand; then it is the only representative of the Hypsids in those islands, though a elosely allied, but abundantly distinct species, occurs in Australia. Blaek, with sharply defined white markings and a yellow body, it looks the very picture of a distasteful species. Its flight is slow, flapping its wings like a butterfly, for which it is usually mistaken by the uninitiated. It is distinctly hard to kill; when pinehed it exudes a yellow juice, which is tasteless; but I did not detect any definite scent. Formerly its larva fed on various native species of Senecio, but since the introduction and wide-spread growth of Ragwort it has attached itself to that plant, on whieh both larva and imago are eommon enough. There is every reason to expect that it will increase in abundance, and certainly no one will grudge it its food.

On the same Rata bush I took the most eonspicuous of New Zealand butterflies, "Pyrameis gonerilla, Fabr., a handsome insect elosely allied to our Red Admiral, more beautiful perhaps in eolour, but scarcely as graeeful in its flight. Bombus leortorum, Linn., a recent introduction, reminded me of home, as did the familiar flies, Eristalis tenax, Calliphor'a eryttrocepllala, Meig., and Lucilia sp.; but another eommon fly, Pollcnia stygia, is eonfined to Austrilasia. Two immature Stick-inseets (Pliasmidac) complete the list of visitors to the white flowers of the Rata that afternoon.

'The generic name Nyclcmera is now confined to a fow large species from Africa, placed among the Lymantriids. 


\section{NAPIER (Nor'Ti Island), lat. $39^{\circ} 31^{\prime} \mathrm{S}$. January 28th, 1910.}

From Wellington we went to Auckland by sea, and as the steamer called at Napier, we got an afternoon's collecting there. Acting on the advice of Mr. A. Hamilton, of the Dominion Museum, we made for a place where he told me that Pyrameis itea, Fabr., occurred, viz. a footpath from the Shakespear Road up the back of the Bluff. It was a steep track above a quarry, bordered on either hand by abundance of flowers, Red Valerian (Centranthus ruber) among them. One might have been climbing a chalk down in Surrey or Sussex. The abundance of a dark-flowered Scabious (Scabiosa atropurpurea), which had doubtless escaped from some neighbouring garden, helped to dispel the illusion, yet *Mnesictena flavidalis, Doubl., a small, dark specimen, might perhaps have passed for an English Pyrale, or Emmiltis rubraria for an English Acidalia, but the Lycaenids fell far short of the beauty of our Chalk-hill Blue, or even our Common Blue. ${ }^{*}$ Chrysophanus sallustius was fairly abundant, but the dingy Zizera labradus, Godart (the Lycacna phoebe, Murray, of Mr. Hudson's book), was to be had in still larger numbers. I saw three or four *Pyrameis gonerilla, Fabr., but not a sign of $P$. itea. A solitary * Deilemera annulata put in an appearance. The pretty, day-flying Acronyctid, well-named Cosmodes clegans, Don., a species that is commoner in Australia, greatly delighted me; it is neatly marked with green and white. The only example of the cosmopolitai Plusia chalcitcs, Esp., that I have ever happened upon was, unfortunately, so worn as to have lost all its beauty; it might easily have been mistaken for gamma. Mrs. Longstaff found at rest upon a stone a very cryptic Geometer, Phrissogonus laticostatus, Walk. The vulgar Eristalis tcnax and an active Homopteron completed my bag.

Mrs. Longstaff could find no Mollusca save Helix aspersa, the type and the variety fascicuta, Pic.

Two moths came to the lights of the "Mokoia" as she was lying at the wharf- ${ }^{*}$ Crambus flexuoscllus and *Elhamma (Porina) corvinata, Walk.

Gisborne (Nortu Istand), lat. $38^{\circ} 35^{\prime} \mathrm{S}$.

$$
\text { January } 29 \text { th, } 1910 .
$$

The ship reached Gisborne early, and I took a short stroll, from $8.0 \mathrm{a.m}$. to 9.30 a.m., along the shore at the foot of the bluff to the north of the town. 
Almost my first remark (to myself) was, "Well, the Scotsman has brought his thistle with him to the Antipodes." On going closer to the plant I saw some insects on its flowers. Lo! Bombus hortorum and Eristalis tenax. More than this, under every stone and bit of driftwood above high-water mark was abundance of our garden Snail, Helix aspersa. It seemed scarcely worth while to have travelled so far.

The only butterfly on the move at that early hour was Zizera labradus, the only moths single examples of * Deilemera annulata, *Inesictena flavidalis, and *Crambus sublicellus, Zell., together with several Emmiltis rubraria.

The vulgar-looking Fly * Sarcopłaga impaticns, Hutton (nec Walk.), is perhaps not as common as it looks.

Under flotsam and jetsam were plenty of the Earwig, Anisolabis littorea, White, for the most part immature. A solitary example had been taken at Napier, at least $100 \mathrm{ft}$. above the sea-level. A Cockroach, *Platyzosteria novae-zealandiae, Brunn., had but a moderate odour, which was evanescent.

Under dead wood, etc., I also found the introduced Slugs, one Limax maximus and many Agriolimax agrestis, as well as several Vitrea cellaria, Müll., f. sydneyensis, Cox.

AUCKLand (North Island), lat. $36^{\circ} 50^{\prime} \mathrm{S}$.

January 30th-February 6th, 1910.

Like Wellington, this is a finely situated and a busy town, but, unlike Wellington, its traffic is not forced into a few streets, the city being spread out over a number of low hills, hence it does not strikc one as such a bustling place. Hcre I saw the one building in the Dominion that struck me as really admirable. St. Matthew's Church stands high and has a fine square tower; it is built tluroughout of the famous white Oamaru limcstonc, which has a rcmarkably fine effect, especially in the interior, looking like white marble. Its style is Perpendicular, both simple and dignificd; I thought it by far the finest building in the Dominion. There is an admirable ccclcsiastical custom in New Zealand. In many of the churches there are women in the choirs, but these womcn are all drcssed alike, wearing collegc caps, broad white Eton collars, and either surplices or black gowns reaching to the feet. The dress is becoming, but effectnally excludes feminine rivalry. I saw six women so dressed in one church, twentyone in another.

During our stay in Auckland the hcat was almost tropical, and I 
was sorry that my "whites" had been left at Wellington; nevertheless there was no corresponding tropical abundance or varicty of inscct life, though it must be admitted that only twice did I get outside the cultivated area.

In the hotel a few very common insects turned up, some of them at any rate attracted by the lights: ${ }^{*}$ Crambres flexicosellus, Plutella maculipennis, Curt., Borkhausenia pseudo-spretella, Stain., and the Muscid fly, Pollenia stygia. There was, in addition to these, the Geometer, Xanthorrhöe vcnipunctata, Walk, which Mr. Prout tells $m e$ is scarce.

The Domain is a large park, comprising open grass-land, a cricket ground, an embryonic Botanical Garden, as well as a portion of the indigenous "bush." It is a pity that here, as elsewhere in Ner Zealand, it has been the practice to plant Australian gum-trees, Californian pines, or English oaks, to the exclusion of the trees native to the island, and the Domain, in common with other open spaces, has suffered from this, a fashion from which I have some reason to believe that New Zealanders are beginning to shake themselves free.

The insect in the Domain that most thrust itself into notice was the small moth-like Cicada, Scolypopa anstralis, Walk., which was extremely abundant on bushes, and on the bloom of Chinese Privet. On an oak-trunk I found a pupa-case of a much larger Cicada, also the Noctuid moth *Morrisonia insignis, Walk. The only other moth found in this disappointing locality was the very common Emmiltis rubraria, which was kicked up. Sweeping yielded some fetid Bugs, Rhopalomorpha obscura, White, and Tholosanus sp., and any number of the Fly ${ }^{*}$ Sarcophaga impaticns. The Domain did not produce a single butterfly.

Mount Eden is interesting as a well-preserved volcanic crater, commanding an extensive view which embraces many other extinct craters; moreover, the municipal authorities have done well to securc it as a public park, but if the horticulture of the Garden of Eden did not attcmpt anything bcyond a grove of Pinus insignis, I can only say that it has bcen much over-ratcd. The very insects also secm to have a poor opinion of the place, since I got nothing beyond several *Crambus sublicellus and two or three Earwigs.

One-tree Hill is another volcanic cone plantcd with Pinus insignis. It produced *Dcilemera annulate, *Mnesictcna flavidalis, and abundance of * Sarcophaga impatiens, while a number of Dragon-flies that wore exceedingly hard to catch hamnted its crest.

One day wc landed at Takuna Point. near Devonport, to lonk for 
marine shells, a search that met with but indifferent success as the tide was too high.

Zizerc labradus was there to be seen in some numbers. I took one Geometer, Anachloris subochraria, Doubl., and might have taken more; it is an Australasian species. A Sphegid, Tachysphcx depressus, Sauss., was not uncommon, making short flights close to the bare dried mud of a salt marsh.

Cemetery Gully, a gorge near the middle of the town, which Commander Walker found somewhat prolific, yielded me only a pair of Plumes, Alucita monospilalis, Walk., and a male Tortrix postvittanc, Walk., an Australasian species.

Kauri Gully is so called because a few survivors of the magnificent native Pine of New Zealand, *Agathis australis, Salisb., are there preserved in a patch of bush, traversed by a stream fringed with fine Tree-ferns; the bush is surrounded by a considerable extent of Manuka scrub. This gully was the most promising locality that I had visited, but it produced very little. The tiny Cicada, Scolypopa australis, was common enough; it was fond of settling on the stalks of the fronds of tree-ferns, often several in a row, usually head downwards. The sole Lepidopteron met with was Chito halterellus, Zell., a handsome silver-striped moth, which occurs also in Australia. On sandy paths among the Manuka there were lots of *Cicindela tuberculata, but the little beetles were not easy to see; with them were a couple of Tachysphox depressus. Under some logs near the school-house were plenty of a peculiarly ill-smelling Cockroach, * Platyzosteric novae-zealandiae, and some Crickets.

Hot, muddy, and somewhat dejected by my poor success, I made for a cottage where home-brewed hop beer was to be had; roughly rolling up my umbrella net, I took my seat under the verandah and called for my driuk. When the woman came back with the bottle, she eyed me suspiciously, and said, "I see you are an umbrella mender." Trying my best to conceal the wound inflicted by this thoughtless remark, I unrolled my net, saying, "Well, no, I am not exactly that; you see what sort of an umbrella mine is." But I was not to be let off; she replied, "If you want to catch flies, you had better go into the village." From that day I have been a humbler man.

Pangitoto is the name of all extinct volcano forming an island at the entrance of the harbour. It is covered from base to summit with huge blocks of the roughest of lava, which in turn are imperfectly covered with a scant slirubby vegetation. Its insular position and natural ruggedness have preserved the mountain in its wild condition. 
A native shrub, Veroniea salicifotia, Forst., was conspicuous by its long racemcs of white flowers which were very attractive to the little golden brown *Chrysophanus sallustius; the specimens I took were all females. On the way up-fortunately there is a path-I came across a few Geometers, *Epirrhoë deltoidata, Walk., a very variable species, and the delicate little Asthena pulchraria, Guen., which unfortunately soon loses its pale green colour; in distribution it is Australasian. At and near the summit Noctuac were flying wildly about, but were by no means easy to catch, especially on such a terrain. One proved to be Cirphis unipuncta, Haw., an insect which seems to occur in every continent except Africa; two others were the cosmopolitan Chloridea obsoleta, Fabr. (formerly Heliothis armiger, Hribn.) ; one of them, canght at the bottom of the old crater, was of the grey form, such as occurs in Europe, far less brilliant than most Southern specimens. On reaching the lip of the crater I disturbed a Vanessid; a lucky swoop over my head secured it at the first shot; to my great delight it proved to be Pyrameis itea, a male in fine condition, the only one of the species that I came across in New Zealand. It is interesting to note that Commander Walker's only specimens were taken on the top of Mt. Edcn, so that it would appear to be, like the Painted Lady, a haunter of hill-tops. The crest of the mountain did not strike me as a likely place to find a delicate Demoiselle Dragon-fly, but there I took *Lestes colensonis, White. Under the bark of a dead tree about halfway up I found *Platyzosterice novae-zealandiae and two specimens of a Temnoptcryze, which Mr. Shelford thinks may be new.

Rangitoto is the most perfectly preserved extinct volcano that I have ascended, its crater being unusually well preserved. Though just under $1000 \mathrm{ft}$. in height, it commands a glorious vicw extending over Waitemata Harbour, with all its bays and crecks dotted over with islands far and near, one of them near the N.W. horizon being Great Barrier Island, now kcpt as a sanctuary for native animals and birds. On the other side lies Auckland and the many concs that rise in or around the city.

In the bush on Rangitoto Mrs. Longstaff found a specimen of the Hedgchog-slug, Arion intermedius (minimus), Normand,-a singularly isolated spot in which to find an introduced Mollusc. Higher up I came across Vitrece sydneycusis. On the shore Mrs. Longstaff found dead spircs of *Turritclla fulminata, Hutton, and T. vittata, Hutton.

I must not quit Auckland withont mention of its fine museum, with its well-arranged collection of Maori antiquities and its conrteous 
and accomplished curator, Mr. T. F. Cheeseman, F.L.S., to whom we are much indebted.

We made a special expedition to Shoals Bay on the side of the harbour opposite the city in search of Amphibola crenata, Martin, an air-breathing operculate Gasteropod which lives in brackish water half-buried in the mud. This is a remarkable animal in that having a pulmonary chamber and no gills it would appear to be in a transitional state from a water-dweller to a land-dweller. We found it in considerable abundance in the mud in a Mangrove swamp not far above low-water mark. In the same place we picked up a few dead spires of Turritella rosec, Quoy.

At NGaruawahia, about halfway between Auckland and Rotorua, on February 8th, a pretty and very distinct Noctuid flew into the train. This turned out to be new to science, and has been described by Sir George F. Hampson under the name of *Morrisonia chlorodonta, sp. nov. $\quad$ [See Plate VI., Fig. 2.]

On the higher land we saw from the train something of the peculiar vegetation of New Zealand, the so-called Cabbage-tree, Cordyline australis, Hook.; the Bulrush, Typha angustifolia, Linn., and vast extents of Manuka, now somewhat sombre, but beautiful when in flower.

\section{Rotorua (Ohinemutu), North Island, lat. $38^{\circ} 5^{\prime} \mathrm{S}$.}

February 9 th-16th, 1910.

I must admit to a strong feeling of disappointment in the Hot Lakes. How far this is due to having heard too much about them, and therefore expecting too much; how far to the destruction wrought by the great eruption of Tarawera in 1886; how far to the fact that I lacked time and energy to see some of the more inaccessible sights, I know not, but the impression remains. Volcanic phenomena are not in their nature beautiful, but the reverse. Interfering with, or even putting a stop to, vegetable and animal life, they disfigure the landscape with blains and scars. The interest in such phenomena is scientific, not aesthetic.

We stayed at Whakarewarewa, ${ }^{2}$ about two miles south of the railway station and in the very midst of the hot springs and geysers. Most persons dislike the sulphurous atmosphere, but to the writer it

'Ann. Mag. Nat. Hist. (8), viii., pp. 423, 424 (1911).

${ }^{2}$ It will surprise no one to be told that this formidable Maori name is usually the sesquipedalian namo is to bo assumed 
recalled pleasant bygone days spent in the Glastonbury Kitchen at Oxford. It was strange in the quiet of the night to listen to the bubbling of sulphuretted hydrogen in mud volcanoes not a hundred yards away!

To see Pohoto, one of the principal geysers, in full eruption is a sight well worth waiting for. The Government carctaker has a fairly accurate idea of the hour when the almost daily eruption may be expected, and to watch the uncanny fountain for half an hour or so while it is getting up steam is quite fascinating. The caldron, perhaps 20 feet across, holds crystal-clear hot water of a delicate pale blue tint always on the simmer. Every fer minutes it boils up more fiercely; the successive bubblings-up increase in violence and amplitude; every now and again the water rises higher than before, as the temper of the demon of the springs waxes worse and worse, till the watcher gets into a state of tension in which impatience and fear struggle for the mastery. Several outbursts look promising, but prove illusory, but at last, with a mighty roar and with an alarming throbbing of the ground beneath one's feet, the boiling water rushes up into the air some 80 feet or so. The grand display may last half an hour, or it may be an hour, or even two. While the main fountain shoots up boiling water and steam, other subsidiary fountains round about are also active, but I observed that they did not keep time with Pohoto.

That the phenomenon is due to the water coming in contact with rocks of a temperature above the boiling point, or else with superheated steam, or both, is fairly certain, but it is most difficult to think out the details of the modus operandi. These geysers corer a large extent of country in the North Island; from time to time one or another ceases to work, perhaps to resume its activity after months or years of quietude.

Once a tourist watching the geyser in a timc of repose thoughtlessly threw a stick into it; his retriever bounded forward. There was no time to stop him; he plunged into the ncarly boiling rater and met with a speedy death.

I asked our Maori lady-guide whether accidents often occurred, but she assured me they did not. I expressed some surprise that with so many Maori children playing close around the springs none cver fell in and wcre boilcd. "Oh yes! of course they do; but native children dou't count. Never any tourists." The Maori women, as is well known, unlike thosc of most other savage races, arc not without attractions, but it is to be feared that they are somcwhat hard-hearted towards their offspring. 
Whether it be the sulphurous fumes, the barren nature of the soil, the climate, or the combination of the three, I know not, but the Hot Lakes district has an evil repute as a collecting ground, and certainly my experience goes to confirm that of the New Zealand entomologists. On the whole the hotel itself was the most productive spot; this is said in no bad sense as implying any undue abundance or variety of species predaceous on man, but refers to the harmless frequenters of the electric lights.

The commonest Noctua was unquestionably Persectanic ewingi, Westw. (Melanchra composita, Guen., of Mr. Hudson's book), ${ }^{1}$ of which I took fourteen; *Morrisonic mutans, Walk., which used to turn up later in the evenings, came second in numbers; *Hyssice modercuta, Walk., was a good third, with eight specimens; ${ }^{*}$ Euxoo admirationis, Guen. (sericea, Butl.), running it close with seven. Of the delicate Cosmodes elegans, I was fortunate in securing four, but it does not appear to be easy to get this insect in good condition; Mr. A. Hamilton does not look upon it as a common insect; its general colour is reddish-brown with bright emerald-green markings neatly outlined with white, but it looks very pale when on the wing. Another Australasian ${ }^{2}$ species, Agrotis compta, Walk. (Orthosia immunis, Walk., of Mr. Hudson's book), is very variable, one of my specimens being unicolorous purplish grey. Of the glossy purplebrown * Bityla defigurata, Walk., a single example turned up. Of two Chloridea obsoleta which came to the lights, one straightway betook itself to a double White Dahlia which stood in a flower vase; like too many a tourist, its first idea on reaching its destination was to have a drink. This thirsty soul was orange-tinted, approaching Walker's var. rubescens, but not quite attaining the full glory of many Australian specimens, which have the fore-wings pink.

Besides these more or less well-known things there came no fewer than nine specimens of a pale, silvery-grey moth which appears to be undescribed. I have represented it in Plate VI., Fig. $10^{3}$ To these should be added the Deltoid, * Rhapsa scotosialis, Walk.

The Geometers visiting the lights were not so numerous: the grey *Coremia semisignata, Walk.; the yellow Anachloris subochraria; Phrissogonus laticostatus, and the neatly marked Pug, Microdes quadristrigata, Walk.

" "New Zealand Moths and Buttorflios," G. V. Hudson, F.E.S., 1898.

"I apply the torm "Australasian" to species which occur in Australia, Tasmania, and New Zealand, but not elsowhere.

${ }^{3}$ Since described by Mr. G. W. Howes (Trans. New Zealand Inst., 1911), under the name of Morrisonia sequens, sp. nov. 
There were several Pyrales: ${ }^{*}$ Mnesictena flavidalis; the variable *Scoparia submarginalis, Walk., several; "S. inclistinctalis, Walk.; S. lcptalca, Meyrk. ; *S. philcrga, Meyrk.; the Hydrocampid, Nymphula nitens, Butl., (2); the Phycid, Homoeosoma vagcllum, Zell., (2); the handsome silver-striped Chilo haltcrellus; *Crambus angustipernis, Zell.; ${ }^{*} C$. sublicellus. By far the fussiest and noisiest visitors were two large brown Longicorn beetles, *Ochrocydus huttoni, Pascoe, which is considered a good thing.

Quite a number of Tortrices came to light: one $*$ Tortrix lencaniana, Walk., a male; *T. cxcessana, Walk., one of each sex, and several T. post-vittana, Walk., mostly females. The last-named, Mr. Durrant says, is an Australian species which has spread to New Zealand, to the Sandwich Islands, and other places. This was also taken in the hotel garden on the wing at dusk accompanied by Ctcnopseustis obliquana, Walk., another species that is spreading widely, and the cosmopolitan Hemerophilid, Porpe bjerkandrclla, Thunb.

The domesticated Borkhauscnia pseudo-spretella, Stain., and several Blow-flies, Pollcnia stygia, were inmates of the hotel.

In the small garden I took * Crambus apiccllus, Zell.; the HumbleBee, Bombus harrisellus, Kirby; two small Bees, Paracolletes vestitus, Smith, and the Asilid fly, ${ }^{*}$ Scropogon fugicns, Hutton.

The Geyser Reserve at Whakarewarewa and the Public Gardens at Rotorua were alikc singularly barren of insect life. Dragon-flies were the most prominent objects, especially Demoiselles, *Lestes colensonis, being especially common near the lake. The Manuka bushes gave shelter to *Crambus flexuosellus, odd specimens of "Scoparic cucarpa, Meyrk., and *Sestra flcxata, ${ }^{1}$ Walk; ; a brace of Asthene pulchraria, and sundry Bugs, *Nysius zcaļandicus, Dall., while * Cicindela tuberculata ran or flew about the paths. The sole butterfly was Zizerc labrcudus.

Excursions to various points on the shores of Lakes Roto Rua and Roto Iti did not yield much more. The little uninteresting Zizcra labradus was generally abundant, shoming a partiality to Vervain (Verbcna officinalis, Linn.), an introduced plant. This reminds me that in moist meadows Bartsia viscosc, Linn, another introduced plant, grows in the greatest abundance, though in England it is quite local. Again, the introduced Bramble, in spite of being scheduled by Act of Parliament as a "noxious wecd," was growing luxuriantly in and around the Marori village of Te Awahou, and

${ }^{1} \mathrm{Mr}$. Hudson, by some accidont, has rerersed flexata and humeraria, but I bave examined both the types in the British NIuscum, and compared them with Walker's descriptions, so that there is no doubt about the mattor. 
producing fruit the like of which as regards abundance, size, and flavour I have not seen approached in the old country. "But ne'er the rose without the thorn." And if you should put into your mouth a certain small Hemipteron that is too apt to lurk among the luscious drupes, well, you will rue the day. Yet another English plant, the familiar Ragwort, harboured-not the Cinnabar-but both larvae and imagines of $*$ Deilemerce annulata, as well as abundance of the Bug, *Nysius zealandieus. With the common Emmiltis rubraria, a specimen of *Asthena rubropunetaria, Doubl., was taken. Sweeping Manuka bushes resulted in the capture of the shiny green beetle, Calonota festiva, Fabr. The Asilid, *Neoitamus varius, White, which I found by the exquisitely clear water of the cold spring at Hamurana, was a fly new to me, but Bombus harrisellus was familiar enough. It is not many years since Bombus hortorum was purposely introduced into New Zealand, and it is remarkable that the form larrisellus, which is comparatively scarce in England, is in New Zealand so common that my impression is that there was one of the melanic form to every two or three typical specimens. As in the old country, no intermediates were met with. Surely this is a case about which the Mendelians might have something to tell us.

In the clear stream that flows from the Hamurana Spring, Mrs. Longstaff found several Water Snails. The most abundant was * Potamopyrgus corolla, Gould, both the smooth and the spiny forms; * Isidora novae-zealandiae, Sowerby; Amphipepla arguta, Hudson, and Sphcierium lentieulum, Deshayes.

At Okere on Lake Roto Iti we were told that the quantities of shells of "Diplodon menziesi, var. hoehstetteri, Dunk., had been left there by the Maoris, who dredge the bivalves out of the lake for food; the valves are some $2 \frac{1}{2}$ inches long.

On the top of a small mountain, Pohaturoa, which overlooks the Geysers, I took three nales of the Southern form of Pyrameis cardui, known as $P$. kershawi. This is distinguished from the type by a row of blue spots on the hind-wings, but in the absence of other distinctions this scarcely seems enough to raise it to specific rank. I am the more confident in this opinion since the Hope Collection contains two specimens with like blue spots, one from Cyprus, the othor from Mongolia. Moreover, in the fine old Dale Collection there are three similar British examples. It is interesting to bear in mind that somewhat similar blue spots occur in many specimens of Chrysophunus plulceces, and ${ }^{*} C$. sullustius. On the samo mountain I took a second specimen of the Asilid, *Neoitamus varius.

One day I drove to the foot of Mt. Ngongotuha, not to the 
summit, as did Commander Walker and Dr. Swale. The ascent is steep, but the track through the bush is quite wonderful; the ground is carpeted with ferns of many kinds, the trunks of the forest-trees are draped in climbing ferns, and a considerable proportion of the trees overhead are themselves ferns. I certainly thought that I had seen many ferns in Jamaica (amongst other places), but truly N'ew Zealand is their head quarters. In this dense bush, which the sun could only pierce here and there with its rays, I saw remarkably few insects. The sole record that I have is that of the Geometer, *Pseudocoremia productata, Walk. But as an entomologist I have long had a prejudice against ferns as cover for insects.

The summit is comparatively flat and the bush more open. Here I came across an old friend, *Griselinea littoralis, Raoul, a bright yellow-stemmed evergreen shrub that I have grown at Mortehoe for many years. There $I$ have often admired its marvellous power of resisting the onslaughts of the sea wind, a power that seems to be due to the flexibility of its twigs, which is such that they may almost be tied into knots. In the more open bush on the summit there was a good deal of the Veronica salicifolia, and, as on Rangitoto, its flowers proved to be attractive to insects, though here no Lepidoptera were found on them. There was, however, abundance of the little Bee, Paracolletes vestitus; a black Pompilid, Salius monachus, Smith; and three of those strange little Weevils, "Scoloptcrus penicillatus, White, black fellows with sharp spikes on their elytra; if not absolutely indigestible, they must at least be as pungent as cayennepepper. ${ }^{l}$

It is curious that so very few things were to be found in such a promising-looking place; neither *Chrysophanus sallustius nor * Deilemera amulata were at all common. TThough I saw no water on the mountain, there were the usual Demoiselles $u p$ to the rery summit, $2550 \mathrm{ft}$. A Syrphid peculiar to the Dominion, * Helophilus incptus, Walk; a Saropogon sp., ơ; and the Asilid, ${ }^{*}$ N'ciotamus varius, complete my short list.

I descended by the more circuitous but more open carriage road, and, especially about halfway down, beat out a fair number of Geometers, of which a fraction was secured, comprising the greenish Asthcna pulchraria, the pale grey * Corcmia cincraria, Doubl., and the variable * Epirrhoë deltoidata. The Tutu (Coricuria mscifolia, Linn.) was the shrub which appeared to be the shelter favoured by moths. Near some water at the foot of the mountain I saw the first Zizcra labredus for that day.

1 An allied species is figured ou Plato VI., Figs. 6, 7. 
Another day we drove by motor-car over the soft pumice roads to Wairoa by way of Okareka Lake and through the TikITAPU Bush. The latter would appear to have somewhat recovered from the dire effects of the eruption, and the chirruping of cicadas filled the air. Whether the fine green Melampsalta muta, Fabr., was the musician, as seems likely, I know not, but if it was, what in the world induced Fabricius to call it mute? I only succeeded in catching three, whereof one settled on the motor, another on my face. My wife found a Stick-insect on her dress. The chauffeur picked up on the road the large brown Cicada, Melampsalta cingulata, Fabr., which appeared to have recently died. The common New Zealand Tigerbeetle, ${ }^{*}$ Cicindela tuberculatcu, again put in an appearance.

Had it been Natal the grassy borders of the road would have been gay with butterflies, but as it was New Zealand I had to be content with a few specimens of a Clorysophanus, that I had not before met with-*fcredayi, Bates. ${ }^{1}$ Here and there Zizcra labradus turned up, but not in any numbers, and the only other butterfly seen that day was * Pyrameis gonerilla, which occurred near Lake Okareka. Close by, on a bit of swampy ground covered with interesting vegetation, I captured two of the pretty littlo grey Geometer, Adeixis inostentata, Walk., which Mr. Prout says occurs also in Australia; no doubt I could have got more had not time pressed. In the same swamp sundry Dragon-flies and the Asilid, "Ncoitamus varius, were found.

In the bush sweeping the flowers of the Veronica salicifoliaon which most of the ${ }^{*} C$. fcredcuyi were taken-yielded the small Longicorn, Naomorpha linecutc, Fabr., the little Bee, Paracollctes vestitus, and the spiky-backed Weevil, * Scolopterus tetracanthus, White [see Plate VI., Figs. 6, 7], insects that must be handled carefully; the Bugs, Tholosanus proximus, Dall., and Ccrmatulus nusulis, Westw, both extending to Australia and Tasmania.

The sole Geometer met with in Tikitapu was the now familiar *Coremia cineraria. A crowd of Bugs, Ncuroctenus sp., were found under the bark of logs, their flattened shape well suited to the narrow accommodation.

Mrs. Longstaff found quite a number of Land Shells in Tikitapu Bush, all small species, some minute and insignificant lookingas indeed are most of the Land Molluses of New Zealand. They were chiefly found under the bark of logs, or on the shaggy trunks of fallen Tree-ferns. Several Delos jcffreysiana, Pfeiff., Endodonta

1 Mr. Hudson calls this enysii, Butl.; I have, howevor, examinod the types in the British Museum, the two are unquestionably conspecific, and Bales' namo has
priority. 
(Charopa) eoma, Gray; E. anguieulus, Reeve, also var. montivaga, Suter; E. bianca, Hutton, f. montana, Suter; E. tapirina, Hutton; Thalassohelix ziezae, Gould; T.zealandiae, Gray; the endemic Slug, *Janellu bitentaculata, Quoy, sub-sp. rufovenosa, Suter, and, here as everjwhere else, the introduced Agriolimax agrestis.

At Wairoa *Epirrhoë deltoidata, and Anachloris suboehraria, were to be had, but not many of them; here also the chauffeur caught a large fly ${ }^{*}$ Hystricia lupina, Svederer. Somewhere that day I took a second example of the Saropogon found on the top of Ngongotaha.

By the roadside above Lake Roto Kakahi was a little cliff of pumice sand about which flew numbers of Gasteruption unguieularis, Smith, a strange-looking and still more strangely named Evaniid Hymenopteron, of which the larva is said to be parasitic on other hymenopterous larvae. Close by I swept three pretty Tortrices off the Veronica: *Heliostibes illita, Feld. \& Rog., of which the National Collection possessed but one specimen; its hind-wings are black, marked and fringed with orange.

In the train between Rotorua and Taumaranui (at Otarohanga), I captured the Cicada, Seolypopa australis, and at a way-side station, Te Kuiti, found plenty of Zizera labradus, together with abundance of Emmittis rubraria.

\section{Taumaranui (North Island).}

February 17th and 18th, 1910.

Many moths came to the humble hostel where we slept. Far the commonest of these was Emmittis rubraria, which appenred in numbers; the fine *Hemerophila dejeetaria, Walk. (pannularia, Guen.), turned up here for the first time, as did two specimens of the smaller * Epyaxa subidaria, Guen., while among the more ordinary things were * Coremia semisignata and *Pseudo-eoremia melinata, Feld., with which I afterwards became very familiar. The Noctune were represented by Persetania ewingi, *Norrisonia mutans, *Euroa admirationis, Guen., also the tiny Plusiid, Hypenodes exsularis, Meyrk., which is only three-quarters of an inch in expanse, and might well pass for a Phycid. Then there were a fair number of Pyrales, including * Meeyna maorialis, Feld., the spidery-legged Seeliodes cordalis, Doubl., and the fidgety Diasemia grammalis, Doubl., the last two being Australasian in distribution. There was also a *Tortrix lencaniana, a female.

But better than all these was a second specimen of the new 
* Morrisonia, taken in the train at Ngaruawahia on February 8th. Most of the New Zealand Noctuids are extremely variable, and * M. chlorodonta would appear to be no exeeption to the rule. Whereas in this specimen the base, the stigmata, the area just below the latter, and the subterminal line were all olive-green during life, the first specimen taken had the margins of the stigmata and the subterminal line white.

The next day I walked round the plaee, and passing the first pumice-stone quarry that I had ever come aeross went up on to the bluff that overlooks the little town. A worn Chloridec obsoleta was caught flying wildly in the sun. Anachloris subochraria reealled our Yellow Shell both in eolour and ways, but was not eommon. I picked up a stray ${ }^{*}$ Crombus sublieellus. A small white-flowered tree, *Hoheria sp., which reminded me of the Nova Seotian Snowy Mespilus (Amelanchier sp.), had attractive blossoms at which were both *Chrysophanus sallustii and *feredayi, together with a Bee and a pair of Flies, Odontomyia chloris, White, having the abdomen green at the sides and a paler green beneath, besides a number of the spiny, bronze-blaek Weevils, *Seolopterus penieillatus. In the valley, between the bluff and the railway * Pyrameis gonerilla was flying in some numbers about and around its food-plant, the formidable shrubby Nettle, *Urtica ferox, Forst., on which plant I also took ${ }^{*}$ Crambus flexuosellus.

About the town the little Acidalia-like Emmiltis mubraria was everywhere to be seen; on every piece of rough grass between the houses and the river it simply swarmed; never do I remember to have seen any Geometer in sueh abundance. Though it came freely to light, it must be to some extent a day-flyer, sinee I saw it feeding in the afternoon sunshine on the flowers of Ragwort by the roadside, and on those of the Canadian Golden-rod (Solidago sp.) in gardens. As might have been cxpectcd *Deilcmerca annulata was to be seen on the same flowers. I should not be surprised if this Golden-rod were to naturalize itself and add one more to the many statutory noxious weeds.

Some lush meadows by the river were so full of flowers, cspeeially the introduced Musk (Mimulus moschatus), that I felt sure they must harbour many inseets, but the fact did not bcar out the forecast. Beyond the aforcsaid Geomctcr, plenty of Ncw Zealand's Common Blue, some Dragon-flies, *Lestes colcnsonis, and a number of the familiar little Syrphid, Mclanostoma mellinum, Linn., ${ }^{1}$ the land seemed to be singularly barren.

${ }^{1}$ This I should take to bo an introduced specios. Among my spocimons was a 
* Sarcophaga impatiens turned up again at Taurnaranui, and I had the good fortune to get at the same place a female of *Tabanus impar, Walk., of which the National Collection has but a solitary male, also from New Zealand. As Mr. Austen is making a special study of the genus I thought it best to mate this fly with that in the Natural History Museum.

\section{The Wanganu River.}

The voyage down the Wanganui River from Taumaranui to the sea is one of the sights of the world. It may be done in two days, but it is far pleasanter to take three, as we did, staying the night at Ohura. During the first day's voyage the river, broken by a succession of rapids, winds from side to side of a comparatively open valley. The mountains on either hand running up to $2000 \mathrm{ft}$., or it may be higher, often expose on their flanks fine sections, some at any rate appearing to be of pumice, like that near Taumaranui station. Inhabitants are few and far between, the slopes being covered with seemingly trackless forests. Most of the trees are evergreen and sombre, albeit pines are few, but here and there rose a handsome flowering tree, though it was late in the year, since the Southern February corresponds to the Northern August, and flowers were for the most part over. A brighter tint of green is given to the lower parts of the bush by the numerous Tree-ferns of various species, some tall and slender, others short and robust; a common kind liaving the underside of the fronds a silvery white. It is most fortunate that the bush through which the Wanganui flows has hitherto remained almost unscathed by fire.

An afternoon at Ohura, where the house-boat, a floating hotel, is moored, should have provided good sport, so at least one felt justified in hoping, but once again the bush proved sadly disappointing. The dingy little Zizcra labradus was indeed common enough, and I sar more than one * Pyrameis gonerilla, but no other butterflies. At the top of the cliff, in a small clearing, stood a solitary Salix alba, of course an introduced tree, but it had a very ancient appearance owing to the fact that it was clothed with indigenous ferns and other epiphytes. On its trunk were abundance of the pupa-cases of a large Cicada (? Mclampsalta cingulata); the perfect iusects sang loudly in the branches far above my head, but declined altogether to venture within reach of the net. It was a fascinating experience to

fomalo, which Mr. Auston said ho could not match with anything in tho British Museum, but in tho abscuco of a corrosponding malc he could say nothing further. 
walk about in a large grove of lofty Tree-ferns, though it must be admitted that they are scarccly beautiful when seen from below on account of the untidy, ragged tangle of dead and dying fronds.

In more open parts * Uropetalc carovei, White, and other dragonflies hawked about. Sweeping the Manuka produced a few Calonota festiva, but Commander Walker tells me that he once saw the branches of the Tea-trees actually bowed down by the weight of immensc numbers of these shiny-green beetles.

That night a second specimen of the fine Boarmiid, *Hemerophila dejectaria, came on to the house-boat.

At Ohura Mrs. Longstaff found several of the Slug Agriolimax laevis, Müll.; they were of a very dark brown colour, almost black.

Roused soon after dawn, we were given breakfast and started on our second day's voyage. The gorge was filled with white mist, the sun not having as yet penetrated its chill depths. It was a glorious sight to witness the victorious combat between the warming rays and the dank vapour. The greater part of our 60 miles' journey was through what in the Americas would be called a cañon, for the valley is contracted with steep craggy sides. Indeed for some hours we scemed to be imprisoned in a narrow dark gorge, the deep, clear swift stream gliding noiselessly between vertical walls of dark coloured rock clothed with filmy-ferns (Hymenophyllum), or moss, or such other vegetation as could find a roothold. Above the beetling crags hung the feathery Tree-ferns; above these in turn we saw now and again the mountain tops closing in the whole with a still more lofty rampart. Our prison walls might be anything from 20 feet to over 100 feet in height; often for a mile or more there was scarce standing room at the water's edge on either side, so that a sunken rock, or still more deadly snag might wcll have entailed a swim for dear life of half a mile or more. The beauty, the strangeness, and the solitude of the whole scene were quite awe-inspiring. Anon the walls would recede and the gorge open, this meant a rapid, after passing which another gorge would be entered. The only liviug creature was an occasional Cormorant that seemed indignant at our intrusion, but the roughest of ladders fixed in two or three places gave access to the bush above, and proved that sometimes at any rate the varied wants of man led him to go up or down those dark and slimy walls.

Doubtless the voyage has lost much of its romance sincc Maori canoes gave way to Thorneycroft stearn-launches, but it must not be hastily assumed that increased safety always goes with increased comfort. The rapids are far too numerous and tortuous for any pilot 
to get more than a very general knowledge of the dangrers to be avoided, and consequently the launches bump frequently and heavily. I thought at the time that it was a great mistake to use steel-built eraft on such a river. The most suitable boats would be doublestraked wooden vessels, built as whaling ships are. The very next launch to ours struck a snag and sank just as she was being beached. Luckily it was a place where there was standing room, and what is more, the means of making a fire, so that beyond wet feet and skirts and soaked baggage, the sufferings of the passengers and crew were not serious. Two men made a raft, and went in the darkness seven miles down the river for help, for there was no telegraph, not eren a road through the bush. After waiting some hours, another launch was sent up in the darkness to pick them up, and after doing so was itself twice within an ace of being wrecked, and that in a much more dangerous place, where the water was deep. The rescuing party had not the foresight to earry any food, so the forlorn passengers had but a cup of tea and two or three biscuits apiece between lunch one day and breakfast the following morning. Among them was a lady who a few weeks before had suffered a much more serious shipwreck in The Sounds, and, with her fellowpassengers, had been taken off a rock by H.M.S. "Pegasus." Such is holiday making in New Zealand!

\section{Pipiriki, Wanganui River.}

February 20th-22nd, 1910.

Pipiriki overlooks two of the more open reaches of the river where the rapids are perhaps at their worst.

Once again the hotel proved to be the best collecting ground. It is a large wooden building only just opened, replacing a previous structure that had been burned down a few months before.

Although *Dcilemera annulata was unusually abundant in the locality, I was surprised when several of them came to light; it ras more in accordance with the fitness of things to welcome Persectania ewingi, ${ }^{*} P$. atristriga, Walk., *Morrisonia insignis, and even the cosmopolitan Cirphis unipuncta, Haw.

With the Noctuae came several Geometers: Epyaxa subidaria, * Selidoscma panagrata, Walk.; *Pscudo-corcmia suavis, Butl.; Asthena pulchrarice, and Emmiltis rubraria, althongh this last was nothing like as common as at Taumaranui; by far the most conspicuous of the family was *Hemcrophila dejcctaria, of which I got no less than eight. 
Pyrales were also fairly numerous, the commonest being * Mecyna marialis, the restless little Diasemia grammalis, and the pretty Sceliodes cordalis, which rests in a peculiar attitude: standing like a gnat on the tips of its middle and hind tarsi, the costae of the fore-wings making an angle of about $100^{\circ}$; not only are the fore-wings somewhat drawn back, so as to cover the hind-wings, but the latter are drawn away from the abdomen, which in its turn is curled up on high. Other Pyrales that came singly were *Seoparia chalicodes, Meyrk.; ${ }^{*} S$. periphanes, Meyrk.; ${ }^{*} S$. minualis, Meyrk., and *Crambus flexuosellus, also * Tortvix lcucaniana. With these were several of the Swift, *Elhamma (Porina) signata, Walk., some of them of the variety novae-zealandiae. Sundry other creatures, Beetles and Grasshoppers, and the Cockroach, ${ }^{*}$ Platyzosteria novcu-zealandiae joined the merry party, together with a Fly, Exaireta sp., which is not in the National Collection.

On the top of a small hill, perhaps $600 \mathrm{ft}$. above the river, were two large plants of Ragwort in full flower, each of them harboured 36 * Deilemera annulata. This moth was indeed to be seen everywhere at Pipiriki. Near the same spot I missed a very fine Pyrameis kiershawi, that must have recently emerged, and not far away I came across ${ }^{*}$ Chrysophanus sallustius.

One afternoon we went a short distance down the river in a Maori canoe. Mrs. Longstaff found two species of fresh-water Shells in the river; *Potamopyrgus corolla, which was literally in thousands, the spiny form greatly prepondcrating over the smooth; and the fresh-water Limpet, * Latia ncritoides, Gray, which was in plenty, adhering to conferva-covered stones. In the bush on the bank, perhaps a mile and a half below the hotel landing place, my wife found, under the bark of introduced Willow-trecs, numerous examples of a tiny Snail, which Mr. H. Suter, of Auckland, considers to be a new sub-species of * Laoma eelia, Hutton, sub-sp. laevis, Suter. She also found the pretty Flammulince crebriflammis, Pfeiff.; Therasia valeria, Hutton, and T. subincarnata, Suter, and among dead leaves of Karaka (Corynoearmus laevigatus, Forst.), a specimen of the introduced Slug, Milax gagates, Drap., var. ravus, Williams, which differed from other specimens taken in New Zcaland or elsewhere by its rich amber colour-much like the fruit of the tree under which it was found; the commoncr var. plumbea, Moq.-Tand., of the same was found close by, together with the cndcmic *Janella rufovenosa.

By sweeping rank herbage I got a few specimens of an Australnsian Bug, Tholosanus proximus, as well as half a dozen of the very 
singularly shaped little Weevils, "Rhadinosomus acuminutus, Fabr., which have both head and thorax greatly elongated, the elytra terminating in a spine [Plate VI., Fig. 4]. As Mr. Arrow says, they look almost like "silver fish" (Lepisma); they vary considerably in size.

Under willow-bark I found sundry small Beetles not yet determined, but amongst them was a female of the Cockroach, Temnopteryx sp., first met with on Rangitoto.

Near the landing place I took Cosmodes elegans on the wing, but cannot be sure whether it was flying of its own accord, or had been disturbed.

On the high ground were found the Flies, *Saropogon clarliii, Hutton, and ${ }^{*} S$. fugiens, Hutton. The handsome big Syrphid, * Helophitus tritineatus, Wied., flew into our bedroom, as did the large Dragon-fly, *Uropetala carovei, which appeared to be common in the district.

Other insects found at Pipiriki were *Coremia semi-signeta, *Mnesictena flavidalis, *Scoparia diphtheralis, Walk.; the Fossor Tachysphex depressus; the Flies, Eristalis tenax, Melanostoma mellinum, and *Tabanus truncatus, Walk., a male, as well as the common Tiger-beetle, * Cicindela tuberculata.

It was at Pipiriki that I measured a fine frond of the Tree-ferm Cyathea dealbata, Swartz; it was 15 feet long.

Mr. Robert Firth, a carpenter at work on the building, was good enough to give me two specimens of the beautiful black and white Geometer, * Declana atronivea, Walk., also two specimens of the rery remarkable elongated Weevils, *Teramocerus barbiconnis, Fabr. [see Plate VI., Fig. 5], and one of the Longicorn Prionophus reticularis, White, all of which he had taken about buildings during the previous week. He said that neither of the first two was common. Mr. Firth at one time had been a fern collector, and he told me that he had once come across a Maori stone axe sticking into a tree and covered with the stems of creepers : an interesting and singular find.

The third day's voyage-down to the town of Wanganui-mas perhaps the most picturesque of the three, since the river was more open.

Masterton, Wairarapa.

February 25th-March 1st, 1910.

In "Waiomi," the hospitable home of Mr. Donald Donald, I found Moths wero looked upon as enemies, because they so often broke the mantles of the gas lights. First and foremost in numbers 
and general obviousness was Pcrsectania ewingi, which I at once christened the Mantle-moth. Amongst a crowd of them I found a single * P. steropastis, Meyrk. Only a little less common than the Mantle-moth was * Morrisonia mutans. Several other species came in smaller numbers, to wit: * $M$. prionistis, Meyrk.; * $M$. lignana, Walk.; * M. homoscia, Meyrk.; * Bityla defigurata, and the pretty little Cosmodes elegans. More excitement was, however, caused by the appearance of a larger moth in the kitchen, where, to the surprise of domestics, I secured the handsome Australian Dasypodia selenophora, Guen., in fine condition; it has a large steely-blue ocellus on the fore-wings which gives it quite a tropical look; as it is not considered common in New Zealand, I was fortunate in getting a specimen. Our familiar friend Agrotis ypsilon, Rott. (suffusa Huibn.), deserves mention; it is not very common in the Dominion, but I saw several. Judging from the long series in the National Collection I should say that while the form with a dark central band seems to be equally common in New Zealand and North America, the form with a dark costa is more prevalent at the Antipodes than in other parts of the world. Sir George Hampson notes that the hind margin of the hind-wing is darker in New Zealand examples. ${ }^{1}$

So much for the Noctuae. The most conspicuous among members of other families was *Hemerophila dejcctaria; then there was the little sulphur-coloured * Asthcna undosata, Walk. ; ${ }^{*}$ Cidaria similata, Walk.; and the common Emmiltis rubraria. A solitary Sceliodes cordalis was the sole Pyrale seen.

I suppose the Tineid, *Borkhauscnia griseata, Butl., should have precedence over the Swift, *Elhamma signata, which proved to be common as soon as I had found out its ways; its plan seemed to be to slink in quietly and almost at once settle down below a lamp, on or near the skirting-board.

In the garden the white flowers of the Lace-bark, called by the Maoris "Hoihere" ("Hoheria populnea, A. Cunn.), were very attractive to such insects as were to be had. On them I netted * Chrysophanis sallustius and *feredayi, also an occasional *Pyramcis gonerilla. The only Aculeate was Apis mellifica, var. ligustica, but there were several somewhat striking Flies:- the shining-blue * Hclophilus latifrons, Schiner (hochstctteri, Nowicki); Pycnosoma sp.; Odontomyia chloris, conspicuous by its partly green abdomen; Pollcnia stygia, and the large *Hystricia signata, Walk.

In dead wood I found a colony of "Monomorium antarcticum, White, var. Sweeping produced abundance of * Sarcophaga im aticns. 
Mr. Harley Donald gave me a Weevil, Otiorrhynctus sulcutus, Fabr., which he had found in the town: it is cosmopolitan.

Mrs. Arnott was good enough to bring me specimens of the Cockroach, Cutilia sedilloti, Boliv., and the deep green Mantid * Orthodera novae-zealandiae, Colenso, taken in the bush near her house.

One afternoon Mr. Donald drove us over to Matakiwi, a few miles from Masterton, where a bit of bush survives on the bank of an excellent trout stream. Again we were disappointed. A large clump of Veronica salicifolia in full flower afforded sustenance to the two Chrysophani which fed side by side, but we saw no other Lepidoptera that day. Tearing the bark off logs and digging into the rotten wood, operations in which mine host exhibited great energy, were by no means productive. The commonest Beetle was a Tenebrio with a pungent odour; we also got a few specimens of Cilibe elongatus, Brème, and with them the Bug, Rhopalomorpha obseura, and a lot of the Ant, Ponera castanea, Mayr.

While engaged in this almost fruitless search we happened upon five examples of *Peripatus novae-zealandiae, Hutton. Curious-looking creatures they are, and to me at any rate extremely repulsire. It is now generally agreed that they are primitive Arthropods, having certain affinities with the Annelida. My specimens varied in length from 30 to 40 millimetres, their antennae were black, the body bluish black above, paler beneath, covered with brownish-orange tubercles; the feet were grey beneath.

Mrs. Longstaff took a fine specimen of the introduced Slug, Arion intermedius, of an unusually deep yellow colour, also a very dark brown example of Agriolimax laevis. In the river she found Amphipepla ampulla, Hutton, and "Isodora tabulata, var. moesta, Adams.

On the railway journey from Masterton to Wellington, at Summit Station, $1140 \mathrm{ft}$., I took * Crambus tuhualis, Feld., then new to me, as well as the common ${ }^{*} C$. flexuosellus.

\section{WELLINGTON.}

March 2nd, 1910.

On my second visit to Wellington I had the pleasure of seeing some of that season's additions to the collection which Mr. Augustus Hamilton is making for the Dominion Musoum. Mr. Hamilton has determined to make the collection under his chargo the standard 
one of New Zealand, and in partieular is taking steps to seeure long series of the many very variable moths of the islands. But there was a greater pleasure in store for me: a night's sugaring with Mr. Hamilton himself, his son, and a Coleopterist whose name has escaped me. The scene of our operations was the wilder part of the Botanical Garden, where the treacle and rum had been spread upon the stems of the numerous Tea-trees. Part of the round was new, part old. Moths were there in swarms; we must have seen more than a thousand. Since many of them were new to me I was as excited as a beginner, yet quite bewildered, not knowing what to catch and what to leave.

My now familiar friend, Persectania ewingi, was far and away the commonest moth, and may perhaps have made up three-fourths of the whole number, it was accompanied by a eouple of ${ }^{*} P$. atristriga, a very distinct species. The great genus Morrisonia is best represented in New Zealand, although there are a few North American forms; that night I met with * $M$. insignis and * $M$. mutans, both extremely variable species; the somewhat indefinite ${ }^{*} M$. lignana, and the more distinct ${ }^{*} M$. prionistis ; also several new acquaintances : * M. ustistriga, Walk. ; *M. ochthistis, Meyrk. (vitiosa, Hudson, nce Butler), and the pretty green * $M I$. plenc, Walk., which was among the commonest. With all these genuine New Zealanders there was a single straggler of the almost eosmopolitan Cirphis unipuncta, which occurs in every continent with the exception of Africa. The Deltoids were represented by one * Rhapsa scotosicalis.

With * Corcmia semisignata was to be seen the much less common * Pasiphila indrctata, Walk.; I also secured an example of * Dcclana floccosa, Walk., one of a most interesting genus peculiar to New Zealand; they are fair-sized robust insects, whose fore-wings, both as regards their shape and the numerous raised scales, at once bring to mind Peroneids of the genus Leptogramma, their shaggy look being quite unlike that of any other Geometers of my acquaintance.

But Lepidoptera were not the only insects found on the sugared stems. There were sundry small cryptic Longicor'us: * Somutidia untarctica, White, and other beetles. Then there were large Tipulcuc of a bright green colour. Among the Orthoptera, besides the Cockroaches, Cutilia seclilloti and Allacta latipcnnis, Brunn., two of each, were numerous individuals of the far more striking-not to say alarming - wingless Locustids, the huge * Deinacride mcgaccphala, Buller, called by the Maoris "Weta." One of then when taken was in the act of devouring a hapless "Norrisonia mutans, and finished up its carciss on the way home in the pill-box. Although a much 
larger species is found in some parts of the Dominion, the mandibles of the male of the common Wellington kind are sufficiently formidable to justify amply the remark of one of the "sugarers," that fewer lovers would walk in those gardens of an evening, if they had any idea how numerous were these awe-inspiring Wetas.

\section{Lyttelton and Christchurch (Soutil Island).}

March 4th, 1910.

The beautiful little harbour of Lyttelton secined to me likc a Scotch loch, so shut in is it with mountains. Our time only permitted of a flying visit to CHRISTCHURCH, which is a sort of colonial Cheltenham. We hurried off to the museum to gaze reverently at the wonderful collection of remains of the * Moa (Dinornis) for which it is justly famous. I also had a glimpse of the celebrated Fereday collection of insects. The Domain is more civilized and park-like than some I had seen. The collection of New Zealand plants within a ring fence, forming a separate garden by themselves, especially pleased me. As I have noticed in England so at Christchurch, Crambi seem fond of seeking refuge in dense bushy Conifers: the prevalent species on this occasion were * flexuosellus and *tuhualis. However, rain cut short my peregrinations, and as I went out I approached a statue from behind, when suddenly its back and shoulders struck me as familiar, they were surely those of my old teacher George Rolleston; on walking round I saw that the effigy was that of the Hon. William Rolleston, formerly Prime Minister of New Zealand, and a jounger brother of the Oxford Professor!

The guide-book states that Christchurch Cathedral was desigued by Sir Gilbert Scott, the local architect being Mr. E. W. Mountford. It might have been a more inspiring building, if the local architect had made the design as well as superintended the carrying of it out. This remark is made by one who knew something of both men as well as their works.

When we got back to the ship some of the New Zealanders greeted us with, "Well, did not Christchurch strike you as very likc England?" to which I maliciously roplied, "Yes; the streets werc muddy, and it rained most of the time." 
Dunedin, South Island.

March 5th-7th, and March 19th-21st, 1910.

If it be true, as I am quite disposed to admit, that Christchurch is an especially English-looking town, there is no doubt whatever as to Dunedin being Scottish. The buildings, especially the churches, have a thoroughly Scottish look, and all the streets have Scottish names.

All the more credit to the Scots, for the town is admirably laid out, and from many points of view - especially that of the entomologist-it was a grand idea to reserve a strip of bush all around its landward sides forming the "Town Belt." I wonder whether some entomologist had a hand in this wise scheme.

The high ground above the Town Belt commands grand views over city and harbour, with the big surf rolling in beyond the sandhills. Earlier in the year, and with weather of a less pronounced Scotch type, insects might have been more abundant by day in what remains of the bush; but, even as it was, I managed to pick up a few things. On tree-trunks a few of the pretty little Pug, * Helastia mueosata (bilineolata), Walk., were to be found, while beating drove out an occasional * Probolaec faleata, Butl., * Astluena subpurpureata, Walk., or a delicate green Tortrix, ${ }^{*}$ Nymphostola galactina, Feld. $\&$ Rog., reminding me of our T. viridana, though larger and paler, but unlike our British green Tortrix, this is a rarity, according to Mr. Durrant. Another Tortrix found there was ${ }^{*}$ Carposince adreptella, Walk. I also obtained, by beating, the Weevil, Empoeotes eensorius, Pascoc, and dark specimens of the Bug, Onoconticus vittata, Fabr. In the bush near the cemetery the Pyrale, Mnesietena notata, Butl., turned up, it is alike pretty and distinct. One of the commonest trees in the bush was * Fuelusia excorticata, Linn.; its small flowers were not out at the time of our visits, but the trees were very conspicuous by thcir untidy, loose, papery bark.

But quite my best "find" in Dunedin, if not indeed in New Zealand, was Mr. George W. Howes, F.E.S. Owing to a change of his abode I had quitc a hunt for him, but ultimately after dark ran him, so to say, to earth. He lives on the outskirts of the town adjoining the best sugaring town in the Town Belt, and there, under" Mrs. Howes' guidance, I found him, like many other " good things" -at sugar! Mr. Howes generously placed his "round" at my disposal, and in his genial company I had threc nost profitable nights-March 5th, 19th, and 20th-inoths being plentiful on each occasion. 
Perhaps the commonest Noctua was the pretty green * Morrisonis. plena, which came in considerable numbers; then there were many ${ }^{*} M$. prionistis; several ${ }^{*} M$. ustistriga; a single ${ }^{*} M$. homoscia; numerous ${ }^{*} M$. mutans, variable as its name implies; of * $M$. decorate, Philpott, a species only recently detected, I was fortunate in securing seven; two * $M$. agorastis, Meyrk. ; several * M. stipata, Walk., a rather large species, notable for the curious tufts of long hair which adorn the sides of the abdomen of the male; a few of the handsome dark * M. tartaraca, Butl., turned up, together with * M. ochthistis, Meyrk. (vitiosa, Hudson, nec Butler), and *M. vitiosa, Butl. (proteastis, Meyrk.). The last two species are decidedly confusing, though unquestionably distinct; they were somewhat mixed up even at South Kensington. Of the dark shiny * Austramathes purpurea, Butl., with its overhanging eyelashes, I took two. Persectania ewingi had by this time ceased to be of much account, but $P$. atristriga still interested me somewhat. * Hyssia moderata came alone to the treacle, but of * Leucania sulcana, Fereday, I got two, and of * Tmetolophota propria, Walk., three specimens. In contrast to these the singular and beautiful * Erana graminosa, Walk, which when living is of a brilliant green, was quite common. So much of its long and ample hind-wings as projects beyond the skimpy, both short and narrow, fore-wings is of the same green colour as they are. This

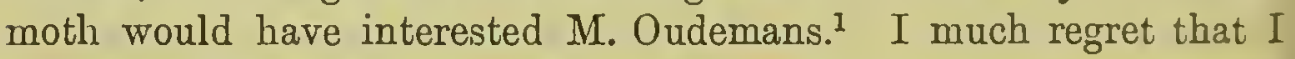
never saw this insect at rest under natural conditions. The curious Deltoid, * Rhapsa scotosialis, was fairly common, but I was not able to detect any scent in comnection with the tuft of hairs under the costa of the male.

Among the autumn Geometers, which seem in New Zealand to be as fond of sugar as are the Noctuae, the most remarkable were certainly those of the genus Declana and its allies, a group that would appear to be confined to the Antipodes. As I said before, they are stoutly made, shaggy insects, which look like gigantic caricatures of Peroneids, or perhaps Notodontids, rather than Geometers. * Declana floccos $a$ and "Anatossa nivcata, Butl., were both fairly common. The Boarmiid, * Selidoscma panagrata, turncd up in some uumbers, but * Hemcrophila dejectaria was not as common as I had found it on the Wanganui. Two specimens of * Xynonia alcctoraria, Walk., were so very different that $I$ was for some time disposed to think them distinct species, and to call the more abcrrant * $X$. achroiavia, Fcld., but until evidence to the contrary-by breeding-is forthcoming, it is best to consider them conspecific, as I believe Mr. Howes does.

1 Soo Chaptor X., $\$ 11$, infra. 
One of the commonest of the family was * Pseudo-corcmice melinatu; with them were two * P. productata. The hook-tipped * Gargaphia muriferata, Walk., is very common in some parts of New Zealand, but I took one only. The delicate * Asthence undosata was common, but * A. subpurpureatc comparatively scarce; both looked out of place at sugar. * Coremia cegrota, Butl., and ${ }^{*} C$. semisignata both visited the sweets, but not in any numbers, and the same is true of the lovely green * Epyaxa beata, Butl., *Cidaria similata, and * Hclastia mucosata (also green). In contradistinction to those species, the hook-tipped * Probolcea falcata, and * P. mcgaspilata, Walk., as well as *Coenocalpe gobiata, Feld., were all three common enough, the lastnamed always reminding me of our British Phibalapteryx tcrsata.

Even in New Zealand the Pyrales hardly go to sugar as freely as they go to light, but the genus Scoparia is exceptional in this respect. Our list of sugar-frequenting Pyrales at Dunedin comprised * Mncsictena flavidalis, * Adena hybreascilis, Walk., a pretty and extremely variable insect, ranging from purple-grey to orange, and the little Endotrichid, * Diplopseustis pericrialis, Walk. Then of * Scoparia augastis, Meyrk., we took three, but of ${ }^{*} S$. cymatias, Meyrk., $S$. minualis, S. philerga, and Xeroscopa rotuella, Feld., single specimens only.

The extremely variable Tortrix, Ctcnopscustis obliquana, came to the sugar in considerable numbers, nearly all females. Others of the group were *Tortrix excessana, the sexes almost balanced; *Carposina excochana, Meyrk., a male, while the rare * Nymphostola galactina also put in an appearance occasionally. In addition we took a female * Cnephasia jactatana, Walk., which Mr. Durrant says is a very good thing. A* Deinacrida sp. was not as numerous as his big brother had been at Wellington and not nearly as formidable looking. Two of the Longicorns, * Somatidia antarctica, were very likely not attracted by the sugar at all, but had other business on the trees, and the same may likely enough be true of the Tenebrionid, Artystona obscura, Sharp, and Cilibc clongatus. The endemic Slug, * Janclla papillata, Hutton, also visited the sugar.

I was exceedingly anxious to see alive that highly characteristic New Zealand butterfly the silver-washed Satyrid, * Argyrophenga antipodum, Doubl., but it would appear that I was quite too late; very probably the bad weather had cleared off the last stragglers. In vain did I try every place that Mr. Howes could suggest.

On the Hill above Normanby, to the westward (March 7th), I picked up * Coremia semisignata, " Epyaxa scmifissata, Walk., * Asaphodes abrogata, Walk., which was common in one field among grass, 
as well as two spccimens of an Asaphodes, which Mr. Prout thinks may possibly be distinct from the preceding. Among smaller things were * Scoparia submarginalis, * Crambus tuhualis (which also turned up in the hotel), and ${ }^{*} C$. vittellus, Doubl., and a malc of the Tortrix * Proselcna homionana, Meyrk. The Heteromerous beetles, Artystona obscura, and Adelium. sp., were found under the bark of dead trees.

On Opaho Hill (March 19th) and about the rifle-ranges we got nothing but * Coremia semisignata, * Asaphodes abrogata, Emmiltis rubraria, *Crambus tuhualis, and the now familiar Asilid *Necitamus varius. The Tiger-beetle, * Cicindcla latecincta, White, was fairly common, and Mr. Howes found one eating a small centipede. He also called my attention to a * Deilemera annulata which had just flown into a spider's web. The captor was grey, singularly like in colour to the dead Manuka to which her web was attached. Having mummified the moth the spider tried to haul it up into her diningroom, but after vain attempts descended and cut away a thread which kept the moth down. Having at last pulled up her unfortunate victim, she proceeded to suck its juices, an operation that we watched for some minutes.

St. Kilda sand-hills were visited on March 6th under most unfavourable conditions, and in spite of much struggling about in the extremely dense growth of the Yellow Lupin (Lupinus arborcus, Sims)-which had been introduced from California, and most effectually employed, to hold the sand in position-I got nothing save * Mnesictena flavidalis, ${ }^{*}$ Crambus angustipennis, and a few Tortrices, to wit, three males of Pyrgotis plagiatana, Walk, and one female Ctenopseustis obliquana. With the moths was an unnamed Ichneumon-fly, while the Beetle, Cilibe clongatus, was found under a plank.

Mrs. Longstaff found at St. Clair abundance of the Top Shell, Diloma nigerrima, Chemnitz, also a few specimens of the abnormal Limpet, * Siphonaria australis, Quoy, which lives at, or even above, high-water mark, but is provided with both a pulmonary carity, and a branchia, and appears (likc Amphibola) to be passing from an aquatic to a terrestrial existence.

At Dunedin we had the plcasure of staying in the same hotel with Mr. H. Suter and his wife. ${ }^{I}$ The former was kind enough to name Mrs. Longstaff's shells, and to give her much valuable information about them.

1 We regret to have since heard of her death. 
Tumsden (Soutir Ist.1ND), 27 miles below Lake Wakatipu.

$$
\text { March 8th, } 1910 .
$$

As the train on its journey northwards approaches the mountains near Lumsden Station it passes through a quantity of Tussock-grass. The wind caused by the train roused many small moths, not a few of which entered the train, but having a very limited supply of pillboxes accessible, I was able to box but six. These turned out to be one * Coremia semisignata, one * Scoparia paltomacha, Meyrk., one * Crumbus sublicellus, and three indifferent specimens of a new species of the latter genus which Mr. E. Meyrick, F.R.S., has described as *Crambus obstructus, sp. nov., adding: "It comes nearest to ${ }^{*} C$. vittellus, Doubl. This makes the 38th New Zealand Crambus, all endemic, besides an endemic genus developed from Crambus (Orocrumbus) with six species; whilst in Australia there are only two species of Crambus, both immigrants." 1

Lake WaKatipu (South Island), lat. $45^{\circ} \mathrm{S}$, altitude above sea, $1069 \mathrm{ft}$.

Narch 8th-18th, 1910.

The somewhat severe beauty of Wakatipu is enhanced by the lake being closely shut in by mountains on every side tliroughout its whole length of nearly fifty miles. If the snow-fields and glaciers at its head bring Switzerland vividly to mind, the lower mountains, with their rugged slopes clothed in dense bracken with here and there woods of birch-like beech, have rather a Scotch character. Unfortunately forest-fires have left many sad scars upon the mountains.

Mr. Howes joined us at the foot of the lake, and his companionship greatly increased my pleasure besides adding to my spoils, for without him I should have done but little night work.

We arrived at Queenstown too late to sugar, so made arrangements to ascend Pen Lomond the next morning. As we rode up, the view looking back over the lake was indescribably lovely; I have seen nothing finer anywhere. The weather had been threatening from the first, and when we drew rein at the hut, just below the col, or saddle, the heavens opened and it began to pour. We waited in the hut, hoping argainst hope, and gazing wistfully up into the cloud where we knew that the summit must be. The saddle is about $4700 \mathrm{ft}$.

'Entomologist's Monthly Magazine, 2nd Sor., vol. xxii., p. 82 (1911). Mr. Meyrick tells me that neither of the Australian Crambi ocoura in Now Zonland. 
above sea-level, the summit $1000 \mathrm{ft}$. higher. We ate our lunch to pass the time, but finally gave up all hope and walked disnally down.

Under such distressing circumstances it was only to be expected that the bag would be but a small one. Belated blossoms of * Gentiana corymbifera, T. Kirk, and of the Shepherd's Lily (* Ranunculus lyallii, Hooker), gave us hints of what the New Zealand alpine Flora must be in its prime. At the higher elevations I got nothing but a Grasshopper, which was much in evidence, and a solitary example of what I take to be * Scoparia axena, Meyrk. On the lower slopes whenever the sun shone the pretty little * Notoreas brephosata, Walk., was to be seen commonly enough, though (as Mr. Hudson truly remarks ${ }^{1}$ ) not too easy either to see or to capture. It derives its name from its striking resemblance to a very small Brephos parthenias, Linn., just as a very nearly allied New Zealand moth is called * Dasyuris partheniata, Guen., although both belong to quite another sub-family of the Geometers. Amongst the common brephosata I found a worn example of $* N$. perornata, Walk. Somewhat lower down flying about bare stony places in the sunshine might be seen the tiny * Arctesthes eatapyrrha, Butl. This pretty insect Mr. Hudson (following Meyrick) includes under Lythria euclidiata, Guen., an Australian species; to me, however, the two insects appear abundantly distinct, and Mr. Prout is of the same opinion. As the lake is approached *Asaphodes abrogata and *Coremia semisignata both become common.

That night the rain made sigaring quite out of the question.

The next morning we tried the hill slopes immediately above the town, but, taking what proved to be an ill-judged course, we wasted much time and energy in contending with natural obstacles. Some of the lower slopes around Lake Wakatipn are extraordinarily difficult to climb. It goes without saying that they are steep and rough in the extreme, but they look most innocent in their mantle of fern. This fern-our familiar Bracken (Ptoris aquilina, Linn., var. cseulenta, ${ }^{2}$ Hook.) -is found, on closer acquaintance, to form a dense tangle about 5 or 6 feet high. I have myself met with Bracken in Jamaica and Ceylon, but I have no hesitation in admitting the superiority of Antipoden Pracken to all other. The difficulty of

1 "New Zealand Moths and Butterflies," p. 75. Mr. Hudson refers with approval to Lord Walsingham's addross to the Entomological Soeiety in 1891, in which the thon President expressed the opinion that the brilliantiy coloured hindwings of many day-1lying moths dazzled the eje, so as to make it eren more diffieult for a pursuer to mark tho spot whore ono of them alights than it rrould be otherwise.

In tho old days the rhizomo was an important article of diet with the Maoris. 
forcing one's self through the thickets was of course intensified when the Bush Lawyer (Rubus australis, Forst.) intervened with his many tangling points of argument. Painful experience makes me consider our British Bramble a more deadly foe than the New Zealander. Its prickles are longer and more viciously curved. On the other hand our Bramble is an open fighter, and one need not accept his challenge. The Bush Iawyer, however, is stealthy and underhand in his line of action, preferring ambuscade to front attack, and he wears a sweetly innocent-looking face that seduces the unwary new chum. When fern and bramble found allies in hidden rocks a fall often resulted, and the tired entomologist after extricating himself and recovering his feet had to disentangle his net from the clutches of the Lawyer with such patience as he might haply have left. It is not surprising that a morning so spent added no new species to our list. Another terror of that hillside -and indeed of the whole district-was the Piripiri (Acaenc sanguisorbae, Vahl., Nat. Ord. Rosaceae), commonly known as the "bid-abid," a most innocent-looking plant which is, however, so prolific of burrs that a large portion of one's time was spent in picking them off the net. Later in the day I captured in the Domain-here a civilized park, not a bush reserve-a specimen of the cosmopolitan Zinckenia fuscialis, Cram.

Mr. Howes found a few Snails that morning, and gave to Mrs. Longstaff a specimen of * Laoma celia, Hutton, one of Allodiscres mossi, Murdoch; as well as three *Janella papillatc, Hutton, besides Agriolimax agrestis.

In the afternoon MIrs. Longstaff dredged in the shallow parts of the lake for Water Snails. The bottom was in places black with * Potamopyrgus badia, Gould, both the smooth and the spiny forms occurring together. It is said that numbers of this mollusc are found in the stomachs of the Trout. But whatever effect the introduction of those voracious fishes may have had upon the fresh-watcr fauna of New Zealand, it does not seem probable that the Potamomyrgus will be soon exterminated. The only other shells met with were * Isidora lyrata, Woods; *Diplodon (Unio) menziesi, Gray; * Pisidium novae-zcalandiac, Prime; and *Sphacrium novaezealandiac, Deshayes.

Nr. Howes, a month before our visit, had left a cyanide-bottle with Mr. T. E. Haines, a very intelligent Queenstown tradesman, who had preserved therein quite a number of moths which had visited the lights of his shop. The most numerous among them were * Asaphodes abrogata; the most notable * Morrisonia phricias, 
Meyrk., and * morosa, Butl.; * Tmetolophote propria, and * Leucunic, scmivittata, Walk., as well as the Phycid, "Sporophyla denospora, Meyrk. All of these Mr. Howes was good enough to pass over to me.

On March 10th, we sugared on the path to the waterworks; it was a good night, but the number of accessible trees in the gully is small. * Hyssia moderata was common; * Morrisonia tartaruea and * $M$. prionistis were also present in fair numbers, and with them were several * $M$. insignis, * $M$. phricias, ${ }^{*} M$. mutans, ${ }^{*} M$. lignana, and ${ }^{*} M$. ustistriga, as well as two each of * $M$. ochthistis, and *M. dotata, Walk. Besides these there was a specimen of a grey Noctuid of which we subsequently secured a goodly number. Mr. Howes had taken a single example of the same insect at Dunedin in March, 1907 , but it was not until we had secured a long series that it was clearly proved to be undescribed. Mr. Howes was good enough to give it the name * Morrisonic longstaffi, sp. nov.'

There were, furthermore, quite a number of Geometers: single examples of * Ipana lcptomera, Walk. (allied to Declana); the rare *Xyridacma hemipteraria, Guen.; the Pug, * Hclastia mucosata, and the delicate green Asthena pulchraria; two *Psendo-coremia lupinata, Feld., and a number of * Corcmice semisignata.

The representative Pyrales were * Inesictena notata, N'ymphula nitens, Butl., the scarce * Scoparia paltomacha, and several of the common and variable, ${ }^{*} S$. submarginalis.

\section{Paradise, Wakatipu.}

Though difficult of access "PARADISE" is quite an eartlily place. The drive from the head of the Lake, a dozen miles or so, affords excellent carriage exercise culminating in the passage of the Rees River. This may be described as a vast tract of stones traversed by an uncertain number of streams-seven at the time of our visit. Coming down from the glacier of Mt. Earnslaw, $9200 \mathrm{ft}$., the Rees is a turbulent torrent subject to sudden freshets, and given to such whims and fancies that the topography of the fords is subject to much uncertainty. After a very heavy fall of rain the best track for vehicles is marked out with flags, but there is still ample scope for good driving. More than once the horses were on the point of swimming, and I do not yet quite grasp how they succeeded in dragging the waggonotte over the huge boulders, and up seemingly impossible banks. It did not take much to persunde us that the

' G. W. Howes, Trans. Nen Zcaland Inst., vol. xliii., p. 128, Pl. I, Fig. 3 (1910). 
road was often impassable; indeed the flood had been so high a few days before that it was not possible to get either into, or out of, Paradise. However, after much plunging and splashing, all difficulties were at last surmounted, and then peacefully driving through a grand bit of Beech forest along the shore of Diamond Lake, we at last entered Paradise by "Heaven's Gate," and had our choice of two accommodation houses, yclept "Arcadia" and "Elysium"!

Paradise Flat is the name of a township, which resembles indeed Eden in "Martin Chuzzlewit" in so far as the town only exists in imagination, but affords a decidedly more pleasant place of residence. At first we thought it might be difficult to live up to the name, but the cold at nights gave a reassuring earthly character to our temporary abode. Our accommodation house provided all the necessaries, and a few of the comforts of terrestrial existence. Perhaps its lamps were somewhat dim, but it is remarkable that they attracted so few moths. However, Borlihansenia psendo-spretella made us feel quite at home.

The township derives its name from a flat stretch of grass land about two miles long, by one mile broad, closed in by mountains on every side except the south-east. Mount Earnslaw lies nearly due north, but its permanent snowfield and glacier are shut out from view by its own lower ridges. To the north and north-west Mt. Sommer (7400 ft.), and other mountains of fine rugged outlines, with their craggy summits capped with snow, seem to wall in the valley. The lower slopes of Mt. Earnslaw and Mt. Alfred opposite to it, are clothed with sombre Beech woods. Between "Arcadia" and the Diamond Lake was a clump of trees, and on the lower ground beyond a golden field of the introduced Ragwort.

There is no doubt that for day work we were too late in the year, though possibly sugar was at its best. The chief insect to be obtained on the flat was * Chrysophanus boldenurum, White, which was very common on stony ground where there was but little herbage, the males far out-numbering the fomales. It is a pretty and very distinct butterfly-purple-blue, not coppery. *Arctesthes catapyrrha was to be got on the same ground, and *Coremia semisignata was frequently, and *Coenocalpe gotiata occasionally disturbed. Other insects met with near the house were * Mncsictcna flavidalis; * Scoparia foredayi, Knaggs; *S. cleodoralis, Walk., and * Crambuis flexuosellus.

On the Pagwort in the noon-day sun we found * Morrisonia mutans, Persectania evoingi, and the Fly, ${ }^{*}$ Syprptus ortas, Walk. Other flies taken on the flat were Odontomyia chloris and "Iystricia signuta. 
Removing bark from dead wood was an unprofitable occupation, producing nothing beyond * Adelium harpaloides, White, and countless Bugs of the genus Neuroetenus.

It is a good rule when collecting near the coast to make for the sea-shore, and when collecting among mountains to make for the higher levels. Accordingly our first expedition was up the slopes of Mt. Earnslaw.

To reach the upper limit of the bush involved a climb of about $3000 \mathrm{ft}$. Although there was not even the pretence of a path it was wonderfully easy going for primaeval forest. The trees are practically confined to a species of mountain Beech, almost universally spoken of as Birch. There are several species of these Southern beeches (Fagus, the Nothofagus of some authors), which all have small, somewhat leathery leaves, and are for the most part evergreen. It seems reasonable to assume that this peculiar foliage is specially adapted to throw off the snow, for no signs of branches having been torn off are seen. At the lower edge of the bush the trees were large, many of them truly noble specimens, but they decrease in size with the altitude until the quite sharply defined upper limit is reached. As with their Northern allies, these beeches like to have the ground to themselves, and there is little undergrowth save young plants of the same species. Bush Lawyers are fortunately few and far between, so that one walked or scrambled over velvety moss with little interruption. Ferns were insignificant in comparison with the North Island.

Above the limit of trees, but before the grassy slopes were reached, was a belt of small scrub through which it was quite difficult to force one's way, and in which it was impossible to catcl the few moths that were flying rapidly in the sun. These Mr. Howes believed to be *Dasyuris partheniata, a Geometer all 1 to, but larger and less brightly coloured than *Notorecas brephosata. We saw a single *Pyrameis gonerilla, near the top of the wocd, a species which Mr. Howes says is not nearly so common in the Wakatipu district as it is about Christchurcl.

The greatest height that I attrined we estimated to be about $3700 \mathrm{ft}$. above the flat, say $5000 \mathrm{ft}$. above the sea. The most exalted insect that I came across was the familiar Blow-fly, Calliphora crythrocephalc, together with some Beetles and a Grasshopper as jet undetermined. There was also a rare Plume, * Stcnoptitia oritcs, Meyrk., of which Mr. J. H. Durrnnt had previously seen the unique type only, $\Lambda$ little lower down a Syrphus, not in the National Collection, was taken. Not a very distinguished company to find 
on stony screes amidst a Flora that was truly Alpine. Mr. Howes is pretty confident that he saw * Erebiola butleri, Fereday, but a butterfly rushing swiftly over a scree has pretty well its own way. By industriously turning over stones Mr. Howes found an empty pupa-case of an Erebiola, together with several of the Arctiid, * Metacrias huttonis, Butl. He also found larvae of * Hyssia nullifera, Walk., in the stems of the "Spear-grass." 1 A few of our old friends "Notoreas brephosata and *Arctesthes catapyrrha, completed the small company. It was indeed evident that it was quite too late in the season for day work at high altitudes, moreover the famous Alpine flowers were almost all over, a few belated specimens of the Shepherd's Lily being almost the sole survivors.

Another day we went about $1000 \mathrm{ft}$. up Mt. Alfred, a much lowcr mountain on the opposite side of the valley. Insects were more numerous but for the most part the same as occurred on the flat. The few exceptions were * Xerocopa cyameuta, Meyrk.; a Scoparialike moth which would appear to be uncommon; the Ant, * Monomoriam antarcticum, of the typical form; two * Cicindela parryi, and another Beetle, a species of Odontria.

In the wood at the highest point that we reached, Mr. Howes found under bark of Beech (Fagus? fusca, Hook.) a number of the tiny Snail, *Lcioma celia, Hutton, and several specimens of what $\mathrm{Mr}$. Suter says is a new sub-species, to which he has given the name alboviridis.

Mrs. Longstaff obtained by dredging in the Diamond Lake with impromptu instruments, besides * Diplodon menziesi, * Isodora lyrata, and abundance of Potamopyrgus badius and *Sphaerium novae-zcalandiae, a single specimen of Amphipepla ampulla.

Land shells were not common, but one or other of the party picked up on the flat, chiefly under bark or logs:- several * Endoclonta (Charopa) otagoensis, Suter, one E. sterliana, Suter, one $E$. bianca, one E. (Aeschrodomus) barbatula, Reeve, two Flammulina pilsbryi, Sutcr, one of the very tiny $F$. feredayi, var. glacialis, Suter, one Thalassohelix traversi, E. A. Smith, and one * Laoma phrynia, Hutton. All these were small shells, and such as may be easily overlooked. We did not have the good fortune to enter the circumscribed area of distribution of the only large New Zcaland land shclls of the genera Placostylus and Paryphanta. The poverty of the Ncw Zealand land mollusca is indirectly shown by the rapidity with

1 *Aciphylla squarrosa, Forst., Nat. Ord. Umbelliferae; tho gonus is confined to New Zealand. Not bo coufounded with tho Spcar"grass of India (soe above, p. 70), which is a true grass. 
whieh Hclix cuspersa, and scveral European slugs have spread over the eountry: there were evidently vaeant spaees waiting for thern, so to say.

The beeehes along the lower margin of the bush between "Elysium" and the lake afforded an ideal sugaring ground, with which we sometimes ineluded the more scattered trees on the lower grass-land. When going to and from our sugar we were somewhat put out by having to eross barbed wire fences that appeared to have no other objeet than to annoy, but at last it dawned upon us that they were there to define a street through the township, although the said township comprises but three houses, none of which abut upon the future street.

We got five nights sugaring on this splendid ground and have no reason to eomplain of the results. Agrotis ypsilon; *Hyssia griscipennis, Feld., in fair number's; * Morrisonia plena, abundant; * M. mutans, common; * M. vitiosa, eommon; *M. v'ubescens, Butl., one; * $M$. ustistriga, one; * $M$. stipata, several; * $M$. dotata, one; *M. longstaffi, Howes, one ; $M$. ochthistis, two; * M. tartaraca, two; * Mr. lignana, one; $M$. pluricias, rather common though not generally eonsidered so ; Morrisonic alopa, Meyrk, this speeies, included by Mr. Hudson (following Mr. Meyriek) in Leueanic, but placed by Sir George Hampson in Morrisonia, had hitherto been looked upon as a great rarity, but at Paradise during our visit it was quite eommon; it always reminded me of our Sideridis (Lencania) lithargyrea, Esp.; * $M$. merope, Hudson, we took a splendid speeimen of this grand inseet, it is a rather large Noctuid, blue-black with metallic green markings; it is eonsidered to be a great rarity, and it certainly looked the part under the bright light of the aeetylene lamp; * Icucania semivittata, several ; * L. suleana, one ; * $B i \cdot$ 'la defigurata, fairly common; Pcrsectania cwingi, common; *Imet -phota propria, one; *Ariathisa (Orthosia) comma, Walk., two; * Rhapsa scotosialis, three.

The list of sugar-frequenting Geometer's is even a longer one than that of the Noetuids. * Hencropthila dejcctaria, one; * Sclidosema panagrata, several; *Psendo-coremia lupinata, five; $P$. malinata, several; *P. productata, threc; *Dcclana griseata, Hudson, one, a speeies not represented in the British Museum; *D. floccosa, two; a very fine Dcclana, with wcll-defincd black markings, visited my sugar onee when I was some distance from Mr. Howes, though I felt quite certain that it had bcen bottled all right, somehow I never saw it again; * Ipana leptoncera, two ; *Gonophylla fortinata, Guen., two; Asticena mulchraria, several: this is of a very delicatc green when quite 
fresh; the pale grey * $A$. subpurpureate, three; $A$. visata, Gucn., two; * Tatosoma agrionata, Walk., two males: this was miy first, and only acquaintance with living specimens of this peculiar genus, in which the male is conspicuous by its abnormally long abdomen and contracted hind-wings, its nearest ally in the British fauna is Lobophora; Coremica cugrota, abundant; ${ }^{*} C$. semisignate, abundant; * C. cinercuria, abundant; *Epyaxa semifissata, two; E. rosearia, Doubl., one; * Coenocalpe gobiata, common: this is so variable that it is hard to say whether or no two species are included under the name; * Xyridacma hemipteraria, one, considered somewhat of a rarity by Mr. Howes; the dark green * Cidaria similata, abundant; *Elvia glaucata, Walk., we took three of this very pretty little spccies; lastly, * Helastia mucosato, one.

If my records are to be trusted, the only Pyrales that visited the sugar at Paradise were members of the genus Scoparia. Of these * submarginalis was common enough; of *minusculalis, Walk., three came; but only single individuals of * philerga, * cstragalota, Meyrk., and *charcuctc, Meyrk. There were several specimens of *Tortrix escesscuna, also a worn Tineid of the Laverna group.

Several of the Cockroach, Temnopteryx sp., which I had previously inet with in several places, and a few of the Weevil, Rhynucodes ursus, White; one Artystonce obscurc, as well as two of the Longicorn, ${ }^{*}$ Sometidia antarcticce, were found upon the trees, but whether the three latter were attracted by the sugar is questionable.

The return journey to Queenstown gave us a little time at Glenorchy at the head of the lake. In the small garden of the hotel, on an ill-kept lawn a Geometer, an Asaphodes, previously taken near Dunedin, was somewhat common. Mr. Prout considers it to be new and has promised to describe it in duc course. Under driftwood at the edge of the lake were a vcry few beetlcs, including Odontric, sp. Mr. Howes had left one of his cyanide-bottles with the hotel proprietor, it now contained a few of the large *Hyssic nullifero.

On our way up the lakc, when the steanncr called at Kinloch, Mr. Howes found several small Land Shells; two *haropo otcogocnsis, Suter, and eight Acschrodomus stipulatus, Riceve. 


\section{QUEENSTOWn (Lake Wakatipu).}

\section{March 16th.}

On our arrival $\mathrm{Mr}_{\mathrm{r}}$. Howes at onee rushed out and sugared a few trees near the town. There were not many moths, amongst them the predominating speeies was Persectania ewingi and with it were a very few *Hysia moderata, * Morrisonia phrieias, * $M$. tartaraea, * M. prionistis, * M. mutans, a couple of * Coremia semisignata, and a * Crambus sublicellus. The feature of the evening was a splendid specimen of what Mr. Hudson ealls * Melanchra pictula, White; a green and blaek insect with white reniform stigma and pink hindwings, now called by Sir George Hampson, * Miselia meyricci.

That night Mr. Howes eaptured at the lamp in the hotel porch a very fine specimen of * Euxoa admirationis, of a markedly grey tint.

Beyoud taking a few * Chrysophanus boldenarum on the shores of the Frankton Arm, I did little the next day till late afternoon when we rode about $2000 \mathrm{ft}$. up Ben Lomond, sending the horses baek. Mr. Howes scrambled down to the edge of the bush to lay on the sugar, while I took the "billy" to feteh water-a process that somehow brought to my mind the doings of the 10th Legion under Julius Caesar. It was mueh further than I thought, and, too late, I regretted the premature dismissal of my horse. Truly there mas mater in the ravine below the sugaring ground, but it was hopelessly inaceessible, so I had to elimb up quite $500 \mathrm{ft}$. to a tiny stream to fill my billy, moreover I had to carry it down again without spilling. For this diffieult operation I luekily proved to have a natural talent. Proudly depositing my (nearly) full tin in a position of security I set to work to build a fire-place and to collect dead wood. When all was ready $\mathrm{Mr}$. Howes turned up with brush and pot. I can recall few things more delightful than sitting at the close of day on the mountain-side in the one approximately level spot, drinking our tea and eating our food with the proud feeling that we were doing what no mortal entomologist had ever done before. The solitude, the wild beauty of the place and the keen sense of antieipation were most delightful.

The upper edge of the bush had been sugared: mostly small trees clinging on to the rocky soil, and needing free use of the knife to elear their stems of superfluous twigs. Of a track there was no manner of trace, but by skilful use of toes and heels it was just possible to walk on what was little better than a Cumberland scree. 
It is not a little to our credit that, according to my recollection, we did not fall down more than twice each, moreover no serious danagc was done to bones, or lamps, or killing-bottles.

We met with our reward. Moths were scarcely numerous, but the quality was good. There were odd specimens of * Morrisonia ochthistis, "II. homoscia, *M. ustistriga, * M. mutans, * M. dotata, ${ }^{*} M$. phricias, and * Tmetolophota propria. Both Persectania ewingi and *Morrisonia prionistis were fairly common. Of *Morrisonia longstaffi I was fortunate in bringing home five specimens, but our great take was Miselia meyricei of which we got several, it is usually considered quite a good thing, besides being so beautiful. Mr. Howes saw, in addition, * Miselia pessota, Meyrk., but unfortunately it got away. Moths of other families were conspicuous by their absence.

Thus ended, very appropriately, our expedition to Lake Wakatipu, an cxpedition which I shall always associate in my mind with boyish collecting with John Blackburn on the shores of Loch Rannoch. Each Lake owns a Kinloch; the terrain of the two places is similar; the general character of the fauna is also similar. It is especially notable that the moths of the Highlands of Scotland and those of the Highlands of New Zealand are alike extraordinarily variable.

\section{LyTTELTON (SOUTH IslaNd).}

March 23rd, 1910.

On the occasion of my second visit to the beautiful lake-like harbour of Lyttelton I did not go far inland. Mrs. Lougstaff was very anxious to get living specimens of Turritella vittata, which Mr. Suter had told her wcre to be obtained in the harbour. Accordingly we set off to the locality indicated, Magazine Bay, but were just too late, for the tide had turned, and although there werc dead spires in abundance, no living animals werc within reach.

Magazine Bay was not very productive in the inscet way, but "Pyrameis gonerilla, "Chrysophanus sallustius, * Mnesictena flavidalis, * Crambus ramosellus and Eristalis tenax all turned up, iwhile Emmiltis rubraria was abundant in a circumscribed spot. It is noticeable that I did not see this last specics in the Wakatipu district.

In the afternoon $I$ ascended Mount Pleasant, at the head of the harbour; with an official altitude of $1638 \mathrm{ft}$., it rejoices in the native narne of Tauhuno-korokio. It is a pretty little mountain commanding 
a wide-ranging view, and earlier in the season should afford good collecting ground. $*$ * gonerilla and $*$. sallustius occurred alike on the lower slopes and on the very summit. In vain did I tramp ups and down acre after acre of rough tussock-grass (Poa cuespitosa, Forst.), in the hope of perchance picking up a belated specimen of * Argyrophenga antipodum; there was nothing to be found but * Asaphodes abrogata in the grass, and * Scoparia axena on lichencovered rocks. At about $900 \mathrm{ft}$. a female of * Coremia bultulata, Guen., was taken flying in the afternoon sun, and at a little lower level Asthena undosata, and the common * Coremia semisignata. Almost by an accident a *Morrisonia mutans was seen on a grey treetrunk, which it very closely resembled in colour. There were a few beetles under stones in what remains of the bush-Cilibe elongatus, Brème, and one of the large and handsome, but very evil-smelling Carabid, * Megadromus viridilimbatus, Motsch. Under a stone I found six small Snails, Therasia valeria, Hutton.

My last night in New Zealand was spent very pleasantly with Mr. Hudson, in his well-situated house overlooking Wellington, chatting over his fine collection.

\section{AUSTRALIA.}

\section{Sydney, New South Wales, lat. $33^{\circ} 50^{\prime} \mathrm{S}$.}

March 30th-April 5th, 1910.

If you are going to Sydney as a stranger do not arrive on Easter Monday, when The Cup is run for, especially if the Agricultural Show be going on at the same time. The "Manuka" arrived a day before it was expected, so my son did not meet me. Every hotel was full, as were the many boarding-houses. After much tramping about we had to put up with two very dirty trestle-beds, in the attic of a thirdrate boarding-house; the women servants were ont, the men servants were drunk!

Quite apart from its well-praised harbour, Sydney pleased me more than any city of Australasia. Its very irregularities make it interesting. It seems to sit upon its site in a dignified manner. True, its suburbs, though open and airy, are depressing, like most suburbs, but the business quarters of the city have a solid respectability, and its flower-bedecked park or Domain forms a delightful centre for its busy life. 
In the said Domain I took a specimen of Papilio sarpedon clorcdon, Feld., which with fluttering wings was regaling itself at a bed of Zinnias. A second very small specimen was taken at Balmoral on the north side of the harbour. In the Botanic Gardens, adjoining the park, there were numbers of butterflies. Belenois teutonia, Fabr., was in abundance about the Capparis bushes on which its larva feeds. There were many pupae on the Capparis, but for some unaccountable reason none of them produced butterflies. Of two Precis velleda, a male was "very dry," a female intermediate. Single examples of Polyommatus baeticus, Linn., and Zizera labradus were taken. Skippers were very numerous, Telesto perronii, Latr., predominating, all captured were males; of Telicota sperthias, Feld. (which seems to me to be very closely allied to, if not identical with (ungiades, Feld.), two males and a female were captured. I also secured an insect identical with that labelled Ocybadistcs (?)flavogultata, Plötz, in the British Museum Collection. The cosmopolitan Pyrale, Zinckenic fascialis, Cram., was abundant among the S. American plant, Gomphrena globosa, Linn. One specimen of the blue-black Wasp, Discolia soror, Smith, turned up.

At Rose Bay, a suburb between Sydney and the sea, there is a little bush left. This harboured fewer insects than I had expected, but there was one that much interested me. Tisiphone abeona, Don., is a very handsome Satyr, a large nearly black butterfly with creamy markings. It was almost confined to the immediate neighbourhood of a small spring-not a common object in the New South Wales landscape-and had a remarkably slow, dancing, flapping flight. I could not detect any trace of scent in either sex, dead or alive. The only other butterflies taken in the bush were single specimens of the Satyr, Iypocysta irius, Fabr., and the Skipper - lascivia, Rosenstock (for which a generic name is at present wanting), but Zizera labradus was common in a damp meadow below the wood, where also a bright green Tryxulis sp., was abundant. I also got at Rose Bay a specimen of the Lithosiid, Asura lydia, Don., a black and yellow somewhat Syntomid-like moth; two of the Australian Ladybird, Coccinella conformis, and a Bombyliid of the genus Anthrax, not represented at South Kensington; besides these there were a few Ants, Ectatomma metallicum, Sinith, found under a stone.

At Woolahara Point, not far from Rose Bay, I took two Syntomis annulala, Fabr., flying late in the afternoon, also single examples of the Skippers, Ocybadistcs (?) flavoguttatus, and - lascivia, Rosenstock. I also saw several of my old friend Zinckenia fascialis, and found an Adelinm crawling on a rock. Miss Ruby Gower kindly 
gave me a specimen of the fine bnff-coloured Australian Lymantriid, Colussc cxcisa, Walk., a male, which she had found in the house.

Acting on the advice of Mr. G. A. Watcrhouse, B.Sc., I made two expeditions by rail to Como on the south bank of the River Georges, a well-known suburban locality, about twelve miles SS.W. of Syduey, not very far from the spot where Banks made his collection, which was afterwards named by Fabricius, so that it is not surprising that many of my captures were of Fabrician species.

To wander in the Australian bush, where the Gum-tree has its home, was a new experience, but I wish it had been earlier in the year. It was soon evident that the prevailing butterflies were Satyrines and Hesperids. The large Hcteronympha merope was quite common, it is more wary than is usual with Satyrs, and somewhat swift of flight. Curiously enough I saw at Como nothing but females, just as at Hobart, ten weeks previously, I had seen nothing but males; moreover so unlike are the two sexes that I had no idea that they were one species. It is remarkable that the female of merope has a distinct sweet scent of the Philadelphus type. Perhaps the commonest butterfly was Hypocysta irius, Fabr. (adiante, Hübn.), but of its congeners, $H$. antirius, Butl., and $H$. euphemia, Dbl. \& H., I took but one each. Xenica achanta, Don., a very golden-looking insect on the wing, was suggestive of $P$. megaera; unfortunately, though common, it was in poor condition. Near the railway station I picked up a couple of Yphthima arctons, Fabr., which took my thoughts back to India.

Precis velleda was somewhat common, but I did not see any other Nymphalines.

The only Danainc was a female Danaida archippus, Fabr. (plcxippus, auct. nec Linn.). ${ }^{1}$

Theclinesthes (Nacaduba, Utica) onycha, Hew., Nacaduba bioccllata, Feld., and Zizcra labradus were all the Blues that I took, and judging from their condition the family was about over. At Como I saw but one Pierine species, bnt that a notable one; the male of Delias nigrina, Fabr. (the only sex that I secured) is white above, black beneath, a startling colour scheme. A fair number werc seen flying about the flowers of a tall gum-tree, but they rarely condescended to come down. ${ }^{2}$

Skippers, as has been said, wcre much in evidence, affording a marked contrast to New Zealand, where they are $m$ known. Of the brilliant tawny Telicota augias, Linn., which occurs throughont the

1 Mr. G. A. Waterhouso calls this megalippe, Hübn.

? See bolow, p. 535. 


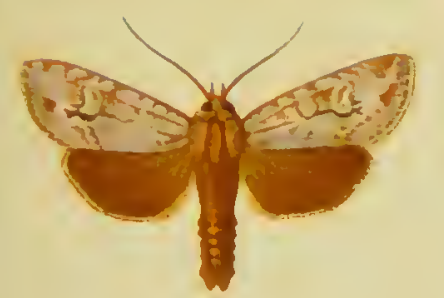

1

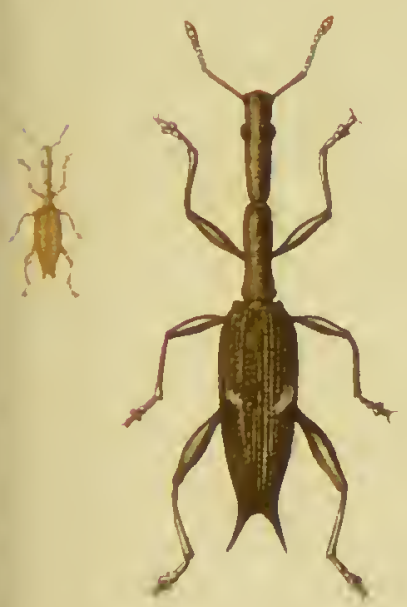

4

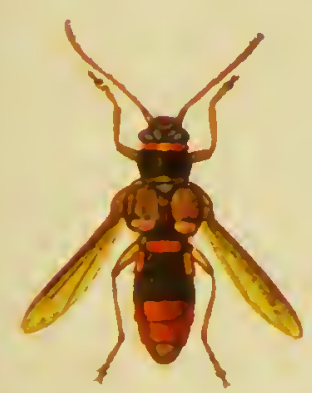

8

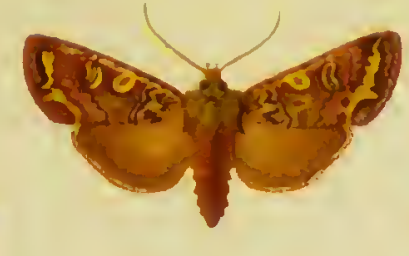

2
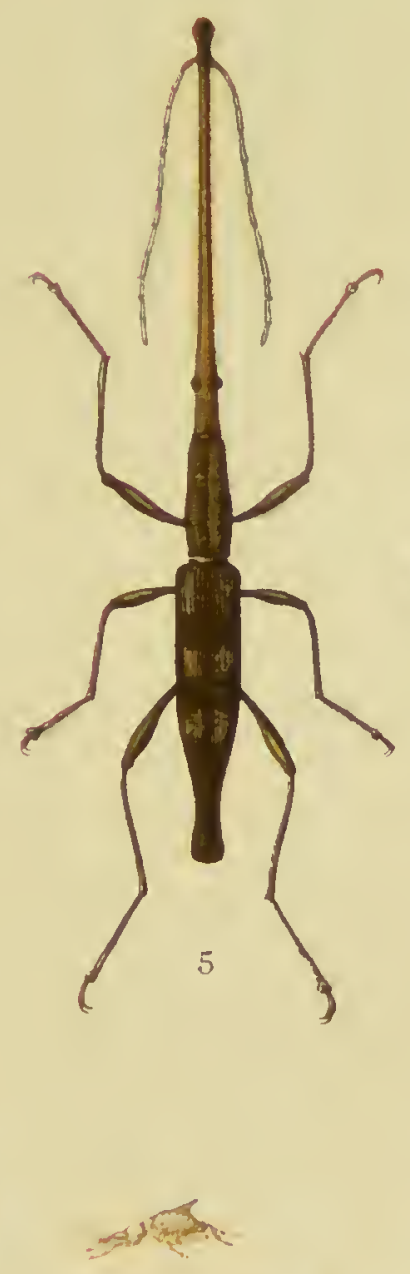

$\therefore-1$

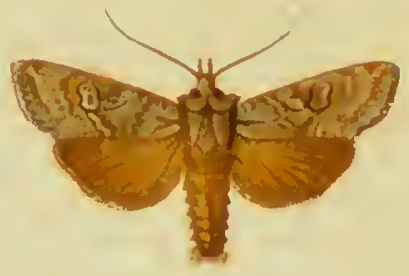

3
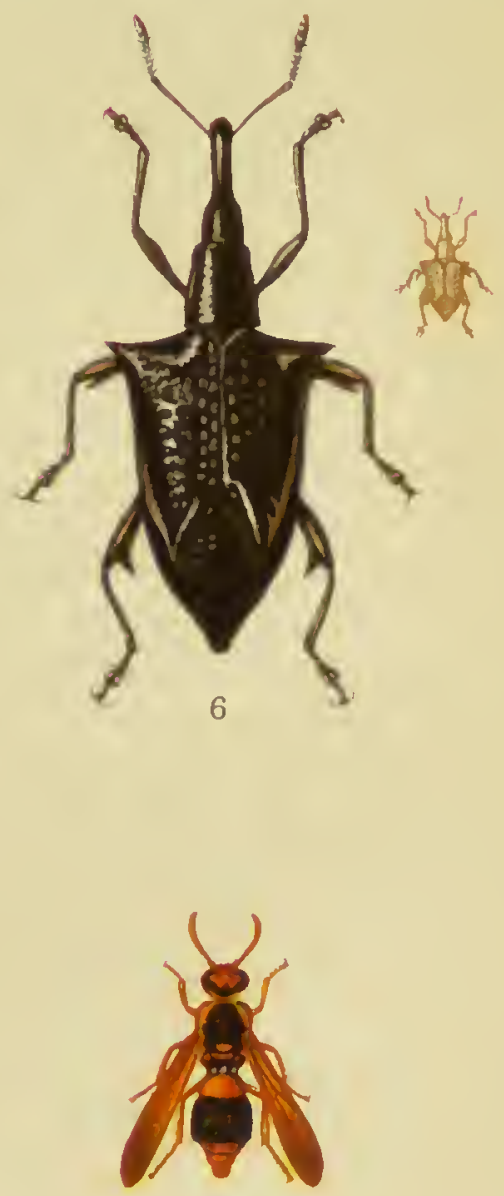

9

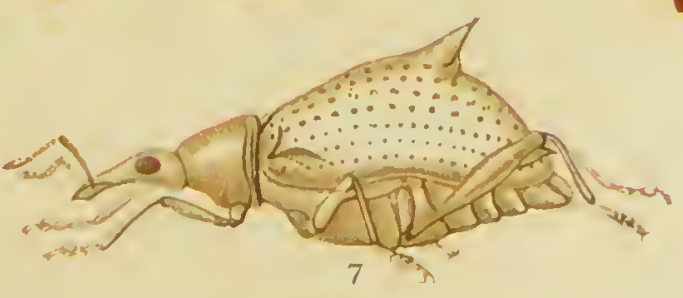

H. and Edgur S. Knight del.

West, Newman Chromo.

1. MORRISONIA SEQUENS.

2 MORRISONIA CHLORODONTA

3. MORRISONIA LONGSTAFFI.

4. RHADINOSOMUS ACUMINATUS
5. TERAMOCERUS BARBICORNIS

6. SCOLOPTERUS TETRACANTHUS.

7. THE SAME SIDE VIEW.

8. ESTHESIS VARIEGATUS. 

Oriental Region, I took three; of Patlasingha phigalia, Hew., two, of $P$. petalia, Hew., one, remarkable among Skippers by having an ocellus-like mark on the underside of the hind-wings; Trapezites iacchure, Fabr., one, worn; Ocybadistes (?) flavoguttatus, one; Tclesto doubledcyyi, Feld., a female, T. perronii, a female, and Oxytoxic ismene, Newm. (paruulus, Plötz), one.

Conspicuous among the Moths was the Agaristid, Phalaenoides tetraplenerc, Meyrk., of which I fancy I saw several, but only secured a single female; the British Museum has males only, from Queensland. Of Syntomis connulcute (the typical form) I took three, it is evidently very common in the Sydney district. The black and yellow Lithosiid, Asura lydia, turned up again. There were but two Geometers, Epidesmia tryxaria, Guen., an Oenochromiid which is superficially like our Panagra petraria, Hübn., and Idiodcs inspircta, Guen., which is doubtfully distinct from mitigata, Guen. The sole Pyrale was Endotrichuc pyrosalis, Guen.

Hymenoptera were moderately plentiful. Of Apis ligustica I took three, two of them in the deadly embrace of Asilus discutiens, Walk. On the characteristically Australian "bottle-brush" flower of a species of a Callistemon, I took Prosopis alcyonea, Erichs. (vidua, Smith). The blue Crocisc nitidula, Fabr., was brilliant, even for its genus. I took but one Dielis formosa, Guér., though others were seen. On a Mlimosa flower I saw, as I thought, a very fierce-looking, black and orange Wasp, it was easy to sweep it off the flower with the net, but difficult to coax it into the cyanide-bottle; for some occult reason I had an especial fear of that insect, recalling a yarn of Commander Walker's about a specially deadly wasp of those latitudes. At last it went into the bottle and I thought no morc about it, until on getting back to my hotel at Sydney, I turned the contents of the bottle out, to find that my Wasp was a female Longicorn beetle, Esthesis varicgatus, Fabr.! Mr. G. Meade-Waldo and Mr. Rowland E. Turner think that its model is probably Rhynchium abispoides, M.-Waldo, but it is also very like a small male of Salius bicolor, Fabr., of which I had caught a female at the same place three days before [sce Plate VI., Figs. 8, 9]. On the stem of a Eucalyptus I found the Sawfly Ptcrygophorus (Pcrge) cinctus, Klug, half-dead. Communities of Componotus novac-hollandiac, Mayr, were not uncommon.

An expedition to Edward's Bay, on the north sidc of the harbour, in search of Marine Mollusca was productive of a large number of specimens which have not yet been worked out.

By the kindness of Mr. R. Hedley we attended the annual 
mecting of the Linnaenn Society of New South Wales, and had a very pleasant evening; another evening I spent with Mr. G. A. Waterhouse, and his collaborator Mr. G. Lyell, junr., discussing their forthcoming work on the butterflics of Australia. One afternoon we went to the finc University Building, wherc Professor David gave us tea, illustrated by a private exhibition of a wonderful set of lanteru slides of the Antarctic Expedition.

\section{Hobart, Tasmania.}

April 8th and 9th, 1910.

Our second visit to Hobart gave us part of two days ashore. A walk in the Gum-woods above the Cascade Brewery showed them to be singularly barren of insect life, probably in great part owing to the paucity of undergrowth. Two worn specimens of the Satyr, Xenica klugii, Guér., were taken, also a tattered male of Heteronympha merope, a couple of Emmiltis rubraria, and one Asthena visata, both New Zealand friends. I also got two of the Crambid, Talis grammellus, Zell.

The next morning was spent in the Botanic Garden, where Prccis velleda, small "dry" specimens, was Hying in swarms about French Marigold and Heliotrope. I never saw any of the genus so abundant elsewhere. The only other butterflies were the widely-distributed but unattractive Zizera labradus and a few females of Heteronympha merope. I beat out a Lithosiid, Palacosia bicosta, Walk., a moth very like our Lithosia griseola, Hübn.

\section{Melbourne, Victoria, lat. $37^{\circ} 47^{\prime} \mathrm{S}$.}

April 11th and 12th, 1910.

To my mind the magnificent Botanic Garden is the chief glory of Melbourne, a city which has the distinction of containing a larger proportion of the population of the state of which it is the capital than is the case anywhere elsc.

Besides plenty of Zizera labradus, a female Heteromympha mcrope and the almost inevitable Eristalis tenax, I had the pleasurc of taking in the gardens several specimens of Pyrameis itea, chiefly at the flowers of the Mexican Lantana sellowiana, Lnk. \& Ot.

The next morning I went to Sandringham, a sen-side resort on the shore of Port Philip Bay. On a heath-like expanse wcre many low shrubs of what I took to be Callistcmon salignus [Nat. Ord. Myrtacene], 
whose yellow bottle-brushes irresistibly reminded me of male sallows, however, they yielded nothing but Apis ligustica and some obscure little flies. It was too dull and windy to do any good, but just before leaving I glanced over some close palings with the result that I soon found Zizera labradus, very cryptic; Hemerophila mundifer $a$, Walk., and three other moths which puzzled me greatly at the time. They were exactly the colour of the fence; their wings folded in such a way as to make them resemble a Footman, or a very small Shark. They turned out to be the Geometer, Chlcnias carburaria, Guen.; a closely allied species is actually called umbraticaria.

\section{Adelaide, South Australia, lat. $35^{\circ} \mathrm{S}$.}

$$
\text { April 14th, } 1910 .
$$

We took train to the city and then motor-car to Waterfall Gully. There was nothing to be seen save Danaida archippus and Heteronympha merope, females.

Alongside the quay where the steamer was moored, was a quantity of made-ground, in part at any rate the result of dredging. An almost fruitless search for insects in country very like parts of Braunton Burrows only yielded a Crambid, Argyria pentadactyla, Zell., and a couple of Earwigs, but a very few minutes before the hour of sailing I came across a place where wind and rain had exposed immense numbers of marine shells-mostly Gasteropods. In a very short time I picked up a considerable number: they have not yet been worked out but appear to comprise Fusus, Turritella, Conus, Oliva, Bulla, Murex, Natica, Cerithium, Trochus, Pleurotoma, Pecten, and Venus. The majority are unquestionably recent, but some would appear to be semi-fossilized: among them are numbers of Foraminifera resembling Nummulites. It would have been far more profitable had we spent the whole day over these shells, a large proportion of which were in excellent preservation.

\section{Fremantle, Western Australis, lat. $32^{\circ} 20^{\prime}$ S.}

$$
\text { April 18th, } 1910 .
$$

The Great Australian Bight was exceptionally benignant when we crossed it, and might almost have set an example to the proverbial mill-pond. At Fremantle we spent such time as was at our disposal in driving to Apple Cross, on the Swan River. 'The bush was interesting because curious, but I might have had better collecting on 
the Sahara. The only butterflics were a couple of Polyommatus basticus and one Nacaduba biocellata, Feld. (armillatus, Butl), taken at the flowers of what secmed to be a species of Broom. A Gum-tree in flower had attracted Apis ligustica, Paracolletes plumosus, Smith, and $P$. bicolor, Smith, as well as Epactiothynnus cygnorum, Turner. All thesc were taken at Palmyra, a suburb of Fremantle. The bush yielded the wasp, Salius bicolor, Fabr., and an Acridian, voila tout!

This yarn was told by a humorous Scot, if ever there was one, on the North Pacific, but was brought to mind by the Scottish city of Dunedin :-

One New Year's morning a Scotch Minister sallied forth accompanied by his ruling Elder to call upon his chief parishioners, as is the custom. It was a fine morning, but cold. All went well, they found almost every one at home and wished each in turn "a guid New Year," which was duly reciprocated. The!Minister was welcome to his hospitable parishioners; as has been said it was a cold molning and naturally enough the whisky bottle was handed round.

Noon drew near, and soon after leaving a house the Minister, addressing his Elder, said-

"Sandy McPherson, I'm thinkin' that mebbe we've drunk a drap mair whusky than is seemly for folk in our responsible poseetion. Will ye juist walk on a wee bit, and I'll bide here and see whether ye can walk straight or no."

The Elder thus exhorted walked on a hundred paces or so, when the Minister again addressed him?

"Ye can turn back, Sandy, ye're dacin fine, but," dropping his voice, "wha's that wi" ye?"

On the voyage home, when in the Red Sea beforc dawn on May 5 , I had a lovely sight of Halley's Comet, Venus, and the New Moon in conjunction, all close to the castern horizon.

On May 18, at 4 a.m., in the Bay of Biscay, the hoad of the Comet was below the horizon, but the tail, which was hazy and pointed at the end, appeared to be at least $21^{\circ}$ broad and cxtended at least $50^{\circ}$. Timagine it must have been very near to the earth. 


\section{CHAP'IER X}

\section{BIONOMIC NOTES, CHIEFLY ON BUT'LERLIES ${ }^{1}$}

$\S 1$, Scents- $\$ 2$, Coloured Juices- $\$ 3$, Tenacity of Life- $\$ 4$, Mutilations by Foes$\S 5$, Experiments on Palatability- $\S 6$, Successful Mimicry- $\$ 7$, Poculiarities of Flight- $\$ 8$, Heliotropism- $\$ 9$, List and Shadow- $\$ 10$, Inverted Attitude$\S 11$, Attitudes at Rest-§12, Some Cosmopolitan Lcpidoptera-§13, Seasonal Forms- $\$ 14$, Sclection of Coloured Resting Places.

\section{INTRODUCTORY.}

WhEN travelling in a country new to him it is almost inevitable that an entomologist's time should be chiefly taken up with searching for insects and securing specimens; his temptation is to become a mere collector, his chief ambition to discover species new to science. Further, such observations of more scientific value as he may find time to make are but too apt to be isolated, imperfect and inconclusive. Yet something may be done even during a flying visit, and a subsequent judicious arrangement of the notes made at the time may provide useful material for further work by the samc naturalist, or by a more capable or more fortunately circumstanced observer following his footsteps.

But it may be objected to such a book as this, that it is madc up of trivial details, that it is loaded with wcarisome repetitions, that everybody has long bcen familiar with the facts brought forward-in short, that it is but a laborious "demonstration of the obvious." 2 So be it. For the sake of argument these propositions might all be arlmitted, and yet the time spent in writing the work, and cven the space occupied by it upon the bookshelf, bc amply justified.

'The immortal work of Lyell, of Darwin, and of Wallace was largely built upon seeming trivialities, on facts many of which were

1 This chapter is based upon two paper's read bofore the Entomological Socioty of London, viz.: "Some Rest-Attitudes of Butterflies," Trans. Ent. Soc. Lond., 1906, pp. 99-118; and "Bionomic Notos on Butterflics," ibul., 1909, pp.607-673. The term "Bionomics" is duc to Sir Edwin Ray Lankestcr, K.C.B., F.R.S., and may bo shortly defined as that scetion of Biology which doals with the laws regulating the mutual relations of living organisms.

2 W. Bateson, F'.R.S., Report of British Association, 1901, p. 577. 
obvious, and therefore to some persons unintercsting. But with what different eyes do we now look upon those same facts, filled as they are with new meaning! Surely present-day naturalists cannot do better than follow humbly in the footsteps of those "old masters," observe, record, and arrange facts, extract and dress the ore ready for some future metallurgist to smelt, so that some future smith may have the wherewithal to forge useful tools or works of art.

Far more experienced observers than the writer have unfortunately lacked the time or the inclination to place their facts on record. Indeed, it is one of the saddest things in the history of science that so much knowledge has perished with the gleaners. ${ }^{1}$ Again, even though the facts may have been recorded previously, it is surely well that they should be confirmed time after time before hasty inferences are drawn. Yet again, it is surely desirable to find out how far the facts extend, to what species, genera, families; to what degree they are developed; whether they vary in the two sexes, in the individual, the species, the genus; how they are distributed in space and time and season. Lastly, it is just possible that here and there a seemingly small fact, a residual phenomenon of real import, may have hitherto escaped observation, or at any rate may not have been recorded.

It has been the author's idea to place together in some sort of order those of his observations which have from time to time appeared to him to be of real importance, with a view to focusing, as it were, all the scattered facts, in the hope of illuminating, even to a small degree, sundry holes and corners in the great mystery of evolution.

\section{$\S 1$. Scents of Butterflies.}

Doubtless from the earliest days that insects have been collected entomologists have from time to time noticed scented butterflies, and the records of such occurrences must be scattcred here and there through entomological literature, but so far as I am awarc Fritz Müller was the first to takc up the study of the subject seriously. As early as 1876 he suggested that all the various brands, tufts of hairs, pouches, and the like, which arc peculiar to the males of various butterflies, might be odoriferous organs, although up to that time he had himself actually detected sccnts in but few species."

1 Col. C. T. Bingham's diaries were in my mind whon writing this; ho died the woek after the original paper, on which this ehapter is founded, was read. He was a keen obsorvor, and tho most genial of men.

2 Jenaische Zeitschrift für Naturwissenschaft, 1876, XI., p. 99. By the kind assistanco of Mr. E. A. Elliott and Prof. Poulton I am onabled to gire in an Appendix trauslations of this and other papers by Fritz Müllor. 
In 1878 Fritz Müller followed this up with an extremely interesting communication to the Entomological Society of London, ${ }^{1}$ dealing chiefly with the scents actually found by him in the field, scents often associated with the special structures referred to.

Mr. J. Wood-Mason, in 1886, published an account of the results of some of his observations in Cachar (Assam). ${ }^{2}$

Dr. F. A. Dixey, F.R.S., took up the study where Fritz Müllcr left it, and has been for some years engaged in investigating the anatomical structures connected with the production and distribution of the scents, devoting especial attention to the Pierinae. He gave the scientific world the first instalment of his results in his able Presidential Address to the Entomological Society, in January, $1910 .^{3}$ Entomologists have been long looking forward to the publication of his researches, and it is to be hoped that before very long the complete work will see the light.

Dr. Dixey's first field observations appear to have been made in 1899. Four years later, at Mortehoe, shortly before I sailed for India, he called my attention to the strong and distinct scent of Ganoris napi, Linn., closely resembling that of the Lemon Verbena, Lippia (Aloysia) citriodora. ${ }^{4}$

We made some joint observations that summer which I repeated and amplified the next year. Dr. Dixey gave a detailed and very lucid account of these early observations to the Entomological Society, an account that will well repay perusal. ${ }^{5}$ Meanwhile, at Dr. Dixey's request, I had made a few observations on Indian butterflies in $1903-4 .^{6}$ It is curious that to this day so few persons are practically acquaintcd with the scent of the Green-veined White. When, at the Brussels Conference, in 1910, I caught a male G. napi in thc heautiful garden of the Congo Museum, and demonstrated the sccnt to half a dozen entomologists present, none of these gentlemen had perceived the scent bcfore, though at least one of them was a vcry eminent observer.

" "Notes on Brazilian Entomology," Trans. Ent. Soc. Lond., 1878, p. 211.

" "The Rhopalocera of Cachar," by J. Wood-Mason and L. de Niebville. Journal Asiatic Society of Bcngal, vol. xv., 1886, pp. 343-393. It is stated on p. 344 that this paper was written in 1881, but its publication was dolayed. Tho insects were taken "between Narch 26th and October 4th," but the year is not given.

3 Proc. Ent. Soc. Lond., 1909, p. Ixxxiii.

'See A. Weismann, "The Evolution Theory," 1904, translated from Socond German Edition, 1904, pp. 217, 218. Also Barrett's British Lcpidoptcra, 1893, vol. i. p. 26; also Standfuss, Handbuch der paliarktischen Gross-Schmettcrlinge, 1896, p. 108.

s Proc. Ent. Soc. Lond., 1904, pp. Ivi.-lx. Seo also Longstaff, Entom. Month. Mag., 1905, pp. 112-115.

"Longstafi, Trans. Ent. Soc. Lond., 1905, pp. 136-198. 
In 1905 I had the pleasure of travelling with Dr. Dixey in South Africa, and shortly after our return he communieated to the Socicty the results of our observations in that country. His papers ${ }^{1}$ deserve vcry careful study. They eall for one remark from me, and that is this : eonsidering the difficulty of the subjeet it is quite remarkable how elosely we agreed in the great majority of eases; where we differed our very differenees proved the honesty and independence of our observations. There is no question in my mind that Dr. Dixey's olfactory organ is keener than mine to deteet an odour, it is also more diseriminating to analyze its nature, and his better memory of scents enables him to draw more aceurate comparisons than I ean.

Although Dr. Dixey's endeavours to preserve scents have met with some suceess, it nevertheless remains true that the greater part of the evidence for their existenee takes this form: "On such and such an oeeasion, I, A.B., examined sueh and such a butterfly, and deteeted an odour, which seemed to me at the time to resemble sueh and such an odour, with which I was more or less familiar."

Under these circumstanees it is obviously desirable that wc should have more investigators, more witnesses.

At this stage of the investigation it seems well to bring together all the evidence, in brief, arranged systematically as the insects stand in our eabinets. Wherever I am not personally responsible, in whole or in part, for the statements made, I have placed the paragraph in square brackets []. This does not, of eourse, suggest that sueh observations are inferior in value to the others, but aroids the eonstant repetition of the observer's name.

During the last few years, it has been my privilege to have somewhat unusual opportunities of pursuing this matter, so I venture to offer some suggestions as to the modus opcrandi.

Observations may be made in the ficld, if there be not too much wind; but better results are often obtained indoors; it is, however, essential that these should be made before the inseets become stiff. I find it best to take up the inscet with foreeps in such a way that by gentle pressure on the sides of the thorax the wings may be made to open, so that the nose may be brought quite elose to their upper surface. A geutlc inhalation gives better results than a suiff. If no secnt be detected, it is well to cxhale gently on to the butterfly's wings, and then try again. If after repeating this three or four times no result is obtained, a camel's-hair pencil (which must be clean) may be applied to the brands, tufts, or other speeial structures.

' Dixcy, Proc. Ent. Soc. Lond., 1905, pp. liv.-lix.; also ibid., 1906, pp. ii.-rii. 
I think it well to note whether the result is obtained in the field, or in the house, and in the latter ease whether the inseet was alive or dead. My practice is to examine in the house every specimen eaptured, but I fear that too often the examination has been very hasty, not to say perfunetory.

A final warning. Beware of faeeal odours due to pinehing the butterfly. Again, a "mousy odour" is in several eases recorded; this is not confined to one sex, and is met with in butterfles belonging to various families, but only after death. This I believe to be a produet of decomposition of either the animal juiees or the faeces. The odour resembles that of acetamide, and not improbably may be diue to that substanee, or some compound ammonia.

Mr. F. R. D. Onslow has suggested that butterflies might coneeivably derive their scents from direct eontact with flowers. Without denying the possibility of this I can only say, after somewhat extensive experienee, that the explanation does not fit the faets. It has, however, oceurred to me as possible that occasionally the seent might be derived from the opposite sex.

It may be added that I am at one with Fritz Mïller and Dr. Dixey in dividing the seents of butterflies into two eategories: (1) Attraetive seents; in the very large majority of eases eonfined to the male sex; and (2) Repulsive or proteetive seents, usually common to both sexes, and often stronger in the female.

There are indeed a few notable exeeptions, but so far as the faets are available, it would appear that, speaking generally, the Picrinae, Satyrinae, and Lycaenidae yield scents belonging to the first class (attractive), whereas the Danainae, Acrcieinae and Helieoniinac produce repulsive seents. The Ithomiinae, Nymphalinae and Papilioninac contribute seents of both elasses. Of other groups little or nothing is known as regards scents.

It is quite certain that in some butterflies two quite distinct seents may be deteeted in the same individual, one transient, the other more persistent: it is not improbable that herein may be found the explanation of some apparent exeeptions, or diserepancies.

Dr. Dixey has called attention to the somewhat surprising fact that (with a few possible exeeptions) the seents that are believed to be attraetive to the opposite sex are agreeable to the average human perception, whereas those that are believed to be repulsive (and therefore protective) are for the most part disagreeable, or even disgusting. 


\section{ITHOMIINAE.}

\section{NYMPHALIDAF。}

[Dircenna xantho, Feld. (lenea, Cram.). (Brazil, 1876, 1878).1 Fritz Müller records a rather strong, most agreeable, vanilla scent in the male.]

[Ceratinia eupompe, Hübn. (Brazil, 1878). Fritz Müller records a rather faint scent in the male.]

[Mechanitis lysimnia, Fabr. (polymnia, Linn.). (Brazil, 1878). Fritz Müller records a very faint scent in the male.]

[Thyridia megisto, Feld. (Brazil, 1878). Fritz Müller records an odour in both sexes, but much fainter in the female.]

[Ithomia sylvo, Hübn. (Brazil, 1878). Fritz Müller records a rather faint odour in the male.

He seems to claim a scent for the whole group of Ithomiines: "The males have a tuft or pencil of long hairs near the anterior margin of the hind-wings, which in all our Brazilian species emits a more or less distinct odour."]

Tithorea megara, Godart. (Trinidad, 1907). Three males had a very distinct, or even strong, scent, which was compared by both Mrs. Longstaff and myself to Stephanotis, but I thought that it had. in addition a spicy, or dusty element. A female was scentless.

Athesis clearista, Doubl. (Venezuela, 1907). A male had a slight sweet flowery scent, both alive and dead : it appeared to be associated with the brushes on the hind-wings.

Leucothyris victorina, Hew., and L. phemonoë, Doubl. (Venezuela, 1907). A male of each of these species had an offensive odour, which in the latter seemed to be associated with the tufts or brushes on the hind-wings.

\section{DanAINAE.}

Danaida chrysippus, Linn. (India, 1904; South Africa, 1905; Ceylon, 1908 ; Egypt, 1909). There is no doubt whatever, that, to use Dr. Dixey's words : "The scent in both sexes" is "of a strong and disagreeable nature, like that of cockroaches, often stronger in the female." It has also been compared to the odour of musk-rats. It appear's to me that the odour is not comnected with the glands on the hind-wings of the male.

Danaida archippus, Fabr. (plexippus, anct., nec Limn., crippus,

1 The date given to all Fritz Müller's notes is 1878. His payer was read in June of that year. He speaks of "tro years ago," and implies that the obserrations hare been made sinee. From this one may infer a date of $1876,187 \%$, or 1878 . Where the seent of the butterfly had been mentioned in Fritz Müller's earlier paper the date 1876 is also given. 
Cram.). [Fritz Müller (Brazil, 1878) spoke of a rather disagreeable odour "extremcly strong in Lycorea sp. and Ituna ilione, less so in D. gilippus, and rather faint in D. erippus." It is not quite clear whether he confines this odour to the male sex, but it may be fairly inferred from the context that he does so.]

(Jamaica, Tobago, Panama, Venezuela, 1907). 15 đ, 2 ㅇ. All had a scent, similar in quality and intensity in both sexes; it is described in my notes as slight, moderate, or strong, and is compared to that of a cockroach, a musk-rat, a rabbit-hutch, or musty dung; twice it is qualified as "scarcely unpleasant," and "scarcely disagreeable." (Australia, 1910). 1 \$, 3 ․ A strong musk-rat scent when alive.

Danaida plexippus, Linn. (genutia, Cram.). In India in 1903-4, I sometimes detected an unpleasant scent in this species, but did not record the sex of the specimens examined. On other occasions the results were negative, and it seems probable that in this species the odour is not very strong.

(Mátherán, Bombay Presidency, 1908). A male had a slight musk-rat odour in the field, none at home though still alive.

Danaida jamaicensis, Bates. (Jamaica, 1907). 2 o, 2 \%. Of the two males the scent is described respectively as "strong rabbit-hutch odour," and "decided odour, (?) cockroach, scarcely disagreeable." Of the females it is noted "both with a strong cockroach smell, perceptible next day: my wife, however, described the odour as slightly fusty."

Danaida eresimus, Cram. (Colombia, Venezuela, 1907). Of two males it is noted "(?) very slight pleasant scent"; of a female "strong (?) musk-rat odour when alive."

[N.B.-These last two are probably forms of D. gilippus, a butterfly observed by Fritz Müller.]

Tirumala limniace, Cram. (India, 1904). I detected in a male a very faint scent, suggesting old cigar-boxes. Observations made on other occasions were doubtful or negative.

Tirumala septentrionis, Butl. (Ceylon, 1908). 11 males were examined, 9 of them yielded a scent, noted as slight, moderate, or decided, and described as pleasant or sweet, and in two cases compared (with, however, some hcsitation) to clover. In four individuals the genital tufts were displayed; certainly in one of thesc no scent was perceptible (though subsequently detectcd in the housc). In another instance it is noted that the sccnt was not connected with the sexual pouch on the hind-wing.

Seven femalcs were cxamined: in six the result was negative or 
doubtful; in the other a slight scent was found and compared in the field to Stephanotis, but Mrs. Longstaff in the house said "(?) ginger."

The late Col. Bingham said, "The Danainae have without exception developed what to our senses, at any rate, is an acrid disagreeable odour and taste accompanied with a tough leathery consistency of body, that to a certain extent protects them from insectivorous enemies." I This species is exceptional among Danaines, having a decidedly agreeable scent, stronger in the male.

Chittira fumata, Butl. (taprobana, Feld.). (Ceylon, 1908). Out of four males and four females a scent was noted in two of the latter only, described in the field as "a slight musty scent," but on reexamination in the hotel compared to stale tobacco-smoke. In 1904 the results obtained were more positive- "it has the acetylene odour of Crastia core, but not so strong and with a difference." 2

Parantica aglea, Cram. (ceylanica, Feld.). (Ceylon, 1908). A distinct scent was detected in fifteen males out of seventeen, and in eleven females out of fourteen. In the male the scent varied from very slight to strong, twice indeed it was so strong as to be clearly perceptible when the insect was fluttering in the net. In quality it was in thirteen examples compared to acetylene (it being specially noted in one instance as "not Hamamelis"); in the other two specimens it is described as "acetylene plus cockroach," but these, when re-examined in the house, were described as "cockroach only" and "slightly musty" respectively. In six specimens in which there was a decided, or even strong, scent in the field, none was detected in the house; in others the scent at home was slighter, or described as "musty," but in one specimen it was compared to sweet hay. In all the eleven females the scent is compared to acetylene, with the remark in one instance "not so pungent as Euploca ascla." Two other female specimens were said to have a musty odour.

I am satisfied that in $P$. aglea the scent is more transitory, possibly more volatile, than in the majority of scent-yielding butterflies.

At Kandy in 1904, I had noted of this species : "I was surprised to find that a male, when fluttering in the net, gave out a strong scent like that of Crastia corc, i.c. very like acetylene."

Amanris albimaculata, Butl. (S. Africa, 1905). Dr. Dixey and the author were at one as to both sexes of this insect yielding a similar smell of musty straw, accompanied by an evanescent sharp or pungent scent like that of vinegar.

1 "Famm of British India: Butterflies," 1905, rol. i. p. 2.

See above, p. 118. 
[Amauris scheria, Boisd. (S. Africa). In this distinct, but closely allied species, Mr. G. A. K. Marshall found a strong smell which reminded him somewhat of that emitted by many Ladybirds.]

Euploea (Crastia) core, Cram. (India, 1903-4). A male had a faint scent that suggested to me rancid oil, or old lamps. Mr. Edwin Scott compared the strong scent of a male to acetylene. ${ }^{1}$ At that time I thought the scent was connected with the anal tufts. At Mítherán, 1908, I confirmed this scent in three males and two females; in one of the latter it is described as "musk-rat + acetylene," but in two specimens I noted the scent (when examined in the house) as like that of acetic acid, although in the same specimens I had in the field noted the odour of acetylene. Doubtless the scent has two elements, one more persistent than the other. One male was noted as emitting no scent though the tufts were everted.

Linploea (Crastia) asela, Moore. (Ceylon, 1908). In thirty-two out of thirty-cight males and in seventeen out of nineteen females examined a scent was noted in the field. In four males and one female my notes record that no scent was detected, as regards the others they are silent. Again, it is clearly recorded that on recxamination in the hotel in thirteen males and five females no scent could be detected, moreover when a scent was noted at home it was in the large majority of specimens (especially among males) much fainter than it had been in the field.

In both sexes the scent varied considerably in strength: it was, I think, quite as strong in the females as in the males, though certainly the three spccimens in which the scent was strong enough to be obvious through the net were all males. In one male the scent was described as not unpleasant; in five examples-one male, four femalcs-it is described as pungent and compared to acetic acid. To one female the note is: "strong pungent odour, acetic acid: distinct at home, still pungent (insect alive). The scent adhered to the fingers after pinching."

As with Parantica the scent of Crastia would appear to be more volatilc than in the Pierinac or in Danaida.

Having abundant material I made some endeavour to ascertain the source of the scent. Fifteen times it is noted that the malo genital tufts were fully everted when the insect was examined, nevertheless in five no scent could be detected, although in the others it was more or less strong. Thcre is a special note to one specimen: "the acctylcne odour secmed to come from the tufts," but,

I Soe above, pp. 95, 96. 
on the other hand, in four cases it is noted that the scent appeared to come from the wings, in one of these from their upper surface.

I then tried the effect of rapid dismemberment immediately after pinching:-

(a) A male seen on the wing with tufts displayed. It was caught, pinched and the abdomen amputated. The abdomen yielded no scent, but what I may term the torso had a slight acetylene scent, which appeared to come from the wings.

(b) A male with the tufts displayed: the amputated abdomen yielded no scent, but the wings a moderate acetylene scent.

(c) A male with the acetylene scent: amputation proved that it was certainly not connected with the abdomen.

(d) A male was dismembered: the scent appeared to come from the thorax.

(e) A female with pungent odour was dismembered: the scent appeared to originate in the thorax.

(f) A female was dismembered: the scent appeared to come from either the thorax or the base of the wings.

From these facts I am forced to the conclusion that in Crastia and in Tirumala the scent-which moreover is common to both sexes-whatever its source may be, is independent of the genital tufts which form such a conspicuous feature. This conclusion is contrary to my first impression-and certainly contrary to the impressions of such an experienced collector as Commander J. J. Walker, R.N.

Enploea (Crastia) amymonc, Godart, f. kinbcrgi, Wallgr. (China, 1904). The acetylene scent was noted in several males, once it was so strong as to be obvious as soon as the insect was in the net.

Euploea (Trepsichrois) midamus, Linn. (supcrba, Herbst.). (China, 1904). The acetylene odour of a female was perceptible when it was in the net.

[Euploea (Trcpsichrois) muleiber, Cram. (Borneo, 1903). Mr. Shelford found the crersible tufts in the male to be swectly scented.] ${ }^{1}$

Euploca (Padenma, Salpinx) Kollari, Feld. (Calcutta, 1903). A single male had a slight, peculiar, rather disagrceable scent.

Euploca (Salpinx) sinhala, Moore, considered by Bingham to be a local race of the preceding. (Ceylon, 1908). Two malcs wcre cxamined with the following results :-

(a) Acetylenc odour, moderate in the field, slight at home. (b) Modcratc acetylene scent in the field, none in the house. It 
was alive; on pinching it again the tufts were protruded and there was a momentary strong acetylene scent. Of course it does not necessarily follow that the scent einanated from the tufts.

Euploea (Narmada) montana, Feld. (Ceylon, 1908). Five males all had a strong, or at any rate decided, acetylene odour in the field; at home either no scent at all, or at most a faint musty odour. In one case the strong acetylene odour seemed to come from the upper surface of the body or wings, while there was a suspicion of a sweet scent (compared with some hesitation to sassafras) which seemed to come from the tufts. Two living females yielded an odour of acetic acid, which in one persisted slightly after death.

[Euploea (Danisepa) rhadamanthus, Fabr. (Assam, 1881). Of this species Wood-Mason says: "the eversible caudal rosettes of the males are finely vanilla-scented."]

\section{SATYRINAE.}

[Antirrhaea archaea, Hübn. (Brazil, 1878). Fritz Müller says the male emits a strong odour.]

Satyrus semelc, Linn. (England, 1903, 1904). Dr. Dixey and I are agreed that the male has a slight scent; he compares it to that of chocolate or sandalwood; to me it rather suggests snuff, or an old cigar box.

Epinephele janira, Linn. (jurtina, Linn.). (England, 1904). Dr. Dixey and I both think that the male had a very slight odour; to me it appears somewhat pungent, and suggests old cigar boxes.

Pararge megaera, Linn. (England, 1904, 1908). Dr. Dixcy detccts in the malc " a faint, but heavy, sweet odour suggestive of chocolate cream"; he connects it with the brand on the fore-wing. In a few specimens out of many I detected a slight odour of chocolate (not of vanilla), but am unable to connect it with the brand. Expericnce with this species makes mo feel quite certain that Dr. Dixey's nose serves him better than mine docs me.

Pararge schatera, Koll. (India, 1903). I suspected the existence of a very slight sweet scent, that appcared to be unlikc that of any othcr species examined up to that timc.

Melanargia galathca, Limn. (England, 1906). Two malcs had a slight but distinct musky scent.

Mycalesis safitza, Hew. (S. Africa, 1905). Dr. Dixey found in the tufts of the male of this butterfly a very strong odour of chocolate. I noted a similar sccnt, but not especially strong.

Mycalesis perspricua, T'rim. (S. Africa, 1905). D): Dixcy and I agreed that there was a strong odour in this butterfly, distinct from 
that of the last, but we were in only partial argrecment as to its character. However, we had but two specimens available.

Mycalesis mineus, Linn., f. polydeeta, Cram. (Ceylon, 1908). In two males exposure of the pencils of hairs on the hind-wings produced a strong scent, which I compared to burnt sugar, my wife to coarse brown sugar, or treacle.

[Myealesis suaveolens, W.-M. \& de N. (Assam, 1881). WoodMason notes: "The scent-glands and fans ... emitted a powerful and delicious odour resembling that of vanilla for some hours after the death of the insect."]

[Lethe rohria, Fabr. (Assam, 1881). Wood-Mason notes: "Thc males of this species emit a delicious vanilla-like scent.]

Yphthima ceyloniea, Hew. (Ceylon, 1908). In a few males of this abundant species a very slight scent of chocolate was detected.

Calisto zangis, Fabr. (Jamaica, 1907). In ten males, nearly all those examined, there was a scent varying from faint to strong, compared to treacle, chocolate, burnt sugar, or caramel, but in onc instance described simply as aromatic. The male of this species has a very conspicuous brand. Ten females were without scent.

Heteronympha merope, Fabr. (Tasmania, Australia, 1910). This butterfly is remarkable for the striking difference between the seres, the males are much the larger and handsomer insects. I found in four males a faint but distinct scent, of a sweetish character, somotimes suggesting treacle, sometimes tobacco. In eight fcmalcs I found a decided scent, sweet and flowery. Mry wife said, "sweetish, like some flower, not quite 'Syringa,' not so strong." I once compared it to Philadelphus, ${ }^{1}$ but in two othor specimens it seemed to me to have rather a balsamic charactcr. I do not recall any other butterfly in which the female has a sweet flowery scent stronger thau that of the male.

ELYMNIINAE.

[Elymnias undularis, Drury. (Assam, 1881). Wood-Mason noted that the males emit a strong odour resembling vanilla, the fomales bcing scentless.]

Elymnias fraterna, Butl, cousidered by Bingham to be an insular race of the proccding. (Ccylon, 1908). Four males had an odour like that of vanilla-sccuted chocolate: once M[rs. Longstaff comparcd it to very strong honcy, or coarse brown sugar.

1 Tho Mock-orange, Philadelphus coronarizs [Nat. Ord. Saxifragaccac], is commonly called "Syringa," a name more properly given to the Lilac, Syringa prersica [Nat. Ord. Olcaccac]. 
Morphinae.

[T7caumantis diorcs, Doubl. (Assam, 1881). Wood-Mason notes that the seent-fans of the male are vanilla-seented.]

[Stichophthalma camadeva, Westw. (Assam, 1881). Wood-Mason notes: "The gland, covered by a pateh of modified seales, and by an ereetile wisp of hairs on each hind-wing in the male, secretes a fluid that gives out a pleasant odour distinet from, but so faint as barely to be perceptible in the presence of, a much stronger odour (resembling that of sable fresh from the furrier's shop), which is common to the two sexes."]

[Morpho hercules, Dalm.; Mr. epistrophis, Hübn.; M. mcnelans, Linn.; MT. aetilltes, Linn. ; M. adonis, Cram. ; and M. cyttcris, Godart. (Brazil, 1878). Fritz Müller reeorded that the males of all these butterflies produced a very distinet odour, which in the last two species was most agreeable, resembling vanilla.]

Brassolinae.

[Fritz Müller (Brazil, 1878) noted very distinet odours in the males of various speeies of Caligo, Opsiphanes and Dasyophthalma, the odour being particularly strong in the latter.]

NyMphalinaE.

[Myscelia orsis, Drury. (Brazil, 1878). Fritz Müller observed an unusually strong odour in the males of this speeies, as well as in those of the next following.]

[Epicalia acontius, Linn. (Brazil, 1878).]

[Ageronia arethusa, Cram. (Brazil, 1878). Fritz Mïller noted a rather strong odour in the male.]

[Didonis biblis, Fabr. (Brazil, 1878). Fritz Muiller noted in 1876 that the male had a pleasant odour like heliotrope, the female an unpleasant smell; in 1878 he wrote : "so far as odours are eoneerned [this is] the most interesting of all butterflies that I know." There is a strong disagreeable odour eommon to both sexes. The males have in addition two other scents eomparable to heliotrope and musk respeetively ; the latter faint.]

I mueh regret that in the specimens of this handsome, and very conspicuous butterfly, which passed through my hands during the winter of 1906-7, I did not notice any seent.

[Prepona lacrtes, Hübn. (Brazil, 1878). Fritz Miller noted a listinct odour in the male. In 1876 he had deseribed this as " a not strong but unmistakable odour, like a bat."]

Byblia goetzins, Herbst. (S. Africa, 1905). Dr. Dixey found in the males a very distinct and agreeable odour of sweet chocolate with a suggestion of vanilla. I found a similar scent in the only 
specimen that I examined-a female. If the latter observation be correct it is remarkable.

Charaxes varanes, Cram. (S. Africa, 1905). Dr. Dixey's ${ }^{1}$ words are: "A o, on being squeezed, emitted an odourless juice. Another was noted by Dr. Longstaff as having a 'treacly' odour. A female was thought by him to have a smell like cow-dung. To me the scent of the same specimen recalled that of Danaida chrysippus." These results are not concordant; however, the observations were few in number.

Salamis anacardii, Linn. (S. Africa, 1905). Both sexes have an animal-like odour, suggesting to me rabbit-hutches; it appears to be stronger in the female.

Neptis agatha, Cram. (S. Africa, 1905). Dr. Dixey noted in three males from Natal, a strong and very disagreeable scent, like that of $D$. chrysippus, but more intense. Two male specimens which I took on the Zambesi had a slight scent, which I described as sweet. There is, moreover, according to Dr. Dixey, a difference in the aspect of these insects from the two localities.

Neptis jumba, Moore. (Ceylon, 1908). A faint sweet chocolate scent was detected in a male in the house. A somemhat similar scent was suspected in another male and in a female. On the other hand, no scent was recognized in the much commoner $N$. varmona, Moore.

[Hypolimnas misippus, Linn. (S. Africa, 1905). Dr. Dires detected in a male a smell like coffee, not very strong.]

Hamanumida dacdalus, Fabr. (S. Africa, 1905). Dr. Dixey and I agree that the male has a smell of the burnt sugar type.

Precis clelia, Cram. (S. Africa, 1905). I detected a treacly scent in a male.

Precis iphita, Cram. (Ceylon, 1908). Two males out of several examined yielded a slight treacly odour.

Precis almana, Linn. (Mátherán, India, 1908). A male had a slight sugary scent.

Cynthia ascla, Moore. (Ceylon, 1908). Five males out of eight had a peculiar, slight, sweet scent, compared at the time to sassafras, or to French-polish.

Victorina stclcncs, Linn. (Jamaica, 1907). Five males appeared to liave a slight flowery scent; in one it suggested Chrysanthemum.

Colcenis cillenc, Cram. (Jamaica, 1907). In eight males out of eleven examined there was a scent, decided, but never strong. Its character was noted as "peculiar," "sweetish," "pleasant," 'Proc. Ent. Soc. Lond., 1906, p. iv. 
" distinctly aromatic," "resinous," " drug-like," or " medicinal " ; it suggested to me at one time or another tar, Canada-balsam, and pure carbolic acid, but my wife compared it to ginger, or a mixture of ginger with jasmine. It is evident that this scent puzzled me greatly at the time, but subsequent experience with other scents makes me think that sassafras would probably be the best comparison.

Dione vanillae, Linn. (Jamaica, 1907). Of seventeen males examined thirteen exhibited an odour varying from very faint to very strong: in character this was distinctly disagreeable, and I noted it as "mpleasant," "like cow-dung," or "like asses," but more usually as "like a stable." My wife considered it "nnpleasant," or " offensive." Mr. Abell thought it "musky."

Dione juno, Cram. (Venezuela, 1907). A single male had a slight stable-like odour.

\section{Heliconitnae.}

[Fritz Müller (Brazil, 1878) says that the butterflies of this sub-family possess a disgusting odour, generally stronger in the female sex. Moreover he says that Colaenis and Dione cannot be separated from Heliconius and Eueides. He mentioned the occurrence of scents in these genera in his earlier paper, but without details. See Appendix, \$§ IX.-XII.]

Eueides aliphera, Godart. (Trinidad, 1907). Three males were examined: two with a negative result; the third was noted as having "a strong Dione scent," i.e. an odour like that of a stable, or of asses. Two females were also examined; they both had decided odours described respectively as:- " peculiar scent, (?) acetylene; strong when alive," and as "strong Dione scent when living; slight flowery scent when dead."

Heliconius euryacles, Riff. (Trinidad, 1907). Two males were examined: one had a peculiar, rather pleasant, smell, the other none. Two females were also cxamined, one with a doubtful result, the other had a slight odour like that of the species next mentioned, but it was only perceptible during life.

Heliconius hydarus, Hew. (Trinidad, Tobago, Veneznela, 1907). Eleven malcs were examined: three gave a negative result and one was doubtful, but the remaining seven had a scent which varicd from very slight to very strong, and was described as musty, like acetylene, or like hazeline (a preparation of Witch-hazcl, Hamamclis virginica). This last comparison, which struck me as good, is due to Mr. G. H. Sworder of Cocoa Wattie, Tobago, who was familiar with the scent of the bnttcrfly. Eight females wcre examined, only onc witl ncgative 
results; in the other seven the scent varied from slight to strong, and was described as "disagreeable," "like acetylene," or "like hazeline." In one male and one female the scent was so strong as to be easily discerned when the butterfly was fluttering in the net.

Five of the above butterflies were captured in Trinidad on April 14th, 1907, and were examined for scent when their enclosing papers were opened at Oxford on May 6th, or three weeks after death. One of them-H. euryades, q-had none; the others$H$. hydarus, 3 o, 1 f-had a slight, but quite decided, scent. Yet, curiously enough, in the case of two of these male hyclarns, I did not find it possible on the day of capture to be sure that they had any perceptible scent. Finally, when a drawer containing all my black and red Heliconii was opened on July 15th, or three months after death, the odour, though faint and evanescent, was distinctly perceptible in spite of the presence of naphthalene.

I have since heard from a professional setter of butterflies, whose name I do not know, that he had often noticed when setting Helieonii, that they had a peculiar scent.

Helieonius charithonius, Linn. (Jamaica, 1907). With this species the majority of observations gave negative results, nevertheless in three males and two females a slight pleasant flowery scent was detected. In one example of each sex this was confirmed by $m y$ wife, who described the odour as sweet.

\section{ACraEINAE.}

[Actinote thalia, Linn. (Brazil, 1878). Fritz Müller noted a disgusting odour in both sexes.]

In 1907 at Carácas I failed to detect any scent in Actinote antaeas, Dbl. \& $\mathrm{H}$.

[Planema aganice Hew. (S. Africa, 1905). Dr. Dixey stated that the green juice exuded from a male specimen had a by no means unpleasant odour like that of a crushed cabbage leaf.]

Aercaca alboradiata, Auriv. (S. Africa, 1905). Dr. Dixey and concur in stating that both sexes have a distinct musty odour, like old hay or straw.

Acruec anemosa, Hew. (S. Africa, 1905). Dr. Dixey and I are in substantial agreement. The males have a musty odour, which Dr. Dixey also found in a female. Mr. G. A. K. Marshall says that this is the only Aerceca in which he has noticed a strong odour.

Acraea eneedon, Linn. (S. Africa, 1905). I found a slight nupleasant odour in both sexes.

Acraen donbledayj, Guér. (S. Africa, 1905). Dr. Dixey and I coneur as to a musty odour in the male; I found it in the female also. 
Acraeci atolmis, Westw. (S. Africa, 1905). I found a faint odour in both sexes.

Acraca caldarenc, Hew. (S. Africa, 1905). Dr. Dixey found a distinct smell of musty straw in the female; I came across a slighter odour of similar character in a male.

[Acraea atergatis, Westwr. (S. Africa, 1905). Dr. Dixey found a similar musty odour, accompanied by a strong ammoniacal scent, like that of stable-litter. He does not mention the sex.]

\section{LYCAENIDAE.}

Lycaena icamss, Rott. (England, 1904). Both Dr. Dixey and myself have found in the male of the Common Blue a decided scent suggestive of chocolate sweetmeats.

Chrysophanus astrarche, Bergstr. (England, 1908). I found in a male the odour of chocolate, not flavoured with vanilla.

Cyaniris singalensis, Feld. (Ceylon, 1908). Six out of eight males had a scent of varying intensity, described in all cases as sweet, once as luscious, and once as Freesia-like.

Nacaduba atrata, Horsf. (Ceylon, 1908). Two males had a sweet flowery scent, confirmed by Mrs. Longstaff, and in one case compared by her to "very, very faint jasmine."

Lampides elpis, Godart. (Ceylon, 1908). Five males, all those examined, had a sweet scent, which in one specimen was compared (with some hesitation) to clover.

Lampides lacteata, de Nicév. (Ceylon, 1908). Nine males were examined, all had a distinct smell which was compared to vanilla biscuits, or chocolate sweets.

It is interesting to note that these two closely allied species have quite different scents.

Lampidcs celeno, Cram. (Ceylon, 1908). A minority of the numerous males examined had a faint sweet scent.

Catochrysops hanno, Stoll. (Jamaica, Trinidad, Tobago, Colombia, Panama, Venezuela, 1907). One male was noted to have a very strong, sweet, Frecsia-like scent, but most of my specimens of this tiny butterfly appeared to be odourless.

Polyommatus baeticus, Linn. (Ceylon, 1908). About half of the males examined had a slight scent like that of Meadow-sweet.

T'urucus theophrastus, Fabr. (Sûdân, 1909). A male had a moderately strong, sweet, luscious scent.

Polyniphe dumcnilii, Godart. (Venezuela, 1907). Ten males of this little black and white butterfly gave positive results of a surprising character. In the majority of cases the orlour was strong, or even very strong; moreover it was disagreonble; and I compared 
it to horse-urine, but more usually to pig-sties, or, perhaps more correctly, to pigs. At first it seemed scarcely credible that so small a butterfly could smell so strongly. My only female specimen was odourless.

Rapala lazulina, Moore. (Ceylon, 1908). Three males yielded a scent like vanilla biscuits.

Theclopsis tephrcueus, Hübn. (Venezuela, 1907). A strong peculiar, rather disagreeable odomr was detected in a male of this species.

Tmolus cambes, Godm. \& S. (Venezuela, 1907). I noted in a male a treacly smell; my wife compared it to coarse brown sugar.

Tmolus palegon, Cram. (Venezuela, 1907). A male had an odour of chocolate.

[Thecla atys, Cram. (Brazil, 1878). Fritz Müller found an unusually strong odour in the male of this species, also more or less distinct odours in various other species the names of which he did not know. In the case of T. atys (in 1876) he described the odour as "bat-like."]

PieirinaE.

Catopsilia pyranthc, Linn. (gnoma, Fabr.). (Assam, 1880; India, 1904; Ceylon, 1908). Wood-Mason noted that the tufts of hair on the wings of the male smelled like jasmine. I confirmed this in India, but thought that a closer comparison was to Polianthes tuberosa. After my second visit to Ceylon, in 1908, I wrote as follows :-

"The number of specimens taken was very much smaller than of pomona, but the scent was more easily detected in the male, and more decided in the female than in that species. In both sexes the scent was compared to Stcphanotis, but in one male to Frcesia, and in one female, Mrs. Longstaff thonght the odour was 'a little bit hair-oily.'"

Catopsilia pomona, Fabr. (crocale, Cram., catilla, Cram.). (Ceylon, 1904). I detected a slight jasmine-like scent in the male on stroking the "scent tufts" on the hind-wings.

(Ceylon, 1908.) The sweet scent associated with the fringes of the male was confirmed; this I compared to Frecsic, or Stephanotis. Ont of twenty-seven females examined the result was negative in eighteen, but in the other nine a slight, usually very slight, sweet scent without other special character was noted.

Catopsitia florclla, Fabr. (S. Africa, 1905). On exposure of the tufts of hair-like scales on the hind-wings a very strong sweet scent is emitted. Dr. Dixey compared it to Jasmine, I to Polianthes, or 
Freesia. (Sûdân, 1909). The scent in the male was confirmed, a faint odour was suspected in the female.

[Mctura cipris, Fabr. (Brazil, 1878).

Phoebis argante, Fabr. (Brazil, 1876, 1878).

Rhabdodryas trite, Linn. (Brazil, 1878).

Callidryas enbule, Linn. (Brazil, 1878).

Fritz Müller perceived a musk-like odour in the males of the above four species; it was unusually strong in cipris, very distinct in argante, faint in trite and eubule. In the females of argante and entbule he found a very strong peculiar odour, in which some volatile acid seemed to predominate.] I give my results :-

Phoebis agarithe, Boisd. (Tobago, 1907). Of three males examined, two yielded a scent noted as being "sweet, neither strong nor pleasant."

Callidryas excoule, Linn. (West Indies, Northern Coast of S. America, 1907). In no less than thirty-two out of the thirty-three males tested a distinct scent was readily perceived, indeed in the great majority of cases it is noted as strong, twice as very strong. In quality the scent was agreeable (Mr. Abell termed it delicious) and was compared by me to Stephanotis, or Freesia, but Fritz Müller had termed it musk-like; and Miss Murtfeldt had spoken of it as "a slight violet odour." I With the twenty-two females examined the result was very different; in nine it was negative, but in the remaining thirteen a scent was detected, which, though usually described as very slight, or slight, and never as strong, was often distinct enough. In quality the scent of the female eubule was disagreeable; somewhat sweet, but recalling bad pomade, or rancid butter, or butyric acid (as Dr. Dixey aptly suggested of another butterfiy).

Gonepteryx rhamni, Linn. (Algeria, 1905). Gonepteryx cleopatra, Linn. (Algeria, 1905). I give my observations on the scents in these butterflies in full, as originally published. ${ }^{2}$

"At Hammam Meskutine, Algeria, on March 15th, 1905, while examining my captures towards the close of the day prior to writing the data on their cnvelopes, I was struck with the swcet scent of a male Gonepteryx cleopatra, Linn. All the three dead specimens which I had taken that day had the scent, but in two it was faint. On March 19th, at Bougie, I confirmed this in a living specimen, describing the scent at the time as "swect, rich, thick-suggesting Freesia."

'Scudder, "Butterflies of the Eastern United States," vol. ii. p. 1047.

${ }^{2}$ Proc. Ent. Soc. Tiond., 1905, pp. xxxv., xxxvi. 
"At Hammam R'ihra I submitted living malc cleopatre to four ladies; one conld not detect the scent, another could not describes it, a third compared it to Primrose, the fourth compared it first to Gorse, then to faint 'Syringa' (meaning Philadelphus coronarives). Personally after more expcrience I hesitate between Freesio, and Philadelphus. Altogether up to March 31st, when it was getting over, I examined nineteen male $G$. clcopatra and found the scent quite distinct in all save one.

"Though not as abundant in Algeria as G. cleopatra, our more familiar $G$. vhamni is sufficiently common, and naturally I examined that species, or form, for scent. To my great surprise out of ten specimens examined not one had a scent at all like that of cleopatra, indeed in most of them I could detect no scent whatever: One day in the hotel garden at Hammam R'ihra, I caught within a space a few yards in extent, and within a quarter of an hour, five butterflies in the following order:-1 ot rhamni, 3 of cleopatra, 1 i rhamni; all the three cleopatra had the scent, but neither of the rhamni.

"The one specimen of cleopatra in which no scent was detected was tested on a day when my nasal mucous membrane was somewhat inflamed, moreover a neighbouring pig-sty was distinctly a disturbing element. For these reasons $I$ do not include in the above numbers 2 of rhamni examined under the same conditions with negative results.

"The living Goneptcryx can be easily held by the thumb belor and the forefinger above the thorax, the wings being expanded, and so examined without appreciable injury to the specimen, in a way that the more delicate structure of most butterflies renders impossible.

"These surprising results struck me so much at the time that I took care to assure myself that I was not deceived, but I trust other cntomologists will repeat the observations when opportunity offers. Such a difference in the scent of the two forms must imply a physiological differcnce that wonld point to a specific distinction.

"In North Devon on the 29th of May, 1905, T examined a o G. rhamni but conld detect no scent."

In the discussion which followed, Dr. F. A. Dixey said :-

"The facts relating to the scent of Goncpteryx clcopatra and G. rhamni which have jnst becn laid before us by Dr. Longstaff are of very grcat intercst, and certainly point in the direction of a real distinction betwecn the two forms. I have occasionally detected a slight scent in British specimens of G. rhamni $\hat{\delta}$, as recorded in our 
'Proceedings ' for 1904, p. lviii, but nothing like what Dr. Longstaff describes in G. cleopatra."

[Colias cdusa, auct. (England, 1900). Dr. Dixey determined the existence in the male of an odour which he compared to Heliotrope. $\left.{ }^{1}\right]$ Iu Algeria I failed to detect any scent in C. edusa.

Colias eleetra, Linn. (S. Africa, 1905). Dr. Dixey found in a male a scent like that which he had previously found in C. edusc. I found a somewhat less agreeable odour.

Colias nilgiriensis, Feld. (India, 1904). I suspected a slight scent in two males of this species.

Colias hyale, auct., f. marnoana, Rogenh. (Sûdân, 1909). I found a very slight scent in both sexes, and doubtfully compared it to chocolate sweets, or to cloves. It is well to add that, according to my experience, it is very difficult to detect scents in the genus Colicts; the volume of scent, if one may use the expression, seems to be very restricted, requiring the keenest sense for its apprehension. Dr. Dixey informs me that the hycle group of Colias is without "scent patches."

Terias cuterpe, Ménét. (Jamaica, 1907). I had ample opportunities of studying this very common Jamaican butterfly. Of twentyone females taken not one was scented, but thirty-one out of thirty-nine males indubitably were. Their odour varied from "very slight" to "strong" (seventeen specimens); my wife described it on various occasions as a slight pleasant smell," "strong, like Syriuga," "a very soft gentle smell, might be Jasmine," and "very slight, sweet, Jasmine or Syringa." Mr. A. P. Ponsonby, when out with me one day, suggested Gorse. To my own judgment the scent resembled rathcr Clove-pink, but was still more like Pink Bind-weed (Convolvulus curvensis, Linn.).

Terius delice, Cram. (Jamaica, Panama, Colombia, Venezuela, 1907), and T. phicule, Cram. (Venezuela, 1907). Results conflicting, but in the large majority of cases negative.

Terius albulu, Cram. (Trinidad, Tobago, Colombia, Venezuela, 1907). Results uniformly negative.

Terices nise, Cram. (Trinidad, Tobago, Panama, Venezuela, 1907). Out of cight males taken five had a scent, varying from very slight to very strong; it was compared to that of Pink Bind-weed. A slight scent was detected in a female specimen; this was confirmed by Mrs. Longstaff.

T'erias messulina, Fabr. (Jamaica, 1907). In six males out of ten a scent was noted; it is described in my notes as distinct or

' Proc. Ėnt. Soc. Lond., 1904, p. Ivii. 
strong, and compared to Pink Bind-weed and to spicc. It is also noted as "distinct from that of euterpe, more dusty, less specific," but another specimen "more spicy than Bind-weed."

Terias westwoodii, Boisd. (Jamaica, 1907). Only three males were taken; all had a scent, described in one example as "spice odour, not quite the same as euterpe."

Tcrias libythea, Fabr. (Ceylon, 1908). In several male specimens -at least five-a faint scent was detected, which I compared to that of Convolvulus arvensis.

Terias heeabe, Linn. (India, \&c., 1903-4, Ceylon, 1908). I failed to detect any scent in this common Terias or any of its allied forms.

[Leptalis thermesia, Godart. (Brazil, 1878). Fritz Müller says that the male emits a very strong odour disagreeable to human noses.]

[Leptalis astynome, Dalm. (Brazil, 1878). Fritz Müller found a similar but much fainter odour, in the male of this species.]

Leptalis (Enantia) melite, Linn. (Brazil, 1878). Fritz Müller found in this species also that the male had a faint disagreeable odour. My experience was different, the only specimen that I took (Venezuela, 1907) had a scent like Mignonette.

Meganostoma cerbera, Feld. (Venezuela, 1907). One out of three females taken is noted as having had "a slight, very sweet scent; (?) clover."

Ixias eingalensis, Moore. (Ceylon, 1908). The nine males examined all had a sweet, but only moderately strong scent, which reminded me of Meadow-sweet. Four females were scentless.

Hebomoia australis, Butl. (Ceylon, 1908). Nine males, all those examined, had a heavy sweet scent, in most of them strong, in all decided : my wife and I compared it to the flowers of Mango, or to Cinnamon. In three females out of four there was a similar scent.

[Tercuelus ione, Godart. (S. Africa, 1905). Dr. Dixey found the scent of the male not always easy to detect, but sweet and flowery.]

Teraeolnes protomedia, Klug. (Sûdân, 1909). The male has a distinct, scarcely agreeable scent, hard to describe.

Teraeolus annae, Wallgr. (S. Africa, 1905). Dr. Dixey sometimes found the scent of the male strong like "Syringa" (Philadelphus). I found it faint and like that of Ganoris brassicac.

Teracolus hatimede, Klug. (Sûdân, 1909), A dead male had a somewhat disagreeable odour.

Teracolus phisalia, Godart. (Sûdân, 1909). A dead male had a sweet, luscious scent. 
Teracolus daira, Klug. (Sîdân, 1909). A fcmalc had a scent like Clove-pink, both in the field and in the house.

Tcracolus oncphalc, Godart. (S. Africa, 1905). Both Dr. Dixey and I found in the males a "white-flower perfume," but the former usually found a musky constituent in addition.

[Teracolus achinc, Cram. (S. Africa, 1905). Dr. Dixey found in the males an odour like that of Honeysuckle.]

Tcracolus auxo, Lucas. (S. Africa, 1905). We both found a sweet scent in the males, which appeared to my companion to be "heavier" than it did to me.

Teracolus eris, Klug. (S. Africa, 1905). Each of us found a male with a distinct flowery scent.

Nepheronia ceylanica, Feld. (Ceylon, 1908). The male of this beautiful butterfly has a more or less distinct scent, which I compared to Freesia. A female had a similar scent, though slight, which my wife compared to Frangipani.

Nephcronia 7ippia, Fabr. (Mátherán, India, 1908). A fine male had a very slight burnt-sugar scent.

Eronia cleodora, Hübn. (S. Africa, 1905). Both Dr. Dixey and I found a flowery scent in the males, but, as in so many cases, my friend's conclusions were somewhat more positive than mine.

Euchloë cardamines, Linn. (England, 1905, 1906). In a few males out of many tested, I have found a fairly distinct, though faint scent, sometimes described as musky, once as very sweet.

Daptonoura lycimnia, Cram. (Venezuela, Trinidad, 1907). The three males taken all had a strong, sweet, flowery scent, suggesting Freesia. Of three females one bcars the note "rich sweet scent." There is no doubt whatever about the sex of the individual, neither can I suggest by way of explanation that the note really applies to another individual. This is perhaps the most marked of a very few exceptional cases in which a strong agreeable scent has been observed by me in a female Pierinc; for some time my own view was that in each such instance I had been deceived-possibly by a neighbouring flower, or by the scent of another butterfly adhering to fingers or forceps. However, in the case of D. lycimnia, Fritz Müller (Brazil, 1878) obscrved that the female during courting emitted from her genitalia an odour which he described as " rather faint, though quite distinct ... very different from that emitted by the wings of the male." Fritz Müller found the latter very delicious, but rather faint and often hardly distinguishablc.

[Daptonoura ilairc, Godart. (Brazil, 1878). Fritz Mïller obscrved 
a rather strong odlour in the malc. In 1876 he had said that the odour was faint.]

Pinacopteryx charina, Boisd. (S. Africa, 1905). Dr. Dixey and I occasionally found a flowery scent in the male of this butterfly; the compared it to Mignonette.

Pinacopteryx pigea, Boisd. (S. Africa, 1905). We both found a distinet, sometimes strong, scent in the inalc, like Honeysuekle.

Belenois gidiec, Godart. (S. Afriea, 1905). In some of the inales Dr. Dixey and I found a flowery seent, which he compared to that of roses.

Belenois mesentina, Cram. (India, 1904). The male was found to have a faint, sweet, flowery scent which did not appear to me to be quitc like that of any other insect. (S. Africa, 1905). Dr. Dixey found in a male a scent much like that: of $B$. gidica. (Sûdàn, 1909). Males were found by me to have a slight scent, sometimes described as musky, but once as luscious.

Belenois severina, Cram. (S. Africa, 1905). Both Dr. Dixey and I found much individual variation in the males. He compared their scent to sweet-briar; I thought it like that of $G$. brassicac, but stronger and more luscious.

Belenois thysa, Hopff. (S. Africa, 1905). Wc agreed that the males had a strong, distinet odour. Dr. Dixey compared it to that of roses, I rather to Bluebell (Scilla nutans), but sometimes to Frecsia.

Belenois teutonia, Fabr. (Australia, 1910). A slight scent was suspeeted by me in sundry males, but nothing at all definite.

Delias encharis, Drury. In India during the winter of 1903-4 I observed the scent of this speeies and compared it to that of Ganoris rapac, or sweet-briar. On that occasion I made sure of the scent in the male, and more than suspected its presence in the female.

My more recent experience (Ceylon, 1908) euables me to speak with greater confidence. Of eighteen malcs cxamined a scent was detected in scventeen; in four of these the scent was very slight, or indefinable, but in twelve it was strong, or very strong, and eompared to that of swcet-briar. Ont of ninc females cxamined in three no seent could be detceted, but in six spccimens there was more or less seent, but in no ease was it strong; this was deseribed as "swect," "dusty or musky," and " faint sweet-briar." Mrs. Longstaff said of the last specimen "very slight lemon-verbena; yes, perhaps more like sweet-briar" ; but of another speeimen she said, "it has a little gentle sort of sincll, (?) ginger, or (?) coarse brown sugar." 
[Delias hierte, Hübn,, var. indica, Wallgr. (Cachar, 1881). WoodMason noted that both sexes have a strong, grateful musk odour.]

Delias nigrina, Fabr. (Australia, 1910). A male was thought by me to have a very slight scent.

Leptophobia aripa, Boisd. (Venezuela, 1907). Seven males out of eight examined had a distinct or even strong scent, which I compared on various occasions to Orange, Freesia, and Mignonette.

Pieris calydonia, Boisd. (Venezuela, 1907). Three males of this species-all that I captured-had a distinct flowery scent, in one described as "like that of G. brassicae," in another as "somewhat sickly."

Pieris(Perrhybris) sp.—apparently undescribed-near sevata, Feld. (Venezuela, 1907). The only specimen taken, a male, had a "faint, sweet, flowery scent" (see above, p. 320).

Catophaga panlina, Cram. (Ceylon, 1904, 1908). The results of my 1904 observations were only in part confirmed. In both years the scent was noted in the male only; in 1904 it was described as "like sweet-briar, but swecter and more luscious," whereas in 1908 it was variously described as "sweet," "very sweet, (?) Freesia," "flowery," "decided Meadow-sweet," "decided Stephanotis," "extremely sweet."

Huphina nerissa, Fabr. (India, 1904; Ceylon, 1908). The results of many observations were concordant; the males have a distinct sweet-briar scent.

Ganoris napi, Linn. Of this species it is sufficient to say that its pleasant and very distinct scent is perhaps the best known of all, as it is the easiest to detect. Though very like the scent of Lemon Verbena, it is not identical with it. Out of forty-six male specimens examined at Mortehoe one summer the scent was present in all, but it was not present in any one of thirty-five females examined, though I am disposed to think that the female has a very faint scent more like that of $G$. rapae.

Many times I have known by the scent alone, the moment that I have got it into my net, that a small White was a male napi. There are but two other butterflies in which I have found the Lemon Verbena scent: they are Ganoris meletc, Méuét., and G. olcracea, Harr., butterflies which are usually held to be respectively the Japanese and North American forms of G.napi.

Ganoris rapae, Linn. (England, 1899 (Dixey), 1903, and later). There is no manner of doubt that the males of this very familiar species also have a scent. But it is not as obvious as in G. napi; the scent is neither as strong nor as distinctive. Originally Dr. Dixcy 
eompared it to that of Mignonette, but I think all are now agreed that Prof. Selwyn Image's eomparison to sweet-briar is better, though even that is not exact.

Ganoris canidia, Sparrm. (India, China, 1903, 1904). The male has a seent like that of $G$. rapae (see especially pp. 98, 127, supra).

Ganoris brassicae, Linn. (England, 1903, 1904). It is more difficult to deteet the seent in this than in either of our other common Whites, but neither Dr. Dixey nor myself have the slightest doubt of its existence. He eompared the scent to that of Scarlet Geranium petals; I eompared it to the flower of Rape. A lady visitor at Mortehoe suggested violet-powder-i.e. orris root-which is the best eomparison. The scent appears to be confined to the male.

Mylothris agathina, Cram. (S. Afriea, 1905). The males of this speeies have a strong, pleasant seent, exaetly that of sweet-briar.

Mylothris rïppellii, Koeh. (S. Afriea, 1905). We could neither of us make any distinetion between the seent of the males of this and the last speeies.

Mylothris trimenia, Butl. (S. Afriea, 1905). The scent of the male is quite distinet from that of the two preceding species. It reminded Dr. Dixey of Sweet-pea ; it reminded me of Clover.

Synchloë helliea, Linn. (S. Afriea, 1905). Dr. Dixey compared the scent of the males to that of Gorse. I recorded a male as haring a very slight, heavy, flowery odour. During a passing eall at Cape Town, in 1909, I caught a solitary male with a sweet odour which seemed to me to have a resinous element.

PAPILIONINAE.

Ornithoptera darsius, Gray. (Ceylon, 1908). When at Kandy four years previously Mr. W. G. Freedley, junr., told me that the males of this speeies had a seent like Sassafras, but I had no opportunity then of confirming his statement. Every male that I examined during my more recent visit had a scent, some had a strong seent. At first I compared this to Cinnamon and to Cauada-balsam; to Mrs. Longstaff it suggested Rosemary or "rose-scented hair-oil." Later by the kindness of the Apothecaries' Company of Colombo I reeeived through the post a sample of the oil of Sassafras, so that I made a direet eomparison, with the result that the odours of the oil and the butterfly appeared to be almost identieal. The female had an odour like musty straw.

Papilio hcctor, Linn. (Ceylon, 1908). The male has a musty odour.

Papilio aristolochiae, Fabr. (Assam, 1881). Wood-Mason noted in the male a strong and slightly pungent odour resembling that of 
(?) Bachelor's Buttons, or of the rose with a trace of acetic acid. (Ceylon, 1908). I found that both sexes have an odour like musty hay. To a male specimen there is a note: "decided disagreeable smell, (?) like new black net."

[Papilio doubledayi, Wallace. (Assam, 1881). Wood-Mason said that the male of this species had a musk-scented body.]

[Papilio dasarada, Moore. (Assam, 1881). Wood-Mason noted that the female had the strong scent of caged porcupines with a touch of musk.]

[Papilio astorion, Westw. (Assam, 1881). Wood-Mason noted in the female a strong and disgustingly rank musky odour.]

Papilio demodocus, Esp. (S. Africa, 1905). Both Dr. Dixey and I found an odour of fusty packing straw in both sexes of this species. I found it stronger in the female. Dr. Dixey sometimes found an element in the odour suggestive of cabbage-water, or a kitchen sink.

Papilio demolcus, Linn. (erithonius, Cram.). (Ceylon, 1908). A smell like fresh straw was detected in one specimen, a male; in another (a female) there was "a slight peculiar scent in the field: stronger in the house." At Mátherán (1908) a male had an odour like fresh straw.

Papilio dardanus, Brown. (S. Africa, 1905). The male has an odour of the musty straw type.

Pupilio telephrus, Feld. (Ceylon, 1908). A specimen had a slight sweet scent at home.

Papilio lyaeus, Doubl. (S. Africa, 1905). Some of the males examined had a scent which I described at the time as "sweet, luscious, flowery."

Papilio leonidas, Fabr. (S. Africa, 1905). Dr. Dixey thought the scent of the male to be like that of $D$. chrysippus, but $I$ found in several males what I described as a "strong sweet, "white-flowcr" scent, followed by something more spicy." The discrepancy must be admitted, but in all probability a greater supply of material would have cleared it up.

Papilio polydamas, Linn. [(Brazil, 1878). Fritz Müller found a very strong odour in the male scx. He goes on to say, "There appear to be two sets of males emitting equally strong, but quite different odours. This would be analogous to the case of the two sets of differently-coloured females in some species of this genus."]

(Janaica, Trinidad, Venezuela, 1907). I detceted an odour resembling that of musty hay, or straw, in two specimens of each sex. My wife comparcd the scent to Rue. My specimens were of the form $P$. polycrates, Hopff. 
[Papilio hyperion, Hübn. (Brazil, 1878). Fritz Müller found that the males had a very strong odour.]

[Papilio scamander (? grayi) Boisd. (Brazil, 1878). Fritz Müller found a strong, most agreeable odour in the males.]

[Papilio protesilaus, Linn. (Brazil, 1878). Fritz Müller found "a very strong, or rather disagreeable, odour, in the male."]

[Papilio nephalion, Godart. (Brazil, 1878). Fritz Müller found a faint agreeable odour in the male.]

Papilio parinda, Moore. (Ceylon, 1908). A male was noted as having a scent like tea, but nothing of the kind was observed in any other specimens examined.

Papilio polymnestor, Cram. (Mátherán, India, 1908). A male had a somewhat musty odour.

Papilio curimedes, Cram. (Venezuela, 1907). A male had a strong musty straw odour.

Papilio aeneides, Esp. (gargarus, Hübn.). (Trinidad, 1907). A living female had a smell of musty straw, which persisted after death.

[Papilio alcinous, Klug. (Japan, 1886). Of this species Pryer says: "The male emits a peculiarly sweet, musky odour when alive. The female also emits a faint odour, but to me this is as unpleasant as that of the male is pleasant." I I met with this insect near Nagasaki in 1904, but unfortunately did not examine it for scent.]

HESPERIDAE.

[Plesioneura eligius, Cram. (Brazil, 1878). Fritz Müller noticed in this species, as well as in a species of Achlyodes, that the pencil of long hairs on the hind tibiae of the males emitted a very faint odour.]

[Gegenes occulta, Trim. (S. Africa, 1905). Dr. Dixey found a vcry distinct chocolate scent in a male.]

As yet I have never been able to satisfy myself that any of the many Skippers examined are scented. It seems probable that some special manipulation may be requisite to elicit scents in this group. ${ }^{2}$

\section{§ 2. The Coloured Juice exuded by certain Lepidoptera.}

It has long been known that some butterflies, notably Danainac and Acracinac, yield a copious yollow or green juice on pinching, and this has been commonly associated with the known, or suspected, distastefulness of the insects themselves. ${ }^{3}$ A deroted student of

"H. Pryer, "Rhopalocera Niphonica", 1886, p. 4 ; see also p. 135, supra.

2 Seo $\Lambda$ ppondix, § VII.

${ }^{3}$ Seo Dixoy, Proc. Ent. Soc. Tsond., 1906, pp. iii., iv., vi., vii. 
entomology, the late Prof. Félix Plateau, ${ }^{1}$ tried to get to the root of the matter by eating, or at any rate chewing, Abraxas grossulariatce and its larva and pupa. Mr. Marshall has also tried many tasting experiments with South African butterflies. ${ }^{2}$ The results were in both cases inconclusive. Prof. Poulton thinks that this is only what might have been expected, since we have no right to suppose that a given butterfly tastes the same to us as to an insectivorous bird. It might be added that the likes and dislikes of our domesticatod mammals differ from our own. I must confess that no enthusiasm has so far availed to bring me to the point of chewing a butterfly. However, occasionally I have ventured to taste a minute drop of the yellow liquid, with somewhat unsatisfactory results.

Telchinia violae, Fabr. (India, 1904). "When injured a yellow juice exudes; a minuie drop of this placed on the tongue tasted somewhat bitter and disagreeable, but the flavour was by no means strong." 3 (Ceylon, 1908). "The yellow juice slightly bitter."

Crastia asela, Moore. (Ceylon, 1908). In two males the juice was found to be tasteless: in another it had a slight, (?) bitter taste. In two females it was noted as "nearly tasteless," "tasteless, or nearly so."

Pademma sinhala, Moore. (Ceylon, 1908). The yellowish juice of a male is recorded as "(?) tasteless."

Trepsichrois midamus, Linn. (superba, Herbst). (Hong-Kong, 1904). "The yellow juice expressed by pinching has no marked taste."

Acrcee natalica, Boisd. (S. Africa, 1905). The yellow juice slightly acrid.

A yellow juice, similar in appearance, has been noted in certain Heterocera believed to be distasteful. I give the instances which have attracted my attention.

Obeidia tigrata, Guen. (Hong-Kong, 1904). A conspicuous dayflying Geometer, allied to our Magpie-moth. Of this my note is: "Has a somewhat slow flight, and on the wing looks like a yellow butterfly; abundant and decidedly gregarious, many flying about one tree in the afternoon. When pinched it exudes a yellow juice having a bitter taste." I do not appear to have examined it for scent, but, whether or no it possesses an evil odour, it has other characteristics of a distasteful species.

Cartaletis libyssa, Hopff. (S. Africa, 1905). Dr. Dixey noted of

IMem. de la Soc. Zool. de France, Tomo vii., 1891, p. 375, § 7.

'Trans. Ent. Soc. Lond., 1002, pp. 105-414.

${ }^{3}$ Sce abovo, p. 88. 
this remarkable Geometer, "which no doubt belongs to the synaposcmatic group headed by $D$. ehrysippus, exuded when pinched a yellowish juice like that of an Acraea. The juice was scentless." 1

Eusehema transversa, Walk. (Ceylon, 1908). Of this handsome, very slow-flying, diurnal Geometer I recorded that it was extremely tenacious of life, but that its yellow juice was tasteless.

Chalcosia venosa, Walk. (Ceylon, 1908). This day-flying moth flutters much about trees (especially Litsaea zealanica, N. ab. E.), moving, however, faster from one tree to another, when its flight is somewhat "vapouring." It is tenacious of life, resisting alike pinching and chloroform. It has a peculiar, faint, disagreeable odour, and exudes a yellow juice, the flavour of which still invites investigation.

Deilemerce (Nyctcmera) annulata, Boisd. (New Zealand, 1910). This abundant moth is very tenacious of life; when pinched a yellow juice exudes which is tasteless, and if not also inodorous, very nearly so.

In contrast to these somewhat ambiguous results is the conspicuous S. African Acridian, Phymateus leprosus, Serv., which when touched emits copiously from the mouth a dark olive-green, very fetid fluid; accidentally tasted, this proved to be both bitter and unpleasant. ${ }^{2}$

\section{§3. Tie Tenacity of Life of Protected Species.}

That the Danainae and some other butterflies have unusually tough integuments which enable them to resist injuries such as would rapidly prove fatal to the butterfly of ordinary constitution has been long well known. ${ }^{3}$ So far the undou'bted fact rests to a great extent upon general statements, but it has occurred to the writer that it may be capable of approximate numerical expression.

With tropical collectors it is a familiar experience that at the close of the day, on opening the paper envelopes to cxaminc their captures, many of the buttcrflies are found to be still living. It is an equally general experience that this is cspecially frequent with Danainae.

It has for some time past becn my practice to enter in my notebook against the data referring to such long-lived individuals, "Tcn. vit." (Lcrax vitae). During my visit to Ceylon in the carly montlis

1 Proc. Ent. Soc. Lond., 1906, p. vi.

2 Soo above, p. 204.

"Seo c.g. Poulton, "Essays on Evolution," 1908, pp. 279. 316. Cf. Bingham, "Fauna of British India: Buttorllies," 1905, vol. i., p. 2. Also Marshall, Trans. Ent. Soc. Lond., 1902, pp. 322, 323. 
of 1908 , I paid closer attention to the matter than previously, and feel confident that in the large majority of cases when a butterfly survived the first pinching the fact was duly rccorded. The converse fact, that the insect was found dead in the envelope, was very rarely noted.

Somebody will doubtless lodge the plausible objection that many of the butterflics in the table are large insects: consequently that they should often survive a pinch, such as proved almost uniformly fatal to smaller species, is only what might have been expected. This objection is disposed of by the fact that such a large butterfly as Cynthice asela, Moore, was never (thirteen specimens) found alive in the paper at the end of the day; the same is true of Cethosice nietneri, Feld. (nine specimens), and of the robustly made and swift-flying Hebomoia australis, Butl. (thirteen specimens). Again, Catopsilia pomona, Fabr., is a fairly robust butterfly, yet out of forty-nine specimens three only, a $f$ and two $q$, were noted as tenacious of life.

From my note-books and previously published papers I find that this resistance to death has forced itself upon my attention in the following species :-

Trepsichrois midamus, Linn. (Hong-Kong, 1904).

Crastia amymone, Godart, f. Kinbergi, Wallgr. (Macao, 1904).

Danaida chrysippus, Linn. (India, 1903, Sûdân, 1909). Noted as resistant to cyanide as well as to pinching.

Parnassius hardwickii, Gray. (Himálaya, 1903). Delicate looking though it be, it is strangely tenacious of life. ${ }^{1}$

Telchinia violae, Fabr. (India, 1904).

Chittira fumata, Butl. (Ceylon, 1904).

Acraea cabira, Hopff. (S. Africa, 1905). Noted as resistant to chloroform as well as to pinching. ${ }^{2}$

Danaida archippus, Fabr. (Jamaica, 1907).

Danaida eresimus, Cram. (Venezuela, 1907).

Danaida jamaicensis, Bates. (Jamaica, 1907).

Heliconius churithonius, Linn. (Jamaica, 1907). Mr. P. A. Buxton writes that he found this species and the preceding hard to kill.

Heliconius hydarus, Hew. (Venezuela, 1907).

Actinote antaeas, Dbl. \& H. (Venezucla, 1907).

1 In the discussion which followed tho roading of tho prper Dr. Chapman remarked that threo or four pinches scarccly availcd to kill tho common Alpine Parnassius apollo, Linn.

${ }^{2}$ Mir. W. S. Loat, quotod by Dixoy, Trans. Ent. Soc. Lond., 1903, p. 119, says of Acraea vinidia, How., on the Whito Nile, "takes a long time to dio whon put in tho
killing.bottle." 


\section{Observations in Ceylon.}

An examination of the following list of observations in Ceylon, January to March, 1908, shows, among other things, that whereas three-quarters of the specimens of Papilio hcetor taken, and threefifths of those of $P$. aristolochiae, are recorded as tenacious of life, this is not noted of any of the nine specimens of $P$. polytes, five of $P$. mooreanus, four of $P$. dcmoleus, three of $P$. teredon, seven of $P$. crino and fourteen of $P$.agamemnon.

DANAINAE.

Parantica aglea, Cram. . . . . . . 31 . . 17

Tirumala septentrionis, Butl. . . . . 18 . . . 9

Pademma sinhala, Moore . . . . 2 . . 2

Narmada montana, Feld. . . . . . 6 . . . 4

Crastia asela, Moore . . . . . . 51 . . . 33

core, Cram. (Mátherán) • . 6 . . . 4

Chittira fumata, Butl. . . . . . . 8 . . . 2

Danaida plexippus, Linn. . . . . . 1 . . . 1

PaPilioninaE. chrysippus, Linn. . . . . . 4 . . . 0

Ornithoptcra darsius, Gray . . . . 9 . . . 4

Papilio hector, Linn. . . . . . . . 8 . . . 6

aristolochiae, Fabr. . . . . 15 . . . 9

parinda, Moore . . . . . 13 . . 4

lankeswara, Moore . . . . 3 . . . 1 jason, Esp. . . . . . . . 3 . . . 1

teredon, Feld. . . . . . . 3 . . . 0

crino, Fabr. . . . . . . . 7 . . . 0

agamemnon, Linn. . . . . . 14 . . 0

polytes, Linn. . . . . . . . 9 . . . 0

mooreanus, Rothsch. . . . 5 . . . 0

demoleus, Esp. . . . . . . 4 . . . 0

ACRAEINAE.

Telchinia violac, Fabr. . . . . . . 10 . . 3

NYMPHALINAE.

Hypolimnas bolina, Linn. . . . . . 9 . . . 2

Pierinae.

Delias eucharis, Drury . . . . . . 26 . . 3

Catopsilia pomona, Fabr. . . . . . 45 . . . 3

HeTEROCERA.

Chalcosia venosa, Walk. . . . . . 12 . . 4

Deilemera nigrovenosa, Moore . . . . 4 . . . 2

Euschema transver'sa, Walk. . . . . 2 . . . 1 
To this list I may add Deilemera annulata, Boisd., an abundant New Zealand moth, of which I noted in 1910, "This conspicuous, slow-flying, abundant Hypsid moth is decidedly tenacious of life." 1

The conspicuous Venezuelan Geometer Josiomorpha cruciata, Butl., comes into the same category.

So far as my observations go there is no difference in the powers of the two sexes of the butterflies here dealt with to resist injuries.

\section{\$4. Butterfles bearing Marks of the Attacks of Foes.}

This very interesting bionomic point we owe almost entirely to Prof. E. B. Poulton, F.R.S., and Mr. G. A. K. Marshall. ${ }^{2}$ The following lists of butterflies presumably injured by enemies, noted by me in the course of my travels, amply prove Prof. Poulton's statement that if only looked for many such specimens may easily be found. In nearly every case the injury is symmetrical, i.e. affecting the corresponding parts of both right and left wings, so that the probability of the injury being the result of accidental damage during flight by branches or thorns is very small.

It will be seen that it is nearly always the hind-wings that have borne the brunt of the attack.

\section{Observations in India, 1903-4.}

Precis lemonias, Linn. (a) Right hind-wing; ? lizard. (b) Anal angles of hind-wings, symmetrically.

Precis almana, Linn. Large pieces missing from both hind-wings, in part symmetrical.

Hypolimnas misipmes, Linn. of. Both hind-wings, injury in part symmetrical.

Pyrameis cardui, Linn. Apex of both fore-wings, and anal angle of left hind-wing.

Vanessa kashmirensis, Koll. A large piece of hind margin of hind-wings bitten out square, sparing the anal angles; ? lizard.

Orsotricena meda, Fabr. A well-marked bite on hind margins of hind-wings above anal angle; closely corresponding.

Yphthima hïbneri, Kirby. The whole of the hind margin of both hind-wings bitten off ncarly symmetrically.

1 See above, p. 448.

"Poulton, "Essays on Evelution," 1908, pp. 270, 281-283, 325, as woll as the references there given. Even Prof. Punnett admits the oogency of this line of argument, but considers that the injurios are mainly due to Lizards. Spolia Zcylanica, vol. vii., Part xxv., p. 12 (1910). 
Curctis thetis, Drury. (No details recorded.)

Ilerda epicles, Godart. 9 . All the hinder part of hind-wings.

Pratapa deva, Moore. Anal angles, tails and large part of hindwings bitten off absolutely symmetrically.

Polyommatus baeticus, Linn. Two-thirds of hind-wings gone.

Colias fieldii, Ménét. ․ Hind-wings possibly bitten by a birdsomewhat symmetrically.

Catopsilia pyranthe, Linn. A symmetrical bite out of both hindwings.

Ixias pyrene, Linn. o. Fore-wings almost symmetrically bitten near the tip of the costa.

Terias heeabe, Linn. ․ "Bird-pecked."

Terias laeta, Boisd. Dr. Dixey wrote: "Is prettily mutilated by a bird."

Ganoris canidia, Sparrm. ․ All the hind margin of the hindwing (? wings) gone.

Belenois mesentina, Cram. q. Hind margins of hind-wings symmetrically bitten: ? by lizard.

Teracolus ctrida, Boisd. o. Apex of left fore-wing, all its hind margin, and apex of left hind-wing gone: ? a case of successful "direction."

Papilio hector, Linn. A remarkably symmetrical bite of the tip and half hind margin of both hind-wings. The very "warning marks" snapped at.

Papilio pammon, Linn. ㅇ. Bitten by bird.

Observations in Ceylon, 1904.

Tirumala septentrionis, Butl. A 9 with hind-wings much broken, but only in part symmetrically; a with a double bite near the anal angles of the hind-wings.

Cirrhochroa cognata, Moore. The hind-wings very symmetrically chipped near the anal augles : ? by bird.

Hypolimnas bolina, Linn. of. Anal angles of the hind-wings injured, in part symmetrically.

Argynnis hyperbius, Johauss. (niphe, Limn.), f. Apex of both hind-wings and anal angles of both fore-wings symmetrically bitten.

Lethe drypetes, Hew. (a) Hind margin of hind-wings bitten of' in fair agreement. (b) Both hind-wings bitten at amal angle.

T'erias hecabe, Linn. ․ Hind-wings bitten more or less symmetrically. 
Catophaga paulina, Cram. of. A symmetrical injury to the tips of the hind-wings.

Papilio aristolochiae, Fabr. The tips of the hind-wings bitten off in striking symmetry.

Papilio dissimilis, Linn. Anal angles of hind-wings and more bitten off fairly symmetrically.

\section{Observations in China, 1904.}

Papilio paris, Linn. Large pieces bitten out of fore and hindwings almost symmetrically.

\section{Observations in Japan, 1904.}

Blanaida goschkevitschii, Ménét. The anal angles of both hindwings symmetrically bitten off, otherwise in fine condition.

Gonepteryx rhamni, Linn. §. Symmetrically pecked by a bird, all four wings implicated.

It will be noted that this list includes no Dancida nor Euploea, but does include two Tirumala septentrionis, and two Papilios with conspicuous red "warning marks."

In Ceylon a bird was seen to make a swoop at a male Catophaga paulina, but missed it. I may here add that at Yokohama, May 19th, 1904, I saw a dragon-fly of moderate size, Orthetrum japonicum, Uhler, carry off a Blanaida goschkevitschii, a butterfly resembling a very large Pararge megcuera, which did not appear to struggle at all.

Observations in Algeria, 1905.

Euchloë belic, Linn. q. Very sharply-cut snip out of each hindwing, larger on left: ? by bird.

Ganoris brassicae, Linn. Caught fluttering about flower-bed close to the ground, had been nearly done to death by a (?) bird; nearly the whole of both hind-wings and three-fourths of the forewings gone.

\section{Observations in South Africa, 1905.}

P'recis scsamus, Trim. A piece out of one hind-wing.

T'arucus telicanus, Lang. ?. Fore-wings injured: ? by bird.

Pinacopteryx charina, Boisd. o. (a) Anal angles of hind-wings bitten : ? by lizard. (b) Both anal angles of hind-wings bitten off: ? by lizard. 
Neotropical Butterflics (West Indies, Venezuela, etc.), 1907.

Euptyehia pharella, Butl. A small symmetrical injury to tips of fore-wings : ? by bird.

Euptychia hesione, Sulz. Symmetrical injury to middle of hindwings : ? by bird.

Anartia jatrophae, Linn. A big unilateral injury involving both right wings, noted before capture.

Cystineura doreas, Fabr. Symmetrical injury to tips of hind-wings.

Didonis biblis, Fabr. ․ Injury to anal angles of both hind-wings.

Myscelia cyaniris, Hew. Symmetrical injury to hind-wings: ? by bird. lizard.

Aganisthos orion, Fabr. Symmetrical injury to hind-wings : ? by

Colacnis cillenc, Cram. $\delta^{*}$ (a) Nearly symmetrical injury to anal angles of fore-wings. (b) Symmetrical injury to hind-wings: ? by lizard. wings.

Heliconius charithonius, Linn. of. Symmetrical injury to hind-

Theela togarna, Hew. 9 . Symmetrical injury to hind-wings, involving lobes and tails.

Glutophrissa drusilla, Cram. of. Symmetrical injury to both hind-wings : ? by lizard.

Terias delia, Cram. ․ Symmetrical injury to hind-wings.

Terias messalina, Fabr. ‥ Symmetrical injury to hind-wings.

\section{Observations in Ceylon, 1908.}

Crastia asela, Moore, . . Nearly all hind-margin of right fore-wing and apex of right hind-wing gone.

Crastia core, Cram. (Mátherán, India). Symmetrical injury to hind-wings.

Narmada montana, Feld. o. Symmetrical injury to fore-wings.

Yphthima eeylonica, Hcw. Small symmetrical injury to forewings: ? by bird.

Melanitis leda, Linn. Symmetrical injury to anal augles of forewings : ? by bird.

Ncptis varmona, Moore. Symmetrical injury to forc-wings: ? by lizard.

Cethosia nietneri, Fcld. . . (a) Symmetrical iujury to middle of hind-wings. (b) Symmetrical injury to tips of fore-wings. 
Cynthia ascla, Moore. (a) ?. Large symmetrical injury to hindwings : ? by lizard. (b) \&. Symmetrical injury to hind-wings : ? by bird.

Cirrhochroa cognata, Moore, $q$. Symmetrical injury to hindwings.

Hypolimnas bolina, Linn. (a) q. Symmetrical injury to forewings : ? by bird. (b) of. Symmetrical injury to tips of fore-wings.

Pyrameis cardui, Linn. of. Symmetrical injury to hind-wings: ? by lizard.

Lampides celeno, Cram. §. Symmetrical injury involving whole hind-margin of hind-wings and an angular piece of fore-wings : ? by lizard.

Delias eucharis, Drury, ‡. Symmetrical injury to hind-wings.

Catopsitia pomona, Fabr. (a) o. Two symmetrical (?) bites involving both hind-wings. (b) \%. Symmetrical injury to hind-wings : ? by bird. (c) d. All four wings syrnmetrically injured by one small bite : ? by bird.

Ornithoptera darsius, Gray, q. Long narrow symmetrical injury to hind-wings : ? by bird.

Papilio agamemnon, Linn. Symmetrical injury to hind-wings: ? by lizard.

\section{Observations in India (Mátherán), 1908.}

Crastia core, Cram. A male with a symmetrical injury involving both hind-wings.

Zezius (Thecla) chrysomallus, Hübn. A male had been bitten.

Observations in thc Sûdân, 1909.

Colias hyale, auct., f. marnoana, Rogenh. (a) Symmetrical injury affecting fore and hind-wings. (b) Injury involving all four wings.

Belenois mesentina, Cram. ‡. A large piece out of all four wings. Teracolus halimede, Klug. A large piece out of one hind-wing.

\section{\$5. Experimental Evidence as to the Palatability of Butterflies.}

The following experiments, conducted at the suggestion of Prof. Poulton, are a small contribution to the mass of facts accumulated by Mr. G. A. K. Marshall and Mr. Frank Finn. ${ }^{1}$

1 Marshall, Trans. Ent. Soc. Lond., 1902, pp. 297-397; Finn, Journ. Asiat. Soc. Bengal, lxiv. Pt. ii. 1895, p. 344 ; Ixv. Pt. ii. 1896 , pp. 42 ; lxvi. Pt. ii. 1897, pp. 528, 613,667, 668; quoted by Poulton, "Essays on Evolution," 1898, pp. 269, 317. See also Marshall, Trans, Ent. Soc. Jiond., 1908, pp. 137-142. 
At our hotel at Kandy were two Mainas (Gracula), talking birds of the Starling family (Sturnidae). These birds, which were very tame, were confined in two fairly roomy cages three or four yards apart. I will call the birds $\mathrm{A}$ and $\mathrm{B}$.

None of the butterflies offered to the birds was stiff; all had been killed earlier in the same day.

January 19, 1908. Bird A was given 5 dead butterflies in the following order:-Atella phalantha, Polyommatus baeticus, Loxura arcuata, Neptis varmona, Telchinia violae. The bird gave the Loxura a few pecks and then let it alone. The tough integument of the Telchinia seemed to give the Maina much trouble, but it showed no evidence of disgust. The other three butterflies were taken greedily, the bird, like Oliver Trist, obviously asking for more. It shook the butterflies as a dog shakes a rat.

January 21, 1908. Bird A appeared to be very anxious to be fed. I gave it a dead Catopsilia pomona, $q$, which was pecked to pieces: next a dead Parantica aglea, it ate its abdomen: then a dead Papilio aristolochiae, after giving this several pecks it was left and not touched again. I then gave it two Crastia asela, both alive; the fact of life seemed to interest the bird and it tried each of the specimens twice, but then appeared to be disgusted and refused even to look at any of the following, of which dead individuals were put into its cage: Papilio agamemnon, Jomides bochus, a small Lycaenid (probably either a Catochrysops or a Nacaduba), Loxura arcuata and Neptis varmona.

Same day. Gave bird B a dead Atella phalantha, which it ate; after this a living Crastia ascla, it pecked this several times but did not eat it.

January 23, 1908. Bird A was busy preening its feathers and appeared to have just been fed; I could not attract its attention. While thus engaged bird B sought to attract my attention, so I gave it in succession dead specimens of:-Ergolis sp., Tclchinia violae, Delias cucharis and Papilio aristolochiac. It gave the two first a few pecks; the Dclias it pecked once or twice, but it gave the Papilio a single peck only. Perhaps it was not hungry.

I then put the last two butterflies into the cage of bird $A$. It pecked the Dclias several times, but the Papilio only once or twice. After this it declined even to look at the Papilio any more, but came to the front of its cage uttering again and again sounds ridiculously like "No good! No good!" 
February 2, 1908. Gave Maina A a dead Nissanga patnia which it appeared to eat.

February 4, 1908. The Mainas had evidently been fed; there was food in their cages, which bird $\mathrm{A}$ had upset.

Gave $\mathrm{A}$ an Ergolis sp., which it ate.

Gave B a Nissanga patnia; it ate it.

Offered a living Hypolimnas bolina, of, first to one bird, then to the other; each pecked its wing, but no more.

Bird A would not look at Cirrhochroa cognata.

I came to the conclusion that the birds were not hungry, and therefore the observations of little value.

February 7, 1908. Offered to two young chickens first a Papilio aristolochiae and then a $P$. polytes, s. One of them looked at the first-named and then walked away; neither looked at the polytes.

The same two butterflies were then offered to Maina A, which pecked at both several times, then wiped its beak and left them.

This day's experiments were considered unsatisfactory at the time; it was nearly 6.0 p.m., and perhaps the birds were sleepy.

February 14, 1908. Gave bird A a Lampides sp.; it ate it and looked about for more.

February 15, 1908. Gave bird A two Yphthima ceylonica and one Lampides sp.; it ate them all three. A Neptis varmona was then offered to the same bird, which gave it but one peck. The Neptis was then offered to bird B, which also gave it one peck.

February 16, 1908. Gave to bird A three butterflies, Lampidcs sp., another Lycaenid (species not noted), and a Nissanga patnia: it ate them all up completely. Another specimen of the Nissanga was swallowed at the second attempt. An Ergolis sp. was also eaten and swallowed. I then offered the same bird a Papilio aristolochice, this after a peck or two was left. The same specimen was then offered to bird $B$, which would not touch it. It was then handed back to bird $A$, which gave it another peck and again left it.

So far as these experiments teach anything, it would appear that these Mainas would eat with relish Nissanga patnia, Yphthima ceylonica, Atella phalantha, Ergolis sp., and Lampides sp.

On the other hand, Papilio aristolochiac and Crastica ascla wero distinctly distasteful. 
The evidence as to the other species experimented with fails to convince me one way or the other.

During the summers of 1909 and 1910 Mr. R. I. Pocock, F.P.S., conducted an important series of experiments in the gardens of the Zoological Society of London. Butterflies of many species, a few Moths, Lepidopterous larvae; conspicuous Beetles, such as Carabus, Timarcha, Rhagonycha, and Coccinella; Bees and Dipterous flies that appear to mimic them, as well as several creatures belonging to other groups, were offered to various Mammals and Reptiles, as well as quite a large number of Birds.

Mr. Pocock, after explaining the difficulties attending his experiments, says: "Two facts struck me very forcibly. . . . The first was the exceeding keenness of the birds for the insects brought to them. ... The living prey was evidently a great treat to them; and over and over again I was impressed with the persistence shown by birds in persevering with insects that were obviously not to their liking, returning to the morsels repeatedly as if food of such a nature was too good to be wasted ... it is quite clear that the plain record of an insect being eaten is no proof of its palatability. Better evidence ... is supplied by the behaviour of the bird towards it. . . . The second fact ... the insectivorous birds in our aviaries seemed to know at once what the butterflies were; they were on the alert the moment one was liberated and pursued it with determination and precision, folloming its every turn and twist, and either catching it upon the wing or pouncing upon it after settling. ... Again, unless the species of butterflies used for the experiments are, or were in the past, habitually preyed upon by birds, whence comes the extraordinary skill the liberated specimens ... displayed in dodging the swoop of the birds in mid-air? ... With regard to the experiments on mimicry, especially those made with Volucella bombylans and Bombus hortorum, it appears to me that they satisfy all that the theory, as propounded by Bates, demands. . . . They show that several species of birds, after learning by experimental tasting that Bombus hortorum is unpalatable, refused to touch Volucella bombylans." 1

The paper deserves careful perusal, and the writer is proud to have been able to supply some of the material for the experiments.

1 "On the Palatability of Some British Insects, etc.," R. I. Pocock, F.R.S., etc. With notes by Prof. E. B. Poulton, F.R.S. Proc. Zool. Soc. Lond., 1911, pp. 809-868. 
§6. Mimics in the Field deceiving MaN.

It may not be without interest to record a number of cases in which a collector with defective eyesight has actually been deceived (at any rate momentarily) by Mimics in the field.

Benares, November 30, 1903. When I first captured Hypolimnas misippus, 9 , I believed it to be a variety of Danaida chrysippus, and I think it probable that other specimens were passed over, as males were very common.

Anántapúr, February, 1904. This note was made: "Several times saw the of $H$. misippus reconnoitring $D$. chrysippus as if in doubt as to its identity."

Malakand, October 29, 1903. Argynnis hyperbius, o, flying about flowers was noticed to resemble Danaida plexippus, which was in abundance at the same flowers, though in this case there was no actual deception.

Konúr, Nilgiris, February, 1904. On one occasion I watched for some time a female of Argynnis hyperbius, under the impression that it was Danaida chrysippus. The resemblance on the wing is greater than might be supposed.

Horton Plains, Ceylon, March 23, 1904. The female Argynnis hyperbius on the wing looked very like Danaida chrysippus.

Hatton, Ceylon, March, 1908. The following extracts from my notebook point to the striking difference in the general look of the two sexes of $A$. hyperbius when on the wing:-

"a female, captured as Danaida chrysippus."

"a male, looked like a Fritillary."

I would urge strongly that the resemblance of model to mimic may be much closer in the field than in the cabinet. To some extent the converse is probably true.

Báliganj, Calcutta, December 5, 1903. "The female Elymnias undularis, Drury, is a very fair mimic of Danaida plcxippus, but its flight is weaker."

Kandy, February 9, 1908. A tattered $q$ of Elymnias fraterna, Butl., was taken for a tattered Danaida chrysipprus.

Haragáma, Ceylon, February 13,1908. A female Nephcronia ccylonica, Feld., on a Lantana flower, was taken for Parantica aglea.

Durban, S. Africa, August, 1905. Acruca cncedon, Linn., a somewhat feeble insect with slow flight, was, in spite of its small size, twice momentarily believed to be $U$. chrysippus, which was seen in the same spots on the same days. On the other hand, 2 M 
a small female $D$. chrysippus was actually mistaken for $\Lambda$. cnccdon.

Durban, August, 1905. "Of Belcnois thysa, Hopff., we took two males; when on the wing they were very like the males of Mylothris agathina, Cram., in flight and general aspect. Indeed as seen in the net the Belcnois so closely mimics the Mylothris that one of us, though specially on the look-out, was completely deceived, and this even when the two insects were taken the same morning" (see above, pp. 193, 194).

Durban, August, 1905. ". . the curious Geometer Cartaletis libyssa, Hopff., of which several were seen, but only one taken. It flies rather high, with feeble fluttering action, and when on the wing somewhat recalls Danaida chrysippus." I do not think that in this instance I was actually deceived.

Kandy, March, 1904. Of the tail-less Papilio lankeswara, Moore, f. dissimilis, Linn. (the pale form), I took three, but probably saw more since it so very closely mimics Tirumala limniace, or a large Parantica aglea, as easily to pass for one of those insects; it is indeed most easily distinguished from them by its habit of fluttering while feeding upon a flower.

Near Peradeniya, Ceylon, January 29, 1908. I was with that experienced and keen-eyed entomologist, $M_{r}$. E. E. Green, when after several attempts he netted a $P$. lankeswara, f. dissmilis, under the impression that he was catching Tivumala scptcntrionis, Butl. (see above, p. 364).

Kandy, March 2, 1908. I myself took a female $P$. dissimilis which I imagined to be Tirnmala scptentrionis as it flew past.

Haragáma, Ceylon, February 18, 1908. Took a female P. lankicswara, f. clytia, Linn. (the dark form), believing it to be Crastia asela, Moore. This dimorphic mimicry is very remarkable.

Mortehoe, Devon, July, 1902. The first Acgcria crabroniformis, Lewin, that I ever saw alive was at rest on the trunk of a black Poplar. Under the idea that it was a hornct I knocked it down and put my foot on it before discovering my mistake. The thought passed through my mind: "Well, I liave been here all these years and never saw a Hornet in the district before." 1 Kandy, February 21, 1908. A specimen of the Clearwing, Mclittia chalciformis, Fabr., seen hovering over a flower was first thought to be a Bombylius, then a Skipper. It distinctly hummed in the net. This instance is quoted to show that the moth, though not suggesting a protected insect, certainly deceived the observer.

' Longstafi, Enilom. Month. Mag., 2ud Ser., vol. xv., 1903, p. 196. 
Simon's Town, S. Africa, October 3, 1905. I had much difficulty in distinguishing during life some flies-? Ploas sp., and Proraehthes sp.--from certain small black, white-ringed Bees, Halictus albofasciatus, Smith, of, which buried themselves in the flowers of a large Mesembryanthemum; in the cabinet the insects look distinct enough, but during life the resemblance, especially in their movements and habits, was quite remarkable (see p. 250, supra).

Mátherán, W. Ghats, 1908. At the cnd of March, in a time of extreme drought, insects of various orders were, naturally enough, attracted to such pools as were left about the nearly exhausted springs. Among the visitors were many long-waisted Wasps of which I secured a fair number, belonging, as I supposed on a cursory glance, to several species. When Mr. A. H. Hamm had set these for me at Oxford, he remarked, "I see that you have taken a lot of Conops along with the wasps that they mimic." Critical examination revealed :- Hymenoptera : Eumenes flavopieta, Blanch., three; E. cdwardsii, Sauss., one; Icaria ferruginea, Fabr., four; Polistes narginalis, Fabr., var. stigma, Fabr., one. DIPTERA: Ceria, sp. nov. (near trinotata, de Meijere), three; Ceria eumenoides, Saunders, seven. How close was the mimicry of Fly to Wasp may be judged from the figures on Plate IV. The mimicry of Icaria by C. ermenoidcs had been noticed by Col. C. G. Nurse in 1899, also at Mátherán. ${ }^{1}$

Mortehoe, Devon, August, 1908. Two specimens of the common British fly, Conops flavipcs, Linn., suggested to me when alive a Trochilium (Clear-wing Moth) rather than a Wasp. But the next one that I came across was netted on the wing as a small wasp. Subsequently other spccimens were seen running about oll leaves (especially of Hydrangea), and the close resomblance of their moments to those of a Vespid were noticed on at lcast two occasions. The abdomell was frequently raised and depressed, and there was a general fidgetiness of mannor that was highly suggestive of a wasp, but, unlike a wasp, the antennae remained rigidly porrected, so as to be strangely conspicuous.

Mortehoe, Devon, 1306, and subsequently. The Syrphid fly, Chilosia illustratc, Harr., which is to be seen commonly enough on Ragwort flowers and various Umbellifers, is a fairly close mimic of Bombus sylvarum, Linn., and the more locil Podalirius furcalus, Panz. They may often be scen side by side on the same flower-head, and it requires a little care to distinguish them,

1 See above, p. 392. 
though I cannot remembcr having made any mistakes of diagnosis myself. The mimicry is sufficiently elose to have deceived for the moment such an experienced hymenopterist as Dr. H. Swale.

Mortehoc, Devon, 1909. Of the Syrphid fly, Volucella bombylans, Linn., both forms occur, plumata and bombylans; they are close mimies of Bombus terrestris and Bombus lapidarius respectively, and I have actually taken the latter form of the fly for the Bumble-bee.

Mortehoe, Devon, 1909. The Syrphid fly, Arctophila mussitans, Fabr., is so extraordinarily like the tawny Bumble-bee, Bombus agrorum, on the wing that I have several times been thoroughly deceived. I have taken the two insects together, on the same day, on the same patch of Centaurea nigra; the Bumble-bee very common, the fly comparatively scarce-all the classical conditions of Batesian mimiery.

New South Wales, 1910. I do not think that I have ever been so completely taken in as at Como, near Sydney, on the 2ud of April. On the flower of a shrubby Acacia, well within reach and clear sight, was, as I thought, a fine wasp. It was easily netted, but not so easily bottled. I pursued it up and down the net with cyanide-bottle, taking great care not to be stung. Once corked up I thought no more about it, until on turning out the bottle after the day's work I found a black and orange Longicorn beetle! The female of Esthesis variegatus, Fabr., has extremely short elytra, and as the beetle sat on the flower its wings were extended on either side, as one often sees in Fossors (see Plate VI., Figs. 8, 9). I did not observe any wasp very like it (but see above, p. 485).

Mortehoe, 1907, and subsequently. My garden is umusually rich in Diptera mimics, though the number of individuals is mostly small. This is true of the enormous black Tachinid fly Echinomyia grossa, Linn., which in appearance, voice and manner is a good mimic of Bombus hortorum, var. harriscllus. As neither is common, I have not seen them together, though I have taken them within a few yards of one another. That they can be distinguished on the wing is doubtless true, but I venture to think that it is also possible to confound them.

Of course we can form but a very imperfect idea of the sense impressions of the lower animals. We know by their actions that hawks sec their prey from a considerable distance. The phemomena 
of mimicry compel the inference that insectivorous birds, and possibly lizards, appreciate comparatively minute differences of shape and colour, yet it is quite conceivable that they cannot distinguish these at a greater distance than a myopic man. We know even less about the sense impressions of insects, in spite of the patient observations of Forel and Lubbock, and the brilliant experiment of Exner. The whole subject is discussed in detail by Dr. Auguste Forel, who seems to have established the fact that insects have a very keen perception of movement-possibly far more acute than their sense of form and colour.l It has often occurred to me when collecting butterflies that it is just possible that they can smell a collector as far as they can see him.

Some opponents of mimicry seem to think that they have proved their case when they declare that model and mimic can be distinguished, or when they cite cases of birds attacking distasteful species.

Since the last paragraph was written powerful attacks upon the whole theory of mimicry have appeared. Those of Col. N. Manders deserve special attention on account of the wide experience of their author. His chief point is that he denies that birds exercise discrimination in their attacks on butterflies. ${ }^{2}$ I agree with Professor R. C. Punnett, ${ }^{3}$ that the first steps towards mimicry present great difficulties, but I fail to see that Mendelism has any light to throw on the subject. It is remarkable that Professor Punnett, whose power of diagnosing insects on the wing appears to be exceptional, should nevertheless have been deceived by the resemblance to Butterflies of a Dragon-fly (Rhyothemis variegata, Johanns.), and a Homopterous Bug (Hansenia glauca, Kirby). As regards the latter, which I saw two or three times at Kandy, I have a note: "very blue on the wing, but flight much slower than a Lycaenid." Again, is Professor Punnett justified in his assumption that a bird reasons about the flight of a butterfly in the way that a scientifically traincd naturalist does? Such severe criticisms as these two authors have published cannot but increase our knowledge of a difficult subject, but the coup de grâcc has not yet been delivered.

Once more it must be repeated that no supporters of the theory claim that the disguise is never seen through, nor do they claim that distasteful species are never eaten. In the severe struggle for

'Forel, "Tho Senses of Insects." Translatod by Maclood Yearsley, 1908, passim.

"Manders, Trans. Ent. Soc. Lond., 1911, pp. 117-425; also, Proc. Zool. Soc. Lond., 1911, pp. 696-749.

3 Punnett, Spolia Zeylanica, vol. vii., part xxv., 1910, pp. 1-24. 
existcnce, if the mimetic guise often, or even occasionally, lcards to the escape of the protected specics, it must be a great advantagc to it. The same argument applies to distasteful qualities.

The question to be decided is not, "Is the disguise always successful in deceiving all enemies?" but rather "Does it ever deceive any enemies?"

\section{§ 7. Notes on the Flight of Sundry Butterflies.}

Too many systematic works deal with insects as mere cabinet specimens, though there are notable exceptions. Not the least valuable part of the late Mr. C. G. Barrett's great work on the "Lepidoptera of the British Islands" is his vivid description of their habits and flight. Again in Moore's "Lepidoptera of Ceylon" the short notes on the mode of flight of many species supplied by Capt. H. Wade-Dalton, Mr. F. M. Mackwood and more frequently Capt. F. S. Hutchison are of great interest. The value of the notes in the last-named work is not diminished by the fact that the observers are not always agreed. The habits of the sexes are usually different; the time of day, not to speak of the weather, greatly affects their flight; probably the time that may have elapsed smce emergence from the pupa is another important factor. From these facts it follows that hasty generalizations based on even the most accurately recorded observations may be misleading if the qualifying circumstances be left out of account.

The first fact that I would emphasize is the rapid flight of the Whites and Yellows. ${ }^{1}$ That Pierines may be secn fluttering about flowers is true enough, e.g. Colias cdusa is not always difficult to catch. Nevertheless the Pierine has a knack of flying straight ahcad in a business-likc manncr, as if bound to reach some distant place at a definite time, in a way that the Satyrine rarely, if ever, adopts. Again, though the Nymphaline may go off at a great pace for a short distance, it usually soon returns to its beat. Among many swiftly flying Picrincs that I have come across, are:- the allied gencra Catopsilia, ${ }^{2}$ Callidryas ${ }^{3}$ and Goneptcryx; Catophaga paulina; the Neotropical Glutophrissa drusilla, and morc espccially Picris phileta; ${ }^{4}$ the powcrful Oriental Hebomoia; ${ }^{5}$ again Ixias pyrene

'See alove, pp. 44, 58, 98 .

3 See above, pp, 2 SG, 331.

2 See abore, p. 5 s.

- See above, p. $25 \%$.

Soo abovo, pp. 102, 111, and subsoquent oxperience in Ceylon. 
though not equal to the last-named, is a swift flyer, as are also many of the Teraeoli, notably the South African T. cris. ${ }^{1}$

Commander J. J. Walker, R.N., writing of Euchloë bclemia, Esp., at Gibraltar, Tangier, etc., said: "It has a very strong, swift, and erratic flight, and is by no means easy to catch." 2 Even the little Terias, which seems to go slowly, will be found to move so fast that a large proportion get away, though in this instance the mode of cscape is commonly to dart downwards so that the net passes over the butterfly, and to the annoyance of the collector it rises again from the ground. There seems to me to be practically no doubt that the swift flight of the Whites and Yellows is due to their exceptional conspicuousness as compared with other butterflies. That they are exceptionally conspicuous is obvious enough.

Yet not all Pierines are rapid flyers; there are marked and significant exceptions. Thus, many years ago, Dr. A. R. Wallace, ${ }^{3}$ writing of the Oriental genus Thyca (Delias), said: "They have a very slow and weak mode of flight." Again, at East London, Dr. Dixey called my attention to the "slow, fearless, fluttering flight" of Mylothris agathina, Cram. Both Delias and Mylothris furnish well-known models, closely mimicked by other Pierines. Dr. Dixey noted that the flight of the mimic Belenois thysa, Hopff., closely resembled that of its model Mylothris agathina, but Mr. E. E. Green tclls me that Prioneris sita, Feld., a very close mimic of Delias euehuris, Cram., is a swift flyer.

On March 30th, 1910, at Como, 12 miles S.S.W. of Sydney, New South Walcs, I saw a number of males of Delias nigrina, Fabr., flying about the tops of Gum-trees (Eueculyptus sp.) that were in flower. They kept for the most part 30 or 40 feet from the ground, rarely coming down within reach. The upper side of the male is white with an apical black mark, the lower side mostly black. The effect of this strangcly contrasted colouring was curious. The black and white surfaces showed alternately as it flew slowly about the flowers, and at first I took the butterfly for something much larger than it really was-to me it seemed a huge Papilio-I have scldom becn so deceived in the size of an inscct. The movement of the wings gave the butterflies a distinctly blue look, as night have becn expceted from the partial mingling of black and white.

Probably belonging to a different category are two smallcr Pierines

1 See above, p. 222.

${ }^{2}$ Entom. Month. Mag., vol. xxiv., p. 181 (1886-1887); also Trans. Ent. Soc. Tsond., 1890, p. 369.

${ }^{3}$ Trans. Ent. Soc. Tsond., Ser. 3, vol. iv., 1865-8, p. 309. 
of dissimilar structure, but similar appearance, the Palaearctic Leucophasia sinapis, Linn., and the Oriental Nychitona siphir, Fabr., ${ }^{1}$ which are among the very feeblest fliers of my acquaintance.

The slow gliding, floating (Hutchison), or skimming flight of certain Nymphalines, such as Neptis, Rahinda, Ergolis, and Eurytela, is well known to tropical collectors; what its significance may be I know not. My experiments indicate that Ergolis is palatable. ${ }^{2}$

It has not been my good fortune to capture that fine butterfly Parthenos eyaneus, Moore, but at Kandy I watched its tantalizing movements for some time as it flew to and fro far above my longest net-stick. Messrs. de Nicéville and Manders say of this species, "not rare, but is difficult to catch. It has a remarkably distinctive mode of flight, which makes it recognizable at once on the wing." 3 As those naturalists made no attempt to describe its peculiarity I will endeavour to do so:-The wings appear to be seldom raised much above the horizontal, but at comparatively long intervals they are strongly depressed with a jerk, the fly then gliding along for two or three yards. In marked contrast to this is the flight of Papilio parinda, Moore, attended with obvious flapping in which the wings are much raised but never appreciably depressed below the horizontal. I am glad to be able to add that Mr. E. E. Green agrees with the general accuracy of this description.

The slow heavy flight of the Danaines is of course familiar; I might specially mention Crastia asela, Moore; Narmada montana, Feld.; Chittira fumata, Butl.; and Parantica aglea, Cram. I am, however, not aware that the peculiar dancing movement-up and down-of the two last-named has been placed on record: Jet it was often so marked as to enable me to diagnose the insects at a considerable distance. At Kandy late in the afternoon, when other butterflies were getting scarce, $P$. aglea might often be seen slowly dancing about in all directions.

At the Falls of the Zambesi I noted Papilio lconidas, Fabr., as flying slowly "with the manner of a Danaid"; this made me suspect it to be a mimic, as I afterwards found to be the case." Mr. Marshall, who is quite familiar with the insect, whereas I have seen but very few specimens, speaks of $P$. leonidas as having a strong and rapid flight, and always going straight ahead. ${ }^{5}$ I think there must have

1 Sce abovo, p. 61. Also Ceylon, 1908.

2 Supra, pp. 526, 527.

3 Journ. Asiatic Soc. of Bengal, vol. 1xriii., 1899, p. 188.

- Seo above, p. 229.

strans. Ent. Soc. Jond., 1902, p. 507. 
been some special circumstance that caused my specimens to behave in an unusual manner. Certainly its alleged model, Tirumala pctiverana, did not put in an appearance.

The flight of Cethosia nietneri, Feld., another Ceylon butterfly, is I think about the slowest and weakest that I have observed, and this alike whether it be high up or near the ground. The S. African Nymphaline, Salamis anacardii, Linn., is another remarkably slow flyer. ${ }^{1}$

As a general rule tropical butterflies seem harder to catch than British. Certainly this is not entirely to be explained by the heat, nor even by swiftness of flight. The slow-flying Mycalesis seldom moves far, and is for that very reason hard to catch as it seldom gets quite clear of the herbage amongst which it is found. Again, Elymnias often refuses to move more than two or three yards when disturbed, yet is hard to catch because it will not get clear of the bushes, in the middle of which it loves to flutter. A very different butterfly, the exquisite blue Nepheronic ceylanica, Feld., a quick flyer, often takes refuge in bushes when pursued; Teracolus puellaris, Butl., has a similar habit. Bclenois mesentina, Cram., and the two common Indian species of Ixias seem to spend much of their time flying through and through thorn bushes. ${ }^{2}$

Between Nuwára-Eliya and Hakgála, Ceylon, March, 1904, my attention was called to the curious habit of the male Catophaga paulina, Cram., of flying in strings as though tied together by an invisible thread. I witnessed this again at Haragáma, Ceylon, January 20th, 1908. Soon after mid-day large numbers of the ${ }^{t}$ were seen flying down the bed of the stream, sometimes in ones and twos, but often three, four, or five together in strings. On the same day clusters of a score or more were seen drinking at wet sand; when disturbed they would quickly come back to the favoured spots, as many as five to seven together, in strings, all conforming to the movements of their leader like wild geese. ${ }^{8}$

Melanitis ismene, Cram. (leda, Drury ncc Linn.), is an insect which I have met with at divers times, and in divers places, but unfortunately have never come across it in any numbers. At the beginning of February, 1908, I twice witnessed its evening flight-at about 6.30 p.m. when it was nearly dark. My net-stick consists of two lower joints of a salmon-rod; on the occasion referred to the buttjoint, which is partly covered with cork, was lying near me on the ground. The butterfly flew in jerks, making short circuits and

' See above, pp. 190, 193.

2 See nbove, pp. 57, 62, 73.

3 Seo above, pp. 118, 370. 
returning again and again to settle on my liat, my net, or the netstiek on the ground. It strnck me at the time that it might probably be guided by the sense of smell, espeeially as it selected the part of my net-stick that was most handled. Yet it is quite possible that the butterfly was attraeted by my white tropical clothing, and by the light colour of the eork, whieh was fairly conspieuous in the inereasing gloom under the palms.

The Ceylon Papilios would appear to be more easily netted in the afternoon than in the morning; this is especially true of Ornithoptera darsizes, Gray, and P. parinda, Moore.

$P$. demoleus, Linn., is swift of flight; so is $P$. agamemnon, Linn., which has a darting movement. The last-named is quite an inconspieuous butterfly whether on the wing or at rest, affording a marked eontrast to the glorious $P$. crino, Fabr., which is startling in its almost luminous brillianee.

The flight of $P$. hector, Linn., is not espeeially swift, but is marked by the straightness of its eourse, seeming to keep on one level. Its black, white, and searlet colouring is very obvious in flight, and the strong eontrast of colours seems to make the movement of its wings more obvious and more rapid in appearance.

In marked contrast with the last is $P$. aristolochiae, Fabr., which sails about slowly and quietly with little obvious flapping of the wings; it moves in a stately way as if eonfident in its immmuit? from attaek and is the most easily caught of all the group.

$P$. polytes, Linn., two of whose polymorphie females mimie hector and aristolochiac respectively, behaves very differently from them, and seems to trust mueh to swiftness of flight; my observations ehiefly relate to the $\delta$, and I have an impression that the flight of the $q$ is slower, but this requires confirmation. "Though well hnown to Indian entomologists I am not aware that the eontrast in flight between polytes and aristolochice has yet been plaeed on reeord." Sinee this was written, ${ }^{1}$ Prof. Pmnett ${ }^{2}$ and Col. Manders ${ }^{3}$ have ealled attention to the differences between the flight of the three Swallow-tails, thongh they speak from a different point of view.

It is a notable habit with many Papilios that, when settled on flowers, feeding, they keep their wings in almost constant morement. This has been noted in all the following speeios:- 0 . darsins, which, when feeding, oeeasionally stops fluttering, dropping the fore-rings baek (towards the abdomen); $P$. parinda, $P$. hector, $P$. aristolochiac,

1 Trans. Ent. Soc. Lond., 1909, 1. 640.

2 Spolia Zcylanica, vol. vii., part xxv., 1910, p. 7.

${ }^{3}$ Proc. Zool. Soc. Lond., 1911, p. 714. 
$P$. polytes, $P$. agamemnon (in which specics the habit is very marked),

$P$. demoleus, $P$. demodoeus, $P$. dissimilis and P. helenus, $f$. mooreanus, Rothsch.

I was much struck by specimens of the last-named in the forest at Hatton, Ceylon (March 5th, 1908), settled on very dark-grey rocks drinking, with their wings about three-quarters expanded, but with the fore-wings drawn back so as almost entirely to conceal the conspicuous cream-coloured spot on the hind-wings. For the moment I thought that there was before me some other species, entirely black on the upper side.

P. sarpedon, Linn., f. teredon, Feld., and P. jason, Esp. (telephus, Feld.), do not flutter when drinking.

The exceedingly slow flight of sundry day-fiying and almost certainly distasteful moths is referred to in many places in the earlier chapters. ${ }^{1}$

\section{$\S 8$. HELIOTROPISM.}

Heliotropism, or the habit of turning towards the sun, is a phenomenon familiar to botanists.

Professor G. H. Parker appears to have been the first (1903) to describe what he terms "Negative Heliotropism" in the case of Vanessa antiopa, Linn., in the United States. He clearly establishes that when this butterfly after a flight settles in full sunshine, it does so with wings fully expanded, and then speedily so adjusts its position as to place the axis of the body as near as may be parallel to the sun's rays, with its head turned away from the sun. He records his numerous observations in great dctail, and states that some species of the genus Grapta have the same habit. The object of the crcature thus turning its tail to the sun is, he believes, to display its colouring to the greatcst advantage. ${ }^{2}$

Some time after the rcading of my first paper dcaling with the subject ${ }^{3}$ Professor Poulton called my attention to the following interesting observation by Mr. IE. E. Grecn:- "Melanitis ismene is an adept at concealing itsclf. It usually pitches amongst fallen leaves where its form and coloration are sufficicnt conccalment. But cven on bare ground the insect is often extremely difficult to localize,

1 See e.g. pp. 128, 195, 320, 391.

2 Mark Anniversary Volume, Cambridge Univorsity, Mass., U.S.A., 1903, pp. 453469. Prof. Parker gives a bibliography of tho subjoct. I mm indebted to Prof. E. B. Poulton, F.R.S., for this reforence.

3 Trans. Ent. Soc. Tsond., 1905, p. 136. Read, Doc. 7 th, 1904. 
though the approximate spot may have been carefully noted. I have watched the fly, immediately after pitching, alter its position $s$, that its axis is directed towards the sun, thus casting no shadow." I

When in India in 1903 I several times noticed that when a butterfly with a cryptically coloured underside rested on a flat surface, the shadow cast by it was often far more conspicuous than the butterfly itself. Obviously, therefore, in such a case economy of shadow might afford considerable protection.

Now, near Simla, in October, 1903, when watching Pararge sehalira, Koll., a butterfly resembling $P$. megaera, I noted three individuals in succession settled with their tails to the sun so as to reduce the shadow to a mere line. This was unfortunately just as I was learing the district where the species occurred, but I did not observe any instances to the contrary. These observations were made quite independently of Mr. Green, and possibly at about the same time.

During my visit to Algeria in the spring of 1905 , the subject of heliotropism was further investigated, and my results were communicated to the Entomological Society shortly after my return :-

Following up my observations on the attitude at rest of Pararge schakrc, made near Simla, in October, 1903, I paid a good deal of attention in February and March of the present jear (1905) to P. meone, Cram., a butterfly that I found in varying numbers in all the parts of Algeria that $I$ visited. This is either a Southern form of $P$. aegeria, Linn., or a closely allied species in which the yellowish spots are replaced by fulrous. It is fond of settling on sandy roads, rocks, walls, or the leares of trees or shrubs, comparatively rarely visiting flowers. It first pitches, invariably I might say, with its wings about threequarters expanded, and, almost always with its head turned away from the sun, the axis of the body being rarely more than $45^{\circ}$ to either side. Immediately after settling it more often than not adjusts itself, by a quick movement, so as to make its tail point fairly accurately to the sun. After this adjustment, if at all, it closes its wings over its back, and as a necessary result its shadow is reduced to, or approximates to, a mere line. There can, I think, be no doubt that this habit is a great protection to the insect, since when resting on fairly flat surfaces the shadow of a Satyrine or Nymplaline butterfly with cryptic underside is often more conspicuous than the fly itself.

' "Notes on some Coylon Butterflies," Spolia Zeylanica, rol. ii., pt. ri.. 1904, p. 76 . 
I quote two cases from my notes:-

Feb. 8, Guyotville. Watched a specimen settle about twenty times. The wings were always at first expanded about threefourths, an adjustment of its position was in most cases made immediately, and after that the wings were raised over the back. In about twelve individuals the orientation was perfect and the shadow a minimum; in seven or eight the orientation was imperfect, with a maximum error of about $45^{\circ}$, but usually much less.

Feb. 25, Biskra. Watched one settle three or four times, always with a shadow near the minimum.

Only one specimen of $P$. meone was ever seen to settle facing the sun; it did so three times, a fourth time turning its tail in the usual way. This was at Biskra on March 5th, and I noted at the time that the sun was not shining strongly. Two only were observed to settle with the axis of the body at right angles to the sun. One of these appeared to be crippled in the legs, since it alone always leaned to the same side. A third specimen, feeding on Laurustinus flower in the Chabet Gorge on March 18th, did not appear to orient itself by the sun.

In conclusion, except early in the day, or when the sun is dull, or when feeding on flowers, $P$. meone settles with the axis of the body turned so that its tail points more or less accurately to the sun; therefore, when the wings are raised, in the attitude of repose (as is more common towards the afternoon), the shadow is reduced to insignificant dimensions.

Pyrameis cardui, Linn., is an abundant butterfly in Algeria. It is not so easy to watch as $P$. meone, for it is a strong flyer and much more wary ; moreover, many of the specimens were seen in exposed places during windy weather. Nevertheless, I can say confidently that it generally settles with its tail to the sun, though it does not do this with the regularity of meone. I saw two specimens turn their heads to the sun, and a third settle twice with its body axis at right angles, though the third time it settled normally. The first two frcshly-emerged specimens, at Hammam R'ihra, March 25th, did not oricnt as well as those that had hybernated.

These observations confirm those of Professor G. H. Parker: on Vanessa antiopa, Linn., and on a Grapte in the United States, and supply a rcason for the habit that does not appear to have occurred to him, namely, conccalment when in repose. ${ }^{1}$

1 Proc. Ent. Soc. Lond,. 1005, pp. xxviii-xxix. 
In the discussion which followed, Mr. C. O. Waterhouse suggested a third possible explanation of this habit, viz. that this special attitude exposed not only the wings, but the insect's body, most completely to the sun's rays. Doubtless we may fairly suppose that such an essentially sun-loving creature as a butterfly finds them agreeable.

I studied the matter further both in Devonshire and South Africa, and here quote the relevant passages of a paper on Some RestAttitudes of Butterflies; ${ }^{1}$ merely adding by way of explanation that I have found it convenient to make use of the word Oricntation and to speak of a butterfly with its tail pointed accurately towards the sun as correetly oriented.

After somewhat intimate acquaintance with $P$. meone, in Algeria, it was pleasant, in May, 1905, to study its Northern form, P.acgcria, which is common in and about my garden at Mortehoe, North Devon, and this was the more pleasant because our butterfly is undeniably more beautiful than its Southern sister.

I have notes on ten specimens observed, and it may be instructive to give them in detail.

May 3. Observed two P. cuegeria; one settled several times with tail to the sun, the other was less particular.

May 9. Saw aegeria settled with wings open and tail directed towards the sun.

May 15. Saw one specimen of acgeria settle twice with fairly accurate orientation; another specimen settled first accurately oriented; then it settled again with the body nearly at right angles to, but with the head somewhat towards, the sun; thirdly, it settled again at right angles, but with its head turned to the opposite side.

May 19. Watched three specimens of acgeria and saw each of them orient itself accurately twice. The same day I saw another specimen orient itself four times.

My last observation was made on all acgcria within a few yards of my study window; this I disturbed many times with a view to noting its behaviour; out of seventeen occasions it oriented itself correctly but five times, it faced the sun once, but placed itself at right angles to its rays no less than eleven times.

The unusual behaviour of this butterfly gives strong proof that individual flies may differ much in behaviour, and as I should be disposed to describe it, in moral character. What entomologist who 1 Trans. Ent. Soc. Lond., 1906, pp. 97-106. 
has sugared regularly in the same place has not observed among common Noctuae some individuals bolder and greedier than others?

I often saw meone settle on sandy roads, rocks, or walls, but the acgeria here referred to were for the most part settled on leaves, and the question of protection by economy of shadow could scarcely arise in their case.

The next subject of observation was Purarge megucra, Linn., which was especially interesting to me as nearly allied to $P$. schakra, the common Himalayan butterfly in which I first noted heliotropism in October, 1903.1 The spring brood was not so numerous as the summer brood usually is, and only ten specimens were noted settled. Of these the first, a female, was watched on a Devonshire "dry ditch," settling for the most part on the rough slates of which it was built, that is to say, on surfaces not always well adapted for precise orientation. It was, however, observed to settle several times with its tail to the sun, and on one of these occasions it raised its wings over its back so that its shadow was scarcely visible, but two or three times it settled at right angles to the sun. Six other specimens were observed with their wings open, settled for the most part on flat ground, and all correctly oriented (one observed twice). Another specimen was first seen settled on the flowers of Potentilla tormentilla, Sibth., at right angles to the sun, but afterwards on Scilla nutans, Sm., correctly oriented. Yet two other megaera were secn settled, one on the road, the other on a flat stone, both with their wings closed up, correctly oriented, so as to throw practically no shadow.

The following note may be added:-

Mortchoe, September 14, 1907, late afternoon. $P$. megaera found asleep upon the face of a rock, about 3 fcet above ground: its head up, antennae porrected but separated; wings in close coutact; fore-wings drawn back so that no fulvous colour was exposcd. Mortehoe, August 24, 1911, 5 p.m. P. megaerc at rest on a rock in dcep shade. Attitude as in last paragraph.

Epinephele tithonus, Linn.-The following observations show that the habits of this butterfly, as regards orientation, are similar to those of P'ararge megaera:-

Mortchoe, July 20, 1906. A specimen observed settled across the sun, with wings closed.

Same place and day. Another specimen secu to settle twice; oriented, with wings open.

1 Trans. Ent. Soc. Lond., 1905, p. 67. 
Mortehoe, August 11, 1907. A specimen settled on the ground, oriented, wings three-quarters open.

Mortehoe, August 15, 1907. A specimen settled on grass; across the sun, wings closed. It was disturbed by a $\delta E$. junira, it settled again and this time oriented and closed its wings, making no shadow.

Same place and day. A tot settled on a leaf, oriented, wings open.

Same place and day. A f seen to settle three times on leaves, with wings open; twice it faced the sun and then partially adjusted itself; the third time it oriented correctly.

Same place and day. A of settled on grass, oriented, wings half to fully open.

Same place and day. A $q$ on a bramble leaf, oriented, wings threequarters to fully open: it was twice observed to close its wings, leaving little shadow; the eye-spot on the fore-wing was exposed.

Same place and day. A f on a leaf of Heracloum, wings threequarters open, oriented; it momentarily closed its wings, leaving no shadow.

Same place and day. A ơ on a bramble leaf, oriented, wings threequarters open.

Same place and day. A of on a bramble leaf, wings quite open, imperfectly oriented.

Same place and day. A $q$ twice seen settled across the sun, wings closed, but eye-spot visible.

Mortehoe, August 22, 1907. A $q$ oriented, wings three-quarters open.

Mortehoe, August 24, 1907. A o half-oriented.

Same place and day. A $q$ on a leaf, imperfectly oriented.

Epinephele hyperanthus, Linn.-This is a restless butterfly, and takes long to settle; however, I have this note:-

Mortehoe, July 20, 1906. Four E. hyperanthus seen to orient, with wings three-quarters open.

During May, 1905, hybernated specimens of Vanessa io, Linn., were unusually common at Mortehoe, and the attitudes of at least fifteen different individuals were noted on seven different days. Of these, eleven, or three-fourths, oriented themselves correctly so as to turn their tails to the sum. Of the minority, the one-fourth that settled otherwise than with tail to the sun, two were settled on the flowers of the Wild Hyacinth or Blue-bell (Scilla mutans), and of these one was facing the sun. A third specimen, settled on flowers 
of Lilac (Syringa persica), appeared to be quite indifferent to the sun's direction. The fourth was at first settled facing the sun, but it very soon moved, settled again, and at once adjusted its position so as to be perfectly oriented with tail to the sun. I subsequently watched the same butterfly settle three times, the first time with tail turned to the sun correctly, but the second and third times it alighted on Blue-bells and did not orient itself.

Vanessa urticae, Linn., was far less common and only two specimens offered themselves for observation, of which the first was twice seen to adjust itself to correct orientation, but the second, on the same Lilac bush with the $V$. io mentioned above, appeared, like it, to be indifferent to the sun's direction.

From the preceding observations it may fairly be inferred that Vanessa io (and probably also $V$. urticae) when settled in full sunshine, except sometimes when feeding on flowers, habitually places itself so that its tail is directed towards the sun. As however the butterflies were not seen to close their wings over their backs nothing can be said as to the shadow question.

The next species that came under my notice was Melitaea aurinicu, Rott., which was very abundant in a restricted North Devon locality. All the specimens observed were settled on flowers or low plants; in the great majority the wings were fully expanded, though a few had the fore-wings drawn back so as to form an approximation to the Deltoid shape. In order to secure perfect fairness my method was to record the position of evcry specimen seen so long as the sun was shining brightly. Three series of observations were thus made, with the following results :-

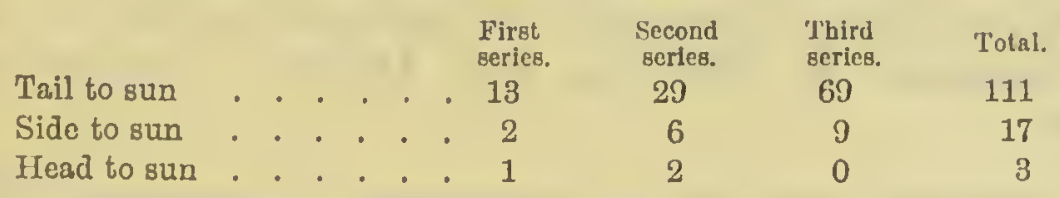

Adjustments after settling were often noticed, occasionally repeated adjustments. When there was a wind they settled at first with their heads to it, one butterfly succeeding in orienting itself only after much struggle. When the sun was not shining they were often noted settled at right angles to its direction.

Under the circumstances in which this local butterfly, M. aurinic, occurred, it is difficult to see that the amount of shadow thrown could have been of any moment, though doubtless its colours would show up more if the undersides of the hind-wings when at rest had the sun shining directly on them rather than tangentially. 
Observations in South Afriea, 1905.

The visit of the British Assoeiation to South Africa gave me more extended opportunities; it gave me moreover the advantage of Dr. F. A. Dixey's co-operation, whieh was the more valuable by reason of his extraordinary patience in observing and minute accuracy in recording results.

Eurytela hiarbas, Drury, is a Nymphaline butterfly, with a very Satyrine aspeet and habits not unlike those of $P$. aeyeria. It is common in woods round East London and Durban, affecting partial shade. At East London I saw it in a small wood within 100 yards of high-water mark. It does not seem to be attraeted by flowers, but moves about bushes with a slow gliding flight; it may settle on leaves, or on the ground, the wings being commonly three-fourths expanded, though sometimes more fully. When thus settled the wings are often slowly shut in part and again opened, though I never sarv them quite shut. On at least three several days they were noted to have their tails turned to the sun, but the orientation was imperfeet, often $15^{\circ}-30^{\circ}$ out, and oceasionally they settled with the body axis at right angles to the sun.

Precis elelia, Cram., is a Nymphaline butterfly that is eommon and widely distributed in South Africa. The dark upper surface of the wing is rendered very eonspicuous by white spots near the tip of the fore-wing and a large blue spot on the hind-wing, but the underside is marbled with shades of light grcy and is very quict and unobtrusive. As regards its habits I cannot do better thn quote Dr. Dixey's very graphie account of its bchaviour as observed in the Old Cemetcry, at Sydenham, near Durban, in the middle of Angust :-

Common at one spot in the eemetery. It has a habit of flying a littlc way, sometimes in pursuit of another butterfly, making a round and returning to the same, or mearly the same plaec. It scttles on the ground, or on a low plant, nearly always turning its back to the sun, and often elosing its wings over its baek. I saw onc settle at right angles to the sun, ensting a broad shadow; but as there happened to be sevcral objects close by easting similar shadows, it was not very eonspicuons. Presently the same individual flew up and settled down again, this time on a bare pieee of earth and with its baek to the sun in the usual way. 
Auother note, also relating to Sydenham, is :-

$P$. clelia seen to settle, and then rapidly turn its back to the sun; it did not close its wings. $P$. clelia seen here seems always to turn its back to the sun.

To Dr. Dixey's description I would add that the wings are usually about three-fourths expanded, nearly as with Vanessa utalanta, Linn., at home. One specimen was observed to settle with tail to the sun five consecutive times. It was only occasionally that I saw them close their wings over their backs, when the shadow was reduced to a minimum, but I did observe this several times, both in the neighbourhood of Durban and at the Victoria Falls. As a rule $P$. clelia seemed to pitch correctly, but now and then it was seen to adjust itself.

Precis cebrenc, Trim., is another common and widely distributed South African butterfly. Though very differently coloured from $P$. clclia, it is nearly, though not quite, as conspicuous when the upperside is displayed, but the almost uniformly clay-coloured underside is scarcely distinguishable against certain backgrounds, such as sand, clay, or rock of a grey or yellow tint. It is fond of frequenting dry spruits, or watercourses, scttling on the rocks or' boulders, but in the Zambesi country $\mathrm{Dr}$. Dixey often saw it settle in trees. It was repeatedly observed to orient itself fairly accurately, but did not appear to close its wings as often as $P$. clelia. A note made by me at Ladysmith, August 26th, says :-

Oriented within about $10^{\circ}-15^{\circ}$; settled often upou cliffs of yellow sand or mud on which it was moderately conspicuous. One specimen was repeatedly observed to close its wings, its shadow was then near the minimum and the inscet inconspicuous.

Precis natalica, Fcld, a rather dingy specics, though generally distributed, was much less common than the two preceding. It is somewhat of a shade-lover and usually settled on the ground or on a leaf, its wings more spread than clclia or cebrenc. Except when settled in the shade its tail was directed towards the sun. One was seen to close and open its wings, another was watched for some time and observed over and over again to orient itsclf correctly, and twice to close its wings so as to leave practically no shadow.

Precis elgiva, Hew., is not uncommon in woods ncar Durban, it was noted as sitting with wings fully expanded and tail to the sun.

Precis sescumus, Trim., is a dark, handsome insect, fond of hiding itself in ditehos and under dark banks, often several togetlier; this 
is not always donc with a vicw to seek sheltcr from the wind, though sometimes that seemed to be the object. It pitches on or close to the ground, with the wings fully expanded, just as $P$. natalica; in this position it is less conspicuous than might be supposed, especially when it settles on dark clay, or peaty soil, as it appeared to be fond of doing. Both Dr. Dixey and I saw it orient itself like its congeners, sometimes with adjustment. On one occasion only did I see it closc its wings over its back, casting, as a result, a minimum shadow.

Another Precis, nearly the colour of the red soil, but more orange in tint, was observed to orient with tail to the sun. This I saw several times but failed to catch; it was on August 18th, on somewhat open ground at the edge of a large banana garden above the Congella Woods, Durban. I thought at the time that this was $P$. octaria, Cram., the wet-season form of $P$. sesamus, but it is just possible that it may havc been $P$. cloantha, Cram., which I took on the other side of Durban. With the possible exception of this doubtful Precis all my remarks about South African butterflies apply to dry-season forms.

Hamanumida daedalus, Fabr., is a common African Nymphaline that we only met with on the banks of the Zambesi. We both noted that it usually flies near the ground, on which it settles with the wings closely appressed to the surface. It occasionally flaps its wings, but as long as they arc still it is very inconspicuous, its grey colour approximating closely to that of the sand, the whitish spots aiding its concealment by breaking up the surfacc. One was observed to walk about on mud regardless of the sun's direction, but it finally settled down with tail to the sun and wings spread out in the usual way.

[Abisara (Zemeros) flegyas, Cram., a common Oriental Erycinid, has a strikingly similar pattern to the last-named Nymphalid, but I do not know what its favourite resting-places are.]

Pyrameis cardui, Linn. I summed up my observations on this butterfly in Algeria in the following words:-

I can confidently say that it gencrally scttlcs with its tail to the sun, though it does not do this with the regularity of Pararge meonc. I saw two specimens turn thcir heads to the sun, and saw a third settle twice with its body at right angles, though the third time it scttled normally. ${ }^{1}$

At Durban, on August 21st, I watched this cosmopolitan butterfy orient, but full weight must be given to the following very definite observation of Dr Dixey's when watching lizards :-

1 Proc. Ent. Soc. Iond., 1905, p. xxix. 
Ladysmith (North East Defences), August 27th. Watched several $P$. cardui, which settled frequently. They would settle at any angle with regard to the sun, but perhaps rather more often with back to it. They fanned their wings, and often shut them up tight (keeping them so for some time) in any position with regard to the sun.

This was late in the aftermoon, but I do not gather from $\mathrm{Dr}$. Dixey (nor from personal recollection) that the sunlight was feeble, or that there was a strong wind, or that the butterflies were feeding or drinking-all disturbing causes. There can, I think, be no doubt that the habit of heliotropism is not as fixed in the Painted Lady as in many Nymphalines.

That this butterfly, often at any rate, does orient, is clearly proved by subsequent experience. In Egypt, in 1909, I saw many $P$. cardui, and find these notes:-Pyramids, January 4th, P.curdui, seen to orient twice. Aswân, January 23rd, P. cardui, abundant; many oriented. Aswân, February 25th, P. curdui, abundant; many specimens fresh, but chipped; several seen to orient-practically all those seen settled on the ground.

Again, in the Botanical Gardens, Hobart, Tasmania, P. cardui, f. liershawi, McCoy, was seen to orient twice.

Among our notes on heliotropism there are but three references to Pierines. The first is interesting as tending to negative the suggestion that the purpose of heliotropism is to mimimize the butterfly's shadow and so aid in its concealment. Dr. Dixey writes :-

Durban (The Bluff), August 16th. Tcracolus ione, Godart (speciosus, Wallgr., jobina, Butl.), o. When first seen it was settled in the sunshine with wings expanded; then it flew a short distance and settled on a reddish sandy patl.. Clond came over the sun, and the butterfly closed up its wings, so that only the hind-wing and tip of the fore-wing were visible.

In explanation of this note Dr. Dixey emphasizes the fact that in the diy-season form of ione, the underside of the hind-wing and the tip of the fore-wing are reddish, hence the tightly closed attitude is cryptic on red soil. ${ }^{1} \mathrm{He}$ adds that doubtless when the butterfly

The observant traveller must have been struck by the prevalence of red soils in tropical countries. The two following notes on the origin of rod soils may be of interest to the entomologist :-

Mr. R. D. Oldham, F.R.S., of tho Geological Survoy of Indin, writing of the Basal Carboniferous Conglomerate of Ullswater, says: "The red colour of the finegrained material suggests tropical or subtropical conditions, as the formation of red 
contemplates a long stay (as at night, or when the sun goes behind clouds) the closed-up attitude is adopted to take advantage of its cryptic colouring, and not to minimize its shadow.

The other observations were made on Belenois severina, Cram., a white butterfly that we found very abundant at Durban.

Dr. Dixey says :-

$B$. severina, of and + ; when clouds come over the sun, this species generally settles on a grass stern, and, closing its wings tightly, becomes part of the picture. It certainly generally turns its back to the sun when it settles in sunshine, and then does not often close up its wings.

My note is as follows:-

$B$. severina, 2 o seen to settle across the sun, early in the day. Late in the afternoon many of severinc seen settled with wings three-quarters open, and tail more or less to the sun; but where much exposed to wind the wings were closed and the head turned to the wind, so as to be almost across the sun.

It is worthy of remark that throughout all these observations of heliotropism, I cannot recall a single case in which an adjustment, or subsequent movement of the butterfly after pitching, tended to throw it out of orientation. Hence it is fair to assume that if the insects had been watched longer after pitching positive results would have been observed in a larger proportion of cases.

But, be that as it may, beyond doubt it is a habit with a number of butterflies, especially Nymphalines, to settle with their tails to the sun. Whether they do this, as Professor Parker supposes, to display their charms to the greatest advantage, or whether the first impulse was given by the light or warmth of the sun's rajs, I am unable to determine, but that in such species as Pararge megaera

soils is at the present day so much more common in tropical than in temperatc regions that it may almost be regarded as a characteristic of a hot climate." G'eological Magazine, 1900, p. 564.

Again, Mr. J. J. H. Teall, F.R.S., speaking of the Kouper Marl, etc., at Sidmouth, said that he thought "that the red colour of the formation was mainly duc to the sub-aërial decomposition of rocks containing ferriferous compounds, under conditions similar to those prevailing at the present day in India, the Southern States of Eastern North America, Brazil, and parts of Africa, in short, to what might be termed the lateritic type of decomposition. Under this mode of decomposition the iron becomes oxidized, and deposited as a ceating on the grains of quartz and other undecomposed minorals. The red material thus produced would mantlc the slopes, fill up the hollows, or be spread out as flat fans over the low ground by torrential action. It would also be deposited in lakes, lagoons, or seas."-Procecdings of the Geologists' Association, July, 1899, p. 141. 
and Precis clclice the diminution of the shadow when the wings are closed helps to conceal the butterflies from their enemies I have no longer any doubt.

Further observations will show how far the habit is general within the families in which it has been observed, and whether it prevails in other families.

In the discussion which followed the reading of this paper (March 7th, 1906), the President (Mr. F. Merrifield) threw out the suggestion that possibly the object of negative heliotropism might be to enable the bntterfly to see to the greatest advantage. This is in agreement with Mr. Marshall's remark that orienting butterflies are always very much on the alert.

Dr. T. A. Chapman said that the heliotropic attitude, with tail to the sun, was familiar to observers of Vanessas and other Nymphalines, and some other butterflies of the European fauna. During their active period, when settling, usually on the ground, the butterflies in question assumed that orientation, and spread their wings flat on the ground with the head a little raised, making the greatest display of their colours, but chiefly appearing desirous to secure as vertical a sun as circumstances allowed; this might be different in the tropics. ${ }^{1}$

To this explanation Professor E. B. Poulton advanced an objection, that when the orienting butterfly closed its wings the exposure of both body and wings to the sun's rays is reduced to a minimum.

\section{Observations in the W. Indies, 1906-7.}

Constant Spring, Jamaica, January 8th, 1907. Precis lavinia, Cram., f. zonalis, Feld. Not uncommon, but hard to catch; usually settled on the ground with wings open; seen to orient and to put its wings up, causing little shadow; seen also to adjust itself after settling, so as to make the orientation more perfect; but sometimes seen to face the sun.

Maraval, Trinidad, December 19th, 1906. Anartia amalthca, Limn. Flies near the ground; settles with wings three-quarters open; orients, but not always.

Same place and day. Ancrtia jatrophce, Linn. Has a ghostly flight ; settles on the ground; orients.

Colon, Panama, December 28th, 1906. A. jatrophae. This species orients, but not very regularly.

1 Proc. Ent. Soc. Lond., 1906, p. xxvii. 
Constant Spring, Jamaica, January 3rd, 1907. A. jatrophue. Oricnts, but not very aceurately; often eloses its wings, and is then very cryptie among whitish dead grass.

Same plaee, January 5th. A. jatrophae. The eommonest Nymphaline: flies fast, elose to the ground, looking very white. Usually settles on the ground or elose to it; does not frequent flowers much; settles with the wings fully cxpanded, but often closes them over its back. Orients, but not accurately. Has, however, been noted with its wings up facing the sun; also once or twice aeross the sun.

Ramble, Jamaiea, January 24th, 1907. A. jatrophae. Orients.

Montego Bay, Jamaica, February 2nd, 1907. A. jatrophae, seen twice to settle on the whitish sand of the seashore, to orient and elose its wings, making no shadow.

Port Antonio, Jamaica, March 4th, 1907. The sun nearly vertical. Victorina stelenes, Linn., settled on leaves, once facing the sun, onee head downwards, tail to the sun, wings closed and no shadow.

Ramble, Jamaiea, January 24th, 1907. Cystineura dorcas, Fabr. Flies very slowly, elose to the ground. Settles with wings nearly wide open, but it sometimes closes and then quickly re-opens them. When feeding on flowers, especially the Composite, Bidens leucanthus, W., it is indifferent as to its position with regard to the sun, but otherwise it usually orients, though it occasionally faces the sun.

\section{Observations in Ceylon, 1908.}

Precis iphita, Cram. This species was often observed. It most often settled with its wings elosed, but frequently they were fully expanded. Though one specimen was seen to settlc twiee across the sun, it more usually either faeed the sun or turned its tail to it.

Vanessa haronica, Moore. One seen to orient with its wings elosed.

Yphthima ceylonica, Hew. This speeies, which kecps elose to the ground, settled oceasionally with the wings open, more often half open, but most commonly closed. As regards orientation, it was noted to have its tail to the sum ten times (once by adjustment), as ngainst seven times that it was aeross the sun.

Ergolis taprobana, Westw., and E. ariadne, Linn. These may be conveniently taken together. They have a skimming or gliding flight which is not always ehecked by rain. They settle commonly with 
their wings fully expanded, but sometimes close them only to open them again. Most often they orient, but sometimes imperfectly; one was seen to adjust itself.

Nissanga patnia, Moore. This butterfly settled with its wings up (one exception) and, so far as I observed, with the eye-spot exposed. In the majority of cases it oriented.

Neptis jumba, Moore; N. varmona, Moore; and Rahinda sinuata, Moore. These three species may be conveniently taken together. They all have the same gliding flight and all settle most frequently with the wings fully expanded, though often closed. As regards orientation less than half the specimens observed appeared to pay any attention to the direction of the sun's rays, though one varmona was certainly seen to adjust its tail to the sun.

Castalius rosimon, Fabr. Two specimens seen to orient with wings up.

\section{Observations in England.}

Argynnis paphia, Linn. Mortehoe, 1907, and later. I have several times seen this butterfly orient.

Lycaena corydon, Fabr. Berkshire Downs. I once saw this orient.

Iycaena icarus, Rott. Mortehoe. The constant habit of this species is to orient with the fore-wings set further from the hindwings than in most butterflies.

Hesperia malvae, Linn., and Thanaos tages, Linn. Both orient habitually.

\section{§ 9. "List" AND SHADOW.}

"List" may be exactly defined as an attitude resulting from a rotation of the insect about its longitudinal axis, as heliotropism results from a rotation about an imaginary vertical axis at right angles to this. Heliotropism corresponds to the movement of a vessel in answer to the helm. Most vessels, independently of wiud, waves, or tide, have a tendency to lean somewhat to one side or the other; this inclination is termed by sailors " a list," and, although I am aware that the analogy is not quite close, since the insect may lean at one moment to one side, at another to the other, I shall for brevity term such an inclined or tilted position a list.

So far as I know, this list was first observed by Col. C. T. Pingham, in 1878 , in a Mclanitis, but the observatiou was not 
published till long afterwards. The extracts from his diary of that year, brought to light by Prof. Poulton, give a most vivid description of some phases of the struggle for existence as it may be seen in a tropical forest. Col. Bingham says :-

The Melanitis was there among dead leaves, its wings folded and looking, for all the world, a dead dry leaf itself. With regard to Melanitis, I have not seen it recorded anywhere that the species of this genus when disturbed fly a little way, drop suddenly into the undergrowth with closed wings and invariably lie a little askew and slanting, which still more increases their likeness to a dead leaf casually fallen to the ground. ${ }^{1}$

E. H. Aitkin's papers in the Times of Indice reappeared in 1894 as "A Naturalist on the Prowl." His description of this habit of Melanitis has been already quoted (p. 75, supra). Dr. Dixey called my attention to this passage (as he has to so many other things), and to the similar habit of Satyrus scmele, linn. In the summer of 1903 we watched many specimens of the latter butterfly at Mortehoe, and found that, as a rule, they settled on the ground "in three motions": -(1) the wings are brought together over the back; (2) the forewings are almost completely drawn between the hind-wings; (3) the whole is thrown over to right or left (indifferently), to the extent of $30^{\circ}$ or $40^{\circ}$ or even $50^{\circ}$. I have observed that in confinement the third movement sometimes precedes the second. It is remarkable that the creature seems to attach more importance to this tilt or list when settled in sunshine than in shade. Of this I feel assured from observations on the butterflies confined in a large paste-board box covered with a piece of glass. Epinephele jurtina, Linu., and $E$. hyperanthus, Linn., similarly observed in confinement, arc also often seen out of the upright, but the list in their case does not exceed $15^{\circ}$ to $20^{\circ}$. In confinement I have once observed Pararge acgcria, Linu., and $P$. megaerc, Linn., sitting with a list of about $25^{\circ}$.

My Indian experience (1903) enabled me to add threc species to the "listing" butterflics:-Myealesis indistans, Moore, slight list; Hipparchia parisatis, Koll., $20^{\circ}$ to $30^{\circ}$; Aulocera swaha, Koll., $45^{\circ}$ to $50^{\circ}$. In the last-namcd spccics the same individuals were obscrved sometimes to go over to the right, somctimes to the lcft; one was seen to make three cfforts, getting further over cach time. A specimen of $H$. parisatis was obscrved walking about with a list of $20^{\circ}$.

I Trans. Ent. Soc. Tond., 1902, p. 363. All the extracts there given deserre the most careful study. 
To these observations I may add that at Yokohama, May 19th, 1904, Blanaida gosehkevitschii, Möschl., a Satyrine like a large $P$. megacra, was observed with a list of $40^{\circ}$.

At this stage the eonclusion reached was :-

There is no doubt that this sideways attitude makes the insects less conspicuous when resting on a flat surfaee, but I have satisfied myself from observations on English Satyrids that the attitude is more often adopted by the butterflies when sitting in sunshine than in shade. Now if the list be away from the sun the shadow would be increased, but if towards the sun it would be diminished, in some cases even to extinction. Numerous observations are required to determine whether the list has any relation to the sun's position. I would, however, remark that in the case of a butterfly with cryptic eolouring on the underside the shadow is often far more conspicuous than the butterfly itself, as I frequently observed in India. Obviously, therefore, eeonomy of shadow might be a considerable protection. ${ }^{1}$

\section{Observations in South Africa, 1905.}

On the voyage ont to South Africa the usual call at Madeira gave us little more than a glimpse at its butterflies. The loeal raee of Satyrus semele, Linn., was eommon on the Caminho do Meio at an altitide of about $800 \mathrm{ft}$., and Dr. Dixey has this note:-

Settled on the ground, low herbage, walls and tree-trunks. The fore-wings are depressed with a snap as in the English semele. Two were speeially noted settling in sunshine (not strong) both turned head to sun and listed-one to port and one to starboard.

My note is :-

A specimen seen settled head to sun, list $30^{\circ}$ to starboard.

It was of course only to be expected that on the fifth day from leaving Southampton we should both use nautical phraseology.

South Afriea eontributed little to increasing our knowledge of the list. The genus Pseudonympha, somewhat suggestive of Erebia, is charaeteristie of Cape Colony; at East London I observed several $P$. cassins, Godart, at rest, but did not see any list.

Mycalesis safitza, Hew. Though I took many odd specimens of

1 Trans. Ent. Soc. Lond., 1905, pp. 135, 136. 
this dingy butterfly, I never found it really common, and have but two notes of its resting attitude:-

Berea, near the hotel, Aug. 14th, seen to settle in the shade, And, wings upright.

Congella, Aug. 18th. This species does not appear to orient: a slight list away from the sun, but sun not very bright at the time of observation.

Dr. Dixey, however, obtained more positive results:-

Durban (Botanic Garden), Mycalesis safitza has a very strong list when settled in the open; it may be to right or left in the same individual.

Durban (Botanic Garden), saw Mycalesis safitza settled on bare ground; it had a strong list to the left. Saw it fly and settle in bright sunshine; once with its back to the sun, with list to left; once with head to sun, right list; once at right angles to sun, throwing a broad shadow.

It would therefore seem that Mycalesis safitza may be included among the Satyrs with a list, but this does not appear to help concealment by diminishing the shadow, as I had suggested would be the case if the list were towards the sun.

\section{Observations in Jamaica, 1907.}

My visit to the West Indies enabled me to determine that at least one Neotropical butterfly, also a Satyrine, is to be connted among the "listers."

Calisto zangis, Fabr.-This is quite a shade-loving butterfly; it keeps close to the ground, flying amongst herbage, usually for a very short distance at a time. It was once seen flying freely on a rainy day.

Mackfield, 'Jamaica, January 29th, 1907. Three C. zangis seen to settle (one of them twice) with a list away from the sun of about $30^{\circ}$ from the vertical.

Christiana, Jamaica, Febrnary 2nd. C. zangis seen to list away from the sun.

Mile Gully Mt., Jamaica, February 14th. C. zangis seen to settle and then, with a jerk, list about $30^{\circ}$.

Port Antonio, Jamaica, March 4th. Three C. zangis seen to list from the sun, usually but $20^{\circ}$ to $30^{\circ}$; one was seen to increase the list by two moveruents. 
During my visit to Ceylon in the spring of 1908 I did not see any butterflies list.

In his "Butterflies of British India" (vol. i., 1905, p. 47) Col. Bingham writes: "The Satyrinae are shade-loving insects; most of the forms have comparatively a weak flight, and frequent the undergrowth, long grass, or dense cvergreen forests. Many are cryptically coloured on the underside, and their method of suddenly dropping after a short flight, and resting all askew, heightens their likeness to dead or decaying leaves casually blown down." It is greatly to be regretted that considerations of space prevented the author from giving us more such information from his stores of knowledge.

I now give some later observations on "list" in English Butterflies.

Coenonympha pamphilus, Linn.-Early in June, 1906, Mr. W. J. Kaye told me that he had recently noted in Surrey, C. pamphilus settled with its wings up, but leaning over in such a way that the sun's rays fell vertically upon its wings. This was a new idea to me. Going down to Devonshire the next day I naturally wished to confirm Mr. Kaye's observation, but though I have seen the butterfly in some abundance at Mortehoe, its appearance there is uncertain, so much so that neither in 1904 nor in 1907 did I come across a single specimen in the parish. However, in 1906 I succeeded in finding three specimens, which I observed with the following results :-

Mortehoe, June 10th, 1906. C. pamphilus: a specimen seen to scttle six times; always across the sun; with head somctimes to the right, sometimes to the lcft; the wings up; in every case with a list away from the sun so that its rays were about normal to the wing surface.

Mortehoe, Junc 13th, 1906. A specimen seen to settle sevcral times; across the sun; the wings up, but with no list.

Mortehoe, June 14th, 1906. $\Lambda$ specimen seen to settle sixteen timcs; always with wings up and across the sun; on twclvc occasions with a list away from the sun.

Biraunton Burrows, Septembor 10th, 1907. C.pamphilus (the only ouc seen that year) scttled across the sun, with head to the wind, and a list away from the sun.

Morte Point, September 5th, 1908. C. pamphilus rather common at one spot; the wind was so strong as to compel them to kecp their hoads to it regardless of the sun. A specimen was scen 
to list three times to the right, slightly, and once to the left, strongly.

Satyrus semele, Linn.-The behaviour of this butterfly may be compared with that of the last-named.

Mortehoe, July 20th, 1906. A number of S. semele observed to settle. All put their wings up; two oriented with tail to sun; one faced the sun; twenty-four placed themselves across the sun, of these one was noted as listing about $30^{\circ}$ towards the sun, but eight listed away from the sun, only one, however, to an extreme degree.

Same place and day. Three S. semele put into a large glass-covered box. Observed the same afternoon, at 6 p.m., in sunlight; all three were sitting across the sun and listed away from it $35^{\circ}$, $45^{\circ}$, and $55^{\circ}$ respectively.

Mortehoe, July 31st, 1906 . Several semele noted, settled across, and tilted a little away from the sun.

Mortehoe, August 22nd, 1907. Three semele observed at rest, all across the sun, and listed away from it $30^{\circ}, 40^{\circ}$, and $25^{\circ}$ respectively. Lundy Island, August 27th, 1907. A semele listed away from the sun about $50^{\circ}$.

Here I may insert an observation made by Mr. E. G. Waddilove at Bournemouth in the autumn of 1906 :-

"A Grayling settled on a patch of bare black peat-earth, shut up its wings vertically and crawled at once some two yards to the edge of the patch to where some fir-needles, a cone or two, and a few brittle twigs were lying, and then becoming stationary threw itself over at an angle of some $45^{\circ}$ square to the sun. It thus became quite indistinguishable from its surroundings." (From a letter to the author.)

The late Mr. C. G. Barrett, in an admirable account of the habits of the same butterfly, wrote as follows:-

“. . . it even seems to lie down sideways, or at any rate to so greatly slope its closed wings as to appear prostrate." 1

Epinephcle janira, Linn.-Our commonest butterfly is especially interesting, since its habits are irregular and partake of those of C. pamphilus and S. semele.

1 "Lopidoptera of the British Islands," 1893, vol. i. p. 35: 
Mortchoe, July 20th, 1906. E. janirc. Four speeimens oriented; of these, three had the wings open, one elosed. Eleven speeimens were settled aeross the sun, with wings elosed; eertainly one of the latter listed from the sun.

Mortehoe, July 30 th. Some notieed to orient; others sitting aeross the sun.

Mortehoe, August 11th, 1907. One of and two $q$ oriented; wings three-quarters open. Others were seen aeross the sun and one of these listed. The wind was, however, this day too strong for trustworthy observations. The butterflies mostly sat head to the wind.

Mortehoe, August 15th, 1907. Several speeimens noted settled on grass, on or near the ground. Of these three of oriented, one with the wings quite open, the other two three-quarters open. A $q$ oriented with the wings open; another $q$ settled on a leaf oriented with the wings three-quarters open. Another $q$ sat aeross the sun, had its wings up, and listed away from the sun. The eye-spot on the fore-wing was sometimes obseured, sometimes in part visible.

Mortehoe, August 16th, 1907. A q seen to settle three times aeross the sun, with its wings elosed, leaning away from the sun. Yet another $q$ was seen to settle three times; twiee aeross the sun, with wings elosed, but on the third oeeasion with its wings open and fairly oriented.

Mortehoe, August 22nd, 1907. A $q$ observed to settle three times, (1) oriented; (2) aeross, with slight list away fronı the sun; (3) oriented.

Mortehoe, August 24th. A q settled on a leaf oriented.

\section{The effect of a list on the shadow.}

It is worth while earefully eonsidering the precise effeet of a list on the shadow of a butterfly sitting with the axis of its body at right angles to the sun's rays.

To make the matter elear I have eonstrueted three diagrams. The diagrammatie butterfly is in eaeh figure supposed to be settled with its tail towards the observer, but turned somewhat to the left so as (in two of the three diagrams) to expose the underside of the right wings obliquely to the observer. The sun is supposed to be to the right of the observer and nearly to the right of the butterfly. The sun's elevation is taken to be $50^{\circ}$, represcnting a eondition that 
is fulfilled in Europe during some part of every day near midsummer, and in the tropics during some part of every day in the year.

When the butterfly is upright its shadow is nearly as long as its wings, and is fully exposed to view (see Fig. 16).

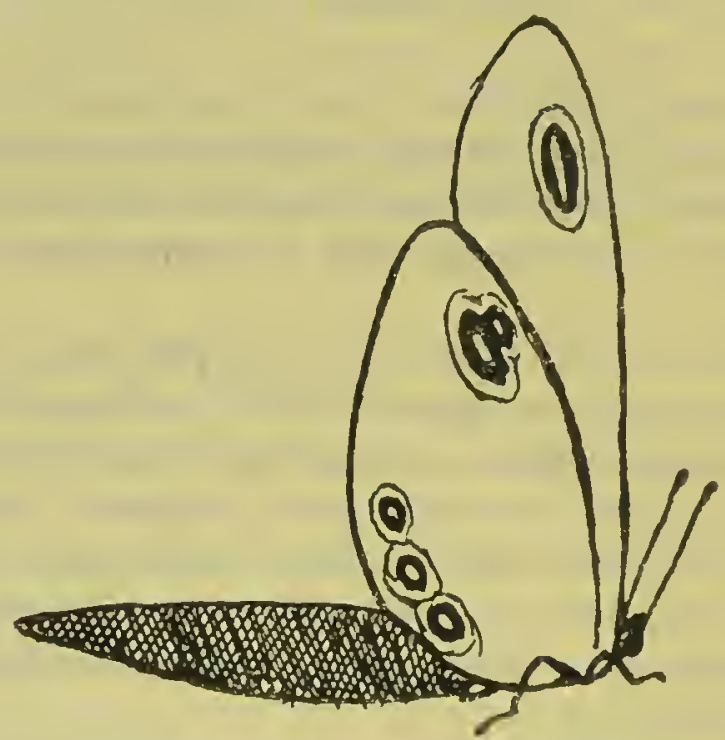

FIG. 16.-Shadow of butterfly-upright.

If the butterfly were to list towards the sun its shadow, still fully exposed to view, would diminish until the list became equal to the sun's altitude, when there would be no shadow. In this position, moreover, its wing surfaces would be least illuminated.

Supposing the butterfly to increase its list; this wonld bring the sun's rays on to the under surface of its left wings and so throw

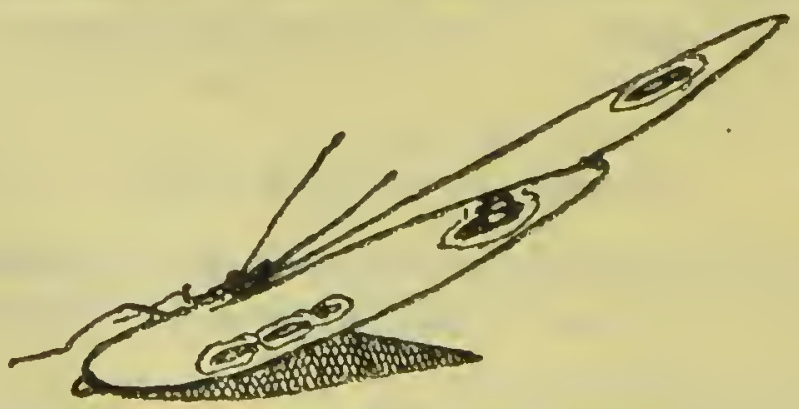

FIG. 17.--Shadow of buttorfly-listing $65^{\circ}$ towards sun.

the shadow to the right, or towards the sun (see Fig. 17). The shadow would continue to increase in length until, when the butterfly's wings touched the ground, it would equal them in length. On the other hand, as the shadow increased in length it would be more and more concealed from view. 
But as a matter of fact, the list has almost always been observed to be away from the sun. Such a list increases the length of the shadow until the list amounts to $40^{\circ}$ (under the conditions assumed) and so brings the wings into a position normal to the sun's rays (see Fig. 18). The length of the shadow is then at its maximum and longer than the wings.

A further list would diminish the shadow until, when the wings touched the ground, it would equal their length.

A little consideration will, however, show that by listing the butterfly, so to say, covers up its own shadow more and more, so that while a slight list produces little effect on the shadow, a considerable list $-45^{\circ}$ and upwards-would make the shadow less conspicuous than that cast by the same butterfly in the upright position.

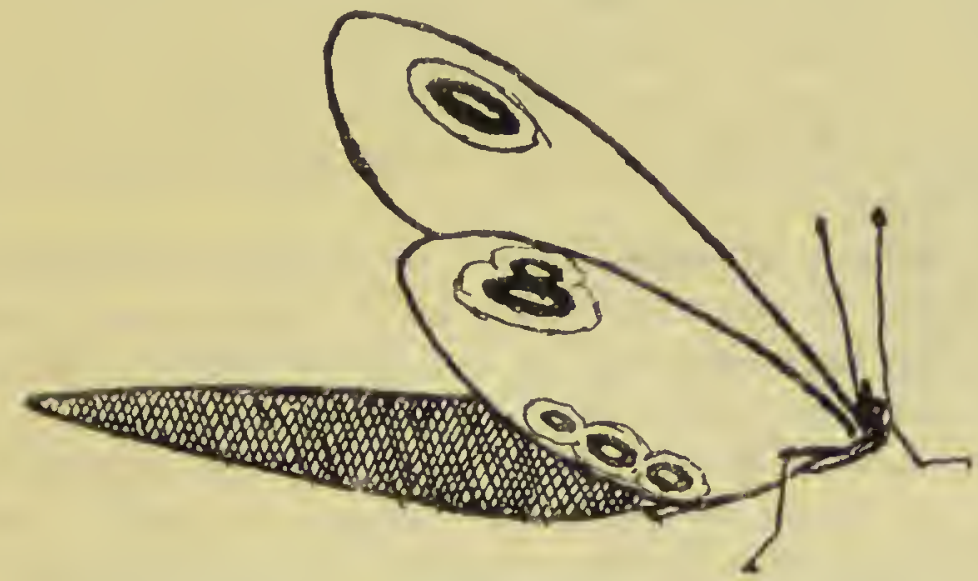

Fia. 18.-Shadow of butterfly-listing $40^{\circ}$ from sun.

My conclusion accordingly is that, so far as regards the shadow cast, no list from the sun can be protective to the insect unless it be extreme. Again, a list from the sun, by resulting in the maximum illumination of the wing surface, can hardly aid concealment. At the same time, it cannot be denied that a butterfly by placing itself out of the upright, may thercby be protected in so far as it may then be more difficult to detach it from its surroundings. This would certainly appear to have been the case with the Melanitis recorded by Col. Pingham and by "E. H. A.," also with the S. semele obscrved by Mr. Waddilove.

Barrett's remark as to a rarer British buttcrfly, Grapta c-album, Linn., deserves quotation :-

". . f fond of sunning itself in roads, on warm walls, or on the ground upon dead leaves in sheltered valleys. Here if the 
sun becomes overclouded, it will sometimes close its wings and almost lie down, in such a manner that, to distingriish its brown and green marbled underside from the dead leaves is almost impossible." 1

Here Barrett says if the sun becomes overclouded, but I have observed the list (in other butterflies) during bright sunshine only.

It will be remembered that Prof. Parker (p. 539, supra) states that some American species of the genus Grapta orient themselves, so that it would appear that both heliotropism and list occur in the same genus.

When my attention was first drawn to the subject of heliotropism by observing the habits of Pararge schatera, Koll., in the Simla district in October, 1903, I was disposed to associate that habit with list, and suggested that both had probably been selected, since they appeared to assist to a notable degree in the concealment of the insect from its foes. The evidence now available is more ample, though still far short of what would be requisite to establish definitely any explanation.

Prof. Parker's explanation that by negative heliotropism the insect displays its colouring to the best advantage, can scarcely be applied to list, for while it may be true that by listing a butterfly displays its underside, that underside is in listing butterflies usually cryptic, even when in our cabinet it appears the more brilliant of the two. Moreover, in the listing position the most conspicuous feature of the pattern is often concealed by the hind-ring, so that the listing butterfly exposes to the sun one hind-wing only, and a small portion of the corresponding fore-wing.

That under special circminstances there is an economy of shadow in both heliotropic and listing butterflies is muquestionable. On the other hand, the negatively heliotropic butterfly with wings expanded, and the listing butterfly with wings closed, both place their wings as nearly as may be normal to the sun's rays, exposing in the one position their upper, in the other their under, surface. Is it possible that the direct rays of the sun, falling normally on either surface of the wings, afford a pleasurable sensation to the insect? Or is the exposure of the insect's body to the sun, common to some extent to both these attitudes, the end obtained? The obvious love of most butterflies for hot and sunny corners unquestionably suggests some such explanation. Perhaps the two explanations may both be true, - that heliotropism and list combine the pleasures of isolation with 
the minimum of risk. As far as the evidence at present available goes this explanation commends itself as the most probable.

Dr. Chapman tells me that he has observed a marked list in a Spanish species of Erebia, and my own experience of list is confined to the Satyrines, a group of feeble flyers, be it noted, with (at any rate in the great majority of species) cryptic under-sides.

As regards other families, I have come across but one reference to such a habit among the Pierines. Mr. W. H. Edwards, in his "Butterflies of North America," 1897, quotes Mr. William Couper's observation as to a habit of Colias philodice, Godart, in Anticosti :-

"When it alights on a flower, instead of being erect on its feet it lies sideways, as if to receive the warmth of the sun."

The original passage occurs in the "Canadian Entomologist," vol. vi. p. 92,1874 ; if therefore this be truly such a list as is under discussion, Mr. Couper deserves the credit of having first recorded it, but at present $I$ am doubtful on the point.

Professor Poulton, in a discussion at the Entomological Society, stated that on one occasion many years ago, he had observed a pronounced movement in the nature of a list in the Green Hairstreak (Thecla mibi). The butterfly was observed at rest on the flat surface of a leaf at Birdlip, Gloucestershire, and it let itself down so completely that it seemed to lie flat on the leaf. The obliteration of shadow was very marked, and had at the time forced itself upon his mind as the significance of the attitude. ${ }^{1}$

Mr. Rowland-Brown said that he had also observed an extreme list in the same butterfly. He has since been good enough to call my attention to a note in No. 13 of the Bulletin dc la Société Entom. dc de France, 1909, pp. 211,212, on the egg-laying habits of Pararge maera and $P$. meguera, in which it is stated that the latter, creeping in to lay her eggs, lies almost flat on the ground-“elle plie ses ailes, rentre les ailes supérieures cntre les ailes inférieures, puis les incline parallèlement au sol; elle entre alors sous les brins de l'herbe ... " (J. de Joannis).

Dr. T. A. Chapman ${ }^{2}$ has published some interesting notes on heliotropism, and more especially on list in Callophrys (Thecla) rubi and Thestor ballus.

Mr. L. B. Prout netted a specimen of the Green Hairstreak which settled on his finger in such a position as resulted in the vertical exposure of the under surface to the sun. When Mr. Prout moved his finger the butterfly changed its position in a corresponding

\section{Proc. Fint. Soc. Tuond., 1906, p. xxviii.}

2Entomological Record, vol, xviii., 1906, p. 168. 
manuer; the experiment was repeated several times with the sane specimen, always with the same result. ${ }^{1}$

As before stated Mr. G. A. K. Marshall insists on the relevant fact that orienting butterflies are very much on the alert, moreover in a letter to the author he says that he has observed that three S. African butterflies, Precis cebrene and Hamanumida daedalus, at Salisbury, and Mycalesis campina, Auriv., in Chirinda forest, when sunning themselves closed their wings with a snap when a heavy cloud passed over the sun.

It would be most interesting if it could be shown that orienting butterflies on the approach of an enemy close their wings in the same manner. To obtain such evidence might well be difficult, but good evidence on the point would be crucial.

\section{\$ 10. The Inverted Rest Attitude of Lycaenids and some other ButTerflies.}

It was at Benares, at the end of 1903 , that my attention was first drawn to the fact that the curious lobes at the anal angle of the hind-wings of certain Lycaenids-species of the genera Aphnaeus, Pratapa, and Rapala - are everted so as to be nearly at right angles to the plane of the wing. The diagram on p. 69 supra (Fig. 5) shows that this eversion of the lobe helped in the suggestion of a head at the posterior end of the body. The original sketch for the diagram was made before I had heard of the "false head theory." The resemblance would of course be more striking if the Lycaenids in question, like so many of the family, habitually rest with the head downwards.

Prof. Poulton discussed the "false head" at some length in his notes to Mr. G. A. K. Marshall's paper on "The Bionomics of South African Insects." 2 He there showed by a reference to Kirby and Spence that the resemblance of the tails of some Ljcaenids to antennae was observed early in the nineteenth century. I venture to give the passage in full :-

Dr. Arnold has made a curious observation (confirmed by Dr. Forström with respect to others of the genus) on the use of the long processes or tails that distinguish the secondary wings of Hespcria iarbas. These processes, he remarks, resemble antennae, and when the butterfly is sitting it keeps them in constant motion; so that at first sight

1 Entomological Record, vol. xviii., 1906, p. 214.

3 Trans. Ent. Soc. Lond.. 1902, pp. 373-375. 
it appears to have a head at each extrcmity: which deception is much increased by a spot resembling an eye at the base of the processes. These insects, perhaps, thus perplex or alarm their assailants. ${ }^{1}$

Hesperia iarbas at first puzzled me, but it would appear to be the insect now known as Deudorix (Rapala) iarbas, Fabr., and the very close ally of $D$. melampus, Cram., one of the insects in which I first noticed the peculiar structure of the anal lobe, about eighty-six ycars after Dr. Arnold's observation.

I remember well seeing a Lycaenid at rest on a leaf at Solon, on the road to Sinla, in October, 1903, and noticed its tails waving about, as I thought at the time blown by the wind.

On March 12th, 1904, the pretty white, black, and orange Talicada nyscus, Guér., was positively swarming ncar Kandy. I repeatedly watched it settle with its head upwards and immediately turn about so that its head looked downwards. ${ }^{2}$

At Mortehoe, June 5th, 1905, Mr. A. L. Onslow and I searched from sundown to dusk for Emmelesia albulata, Schiff, in a field adjoining my house; we failed in our search, but incidentally came across a number of Lycaena icarus, Rott., asleep on the stems of grasses, etc. Out of fifteen specimens, twelve had the head down, three had the head up. ${ }^{3}$

The lobed and tailed Lycaenids are not too easy to observe; they are active and commonly fly about the tops of shrubs or small trees; when at rest they are not conspicuous and when disturbed dart swiftly off.

Dr. Dixey noted :-

August 20th. Durban (Botanical Garden). Saw an "amphis-baenoid" Lycaena settled twicc; the first time horizontally, the second time head downwards. On both occasions the false head looked much more like a head than the rcal one did. There was a constant slight movement of the hindwings; and a waving of the falsc antennae.

Unluckily this specimen eluded capture. Again Dr. Dixey noted:-

August 16th. Durban (The Bluff). Saw a Lycaenid settled on the top of a leaf horizontally. The false head was

1 "An Introduction to Entomology," vol. ii. p. 255. First Edition, 1817.

2 See abovo, p. 114.

3 When this butterfly first settles on flowers in full sunshine it oxpands its wings very fully, the primarios boing drawn somowhat away from the secondaries. 
mueh more conspieuous than the real head, which was almost concealed; the real antennae were quite concealed.

This proved to be Virachola antalus, Hopff.; I have a note referring to the same species:-

A Lyeaenid boxed off a plant elose to the ground; it was sitting with the head downwards, but the false head was missing, having been bitten off, probably by a lizard.

Dr. Dixey was more fortunate than I with Axioccrces harpas, Fabr., since he notes:-

September 9th. Bulawayo, Rhodesia (near the Waterworks). This speeies was abundant at the eatkin-like flowers of a shrub said by Mr. Davey to be a species of Combretum. When settled, it closely resembled (at a little distanee) the seed vessels, of which many remained on the plant, though the latter was just coming into flower. On a near view, the false head of the Lyeaenid looks extremely life-like, and is moved about by the butterfly in a most deceptive manner. The species settles either horizontally or head downwards. Attention seems to be drawn to the false head by alternate partial folding and unfolding of the everted margin of the hind-wing, while the butterfly is settled.

Coming now to my own observations, the false head was noted during life in five specimens (all females) of Argiolaus silas, Westw., but in none of them was the attitude at rest determined, indeed the insects usually settled high up on the trees beyond my limit of elear vision.

September 10th. The Matopos, Rhodesia. A male of the beautiful Stugeta bowkeri, Trim., was twice seen to settle with its hend downwards on the catkin-like racemes of the shrub Sclcrocarya caffra. The false head was very obvious. It opened and shut its hindwings while settled.

September 28th. East London (Buffalo River). A specimen of Phasis chrysaor, Trim., was seen settled head downwards.

August 14th. Durban (near Sydcnlam "Old Cemetery"). A female Hypolycaena philippus, Fabr., exhibited a false liend, but was not seen at rest.

September 15th. Victoria Falls. A speeimen of Catochrysops malathana, Boisd. (asopus, Hopfi.), was seen in the Rain Forest settled with its head downwards.

September 26th. East London. Two specimeus of Tarncus telicanus, Lang, were seen in the Quecn's Park sitting horizontally. 
They were moving their hind-wings alternately in the planc of the wings, exactly as I had seen a Lampides do in the Nilgiris.

North Devon, September 1st, 1907. Walking with Mr. H. Champion along the Woolacombe sandhills late in the afternoon we observed thirty-nine specimens of Lycaena icarus, asleep on Marram, Privet, etc. No less than thirty-eight of these were sleeping with the head down, while the exceptional one was horizontal. In many instances the fore-wings were drawn so far back that the costae of the hind-wings overlapped those of the fore-wings. The antennae were porrected and near together. ${ }^{1}$

Mortehoe, September 11th, 1907. A + L. icamus at rest on a Ragwort flower moved its hind-wings alternately.

Carácas, Venezuela, March 3rd, 1907. The dingy little Catochrysops hanno, Stoll, was seen sitting head downwards, opening its hind-wings at intervals.

Walderston, Jamaica, February 16th, 1907. Calycopis pan, Drury. The lobe of the hind-wing is everted as in Aphnacus, Argiolaus, etc.

St. Ann's, Trinidad, April 1st, 1907. A $q$ of Thecla spurius, Feld., seen sitting head down; the hind-wing is folded; the lobe is large.

The Zebra-like Thccla linus, Sulz., is a common species in Trinidad. The lobe of the hind-wing is everted, but not quite to a right angle; it is curious that the tails are crossed, so that the tail of the right wing imitates the antenna of the left side and vicc versâ. [Mr. Knight has made this very clear in Fig. 12, p. 326, supra.] The tails were seen to move slightly, and the false head looked more like a head than the real one. Though I have no note to that effect, I feel sure that I saw this species sitting head downwards.

My later Ceylon experience (Jan. to March, 1908) enabled ine to add nine more species in which I have observed the inverted

1 In tho fourth Roport of the Rugby School Natural History Society, 1870, p. 17, is an interesting note by Mr. Arthur Sidgwiok, which I give at somo longth as the Report is not easily accossible. "On August 13th, 1870, I noticed on the road from Bez to Gryon, in tho Rhone Valley, a largo number of tho Chalk-hill bluo (Polyommatus corydon), on the umbelliferous plants by tho roadside. It was just sunset, and they werc all at rost. Their colour and shapo offectually protectod thom from notice. . . . I noticcd that thoy all rosted head downwards. It occurred to mo that oven this apparently trifling detail of instinct or habit might bo protcctivo. Tho cye in wandering over a plant is arrested more casily than one would suppose by any outine out of accord with the gonoral lines on which the plant is constructed." The noto is accompanied by skotches showing that tho butterfly resting head downwards is less conspicuous than one in tho opposite position. 
attitude, making in all nineteen species of Lycacnidae. It seems probable that sufficient observations are alone required to prove the habit to be general in that family.

Zizerc otis, Fabr., f. indica, Murray. + . One observation.

Evcres parrhasius, Fabr. ․ Two observations.

Nacaduba atrata, Horsf. o. Three observations.

Jamides bochus, Cram. ․ One observation.

Lampides elpis, Godart. of. Two observations: in one the butterfly settled head upwards, but turned round immediately.

Lampides celeno, Cram. 10 o, 1 \%.

Polyommatus baeticus, Linn. Both sexes. Nine observations.

Surendra qucrcetorum, Moore. ㅇ. One observation.

Loxurca arcuata, Moore. One observation.

The "sawing" movement of the hind-wings observed at Kallár in the Nilgiris during 1904 in Lampidcs sp., and during Tarucus tclicanus, Lang, and at East London, S. Africa, during 1905, was again observed in several Blues in Ceylon during 1908, viz. :-

Talicada nysens, Guér.

Evercs argiadcs, Pall.

Lampides ccleno, Cram.

Polyommatus baeticus, Linn.
Six observations.

Two observations.

Three observations.

Six observations.

Prof. Poulton explains this movement ${ }^{2}$ as assisting in the deception of the false head, but the explanation scarcely satisfies me since butterflies at rest do not usually move their antennae. It is, however, possible that movement as movement may challenge attack; compare the case of the Maina mentioned above ${ }^{3}$ also Col. Mander's experience. ${ }^{4}$

1 Compare Trans. Ent. Soc. Lond., 1905, pp. 85, 86, 127. Mr. Marshall mrites: "I am quite satisfied that this (head down) is tho usual position in Lycacmidac, and could add numerous speeies to your list, sueh as: Aphnacus, Spindasis, Axiocerces, Iolaus, Stugcta, Hypolycacna, Minacraca, Myrina, otc.. ete., but the simplest way" is to montion the speeies which do not do it. Of these I know three only in South Africa: viz. Alaena nyasac, A. amazoula, and Pcntila tropicalis-all distastoful spocies. Similarly this is the normal position in South Afriean Nymphalinac, riz. Atclla, Lachnoptcra, Hypanartia, Prccis, Catacroptera, Crenis, Charaxes, Euratia and Salamis, which are all the gonora I ean think of at the moment in which I have netually obsorved it. On the other hand, all the Danainae and Acracinae hang with wings down. It is possible this may prove to be a good criterion of palatability, for the head-down position gives the inseet a muoh better opportunity of launching into a rapid flight, and thus ovading attrek, which is not of sueh great eonsequence to distastoful species."

" "Essnys on Ivolution," 1908, pp. 282, 325, and the referenees there giren.

Pago 526.

+ Proc. Zool. Soc. Lond., 1911, p. 738. 
As regards the lobes to the hind-wings of so many Lycaenids the following additional facts may be noted :-

Aphnaens (Spindasis) vulcanus, Fabr. Ceylon, 1908. In this speeies, which has a habit of eurvetting rapidly about before settling on the ground, the lobes, which are small, are everted. The hindwings are folded in sueh a way as to make a very slight convexity between the two tails, the nervures corresponding to the latter lying in re-entrant angles.

Rapala lazulina, Moore. Ceylon, 1908. The lobes are everted.

Loxura arcuata, Moore. Ceylon, 1908. This species has a peeuliar darting flight. The arrangement of the wings at rest is somewhat complicated: the lobes, which are small, are half, or perhaps three-quarters, everted, showing an eyc-spot when the insect is looked down upon from above ; the long tails appear to be somewhat twisted-one overlying the other, their black and white tips eurved upwards. The portion of the hind-wing between the extremity of the abdomen and the lobe is bent inwards. As touehing the very nearly allied Indian species, L. atymnus, Cram., I noted at Calcutta in 1903, "its wings are much plaited longitudinally, and when at rest its extrcmely long tails, crumpled look, and brown colour give it quite the appearanee of a dead leaf."

T'arucus theophrastus, Fabr., Sûdân, 1909, was seen to "saw" with its hind-rings.

Catochrysops eleusis, Dem. Egypt, 1909. This was several times discovered settled hoad downwards, and also seen to settle with its head up and immediately turn round. On one oceasion while I was looking at two of them settled head downwards on a flower-head of grass, a third settled just above them, head up, but at once turned round, so that there were three of the pretty little butterflies sitting one above the other within a eouple of inches.

Cyaniris argiolus, Linn., Hassocks, Sussex, July 24, 1911, seen to settle three times head upwards and at onee turn round.

Mr. Frank Littlewood, of Kendal, records "on the 14th (August, 1910) I took a grand series of Chrysophanus phlacas on the border of the Moss. ... During the day the heather-bloom seemed to be a great attraction, but towards evoning, in an adjacent eornfield, numbers were observed resting, with wings opened towards the waning sun, on the ripe heads of the eorn, and a pretty picture they presented, dotted about the field like so many brilliant flowers. With a solitary exeeption all were head downwards."-Entomologist, 1911, p. 72.

Neither the inverted attitude nor the everted lobe would appear 
to be confined to the Iycaenidae, as the following exanples prove.

The common Jamaican Satyrine, Calisto zanyis, Fabr, has a peculiarity of construction which appears significant. The anal angle of the hind-wing is somewhat produced, moreover on either under surface, at the angle, there is a small ocellus. When at rest the wings are raised over the back in the usual manner; the abdomen is covered by the hind-wings, which are folded closely under it, but the anal prolongation of the wing is everted at right angles, as in the lobed Lycaenids, and as in them the ocellus may be seen from above. On every occasion on which I noted the butterfly at rest it was upon the ground, so that I do not know whether it ever adopts the inverted attitude and is protected by a false head. But whether that be so or not, the approach to Lycaenid structure in a Satyrine is interesting.
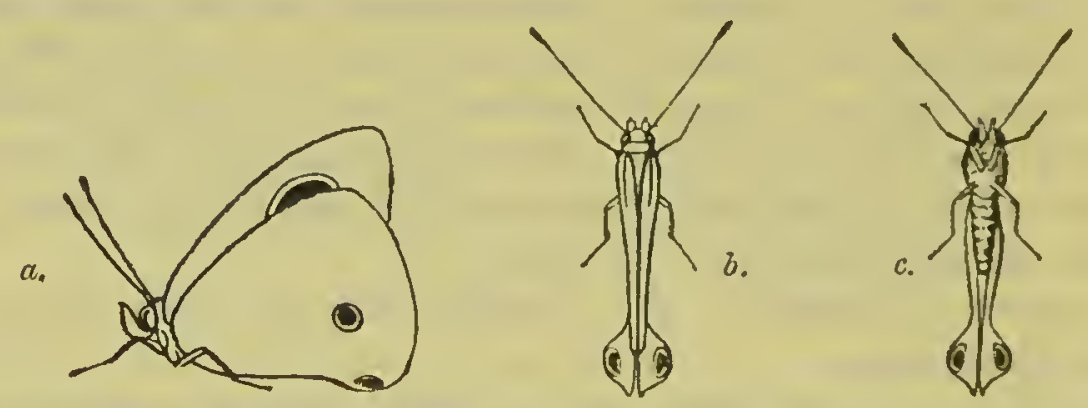

FIG. 19.-Calisto zangis at rest: (a) side view, (b) from above, (c) from below.

At first I thought that the eversion of the lobe in $C$. zangis might be due to the pressure of the curved surfacc of the pill-box in which the butterfly was confined, but subsequently I was abmndantly convinced that such is not the case, for when the butterfly rests on a flat surface with which the wing does not come in contact it is everted just the same.

There is a well-developed lobe in the Oriental and Ethiopian Nymphalinc genus Cyrestis, while the allied Neotropical gemus Megalura lias a somewhat similar structure (pointed out to me by Prof. Poulton), but I am not aware that the bionomic significance of these has as yet been worked out.

The fine large, blue-grey Nymphaline Peridromia foronia, Hübu., is a strong flycr, which has the unusual habit of settling upon treetrunks, usually choosing palms with silvery-grcy stems. The butterflies harmonize wonderfully with the silvery-grey stems as they sit with wings fully expanded like Geometers, but always head 
dowmwards as noticed by Darwin in Brazil. ${ }^{1}$ When disturbed they will return to the same tree again and again. I met with this species at Colon, La Guaira, and Trinidad, and noticed these points on each occasion.

Another large Nymphaline which appear's invariably to sit head downwards is Aganisthos orion, Fabr., of which I saw several in Jamaica. The favourite resting-place seemed to be the trunk of a Logwood tree, Haematoxylon eampeachianum, Linn., from one to four feet from the ground. This species rests with its wings closed above its back, and although the underside is cryptically coloured, the butterfly may be seen in profile from a considerable distance.

The pretty little Nymphaline, Dynamine theseus, Feld., with which I was familiar in Venezuela, Trinidad, and Tobago, often reminded me of a Lycaenid in its rapid flight and other ways; thus I saw it several times settle head downwards and then quickly move its wings, though I was not able to get near enough to make out the exact nature of the movement.

\section{§ 11. General Remarks on the Rest Attitudes of Butrerfleies.}

That the term "Rest Attitude" is used very loosely in this chapter I am well aware. A butterfly may be conceived as resting in several stages. First, it may settle to feed. Sphinx feeds on the wing; many a Papilio settles on a flower to feed, but flutters while sucking the honey, this, e.g., is the habit of $P$. erithonius, Cram., $P$. hector, Linn., and $P$. dissimitis, Linn. Thus in Ceylon I found that the best way of distinguishing the last-named from the Danaids, which it mimics so closely, was by this fluttering. I am, however, not certain whether all the species have this habit. Many moths, notably Plusia, are intermediate between Sphinx and Papilio in this respect. The vast majority of butterflies feed with their wings still, cither morc or less widcly spread out, or closed over the back. The Hesperidcue rest in so many different ways as to be worthy of special consideration.

As all English collectors know, our two common Skippers, Ilesperia thaumas, Hufn., and H. sylvanus, Esp., when settled on flowers elevate the fore-wings, which are somewhat drawn back, but hold the hind-wings almost horizontally. I have seen several exotic species adopt the same peculiar attitude, but the only two of which

" "Journal of Roscarches," otc., Ed. 1860, p. 33. Comparo IV. J. Burchell's observations (1825-1836), quoted by J. C. Moulton, Ann. Mag. Nat. Hist. (8), ii., pp. $184-7$ (1208). 
I call find notes to that effect are the common, insignificant little Gegenes letterstedti, Wallgr., of S. Africa, Cymaenes silius, Latr., which I came across in Tobago, and the Canadian Atrytone hobomok, Harr.

Many species, such as Parnara mathias, Fabr., Notoerypta feisthamelii, Boisd., and Badamia exclamationis, Fabr. (Ceylon); Carystus coryna, Hew. (Venezuela), and Catia drurii, Latr. (Jamaica), settle with all the wings in the vertical position, the fore-wings being often much drawn back between the hind-wings. The Sinhalese Parnara colaea, Moore, holds the hind-wings in an intermediate position.

In marked contrast to all those previously mentioned many Skippers settle with their wings spread out as flat as Boarmiid moths, such are: the S. African Pterygospidea flesus, Fabr., Eretis djaelaelce, Wallgr., and Sarangesa motozoides, Holland; the Indian Sarangesa dasahara, Moore, and Celaenorihinus ambareesa, Moore; the Sinhalese Tagiades obseurus, Mab. (distans, Moore); Caprona ransonetti, Feld.; Hantana infernus, Feld. ; and Celaenorrhinus spitothyrus, Feld.; the Jamaican Hesperia syriehthus, Linn., Anastrus simplieior, Möschl., and Ephyriades otreus, Cram., settle in a similar posture.

Many species settle with the wings nearly but not fully expanded, such are the S. African Parnara fatuellus, Hopff. and our own Nisoniades tages, Linn., and Syrichthres malvae, Linn.

Eudamus proteus, Linn. The rest attitude of this common species, as seen in Jamaica, is very striking. It was noted to rest with all the wings up, but partly open and with the fore-wings much sloped back. At the same time the conspicuous tails remain horizontal, nearly at right angles to the wings; for a great part of their length they overlap, but their extremities are divergent. If Mr. Knight's drawings do not represent this attitude quite as clearly as I should have liked, it is because I was not able to supply the artist with adequate material. The tails appear to be an impediment to the insect's flight, which is remarkably slow and quiet for one of the group. (See Fig. 10, p. 288.)

I have described above (pp. 191, 192, and Fig. 7) the curious folding of the hind-wings in the S. African Rhopalocampta kithloa, Wallgr. Something of the same kind may be seen in the S. African Gegenes letter'stedti, Wallgr., and Parnara fatuellus, Hopff., as well as in the Sinhalese Telicota bambusae, Moore, Parnara mathias, Fabr., Bibasis sena, Moore, and Badamia exclamationis, Fabr.

All who have ever set $N$. tages must have observed that its ample wings are somewhat convex. The same characteristic is even 
more marked in certain Neotropical Skippers, such as Gorgythion begga, Prittw., Cycloglypha thrasybulus, Fabr., and Chiomara gesta, H.-Schäff.-all met with in Venezuela,-and Systasea erosa, Hübn., in Tobago. In the last species the convexity is extreme.

Mr. Meyrick includes our malvae and tages in the same genus, Hesperia; but the difference in the form of the fore-wings is very obvious during life, as is the difference in the resting attitudes, and the distinctions seem to me to have generic value. Indeed it is because the grouping of the Hesperids into genera appears to be still in an inchoate state, that I think it better to deal with species rather than to attempt to generalize.

Apart from feeding on flowers, butterflies often rest from flight on the ground, on the upper side of leaves, or on tree trunks. Such a state of rest is more reposeful than that first described, but in many species it is varied by occasional closing and reopening of the wings; or in some Lycaenids by curious horizontal movements of the hindwings only. A few Skippers, such as Badamia exclamationis, Hantana infernus, Celaenorrhinus spilothyrus, Caprona ransonnetti and Pterygospidea flesus, may occasionally be seen (even in bright sunshine) to settle on the under side of leaves. Most of these are conspicuous insects and some of them are less swift of flight than many of the family, and there is no doubt whatever that the concealment must afford them considerable protection.

The actual habits of butterflies when asleep are but little known, the great majority almost certainly close their wings over their backs, the fore-wings being more or less withdrawn between the hind-wings, but some of the larger Skippers, such as Caprona, etc., probably sleep with them spread out, like Geometers. Certainly our common Skippers, Hesperia sylvanus, Esp., and H. thaumas, Hufn., adopt the usual butterfly attitude, but many years ago $\mathrm{Mr}$. Roland Trimen called attention to the fact that Nisoniades tages, Linn., slecps with the wings inclined so as to form a roof, like many Noctuids. ${ }^{1}$ The folding of the posterior third of the hind-wing alluded to above is another point of resemblance of the Hesperidae to the Noctuae.

As regards the sleeping attitudc of Hesperia I again quote Dr. Dixey :-

Mortehoe, July 14th, 8.35 p.m. Saw H. sylvanus resting; wings turned up flat over back, not in characteristic "Skipper" attitude.

As has been already stated, many Lycaenids (possibly all) sleep

'Barrett, "Lepidoptera of the British Islands," vol. i. p. 309. 
head downwards. In some Butterflies, notably Euchloë and Synchloë, when the creature is at rest the hind-wings (which almost conceal the fore-wings) do not approach the stem on which it sits, but the abdomen is elevated some $30^{\circ}$ to $40^{\circ}$ and quite concealed between the hind-wings. This attitude greatly increases the similarity of the insect to a leaf. ${ }^{1}$

The notes of a number of observations on common English Butterflies, kindly placed at my disposal by Dr. Dixey, may be quoted here-

1897, July 12. Mortehoe. S. semele; flight more rapid than that of $H$. janira; it is also more apt to settle. When settling, chooses if possible a bit of grey rock or bare pathway. Sits with antennae expanded and projecting forwards, body raised somewhat on legs. At first settling, eye-spot of fore-wing generally just appears; then by a definite sharp movement the wings are further closed, and the eye-spot is visible no longer. $H$. janira as a rule shows eye-spot while resting [i.e. during temporary rest in daytime].

July 13. Mortehoe. Watched $V$. urticae at rest, quite 5 minutes without stirring. It raised its wings but did not completely close upper-wing behind lower, so leaving a (roughly) equiralent triangle of upper-wing showing, including the whole of the dark costal mark.

July 14. Mortehoe. H. hyperanthus at rest shows eje-spot of fore-wing, like $H$. janira [i.e. at temporary rest].

At 8.25 p.m. saw H. janira settle down to rest. Eye-spot of forewing quite concealed.

July 15. Mortehoe. Saw H.janira settled (in sumsline) with eye-spot of fore-wing quite covered.

Saw $G$. napi settled. with about half of discoidal cell of fore-wing showing. Afterwards saw one with only tip of fore-wing showing.

August 11. Mortehoe. P. megaera at rest does not slmt up like $S$. semcle (at least not during temporary rest in lours of flight). It usually sits with wings almost completely expanded.

Aug. 13. Mortehoe. Saw H. tithonus at rest; wings entirely closed up. A cloudy evening.

1898, August 9. Mortehoe. Saw H. tithonus, $q$, settled on a bramble-leaf in sunshine, eye-spot showing. Cloud came over the sun, and tithonus shut up, eye-spot becoming invisible.

1 Seo above, p. 162, and Plate V., Fig. 10. 
Opened again when cloud passed. [Compare the observation on Teraeolus ione, p. 549, supra.]

Recently M. J. Th. Oudemans has published an interesting memoir entitled "Étude sur la Position de Repos chez les Lepidoptères." 1

M. Oudemans treats of only one aspect of the subject, but this he deals with exhaustively by numerous observations on living specimens of all the chief groups of Macrolepidoptera. His conclusions may be shortly expressed, almost in his own words, thus:Lepidoptera have a sleeping-dress; this dress forms a harmonious whole. The different parts which contribute to form the whole dress harmonize in their colours and usually in their patterns. ${ }^{2}$ The parts of the insect which are concealed during rest are quite frequently strongly contrasted in colour or pattern to the exposed parts. M. Ondemans explains the facts by the influence of exposure to light. ${ }^{3}$

M. Oudemans does not allude to the points chiefly dealt with in this section, but one of his beautiful photographs shows Chrysophanus phlaeas, Linn., sitting with abdomen tilted up at an angle of about $45^{\circ}$ to the thorax, as I have shown in the figure of Euehlö belemia, Esp., on Plate V. He does not, however, call attention to its peculiar attitude. That it must greatly increase the resemblance to a dead leaf is obvious enough.

\section{§ 12. Cosmopolitan Lepidoptera.}

Next to novelties and raritics the inscets that interest me most are the commonest species, and more especially those to which the adjective " cosmopolitan" may fairly be applied. We know next to nothing of the conditions which determine whether a species shall be scarce or abundant, local or widcly spread.

It may be of interest to append a list of such species as $I$ have in my wanderings found in districts far apart.

Polyommatus baetiens, Linn.

Simla, 1903; Pesháwar, 1903; Kháibar Pass, 1903; Malakand,

1 Verhandelingen der Koninklijle Akademe van Wetenschappen, vol. x., No. 1. Amsterdam, 1904. (Read at Berlin, International Congross of Zoology, August, 1901.)

2 Compare my remarks on the green Noctuid from Now Zealand, Erana graminosa, Walk., p. 468, supra.

${ }^{3}$ Compare Dr. M. Standfuss, Die Bezichungen zwisehen Färbung und Lebensgewohnheit bei den Palaearetischen Grossschnetterlingen. Vierteljahrsschrift der naturforsch. Gesellschait in Zürich. xxzix Jabrgang, 1894. (Read Novembor 6th, 1893.) 
1903 ; Naini Tal, 1903; Benares, 1903; Jhánsi, 1904; Mt. Abu, 1904 ; Bijápúr, 1904 ; Anantápúr, 1904; Nilgiris, 1904; Ceylon, 1904 and 1908 ; Durban, 1905; Bechuanaland, 1905; Matherán, 1908; Egypt, 1909 ; Sûdân, 1909; Sydney, N.S.W., 1910 ; Fremantle, 1910.

Pyrameis cardui, Linn.

England: Wandsworth, Bonchurch, Mortehoe; Simla, 1903 ; Kháibar Pass, 1903; Kamáon, 1903; Darjiling, 1903; Nilgiris, 1904; Japan, 1904; Biskra, 1905; Kabylia, 1905'; Algiers, 1905; East London, 1905; Durban, 1905; Colenso, 1905 ; Ladysmith, 1905; Johannesburg, 1905; Kimberley, 1905 ; Stormberg, 1905 ; Port Elizabeth, 1905; Cape Town, 1905; Ceylon, 1908; Egypt, 1909; Sûdân, 1909; Tasmania, 1910; New Zealand, 1910.

\section{Utetheisa pulchella, Linn.}

Teneriffe, 1887; Kháibar Pass, 1903 ; Kamáon, 1903 ; Lucknow, 1903 ; Anantápúr, 1904; Hong-kong, 1904; Ladysmith, 1905; Cape Colony, 1905; Sûdân, 1909.

Agrotis ypsilon, Rott.

England: Mortehoe; Jamaica, 1907 ; Egypt, 1909 ; Sûdân, 1909 ; New Zealand, 1910.

Cirphis unipuncta, Haw.

Mortehoe, 1897; Yang-tse-kiang, 1904; New Zealand, 1910.

Prodenic litura, Fabr. (littoralis, Boisd.). 1909 .

Allahabad, 1904; Sukna (Darjiling), 1904; Egypt, 1909; Sûdân,

Scopula ferrugalis, Hübn.

England: Devonshire; Algeria, 1905 ; Madeira, 1905; Durban, 1905 ; Port Elizabeth, 1905.

Zinckenia fascialis, Cram. (rccurvalis, Fabr.).

Kálka, 1903; Lahore, 1903; Benares, 1903; Ceylon, 1908; New Zealand, 1910; Sydney, 1910. [It is said to occur also in the Ethiopian and Neotropical Regions.]

Nomophila noctuella, Schiff.

England; Bermudas, 1901 ; Nilgiris, 1903 ; Biskra, 1905 ; Port Elizabeth, 1905; Johannesburg, 1905; Colesberg, 1905; Jamaica, 1907 ; Egypt, 1909 ; Sûdâu, 1909 ; . . .

Eromene occllca, Haw.

Mt. Abu, 1904; Queenstown, Cape Colouy, 1905; Egypt, 1909 ; Sûdân, 1909.

Etiella zinetenella, Treit.

Bijápúr, 1904; Johannesburg, 1905; Victoria Falls, 1905 ; Ceylon, 1908. 
Plutella maculipennis, Curt. (crueifcrarum, Zell.).

England; Rannoch, 1868; Biskra, 1905; Hammam Meskutine, 1905; Norval's Point, Cape Colony, 1905; Gwaai, Mashonaland, 1905; Egypt, 1909; New Zealand, 1910.

\section{$\S 13$. Seasonal Dimorphism.}

Seasonal Dimorphism has long been a subject of study in the Oriental and Ethiopian regions, but in the Neotropical world comparatively little attention has been paid to it. ${ }^{1}$ A visit of less than four months, and those within the limits of the winter, or dry season, affords but little opportunity for the investigation of such a difficult question-and the difficulty is increased by the paucity of cabinet specimens bearing adequate data-nevertheless I venture to offer the results of my observations for what they may be worth.

In the Old World we see in certain genera of the Satyrines that the same species exhibits two forms, characterized by the presence or absence of ocelli on the under surface of the hind-wings. Similarly two forms are met with in the Nymphaline genus Precis; ${ }^{2}$ in the one ocelli on the under side of the hind-wings are well developed, but in the other they are rudimentary or entirely absent. With the absence of ocelli is often associated a more angulated form of the wings, which are sometimes tailed, while the whole under surface is often of a redder colour, and the insect when at rest is cryptic, sometimes resembling a dead leaf. Again, in many Pierines there are also two forms, the one characterized by the black markings on the upper surface being more pronounced, and sometimes by a suffusion or irroration of black scales; whereas in the other form there is an irroration of reddish scales on the under surface, with or without reddish or purplish markings. ${ }^{3}$ Now these two forms have long been recognized as occurring for the most part in the wet and dry seasons respectively, though it must be admitted that in Terias and Catopsilia,

I See Dixey, Proc. Ent. Soc. Lond., 1898, p. xxxix.

2 Including Junonia.

3 In Catopsilia, Callidryas, and Ixias tho disco-cellular spots on tho undor sido of both fore- and hind-wings aro usually larger, with largor whito contros and altogether more conspicuous in tho dry soason. Moroover, in Txias dry-season specimons have on the Iunder side of tho hind-wing a sorios of reddish, or purplish, post-discal spots, which when fully dovolopod have whito contros (ospecially in I. pyrene), and call to mind the similarly placed ocelli so woll known in tho wet-season forms of Mycalesis and Precis, and indeed thoy aro not unliko the rudimontary ocelli scon in intermediato specimons of those genera, though thoy novor attain to tho complicatod "peacock-feathor" pattern so charactcristic of many Nymphalidac. 
the correspondence is not nearly so close as in Myculesis, Precis and Teracolus. However, for convenience thesc are usually spoken of as wet-season forms and dry-season forms, or even for shortness as "wet" and "dry."

When at rest, with wings closed above its back, the dry-season insect is usually more cryptic than the wet, resembling in some instances red soil, in others a dead or discoloured leaf. It is notable that the dry-season form is commonly more marked and more persistent in the female sex.

If among Neotropical butterflies similar pairs of forms are met with, I propose provisionally to speak of them as "wet" and "dry," and then to inquire to what extent they are found in the corresponding seasons of the year.

Calisto zangis, Fabr. (Jamaica). Although there is some variation in the size of the ocelli on the under side of the wings in $\mathrm{my}$ specimens, I am unable to divide them into seasonal forms.

Euptychia hermes, Fabr. (camerta, Cram). In the wet-season form the ground colour of the under side is of a bluish-grey, the transverse lines are distinct and the ocelli well marked.

In the dry-season form the ground colour is browner in tint, the transverse lines are faint and the ocelli are minute.

I give, in a tabular form, a statement of all the specimens that I took, divided into the three classes: "dry," "wet," and "intermediate." The specimens classed as intermediate I have attempted to divide according as they seem to approach nearer to one form or the other. Males and females are distinguished and the dates of capture given.

Euptychia hormes, Fabr.

\begin{tabular}{|c|c|c|c|c|c|}
\hline Place. & Dry. & & ermediate. & Wet. & Date of cspture. \\
\hline $\begin{array}{l}\text { Trinidad : } \\
\text { Panama : } \\
\text { Venezuela : } \\
\text { Trinidad : } \\
\text { Tobago : } \\
\text { Trinidad: }\end{array}$ & $\begin{array}{c}\ldots \\
\delta \ddot{\delta} q \delta \\
\ldots \\
\ldots \\
\ldots\end{array}$ & 89 & 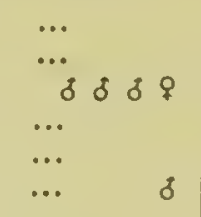 & 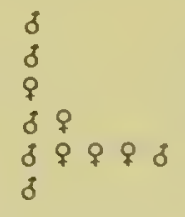 & $\begin{array}{l}19 \text { Dec., } 1906 . \\
28 \text { Dec., } 1906 . \\
22-29 \text { \Iarch, } 1907 . \\
1 \text { April, } 1907 . \\
6,7 \text { April, } 1907 . \\
12 \text { April, } 1907 .\end{array}$ \\
\hline Totals & $48,1 \%$ & 18 , & $9 ; 48,19$ & $68,5 \%$ & \\
\hline
\end{tabular}

It is somewhat remarkable that the specimens from Tobago were all distinctly "wet" though the country showed every sign of extreme 
drought. Here the distinction between the forms might be local and not seasonal; or, as I am disposed to think, a seasonal form may have become localized.

Precis lavinia, Cram. The nomenclature of this species is in great confusion. Messrs. Godman and Salvin brought together the various forms found in Central America under the name coenia, Hübn., including what is generally known in the West Indies as genoveva, Cram. Mr. G. A. K. Marshall has recently arranged the genus Precis in the National Collection, and I am happy to find myself in complete agreement with one whose knowledge of the genus is so intimate. Cramer figured three forms, all from Surinam; a t which he called lavinia, a $q$ which he called evarete, and a $q$ which he called genoveva. The last two I agree with Mr. Marshall in considering to be dry-and wet-season forms respectively. The insect is extremely variable in ground colour, in the size of the ocelli on the upper surface (especially the anterior ocellus on the hind-wing), in the presence or absence of a greenish gloss, or "glance," and in the presence or absence of a transverse white band on the fore-wings (zonalis, Felder). In some specimens from Guiana this white band is replaced by a purplish gloss. It is almost impossible to divide these varieties into local races since the various forms overlap considerably, and the most widely different forms are found in Mexico. However, speaking generally, it may be said that the form coenia, Hübn., prevails in the United States and northern Mexico; that the form zonalis, Feld. (genoveva, auct.) prevails in the West Indies (approaching to coenia in the Bahamas); that the type form lavinia, Cram., of which the of has a hind-wing with a green gloss, prevails in Brazil ; lastly a brown form is found in Peru.

But what does not seem to have been generally noticed is that all the numerous varieties are themselves dimorphic. That is to say, that (as in the Indian species of Precis) they may be divided, as regards the colouring of the under surface of the hind-wings, into (1) those with several ocelli, of which two at least are couspicuous, (2) those in which the ocelli are merely indicated by black dots, or are entirely wanting, and (3) individuals intermediate in this respect. Analogy with the East would lcad one to call the first wct-scason forms and the second $d r y$-seceson forms. 
Precis lavinia, Cram.

\begin{tabular}{|c|c|c|c|c|}
\hline Place. & Dry. & $\begin{array}{c}\text { Inter- } \\
\text { mediate. }\end{array}$ & Wet. & Date of capture. \\
\hline $\begin{array}{l}\text { Barbados . } \\
\text { Mt. Hope, Panama. } \\
\text { Constant Spring, Jamaica } \\
\text { Mandeville, Jamaica . } \\
\text { Port Antonio. } \\
\text { Constant Spring, Jamaica } \\
\text { Panama City . } \\
\text { Carácas, Venezuela. : } \\
\text { St. Ann's, Trinidad. } \\
\text { Tobago. . . . . . }\end{array}$ & 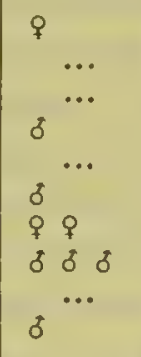 & $\begin{array}{c}\cdots \\
\cdots \\
\delta \\
\cdots \\
\cdots \\
\cdots \\
\cdots \\
\delta \\
\delta\end{array}$ & 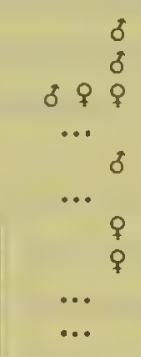 & $\begin{array}{l}19 \text { Dec., } 1906 . \\
28 \text { Dec., } 1906 . \\
31 \text { Dec., } 1906-8 \text { Jan., } 1907 . \\
20 \text { Jan., } 1907 . \\
25 \text { Feb., } 1907 . \\
7 \text { March, } 1907 . \\
12 \text { Irarch, 1907. } \\
19-28 \text { MIarch, } 1907 . \\
1 \text { April, 1907. } \\
\text { 6-8 April, 1907. }\end{array}$ \\
\hline Total . . & $7 \delta, 2$ q & $4 \delta$ & 46,49 & \\
\hline
\end{tabular}

I brought home twenty-one specimens; of these six were taken between December 18th and January 8th, five of them were "wet," only one "dry."

Fifteen were taken between January 20th and April 9th; of these eight were "dry," three "wet," and four "intermediate."

As the dry season advanced the "dry" form more or less displaced the "wet" form.

Dated specimens in Mr. W. J. Kaye's collection taken in the wet season are mostly "wet," as above defined; the same applies to specimens in the Hope Collection. Judging from the condition of many of the specimens I met with, it is a long-lived insect and therefore considerable overlapping may be anticipated.

Anartia jatrophae, Linn. Two forms are fairly well marked:-

Wet-season form. Under side. Ground colour nearly white; markings often conspicuously edged with scarlet. Ocelli black with blue centres. No transverse bar on hind-wing.

Dry-season form. Under side. Ground colour shaded with grey; markings edged with ochreous or reddish-brown, ocelli often blue only, orange-ringed. Hind-wing with a transverse grey bar. 
Anartia jatrophae, Linn.

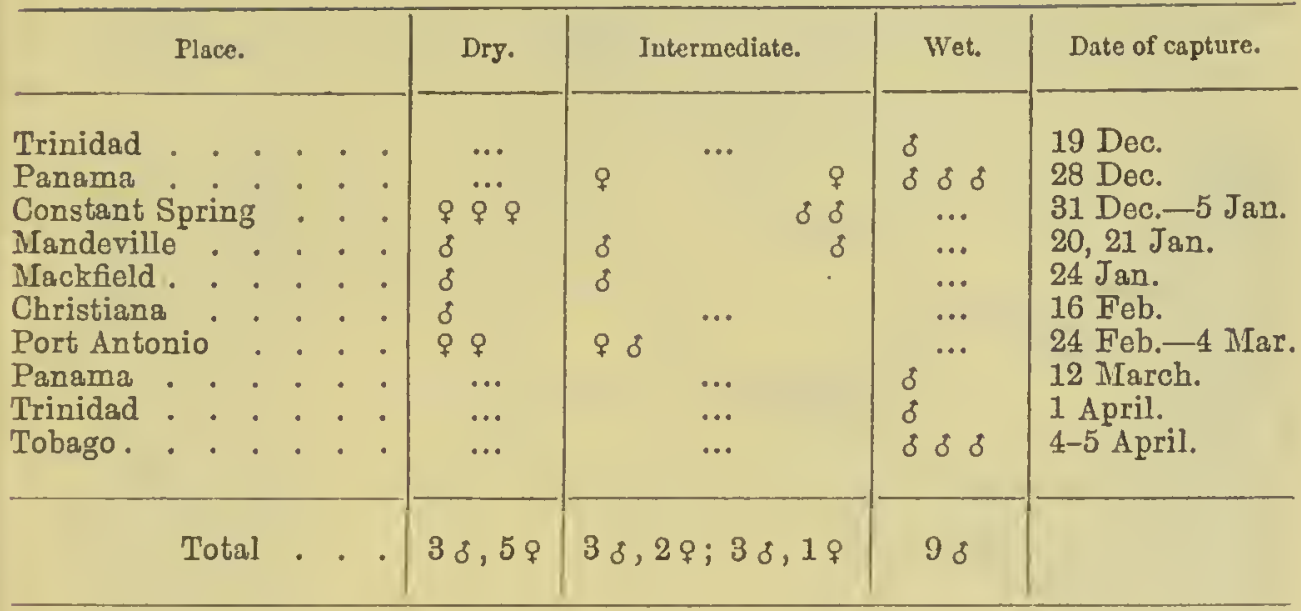

The table would appear to point to the forms being local rather than seasonal. The "dry" specimens, it will be observed, were all taken in Jamaica and were all of the race, or sub-species jamaicensis, Möschl, ${ }^{1}$ but, on the other hand, not all the jamaicensis were "dry."

Callidryas eubule, Linn. The two forms are abundantly distinct, more especially in the male sex.

Dry-season form. of Under side. Hind-wing, and all exposed part of fore-wing, irrorated with red-brown; the markings strong; stigmata clearly outlined.

o Under side. As in male but reddish irroration darker.

Wet-season form. of Under side. No irroration: brown marking very faint; stigmata faintly outlined.

o Under side. Reddish irroration very faint.

Intermediate specimens are frequent, approaching now one, now the other form.

It may be at once admitted that these two forms of $C$. eubule are not restricted to the respective seasons to anything like the extent that is observed in the case, e.g., of the S. African Preeis oetavia, Cram., and its "dry" form P. sesamus, Trim. Thus on January 12th, 1907, C. eubule was seen in numbers flying about a weedy field at Temple Hall, on the road between Constant Spring and Castleton, Jamaica. Three examples were secured; a female of well-marked "dry" and one of equally well-marked "wet" type, whereas the third, a male, may be described as "intermediate, inclining to wet." I was informed that there had been no rain for three weeks. 
Callidryas eubule, Linn.

\begin{tabular}{|c|c|c|c|c|}
\hline Place. & Dry. & Intermediate. & Wet. & Date of capture. \\
\hline 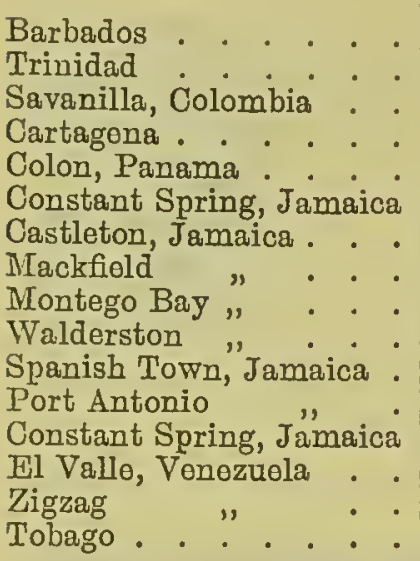 & 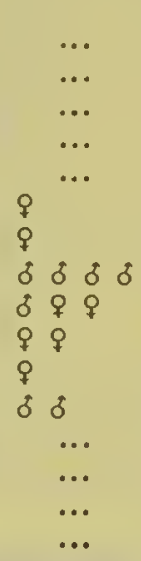 & 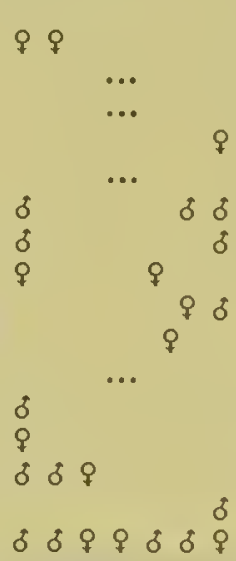 & 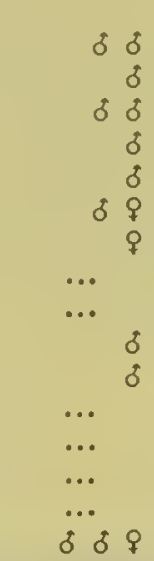 & $\begin{array}{l}18 \text { Dec., } 1906 . \\
19 \text { Dec., } 1906 . \\
22 \text { Dec., } 1906 . \\
23 \text { Dec., } 1906 . \\
28 \text { Dec., } 1906 . \\
\text { 1-9 Jan., } 1907 . \\
11-12 \text { Jan., } 1907 . \\
\text { 25-27 Jan., } 1907 . \\
\text { 4-5 Feb., } 1907 . \\
\text { 7-18 Feb., } 1907 . \\
\text { 21-22 Feb., } 1907 . \\
\text { 3-5 MIar., 1907. } \\
7 \text { Mar., 1907. } \\
\text { 26-27 Mar., 1907. } \\
\text { 29 MIar., 1907. } \\
\text { 3-10 Apr., 1907. }\end{array}$ \\
\hline Totals . . & $7 \delta, 7 \%$ & $14 \delta, 12 \%$ & $12 \delta, 3$ \% & \\
\hline
\end{tabular}

It will be observed that (as with $A$. jatrophae) no distinctly "dry" specimens were taken out of Jamaica. There is also evidence (very ambiguous in the case of Tobago) that the "dry" form tended to displace the "wet" as the season advanced.

Further, I had the advantage of examining Mr. W. J. Kaye's series of this insect. Of six specimens taken in Jamaica in the month of August (wet season) five are of the "wet" form, one of the "dry." Of two specimens taken in Trinidad in July, one is "wet," the other "intermediate," another taken in September is also "intermediate." A specimen taken in British Guiana in either November or December is "wet."

These facts are fairly in accord with the theory that the dimorphisin is seasonal in C. cubule, especially if due allowance be made for the fact that the insect has the appearance of being long-lived.

Terias outerpe, Ménét. (Jamaica). My sixty specimens exhibit but very trifling differences that can be set down to possible seasonal dimorphism.

The specimens that I am disposed to regard as exhibiting dryseason coloration may be distinguished by the following characters on the under surface.

The reddish-orange edging of the wings is more conspicuous. The hind-wiugs are irrorated with purplish-brown scales, and the 
purplish markings (especially the borders of the apical pink patch) are more conspicuous.

I do not give the results as set out in the following table with much confidence, and the division of the intermediate specimens into those inclining rather to "wet" or to "dry" respectively should not carry much weight. Subject to these limitations, it will be seen that the specimens considered as "wet" were commonest at the two extremities of the period, those considered as "dry" prevailed throughout the first half of February.

Tericus euterpe, Ménét. (Jamaica).

\begin{tabular}{|c|c|c|c|c|c|}
\hline Place. & & Dry. & Intermediate. & Wet. & Date of capture. \\
\hline $\begin{array}{l}\text { Constant Spring } \\
\text { Castleton :" } \\
\text { Mandeville: } \\
\text { Mackfield : } \\
\text { Montego Bay : } \\
\text { Walderston. : } \\
\text { Christiana : : } \\
\text { Walderston : : } \\
\text { Port Antonio : } \\
\text { Constant Spring }\end{array}$ & 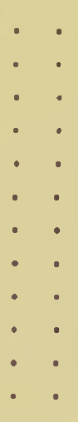 & 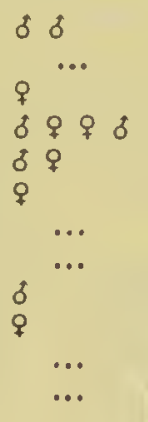 & 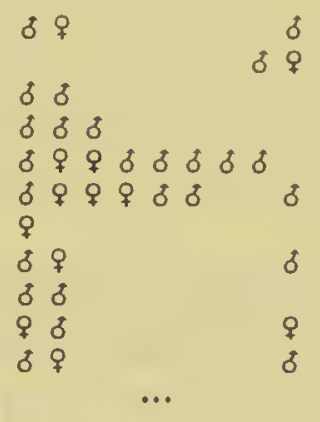 & $\begin{array}{lll}\delta & 8 & 8 \\
\delta & & \\
q & 8 \\
& \ldots \\
9 & 8 \\
& \cdots \\
& \cdots \\
& \cdots \\
& \cdots \\
& \cdots \\
& \cdots\end{array}$ & $\begin{array}{l}31 \text { Dec. }-4 \text { Jan. } \\
\text { 8-10 Jan. } \\
\text { 11-12 Jan. } \\
\text { 17-22 Jan. } \\
\text { 24-27 Jan. } \\
29 \text { Jan.-2 Feb. } \\
4 \text { Feb. } \\
8-14 \text { Feb. } \\
16 \text { Feb. } \\
18 \text { Feb. } \\
25 \text { Feb.-1 Mar. } \\
7 \text { March. }\end{array}$ \\
\hline Total . & - & $68,6 \%$ & $20 \delta, 10 \% ; 5 \delta, 29$ & $7 \delta, 4 \%$ & \\
\hline
\end{tabular}

Terias delia, Cram. (Jamaica, N. Coast of S. America). The extreme seasonal forms are quite distinct.

\section{of UPPER SIDE.}

Wet-season form.-Ground pale ycllow; costa broadly black; longitudinal black stripe broad.

Dry-season form.-Ground full yellow; costa faintly grey; longitudinal black stripe narrower.

\section{o Uprer Side.}

Wet-season form. - Ground white; costa hroadly grey.

Dry-season form.-Ground of forewing palc yellow extending to costa.

\section{of Uxder Side.}

Wet-season form.-Uniformly white.

Dry-season form.-Hind-wings and costal threc-fourths of fore-wings yellow irrorated with brown.

\section{은 UNDR SIDE.}

Wet-season form.-Fore-wing white; border pale yellow; hind-wing pale yellow irrorated with grey.

Dry-seuson form.-Fore-wing yellow, its tip and all lind-wing pinkish-orange irrorated with darker. 
Terias delia, Cram.

\begin{tabular}{|c|c|c|c|c|}
\hline Place. & Dry. & Intermediate. & Wet. & Date of capture \\
\hline 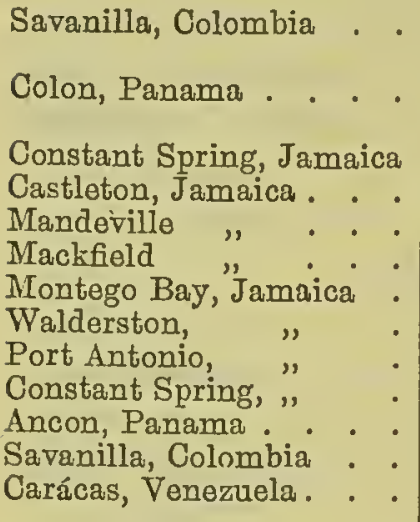 & 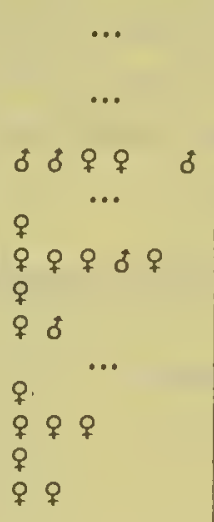 & 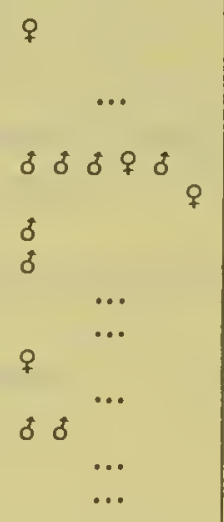 & 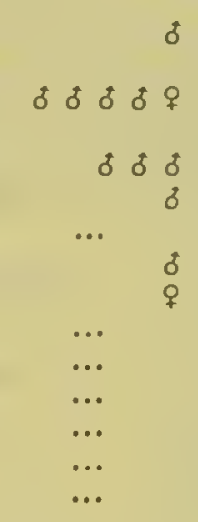 & $\begin{array}{l}22 \text { Dec., } \\
\text { lydia. } \\
28,29 \text { Dec., } \\
\text { f. lydia. } \\
\text { 1-8 Jan. } \\
12 \text { Jan. } \\
22 \text { Jan. } \\
24-26 \text { Jan. } \\
4 \text { Feb. } \\
12 \text { Feb. } \\
25 \text { Feb. } \\
7 \text { March. } \\
11,12 \text { Mar. } \\
15 \text { March. } \\
18-25 \text { Mar. }\end{array}$ \\
\hline Total . & $5 \delta, 16 \%$ & $8 \delta, 3 \% ; 1$ 앙 & $10 \delta, 2$ 우 & \\
\hline
\end{tabular}

An examination of this table shows clearly that the "dry" form became more prevalent as the season advanced, whereas the "wet" form disappeared. The first seven specimens, taken at Savanilla and Colon, December 22nd-29th, are of the form lydia, Feld. The last specimen taken, at Carácas, March 25th, is of the extreme "dry" form persistens, Butl.

A male taken above Constant Spring, c. $1000 \mathrm{ft}$., on January 1st, another male taken a little to the west of Constant Spring, c. $500 \mathrm{ft}$., on January 8th, and a male taken near the railway at Panama on March 12th, all approach the form lydia, Feld., in having the longitudinal black streak broader than usual. On the other hand, the width of the streak in the form lydia varies considerably.

An aberrant male of the "dry" form taken on the foot-hills above Constant Spring on January 1st, is cntirely without the black streak, the orange scales alone marking its position.

Terias elathea, Cram. (Jamaica, Venezuela), appcars to be specifically distinct from delia, but is certainly very closely allied to it; the females are difficult to distinguish, and some specimens of the male sex not casily scparable. What I takc to be the "wet" form has the under sidc irrorated with grey; the "dry" form with reddish. 


\section{Terias elathea, Cram.}

\begin{tabular}{|c|c|c|c|c|c|}
\hline Place. & & Dry. & Intermediate. & Wet. & Date of capture. \\
\hline $\begin{array}{l}\text { Constant Spring, Jamaica } \\
\text { Montego Bay } \\
\text { Port Antonio } \\
\text { Carácas, Venezuela ." . . }\end{array}$ & 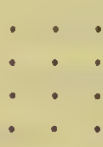 & $\begin{array}{l}\stackrel{?}{?} \\
\quad \ldots \\
\quad \ldots \\
\quad \ldots\end{array}$ & $\delta \delta^{\cdots}$ & 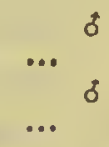 & $\begin{array}{l}\text { 1, } 2 \text { Jan. } \\
3 \text { Feb. } \\
3 \text { March. } \\
\text { 18-20 March. }\end{array}$ \\
\hline Total . & . . . & $1 q$ & 38 & $2 \delta$ & \\
\hline
\end{tabular}

In one of the Carácas specimens the black streak is very faint and might be described as obsolescent, in the other there is no trace of the black streak and scarcely any orange.

It will be observed that this aberration was in both species met with in "dry," or somewhat "dry" specimens, but I scarcely think that it can be considered as the extreme "dry" form, at all events without more material.

Pieris phileta, Fabr. (Jamaica, Venezuela, Tobago). In this species the seasonal differences are well known.

Wet-season form. Under side. Wings white, with but faint traces of yellow.

Dry-season form. Under side. Hind-wing and tip of fore-wing yellow; veins and lines in interspaces brown.

Pieris phileta, Fabr.

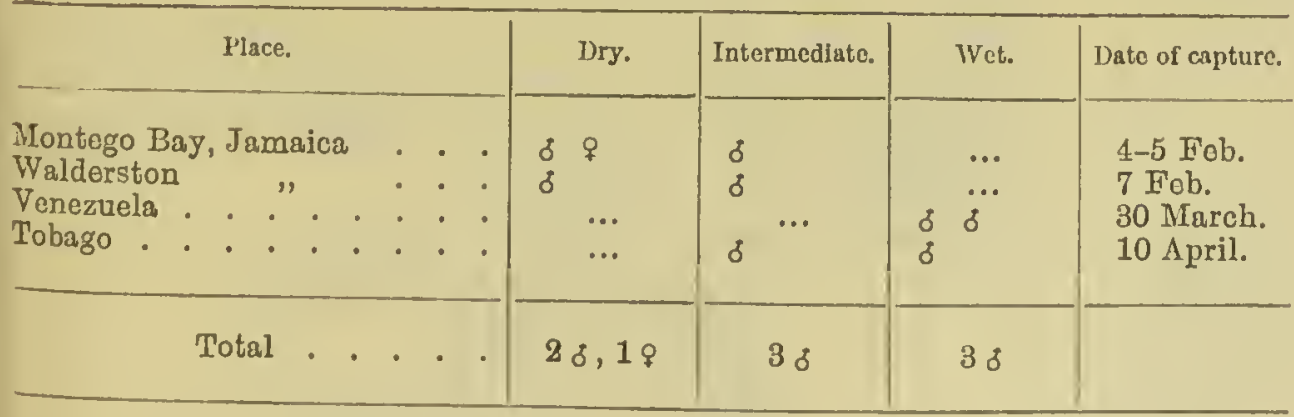

Herc again the forms secm to depend on locality more than season.

In case any one should desire to examine morc closcly into the matter I append notes on the weather conditions during the period in which I was collecting. 


\section{Meteorological Notes. West Indies, etc.}

Dec. 18. Barbados. End of rainy season : a shower that moming early. Much rain in November. "Christmas Winds" prevailing.

Dee. 19. Trinidad. "Mueh rain lately": very wet season: rain that moruing; ground wet.

Dec. 20. La Guaira. Muddy streets and the appearance of mueh recent rain.

Dee. 22. Savanilla. Woods very dry: run-to-seed.

Dec. 23. Cartagena. A dry, burnt-up look.

Dec. 27. Puerto Bello. Rain all day: also rain the day before.

Dee. 28. Colon. Heavy shower this morning. Very heavy rain reported November and early December.

Dee. 31. Constant Spring. No rain for three weeks: unusually cold at Christmas. Country very dry and run-to-seed.

Jan. 7.

Jan. 15-16.

Jan. 16.

Jan. 19.

Jan. 21-22.

Jan. 24.

Jan. 25.

Jan. 29.

Jan. 31.

Feb. 2.

Feb. 7.

Feb. 11.

Feb. 12.

Feb. 13.

Feb. 15.

Feb. 16.

Constant Spring. A smart shower.

" $\quad$ Trifling shower in the night.

Mandeville. No rain for eight weeks : vegetation very dry. Several showers : eloud most days.

" Some rain in the night.

Mackfield. Reported to have been an exceptionally wet season: heavy rains November and up to December 12th; nothing but trifling rain sinee; vegetation and soil very dry.

Mackfield. Rain afternoon and evening.

" Rain in early morning.

" Two heavy showers this afternoon.

Montego Bay. Heavy showers about four or five days before our arrival: before then no rain for a fortnight. Walderston. No rain since November 13th, except trifling showers February 3rd.

Walderston. Rain at dusk and early evening.

Rain afternoon and evening.

Wind and drizzle.

Slight rain in aftermoon.

Heavy shower in afternoon.

Feb. 20-23. Spanish Town. Rain while we were there and several showers the previous week.

Feb. 24. Port Antonio. "No rain in January : some last week." Another informant, "Very dry up to the time of the earthquake (January 14th), frequent showers sinee." 
Feb. 24-Mar. 5. Port Antonio. Rained nearly every day or night of our stay. Heavy rain February 27th.

March 7. Constant Spring. "A good rain eight days ago, and other showers since the earthquake (January 14th);" nevertheless everything looked very dry.

March 11. Panama. Country very dry.

March 20. Carácas. I was informed "last year was very wet, up to January 25th; since then it has been our dry season, though there was some rain last week."

March 21. Carícas. Heavy shower late afternoon.

March 22. " Very heavy rain mid-day and afternoon.

March 23. " Heavy rain mid-day and afternoon-many hours.

March 29. La Guaira. The road down showed traces of heavy rain within a few days.

April 4. Tobago. Everything very dry, but was informed that there had been "some nice showers at night during March."

April 8. Tobago. Very heavy showers.

April 12. Trinidad. Heavy rain.

April 14. $\quad " \quad$ A shower.

\section{Seasonal Dimorphism in India and Ceylon.}

With a view to seeing what light, if any, my fragmentary observations in India and Ceylon during the winter of 1903-4 might throw upon this puzzling subject, I have adopted the following method:-

In the Register, or Index, of my captures, I noted to every Pierine Dr. Dixey's estimate of its seasonal character, and then made my own (far less weighty) estimates of the seasonal charactcrs of the gencra Precis, Melanitis, Mycalcsis, and Yphthima, and finally analyzed the results for localities, or groups of localities. Without prejudice, I took Catopsilia gnoma to represent the dry-season form of $C$. pyranthe, and in like manner Catopsilic catilla and pomona to be dry-season forms corresponding to a wet-season form $C$. crocalc.

It must be borne in mind that such a classification is necessarily very vague, for while the extreme forms are casy to placc it is most difficult to assess the numerous intermediate spccimens. 


\begin{tabular}{|c|c|c|c|c|c|c|}
\hline & $\begin{array}{c}\text { Wet } \\
\text { Beason. }\end{array}$ & $\begin{array}{c}\text { Some- } \\
\text { what wet. }\end{array}$ & $\begin{array}{c}\text { Inter- } \\
\text { mediate. }\end{array}$ & $\begin{array}{c}\text { Some- } \\
\text { what dry. }\end{array}$ & $\begin{array}{c}\text { Dry } \\
\text { season. }\end{array}$ & \\
\hline 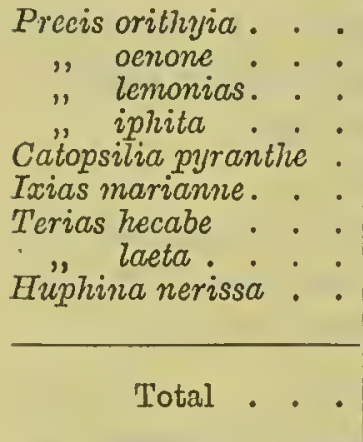 & $\begin{array}{r}2 \\
\dddot{1} \\
\dddot{1} \\
\ddot{1} \\
\ddot{7} \\
\ddot{3}\end{array}$ & $\begin{array}{c}2 \\
\dddot{1} \\
\ldots \\
\ldots \\
\cdots \\
\ddot{2} \\
3\end{array}$ & $\begin{array}{c}\ldots \\
\ldots \\
\ldots \\
\ldots \\
\dddot{1} \\
1 \\
2 \\
\ldots\end{array}$ & $\begin{array}{c}\ldots \\
\ldots \\
\ldots \\
\ldots \\
\ldots \\
\ldots \\
\dddot{1} \\
\ldots\end{array}$ & $\begin{array}{c}4 \\
6 \\
3 \\
1 \\
1 \\
\cdots \\
\cdots \\
\cdots \\
\cdots\end{array}$ & $\begin{array}{l}\text { Simla and Kálka, } \\
\text { Oct. 10-20, } 1903 . \\
\text { Slight showers. }\end{array}$ \\
\hline 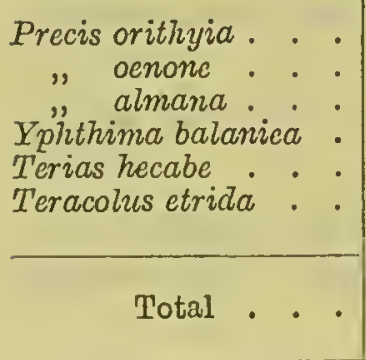 & $\begin{array}{c}\ldots \\
\cdots \\
\dddot{1} \\
1 \\
\cdots\end{array}$ & $\begin{array}{c}\ldots \\
\cdots \\
\cdots \\
\cdots \\
\cdots \\
\cdots\end{array}$ & $\begin{array}{l}\ldots \\
\ldots \\
\ldots \\
\ldots \\
2 \\
\ldots\end{array}$ & $\begin{array}{l}\ldots \\
\cdots \\
\cdots \\
\dddot{2} \\
1\end{array}$ & $\begin{array}{r}3 \\
2 \\
4 \\
\ldots \\
1 \\
\ldots\end{array}$ & $\begin{array}{l}\text { Pesháwar and Mala- } \\
\text { kand, Oct. 22-29, } \\
\text { 1903. No rain. }\end{array}$ \\
\hline 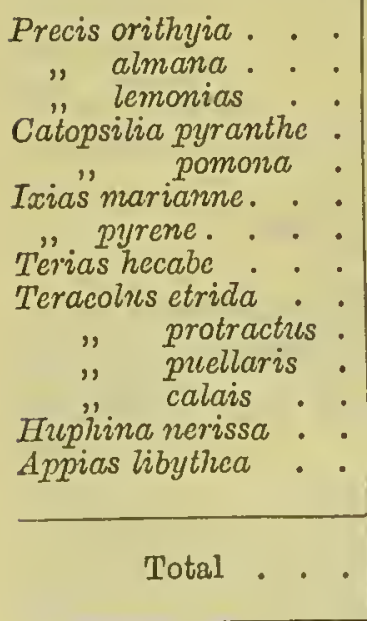 & $\begin{array}{r}\cdots \\
\cdots \\
\ddot{7} \\
\cdots \\
\cdots \\
1 \\
5 \\
\cdots \\
2 \\
1 \\
2 \\
\cdots \\
\cdots\end{array}$ & $\begin{array}{l}\cdots \\
\cdots \\
\cdots \\
\dddot{1} \\
\dddot{2} \\
\cdots \\
\cdots \\
\cdots \\
\dddot{2} \\
\cdots \\
\cdots\end{array}$ & $\begin{array}{l}\cdots \\
\cdots \\
\cdots \\
\cdots \\
\dddot{1} \\
1 \\
\dddot{2} \\
\dddot{1} \\
\cdots \\
\cdots \\
\cdots\end{array}$ & $\begin{array}{c}\dddot{1} \\
\cdots \\
\cdots \\
\dddot{1} \\
\cdots \\
\dddot{2} \\
\dddot{1} \\
\cdots \\
\cdots \\
\cdots\end{array}$ & $\begin{array}{r}1 \\
2 \\
4 \\
\ldots \\
\cdots \\
3 \\
\cdots \\
\cdots \\
2 \\
\cdots \\
3 \\
\dddot{2} \\
2 \\
1\end{array}$ & $\begin{array}{l}\text { Lahore, Amritsar } \\
\text { and Delhi, Oct. } \\
31-N o r .12,1903 . \\
\text { No rain. }\end{array}$ \\
\hline 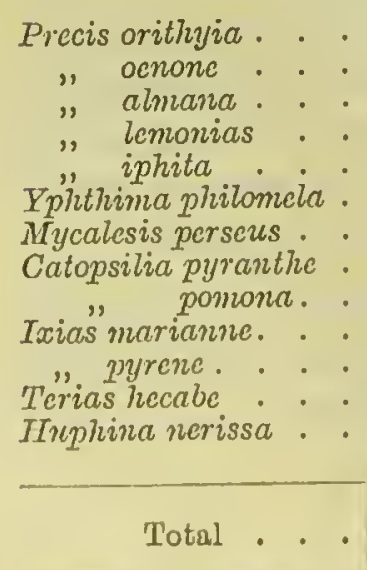 & $\begin{array}{l}\cdots \\
\cdots \\
\cdots \\
\cdots \\
\cdots \\
\dddot{\cdots} \\
\cdots \\
\cdots \\
\ddot{1} \\
1\end{array}$ & $\begin{array}{l}\cdots \\
\dddot{1} \\
1 \\
\cdots \\
\dddot{1} \\
\cdots \\
\cdots \\
\cdots \\
\cdots \\
\cdots\end{array}$ & $\begin{array}{l}\cdots \\
\cdots \\
\cdots \\
\cdots \\
\cdots \\
\cdots \\
1 \\
\cdots \\
\cdots \\
\cdots \\
\cdots\end{array}$ & $\begin{array}{c}2 \\
\dddot{1} \\
\cdots \\
\cdots \\
\cdots \\
\cdots \\
\cdots \\
\cdots \\
\cdots \\
\cdots \\
\cdots\end{array}$ & $\begin{array}{c}2 \\
2 \\
\dddot{2} \\
3 \\
1 \\
1 \\
2 \\
\cdots \\
1 \\
1 \\
1 \\
\cdots\end{array}$ & $\begin{array}{l}\text { Náini Tál, Luck- } \\
\text { now and Benares, } \\
\text { Nor. 16-Dec. 2, } \\
\text { 1903. No rain. }\end{array}$ \\
\hline
\end{tabular}




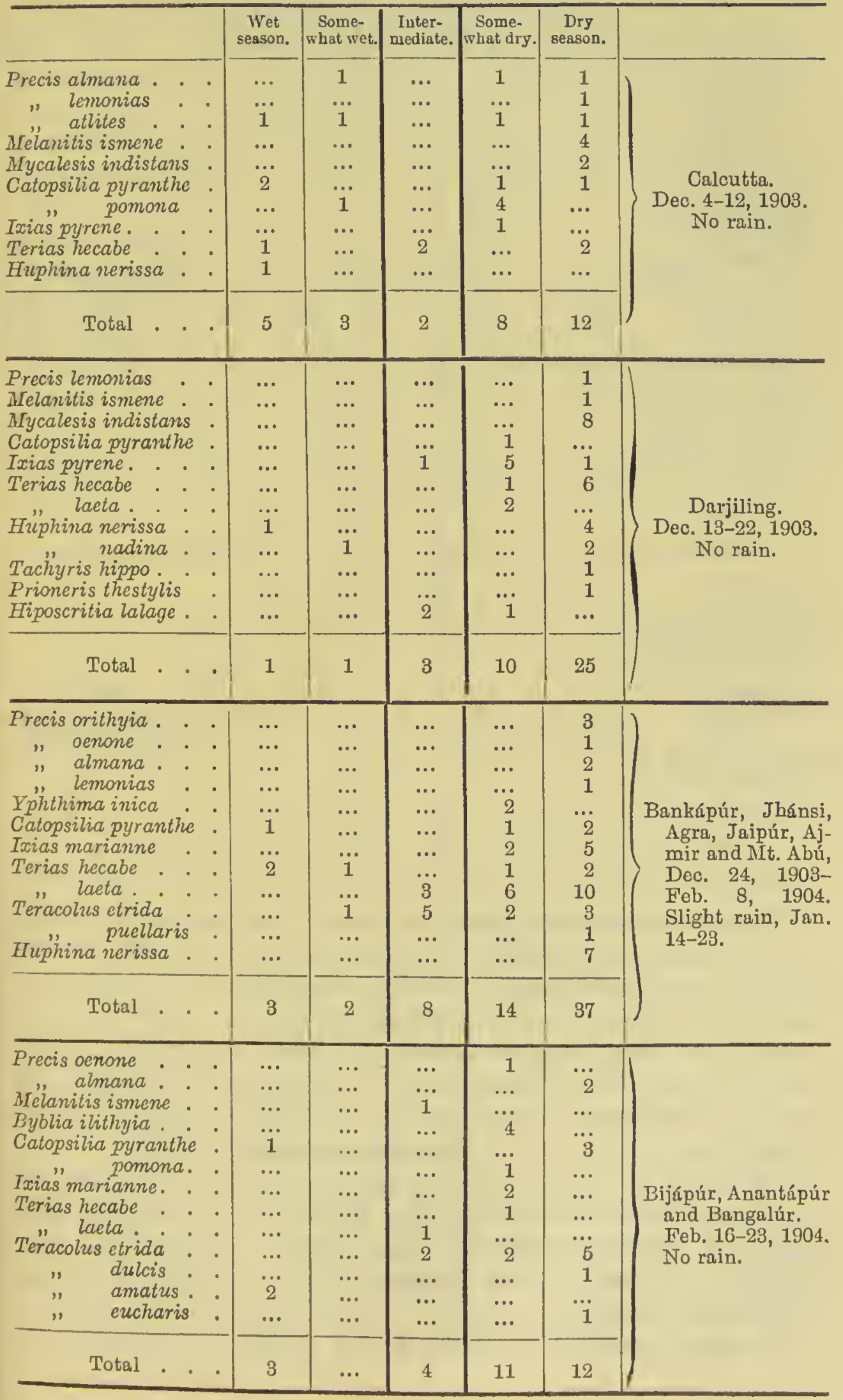




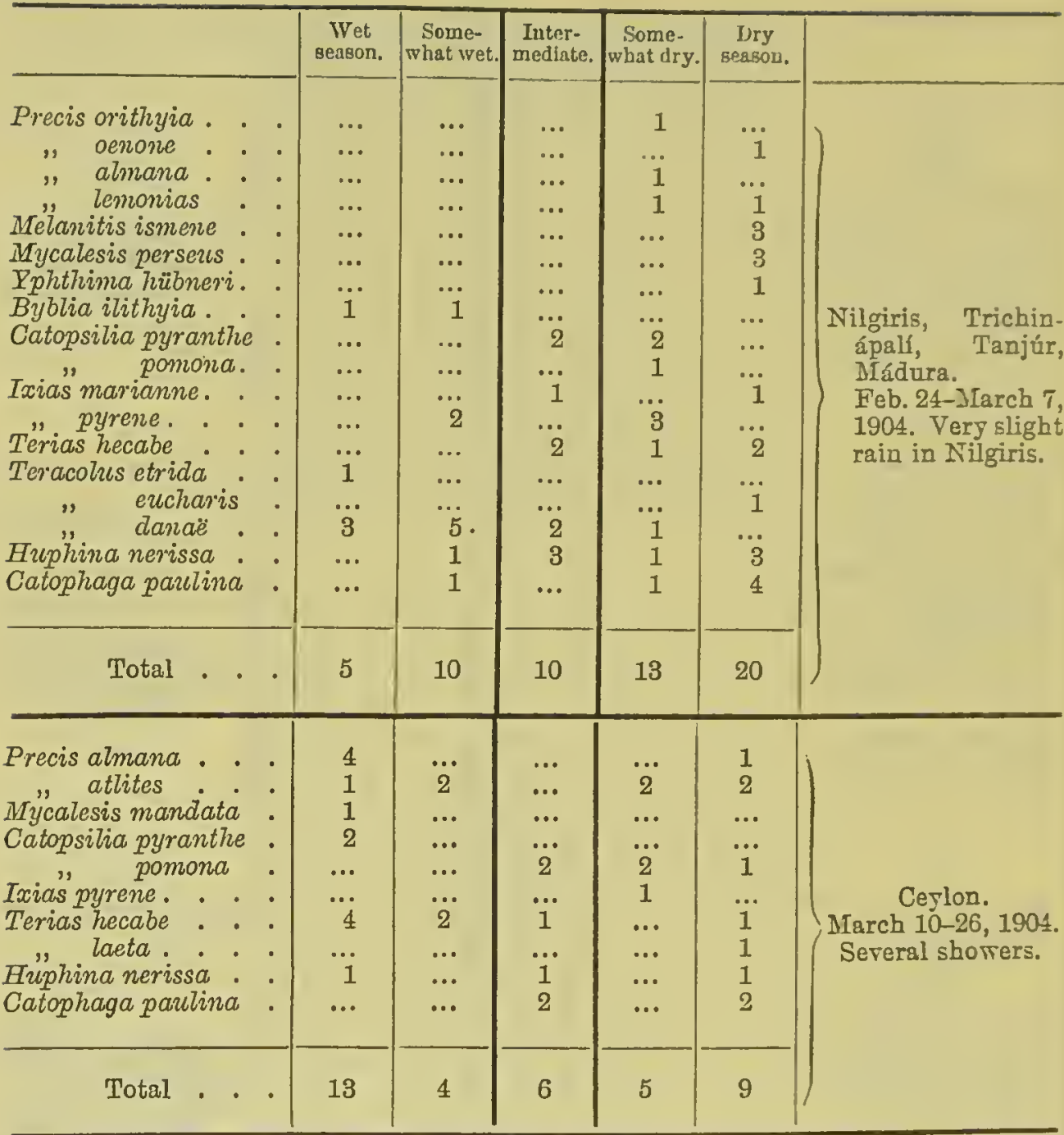

There was a storm at Simla on October 10th, and a few trifling showers during our expedition to Bághi, but we saw no sign of rain after that, and indeed scarcely a cloud, save at Kurseong, until January 14th, when there was a thunderstorm at Jhánsi. There were then several very slight showers terminating with a long but not heary rain on January 23rd. There was a very slight fall at Konúr on the night of February 29th-March 1st. Then no further rain till Kandy, March 10th. There were several showers in Ceylon.

At Simla the effects of the monsoon were not quite past, and wet-season forms were slightly more numerous than dry; the same applies to Ceylon. At all the other places, as might have been expected, dry-season forms predominated. Calcutta occupies an intermediate position.

It must, however, be admitted that to prove a species to be 
dimorphic is not necessarily to prove that the forms are associated with seasons. In the genus Precis, so far as my very few observations (limited to the dry season) are worth anything, the two forms ocellated and non-ocellated seem to be closely associated with wetness and dryness respectively. Catopsilia pyranthe, as Dr. Dixey ${ }^{1}$ has shown, occupies a far less clear position, and I may add that Terias hecabe did not appear to me to follow any rule. The two forms were taken together in most places.

Many dwarfed specimens of the genus Precis were met with as the season advanced; with the exception of one, $P$. almana, form asterie, they were all of the "dry" type, most of them markedly so. The smallest Terias hecabe was of the "dry" form, so was a dwarf T'eracolus dulcis ; two dwarfed T. etrida were "dry," two were "intermediate." A dwarf Belenois mesentina was "dry," but a dwarf Catopsilia pyranthe and a dwarf Huphina nerissa were "intermediate," while a dwarf Teracolus calais was actually of the wet-season form. ${ }^{2}$

Weather in Ceylon-1907-8.

I add, as an Appendix to Chapter VII., an abstract of my notes on the rain during my visit.

1907.

Nov. 1. [Heavy rain at Colombo. Reported to me.]

Dec. 25. [Shower about Christmas Day. Reported to me.] 1908.

Jan. 1. [Another shower about New Year's Day. Reported to me.]

6. Thunder-shower: streets wet when we landed.

7. Mt. Lavinia. Some rain.

8. Kalutara-drops on leaves-few insects before $10.30 \mathrm{a} . \mathrm{m}$.

11. Mt. Lavinia. Heavy thunder-shower.

15. Kandy. Rain most of day : heavy in afternoon and evening.

16. Kandy. Slight rain, thunder.

17. Kandy. Very slight rain.

26. Kandy. Rain all evening: not heavy.

27. Kandy. Dull day: everything wet; heavy rain, evening.

28. Kandy. Slight rain, evening.

29. Kandy. Slight rain in morning.

Feb. 19 and Feb. 20. [Heavy rain reported at Hatton.]

" 21. Kandy. Very slight rain, afternoon and evening.

'Seo Dixey, Trans. Ent. Soc. Lond., 1902, p. 189 ; and Proc. Ent. Soc. Lond., 1904, pp. lii., liii. Also Col. N. Manders, Trans. Ent. Soc. Iond., 1904, p. 701.

Sec above, p. 68, footnote. 
Feb. 22. Kandy. Some rain morning, rather heavy 11 p.m. [reported heavy, Anantapura].

"24. Dambulla. Showery.

25. Anantapura. Heavy showers throughout morning.

Mar. 5. Hatton. Very slight rain, afternoon.

6. Hatton. Rain midday for over an hour.

"7. Hatton. Heavy rain, 2-3 p.m. Thunder.

" 14. Bandarawela to Nuwara Eliya. Heavy rain, noon to 5 p.m.

" 15. Nuwara Eliya. Heavy rain, 2 p.m. Thunder, 4 p.m.

„16. Nuwara Eliya. Heavy rain, noon to 1 p.m.

\section{§14. The Selection as Resting-Places of Yeluow Leates by YELLOW BUTTERFLIES.}

Intimately bound up with the attitude at rest is the question whether or no insects select resting-places of a character likely to make the most, so to say, of their cryptic colouring.

As there still appear to be entomologists of wide experience who doubt whether butterflies, impelled by instinct, ever select restingplaces of like colour with themselves, it seems worth while to bring together the following facts.

Mr. A. H. Hamm has made some striking observations tending to an affirmative answer to this question. ${ }^{1}$ He stated that in 1904 he had some thirty plants of Cactus Dahlia growing in his garden: two were pure white, the rest of various colours. On three evenings he saw a male of Ganoris rapae at rest, each time on a white flower. In the discussion which followed, Dr. T. A. Chapman mentioned that he had once followed a specimen of Colias edusa for a cousiderable distance, and observed that it invariably came to rest upon a jellow leaf. Following up his observations in 1905, Mr. Hamm obserred five more examples of Ganoris rapae. Two were well concealed among the flowers of the White Dead-nettle (Lamium album), three were resting on the silvery undersides of Bramble leaves. In the interesting discussion which followed, Mr. H. Rowland-Brown said that he had known Ganoris napi rest for the night on the white flower of a Loueojum. Col. J. W. Yerbury mentioned the case of Euchloë euphenoides and Zegris eupheme in Spain roosting on the flower heads of Biscutella [a Crucifer with yellow flowers]; Dr. T. A. Chapman said he had seen the same thing in the Sonth of France. I have myself observed at Mortehoe (August 15th, 1910) a male

2 Proc. Ent. Soc. Lond., 1904, p. 1xxv., and Proc. Ent. Soc. Lond., 1905, p. Ixxiii., and tho intoresting discussion following the lattor paper. 
Ganoris rapae asleep upon a yellow Dahlia; it was fairly concealed. I could not find any other specimens. Again, in the same place a week later, I found a male G. napi asleep on a greyish-white corymb of Hydrangea; it was extremely cryptic so far as colour was concerned.

Many years ago the late Mr. Geo. Norman and myself took a lot of Polia chi, Linn., at rest close to the hydropathic establishment at Forres, and we were much puzzled by the fact that, while many were taken on whitewashed walls, where they were difficult to detect, quite as many were found resting on dark tree-trunks and could be easily seen at many yards' distance. Can this indifference to background be accounted for by distastefulness? Or is the species only learning to take advantage of the artificial white background?

In the Bághi Forest, near Simla, I was struck by the way in which the conspicuous yellow Terias hecabe, Linn., disappeared when it settled on a low shrub with oval leaves fading to a yellow tint, the rounded form of the wings aiding its concealment. ${ }^{1}$ But the most convincing case that up to that time had come under my own observation was a large yellow butterfly (I had no net, but think it was probably Catopsilia catilla, Cram.) which I saw in the garden of the University of Bombay. I saw this settlc again and again, invariably on a small shrub with yellow leaves. The very conspicuous fly would vanish suddenly, and it was only after several attempts that I succeeded in catching sight of it when settled, so strong was the protective resemblance (Fcbruary 10th, 1904).

It is a singular coincidence that on passing through the garden of the University of Bombay, March 22nd, 1908, I again saw a Catopsilia and watched it settle on a shrub; this was not a yellowleaved plant, as on the former occasion, but its leaves varied a good deal in colour, and the butterfly settled on the yellowest; it was certainly much less conspicuous than it would have been oll the greenest lcaf. A German fellow-traveller whosc attcntion I callcd to the butterfly agreed as to the partial concealment by the similarity in colour. ${ }^{2}$

In an analogous South African case I am able to supply fuller details :-

Eronia cleodora, Hübn., is a common Natal Picrinc. Few insects are morc conspicuous in the nct than this bcautiful fly with its combination of crcamy-white, jet black, and dccp yellow, and one might well wonder how it could possibly manage to hide itself. I watched it settle once upon the ground, and strangcly cnough it was not conspicuous when its wings werc closed and the brilliant ycllow

1 Sec abovo, p. 46.

"See above, p. 9.1. 
of the underside was fully exposed to view. 'Then I twicc sav it settle on grass; when the wings were half open it was very conspicuous, but when they were closed it was far otherwise. Eour times I saw specimens go to rest on the leaves of a coarse plant, called by the natives $u$-Bomaan, which forms the bulk of the undergrowth of the scrub on The Bluff, at Durban. Each rested with its wings closed and hanging down more or less, in which position its general shape was not unlike that of a leaf, while its colour, yellow blotched with purplish-brown, had a striking resemblance to the many yellow, eaten and blotched leaves upon the shrubs. The brilliant insect lost itself in its surroundings, although this was not a case of definite leaf mimicry as in Kallima or even in Precis. A rough coloured sketch made at the time gave (apart from artistic shortcomings) a faithful representation of some of the leaves. From this sketch and specimens of the butterflies Mr. Horace Knight made a beautiful painting, reproduced on the frontispiece of this volume.

Dr. Dixey has a note which confirms the above:-

The Bluff, Durban, August 16th. Eronia clcodora, of, observed to settle near leaves which, turned yellow and showing slits and circular holes, closely resembled its under surface.

Mr. J. Medley Wood, the Director of the Natal Botanic Gardens, kindly writing to give me the name of the plant, says that the food plants of K. cleodora are Capparis zeyheri, Turcz, and Nicbuhria pedunculosa, Hochst., of the same Natural Order. ${ }^{1}$

Perhaps the most tropical-looking butterfly that we met with in South Africa was the large Nymphaline, Salamis anacardii, Liun.; nearly four inches across the wings, greenish-white, with a strong pearly lustre, it is a very beautiful creature. Its flight is very reak. Mr. A. D. Millar of Durban said that it was fond of resting in a particular tree or shrub with glaucous leaves.

Dr. Dixey has a note:-

Sydenham, Durban, August 15th. Watched Salamis anacardii. It flew in a slow, flappy, undccided way from side to side of the road, settling cach time for a second or two on a tree. Presently it reached a tree whosc leaves werc about the same size as the anacardii when resting with wings orer its back. Herc it settlcd, bcneath a cluster of leares, being fully cxposed to view and yet wcll concealcd. It remained quiescent until forcibly disturbed.

\footnotetext{
1 Soc above, p. 181 and footnote.
} 
I have no manuscript note, but remember well that before Mr. Millar mentioned the fact of anacardii having a proclivity for such trees, I saw one take refuge in a shrub, or small tree, having large glaucous leaves; and I am almost sure that I beat another specimen out of the same kind of tree, but I failed to see the insect at rest. With these may be compared Mrs. Barber's observation on the care exercised by Papitio dardanus, a $\delta$, in selecting a suitable resting-place. ${ }^{1}$

Writing of Colias philodice, Godart, Mr. W. H. Edwards says : "On marigolds and brilliant single zinnias they delight to pasture, for they have a keen sense of colour. I have known one of them alight on an amethyst in a lady's ring, after hovering about its owner so persistently as to attract attention, and it rested some seconds." 2

Mr. S. H. Scudder quotes the following interesting observations on the same butterfly, which is called in America the "Sulphur."

"Dr. Minot once observed that when searching for its honied food the butterfly most frequently alighted on yellow flowers; and Dr. Packard has recorded that in a field where white asters and yellow golden rods were abundant the yellow sulphur butterfly visited the flowers of the golden rod much oftener than those of the aster, while the opposite was the case with Pieris rapae." 3 Again, in another place, he says, "and Jenner Weir has noticed how the white butterflies settled on the variegated leaves in his garden." 4

The preference shown by the two butterflies for golden rod and asters respectively is interesting. These genera, highly characteristic of North America, are closely allied Compositae. On the other hand, $P$. rapae was introduced into the country in 1860 or thereabouts.

Some of Dr. Dixey's notes of his observations on common English butterflies have a bearing upon the point under discussion.

July 12th. Mortehoe. Watched G. brassiccle, o, resting on a bramble flower; wings closed so that the tip was the only part of fore-wing visible.

Ausust 12th. Mortehoe. Saw G. rapae, os settled, towards dusk (nearly 8.0 p.m.), on a bramble leat in a hedge. Wings vertical. On left side none of fore-wing showing but bare apex. On right side a large part of fore-wing showing. On

1 Trimen, "South African Buttorflies," vol. ii. p. 254. Quoted by Marshall, Trans. Ent. Soc. Lond., 1908, p. 122. Soo also Dixey, Proc. Ent. Soc. Lond., 1906, pp. xxviii., xxix.

2 "Butterflies of North America," vol. ii., 1897, sub philodicc (not paged).

3 "Butterflics of New England," 1889, vol. ii. p. 1124.

' Ibid., vol. ii. p. 1102. 
careful examination this was found to be due to the fact that the right hind-wing was split, and the fore-wing had got caught in the cleft, thus preventing complete closure on that side.

August 23rd. Watched Whites in Sandy Lane. When settled for rest they look very much like turned-back leaves of bramble, near or on which they are fond of settling when meaning to remain settled for some time. In bright sunshine they often settle on flowers with wings partly or entirely spread, but in dull windy weather, like this morning's, they are apt not to fly unless disturbed, and then to settle again very soon. I disturbed one G. rapae, ot, eight times and watched it settle again seven times. Five times it settled on bramble, although there was plenty of other vegetation. Of the other two settlings, the first was on the head of a yarrow, and the second on another low plant close to a spray of bramble with recurved leaves, which it closely resembled at a little distance.

August 27th. Saw G. brassicae, of, settle twice on bramble and close up its wings.

1898. September 7th. Have several times lately, when coming up Sandy Lane at dusk, seen G. rapae, settled, apparently for the night. Generally on bramble, wings quite closed. They will allow themselves to be seized with fingers or forceps, but then generally wake, and fly off if let go.

August 8th. Observed that $L$. icarus is fairly well protected (i.e. concealed) on heads of bramble-blossom when wings are closed.

1904. Highcliff, Hants, August 8th. Watched G. brassicae, $\delta$, settle down for the night about $7.15 \mathrm{p} . \mathrm{m}$. After much fluttering about the stems of tall grasses, it came to rest on a hend of hawkweed in the pappus condition, and remained there with wings hanging downwards and closed over its back.

I now give the notes of my experiences in the New World.

Barbados, December 18th, 1906. A $q$ of Callidryas cubulc, Limu., was seen, when a clond passed over the sum, to flutter about some herbage for a short time, as though looking for something, and finally to settle on a yellow leaf of the Life Plant, Bryophyllum calycinum, Salisb.

Constant Spring, Jamaica, Jamuary 8th, 1907. Two specimens of 
C. encule (sex not reeorded) were seen, when the sky was dull, to settle on the lower, yellowish leaves of Plumbago scandens, Linn., elose to the ground.

Maekfield, Jamaiea, January 27th, 1907. I was watehing the movements of a $\delta^{+} C$. eubule, when a eloud passed over the sun; after fluttering about for a very short time it settled in the middle of a yellow, lower leaf of Bryophyllum.

Montego Bay, Jamaiea, February 4th, 1907. A o C. eubule was seen flying aeross the raee-eourse. The track was carpeted with short grass of a rieh full green, but amongst the grass were long trailing stems of the Ipomoec pes-caprae, Sw.; on one of these stems was a solitary bright-yellow leaf, far from any other of like eolour: on this the yellow butterfly settled.

Montego Bay, Jamaiea, same day. A 9 C. eubule was seen to settle on an isolated yellow leaf of a ereeper in a hedge, about six feet from the ground, all the surrounding foliage being green.

Constant Spring, Jamaica, January 4th, 1907. A dull afternoon : a + Terias euterpe, Ménét., was seen to settle close to a leaf of its own size, shape and colour.

Same plaee and day. A o $T$. euterpe was watehed for some time and repeatedly disturbed; it seemed to avoid dark green foliage, and always settled on a low plant with yellow-green leaves.

Maekfield, Jamaiea, January 27th, $1907 ; 4.30$ p.m. A speeimen of T. euterpe seen to settle four times as follows:-

(1) On a yellowish leaf of Bryophyllum: it was, however, but ill eoneealed thereby.

(2) On a pale green leaf.

(3) On a yellowish-green, finely-cut fern (Adiantum sp.).

(4) On a yellow-green leaf of a Convolvulus (or perhaps Ipomoea).

In this ease the coneealment of the inseet was remarkable. Same plaee and day. Another speeimen of 7 . euterpe was seen to settle on the underside of a yellowish leaf of the Bryophyllum.

Same plaee and day. A $q$ of 7 . cuterpe was seen to settle three times :-

(1) On a yellow leaf of Bryophyllum; fairly eryptic.

(2) On a light green leaf of an unknown plant, somewhat eryptic.

(3) On a leaf of Bryophyllum less yellow than (1), the result less cryptie.

Maekfield, Jamaiea, January 31st, 1907. Three speeimens of $T$. euterpe (sex not determined and speeimens not preserved) were watched with the following results respectively:-

(1) Seen to settle on a yellow leaf of Bryophyllum. 
(2) Seen to settle three times: twice on yellow leaves of Pryophyllum.

(3) Seen to settle seven times. Twice on yellow leaves of Pryophyllum (in one case it was very well concealed); twice on a yellow fern (? Polypodium sp.); one other time it was well concealed, but the plant not noted; on two occasions it was less well concealed.

Constant Spring, Jamaica, January 1st, 1907. A $q$ of Terias (?) elathea, Cram. was seen to settle in the shade on a leaf of the same colour as the underside of its hind-wings.

Haragáma, Ceylon, February 13th, 1908. I watched a specimen of Ixias pyrene, Linn., f. cingalensis, Moore, a $q_{1}$ settle three times upon the yellowish leaves of Bryophyllum.

It should be noted that the faded leaves of the Bryophyllum have their margins tinted a purplish-red, resembling in colour the markings found on the underside of dry-season specimens of Callidryas eubule and Ixias pyrene.

Lion's Rump, Cape Town, January 1st, 1910. A male of Synchlö̈ hellica, Linn., found asleep on a white flower-head of Antennaria sp. It was certainly cryptic. Time 7 a.m.

"With such facts before me I cannot but believe that the butterflies in question instinctively sought out leaves more or less closely resembling themselves in colour, with a view to concealment. Undoubtedly the most conspicuous butterflies on the wing are Whites and Yellows; on the move they are protected by their extremely rapid flight, but when at rest they stand in need of special protection. Many of these butterflies are restless and rarely settle, except to feed on flowers, to drink at damp places, or in the case of females to oviposit; to see them go to rest requires both time and patiencc; the best way being to watch them the moment that a cloud passes over the sun. I have very little doubt that our own Brimstone and Clouded-yellows if watched patiently will be found to seek out yellow resting-places."

With these words I concluded the section of my paper dcaling with this subject. ${ }^{1}$ Soon afterwards it came to my knowledge that Dr. Chapman had scen Colias cdusa select yellow leaves to rest upon. ${ }^{2}$ And the next ycar Mr. R. 'Trimen, F.R.S., wrote me as follows :-

"At Dornbirn, N. Tyrol, on July 18th, 1904. Opposite the hotcl verandah where I was sitting there was, just across the road,

I Trans. Ent. Soc. Iond., 1908, p. 649. Read Octobor 7th.

= Proc. Ent. Soc. Tond., 1904, p. Ixxvi. 
a long hedge of various shrubs. It was very hot, with brilliant sunshine (early afternoon). A t rhamni came coursing along the hedge; I could see it approaching from some distance. It did not fly very rapidly, and I noticed that it once or twice interrupted its onward flight, by staying to flutter about part of the hedge, but it did not actually stop. It passed in front of me, and a little further on I saw it fluttering about some greenish yellow foliage in the hedge. It got among the leaves and did not reappear.... I slowly approached the spot ... it was some little time before I could discover it, but I was at length rewarded by finding it at rest (fore-wings well down between hind-wings) on a leaf which in colour was very close to that of the underside of rhamni's wings. The leaf was large and pendant, and the outline of the resting butterfly scarcely showed against it."

Since then I have not added to my experience in this matter, but am thoroughly convinced of the reality of the habit.

In bringing this part of my subject to a close I venture to make a remark which has a wide bearing on the whole question of cryptic and mimetic resemblances.

Butterflies are most numerous and varied within the tropics. In the tropics the length of daylight varies much less than in temperate zones, and is many hours shorter than in the temperate summer. At the equator the sun is above the horizon for twelve hours every day; at the tropics the sun is above the horizon from a minimum of ten and a half hours to a maximum of thirteen and a half hours.

But although the sun is visible for these long periods, not so the butterflies. Very few comparatively are to be seen on the move before 9 a.m., and few after 3 p.m.

Now my point is that tropical birds, lizards, and other insectivorous animals have some six to eight hours of full daylight in which to hunt butterflies, when the latter are more or less at rest. This is a fact not usually allowed for in the discussion of questions of protective resemblances or mimicry, but it emphasizes the need for concealment.

To those whose tastes lie in that direction, few occupations aro more delightful than that of the field-naturalist; yet if he, or she, is to advance our knowledge there are certain requisites:-patience, industry, and method. The successful butterfly hunter is by no means the idle and frivolous person that many take him to be: the 
mere preservation of his specimens and records day by day is the work of many hours. Again, he is constantly brought into contact with problems that the most active brain may find it hard to grasp, let alone to solve.

The study of Nature in the field, no less than in the laboratory, is far from tending to simplify our explanations of the facts that meet our eyes. Each discovery does but open to our view new domains of the unknown. Theories that in our youth charmed us by their simplicity and completeness, prove in our old age to be hopelessly inadequate, so that if we are honest, we must admit the truth of the paradox, that every addition to our knowledge does but increase the vastness of our ignorance. 


\section{APPENDIX}

\section{INTRODUCTORY NOTE}

THE numerous important writings of the great naturalist, Fritz Müller, who died May 21, 1897, are scattered through a variety of publications, some of which are difficult of access. Thus many of them are only to be found in the pages of the defunct German Kosmos, while many others written in Portuguese appeared in the publications of the National Museum of Rio de Janeiro. Ever since 1897 Dr. A. Möller, of Eberswalde, has been collecting the materials for an exhaustive work, in which all these scattered papers will be re-published, together with the letters and life of Charles Darwin's illustrious friend and warm supporter in the great controversies which followed the appearance of the Origin of Species in 1859. To the results of Dr. Möller's labours, now all but complete, all naturalists are looking with the keenest interest.

It is probable that, up to the present time, Fritz Muiller's writings are best known, and have produced their greatest effect in English-speaking countries. This is to be accounted for by his speedy entrance into the Darwinian controversy-Fïr Darwin was published in 1864, and appeared in English in 1869; by his important contributions to the problem of Insect Mimicry, a subject rendered specially English by the writings of Bates, Wallace, Trimen, and Meldola; and by the fact that many of his observations were recorded in Lnglish, and were published in this country, together with others which were translated and givon to English naturalists by Meldola, almost as soon as they appeared in their original form. Thus the brief paper by which Müllerian Mimicry became known to the world appeared in Kosmos (p. 100) in 1879, and in the same year in the Proceedings of the Entomological Socicty (p. xx). 
It is, however, very different with the important and interesting subject dealt with in this Appendix. With the exception of one or two bricf notes and a single paper of great importance (Trans. Ent. Soc., 1878, p. 211), nothing written by Fritz Müller on the production and emission of scents by butterflies and moths has hitherto appeared in this country. When, therefore, my friend, Mr. E. A. Elliott, very kindly consented to translate Fritz Müller's papers for me, it appeared that by far the best use that could be made of those which dealt with this subject would be to publish them in close association with later work along the same lines. Such work has attracted the attention of my two friends, Dr. F. A. Direy and Dr. G. B. Longstaff, the former for many years, the latter more rccently. I was, therefore, extremely pleased when Dr. Longstaff agreed to publish these translations as an Appendix to a volume in which Dr. Dixey's and his own researches on the scents of butterflies are brought together. Dr. Longstaff, when he first read these papers, expressed the regret that he had not known of them during his South American journeys. That regret need now be felt no more by any English naturalist; for the difficulty of the language and the still greater difficulty of the medium of publication are alike removed in the following translations.

It is important to remember that many of Fritz. Müller's observations here recorded still remain muique and unconfirmed. The power of distinguishing the scents emitted from particnlar organs on the wings, legs, or body of Lepidoptera, a power which Fritz Müller and his children (p. 611) exhibited in so remarkable a degree, has hitherto only rarely been possessed by other naturalists. Now, however, that thesc many records are published in a collected form, we may hope that still further attention will be directed to this aspect of the subject.

Among the observations in the following papers which become of special interest in the light of recent work, I may mention the peculiar development of air-vessels bencath the scent-brands (pp. 612, 637), a subject on which Dr. Dixey contributed a paper to Section D of the Portsmouth meeting of the British Association in the present year (1911). Furthermore, Fritz Müller's suggestions that there is connection batween the anal brushes and the scent-pockets on the 
hind-wings of male Danainae (p. 619) becomes of the greatest importance in relation to Mr. W. A. Lamborn's recent discovery that the scent-brands of the African Danaine genus Amauris are actually stroked with the brushes (Proc. Ent. Soc., 1911, pp. xlvixlvii). Attention must be also directed to the interesting evidence of "convergent" evolution supplied by the scent-organs described in the sixth paper. The striking statement with which this memoir concludes will come as a surprise to many readers, especially when they remember the date of publication-1878. It should be noted, however, that the scales of Lepidoptera are so extremely variable in form and size-as may be seen even upon the surface of one and the same wing - that the independent production of almost any organ that conld arise from modified scales would appear to be an usually easy task for convergent evolution. In contrast with the argument for convergence derived from the scent-organs is the masterly use, in the last four papers, of the same structures as evidence for systematic affinity.

In conclusion, I desire to thank Mr. E. A. Elliott for the great trouble he has taken to render these translations as accurate as possible, and Dr. Longstaff for accepting my suggestion that these valuable papers should appear in their present form.

E. B. POULTON.

OXFORD,

Dec. 31, 1911. 


\section{TRANSLATIONS \\ By Ernest A. Elliott, F.Z.S., F.E.S., OF PAPERS BY FRITZ MÜLLER, Ph.D.}

\section{§I. On Hair-tufts, Felted Patches, and similar Structures on the Wings of Male Lepidoptera.}

THE males of numerous species of diurnal Lepidoptera are characterized by the presence of speeialized hair or seales on their wings. I will here bring together what I have been able to find on the subject of these struetures in the few works on Isepidoptera to whieh I have aeeess. The arrangement of genera adopted below is that of Kirby's Catalogue of Diurnal Lepidoptera, 1871.

\section{Danainae.}

\section{NyMPHALIDAE.}

Danais.-The males have a patch of peculiarly constructed scales on the first braneh of the median or on the submedian [nervure] of the hindwing ; sometimes it takes the form of a sac, which opens on the upper surface of the wing, and is filled (at least in dried specimens) with a bromn dust.

Amauris (Danais, Seet. 1, Doubld., Gen. D.L.).-The males hare a patch of peculiarly shaped, closely packed scales on the submedian of the hind-wing, not far from the anal angle.

Euploea.-In the male the inner margin of the fore-wing is usually rounded and projects, so as to cover a considerablc portion of the hindwing. The males of certain specics possess, towards the inner margin of the fore-wings, one or more short strcaks, formed of palc, pcenliarly shaped seales, prescnting a dnll, somerrhat chalky appearance. That part of the hind-wing which is covcred by the projeeting part of the fore-ring is often clothcd with scales of a vcry remarkable shape. They are elongate, hairlike, basally rather broader, and end in an ovate culargement, resembling

1 Jenaische Zeitschrift für Natumvisschschaft, XI. (New Series, IV.), 187T, pp. 99-114.

The original footnotes are initialed "F.MI.," those added in preparing this Appendix for publication, "E.A.E." or "E.B.P."

Squaro brackets, [ ], in the $\Lambda$ ppendix are used to indicato editorial matter. 
the antennae of Pieris. In other species the scales on this spot are distinguished chiefly by their greater size.

The males of Athesis, Thyridia, Olyras, Dircenna, Ceratinia, Sais, Mechanitis, Ithomia, Melinaea and Tithorea, that is to say, of nearly all the genera which have been recently transferred from the Heliconinae to the Danaince, have "a tuft of hair" on the upper" side of the hind-wing in front of the subcostal " (Herrich-Sehaeffer), or more correctly, as Doubleday describes it for Olyras, "an elongate spot, covered with very long delicate hairs." In the male of Lycorea, which also belongs to this group, ${ }^{1}$ the hair-tuft is wanting, according to Herrich-Sehaeffer, but they have (Doubleday) "a large tuft of hair on each side of the last abdominal segment, which can be for the greater part retracted into the abdomen."

\section{Satyrinae.}

In the male of Antirrhaea (Anchiphlebia, Butl.) archaea the inner margin of the fore-wing is arched as in Euploea, the costal margin of the hind-wing being also strongly arched, and on the under side of the forewing is a patch of hairs arranged like the teeth of a comb ("plaga peetinatim cirrata").

In Gnophodes morpena, as in species of Euploea, the hind wings of the males bear a large oval white patch near the costal inargin.

The male of Melanitis suradeva (cyllogenes, Butl.) has a large, dark, silky patch on the fore-wing.

In Satyrus roxelana, clymene, maera, megaera, hiera, in Epinephele lycaon, janira, ida, tithonus, in Hipparchia semele and arethusa, the males have a patch of dark hair on the fore-wings.

Mycalesis. - "The most important character of this genus consists in the presence of a tuft of long hairs, either on the upper surface of the fore-wings, where there is a small slit, or pocket for their reception, or on the hind-wings, where they are covered by the inner margin of the fore-wings. This tuft of hair occurs, as usual, in the male only, and according to its position the genus can be divided into two groups" (Westwood).

The males of Bic actorion are distinguished by (1) a tuft of long pale leather-brown hairs near the inner margin of the hind-wings, which can be crected or depressed at will, and whell at rest, are cnclosed in a long pocket, and also by (2) a patch with long black silky hair ncar the anterior margin of the hind-wings. This latter patch is covered by a bare spot on the under side of the fore-wings, close to the inner margin.

3. Elymniincee.

Elymnias (Melanitis, Westw. Gen. D.L.).-The males have a tuft of hair on the upper side of the hind-wings, near the base.

'Lycorea is now included in the Danainae propor, all the other genera mentioned in the above paragraph boing included in an allied sub-family, the Ithomiinae or Neotropinac.-E.B.P. 


\section{Morphinae.}

Amathusia.-In the male there is on the upper side, near the inner margin of the hind-wing, parallel with the apex of the abdomen, a small, obliquely projeeting tuft of hair : between this tuft and the first branch of the median is an elongate fold of the wing, in which a few long pale hairs are hidden.

Zeuxidia.-The inner margin of fore-wing in the female is almost straight, in the male greatly expanded and rounded. The hind-wings of the male have on the upper side, in the spaee between the eostal and subeostal, an oval spot of pale leather-brown hairs; also in the middle of the cell a long ovate spot of brown, longitudinally direeted hairs, and between this and the inner angle of the eell a series of hairs pointing obliquely towards the abdomen.

The male of Discophora has a silky spot in the middle of the upper side of the hind-wing.

Tenaris (Drusilla, Swains.).--Inner margin of fore-wing in the female is almost straight, in the male expanded at its base and emarginate at its eentre. On the hind-wings, near the base, eoneealed under the expansion of the fore-wing, a tuft of hair ; a seeond, longer tuft near the inner margin, lies opposite to the apex of the abdomen.

Clerome.-Inner margin of fore-wing in the male slightly produeed. Hind-wing upper surface in the same, near extremity of the thorax, a tuft of fine hairs.

Thaumantis. - In the male a tuft of hair on the upper side of hindwings, partly covered by the inner margin of fore-wings.

\section{Brassolinae.}

Opsiphanes.-The mpper surfaee of the hind-wings of the males bears a brush of long hair, placed in the eell, near the origin of the first branch of the median; also a seeond tuft near the inner margin, close to the submedian, and about opposite to the middle of the abdomen. In Opsiphanes soranus an additional buneh of eurved, leather-brown hairs between eostal and subeostal. In Ops. cassice I also observe, near the base of the wings, between costal and subeostal, a buneh of delieate hairs, but these are straight and of the same eolour as the wings, and opposed to them, on the under side of the fore-wings, is a small dull grey spot betreen the median and submedian, close to the latter.

Caligo.-Hind-wing of the male with a small tuft of hair near the inner margin, opposite to the middle of the abdomen.

Narope.-"The submedian in the fore-wing of the male is eurred in order to make room for a peueil of long orange-eoloured hairs, springing from the under side between the medinu and submedian. Opposite to this is a smooth aren on the upper side of the hind-ring."

Dasyophthalma.-Inner margin of fore- ring more arched in the male than in the female; on the npper side of the hind-wing in the former is an oval velvet spot, whiel is intersected by the subeostal and its braneh; 
a small oval spot near the base of the cell is devoid of scales, but furnishcd with an erect tuft of hair.

\section{Acraeinae and 7. Heliconinae.}

In the few genera of both these groups similar male characters appear to be absent. ${ }^{1}$

\section{Nymphalinae.}

The male of Lachnoptera has on the upper side of the hind-wings, near the costal margin, a characteristic spot of hair-like scales. These are long, almost linear, deeply emarginate and slightly expanded at thcir flattened bases, apically narrowed to a slender stalk and cnding in a fan-likc platc with a fringed margin.

In Jyscelia orsis the " hind-wing is furnished with a brand extending from interspace five to seven "(Herrich-Schaeffer).

In the males of Didonis biblis I find on the under side of the fore-wing, near the inner margin between the submedian and median, at the spot where the latter emits its first branch, a jet-black patch of considerablc size, which may be easily overlooked on the dark ground; a similar smaller spot lies close to it, nearer the base. Opposed to this lies a small spot on the upper side of the hind-wing.

Prepona.-In the male a tuft of hair springs from the edge of the hind-wing groove which encloses the abdomen, and opposite to it on the abdomen is an oval brand, surrounded by a bare border.

Agrias._. "Some, if not all the species have tufts of hair on the wings" (Butler).

\section{Lemonitdae (Eryolmidae, Swains.).}

No examplc of a male characterized by special hairs ol scalcs is known to me in this family.

\section{LYCAENIDAE.}

Thecla.-In very numcrous spccies the forc-wings of the malc are marked with a roundish velvcty or fcltcd patch, ncar thc apcx of the cell, the patch not infrequently causcs a more or less considcrable displaccment of the nervures, so that the difference betwecn the ncuration of male and female is sometimcs as great as that between species of different gencra. The size, shapc and position of this "brand "vary considcrably. Usually it is of a dark colour, and then, if placed on a similarly colourcd surface, is often distinctly scen, as a dark spot on an othcrwisc colourless mombrallc, only after removal of the scalcs. Morc rarely it is palc (yellow or whitish) on a dark (black or bluc) ground, as for cxample in 'Theclc ambrax, Wcstw.

1 The males of an important section of tho Heliconinae aro charactorizod by the breadth of the glistening area covered with modified scales on the under surface of the fore-wing and of the hind-wing area by which it is covorud.-E.B.P. 
(Gen. D.L., Plate LXXV., Fig. 7). In Thecla bosora, Hcw., the upper side of the wing is dull blue, the fore-wing with broad brown anterior margin and borders, the brand very large and shining blue.

\section{Pierinae.}

\section{PAPILIONIDAE.}

In the males of Leptalis the inner margin of the fore-wings and the costal margin of the hind-rings are not uncommonly produced, as in Euploea. In such species there is on the hind-wing abore, and on the fore-wing beneath, a large shining arca covered with very small, closely placed scales, and in the middle thereof an oval, dull chalk-white or ashgrey patch. When the wings are expanded, the patches of both wings lie directly one on the other.

The male of most species of Callidryas has near the base and the costal margin of the hind-wing a chalky patch ("sac glanduleux," Boisduval), the size, shape, and colour of which vary greatly with the species. Somctimes it is covered by a mane of long hair springing from the cell. In other cases there is a patch opposite to it on the under side of the forcwings, betwcen the median and submedian. This opposed patch and the mane appear each to exclude the other; where I find the mane (argante, trite), the fore-wing patch is wanting; where the latter is present (philea, statira), the mane is absent.

Some species (as the Indian pomona) bear hairs also on the inner margin of the fore-wing. Finally, in some cases (eubule) both hairs and brands are wanting, though the patch on the hind-wings may not be absolutely untraceable.

In a few species of Nathatis, Gonepteryx and Colias, similar patches appear in the males.

\section{Papilioninae.}

The first of the divisions of the genus Papilio as recognized by Felder contains $P$. priamus, and the allied species of the now oncc again abandoned genus Ornithoptera. In the males of this division the inner margin of the hind-wings is much produced, and folded so that the upper surface lies within ${ }^{1}$; the outer side of the folded margin is more diffusely scaled, and furnished along the submedian with a manc of brownish crect bristles; the basal half of the fold is again rolled inwards; the inuer surface of the entirc margin of the upper side of the wing is covered with black scales, without hairs.

In the male of the second subdivision, which, like the first, is made up of species of the former genus Ornithoptera, the inner margin of the

1 Dr. Karl Jordan informs mo that the upper surface lies within only in papered specimens in which tho margin has beon pressed down. In nature the fold stands vearly upright, lenuing towards the abdomen, and only its extreme base is again rolled inwards as described in the text.-E.B.P. 
hind-wing is similarly folded, but the second fold of its basal half is turned ontwards, and not inwards. The inner surface of the first fold, and that part of the wing hidden by it is brownish white, somewhat iridescent, and densely covered with a pelt of the same colour.

In the fifth division, which, together with their nearest allies, Felder ealls American Ornithopter,${ }^{1}$ the formation of the hind-wing in the male is similar to that of the second division; it is deeply emarginate at the anal angle, the greatly developed inner margin is inwardly folded, the basal part again outwardly, the hidden surface covered with brownish white scales, and, as far as the submedian, densely clothed with a wonderful silky white pelt.

\section{HeSPERIDAE.}

In sercral genera the anterior margin of the forc-wings is folded (" eostal fold," Herrich-Sehaeffer), and the enelosed part thiekly covered with pale down. In other species (Ismene oedipodea), the male has a large velvety patch near the base of the fore-wing; in others (Hesperilla), the males are characterized by a "seale blister" [Sehuppenwulst] of the forewings, while in Caecina the inner margin of the fore-wing is produced near the base, is smooth beneath and eovers a tuft of hair on the lind-wing.

So far for the diurnal Lepidoptera. That sueh strnetures are not wanting in the Heteroeera is shown by Calesia comosa, Guen., whose male has a large hair-tuft on the upper side of the fore-wings.

Howcver ineomplete the above review may be, it will suffiee to prove the wide distribution of analogous structures among diurnal Lepidoptera, as well as their astonishing variety. What an immense difference between the incredibly thick, snow-white, silky eovering of hairs on the broad folded part of the hind-wing of Papilio nephation, the largc chalky patch on the hind-wing of Calliclryas trite, eovered by a long mane, and hidden under the inner margin of the fore-wing, the delicate hairy tuft in the centre of the hind-wing of Opsiphanes cassice, and the eoal-black spot in the middle of the Morpho-like blue of the fore-wing of I'hecla / And yct among all these differenees certain cominon features arc to be found. Common to most of these structures is the faet that they are not usially exposed, but enclosed, it may be, and this is the most usual arrangement, between the inner margin of the fore, and the eostal margin of the hindwings, or between the inner malrgin of the lind-wings and the abdomen, in a folded part of the anterior margin of the fore, or the inner margin of the hind-wings, or finally in special furrows, slits or poekets. Not infrequently the tuft or spot lies opposite to a bare patch or to a similar

1 T'his designation is justified by the pupa of our $P$. nephalion, which lives on Aristolochia, and is entiroly similar to that of Ornithoptcra heliacon.-F.M. 
brand on the other wing or on the abdomen. Where brands or tufts lie free on the surface of the wings, they are on the upper side, so that in this easc, when the butterfly rests with raised wings, they are hidden between them. They nevcr appear to occur on thc under side of the hind-wings, or on that part of the fore-wings left uncovered by the hindwings. The scales of the "brands" are usually placed very close together and therefore stand almost upright, and are fastened far more securely than the ordinary scales of the wings. Aftcr removal of the scales the patches are recognizable not only by the densely packed points of attachment of the scales, but the membrane is also as a rule more or less cloudy or even dark coloured. Not infrequently they are traversed by arborescent branched or net-like air-tubes. The tufts, manes or bunches of hair concealed between the wings, or between wings and abdomen, tend to erect themselves when the wings are opened out or drawn away from the abdomen. Possibly all the tufts which lie free on the surface of the wings may be also capable of voluntary erection; in Opsiphanes cassiae the tuft lying in the middle of the cell of the hind-wings can be spread out into a complete hemisphere.

By far the most common structure-a brand or tuft on the costal margin of the hind-wings, between the costal and subcostal [nerrures], and covered by the inner margin of the fore-wings, occurs in such extremely different insects, ${ }^{1}$ that inheritance from a common ancestor is scarcely to be thought of, for such inheritance would necessarily imply, not only that the structure existed in the male of the original ancestral form of all diurnal Lepidoptera, but that it has been lost by the majority of his descendants. But with almost equal right one would also hare to ascribe to this original male the patch or hair-tuft on the inner margin of the hind-wing, which occurs in the Danainae, Satyrinae, Morphinae, Brassolinae and Nymphalinae, and in a kindred form in the Papitionidae. It is far more probable that the furnishing of the males with special scale brands and hair-tufts occurred at a later stage and independently in the several groups. An argument in favour of this is the great varicty to be scen within the same family, or eren in the samc gcnus (Ifycalesis). Whatever, thercforc, these brands and tufts, scattercd through the most widely separatcd groups of diurnal Lepidoptera, posscss in common, must. since it can scarcely be traced back to a common source, be considered as an adaptation to some similar purpose. As to what that purpose is, not even conjectures have, as far as I know, been made public hitherto [1876].

Chance revealcd to me the meaning of the brauds and hairs in a single species, and I presumed that these struetures rould hare the same significance in all, a presumption I have sinec been able to confirm by the stndy of several species belonging to different families.

1 In Danainac (Euploca, Ithomia and their allios) ; in Satyrinac (Mycalesis, Bia); in Morphinac (Zcuxidia); in Brassolinac (Opsiphanes); in Nymphalinac (Lachnoplera); in Picrinac (Leptalis, Callidryas); and in Hesperidac (Caccina).-F.M. 
I had caught a freshly emerged male of Callidryas argante, and, in order to show to a friend the mane-like pubescence of the hind-wings, I drew the fore- and hind-wings apart. I then perceived a distinet, somewhat musky, seent, and eonvinced myself that it eame from the hairs, which ereeted themselves as the wings were parted. This observation I have repeated with numerous males of the same speeies, and it was only with old, worn and battered speeimens that the scent could not be perceived. I have since had opportunities of smelling only a few similarly equipped butterflies. On one male of Prepona laertes, I found a not very strong, but yet unmistakable seent, arising from the tuft on the hindwings. Several of my children not only pereeived the same scent, which they (very appropriately, I consider) spoke of as bat-like, but they also pointed to the same spot as its seat. A male of Dircenna xantho, gave off a not strong, agreeable, vanilla-like scent; here also, I asked my children to seek for its souree, which they agreed with me was to be found in the "hair-tuft." Far more powerful than in the three above-named species is the scent, bat-like, as in Prepona, which proeeeds from the large black patches on the fore-wings of one of the finest of our Theclas (T. atys, Cr.). This odour ean be distinetly pereeived even several weeks after death. The upper side of the fore-wings in the male of this Thecla is blue, bordered with black; the black border widens from the posterior angle, where it covers about one-fifth of the length of the wing, to the apical angle, where it covers about one-third; the anterior margin is also black as far as the costal nervure. In the central blue area are two large, deep black patehes, separated by a blue streak, marking the position of the transverse vein which closes the eell. Thus one patch, the smaller, lies inside, the other, the larger, outside the ecll. The inner is pentagonal with rounded corners, and entirely oecupies the end of the cell, extending along the subeostal nearly to the origin of its first braneh, along the third branch of the median about half as far, and bounded at the base by two lines which mect at right angles on the aborted basal part of the discoidal. 'The outer' patch, separated from the inner by the transverse veins, touehes in front the upper diseoidal vein, and behind the seeond braneh of the median, surpassing the inner spot in this direetion by about one-third. It forms an oblique-lying oval area, whose axes are about as 5 to 6 . The lower discoidal and the median intersect it, and from each of the sections thus formed a triangular blue spot extends into the blaek border of the wing. 'The surfaec of these patches amounts to about one-tenth of the entire wing. Their closely paeked seales adhere very strongly, and after removal, the onter patch is translucent with a slightly yellowish tint, the inner very dusky and almost opaque; the membrane of the latter bulges somewhat on the lower surface of the wing. On microscopic examination the onter patch shows, besides the crowded soekets of the suales, only a few delicate, scarccly branched air-vessels, which enter it from the neighbouning nervures. On the other hand, one sees in the inner patch (cspecially 
when looked at from beneath) a rather close net-work of largish air-vessels, with red-brown, transparent points encloscd in the meshcs.

The brand on Callidryas argante is also traversed by branched arborescent air-vessels. It is somewhat paler than the surrounding area, from which it is not sharply demarcated, but after removal of the scales it stands out more distinctly as a dull spot. This brand lies in the obtuse angle between the subcostal and its branch, and is separated by a pale border from both veins, from which air-vessels pass into it. It is about $3 \mathrm{~mm}$. long, by $0.6 \mathrm{~mm}$. in greatest breadth. The mane which covers the spot is composed of hairs of about $5 \mathrm{~mm}$. long, arising from a strip, about $1.3 \mathrm{~mm}$. in breadth, which extends from the base of the cell for about $10 \mathrm{~mm}$. along the subcostal. ${ }^{1}$

Having thereforc demonstrated by actual observation that the purpose of the patches and hair-tufts in the males of Callidryas argante, Thecla, Prepona laertes and Dircenna xantho, species from widely differing families, is to cxhale sccnts, which are probably agreeable to their females and cntice them to pair, I am led to infer that this is the meaning of all similar structures on the wings of male Lepidoptera, not only because of the unmistakable similarity amidst such great diversity, but even more on account of the previously mentioned peculiarities which render them cspecially suitable for such a purpose. They are usually sheltered from cxposure to the air, encloscd between the fore and hind wings or in some other manner, or at least, while at rest, concealed between the closed upright wings. Thus the scent is not diffused at the wrong time and so wasted, but collects betwecn the denscly packcd scales, among the hairs, brushes or mancs. One could hardly find a more effective method of cmploying any odorifcrous substance, than that of saturating with it the hairs of a brush, and then suddenly opcning them out in all dircetions, so as to provide an cnormous surfacc for evaporation.

Just as the Agcronias, four spccies of which I had an opportunity of observing in some numbers during the past summer, only make the remarkablc crackling sound on the wing and during courtship, so also in all probability, the butterflics equipped with brands, tufts, ctc., only distributc thcir scent under the same circumstances.

I recently captured a pair of Hesperia orcus, which wcrc fluttering close together, and appeared to be almost on the point of pairing. When I took out the malc, which had becn killed by a pinch while still in the net, I found that the costal fold of onc side was raised and spread out in the planc of the wing. I had never scen such a thing on any other

${ }^{1}$ Argante is accompanied in this locality by a rery similar paler species or raricty which agrees very well with Boisdurnl's deseription of C. agarithe, and cmits a scent just like that of argante. The brand in this form is larger, not only extending to the subeostal and its branch, but filling the aente angle between these two nerrures. Among the specimons I happen to have in hand, I find no transition forms between the two.-F.M. 
oecasion, either in the male of orcus or of any other Hesperid, and I could not unclerstand how by pinehing the thorax I had brought about the unfolding. Probably it had been already accomplished by the ardent male himself.

From the very first I never expeeted to find in all the above-mentioned speeies any striking scent, or indeed one that would bc pereeptible to the human nasal organ. Our sense of smell is very imperfectly developed, even in eomparison with many mammals, and its inferiority may bc far more pronounced when compared with certain insects, espeeially Lepidoptera. It is well known that the females of Moths attract the males from almost incredible distances; and the certainty with whiel butterflies are able to diseover the food-plants of their larvae, suffices to prove the keenness of their scent. Thus, to the female butterfly a scent which is not perceptible to the human nose, may appear quite strong. I was, therefore, not surprised at being unable to detect any seent from the brands of several speeies of Thecla, or from the large, mane-covered ehalky pateh of Callidryas trite, ${ }^{1}$ and I do not find in this inability any objection to my explanation as to the purpose of such structures.

I may be permitted to take this opportunity of also mentioning some other seent-distributing organs of diurnal Lepidoptera.

The males of most species of Glaucopidae are able to protrude two long hollow tubes from the apcx of the abdomen. Sometimes (Leucopsumis sp.) these tubes are longer than the body, and on protrusion curl up like rams' horns. They are as a rule beset with hairs, which are erected in the act of protrusion, and they usually give off a more or less powerful, and to us unpleasant, smell : especially strong, and in this case not unpleasant, is the scent of the magnificent Belemnic incuratc (Euchromic eryx), recalling at the same time prussic acid and chloroform. Entirely similar, strong smelling tubes I found in a moth, the name of which I do not know. ${ }^{2}$

With all their external differences, these tubes of the male Glaucopidae are adapted to fulfil the two requirements of a seent-distributer whieh we noted in the butterflies:-protection against unnecessal'y evaporation, and the exposure of a large surface, when the scent is to be emitted.

It is worth noting that within the group of the Ithomiinae and their allies, both these struetures occur, and appcar to represcnt each other. In Lycorea ${ }^{3}$ the tuft on the anterior margin of the lind-wing, which oecurs in most of the Ithomiine genera, is wanting; but then the males possess

1 Seo torminal note, p. 615.

2 Identified by Dr. Staudinger as a species of Cryptolechia.-F.M. [The classification and synonymy of the moths roforred to in the above paragraph have been entirely changed sinee the date at which this memoir was written. Glaucopis = Syntomis. Lencopsumis is a Hypsid, Belemnia an Arctid, Luchronnia a Syntomid. See also Nature (1874), p. 102, for a letter dealing with the Glaucopidae, written April 20 [1874], by F. Müller to Charles Darwin.-F.P.P.]

3 See note 1 on p. 605 . 
at the apex of the abdomen a partially retractilc bunch of hair. Similarly among the Pierinae. Here, too, thcre are spccies-one at least is known to me-in which the scent originates, not in the wings, but from the apex of the abdomen. The male of Daptonoura ilaire possesscs on the ventral surface, just anterior to the anal valvulae, a non-retractile brush of hair, about $4 \mathrm{~mm}$. in length. The brush when at rcst, is closely pressed to the ventral margin of the anal valvulae, extending slightly beyond them. By pressing the abdomen it can be spread out on all sides, and then emits a very distinct, though feeble scent. I have never taken thc female of this species, but do not doubt that the brush of hair occurs only in the male, and that the scent serves to attract the opposite sex, and not as a warning to foes. Scents which serve this latter purpose are usually given off instinctively by the insect as soon as it is captured. Thus the females of various "Maracujá butterflies" (Heliconius, Eueides, Colaenis, Agraulis) when seized, protrude from between the seventh and eighth dorsal plates two fleshy glands, which meet along the middle dorsal line, and exhale a more or less penetrating scent, while the male, under similar circumstances, separates the anal valvulae, on the inner side of which similar glands are situated. If one catches a male of Didonis biblis, it protrudes on the dorsal surface, between the fourth and fifth segments, two roundish bodies, meeting along the centre line, covered with short grey hairs and emitting a scent: pressing the abdomen causes the protrusion of two similar bodies between the fifth and sixth segments; these are beset with longer white hairs, which on protrusion radiate in all directions. I regret that I harc not been able to ascertain whether such glands exist in the female.

The Ithomiae of the Amazon, which have been made so celebrated by Bates as the models for Leptalis and other mimicking Lepidoptera of that locality, are said to be protected against birds by a disagreable scent. Is this the same scent as that emitted by the closely allicd Dircenna xantho, and is it emitted by the hair-tufts of the males? If that rere so, one could understand the hundred-fold predominance of the males recorded by Bates, and the entire correspondence betwcen the sexes in pattern and colour. If the possession of a scent repulsivc to pursuers wcre confined to the males, and the scxes in equal numbers, thon thcir cncmies rould securc a palatablc mouthful just as often as a disagrccablc one, and would scarccly be induced to give up the capturc of Ithomiae. Bnt this ronld follow the more surcly according as the males predominated, and the less often the chasc resulted in an agrecable morsel. Again, the fcmalcs, being indistinguishablc from the malcs, rould, although wanting the protective scent, sharc in the secnrity which the malcs orre to their tufts. Hence, in this case, the similar coloration of the scxcs confers upon the fcmale a protective resemblance, established and maintained by natural selection, as in the mimicking Leptalis.

I close with the hope that investigntors who hare access to rich collections will give us further information regarding the distribution of 
these structures and their minute anatomy, and that observers of living insects will soon add to our knowledge of the scent emitted by tufts, brands, and similar structures. To urge such investigations is the sole object of these lines, for that which I am myself able to offer is scarcely worth recording.

Itajahy, Santa Catharina, Brazil, April, 1876.

\section{SUPPLEMFint.}

In the course of the last month, in addition to a crowd of male Ditonis biblis, which are taken almost daily in quantity, I have had the opportunity of examining also a fair number of females, which are, at least in this locality and at this time, far rarer than the males.

The females possess only the two anterior glands, the posterior pair being entirely absent: the anterior glands are rather smaller, the hairs or rather the hair-like, battledore-ended scales, are fewer than in the male, but the scent is not less powerful. This smell, as also that of the corresponding anterior glands of the male, was pronounced almost unanimously by my children to be disagreable, and even repulsive, whereas that of the posterior pair in the male was unanimously described as agreeable, and flower-like, recalling hcliotrope. 'These posterior white glands, wanting in the female, stand out so sharply on the black abdomen, that they look attractive, and it seems probable that they charm the female not only by their scent, bnt by their ornamental appearance. This would also apply to the patches on the fore-wings of the males of Thecla, when they show up light on a dark ground, or glow with lustrons blue, as in Thecla bosora.

May, 1876.

Fritz Miiller's important paper, read June 5, 1878, "Odours emitted by Butterflies and Moths" (Trans. Ent. Soc., 1878, pp. 211-221), may be looked upon as a further supplement to the above memoir. Seo also tho discussion in Proc. Ent. Soc., 1878, p. zxvii. The following extract from a letter to his brothor Hormann Mïller is published in Carus' Zool. Anzeig., I. (1878), p. 32 :-

"It appcars, that from constant practice, my nose is becoming evor koener. With Daplonoura lysimnia I now dotect an agrocable scent from each nowly oaptured malc. Two ycars ago I always found Callidryas trite, malo, dovoid of scent: yostorday I caught a male with a distinct smell. In Didonis biblis, malo, the black patch on the under side of the forc-wing also smolls like faint musk, so that this creature dovolops thrce differont sconts. In Callidryas, the fomalo also bas strongly scentod glands on the genitalia, which, when excited, she cxserts : their odour is sharp [or acid], that of the malc, musky."

Itajahy, April 16 [1878].

An interesting reviow of the above momoir (§ I.), signed " $\mathrm{K}$ " - probably Dr. Ernst Krauso - is to be found in Kosmos, I. (1877), pp. 260, 261.-F.B.P. 


\section{§II. On the Sexual Spots of the Males of Danais erippus and D. gilippus. ${ }^{1}$}

\section{Plate A.}

IN the account which he gives of the generic characters of Danais. Doubleday ${ }^{2}$ makes the following statement as to the sexual differences which are found on the wings of these butterflies :-

The males of the first group (containing the African species now included in the genus Amauris ${ }^{3}$ " "have a patch of peculiarly formed and closely placed scales situated on the submedian nervure of the posterior wings, not far from the anal angle." In the second group (to which belong all the American species) the "sexual spot" is found on the first branch of the median nervure. In the third group the sexual spot is placed either on the same branch or on the submedian nervure, and is in the form of a perfect pocket, opening on to the upper surface of the wing, at the bottom of which, at least in dried specimens, a little dark porrder is found. In the species of the fourth group (now forming the genus Ideopsis ${ }^{4}$ ) the sexual patch is absent from the hind-wings.

Recent discoveries "show that the sexual marks which characterize the wings of many male butterflies are scent-organs, and they exhale at times a distinct odour, which is undoubtedly agreeable to the females of the respective species. I thcrefore proceeded to examine the sexual spots of our two species of Danais (Danais erippus, Cram. and D. gilippus, Cram.) and found in them a most interesting structure, which appears to mc worthy of detailed description. The "sexual spot" (I provisionally retain Doubleday's name for the structure until its functions are definitel ascertained) is placed, in our D. erippus and D. gilimpres, on the hind-wings, between the submcdian nervure and the first branch of the mcdian, being only separated from the lattcr by a vcry narrow intcrval, which in D. crippus barely equals, and in $D$. gilippus scarcely cxeceds, the diameter of the branch itself (Pl. A, Figs. 1, 2, 7, 8). It is visible on both sides of the wing, forming a small black swelling more promincnt on the upper surfacc. The

1 Archivos do Muscu Nacional do Rio de Janciro, II. (1877), pp. 25-29. By Dr. Fritz Müller, Travelling Naturalist for the Natioual Museum.

2 Doubleday, Wostwood, and Hewitson, Gencra of Diumal Lepidoptera, p. 89.-F.M.

${ }^{3}$ Kirby, A Synonymic Catalogue of Diunnal Lcpidoptcra, 1871, p. 8.-F.M.

+ Kirby, loc. cit., p. 2.-F.M.

s Fritz Müller, Kosmos, I., 1877, p. 391 [see § X., p. 655].-F.MI. 
blaek eolour is not dne to the eovering of ordinary seales only-for it persists when they are removed-but to the membrane itself, which at this part is both darker and of a firmer consistence. The sexual spot is elliptical in shape, with the major axis parallel to the nervure. It is much larger in the smaller speeies, viz. D. gilippus, being about $4 \mathrm{~mm}$. long, by from 1.5 to $2 \mathrm{~mm}$. wide; while in erippus it rarely exceeds $2 \mathrm{~mm}$. in length, by 6 [0.6 is evidently intended] in width. The sexual spot is shaped like a leaflet of wood-sorrel [usually called "obeordate"], and forms, as Doubleday described in some speeies of his third group of the genus Danais, a kind of pocket, opening on the upper surface of the wing, where there is, on the posterior margin of the spot, a narrow slit occupying half, more or less, of its length. The lower wall of this pocket or cavity is formed by the actual membrane of the wing; the upper wall is separated from the lower, a little distance from the nervure, at a very acute angle. The free or posterior margin of this wall curves or rolls round towards the interior of this cavity, as is well seen in transverse sections (Pl. A, Figs. ? and 9 ).

I have noticed that in the living inseet the free margin of the upper wall is pressed closely against the lower wall, thus elosing the cavity on all sides; yet it is easy to pass through the slit which separates the walls some slender object, as may best be understood by means of Figs. 3 and 9 . The membrane of the wings of insects is composed, as is well known, of two layers which generally adhere together. These two layers exist also in the walls of the spot, or, to express it better, of the sexnal cavity, but may easily be separated, and, in fresh specimens, usually have between them a good deal of blood. The extcrnal layer, as already stated, is tough [indurated or hardened], blaek, and covered with ordinary scales. The internal layer, which is much thinncr than the other, presents a somewhat different aspeet in our two species.

In D. erippus it cxhibits small eireles of about $0.01 \mathrm{~mm}$. clinmeter, a little more transparent than the rest of the membranc. From the centre of each rises a straight hair, about $0.06 \mathrm{~mm}$. long. The eircles arc plaeed in regular lines, about 0.03 to $0.06 \mathrm{~mm}$. apart. Altcrnating with these circles are opaque grey scales, distinguished from the ordinary ones by their smaller sizc and by their shape (Pl. A, Fig. 4).

In D. gilippus (Pl. A, Fig. 10) the eireles are much closer together-so mneh so that in plaees they almost? touch : although more transparent than the rest of the membrane, they are less so than those of $D$. erippus. The hairs are wanting, but one sees in the eentre of cach cirele a small spot, the last vcstige which proves their former existence. The scalcs arc far smaller than those of $D$. crippus, being about $0.04 \mathrm{~mm}$. in length, as compared with 0.08 . Probably these little seales are the "grey dust" found by Doubleday in eertain other species of Danais.

It is not possible to detect any odour arising from the wings of the males of cither of the two species found in the Province of S. Catharina, 
but beforc passing on to discuss the biological significance of the sexual spots it will be well to describe briefly another organ, peculiar to the rnale sex, which appears to have hitherto escaped the attention of entomologists. If one strongly compresses the abdomen, there is cverted on each side of the last segment a finger-shaped membranous tube with closed apex (Pl. A, Figs. 6 and 12), which is covered with dark hairs, erected as the tube passes out of the abdomen, and exhaling at the same time a somewhat strong odour in D. gilippus, and one less strong, though still perfectly distinct, in $D$. crippus - a difference which cvidently depends upon the fact that the hairs are far more numerous, as well as thicker and longer, in the firstnamed species. On being withdrawn into the abdomen, the tube is turned ontside in or introverted, so that the surface which was external becomes internal, forming a sheath or case round the hairs, which then appear to spring, in the form of a tuft, from the bottom of the tube.

Such are the facts. It remains to discuss them. The wings of many species of butterflies bear, in the male sex only, scales of peculiar form, often collected together in well-defined patches, and in some cases concealed in furrows or folds of the wings-scales and patches which undoubtedly act as scent-organs. It appears probable that the modified scales concealed in the cavity of the sexual spot in D. erippus and gilippus serve, or may have served, the same purpose. It may perhaps be possible to find among the different species of Danais intermediate forms, linking the pockets of the American species with the patches which are seen on the hind-rings of the males of Amauris.

Further, not only is there no perceptible scent exhaled from the rings of the male $D$. crippus and gilippus, but it appears extremely unlikely that such a function would be exercised by a cavity communicating with the air only by a narrow slit, and, in addition, having apparently no mechauism on the wing by means of which it could be opened; and as there are, at the extremity of the abdomen, organs mhose scent-distributing functions cannot be doubted, it is natural to conjecture that the sexual spots of D. erippus and gilippus are scent-organs reduced to a mdimentary state b5 the development of the other organs at the apex of the abdomen, which better fulfil the same functions. We might cite in support of this conjecture certain analogous facts which exist in other families of butterflies. On the other hand, the blood in the walls of the sexnal cavities-present in an amount that is rare in the wings of these insects-appears to forbid us to consider them as rudimentary organs, and the facts may perhaps be met by the supposition that the devclopment of the wing-organs is in inverse ratio to that of the abdominal organs, and that they mas show themselves sometimes more, sometimes less developed. Whether this is correct or not remains to be seen.

In $D$. gilippus these organs, both of the wings and of the abdomen, are far larger than in D. erippus, in spite of the latter species being much the larger of the two. 
In doubtful cases one inust not pass over any circumstance, however unimportant it may appear, and I therefore mention the fact that in some males of $D$. erippus, otherwise perfect, a very small portion of the wing, close to the orifice of the sexual cavity, was entirely demuded of scales, as if they had been repeatedly rubbed away by introducing sometbing into the slit. Is it not possible that some odoriferous substance may be produced in the interior of the sexual spot, and that the hairs of the abdominal organs introduced into its cavity may become impregnated with this substance?

The position and shape of these sexual cavities is such that the extremity of the abdomen might easily be applied to them, and as the hairs of the abdominal organs unite in the form of a brush, it would not be impossible, or even difficult, to introduce them into the depths of the carity.

I confess, frankly, that this idea appears to me to be well founded, but it is only by a comparative study of the numerous species of Danais that we can arrive at a definite solntion of this interesting problem. 


\section{EXPLANATION OF PLATE A.}

male.

The Figs. 1-6 refer to Danais erippus, male; 7-12 to D. gilippus,

Figs. 1 and 7.-Hind-wing, upper surfacc, natural size. The numbers of the nervures are those of Herrich-Schaeffer, but the nomenclature is that of Doubleday.

$1 a$, internal nervure.

16 , submedian nervure.

2 , first branch of the median ncrivure.

3 , second ," , ,

4, third ", " ,

5 , discoidal nervure.

6 , second branch of the subcostal nervure.

7 , first

8 , costal nervure.

$p$, precostal nervure.

$s$, sexual spot (Doubleday).

Figs. 2 and 8.-The sexual spot, magnified 5 times.

$n$, first branch of median nervure.

$s$, sexual spot. times.

Figs. 3 and 9.-Transverse section of the sexual spot, magnified 15

$n$, first branch of median nervure.

$i$, lower wall of the cavity of the sexual spot.

s, upper

Figs. 4 and 10.-Part of the inuer membrane of the carits, magnified 180 times.

$a$, points of insertion of scales.

$b$, one of the scales.

$c$, points of insertion of the hairs, which are wanting in D. giliprus. only the points [of insertion] remaining.

Figs. 5 and 11.-Ordinary scales from the upper surface of the hindwings, magnified 180 times.

$a$, lower scales.

$b$, upper scales.

Fig. 4b.-Onc of the samc scalcs in its natural position.

[Fig. 5b.-Is not mentioned in text or cxplanation; it moloubtedly represents the arrangcment of the scalcs shown scparately in Fig. 5. riz. those of D. crippus.-E.A.E.]

Figs. 6 and 12.-Scent-organ, secn from abore, twice the natumal sizc.

a, last abdominal scgment.

$b$, sccnt-organ. 

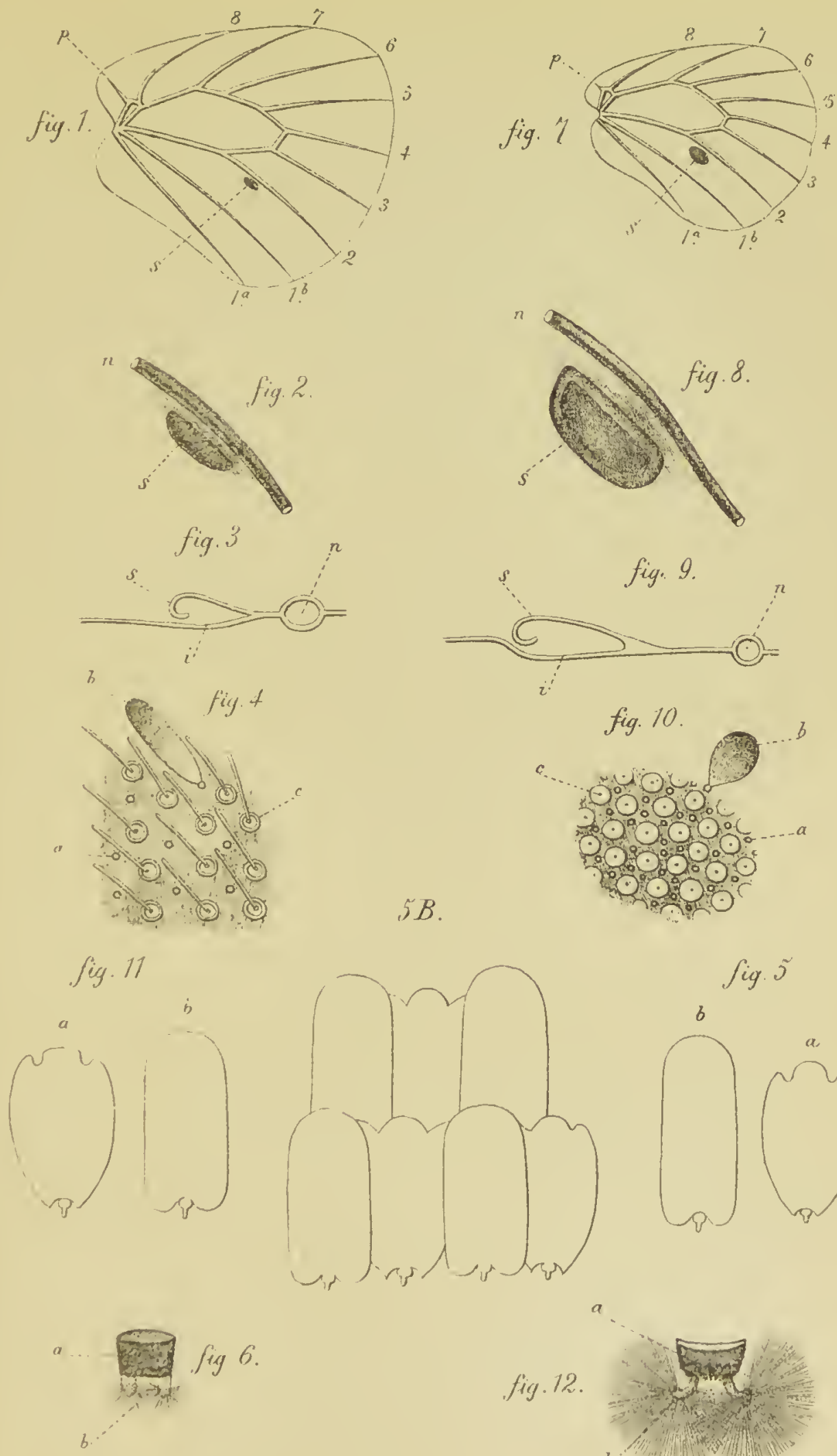

$5 B$
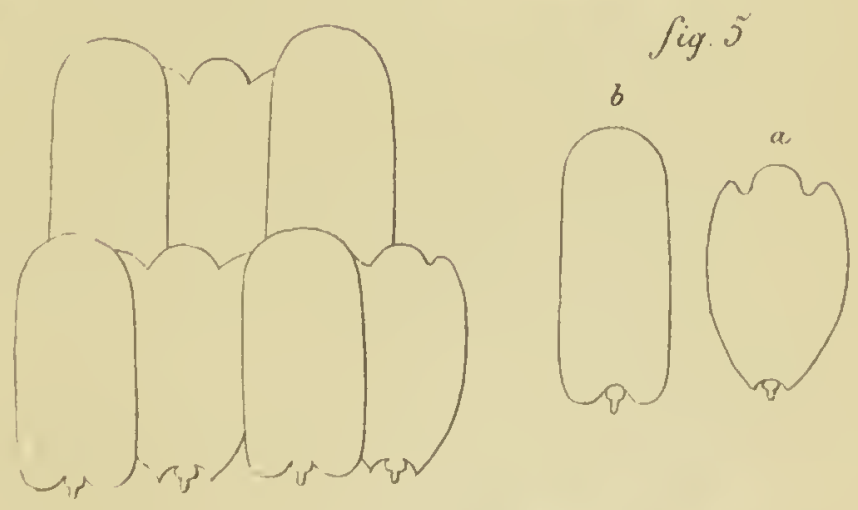

$$
a
$$

fig. 12.

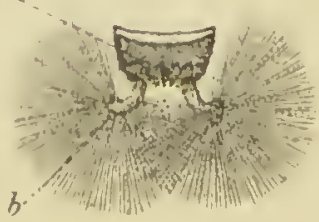





\section{§ III. On the Scent-oryans of the Butterfies, Epicalia acontius, Linn., and Myscelia orsis, Drury. ${ }^{1}$}

Plate B.

The [Nymphaline] genus Epicalia, Westw. (or Catonephele, Hübn.), has aequired a eertain eelebrity (Darwin, Descent of Man, 1871, vol. i. p. 388) from the extraordinary differenee in eolour exhibited by the two sexes in many of its speeies. Thus, if we eompare Epicalia numilia, Cram. with $E$. acontius, L., we see that the females of the two speeies, and in like manner the males, resemble each other far more elosely than do the females their respeetive males. The males of both these speeies are ornamented with large and splendid orange markings on a ground of blaek velvet. $E$. numilic has three separate elliptieal spots (two on the fore-rwing and one on the hind), while $E$. acontius (antiochus, Fab.) has one sueh spot on the fore-wing, uniting with one on the hind to form a band erossing both wings. In the females the wing spots are of a sulphur yellow and of an entircly different shape from those in the opposite sex: in E. acontius (meilea, Fab.) they are very numerous and are arranged in three parallel lines. In faet, the differenees between the two sexes are so great, that Westrood plaeed them in different genera, giving the name of Myscelic medec to the female of Epicalia acontius.

'The two speeies which I have just mentioned-the only Epiealias as yet met with in the provinee of Santa Catharina, are most interesting, inasmueh as the males, whieh are otherwise very similar, exhibit the most remarkable differences in respeet to their scent-organs. In the males of E. numitic I have not found it possible to detect the slightest vestige of such organs, and they appear to be entirely wanting in these insects. In the males of $E$. acontius, on the eontraly, they ittain a somewhat unusual degree of development, and exhale a very strong odour. These scentorgans are hidden between the fore and hind-wings, oeeupying the upper surface in the latter, the lower in the former. On the hind-wings there is seen (Pl. B, Figr. 11), close to the orange spot (b) a still larger pateh of grcy eolour $(m)$, whieh laeks the velvety appearanee of the rest of the wing, and may rather be eompared to a kind of felt. This felted patch ("Filzfleek," Herrieh-Schaeffer) is hounded hy the dotsal [eostal] (s) and

'Archivos do Museu Nacional do Rio de Janciro, II. (1877), pp. 31-35. By Dr. Fritz Müller, Travelling Naturalist for tho National MLuseum. 
discoidal [radial or second discoidal] (5) ncrvures, and [within the cell] by i line from the point of separation of the costal and subcostal to the point at which the lower discocellular leaves the discoidal; it runs along the costal nervure for about two-fifths of its length, and along the discoidal to a point midway between the margin of the wing and the point of separation of the costal and subcostal. This spot occupics about oneeighth of the surface of the wing, being nearly a semicircle of $12 \mathrm{~mm}$. diameter, while the whole wing is about equal to a circle of $24 \mathrm{~mm}$. diameter.

This patch is usually covered by the fore-wing, the lowcr surface of which is provided (Pl. B, Fig. 11, $m^{\prime}$ ) with a patch, opposite to that on the hind-wing, and almost identical in its felted appearance, colour, form, and sizc. It is, howcver, less conspicuous, not only from contrasting less with the colour of its surroundings, but also from being entirely corered with a mane of black hair, inserted along the internal [submedian] nervure (1). This felted patch on the fore-wings extends from the internal [submedian] nervure (1) to the angle formed by the second and third branches (nervures 3 and 4) of the median, and, as in the hind-wings, an insignificant part of the patch enters the cell.

The mane, which has been just mentioned, starts from the posterior margin of the patch, or, what comes to the same thing, from the anterior margin of the interual [submedian] nervure. If this nervure be considered as divided into five equal parts, the second and third of these parts, counting from the base of the wing, are occupied by a mane composed of finc [in the sense of "beautiful "] black hairs of about $7 \mathrm{~mm}$. in length. This mane covers exactly and entirely the felted patch of the fore-rings, and at the same times separates it from that on the hind.

The scales of the felted, or odoriferous patch (Pl. B, Fig. 13) arc distinguished from ordinary scales (Fig. 12).

First, by their shape, which chiefly differs in the non-dentatc cnds.

Second, by their size. Of the ordinary sealcs on the upper surface of the wings, the ovcrlying ( $\mathrm{Pl} . \mathrm{B}$, Fig. $12 \mathrm{~s}$ ) run about $0.14 \mathrm{~mm}$. in length by $0.06 \mathrm{~mm}$. in brcadth; the underlying (Fig. 12 i) about 0.1 long by 0.08 broad. The ovcrlying scent-scalcs (Fig. 1s s) measure from $0.33 \mathrm{~mm}$. long by 0.1 broad; the undcrlying (Fig. $13, i$ ) about 0.24 long by 0.11 broad. ${ }^{1}$

Third, in being much more opaque and apparently without the longitudinal lines found on ordinary scales.

Fourth, in being more firmly fixed to the membrnuc of the wing: so that by passing a brush over the surface of the wing, one can remore the ordinary scales and leave those of the felted patch.

All thesc diffcrences between the ordinary and the secnt-scales exist in ncarly cvery species which bears seent-patehes upon its wings. The

1 Tho roferonco letters $s$ and $i$ aro aecidentally transposed in Fig. 13 of the original plate.-E.B.P. 
characters which distinguish the patches of E. acontius from those of most other species are as follows :-

First, the difference which is observed between the over- and underlying scales; for it is the general rule for the scent-scales to be all of onc form, without any distinction betwcen the upper and lower.

Second, the fact that the pits or sockets in which the scales are implanted are placed at about the same distance apart on the scent patches (Pl. B, Fig. 15) as on the rest of the wing (Fig. 14); whereas, as a rule, the scent-scales are more closely placed than the ordinary ones.

The pits of the scent-scales are larger, and surrounded by a dark elliptical or circular area, as is also frequently seen in other species.

Again, it is worth noting that a considerable modification in the shape of the wing accompanies the development of the scent-patches. The inner (or posterior) margin of the anterior wings is nearly straight in the females of $E$. acontius (Pl. B, Fig. 10), and in both sexes of E. numilia (Fig. 9), but in the males of E. ccontius (Fig. 11), it is greatly arched, and in such manner as to corer a much larger part of the lower wings. In a similar manner the costal border of the hind-wings is enlarged. Hence it follows that in the female of E. acontius (Fig. 10) the form of the wings approaches more nearly to that of the male E. numitia (Fig. 9) than to that of its own male (Fig. 11).

Closely allied to Epicalia is the genus Myscelia, represented in the province of Santa Catharina by $M$. orsis, Druly. I have recently becn able to examinc a malc of this species, in which Herrich-Schaeffer ${ }^{1}$ describes a felted spot ("filzfleck") on the upper surface of the hindwing (Pl. B, Fig. $1 \mathrm{~m}$ ), between the fifth and seventh nervures, that is to say, between the discoidal [radial or second discoidal] and the first branch of the subdorsal [subcostal]. It requircd little to convince me that the above-mentioned patch exhales is strong scent, which, like that of $E$. urontius male, greatly resembles inusk. The patch, which occupies about onc-ninth (36 squarc mm.) of the surface of the wing (315 squarc mm.), also extends a little beyond the nervures which Herrich-Schaeffer assigns as its limits. Its colour is entirely black, while the surrounding arca of the wing, which, like the spot, is overlapped by the fore-wing, is greyish, the lise being of a brilliant bluc. The structure of the patch differs little from that of $E$. acontius, and it is therefore unnecessary to give uny detailed description. The scent-seales differ in that they do not greatly exceed the ordinary ones in sizc, while the forc-wings are destitute of sccnt-organs.

Thus, in respect to the felted patches, the malc of Myscelia orsis occupies an intermediatc position between Epicalic mumilia, which has no such structures, and $E_{2}$.ccontius, which bcars them on the fore-wings as well as the hind. In view of these facts, it is permissible to donbt whether any

1 Prodrom. Syst. Lepidopt, fasc. i., 1861, p. 27, No. 79.-F.M. 
definite line of division between these two genera has been proved to exist. As regards the females also it is well known that $M$. orsis and $E$. acontius agree perfectly in the arrangement of the spots on the wings, spots which, entirely yellow in the latter, white in the former species, are very different from those of the female of $E$. numilia. This comparison of the female patterns may further contribute to strengthen the doubt expressed above. ${ }^{1}$

I See also Fritz Müller's paper on "Epicalia acontius. An unequal pair" (Kosmos, IV. (1878-9), pp. 285-292), of which an abstract by H. Müller appears in Carus' Zool. Anzeig., I. (1878), p. 13.-E.B.P. 

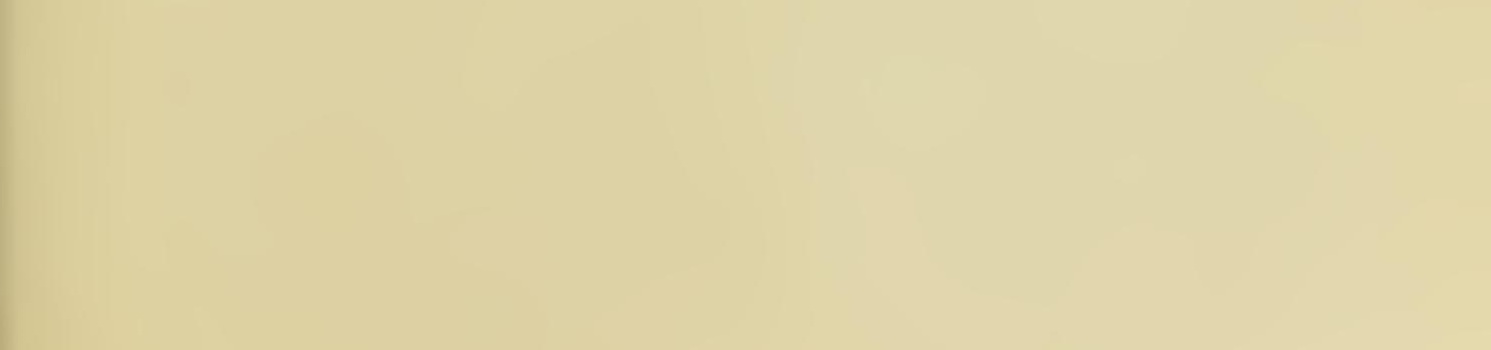

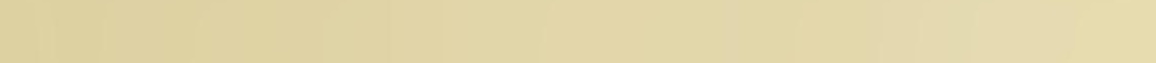




\section{fig. 1.}

$s$
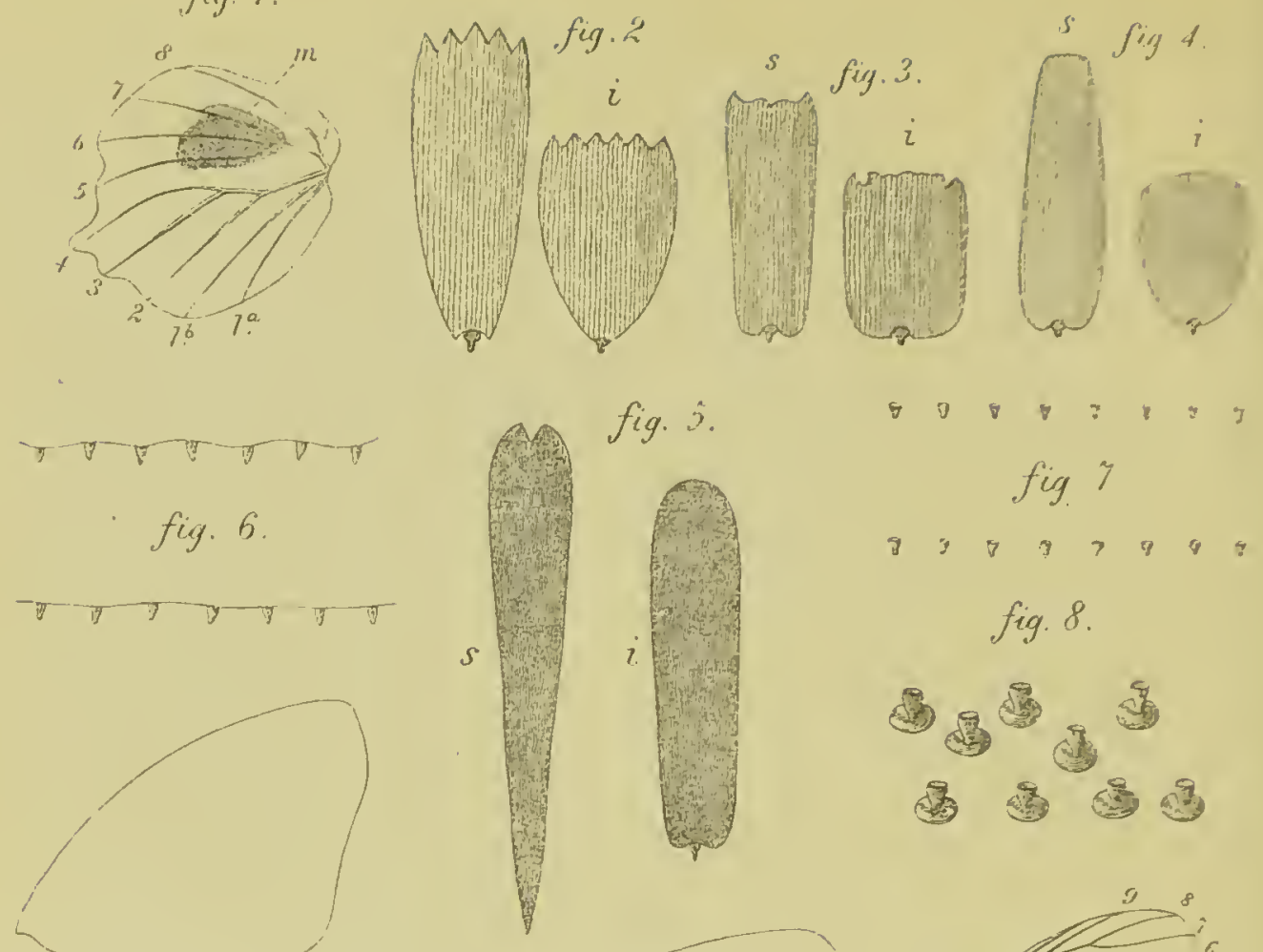

중 3

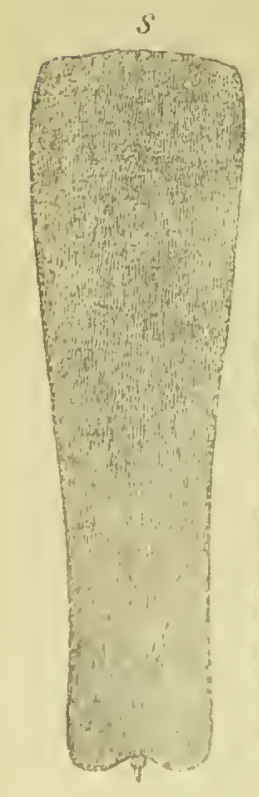

fig. 13

fig. 10
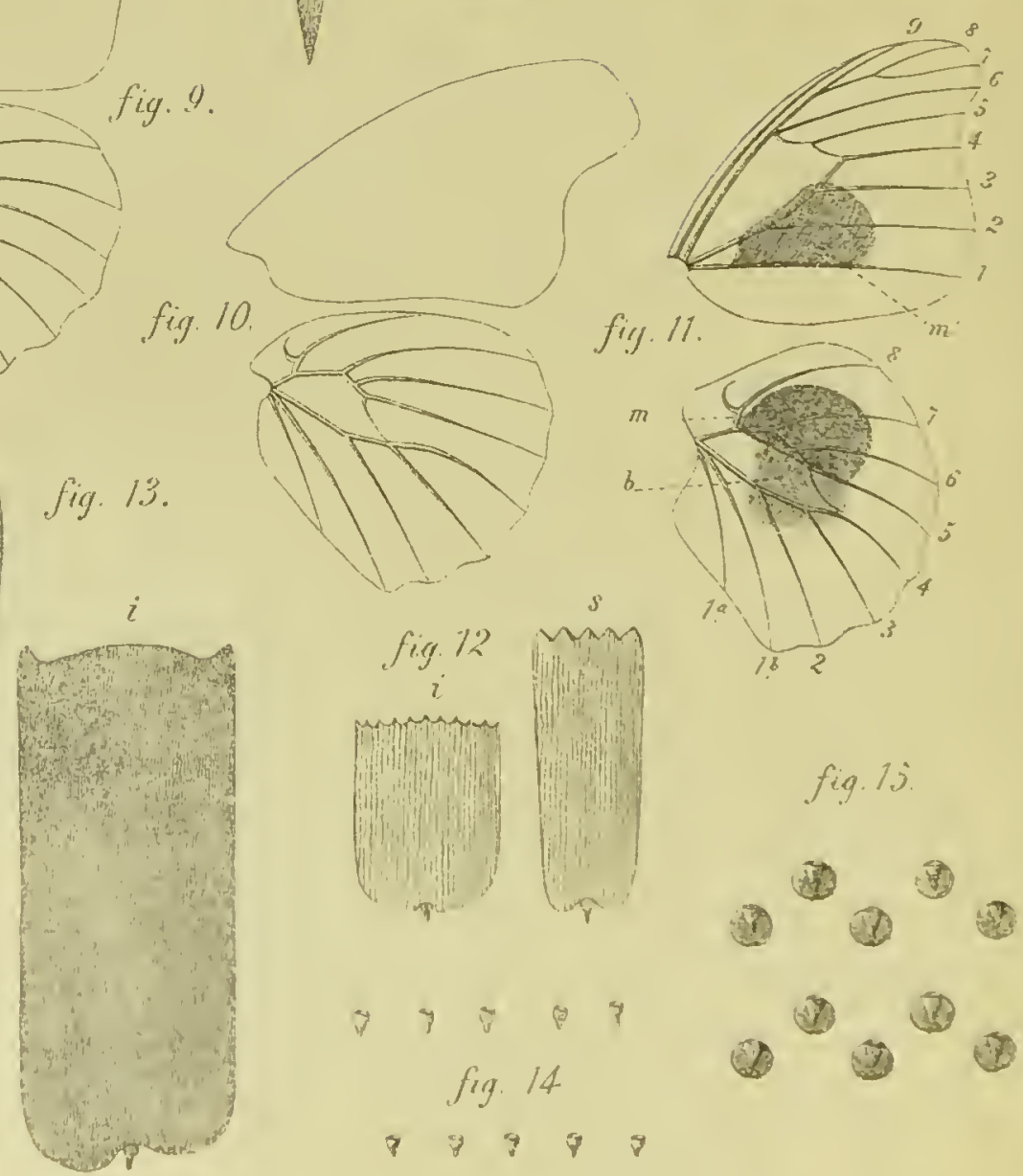


\section{EXPLANATION OF PLATE B.}

The Figs. 1, 9, 10 and 11 are natural size, the rest magnified 180 times.

The Figs. 1-8 refer to Myscelia orsis, male. Throughout the plate, $s$, upper, $i$, lower scale.

Fig. 1.-Hind-wing of Myscelia orsis, male. m, felted or scent patch.

Fig. 2.-Scales from the lowel surface of the [hind-] wing.

Fig. 3.-Scales from the disc of the upper surface.

Fig. 4.-Scales from the hind margin of the upper surface of the hind-wing.

Fig. 5.-Scales from the felted spot.

Fig. 6.-Sockets of scales on the lower surface of the hind-wing. As in many other species, the sockets of the lower surface differ from those of the upper by being joined by a thread.

Fig. 7.-Sockets of the ordinary scales on the upper surface of the hind-wing.

Fig. 8.-Sockets of the scent-scales.

Fig. 9.-Outline of the wings of Epicalia numilia, Cram., male.

Fig. 10.- " " Epicalia acontius, Linn., female (medea, Fabr.).

Fig. 11.-Outline of the wings of Epicalia acontius, Linn., male (antiochus, Fabr.).

$b$, orange spot on hind-wing.

$m$, felted spot on same wing.

$m^{\prime}$, felted spot on the lower surface of the forc-wing, covered by a mane of black hairs.

Fig. 12.-Ordinary scalcs from the upper surface of the disc of the hind-wing of Epicalia acontius, male.

Fig. 13.- Scales from the felted spot on the same wing. ${ }^{1}$

Fig. 14.-Sockets of the ordinary scales on the same wing.

Fig. 15.-Sockets of the scent-scales on the felted spot of the same wing.

1 The reference letters $s$ and $i$ are accidentally transposed in Fig. 13011 the original plate.-E.A.E. 


\section{§ IV. On Scent-organs on the Legs of certain Lepidoptera. ${ }^{1}$}

Plate C.

DARWIN, speaking of sexual selection, and the secondary sexual characters of insects; makes the following statement :-

"The sexes of many species in all the orders present differences, of which the meaning is not understood. . . . They abound in the Lepidoptera: one of the most extraordinary is that certain male butterflies have their fore-legs more or less atrophied. . . . The wings, also, in the trro sexes often differ in neuration, and sometimes considerably in outline, as in the Aricoris epitus. . . . The males of certain South American butterflies have tufts of hair on the margins of the wings, and horny excrescences on the discs of the posterior pair. In several British butterflies, as shorn by Mr. Wonfor, the males alone are in parts clothed with peculiar scales." 2

Almost all these sexual differences in the Lepidoptera-completely inexplicable only a few years ago-have now become clear and intelligible sincc the discovcry has been made that they are directly or indirectly concerned with the production or diffusion of a peculiar scent which must certainly be agreeable to the females. Foremost in this category are, first, the tufts or manes which are frequently found on the anteriol margin of the hind-wings, and produce a scent which is strongest in Callidryas cipris, but very perceptible and very agreeable in Dircenna xantho [Ithomiince], and in other species; secondly, the "specialized scales" of very varied forms, which exist on the wings of the males of many species of Satyrinae, Heliconinae, Nymphalinae, Pierinae, ctc., to which Bernard Deschamps ${ }^{3}$ gavc the name of "plumules"; thirdly, the "horus excrescences" or "sexual spots" which are secn on the disc of the hind-rings of Danais erippus, and gilippus."

As to the sexual difference in the disposition of the ring renation, this also, in most, if not in all cases, orres its existcncc to the male scent-organs, which in some way displace certain nervures; is may be easily rerified in the gencra Dircenna, Mrchanitis, Thecla (e.7. T. acmon), among diurnal,

1 Arehivos do Mruscu Nacional do Rio de Janciro, II. (1STT), pp. 37-42. By Dr. Fritz Muiller, Travelling Naturalist for the National MIuseum.

2 Descent of Man, 2nd Edition, 1874, pp. 276, 27\%.-E.B.P.

${ }^{3}$ Annales des Sc. Nat. 1835, III., p. 120. Quoted by Cleuu, Encyclop. d'Hist. Nat. Tapillons, I., p. 8.-F.MT.

In the Jen. Zeitschr., XI. (1877) [viz. § I of this Appendix], is published a resums of what our authors have written, which may be consulted as to scentorgans on the wings of butterflies, and is the first attempt to demonstrate the functions of these organs. - F.M. 
and in Rhamphidium, among noctnrnal, Lepidoptera. The outline of the wings is also frequently modified by the presence of these scent-organs.

Furthermore, both the organs themselves, and the sexual differenees resulting from them are by no means restricted to the wings. In many species, espeeially among the Heterocera, they are placed in the abdomen ; while in some others they are developed on the legs. Inasmuch as the abdominal organs are, in the state of repose, almost always withdrawn either into the interior of, or among the scales of, the abdomen, they have entirely escaped the attention of entomologists. In faet, the only notiee I have eome aeross refers to the genus Lycorea, the males of which, as Doubleday states," "have a large tuft of hair on each side of the last segment, eapable of being withdrawn to a great extent into the interior of the abdomen." Like the Lyeoreas and Itunas, the males also of Danais, Morpho, Glancopidae, ${ }^{2}$ Cryptolechia, and various other nocturnal Lepidoptera, possess scent-organs situated at the extremity of the abdomen, sometimes taking the form of tufts, sometimes of mammiliform or digitiform protuberances, or filiform tubes of considerable length, and exhaling in nearly all eases a strong seent. It is rarest for these organs to be placed on the dor'sum, as in Didonis biblis, or ventrally, as occurs in the Sphingidae. While in many cases these scent-organs were well known, but their functions undiscovered, it is different with the Sphingidae. In this group it has been known, for some years, that the males of certain speeies exhale a strong scent of musk, but no one has been able to find the spot from whence the seent emanates. It emanates from two tuf ts sitnated at the base of the abdomen, which are capable of retraction into a kind of groove formed by the scales of the first two segments.

Finally, as to the tufts and analogous appendages which oceur on the legs of certain Lepidoptera, but in the males only, no one has, so far as I know, up till now, discovered any funetion for them to fnlfil. In diurnal Lepidoptera such organs sccmed to be confined to the Hesperidae, among which two different forms of them are to be found. According to Wcstrood, the male of onc species from Java, Ismene oedipodea, Swains, has the tibiae of the third pair of legs of cxtraordinary size, and covered with dense hairs : in various other specics of the family, these same tibiae are, in the male, furnished with a long tnft of hair. These tibial tufts have been utilized by Herrich-Sehaeffer and other anthors to charactcrize eertain genera of the Hesperidae, as Achlyodes, Antigonus, ete. Whon onc sees in a Hespcrid, shown, by the characters indicated by Herrich-Sehaeffer, to belong to the genus Antigonus, that the tibial tufts can be retractcd

' Doubleday, Westwood and Hewitson, Genera of Diurnal Lsepidoptera, p. 196. Bundjes of hair, like those mentioned in the text, are shown in the figure of Ituna phenarcte (PI. XVI., Fig. I). I have also seen them in the males of Ituna ilione.-F.M.

= Seo note 2 on p. 613.-E.B.P.

${ }^{3}$ Doubleday, Westwood and Hewitson, loc. cit., p. 574.-F.M. 
into a kind of groove formed by the seales of the abdomen, one cannor doubt that the tufts in question are seent-organs, seeing that they possess one of the most essential eharaeteristics of these organs, viz. the speeial protection whieh, during respose, guards against the dissipation of the seent. I have, in faet, had the satisfaetion of finding a moth whose tibiae emitted a peeuliar perfume, which, without being strong, was yet perfectly perceptible even to us, with an olfaetory sense far inferior to that of most Lepidoptera. It was one of the larger speeies of the family of the Erebidae, ${ }^{1}$ having a wing expanse of 0.19 metre a species no one eould overlook. In the females of this Erebid, the tibiae of the third pair of legs are slender in form, and, as is usual with the Lepidoptera, intermediate in thiekness between the femora and tarsi (Pl. C, Fig. 10). In the males, on the eontrary, these tibiae are extremely thick (Pl. C, Figs. 11 and 12), so that their breadth $(4 \mathrm{~mm}$.) equals one-third of the length $(12 \mathrm{~mm}$.). The outer surfaee is slightly eonvex, and on the inner there is a longitudinal groove beginning about 3 or $4 \mathrm{~mm}$. from the base, and beeoming deeper towards the apex of the tibia, as is best seen in transverse seetions (Fig. 14). The entire inner surface, except the extreme tarsal apex and part of the groove, is covered with hairs of 4-6 mm. in length, but shortest along the npper margin (Fig. 13). These hairs are capable of being erected, forming a kind of very dense brush, and it is in the state of erection that their seent can be pereeived.

In the state of repose, the median hairs lie in the longitudinal furrow parallel with the axis of the tibia, and are covered by a thick layer of the lateral tibial hairs ; these again are eovered by the dense hairs on the lower edge of the femur, whieh also are far more developed in the male sex. In this manner the lower hairs, and espeeially those lying in the tibial groove, are suffieiently proteeted by the superimposed marginal hairs and those of the femur, against loss by evaporation of any odoriferous substance with which they may be impregnated while in a state of repose, whereas, on being ereeted, they exhibit an enormous surface which promotes a eorresponding evaporation of the scent. It may be noted that even Linnaeus gave to one of the species of Erebidae the name of Noctua odora, probably in eonsequenee of its strong seent; but whether this was peeuliar to the males or produeed by the tibine he does not say. There are in the same family other species, whose males have the tibine of ordinary form, without the exeessive hairiness of the one abovementioned, but furnished instead with a long tuft of hair issuing from the inner side of the base. Finally, still other species of Erebidae appear to be destitute of any scent-organs on the legs. Certain genera of the Hesperidae are also characterized by the tufts borne by the males on their posterior tibiae, while the males of the moth genus Herminia (included by some entomologists in the Pyralidae, by others, e.g. Spejer, in the Nocluinae) are usually furnished with larger or smaller tufts on their

1 Ercbus and its allios are Noctuirlac of the sub-family Noctuinac.-E.B.P. 


\section{SCENT-ORGANS ON LEGS OF LEPIDOPTERA 629}

tibiae, bnt in this case it is the front tibiae which present this male distinctive character. ${ }^{1}$

In the family of the Geometridae, a beautiful and instructive instance of these scent-tufts, borne by the posterior legs, is yielded by Pantherodes pardalaria, Hübn., an insect which seems to inlabit the whole of Brazil, from the Equator to the Tropic of Capricorn. Spix and Martius took it ou the Rio Negro, ${ }^{2}$ also, at least in certain years, very frequently in the Province of Santa Catharina. This species also has the tibiae of the third pair of legs much larger in the males (Pl. C, Figs. 2 and 4), than in the females (Fig. 1), but they do not attain extraordinary dimensions. The inner surface is grooved by a longitudinal furrow (Fig. $3 b$ ) in which is hidden a tuft of long and fine hair, springing from the base of the tibia (Fig. $3 a$ ). The diameter of these hairs is from 0.004 to $0.01 \mathrm{~mm}$., and their length equal to that of the tibia itself. The colour of the tuft varies in different individuals; some of the hairs are a bright bay, others varying from dark grey to nearly black, sometimes one colour, sometimes the other predominating. Along the margins of the groove are scales (Pl. C, Fig. 9), distinguished from those which cover the rest of the tibia (Fig. 8), by their much greater size, as well as by their shape and colour. Some of them at times reach a length of nearly $0.001 \mathrm{~mm}$., and rarely a third as long again: some are asymmetrical, with the shape of the creseent moon, others symmetrical, with parallel sides and three or sometimes two teeth at the apex. Finally, these larger scales on the margins of the groove are pale straw-colonred; the smaller ones on the rest of the tibia being of a lighter or darker grey. Bending over thc edge of the groove, these large scales form a kind of tent (Pl. C, Fig. 6 $c$ and $d$ ), those on the lower margin being partly covered by those on the npper. There is thus prodnced by different means, but with equal efficiency, a covering which prevents the loss of any aroma which the tnft may contain. When the tibia is extended, the tuft begins to rise from its concealment, and erect itself, spreading out its hairs on all sides, bnt without exhaling any sccnt pereeptible to the human nose, or at least not to mine.

Without doubt in the vast group of the moths, of which np to the present only a quite insignificant number has been examined, there must exist numerous other cases in which a scent apparatus is borne by the egs, the wings and other parts of the body. The object of thesc lines is simply to assist towards the complcte clucidation of the subject with which they deal, and to point out to the young naturalists of Brazil a vast ficld, as yct unexplored, and promising a harvest of new and interesting facts.

1 "Tibia onlarged and furnished with a tuft of orectilo hairs." Chenu, Encyclop. d'Tist. Nat., Papillons, II., p. 215.-F.M. [Sir Goorge Hampson informs mo that IIerminia bolongs to the Noctuidae, sub-family IIypeninae.-E.B.P.]

2 Perty, Delcctus Animalium Articulatorum, 1830, p. 163; PI. XXXII., Fig. 11. Perty here calls it Phalaena perspicillum.-F.M. 


\section{EXPLANATION OF PLATE C.}

Figs. 1-9 refer to Pant7erodes pardalaria.

Figs. 1-4 are magnified 3 times.

Fig. 1.-Left hind leg of female.

Fig. 2.-Left hind leg of male.

Fig. 3.-The same as Fig. 2, cut across the middle of the tibia.

a, upper part with the tuft which springs from the base of the tibia. View of the outer side.

$b$, lower part with the groove in which thc tuft lies. View of the inner side.

Fig. 4.-The same leg with the tuft expanded, seen from outside.

Figs, 5 and 6 are magnified 15 times.

Fig. 5.-Tiansverse scction of the femalc tibia.

Fig. 6.-Transverse sections of the male tibia, taken at the positions indicated in Fig. 2. + indicates the upper edge; = the cxternal surface.

Figs. 7-9 are magnified 90 times.

Fig. 7.-Scales from the upper surface of the fore-wings.

$a$, upper scale.

$b$, lower scale.

Fig. 8. - Scales from the outer surface of the tibia.

Fig. 9.- Scales from the edge of the groove on the inncr surface of the tibia.

Figs. 10-14 refer to an Erebid having a wing cxpanse of $19 \mathrm{~cm}$.

Figs. 10-13 are twicc the natural sizc.

Fig. 10.-Left hind lcg of female.

Fig. 11.- Left hind leg of malc, view of outcr cdge.

Fig. 12. - Right hind leg of male, view of the inner cdgc.

Fig. 13.-Junction of tibia and femur, seen from above, with the hairs crected.

$s$, hairs on the upper edge of the tibia.

$i$, hairs on the lower edgc of the tibia.

Fig. 14.-Magnificd four times. Transverse sections of the malc tibia taken as indicated by the dotted lines in Fig. 11. + indicates the upper cdge ; = the outer surface. 

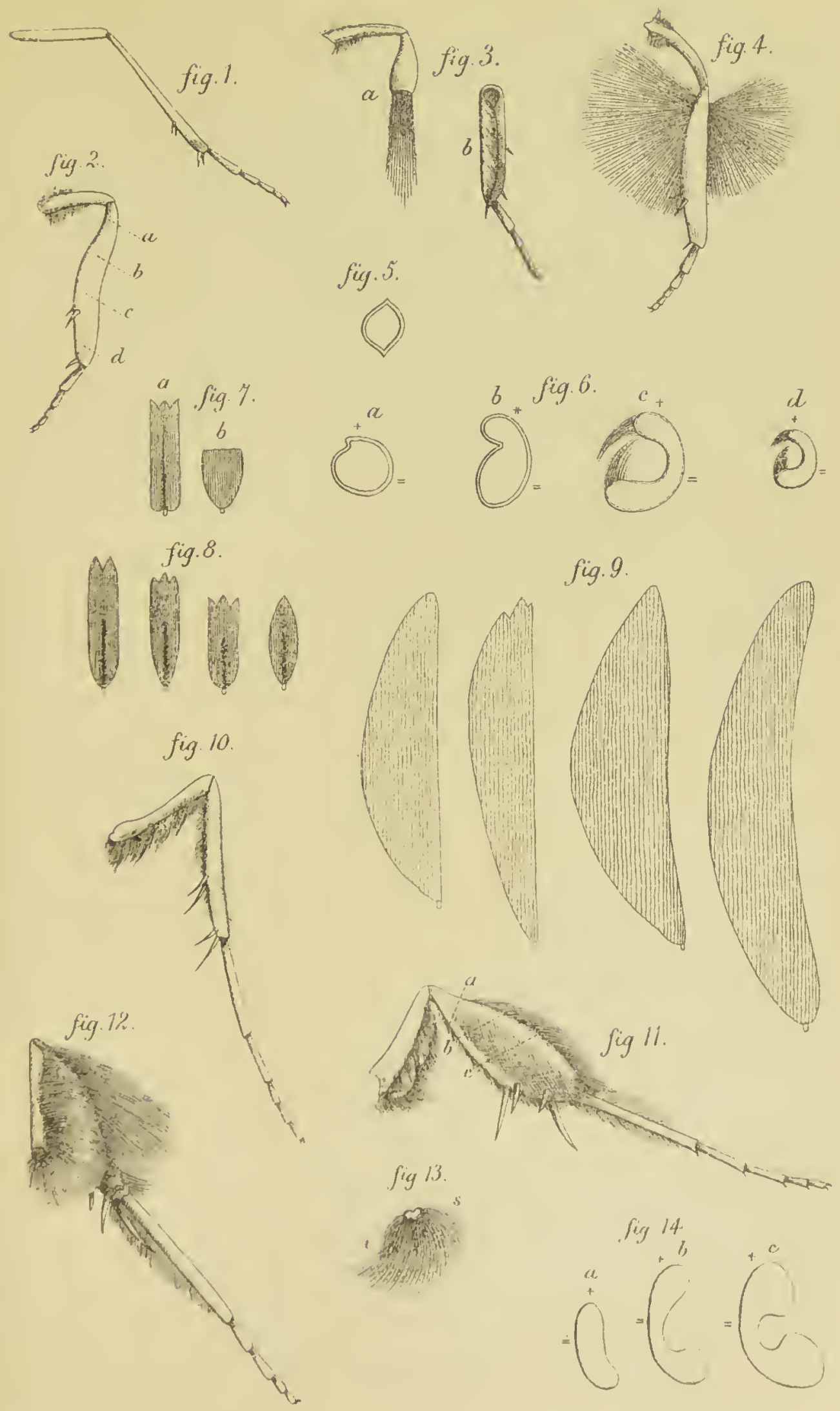



\section{$\S$ V. On Scent-organs on the Leys of certain Lepidoptera (Supplement). ${ }^{1}$}

Plate D.

I CONCLUDED my notice on the odoriferous organs which distinguish certain male butterflies, by saying that the subject promised a harvest of new and interesting facts. It appears to me to be, in fact, an inexhaustible mine. Scarcely a fortnight has passed and I am able to add to the structures described in that paper two others-and these the most singular I have encountered among our Lepidoptera-found in the males of two species of Erebid moths.

One of them is a dwarf in this family of giants, whose expanse, with open wings, does not exceed 4 centimetres. In some species of the same family, as in various Hesperidae (Achlyodes, Antigonus, etc.), the scentorgans consist of a tuft of long hairs rising from the base of the hind tibiae. 'The organ in these species of Erebids presents a similar form, but arises from the base of the anterior and not of the posterior tibiae. The tuft is composed of black hairs, whose length $(4 \mathrm{~mm}$.) exceeds that of the tibiae ( $2 \mathrm{~mm}$.), as also of the femora $(3 \mathrm{~mm}$.$) . Just as in some Hes-$ peridae, the scent-tuft of the hind legs is hidden between the hind coxac and the base of the abdomen, so in the Erebids in question it is appressed lengthways along the under side of the femur, whose margins are bordered with pale hairs, forming a sort of case for the tuft (Pl. D, Fig. 1). The front tibia can not only be extended so as to form a straight line with the femur, as is observed in other Lcpidoptera, but can go even beyond this (Fig. 2) ; and it is by means of this execssive extension, that the scenttuft is unsheathed or drawn out of its ease, being at the same time crected. In the second species, whose expanded wings ncasure about 6 ecntimetres, the scent-organs occupy the feinur of the second or middle pair of legs.

These organs are most interesting, not so much on account of their unusual position as for their size, and for their verily monstrous proportions, forming as they do a kind of ball, a globose or ellipsoidal body, whose diameter equals the length of the fernur (Pl. D, Figs. 5, 6, 7). Neither in the front nor in the hind legs (Fig. : $)$ is there any difference between the two sexes of the species: the intermediate legs of the male, on the contrary, not only exhibit the profound modification of the femur, due to the development of the seent-organs, but are also distinguished from those of the female (Fig. 4) by the greater length of the first tarsal joint. The

' Archivos do Mruseu Nacional do Tio de Janciro, II. (1877), pp, 43-46. By Dr. Fritz Müller, Travelling Naturalist for the National Museum. 
femur is about $6 \mathrm{~mm}$. long in the female, $7 \mathrm{~mm}$. in the male, the tibiae $5 \mathrm{~mm}$. in both sexes, the first tarsal joint $3 \mathrm{~mm}$. in the female, $4 \frac{1}{2} \mathrm{~mm}$. in the male, the other tarsal joints $4 \frac{1}{2} \mathrm{~mm}$. in both sexes. The mobility of the femur, evidently hindered by the scent-organ, may in some measure be compensated by the increased length of the first tarsal joint.

The femur of the male (Pl. D, Fig. 5), with a breadth of $2 \frac{1}{2}$ mm., slightly more than one-third of its length $(7 \mathrm{~mm}$.), is at the same time greatly flattencd, so that the dorsal and ventral surfaces approach closely and almost touch. The ventral surface is slightly convex, the dorsal concare. The scent-organ, which occupies the concave surface of the femur, is composed of an interior, strongly odoriferous, and an exterior protective part. The former is made up of innumerable very large scent-scales (PI. D, Figs. $2 b$ and 11), entirely covering the dorsal surface of the femur: they have the form of a narrow ribbon about $0.03 \mathrm{~mm}$. wide and 2-3 mm. long, but longer still on the anterior or superior margin of the femur. The apex of each scale is expanded into a larger or smaller oval club (about $0.06 \mathrm{~mm}$. wide and $0.25 \mathrm{~mm}$. long).

Many of the scent-scales adhere together in consequence of this terminal enlargement, and the surface of the compact mass thus formed is necessarily larger than its base, that is, than the area of the femur from which it springs (Pl. D, Fig. 9). When detached from the femur, the scentscales have an appearancc like that of some kinds of cotton removed from the capsule, forming a fluffy mass of incredible size : it seems impossiblc, indeed, that such a volume could have been contained in so limited a space. The scent-scales are everywherc protected and corered by an edging of large scalcs and hairs, inserted all round them on the margins of the femur. The innermost scales of this border, which lie immediately upon the scent-scales (Pl. D, Fig. $12 b$ ) are orate, usually about $1 \cdot 5-2$ mm. in length by $0 \cdot 6-1 \cdot 2$ broad. The scales outside those just described hare their base prolonged into a sort of petiole (Fig. $12 \alpha$ ), outside tliesc again the pctiole becomes thimer and thinncr, the club, at the same timc, narrower and narrower (Fig. 12 c), until finally the scalcs are inscnsibly transformed into hairs (Fig. 12 d), which betray thcir origin solcly bs a slight cnlargcment of the apcx. These hairs, forming the outer layer of the covering of the sccnt-scalcs (Fig. 9 d), are longest on the antcrior or superior margin of the femur, and especially long at the basc of that margin, where they excecd the lcngth of the femur itsclf.

Therc are thus in the family of the Ercbidae some spccies rhose males arc provided with sccnt-organs on the tibiac of the hind logs; others posscssing these organs on the tibine of the front legs, others on the femora of the middlc legs, and finally others whose legs show no tracc of any apparatus which could serve as a sccnt-organ. From this we may conchnde that the organs in question were not inherited from a common ancestor, but acquired later by the rarions specics which now cujor thesc attractive scxual possessions. 


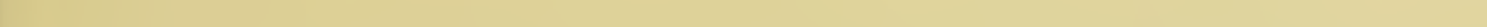



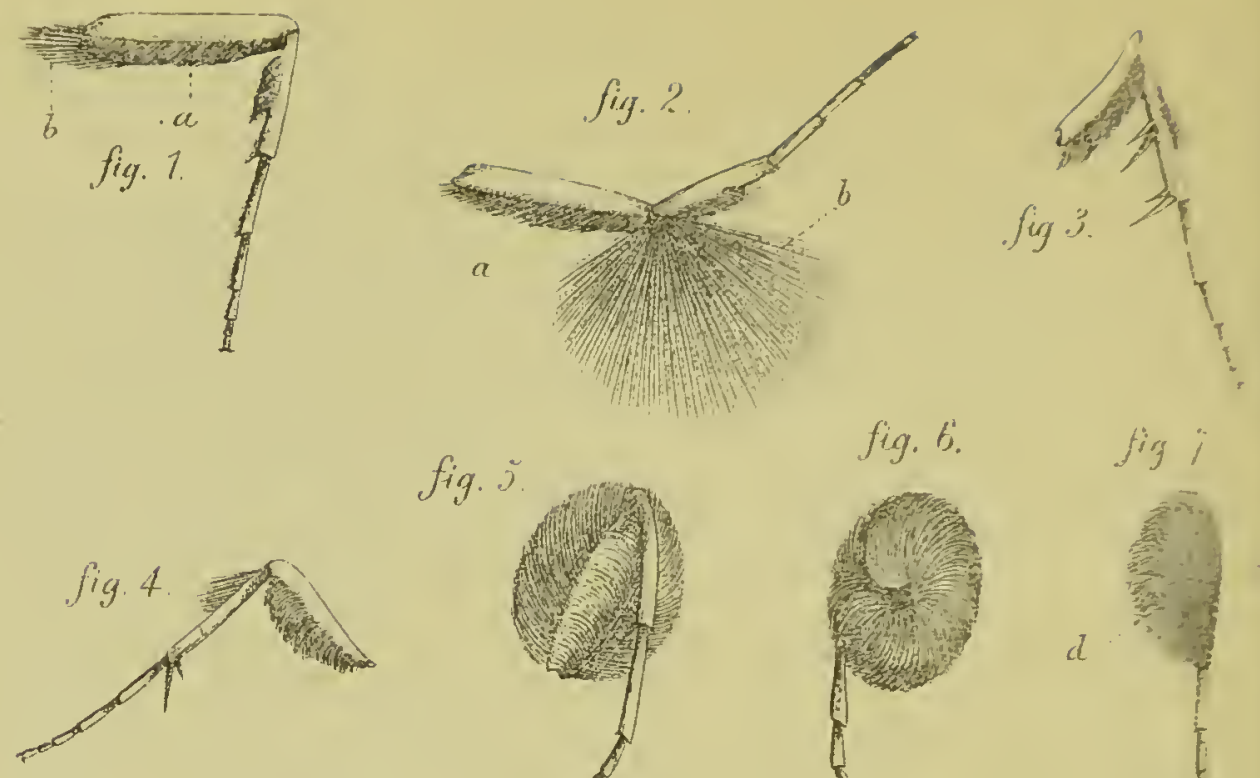

fig. 6.

figg $i$

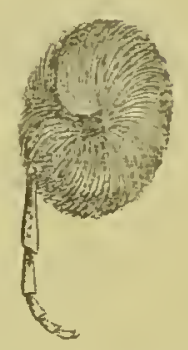

fig. 8 .
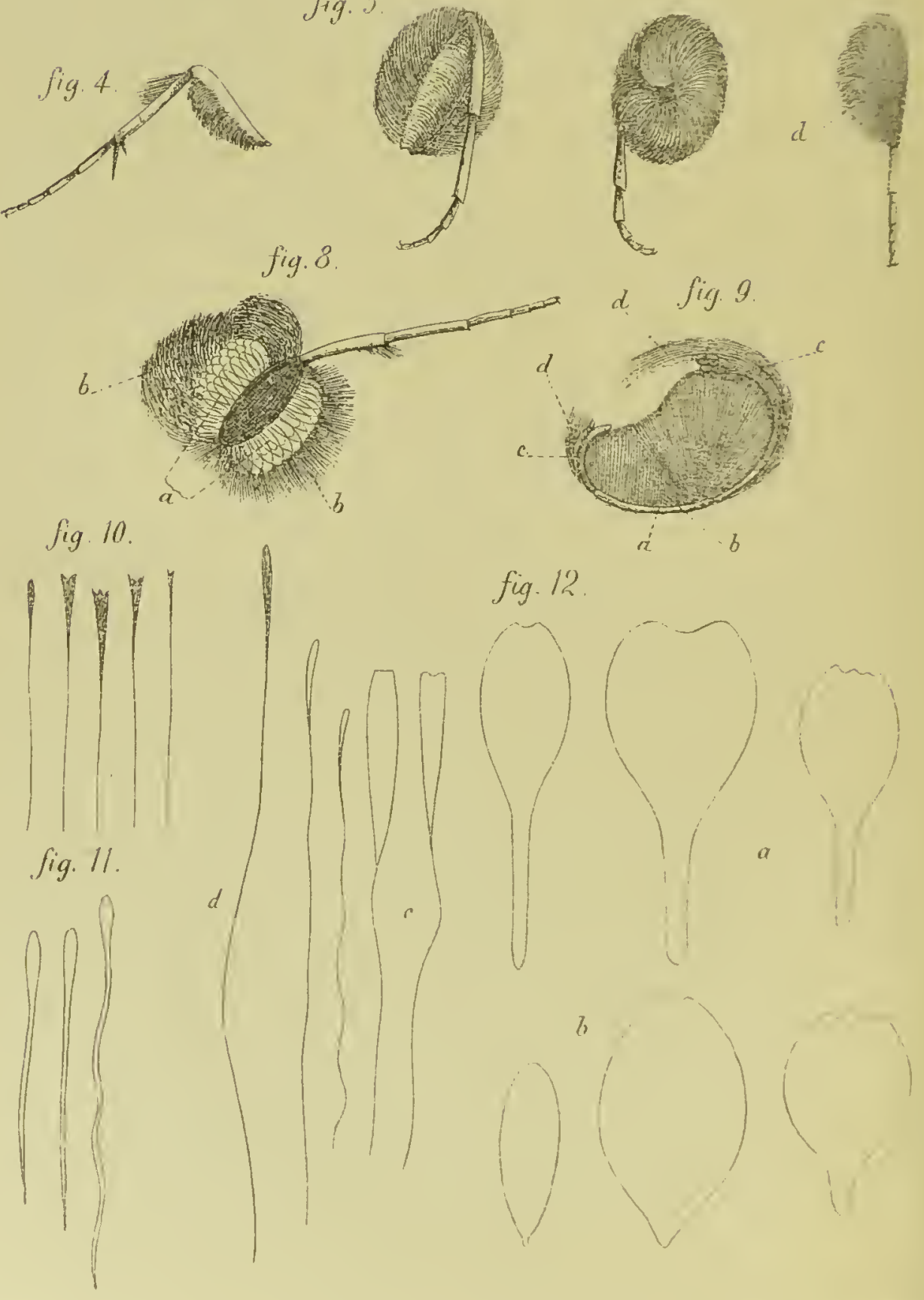


\section{EXPLANATION OF PLATE D.}

Fig. 1.-Magnified 5 times. Front leg of the male of a small species of Erebid. $a$, pale hairs fringing the edge of femur; $b$, tuft of hair springing from the basc of the tibia, hidden between the hairs of the femur.

Fig. 2.-The same leg with the scent-tuft erected.

Figs. $3-8$ are twice the natural size.

Figs. 3-12 refer to a different species of Erebid.

Fig. 3.--Right hind leg of male.

Fig. 4.-Left intermediate leg of female.

Fig. 5.-Left intermediate leg of male, seen from the ventral side.

Fig. 6.-The same from the dorsal side.

Fig. 7.-The same, seen from the anterior or uppcr unargin of the femur. $d$, dorsal side; $v$, ventral side.

Fig. 8.- Right intermcdiate leg of male, seen from the dorsal side, after removal of the scent-scales. $a$, scales; $b$, hairs on the edge of the femur, protecting the scent-scales.

Fig. 9.-Magnified 5 times. Transversc section of the scent-organ. $a$, femur ; $b$, scent scales ; $c$, protecting scales ; $d$, hairs.

Figs. 10-12 arc magnified 15 times.

Fig. 10.-Dart-like scales from the intermediatc femur of fcmalc.

Fig. 11.-Scent-scales covering the dorsal side of the intermediato fcmur of male.

Fig. 12. - $a$, petiolate scalcs; $b$, the inner ovate scales ${ }^{1}$; $c$, hair-lilic scalcs; $d$, hairs of the fringe which protects the scent-scales.

1 In the original, the descriptions of $a$ and $b$ in Fig. 12 worc accidontally transposed, a boing described as ovate; $b$ as potiolate.-E.A.E. 


\section{$\S$ VI. On the Scent-organs of Antirrhaea archaea, $L$ Hü, n. ${ }^{\mathrm{I}}$}

Plate E.

The sexual differenee in [the Satyrine butterfly] Antirihaea archasa," produeed by the scent-organs of the males, has been mentioned by various authors. Thus Westwood (Gen. Dium. Lepidopt., 1851, p. 365), makes Antirrhaea the third seetion of the genus Haetera, and distinguishes it by the [fore]-wings of the male being dilated on the inner margin and furnished with a mane-like hairy tuft beneath. Butler (Cat. Satyrid. Brit. Mus., 1868, p. 106), taking Antirrhaca archaea as the type of a new genus, Anchiphlebia, mentions among the distinetive characters of this genus not only the convex inner margin and the "plaga peetinatim eirrosa [eirrata]" of the fore-wings, but also a very noticeable difference between the two seres in the neuration of the hind-wings:- "alae venis posticarum prima et secunda subcostalibus ad origines mari valdc approximatis et subparallelis." Butler, at the same time, illustrates the elaracters in question by a figure (l.c., Pl. V. 3).

Now tufts of hair, beards or manes, are in general the ehief part of the seent-organs of male Lepidoptera : in most eases also, these organs are aceompanied by more or less profound modifications of the nerrures of the wings. It seems therefore very strange that the males of Antirrhaca archaea should have a mane on the fore-wings, and modified reins in the hind ones, since, aceording to existing deseriptions and figures, these hindwings show no indieation of any seent-organs. In consequence of this anomaly, real or apparent, I examined with the keenest interest screral individuals of both sexes of this somewhat rare butterfly, which I met with for the first time in the Provinee of Santa Catharina in Jannary of the present year.

As soon as I took hold of them, I was eonvineed that the males, and these only, were endowed witl a most distinet seent, cmitted from the very elegant mane on the fore-wings. Nor was I long in reeognizing that the anomaly is only apparent, for a seent-organ of a most peeuliar hind extends along the modified nervures of the hind-rings, and, comparing my speeimens with Butler's plate, it required little to eonvinee me that

1 Arelivos do Muscu Nacional do Rio de Janciro, III. (1878), pp. 1-7. By Dr. Frity Mrüllor, Travolling Naturalist for the National MIusoum.

" Antirhaca archaca, fomalo, is figured by Dr. Chonu, Encyclop. d'Hist. Nat., Papillons, I., p. 299, Fig. 514.-F.AI. 
he has incorreetly drawn the mane of the fore-wings, giving to the hairs a wrong direction.

I consider, therefore, in view of the errors and omissions in the existing descriptions and drawings of the seent-organs of Antirrhaea archaea, that it is desirable to figure and describe thein afresh.

The inner margin of the fore-wing forms in the female (Pl. E, Fig. 1), a nearly straight line from the base of the wing to the end of the intermal [snbmedian] nervure: in the males, on the contrary (Fig. 2), the inner margin forms, between these points, an almost regular are of 120 degrees of a circle whose centre lies at the apex of the angle formed by the median nervure and its first branch. Furthermore, the internal [submedian] nervure, after making an obtuse angle ${ }^{1}$ near the base, is straight in the females, curved like an $\mathrm{S}$ in the males. Thns in this sex the arca included between the internal [submedian] nervure, the median and its first branch is larger in the ratio of 4 to 3 , and the greater part of this area is occupied, on the nnder surface of the wing, by the characteristic mane of pale hairs. This mane eommenees at a short distanee from the base of the wing, the line of insertion following for a little more than two-thirds of its length, the internal [snbmedian] nervure, from which it is separated by an interval about eqnal to the diameter of the nervure itself. Beyond this point the mane, gradually diminishing the radius of its curve, turns forward (that is, towards the dorsal [costal] edge of the wing) terminating at a little distance from the first branch of the median. Towards the base of the wing the hairs of the mane (Pl. E, Fig. 5) are straight, and about $3 \mathrm{~mm}$. long ; in the middle $12-16 \mathrm{~mm}$.; towards the apex about $8 \mathrm{~mm}$., and blunt at their free extremities. At the spot where the mane turns away from the internal nervure the hairs are thicker, being about $6 \mathrm{~mm}$. long, and bent into a slight eurve with its convexity towards the base and inner margin of the wing.

The hairs are not disposed in a single row, bnt, ns may be best seen by their points of inscrtion, in 3, 4, or 5 layers, the number rising to 10 or more in the first two millimetres nearest the base of the wing. When the mane is removed, that part of the wing which lay beneath does not show any perecptible differenee from the surronnding parts, yet mieroseopic cxamination reveals a profound distinetion in the arrangement and form of the scales.

The ordinary seales of the parts snrronnding the organ (Pl, E, Fig. 10) are disposed in regrular rows, made np of lower, or suecubi, alternating with upper, or incubi. 'The distance between the rows is about $0.08 \mathrm{~mm}$., that between the scales in the row about $0.03 \mathrm{~mm}$. 'The upper seales, or ineubi (Fig. $10 a$ ) are longer $\left(0^{\circ} 2\right)$, narrower $\left(0^{\circ}(0.3)\right.$, and at the same time darker ; the lower, or suceubi ( ${ }^{\prime} \mathrm{ig} .10 \mathrm{~b}$ ) shorter $\left(0^{\circ} \cdot 3\right)$, broarder $\left(00^{\circ} 05\right)$, and paler'; but their apiees are either' rounded, like those of the ineubi, or dentate.

1 "Obtuse angle" is obscure. The submedian makes an acute angle with tho median in both sexos.- E.B.P. 
The scales under the mane are not disposed in rcgular lines, nor are they divided into succubi and incubi: thcy are much fewer than the ordinary seales, and do not entirely eover the wing. Near the base of the wing (Pl. E, Fig. 11) they are far smaller than the others, having about the length, more or less, of the ordinary suecubi with the breadth of the ineubi. Towards the outer margin of the wing they gradually increase in size, so that at last (Fig. 12) they can searcely be distinguished from the ordinary suceubi with rounded apex. In eolour and texture the scales of the organ resemble the ordinary suecubi, showing, like these, the very distinet longitudinal striation which is usually not. to be seen in scentseales. All other distinctivc eharacters of the scent-seales are wanting. Another singular and notable distinction between the area covered by the mane and the surrounding parts is found in the direetion of the scales. They are, as a general rule, turned with apices pointing towards the outer margin of the wing (that is towards the right in Pl. E, Fig. 5); but those below the mane follow more or less exactly the direction of the hairs which cover them (thus, in Fig. 5 the scales at the base are directed towards the top, those of the terminal part towards the left), so that at a eertain point seales which are very close together and only separated by the insertion of the hairs yet point in entirely different directions. ${ }^{1}$

When the seales of the fore-wings are removed, we see, in the space eovered by the mane, a very opaque spot, elliptic in shape, measuring seven by three mm. If we draw a straight line from the vertex of the angle formed by the median nervure and its first branch to the point where the mane turns away from thc internal [submedian] nervure, this line eoineides with the major axis of the ellipse. The opaeity of the spot, otherwise hardly noticeablc, is due to innumerable small dark-bordcred points or circular pits of scarccly $0.002 \mathrm{~mm}$. diameter, whieh are herc scattered on the wing membrane.

As with the inner or posterior margin of the forc-wing, so also with the anterior [eostal] margin of the hind-wing, which is almost straight in the female (Pl. E, Fig. 3) and distinctly arched in the male (Fig. 4). The upper surface of these wings is of a fawn eolour, and on it we scc, in the malcs, tro spots which are distinguished by their brillianey and their eolour. The larger (Fig. $4 m^{\prime}$; Figs. $7,8,9$ ) surrounds the angles formed by the upper discoeellular nervure and by two branehes $(6,7$, in Figs. 6-8) of the subeostal, and is prolonged betwecn thesc two branches as far as they run npproximatcly parallcl. 'The irregular quadrilateral basc of the spot is dull ash-eolour, its prolongation whitish, and thus more visible. The lowcr spot (Fig. $4 \mathrm{~m}^{\prime \prime}$ ) oecupics the angle between the two internal ncrrures [submedian and internal]. Both spots are thickly corered with scales, which, in thcir complcte opacity and want of the longitudinal strintion,

1 The hairs of the mane start from a strongly curved base line, and are directed towards a common centre. Hence those in the middle of the eurre point in opposite directions, as do the seales between whioh they arise. - E.A.E. 
resemble the scent-scales of many other Lepidoptera. The shape of the scales on the smaller spot (Pl. E, Fig. 15) do not differ greatly from the ordinary incnbi (Fig. 13 A) of the adjoining parts of the wing; thosc of the larger spot (Fig. 16) are, on the contrary, so narrow as to be almost mistaken for hairs. The latter are $0.16 \mathrm{~mm}$. in length; those of the smaller spot $0.13 \mathrm{~mm}$., by 0.025 to 0.03 broad.

After removing the scales, the spots become much morc conspicuons than before, differing not only by the amount of their opacity, but also by their horn-like colour, rather pale in the smaller spot, but darker at the base and still somewhat dark in the prolongation of the larger. The smaller spot contains the ramifications of a few slender air-vessels, springing from the two [internal] nervures bounding the spot. In the larger spot these air-vessels attain a much greater, and sometimes a truly enormous, development, although different individuals vary greatly in this respect. The majority of the air-vessels which run through this spot are more or less dilated at their bases, and tortuous, resembling varicose veins (Pl. E, Fig. 8). In some individuals the dilatation of the airvessels extends so far that they occupy nearly the whole area of the sccntspot, losing at the same time their capillary ramifications (Fig. 9). In Fig. 7 this same degree of varicosity is exhibited by the air-vessels between the two branches ( 6 and 7 ) of the subcostal nervure, and to the left of the upper discocellular, whereas on the right of the latter nervure there are various forms transitional between the ordinary air-vessels and those which are excessively dilated and destitute of capillary branches.

The variability of the air-vessels also extends, though in a much less degree, to the nervures which traverse the spots and from which these airvessels arise. The two branches of the subcostal nervure ( 6 and 7 ) may be either nearly parallel (Pl. E, Figs. 4 and 8), or convergent (Figs. 7 and 9), sometimes almost meeting. In the females on the other hand (Figs. 3 and 6) these branches diverge from thcir point of origin. 'The upper' discocellular nervure traverses the spot either in a straight line (Fig. 8) or in a slight curve (Fig. 9).

This extraordinary variability of the air-vessels of the scent-patches affords an excellcnt examplc of a law admirably discussed by Dar'win (Origin of Species, 4th Ed. p. 177) that " $a$ part devcloped in any species in an cxtraordinary degree or nnanner in comparison with the same part in allied species, tends to be highly variable." Althongh the scent-patch with its greatly modified veins and air-vesscls is not confincd exclusivcly to Antirrhaea archaea, it appears to be restricted to the three allied species united by Butler in the genus Anchiphlebia.

Another notable point is the separation of the scent-organ into two parts, for it appears that to the hind-wings is rcserved the production, to the fore-wings the croission and exhalation of the scent which is intended to attract the amorons fornales. As to the dark spot on the anterior wings, it secms to be a rudimentary scent-organ, which, thongh it is as 
yet uncertain whether it is in a state of evolution or retrogression, must eventually either be perfected or disappcar.

Comparing the sccnt-organs of Antirrhaca archaca with those of Epicalia acontius, which I have prcviously described, wc find an almost complete agreement between their componcnt parts. In both species those margins of the wing which overlap each other, are considerably dilated and arched in the male sex : in both the under side of the upper wing is furnished with a mane of long hair inserted along the internal [submedian] nervure, and covering a scent-patch, well developed in the Epicalia, rudimentary in Antirrhaea. Opposite the mane, there is in both species on the upper surface of the lower wing, a scent-patch, whosc central part occupies the angle betwecn the two branches of the subcostal nervure, extending from thence into the three adjoining areas of the wing. Now all this would be very simple, and would bc easily explained if the trro species belonged to the same, or to allied genera, for then all the characters in which their scent-organs correspond might have been derived from a common ancestor. So far from this being the case, however, they arc of two very different sub-families, Antirrhaea being claimed by the Satyridae and Epicalia by the Nymphalidae, while even the nearest relatives of both are destitute of similar organs. They are completely wanting, for instance, in Epicalia numitia. Hence, there can be no doubt that the scent-organs havc been independently developed in these two species, and that erersthing they have in common is solely duc to the circumstance that ther are adapted to fulfil the same function. The two organs are not " homologous," but simply "analogous," and they furnish a most notable example of "convergence," to use the modern term for a resemblance caused, not by inheritance, but by adaptation to similar circumstances. I know of no other case which proves so clearly and irrefragibly, and attests with such force, the trnth of a principle which should nerer be lost sight of in morphological studies, viz.-when in trro species certain organs which serve the same fuuction, are found in the same place, are composed of thc same parts occnpying the same relativc positions, and cxhibiting similar forms-all this by itsclf constitutes no sufficient proof that these organs arc homologous, nor does it give ground for placing the two species in the same family. 


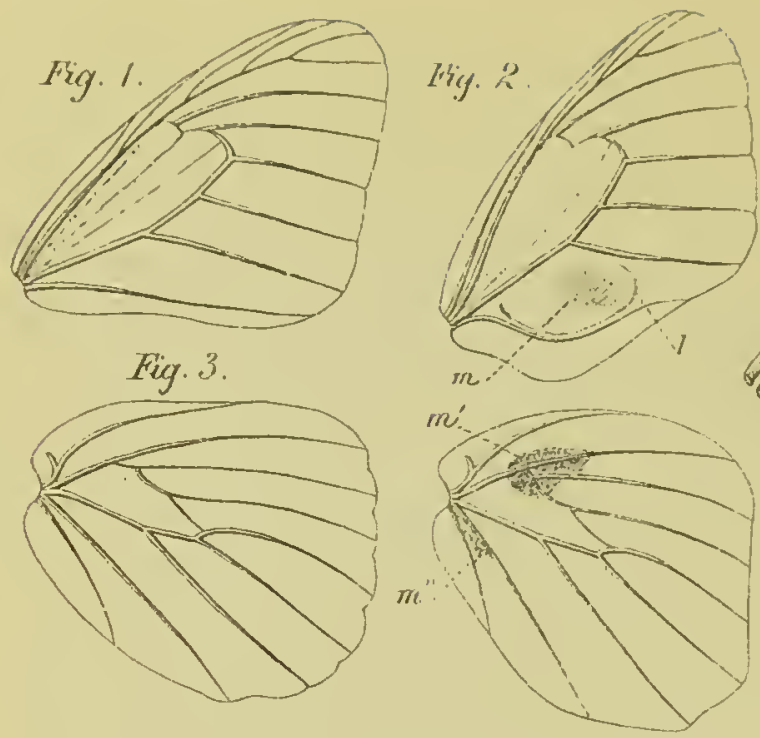

Fig. 6

Fing +
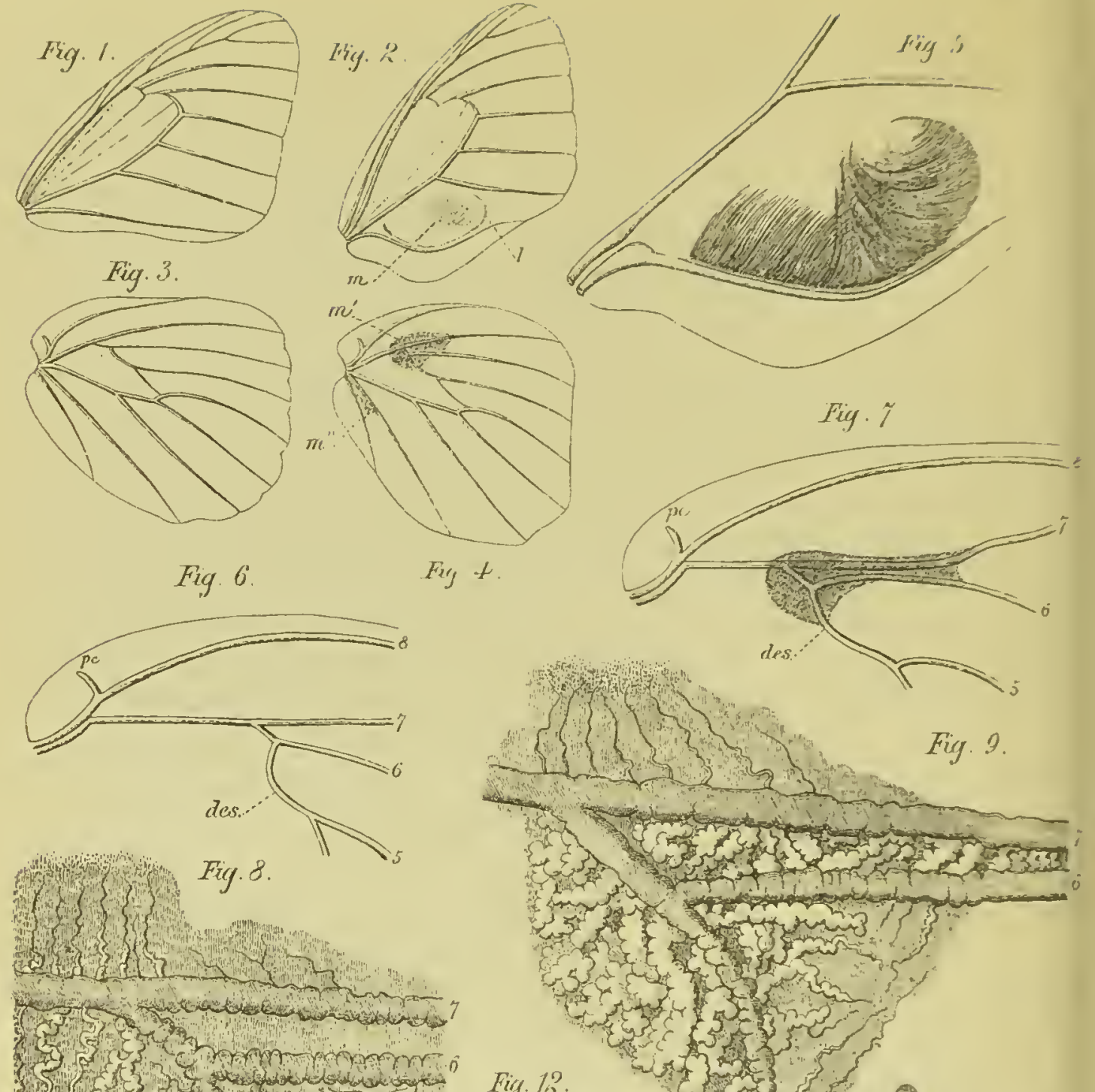

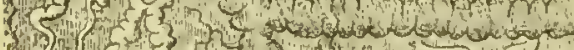
(15) En $7(3)+3$
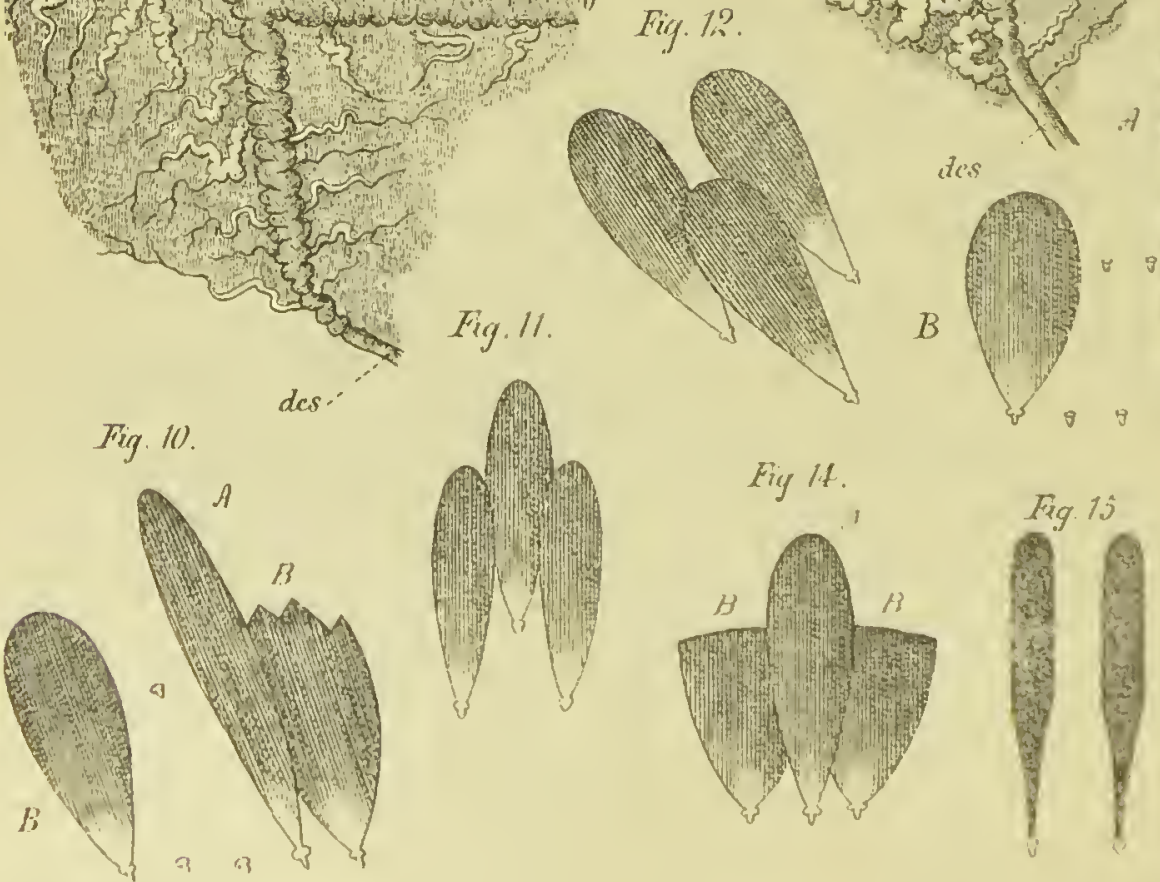

Fig. 9.
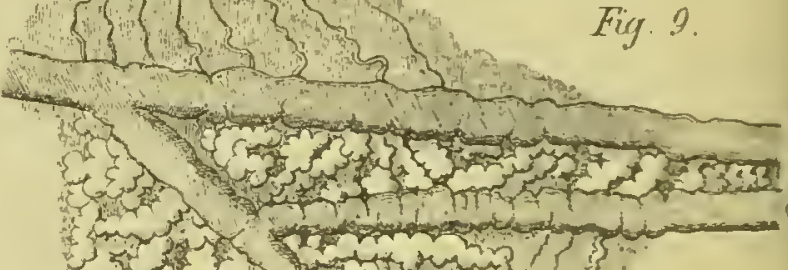

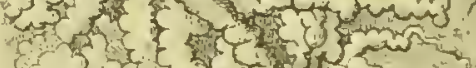
5 की
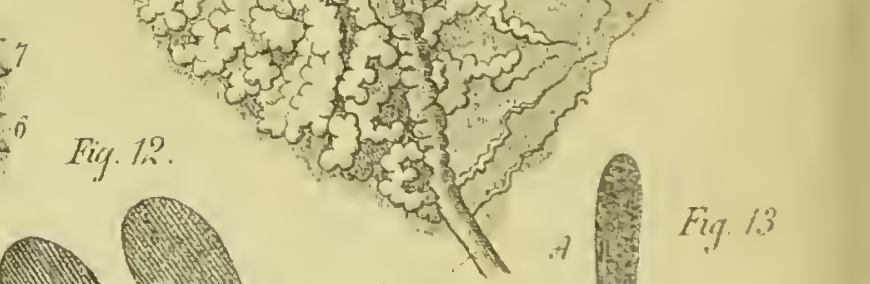

Fig. 1.3

Fing it.
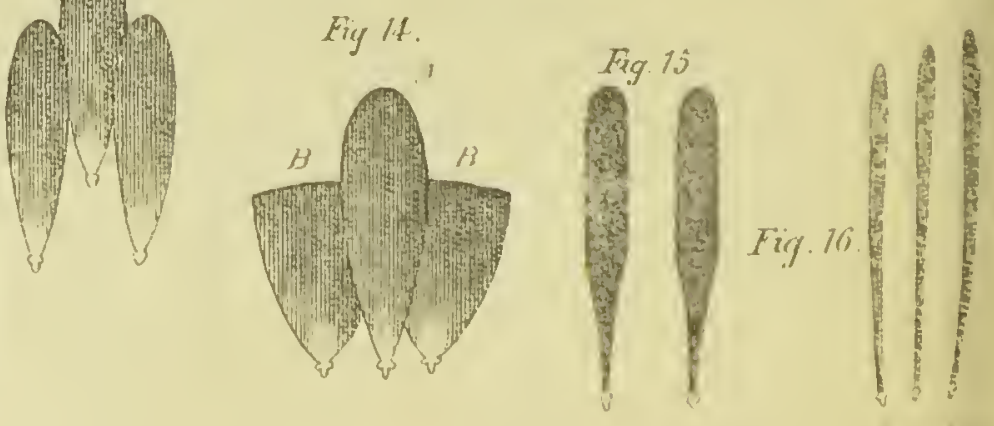

Fritz Müller del

SCENT OPGAN OF THE NALE SATYRINE BUTTERFIY ANTIRTHAEA ARCHAEA 
All the figures refer to Antirrhaea archaea, Hiibn. Figs. 1-4 are of natural size; 5,6 , and 7 magnified 3 times; 8 and 9 magnificd 15 times, and the remainder 180 times.

Fig. 1.-Fore-wing of female, after removal of scales. Note in this figure and the next, the well-developed nervures, and, in addition, distinct traces, in the cell, of the discoidal nelvure divided into two branches, and of the posterior branch of the subcostal.

Fig. 2.-Fore-wing of male. $l$, line of insertion of the mane, dilated at base; $m$, opaque patch.

Fig. 3.-Hind.wing of female.

Fig. 4.-Hind-wing of male. $m^{\prime}$, larger scent-patch, covered by the manc of the fore-wing; $m^{\prime \prime}$, smaller patch, concealed between the wing and the abdomen.

Fig. 5.-Mane on the under surface of the fore-wing of male. In Butler's figure (Catal. Satyrid. Br. M., Pl. V., Fig. 3), the hairs appear to be attached by their anterior extrenities and to point downwards. Can this be a specific difference? It is more probably an error.

Figs. 6 and 7.-Part of hind-wings, showing the difference betwcen the nervures of the female (Fig. 6), and the male (Fig. 7). 5, discoidal nervure; 6 , the second, and 7 , the first branch of the subcostal; 8 , the costal nervure; des, upper disco-cellular nervure; $p c$, precostal nervure.

Figs. 8 and 9.-Larger scent-patch of male, after removal of scales ; takien from two different individuals to show the great variability of the air-vessels. To simplify the figure, the points of inscrtion of the scalcs have been omitted.

Fig. 10.-Ordinary scales from the lower surface of the forc-wings. $A$, incubi ; $B$, succubi. ${ }^{1}$

Figs. 11 and 12.-Scales from the arca covered by the mane.

Figs. 13 and 14.--Ordinary scalcs from the upper surface of the hindwings; - those in Fig. 13, from the angle between the two internal nervures; those in Fig. 14, from the space betwecn the discoidal and the sccond branch of the subcostal. A, incubi; $B$, succubi.

Fig. 15. - Scale from the smaller scent-patch.

Fig. 16.-Scales from the larger scent-patch.

1 The reference letter $\mathrm{B}$ is omitted from Fig. 10 in the original plate, and both $A$ and $B$ from Fig. 14.-E.A.E. 


\title{
$\S$ VII. On the Costal Fold of the Hesperidae.'
}

\author{
Plates F and $G$.
}

WHeN writing of the sexual differences of the Hesperidae, Westrood ${ }^{2}$ says that "in some groups the fore margin of the fore-wings is recurved in the males, the enclosed space being thickly clothed with pale-coloured dorn." Herrich-Schaeffer gave to this recurved margin of the fore-mings the name of "costal fold," making use of it as a distinctive character of the genera in which it occurs. ${ }^{3}$

I was convinced that until the costal fold of all species known to possess it had been submitted to a microscopic examination and compared with one another, it would be impossible to form an opinion as to its function ; also that, from a purely systematic point of view, this strncture, being at once varied and divcrse in ver'y similar species, was well deserring of close study.

Of the many hundreds of Hesperidae furnished with a costal fold. I have only been able to secure less than a dozen-too few to permit me to draw any general conclusions from my observations : I publish them more for the purpose of arresting the attention of entomologists than for their own value.

In the Hesperidae, as in many nocturnal Lepidoptera, the anterior margin of the fore-rwings is occupied by a ncrvure unnamed by Lepidopterists, which, as I shall frequently montion it, I call the marginal nerrure (M in Figs. 2, 7, 13, 20, 24, 26, Plates F, G).

The spccies in which I have examined the costal fold are the follorring: ${ }^{4}$

Telegonus midas, Cram. (Pl. F, Figs. 1-5).-If the costal margin of the fore-wings be divided into five cqual parts, the costal fold occupics the second and third, counting from the basc, and is about $15 \mathrm{~mm}$. long by $1.5 \mathrm{~mm}$. broad. The fold extends along the margin of the wing, and rescmbles a figurc bounded by two arcs of a circle and divided into two parts by their common chord (Figs. 1, 2). 'Thesc two parts arc composed of the reflexed margin of the wing, bounded by the marginal nerrure, and that part of the wing which it covcrs. Both the arcs bounding this figure

1 Archivos do Museu Nacional do Rio de Janciro, III. (187S), pp. 41-50. By Dr. Fritz Müller, Travelling Naturalist for the National MIuseum.

" Doubledny, Westwood, Gen. of Diunnal Lspidopt., 1852, p. 506.-F.MT.

3 Herrich-Schaeffer, Prodrom. Syst. Lepidopt., fasc. iii., 1868, p. 52.-F.MI.

4 I follow the nomenclature of Kirhy's Cat. Diumal Lepidopt., 1871.-F.M. 
are borkered with lnstrous, straw-coloured scales. A third fringe of scales of the samc colour, but thinner and longer, is inscrted along the common chord, entirely covering the folded part of the wing. The length of the sciles of this third fringe equals or slightly exceeds the width of the fold ; they are longest in the middle of the chord $(1.5-2 \mathrm{~mm}$.) where they are furthest from the arc; they all have a long, narrow blade, which in some is gradually widened, fan-like, into a narrow triangle, with its apex more or less dentate (Fig. $3 a$ ) ; others (Fig. $3 b$ ) are filiform, terminating in an oval lamina, or in a narrow, apically rounded ribband. The scales which bound the area covered by the fold (Fig. 4) are of very varied shape, bnt mostly oval or claviform : nearly all have a dark terminal spot, full of opaque granules, separated from the rest of the scale by a transparent aureola. These dark spots are sometimes very small, reduced to a mere dot, but sometimes occupy the whole width of the scale: they are not always exactly terminal, being sometimes displaced to one side : rarely two spots are to be seen on the same scale. The aureola which surrounds the spots is usually circular, but is sometimes less regular in shape.

The longitudinal striae which cover the scales pass over the aureola also, but become confused and indistinct on the dark spots. The opacity and granulation of the dark spots are characters frequently met with in scent-scales, and since the apices of the scales with dark spots are covered by the free margin of the fold, it appears not improbable that they are odoriferous. Thus these scales may discharge at the same time two very different functions, the basal part serving to close the fold, the apical acting as a scent-organ.

On removing the scales from the straight line which, cutting longitudinally through the fold, separates the recurved part from the rest of the wing, it is seen that the space between these scales and the folded part of wing is covered with a dark grey powder, composcd chiefly of separate particles (Fig. $5 a$ ), measuring about $0.016-0.025 \mathrm{~mm}$. long by $0.004 \mathrm{~mm}$. broad; their sides, generally parallcl-more rarely converging towards one endare transparent, ycllowish, and usually traversed by a morc or less dark and opaque longitudinal line. Between thesc particles are others (Fig. $5 b$ ), joined end to end by very fine, short threads, likc more or less distinctly jointed hairs (Figs. $5 c, d$ ).

The origin of the powder which fills the cavity of the costal fold is revealed by these articulated hairs, for it is composcd of their fragments. Finally, to complete the description of the scales found in the costal fold of 'Telegonus midas, I may mention ccrtain narrow scales, about $0.6 \mathrm{~mm}$. long by $0.016 \mathrm{~mm}$. broad, which I found in the cavity of the fold, without being able to ascertain exactly where they were inserted.

Telegonus (?), undetermincd species from S. Bento (Pl. F, Figs. 6-9).'This species, of which I was only able to secure one specimen, much worn, but with the costal fold well prescrved, is remarkable both for the extent of this fold, which occupies nearly threc-fifths of the costal margin (Fig. (i), 
and for the unusual size of the marginal nervurc (Fig. 7, M), which is indeed much larger than the costal and subcostal nervures (Fig. $7 \mathrm{c}$ and $8 c$ ). The carity formed by the costal fold is bounded and closed beneath by very numerous scales arising along the straight line which separates the folded margin from the rest of the wing, and above by the margin of the fold. A fringe of smaller scales is inserted along the marginal nervure.

The "pale-coloured down" in the interior of the costal fold arises from the upper surface ${ }^{1}$ (lit. "wall "), both of the marginal nervure and of the folded margin of the wing (Fig. 7). It is composed entirely of articulated hairs, with joints, which are mostly separated (Fig. 8), varying greatly in size, averaging $0.04-0.06 \mathrm{~mm}$. long by $0.008-0.01 \mathrm{~mm}$. broad : those which are united in greater or less numbers are usually very much narrower (Fig. 9). The joints are transparent, but with some dark dots.

Telegonus mercatus, Fab. (Pl. F, Figs. 10, 11). - The costal fold (Fig. $10 \mathrm{P}$ ) is smaller than in the two preceding species, only extending over about one-third of the anterior margin of the wing; its breadth is rather more or less than half that of cell 12 (adopting Herrich-Schaeffer's ter'm for the space between the costal nervure and the anterior [costal] margin of the wing). In the interior of the fold one finds a series of most curious scales (Fig. 11). Some, in the first place, represent the primitire form from which the others may be derived; they are long, stout scales (Fig. $11 \mathrm{i}$ ), about $0.3 \mathrm{~mm}$. long, of which about one-sixth is taken up by the terminal triangular or oval lamina, the remainder by the stalk. Some are contracted below the terminal lamina, forming a sort of neck. In other similar but smaller scales (Fig. $11 g, h$ ), the neck is very much narrower, and the terminal lamina does not exceed, or even equal, the lower part of the stalk in breadth. The metamorphosis of the scales continues in the same direction (Fig. $11 e, f$ ) reaching at last a specialized form, in which the neck connecting the terminal lamina with the stalk, is reduced to a very fine thread (Fig. $11 c, d$ ). Finally, there arc scalcs, similar to the last-named, but ending in a finc, sometimes almost imperceptiblc thread, without any terminal lamina (Fig. $11 a, b$ ).

It is certain that some of these scales were originally prorided with a lamina, for I found loose several of these appendages, similar to the oncs shown in Fig. $11 c, d$. It seems to me, however, that somc of the scales never possessed this structure, for the number of the separated laminac mas not equal to that of the scales.

Hesperia syrichthus, Fab. (Pl. F, Fig. 12-18).-This spccics, which is not so prevalent in Sonth America as in Central Amcrica and the sonthern parts of the United States, is very common in the province of Santa Catharina.

The costal fold is somewhat large, and occupies the basal half of the costal margin of the wing, cxtending to the costal ncrvurc (Fig. 12).

${ }^{1}$ The whole of the interior of the fold is of course the upper surface of the wing.-E.B.P. 
The narginal nervure (Fig. 13 M) is furnished with more or less curved scales of oval or orbicular shapc (Fig. 14). The whole internal surface of the costal fold, from the costal to the marginal nervure, is clothed with scales or thick hairs of various forms.

Along the curved margin there are pale scales (Fig. 15), oval in shape, about $0.01-0.03 \mathrm{~mm}$. in breadth, and with rounded apex. At the base of the angle formed by this margin and the rest of the wing, the scales are less pale, opaque, very narrow, tapering to a fine point (Fig. 18), and about $0.08 \mathrm{~mm}$. long by $0.005 \mathrm{~mm}$. broad. Finally, on that part of the wing which is covered by the folded margin there are scales of two very different shapes : the first (Fig. 17) are lanceolate, about $0.14-0.17 \mathrm{~mm}$. long by $0.03-0.04 \mathrm{~mm}$. broad; the second (Fig. 16) arc far more slender, transparent, tubular, varying from 0.2 to $0.27 \mathrm{~mm}$. in length, and from 0.002 to $0.006 \mathrm{~mm}$. in breadth. Gradually diminishing in size, these latter scales are terminated by an extremely fine thread, bearing at its apex a very small lamina, shaped like an obtuse-angled isosceles triangle. The sides of this triangle are marked with very fine, almost imperceptible lines, which, at first sight, are only seen at the base as straight lines perpendicular to the extremity of the sustaining thread. ${ }^{1}$ These singular scales of Hesperia syrichthus (Fig. 16), although apparently so different from those of Telegonus mercatus, may, ncrertheless, be easily derived from the same form (Fig. $11 \mathrm{i}$ ).

Leucochitonea arsalte, Linn. (Pl. G, Figs. 19-22). The costal fold of the males is much smaller than in the last species, occupying scarcely onethird of the costal margin of the wing, and less than half the breadth of the spacc between the margin and the costal nervure.

The down enclosed in the fold arises only from the surface of the folded margin, and is protected by two lines or fringes of scales, one of which is inserted along the marginal nervure (Fig. $20 \mathrm{M}$ ), the other along the straight line which separates the folded portion from the rest of the wing: the latter scales are about as long as they are broad, but much shorter than those on the marginal nervure. The down is composed of scales of two different forms, similar to those in Hesperia syrichthus.

Those of the first form (Fig. 21) arc like a spear head; the length is about $0.15 \mathrm{~mm}$.; the brcadth varies from one-ninth to one-fourth of the length, and is greatest at, or close to, the point of insertion, from whencc a line runs almost straight to the sharp apex of the scalc. These scalcs, which cridently correspond to thosc of Hesperia syrichthus in PI. F, Fig. 17, are pale, transparent, the apex more or less opaque, the base having almost always a longitudinal stripe, composed of opaque granules. The scales of the second form (Fig. 22) corresponding with thosc in PI. F, Fig. 16, arc about the same length, $0.15 \mathrm{~mm}$., but so slender as almost to deserve the name of hairs, being rarcly as much as $0.002 \mathrm{~mm}$. broad, and usually

'It is probable that the moaning of this difficult passago would bo more clearly conveyed by substituting the words "radiating from" for "perpondicular to."E,A.E., E.B.P. 
inuch less; they tcrminate in a very fine thread, having at its apez a punctiform button, which is sometimes wanting.

Thymele simplicius, Stoll. = eurycles, Latr. (Pl. G, Figs. 23-28). Herrich-Schaeffer ${ }^{2}$ distinguishes thrce varieties of Eudamus (Gonuruis) eurycles, as he calls the species designated Thymele simplicius in Kirby's Catalogue. The first variety, which I have not scen here, has no trausparent points or spots on the wings, and three costal spots on the under side only. In the second variety the three costal spots are visible on both sides of the wing, and it has a row of transparent dots along the basal half of the anterior [costal] margin. The costal fold is always present in the males of this second variety, which I bave several times met with here. In the third variety the transparent dots and spots form a narror band, sometimes stopping short of the third cell [viz. the internervular space above the second branch of the median] (as in Fig. 25), sometimes cxtending beyond the second nervure or first branch of the median (as in Fig. 23). According to Herrich-Schaeffer, both the male indiriduals, whose fore-wings ${ }^{2}$ are represented in Figs. 23 and 25 , belong to this third variety, although in one (Figs. 23, 24) there is no trace of a fold, while in the other (Figs. 25, 26) it is well developed.

As this third variety is abundant on the Rio Itajahy, I hare been able to examine a large number of individuals, and to confirm the fact that the fold is wanting from all the males in which the transparent band enters the first cell (Fig. 23), and is present in all whose band does not cxtend beyond the second nervure (Fig. 25). In the individuals furnished with a costal fold, the transparent spots differ greatly in number and size : there is an infinite number of forms intermediate betmeen HerrichScliaeffer's second variety and othcr similar males without the costal fold, but possessing, like the former, the transparent spots in cells 3 and 6 and barely distinguished by the absence of the transparent spot in cell 1 . There is also considerable variation in the scales composing the domn in the costal fold.

The scales represented in Fig. 27 belong to indiriduals with only three costal spots-in cells 7 to 9 -and wanting the transparent spot in cell 3 (Fig. 25): those in Fig. 28 werc takcn from a male with four costal spots in cells 6 to 9 , and a transparent spot in coll 3 . The scrles cnclosed in the costal fold show two principal forms. The first (Fig. $27 a, b, c, d$; Fig. $28 a, b)$ are distinguished by a lanceolatc basal part, narroming gradually to a morc or less filiform terminal part, which is again expanded into a kind of lamina or triangular fan. The length of these scales in some males scarcely reaches $0.08 \mathrm{~mm}$. to $0.16 \mathrm{~mm}$. (Fig. 2S), in others rising to $0.2 \mathrm{~mm}$. to $0.3 \mathrm{~mm}$. (Fig. 27). The scalcs of the second form are about the same length as the first, usually narrower (Fig. 27 e; Fig. 28 d), but sometimes perfectly capilliform (Fig. $28 d)$; they are drawn ont rery

1 Prodrom. Syst. Lepidopt., fasc. iii. 1868, p 61.-F.M.

2 The word used is "interiores."-E.A.E. 
gradually into an extremely fine thread, at whose extremity a very small punctiform button may sometimes be found (Fig. $27 \mathrm{e}$ ). There are also usually other scalcs, shorter, broader, and opaque, resembling thosc of the first type (Fig. $27 \mathrm{f}$; Fig. $28 \mathrm{c}$ ). The costal fold occupies about the middle of the anterior margin of the wing, and is rather narrow.

If in all the districts inhabited by Thymele simplicius the males without the costal fold are chiefly distinguished, as they are here, by thc prolongation of the transparent band beyoud the second nervure, I consider that they should be ranked as a distinct species, and not as a mere variety. However this may be, it is worthy of notice that of two similar forms, included by Herrich-Schaeffer and others under a single variety, one has the costal fold well developed, while the other is entircly destitute of it.

It appears that this absencc of the costal fold in some males of Thymele simplicius has not been previously noticed. Such males have probably been mistaken for females, just vecause of the want of these folds, a mistakc pardonable in any one unable to examine the living insects, in which case the sexes are easily distinguished by the genitalia.

Thymele protillus, Herr.-Sch. (Pl. G, Fig. 30). The costal fold cover's about half the anterior margin of the wing, and extends a little beyond the transparent spot in cell 12. There are in the interior of the fold :1. Scales of about $0.3 \mathrm{~mm}$. long, with lanceolate base, tcrminated by a lamina which is either rounded, oval, triangular, or cordiform, and of variable breadth (Fig. 30 a); 2. Very fine hairs of the samc length (Fig. 30 b) ; 3. Narrow scales (Fig. $30 \mathrm{c}$ ) almost parallel sided, about $0.12 \mathrm{~mm}$. long and scarccly $0.004 \mathrm{~mm}$. wide, terminating abruptly in a very fine, almost imperceptible thread; 4 . Not very abumdant fragments of the articulated hairs (Fig. $30 d)$.

Thymele proteus, Linn. (Pl. G, Fig. 29). In this species, which is very similar to the last, the costal fold does not extend bcyond the transparcnt spot in cell 12, and is cven narrower than in Th. prolillus. In the fold, jointed transparent hairs predominate (Fig. $29 \mathrm{c}$ ): the joints are $0.016 \mathrm{~mm}$. to over $0.03 \mathrm{~nm}$. long, and rarcly more than $0^{\circ} 004 \mathrm{~mm}$. widc. There arc usnally 7 to 12 of these joints united together. Besides these therc arc other scales of which the majority arc about $0.2 \mathrm{~mm}$. long by $0.02 \mathrm{~mm}$. broad: they are pale, and traversed by a longitudinal, granular, opaque stria. In form they are slightly attcnuate towards the base, and tcrminate in $n$ small clliptical lamina, the width of which does not excecd, or even equal that of the base (Fig. 2!) a). T'here arc some smallcr scales of a similar shape with a mucli narrower terminal lamina, and without the opaque longitudinal streak (Fig. 29 b).

Entheus vitreus, Cram. The costal fold of this clegant species is very narrow, and encloses jointed, transparent hairs. The joints, of which about ten or more are connected, are 11 sually $0.015 \mathrm{~mm}$. long by $0.004 \mathrm{~mm}$. wide, but they are very variable in both these dimensions. 
Besides these species, I havc examined the costal folds of several others whose names I do not know. Inasmuch as observations such as these, which cannot be verified by others because the species are unknown, are of little value, I will confine myself to a few words on the most notable forms of scales or hairs which I found in these undetermined forms.

In a species of Telegonus (with transparent yellow spots, and a large silvery spot on the under surface of the hind-wings) the costal fold contained chiefly hair-like scales, transparent and very long (about $0.36 \mathrm{~mm}$.) terminating suddenly in a very slender thread (Pl. G, Fig. $31 \mathrm{a}$ ). There were also present other scales (Fig. $31 b$ ) like the smaller ones of Thymele proteus (Fig. 29 b), and a few fragments of jointed hairs.

In another speeies, the joints, which are very variable in length and breadth (PI. G, Fig. 32), were united by very long filaments, which still adhered to the separated joints.

Finally, in a species closely resembling Achlyodes thraso, Hübn., the costal fold, which is very narrow, enelosed lanceolate, more or less opaque scales (Pl. G, Fig. 33 b, c), transparent threads (Fig. 33 a), remarkable for being furnished with a sort of transparent, fusiform root, or resicular appendage, of about $0.025 \mathrm{~mm}$. long by $0.008 \mathrm{~mm}$. broad. Among other Hesperidae I once met with a similar root on a single scale in the fold of Telegonus mercatus (Pl. F, Fig. 11 a). In the sub-family of the Pierina the scales dispersed over the surfaee of the wings in the male are almost always furnished with vesicular appendages.

As to the function of the folds in the Hesperidae, I think there can be no doubt that they belong to the class of scent-organs, which, infinitely diversified, distinguish the males of so many other Lepidoptera. A structure very similar to that of the Hesperidae is found in certain species of the geulus Papitio, not, indeed, on the costal margin of the forewings, but on the inner margin of the hind-wings, which is folded orer, and covers either a peneil of long hairs, or a densc pale dorn. In Papilio protesitaus the black brush exhales a strong, disagrecable odour, whereas the pale down of $P$. nephation diffuses a pleasing aroma. That the fruction of the marginal fold on the hind-wings of Papilio is that of [preparing and diffusing] odours is evident, and by analogy it is also the use of the costal fold of the Hesperidae; for it is in erery may probable that these similar strnctures excreise the same function. 

Appendix (VII)
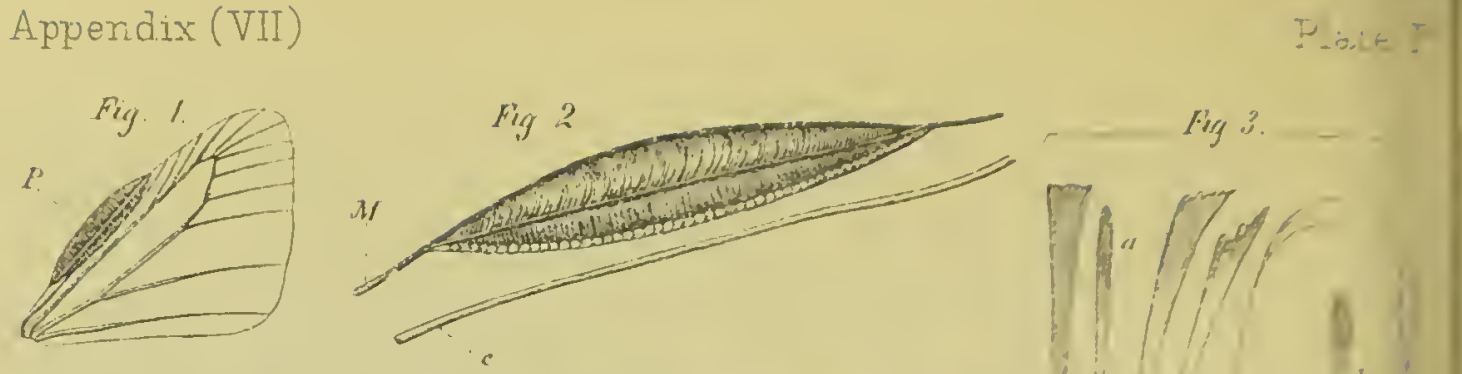

Fing ${ }^{3}$

\section{Fig. 1 .}

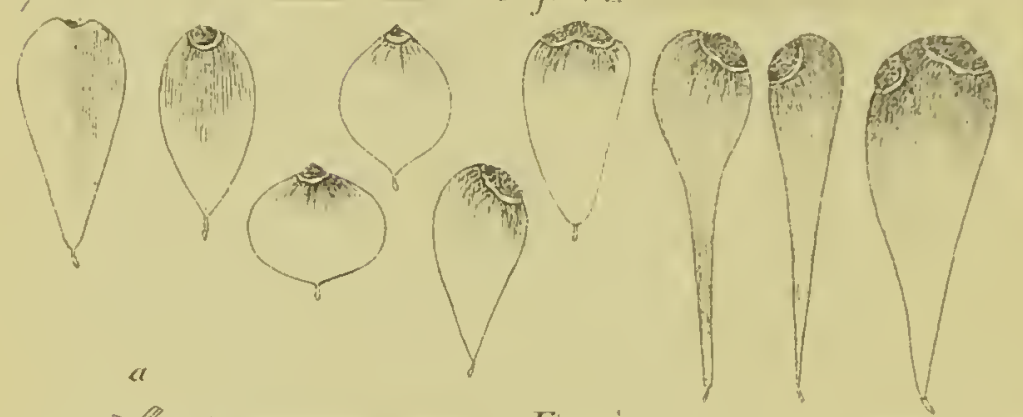

D D

Fig. j.

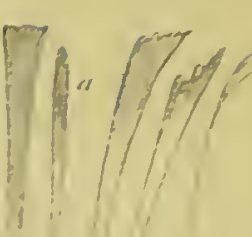

Fing. 6.
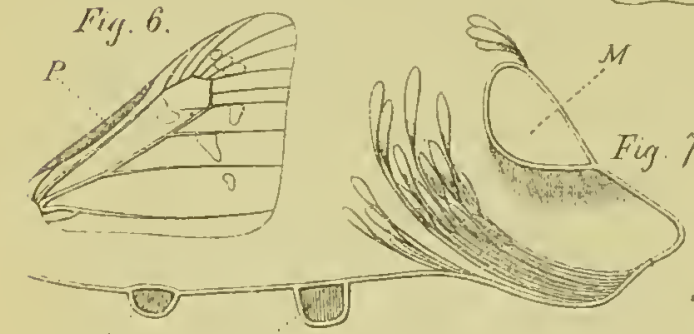

Fing ช.

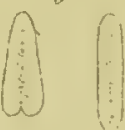

$\operatorname{lig} 9$
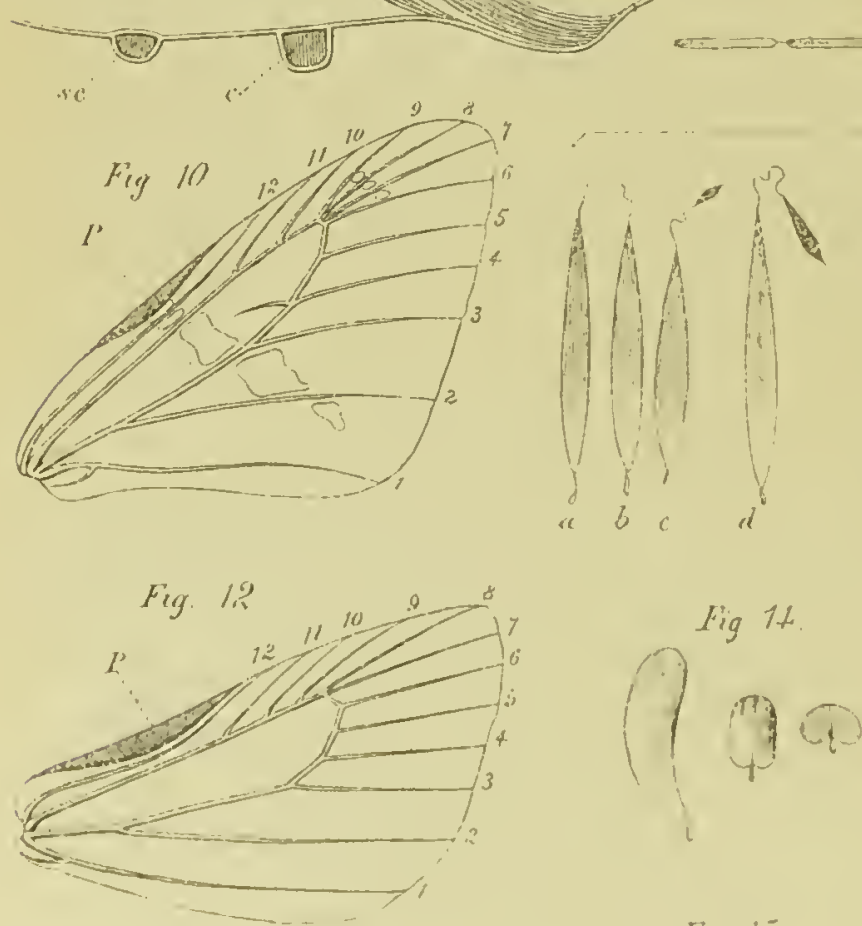

Fig 11

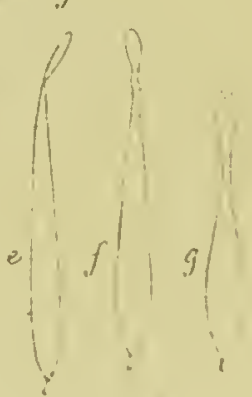

Fin 13

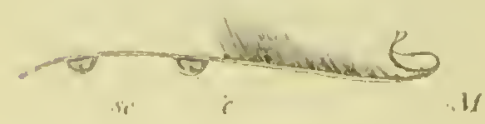

Fig 15

111

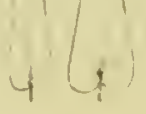

Fritz Muller del. 


\section{EXPLANATION OF PLATE F (Figs. 1-18).}

\section{Figs. 1-5.-Telegonus midas, Cram.}

Fig. 1.-Natural size. Fore-wing with the costal fold opened out (P).

Fig. 2.-Magnified 3 times. Costal fold opened out. M, marginal nervure; $c$, costal nelvure.

Fig. 3.-Magnified 25 times. Scales inserted along the line between the folded margin and the rest of the wing.

Fig. 4.-Magnified 25 times. Scales from the area covered by the [free] margin of the costal fold.

Fig. 5.-Articulated hairs, forming the source of the dark grey powder in the costal fold, magnified 180 times. $a$, detached particles; $b$, jointed hairs ; $c$ and $d$, imperfectly jointed hairs.

Figs, 6-9.-Telegonus, sp. ?, from S. Bento.

Fig. 6.-Fore-wing with closed fold (P), natural size.

Fig. 7.-Transverse section through the middle of the costal fold, magnified 25 times. M, marginal nervure ; c, costal nervure; sc, subcostal nervure.

Fig. 8.-Detached joints of hairs from interior of the fold, magnified 180 times.

Fig. 9.-Articulated hair, magnified 180 times.

Figs. 10, 11.-Telegonus mercatus, Fabr.

Fig. 10.-Fore-wing, with the costal fold (P) closed, twice natural size. 1 , submedian or internal nervure ; $2,3,4$, first, second, and third branches of the median nervure; 5 , second ; 6 , first branch of discoidal nervure; $7,8,9,10,11$, fifth, fourth, third, second and first branches of the subcostal nervure; 12 , costal nervure.

Fig. 11.-Scales from the interior of the fold, magnified 180 timcs.

Figs. 12-18.- Hesperia syrichthus, Fabr.

Fig. 12.-Fore-wing, magnified 3 tinaes. P, costal fold.

Fig. 13.-Transverse section across the costal fold, magnified 25 times. M, marginal; $s$, costal ; $s c$, subcostal ncrvures. times.

Fig. 14.-Scalcs inscrted along the marginal ncrvure, magnified 30

Figs. 15-18 arc magnified 180 times.

Fig. 15.-Scalcs from the lower surface of the folded margin.

Figs. 16, 17.- Scalcs from the arca covered by the folded margin.

Fig, 18. - Scales from the dcepest part of the angle formed by the folded margin with the rest of the wing. 


\section{PLATE G (Figs. 19-23).}

Figs. 19-22,-Leucochitonea arsalte, Linn.

Fig. 19.-Fole-wing, magnified 3 times. P, costal fold.

Fig. 20.-Transverse section through the iniddle of the fold, magnified 25 times. times.

Figs. 21, 22.-Scales from the interior of the fold, magnified 180

Figs. 23-28.-Thymele simplicius, Stoll., male.

Fig. 23.-Fore-wing of male without costal fold, twiee natural size. The cells are numbered according to Herrich-Schaeffer.

Fig. 24. - Transverse section of the same wing aeross the part occupied in other males by the costal fold, magnified 25 times. MI, $c, s c$, marginal, costal and subcostal nervures.

Fig. 25.-Fore-wing of male with costal fold (P), twice natural size.

Fig. 26.- Transverse section across the middle of the eostal fold, magnified 25 times. M, c, marginal and costal nervures.

Figs. 27-33 are magnified 180 times.

Fig. 27.-Seales from the interior of the costal fold.

Fig. 28. - Scales from the same part of another speeimen.

Fig. 29.- Thymele proteus, Linn., male. Scales from the costal fold.

Fig. 30.-Thymele protillus, Herr:-Sch., male. Seales from the costal fold.

Fig. 31.-Telegonus, undetermined speeies. Scales from the eostal fold.

Fig. 32.-Fragments of articulated hairs from the costal fold of an undetermined Hesperid.

Fig. 33.-Hairs and scales from the costal fold of a species closely resembling Achlyodes thraso, Huibn. 
Appendix (VII)
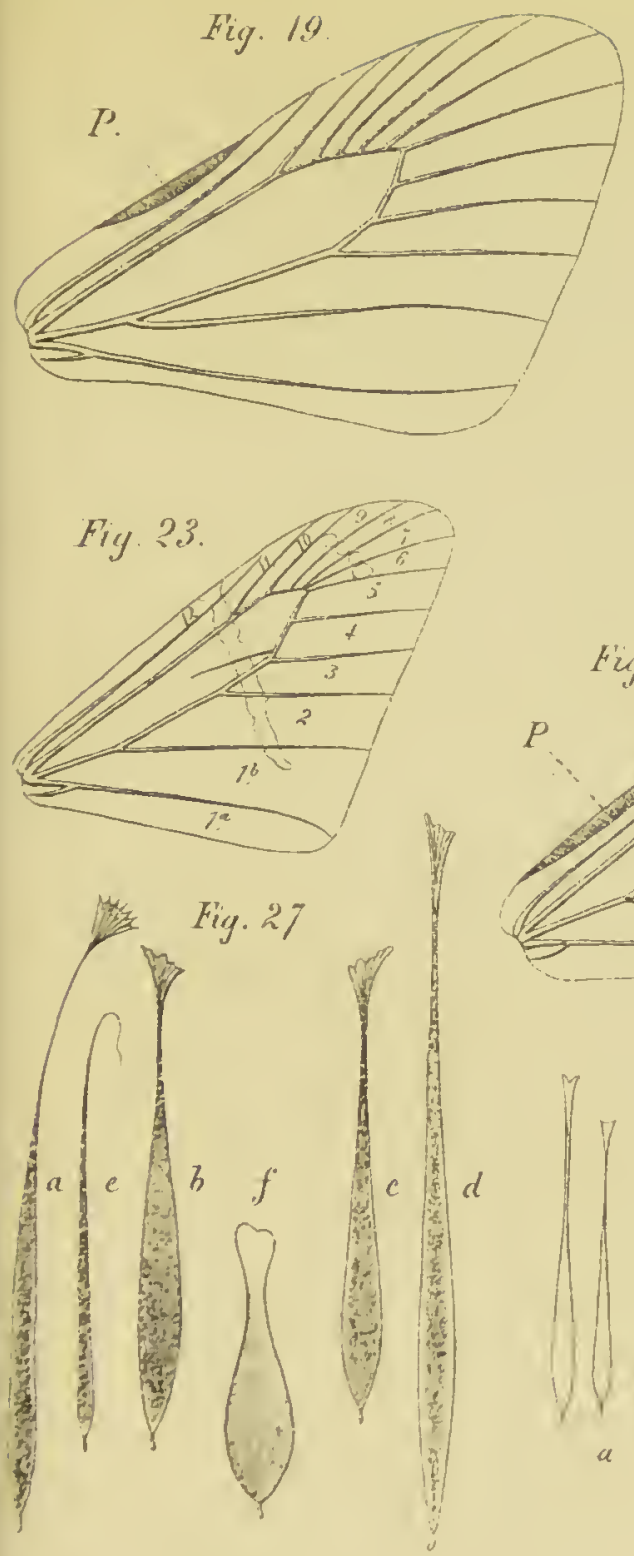

Fing. 30

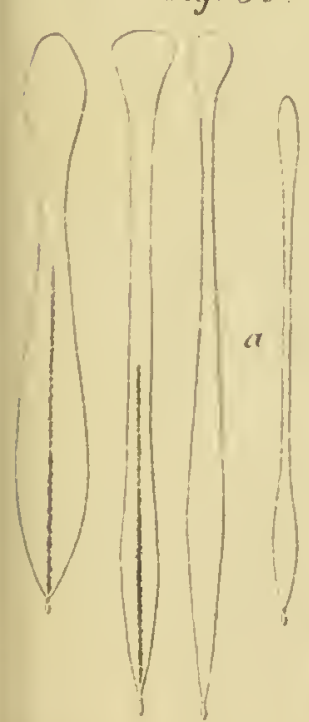

Fritz Muller del
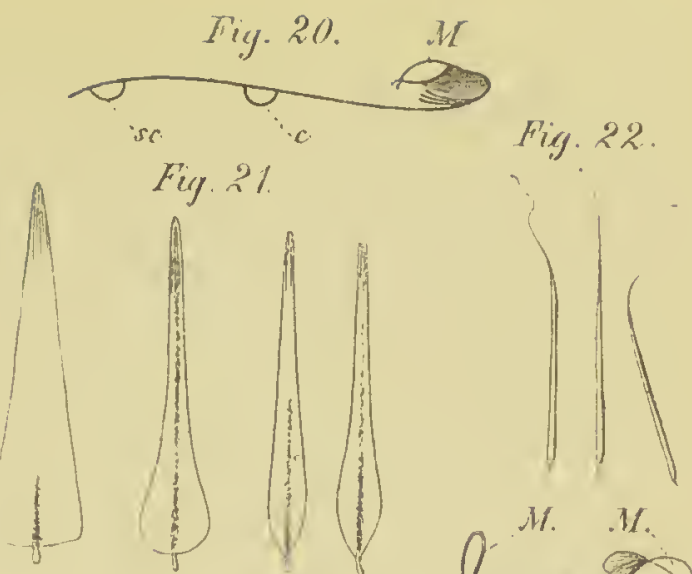

Fin. 25
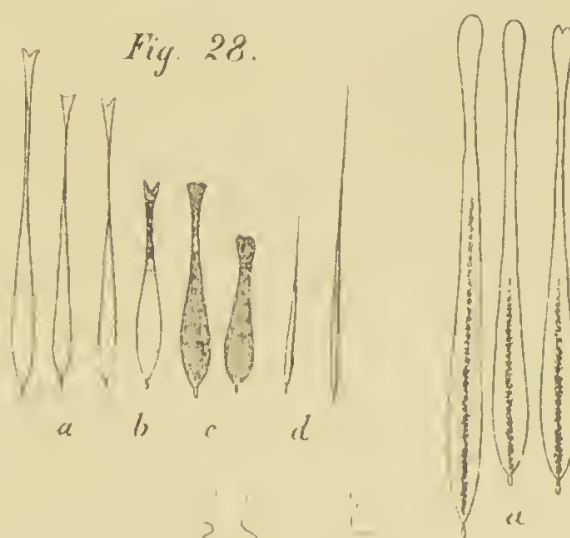

Fig. 29.

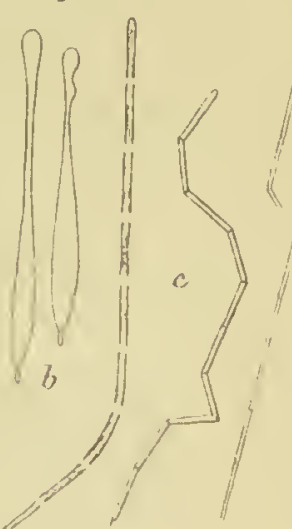

Fiy. 32?

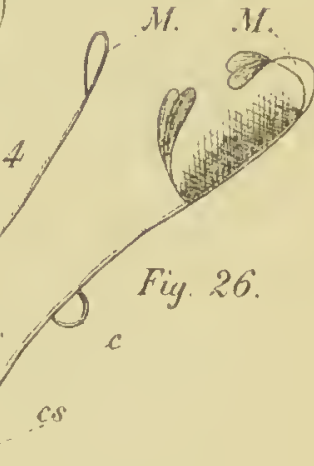

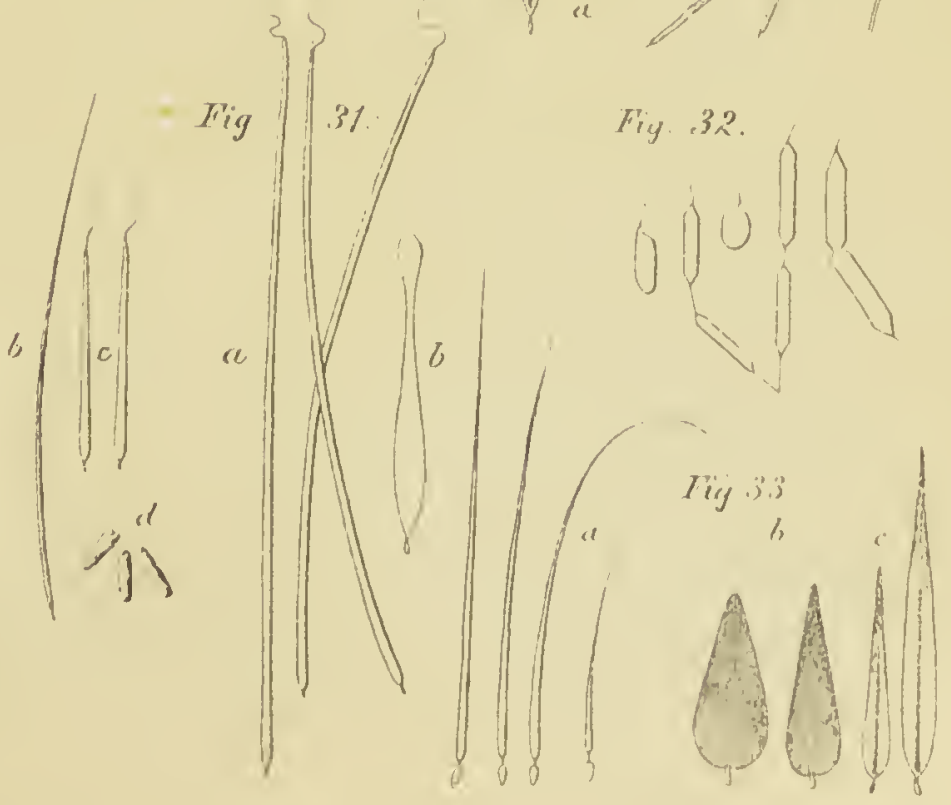





\section{§VIII. Where is the Seat of the Musky Scent in Hawk Moths? ${ }^{\mathrm{I}}$}

I. Axong the thousands of European collectors of Lepidoptera not one appears to have asked this question. And yet with the question the answer would have immediately suggested itself ; for in secking the source of a strong smell one has only to follow one's nose.

While in Europe the Convolvulus Hawk Moth is not uncommon, and the musky scent of the male has long been known, I have to-day ${ }^{2}$ for the first time taken in this locality a musk-scented male Hawk Moth, of a small species, only $40 \mathrm{~mm}$. long, the name of which I do not know. It was flying round the many-blossomed, large blue heads of an Agapanthus in my garden.

It was at once evident, on smelling it, that the very powerful scent came from the ventral side of the abdomen. As I held the moth upside down between my thumb and forefinger, I noticed, that, when it fluttercd its wings, a pale brush of musk-scented hairs was spread out on each sidc of the base of the abdomen. When the creature became quiet, the tuft was again withdrawn into an elongate groove, extending on each sidc ovcr nearly the whole length of the first two segments, and disappeared, in consequence of the scales bounding the groove closing over it. In repose there was nothing to be seen of the tuft, and but little of the groove. The latter can bc made visible in the dcad insect by pressing the abdomen from behind forwards; and the groove is then seen between the scparated scales as a narrow, bare longitudinal streak.

Again, thereforc-but in a new place-we meet with the same efficicnt form of scent apparatus as is found, bearing perceptiblc odours, on the wings and at the apex of the abdomen in various males of diurnal Lcpidoptera. I can scarcely doubt that the "tibial tufts" (HcrriclıSchaeffer) which are found in Hesperidae and Heterocera scrve to diffuse a scent attractive to the females, although $I$ have not becn able to perceive it,-for instance, in the males of Puntherodes purdelaria, a specics

3 Kosmos, III. (1878), pp. 81-85.

2 Nov. 26, 1877. Fritz Müllor gavo a brief account of this observation in a lottor, writton Nov. 27, to Charles Darwin. Extracts from this lettor were read by Moldola to the Entomological Society, and aro published, togother with a reproduction of F. Müller's diagrammatic drawing of tho vontral aspeet of the moth with tho seonttufts extended, in Proc. Ent. Soc., 1878, pp. ii., iii,-E.E.P. 
sometimes common here, a splendid panther-like, golden yellow b]ackmarked [Geometrid] moth, in which these tufts are powerfully developed.

Does the musky scent proceed from the same spot in the males of the Privet and Convolvulus Hawks? Do those Hawk Moths in which the human nose can detect no scent, also possess similar scent-tufts? Both are probable. Iset us hope that these points will soon be settled by actual observation.

II. The second of the above conjectures was founded chiefly on the behaviour of the tibial tufts of Pantherodes pardelaria, which spring from the base of the hind tibiae, extend along their full length, and are usually concealed in a deep longitudinal groove which runs along the inner side of the tibiae, and is covered by peculiar very large scales inserted along its edge. The unfolding of the tuft appears to be brought about by rery vigorous stretching of the tibia.

That conjecture has since been confirmed. On one of our giant-moths belonging to the family of the Erebidae, with an expanse of wing of about $190 \mathrm{~mm}$., I was able to detect a not particularly powerful, but quite unmistakable, peculiar scent emitted from the hind tibiae of the male. In this species the hind tibia is slender in the female, but strongly inflated in the male ( $4 \mathrm{~mm}$. broad by $12 \mathrm{~mm}$. long), and its entire inner surface is covered with a dense forest of hair, which the moth can erect into an enormous brush, while in repose it lies close along the tibia. In this state the hairs along the central line lie undermost, in a shallow groore, covered over by a dense layer of the lateral hairs, which are direeted obliquely towards the central line and the apex of the tibia.'

Even as it is probable that the varied scent-producing structures, nom confined to certain spots on the wings, have originated from scent-scales scattered over the whole surface, so we may, withont difficulty, trace these tibial tufts of Pantherodes pardclaria to the pubescence covering the whole innel side of the tibiae, as shown in the above-mentioned Erebid malcs. We may adopt this conclusion with the less hesitation since re also find in the family of the Erebidae [a further stage of evolution in the presence of] hair-tufts at the base of otherwise hairless hind tibiae.

In the Hesperidae known to me, there is no arrangement for the concealment of the tufts on the tibiae; but I have seen in one of the larger forms, probably a species of Antigonus, that the tibial tufts mere concealed in a groove formed by the scales of the abdomen.

Itajahy, 26 Norember, 1877.

(Signed) Fritz MÜLLer.

1 The Jnvanose Hesporid, Ismene ocdipodca nppears to rosemble these Ercbidac, the malo having the hind tibiae strongly inflatod ("extromely thick") and donsely pubescont ("vory densely hairy"). (Doubleday, Westwood, and Howitson [printed "Hocoitron" in original], Genera of Diumal Lepridontera, p. 514.) It may also be montionod here that Linné himsolf gavo the name of "odora" to a specios of Erobid. I havo porsonnlly no knowlodgo of this species.-F.MI. 


\section{§ IX. The "Maracujá [or Passion-flower] Butterflies."}

THE genera Heliconius, Eueides, Colaenis, and Dione (Agraulis) have been nntil now commonly divided between the two sub-families of the Heliconinae and Nymphalinue. Colaenis and Dione are placed in the latter; Eucides is placed sometimes by the side of Colcenis in the Nympluatinae (by Doubleday and Felder), or again with Heticonius in the Heliconinae (by Herrich-Schaeffer and Kirby).-Neither of these arrangements is in accordance with nature. Colaenis and Dione must be removed from the Nymphalinae, and united with Heliconius and Euceides in a separate sub-family.

The present paper sets forth in few words the proof of this assertion. The four above-named gcnera agree in the following particulars :-

1. All their species inhabit the warmer parts of America, and all, as far as is known, lay their eggs on species of "Maracujá" [or Passionflower] (Passiflorae). This is truc of Heliconins eucrate [narcaea], Eneides isabella and aliphera, Coluenis dido and jutia, Dione vanitlae and juno. No Nymphaline larva has hitherto been found on the Maracujá.

2. The eggs are yellow, shaped like a thimble, and the surface is covered with longitudinal and transverse furrows. Similar eggs do certainly occur among other diurnal Lepidoptera; but whether among the Nymphalinae, I do not know. On the other hand, one finds in the latter sub-family quite aberrant shapes, e.g. those of Siderone, resembling a broad, inverted smooth thimble, flattened at the top.

3. The larvac are spinose. The head bears two spincs (in Dione juno represented only by two short pointed tubercles). The prothorax is usually spineless: in Dione jumo alone is there a pair of small spines. Mesothorax and metathorax bear each two pairs of spines, placed not in the same transverse line, but one pair, the upper, about midway betwecn the anterior and posterior margins, and the other close to the antcrior margin of the segment. The abdominal segments, except the last, have each tbrcc pairs of spines placed in the same transverse line with each other and with the spiracles. The last segment bears two pairs of spines, of which the lower is the more posteriorly placed.

Among the Nymphatinae also there arc many spinous larvae; but I do not know of any having exactly this arrangenent of the spines, which,

' Stcllin Ent. Zcil., XXXVIII. (1877), pp. 192-496. 
however, is found also in Acrcee. It is truc that the number of Nymphaline larvae which I have personally examined, together with those concerning which I have received satisfactory details (from my brother Hermann Mïller') is not very large. But, in addition to spinous larvac, one finds among the Nymphalinae, many others without spines, but with horned heads, as in Siderone and Protogonius.

4. All the Maracujá butterflies confine themselves exclusively to honey from flowers : none of them drink the exuding sap of trees, as do many Nymphatinae, for example Epicalica, Temenis, Callicore, Gynaecia, Ectima, Ageronia, Biblis, Aganisthos, Prepona, Agrias, Smyrna, Paphia, and Siderone. They never seek moisture on the ground like the Nymphaline genera-Hypanartia, Eunica, Haematera, Apatura, etc., or eren on horse-droppings, like Pyrameis. All Maracuja butterflies appear to prefer the same kinds of flowers : thus, for instance, all the species here (Heliconius besckei, apseudes and eucrate [narcaea], Eueides isabella and aliphera; Colaenis jutia and dido; Dione vanitlae and juno) with the exception of the excessively rare Eneides pavana and Dione moneta, risit industriously and continuously a Poinsettia in my garden, to which the Nymphatinae only contribute an occasional visitor in Anartia amalthea, and even this species never remains long on the profusely flotrering bushes.

5. The males of the Maracuji butterflies when seized, open wide the anal valvulae, from the inner side of which then appear tro glands yielding a strong and nauseous smell. The females, on the contrary, emit a similar smell from a yellow gland extruded on the dorsum betreen the last and penultimate abdominal segments. I know of nothing similar among the $N$ iymphalinae.

6. The antennae and mouth-parts of all the species agree in crery important detail, without, it is true, showing anything especially characteristic. This is particularly the case with the appendage beside the mandibles, shaped like a flat clnb, bearing at its apex an obliquely directed bristle. This is the usual shape of the structure, which is probably to be regarded as all organ of taste : in other groups of Lcpidoptcra it takes differcnt and characteristic forms.

7. The hind-wings of the males bear on those parts of the upper surface that arc overlapped by the fore-wings, peculiarly shaped, marginallyfringed scales, "scent-scales," similar to those which occur on the npper surface of the wings of the malc Pieris [Aporia] crataggi. I know of no such scent-scalcs in Nymplatinae or in Acraca.

8. The longitudinal veins and the border [hind or onter margin] of the wings bear, on the muder surface, one or two rows of black hairs In Acraea one finds similar liairs, not only on the fully dereloped reins, but also on the course of the aborted third inner marginal rein [between the median and the submedian] of the hind-wings. I hare been mable to find them in any Nymplatinae that I have cxamined. 
9. The neuration of the wings in all Maracujic butterflies is extraordiuarily similar. This agreement is especially noticeable if onc compares the neuration of the various spccics, and best of all, by the comparison of enlarged drawings. The differencc between Heliconius and Eueides on the one side, and Colaenis and Dione on the other, consists in the fact that the former pair have a closed, the latter an open, cell in the hind-wing ; but this difference is scarcely noticed, so completely does it disappear under the overpowering impression of similarity. To put this into words would require too long an explanation. I therefore confine myself to pointing out a few peculiarities-easily overlooked because of their apparent unimportance-as proof of the close blood relationship of all the Maracujá butterflies.

(a) The median vein of the fore-wing gives off, near the base, a short [interno-median] spur, running towards the inner marginal [submedian] vein, its point curving towards the border [hind or outer margin],--in most species, as in Colcunis [Metamorpha] dido and Dione vanillae, very distinct, but only slightly developed in Colcenis julia and Dione juno. A similar spur is found in some other species of various families, as in Morpho and among the Nymphalince in Adelpha (Heterochroa). But it is wanting, so far as I know, in all the Nymphaline genera, for which any claim to close relationship with the Maracujá butterflics could be made, as also in Acruea.

(b) In the cell of the fore-wings there springs from the angle between the median and subcostal veins, the stump, more or less long and distinct, of the aborted discoidal. This basal stump extends especially far in Encides aliphera, is especially stout in Colaenis [Metamorpha] dido, and least distinct in Colcenis julia. I have sought in vain for any trace of this restige of the discoidal in Acraea and in many Nymphalinate.

(c) Not far from the base of the wing the subcostal vein becomes suddenly thinner at a point where its posterior boundary sharply bends in towards the anterior, the latter prcscrving its direction unchanged. 'This is the spot at which the subcostal formerly divided into its two chicf branches, of which the posterior subsequently disappeared right down to its origin from the anterior. It is sometimes possible, as in Colaenis [Metamorpha] diclo and Heliconius eucrate [narcaea], to tracc fairly distinctly the course of this lost branch of the subcostal through the whole length of the cell. Evcn in specimens of the samc species, this former dividing point of the subcostal is not always equally rccognizable : it is usually most distinct in Heliconius eucrate [narcuea], Dione vanillae and Dione juno. I have not been ablc to detect any trace of it in Acraea or among the Nymphatinae.

(d) As to the hind-wings, I will only remark on the praecostal vein curved towards the base of the wing, which distinguishes the Maracujá butterflies from Acraea and also probably from all thosc Nymphatinae which may claim to approach them. 
It does not appear necessary to discuss the weight of the above-noted characteristics. For Systcmatists of the old school I do not write; for all others, it seems to me, the significance of such characteristics lies on the surface.

One may well inquire how has it been possible, that masters of Lepidopterology ,have managed to misunderstand a relationship which, as I know from my own family, strikes every child at his first sight of the butterflies on the wing-a relationship which constantly receives fresh confirmation as one learns more and more of their development, life-history, and structure?

That Eueides should have been tossed to and fro between Heliconius and Colaenis is comprehensible, so long as these two genera were placed in different [sub]families. For Eueides (at least as imago, since the very aberrant pupa has not long been known) is barely distinguishable from Heliconius by the shorter antennae, and from Colaenis by the closed cell of the hind-wing. Furthermore, Eueides isabella and Heliconius eucrate [narcaea] on the one side, and Eueides aliphera and Colaenis julia on the other, bear such deceptipe resemblance in the form, colour, and markings of the wings, that one might easily take each Eueides for a smaller specimen of the other species. But how it was possible to tear Colaenis away from Heliconius, let him understand who may. In the detailed statement of the generic characters given by Doubleday, one finds the sole and only important character which distinguishes Colaenis from Heliconius to be the open cell in the hind-wing of the former; but this self-same character distinguishes Colaenis in exactly the same way from about 50 out of the 113 genera of Nymphalinae mentioned by Herrich-Schaeffer. Furthermore, HerrichSchaeffer himself states that this very character is insufficient to separate species otherwise similar into different genera, and, in accordance with this opinion, he unites in the same genus Adotias, species with open, and others with closed cell. And yet he places Heliconius in the first, and Colaenis in the tenth family of his diurnal Lepidoptern!

Haeckel's admonition to naturalists to ground themselres more thoroughly in philosophy, and especially in logic, truly appears to be not unnecessary.

Itajahy, Sta. Catharina, Brazil, April, 1877.

The following paper by Fritz Müller should also be consulted: "Acraea and the Maracujá Butterflies as larvac, pupao, and imagines " (Kosmos, II. (187T-S), pp. 21S224).-E.B.P. 


\section{\$X. The Scent-scales of the Male "Maracujá Butterflies." I}

\section{With Plate H, Figs. 1, 2.}

THE sense of smell plays an important part in the sexual relations of many creatures, among which the Lepidoptera are included. The males of many Hawk Moths and Heterocera can scent the virgin females from incredible distances. But on their part also, many male butterflies diffuse scents, which are undoubtedly agreeable to the females and arouse their sexual desires. It has long been known that the Privet and Convolvulus Hawk Moths, especially during flight, diffuse a strong musky scent, although the spot from whence it arises has not hitherto been discovered. The males of a moth of the genus Cryptolechia and those of the Glaucopidae, which are related to the German Zygaenidae, ${ }^{2}$ exsert from the apex of the abdomen two long hollow filaments, sometimes as long as the body, from which proceeds a scent which is often very powerful and to man sometimes appears to be agreeable, sometimes offensive, suggesting, for instance, chloroform and prussic acid. Similarly with the splendid South American butterflies, the gigantic Morphos, whose males extrude from each side of the apex of the abdomen a hairy, strong-smelling gland, of which the scent in the glorious blue $\boldsymbol{M}$. adonis and $\boldsymbol{M}$. cytheris, resembles vanilla. The wings far more frequently than the abdomen are the seat of the scent diffused by the male. To name only a few of the species distinguished by especially strong scents : the male of Papilio protesilaus, a species similar to the "sailing butterflies" ("Segelfalter "), with diffusely scaled, transparent wings, has the inner or posterior margin of the hind-wings broadly folded upwards; if the wings are drawn strongly forwards, the fold opens, and a bristling, dense beard of long black hair is seen, while at the same time a strong scent becomes perceptible. In the family of the Whites (Pierinae) Leptalis thermesia and the Brimstone Callidryas cipris, remarkable for its slightly tailed hind-wings, are notable in this respect: in both the scent emanates from a patch of peculiar scales, situated on the upper surface of the hind-wings near the costal

1 Kosmos, I. (1877), pp. 391-395.

2 Glaucopis $=$ Syntomis. The viow that tho Syntomidac aro noarly related to the Zygaenidae is now abandoned.-E.B.P.

"Dr. Karl Jordan informs me that tho "Sogelfaltor" or "sailing buttorflies" include Papilio podalirius and its allies-tho group called "Cosmodesmus," by Haase, and "Kite swallow-tails," by Rothschild and K. Jordan.-E.B.P. 
margin, and also covered, in $C^{\prime}$. cipris, with a mane of long hairs. In the males of almost all the Brassolinae-largc, Morpho-likc, but less brilliantly coloured insects, which are on the wing especially in the early morning and towards the evening-the hind-wings are furnished with scent-organs in very different positions and of various forms. I noticed an unusually strong musky smell in a Dasyopthatma, taken on the heights of the Serra, and in this species the male bears, on the blue-black upper surface of the hindwing, an oval, ochre-yellow brand, intersected by the discoidal, and behind it in the cell a long pencil of dull yellow hairs, which the insect can erect and expand at will. In the males of many species of Thecla there is on the upper surface of the fore-wing, near the apex of the cell a generally dark-coloured patch, formed by abnormally shaped, very firmly fixed scales: in the larger spccies one call usually detect a scent emanating from this patch. In the splendid Thecla atys it is very strong, so as to be noticeable as soon as one has the creature in the net, and withal disagreeable and bat-like.

All these and other scent-organs have this in common, that as long as the insect is at rest, they are well concealcd and protected against eraporation, it may be between the wings, between the wings and abdomen, in special grooves, or in pockets formed by a folding over of the margin of the wings (as for instance, in the so-called "costal folds" of many Hesperidae), or in the interior of the body, as in the exsertible glands and filaments of Morpho and the Glaucopidae. These brushes and manes form cxtremely effective perfume sprinklers, being saturated with the perfume when at rest, and then, when suddculy spread ont, unfolding an enormous surface for evaporation.

One is fully justified in attributing the same significance to all these similar contrivances, so widely spread among the Lepidoptera, eren where no scent has as yet been detected, and even if such is actually not perceptible to the human olfactory organs.

Naturally these extrcmely diversc types of scent apparatus did not suddenly appear in their present perfection, but must harc been dereloped from more simple conditions. And inasmuch as many of these arc comparatively recent developments, as is proved by their midcly different structurc in closely allied genera, or even within the samc genus (e.g. P(ipilio), the hope that we may yet discover such simpler conditions is not wholly unjustificd. Since sometimes eren rell-dercloped scent-patches (as in Callidryas philea ${ }^{1}$ malc) or hair-tufts (Mechanitis lysimnia malc) do not distributc any perfume perceptible to us, it is natural that ouc must from the first give up all hope of detecting such simple forms by means of the nosc, and must ascertain their significance in some other manner. And it can, as a matter of fact, be demonstrated, that there arc on the wings of varions buttcrflics scalc structures, which can with great probability be regarded as simple, original scent-organs. Among thesc the scent-scales

1 Seo, however, the terminal note on p. 615.-E.B.P. 
of the male "Maracuja butterflies" are especially remar'kable, since therc can be scarcely any doubt as to their true significance.

The "Maracuja butterflies," as I call them after the plant on which, as is well known, the larvae of all the species live, ${ }^{1}$ form a group of closely allied species confined to the warmer parts of South America. ${ }^{2}$ Thcir long narrow wings give them a look all their own, while thcir coloursgcnerally beautiful, pure, and deep-render them, like Morpho, a rcal ornament to the South American landscape.

They have been divided into fonr genera, Heliconiru, Eueides, Colaenis and Lione (Agraulis), and these genera have hitherto been commoulyincomprehensibly one might say, if under the current system of classification anything could be so called-placed in two different subfamilies or families, the Heliconinae and Nymphalinae.

Coldenis and Dione-and even Eueides-have been torn away from their closest rclative Heliconius, and thrown togrether with Ageronia, with Apatura, with Siderone! Allied in the very closest manner by geographical distribution, by the structure of the larva as well as of the imago, even in their preferences for certain flowers, ${ }^{3}$ they do not appear to approach very closely any other genus of diurnal Lepidoptera. Acraea is perhaps nearest, its larvae agreeing in all important points with those of the Maracuja butterflies.

In ali the male Maracujic butterflies that have been examined there are on the upper surface of the hind-wing-near the costal margin and especially along the costal and subcostal nervurcs-among the ordinary scales certain others of very striking shape, such as I have only secn elsewhere in a male "White" of the genus Hesperocharis. The apical marginusually strongly arched-has a dense fringe, which appears as if stuck together with some foreign substancc. The fringes of a Eucides aliphora, which I bred from a pupa and killed in the course of the first day, appeared almost clean. The scales, with the exception of a pale border along the fringed margin, appeared dull and opaque: their stalk, unlike that of ordinary scales, is slender, thin-skinned and flabby, and the socket in which it is inserted is much larger than that of other scales-sphcrical, and broadly dark margined, as if it contained some strongly refractive substancc. The shape, as shown in Plate H, Fig. $1 a-c$, is somewhat variable.

'There havo been found horo on tho "Maracujá" (Passiflora) tho larvao of Ileliconius cucrate [narcaca], Eucides isabella and aliphera, Colaenis julia and dido, Dione vanillac and juno.-F.MI.

2 Tho group extends up to the northern limits of tho Neotropical Rogion, and one or two species even enter the United Statos,-E.B.P.

${ }^{3}$ Poinsettia pulcherrima in my gardon was visitod last year by numorous spocios of Thecla and a few Erycinidae, but only rarely and exeoptionally ly other diurnal Lepidoptera, oxeopting the Maracuja butterflios, of which almost all the loenl specios eame rogularly and remained eonstantly near the plants. Only kueides pavana, which I saw but three or four times, and Dione moneta, which I saw but oneo, were wanting. - F.M. 
In the males of Colaenis [Metamorpha] dido the scalcs occur tsewhere than on the upper surface of the wings. I first obscrved thcir arrangement more accurately in Heliconius besckei (Pl. H, Fig. 2). The scales of the diurual Lepidoptera form, as is well known, transversc rows, each onc nearer the basc of the wing covering the insertion of the succeeding row like slates on a roof. In each row two kinds of scales alternate, those resting on the membrane of the wing (lower scales) being broader and shorter, the others resting on them (covering scales) narrower and longer.

Where, on the area already described, this regular arrangement is fully carried out, the scent-scales take the place of the covering scales; but their points of insertion rarely lie in the same line as those of the other scales, being usually nearer to the base of the wing. Where the arrangement of the scales is less regular-especially along the costal nervure, where the scent-scales are most numerous-these latter are also apparently scattered quite irregularly among the others.

Their significance as scent-scales is indicated by-(1) their restriction to the male sex; (2) their occurrence at that place, where above all others, the scent structures are found. Here, viz. on the part of the hindwing covered by the posterior margin of the fore-wing, is found, among the Danaidae, the scent apparatus in species of Euploea, here the long hair-tufts of Ithomia, Mechanitis and most of the Heliconius-like Danaidae [Ithomiinae]; among the Satyridae, the large white scent-patch of Gnophodes morpena, the hair-tufts of various species of Mycalesis, a patch with long black silky hairs in Bia actorion; among the Elymminae, the hair-tufts of Elymnias; among the Morphinae, the oval leather-bromn patch of Zeuxidia, and the tufts of Tenaris, Clerome and Thaumantis: among the Brassolinae, the oval patch of Dasyophthalma; among the Nymphalinae, the patch of Lachnoptera; among the Pierinac, the sccntpatch of several species of Leptalis, Callidryas, Nathalis, ctc.; among the Hesperidae, the tufts of Caccina; finally among moths (Hyponomentidae) the long light grey hair-tufts of Trichostibas.

3rd. The fringes on the apical margin, which both farour the collection of the pcrfume when the wings are closed, and also its rapid craporation, as soon as the wings arc spread.

4th. The socket in which the stalk is placed, cractly likc those fonnd in scent-patches diffusing a strong unmistakable scent.

Of the genera usually placed near the Maracuja butterflies, I harc only examined Acraca, Argynnis and Melitaea (of the latter both the Alpine specics, collected by my brothcr Hermanu Müller), but hare bcen unable to discover on the wings anything similar to the scent-scalcs of Heliconius, Iiucides, Colacnis and Dione. T'hns cren this inconspicnons charactcr confirms once again the close affinity uniting the mombers of the Muracuji gronp and their isolation.

Besides the scents which the male buttcrflies cmit to make themselres acceptable to the fcmalc they arc courting, many specics produce odours 
which are offensive to insect-eating birds and other enemies, and are thus protective. Such scents can be at once distinguished by the fact that they occur in both sexes alike, and that the insect emits them when in danger, as for instance, when it is caught hold of. The Maracuja butterflies, among others, possess such a protective scent, and it is very powerful. If one takes hold of any species, male or female, there appear at the apex of the abdomen yellow glands, differently shaped and situated in the two sexes, but in both alike emitting the same objectionable scent. This circumstance might well raise doubts as to the significance attributed above to the scent-scales: it might seem strange that the male should possess, in addition to a very strong scent for scaring foes, another extremely weak perfume to attract the females. To this we may reply, that at least one case is known in which both scents occur, their sources of origin being also close together. Didonis biblis, a pretty, medinm-sized, black butterfly with a broad red band along the margin of the hind-wings, has in both sexes, on the dorsal surface of the abdomen, between the fourth and fifth segments, a blackish hairy double gland, which is exserted when the creature is seized, but the male possesses in addition a white-haired gland also double, which stands out in strong contrast against the black abdomen, between the fifth and sixth segments, and is never voluntarily exserted by the captured butterfly: this is entirely wanting in the female. With carc, it is possible to press forward alternately the anterior and posterior gland, and to assure oneself of the difference between the perfumes. By means of this example, the significance attributed above to the scent-scales of the male Maracujá butterflies-which can scarcely be contested-loses that strangeness which it would possess were it an isolated casc. 


\section{EXPLANATION OF PLATE H.}

Fig. 1.-Scent-scales of male Maracujá butterflies, magnified 180 times. a, Heliconius apseudes; b, H. besckei; c, Eueides aliphera; c. Colaenis [Metamorpha] dido; e, Dione juno.

Fig. 2.-Arrangement of scales in Heliconius beschei. a, lower scales; $b$, covering scales; $c$, scent-scales.

Fig. 3.-Part of inner marginal [submedian] vein of fore-wing of Dione vanillae, male, $90 ; 1$.

Fig. 4.-Part of vein 4 of Colaenis [Metamorpha] dido, male, $45 ; 1$.

Fig. 5.- " " 2 of Colaenis jutia, male, $90 ; 1$.

Fig. 6.-Scent-scales of Colaenis jutia, male. A, hind-wing; B, forewing.

Fig. 7.-Scent-scales of Dione vanillae, male.

Fig. 8.- " " "Euptychia hesione, malc.

Fig. 9.- " " " Erebia goante, malc. 


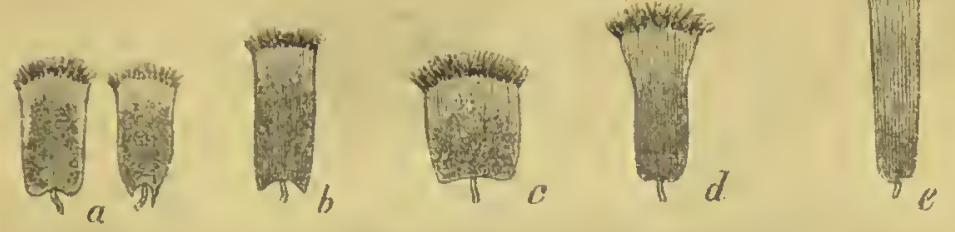

F'IG. 1.

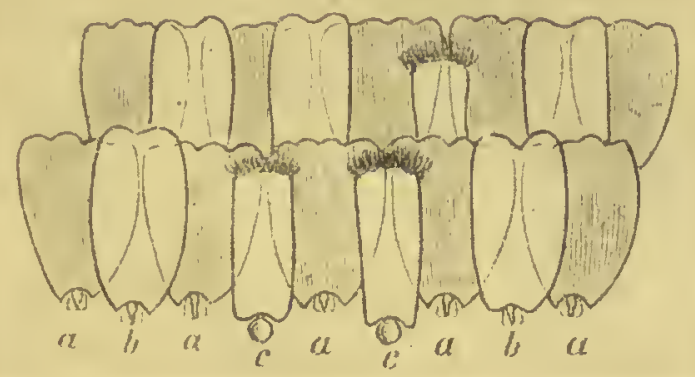

FIG. 2.

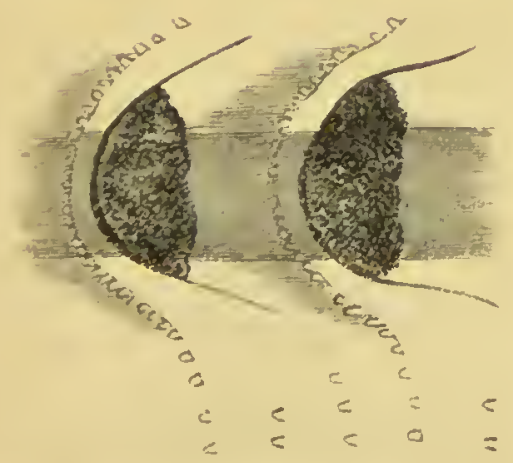

FIG. 3 .

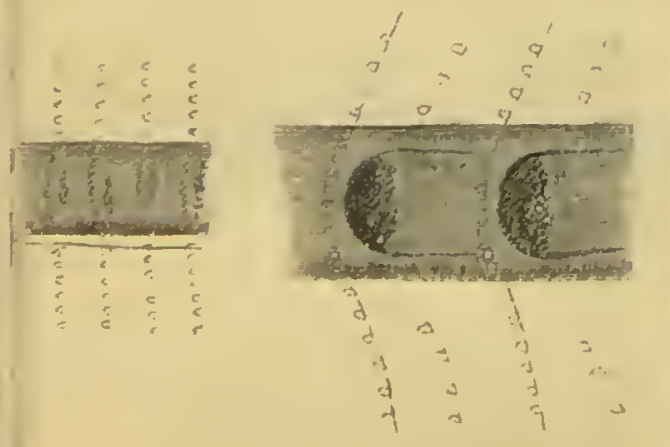

FIt. I.

Fis: 5 .

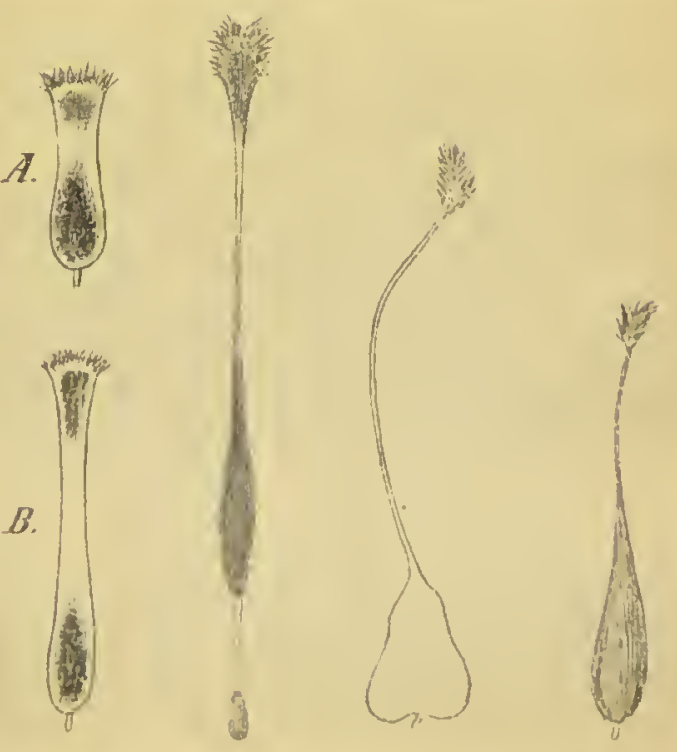

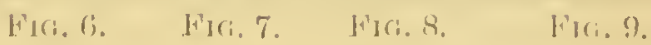

IE'rit\% Müller del.

SGENT-SCALES OH" MATA "MARACLJA BTTERELIES," FTC. 



\section{§XI. The Scent-scales of the Male of Dione vanillae. ${ }^{1}$}

Piats H, Figs. 3-9.

Dione vanillae leads, I might say compels, me to recur to the scentseales of the Maracuja butterflies, because their shape and arrangement in this insect differs so greatly from that of most of its allies.

Although in some years the commonest of the Maracuja butterflies, Dione vanillae has been so scarce this year that I have only recently, at the approach of winter, received the first male. When I looked for scentscales in the usual place, on that part of the hind-wing which is covered by the fore-wing, I could find no trace of them ; but the peculiar appearance of the nervures of the forc-wing showed me at once where to search. The first six veins of this wing (adopting Herrich-Schaeffer's notation; therefore the inner marginal [submedian] vein and the branches of the median and discoidal [radial]) appear on the foxy-red ground colour as broad, inflated black streaks, and further examination shows that these streaks are composed of a row of dilatations running transversely across the vein and separated from one another by the naked, scaleless parts of the vein. On these dilatations stand densely packed scent-scales, whose shape reminds onc rather of those of many Satyridae than of the other Maracuja butterflies.

However much one may be aceustomed to find so-called "secondary sexual characters" taking very different forms in closely allicd spceics, I was surprised to find such a radical differcnce within such an exclusive circle as that of the Maracuja butterflies. The surprisc vanished when I beeame convinced that the arrangement of the scent-scales in Dione vanillae is connected with that of the other Maracuja butterflies, by intermediate forms.

In Heliconius, where the scent-scales are confincd to that part of the hind-wing covered by the fore-wing, they are always most numerous along the veins. In Colaenis dido male, as I believe I mentioned in my first communication, the scales are not eonfined to that one spot, but seattercd over the whole wing, and, as a more accurate investigation has now shown, they occur exclusively on the veins. They arc found on veins $2-8$ of the hind-wings, also on 1-7 of the fore-wings, being most numerous on those veins of the hind-wings which are covered by the fore-wings. All the

1 Kosmos, II. (1877-78), pp. 38-41. 
rows of scales on the wings run, as usual, uninterruptedly, almost straight -being only slightly curved towards the base of the wing-across the veins, on which the scales are more crowded than elsewhere. Here, on the vein between every pair of rows of ordinary scales lies a group of scent-scales in a densely packed transverse double row (PI. H, Fig. 4).

In Colaenis julia, male, the scent-scales of the hind-wing are confined to the veins 7 and 8, which are covered by the fore-wing: they are especially numerous on 7 , the first branch of the subcostal, and are here arranged as in Colaenis [Metamorpha] dido. But besides these, there are scent-scales on the fore-wing also, on veins $1-3$, which even at this stage show an arrangement recalling that of $D$. vanillae. Only the scales of every other row curving towards the base of the wing, run uninterruptedly across the veins and the scales which lie actually on the veins are longer, narrower, and more closely packed than elsewhere, and overhang a semicircular, somewhat depressed patch, covering about two-thirds of the breadth of the vein, a patch which is densely packed with scent-scales (Pl. H, Fig. 5).

In Dione juno, male, the scent-scales appear to be wanting from that part of the hind-wing covered by the fore-wing. It is true that a ferr are sometimes found among the scales taken from that area, but I could nerer determine whether they had been really inserted there. They do, however, occur both on veins 2-6 of the hind-wing and 1-6 of the fore-ming, being arranged as in Colaenis dido. Where they are especially numerous, as on the inner marginal [submedian] vein of the fore-wing, the rors of scales are more strongly curved and on the vein the groups of scent-scales contain more rows, so that the arrangement approaches that of the forewings of Colaenis julia.

Finally, in Dione vanitlae, male ( $\mathrm{Pl} . \mathrm{H}$, Fig. 3), the scent-scales arc confined to veins 1-6 of the fore-wing. On 1 , the inner marginal [submedian] vein, they occupy the distal two-thirds of the length, on 2,3 and 5 the whole length, on 4 they are prolonged basally beyond the end of the cell, while on 6 they begin a little beyond the cell. In this species only every third row of scales runs uninterruptedly across the scent-scale bearing veins, and is strongly curved towards the base. About half of the space between every two of the rows which cross the veins is occupied by a patch of densely packed scent-scalcs, extending beyond the rein on each sidc.

As in the arrangement, so also in the shape of the scales, Colaenis jutia forms a transition between Colaenis dido and Dione vanillae. The scentscales of the hind-wing (Pl. H, Fig. $6 \mathrm{~A}$ ) resemble closely, both in arrangement and shape, those of Colcenis dido, while those of the fore-ring (Pl. H, Fig. 6 B), almost twice as long, far more slender, and contracted into a neck below the apex-to some extcnt recall by their shape the scales of Dione vanillace.

In this last specics the long, rod-like scent-scales (Pl. E, Fig. 7) attain 
a length of about $0.7 \mathrm{~mm}$. An opaque, expanded clavate base, which recalls the scent-scales of some "Whites" [Pierince], is followed first by a slender transparent stalk of about one-eighth of the total length, then by an elongate, narrow lancet-shaped section which again contracts into a slender stalk, finally by a narrow, elongate, rounded and fringed terminal plate. The scales which, in a densely packed semicircle, surround the scent-scale area are three times as long as the other scales, and differently formed: they appear to furnish a sort of protective fence to the scent-scales.

Among the scent-scales of other butterflies known to me, those of various Satyridae are somewhat similar to Dione vanillae.

In colour and marking, and especially in the silvery patches on the under side of the wings, Dione vanillae comes so close to many of the Fritillaries, e.g. the German Argynnis aglaia, that I once more examined these latter butterflies for scent-scales. On those parts of the hind-wing covered by the fore-wing, where I had previously sought them, I had found none; but I have now discovered them, as in D. vanillae, on the nervures of the fore-wings. In the males of Argynnis aglaia and niobe, they appear to be confined to veins 1-4, and are not united into groups, but irregularly distributed. Their shape is similar to those of Erebia goante (Pl. H, Fig. 9). A mole exact description may well be left to those who are able to examine them in a fresh condition.

Finally I give a synopsis of the occurrence of scent-scales in the abovementioned species.

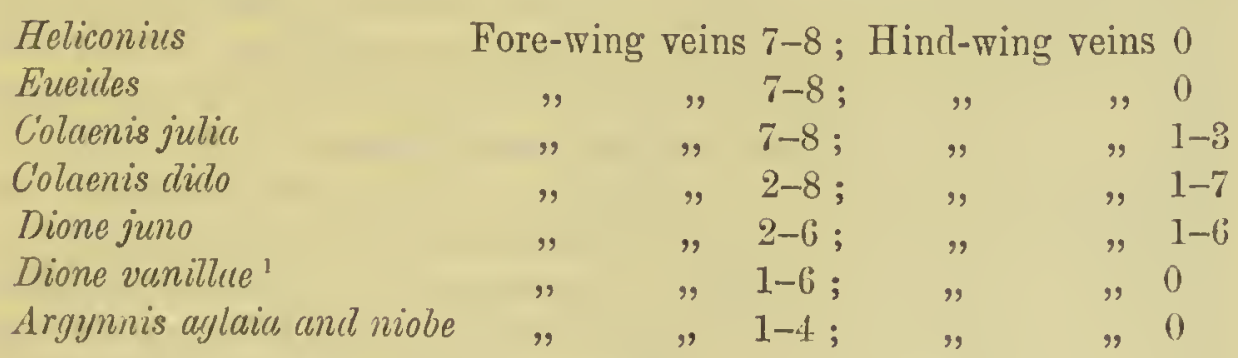

'In this species, as well as in A. aglaia and $A$. niobe, the figures for the fore-and hind-wings are aceidentally transposed in the original table.-E.A.E. 


\section{§ XII. The Stink-clubs of the Female "Maracuja Butterfies."}

Plate J.

THe following paper deals with the female stink-glands in the genera Heliconius, Eueides, Colcenis [including Metamorpha] and Dione (Agrantis) -bound together by the elosest ties of blood-relationship - which, from the food-plant of their larvae, I unite under" the term "Maraeuji butterflies." A female belonging to any of these genera, when one takes hold of it, protrudes from the apex of the abdomen, on the dorsum between the penultimate and last segments, a large, yellowish, nauseous smelling gland (Pl. J., Fig. 1 W, Fig. 3 A, W) divided into a right and left eonvex half by a shallow furrow. The males of these butterflies possess, on the inner side of the anal valvulae, tro smaller glands which emit the same seent.

I observed a short time ago that a eaptured female of our beautiful green butterfy, Colaenis [Metamorpha] dido, when first seized, quiekly extruded the large stink-gland in the usual manner. When the creature had beeome quiet and was then again disturbed or irritated, the gland was rather slowly exserted, and I then noted that the smell did not increase gradually, but suddenly was noticeably strengthened. It was then seen that this increase was due to the appearanee of two tiny organs whieh I had hitherto overlooked-little stalked clubs, whieh might be eompared to pins or to the halteres of Diptera, of which one is placed on eneb side of and beneath the stink-glands, on the posterior margin of the penultimate segment. One has only to ent off the apex of one of these stink-clubs in order to become eonvineed that the strengthened smell of the stink-gland really proceeds from them.

The agrcement between all the Maraeujis butterflies, in structure and mode of life, down to the smallest detail, led me to believe that the stinkelubs also would not be eonfined to a single speeies, and, as a matter of faet, I have found them in all those I was afterwards able to examine. namely, in addition to Colaenis [Metamorpha] dido, in Heliconius apseudes. besclkei and eucrate [narcaea], Eneides isabolle, Dione juno, and vanillae. Thus these stink-clubs furnish further proof of the close relationship between four genera whieh have hitherto always been dirided between the two sub-families of the Helironinae and Nymphalinae, Eueides being

1 Ticitschr. Wiss. Zool., XXX. (1878), pp. 167-170. 
placed sometimes in the former group (Herrich-Schaefer, Kirby), sometimes in the latter (Doubleday, Felder). Partly for this reason, partly on their own account, these peculiar structures are worthy of further notice.

The stink-clubs, as already mentioned, are situated, one on each side, on the posterior margin of the penultimatc abdominal segment, below the stink-gland, and at the apical angle of the ventral plate of the segment. From thence, when the stink-gland is exserted, they are directed backwards and outwards. They consist of a chitinous stalk about $1 \mathrm{~mm}$. in length, with a terminal club. The thickening is very gradual, and in Heliconius apseudes and eucrate [narcata] (Pl. J, Fig. 5 A, B) the elub reaches barely twice the diameter of the stalk. The pear-shaped extremity is somewhat thicker in Eueides isabella (Pl. J, Fig. 6 A, B), and still more so in Dione juno (Pl. J, Fig. $7 \mathrm{~B}$ ): it is approximately spherical in Dione vanillae (Pl. J, Fig. 8 A), Heliconius besckei (Pl. J, Fig. 4 A), and Colaenis [Metamorpha] dido (Pl. J, Fig. 2 B), the diameter of the club head being nearly $0.5 \mathrm{~mm}$. in the last-named species.

The stalk is usually of a lighter or darker brown : in Eueides isabella (of which I have only examined a freshly emerged female) it is quite pale, almost colourless, but in Dione juno it is black. The head is usually paler than the stalk, and of a yellowish or brownish tint: I found it darker than the stalk in Dione vanillae.

The head of the stink-club is covered with scales, which exhibit different forms in the different species. Those of Heliconius, especially $H$. apseudes (Pl. J, Fig. 3 B), approach nearest to the usual appearance of butterfly scales. Here one finds a few entirely regular scales, whose lateral margins are straight from the very point of attachment, diverging from each other at a more or less acutc angle, and finally ending in about five long sharp teeth on the apical margin-scales such as one finds not uncommonly on the wings of many Heteroccra. The apical teeth, which are sometimes almost thorn-like, are of a stronger consistence than the flat basal part which often seems to be folded or crumpled. Among these are numerous less regular seales, which ean, however, be traced to the same type form. The seales of Heticonius besckei (Pl. J, Fig. $4 \mathrm{~B}$ ) and H. eucrate (narcaea) (Pl. J, Fig. $5 \mathrm{C}$ ) are similar, but as a rule even less regular and more bent or distorted.

In Eueides isabella (Pl. J, Fig. 6 C) these seales are of stronger build, and their lateral margins, before diverging, run a short distance parallel, and thus form a stalk which extends to about one-third or one-half of the entire length: the "palm" " is smaller than in Heliconius and usually dividcd into three long pointed tecth.

Far coarser is the shape of the scales on the stink-club of Dione vanillae (Pl. J, Fig. 8 B); the palm has here cntirely disappeared, and

"Gorm. "Sproite" = any spread-out part, such as the palm of a band, which the scale closely resembles.-E.A.E. 
there remain only the stalk and the long sharp thorn-like teeth, so that the seales resemble two- to four-pronged forks, often wonderfully bent and twisted.

The seales of Dione juno (Pl. J, Fig. 7 B) are metamorphosed in an entirely different manner, and ean searcely be reeognized as scales. An elongate, but rarely straight, stalk is widened at the apex into a tiny "palm," whieh may even be entirely wanting. From the palm, or from the apex of the palmless stalk, spring one, two, or rarely three bristles, either immediately, or separated from the palm by another kind of stalk whieh is usually straight and also mueh shorter and thinner than the basal one. These various parts stand at all sorts of angles to each other, thus making an ineredible number and variety of strange forms. It may also happen that the stalk instead of widening into a palm, forks, and each braneh of the fork bears one or two bristles.

In eontrast with the stiff, forked thorns of Dione vanillae are the scales on the stink-clubs of Colaenis (Pl. J, Fig. 2 C), which are metamorphosed into flabby, thin-skinned, usually strongly folded and erumpled plates, without any notehing of the apical border.

Whatever may be the form of these scales, they can hardly be seen on the fresh stink-elub, exeept perhaps in inseets that have just emerged. Among them is heaped a yellow, seented mass, whieh is also exuded from the surface of the stink-gland. The seales are stuek together and often eompletely eovered by this substance, so that the stalk bears at its apex a nearly smooth or slightly rough ball, with a diameter two or three times as large as that of the club itself (Pl. J, Figs. 2 A, 5 A, 7 A). With aleohol, ether, or benzine, this stieky mass ean be softened, partly dissolred, and finally more or less eompletely removed. The undissolved residue takes the form of strongly refraetive, more or less spherieal particles (Pl. J, Fig. $5 \mathrm{~B}$ ) or of irregular clots.

I have not found similar stink-elubs in any Lepidoptera exeept these females of the Maracujá butterflies. It appears, as a general rule. that the stink struetures found in both sexes are mueh less wide-spread and much less varied than the seent-glands peculiar to the male, of whieh, now that attention has been direeted to them, new and astonishing forms are almost daily discovered.

Itajahy, Sta. Catharina, Brazil, June, 1877. 


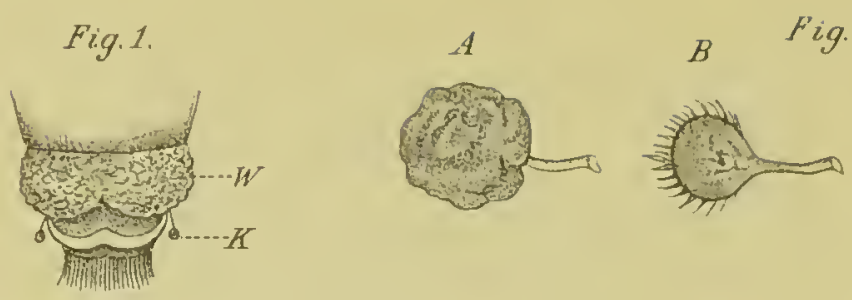

Fig. 3.
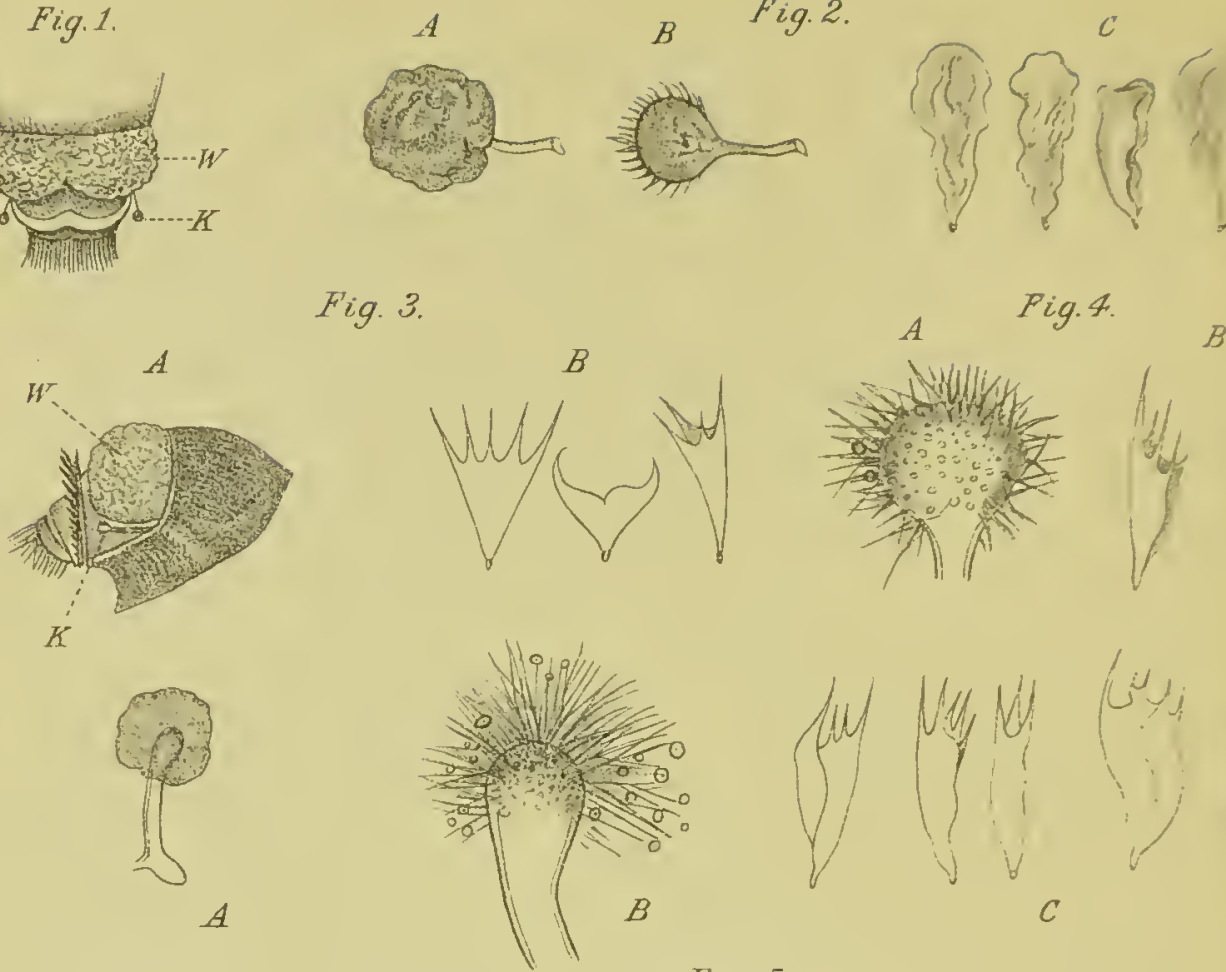

Fig. 4. $B$

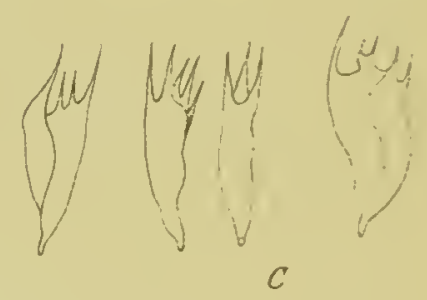

Fig. 5 .

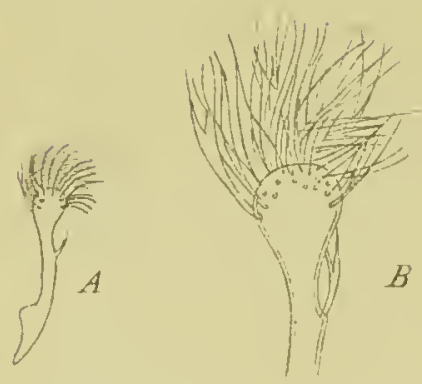

Fig. 6.

Fig. 7.
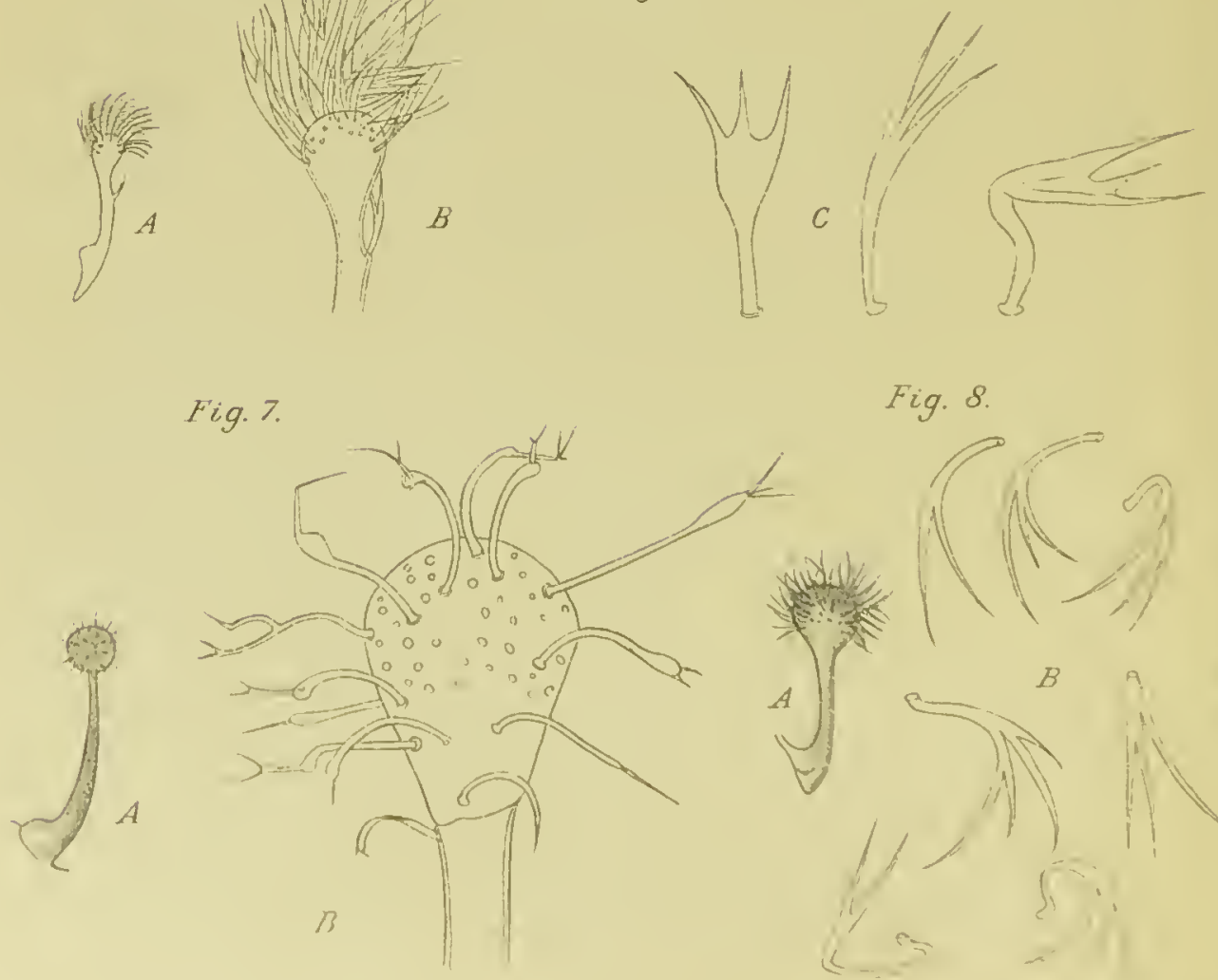

Fig. S.

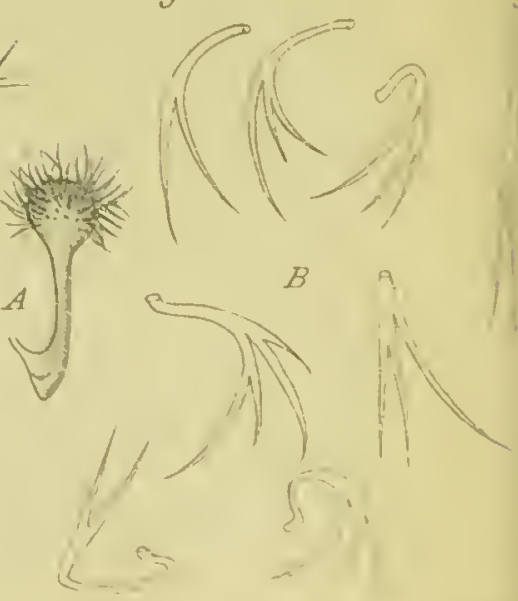




\section{DESCRIPTION OF PLATE J.}

Fig. 1.-Colaenis jutia, female. Apex of abdomen with protruded stimk-glands, seen from above, about 5 times natural size. W, stinkgland; $\mathrm{K}$, club.

Fig. 2.-Colaenis [Metamorpha] dido, female. A, stink-club in fresh condition; $15 ; 1$. B, the same cleaned, $15 ; 1$. C, scales from club, $90 ; 1$.

Fig. 3.-Heliconius apseudes, female. Apex of abdomen, lateral view, with the stink-gland artificially forced out, $15 ; 1$. W, stink-gland. K, club. B, scales from club, $90 ; 1$.

Fig. 4.-Heliconius besckei, female. A, head of stink-club, cleaned, $45 ; 1$. B, scales of same, $90 ; 1$.

Fig. 5.-Heliconius eucrate [narcaea], female. A, fresh stink-club, $15 ; 1$. B, head of same cleaned, $45 ; 1 . \quad$ C, scales of same, $90 ; 1$.

Fig. 6.-Eueides isabella, female. A, stink-club from a freshly emerged insect, 15;1. B, head of same, $45 ; 1$. C, scales of same, $90 ; 1$.

Fig. 7.-Dionc juno, female. A, a fresh stink-club, 15; 1. B, the head, clcaned, only a fow of the appendages shown, $90 ; 1$.

Fig. 8. -Dione vanillac, female. A, a stink-club, 15; 1 . B, thornlike scales from same, $90 ; 1$. 



\section{INDEX}

Abacetus, Dej., 179

abbreviatum, Boisd., Adelium, 440

abdicalis, Walk., Entephria, 129

abdominalis, Fabr., Serinetha, 362

A bell, Mr., 271, 503, 507

abeona, Don., Tisiphone, 483

aberration, 101, 102, 257, 304, 308, 310,

$311,315,323,324,329,345,353,354$, $405,406,407$

abietaria, Hübn., Boarmin, 11

Abisara, Feld., 79, 127, 349, 391, 548

abispoides, MI.-Waldo, Rhynchium, 485.

Plate VI., Fig. 9

Abraxas, Lueach, 118, 138, 141, 143, 517

abrogata, Walk., Asaphodes, 469, 470, $472,473,482$

abruptaria, Thunb., Hemerophila, 172

Abú, Mount [India], 93

Abû Fêdah [Egypt], 429

Abû Gurâb [Egypt], 433

Abû Hamed [Sûdân], 423

Abû Roâsh [Egypt] , 434

Abû Simbel [Nubia], 402, 405

Abydos, 428, 429

Acacia sp. [Leguminosae], 407, 410, 411, 413

acaciae, Ḱlug, Taragamn, 428

Acaena sanguisorbae, Vahl [Rosaceae], 473

Acanthaspis, Am. \& Serv., 97, 221, 249, 359

dcanthocephala, Lap., 257

Acantholepis, Mrуг, 179, 201, 201, 233, 249

Acantholipcs, Lcd., 408

Acantholycus, Bourg., 189, 241

Acanthonyx, Hmpsn., 203

acanthurn, Westw., Diploxys, 211

Acanthyllis tragrcanthoidos, Pomol [T/eguminosae], 159

Acavus grcvillei, Pfr. [Mollusca], 343

aceris, Cram., Neptis, 80, 81, 83, 84

acervata, Klug, Adesmia, 159, 160

Achrea, Hübn., 358

achantr, Don., Xenica, 484

Achatina zebra, Chom. [Mollusca], 182 ;

A. simplex, Smith, 201

achemon, Fabr., Cosmosoma, 290

achoronta, Frbr., Coen, 284

Achcrontia, Hübn., 24, 360 achine, Cram., Teracolus, 188, 191, 1.2 , $197,212,217,222,235,239,241,511$

achilles, Linn., Morpho, 501

Aohlyodes, Hübn., 516

achroiaria, Feld., Xynonia, 468

Achryson, Serv., 295

Acidalia, Hübn., 8, 20,

Aciphylla squarrosa, Forst. [Umbelli. ferae], 477

Acleros, Mabille, 191, 198

Acmoeodera, Eschsoh., 177

Acolastus, Scudder, 289

Acontia, Hübn., 358

acontius, Linn., Epicalia, 501

Acraea, Fabr., 186, 187, 190, 195, 196 , $204,211,212,213,214,219,220,221$, $222,223,225,226,228,231,232,422$, $504,505,517,519,529$. See also Actinote, Pareba, and Telohinia

Acraga, Walk., 291

Acridium, Geoff., 159, 169, 174, 176, 195, $206,233,245,413,418$

Acrobasis, Zell., 172

Acronycta, Treit., 15, 20, 24

Acropteris, Hübn., 81

Acrotylus, Fieb., 158, 175, 177, 209

acte, Mooro, Ticherra, 81

Actias, Loech, 129

Actinoto, Hübn., 279, 305, 306, 310, 314, $323,504,519$

actuaria, Walk., Idaoa, 359

rcuminatus, Fabr., Rhadinosomus, 402.

Plato VI., Fig. 4

Acupalpus, Latr., 204

acutipounis, Butl., Enantia, 256

acutus, Porez, Colletes, 165, 177

adroquata, Bork., Emmolosia, 20

Adam's Poak [Coylon], 116, 117

adamsi, Lathy, Sphronogona, 286

adansoni, Latr., Apis, 179, 198, 199, 207, $213,220,235,248,249$

Adansonia digitrta [Sterculiuceac], 218

adaptation of grasshopper's log for swimming, 375, Fig. 13

Adoixis, Warron, 455

Adela, Latr., 14

Adolaido, 487

adolica, Kirsch, Orprona, 189

Adolium, Kirby, 440, 470,476, 483

Adolpha, Hübn., 255, 324 
Adona, Walk., 469

Adenocarpus sp. [Lcguminosae], 28

Adesmin, Fisch., 158, 159, 160, 164, 165, $166,225,399,401,427,430,431$

adductalis, Walk., Sylepta, 359

Ad Duwêm [Sûdân], 416, 417, 426

adiante, Hïbn., Hypocysta, 484

Adiantum capillus-veneris [Filices], 33

adippe, Linn., Argynnis, 11

adjurellus, Walk., Schoenobius, 340

admirationis, Guen., Euxoa, 451, 456, 480

admixtalis, Walk., Bradina, 48, 192

Adolias, Boisd., 346

adonis, Frbr., Lycaena, 8

adonis, Cram., Morpho, 501

Adoretus, Lap., 413

adreptella, Walk., Carposina, 467

adusta, Esp., Hadena, 16, 22

adusta, Plötz, Heliopetes, 308

adusta, Wied., Xylorrhiza, 362

advenaria, Hübn., Epione, 143

advertisements, Chinese, 131, 132

Aegeria,"Fabr., 530 Japanese, 135

aegeria, Linn., Pararge, 79, 154, 155, 169,

$292,540,542,543,554$

aegistus, Fabr., Sematura, 292, Fig. 11

aegnusalis, Walk., Epicrocis, 359

aegon, Schiff., Lycaena, 8

Aegopsis, Burm., 333

aegrota, Butl., Coremia, 469, 479

aegyptiaca, Guér., Myzine, 409, 428

aegyptiacum, Linn., Acridium, 159, 169,

$174,176,413,418$

aegyptius, Wied., Syrphus, 192, 400

aelianus, Fabr., Lampides. See celeno

Aellopus, Hübn., 229, 263

Aemene, Walk., 357

aenea, Walk., Rhinia (Idia), 413

aenea, Latr., Usia, 177

aeneides, Esp., Papilio, 326, 516

aeneipennis, De Geer, Xylocopa, 298,

$316,321,333$

aeola, Dall., Jadera, 297, 333

aequilineata, Walk., Docirava, 44

aequinoctialis, Linn., Homophoeta, 265

Ac̄ria, Hübn., 310, 312

Aerva javanica, Juss. [Amarantaccae], $407,410,412$

Aeschrodomus stipulatus, Reevo [Mollusca], 477, 479. See also Endodonta restuans, Linn., Xylocopa, 396, 400, 402, $411,417,421,428,429,435$

Aotheria olliptica, Lam. [Mollusca.], 426 ;

A. tubifora, Sow., 426

aethiops, Esp., Erebia, 19, 25

affinis, Walk., Acanthocephala, 257

iffinis, Butl., Acantholipes, 408

affinis, Adams, Diopsis, 217. Plate II.,

Fig. 5

affinis, Píring., Harpalus, 210

affinitata, Guen., Eucosmin, 319

Affrevillo [Algeria], 175 africana, Pallas, Gryllotalpa, 428

africana, Chap., Physodactyla, 245

africana, Linn., Polyphaga, 436

africana, Butl., Xantho-spilopteryz, 233

africanus, Verrall, Helophilus, 230

afternoon, more fomale butterflios seen

during, 371,421

Agalope, Walk., 42, 44

agamemnon, Linn., Papilio, 104, 112 , $337,355,371,383,520,525,526,538$, 539

aganice, Hew., Planema, 197, 504

Aganisthos, Boisd., 284, 524, 571

Agapanthia, Serv., 175

agarithe, Boisd., Phoebis, 331, 507

agatha, Cram., Neptis, 190, 197, 222, 228, 502

agathalis, Walk., Pyrausta, 293

agathina, Cram., Mylothris, 183, 186, 188, $191,193,197,234,241,514,530,535$

Agathis australis, Salisb. [Coniferae?, 447

Agave sp. [Amaryllidaceae], 168, 150

agenor, Linn., Papilio, 80

Ageronia, Hübn., 257, 321, 324, 501

agilis, Smith, Larra, 237

aglaope, Motsch., Ganoris, 137

aglea, Cram., Parantica, 10S, 110, 111, $120,339,344,367,369,370,381,336$,

$496,520,526,529,530,536$

agleoides, Feld., Danais, 124

Aglossa, Latr., 18

agna, Godm. \& S., Aëria, 312

agnosia, Hew., Ithomia, 312

Agonopteryx, Hübn., $160 . \mathrm{Sec}$ also Depresśaria

Agonoscelis, Spin., 192, 215

agorastis, Meyrk., Morrisonia, 468

Agra, 91

agra, Hew., Thecla, 307 .

agrestis, Fabr., Nomada, 174, 177

Agria, Desv., 209, 398, 400, 413, 416, 432

Agriolimax agrestis, Limn. [Mfollusca], $441,445,456,473$; A. laeris, Miìll., 459,464

Agrion, Fabr., 317

agrionata, Walk., Tatosoma, 479

Agriopis, Boisd., 9

agrorum, Fabr., Bombus, 532

Agrotis, Ochs., 7, 14, 16, 18, 27, 64, 166,

$172,176,291,397,402,416,421,427$,

$428,429,451,463,475,576$. Sce also

Euxoa

ahonoum, Dhlb., Hedychridium, 412

Aitkin, E. H., 75, 55t, 561

Ajurí, 92, 93

Akbar the Great, 62, 91

akbarella, Rag., Oligochroa, 49, 62

Akis, Herbst, $15 \mathrm{~S}$

Almenn, Boisd., 189, 568

Alam Bagh, 66

alnua, Heliopetes, Reak., 303

Alann, Walk., 374

Alaus, Eschsch., 239 
alba, Trimon, Pinacopteryx, 191 albata, Feld., Thecla, 326

Albatross, 439

albicans, Walk., Elousa, 291

albicilia, Moore, Sarangesa, 356

albieineta, Klug, Cereeris, 410

albifaseia, Walk., Zalissa, 128

albigena, Lep., Podalirius, 400, 427, 432, 433

albilatera, Stri., Pseudo-deropeltis, 239

albimaeulata, Butl., Amauris, 187, 190,

$196,235,241,246,496$

albimedius, Walk., Tabanus, 393

albinus, Lanzkneeht, Danaida, 406

albipuncta, Fabr., Cirphis, 172, 176

albipunctella, Hubn., Depressaria, 14

alboeincta, Rad., Megachile, 399, 402, 403,411

albofaseiata, Th., Andreua, 163, 171

albofasciata, Moore, Gomalia, 189, 195, 232

albofasciatus, Smith, Halietus, 250, 581

albomaculata, MIcq., Catabomba, 164, 165, 434

albonotaria, Brem., Zettienia, 138, 143

alboradiata, Auriv., Aeraea, 219, 220, 221, $222,223,228,504$

albosignata, Oberth., Caradrina, 77

albula, Cram., Terias, 256, 257, 305, 306,

$315,319,321,326,330,509$

albulata, Schiff, Emmelesia, 11, 565

Aleadia sp. [Mollusca], 302

aleesta, Cram., Nyehitona, 197

alcibiades, Fabr., Papilio, 49, 127

Alcides, Dalm., 362

alcinous, Klug, Papilio, 134, 516

aleippoides, Moore, Danaida, 406

alcippus, Cram., Danaida, 395, 405, 406, 417

Aleis, Curt., 319

aleyonea, Erichs., Prosopis, 485

alectoraria, Walk., Xynonia, 468

alexis, Stoll, Lampides, 73, 84

alcxis, Nloore, nec Fabr., Parata, 357

alexonaria, Walk., Oenothalia, 292

Alfred, MIt. [N. Zcaland], 475, 477

Algcr, 154, 155

algeriana, Lueas, Thalpomena, 170, 174

algericus, Brunn., Pumphagus, 161

algira, Lepel., Eucera, 165, 177

Ali Musjid, 50

aliphera, Godart, Euoidos, 255, 324, 503

Allaeta, Sauss. \& Z., 465

Allamanda sp. [A pocynaccac], 59

Allen, C. E. E., 226, 227, 231

Allodiseus mossi, Murdock [Mollusca], 473

almana, Linn., Procis, 51, 55, 58, 60, 68, $71,73,85,96,107,120,121,123,317$, $366,390,502,521,588,539,590,591$

alni, Linn., Aeronycta, 15

Aloa, Walk., 340

Aloë arboreseens [Tiliaccae], 180, 201; A. feros, 180,182
Aloëides, Irübn., 212, 215

alopa, Meyrk., Morrisonia, 478

alope, Druee, Aneery $x, 292$

Aloysia eitriodora [Verbcnaccae], 491

Alphitopola, Dej., 238

alpina, Dale, Scoparia, 21

alpinalis, Sehiff., Scopula, 21

alternana, Wilkin., Sericoris, 19, 21

Aluaea, Walk., 262

Alucita, Fabr., 7, 361, 447

alveolus, Hübn., Syriehthus, 8

alysos, Moore, Plesioneura, 356

Amâda [Nubia], 402

amalthea, Linn., Anartia, 255, 306, 313 , $319,321,324,329,551$

amalthea, Fabr., Melipona, 265, 316, 327 , 332

amanga, VVestw., Axiocerees, 223, 225

amaryllis euryades, Riff., Heliconius, 255

amatus, Fabr., Teracolus, 94, 376, 380, 589

Amauris, Hübn., 185, 187, 190, 196, 235, $241,246,496,497$

amazonum, Smith, Tachytos, 260

amazoula, Boisd., Alaena, 189, 568

ambareesa, Moore, Celaenorrhinus, 391, 572

ambiguus, Per., Podalirius, 158, 165

Amblyscirtes, Seudd., 150

American energy, 264, 303

amethystinum, Fabr., Stilbum, 397, 398, 412

amista, Germ., Serinetha, 246

Ammalo, Walk., 290, 318

ammonia attractive to butterflies, 377

Ammophila, Kirby, 207, 224, 230, 240, $396,410,434$

Ampelopsis sp. [Ampelideac], 45, 63; A. veitehii, 145

ampelos, Edw., Coononympha, 148

Amphibola cronata, Martin [Mollusca], 449,470

Amphipepla ampulla, Hutton [Mollusca], 464,477 ; . arguta, Hudson, 458

Amphipyra, Oehs., 12

Amphirene, Doubl., 314

Amphisa, Curtis, 21

Ampittin, Moore, 106, 356

ampla, Walk., Lymantria, 360

Ampulex, Jur., 239, 412

Ampullaria kordofana, Parreyss [M lusca], 424 ; $\Lambda$. wernei, Phil., 424

Amritsar, 60

Amsaeta, Walk., 340

amuronsis, Mén., Leptosia, 140

umymone, Godart, Crastia, 131, 498, 519

Amyna, Guen., 361, 386

amyntas, Linn., Acolastes, 289

Amynthia, Swains., 315

anacardi, Limn., Salamis, 186, 187, 190, $193,197,502,597,594,595$

Anachloris, Moyrk., 447, 451, 456, 457

anadyomenc, Feld., Argynuia, 139

Anaca, Hübr., 308 
Anagoga, Hübn., 138, 143

analis, F'abr., Pompilns, 64

ananiformis, Linn., Lagocheirus, 295

Anantrípúr, 95, 96, 97

Anartia, Hübn., 255, 264, 278, 279, 283,

$304,306,313,319,321,324,329,524$,

$551,552,580,581,582$

Anastrns, Hübn., 289, 572

Anatossa, Warren, 468

Anaulacus, MacL., 247

anaura, de Nicér., Castalius, 80

Anax, Leach, 248, 437

Anceryx, Walk., 292

Anchocelis, Gnen., 9

Anchylopera, Steph., 14

ancient times, butterflies of, 395

Ancistrocerus, Wesmael, 170, 173. See

Odynerus

Ancon [Panama], 303, 304

ancorifrons, Boh., Strophosomus, 192

Ancylodes, Rag., 402

Ancylolomia, Hübn., 359

André, E., 103

andreao, Linn., Dysdercns, 297

Andrena, Fabr., 158, 163, 164, 165, 168 ,

$169,170,171,173,176,399,403,435$

andreniformis, Smith, Apis, 375

andromica, Hew., Hymenitis, 310, 312

anemone, Feld., Terias, 137

anemosa, Hew., Acraea, 219, 220, 222, $225,228,232,504$

anerastiodes, Warr. \& Roth., Polyocha, 409

Anesychia, Steph., 172

angolanns, Goeze, Papilio, 217, 222

angularis, Stål, Acanthaspis, 359

angularis, Dall., Gonopsis, 206

angulata, Fabr., Pimelia, 396, 397

angulatr, Walk., Rhynchina, 358

angustana, Hübn., Eupoecilia, 20

angustea, Steph., Scoparia, 168, 172

angusticollis, Spin., Polybia, 317

angusticollis, Deyr., Zophosis, 214

angustifrons, A beille, Trichodes, 434

angustipennis, Zell., Crambus, 452, 470

angustipennis, Boh., Harpalus, 205,

anieta, Hew., Phyciodes, 305, 307, 309,

$310,313,319$

Anisodactylus, Dcj., 231

Anisodes, Guon., 262, 293, 332

Anisolabis, Fieb., 445

Anisonyx, Latr., 249

anna, Wllgr., Teracolus, 188, 212, 510

annexa, Kohl., Cerceris, 410

Annonna [Algeria], 168

annulalis, Hiibn., Nacoleia, 293

annnlaris, Linn., Polistes, 309, 317, 321,

327

anmulata, Boisd., Dcilomera, 443, 144,

$445,446,453,454,457,460,461,470$,

518,521

aunulatr, Fabr., Syntomis, 483, 485

annulatus, MI.-Waldo, Labus, 214

Anomala, Samouolle, 382, 388 anomala, Haw., Stilbia, 16, 15

Anomalipus, Guér., 190, 211

Anomoeotcs, Feld., 198

Anopheles, MIeig., 97, 100, 101

Anoplochilus, Burm., 246

Anosia, Hübn., 76, 329. See also Danaids

antaeas, Dbl. \& H., Actinote, 305, 30C, $310,314,323,504,519$

antalus, Hopff., Virachola, 189, 194, 198, $420,422,566$

Antarchaea, Hübn., 418, 419

antarctica, White, Somatidia, 465, 469, 479

antarcticum, White, Nonomorium, 463, 477

Antennaria sp. [Compositae], 440, 528

Antestia, Stål, 190

Anthia, Web., 161, 163, 164, 166, 218 , 435

Anthidium, Fabr., 170, 174, 177, 392, 411

Anthophora, Latr. See Podalirius

Anthracias, Stev., 198, 362

Anthrax, Scop., 177, 214, 384, 386, $₫ 13$, 483

Anticlea, Steph., 11, 14

Antigastra, Leder., 198, 239, 391

antigone, Boisd., Teracolus, 212, 217. $222,227,228,231,232$

antiopa, Linn., Vanossa, 14, 25, 140, 539, 541

antiphates, Cram., Papilio, 127

antipodum, Doubl., Argyrophenga, 469, 482

antirius, Butl., Hypocysta, 4St

Antirrhaea, Hübn., 499

Antithesia, Steph., 19

ants, abundance of, in S. Africa, 205

Anuradhapura, 86, 375-377

anynana, Butl., Mycalesis, 227, 228

aoris, Doubl., Cirrhochroa, 82,83

Apate, Fabr., 221

Apatura, Fabr., 25, 316

ape, 175

Aphaenogastor, Mayr, 165, 169, 173, 210 , $396,409,431,434$

Aplanus, Lap., 340

Aphelia, Steph., 19

Aphnaeus, Hibu., 68, 69, Fig. 5, 73, 220, $285,351,564,567,568,569$. See also Spindasis

Aphodius, Ill., 160, 169, 205

A phrissa, Butl., 326

apicalis, Fulur., Balavinus, 239

apicata, Dist., Acanthaspis, 97

apiccllus, Zcll., Crambus, 452

Apion, Herbst, 175

Apis, Linn., 158, 161, 163, 168, 170, 174, $176,179,180,198,199,207,213,220$,

$232,235,248,249,253,254,256,265$,

$298,340,361,365,375,392,429,435$, $441,463,485,487,458$

Apisa, Walk., 408

Aplccta, Guen., 16

Apodcrus, Oliv., 238 
Apogouia, Kirby, 359, 388

apollo, Linn., Parnassius, 519

Apopestes, Hübn., 172

Apophylia, Chevr., 374

Aporus, Spin., 411

appendiculatus, Gyll. Hipporrhinus, 182 appiades, Ménét., Euthalia, 80

Appias, Hübn., 57, 286, 354, 588. Sec also Catophaga

approximata, Dey., Zophosis, 163, 164

aprilina, Linn., Agriopis, 9

Apterogyna, Latr., 409, 432

Apteroln, Muls. \& Rey., 174

apunctifera. Sce epunctifera

aquatic grasshopper, 375, Fig. 13

Aquilegia canadensis, Linn. [Ranuneulaceae], 150

Arabic, difficulties of, 429

arabica, Oliv., Mutilla, 432

Arachnida, 95, 158, 160, 179, 200, 206, $208,221,300,317,345,363,372$

Araschnia, Hübn., 142

Arashiyama [Japan], 137

arbela, Hübn., Sphaenogona, 306, 308, $309,310,315$

arcas, Cram., Papilio, 306

arch, false and true, 62, 63, Fig. 4

archaea, Hübn., Antirrhaea, 499

archesia, Cram., Precis, 184, 203, 222, 235,241

archesia, Cram., Remigia, 291

archippus, Fabr., Danaida, 25, 76, 264,

$280,304,306,314,321,323,329,484$, $487,494,519$

Arctesthes, Meyrk., 472, 475, 477

Arctia, Steph., 8

arctous, Fabr., Yphthima, 484

Arctophila, Schin., 532

arcuata, Moore, Asurn, 357

arcuata, Moore, Loxura, 113, 351, 526, 568,569

Arcyophora, Gucn., 211, 220

ardates, Moore, Nacaduba, 48, 121, 3t0, 374,391

ardens, Smith, Anthidium, 392

Arc, Walk., 290

Areca catechu [Palmaccac], 101, 104

arcnaria, Fabr., Aphaonogastor, 396,431 , 434

arcnaria, Sol., Pimelia, 158

arenarium, Fabr., Opatrum, 200, 205, 249

Arenipses, Hmpsn., 409

arenosa, Butl., Tephrina, 186, 202

areola, Esp., Xylocampa, 172

arcs, Feld., Prenes, 279, 289

areste, Hew., Arrhopala, 79

arethusa, Cram., Ageronin, 501

a.rgnnte, Frbr., Phoebis, 507

argentata, Frbr., MIcgachile, 411, 432

argentata, Minnn., Psiloptera, 432

argentatus, Fabr., Graphostcthus, 363

argcntea, Brullé, Ammophila, 207

argentea, Warr., Bapta, 293

argia, M'́net., Zizorn, 66, 1.27, 130, 133 argiades, Pallas, Everes, 121, 137, 140, 142,568

Argina, Hübn., 66

Argiolaus, Druce, 185, 235, 246, 285, 560, 567

argiolus, Linn., Cyaniris, 169, 171, 569

Argynnis, Fabr., 8, 11, 41, 42, 44, 45, 46, $54,55,64,66,82,99,100,115,119$, $139,382,388,522,529,553$

Argyractis, Hmpsn., 220, 223, 293

Argyramoeba, Schin., 231, 393

Argyresthia, Hübn., 19

Argyria, Hübn., 487

argyridana, Butl., Hiposcritia, 79

argyrodines, Bates, Charis, 314, 320, 325

argyroneurus, Zell., Talis, 440

Argyrophenga, Doubl., 469, 482

argyropyga, Kohl, Notogonia, 164

ariadne, Linn., Ergolis, 73, 75, 96, 102, $105,114,349,381,552$

Ariapeta Road ['Trinidad], 322-328

Ariathisa, Walk., 478

Arina, Desv., 234

Arion intermedius, Normand [Mollusca], 448,464

arion, Linu., Lycaena, 25

aripa, Boisd., Leptophobia, 306, 311, 513

Arisarum vulgare, 'Targ.-Toz. [Araceae], 175

Aristolochia longa, Linn. [Aristolochiclceac], 175

aristolochine, Fabr., Papilio, 61, 74, 84, $85,87,94,95,96,98,101,105,111,121$, $337,355,369,371,373,381,387,391$, $514,520,523,526,527,538$ ।

armiger, Hübn., Heliothis, 318, 448

armillatus, Butl., Nacaduba, 488

arnabia, Cram., Biston, 292

Arnebia sp. [Boragineae], 407, 410

Arnold, Dr., 564, 565

Aroa, Walk., 129, 236, 246, 358, 360, 37.l, 387

Arrhenoplitis, Kirby, 290

Arrhopala, Boisd., 79, 80, 82

Arrow, G. J., 162, 163, 221, 372, 436, 462

arsalte, Linn., Hcliopetes, 259, 265, 308, 321,326

Arsinoï, Lap., 195

Artesia, 210, 232

Arteurotia, Butl. \& Druce, 308

Artocarpus incisa, Limn. [Moraceac], 267

Artystona, Bates, 469, 470, 479

Asama-yama [Japan], 141

Asaphodos, Meyrk., 469, 470, 472, 473, 479,482

Asarkinn, Macq., 384

Ascalaphus, Fabr., 262

ascalaphus, Stgr., Staphylus, 320, 326

Asclepias sp. [Asclepradaceac], 57, 168, 280,321

asela, Moore, Crastia, 110, 114, 118, 399, $344,345,346,367,369,371,377,379$ s $381,382,386,387,496,497,517,520$, $524,526,527,530,536$ 
asela, Moore, Cynthia, 112, 348, 367, 502, 519,525

" ashes," volcanic, 29 note

Aslistead Common, 15

asirtica, Ménét., Papilio, 46

asiaticus, Sharp, Cybister, 393

Asida, Latr., 169, 195

Asilus, Linn., 485

asopo, Feld., Pteronymia, 312, 332

asopus, Hopff., Catochrysops, 189, 229, 231,566

asp, 160

Asparagus plumosus [Liliaceae], 193

Asphaera, Chevr., 327

asphodeli, Latr., Agapanthia, 175

Asphodelus microcarpus, Viv. [Liliaccae], $168,174,175$

Aspidomorpha, Hope, 238, 246

Aspilates, Treit., 8, 172

Aspongopus, Lap., 238, 397, 401

assimilella, Treit., Depressaria, 8

asterie, Linn., Procis, 120, 123, 347, 591

asterope, Klug, Yphthima, 203, 204, 213, $222,227,228$

Asthena, Hübn., 11, 448, 452, 453, 454, $460,463,467,469,474,478,482,486$

Astictopterus, Feld., 127, 356

astola, Moore, Neptis, 45, 64, 65, 79, 80 , $82,84,119$

astorion, Westw., Papilio, 515

astragalota, Moyrk., Scoparia, 479

astrarche, Bergstr., Chrysophanus, 505

astynome, Dalm., Leptalis, 510

Asura, Walk., 117, 357, 388, 483, 485

Aswân, 398-401, 421, 425, 427, 549

asychis, Cram., Chiomara, 308

Asyût, 397, 429

atalanta, Linn., Vanessa, 547

atalantata, Guen., Heterusia, 308, 316

Atbara Junction, 403, 411, 422, 423

Atechna, Chevr., 238, 239

Atella, Doubl., 41, 45, 47, 48, 55, 58, 73, $85,88,90,102,116,185,193,197,222$, $239,241,282,339,348,367,373,383$, $387,390,526,527,568$

Atelocera, Lap., 185

atergatis, Westw., Acraea, 220, 222, 505

aterrina, Forster, Brachypelta, 164

aterrima, Butl., Odezia, 142

Athalia, Leach, 185, 236

athamas, Drury, Charaxes, 83, 367

athenion, Hübu., Thymelicus, 301

Athesis, Doubl., 310, 312, 313, 494

Athyma, Westw., 42, 44, 55, 64, 80

atlantica, Ramb., Lymantria, 172

atlantica, Lucas, Srturnia, 168

atlites, Johanss., Precis, 73, 113, 120, $123,124,283,339,347,589,590$

atolmis, Westw., Acroon, 220, 222, 223, $225,228,505$

atomaria, Fabr., Gymmoloma, 182

atopalis, Walk., Bradina, 192

atratn, Horsf., Nacadubr, 349, 367, 505, 568 atrata, Meig., Usia, 174

atratus, Fabr., Scaurus, 163

atriceps, Per., Podalirius, 165

atristriga, Walk., Persectania, 160, 465, 468

atro-albus, Lep., Podalirius, 176, 177, 434

atronivea, Walk., Declana, 462

atropos, Linn., Acherontia, 24

Atrytone, Scudd., 152, 153, 572

Atta, Fabr., 304, 332

Attagenus, Latr., 250

atticus, Fabr., Tagiades, 101, 356

attitudes at rest. See resting

atymnus, Cram., Loxura, 73, 75, 113, 351, 569

atys, Cram., Thecla, 506

Auckland, 445-449, 461

Audea, Walk., 203

augastis, Meyrk., Scoparia, 469

augiades, Feld., Telicota, 483

augias, Linn., Telicota, 62, 66, 68, 127, 484

Augochlora, Smith, 260, 298, 316, 332

augur, Fabr., Noctua, 16

augustana, Hübn., Hypermecia, 19

augusti, Sauss., Nectarina, 321.

aulaco-chiloides, Crotch, Episcaphula, 195

Aulacophora, Chevr., 396

A ulocera, Butl., 40, 46, 554

aunus, Fabr., Cecropterus, 256

auraria, Smith., Tespa, 51

aurata, Linn., Cetonia, 8

aureum, Linn., Grapta, 133

auricularia, Linn., Forficula, 441

qurifascia, Brullé, Chrysis, 412

aurinia, Plōtz, Serdis, 289

aurinia, Rott., NIelitaea, 545

aurocostalis, Guen., Glyphodes, 294

ausonia, Cram., Glyphodes, 327

Austen, E. E., 392, 393, 432, $45 \mathrm{~S}$

australe, Emery, Nonomorium, 209

australis, Walk., Scolypopa, 446, 447, 45ั6

australis, Butl., Hebomoia, 354, 369, 510. 519

australis, Périug., Usagaria, 215

Austramathes, Hmpsu., 468

Autoceras, Feld., 294

Automolis, Hübn., 290

autraniaua, Sauss., Deropeltis, 198

autumnana, Hübu., Peronea, 24

auxo, Lue., Teracolus, 188, 511

avanta, MLore, Iphthima, 126

Arentia, Dup., 14

Aricennia nitidn, Jacq. [Pcrbcnaccac], 260

arius, Cram., Charis, 325

axe, MIaori stone, 462

axenn, Meyrk., Scoparia, 472, 482

Axiocerces, Hibu., 1S9, 212, 214, 223, $225,231,232,241,566,568$

ayresii, Triui., Parmara, 205

Azalen sp. [Evंicrccac], 125, 142, 143, 145 
Azanus, Mooro, 373, 380, 402, 407, 416, 419

Azochis, Walk., 332

Baccha, Fabr., 246

Bactra, Steph., 21, 409

bada, Moore, Parnara, 356

badaca, Herr., Thecla, 326

Badacara, Moore, 99

Badamia, Moore, 357, 572, 573

badia, Swinhoe, Metachrostis, 62

badiella, Hübn., Depressaria, 14

Badrashên [Egypt], 397

Baeoglossa, Chaud., 209, 210

baeticus, Linn., Polyommatus, 41, 49, $51,55,64,68,91,93,94,96,98,118$, $189,198,211,350,368,373,386,388$, $391,399,401,402,407,416,419,421$, $427,430,434,483,488,505,522,526$, 568,575

Bảghi [Simla], 40, 45, 46, 590, 593

Bagous, Germ., 224

Bainbrigge-Fletcher, T., 361

baja, Fabr., Noctua, 16

Baker, Henry, 299

Balaninus, Germ., 238

baldus, Fabr., Yphthima, 72

Baliana [Egypt], 428

Báliganj [Calcutta], 72

ball-cartridge in church, 61

ballus, Fabr., Thestor, 167, 171, 175, 563

Balmoral, [Sydney], 483

balteata, De G., Gametis, 237, 238, 241

balteatus, De G., Syrphus, 229

balyi, Chap., Eurysthenes, 250

Bamboo, Giant. Sec Dendrocalamus

bambusae, Moore, Telicota, 73, 356, 384, 572

banana, wild [Musaccae], 77 ; "stem " of, 301

Bandaraivela, 385, 386

Banff [Canada], 151

Bangalúr, 97

Bankapúr, 85, 86

Banks, Sir Josoph, 484

hanksii, Fabr., Chrysomola, 155

Bantia, Stả, 239

Baobab-tree, 218

Baoris, Moore. Sce Parnara

Bapta, Steph., 293

Bára [Pcsháwar], 49

Baracus, Mooro, 117, 118, 119, 386, 888

Barbados, 252-254

barbara, Linn., Aphaenogaster, 168, 169, $173,210,409,431$

Barber, NIrs., 595

barbicornis, Fabr., Teramocerus, 462. Plate VI., Fig. 5

Baridius, Schönh., 161

Barrett, C. G., 25, 34, 534, 558, 561, 562, 573

Bartlett, H. F. D., 254

Bartsia viscosa, Linn. [Scroplularincac], 452

Barwa Sugar [India], 90 basalis, Hmpsn., Rivula, 120

Basicryptus, H.-Schäfi., 245

Bates, H. W., 3, 103, 528

Bateson, W., 489

bathing, mixed, in Japan, 139

Battye, Capt., I.M.S., 89

bazalus, Hew., Arrhopala, 80

beata, Butl., Epyaxa, 469

Beaumontia grandiflora [Apocynaccac], 267, 291, 292

beetles, sounds produced by, 161, 221, 294,435

begga, Prittw., Gorgythion, 315,573

bolemia, Esp., Euchloë, 159, 162, 167, 170, 171, 176, 177, 535, 575. Plate V., Fig. 10

Belenois, Hübn., 41, 44, 47, 48, 49, 55, $57,60,61,62,65,87,88,90,91,92,93$, $94,183,186,188,190,191,193,194$, $197,217,222,223,225,226,227,228$, $234,239,241,406,414,416,417,420$, $483,1512,522,525,530,535,537,550$, 591

belgiaria, Hübn., Scodiona, 20

belia, Linn. (eupheno, Linn.), Euchloë, $170,171,175,177,523$

bella, Linn., Utetheisa, 279, 290

bellatulus, Sauss., Odynerus, 400, 420

belledice, Hübn. (belia, Cram.), Euchlö̈, $162,167,171,175$

bollicosa, Guér., Hispa, 230

Bellis integrifolia, Michx. [Compositac], 150

bellona, Fabr., Brenthis, 153

Belonogaster, Sauss., 185, 204, 207, 211, $214,224,226,237,240,245$

Belostoma, Latr., 297

belzebul, Fabr., Phanaeus, 295

Bembex, Fabr., 220, 410, 414, 435

Benares, 67-70, 564

bengalense, Dahlb., Sceliphron, 380, 381, 392

bengalia, De Nicév., Catochrysops, 71

Bengáli's fear of Patháns, 71

Beni Mora Oasis [Bislira], 159

beninionsis, Beauv., Ammophila, 224, 230

Ben Lomond [N. Zealand], 471, 472, 480

bcon, Cram., Thecla, 330

Berea, the [Natal], 186, 190, 556

Bcrmudas, The, 99, 149, 252, 368

Bertholdia, Schaus, 318

Bethune-Baker, G. 'T., 418

bianor, Cram., Papilio, 127, 140, 142

Bibasis, Moorc, 357, 572

Bibio, Gooffr., 177

biblis, Fabr., Didonis, 308, 325, 501, 524

bibulus, Fabr., Lachnocnoma, 189

bicolor, Smith, Paracolletes, 488

bicolor, Fabr., Salius, 485, 488

bicolor, Charp., Stenobothrus, 158, 159

bicosta, Walk., Palaeosia, 486

bicostata, Klug, Adesmia, 399

bicostata, Fihr., Asida, 195

bicostatus, Sol., Erodius, 163, 164 
bicostella, Clerck, Plourota, 20

bidens, Linn., Scolia, 177

Bidens leucanthus, W. [Compositac], 283, 552

bigibbulus, Beauv., Euchistus, 297, 317

Bijápúr, 94, 95

bilateralis, Thunb., Khoina, 246

bilineolata, Walk., Helastia, 467. Sce also mucosata

bimaculata, Gerst., Ischnoptera, 230

bimaculatus, Panz., Podalirius, 411

bimaculatus, Dewitz, Opharus, 291

Bingham, Col. C. T., 102, 112n, 119, 182, $185,196,207,214,220,230,237,245$, $249,250,284,338,339,346,347,353$, $490,498,500,518,553,554,557,561$

biocellata, Feld., Nacaduba, 484, 488

bioculata, Burm., Hierodula, 413, 434

bionomics, definition of, 489

bionomics of butterflios, 27, 489-600

bipartita, Brullć, Andrcna, 403

bipunctella, Fabr., Anesychia, 172

bipunctifer, Walk., Schoenobius, 97, 340, 359

birds, injuries caused by, $44,86,114,140$, $171,185,197,198$, \&c. See injuries. Attack on butterfly by, 110

Birmandreis [Algeria], 155

Biscutella sp. [Cruciferae], 592

biskarensis, Lucas, Adesmia, 159, 160, 165

Biskra, 156-166

Biston, 'Leach, 5, 14, 292

bistriana, Haw., Peronea, 24

bistriga, Walk., Melipotis, 291

bite of ant, 298, 299; of acridian, 299

Bityla, Walk., 451, 463, 478

Bizone, Walk., 357

bjorkandrella, Thunb., Porpe, 452

Blackberries, 452, 453

Blackburn, J. B., 13, 15, 17, 19, 20, 22, 23,481

Blackburn, Rev. T., 13, 20

Blackfoot-Crossing, 26

Blackmore, Trovey, 5, 7, 9, 12, 13, 14

Blacodes, Dej., 182

Blanaida, Kirby, 134, 136, 139, 141, 143, 523,555

blanchardiana, Sauss., Quiroguesia, 54

blanda, Guér., Psoudagenia, 392

blandiata, Hübn., Emmelesia, 20

blandina, Fabr., Erebia, 19, 25

Blatta, Linn., 199, 200, 233, 239

Blattella, Caud., 421

Blaps, Fabr., 26, 156, 160, 100, 401

Blonosia, Lap., 182

Blopharipoda, Br. \& Borg., 363

Blopbaropsis, $: 161,167$

Blidah [Algoria], 170, 175, 176

blitoalis, Walk., Noorda, 409, 421

block-bouses, 232

Bloemfontein, 207

"Blues." Sce Lycaonidao

Bluo Nile, 414, 425

Bluff, the [Durban], 192-196, 59t
Blymorphanismus, 221

Boarmia, Treit., 11, 16, 17, 100

boaz, Fabr., Oryctes, 203

bochus, Cram., Lampides, $83,118,350$, $368,386,526,568$

Boer trenches, 200, 201

boghariensis, MIacq., Bombylius, 168, 170, 171

bohemani, Auriv., Episus, 209, 210

boisduvalii, Wallgr., Crenis, 190

bolanica, MIarshall, Yphthima, 51, 558

Bolboceras, Kirby, 88

boldenarum, Whitc, Chrysophanus, 475, 480

bolina, Linn., Hypolimnas, 36, 48, 62, 65, $67,104,113,348,367,370,383,520$ $522,525,527$

Bolivar, Señor, 199

Bolla, Mabille, 321

Bombay, 35, 94

Bombus, Latr., 51, 79, 168, 174, 316, 143 , $445,452,453,528,531,532$

bombycinus, Rog., Myrmecocystus, 161, $163,164,166,432,434$

bombylans, Linn., Volucella, 528, 532

Bombylius, Linn., 64, 168, 169, 170, 174, $177,249,361,433,530$

Bonchurch, 8

Borassus flabelliformis [Palmaccae], 314

Borkhausenia, Hübn., 446, 452, 463, 475

Borolia, Moore, 203

Bostra, Stål, 359, 382

Bostrychus, Lac., 232

Bo-tree (Ficus religiosa), 86, 87, 376

Botys, Latr., 8, 22, 143. See Nicrostega

Bougainvillea speciosa [Nyctagincae], 56, $57,60,288,298$

Bougie [Algeria], 169, 170, 507

Bou Medfa [Algeria], 170, 175

borvkeri, Trim., Stugeta, 213, 223, 566

Box Hill, 15

braccatus, Perez, Colletes, 165, 403, 128

brachialis, Stil, Petalochirus, 363

Brachinus, Web., 419

Brachyacantha, Cherr., 296

Brachybasis, Sélys, 198, 230

Brachycorus, Fabr., 155, 205, 209

brachygonia, Hmpsn., Eublemma, 402

Brachypelta, Am.\&:Scrr., 164

Brachyponera, Forol, 409

Brachyrrhynchus, Lap., 963

brachystcgino, Mrsbll., Rhabdinocerus, 224

Bradiua, Ledcr., 48, 192

brahminus, Laf., Chlaenius, 428

brassicac, Linn., Ganoris, 51, 170, 171, $175,510,512,514,523,595,596$

Bratlwaite, Rer. S. R., 275

Brcnthis, Hübn.. 153

Brcphos, Ochs., 9, 472

brcphosata, Walk., Notorcns, 472, 476, 477

brotonii, Guér., Salius, 420

brcvicollis, Wiod., Cicindoln, 250 
brevicorne, Fabr., Mogymenum, 374

brevipennis, Walk., Ilema, 357

brightwelli, Kirby, Agrion, 317

brigitta, Cram., Terias, 183, 207, 212, 214, $220,222,223,225,228$

British Association, 25, 178, 546

Brocken, Spectre of the, $31,32,33$

brochias, Meyrk., 'Tipha, 388

bromius, Mabille, Pellicia, 316

bromus, Leech, Parnara, 127

brongusaria, Walk., Semiothisa, 202, 232, 236

brunnea, Fabr., Noctua, 16

brunneata, Thunb., Fidonia, 19

brunneriana, Costa, Bantia, 239

brunneus, Nurray, Bostrychus, 232

Bryonia sp. [Cueurbitaceae], 48

Bryophyllum calyciuum, Salisb. [Crassulaceae ], 253, 268, 312, 368, 369, 596, 597, 598

bubastus, Cram., Callicista, 260, 330

Buchanan-White, Dr., 25

Buckler, IV., 25

Buckmaster, Rev. C. J., 9, 12, 14, 15, 26

Buddha Gáya [India], 86, 87

Buddhists, 47, 48, 84, 86, 93, 117, 342, 373,376

Buddleia sp., [Loganiaeeae], 207

Buffalo River [S. Africa], 240-245

bufonius, Klug, Poecilocerus, 132

building of Kingston (Jamaica), bad, 266

Bulaea, MLuls., 158, 413

Bulawayo, 211-215, 231, 566

bulbulata, Guen., Coremia, 482

Bulimus decollatus, Linn. [Mollusca], 171 ; B. oblongus, Linn., 253, 300

buquetii, Boisd., Leuceronia, 181, 420, 422

Burchell, W. J., 571

burejana, Brom., Araschnia, 142

Burri [Khartûm], 405, 410, 412, 413

burrs, $70,83,258,473$

Bush Lawyer, 473,476

bushes, butterflies flying through, 57,59 , $62,73,261,339,370,537$

Bustard, Houbara, 166

Butler, A. L., 405

butleri, Fereday, Ercbiola, 477

butleri, Auriv., Parata, 357

Butterflies, flight of :

apparontly spinning, 195, 337

hours of, $79,191,368,599$

in strings, 118,370

peculiaritios of, $112,347,534-539$

slow, $61,71,84,110,139,183,184,190$, $191,193,196,197,229,264,281,283$, $339,344,348,385,483,534-538,594$ swift, $44,57,59,83,93,102,110,111$, $112,114,118,153,191,192,194,222$, $227,264,265,279,281,287,315,326$, $331,338,348,351,355,367,369,430$, $535-538$

butterflies drinking, 25. See drinking buttorflies in Egyptinn paintings, 395

butterfly-nots, 36
Buxto11, P. 1., 257, 519

buxtoni, Buti., Acraca, 186

Buysson, MI. le Vicomte du, 412

Byblia, Hübn., 95, 105, 184, 186, 187 , $190,193,197,204,222,234,235,241$, $246,501,589,590$

byssinus, Klug, Podalirius, 411

cabira, Hopff., Acraea, 186, 190, 196, 519

Cacyreus, Butl., 179, 227, 235, 248, 250

cadmus, Cram., Coea, 284

Caduga, MLoro, 80, 81

creculus, Hopff., Hypolycaena, 213, 223

Caenina, Feld., 189

caenosus, Gyll., Bagous, 224

Caerois, Hübn., 103

Caesalpinia sp. [Leguminosae], 417

caesarea, Goeze, Diacrisia, 14]

Cresar's Camp [Ladysmith], 202

caesiata, Lang, Larontia, 17, 20!

caesonia, Stoll, Meganostoma, 315

caespitum, Linn., Tetramorium, 173

caffer, Boh., Euleptus, 199

caffer, Deyr., Zophosis, 202, 203, 204, 215

caffra, Guen., Gracillodes, 198, 223

caffra, Spin., Plectroctena, 205

caffra, Wallgr., Thyretes, 203

caffra, Linn., Xylocopa, 214, 224, 236

caffraria, Smith, Mesoponera, 200, 211

Caiman [Reptilia], 303

Cairo, 430-438

caja, Drury, Agrion, 317

caja, Linn., Arctia, 8

calais, Cram., Teracolus, 61, 420, 421 , 588,591

Calamus sp. [Palmaceae], 343

O-album, Linn., Grapta, 137, 142, 176, 561

calcarntus, Lepel., Podalirius, 164

calchas, H.-Schäff., Cogin, 316, 326

Calcutta, 70-77

caldarcna, Hew., Acraca, 213, 222, 505

caledoniana, Steph., Poronea, 22

Calendula algerionsis, Boiss.-Reut. [Compositae ], 173 ; C. arvonsis, Linn., 173 ; C. monardi, Boiss. Reut., 177

crlice, Hopff., Castalius, 198, 232

calidasa, Moore, Limenitis, 116, 367, 383

Crlidomantis, Rohn, 419

californica, Boisd., Vanessa, 150

Caligo, Hübn., 321, 331, 501

Cnlisto, Hübn., 280, 500, 556, 570, 578

Calla aethiopica [Araeeae], 244

callias, Suff., Cryptocophalus, 230

Callicista, Groto, 260, 330

Callicoro, Hübn., 308, 314

Callidryas, Boisd., 103, 252, 253, 254, 256, $258,261,264,279,285,286,306,308$, $320,826,330,352,507,534,577,581$, $582,596,597,593$

Callimormus, Scudd., 331

Calliomma, Walk., 292

Calliphora, Dosv., 168, 251, 443, 476

Callipsycho, Scudd., 285, 307, 314 
Callistemon sp. [My/rtaccac], 485, 486 Callophrys, Bilb., 563 callosicollis, Mrshll., Ellimonistes, 244. Plate II., Fig. 3

Calluna vulgaris, Linn. [Evicaceac], 21 callunae, Palmer, Lasiocampa, 20

Calochroa, Hope, 138

Calochromus, Guér., 440

Calonota, Hope, 453, 459

Calophasia, Steph., 172

Calopieris, Auriv., 407, 414, 422

Calotes, Cuv. [Reptilia], 341

Calotropis procera, Willd. [Asclepiadaceae $], 402,405,406,410,411,412,413$

Calycopis, Scudd., 2S5, 567

calydonia, Boisd., Pieris, 320, 321, 513

Calysisme, Moore. See Mycalesis

camadeva, Westw., Stichophthalma, 501 cambes, Godm. \& S., Tmolus, 257, 506 camel police, 56

camcls, 36, 51, 156, 430

camelina, Leach, Hippobosca, 159, 163

Camena, Hew., 77

camerta, Cram., Euptychia, 255, 306, 329,578

Camghouran, 15, 16, 17, 22

camiba, Moore, Apatura, 346

Campanularia sp., Lam. [Hydrozoa], 334

campina, Auriv., Mycalosis, 227,564

campoliliana, 'Treit., Grapholitha, 19

Camponotus, Mayr, 163, 168, 173, 179, $189,196,199,205,211,220,230,232$,

$237,245,298,309,317,409,441,485$

Camps Bay [S. Africa], 179, 180

Camptogramma, Steph., 14, 120

Camptolenes, Cherr., 246

Camptopus, Am. \& Serv., 174, 175

cana, Erichs., Cystineura, 258, 261, 283, $319,325,330$

canaco, Johanss., Vanessa, 99, 348

Canary bird, 28

Canary Islands, 166

cancellalis, Zell., Sameodes, 377

candida, Dej., Cicindela, 246

candidalis, Walk., Alucita, 361

canescens, Walk, A pisa, 408

canescens, Walk., Homoptora, 203

canicularis, Limn., Homnloinyia, 186

canidia, Sparrm., Ganoris, $44,48,49,51$,

$54,64,79,82,84,98,127,190,133,514$, 522

canopus, Trim., Netrobalane, 189

canthara, Doubl., Nica, 319, 321

Cantharis, Linn., 175

Canthon, Hofim., 317, 321

Canton, 131-183

Capc Town, 178-180, 248-251, 514

capensis, Mayr, Acrntholepis, 179, 249

capcnsis, Mayr, Aplaonognster, 210

capensis, Limn., Ceroctis, 250

caponsis, Fabr., Cicindoln, 246

caponsis, Lopel., Xylocopa, 249

capicola, Handl., Bembex, 220

cinicola, Doj., Jlarpalus, 201 capitata, Walk., Alana, 374

capitata, dc Gecr, Gonia, 161

capitata, Smith, MIclipona, 305, 316, 327

capitata, Smith, Mryzine, 211, 224

Capparis sp. [Capparideac], 483, 594

Caprona, Wallgr., 104, 116, 189, 371, 572 , 573

Carabus, Linn., 16, 138, 155, 528

Carácas, 39, 305-319, 567, 584, 585, 587

Caradrina, Hübu., 16, 77, 168, 172,186 , $398,408,416,421,428$

Caralluma lutea [Asclepiadaccas], 221

caravan, 51, 156

carbonariella, Fisch., Phycis, 12, 20

carbonarium, Pascoe, Ethas, 377

carburaria, Guen., Chlenias, 487

cardamines, Linn., Euchloë, 8, 511

cardinalalis, Guen., Pyransta, 293

Cardiophorus, Esch., 192

cardui, Linn., Pyrameis, 6, 8, 14, 24, 42, $51,65,77,78,98,139,158,159,162$, $165,169,171,176,177,184,187,199$, $201,203,204,205,207,209,233,235$, $247,248,250,382,385,397,399,40 \tau$, $421,427,428,433,434,441,453,521$, $525,541,548,549,576$

carinatulus, Sauss., Odynerus, 221, 227

carimatus, Sol., Erodius, 177

cariniceps, Reichs., Microtelus, 160

Carlisis, Still, 238

carnaria, Linn., Sarcophaga, 196, 246

carovei, White, Uropetala, 459, 462

carpenters before stone-masons, 92,142

carpini, Schiff., Saturnia, 20

Carpocoris, Col., 174

Carposina, H.-Schäff., 467, 469

Cartagena de las Indias, 260, 261

Cartaletis, Warren, 195, 517, 530

Carystus, Hübn., 916, 572

cassiae, Linn., Opsiphanes, 803

Cassida, Linn., 78

cassiope, Fabr., Erebia, 22

cassius, Godt., Pscudonymplaa, 199, 235, $241,246,250,555$

cassius, Cram., Leptotes (Tarucus), 261, $285,305,307,314,325,330$

Castalius, Hübn., SO, 10:1, 106, 121, 198, $231,232,338,350,367,368,391,553$

castanca, Mayr, Poncra, 464

castancus, Esch., Sccliodis, 399, 401, 413

cnstruoptcra, Mloorc, Bostra, 3S2

Catabomba, Sack., 16. 165, 236, 251, 434

Catacroptora, Farsch, 1S7, 568

catalaunalis, Dup., Antigastrn, 391

catalaumaria, Guen., Tephrima, 37 , 202

catamaran, 336

Catantops, Schaum, 155, 190, 199, 20T, $237,240,245$

cataplaues, Hïbu., Apopestes, 172

catapyrrha, Butl., Arctesthes, 472, 475, 477

Cathnrsius, Hopc, 365, 37T, 400, 413

Catia, Godunan, 289, 572 
catilla, Cram., Catopsilia, 68, 94, 108, $121,352,506,587,593$

catillus, Cram., Eudamus, 265, 288, 308, 326,331

Crtocala, Schrank, 12

Catochrysops, Boisd., 48, 62, 66, 68, 71 , $73,88,94,96,124,189,229,231,258$, $360,265,285,304,307,314,325,330$, $350,373,377,380,390,401,402,407$, $422,428,505,526,566,567,569$

Catonephele, Hübn., 319

Catophaga, Hübn., 57, 98, 102, 103, 110, $114,115,118,354,368,370,373,374$, $377,381,382,513,523,534,537,590$

Catopsilia, Hübn., 47, 48, 57, 58, 63n, 64, $66,68,71,73,75,84,85,90,94,96,97$, $102,105,106,108,110,121,124,127$, $211,214,225,252,254,338,352,369$, $373,374,377,378,380,381,382,383$, $386,391,403,406,422,506,519,520$, $522,525,526,534,577,587,588,589$, $590,591,593$

Catorrhintha, Stil, 305

caudata, Butl., Elymnias, 101

cebrene, Trimen, Precis, 184, 187, 202, 201, 222, 231, 547, 564

Cecropterus, H.-Schäff., 256

Cedestis, Zell., 19

Cedrus deodara [Coniferae], 40

Celaona, Steph., 16

Celaenorrhinus, Hübn., s0, 116, 383, 391, 572,573

Celama, Walk., 129

coleno, Cram., Lampides, 73, 79, 83, 84, $96,104,105,106,113,114,338,349$, $368,373,378,381,386,505,525,568$ celerio, Linn., Choerocampa, 59

Cclonites, Latr., 432

celsalis, Walk., Glyphodes, 359

celsum, Walk., Leptosoma, 128

cenca, Stoll, Papilio, 186, 194, 235

ccnis, Cram., Zonosoma, 80

censorius, I'ascoe, Empocotes, 467

Centaurea aegyptiaca, Linn. [Compositae], 433 ; C. nigra, 532 ; C. pullata, 175

centaureata, Fabr., Eupithecia, 176

centaurus, Fabr., Arrhopala, 80

Centranthus ruber, D. C. [Valerianaceac] $14,26,27,444$

Centris, Fabr., 253, 327

Centrocarenus, Fiob., 174

C'entrocoris, Kol., 174

ccphalotes, Linu., Atta, 332

Cephonodes, I Iübn., 96, 213

Cerastes comutus [Reptilia], 160

Ceratina, Latr., 174, 207, 298, 361, 375, 400,411

Ceratinia, Hübn., 312, 491

Ceratoma, 265, 296

cerbera, Feld., NIcgrnostoma, 308, 315, 510

Cerceris, Latr., 384, 410

Ceria, Scop., 392, 398, 581
Cerioides, Rond., 392, 393. Plate IV. Figs. 5-8

Cermatulus, Dall., 455

Ceroctis, Mars., 211, 226, 239, 250

Ceropria, Lap., 362

Cerura, Schrank, 22

cervinata, Walk., Elhamma, 444

cervina, Mooro, Euproctis, 358

Cervis unicolor [Mammalia], 119

ccspitalis, Schiff., Herbula, 46, 407

cespitalis, Boisd., Hesperia, 150

Cethosia, Fabr., 112, 348, 367, 381, 385, $519,524,537$

Cetonia, Fabr., 8

ceylanica, Feld., Nepheronia, 104, 114, $370,511,529,537$

ceylanica, Feld., Parantica, 108, 339, 378, 496

ceylanicus, Mrotsch., Nysius, 362

Ceylon, 108-121, 335-388, 506, 518, 519, $520,523,567,571,590,591$

ceylonensis, Jac., Hoplosoma, 340

ceylonica, Moore, Halpe, 356

ceylonica, Moore, Papilio, 355

ceylonica, Hew., Yphthima, 100, 101, $109,112,121,338,346,364,367,369$, $377,380,383,385,387,500,1524,527$, 552

Chaetocnema, Steph., 217

Chaetolyga, Rond., 237, 363

chafer, derivation of word, 401

Chaïba, Forcst of, 171, 172, 174

Chakdurra [Indian frontier], 54,55

chalciformis, Fabr., Melittia, 361, 530

Chalciope, Hübn., 210

chalcitis, Esp., Plusia, 444

Chalcopelia afra [Aves], 219

chalcoptera, Lac., Lema, 230

Chalcosia, Hübn., 128, 360, 518, 520

Chalcosiinae, 42 note

chalicoda, Lucas, Dioxys, 164

chalicodes, Meyrk., Scoparia, 461

Chalicodoma, Lopel., 164, 174, 177, 212, $237,398,429$

Chalk River [Canada], 153

chalybeatus, White, Promecidus, 289

chalybous, Sauss., Zethus, 317

Chrmaeleon, Gron. [Reptilia], 180, 342 , 402; C. dilepis, Jueach, 212, 216 ; C. pumilis, Daudin, 180, 215, 216

Chamaerops humilis, Linn. [Palmaccac], 175

Chamaita, Walk, 357

chamomillae, Denis, Cucullia, 172, 176

Champion, H., 567

Chapman, Dr. T. A., 519, 551, 563, 592, 598

characta, Moyrk., Scoparia, 479

Charaxcs, Ochs., 83, 185, 187, 197, 217, $222,235,367,374,502,568$

Chariosterus, Lap., 297

charina, Boisd., Pinacoptoryx, 181, 18s, $191,194,197,284,239,241,246,512$, 523 
Charis, Hübu., 314, 320, 325

charithonius, Linn., Holiconius, 281, 306, $307,310,314,504,519,524$

charlonia, Donz., Euchloë, 162, 167

Charltona, Swinh., 129

Charopa coma, Gray. [Mollusca], 456; C. otagoensis, Suter, 479 . See also Endodonta

charybdis, Dbl. \& H., Pyrrhopyge, 316

Cháubattia [Kamaon], 65, 66

cháukídar, 52

Cheeseman, T. F., 449

Chelonia, Latr., 141

chenui, Guér., Yphthima, 98, 100

Chesias, Treit., 168

Chetma Oasis [Algcria], 158

chi, Linn., Polia, 593

Chiffa Gorge [Algeria], 175

Chilades, Moore, 62, 66, 68, 86, 88, 106, $260,349,365,373,388,401,407$

Chilo, Zinck., 418, 447, 452

Chilocorus, Leach, 179

Chilomazus, Zang, 384, 388

Chilomenes, Chevr., 179, 214, 245

Chilosia, Meig., 531

China Peak [India], 64

chinensis, Leech, Mjcalesis, 126, 131

chinensis, Cram., Calochroa, 138

Chiomara, Godm., 306, 308, 310, 316, 320,573

Chionaema, Feld., 357

chionephra, Hmpsn., Paromphale, 220

Chitrál, relief of garrison, 55

Chittira, Moore, 118, 119, 382, 388, 496, $519,520,536$

Chlaenius, Bon., 205, 386, 418, 419, 428

Chlenias, Guen., 487

chloralis, Hmpsn., Stemmatophora, 220. Plate II., Fig. 9

chlorea, Cram., Sphingomorpha, 231

Chlorida, Serv., 295

Chloridea, Dunc., 176, 318, 402, 448, 451, 457

chloris, Mocs., Chrysis, 412

chloris, White, Odontomyia, 457, 463, 475

chlorodonta, Hmpsn., IIorrisonia, 449, 457. Plato VI., Fig. 2

chloroform, 37, 39, 201

chlorotica, Spin., Bembex, 435

Chocrocampa, Dup., 59, 386

Cholus, Germ., 296

choredon, Feld., Papilio, 483

Choroutes, Troit., 14

Christchurch [N. Zealand], 466, 476

Chrotogonus, Serv., 396, 100, 401, 420, 434 chrysaor, Trim., Phasis, 241, 566

chrysippus, Linn., Danaida, $51,55,57$, $61,67,70,72,82,85,90,95,96,100$, $102,105-107,110,120,184,186,187$, $190,193,195-197,199,203,206,222$, $225,226,228,231,235,241,344,346$, $367,377,382,386,390,395,397,398$, $399,405,406,417,418,419,420,421$, $430,494,502,515,518,519,520,529$
Chrysis, Linn., 165, 412, 432, 4:3

chrysitis, Gerst., Pseudo- colaspis, 225

Chrysocoris, Hahn., 113, 362, 378, 351, 384

chrysogaster, Walk., Halisidota, 230

chrysographella, Koll., Ancylolomia, 353

chrysomallus, Hübn., Zezius, 391, 525

Chrysomela, Linn., 155

chrysonome, Klug, Teracolus, 407, 422

chrysonuchellus, Scop., Crambus, 15

Chrysopera, Hmpsn., 358

Chrysophanus, Hübn., 41, 42, 63, 65, 13\%, $141,150,155,158,175,177,443,444$, $448,453,454,455,457,461,463,461$, $475,480,481,482,505,569,575$

Chrysophyllum cainito, Linn. [Sapotaceae], 284

chrysostigma, Burm., Orthctrum, 174

chrysotheme, Steph., Colias, 151, 152, 153

Chrysotoxum, Oken, 155

Chūdō [Japan], 136

Chu Kiang River [China], 131

Chūzengi [Japan], 142, 143

Cicada, Linn., 299

cicatricosus, Lucas, Scarabaeus, 174

Cicindela, Linn., 138, 165, 216, 250, 254, $443,447,452,455,462,470,477$

Cidaria, Treit., 17, 21, 22, 43, 44, 172, $463,469,479$

ciliata, Walk., Acraga, 291

ciliata, Fabr., Dielis, 173, 175, 176, 177

ciliatus, Oliv., MIelyris, 245

Cilibe, Kirby, 464, 469, 470, 4S2

ciliella, Stain., Dcpressaria, 14

cillene, Cram., Colaenis, 2S1, 502, 524

Cimex, Linn., 247

cinchona plantations, $79,50,52$

cincta, Lepel., Icaria, 189, 212, 237, 215, 416

cincta, Fabr., Vespa, 340, 361, 392

cinctigutta, Walk., Rhanidophora, 195

cinctus, Klug, Pterygophorus, $4 \$ 55$

"cinders," volcanic, 29 note

cinerana, Haw., Grapholitha, 20

Cineraria sp. [Compositae], 40, 168

cincraria, Doubl., Corcmia, 454, 455, 479 cingala, Moorc, Paruara, 357

cingalensis, MIooro, Ixias, 102, 114, 369, 510,598

cingalousis, Brenskc, Lachnosterna, $3 \$ 4$ cingulata, Latr., Euryscopa, 265

cingulata, Fabr., MIclampsalta, 455, 45S

cingulatus, Fabr., Dysdercus, 340, 363, 365

cingulifor, St:\$1, Oncopcltus, 307, 32 S

cipris, 'Fabr., Metura. 507

circumflcxa, Limu., Plusia, 428, 429

circumfumatr, Warr., Phaeochlaena, 310 circumlatus, Stîl. Lygacus, 817

Cirphis, Walk., 133, 172, 176, 291, 31s, $397,417,419,421,428,429,448,460$, 465,576

Cirrhochron, Doubl., S2, 83, 112, 114, $348,349,522,525,527$ 
cirtana, Pcr., Nomada, 171

Cistus sp. [Cistaceae], 257

cissus, Godart, Everes, 213, 229

citraria, Hübn., Aspilates, 8, 172

citrina, Mloore, Euproctis, 358

citrinarius, Motsch., Parnassius, 140

Citrullus colocynthis [Cucurbitaceae], 401

Ciret-cat, 82

clarkii, Huttou, Saropogon, 462

clavipes, Boh., Harpalus, 233

clavipes, Walk., Pseudoblaps, 374

clearista, Dbl. \& H., Athesis, 310, 312, 313,494

clelia, Cram., Precis, 186, 187, 193, 197, $222,225,502,546,547,551$

cleobis, Godart, Camena, 77

cleodora, Hübn., Eronia, 184, 191, 194, 197, 231, 239, 241, 511, 593, 591, Erontispiece

cleodoralis, IValk., Scoparia, 475

Cleome arabica, Linn. [Capparideae], 158

Cleonus, Schönh., 163, 164, 166, 208, 396 , 435. See also Pychnodactylus

Cleopatra bulimoides, Oliv. [Mollusca], 424,425 ; C. morrelli, Preston, 1225

cleopatra, Linn., Gonepteryx, 167, 169, $171,176,507,508,509$

Clerodendron infortunatum [Verbena ceae], 338

Clerome, Boisd., 126

Cletus, Stůl, 386

Clinteria, Burm., 51, 384

Clisiocampa, Curtis, 153

Cloantha, Gucn., 172

cloantha, Cram., Catacroptera, 187, 548

Clostera, Steph., 22

cluster of Danaida plexippus, $75 ; \mathrm{Da}$ naida archippus, 76; Heliconius, 281

clustering of Stilbum when slcoping, 399,400

Clypeaster aegyptiacus, Mich. [Echinodermata], 436

clypeatus, Burm., Adorotus, 413

clytemnestra, Cram., Hypna, 308

clytia, Linn., Papilio, $111 n, 1371,530$

cnejus, Fabr., Catochrysops, 48, 62, 377 , 380

Cnephasia, Curt., 469

Cncthocampa, Steph., 172

cnicella, Treit., Depressaria, 24

C-nigrum, Linn., Noctun, 16, 172

coarctata, Ijinn., Eumones, 434

coarctatus, Spin., Philanthus, 400, 410

Coccinella, Linn., 163, 161, 169, 364, 396, $399,413,415,416,419,421,428,429$, $430,433,434,440,483,528$

coccinolloides, Westw., Derispia, 362, 364. Plate IV., Fig. 13

Coccoloba uvifora, Jacq. [Polygonaceae], $254,330,332$

Coccyx, Treit., 21

Cocoa Wattie [T'obago], 328-333

Cocvtius, Hïbn., 292
Codroy R. [Newfoumdland], 149

Coea, Hübn., 284

coelata, Moore, Pseudo-micronia, 358

Coeliaxis layardi, Ad. \& Aug. [Mollusca], 240

Coelioxys, Latr., 412

coelocera, Smith, Chalicodoma, 212, 237

Coelolophus, Mäkl., 359

coenia, Hübn., Precis, 282, 329, 579

coeno, Dbl. \& H., Ceratinia, 312

Coenocalpe, Hiibn., 469, 475, 479

Coenonympha,1 Hübn., 21, 148, 167, 169, $171,176,557,558$

coerulea, Sauss., Montezumia, 304

coerulescens, Latr., Osmia, 170

coeruleus, Thunb., Formicomus, 179

Cogia, Butl., 316, 326

cognata, Sol., Blaps, 156

cognata, Moore, Cirrhochroa, 112, 114, $348,522,525,527$

cognata, Schönh., Macroma, 195, 212, 237

colaca, MLore, Parnara, 357, 377, 572

Colaenis, Hūbn., 279, 281, 306, 319, 324 , $502,503,524$

Colasposoma, Lap., 238

Colenso, 199-201

colensonis, White, Lestes, 448, 452, 457

Colesberg Junctiou [S. Africa], 207

coleta, Cram., Deilemera, 360, 374

Coleus sp. [Labiatae], 268

Colias, Eabr., 8, 34, 41, 44-46, 51, 55, 60, $78,99,141-143,151,152,153,154,158$, $165,167,169,171,181,183,188,203$, $207,235,241,246,247,406,430,509$, $522,525,534,563,592,595,598$

collaris, Eabr., Dielis, 177

collaris, Eabr., Sycanus, 363

collaris, Lepel., Xylocopa, 361

collecting under oscort, 54

Colletes, Latr., 159, 164, 165, 177, 403, 412,428

Colombo, 108, 120, 121

Colon, 261-265, 303, 304, 584

coloration, cryptic, $12,13,21,46,51,51,94$

colossicum, Stil, Belostoma, 297

colour, motallic, in Hymenoptera, 412

colours, selection of, by Butterflies, 46 ,

94, 194, Frontispiece, 592-599

Columbus, Christophor, $31 n, 263$

Colussa, Walk., 484

combiuans, Walk., Erchcia, 358

combinata, Plöt\%, Thymelicus, 239, 326

Combretum sp. [Combrctaceae], 212, 213, $214,222,224,225,226,232,566$

combusta, Dup., Xylophasia, 16

Comet, Donati's, 6; Halley's, 488

Comibaenn, Hiibn., 220, 227

comma, Walk., Ariathisa, 478

commassire, Walk., Aellopus, 22?)

Como [N.S. Wales], 484, 485

componsata, Walk., Craspedia, 293

complanata, Newm., Popillia, 334

complanata, Sol., Zophosis, 431, 439, 435 
composita, Guen., Melanchra, 451. Sce also Persoctania ewingi compressicornis, Latr., Oxycoryphus, 419 compressicornis, Klug, Scarabaeus, 435 compta, Walk., Agrotis, 451 comptoni, Kaup, Chilomazus, 384 comyntas, Godart, Everes, 150, 152 Comythovalgus, Kolbe, 236 Conchia, Hübn., 207 conchylalis, Guen., Cydalima, 84 Conchylodes, Guen., 321 concinnus, Dall., Hypselonotus, 265 conferanda, Butl., Lampides, 96, 104, 106

confinis, Hope, Clinteria, 51 conflictaria, Walk., Epiplema, 360 conflua, Treit., Noctua, 16 conformis, Boisd., Coccinella, 440, 483 confusa, Auriv., Lethe, 126

Congella [S. Africa], 196-198, 556 congener, Gerst., Haplolycus, 189 congruata, Walk., Racheospila, 292 connectens, Thunb., Hyperaspis, 257, 296

Conolophia, Warren, 228

Conops, Linn., 392, 531

Conorrhinus, Lap., 363

consanguineus, Péring., Omostropus, 215 conscitaria, Walk., Conolophia, 228

consentanea, Walk., Craspedia, 402, 408, 428

consobrina, Luc., Pimelia, 162

consobrinalis, Zell., Endotricha, 418, 429 consobrinus, Duf., Odynerus, 155, 158, 173

consonaria, Hübn., Ectropis, 143

conspersa, Walk., Narosa, 358

conspersus, Burm., Lissogenius, 240, 246

conspicillaria, Snell., Anisodes, 293

conspicuus, Smith, Camponotus, 298

Constantine, 167

Constant Spring [Jamaica], 268, 271, 272, $279,281-302,552,584-587$

constrictus, Fabr., Acantholycus, 189

Contal [S. Africa], 233

conterminella, Zell., Depressaria, 19

contigua, Vill., Hadena, 15, 16

continua, Fabr., Ephutomma, 396

contracta, Butl., Catochrysops, 88

coutrahens, Walk., Opatrum, 340

convex fore-wings, $331,572,573$

convexus, Hausm., Scarabaeus, 246

convolvuli, Linu., Sphinx, 24, 34, 62, 251

Convolvulus sp. [Convolvulaceac], 72, 266,

$267,340,597$; O. arvonsis, peculinr scout of, $330,386,509,510$

Cook, Capt., 389

Coombo Wood, 5, 9, 10, 11, 14

Cooper, E., 8, 11, 12

Copicucullia, Sunith, 408, 121 . Platc V., Fig. 9

Copper-smith (Barbet) [Aves], 3.1

coppryi, Guen., Orthogramma, 292

Copris, Gooff., 169, 174, 359, 377, 387
Coptodera, Dcj., 340, 362, 394

Coptosoma, Lap., 361

coracina, Esp., Psodos, 21

corades, Feld., Callimormus, 331

Coranus, Curt., 363

Corbicula artini, Pallary [Mollusca], 425 ; C. consobrina, Caill, 425

cordalis, Doubl., Sceliodes, 456, 461, 46? cordata, Linn., Euglossa, 317

cordiger, Klug, Graphipterus, 202, 205, 210

Cordyline australis, Hook [Liliacsae], 149 core, Cram., Crastia, 61, 66, 70, 71,72 , $75,85,95,97,104,110,339,390,496$, $497,520,524,525$

Coremia, Guen., 21, 451, 454, 455, 456, $462,465,469,470,471,472,474,475$, $479,480,482$

coreoides, Moore, Narmada, 101, 315. See montana

coreta, Godart, Narmada. See montana coriacea, Waterh., Apogonia, 333

coriandri, Per., Colletes, 159, 164, 165

Coriaria ruscifolia, Linn. [Coriarieac], 454

corinneus, Bert., Papilio, 217, 222

Cormorants, 90,459

corniculans, Wallgr., Ozarba, 239

corniculatus, Fảhr., Hipporrhinus, 205

corollae, Fabr., Syrphus, $16 \pm$

coromandelicum, Lepel., Sceliphron, 392 coronata, Oliv., Prionotheca, 435

Coronilla valentina, Linn. [Leguminosac], 174

coronis, Cram., Huphina, 127

cortica, Plötz, Megistias, 331

corticana, Hübn., Antithesia, 19

corticea, Schiff., Euxoa, 46

Corvus splendens [Avcs], 336

Coryanthes maculata punctata, Lindl. [Orchidacene], 317

corydon, Fabr:, Lycnena, 553, 567

corydon, Fabr., Perichares, 2SS, 319

Corymica, Walk., 117

coryna, Hew., Carystus, 316, 572

Corynocarpus laevigatus, Forst. ['Anacardiaceae], 461

Corynodes, Hope, 375, 379

Corypha umbraculifera, Liuu. [Palma. ceac], 108

Coryphocora, Burm., 117

cosmicus, Smith, Camponotus, 199, 215

Cosmophila, Boisd., 120, $35 \mathrm{~S}$

cosmopolitan Lepidoptora, 575-577

Cosmodes, Guen., 444, 451, 462, 463

Cosmosoma, Serv., 290, 318

costalis, Sélys, Mnais, 138

costata, Moorc, Idaen, 11T, 120

costipennis, Spin., Sphex, $30 \pm$

costosa, Haw., Deprossaria, 24

costulatus, Kriech., Halictus, 173

cothnrnata, Forsk., Adesuia, 399, 401, 427

cotton cut-worm, $397 n$. 
Cotyledon sp. [Crassulaceae], 180 counter shading, 216

Couper, Tilliam, 563

couperi, Grote \& Rob., Plebeius, 152

cowiana, Butler, Cystineura, 325

coxaria, Guen., Anisodes, 293

Crabro, Fabr., 265, 392

crabroniformis, Lewin, Aegeria, 530

crabroniformis, Fabr., Trichodes, 434

Crambus, Fabr., 12, 15, 20, 21, 223, 233,

$290,382,442,444,445,446,452,457$, $461,464,466,470,471,475,480,481$

Cranes, 415

Craspedia, Hübn., 129, 192, 236, 293, 359, 402, 408, 428

crassella, Feld. \& Rog., Timyra, 394

crassicollis, Walk., Catharsius, 377

crassus, Boh., Paederus, 201

Crastia, Hübn., 61, 66, 70-72, 75, 85, 95, $97,104,110,114,118,131,339,344$, $345,346,367,369,371,377,379,381$, $382,386,387,390,496,497,498,517$, $519,520,524,525,526,527,530,536$ crataegata, Linn., Rumia, 17 craters, volcanic, 446, 447

Creatonotus, Hübn., 113, 340, 358

Cremastogaster, Lund., 205, 240, 250

crenana, Hübn., Phlaeodes, 22

Crenis, Boisd., 190, 568

cretica, Led., Sesamia, 399, 408, 416, $427,428,429$

creusa, Dbl. \& H., Euchloë, 152

cribraria, Clerck, Argina, 66

crinipes, Smith, Podalirius, 159, 161

crinita, Fell., Polistes, 298

crinita, Klug, Thriptera, 399, 401, 402

crino, Fabr., Papilio, 104, 355, 371, 520, 538

cristifera, Walk., Hyperlopha, 381

critias, Feld., Euterpc, 315

crocale, Cram., Catopsilia, 124, 352, 377, 506,587

croceicincta, Hmpsn., Enispa, 358

Crocidophora, Ledor., 293

Crocisa, Jur., 75, 192, 392, 411, 412, 485

Crocodile Pools [S. Africa], 232

Crocodiles, 415

crocodilus, Sauss., Gavialidium, 375

Crocothemis, Brauer, 217, 223

croesus, Nowm., Democratos, 295

Crois Craig [Perthshire], 19

crolus, Gram., Thecla, 314

Grotch, Dr. G. R., 26, 27, 30, 166

Crows, familiarity of Indian, 87, 336

cruciana, Zott., Hypormecia, 19

cruciata, But1., Josiomorpha, 316, 521

cruciferarum, Zoll., Plutella, 20, 158,

207, 577. See maculiponnis

cruentatus, Latr., Camponotus, 173

cruentus, Erichs., Hister, 233

Crudaria, Wall., 212

crux, Thunb., Physorrhynchus, 181, 196, 240,245 cryptic attitude, 162, 199, 206, 292, 383. Plate V., Fig. 10

cryptic coloration, $12,13,21,46,51,54$, $87,94,117,129,161-163,166,167,186$, $189,194,202,209,210,212,222,233$, 236, 246, 257, 284, 383, 431, 443, 444, Frontispiece

cryptic form, 175

cryptic underside, $82,187,283,316,369$

Cryptocephalus, Geoffr., 230, 239, 244

Cryptomeria japonica [Coniferac], 141, 143,144

Ctenopseustis, Meyrk., 452, 469, 470

ctenopus, Miscophus, Kohl., 432

Ctenucha, Kirby, 316

cubicularis, Bork., Caradrina, 16, 168

Cucullia, Schrank, 172, 176

cucurbitina, Rossi, Ceratina, 174

Culex, Linn., 97

cupentia, Cram., Prodenia, 291

Cupha, Billb., 112, 114, 126, 348, 367

Cupido, Hübn., 152

cupreum, Linn., Oedisternon, 250

Cupressus macrocarpus [Coniferac], 397

cuprella, Thunb., Adela, 14

Curetis, Hübn., 73, 137, 374, 522

curtisellus, Don., Prays, 24

curvicornis, Westw., Aegopsis, 333

cuspidea, Hüibn., Euclidia, 153

Cutilia, Stål, 464, 465

cyameuta, Meyrk., Xerocopa, 477

cyanea, Linn., Synoeca, 265, 305, 317, 321

cyanea, Smith, Xylocopa, 168

cyanescens, Brullé, Xylocopa, 174

cyaneus, Oliv., Dasytes, 175

cyaneus, Moore, Parthenos, 347 ; peculiar mode of flight, 536

cyaniris, Hew., Myscelia, 306, 524

Cyaniris, Dalm., 42-44, 46, 80, 33, $116,117,119,134,137,140,142,152$, $169,171,349,363,367,383,388,505$, 569

cyanopterum, Sauss, Rhynchium, 411

Cyano-phyceao, 389

Cyanurum, Forst., Stilbum, 362

Cyathea dealbata, Swartz [Filices], 462

Cybdelis, Boisd., 307

Cybistor, Curtis, 260, 393

Cyclocophala, Latr., 295

Cycloglypha, Mabillo, 315, 573

Cyclonotum, Doj., 296

Cyclopides, Hübn., 247

Cydalima, Lodor., 84

Cydosia, WVostw., 291, 332

cygnorum, Turnor, Epactiothynnus, 488

cylindrolla sp. [Mollusca], 302

cylindrica, Gahan in MSS., Oborea, 362

cyllaria, Cram., Erchoia, 358

Cymaones, Scudd., 289, 326, 381, 572

cymatias, Moyrk., Scoparia, 469

Cymatophora, Trcit., 16, 20

cymochlos, Doubl., Papilio, 256, 314, 326

cymothoë, Klug, Ithomin, 312 
Cynoglossum cheirifolium, Linn. [Boraginaceae], 168

Cynthia, Fabr., 112, 348, 367, 502, 519, 525

Cyperus papyrus [Cyperaceae], 218, 416

Cyrtacanthacaris, _- 239

Cyrestis, Boisd., 80, 570

cyrus, Fabr., Papilio, 131, 355

cyssea, Stoll, Syntomis, 357

cysseoides, Butl., Syntomis, 357

Cystineura, Boisd., 258, 261, 283, 319, $325,330,524,552$

cytherea, Linn., Adelpha, 255, 324

cytheris, Godart, Morpho, 501

Dacus, Meig., 340, 413

daedalus, Fabr., Hamanumida, 222, 502, 548,564

Daimio, Murr., 142

daira, Klug, Teracolus, 407, 416, 417, 419, $420,422,511$

Dakkeh [Nubia], 401, 402

Dalceridae, Neumög. \& Dyar, 291, 292

daleana, Doubl., Sericoris, 19, 21

Dâll [Perthshire], 19

Dalsira, Am. \& Serv., 206

dama, Fabr., Onthophagus, 359

damarensis, Trim., Zeritis, 210

Dambulla, 373-375

dana, De Nicév., Nacaduba, 391

danaë, Fabr., Teracolus, 105, 106, 590

Danaida, Latr., 25, 51, 55, 57, 61, 67, 70 , $72-76,82,85,90,95,96,100,102,105$, $106,107,110,120,124,184,186,187$, $190,193,195-197,199,203,206,222$, $225,226,228,231,235,241,261,264$, $280,304,306,308,314,321,323,329$, $344,346,363,367,377,382,386,390$, $395,397-399,402,405,417,418,419$, $420,421,430,484,487,494,495,497$, $519,520,523,529,530$

Danais, Latr., 124. See also Badacara, Caduga, Danaida, Parantica, Radena, and Tirumala

dancing flight, $344,388,483,536$

danicus, Linn., Pachytylus, 155

Danisepa, Moore, 499

Daphnis, Hübn., 360

daplidicc, Linn., Synchloë, 33, 170, 175

Daptonoura, Butl., 256, 306, 315, 320, 511

dardanus, Brown, Papilio, 186, 188, 191. $194,235,515,595$

Darenth, 5, 9, 11, 15

daretis, Hew., Lothe, 116, 119, 382

darcs, Plötz, Thymolicus, 316

Darjiling, 77-84

darsius, Gray, Ornithoptera, 110, 115, $337,356,371,381,514,520,525,538$

Darwin, Charles, 264, 290, 324, 389, 489, 571

dasarada, Moore, Papilio, 515

dasahara, Moore, Sarangesa, 391, 572

Dasychira, Stoph., 22, 120

1)asydir, Guen., 22
Dasylabris, Radz. See Jutilla, 432

Dasyophthalma, Westw., 501

dasyops, Wied., Chaetolyga, 237

Dasypoda, Latr., 250

Dasypodia, Guen., 463

Dasytes, Payk., 175

Dasyuris, Guen., 472,476

data, importance of, 37,38

dautici, Rossi, Odynerus, 434

davendra, Moore, Epinephele, 51. Plate I., Fig. 1

Davey, Mr., 566

David, Prof. T. W. E, 486

Davis, C. T., 10

davus, Fabr., Coenonympha, 21

deaf and dumb, sign language useful, 26

Deal, 8

Decatoma, Dej., 242

decem-guttata, Fabr., Anthia, 248

decem-guttata, Fabr., Oedionychis, 265

deceptor, Péring., Harpalus, 205

deceptus, Smith, Halictus, 245

deciãia, Hew., Castalius, 350, 367, 391

decipiens, Spin., Coelioxys, 412

decipiens, Germ., Loboptera, 169

deckeni, Gerst., Pseudagrion, 223, 226, 231

Declana, Walk., 462, 465, 468, 474, 47S

decolorata, Hiỉbn., Emmelesia, 14

decorata, Philpott, MIorrisonia, 468

decoys, 102, 103, 371

decrescens, Walk., Plotheia, 120

Decticus, Serv. See Poecilocerus

defensata, Walk., Pterocypha, 293

defigurata, Walk., Bityla, 451, 463, 478

definita, Beth.-Baker, Trichiura, $41 \mathrm{~S}$. Plate V., Fig. 3

degreyana, McLachl., Eupoecilia, 20

dehaani, Feld., Papilio, 140

Deilemera, Hübu., 114, 22S, 360, 374, $443,444,445,446,453,454,457,460$, $461,470,518,520,521$

Deilephila, Ochs., 33, 163, 165, 402, 407, 408, 421, 428

Deinacrida, White, 465, 469

Deiopeia, Steph., 26, 33, 51. See also Utetheisa

dejectaria, Walk., Hemerophila, 456. $459,460,463,468,478$

Dekn [S. Africa], 231

Delbi, 60-63

delia, Cram., Terias, 259, 260, 265, 2ST, $304,315,509,524,583,584$

Delias, Hübul., $61,66,70,71,74,85,105$, $110,121,398,351,377,384,386,4 S 4$, $512,513,520,525,526,535$

dolicata, MIöschl., Automolis, 290

delila, Fabr., Colaenis, 281

Delos jeffreysiaun, Pfeiff. [Mollusca], 455

Delphinium sp. [Ranunculacenc], 46

deltoidata, Walk., Epirrhoë, 44S, 454, 456 demotrius, Cram., Papilio, 137, 140, 142

Democrates, Burm., 295

demodocus, Esp., Papilio, 185, 188, 191. $197,205,225,227,235,406,422,515,539$ 
demolcus, Linn., Papillo, 49, 56, 61, 66, $67,74,85,94,96,100,103,188,337$, $355,391,515,520,538,539$

Dendera [Egypt], 397, 398

Dendrocalamus giganteus [Gramincac], 108

Dendrocera, Hmpsn., 359, 364

de Nicéville, L., $68,70,72,86,329,348$, 491,536

dcnospora, Meyrk., Sporophyla, 474

dentata, Rossi, Drypta, 175

denticulatus, Oliv., Trox, 209

dentipes, Fabr., Dichelus, 242, 248

Denton, S. W., on decoys, 103

denudation of kopjes, 207-208

Depressaria, Haw., 8, 14, 19, 24, 160

depressum, Linn., Stirastoma, 327

depressus, Walk., Pododus, 215

depressus, Sauss., Tachysphex, 447, 463

Derispia, Lewis, 362, 364

Dermestes, Linn., 59, 209, 247

Derocalymma, Burm., 202, 418

derogatella, Walk., Eretmocera, 217

Deropeltis, Burm., 182, 198, 200, 248

desert, struggle for existence on the, 159 $165,166,398,399,402,408,434$

descrticola, Oberth., Melitaea, 164, 431

Dcsert Wheatear, cryptic colouring, 166

desinens, Walk., Platysoma, 374

Desmia, Westw., 293

detersa, Walk., Lymantria, 94

Deudorix, Hew.,1227, 565

deva, Moore, Pratapa, 68, 522

Devarodes, Warren, 310

Deverra tortuosa, Desf. [Umbellifcrae], 396

Devil's Lake [Canada], 25

Devon's Post [Ladysmith], 203, 204

Dcxia, MLeig., 388

dharma, Moore, Neopithecops, 349

Diabrotica, Chevr., 296, 333

Diacrisia, Ḧ̈̈bn., 129, 141, 142

Diadema, Boisd., 48

Dialeuca conspcrsula, Ads.; D. subconica, Ads. [Mollusca], 302

Diamond Lake [N. Zcaland], 477

Diasemia, Hübn., 359, 456, 461

Diatraea, Guild., 332

Dicaeum, Cuv. [Aves], 118

Dicentria, H.-Śchäff., 319

Dichaetomctopia, Macq., 206

Dichclus, Lep. Serv., 243, 248, 250

Dichorda, Warren, 293, 332

Dichorrhagia, Butl., 139

Dichromia, Guen., 361

Dicranocncmus, Burm., 248

Dicranotropis, Faust, 396

didia, IIöschl., Pellicia, 316

Didonis, Hübn., 308, 325, 501, 524

didyma, Esp., MIclitaca, 164, 165, 431

Dielis, Sauss., 173, 175-177, 186, 214, 254, 298, 485. Sec also Elis and Scolia.

dicmenalis, Gueu., Nacoloin, 359
Dieuches, Dohrn, 97

diffusa, Walk., Eupterote, 113

digramma, Walk., Raparna, 97

dilatata, Klug, Adesmia, 430

dilectus, Moore, Cyauiris, 83

Dilkusha Palace [Lucknow], 66, 68

Diloma nigerrima, Chem. [MIollusca], 470

Dilophonota, Burm., 304, 319, 327

dilucidus, Péring., Xenitenus, 211

diluta, Feld., Zizera, 42, 54, 55, 58, 65, $134,137,143$

dimidiata, Plötz, Pellicia, 316

dimidiatipennis, Sauss., Eumeues, 92, $93,204,399,400,411$

dimidiatus, Fabr., Telephorus, 362, 372

dimorphism, sexual, 57, 60, 67, 399, 411

dina, Poey, Terias, 287

Dindymus, Stål, 363

Dineutes, Lap., 393

Dinocoris, Burm., 328

Dinornis, Owen [Aves], 466

Diodontus, Curtis, 411

Diomedea exulans [Aves], 439

dionaea, Hcw., Ceratinia, 312

Dione, Hübn., 279, 281, 306, 324, 503

dionysius, Fabr., Philagnathus, 374

Diopsis, Dahl., 217, 229, 237

diores, Doubl., Thaumantis, 501

dioscorides, Fabr., Ampittia, 356

Dioxys, Lepel., 164, 177

diphtheralis, Walk., Scoparia, 462

Diplodon, Spix. [Mollusca], 453, 473, 477

Diplopseustis, Meyrk., 469

Diploxys, Am. \& Serv., 211

Dirades, Walk., 340

Dircenna, Doubl., 313, 494

direction mark attacked, 92

discalis, Walk., Aroa, 236, 246

discalis, Moore, Surcndra, 351

discincta, IIll., Dasypoda, 250

discoidea, Fabr., Acmoeodora, 177

Discolia, Sauss., 220, 361, 365, 483

discolor, Fabr., Rhinia, 363, 365, 38 '́

discriminans, Moore nee Walk., Ophiusil, 361

discutiens, Walk., Asilus, 485

1)ismorphia, Hübn., 256, 308, 315

dispar, Lep., Podalirius, 155, 168, 170, 174,175

disputaria, Guen., 'Tephriua, 62, 94, 397, 408,128

dissimilis, Linn., Papilio, 111, 355, 361, $523,530,539,571$

dissimilis, Fritsa, Podalirius, 174

distans, Nloore, Tagiades, 101, 356, 384, 572

Distant, W. L., 328, 386,1413

distigma, Wied., Argyramoeba, 393

distincta, Möschl., Eulimacodes, 263

distinctus, Sign., Basicryptus, 245

distinguendus, Kohl, Belonogastor, 201

Distroptus spicatus, Cass. [Compositac 267,295

ditruporium, Bork, Agrotis, 27 
divorgons, Behr., Syneda, 151

diversus, Smith, Pompilus, 186

divisa, Klug, Xylocopa, 189, 214, 224, $237,241,245$

Dixey, Dr. F. A., F.R.S., 26, 27, 49, 59, $68,71,88,137,162,178,196,204,212$, $217,225,229,235,238,242,244,247$, $249,320,353,422,433,491-494,496$, $499,501,502,504,505,509-517,519$, $522,535,546-549,555,556,558,565$, $566,573,574,587,591,594,595$

dixeyi, Bingh., Notogonia, 196. Plate II., Fig. 4

Dixon, Miss C. A., 27, 30, 31

Dixon, Waynman, 436

djaelaelae, Wallgr., Eretis, 198, 241, 246 , 572

Docirava, Walk., 44

Dodabetta [Nilgiris], 99

Dodona, Hew., 65, 78

dohrni, Baly, Corynodes, 378,379

dolabraria, Linn., Ellopia, 15

dolosa, Butl., Pachyligia, 141

Dombeya densiflora [Sterculiaceae], 206; D. rotundifolia, Haro., 211, 212, 213, 214,216

domestica, Linn., Musca, 47, 210, 217, 230 domesticus, Linn., Gryllus, 158

domicella, Erichs., Heliopetes, 258, 320

Donald, Donald, 462, 464

Donald, Miss MI. J., 173, 175

Donati's Comet, 6

dorcas, Fabr., Cystineura, 283, 524, 552

dorsalis, Fabr., Dielis, 254

dorsalis, Klug, Macrochilus, 205

dorsata, Fabr., Apis, 361, 365, 392

dorippus, Klug, Danaida, 96, 395, 406

Dorylus, Latr., 84, 203, 247, 359

dotata, Walk., MIorrisonia, 474, 478, 481

doubledayi, Guér., Acraea, 211, 212, 213, $214,231,504$

doubledayi, Wallacc, Papilio, 515

doubledayi, Feld., Telesto, 485

Douglas, J. W., 5

Doves, $92,219,380$

dragonflies, 83, 130 ; catching a butterfly, 143

Dravidian Architecture, 106

Dropanodes, Guen., 293

drewsoni, Sauss., Nischocytta.'us, 317

drinking at mud, or wet sand, Buttorflics, $25,54,55,58,60,86,102,103,104,111$, $114,115,117,139,189,228,224,229$, $232,286,367,368,370,371,373,374$, $377,391,892$

droa, Swinh., Pantana, 128. Plato I., Fig. 2

dromedarius, Linn., Notodonta, 14

Drucc, Hamilton, H.C.J., 257, 261, 289, $316321,325,330$,

Druco, Horbort, 128

drurii, Latr., Catia, 289, 572

drmsilla, Crum., Glutoplurissa, 286, 524, 534 drypctis, Hcrv., Lcthc, 116, 382, 522

Drypta, Latr., 175

dry-season coloration moro persistent in fcmale, 253, 353

dubia, Bigot, Diopsis, 223

dubius, Kohl, Belonogaster, 214, 221 226,245

dulcis, Butl., Tcracolus, 34, 589, 591

Dûm Palm, 403

dumenilii, Godart, Polyniphc, 306, 3 $5 \pi$, $310,325,505$

Dunedin [N. Zealand], 467-4;0

Duomitus, Butl., 292

duplaris, Linn., Cymatophora, 16

duponchelii, Poey, Cocytius, 292

Duranta plumieri, Jacq. [Verbenaceac], $49,57,70,400$

Durban, 185-198, 546, 548, 565, 566

Durbania, Trim., 223

durga, Koll., Dodona, 65.

Durrant, J. H., 20, 319, 452, 467, 469, 476 dusk, Butterflies flying at, 240, 259, 316, 391,537

dwarfed specimens, $61,65,68,83-85,87$. $88,91,94,110,120,133,162,183,18 \mathrm{~s}$. $241,407,417,420$

Dynamine, Hübn., 308, 313, 319, 324, 330, 571

Dysallacta, Leder., 231

dyschera, Sauss., Eumenes, 212

Dysdercus, Am. \& Ser下., 297, 317, 340, 363,365

Dysmachus, Locw, 1S2, 199, 250

Dysphania, Hübn., 128. Sec Euschema

Earias, Hübu., 49, 62

Earnslaw, MIt. [N. Zealand], 474, 475,476 earth-pillars, 310

earthquake of 1692 in Jamaica, 266, 273

earthquake of 1907 in Jamaica: damagc along lino of Geological disturbance, 273; personal cxperiences, 265-272; narrow cscapos, 268-275, 2S6; nature of the movement, $270,271,274$; cffect on nervous systcm. 273,274

carthquale, traces of, in Great Pyramid and in Temple of the Sphinx, 495

carthworm, 196

East London [S. Africa], 183-5, 234-247, 546,566

ebonina, Sauss., Discolia, 220

ebulcalis, Gucn., Nacoleia, 332

cbusa, Cram., Euptychia, 323, 327

occlosialis, Guen., Samia, 293

eccoptcrus, Kiz., Carabus, 135

cchcria, 'Stoll, Amauris, 196, 235, 211 , 497

echcrius, Stoll, Abisara, 127, 349, 391

Fchereria sp. [Crassilaccac], 180

Echinomyia, Dum., 532

Echinops spinosus, Linu. [Compositac], 432,483

Fchium fastuosum [Boraginaccac], 235. 297; Echium sp., 33, 407 
Ecpantheria, Hübn., 290, 318

Ectatomma, Smith, 483

Ecteinanthus origanoidos, T. [Acanthaceae], 191

Ectropis, Hübn., 143, 239

Eden Gardens [Calcutta], 70, 71, 72

Eden, MIt. [N. Zealand], 446

edentata, MIorawitz, Nomia, 412, 420, 423

Edessa, Fabr., 253

Edfú [Egypt], 398

edusa, auctorum, Colias, $8,34,158,165$, $167,169,171,430,509,534,592,598$

Edwards, W. H., 563, 595

Edward's Bay [N.S. Wales], 485

edwardsii, Sauss., Eumenes, 392, 531.

Plate IV., Fig. 4

egena, Charp., Empusa, 418

eggs of Snails, 253

eglanterina, Boisd., Pseudohazis, 151

Egybolia, Boisd., 195, 198, 337

Egypt, 394-403, 426-438

Elaphidion, Serv., 295

elathea, Cram., Terias, 287, 305, 315, 584, 585,598

electra, Linn., Colias, 181, 183, 188, 203, 207, 235, 241, 246, 247, 509

elegans, F'abr., Coryphocera, 117

elegans, Don., Cosmodes, 444, 451, 462, 463

elegans, Kra., Erodius, 164

elegans, Lind., Micronympha, 161

Elephanta, 106

Elephantine, 400

Elephants, 119, 344, 365

elcusis, Dem., Catochrysops, 401, 402, $407,422,569$

elevata, Chcvr., Asida, 169

clgiva, Hew., Prccis, 190, 197, 547

Elhamma, Walk., 444, 461, 463

eligius, Cram., Plesioneura, 516

clima, Moore, Aphnacus (Spindasis), 68, 69, 386, 387, Fig. 5 .

Elis, Fabr., 71, 214, 298, 399, 400, 410, $419,427,434$. See also Plosia and Scolia

El Kantara [Algeria], 156

elko, W. H. Edw., Cocnonympha, 148

ella, How., Spindasis, 232

Ella [Ceylon], 387

Ellimenistes, Schönh., 239, 244

cllioti, F. Smith, Nomia, 361

Elliott, F. A., 490

cllo, Linn., Dilophonota, 319, 327

Ellopia, Trcit., 15, 19, 22

clongatus, Brèmo, Cilibo, 464, 469, 470, 482

elongatus, Dohrn, Clctus, 386

Elousa, IValk., 291

El Outaia [Algcria], 164

clpis, Godart, Lampides, 80, 81, 350, 505, 568

clutata, Hübn., Hypsipctes, 17

EI Vallo [Venozucla], 305-303

Elvia, Walk., 479
Elwes, H. J., 176

Elymnias, Hiibn., 71, 73, 75, 82, 101, 339, $346,500,529,537$

embolina, Butl., Letho, 116

Emery, Prof. C., 409

emittens, Walk., Creatonotus, 340

Emmelesia, Steph., 11, 14, 20, 565

Emmiltis, Hübn., 440, 444, 445, 446, 453, $456,457,460,463,470,481,486$

Empis, Linn., 174, 179, 180

Empoeotes, Pascoe, 467

Empusa, Ill., 175418

Empyreuma, Hïibn., 290

Enantia, Hübn., 256, 315, 510

encedon, Linn., Acraea, 187, 190, 196, $222,225,501,529,530$

Encyalesthus, Motsch., 377

Encyophanes, Burm., 249

Endodonta, Lansberge [Mollusea], 455, $456,477,479$

Endotricha, Zell., 359, 418, 429, 485

Endrosis, Hübn., 17, 18

English, popularity of, in Japan, 136

English, what they have given India, 59

Enispa, Walk., 358

Ennychia, Treit., 8, 337

Enome, Walk., 94. Sce Iymantria

Enoplops, Am. \& Serv., 155

enotata, Guen., Semiothisa, 319

Entelia, Stål, 220

Entephria, Hübn., 129

Entomologist's Monthly Magazine, 9, 10, 15,24

Entomologist's Wcekly Intelligencer, 7

envelopes for butterflies, 37, 38, Figs. 1,2

cnvironment, effect of, 4, 290, 329

enysii, Butl., Chrysophanus, 455

Epacromia, Fischer, 155, 158, 174, 247

Epactiothynnus, Turner, 488

opaphus, Latr., Amphirene, 314

Epous, Kuwert, 316, 331

Ephialtias, Hübn., 316

ophippium, Spin., Androna, 163, 164, 399, 435

Ephutomma, Ashmead, 396

ephyia, Klug, Teracolus, 407, 414, 422

Ephyriados, Hübn., 289, 572

cpibcrus, Mabillc, Mogistias, 331

Epiblema, Hübn., 382

Epicalia, Westw., 501

opicles, Godart, Ilerda, 77, 82, 522

lipicometis, Burm., 399, 430

Epicrocis, Zell., 359

Epidesmia, Westw., 485

Epicrus, Erichs., 296

Epilachna, Chovr., 175, 179, 195, 199, 374

Epilobium hirsutum, Linn. [Onagraccac], 296

Epinephelo, Hübn., 51, 79, 499, 548, 514, $554,558,559$

Epionc, Dup., 143

cpiphytcs, 119, 266

cpiphron, Knoch., Ercbin, 22 
Epiplema, H.-Sehäff., 310, 360

Epirrhoë, Hüibn., 143, 192, 448, 454, 456 Episeaphula, Croteh, 195

epistrophis, Hübn., Morpho, 501

Épisus, Billb., 209, 210

epius, Westro., Spalgis, 113, 349

IEpping, 14

e punctifera, Hmpsn., Sesamia, 408

Epunda, Dup., 16

Epyaxa, Meyrk., 456, 460, 469, 479

equestris, Erichs., Pepsis, 260

Erana, Walk., 468, 575

Erastria, Ochs., 239

erate, Esp., Colias, 51, 55

Eratognathus, $\longrightarrow, 200$

Ercheia, Walk., 358

Erebia, Dalm., 19, 22, 25, 563

Erebiola, Fered., 477

Erebus, Latr., 291, 318

Eremiaphila, Lef., 436

Eremnus, Schönh., 244

eresimus, Cram., Danaida, 261, 250, 30S, 495, 519

Eressa, Walk., 357

Eretis, Mab., 198, 241, 246, 572

Eretmocera, Zell., 54, 195, 19S, 217

Ergolis, Boisd., 73, 75, 81, 85, 96, 102, $105,113,114,349,367,369,381,387$, $526,527,536,552$

ergolis, Walk., Lauron, 291

Erica cinerea, Linn. [Ericaceac], 21

Ericeia, Walk., 97

ericellus, Hübn., Crambus, 20

erieetata, Curtis, Emmelesia, 20

ericetorum, Fabr., Asarkina, 384

Erigeron canadense [Compositae], 362

crikssoni, Trim., Aphnaeus, 220

Eriogaster, Germ., 9

eriphia, Godart, Herpaenia, 420, 422

orippus, Cram., Danais, 494,495

cris, Klug, Teraeolus, 203, 222, 225, 511, 535

Eristalis, Latr., 158, 159, 168, 169, 179 , 186, 192, 198, 237, 241, 251, 399, 400, $428,441,443,444,445,462,481,486$

erithalion, Boisd., Papilio, 314

crithonius, Cram., Papilio, 56, 337, 515, 571. Sce also demolous

erminea, Kohl, Ammophila, 434

ermineus, Moore, Crambus, 382

Erodius, Fabr., 163, 164, 166, 177, 434

Eromene, Hiibn., 93, 234, 397, 400, 401, $402,409,421,428,576$

Eronia, Hübn., 184, 188, 191, 194, 197, $227,234,239,211,511,593,594$

erosa, Hübn., Cosmophila, 358

erosa, Guon., Dichromia, 361

crosa, H.-Schiiff., Psychophasma, 318

orosa, Hübn., Systasea, 331, 573

crostratus, How., Hamenris, 25s, 261, 304 cruption of geysor, 450

erymanthis, Drury, Cupha, 114, 126, 348 Eryngium maritimum, Linu. [Umbcllijerac ], 2.1 ery'thraea, Brulle, Crocotheinis, 217, 223 Erythrina sp. [Leguminosac], 267, 312 crythroeephala, Fabr., Brachyacantha, 296

crythrocephala, MIg., Calliphora, 168,443, 476

erythrocephala, Fabr., Deropeltis, 182, 300,248

erythroeephala, Fabr., Seolia, 410

crythrocnemis, Germ., Harpaetor, 211

Erythrolophus, Swinh., 77

erythrostieta, Hmpsn., Porthesia, 403. Plate V., Fig. 7

eryx, Linn., Lehera, 127

escbria, Hew., Planema, 190, 193, 273

Estcourt, 199

Esthesis, Newm., 485, 532. Plate VI., Fig. 8

esuriens, Fabr., Eumenes, 68, 377, 401, 411

Ethas, Paseoe, 377

ethion, Dbl. \& Hew., Castalius, 338, 350 , 363

Ethiopica, Hmpsn., 186

Ethnistis, Leder., 291

Etiella, Zell., 95, 205, 221, 359, 409, 576

etrida, Boisd., Teracolus, 49, 62, 88, 90, $92,94,104-106,522,558-591$

Eublemma, Hübn., 200, 211, 220, 402

cubule, Linn., Callidryas, 252, 256, 279 , $285,286,306,305,320,330,352,507$, $581,582,596,597,598$

Eucalyptus sp. [MIyrtaceae], 9S, 3ST, 131, $440,441,446,484,485,4 \mathrm{S6}, 535$

cucarpa, Meyrk., Scoparia, 452

Eucera, Seop., 165, 170, 171, 174, 176, 177,397

Eucereon, Hübn., 318, 332

eucharis, Drury, Delias, 61, 66, 70, 71. 74, S5, 105, 110, 121, 33S, 351, 377, 3St, $386,512,520,525,526,535$

eucharis, Fabr., Terncolus, 95, 105, 106, 589,590

Euehistns, Dall., 297, 317

Euchloc̈, Hübn., S, 137, 140, 152, 159, 16:. $167,170,171,175,176,177,139,199$. $511,523,535,574,575,592$

Enchromia, Hübr., 116, 199

Fuclidia, Oehs., 153

euclidiata, Guen., Lythria, 472. Sco catapyrrha

Eueosmin, Steph., 319

Hudamus, Swains., 253, 265, 2S3, 304, $308,310,315,326,331,572$

Eudoma, Cast., 195

Eneides, Hiibn., 255, 320, 324, 503

cugones, Bates, Dodona, $7 \mathrm{~s}$

Eugenia cordata [Myrtacene], 219, 220, 229, 230 ; F. jambos, Limn., 283

Euglossa, Latr., 317, 412

Euglyphia, Hübn., 291

Hulepis, Dalm, 83, 367. Scc Charaxes

Euloptus, Kílug, 199

Eulimneodes, MLöschl., 263 
eulimene, Klug, Calopieris, 407, 414, 422. Plate V., Figs. 1, 2

Eumenes, Latr., 68, 92, 93, 116, 204, 212, $214,230,231,232,237,241,245,309$, $377,381,392,393,398,399,400,401$, $411,414,416,417,419,420,421,427$, $428,432,434,531$

eumenoides, Saunders, Ceria, 392, 531. Plate IV., Figs. 5, 6

eumeus, Drury, Clerome, 126

Eumorphus, Web., 362

Euparypha pisana, MIüll. [Mollusca], 196

Eupatorium odoratum, Linn. [Onagraceae], 281, 286, 287, 298

eupheme, Ramb., Zegris, 592

euphemia, Dbl. \& H., Hypocrsta, 484

eupheno, Linn., Euchloë, 170, 171

euphenoides, Staud., Euchloë, 592

Euphorbia sp., 63, 181, 183; E. guyoniana, Bois.-Reut, 163, 164, 165 ; E. piscatoria, 33 ; E. pulcherrima, 183 ; E. splendens, 192 [Euphorbiaccae]

euphorbiae, Schiff., Acronycta, 24

euphorbiae, Linn., Deilephila, 33, 34, 163

Euphoria, Burm., 310

euphrosyne, Linn., Argynnis, 8

Eupisteria, Boisd., 10

Eupithecia, Curtis, 11, 13, 14, 19, 20, 25, 172,176

Euploea, Fobr., 75, 81, 329, 496, 497, 498, 499, 523. Sce also Crastia, Narmada, Pademma, and Trepsichrois

Eupoecilia, Steph., 20

eupompc, Hübn., Cerntinin, 494

eupompc, Klug, Teracolus, 418, 420, 421, 422

Euponera, Forel, 409

Euprcpocnemis, Fieb., 158, 161

Euproctis, Hübn., 48, 129, 185, 192, 198, $358,360,408,418$

Eupterote, Hübn., 113, 358

Euptoicta, Doubl., 279, 282

Euptychia, Hübn., 255, 264, 304, 305, $306,307,309,310,313,320,323,327$, $329,524,578$

Euralia, Wostw., 568

Euroma, Hübn., 256, 286. Sec Terins

eurimedes, Cram., Papilio, 516

curyades, Riff., Heliconius, 255, 323, 324, 503, 504

eurycles, Latr., Eudamus, 308, 310, 315

Enrycratora jamaicensis, Gmol. [Mol. lusca], 302

eurygnnia, Druce, Pantana, 128

curymedia, Cram., Aëria, 310

curynome, Westw., Noptis, 96, 97, 98, 99, $104,108,113,114,116,1117,119,126$, $131,187,347,390$

Furynotus, Kirby, 246, 247

Iuryscopa, Lac., 265

Eurysthenes, Lcfèvre, 250

Turytela, Boisd., 184, 186, 187, 190, 19:, $235,246,536,546$

Fuschema, Hübn., 128, 360, 391, 518, 520
Eusemia, Dalm., 360

Eustrotia, Hübn., 220

Euterpe, Swains., 315

outerpe, Ménét., Terias, 286, 287, 509, $510,582,583,597$

Euthalia, Hübn., 60, 73, 80, 346, 367

Eutrapela, Dej., 250

Eutrochatella sp. [Mollusca], 302

Euxoa, Hübn., 46, 88, 172, 397, 400, 402, $408,421,423,427,428,429,451,456$, 480. See also Agrotis

evadnes, Cram., Prenes, 306

Evans, Dr. J. W., 105

evarete, Cram., Precis, 282, 579

evarne, Klug, Teracolus, 418, 422

evenina, Wallgr., Teracolus, 227

evening flight of Skippers, 240, 289, 391

evenus, Hopff., Mycalesis, 190

Everes, Hübn., 121, 137, 140, 142, 150, $152,213,229,338,349,368,386,387$, 568

evippe, Drury, Ixias, 77

owingi, Westw., Persectania, 451, 456, $460,463,465,468,475,478,480,481$

Exaireta, Schin., 461

Examination Hall [Canton], 132, 133

excellens, Saunders, Nomioides, 412

excessana, Walk., Tortrix, 452, 469, 479

excisa, Walk., Colussa, 484

exclamationis, Fabr., Badamia, 357, 572, 573

exercise in the Tropies, importance of, 35

exigua, Hübn., Caradrina, 172, 398, 408, $416,421,428$

exiguus, Dej., Harpalus, 182

exilis, Boisd., Chilades, 260

Exmouth, 14

exochana, Meyrk., Carposina, 469

Exochomus, Redt., 206, 231

Exomalopsis, Spin., 298

Exoprosopa, Macq., 212, 393

cxoskeleton, hard or tough, 155, 158, $163,164,177,209,224,240,298,327$, $362,377,431,435,518-521$

expodita, Walk., Ophiusa, 186

exporimonts in fooding birds, otc., 2, 238,

$$
\text { 525-528 }
$$

cxsularis, Meyrk., Hypenodes, 456

extormination of plants and iuscets, 1

eye, loss of sight of, 25

Eysarcoris, Hahis., 97

fabius, Fabr., Charaxes, $367,37 £$

fabriciana, Steph., Simacthis, 8

Fabricius, 484

Frchi Shoya, $1420,421,424,425,426$

fadus, Cram., Acllopus, 263

Frúgu [Simln], 40, 41, 42

Frgus fuscr, Hook. [Amenlacenc] 476, 477

fíbrnci, Fst., Stramin, $23 ; 3$

Faithful, Jacob, 10

fakir, 87

falcata, Butl., Probolacn, 467, 469 
falcularia, Sepp., Drepanodes, 293

fallax, Smith, Podalirius, 392

false head. See head

faremonti, Luc., Adesmia, 158, 160, 164, 165

Farrar, Rev. F. W., 13

fascelina, Linn., Dasychira, 22

fascialis, Cram., Zinckenia, 48, 58, 68, $340,359,473,483,576$

fasciaria, Schiff., Ellopia, 19, 22

fasciata, Brullé, Empusa, 175

fasciata, Moore, Gampola, 357

fasciata, Sauss., Polybia, 307

fasciatella, Hübn., Dielis, 186, 214

fasciatocollis, Thomps., Tetradia, 221

fasciatus, Dall., Oncopeltus, 297

fasciatus, Linn., Trichius, 20

fasciculata, Ed. Saund., MIyzine, 409

fasciculatus, Schönh., Comythovalgus, 236

fasciolaris, Hübn., Melipotis, 318

fasciolata, Klug, Chrysis, 412, 432, 433

fasciolatum, Ramb., Orthetrum, 190, 192,198

fastidiosus, Sauss., Polistes, 199, 245

fastuosa, Lac., Camptolenes, 246

Fathipúr Síkri, 91, 92

fatima, Fabr., Anartia, 264

fatuellus, Hopff., Parnara, 189, 191, 195, $198,229,572$

Fauna of Sûdân, 421-422

faunus, Edw., Grapta, 149, 150

fausta, Oliv., Teracolus, 92

favosa, Fabr., Melipona, 332

Fawcett, W., 126, 301

Fedia decipiens, Pomel. [Valerianaceae], 170

feeding experiments, 2 , 238, 525-528

feisthamelii, Boisd., Notocrypta, 356, $371,383,572$

felderi, Brem., Pterodecta, 138

Felton, Samuel, F.R.S., 299

female butterflies most seen in afternoon, 371, 421

fenestrata, Fabr., Xylocopa, 340

fenestrella, Scop., Endrosis, 17, 18

feredayi, Bates, Chrysophauus, 455, 457, 463

fcredayi, Knaggs, Scoparia, 455, 475

forcntina, Godt., Ageronia, 257, 321, 324

Forns, 33, 45, 77, 145, 267, 447, 454, 455, $458,459,462$

foronia, Liun., Poridromia, 264, 324, 570

forrca, Walk., Pintia, 131

ferrea, Butl., Satsuma, 140

ferrugalis, Hiibu., Scopuln, 172, 175, 181, 195,576

formgana, Treit., Peronea, 22

forruginca, Frbr., Icaria, 372, 392, 531. Plate IV., Fig. 1, 2

ferruginca, Latr., Osmin, 177

ferrugineipos, Lopel., Ammophila, 224, 210

fortoni, Vach., Prosopis, 177

fcssalis, Srvinh., Noorda, 359, 391 festiva, Fabr., Calonota, 453, 453

fostiva, Linn., Chlorida, 295

festiva, Hübn., Noctua, 16

fcstivus, Thunb., Lygaeus, 179

fibulata, Guen., Idaea (Craspedia), 95, 247,359

Ficus religiosa [Urticaceae], 86, F. sp., 218

ficus, Linn., Pachylia, 292

Fidonia, Treit., 19

fidoniata, Guen., Semiothisa, 62

fieberi, Mayr, Limnogeton, 418

fieldii, Ménét., Colias, $41,45,46,55,60$, 78,522

figulum, Dahl., Sceliphron, 327

filicornis, Guen., Hypocola, 318

filipendulae, Linn., Zygaena, 8

Filodes. Guen., 361

fimbriata, Klug, Julodis, 413. Plate T., Fig. 8

fimbriata, Fabr., Plautia, 359, 362, 372

finitimana, Guen., Coccyx, 21

Finn, Frank, 525

Fireflies, 84, 295, 296, 366, 378, 379. See also luminous beetles

Firth, R., 462

fistulosus, Sauss., Odynerus, 359

flabifera, Moore, Nishada, 377

flammatra, Guen., Agrotis, 64

Flammulina crebriflammis, Pfeifi., 461 ; F. feredayi, Suter, 477 ; F. glacialis, Suter, 477; F. pilsbryi, Suter, 477 [Mollusca]

flat-topped trees, 210, 218

Flata, Fabr., 206

flavago, Suff., Cryptocephalus, 239

flavalis, Schiff., Botys, 8

flavicollis, Drury, Loxa, 296

flavidalis, Doubl., Mruesictena, 444, 445 , $446,452,462,469,470,475,481$

flavifimbria, Walk., Ouraptersx, 292

flavifrons, Fabr., Ceutris, 327

Flavinia, Walk., 259

flaviponnis, Gory \& P., Stringophorus, 236

flavipes, 'Pauz., Andreua, 173, 176

flavipes, Hrr., Colasposoma, 235

flavipes, Limu., Conops, 531

flavipos, Spiu., Megachilc, 411, 427, 42S, 429,433

flavogutta ta, Ploetz, Ocybadistes, 4S3, 4S5

flavopictr, Blnuch., Eilmencs, 3S1, 392, 393, 531. Plate IV., Figs. 9, 10

flavorufa, De Gecr, Xylocopa, 237, 245

flavo-siguntus, Dej., Thyrcoptcrus, 193

flavus, Fabr., Salius, 361

flcgyas, Crnm., Zomeros, 79, s0, S2, S3, 127,548

flosus, Fabr., Pterygospiden, 191, 198, $241,572,578$

Flctcher, T. Bainbrigge, 361

flexata, Walk., Scstra, 452

flexula, Schiff., Arentia, 14

flcxuosa, Fabr., Cicindela. 165 
flexuosellus, Walk, Crambus, 442, 444, $446,452,457,461,464,466,475$

flight of butterflies. See butterflies, flight of

flight of moths, slow, 128, 184, 195, 198, $321,360,391,443$

floccosa, Walk., Declana, 465, 468, 478

flora, Swiuhoo, Aloa, 340

floralis, Hïbn., Noctuolia, 407, 409

florea, Fabr., Apis, 375

florella, Fabr., Catopsilia, 211, 214, 225, 403, 406, 422, 506

florella, Cram., Syngamia, 293

floridensis, Morrisou, Leptotes, 285

fluctuata, Linn., Melanippe, 17, 172

fluctuatus, Gerst., Tachysphex, 414, 420

fluid, coloured, exuded by insects, 165 , 202, 256. See also juice

fluting of hiud-wing of Satyrines, 136, 137

fluttering of Papilios wheu feeding, 57 , $111,188,288,337,338,355,383,483$, 571

fluviata, Hübn., Plemyria, 14, 120

Flying-fish, 252

Flying-foxes (Pteropus), 341

foedosa, Guen., Eublemma, 211

fog in Yellow Sea, 133

folding. See hind-wings, bending of

Folkestone, 8

Fontaine Chaude, 159

forcipatus, Burm., Heterochelus, 243, 248

forda, Westw., Arina, 234

Forel, A., 332, 533

forest, peculiar character of S. Africau, 210

forestan, Cram., Rhopalocampta, 189, 192 fore-wings withdrawn behind hind-wings, $43,46,549,554,573,574$

Eorficula, Linn., 441

Formicomus, F'.-Sen., 179

formosa, Guér., Dielis, 485

formosa, Gukr., Euchromia, 189

Forres, 24, 593

forsteri, Fabr., Scantius, 247

Forström, Dr., 564

F'ort Frederick [Port Elizaboth], 247

Fort Frederick [Trinkomali], 337, 379, 380

Fort Garry, 152

fortinata, Guen., Gonophylla, 478

Fossils, 431,436

fosterana, Fabr., Tortrix, 17, 19

foul odours not ropellent to butterfies, $83,127,128,184$

Fountaine, Miss M., 281

foveicollis, Küst., Aulacophora, 396

francilloni, Leach, Hippobosen, 429

Franconia, 25

fraterna, Butl., Elymnias, 339, 346, 500, 529

fratorna, Noore, Pseudo-micronia, 358

fraterna, Vachal, Xylocopa, 236

Frcedley, W. G., Junr., 110, 111, 112, $114,115,131,514$
Freesia refracta, Klatt [Iridaeeae], 352, $506,507,511,513$

Fremantle, 487, 488

frisia, Poey, Phyciodes, 258, 282

Frog, 230

frontalis, Walk., Plotheia, 120

frugaliata, Guen., Somiothisa, 88

Fruhstorfer, H., on Precis, 282

Fuchsia excorticata, Linn. [Onagraceac], 467

fuciformis, Limn., Macroglossa, 11

fugiens, Hutton, Saropogon, 452, 462

Fukushima [Japan], 140

fullonica, Limn., Ophideres, 358

fulvidorsalis, Hïbu., Filodes, 361

fulvipes, Dallas, Lygaeus, 165

fulvitarsis, Brulle, Podalirius, 435

fulvitarsis, Brullé, Psithyrus, 158, 170

fulvo-margiuatus, Dohrn., Melamphaeus, 340

fulvopilosus, de Geer, Camponotus, 220, 232

fulvus, de Geer, Hypselonotus, 256, 304

fumata, Steph., Acidalia, 20

fumata, Butl., Chittira, 118, 119, 382, $388,496,519,520,536$

fumipennis, Loew, Oligodranes, 174

funerarius, Smith, Bombus, 79

furcatellus, Zett., Crambus, 21

furcatus, Panz., Podalirius, 531

furcula, Linn., Cerura, 22

furia, Stdgr., Tithorea, 320

furva, Hübn., Mamestra, 16

furva, Panz., Nomada, 170

fusca, Haw., Phycis, 12, 20

fusca, Beauv., Ranatra, 297

fuscalis, Schiff, , Botys, 22

fuscipennis, Wiod., Harpalus, 249

fusciponnis, Germ., Sphocodes, 177

fuscipunctella, Haw., Tinea, 18

fusco-aëneus, Doj., Harpalus, 233

fylla, Doubl., Abisara, 79

gagates, Smith, Polyrrhachis, 245

gages, Fabr., Blaps, 400, 401

Gahan, C. J., 296, 378

gaika, Trimon, Kizora, 307, 349, 377, 378

Gaillardia sp. [Compositae], 55

galactina, Fold. \& Rog., Nymphostola, 467,469

galathoa, Linn., Molanargia, 499

galba, Fabr., Hosperia, 93, 356

Galbanella, Fisch., Golochia, 19

Gallorucolla, Croteh, 309

grllieus, Linn., Polistes, 158, 170, 173, $176,177,430$

Gallus bankivus [Aves], 376

Gametis, Burm., 237, 238, 241

gamina, Linn., Plusia, 172

Gampola, Mooro, 357

gandoldphoi, Oberth., Oenogyna, 168

gangis, Linn., Creatonotus, 358

Ganoris, Dalm., 7, 44, 48, 49, 51, 54, 64, $79,82,84,98,104,127,128,130,133$, 
$137,140,142,150,152,154,155,158$, $167,169,170,171,175,177,428,430$, $434,491,510,513,514,522,529,592$, 593, 595, 596

Gardenia sp. [Rubiaceae], 213

Gargaphia, Stal., 469

gargarus, Hübn., Papilio, 326, 516

garuda, Moore, Euthalia, 60, 73, 367

Gasteracantha, Latr., 300

Gasteruption, Latr., 456

gastriea, Tasch., Larra, 327

Gastrimargus, Sauss., 66

Gavialidium, Sauss., 375

Gazania sp. [Compositae], 249

Gazella doreas [Mammalia], 403, 437

Geana, Amy. \& Serv., 129

Gebel Ahmed Agha [Sîdân], 424

Gebel Dixon [Cairo], 435, 436, 437

Gobel Enn [Sûdân], 418, 423, 424, 425, 426

Gecko sp. Al. Br. [Reptilia], 200, 201, 342

Gegenes, Hübn., 54, 55, 58, 185, 1S6, 191, $195,198,223,229,236,241,247,400$, 516,572

Gelechia, Hiibn., 19

geminana, Steph., Grapholitha, 19

Genista sp. [Papilionaceae], 174

genoveva, Cram., Preeis, 282, 329, 579

Gentiana corymbifera, T. Kirk [Gentianaceac], 472

genutia, Cram., Danaida, 55, 70, 75, 76, $264 n, 363,495$. See also plexippus

Geometra, Boisd., 16

geometralis, Guen., Lepyrodes, 80

geometrina, Feld., Zerenopsis, 195

geometrinus, Feld., Paches, 307

georgina, Butl., Syntomis, 357

Geotrupes, Frbr., 169

germanica, Fabr., Vespa, 173

gerningiana, Schiff., Amphisa, 21

gesta, H.-Schäff., Chiomara, 306, 310, 316 , 320,573

geta, Godm., Dynamine, 313

Getêna [Sûdân], 416

geysers, 450

Gezira Island [Cairo], 430, 433

gháts, bathing, 67

gházi, 52

Gibbs, MTiss L. S., 219, 224

gideon, Linn., Xylotrupes, 120

gidien, Godt., Belenois, 183, 188, 191, 1.93, $197,222,223,225,226,227,228,512$

giganteus, Fuessly, Tryxalis, 155

gigas, Walk., Macrobrochis, 128

gilippus, Cram., Danais, 495

Giraffe, 213

Gisborne, 444, 445

Giza, Pyrrmids of, 396, 397

glabra, Sol., Tentyria, 396, 431, 435

Glandina sp. [Mollusca], 302

glauea, Kirby, Hansenia, 539

glaueata, Walk., Elvia, 479

glaucippe, Linu., Hebomoin, 102, 103, $114,354,369,371$; peculiar strueture of hind-wing 369 glauconome, Klug, Syachlö̈, 430, 432

glaucopis, Drury, Pidorus, 128

glaueus, Linn., Papilio, 149, 151

Glen Siding [S. Africa], 207

Glenorehy [N. Zealand], 479

globosus, Fabr., Brachycerus, 203

gloriosa, Butl., Pterodecta, 138, 142

Glutophrissa, Butl., 194, 197, 228, 286, 524,534

Glyphodes, Guen., 231, 293, 294, 319, 327 , 359,361

gnoma, Fabr., Catopsilia, 47, 64, 68, 90 , $102,127,506,587$

gobiata, Feld., Coenoealpe, 469, 474 479

Godman and Salvin, IIessrs., 329, 331, 379

Godwin-Austen, Col. H. H., 344

goedartella, Linn., Argyresthia, 19

goetzius, Herbst., Byblia, 184, 186, 1ST, $190,193,197,222,234,235,211,216$, 501

gola, Moore, Padraona, 356

Golden Oriole [Aves], 376

Gomalia, Moore, 189, 195, 232

Gomphidia, Sélys, 143

gomphota, Meyrk., Scoparia, 440

Gomphrena globosa, Linn. [Amarantaccae], 483

Gonepteryx, Leach, 40,42, 63, 140, 154, $167,169,171,176,177,507-509,523$, 534

gonerilla, Fabr., Pyrameis, 443, 444, 455, $457,458,463,476,481,482$

Gonia, Meig, 161

goniodes, Dallas, Holeostethus, 190

Gonophylla, Meyrk., 478

Gonopsis, Serr., 206

gonostigma, Fabr., Orgyia, 10

Gordon's statue, 404

Gorgas, Colonel, 263

Gorge de Chubet [Algerin], 169

Gorgythion, Godm. \& S., 315, 573

goschkevitschii, Ménét., Blauaida, 131 , $136,139,141,143,523,555$

Gosse, P. H., 126, 275, 284, 295, 327

Gôz Abû Gûma [Sùdûu], 417

gracilis, Dej., Polylirma, 233

gracillima, Tasch., Ammoplila, 410

Gracillodes, Guen., 195, 223

Gracula sp. [Aves], 526

graminosa, Walk., Eraua, 468, 575

grammalis, Doubl., Dirsemia, 456,461

grammellus, Zell., Talis, 486

gravarius, Liun., A phodius, 160

grandis, Kiraatz, Micipsa, 431, 432

graudis, Fubr., Megalodaene, 198

grandis, Klutg, Pimelia, 399

granite used with wood construction, 142

Granite Temple, masonry of, 437, $43 \mathrm{~S}$ Fig. 15

Graphipterus, Latr., 160, 161, 163, 164, $166,202,205,210,435$

Grapholitha, Treit., 17, 19, 20, 24 
Grapta, Kirby, 133, 137, 142, 149, 150, $176,539,541,561,562$

Graptostethus, Stål., 363

Grasshopper, water, 375, Fig. 13. Plate IV., Fig. 13

gratiosa, Doubl. \& Hew., Sphaenogona, $257,258,261,308,315,320,326$

Graveson, A., 342

grayi, Boisd., Papilio, 516

Grayvel, Mit. [Perthshire], 20, 21

Greek influence on Buddhist Art, 86

Green, E. E., 103, 109, 117, 120, 341, 347, $353,354,364,366,368,372,374,530$, $535,536,539,540$

gregarious Acridians, 212 ; Butterflies, $73,74,75,76,79,82,85,87,88,118$, 193; Homoptern, 206; Moths, 128 gremius, Fabr., Suastus, 71, 96, 127 grenadensis, Ashmd., Odynerus, 298 grenadensis, Schaus., Thymele, 258, 288 Grevillea sp. [Proteaceae], 115

Griffini, Dr. Achille, 299

gripusalis, Walk., Azochis, 332

griseata, Butl., Borkhausenia, 463

griseata, Hudson, Declana, 478

griseata, Hmpsn., Heylaertsia, 360

griseipennis, Feld., Hyssia, 478

griseipennis, McLachl., Stenopsyche, 141, 143

Griselinea littoralis, Raoul [Comaceae], 454

griseus, Fabr., Belonogaster, 207, 211 , 214

grossa, Linn., Echinomyia, 532

grossulariata, Linn., Abraxas, 517

Gryllacris, Serv., 299

Gryllotalpa, Latr., 359, 428

Gryllus, Linn., 158

Guaira, La (Venczuela), 587. Sce La Guaira

Guanches [Tencrife], 30, 33

guarica, Rcak., Hcliconius, 329

guorini, Sauss., Belonogaster, 214, 224, 220,245

guerini, de Castel., Lophocophala, 363

gucrini, Lucas, Myæino, 409

Guiana, 579, 582

guildingi, Westw., Piczodorus, 297

Gulf-wced, 333, 334

Gunn, D., 231

guns, monster, 95

Gurkas, 56

guttatus, Bram. \& Grey, Paruara, 350

guttigera, Thunb., Eyssurcocoris, 97

guttula, Fabr., Catorrbintha, 305

guttulosana, Walk., Siccin, 357

Guyotvillc [Algeria], 155, 176, 177, 541

Gwaai [S. Africa], 217

Gwálior, 88, 89

Gyaria, Stiıl, 206

Gymnetis, McLachl., 294

Gymnoloma, Dej., 182

Gynandrophthalma, Isac., 240

Gyrinus, Linn., 309 gyrosicollis, Boh., Eremnus, 244

gysselinella, Dup., Cedestis, 19

Habarane [Ceylon], 381

Hadena, Schrank, 8, 15, 16, 19, 22, 176

Haegg, R., 424

Haematera, Doubl., 319

haematodes, Linn., Odontomachus, 298, 332

Haematopota, Latr., 223, 226, 250, 384

Haematoxylon campeachianum, Linn. [Leguminosae], 279, 571

haemorrhoidalis, Fabr., Liris, 186

haemorrhoidalis, C. Waterh., Metriorrhynchus, 441

haemorrhoidalis, Fabr., Oxythyrea, 239, 244

haifae, Habditch, Pseudophia, 428

Haines, T. E., 473

Hajji Ali Gâbri, 437

Hakgála [Ceylon], 118, 537

Halictus, Latr., 164, 168, 173, 177, 180, $182,245,250,298,399,531$

Halisidota, Hübn., 290

halimede, Klug, Teracolus, 416, 417, 418, $419,420,421,422,510,525$

Halley's Comet, 488

Halpe, Moore, 137, 143, 356

Halter, Ramb., 221

halterellus, Zell., Chilo, 447, 452

Haltica, Ill., 217, 230, 296

Hamamelis virginica [Hamamelidaceae], $314,496,503$

Hamanumida, Hüibn., 222, 502, 548, 564

Hamearis, Hübn., 258, 261, 304

Hamilton, A., 444, 451, 464, 465

Hamm, A. H., 531, 592

Hammam Meskutino, 167, 168, 169, 507,

Hammam-es-Salahin, $159,160,161,162$,

Hammam R'ihra, 170-175, 508

Hammaptera, H.-Schäff., 293

Hampson, Sir Georgo F., Bart., 42, 77, $102,116,128,129,186,220,318,400$, $402,408,418,419,440,449,463,478$, 480

Hamurana [N. Zealand], 453

Fannington [S. Africa], 233

hanno, Stoll, Ca tochrysops, 258, 260, 265, $285,304,307,314,325,330,505,567$

Hansenia, Kirkaldy, 533

Hantana, Mooro, 383, 384, 572, 573

hapalina, Butl., Catochrysops, 90

Haplolycus, Bourgcois, 189, 237, 238, 2.11

Haplotracholus, Chaud., 240

Irappy Valley [Hong Kong], 127, $12 \mathrm{~S}$

Hapsifern, Zoll., 359

Haptoncus, MLurr, 364

Haputálo [Coylon], 120

Haragama, 110, 114, 366-372, 537

hardwickii, Gruy, Parnassius, 45, 510. Plato I., Fig. 4

Haro, 92, 166, 181

haronica, MToorc, Vauossa, 99, 100, 348, 383,552 
Harpactopus, Smith, 260

Harpactor, Lap., 241, 246

harpaloides, White, Adelium, 476

Harpalus, Latr., 182, 201, 205, 210, 233, $249,250,434$

harpax, Fabr., Axiocerces, 189, 212, 214 , $223,231,232,241,566$

Harper-Crewe, Rev., 25

harrisellus, Kirby, Bombus, 452, 453, 532

Hart's Hill [S. Africa], 201

hastiana, Linn., Peronea, 22

Hatton [Ceylon], 115, 116, 118, 382-384, 539

haworthii, Curt., Celacna, 16

Hayling Island, 24

hazia, Hew., Thecla, 260

head, false, of Lycaenids, 69, Fig. 5, 185, 198, 326, Fig. 12, 351, 564-570

head, false, of Satyrine, 570, Fig. 19

head, hard, of Negro, 322

Headington Wick [Oxford], 25

hebe, Clk., Atechna, 239

Hebomoia, Hübn., 82, 102, 103, 114, 354, $368,369,370,510,519,534$; peculiar structure of hind-wing, 369

hebraea, Klug, Cicindela, 254

hebraeus, Fabr., Polistes, 54

hecabe, Linn., Terias, $35,43,46,47,48$, $49,51,54,57,61,64,65,66,68,71,73$, $79,83,84,86,88,90,96,98,99,105$, $106,108,110,116,117,119,124,127$, $130,137,338,353,354,364,365,371$, $373,377,379,381-383,384,386,387$, $388,510,522,588,589,590,591,593$

hecate, Butl., Melanippe, 143

hector, Linn., Papilio, 101, 105, 111, 337, $355,373,378,380,381,514,520,522$, 538,571 ; peculiar flight of, 355

Hedley, R., 485

Hedyu, Hübn., 14

Hedybius, Erichs., 249, 250

Hedychridium, Abeille, 412

hegesia, Cram., Euptoieta, 279, 282

hegesippus, Cram., Danaida, 124

Helastia, Guen., 467, 469, 474, 479

helenus, Linn., Papilio, 127, 383, 539

Helicina neritella, Lam. [ [Mollusca], 302

Heliconius, Latr., 103, 255, 281, 304, 306, $307,310,314,319,321,323,829,503$, $504,519,524$

Holiopetes, Billb., 257, 258, 265, 308, 315, $320,321,326$

Heliostibes, Zell., 456

Heliothis, Ochs. See Chloriden

holiotropism in buttorflics, 43, 154, 160, $184,255,346,347,349,367,399,427$, $441,539-553,562$

Helix ฉsporsn, Mull., 441, 444, 445, 473; II. desortorum, Forsk., 437 ; H. fasciata, Pic., 444; H. pis̊na, M[üll., 196; H. nndulata, NLoq.Tand., 441 [Mollusca]

hollicr, Linn., Synchloë, 181, 199, 202, $204,207,209,241,247,514,598$
Hollins, Rev. J., 25

helloides, Boisd., Chrysophanus, 150

hcllotia, Ménét., Evcres, 137, 140, 142

Hellula, Guen., 859, 409

Helophilus, Meig., 230, 454, 462, 4C3

Helops, Fabr., 160

helops, Cram., Ammalo, 290

helvolus, Linn., Dorylus, 203, 217

Helwân, 431

Hemerophila, Stcph., 172, 456, 459, 460, $463,468,478,487$

hemionana, Meyrk., Proselena, 470

Hemipepsis, Dahlb., 224

hemipteraria, Guén., Xyridacma, 474, 479

Hemisalius, Sauss., 33 ?

Hemithea, Dup., 359

Hemitrochus grammicola, Ads. [ $\mathrm{Mol}$ lusca], 302

Henicospilus, Steph., 97

Henley, Hon. F. R., 422

hemrici, Holland, Astictopterus, 127

Heodes, Dalm, 150. See Chrjsophanus

heparata, Haw., Eupisteria, 10

Heracleum sphondylium, Linu. [Tinbel. liferae], 544

Herbula, Guen., 46, 407

hercules, Dalm., Morpho, 501

Herdman, Prof. W. A., 201

hermes, Fabr., Euptychia, 255, 261, $306,307,309,310,313,320,323,329$, 578

hermus, Feld., Nacaduba, 391

Herpaenia, Butl., 420, 422

hesione, Sulz, Euptychia, 255, 306, 320, $323,329,524$

hespera, Fabr., Nephele, 4S, 59

Hesperia, Fabr., 93, 140, 150, 232, 233 , $241,256,261,265,259,304,305,305$, $310,315,331,356,553,564,565,571-$ 573

Hestia, Hübu., 120

Hcterochelus, Burm., 242, 243, Fig. S. $244,248,250$

Hetcronympha, Wallgr., $410,4 S t, 456$. 487,500

Heterotarsus, Latr., 393

Hetcrusia, Hope, 30S, 316

Hever Castlc, 11

Howlott, Dr. G., R.N., 148

Hexachr'ssis, Licht., 215, 372, 392

Hoylacrtsia, Himpsu., 360

hiarbas, Drury, Eurytcln, 1St, 1S6, $15 \%$. $190,193,235,246,546$

Hibiscus sp. [Malvaceae], 232, 408

Hieizan, MIt., 137, 138

Hicrodula, Burnı., 413, 434

hieroglyphica, Cram., Euglyphia, 291

hicroglyphicus, Oliv, Clconus [Dicrnnotropus], 164, 396

hierte, Hiibn., Delins, 513

hilarianus, Sauss., Zctluus, 317

Iillet Abbas [Sñdin], 410,421, 425 , 426 
hill-tops, abundance of butterflies on, 142,355

Himálaya, meaning of, 46

himantopus, Klug, Athalia, 185, 236

Himatismus, Erichs, 221, 399, 402, 413

hindu, Heller, Singhala, 340, 364

Hindugala [Ceylon], 375

Hinduism, 47, 65, 67, 106

Hindustån-Tibet road, 39-47

hind-wings, bending, folding or plaiting of in certain Blues and Skippers; 68, 69, Fig. 5, 73, 86, 192, Fig. 7, 351, 356, 357, 564-570, Fig. 19, 572, 573

hind-wings of Lycaenids, lobed, 66, 68, 69, Fig. 5, 73, 105, 114, 185, 326, Fig. 12, 351, 564-569; of Nymphalines, lobed, 81, 570; of a Satyrine, lobed, 570, Fig. 19

hind-wings, movement of, by Lycrenids, $104,235,338,350,368,401,414,564$, $565,566,567,568,569$; by a Nymphaline, 330

hind-wings of certain Satyrines, fluted, 136,137

hintza, Trim., Lycaena, 231

Hiposcritia, Gey., 78, 79, 80, 98, 589

Hipparchia, Fabr., 51, 54, 55, 554

Lippia, Fabr., Nepheronia, 71, 73, 74, 94, 391,511

hippo, Cram., Tachyris, 82, 84, 101, 589

Hippobosca, Linn., 159, 163, 429

hippoclus, de Nicév., Symbrenthia, 80. See also lucina, Cram.

hippomene, Hübn., Hypanartia, 235

Hippopotamus, 226, 416

Hipporrhinus, Schönh., 182, 205

Hirschfeldia geniculata, Batt. [Cruciferae ], 175

hirta, Thunb., Epilachna, 179

hirtaria, Clerck, Biston, 14

hirtella, Linn., Tropinota, 170, 175, 176 , 177

hirticornis, Hcrbst., Melanotus, 359, 374

hirticornis, Puton, Menaccarus, 163

hirudinicornis, Guen., Phycodes, 391

Hispa, Linn., 217, 330

hispanus, Linn., Copris, 169, 174

hispica, Forsk., Ocnora, 396, 399, 401, $413,428,431,433,435$

hispidaria, Fabr., Biston, 5

hispidus, Web., Trachypholis, 374

Hister, Linn., 195, 238, 382

histrio, Fabr., Crocisa, 75, 392

histrio, Fabr., Cydosia, 291, 332

Hlangwane [S. Africa], 200

Hobart, 439-441, 486, 549

hobomok, Harr., Atrytone, 152, 153, 572

Hobson, C. A., 226

hochstetteri, Nowicki, Helophilus, 463

Hodotcrmes, Hag., 243

Hoheria populnea, A. Cunn. [Malvaceac], 457,463

Holcostcthus, Fiob., 190

Homalomyia, Bouché, 186
Homoeosoma, Curt., 452

Homophoeta, Erichs., 265

Homopsyche, Butl., 357

Homoptera, Boisd., 203, 211, 220, 291

homoscia, Meyrk., Morrisonia, 463, 468, 481

Honey-bird (Dicaeum sp.) [Aves], 118

Hongkong, 124-129

Hooker, Sir J. D., 103

Hoopoe, Upupa sp. [Aves], 61

Hope Collection [Oxford], 27, 39, 51, 453, 580

Hoplotarache, Hmpsn., 263

Hoplocnemis, Har., 243

Hoplopus, Lap., 155, 173

Hoplosoma, Motsch., 340

Hoplinae, Burm., 242, 244

hordonia, Stoll., Rahinda, 65, 347

Horia, Fabr., 327

horsfieldi, Hope, Mimola, 83

Horton's, Lady, Drive [Ceylon], 109, 346

Horton Plains, 119, 385

hortorum, Linn., Bombus, 443, 445, 453, 528,532

hortulanus, Linn., Bibio, 177

hot summer of 1868,24

Hotinus, Am. \& Serv., 113

hottentota, Latr., Gegenes. See letterstedti.

hottentota, Smith, Xylocopa, 204

hottentotus, Sachse, Xantholinus, 238

Howes, G. W., 451, 467, 468, 469, 470, $471,473,474,476-481$

Howick [Natal], 199

Howrah, 75

hralili, Lefebvre, Eremiaphila, 436

Fudson, G. V., 451, 452, 455, 472, 478, 480,482

huebneri, Ménét., Eueides, 320

huobneri, Kirby, Yphthima, 71, 72, 75, $100,126,339,390,521,590$

huegeli, Moore, Cyaniris, 383

Humboldt, A. von, 31

humoraria, Walk., Sestra, 452

Humewood [S. Africa], 247, 248

Humming-birds, 255, 267, 268, 291

huntera, Fabr., Pyrameis, 25

Huphina, Moore, 43, 47, 48, 61, 66, 74, $79,81,82,83,84,85,91,93,102,105$, $107,114,127,354,369,374,377,381$, $391,513,588,589,590,591$

hurga, Schaus, Telogonus, 288

huronalis, Guon., Crocidophora, 293

Hutchinson, Mrs., 25

Hutchison, Cupt. F. S., 534

huttoni, Butl., Motacrias, 477

huttoni, Pascoe, Ochrocydus, 452

Huttú, Mount, 40, 45, $46^{\circ}$

byale, auct., Colias, 51, 55, 99, 111, 406, 509,525

hyalina, Koll., $\Lambda$ galope, 42, 44

hyalinata, Tinn., Glyphodes, 294

Hyblaca, Fabr., 66

hybreasalis, Walk., Adona, 469 
hybridalis, Hübn., Stemopteryx, 99. Scc also noctuella

hybridus, Boh., Harpalus, 210

hydarus, Hew., Heliconius, 314, 319, 323, $324,329,503,504,519$

Hydaticus, Schönh., 393

Hyde Park, 14

hydralis, Guen., Hellula, 409

Hydrangea sp. [Saxifragaccae], 531, 593

Hydrelia, Hübn., 25

Hydrocampa, Latr., 11

Hydrophilus, Geoffr., 321

Hygrochroa, Hïbn., 143

hylas, Linn., Cephanodes, 96, 214

Hylephila, Billb., 265, 289

Hylomela, Grhau, 211, 226, 239

hylonome, Doubl., Actinote, 314

Hymenitis, Hübn., 312

Hymenophyllum sp. [Filices], 459

Hyocyamus muticts, Linn. [Solanaccac], 435

Hypanartia, Hïbn., 321, 235, 568

Hypanis, Boisd., 95. Sce also Byblia

hypaphanes, Hmpsn., Luxiaria, 391

Hypena, Schrank, 43, 192, 358

Hypenodes, Guen., 456

Hyperalonia, Rond., 372

hyperanthus, Linn., Epinephele, 79, 544, 554,574

Hyperaspis, Chevr., 257, 296

hyperbius, Johanssen, Argynnis, 54, 55, $66,82,99,100,115,119,382,388,522$, 529

hyperion, Hübn., Papilio, 516

Hyperlopha, Hmpsn., 381

Hypermecia, Guen., 19

Hyphaene thebrica [Palmac], 403

Hypna, Hübn., 308

hypnois, Hübn., Synia, 318

Hypocala, Guen., 318

hypocrita, Serv., Geotrupes, 169

hypocritaria, Guen., Devarodes, 310

Hypocystr, Westw., 483, 484

Hypoglaucitis, Staud., 402, 408

Hypoleria, Godm. \& S., 310, 312

Hypolimnas, Hübn., 36, 48, 58, 62, 65, $66,67,71,85,95,96,104,113,18 i$, $348,367,370,377,383,502,520,521$, $522,525,527,529$

Hypolycacn̊, Fcld., 189, 191, 213, 223, 566,568

Hyponomeutidne, Steph., 54

Hyposidra, Guon., 358

Hyposphaoria, Lucas, 289

liypothous, Cram., Daphnis, 360

hyppasia, Cram., Trigonodes, .97

Hypsclonotus, Hahn., 256, 265, 801

Hypsipetcs, Stoph., 17

Hypsopygia, Hübn., 418

Hyptis capitata, Jacq. [Iabialac], 265, 316

Hyrin, Stoph., 292, 358

hyriarius, Walk., Frythrolophus, it

Hyssia, Gucn., 451, 468, 474, 477-480

Hystricia, MIacq., 456, 463, 475 iacchus, Fabr., Trapczites, $18 \%$

iambe, Dbl. \& H., Dircenna, 313

Iambrix, Watson, 113, 127, $556,371,381$

iarbas, Fabr., Deudorix (Hesperia), 564, 565

Icaria, Sauss., 189, 212, 237, 245, 372, $392,416,531$

icarus, Rott., Lycacna, 170, 505, 55̃ , $565,567,596$

ichneumon-flies, abundance of, 22

ichneumonea, Linn., Diopsis, 229

Ichthyurus, Westw., 372

ictis, Hew., Aphnaeus, 68, 1386

Idaea, Treit., 83, 95, 117, 120, 172, 192, 247, 359. See also Craspedia

Idaethina, Murr., 340, 364

Idia, Meig., 185, 236, 363, 413. See also Rhinia

Idiodes, Guen., 485

ignita, Linn., Chrysis, 165

Iguana, Daud. [Reptilia], 258

ilaire, Godart, Glutophrissa (Dapto. noura), 286, 511

Ilema, Moore, 357

Ilerda, Doubl., 41, 42, 47, 55, 64, 65, it, 82,522

Ilfracombe, 14

ilione, Cram., Ituma, 495

ilithyia, Drury, Byblia, 95, 105, 184, 204, 589,590

illita, Feld. \& Rog., Heliostibes, 456

illudens, Mabille, Vehilius, $25 \mathrm{~S}$

illustraria, Hïbn., Selenia, 22

illustrata, Harr., Chilosia, 531

Image, Prof. Selwyn, 26, 370, 514

imbella, Walk., Lamoria, 409, 422

immanata, Haw., Polyphasia, 44

immunis, Walk., Orthosia, 451. Sec also compta, Walk., Agrotis

immunis, Gnen., Poaphila, 253, 291, 332

impactella, Walk., Eretmocera, 54

impar, Walk., Tabanus, 455

impatiens, Hutton (nce Walk.), Sarcophngn, 445, 446, 45S, 463

impressifrons, Sol., Pachychila. 15s, 175

impressus, Stíl., Prototettix. 230. 240, 245

ina, Plütz, Methionopsis, 316

inachis, Boisd., Tiallima, S1

inangulata, Gncu., Ericcia, gr

inaria, Cram., Hypolimuas, 96

incanus, Klug, Podalirius, 417

inceptria, Walk., Bonrmia, 100

incerta, Walk., Lyumantria, 94, 9 '

Inchanga [S. Africa], 199

incidalis, Hiibn., Glyphodes, 293

Incisalia. Minot, 150

inclusa, Walk., Dastchira, 120

iucoloralis, Guen., Pyrausta, 58, 236 , 359

iucouclusaria, 'Walk., Obolcola, 236, 246

incondita, Butl., MIctachrostis, 116

inconspicua, Boisd., Parunrn, 228

inconspicuclla, Rngon., Microthrix, 203 
iuconspieuus, Jac., Luperus, 240 inconstans, Lafert, Notoxus, 250 incultus, Fst., Xenorrhiuus, 224 Indian namos, pronuneiation of, 40 role Indians, American, and signs, 26 indica, Fabr., Apis, 340, 361, 365, 392 indicr, Sauss., Discolia, 365 indiea, MIuls., Epilachna, 374 indica, Herbst, Pyrameis, 26, 41, 46, 48, $63 n, 65,77,78,79,98,99,141,388$ indiea, MLurray, Zizera, 48, 96, 106, 349, $365,373,377,568$

indicata, Fabr., Nacoleia, 293

indictinaria, Brem., Anagoga, 138, 143

indicus, Aubé, i Dineutes, 393

indigaeca, Illig., Haltica, 330

iudiscriminata, Hmpsn., Ophiusa, 361

indistans, Moore, Myealosis, 72, 79, 83, 551,589

indistinctalis, Walk., Scoparia, 452

individuality in insects, 542,543

indra, MLore, Hiposcritia, 80

inductata, Walk., Pasiphila, 465

induta, Wied., Ceropria, 362

inenaerabilis, Vogel, Ateehna, 238

ineptus, Walk., Helophilus, 454

inermis, Faum., Iehthyurus, 372

infernus, Feld., Hantana, 383, 572, 573

inficita, WValk., Poujadia, 382

infirma, Nulsant, Epilaehna, 195

Ingagane [Natal], 204

iniea, Hew., Yphthima, 93, 100, 589

injuries inflicted by foes, $44 n$, Fig. $3, a, b$, $18,58,68,71,73,77,82,81-86,88$, $92,94,100,101,110-116,119,127,140$, $154,171,185,194,197,198,265,281$, $287,323,346,348,350,351,352,367$, $371,387,390,406,521-525$

Inkwelo [S. Africa], 204

innotata, Hübn., Eupitheeia, 172

Ino, Leach, 11

inornatana, H.-Sebäff., Anchylopera, 14

inostentata, Walk., Adeixis, 455

inornatus, Bingh., Halietus, 182

insects, paeking for the post, 38,39 ; caro of boxes of pinned, 38

insects taken at sea, 251, 335, 439, 140

insignis, Walk., Morrisonia, 446, 460, 465, 474

insignitalis, Guen., Pyrausta, 293

insolata [? insolita], Butl., Serdis, 289

inspirata, Guen., Idiodes, 485

insubricus, Scop., Acrotylus, 175, 177

insulana, Boisd., Earias, 49, 62

insularis, Casteln., Hydrophilus, 221

insulata, Walk., Ammalo, 290, 318

insulsella, Ragon., Mierotbrix, 203, 207, 221

integumonts, specially hard, 518-521. Sec also exoskeloton

interlectum, Walk., \%onosoma, 80

intermedia, Kirby, Derocalymna, 202

intermedium, Liv. \& Schin., Chryso. toxum, 155 interuata, Guen., Craspodia, 236

interrogationis, Linn., Plusia, 19

interrumpens, Walk., Derispia, 364. Plate IV., Fig. 12

interruptus, Linn., Creatonotus, 113, 308

interruptus, Linn., Passalus, 333

interstineta, Klug, Seolia, 434

interstitialis, Esch., Scalmus, 268, 291, 333

intricata, Klug, Adesmia, 225

intrudens, Smith, Trypoxylon (Seeliphron), 372, 392

inverted attitude. See Lyeaeuids

Iuyantue [S. Afriea], 231

io, Linu., Vanessa, 140, 544, 545

Iolaus, Hübn., 568

ione, Godart, Teraeolus, 188, 194, 510, 549, 575

iopasalis, Walk., Sylepta, 359

Ipana, Walk., 474, 478

iphianassa, Dbl. \& H., Ithomia, 257, 312

Iphiaulax, Foerst, 199, 212, 214, 226, 237, 239

iphidamas, Eabr., Papilio, 315

iplita, Cram., Precis, 47, 64, 65, 83, 99, $104,108,113,347,367,377,381,383$, $385,387,502,552,588$

Ipomoea sp. [Convolvulaccac], 218, 223, $324,226,253,266,597$

Iraota, Moore, 127, 391

iridipennis, Smith, Salius, 372

iris, Linn., Apatura, 25

iris, Paseoe, Promeces, 238

iris, Butl., Taehyphyle, 293, 332

irius, Fabr., Hypocysta, 483, 484

irritans, Smith, Pheidole, 199, 200, 201, 240

irrorella, Wlsm., Timyra, 359, 386

irus, Godart, Incisalia, 150

isabolla, Cram., Eueides, 320

Ischnoptora, Burm., 230

Isidora lyrata, Woods, 473, 477; 1. moosta, Adams, 464; I. novao-zonlandiae, Soworby, 453; I. sorieina, Jiek., 424 ; I. tabulata, Adams, 464 [Mollusca]

Isle of Wight, 8, 14

jsmono, Cram., MIolauitis, 72, 75, 80, 96 , $101,346,364,537,539,589,590$

ismeno, 1 Nowm., Oxytoxia, 485

isocrates, Fabr., Virachola, 86, 351

Isodontia, Patton, 304

Isoglossa woodii, Clarko [Acanthaccac], 194

issaca, Mlooro, Argynnis, 41, 42, 44, 45, 46, 61

italieum, Rond., Chrysotoxum, 155

itor, Fabr., Pyramois, 414, 448, 486

Ithomia, Hiibn., 257, 291, 310, 311, 312, $313,323,332,494$

Ithoiniinae, swarms of, 311, 312, 313

ittona, Butl., MInestlieus, 316

itonia, Hcw., Yphthima, 222, 228

Ituna, Doubl., 495

Ixias, Hiibu., 19, 61, 62, 66, 75, 77, 80, 
$81, \$ 3,86,88,90,95,102,114,354,369$, $370,377,510,522,534,537,577,588$, $589,590,598$

jacintha, Drury, Diadema, 48, 348

JackaI, 56, 67, 166, 341, 433

Jrcoby, Martin, 374

jactatana, Walk., Cnephasia, 469

Jadera, Stål, 297, 333

Jáipúr, 92, 93

Jalapahar, [Darjiling], 79

jalapalis, Schaus, Argyractis, 293

Jamaica : 265-303

Aculeata, 298-299

Beotles, 294, 296

Bugs, 296, 297

Butterflies, 280-290

Land Mollusca, 300-303

Moths, 290-294

Orthoptera, 299-300

Scarcity of insects, 278

Special coloration of butterfies, 290

See also earthquake

Jamaica, parishes, 277 ; map of, Fig. 9 jamaicensis, Möschl., Anartia, 283, 581 jamaicensis, Bates, Danaida, 280, 495, 519

jamaicensis, Schaus, Duomitus, 292

jamaicensis, Walk., Dysdercus, 297

jamaicensis, Fabr., Haltica, 296

jamaicensis, Ernst Oliv., Photurus, 295

Jambosa vulgaris, D.C. [Myrtaceac], 283

Jamides, Hübn., 83, 118, 526, 568. Sec also Lampides

Janella bitentaculata, Quoy, 456; J. papillata, Hutton, 473 ; J. rufovenosa, Suter, 461, 469 [Mollusca]

janira, Limn., Epinephele, 499, 544, 558, 559,574

janthina, Esp., Triphaena, 16

Japan, absence of colour in, 136

art, influcnce of nature on, 144

clogs, 135, Fig. 6

impressions of, 144-146

Japan, furniture, 138

place-names, 140

var enthusiasm, 136

japonica, Guér., Cicindela, 138

japonicum, Uhler, Orthetrum, 143, 523

jarbus, Fabr., Lymnas, 314

Jardin Landon [Biskra], 158, 159

Jarvis, P.W., 281, 303

jasionoata, Crowo, Eupithocia, 25

Jasminum fruticans, Linn. [Jasminaceac], 173, 174

jasonir, Westw., Hestia, 120

jæson, Esp., Papilio, 115, 371, 520, 539

jatrophae, Linn., Anartia, 255, 264, 278 ,

$279,283,304,324,329,524,551,552$, $580,581,582$

javanus, Wiod., Pscudoblaps, 362, 364

javanica, Thunb., 'Tessarotoun, 113 jaws, lcgs usod as, 242, 243, ㄱig. 8

Jebol. Sce Gobol jemina, Hübn., Dircenua, 313

Jenner, J. H. A., 33

Jcrboa sp. [Mammalia], 166

Jerry Abershaw, 10

jesous, Guér., Azanus, 373, 380

Jhánsi, 35, 87, $88,90,530$

Jickeli, C. F., 423

Joannis, M. J. de, 563

jobina, Butl., Teracolus. See speciosu,

Johannesburg, 205-206

Josiomorpha, IFeld., 316, 521

jucundus, Smith, Halictus, 180

juice, coloured, of insects, 88, 126, 123 ,

$165,195,202,204,247,256,339,345$, $349,360,443,516-518$

julia, Fabr., Colaenis, 306, 319, 324

Julodis, Esch., 413

Julus, Linn. [Myriapoda], 238, 240

jumba, Moore, Neptis, 97, 347, 367, 502, 553

juncea, Sauss., Pseudo-deropeltis, 179

juncturalis, Walk., Pyrausta, 66

Jungle-fowl, 376

juno, Fabr., Dione, 306, 503

Junonia, Hübn, 41, 282, 347, 57T. Sce also Precis

jurtina, Lina., Epinephele, 499, 551

Jusufsai, 54

juvenalis, Fabr., Thamaos, 150

jurenculus, 'Shuck., Dorylus, 81

Kabylia, 169, 170

Kala, Swinhoe, Charltona, 129

Kálka [Simla], 35, 47, 48

Kallár [Nilgiris], 100, 101, 101, 563

Kallima, IWestw., $78,81,594$

Kalutara [Coylon], 339, 311

Kamáon, 64, 65

Kami Sakamoto [Japan], 137, 14 ?

Kanchinjanga, sceming transparency of, 78

Kandy, 109-118, 340-362, 496, 514, 526, $536,565,590$

Kandyan Chiefs, 342, 343, 344

liarsandra, MIoore, Zizera, 47, 49, 54, 55 . $94,109,121,336$

karschi, Fricso, Anthidium, 411

Karuizawa [Japan], 141

kashmircnsis, Koll., Tauessa, 41, 46, 63n. $65,77,78,79,521$

kashmironsis, Koll., Zygacna, 51

Kasi Ibrim [Nubia], 402

Katha, Mooro, 357. Sce Ilema

Katuma [S. Africa], 231

Fiauri Gully [Auckland, N.Z.]. 1.17

Ka5c, WV. J., 325, 329, 331, 55\%, 580, 5 S2

Kicdestes, Watson, 195

keithloa, Wallgr., Rhopalocampta, 191, 192, Fig. T, 572

Kiellog, Prof., Vernon L., 76

Konilworth [Kimberlo5, S.A.], 20S, 209

Fiorrcri [Sủdûn], 409

kicrshavi, MIcCoy, Pyramois, 141, 453, 461,549 
Ǩháibar Pass, 50

Kháibar Rifles, 51, 52

Kháirna [Kamaon], 64, 65, 84

Tỉhartûm, 403-413

Kheper, Egyptian for Scarab, equivalcnt to Chafer, 401

Ǩhoina, Péring., 246

Killing agents, 37, 201

Kimberley, 20S-210

kinbergi, Wllgr., Crastia, 131, 498, 519

Kingsley, Rev. C., 334

Kingston [Jamaica], bad building in, 266

Kinloch [N. Zealand], 479, 481

Kinloch Rannoch, 17, 20, 22

Kirby, W. F., 246, 436

Kitchener, F. E., 10, 13

Klip River [S. Africa], 202

klugii, Guér., Xenica, 486

Knaggs, Dr. H. G., 7, 23, 25

Kuight, H., 194, 292, 375, 567, 572, 591

Knollys, Capt. R. WV. E., 53

kohlii, Ducke, Osmia, 158, 174

kollari, Feld., Pademma, 75, 345, $49 \mathrm{~S}$

Kom Ombo [Egypt], 398

Konúr [Nilgiris], 99, 100, 590

Kopjes, Geology of the, 207-208

Kosti [Sûdân], 417, 418, 419, 424, 426

Kótal [Himálaya], 46

Kotagala [Ceylon], 382

Koubba [Algiers], 154

Krananda, Ioore, 129

Kricogonia, Reak., 286

Kudsia gardcns [Dclhi], 60-62, 107

kuhlwoini, Lefcbrc, Syntomis, 236, 241, $2+5$

kunzii, Sol., Pachychila, 175

Kurscong [Darjiling], 77, 590

Kutab, mosque at [Delhi] , 62, 63

Kyōto, 135-138

labdacus, Godm., Megistias, 265, 304

labiatus, Fabr., Mischocyttarus, 317

Labidura, Dum., 396, 413

labradus, Godart, Zizera, 441, 444, 445, $447,452,454,455,456,458,: 483,484$, 486,487

La Brea [Trinidad], 322, 325

Labus, Sauss., 214

lachcsis, Fabr., Achcrontia, 360

Lachnocnema, Trimen, 189

Lachnoptera, Doubl., 568

Lachnostorna, Hopo, 295, 384

lacinia, Hübn., Synchloë, 305, 308, 319, 324

laciniosa, H. Edw., Dicentria, 319

lactca, Swinhoc, Raparna, 97

lactcata, dc Nićville, Lampides, 113, 350,505

lacticinia, Cram., Deilcmora, 360

lacunana, Dup., Soricoris, 20

ladon, Cram., Cyaniris, 83, 152

ladonides, de L'Orza, Zizcra, 134, 137 , 110,142
Lady-birds, migration of, 415

Lady Horton's Drive [Kandy], 109, 346, $351,357,358,361,362,369,374$

Ladysmith, 201-204, 547

Laelia, Steph., 236, 419

laertes, Hübn., Prepona, 501

laota, Boisd., Terias, 47, 48, 79, 86, 88, $91,93,94,391,522,588,589,590$

laeviceps, Smith, Discolia, 361

laevicollis, Sol., Mesostena, 396, 398, 399, 427,435

laevigatus, Brullé, Cybister, 260

laevipennis, Jac., Oothoca, 240, 244

lafertci, Arrow, Pheropsophus, 421

Lagocheirus, Dej., 295

Lagria, Fabr., 230, 245

La Guaira [Venezuela], 256, 257, 305, 319, 320,321

Lahore, 56-59

laius, Cram., Chilades, 62, 86, 88, 349, $365,373,388$

lalage, Doubl., Hiposcritia, 78, 79, 589

Lálkót [Delhi], 62, 63

lamellatus, Oliv., Oxybelus, 411

lamis, Cram,, Nymphidium, 325

Lamium album [Labiatce], 592

Lamoria, Walk., 409, 422

Lampides, Hübn., 73, 79, 80, 81, 83, 84, $96,104,105,106,113,114,118,338,349$, $350,368,373,378,381,386,505,525$, 527, 567, 568

Lampyris, Geoffr., 169, 179

lanccaria, Navás, Nemopistha, 221. Plate II., Fig. 2

lanceolana, Hübn., Bactra, 21, 409

Land Crab, 169

Land Leeches, 382, 384

Land Snails. Sec Mollusca

lanestris, Linn., Eriogaster, 9

lanipes, Guen., Selenis, 262

Lanistcs bolteni, Chem. [Mollusca], 424

lanius, Linn., Gymnetis, 294

lanka, Moore, Cyaniris, 117, 119, 388

Lankestor, Sir Edwin Ray, 489

lankcswara, Moorc, Papilio, 111n, 355, $364,371,520,530$

Lantana camara [Vcrbcnaccac], 56, 70, $71,74,101,104,105,112,126,127,128$, $196,253,266,268,281,306,314,316$, $326,337,348,354,355,367,369,370$, $371,433,486,529$

Lantana sellowiana, Lank \& Otto [ $\mathrm{Vcr}$ bcnaccae], 486

Laoma albo-viridis, Suter, 477 ; L. celia, Hutton, 461, 473, 477 ; L. phrynia, Hutton, 477 [Nollusca]

Laphygma, Guon., 172, 398. Sec also Caradrina

lapidarius, Linn., Bombus, 532

Laputa, Island of, 78

lar, Fabr., Tixoprosopa, 212

lara, Linn., Loptomyrina, 181

Larontia, T'rcit., 17, 20, 22

lariciata, Frr., Tupithecia, 11, 14 
Larinus, Germ., 433

Larra, Fabr., 237, 327

larva describing, 9, 24

lascivia, Rosenstock, $\longrightarrow, 483$

Lasiocampa, Schrank, 20

latecincta, White, Cicindela, 470

lateralis, Fabr., Bombylius, 249

lateralis, Germ., Camptopus, 174, 175

lateralis, Wied., Nemestrina, 433

lateritialis, Walk., Epicrocis, 359

lathonia, Linn., Argynnis, 41

Latia neritoides, Gray [Mollusca], 461

laticostatus, Walk., Phrissogonus, 444, 451

latifasciata, PaIm., Myzine, 410

latifrons, Schiner, Helophilns, 463

latilla, Hew., Pteronymia, 312, 313

latimarginaria, Leech, Krananda, 129

latipennis, Brunn., Allacta, 465

latipes, Morawitz, Nomia, 423

latiuscula, H.-Schäff., Cirphis, 291, 318

lativentris, Friese, Osmia, 412

latreillei, Spin., Osmia, 161, 168

latreillei, Sol., Pimelia, 160

Lauron, Walk., 291

lava, 28

lavaillanti, Lucas, Euchloë, 162

Lavaranche [Algieria], 175

lavendularis, Moore, Cyaniris, 349

laviana, Hew., Heliopetes, 257, 258, 304, 315

lavinia, Cram., Precis, 252, 260, 264, 279, $282,304,308,313,324,329,551,579$, 580

Lawrence, Sir Henry, 67

lazulina, Moore, Rapala, 351, 506, 569

lectularius Linn., Cimex, 247

leda, Doubl., Eronia, 184, 188, 197, 227

leda, Cram., Melanitis, 190, 346, 524, 537

Ledereria, Grote, 257

Lccch, J. H., 135

Leeches, Land, 382, 384

Lehera, Moore, 127

Leionotus, Kirby, 400, 411. Sce Odynerus

lelex, Bates, Phyciodes, 306, 310

Lema, Fabr., 230, 384

Lemonias, Wcstw., 325

lemonias, Limn., Precis, 42, 44, 47, 61, 64, $65,68,71,83,84,85,90,93,96,105$, $107,347,367,377,390,521,588-590$

lenea, Cram., Dircemna, 494

lentalis, Guen., Olybama, 120

leo, Butler, Teracolus, 420

leonidas, Fabr., Papilio, 223, 229, 515, 536

lcopardina, Feld., Zereuopsis, 236

lepeletieri, Lnc., Andrena, 163, 165

lopeletieri, Sauss., Eumones, 231, 232, $411,419,420$

Jepidoptera appearing larger on the wiug, 198,535

Iopita, Moorc, Libythen, 139

Lcpitrix, Nictn., 244, 250

Lepraria ['/sooplyyta], 331

leprosus, Sorv., Phymatcus, 201, 215, 246, 518. Plintc II., lig. T leptalca, Meyrk., Scoparia, 452

Leptalis, DaIm., 308, 510

Lcptogramma, Curt., 15

leptomera, Walk., Ipana, 474, 470

Leptomyrina, Butl., 181

Leptophobia, Butl., 306, 311, 513

Leptosia,'Hübn., 140, 351. Sce Nychitona

Leptosoma, Leach, 128

Leptospermum scoparium, Forst [MIyrta ceae], 442

Leptotes, Scudd., 261, 234, 305, 307, 311, 325,330

Lepyrodes, Guen., 80

leroma, Wallgr., Crudaria, 212

Lestes, Leach, 161, 448, 452, 457

lethe, Fabr., Hypanartia, 321

Lethe, Hübn., $79,80,82,116,119,126$, $382,385,522$.

letterstedti, Wallgr., Gegenes, 185, 186, $191,195,198,229,236,241,247,572$

Leucania, Hïbn., 27, 133, 203, 465, 474, 478. See also Cirphis

leucaniana, Walk., Tortris, 452, 456, 461 lence, Boisd., Terias, 315

Leuceronia, Auriv., 181, 22T, 228, 120, 422

Lencinodes, , Guen., 294, 359

leucocera, Koll., Celaenorrbinus, 80

lencodactyla, Walk., Alncita, 361

lencodesma, 'Feld., Phyciodes, 255, 305, $319,3321,324$

leucogaster, Butl., Metron, 316

Leucojum sp. [Amaryllidaccae], 592

Leucoma, Steph., 80

Lencophasia, Steph., 11, 79, 536

lencothoë, Cram., Neptis, 126, 131

Leucothyris, Boisd., 312, 313, 494

lencospilata, Walk., Comibaena, 220, 227

levada, 311

leviceps, Smith, Discolia, 361

levis, Feld., Anomoeotes, 198

Lhá To, 45,46

Lia sp. [MFollusca], 302

liagore, Klng, Teracolus, 417, 422

libelluloides, Linn., Palparcs, 155

libyssa, Hopff., Cartrletis, 195. 51\%, 530

libythca, Fabr., Terias, 42, 48, S4, S6, Ss, $96,108,364,352,356,357,391,510$

libythen, Fabr., Appias, 57, 5ss

Libythca, Fabr., 80, 113, 139

lichatschovii, Hummcl, Bulaca, 15S, 413

licinia, Cram., Enantia, 256

licnardi, Boisd., Opliusa, 195

life, tenncity of, in protcetcd species, 65 . $82,126,131,196,255,310,316,320$, $337,339,345,346,349,352,355,360$, 518-521

Lifo Plant. Sec Bryoplayllum

light, a Skipper at, 289

light, disadrantages of, as a menus of collccting, 29.1

ligmmn, Walk., Morrisonia, $463,465 \overline{\text {, }}$ 474,478 
ligustica, Scop., Apis, 253, 254, 256, 265, $298,463,485,487,488$

Ligyrus, Burm., 294, 327

lilacina, MLore, Epiplema, 360

Limax maximus, Linn. [Mollusea], 441, 445

limbata, Moore, Cyaniris, 383

limbirena, Guen., Plusia, 203

Limenitis, Fabr., 11, 71, 72, 85, 86, 116, 367,383

Limicolaria flammen, Müll, 423; L. numidica, Reeve, 424 [Mollusea]

limniace, Cram., Tirumala, 55, 57, 70, 72, $73,74,85,96,104,105,110,111,495$, 530

Limnogeton, MIayr, 418

Limochores, Scudd., 289

Limoniastrum guyonianum, Coss [Plumbagineae ], 160, 164

linearis, Linn., Promeces, 180, 248

linearis, Linn., Ranatra, 7

lineata, Fabr., Lepitrix, 244, 250

lineata, Fabr., Naomorpha, 455

lineata, Warr., Sterrha, 201

lineola, Fabr., Amsacta, 340

lineosa, Moore, Caradrina, 77

Ling, unusually large, 21

lingeus, Cram., Cacyreus, 227

linnaei, Stảl, Physorrhynchus, 374, 379

linus, Sulz., Thecla, 326, Fig. 12, 567

Lion's Head [Cape Town], 179, 249

Lippia citriodora [Verbenaceac], 491

lipsiana, Schiff., Peronca, 22

Liptena, Westw., 223, 226

liriope, Cram., Phyciodes, 306, 321

Liris, Fabr., 186

Lissogcnius, Schaum., 210, 246

"list" and shadow of butterflics, 41, 55, $72,75,79,101,126,137,143,553-564$

literana, Linn., Lcptogramma, 15

Lithacodia, Hübn., 358

Lithocolletis, Hübn., 21

Lithorrbiza, Bork., Xylocampa, 172

Lithosia, Fabr., 15, 486

Litsaea zeylanica [Laurineae], 360, 518

Littlewood, E., 342, 569

littoralis, Boisd., Prodenia, 84, 408, 576

littoralis, Pamb., 'Thisoicctrus, 64

littorca, White, Anisolabis, 445

litura, Fabr., Prodenia, 408, 576. See also littoralis

liturata, Clerck, Macaria, 14

lituratus, Fủhr., Rhytirrhinus, 233

lividus, Dist., Aspongopus, 238

livornica, Esp., Dcilophila, 402, 407, 408, 421,428

Lizards, 28, 65, 166, 181, 209, 253, 341, 399, 431; chnnging colour, 341 ; inquiries caused by, $44 n, 68,82,88,110$, $111,116,194,281,350,385,521-525$; tracks of, 166, 399

Loat, W. L. S., 422, 519

lobe of hind-wings. See hind-wings

Lobclia erinu [Campanulricear], 218
Loboptera, Brunn., 169

Locusts, 213, 214, 217, 225, 233 ; classifcation of, 335 note; in Red Sea, 335

Loepa, Moore, 78

logani, Haucock, Scelimena, 375, Fig. 13. Plate IV., Fig. 11

longicornis, Scop., Eucera, 176

longicornis, Latr., Preuolepis, 409

longistylus, Wied., Dacus, 413

Longstaff, Mrs., 27, 31, 253, 258, 296, 300 , $309,323,328,340,344,377,378,385$, $400,408,423,434,436,441,444,448$, $453,455,459,461,464,470,473,477$, $481,506,512$

Longstaff, Dr. Tom G., 65

longstaffi, Howes, Morrisonia, 474, 478, 481. Plate VI., F'ig. 3

longstaffi, Griffini, Gryllacris, 299, 300. Plate III., Fig. 6

longstaffi, Shelford, Ischuoptera, 230. Plate II., Fig. 10

longstaff, Marshall, Myorrhinus, 244. Plate II., Fig. 1

longstaffi, Bingh., Odynerus, 245. Plato II., Fig. 6

lophoptera, Guen., Tetradia, 209, 221

Lophocephala, Lap., 363

loreyi, Dup., Cirphis, 397, 417, 419, 421, 428,429

loripes, Schöuh., Mecorrhynchus, 240

lorza, Boisd., Phalö̈, 320, 321

Lotus arabicus, Liuu. [Leguminosae], 401

Lotus, sacred, 416. See also Nelumbiuu

Loxn, Am. \& Serv., 296

loxoa, Cram., Aluaca, 262

Loxirn, Horsf., 73, 75, 113, 351, 526, 568, 569

Lubbock, Sir John, 5, 533

lucasia, Sauss., Eumones, 214

lucens, Imh., Andrena, 168, 174

lucernoa, Linn., Agrotis, 18

lucia, Kirby, Cyaniris, 152

lucida, Trim., Zizorn, 186, 189

Lucidolla sp. [Mollusca], 302

Lucilia, Dcsv., 174, 248, 443

lucina, Cram., Syuzbrenthia, 65, 80, 82. 83,84

Luciola, Lap., 84, 248, 249, 378, 418

Lucknow, 66, 67

luctifora, Esp., Chelonia, 141

luctuosa, Spin., Molecta, 175

ludicra, Lucas, Zygaona, 172

ludovica, Smith, Ainmophila, 224

lugubris, Blanch., Chrotogouus, 396, 100 , $401,420,434$

Lukosi [S. Africn], 231

lumiuous bcotlos, 327, 333, 378. See also Fircflics

Lumsden [N. Zcaland], 471

luuata, Fubr., Chilomolios, 179, 245

lunatr, Pallas, Dccrtoma, 242

luuata, Walk., Tuproctis, 48

lunata, Jrury, Homoptora, 291

lunifera, \%oll., Erotmoccrn, 198 
luuigera, Steph., Agrotis, 27

Luperus, Geoffr., 240

lupina, Sveder., Hystricia, 456

lupinata, Feld., Pseudo-coremia, 474, 478

Lupinus arboreus, Sims [Legrminosae], 470

lusca, Spin., Bembex, 410

Luxiaria, Walk., 391

Luxor, 398, 427, 428

lyaeus, Doubl., Papilio, 184, 191, 194, $197,235,515$

Lycaena, Fabr., 8, 25, 170, 231, 285, 444, $505,553,565,567,596$.

Lycaenids, drinking habit of. See drinking at mud, \&c.

Lycaenids, inverted attitude of, 114, 198, 241, 326, Fig. 12, 338, 349, 350, 351, $368,564-571$

Lycaenids, manner of dying, 58. See also hind-wings

Lycaenopsis, Feld. See Cyaniris

Lycambes, Stål, 297

Lycanthropa, Thomas, 182

lycimnia, Cram., Daptonoura, 256, 306, $315,320,511$

Lycoid coloration, 186, 237, 238, 246

Lycophotia, Hübn., 7

Lycorea, Doubl., 495

Lycostomus, Motsch., 362, 364

Lyctus, Fabr., 232

Lycus, Fabr., 246

lydia, Don., Asura, 483, 485

lydia, Feld., Terias, 259, 265, 287, 584

Jyyell, G., junr., 486

Lygaeus, Fabr., 158, 159, 163, 164, 165, $179,206,317,402,412$

Lymantria, Hübn., 94, 97, 172, 360

Lymnas, Blanch., 314

Lyndhurst, 11, 12

Lynton, 14

lynx,' 'Fabr., Anisonyx, 249

lyside, Godt., Kricogonia, 286

lysimnia, Fabr., Mechanitis, 494

lysimon, Hübn., Zizera, 47, 181, 186, 189, $191,197,203,204,215,223,225,227$, $229,235,247,336,338,380,407,419$, 421,428

Lythria, Hübn., 472

lythrodes, Ger'm., Acauthaspis, 249

Lyttelton, 466, 481, 482

mareki, MIénćt., Papilio, 134, 140, 142. Plate I., Fig. 5

Macno, 130, 131

Macarin, Curt., 14

maccana, Troit., Poronon, 22

machron, Isinn., Papilio, 46, 48, 137, 141, 142.143

machins, Mcyrk., Timyra, 361

macilentus, Jansou, Papilio, 139, 142

mackenii, Trim., Acloros, 191, 198

MInckwood, l'. MI., 534

McLachInn, R., 7, 15, 20, 25

macoma, 'T'rim, Kedestes, 195
Macraspis, MicLachl., 234

Macrobrochis, H.-Schäff., 128

Macrocera, Latr., 177

IIacroceramus sp. [Mollusca], 302

Nacrocheilus, Hope, 205, 353

Macrocneme, Hübn., 316

Macroglossa, Och8., $6,111,25,64,154,153$, 176, 229, 236. See also Cephonodes

Macroma, Gory \& Perch., 195, 212, 237

Iacromia, Ramb., 226

macrops, Limn., Nyctipao, 358

macularis, Dej., Polysticta, 245

maculata, Fabr., Geana, 129

maculata, Brem. \& Grey, Hesperia, 140

maculata, Sweder., Horia, 327

maculatus, Fabr., Camponotus, 163, 179, $189,196,205,211,232,237,403$

maculatus, Oliv., Hotinus, 113

maculipennis, Curtis, Plutella, 20, 15s,

$168,207,217,430,446,577$

maculosa, Pascoe, Alphitopoda, 238

Nadeira, 26, 555

MĹdura, 106, 107

maera, Linm., Pararge, 563

maerula, Fabr., Amynthia, 315

maevius, Fabr., Taractrocera, 356, 356

Mafeking, 232-3

Magazine Bay [Lyttelton, N.Z.], 481

Mragnificat at Lucknow, 67

maha, Koll., Zizera, 42, 47, 48, 51, 55, $58,64,65,87,134,137,143$

Mahalapye [S. Africa], 211

Mahaweli-ganga [Ceylon], 108, 350, 361

Mahmudia [Sûdân], 424

mahopaani, Trim., Parnara, 223

maia, Druce, Eucereon, 332

Maidenhead, 25

ILaina [Aves], 87, 526, 527

maja, Fabr., Macrocneme, 316

malachurus, Kirbr, Halictus, 164, 16S, 173,177

MLalacosoma, Chevr., 244, 216

Malakand, 53-56

malathana, Boisd., Catochrysops, 159, $229,231,566$

malaya, Horsf., Megisba, 367, 391

Malindi [S. Africa], 231

malrao, Linn., Hespcria, 553, 572, 573

malverucnsis, Jac., Gynaudrophthalma, 240

Namestra, Ochs., 16

mandarina, de L'Orza, Tcrias, 137

mandata, Moorc, Orsotriacun, 109, 346, $367,869,590$

Manders, Col. N., 329, 345, 345, 533, 536, $538,568,591$

Mangifcra iudica, Limn. [Anacardiaccae], 365,510

MInngrovo swamp, 259, 260, 261, 449

manipularis, Gmen., Melipotis, 291

IInutis, Isinu., 230, 242

Mantispa, Ill., 216

"Manunl," Stainton's, 7, 26

Mranukn, 142, 447, 149, 453, 165, 470 
Maoris, 448, 450, 472

maorialis, Feld., Mccyna, 456, 461

Mapeta, Walk., 327

Marasmia, Leder., 58

Maraval [Trinidad], 255-6

marble, white, 91

marchalii, Guér, Callicore, 308

mardania, Cram., Cystineura, 283

margarita, Hïbu., Mylothris, 286

margaritata, Linn., Metrocampa, 17

margaritellus, Hübn., Crambus, 20

margaritosa, Haw., Lycophotia, 7

marginale, Wied., Pycnosoma, 413

marginalis, Schönh., Oxythyrea, 207, 236, 239

marginalis, Fabr., Polistes, 237, 245, 392,

531. Plate IV., Fig. 3

marginalis, Walk., Porthesia, 58

marginata, Dejean, An thia, 435

marginata, Drury, Are, 290

marginata, Beauv., Nezara, 253, 297

marginatus, Latr., Camponotus, 205

margimatus, Wied., Trigonopus, 238, 240

marginepunctata, Göze, Idaea, 172

marginicollis, Harold, Onthophagus, 259

marianne, Cram., Ixias, 48, $61,62,66$,

$86,88,90,95,102,377,588,589,590$

marklini, Stett., Tachina, 159, 163

Marlborough College, 13

marmoratus, Thunb., Gastrimargus, 66

marmoratus, Faldm., Onthophagus, 396

marnoana, Rogenh., Colias, 44, 406, 509, 525

maro, Fabr., Ampittia, 106, 356

marpessa, Hopff., Neptis, 227

Marryat, Capt., 10

Iarshall, G. A. K., 44n, 186n, 199, 219, $224,229,238,244,282,329,497,504$, $517,518,521,525,536,551,564,568$, 579,595

marshalli, Butl., Yphthima, 75, 83, 84, 101

Iaruca, Walk., 319

Mastcrton! [N. Zealand], 462-464

masurialis, Guon., Ophiuche, 192

Iatâi [Hgypt], 429

Matakiwi River [N. Zealand], 464

Matariya [Egypt], 430

Matctsi [S. Africa], 231

Matherán [India], 389-393, 497, 515

mathias, Fabr., Parnara, 49, 55, 68, 104, $113,223,229,339,356,357,371,572$

Matiána [Simln], 40,42, 43

Iatopos, The, 213, 214

maurctanicus, Lucas, Thostor, 171

mauricanus, Ramb., Anax, 248

mauritia, Boisd., Spodoptera, 398, 408, 428,430

mauritialis, Guon., Hypsopygia, 418

mazans, Rcak., Staphylus, 320,326

Mcadc-Waldo, E. G. B., 176

Mcadc-Waldo, G., 214, 485

Mcall-nan-Sac [Perthshiro], 20

Icchanitis, Fabr., 306, 321, 494
Mecorrhymchus, Schöuh., 240

Necyna, Doubl., 99, 456, 461

meda, Fabr., Orsotriaena, 83, 84, 346, 521

meditabunda, Fabr., Edessa, 253

mediterranea, Handl., Bembex, 410, 414

mediterranea, Kriechb., Eumenes, 434

medius, Linn., Bombylius, 174

medon, Stoll, Cocytius, 292

megacephala, Buller, Deinacrida, 465

megacephala, Fabr., Pheidole,1200, 205

Megachile, Latr., 249, 260, 316, 399, 402, $403,411,420,427,428,429,432,433$

Megadromus, Motsch., 482

megaera, Linn., Pararge, 155, 167, 171, $499,540,1543,550,554,563,574$

megalippe, Hübn., Danaida, 484

Megalodacne, Crotch, 198

Megalura, Blanch., 570

megamera, Butl., Ganoris, 137

Meganostoma, Reak., 308, 315, 510

Meganotum, Boisd., 113

megara, Godt., Tithorea, 255, 323, 494

megas, Guen., Remigia, 291

megaspilata, Walk., Probolaea, 469

Megisba, Moore, 367, 391

Megistias, Godm., 304, 316, 326, 331

megisto, Feld., Thyridia, 494

Megymenum, Guér., 374

mejanesi, Guen., Ophiusa, 186

Melamphaeus, Stål, 340

Melampsalta, Kolen., 455, 458

melampus, Cram., Rapala (Doudorix), $66,68,565$

Melanargia, Meig., 499

melanaria, Boh., Baeoglossa, 209, 210

melancholicus, Gahan, Plocederus, 221

Melanchra, Hübn. Sce also Morrisonia, 451,480

melaneus, Cram., Caduga, 80

Melania tubcrculata, Miill., 424; II. victoriao, Dohrn, 225 [Mollusca]

Mclanippe, Dup., 17, 143, 172

Melanitis, Fabr., 72, 75, 79, 80, 96, 101, $190,346,364,524,537,539,553,554$, $561,587,589,590$

melanoidos, Moore, Paranticn, 80

melanomera, Butl., Moganotum, 113

melanostictus, Schaum., Catau tops, 185, $190,199,207,237,240,245$

Molanostoma, Schin., 170, 457, 462

Molanotus, Eschsch., 359, 374

Nolbourno, 486

Molectn, Latr., 175

molote, Ménét., Ganoris, 137, 140, 142, 513

melianoides, Möschl., Borolin, 203

Meligethos, Kirby, 215

melinata, Fold., Pseudo-coromia, 456, 469,478

Molipona, Ill., 260, 265, 305, 316, 327, 332, 365

Molipotis, Hübı., 291, 318, 358. Sce also Errohoia

Mclissodos, Lutr., $32 T$ 
Melissoptila, Holmberg, 327

Melitaea, Fabr., 54, 55, 164, 165, 431, 545

melite, Clerkk., Enantia, 315, 510

MIclittia, Hübn., 361, 530

mellifica, Linn., Apis, 158, 161, 163, 168, $170,174,176,179,180,207,232,253$, $298,316,429,435,441,463$

mellinum, Linn., Mielanostoma, 170, 45\%, 462

melpomene, Linn., Heliconius, 314

Melyris, Fabr., 227, 245

membranaceus, Fabr., Brachyrrhynchus, 363

memnon, Feld., Caligo, 321

memmon, Linn., Papilio, 80

memorata, Walk., Psilocambogia, 83

Menaccarus, Am. \& Serv., 163

mendica, Fabr., Blepharopsis, 161

menelaus, Linn., Morpho, 501

meninalis, Hübn., Pyrausta, 293

menyanthidis, View., Acronycta, 20

meone, Cram., Pararge, 154, 155, 158, 169 ,

$171,176,177,540,541,542,543,548$

mercuriana, Hübn., Pamplusia, 21

merenda, Mabille, Niconiades, 316

merione, Cram., Ergolis, 73, 81, 85, 113, 349

merope, Fabr., Heteronympha, 440, 484, 486, 487,500

merope, Hudson, Morrisonia, 478

Merrifield, F., 551

Mesembryanthemum sp. [Aizoaceac], $180,244,250,531$

Mesene, Westw., 304

mcsenterialis, Walk., Endotricha, 359

mesentina, Cram., Belenois, 41, 44, 47, 48, $49,55,57,60,61,62,65,87, \mathrm{~S} 8,90,91$, $92,93,94,217,223,227,406,414,416$, $417,420,512,522,525,537,591$

Mesoponera, (?) Forel, 200, 211

Misosomia, Hübn., 325

IIesostena, Eschsch., 396, 398, 399, 427, 435

mosozona, Hmpsn., Euproctis, 185

messalina, Fabr., Terias, 287, 509, 524

Messaras, Doubl., 114, 348 . See Cupha

Metachrostis, Hübn., 62, 116

Metacrias, Meyrk., 477

metallicum, Smith, Ectatomma, 483

Motamorpha, Hübn., 103

metaphor in Natural History, 2, 3

motaspilata, Walk., Anisodcs, 332

Meteorological Society, Royal, 32

meteor showcr, 12

Methionopsis, Godm., 316

meticulosalis, Guen., Ternstia, 319

metis, Linn., Cyclopides, 247

Netriorrhynchus, Gícr., 441

Nietrocampa, Lam., 17

Mictron, Godm., 310

Metrosideros scandens, Sol. [Mryrtaccne], 443

Mctura, Butl., 507

moxicants, Castel., Tropistoruus, 309 meyricci, Hmpsn., Miselia, 480, 181

Meyrick, E., E.R.S., 471, 478, 573

michaelisi, Fruhst., Precis, 282, 303

Micipsa, Lucas, 160, 431, 432

Micklcham, 5, 9

Micra, Guen., 172

micra, Hmpsn., Ethiopica, 186

Micraeschus, Butl., 358. Sec Enispa

Microbembex, Patt., 260

Microdes, Guen., 451

Microlestia, Chaud., 179, 182, 218

Micronympha, Kirby, 161

Microstega, Mejrk., 143

Microtelus, Sol., 160

Microthrix, Rag., 203, 207, 221

Microus, Chaud., 247

midamus, Linn., Trepsichrois, 126, 433, 517,519

midrib of leaf, mimicry of, 369

migration of butterfiles, 33; of ladjbirds, 415

Mihintale [Ceylon], 377, $37 \mathrm{~s}$

Milax gagates, Drap. 461; M. plumbca, Moq. Tand., 461 ; II. ravus, Williams [Mollusca], 461

militaris, Linn., Euschema, 128

militaris, Fabr., Lygaeus, 202, 412

militaris, Dalm., Thonalmus, 296

military authorities, folly of our, 125

íillar, A. D., 185, 187, 371, 594, 595

Mimacraea, Butl., 568

Nimela, Kirby, 83

mimic mistaken for model in the field,

$100,111,170,187,190,194,197,250$.

$327,345,346,364,370,382,392,529-$ 534

mimicry, 2, 155, 67, 73, 85, 94, 96, 113,

$114,119,187,197,214,225,229,235$,

$315,355,362,393,4$ S5

mimicry in plants, 175

Mimosa pudica, Linu. [Lcguminosac], 10S, 266

Mimulus moschatus [Scrophularincas], 457

mimus, Say, Dysdercus, 297

mineus, Cram., Mrcalesis, 126, 131, 316, 377,500

Miniloi Island, 335

minima, Brunn., Phaneroptcra, 413

minima, Fues., Lycacna, 25

minorata, Aloorc, Ergolis, 349

minorata, Trcit., Emmuclcsia, 20

Minot, Dr., 595

minualis, Mcyrk., Scoparia, 461, 469

minusculalis, Wrik., Scoparia, 479

minutata, Kirby, Audrcna, 168, 173

minutus, Doj., A bacetus, 179

minutus, Fabr., Diodontus, 411

minutus, Fabr., Odyncrus, 400

miragc, 157, 158, 401, 405

mirnnda, Butl., Abraxas, 13S, 141, 113

MIírit, 61

Mischocyttarns, Sauss., 317

Miscophus, Jnr., 432 
Miselia, Oehs., 480, 481

misippus, Linn., Hypolimnas, 58, 66, 67, 71, S5, 95, 96, 104, 187, 377, 502, 521, 529

missionary schools, 343

mitigata, Guen., Idiodes, 485

mixed bathing in Japau, 139

Mixodia, Guen., 21

Mixophila, Merrk., 382

mixta, Mröschl., Autoceras, 294

Mnais, Sélys, 138

mnasylus, Dbl. \& H., Cybdelis, 307

Inesictena, Meyrk., 444, 445, 446, 452, $462,467,469,470,474,475,481$

Inestheus, Grodm., $31 \mathrm{C}$

Iroa (Dinornis) [Aves], 460

Mochudi [S. Africa], 210, 232

moderata, Walk., Hyssia, 451, 468, 474, 480

modesta, Fabr., Dalsyra, 206

modestus, Godm. \& S., Methionopsis, 316

modestus, Butl., Teracolus, 94, 370

Moduza, Moore. See Limenitis

moerens, Germ., Alaus, 239

moeroraria, Frr., Odesia, 142

Mogi [Japan], 134

Jiogran [Khartûm], 406, 409, 413, 423, $424,425,420$

Molinia caerulea, Moench [Gramineae], 25

MIöller, F., 76

MIöller, Otto, 37, 78, 83

mollifera, Walk., Eupterote, 358

mollina, Hübn., Euptychia, 320

Mollusca, 171, 182, 190, 196, 201, 225, $230,231,240,253,300-303$ (Jamaica), 334, 343, 344, 423-426 (Sûdân), 437, $440,441,444,445,448,449,453,455$, $456,459,461,464,469,470,473,477$, $479,481,482,487$ (Adelaide)

Mollymauks [Aves], 439

molomo, 'Trim., Keritis, 232

molossus, Linn., Catharsius, 365

molpe, Hübn., Nymphidium, 261, 320, 325

Moluris, Latr., 208

monacha, Fabr., Apate, 221

Monachidium, Serv., 195

monachus, Smith, Salius, 454

MIoncreaff, H., 24, 25

Monedula, Coq., 259, 265

monetaria, Smith, 'Tachytcs, 410

mongolicus, Noræwit\%, Celonites, 432

MIongoose, 56, 267, 341

Mongpu [Darjiling], 81

Monkeys, 64, 65, 90, 175, 376, 390

MIonkcy Hill [Colon], 263-265

monochorda, MLoyrk., Psaltica, 384

Monodes, Guen., 291

Nonolepta, Erichs., 228

Monomorium, Mayr, 173, 209, 396, 398, 463,477

monops, Zell., Catochrysops, 285 monospilalis, Walk., Alucita, 447

montana, Felder, Narmada, 115, 345, $377,386,499,520,524,536$. See also coreoides

montana, Butl., Syntomis, 371

moutanus, Feld., Papilio, 355

montanus, Brem., Tagiades, 138, 140, 142

Monterey, bay of [California], 76

Montezumia, Sauss., 304

monticolana, Mann., Pamplusia, 21

Montreal, 153

monuste, Hübn., Pieris, 287, 321, 330

mooreanus, Rothsch., Papilio, 383, 520, 539

morania, Ang., Papilio, 191

morantii, Trim., Parosmodes, 229

Moraviaus, 47

Morice, Rev. F. D., 400, 409, 410, 411, $412,417,420,422,430,433$

morosa, Jans., Euphoria, 310

morosa, Butl., Morrisonia, 474

Morpho, Fabr., 314, 332, 501

Morrell, Mr., 225

Morrisonia, Grote, 446, 449, 451, 456 , $457,460,463,465,468,473,474,475$, $478,480,481,482$

Mortehoe, 26, 27, 34, 99, 103, 143, 454, $513,514,543,544,557,565,567,574$, 592

Morys, Godm., 279, 289, 304

morysalis, Walk., Antigastra, 198, 239

Moslem, 60, 67

Moslem arch, 63

mosquito-netting, 36,37

mossambica, Grib., Xylocopa, 214, 224

mother, the price of a, 77

motozi, Wallgr., Sarangosa, 198, 240

motozioides, Holland, Sarangesa, 189, 572

Mouldy Bug, 13

mould, precautions against, 38

Moulton, J. C., 571

Mount Hope [Colon], 263-265

Mount Lavinia [Ceylon], 336-340

mountain sickness, 29

Mountford, E. W., 466

mozambica, Bert., Spindasis, 207

Mozambique current, 439

Mo\%ufíar púl 87

mucidus, Gerst., Cleonus, 208

mucorea, Firiese, Mlegachile, 433

mucosata, Walk., Helastia, 467, 469, 474, 479

Mulattam Hills [Cairo], 431, 436

mulciber, Cram., Euploea, 498

Miiller, Frit\%., 3, 44n, 324, 325, 490, 491, $493,494,495,501,507,510,511,515$, 516

multiguttatus, Oliv., Graphipterus, 160, 163,164

mummios, head-rests of, 416

mundifera, Walk., Hemerophila, 487

mundissima, Walk., T'imandra, 374

munitalis, Ledr., Etbnistis, 291 
munitata, Hübn., Coremia, 21

muricatus, Kirby, Eurynotus, 246, 247

muriferata, Walk., Gargaphia, 469

Murtfeldt, Miss, 507

Musa sp. [Scitamineae], 77, 301

Musca, Linn., 47, 163, 210, 217, 230, 363

mussitans, Fabr., Arctophila, 532

Mustapha [Algeria], 154, 176

muta, Fabr., Melampsalta, 455

mutans, Walk., Morrisonia, 451, 456, 463, $465,468,474,475,478,480,481,482$

Mutela augustata, Sow., 426 ; M. nilotica, Fér., 426 [Mollusca]

Mutelina rostrata, Rang., 426 [Mollusca]

mutilated butterflies, $44 n$, Figs. $3, a, b$, $48,58,68,71,73,77,82,84-86,88$, $92,94,100,101,110-116,119,127,140$, $154,171,194,197,265,281,287,323$, $346,348,350,351,352,367,371,387$, $390,406,521-525$

Mutilla, Linn., 432

inutilloides, Kohl, Ampulex, 239

Mutiny, Indian, 60, 61, 66, 67

Mut Mîr [Sûdân], 410

muzina, Oberth., Ecpantheria, 318

Mycalesis, Hübn., 66, 72, 79, 83, 85, 101, $112,126,131,186-188,190,193,197$, $214,227,235,241,346,377,385,387$, $390,499,500,554,555,556,564,577$, 578, 587, 588, 589, 590. See also Orsotriaena, and Nissanga

Myelobia, H.-Schäff., 319

Mykerinos, Temple of, 435, 438

Mylabris, Geoffr., 48, 66, 211, 226, 239, $372,377,386$

mylitta, Cram., Dynamine, 324

Mylon, Godm. \& S., 316

Mylothris, Hübn., 44, 183, 186, 188, 191, $193,194,197,234,239,241,246,286$, $514,530,535$

Myopa, Fabr., 177

Myorrhinus, Schönh., 244

Myriapoda, Germ., 238, 464

Myrica gale, Linn. [Ancntaceae], 22, 24

myricae, Guen., Acronycta, 24

Myrina, Latr., 568

myrina, Cram., Brenthis, 153

myrinna, Doubl., Pyrameis, 314

Myrmecocystus, Wesm., 158, 161, 163, $164,165,166,177,396,397,398,399$, $409,418,427,430,431,432,434$

Myrmedonia, Erichs., 215

Myrmeleon, Linn., 223, 231

Myscelia, Boisd., 306, 501, 524

mysorensis, Westw., Orphinus, 359

Myxophycene, 389

Myzine, Latr., 211, 212, 217, 224，409, 428

Nacaduba, Moorc, 48, 121, 349, 367, 374, $391,484,488,505,526,568$

Nacoloir, Walk., 293, 332, 359

nadina, Luc., Huphina, 79, 83, 84, 589

Nagasaki, 134, 516
Nahoou River [S. Africa], 238-240

Naia tripudians [Reptilia], 109

Náini Tál, 63-65

Nakasendō [Japan], 138-141

nakashi work, 59

Nakatsu-gawa [Japan], 138

nanus, Friese, Colletes, 412

Naomorpha, Thoms., 455

Napier [N. Zealand], 444

napi, Linn., Ganoris, 104, 150, 175, 491, $513,574,592,593$

nareda, Koll., Yphthima, 60

narendra, Moore, Hiposcritia, 98

Narkanda [Simla], 43, 44, 45

Narmada, Moore, 104, 115, 345, 377, 336, $499,520,524,536$

Narosa, Walk., 358

nasalis, Westw., Cermatulus, 455

nasidens, Latr., Chalicodoma, 161

Nassunia, Stoll, 200

nasuta, Mocsary, Chrysis, 412

nasuta, Linn., Tryxalis, 50, 54, 121, 436

natalensis, Péring., (?) Eratognathus, 200

natalensis, Boh., Harpalus, 233

natalensis, Boh., Scaptobius, 200

natalica, Boisd., Acraea, 187, 196, 197 , 517

natalica, Feld., Precis, 187, 190, 197, 222, $226,228,547,548$

natalicus, Péring., Acupalpus, 201

natalis, Walk., Amyna, 356

Natural History Societies, School, 13

naval port, Khartûm a, 405

Navás, Father I., 221

nebulosa, Hufn., Aplecta, 16

nechus, Cram., Theretra, 292

Necrobia, Latr., 209

Nectarina, Schuck., 316, 321

Nectarinia metallica [Aves], 213

Neda, Muls., 296

negatalis, Walk., Glyphodes, 231

neglecta, Hübn., Noctua, 16

Negro:

characteristics, 274

fatal contentment, 275

good boatmen, 252

hard head, 322

indoleuce, 275

piety, 275

woulen, 276

nchemia, Boisd., Pscudopieris, 305, 310

Nolumbium speciosum, Willd. [Nymphaeaccae], 124, 416

Nemeophila, Steph., 11, 20, 21

Nemestrina, Oken., 433

Nemophora, Hoffm., 172

Nemopistba, Narás, 221

neobulc, Dbl. \& H., Acraca, 204

Neoitamus, Sack., 453, 454, 455,470

Neope, Butl., 194. Sce Blannida

Neopithecops, Dist., 73, 75, 349, 367, 390

nephalion, Godart, Papilio, 516

Nephelc, Hïbı., 48, 59 
Nopheloleuca, Butl., 292

Nopheronia, Butl., 71, 73, 74, 94, 104, $114,370,378,391,511,529,537$

Nephodes, Doj., 160

Ncptis, Fabr., 45, 64, 65, 79, 80, 81, 82, 83, $84,94,96,97,98,99,104,108,113,114$, $116,117,119,126,131,137,140,142$, $190,197,222,226,227,228,255,339$, $347,367,381,383,384,385,387,390$, $422,502,524,526,527,536,553$

nerissa, Fabr., Huphina, 43, 47, 48, 61, $66,74,81,82,83,84,85,91,93,102$, $105,107,114,127,354,369,374,377$, $381,391,513,588,589,590,591$

Neritina sp. [Mollusca], 302 nesimachus, Boisd., Dichorrhagia, 139 Netrobalane, Mabille, 187 nets, butterfly, 36, 37

Neuroctenus, Fieb., 455, 476

newarra, Moore, Loepa, 78

Newcastle [Natal], 204

Nowfoundland, 149

Newman, E., 7, 9, 14

Nezara, Am. \& Serv., 253, 297

Ngaruawahia [N. Zealand] 449,457

Ngongotaha [N. Zealand], 453, 456

Nica, Hüibn., 319, 321

Nicéville, L. de, 68, 70, 72, 86, 348, 491 , 536

Niconiades, Hübn., 316, 572, 573

ni, Hübn., Plusia, 402

Niebuhria pedunculosa, Hochst [Capparidaceae], 594

Niegawa [Japan], 141

nietneri, Felder, Cethosia, 112, 348, 367, $381,385,519,524,537$

Night-adder, 240

nigra, Brullé, Eumenes, 432, 434

nigra, Sauss., Polybia, 259, 260, 317

nigricans, Linn., Euxoa, 172

nigrilabris, Pcr., Euccra, 170, 397

nigrina, Fabr., Delias, 484, 513, 535

nigripcnnis, Fabr., Apoderus, 238

nigripennis, Butl., Eusemia, 360

nigriplaga, Walk., Ecpanthoria, 290

nigrita, Kohl, Notogonia, 155, 159, 168

nigro-aenea, Kirby, Andrena, 164, 165, 170

nigrocinctus, Lepcl., Podalirius, 174

nigrocoerulea, Smith, Xylocopa, 361

nigrocoeruleus, Tasch., Sphex, 304

nigromaculatus, Goez., Exochoinus, 206, 231

nigroruber, Dohrn, Sphcdanolestcs, 363, 374

nigrosericea, Dours., Andrena, 161

nigrovenosa, Moorc, Doilcmcra, 114, 360, 520

Nikko, 141-14?

nilckenialis, Snell., Lcdereria, 257

nilgiriensis, Moore, Badacara, 99

nilgiricnsis, Fcld., Colias, 99, 509

nilgiriensis, Guer., Lothc, 385

Nilgiris, thc, 97-104 nilotica, Morice, Parnopes, 412

niloticum, Sauss., Rhynchium, 411, 423

Ninus, Kaup, 294, 333

nipalensis, Gray, Ganoris, 51

nipalonsis, Doubl., Gonepteryx, 40, 42, 63

niphe, Linn., Argynnis, 54, 382, 522. See also hyperbius

niphonica, Butl., Cidaria, 43

nireus, Cram., Papilio, 184, 191, 194, 197, 235

nise, Cram., Terias, 256, 265, 306, 315, 330, 509

Nishada, Moore, 377

Nissanga, Moore, 112, 119, 346, 367, 369, $378,527,553$

nitons, Péringuey, Anisodactylus, 231

nitens, Butl., Nymphula, 452, 474

nitida, Smith, Contris, 253

nitida, Smith, Plesia, 298

nitidalis, Cram., Glyphodes, 319

nitidula, Cram., Conchia, 207

nitidula, Fabr., Crocisa, 485

niveata, Butl., Anatossa, 488

nivertus, Dufour, Sphex, 432

nobilis, Klug, Eudema, 198

nobilis, Gerst., Melyris, 227

nobilitata, Fabr., Asphaera, 327

noctiluca, Linn., Lampyris, 169

noctilucus, Linn., Pyrophorus, 295, 327

Noctua, Fabr., 16, 172

Noctuelia, Guen., 407, 409

noctuella, Schiff., Nomophila, 99, 100, $149,158,162,181,205,207,294,397$, $409,419,421,428,429,576$

nocturnal butterflies, 221, 289

Nodularia aegyptiaca, Fér., 425; $N$. mysticus, Bourg, 425; N. parrcyssi, v.d. Busch, 425; N. teretiusculus, Phil., 426 [Mollusca]

Nomada, Fabr., 170, 171, 174, 177

Nomia, Latr., 361, 392, 412, 420, 423

Nomioides, Schenck, 412

Nomophila, Hiibn., 99, 100, 149, 158, $162,181,205,207,294,297,409,419$, 421, 428, 429, 576. Sec also Stonopteryx

Nonagria, Hübn., 399, 419. See Sesamia

Noorda, Walk., 359, 391, 409, 421

norma, Westw., Yphthima, 213, 222, 227, 228

Norman, Georgo, 24, 25, 593

Normanby [N. Zealand], 469

North Bond [British Columbia], 149, 150

north wind in Egypt, 395, 396

Norval's Pont [S. Africa], 207

nostradamus, liabr., Gegenes, 54, 55, 58, 400

notata, Blanch., Hosperia, 261, 305

notata, Linu., Macaria, 14

notata, Butl., NInesictena, 467, 474

notata, Fabr., Osmia, 174

notata, Porond., Polyhirma, 202

note-books, 37

notha, Hiibn., Brcphos, 9 
Nothofagus sp. [Amentaeeac], 476

Notiophygus, Gory, 239

Notocrypta, de Nicév, 356, 371, 383, 572

Notodonta, Ochs., 14, 22

Notogonia, Costa, 155, 159, 164, 168, 196, 298, 333, 392

Notoreas, Meyrk., 472, 476, 477

Notoxus, Geoffr., 250

nouna, Lucas, Teracolus, 162

novae-hollandiae, Mayr, Camponotus, 441,485

novae-zealandiae, Colenso, Orthodera, 464

novae-zealandiae, Brunn., Platyzosteria, $445,447,448,461$

nuba, Wied., Agria, 209, 398, 400,413, 416,432

nubes, H. H. Druce, Thecla, 330, 331.

Plate III., Figs. 3, 4, 5

nubica, Lepel., Crocisa, 411

nubricus, Lepel., Podalirius, 417

nucicolora, Guen., Monodes, 291

nugax, Stål, Acanthaspis, 221

nullifera, Walk., Hyssia, 477, 479

numida, Lepel., Eucera, 174, 176

numidicola, Guen., Cirphis, 291

Nurse, Col. C. G., 392, 531

Nuwára Eliya, 117, 387, 388, 537

nyasae, Hew., Alaena, 568

Nychitona, Butl., 61, 71, 73, 75, 86, 97, $101,106,114,197,338,361,370,373$, 391,536

nyctelius, Latr., Prenes, 256, 279, 289, 315

Nyctemera, Hübn., 360, 443, 518. Sec Deilemera

nycteris, Koll., Rhopalopsyche, 46

nyctimus, Wcstw., Catonephele, 319

Nyctipao, Hübn., 358

nympha, Moore, Chamaita, 357

Nymphaea sp. [Nymphacaecae], 416

nymphalines, inverted rest attitude of, $284,324,330,570,571$

Nymphidium, Fabr., 261, 320, 325

Nymphostola, Meyrk., 467, 469

Nymphula, Schrank, 452,474

nyseus, Guér., Talicada, 97, 98, 113, 114, $117,118,338,349,368,373,381,565$, 568

Nysius, Dall., 362, 452, 453

Nytha, Billb, 51. See Hipparchia

Oases, 158, 399

Obeidia, Walk., 128, 517

Oberen, Meg., 362, 384

obfuscata, Hübn., Dasydia, 22

oblataria, Walk., Enispa, 358

obliqua, Zell., Acrobฉsis, 172

obliqun, Walk., Diacrisia, 129

obliquana, Walk., Ctenopsoustis, 452, 469,470

obliviaria, Walk., Epiploma, 310

Obolcola, Walk., 236, 246

obscurn, Sharp, Artystona, 469, 470, 479

obsenra, Whitc, Rlopalomorpha, 446, 464 obscuraria, MLore, Epiblema, 382

obscurata, Moorc, Phryganodes, 361

obscure-purpurea, De Geer, Pachycnema, 250

obscurus, Kirby, Coranus, 363

obscurns, Mabille, Tagiades, 101, 356, 384,572

obsoleta, Fabr., Chloridea, 448, 451, 457

obsoleta, Klug, Trichiura, 402, 418, 428

obstructus, Meyrk., Crambns, 471

ocalea, Dbl. \& H., Hypoleria, 310, 312

occidentalis, Oliv., Polybia, 260, 317, 327, 333

occulta, Linn., Aplecta, 16

occulta, Trim., Gegenes, 223, 516

ocellea, Haw., Eromene, 93, 234, 397, $400,401,402,409,421,428,576$

ocelli concealed when at rest, 43,574

ochraceella, Tgstr., Tinea, 19

ochraceo-vittatus, Dours, Halictus, 173

Ochrademus baccatus, D.C. [Resedaceae], 432

ochrearia, Rossi, Aspilates, 8, 172

Ochrocydus, Pascoe, 452

Ochromyia, Mracq., 393

ochthistis, MIeyrk., Morrisonia, 465, 46S, $474,478,481$

Ocnera, Fisch, 396, 399, 401, 413, 428, $431,433,435$

Ocnogyna, Ramb., 168

octavia, Cram., Precis, 197, 548, 581

octomaculalis, Fabr., Ennychia, 8, 337

octomaculata, MIcLachl., Sciops, 143

ocnlata, Fabr., Hexachrysis, 372, 392

Ocybadistes, Heron, 483, 485

Odezia, Boisd., 142

odius, Fabr., Aganisthos, 254

Odontomachus, Latr., 298, 332

Odontomyia, Meig., 229, 457, 463, 475

Odontota, Chevr., 309

Odontria, White, 477,479

odorns, Fabr., Erebns, 291, 318

odours of Butterflios. Sce scents

Odynerus, Latr., 155, 15S, 170, 173, 224, $227,245,254,298,317,359,400,411$, 420,434

oecodoma, Sauss, Polybia, 327

Oecophora, Latr., 18. Sce also Borkhausenia

Oediouychis, Latr., 265

Oedisternon, Laf., 250

oenone, Limn., Precis, 47, 48, 55, 64, 65, $68,85,87,90,92,96,107,588,589,590$ Oenothalia, Warren, 292

oenotrus, Stoll, Dilophonota, 304

Oestropsis, Brauer, 221

Ohiya [Coylon], 1:20

Ohurn [N. Zcaland], 458, 459

Oides, Web., 65

Oistin Bay [Barbados], 254

Okarckn, Lake [N. Zealand], 455

Okas, Cap [Algeria], 169

Okere [N. Zealand], 453

Oldham, R. D., 549 
oleracea, Har'r., Ganoris, 150, 152, 513

oleracea, Limn., Hadena, 176

Oligochroa, Rag., 49, 62

Oligodranes, Loew., 174

olivacea, Fabr., Xylocopa, 214, 224

olivata, Bork., Larentia, 17, 22

olivieri, Klug, Apterogyna, 432

Olybama, Walk., 120

Omostropus, Péring., 200, 215

omphale, Godt., Teracolus, 181, 183, 188, $191,194,197,222,225,235,241,246$, 511

Omphra, Latr., 362, 372, 374, 377

Oncacontias, Breddin, 467

Oncopeltus, Sti̊l, 297, 307, 328

Oncotus, Dej., 249

o'neili, Mrshll., Sciobius, 244

One-tree Hill [N. Zealand], 446

Onitis, Fabr., 177

Onslow, F. R. D., 26, 294, 493; A. I., 565

Onthophagus, Latr., 259, 359, 396

onycha, Hew., Theclinesthes, 484

Ootheca, Dej., 240, 244, 249

Ootsi [S. Africa], 232

opacifrons, Fox, Salius, 333

opalina, Koll., Athyma, 42, 44

Opatrum, Fabr., 160, 190, 200, 205, 225, $249,340,413,418,434$

Opeas mamillata, Craven, 231 ; 0 . octona, Chem., 2.31 [Mollusca]

opella, Swinh., Eustrotia, 220

Opharus, Walk., 291

ophiana, Moore, Neptis, 126

Ophideres, Boisd., 358

ophion, Drury, Pterygospiden, 191. Sec also flesus

Ophiuche, Hübn., 192

Ophiusa, Ochs., 186, 195, 318, 361

Ophrys lutea, Cav. [Orchidaceae], 174

opposita, Zell., Platytcs, 294

oppugnans, Walk., Anthracias (Toxicum, Latr.), 362

Opsiphanes, WVcstw., 303, 501

or, F'abr., Cymatophora, 20

Ora, Clark, 419

oranaria, Lucas, Chosias, 168

orangcs in Jamacia, 267

orbona, Fabr., 'T'riphaena, 16

orbonalis, Guen., Lcucinodes, 294, 359

Orchha [India], 90

Orchid, fortilization of, 317

ordinata, Walk., Anisodes, 293

ordinatum, Smith, Anthidium, 392

orcba, Butl., Fuptychia, 304

Orectocheilus, Eschsch., 393

Oressinoma, Westw., 309, 310, 313

Orgyia, Ochs., 10

oricntalis, Linn., Blatta, 233

orientalis, Westw., Dorylus, 359

oricntalis, Niot., Idacthina, 340, 301

orientalis, Doj., Mylabris, 372

oricntalis, Butl., Sphinx, 62

orientalis, Tinn., Vespa, 398, 429, 429, 132,435 orientation of butterflies, $43,154,169$, $184,255,338,346,347,349,367,399$, $427,441,539-553,559$

orion, Fabr., Aganisthos, 284, 524, 571

orites, Meyrk., Stenoptilia, 476

orithyia, Linn., Precis, 41, 42, 46, 47, 48, $51,54,55,58,64,65,68,85,87,88,90$, $105,121,347,363,385,387,588-590$

ornata, Scop., Acidalia, 9

ornatrix, Linn., Utetheisa, 304, 311, 318 , 332

orneodalis, Guen., Tortricodes, 318, 332

Ornithoptera, Boisd., 108, 110, 115, 337, $356,371,381,514,520,525,538$

Orocrambus, Meyrk., 471

Orotava, 27, 29

Orphinus, - 359

orsis, Drury, Myscelia, 501

Orsonoba, Walk., 129

Orsotriaena, Wallgr., 83, 84, 109, 346, 367, 521

Ortalia, MIuls., 189, 204

ortas, Walk., Syrphus, 475

Orthetrum, Newm., 97, 143, 174, 190, 192, 198,523

Orthodera, Burm., 464

Orthogramma, Guon., 292

orthogrammaria, Longst., Orsonoba, 129 note

Ortholitha, Hübn., 202

Orthoptera, packing of, 38

Orthosia, Ochs., 16, 451, 478

orthotoma, Meyrk, Scoliacmฉ, 441

Oryctes, Ill., 203, 359

osbecki, Auriv., Phasis, 181

Oscillariae [Algae], 389

osiris, Hopfí., Lycaena, 231

Osmia, Panz., 158, 161, 165, 165, 170, 174, $177,412,416$

Osorius, Latr., 230

Ostcodes, Guen., 199, 203, 239, 211

Ostrich, tame, 211

ostrina, Hübn., Thalpochares (Micra), 172

Otiorrhynchus, Germ., 464

otis, Fabr., Zizern, 48, 84, 87, 96, 106, $114,349,381,386,387,568$

Otis macquecni, J. E. Gray [Aves], 106

otrous, Cram., Ephyriades, 299, 572

Ottawa, 25

Oudomans, J. Th., 468, 575

Ourapteryx, Boisd., 292

ovipennis, Reiche in MS., Omplera, 372

oviplagalis, Walk., 'Tosale, 332

Oxford, 14, 25

Oxybolus, Latr., 317, 410

Oxycoryphus, Fisch., 419

Oxydia, Guon, 292, 319

Oxypoci [Arachnida], 363

Oxythyroa, MIuls., 16.1, 176, 207, 236, 239, 241

Oxytoxia, Mabille, 485

Oya [Japan], 141

Ozarba, WValk., 239 
Paches, Godm. \& S., 307

Pachnoda, Burm., 211, 413

Pachnodus natalensis, Krauss [Mollusca], 240

Pachychila, Eschsch., 158, 166, 175

Pachycnema, Lepel., 350

Pachydactylus maculatus, A. Smith [Reptilia], 200

Pachylia, Walk., 292

Pachyligia, Buti., 141

Pachyrrhina, Macq., 169

Pachytylus, Fieb., 155

Pachyzancla, Meyrk., 293, 359, 384

packing insects, 38,39

Pademma, Moore, 75, 345, 382, 498, 517, 520

Padraona, Moore, 356

Paederus, Fabr., 201, 418, 419

Paedisca, Treit., 17

paintings of butterflies, ancient, 395

Palacosia, Hmpsn., 486

Palapye Road [S. Africa], 211

palatability, experiments. $2,238,525-528$

paleacea, H.-Schäff., NIyelobia, 319. Plate III., Fig. 8

palegon, Cram., Tmolus, 314, 506

palemon, Cram., Cacyreas, 179, 235, 248 Pálipahári, 92

Pallary, MI., 425, 426

pallens, Rag., Ancylodes, 402

pallens, Muls., Ortalia, 204

pallida, Muls., Bulaea, 158, 413

pallida, Trim., Liptena, 223, 226

pallidicornis, Spin., Chrysis, 412

pallidicosta, Hmpsn., Bostra, 359

pallipes, Jac., Apophylia, 374

pallipes, Still, Paraplecta, 217

Palm Kloof [Zambesi], 226, 227, 228

Palms, 71-73, 75, 85, 108, 218, 266, 343, 344,403

palmyra, Stoll, Euschema, 360, 391

Palpares, Ramb., 155

paltomacha, Meyrk., Scopria, 471, 474

Paltothyreus, Mayr., 224, 227

Paludina capillata, Frauenfeld [Mollusca], 231

palustrana, Zell., Mixodia, 21

pammon, Linn., Papilio, 57, 60, 61, 64, $71,72,74,84,85,96,101,105,106,111$, $114,127,131,337,355,369,371,377$, 386,522 . Sce also polytes

Pamphagus, Thunb., 161

pamphilus, Linn., Cocnonympha, 167, $169,171,176,557,558$

Pamplusia, Gucn., 21

pan, Drury, Calycopis, 285, 567

Panagra, Guon., 141

panagrata, Walk., Solidoscma, 460, 468, 478

Panama "Canal Zone," health of, 264

Panama, 303-304, 584, 587

pandalis, Hübı., Microstoga, 143

pandava, Horsf., Catochrysops, 71, 124

Pandesma, Guen., 421 pandurus, Lepel., Lygacus, 158, 159, 103, 164

pannularia; Guen., Hemerophila, 456. S'ee dejectaria

Pantana, Walk., 128

paphia, Linn., Argynnis, 11, 553

Papilio, Linn., 6, 46, 48, 49, 56, 57, 60 , $61,64,66,67,71,72,74,80,84,85,87$, $94-98,100,101,103-105,106,111,112$, $114,115,117,121,127,128,131,134$, $137,139,140,141,142,143,149,151$, $172,176,184-186,188,191,194,197$, $205,217,222,223,225,227,229,235$, $256,261,279,288,304,306,307,308$, $310,314,315,326,337,347,355,364$, $368,369,371,373,374,377,378,380$, $381,383,386,387,391,406,422,483$, $514,515,516,520,522,523,525,526$, $527,530,535,536,538,539,571,595$

papilionaria, Limn., Geometra, 16

Papyrus antiquorum, Willd. [Cyperaceae], 218, 416

Paracoelioxys, Rudosz., 433

Paracolletes, Smith, 452, 454, 455, 4SS

paracuta, de Nicév., Curetis, 137

Paradise [N. Zealand], 474 479

paradoxa, McLachl., Perissoneura, $13 S$

para]is, Zell., Scoparia, 21

parallelaria, Walk., Tephrina, 382, 386

Parantica, Moore, 80, 108, 110, 111, 120, $339,344,367,369,370,381,386,496$, $497,520,526,529,530,536$

Paraplecta, Shelford, 217

Pararge, Hübn., 41, 43, 79, 154, 155, 15S, $167,169,171,176,177,292,499,540$, $542,543,548,550,554,562,563,574$

Parasiccia, Hmpsn., 129

Parasol Ants, 304, 332

Parata, Mloore, 357

Paratettix, Bolir., 217

pardalinum, Walk., Acridium, 169, 206, 233

Pareba, Doubl., 133

parens, Walk., Melipotis, 291

parietum, Linn., Odynerus, 170, 173

parinda. Moore, Papilio, 111, 112, 34T, $356,368,371,381,383,386,516,520$, 536,538

paris, Linn., Papilio, 127, 523

parisatis, Westw., Apatura, 346

parisatis, Koll., Hipparchin, 51, 54, 55, 554

Parker, Prof., G. H., 539, 541, 550, 562

Prrkinsonia sp. [Leguminosac], 399, 409, 410,417

Parmarn; Moore, 49, 55, 68, 104, 113, 127 , $189,191,195,198,205,223,229,339$, $356,357,371,377,572$

Parnassius, Latr., 45, 140, 519

Parnopes, Latr., 412, 416

Paromphale, Hin psu., 220

Parosmodes, Holland, 229

parrhasius, Fabr.. Everes, 121, 338, 34?, $368,386,387,568$ 
Parrots, 5s, 61

parryi, White, Cieindela, 443, 477

partheniata, Guon., Dasyurus, 472, 476

Parthenodes, Guen., 220

Parthenos, Hübn., 347; peculiar flight of, 536

parrula, Sauss., Eumenes, 309

parvulus, Lepel., Odynerus, 411

parvulus, Ploetz, Oxytoxia, 485

Paryphanta sp. [Mollusca], 477

Pashók [Darjiling], 79, 82, 113

Pasiphila, MIeyrk., 465

Passalus, Fabr., 333

passalis, Fabr., Syntomis, 357, 371

patellimana, Spin., Megachile, 411

Pathans and Bengalis, 71

"patience," epidemic of, 146, 147

Patlasingha, Watson, 485

pato, Trim., Sarangesa, 198

patna, 112, 117, 119

patnia, Moore, Nissanga, 112, 119, 346, $367,369,378,527,553$

patronalis, Walk., Progonia, 358

patruelis, Sturm., Acrotylus, 158

paucula, Walk., Pleonectyptera, 332

paulina, Cram., Catophaga, 98, 102, 103,

$110,114,115,118,354,370,373,374$,

$377,381,382,513,523,534,537,590$

paullula, Swinhoe, Sterrha, 97

pavana, Koll., Chrysophanus, 42, 63n, 65

paykulliana, Fabr., Grapholitha, 19, 24

peacocks, 93

Peak of Tenerife, 26-32

Pcal, S. E., 72, 76

Pearson, A. A., 269

pectinitaria, Fucs., Larentia, 17

Pederutalagalla SIount, 117

pedestris, Sti̊l, Apterola, 174

Pelargonium sp. [Gcraniacecie], 181

peleides, Koll., Morpho, 314

Pelicans, grey, 257

Pcllicia, Bult., 316

pellionella, Linn., Tinea, 18

pellucens, Esch., Pyrophorus, 327

pcllucida, IVeymer, Ithomia, 323, 332

pellucidus, MIurray, Parnara, 127

pcltigera, Schiff., Chloridea, 176, 402

Penang, 122

Penck, Prof. A., 232

penelopc, Fabr., Euptychia, 323

penicillatus, IVhite, Scolopterus, 454, 457

penkleriana, Fisch., Grapholitha, 17, 19

pentadactyla, Zell., Argyria, 487

Pontila, Westw., 568

Pentodon, Hope, 429

Pepsis, Fabr., 260

Pcradcniya Gardens, 108-110, 363, 364

Percus, Bon., 233

peregrina, Walk., Chionema, 357

peregrina, Oliv., Schistocerca, 169, 213,

$214,217,225,335,398,428,429$

Perga, Lueach, 485
Perichares, Scudd., 288, 319

Peridela, Warren, 408

Peridromia, Boisd., 264, 324, 570

perieralis, Walk., Diplopseustis, 469

Perigea, Guen., 291

Perimeles, Godm., 326

Péringuey, L., 179, 200, 242, 243, 247

Peripatus novae-zealandiae, Hutton [Myriapoda], 464

periphanes, Meyrk., Scoparia, 461

Perissoneura, Dist., 138

perius, Linn., Athyma, 55, 64

Peronea, Curt., 22, 24

perornata., Walk., Notoreas, 472

Perrhybris, Hübn, 287, 320, 513. See also

Pieris

perronii, ILatr., Telesto, 483, 485

Persectania, Hmpsn., 451, 456, 460, 463, $465,468,475,478,480,481$

perseus, F'abr., Mycalesis, 66, 72, 85, 101,

112 , 385, 390, 588, 590; variety, 101, 390

persistens, Butler., Terias, 315, 584

persius, Scudder, Thanaos, 150

perspectalis, Hübn., Zinckenia, 293, 319

perspicillaris, Linn., Cloantha, 172

perspicua, Trim., Mycalesis, 188, 499

poruviana, Smith, Megachile, 260

Pesháwar, 49, 50, 52

pessota, Meyrk., Miselia, 481

petalia, Hew., Patlasingha, 485

Petalochirus, Beauv., 363

petalus, Walk., Rhyncomyia, 177

petavia, Stoll, Nassunia, 200

petiolata, Fabr., Eumenes, 116, 392

petiverana, Doubl., Tirumala, 229, 537

petraea, Boisd., Acraea, 187, 196

petraria, Hübn., Panagra, 141

Petrels, 439

Potrified Forest, 436

Phaeochlaena, Hübn., 309, 310

Phaius grandifolius, Lour. [Orchidaccac], 126

Phalaenoides, Lewin, 485

Phalangium, Linn. [Arachnida], 317

phalantha, Drury, Atella, 41, 45, 47, 48, $55,58,73,85,88,90,102,116,185,193$, $197,222,239,241,282,339,348,367$, $373,383,387,390,526,527$

phalerata, Sauss., Temnopteryx, 249

Phaloë, Guér., 320

Phanaeus, MacL., 295

Phaneroptera, Sorv., 413

pharolla, Butl., Fuptycheia, 309, 310, 313,524

phares, Godart, Euptychia, 305

Phasis, Hübu., 181, 241, 250, 566

Phoidole, Westw., 199, 200, 201, 205, 240

Phelypaea violacea,Desf.[Orobanchaccae] 161,165

phemonoë, Doubl., Leucothyris, 312, 313, 494

Phengodes, Hoffin., 383

Pheropsophus, Sol., 421 
phiale, Cram., Terias, 309, 310, 315, 509

Phibalapteryx, Steph., 143

phigalia, Hew., Patlasingha, 485

Philadelphus coronarius [Saxifragaceae], $500,508,510$

Philanthus, Fabr., 155, 396, 400, 410, 423, 434

Philereme, Hüibn., 43, 44

philerga, Meyrk., Scoparia, 452, 469, 479

phileta, Fabr., Picrís, 287, 321, 330, 534, 585

Phileurus, Latr., 319

philippus, Fabr., Hypolycaena, 189, 191, 566

philodice, Godart, Colias, 151, 563, 595

philomela, Johanns., Yphthima, 65, 72, $75,80,100,101,137,588$

phisadia, Godart, Terrcolus, 420, 422, 510

phlaeas, Linn., Chrysophanus, 41, 137, $155,158,175,177,453,569,575$

Phlaeodes, Guen., 22

phlegyas, Butl., Teracolus, 188, 222

phoebe, Murray, Lycaena, 444. labradus, Zizera

Phoebis, Hübn., 304, 331, 507

phoenicealis, Hübn., Pyrausta, 66

Phoenix reclinata [Palmaceae], 218

phoeopteralis, Guen., Pachyzancla, 293, 359,384

Photinus, Lap., 333

Photuris, Le Conte, 295

phricias, Meyrk., Morrisonia, 473, 474, $478,480,481$

Phrissogonus, Butl., 444, 451

Phryganodes, Guen., 361

phryne, Fabr., Huphina, 354

Phrynichus, Karsch, 372

Phtheochroa, Steph., 176

Phthia, Stål, 297

Phya, Druce, 319

Phyciodes, Hübn., 150, 152, 255, 258, $282,305,306,307,309,310,313,319$, 321,324

Phycis, Fabr., 12, 20

Phycochromaceae [Algae], 339

Phycodes, Guen., 391

phylaeus, Drury, Hylcphila, 265, 289

Phyllodromia, Serv., 421

Phyllognathus, Eschsch., 374

Phyllomacromin, Sélys, 230

Phyllotettix, Hancock, 299

Phyllotocus, Fisch., 440

Phymatcus, Thunb., 204, 245, 246, 265 , 518. Platc II., Fig. 7

Physodactyla, Chap., 245

Physorrhynchus, Am. \& Sorv., 181, 196, $240,245,374,379$

picous, Bcauv., Dinocoris, 328

Pico del Teyde, 29, 30

picta, Wicd., Bacch 240

picta, Smith, Crocisa, 192

pictula, White, Nolauehra, 480. Sec moyricci pictus, Fabr., Pocciloeerus, 51, 51

Pidgin English, 122, 123, 131

Pidorus, Walk., 128

Pieris, Schrank, 33, 287, 320, 321, 330, $513,534,585,595$. See also Synchloë pierreti, Sauss., Psammodes, 203

Piezodorus, Ficb., 297

pigea, Boisd., Pinacopteryx, 188, 191, 197, 512

pileatum, Smith, Trypoxylon, 392

pilella, Schiff. \& Denis, Nemophora, 172

pilipes, Fabr., Podalirius, 168, 174

pillow, wooden, persistence of type, 416

Pimelia, Fabr., 26, 158, 160, 162, 165, $166,177,396,397,399,400,402,427$, 435

Pinacopteryx, Wallgr., 181, 188, 191, 191, $197,234,239,241,246,512,523$

pinetaria, Hübn., Fidonia, 19

pinguinalis, Linn., Aglossa, 18

pinned specimens, how to carry, 22, 3S

Pintia, Walk., 131

Pinus insignis [Coniferae], 445

Pionea, Guen., 332

Pipiriki [N. Zealand], 460, 462

pirates, precautions against, 130

pisi, Linn., Hadena, 8, 16

Pisidium novae-zealandiae, Prime [Mollusca], 473

pisistratus, Fabr., Rhopalocamptr, 199

Pistacia lentiscus, Linn. [Leguminosae], 168

pistacina, Fabr., Anchocelis, 9

Pitch Lake, 322, 325

pithecius, F'abr., Catharsius, 377

Pitsani [S. Africa], 232

place-names, Jrpauese, 140; Indian, pronunciation of, 40 note

placida, Moore, Cupha, 112, 114, 34S, 36 T

placidaria, Guen., Anisodes, 262

Placostylus sp. [Mrollusca], 477

plagiatana, Walk., Pyrgotis, 470

plagifera, Walk., Trypheromera, S1, S3

plaiting. Sec hind-wings, bending of

plana, Fabr., Zoplosis, 413, 435

Planema, Doubl., 190, 193, 197, 279, 50 壬

Plquorbis boissyi, Pot. \& Mich. [Mollusca], 424

plantaginis, Liun., Ncmeophila, 21

Platenu, Prof. Fclix, 517

platiualis, Guen., Conchylodes, 321

platynota, Fairm., Pimclia, 177

llatynus, Bon., 180

Platyomus, Schönh., 309

platyptera, Esp., Calophasia, 172

Platysoma, Latr., 374

Platytos, Guon., 220, 294

Platyzostcria, Brunucr, 415, 447, 41S, 461

Plantia, Stil , 359, 362, 372

Plcasnut, NIt. [N. Zealaud], 481

Plcboius, Kirby, 152, 281

Plecia, TVicd., 229, 237

plecta, Linn., Noctua, 16 
plectaria, Gucn., Storrha, 181

Plectroctena, Smith, 205

Plemyria, Hübn., 120

plena, Walk., Morrisonia, 465, 468, 478

Plconectyptera, Grote, 332

Plesia, Jur., 298. See also Elis

Plesioneura, Feld., 356, 516

Plcurodonte, Fischer, many species, 301 [Mollusca]

pleuronota, Blanch., Clinteria, 384

Pleurota, Hiibn., 20

plexippus, Linn., Danaida (genutia, Cram.), 55, 70,72, 73, 74, 75, 76, 85, $90,96,110,264$ note, 344, 363, 367, $390,495,520,529$

plcxippus, auctorum nee Linn. (archippus, Fabr.), Danaida, 25, 76, 264, 306, 329, 484, 494

plinius, Fabr., Tarmeus, 350, 374. Sce telicanus

Ploas, Latr., 250, 531

Plocederus, Thoms., 221

plorans, Charp., Euprepocnemis, 158, 161

Plotheir, Walk., 120

Plotus levaillanti [Aves], 223

plumata, Dc G., Volucella, 532

Plumbago capensis [Plambagincac], 58, 251 ; P. scundens, 597

plumbeus, Fabr., Pompilus, 155

plumipes, Drury, Dielis, 298

plumosus, Smith, Paracolletes, 488

Plumtree [S. Africa], 231

Plusia, Ochs., 19, 172, 203, 234, 402, 428, $429,444,571$

plusioides, Butl., Rhynchina, 358

P'lutclla, Schrank, 20, 158, 168, 207, 217, $430,446,577$

pluto, Fabr., Calliomma, 292

Poa caespitosa, Forst. [Grumineac], 182

Poaphila, Guen., 253, 291, 332

Pocock, R. I., 2, 435, 437, 528

Podalirius, Latr., 155, 158, 159, 161, 164, $165,168,170,174,175,176,177,226$, $259,361,375,377,392,400,411,417$, $427,432,433,434,435,531$

podalirius, Linn., Papilio, 6, 172, 176

Pododus, Am. \& Scrv., 203, 215

poccilaria, H.-Schüff., Caenina, 189

Pocciloccrus, Serv., 51, 51, 432

Pocnia sp. [Mollusca], 302

pocyi, Butl., Appias, 286

Pogonobasis, Sol., 215, 224

Pohaturoa, MIt. [N. Zealand], 453

Pohoto [N. Zoaland], 450

Poinsettia, 183, 184, 234. Sec Euphorbia pulchcrrima

Pokwani [S. Africa], 233

Pole, J., 377

Polia, Ochs., 27, 593

Polianthes tubcrosa [Amaryllideac], 85, 96, 506

policones, Cram., Papilio, 194

poliographus, Motsch., Colias, 141, 142, 143
Polistos, Latr., $54,158,170,173,176,177$, $199,237,245,259,298,305,309,317$, $321,327,392,430,531$

polita, Smith, Atta, 332

polita, Jac., Malacosoma, 244, 246

politia, Cram., Nepheloleuca, 292

politus, H. H. Druce, Thecla, 326, 330

Pollenia, Desv., 174, 439, 443, 446, 452, 463

Polybia, Lepol., 259, 260, 307, 309, 317, 327, 333

polychloros, Linn., Vanessa, 6, 167, 169

polychorda, Hmpsn., Entelia, 220

polycrates, Hopff., Papilio, 288, 515

polydactyla, Hïbn., Alucita, 7

polydamas, Linn., Papilio, 288, 304, 307, 326,515

polydecta, Cram., Mycalesis, 346, 37T, $385,387,500$

polygamy, 91,107

polygonalis, Hübn., Mecyna, 99

Polygonumacre, Kth. [Polygonaceac], 298

Polyhirma, Chaud, 202, 233

polyhistor, Suff., Cryptocephalus, 244

polyhymnia, Feld., Daptonoura, 320

polymena, Linn., Euchromia, 116

polymnestor, Cram., Papilio, 97, 104, 112, $355,391,516$

polymnia, Linn., Mechanitis, 494

Polyniphe, Kaye, 306, 307, 310, 325, 505

Polyocha, Zell., 409

polyodon, Clerck, Cloantha, 172

polyodon, Linn., Xylophasia, 16

Polyommatus, Latr., 41, 49, 51, 55, 64 , $68,91,93,94,98,118,189,198,211$, $350,368,373,386,388,391,399,401$, $402,407,416,419,421,427,430,431$, $483,488,505,522,526,567,568,575$

Polyphaga, Brullé, 436

Polyphasia, Steph., 44

Polyrrhachis, Smith, 213, 224, 245

Polysticta, Hope, 233, 234, 245

polytes, Limn., Papilio, 57, 64, 520, 527, 538, 539. Sec also pammon

Pomasia, Guon., 116

pomona, Fabr., Ca topsilin, 57, 68, 71, 73, $94,97,102,108,110,121,124,338,352$, $369,373,374,378,381,382,383,391$, $506,519,520,525,526,587,588,589$, 590

pomonalis, Gucn., Glyphodes, 301

Pompilus, Fabr., 64, 155, 186, 237, 392, 411

Ponera, Latr., 464

Ponsonby, A. P., 509

Popillin, Scrv., 384

populata, Linı., Cidaria, 17, 21

Populus alba, Linn. [Amentaceac], 24; P. tremula, Linn., 20

porcatus, Sol., Anomalipus, 190

porcellio, Gerst., Derocalymma, 202, 418

Porina, Walk., 44, 461. Sec IElhamina

Porpe, Hübn., 452

porphyrca, Hübn., Agrotis, 16 
Porritt, G. T., 25

Porrostoma, Guér., 440

Port Autonio [Jamaica], 278, 280, 552, 587

Port Elizabeth, 180-182, 247, 248

Porthesia, Steph., 58, 408

postverta, Cram., Dynamine, 30S, 324

postvittana, Walk., Tortrix, 447, 452

Potamopyrgus badius, Gould, 473, 477; P. corolla, Gould., 453, 461 [Mollusca]

Potentilla atrosanguinea [Rosaceae], 40, P. tormentilla, Sibth., 543

pot-hole in granite, a beetle-trap, 400

Poujadia, Rag., 382

Poulton, Prof. E. B., 4, 10, 27, 44n, 68n, $76,111,201,216,490,517,518 n, 521$, $525,528,534,539,551,563,564,568$, 570

Powell, J., 388

praclongana, Guen., Antithesia, 19

praetoriae, Dist., Acanthonyx, 203

Prasinocyma, Warren, 408

pratana, Hübn., Aphelia, 19

Pratapa, Moore, 68, 522, 564

Pratt, Major H. A., 137, 140 ; Mrs., 140

praunsi, Kohl, Belonogaster, 185, 237, 240

Prays, Hübn., 24

precautions in posting insects, 38, 39 ; in packing lantern, 12 ; iu packing chloroform, 39 ; iu carrying insects, 22 ; against mould, 38

Procis, Hübn., 41, 42, 44, 46, 47, 48, 51, $54,55,58,60,61,64,65,68 n, 71,73$, $83,84,85,87,88,90,92,93,96,99$, $104,105,107,108,113,120,121,123$, $126,184,186,187,190,193,197,202$, $203,204,222,225,226,228,231,235$, $241,252,255,260,264,279,282,304$, $308,313,324,329,339,347,363,366$, $367,377,381,383,385,387,390,441$, $483,484,486,502,521,523,546,548$, $551,552,564,568,577,57 \mathrm{~S}, 579,580$, $581,587,588,589,590,591,594$. Sec also Junonia, and Catacroptera

Prenes, Scudd., 256, 279, 289, 306, 315

Prenolepis, Mayr, 409

Prepona, Boisd., 501

Preston, H. B., 225

Preston, Rev. T. A., 13

Pretoria, 206, 207

prickly palms, 72,343

Prioneris, Wallace, 82, 83, 535, 589

prionistis, Meyrk., Morrisonia, 463, 465, $468,474,480,481$

Prionophus, White, 462

Prionotheca, Sol., 435

Probolaea, Moyrk., 467, 469

procax, Périug., Nyrmedonia, 215

processionon, Liun., Cuothocampn, 172, 173

procris, Cram., Limonitis, $71,85,86,367$

I'rodenia, Guc11., 81, 291, 108, 576

prodigiosa, Lirichs., Blaps, 160 prodromus, Brahm., Aphodius, 165

productata, Walk., Pscudo-coremia, 15 's, 469,478

Progonia, Hmpsn., 358

Promachus, Loew., 229

Promeces, Serv., 180, 238, 248

Promecidus, Fåhr., 239

prominens, Noore, Nacaduba, 313

promissa, Esp., Catocala, 12

pronuba, Linn., Triphaena, 16

pronunciation, Indian, 40; Arabic, 170

propinquaria, Leech, Craspedia, 129

propria, Walk., Tmetolophota, 46S, 4ik, 478,481

Prorachthes, Loew, 250, 531

prosapiaria, Linn., Ellopia, 19

Proselena, Meyrk., 470

Proserpina sp. [Mollusca], 302, 303

Prosopis, Fabr., 177, 182, 236, 246, 375, 485

Protea sp. [Proteaceae], 249

proteastis, Meyrk., Morrisonia, 468. Scc vitiosa, Butl.

protesilaus, Linn., Papilio, 516

proteus, Linn., Eudamus, 253, 2S8, Fig. $10,315,572$

protomedia, Klug, Teracolus, 403, 40T, $416,417,420,422,510$

Prototettix, Giebel, 230, 240, 215

protractus, Butl., Teracolus, 57, 555 . Plate I., Fig. 3

Prout, L. B., 293, 40S, 446, 455, 470, 472 , 479,563

proximus, Dall., Tholosauus, 455, 461

prunosa, Moore, Abisara, 349

Pryer, H., 135, 354, 516

Psaltica, Meyrk., 384

Psammodes, Kirby, 20S, 209, 210, 210

Psaryphis, Erichs, 205, 215

Pseudageuia, Kohl, 392

Pseudagrion, Sélys, 223, 226, 231

pseudargiolus, Boisd., Cyauiris, $\$ 3$

psoudelpis, Moorc, Lampides, 113

Pseudoblaps, Gućr., 362, 364, 374

Pseudo-colaspis, Lap., 215, 225

Pseudo-coremia, Buti., 454, 456, 460, 163, 474,478

pscudocrispus, Westw., Lcmonias, 325

Psoudo-deropeltis, Krauss, 179, 182, 239

Pseudohazis, Grotc, 151

Psoudo-macromia, Kirby, 223, 226, 230

Pseudo-micronia, Moore, 358

Psoudonaclia, 1S9, $19 \mathrm{~S}$

Psoudonympha, Wallgr., 181, 199, 235, $241,246,248,249,250,555$

Psoudophir, Guon., 428

Pseudopicris, Godm. \& S., 30 , 310

Psoudosphinx, Burm., 327

pseudo-spretella, Stain., Borkhausenia

(Occophora), 446, 452, 475

Pseudosterrha, Warren, 251

Psilocambogia, Hmpsn., S3

Psilogramma, Roths, \& Jord. ScC Ancerys 
Psilophus, Meig., 384

Psiloptera, Solier, 432

Psithy'rus, Lepel., 158, 170, 174

psittacata, Schiff., Cidaria, 22

Psodos, Treit., 21

Psychophasma, Butl., 318

psylaria, Guen., Pomasia, 116

Pteris aquilina, Liun., var. esculenta

Hook. [Filices], 472

Pterocypha, H.-Schäff, 293

Pterodecta, Butl., 138, 142

Pteronymia, Butl. \& Druce, 312, 313, 320,332

Pterygophorus, Klug, 485

Pterygospidea, Wallgr., 191, 198, 241, 572,573

puberula, Still., Agouoscelis, 215

pubescens Fabr., Campouotus, 409

pubescens, MIurray, Haptoncus, 364

pudicata, Walk., Ortholitha, 202

puella, Moore nec Drury, Chionaema, 358

puella, Boisd., Pseudonaclia, 189, 198

puellaris, Butl., Teracolus, 57, 61, 92, 537, 588, 589

puera, Cram., Hyblaea, 66

Puerto Bello [Panama], 262, 263

pugione, Linn., Empyreuma, 290

pulchella, Linn., Uttetheisa, 26, 33, 51, $64,66,96,97,129,204,233,407,416$, 421,576

pulchellus, Gerht., Phengodes, 333

pulchraria, Gucn., Asthena, 448, 452, $454,460,474,478$

pulchripes, Gcrst., Eumorphus, 362

pullus, Sparm., Sciobius, 195, 244

pulverosa, Warr., Zamarada, 200

pulverosaria, Walk., Craspedia, 192

pumila, Snell., Celoma, 129

pumilata, Hübn., Eupithccia, 172

punctaria, Stoll, Diacrisia, 142

punctata, Sauss., Eumenes, 392

punctata, Druce, Phaoochlaena, 309

punctatissima, Pouj., Parasiccia, 129

puncticollis, Sol., Erodius, 434

puncticollis, Latr., Scarabacus, 160, 163, 164

punctifera, Walk., Euproctis, 192, 198

punctulata, Butlo, Laelia, 236

punctum, Fabr., Amyna, 361

Punnett, Prof. R. C., 521u., 533, 538

Pupisoma longstaffi, Godw.-Aust. [Mol lusca], 344

purondra, MIoore, Sarangosa, 391

purpurca, Butl., Austramathos, 468

purpureopennis, do Geer, Carpocoris, 174

puspa, Horsf., Cyaniris, 80, 349, 363, 367 pustulata, Thunb., NIylabris, 377, 386

puta, Hübn., Agrotis, 172, 176

putli, Koll., Chilades, 66, 68, 88

Putnoy, 14

Pychnodactylus, Chcvr., 435

Pycnosoma, Hmpsn., 113, 163 pygmaea, Snellen, Zizera, 307, 349

pylades, Peringuey, Catharsius, 400

Pyrgomorphinae, Serv., 396

Pyrale taken at sea, 251

Pyrameis, Hübn., 6, 8, 14, 24, 25, 26, 41, $42,46,48,51,63 n, 65,77,78,79,98$, $99,139,141,158,159,162,165,169$, $171,176,177,184,187,199,201,203$, $204,205,207,209,233,235,247,248$, $250,314,382,385,388,397,399,407$, $421,427,428,434,441,443,444,448$, $453,455,457,458,461,463,476,481$, $482,486,521,525,541,548,549,576$

pyramidea, Iinn., Amphipyra, 12

Pyramids of Gîza, 396, 397, 433, 434, 435, 436,549

pyramus, Fabr., Haematera, 319

pyranthe, Linn., Catopsilia, 47, 48, 57, $64,68,71,73,75,84,85,90,96,102$, $105,106,121,127,338,352,373,380$, $381,506,522,587,588,589,590,591$

Pyrausta, Schrank, 58, 66, 143, 236, 293, 359

pyrene, Linn., Ixias, $61,62,66,75,77$, $80,81,83,102,114,369,522,534,577$, $588,589,590,598$

Pyrgotis, Meyrk., 470

Pyrgus, Hübn., 232

pyritosa, Erich., Haltica, 217

Pyrophorus, Ill., 295, 327

pyrosalis, Guen., Endotricha, 485

Pyrrhopyge, Hübn., 316, 326, 331

Pyrus aucuparia 22 ; P. japouica, 144 [Rosaccue]

Qedad, or Camel-grass, 159, 165

quadridens, Fabr., Bolboccras, 88

quadriguttata, Castolnau, 195

quadripunctata, Fabr., Caradrina, 168, 172

quadripunctata, Hmpsn., Dendrocera, 359,364

quadristigmalis, Guen., Glyphodes, 319

quadristrigata, Walk., MIicrodes, 451

Quoon's Park, East London, 183-185, 234-238

Queenstown [Capo Co.], 234

Queonstown [N. Zeulaud], 471-474, 479481

quonavadi, Gron., Pandesma, 421

quercetorum, Moorc, Surendra, 351, 368, 568

quinquo-lineata, Camoron, Prosopis, 236,246

Quiroguesia, Boliv., 54

Rachoospila, Guon., 292

Radona, Mooro, 126

radiata, Ochs., Phycodes, 391

Rabinda, Moore, 65, 113, 347, 367, 536, 553

rahira, Boisd., Acraca, 222

rain,-butterflios and moths flying during, 127, 129, 281, 32:; 329, 319, 369, 552 rain in Cejlon, 591, 592 
rain in India, 588-590

rain in West Indies and Spanish Main, 586-587

rainfall on Western Gháts, 390

Rain Forest, 218, 228-231

rama, Koll., Arrhopala, 82

rama, Moore, Libythea, 80, 113

Ramble [Jamaiea], 280

ramburialis, Dup., Diasemia, 350

ramella, Linn., Grapholitha, 19, 24

ramosellus, Zell., Crambus, 442, 481

Ranatra, Fabr., 7, 260, 297

Randia dumetorum, Lam. [Rubiaceae], 391

ranga, Noore, Athyma, 80

Rangitoto [N. Zealand], 447, 448

Ranikhet [Kamaon], 64, 65

Ranjit River [Darjiling], 82, 83, 103

Rannoeh, 15-24, 481

ransonnetii, Fold., Caprona, 104, 116, 371 , 572,573

Ranuneulus lyallii, Hooker [Ranunerılaeeae], 472

rapae, Linn., Ganoris, $7,140,150,154$, $155,158,167,169,428,430,434,512$, $513,514,592,593,505,596$,

Rapala, Moore, 66, 68, 73, 351, 506, 564, 565,560

Raparna, Moore, 97

Raphanus sativus, Linn. [Crueiferae], $399,427,430$

rapidus, Smith, Podalirius, 226

rastrajo, 266, 328

Rat Portage [Canada], 152

Rattan-palm, 343

Rattray, Mr., 238, 239, 240

rauca, Fabr., Apogonia, 359

ravus, Bingh in MS., Labus, 214

Read, R. A., 27, 2S, 30

reclusa, Fabr., Clostera, 22

rectilinea, Esp., Hadena, 19

reeurvalis, Fabr., Zinckenia, 48, 576.

See fascialis

Red Bank [S. Africa], 217

Red Sen, 35, 488

red soil in tropics, $210,548,549,550$

Rees, River [N. Zealand], 474

reflexus, Smith, Pompilus, 392

Regent's Park, 14

registration of insects, 38, 39

regularis, Butl., Terias, 186, 188, 191

194,107

relative immunity, 4, 534

remba, Mlooro, Huphina, 79

Remigia, Guon., 195, 291

romotata, Guon., Idaea, 83

romus, F'abr., Porimolos, 326

renata, Cram., Euptychia, 323

renatusalis, Walk., Mixophila, 382

Rendle, Dr. A. B., 126

ropanda, Fabr., Remigia, 195, 291

repandata, Linn., Boarmia, 16, 17

ropertus, iValk., Copris, 359, 377

requieni, Sol., Sepidium, 163, 161
Reseda propinqua, R. Br. [Irescdaceac, 177, 434 ; Reseda sp., 170

resting attitudes, 571-575

Retama canariensis [Leguminosas], 23, 29 ; R. retam, Webb, $162,163,161$

retieularis, White, Prionophus, 462

retinella, Zell., Argyresthia, 19

Retribution Hill, Jhánsi, 88

Rhabdinocerus, Sehönh., 224

Rhabdodryas, Gdm. \& S., 507

Rhabdotis, Burm., 211, 214

rhadamanthus, Fabr., Euploea, 493

Rhadinosomus, Sehönh., 462

Rhagonyeha, Eseh., 528

rhamni, Linn., Gonepteryx, 40, 140, 160, $171,172,507,508,523,599$

Rhamnus alaternus, Linn. [Rhamneaceae], 168

Rhanidophora, Wallgr., 195

Rhapsa, Walk., 451, $\leq 65,468,475$

Rhinia, Desv., 363, 365, 382, 354, 413

rhinoceros, Linn., Oryctes, 359

Rhizotrogus, Latr., 175

rhoda, Hmpsn., Areyophora, 211

Rhodia, Noore. See Loepa

Rhododendron sp. [Ericaceae], 40, 63, 117,385

rhombeum, Linn., Phyllotettix, 399

rhomboidalis, Beauv., Braehybasis, 10S, 230

Rhopalocampta, Wallgr., 189, 191, 102, Fig. 7, 572

Rhopaloinorpha, Dall., 446, 464

Rhopalopsyche, Butl., 46

Rhynehina, Guen., 358

Rhynehium, Billb., 224, 411, 433, 155.

Plate VI., Fig. 0

Rhyncodes, White, 479

Rhyneomyia, Desv., 163, 177, 212

Rhyothemis, Hag., 107, 533

Rhytieoris, Costa, 240

Rhytidonota, Eschsch., 421

Rhytirrhinus, Fihr., 233

Riang [Darjiling], $s 1$

ribeana, Hübn., Tortrix, 17, 19

Riehardia africana [Araceac], 244

Riehmond Park, 5

Ricinus eommunis, Limn. [Euphorbiaceac], 81, 102, 309

riparia, Pall., Labidura, 396, 413

Rivula, Guen., 120, 35S

rivularis, Germ., Lrgaeus, 206

rivulata, Hmpsn., Chaleiope, 210

Robinia pseudacacia [Legruminosac], 6

rocks, ellormous size of bloeks, 105, 131

rock-temple, 373

Roeky MIountains, 25, 151

Rohnua, Mlooro, 346. Scc Apatura

rohria, Fabr., Lethe, 79, S2, 385,

Rolleston, William and George, 466

romulus, Cram., Papilio, 355

rosae, Panz., Andrena, 164

Roso Bny [Sydney], 4S3

rosearia, Doubl., Epyaxa, 479 
Rosoires [Sùdân], 419

rosimon, Fabr., Castalius, 104, 106, 121, $338,350,553$

Rosmarinus officinalis, Linn. [Labiatae], 169

Rothschild and Jordan, Messrs., 111, 355

Rothschild, Hon. W., 417

Rothschild, Hon. N. C., 422

Roto Iti [N. Zealand], 452, 453

Rotokakahi [N. Zealand], 456

Rotorua [N. Zealand], 449-456

rotuella, Feld., Xeroscopa, 469

rotundalis, Moore, Terias, 353, 354, 364, 371,373

rotundiceps, Handl., Nomioides, 412

rousselii, Guér., MIyzine, 409

Rowland-Brown, H., 563, 592

rubescens, Walk., Chloridea, 451

rubescens, Butl., Morrisonia, 478

rubi, Linn., Callophrys, 563

rubidata, Fabr., Anticlea, 11, 14

rubiginea, Hmpsn., Salobrena, 293

rubraria, Doubl., Emmiltis, 440, 444, 445, $446,453,456,457,460,463,470,481$, 486

rubricollis, Linn., Lithosia, 15

rubripictata, Hmpsn., Hyria, 292

rubrofasciatus, De Geer, Conorrhinus, 363

rubropicta, Am. \& Serv., Velitra, 374

rubropunctaria, Doubl., Asthena, 453

Rubus australis, Forst., 473 ; R. rugosus, Smith, 384 [Rosaceae]

rudder, loss of a, 429

rudis, Fabr., Pollenia, 174

rudis, Fủhr., Spartecerus, 209, 210

rueppellii, Koch, Mylothris, 183, 234, 239, 246, 514

rueppelli, Liv., Promachus, 229

rufana, Schiff., Peronea, 24

rufescens, MIuls., Coccinella, 419

rufcscens, Butl., Hypna, 308

rufescentaria, Motsch., Zettienia, 143

ruficans, Latr., Melipona, 327

ruficeps, Smith, Pompilus, 237

ruficollis, Linn., Dysdercus, 317

ruficollis, Fabr., Schizonycha, 340

ruficorne, Fabr., Acridium, 195, 245

ruficornis, Oliv., Ccratoma, 265, 296

ruficornis, Fabr., Cyrtacanthacaris, 239

rufigastra, Lepel., Osmia, 177

rufilincata, Warr., Rachcospila, 292

rufipennis, Boisd., Phyllotocus, 440

rufpcnnis, Fabr., Porrostoma, 440

rufipes, Fabr., Camponotus, 309, 317

rufipes, Fabr., Necrobia, 209

rufipes, Dej., Platynus, 180

rufipes, Boh., Trcchus, 205

rufitarsis, Smith, Exomalopsis, 298

rufiventris, Iepel., MIelipona, 327

rufiventris, Spin., Paracoelioxys, 433

rufocinctus, Chaud, Harpalus, 233

rufodentata, Smith, MIelíssodes, 327 rufofusca, Hew., Thecla, 307, 314, 320

rufo-marginatus, Boh., Harpalus, 233

rufonigra, Bingh., Myzine, 212

Rugby, 6, 10, 11, 12, 13, 14

rugiceps, Boh., Osorius, 230

rugosana, Hübn., Phtheochroa, 176

rugoso-punctata, Thunb., MIicrolestia, 182

ruinate, 266

Rumia, Dup., 17

Rumina, Risso [Mollusca], 171. See Bulimus

rumina, Linn., Thais, 171, 172

runeka, Moore, Orsotriaena, 83

rupeum, Sauss., Rhynchium, 224

rurea, Fabr., Xylophasia, 16

Rusina, Steph., 16

russata, Bork., Cidaria, 17

russula, Linm., Nemeophila, 11, 20

rusticella, Hübn., Tinea, 18

rusticum, Oliv., Opatrum, 160

Rye, E. C., 15

ryphea, Cram., Anaea, 308

saba, Fabr., Glutophrissa, 194, 197, 228

sabacus, Trim., Pseudonympha, 181

sabclla, Hmpsu., Arenipses, 409, 421

sabina, Drury, Orthetrum, 97

Sabulodes, Guen., 292

saccharalis, Fabr., Diatraea, 332

sacer, Linn., Scarabaetus, 401, 428, 429, 434,435

sacraria, Linn., Sterrha, 14, 20, 181, $205,233,420,421$

safitza, Hew., Mycalesis, 186, 187, 188, $190,193,197,228,235,241,499,555$, 556

Sagda, sp. [Mollusca], 302

sagittarius, Sauss, Polistes, 392

St. Ann's [Trinidad], 322-328

St. Clair [Duncdin, N.Z.], 470

St. Kilda [Dunedin, N.Z.], 470

St. Leonards-on-Sea, 8, 9

St. Margaret's Bay, 8

Sakkâra [Egypt], 397

Salamis, Boisd., 186, 187, 190, 193, 197, $502,537,568,594,595$

Salatura, Moore, 124. See Danaida

Salius, Fabr., 155, 168, 224, 333, 361, 372 $420,454,485,488$

Salix alba [Amentaceae], 458

sallustius, Fabr., Chrysophanus, 443 $444,448,453,454,457,461,463,481$, 482

Salobrena, Walk., 293

salomonis, Linu., Monomorium, 173, 396

salona, Hew., Callicista, 260, 330

Salpinx, Hübn., 498. See also Euploca

salsala, Moore, Iambrix, 113, 127, 356, 371,381

Sambhur, 119

Sameodes, Snell, 377

Samia, Hübn., 293 
Samsam, Mount [Algeria], 171, 173 sandals, Japanese, 145

Sanda Polla forest [Ceylon], 365, 366 sandaracata, Bingh., Prosopis, 182, 236

Sandringham [Melbourne], 486 sandstorm, 427, 432

sangaica, Moore, Neptis, 137, 140, 142 sanguinea, Linn., Neda, 296 sanguinei-rostris, Thunb., Veterna, 240 sanguineum, Müll, Sympetrum, 248 sanguinicollis, Fabr., Odontota, 309 sanguinicosta, Prout, Prasinocyma, 408 San Juan [Trinidad], 323

Santa Cruz de Tenerife, 33

santiago, Lucas, Eudamus, 253

Saprinus, Erichs., 433, 434, 435

sara, Bates, Dynamine, 308, 319

Sarangesa, Moore, 189, 198, 240, 356, 391, 572

Sarcophaga, Moig., 159, 177, 182, 192, 196, $204,223,246,363,445,446,458,463$

sardoa, Lepel., Andrena, 173

sardoa, Mayr., Aphaenogaster, 168

Sareil [Darjiling], 81

Sargasso Weed, 333, 334

sari, Horsf., Terias, 353, 354

Sárnáth [India], 70

Saropogon, Loew, 452, 454, 456, 462

sarpedon, Linn., Papilio, 355, 383, 483, 539

sassafras, scent of, 111,356

sataspes, Trim., Syrichthus, 232

Satsuma, Murr., 140

saturalis, Fabr., Cicindela, 254

Saturnia, Schrank, 20, 168

saturnus, Butl., Charaxes, 217

saturnus, Butl., Euptychia, 310

satyrina, Feld., Zophyrion, 320

Satyrus, Latr., 499, 554, 555, 558, 561, 574

saucia, Hübn., Agrotis, 7, 14

Saunders, Edward, 155, 163, 164, 165, 170, $173,177,409$

saundersii, Dbl. \& H., Synchloë, 308, 319,324

Savanilla [Colombia], 258-260, 584

savignyi, Klug, Apterogyna, 409

savignyi, Sauss., Calidomantis, 419

savignyi, Gory \& Perch., Pachuoda, 413

Sawing, see hind-wings, movement of

Saxicola deserti, Tomm. [Aves], 166

scaber, Thunb., Paratettix, 217

Scabiosa atropurpurea [Dipsaceac], 444

scabricollis, Gerst., Psammodes, 208, 210

scabriuscula, Eschsch., Rhytidonota, 421

Scalmus, Zang., 268, 294, 333

scrmander, Boisd., Prpilio, 516

scandatula, Feld., Homoptera, 220

Scantius, Stil, 247

scapha, Fab., Enoplops, 155

Scaptobius, Burm., 200

scapularis, Thunb., Holcostcthus, 190

Scaptrobius, Burm., 200

Scarabaeus, Linu., 160, 163, 164, 174, 246. $401,428,429,434,435$
Scarborough [Tobago], 328-333

scatospila, Zell., Eretmocera, 195

Scaurus, Fabr., 169

Scelimena, Scrv., 375. Plate IV., Fig. 11

Sceleodis, Sol., 399, 401, 413

Sceliodes, Guen., 456, 461, 463

Scoliphron, King, 224, 327, 372, 380, 331, $392,410,428$

scent-brand, variation of, 345

scents of diagnostic value, $172,350,505$

scents, difficulty in detecting, 74, 75, 492

scents of female butterflies, $85,86,135$,

$253,261,264,315,320,324,337,338$,

$339,344,345,351,352,369,371,406$,

$417,484,500,507,511$

scents of male butterflies, $43,48,49,70$,

$71,72,74,85,86,87,90-92,91-96,98$,

$99,102,105,107,108,110,111,114$,

$115,118,126,127,130,131,134,135$,

$137,140,141,150,172,183,184,183$,

$197,211,234,235,253,255-258,261$,

$264,265,274,279,310,311,313-315$,

$320,323-325,330,337-339,314,345-$

$350,351,352,355,356,369,370,379$,

$382,383,385,386,391,398,406,407$,

$417,418-421,440,490-516$

sconts, examination for, 492,493

scents in other orders of insects, 199, 203,

$221,224,237,238,247,248,296,297$,

$298,328,332,345,358,360,362,363$,

$369,370,374,379,397,401,464,482$

schakra, Koll., Pararge, 41, 43, 499, 510, 543,562

schistacea, Gerst., Polyrachis, 213

Schistocerca, Stial, 169,1214, 217, 224, 225, $335,398,428,429$

Schizonycha, Dej., 340, 413

Schoonland, Dr. S., 224

Schoenobius, Dup., 97, 310, 359, 41 S

School Natural History Societies, 13

Schrankia, Hübn., 20

schulziana, Fabr., Mirodia, 21

scintillans, Walk., Euproctis, 358, 360

scintillulana, Hübu., Chorcutes, 14

Scilla nutans, Smith [Liliaccae], 512, 543,544

Sciobius, Schönh., 195, 244

Sciops, MacLachl., 143

Sclerocarya caff ra, Sond. [Anacardiaceac], $213,224,566$

Scodiona, Boisd., 20

Scolia, Fabr., 177, 410, 434. Sce also Dielis, and Elis

Scoliacma, MLoyrk., 441

scoliaeforme, Bork., Trochilium, 22

Scolopterus, Whitc, 454, 455, 457

scolymus, Butl., Euchloë, 137, 140

Scolypopa,'Still, 446, 447, 456

Scoparia, Haw., 21, 168, 172, 440, 452, $461,462,469,470,471,472,474,475$, 479,482

Scopula, Schrauk, 21, 172, 175, 181, 195, 576

Scorpion, 158, 160, 179, 200, 206, 399 
scotalis, Hmpsu., Parthonodes, 220. Plate II., Fig. 8

Scotosia, Steph., 14, 143

scotosialis, Walk., Rhapsa, 451, 465, 468, 478

Scott, Edwin, 95, 96, 497

Scudder, S. H., 595

scum on sea, 389

scutellaris, Erichs., Calochromus, 440

soutellaris, Fabr., Syrphus, 400

Scymnus, Kug., 224, 232

"Sea saw-dust," 389

sea, insects taken at, 251, 335, 439, 440

seaside grape, $254,330,332$

seals, 439

seasonal forms, $61,66,68,71,84,86,99$, $101,105-108,116,119,120,123,124$,

$126,127,130,137,183,184,186,188$,

$190,191,193,194,197,212,214,220$,

$225-228,234,235,241,252,253,258$,

$259,261,265,286,304,305,308,315$,

$320,329,330,331,338,346,347,352$,

$353,354,364,365,370,371,377,379$,

$385,390,418,441,577-592$

sea temperatures, 439

seclusella, Walk., Hapsifera, 350

sedecia, Hew., Thecla, 326

sedilloti, Boliv., Cutilia, 464, 465

segetis, Schiff., Euxoa, 402

segetum, Schiff., Agrotis, 416, 428

segmentarius, Germ., Harpactor, 246

selasellus, Hübn., Crambus, 12

selection of colours by butterflios, 46,94 ,

194, frontispiece, 592-599

selenampha, Gucn., Amyna, 361

selene, Hübn., Actias, 129

Selenia, Hübn., 22

Selenis, Guen., 262

selenophora, Koll., Athyma, 80

selenophora, Guen., Dasypodia, 463

Selidosema, Fü̈bn., 460, 468, 478

Selkirk IIts., 151

sellatus, Doj., Chlacnius, 205

Sclous, F. C., 13

Scmatura, Dalm., 292, Fig. 11

semclc, Linn., Satyrus, 499, 554, 555, $558,561,574$

semialbana, Guen., Tortrix, 15

semifnscia, Walk., Asurn, 357

semifissata, Walk., Epyaxa, 169, 479

seminuda, Hmpsn., Laelia, 419. Plate V., Fig. 6

Somiothisa, Hübn., 62, 88, 97, 202, 232, 236,319

semisignata, Walk., Corcmia, 451, 456, $462,465,469,470,471,472,474,475$, $479,480,482$

semisignata, Walk., Fuproctis, 358

Semisinus lineolata, Ads. [Mollusca], 302 semivittata, Walk., Loucania, 474, 478

sena, MIoore, Bibasis, 357, 572

sena, Koll., Ilerda, 41, 42, 47, 55, 64, 65

Senccio, Linn., sp., 180, 184, 189, 195,
$199,207,208,237,241,248,249,250$, 443 ; S. concolor, 250 [Compositac]

sonegalensis, Oliv., Pimelia, 162

senegalensis, Boisd., Terias, 188, 194 , $222,225,228$

senescens, Lepel., Podalirius, 434

senilis, Fabr., Elis, 399, 400, 410, 419, 427,434

sennaarensis, Mayr., Euponera, 409

sonnac, Linn., Callidryas, 252, 258, 261, $264,285,306,330$

Sopedon, Latr., 217, 229

Sepidium, Fabr., 163, 164

septem-punctata, Linn., Coccinella, 163, 164, 169

septentrionis, Butl., Tirumaln, 110, 114, $118,339,344,364,367,373,379,381$, $495,520,522,523,530$

scquens, Howes, Morrisonia, 451. Platc VI., Fig. 1

serapis, Boisd., Papilio, 261, 315

Serdis, Mabille, 289

sericea, Butl., Agrotis, 451. Scc admirationis

sericea, Oliv., Polybia, 309

sericea, Walk., Saroophaga, 363

sericeus, Fabr., Camponotus, 230, 409

Sericoris, Troit., 19, 20, 21

Serinotha, Spin., 246, 362

Serinus canariensis [Aves], 28

Serui [S. Africa], 211

servillana, Dup., Hedya, 14

Sesamia, Guen. (Nonagria), 399, 408, 416, $427,428,429$

sesamus, Trim., Precis, 68n, 184, 156, $187,197,202,203,204,222,225,523$, $547,548,581$

sesostris, Waterhouse, Catharsius, 400, 413

Sestra, Walk., 452

Seti, Tomple of [Egypt], 429

Soth-Smith, D., 335

Setina, Schrank. See Asura, 357

setosum, Sepp., Eucereon, 318

scvata, Feld., Pieris, 320, 513

sevorina, Cram., Belonois, 183, 186, 188, $190,191,193,197,222,226,227,228$, $234,239,512,550$

sevorus, Fihr., Brachycorus, 205

scxdens, Linn., Attr, 304

sex-maculata, Fabr., Anthia, 161, 168, 164

scxpunctata, Fabr., Hylomela, 211, 226, 239

sexual dimorphism, 67, 399, 406, 411

shade-loving Butterflies, 79, 80, 82, 84, $96,126,281,283,313,556$

shadow of Butterflies at rest, 43, 169, 540-541, 543, 544, 553-564

Shah Dara [India], 58, 59

shakra, Koll., Parargo, 41. Scc also schakra

Shanks [S. Africa], 233

Sharp, Miss, 417

shcep, fat-tailed, 59 
Shelford, R., 179, 195, 199, 217, 230, 299, $375,392,448,498$

Shillûks, 416

Shimo-no-Suwa [Japan], 141

Shiojiri-tōge [Japan], 138, 140

shipwreck, a, 460

Shoals Bay [Auckland, N.Z.], 449

shola, 98

Shoshong [S. Africa], 232

siamica, Walk., Coptosoma, 364, 365

sibylla, Linn., Limenitis, 11, 227

Siccia, Walk., 357, 386

sichelii, Mayr., Camponotus, 168

sicula, Rossi, Chalicodoma, 164, 174, 177 , 398,429

siculum, Spin., Anthidium, 170, 174, 177 sidae, Fabr., Mylabris, 48, 66

Sidgwick, A., 13, 567

sight, sense of, in insects, 532,533

sigillaria, Guen., Racheospila, 292

signalling in the merchant service, 440

signata, Drury, Cyclocephala, 295

signata, Walk., Elhamma, 461, 463

signata, Walk., Hystricia, 463,475

signata, Linn., Monedula, 259, 265

signatalis, Walk., Pyrausta, 293

signatus, Walk., Copris, 359

signifera, Walk., Lithacodia, 358

signifera, Walk., Prodenia, 291

signs, communication by, 26

Sikh police, 125

Sikhs, 56, 60

silacea, Boh., Aspidomorpha, 238

silaris, Godm. \& S., 304

silas, Westw., Argiolaus, 185, 235, 246, 566

silhetana, Wallace, Terias, 353, 354, 364, $365,371,383$

silius, Latr., Cymaenes, 289, 326, 331, 572

Simaethis, Leach, 8

similata, Walk., Cidaria, 463, 469, 479

similella, Linn.,1Oecophora, 18

similis, 'Thunb., Epilachna, 199

similis, Hope, Lycostomus, 362, 364

similis, Linn., Radena, 126

similis, Moore, Zizera, 66, 127, 131, 133

simillimus, Smith, Bombus, 51

simillimus, Grib., Hexachrysis, 245

Simla, 35, 36, 39-47, 540, 590

simonsi, Buti., Mycalesis, 214

Simon's Town, 244, 249, 250

simplex, Sol., Pimelia, 160, 165

simplex, Bingh., Prosopis, 236

simplex, Walk., Syntomis, 189

simplex, Trim., Zeritis, 232

simplicior, Möschl., Anastrus, 289, 572

simplicius, Stoll, Eudamus, 304

simplicornis, Sauss., Odynorus, 298

simulans, Walk., Devarodes, 310

simulatrix, Hmpsir., Rivula, 358

Sinapis uigra, Koch [Cruciferae], 399

sinapis, Linn., Leucophasia, 11, 79, 536

sincera, Wcymer, Pieris, 320

sinensis, Walk, Thosea, 129 singala, Feld., Yphthima, 385

singalensis, Moore, Cyaniris, 43, 44, 46, $116,383,505$

Singapore, 123, 124

Singhala, Blanch., 340, 364

sinhala, Moore, Pademma, 345, 352, 498, 517,520

sinuata, Moore, Rahinda, 65, 113, 347 , 367, 553. See also hordonia

sinuatus, Oliv., Brachycerus, 155

Siphonaria australis, Quoy [Mollusca], 470

sita, Kirby, Dindymus, 363

sita, Feld., Prioneris, 535

Siva, statue of, 106

size, apparent, of butterflies on the wing, $98,196,198,535$

Skipper at light, 289

Skipper attitude, 191, 236, 571-573

Skipper, evening flight of, 192, 198, 240, 391

Skippers not to be pinched, 356

Skippers under leaves, 104, 116, 191, 357, 384,573

skulls, Guanche, 33

sleeping-dress of Lepidoptera, 575

slow flight, see Butterflies

slow flight of Moths, 128, 195, 198, 321, $355,360,391,443$

Slow-Torm, 181

Smith, Edgar, 303, 426

Smith, T., 342

Smyth, Prof. C. Piazzi, 30

snails, eggs of, 253

snake, 109, 160, 164, 200, 210, 248, 311, 358,372

suelleni, Wallgr., Eublemma, 220

Sôba, 414, 425

sobrina, Gory \& Perch., Rhabdotis, 211, 214

sobrinulus, Dohrn in MS., Tylinades, 362

socrus, Geyer, Aroa, 129

sodalis, Walk., Copris, 387

Sohâg [Egypt], 397

soil, red, in tropics, 54S, 549, 550

solandriana, Linn., Paedisca, 17

Solanum sp., Tournef. [Solanaceae], 179, 180, 189

Solenauthuslanatus, D.C. [Boraginacene], 174

solida, Walk., Apogonia, 359

Solidago sp. [Compositae], 457

solidum, Emery, Tetramorium, 201

solieri, Boisd., Xylophasia, 176

solita, Walk., Asura, 357, 388

Solomon, 100, 101, 102, 104

Solon [Simla], 41, 47, 565

Solpuga sp., Herbst [Arachinida], 95

Somatidia, Thoms, $465,469,479$

Sommer IIt. [N. Zealand], 475

sorbiana, Hübn., Tortrix, 15

sordida, Himpsn., Abraxas, 118

sordidula, Nyl., Cremastogaster, 205, 240 
sordidus, Fabr., Aphanus, 340

soror, Smith, Discolia, 483

sound produced by beetles, 161, 221, 294, 435

Spalgis, M[oore, 113, 349

Spartecerus, Schönh., 209, 210, 211

Spatha cailliaudi, von Martens, 426 ; S. marnoi, Jickeli, 426; S. rubens, Lam, 426 [Mollusca]

Spear-grass, 70,477

speciosa, Klug., Steraspis, 398, 399, 413

speciosa, Walk., Utethesia, 279, 290

speciosus, Wallgr., Teracolus, 191, 194, 197, 549

Spectre of the Brocken, 31, 32, 33

specularia, Moore, Corymica, 117

specularis, H.-Schäff., Bertholdia, 318

Spence, William, 5, 564

sperans, Feld., Eublemma, 200

Spergula sp., Linn. [Caryophyllaceae], 165

sperthias, Feld., Telicota, 483

Sphaenogona, Butl., 257, 258, 261, 286, $306,308,309,310,315,320,326$

Sphrerium sp. 425 ; S. lenticulum, Desh., 453 ; S. novae-zealandiac, Desh., 473, [Mollusca]

Sphaerolina, Baly, 388

Sphccodes, Latr., 155, 177

Sphedanolestes, Stäl., 363,374

Sphex, Linn., 304, 392, 410, 432

Sphingomorpha, Guen., 231

Sphinx, Linn., 24, 34, 62, 234, 251, 571

Sphinx, Temple of the, 437, Fig. 15, 438

Spilogaster, Macq., 168

spilothyrus, Feld., Celaenorrhinus, 116, $383,572,573$

Spindasis, Wallgr., 79, 105, 207, 232, 386, $387,568,569$. See also Aphnacus spinicorne, Drury, Elaphidion, 295

spinifera, Hübn., Euxor, 88, 397, 400, $402,408,421,423,427,428,429$

spinolae, Lepel., Osmia, 177

spinosa, Fabr., Akis, 158

spinning in flight, appearance of, 337

spinulosa, Boh., Hispa, 217

spinulosa, Klug, Pimelia, 400, 402, 427, 435

spio, Linn., Hesperia, 232, 233, 241

Spion Kop, 201, 202

Spiraea ulmaria [Rosaceae], 869

spirifcx, Linn., Sceliphron, 224, 410, 428

Spirorbis sp., Lam. [Mollusca], 334

splendidum, Fabr., Sphex, 392

splendidum, Fabr., Stilbum, 93, 362, 397, $398,399,400,412$

Spodoptera, Gucn., 398, 408, 428, 430

spoliata, Walk., Idoea, 192

spoliataria, Walk., Ectropis, 239

sponsa, Hansem., Lestes, 161

Sporophyla, Meyrk., 474

spurius, Fold., Thecla, 326, 567

spurius, Burm., Syrichthus, 240, 245

squalidus, Linn., Epicometis, 399, 430 squamifer, Boh., Ellimenistes, 239

squamosus, Burm., Dicrano-cnemus, 248

Squirrels, 61, 87, 341

Stachys aegyptia.ca, Pers. [Labiatae], 432

Stachytarpheta jamaicensis [Verbenaceae], 279, 352, 355; Stachytarpheta sp., 128, 268, 361, 377, 383

stadelmanni, Mayr., Cremastogastor, 250 stagnalis, Guen., Hydrocampa, 11

Stainton, H. 'T., 7, 9, 21, 24, 25

ståli, Bolivar, Tryxalis, 198, $24 \mathrm{C}$

Standfuss, Dr. M., 575

Staphylus, Godm. \& S., 320, 326

statices, Linn., Ino, 11

statira, Cram., Aphrissa, 326

statues, Hindu, 106

stelenes, Linn., Victorina, 268, 283, 314, $325,502,552$

Stelidota, Erichs., 253

stellata, Dist., Euproctis, 192

stellata, Guen., Triphosa, 293

stellatarum, Linn., Macroglossa, 6, 25,

$154,159,176$

stellifer, Butl., Astictopterus, 356

Stemmatophora, Guen., 220

Steneles. See Stelenes

Stenobothrus, Fisch., 158, 159

Stenopsyche, MacLachl., 141, 143

Stenopteryx, Guen., 99. See Nomophila

Stenoptilia, Hübn., 476

Stenozygum, Fieb., 245

Stephanotis sp., Thou. [Asclepiadaceae], $253,338,339,352,494,496,506,507$, 513

Steraspis, Sol., 398, 399, 413

sternicornis, Linn., Sternocera, 374

Sternocera, Eschsch., 374

steropastis, IMeyrk., Persectania, 463

Sterrha, Hübn., 14, 20, 97, 181, 201, 205, $232,233,420,421$

Stichophthalma, Feld., 501

stictica, Linn., Oxythyrea, 164, 176

stictita, Westw., Ateloccra, 185

stigma, Fabr., Polistes, 392, 531. Pluto IV., Fig. 3

Stilbia, Steph., 16, 19

Stilbum, Spin., 93, 362, 397, 398, 399,

400,412 ; clustcring of, when sleeping,

399,400

stipata, Walk., Morrisonia, 468,478

stipella, Doubl., Occophora, 18

Stirastoma, Serv., 327

stockerus, Linn., Chrysocoris, 113, 362, $378,381,384$

stocks used in $1866,11,12$

stone axo in a tree, 462

Stormberg [S. Africa], 233

strabo, Fabr., Catochrysops, 66, 68, 73,

$94,96,373,377,380,391$

Stramia, Marshall, 233

stropens, Latr., Epacromia, 155, 158, 174

stridulation. See sound

strigosa, Walk., Theages, 291

strigulifera, Walk., Craspedia, 236 
Stringophorus, Burm., 236

strings of Butterflies, 118, 370, 537

Strophosomus, Billb., 192, 244

Stugeta, Druce, 213, 223, 566, 568

stygia, Fabr., Pollenia, 439, 443, 446, 452, 463

stylifera, Burm., Hyposphaeria, 239

Suastus, Moore, 71, 96, 127

suaveolens, W.-M. \& de N., Mycalesis, 500

suavis, Butl., Pseudo-coremia, 460

subaënius, Dej., Harpalus, 233

subalbitaria, Swinhoe, Semiothisa, 97

subarcuana, Wilk., Anchylopera, 14

subaurata, Walk., Eressa, 357

subaurea, Guen., Perigea, 291

subidaria, Guen., Epyaxa, 456, 460

subimpressa, Schlett., Cerceris, 410

sublicellus, Zell., Crambus, 445, 446, 452, $457,471,480$

sublutea, Graes., Copicucullia, 408, 421.

Plate V., Fig. 9

submarginata, Walk., Leucoma, 80

submarginalis, Walk., Scoparia, 452, 470, 474,479

submicans, Moraw., Osmia, 165

subnotata, Walk., Aroa, 358, 360, 371, 387

subocellana, Don., Grapholitha, 19

subochraria, Doubl., Anachloris, 447, 451, 456,457

subopacum, Smith, Monomorium, 209, 398

subopalaria, Walk., Sabulodes, 292

subpurpureata, Walk., Asthena, 467, 469, 479

subquadrata, Sol.,;Pimelia, 177

subsericeus, Sauss., Polistes, 317

subspersata, Feld., Hygrochroa, 143

subspissata, Warr., Epirrhoë, 192

substrigosa, Walk., Aroa, 129

subsulcatum, Reich., Opatrum, 418, 434

subsulcatus, Mass., Hister, 195

succenturiata, Linn., Eupithecia, 20

Succinea badia, Mor. [Mollusca], 231 ; S. rugosa, Mor., 424

Sûdân, 403-426; fauna, 421-422 [Insecta], 423-426 [Mollusca]

sudanata, Warr. \& Roth., Peridela, 408

suero, Oram., Selenis, 262

suffusa, Fabr., Agrotis, 397, 463. Sec also ypsilon

sugar-trap, 9

Sukna, 83, 84

sulcana, Fereday, Leucania, 468, 478

sulcatus, Fabr., Otiorrhynchus, 464

sulcrtus, Drury, Phrnneus, 295

sulcicornis, Fabr., Vorlusia, 177

Sulciman bin Arbi, $160,161,162,164,165$, 166

sulphur, 31, 141; spring, 152, 160, 167

sulphuron, Spiu., Microbembex, 260

Sulphuretted hydrogen, 184, 450

Sunbird, 213 superba, Hcrbst., Trcpsichrois, 126, 433, 517

superbiens, Morirc, Tachyter, 410

supergressa, Butl., Epirrhoc̈, 143

Surendra, Moore, 351, 368, 568

surinamensis, Möschl, MIclipotis, 315

surinamum, Linn., Achryson, 295

suspecta, Hübn., Orthosia, 16

Suter, H., 461, 470, 477, 481

suworzevii, Morawitz, Podalirius, 432, 435

sivaha, Koll., Aulocera, 40, 46, 55

Swale, Dr., 454,532

Swan River, 487

Sivát Valley, 53

Swedish Expedition to Sûdân, 422, 424

Sivettenham, Sir Alexander, 273

swift flight. See Butterflies

Sivinhoe, Col. C., 128

Sivorder, G. H., 314, 317, 328, 331, 333, 503

sybaris, Hopff., Tarucus, 203

Sycanus, Am. \& Serv., 363

Sydenham [Natal], 187, 188, 189, 591

Sydney [N.S. Wales], 482-6

Syessita, Pascoe, 236

Sylepta, Hübn., 359

sylvanus, Esp., Hesperia, 571, 573

sylvarum, Linn., Bombus, 531

sylvata, Hübn., Asthena, 11

sylvaticus, Oliv., Camponotus, 409

sylvella, Hew., Ithomia, 312, 313

sylvo, Hübn., Ithomia, 494

Symbrenthia, Hübn., 65, 80, \$2, \$3, 8 壬

Sympetrum, Newm., $24 \mathrm{~S}$

Symphaedra, Hübn., 93

synagrioides, Sauss., Rhynchium, 411

synaposematic group, $23 \mathrm{~S}$

syncellus, Cram., Thecla, 326

Synchloë, Doubl. (Coatlantona, Kïby'), $305,308,319,324$

Synchloë, Hïbn., 33, 170, 175, 181, 199, $202,204,207,209,241,247,430,432$, $514,574,598$

Syneda, Gueu., 151

Synegiodes, Swinl., 7i. Scc Erythro. lophus

Syngamia, Guen., 293

Syuia, Guen., 315

Syuoccr, Sruss., 265, 305, 317, 321

synoecoides, Ques., Lycauthropa, 152

syutaracta, Meyrk., Scoparia, 440

Syutomidre, position of tho, 116

Syntomis, Ochs., 189, 236, 241, 245, 35T, $371,483,485$

Syrichthus, Hope [Coleoptcra], 240, 245

Syrichthus, Boisd. [Ispidoptcra], 8, 232, 572

syrichthus, Fabr., Hcsperia, 256, 265, $289,304,305,308,310,315,331,572$

Syringa persica [Oleaceac], $500,5 \pm 5$

syruiaria, Guon., Alcis, 319

Syrphus, Fabr., 164, 168, 192, 229, 237, $400,475,476$ 


\section{INDEX}

Systasea, Butl., 331, 573

Systoechus, Loew., 209, 213, 245

Tabanus, Linn., 227, 229, 393, 458, 462 tabida, Fabr., Microlestia, 179, 248

Table Mountain, 178, 248, 249

Tachina, Neig., 159, 163

Tachyphyle, Butl., 293, 332

Tachyris, WVallgr., 82, 84, 98, 99, 104, 589

Tachysphex, Kohl, 414, 420, 447, 462

Tach stes, Panz., 260, 410

tredana, Clerck, Coccyx, 21

taeniolalis, Guen., Pionea, 332

Taeniolobus, Chaud, 374, 418

taeniops, WVied., Eristalis, 186, 192, 198, $237,241,399,400,428$

tages, Cram., Desmia, 293

tages, Linn., Nisoniades, 553, 572, 573

Tagiades, Hübn., 101, 138, 140, 142, 356, 384,572

taikosama, Wallgr., Aloëides, 212, 215

Táj Mahál, 91

talaca, Walk., Hyposidra, 358

Talicada, Moore, 97, 98, 113, 114, 117, $118,338,349,368,373,384,565,568$

Talipot palm, 108

Talis, Guen., 440, 486

Tamarix gallica, Linn. [Tamaricaceac], 396,398

"Tamby," 380

tampiusalis, IValk., Nacolcia, 359

Tanjúr, 106

tantalus, Fabr., Hyperalonia, 372

Tanymecus, Germ., 418, 419

T\&oro, V'al de [Tenerifo], 28, 32

taprobana, Feld., Chittira, 382, 496

taprobana, Westw., Ergolis, 349, 367, $369,381,387,552$

taprobanensis, Nooro, Aneylolomia, 359

taprobanis, Walk., Siccia, 357, 386

Tarachc, Hübn., 358

Taractroccra, Butl., 356, 386

Taragama, MLore, 428

Táragahr, 93

Tarawora, Mit. [N. Zcaland], 449

tardus, Sol., Oncotus, 249

tarsata, Morawitz, Ceratina, 400, 411

tarsatus, Fabr., Paltothyrous, 224, 227

tartaraca, Butl., Morrisonia, 468, 474, 478,480

Tarucus, Moorc, 49, 54, 58, 62, 64, 66, 88, $90,93,185,197,203,212,227,229,235$, $241,284,350,374,380,398,400,403$, $407,414,416,420,427,428,429,505$, $523,566,568,569$

taschenbergi, Vachal, Xylocopa, 411

Tasitia, Mooro, 261, 280. Sce Danaida

Tasmania, 439-441

taste, sense of, in man and insects, 517

Tatosoma, Butl., 479

Taumaranui [N. Zealand], 456, 457, 458, 460

'Taungs [S. Africa], 210

taurus, Fabr., Anthracias, 198
Tawila [Sûdân], 420,424, 425, 426

tea-gardens, 80

Teall, J. J. H., 550

Te Awahou [N. Zealand], 453

Tecoma stans, Juss [Bignoniaceae], 59, $410,411,413$

tecta, Boh., Aspidomorpha, 238, 246

Tel-al-Amarna, 429

telata, H.-Schäff., Megistias, 316, 326

Telchinia, Hübn., 87, 88, 96, 97, 102, 105, $106,107,121,339,349,380,517,519$, 520,526

Telegonus, Hiibn., 288

Telephorus, H.-Schäff., 245, 249, 250, 362, 372

telephus, Feld., Papilio, 98, 103, 111, $115,127,371,374,377,381,515,539$

Telesto, Boisd., 483, 485

telicanus, Lang, Tarucus, 58, 64, 66, 88 , $93,185,197,212,227,229,235,241$, $398,400,428,429,523,566,568$

'Telicota, Moore, 62, 66, 68, 73, 127, 356, $384,483,484,572$

Temnopteryx, Brunn., 249, 448, 462, 479

Temple of the Tooth, 342

templetoni, Baly, Sphaerolina, 388

temples, a parallel, 106, 107

Tenacity of life in protected species, 65 , $82,126,131,196,255,280,281,310$, $316,320,337,339,345,346,349,351$, $352,355,360,443,518-521$

tenax, Fabr., Eristalis, 158, 159, 168, $169,179,251,441,443,444,445,462$, 481,486

Tenebrio, Linn., 464

tenebrosa, Hübn., Rusina, 16

tenella, Erichs., Mantispa, 246

tenera, Warr., Hammaptera, 293

tenera, Westw., Mesosemia, 325

Tenerife, 26-34

Tentyria, Latr., 163, 164, 396, 431, 435

tenuiata, Hübn., Fupithecia, 19

temuiscapa, Westw., Xylocopa, 113, 340, $361,375,382,386$

tenuistriga, Hmpsn., Crambus, 233

tephraea, Hübn., 'Theclopsis, 314, 506

Tephrina, Guen., 62, 94, 97, 186, 202, 352, $386,397,408,428$

Tephrosia, Boisd., 143. Sec Ectropis

Teracolus, Swains., 49, 57, 61, 62, 88, 90, $92,94,95,104,105,106,162,181,183$, $188,191,194,197,203,212,217,222$, $225,227,228,231,232,281,235,239$, $241,246,354,376,377,380,403,406$, $407,414,416,417,418,419,420,421$, $422,510,511,522,525,535,537,549$, $575,578,588,589,590,591$

Teramuccrus, Schönh., 462

Torastia, Guen., 319

tcrodon, Fcld., Papilio, 98, 117, 355, 383 , 520,539

Terias, Swains. [Eurcma, Hübn.], 35, 42, $43,46,47,48,49,51,54,57,61,64$, 65, 66. 68. 71. 78. 79. 83, 84, 86. 89, 
$90,91,93,94,96,98,99,105,106,108$, $110,116,117,119,124,127,130,137$, $183,186,188,191,194,197,207,212$, $214,220,222,223,225,227,228,256$, $257,258,260,265,286,287,304,305$, $306,309,310,315,319,321,326,330$, $332,338,353,354,364,365,371,373$, $377,379,381,382,383,384,386,387$, $388,391,509,510,522,524,535,577$, $582,583,584,585,588,589,590,591$, $593,597,598$

terminalis, Burm., Rhyticoris, 240

terminalis, Smith, Halictus, 250

Termites, 180, 182, 205, 223, 210, 245,

342,359 ; dogs and cats eating, 342

terpsichore, Linn., Acraea, 186, 187, 196

terrestris, Linn., Bombus, 168, 174, 532

tersata, Schiff., Phibalapteryx, 143

Tessaratoma, Lepel., 113

tessellata, MIacq., Dichaetometopia, 206

tessellata, Fabr., Empis, 174

tessellatum, Klug, Anthidium, 411

testaceo-pilosa, Lucas, Aphaenogaster, 173

testutalis. Guen, Maruca, 319

tethys, MIénét., Daimio, 142

tetracanthus, White, Scolopterus, 455. Plate VI., Figs. 6, 7

tetradactyla, Linn., MIacraspis, 294

Tetradia, Thoms., 209, 221

Tetramorium, Mayr., 173, 201

tetrapleura, Meyrk., Phalaenoides, 485

tetrio, Linn., Pseudosphinx, 327

teuthras., Walk., Cosmosoma, 318

toutonia, Fabr., Belenois, 483, 512

Thais, Fabr., 171, 172

thais, Fabr., Cirrhochroa, 348

thalassina, Fabr., Epachromia, 158, 247

thalassina, Boisd., Leuceronia, 227, 228

thalia, Linn., Actinote, 504

Thalasso-helix traversi, E. A. Smith, 477 ; T. ziczac, Gould, 456 ; T. zenlandiae, Gray, 456 [Mollusca]

Thallarcha, Meyrk., 440

thallo, 'Linn., Chalcosia, 128, 360

Thalpochares, Leder, 172

Thalpomena, Sauss., 170, 174

Thanaos, Boisd., 150, 316, 553

thapsiella, Zell., Agonopteryx, 160

tharos, Drury, Phyciodes, 150, 152

Thaumantis, Hübn., 501

thaumas, Hufn., Hesperin, 571, 573

Thayer, Abbott, H., 216

Theages, Walk., 291, 316

Thecla, Fabr., 260, 261, 307, 314, 320 , $326,330,331,506,524,525,563,567$

theclata, Guen., Dirades, 340

Thcclinesthes, Röber, 484

Theclopsis, Godm. \& S., 314, 506

Thelidomus aspera, Fér. [Mollusca], 302

Tholyphonus, Tuatr., 345, 363

Theog [Simln], 40, 12

theonus, Lefebre, Jioptotes (Lycacia), 285,325 theophrastus, Fabr., Tarucus, 13, 54, f2, $88,90,380,403,407,414,416,420$, $427,428,505,569$

therapis, Feld., Meganostoma, 315

Therasia subincarnata, Suter, 461; T. valeria, Hutton, 461, 482 [Mollusca]

Theretra, Hübn., 292

thermesia, Godart, Leptalis, 510

thermesialis, Walk., Hypena, 192

thero, Linn., Phasis, 250

theseus, Feld., Dynamine, 309, 313, 321 , 330,571

Thespesia populnea [Malvaceae], 310

thespis, Linn, Cacyreus, 250

Thestor, Hübn., 167, 171, 175, 563

thestylis, Doubl., Prioneris, 82, 83, 589

thetis, Drury, Curetis, 73, 374, 522

theylia, Linn., Choerocampa, 386

Thisoicetrus, Brunn., 64

thius, Hübn., Callipsyche, 295, 307, 31.1

Tholosanus, Dist., $446,455,461$

thomae, Fabr., Harpactopus, 260

Thonalmus, Bourg., 296

thoracica, Fabr., Elis, 71

Thornton, H. L., 328, 332

thorns, 62, 69, 72, 343, 473, 476

Thosea, Wa.lk., 129

thrasybulus, Fabr., Cycloglypha, 316, 573

Thriptera, Sol., 399, 401, 402

Thuja sp. [Coniferae], 63

thunbergi, Billb., MIylabris, 377

Thunbergia fragrans, Roxb. [Acan thaceae] (? = alata, hortorum), 266

Thyca, Wallgr., 535

thyelia, Fabr., Symphaedra, 93

Thymele, |Fabr., 258, 288

Thymelicus, Hübn., 289, 304, 316, 326

thyodamas, Boisd., Cyrestis, 81

Thyreopterus, Dej., 198

Thyretes, Walk., 203

Thyridia, Hübn., 494

thysa, Hopff., Belenois, 193, 197, 512, 530,535

thysbe, Limn., Phasis, 181

Tiberius, Fuwert, 362, 365

Tibetan expedition, $7 \mathrm{~S}, 81,82$

Ticherra, de Nicév, $\$ 1$

ticks, 267, 280

Tignyga, iIt. [Tenerife], 2S, 31, 32

Tiger Hill [Canton], 131

tigrata, Guen., Obcidia, 129. 517

Tikitapu Bush [N. Zealand], 455

Timandrn, Dup., 374

Timarcha, Latr., 528

time of flight of Butterfics, 192, 356, 365 596

timeus, Cram., Chrysophanus, 41

timolcon, Stoll, Irnota, 127, 391

Timyra. WV alk., 359, 361, 334, 356

tinctr, Brahm., Aplecta, 16

tincta, Jur., Diorys, $17 \%$

tinctor, Chrst., Eumcies, 230, 237, 211 , $245,398,399,400,411,414,416,417$. $420,421,427,428$ 
Tiudaria [Darjiling], 77, 83

Tinea, Fabr., 18, 19

Tipha, Walk., 385

Tirumala, Moore, 55, 57, 70, 72, 73, 74, $85,96,104,105,110,111,114,118$, $229,339,344,364,367,373,379,381$, $495,498,520,522,523,530,537$

Tisiphone, Hübn., 483

Tísta Valley [Darjiling], 79, 81

Tithonia diversifolia [Compositac], 352, 365

tithonus, Iinn., Epinephele, 543, 574

Tithorea, Doubl., 255, 320, 323, 494

Tizi Gourzá [Algeria], 176

Tmetolophota, Hmpsn., 468, 474, 478, 481

Tmolus, Hübn., 257, 314, 506

Toads, 200, 202, 253, 342, 372 ; lying in wait for MIoths, 342

Tobago, 328-333, 571, 578, 587

toddy palm, 85

togarna, Hew., Thccla, 314, 320, 524

Toliganj [Calcutta], 74, 75

tomentosus, Fihr., Pychnodactylus, 435

Toong [Darjiling], 77

Tooth, Temple of, 342

topha, Wallgr., Teracolus, 188, 212

Torii-tüge [Japan], 138, 140

Toronto, 25

torrida, Kirby, Pseudo-macromia, 223, 226,230

Tortoisc, 169,182

Tortricodes. Guon., 318, 332

Tortrix, Treit., 15, 17, 19, 21, 447, 452, $456,461,469,479$

tortuosa, Desf., Deverra, 396

Tosale, Walk., 332

tough integuments of Telchinia, 88; Danaida, 82, 118, 518-521. Sce also exoskeleton

Toxicum, Latr., 362

Toyama [Japan], 141, 142

Trabala, Walk., 42

Trachypholis, Erichs., 374

tractipennis, Butl. \& Druce, Arteurotia, 308

Trade Wind, 180, 193, 252, 329, 331

transparent mountain, a, 78

transvorsa, Walk., Euschcma, 360, 518, 520

trapezalis, Guen., Marasmia, 58

Trapezites, Hïbn., 485

Trcchus, Clairv., 205

Trce-ferns, 77, 447, 454, 455, 458, 459, 462

treitliana, Wern., Blattclla, 421

trepidaria, Treit., Psodos, 21

Trcpsichrois, Hübn., 126, 127, 128, 498, 517,519

triangulum, Fabr., Philanthus, 155, 396, 434

triangulus, Spin., Jycambis, 297

tributaria, Walk., Bapta, 293

Tricalysia jasminiflora, Hool. [Rubiacerce], 213
Trichinápali, 105, 106

Trichiura, Steph., 402, 417, 418, 428

Trichius, Fabr., 20

Trichodos, Herbst., 434

tricolor, Fabr., Ootheca, 249

trifasciata, Ramb., Phyllomacromia, 230

Trigonodes, Guen., 97

Trigonopus, Muls., 182, 205, 233, 238, 240

trilineatus, Wied., Helophilus, 462

Trilophidia, Sti̊l., 199

Trimen, R., F.R.S., 219, 229, 242, 244, $573,595,598$

trimenia, Butl., Mylothris, 44, 183, 234 , 241,514

trimmerana, Kirby, Andrena, 164

Trinidad, 254-256, 322-328, 567, 571, 582,587

trinidadensis, Sternb., Aegopsis, 333

Trinkomali, 337, 379-381

trinotata, de Meijere, Ceria, 393, 531

Triphaena, Ochs., 16

'Triphosa, Steph., 293

tripustulatus, Fabr., Macrocheilus, 359

tristalis, Leder., Hypena, 43

tristis, Boisd., Xenophanes, 307

tristrigosa, Butl., Earias, 49, 62

Trisul, MIt. [Kamaon], 65

trite, Linn., Rhabdodryas, 507

tritonaria, Walk., Hemithea, 359

trivia, Schiff., Melitaea, 54, 55

trivittata, Brullé, Eucera, 171, 174

Trochalus, Lap., 221, 244, 245

Trochilium, Scop., 22, 531

trochilus, Froy, Chilades, 401, 407

trochilus, Hübn., MIacroglossa, 229, 236

Trochilus polytmus [Aves], 268

Troides, Hübn., 108

tropica, Guen., Tarache, 358

tropicalis, Guen., Ophiusa, 318

tropicalis, Boisd., Pontila, 568

Tropics, importance of exerciso in, 35

Tropidonotus piscator [Reptilia], 341

Tropidophora insulare, Pfr. [Mollusca], 240

Tropinotr, MIuls., 170, 175, 176, 177

Tropisternus, Sol., 309

Trox, Fabr., 209

truncata, Hufn., Polyphasia, 44

truncatus, Walk., Tabanus, 162

Truxalis, Linn., sce Tryxalis

tryma, Schaus, Ephialtias, 316

Trypheromora, Butl., 81, 83

Trypoxylon, Latr., 392

Tryxalis, Brulle, 50, 54, 121, 155, 198, $214,246,436,483$

tryxaria, Guon., Epidosmia, 485

Tsossebo [S. Africa], 231

tuberculnta, Fabr., Cicindela, 443, 447, $452,455,462$

Tuoly, N., 12

tuhualis, Fold., Crambus, 464, 466, 170

tumulosus, Burm., Ligyrus, 294, 327

Tunbridge Wells, 8, 11

turanica, Moraw., Nomioides, 412 
turbatus, Walk., Onthophagus, 359

turbulenta, Guen., Osteodes, 200, 203, 239, 241

turcicus, Gerh., Chrsophanyus, 137, 141

turfosalis, Walk., Schrankia, 20

turnus, Linn., Papilio, 149, 151

Turner, Rowland E., 304, 485

Turritella carlottae, Watson, 449 ; T. fulminata, Hutton, 448; T. rosea, Quoy, 449; T. vittata, Hutton, 448, 481 [M Lollusca]

tutanus, Fenton, Papilio, 140

tydei, Guill., Ammophila, 396

Tylecote, E. F. S., 347, 360, 366

Typha angustifolia, Linn. [Typhaceae], 449

typhla, Dbl. \& H., Oressinoma, 309, 310, 313

typhon, Rott., Coenonympha, 21

Tyrol, 25, 598

tytia, Gray, Caduga, 81

tytiusalis, Walk., Syngamia, 293

ubaldus, Cram., Azanus, 402, 407, 416, 419

u-Bomaan, 193, 194, 594

Ullapáne [Ceylon], 115

Uloma, Casteln., [? Meg.] 384

ultramarina, Sauss., Synoeca, 265, 305, 317,321

umbrella-mender, an, 447

umbrosus, Chrst., Sphex, 410

unca, Schiff., Hydrelia, 25

undalis, Fabr., Hellula, 359

undecem-punctata, Linn., Coccinella, $396,399,413,415,416,421,428,429$, $430,433,434$

underside of leaves, butterflies on, 104, $116,191,357,384,573$

undosata, Walk., Asthena, 463, 469, 482

undularis, Drury, Elymnias, 71, 73, 75, $82,339,500,529$

undulosa, Kaye, Racheospila, 292

unguicularis, Smith, Gasteruption, 456

unicolor, Latr., Apis, 441

unidentata, Stil, Ranatra, 260

uniformis, Hmpsn., Asura, 117

uniformis, Plötz., Hesperia, 310

uniguttatus, Thunb., Dieuches, 97

Unio, Retz. Sec Diplodon [Mollusca.]

unipuncta, Haw., Cirphis, 27, 133, 448, $460,465,576$

unizonata, Ricarde, Hacmatopota, 384

unpalatability is relative, 4, 533, 534

Upup sp. [Aves], 61

Uraniasspeciosa [Scitamincae], 109

Urellia, Desv., 432

Uropeltidae [Reptilia], 372

Uropetala, Sélys, 459, 462

Uroxys, Westw., 333

ursus, Fabr., Anisonyx, 249

ursus, White, Rhyncodes, 479

Urtien ferox, Forst. [Urticaeene], 457

urtiene, Linu., Vanessa, 545, 574
Usagaria, Péringney, 215

Usia, Latr., 174, 177

Ussher, R. T., 164, 166

ustistriga, Walk., iJlorrisonia, 465, 465, $474,478,481$

ustomaculana, Curt., Coecys, 21

Utakamand [India], 98, 99

Utetheisa, Hübn., 26, 33, 51, 64, 66, 96 , $97,129,204,233,279,1290,304,311$, $318,332,407,416,421,576$

Utica, Hew., 484

vacciniella, Scott, Lithocolletis, 21

Vaccinium myrtillus, Linn. [Ericaccac],

19, 21, 22 ; V. vitis-idrea, Linn., 22

vagata, Moore, Acropteris, 81

vagellum, Zell., Homoeosoma, 452

Vaginula, Sowerby, sp. [Ifollusca], 190, 302

vaillantina, Stoll, Egybolia, 195, 198, 337 valerius, Möschl., Morys, 279, 289, 304

valgus, Linn., Phileurus, 319

Vancourer, 149

Vanessa, Fabr., 6, 14, 25, 41, 46, 63n, $65,77,78,79,99,100,140,150,167$, $169,348,383,521,539,541,514,545$, 547, 552. Sec also Pyrameis

vanillae, Linn., Dione, 279, 2S1, 324, 503

varanes, Cram., Charaxes, 187, 197, 222, 235,502

vardhana, Moore, Cyaniris, 42, 44

varia, Murray, Halpe, 138, 143

variabilis, Loetr., Bombylius, 169, 170

varialis, Walk., Hypena, 358

varialis, Brem., Pyrausta, 143

varians, Walk., Euproctis, 129

variation, $49,54,84,88,90,101,102,130$,

$172,205,241,257,304,308,310,311$.

$315,323,324,329,345,353,354,405$.

406,407

variegata, Thunb., Antestia, 190

variegata, Hmpsn., Audea, 203

variegata, Warr., Philereme, 43, 14

variegata, Limn., Rhyothemis, 107, 533

variegatus, Kolenati, Centrocaremus, 174

variegatus, Fabr., Esthesis, 485, 532.

Plato VI., Fig. 8

variegatus, Frbr., Graphipterus, 435

variegatus, Spin., Philanthus, 410, 423

varius, White, Neoitamus, 453-455, 470

varmoun, Moore, Neptis, S0, 84, 91, 119,

$339,347,367,383,384,385,387,502$,

$524,526,527,553$

varunann, Moore, Chilades, 62, S6, 106, 349,365

rasanta, Noore, Euthalia, 346, 367

Vehilius, Godm., 256, 258

releda, Godm. \& S., Epeus, 316, 331

Velitra, Stril, 374

velleda, Fabr., Precis, 441,483, 484, 486

velutina, Lepel., Vespa, 54

venatr, MLoore, Terias, 364

Venezuela, 256, 257, 305-321, 571

venezuelac, Send., Pyrrhopyge, 326, 331 
venipunctata, Walk., Xauthorrhoë, 446 renosa, Walk., Ctenucha, 316

venosa, Walk., Chalcosia, 360, 518, 520

venosus, Plötz, Vehilius, 256

venusta, Smith, Paramegachilc, 420

venusta, Dalm., Utetheisa, 290

Verbena officinalis, Linn. [Verbenaceae], 452

Verbenaceaespecially attractive to butterflies, 57, 70

veritabilis, Butl., Mechanitis, 306, 321

Verlusia, Spin., 177

verma, Koll., Lethe, 80

vermiculata, Butl., Crastia, 66

Vernonia sp., 118, 119, 355, 357, 361, 388 ;

V. scorpioides, Pers., 314, 316 [Compositae]

Veronica salicifolia, Forst. [Scrophularineae], 448, 454, 455, 464

Verrall, G. H., 174, 229, 237

versicolor, Fabr., Agonoscelis, 192

versicolor, Oliv., Polistes, 259

Verteuil, F. L. J. M. de, 327

Vespa, Linn., 51, 54, 173, 340, 361, 392, $398,428,429,432,435$

vespertina, Fabr., Luciola, 378

vesta, Fabr., Pareba, 133

vestalis, Lepel., Psithyrus, 174

vestalis, Schaus, Theages, 316

vestigialis, Pascoe, Syessita, 236

vestita, Smith, Acantholepis, 201, 201, 233

vestitus, Smith, Paracolletes, 452, 454, 455

vesulia, Cram., Oxydia, 292, 319

vesuria, Plötz, Catia, 289

Veterna, Stål, 240

votulata, Schiff., Scotosia, 14

vialis, Edw., Amblyscirtes, 150

vialis, Burch., Psammodes, 208, 209, 210

viaticus, Fabr.,1Mrmecocystus, 158,161 , $165,177,396,397,1398,399,409,418$, $427,430,431$

viator, Latr., Hodotermes, 243

vibcx, Hübn., Thymelicus, 289, 326

vibidia, Hew., Thocla, 261

viburnana, Fabr., Tortrix, 21

Viburnum tinus, Linn. [Camifoliaceae], 169,541

Victoria, B.C., 148

Victoria Falls, 218-230

Victorina, Blanch., 268, 283, 314, 825, 502,552

victorina, Hcw., Ptcronymia (Lcucothyris), 312, 313, 320, 494

vidua, Smith, Prosopis, 485

vidualis, Frabr., Aspongopus, 397, 401

vigilans, Trim., Pseudonympha, 248, 249

vigintiquattuor-signata, Thunb., Polysticta, 233, 234

villosulus, Smith, Halictus, 173

villosus, Haag, Himatismus, 399, 402, 413

Vimála Sah, Temple of (Mt. Abu), 93

viminalis, Fabr., Ipunda, 16
Vinca rosea [Apocynaceae], 337 ; Vinca sp. 174

vincta, Gerst., Monolepta, 228

vindex, Cram., Hesperia, 232

vindex, Smith, Salius, 224

Vines, Prof. S. H., 389

vinidia, Hew., Acraea, 519

violacea, Linn., Xylocopa, 168, 174, 176

violaceus, Lepel., Podalirius, 377

violaceus, Lepel., Bombus, 316

violae, Fabr., Telchinia, 87, 85, 96, 97, $102,105,106,107,121,339,349,380$, $517,519,520,526$

Virachola, MLoore, 86, 189, 194, 198, 351, $420,422,566$

Virbia, Walk., 332

virginiensis, Drury, Pyrameis, 25

virgularia, Hübn., Idaea, 172

viridata, Per., Audrena, 168

viridifera, Hmpsn., Hoplotarachc, 263. Plate III., Fig. 7

viridilimbates, Motsch., MLegadromus, 482

viridipenne, Burm., Monachidium, 195

viridis, Brullé, Parnopes, 416

viridissimus, Lucas, Cantharis, 175

visata, Guen., Asthena, 479, 486

vishnu, Lefevre, Trabala, 42

vitiosa, Butl., Morrisonia, 468, 478

vitiosa, Hudson nec Butler, Melanchra. See ochthistis

Vitrea cellaria, Müll., 445; V. sydneyensis, Cox, 445, 448 [Mollusca]

vitrei, Sol., Erodius, 177

vitripennis, Meig., Musca, 163

vittata, Bingh., Ceratiua, 207

vittata, Fabr., Oncacontias, 467

vitta.tus, Feld., Baracus, 117, 118, 119, 386,388

vittellus, Doubl., Crambus, 470, 471

Vivipara uuicolor, Olivier, 425 (varieties) [Mollusca]

volcanic rocks, 28,29 (and footuote)

volcanoes, oxtinct, 446, 447, 448

Volucella, Geoff, 528, 532

vomitoria, Liun., Calliphora, 251

vulcanus, Fabr., Spiudaris, 79, 105, 386, 569

vulpinus, Fabr., Dermestos, 209, 247

vulpinus, Burm., Hotorochelus, 242

vulture, Egyptian, 28

Wad Ben Naga [Sudan], 403

Wada [Japan], 140

Wada-tögo [Japan], 138, 141

Witdi A bâ Roûsh [Egypt], 432

Wadî Halfa [Nubia], 403, 422, 423

Wî̀î Hof [Egypt] $, 431,432$

Waddilove, E. G., 558, 561

Wade-Dalton, Capt. H., 534

Waggon Hill [Ladysmith], 202

wahlborgi, Stoll, Carlisis, 238

wahlborgi, Strl, Psoudo-deropoltis, 239

Wainwright, C. J., 34

Wairoa [N. Zealand], 455, 456 
Wakatipu, Lake [N. Zealand], 471-481

Walker, Commander J. J., 337, 442, 447, $448,454,459,485,498,535$

walkeri, Arrow, Anomala, 382

walkeri, Stål, Gyaria, 206

Wallace, Dr. A. R., 1, 268, 489, 535

wallengrenii, Butl., Teracolus, 188

Walsingham, Lord, 54, 159, 160, 409, 472

Wandsworth, 5, 6, 24, 120; Wandsworth Common, 7

Wanganui, R. [N. Zealand], 458, 459, 460,462

Wankie [S. Africa], 231

warning marks, 101

Warrenton [S. Africa], 233

warringtonellus, Zell., Crambus, 12

water-fowl, 415

Waterfall Gully [Adelaide], 487

water grasshopper, 375

Waterhouse, C. O., 542

Waterhouse, G. A., 184, 486

waterhousoi, Kaup., Tiberius, 362, 365

water-lilies, 376,416

Watson, Capt. E. Y., 353

waxy excretion of beetles, $163,232,431$, 433,435

Weir, Jenner, 595

Weismann, A., 491

weitzecheri, Emery, Cremastogaster, 240

Wellington [N. Zealand], 441-3, 464-6, 482

Wellington, Mt. [Tasmania], 440, 441

Wendlandia notoniana, Wall., $[R u b i$ accac], 363

Westermanni, Schönh., Xylinades, 362

Western Ghâts, 389, 390

West Wickham, 14

Westwood, Professor, 27

westwoodii, Boisd., Terias, 287, 332, 510

Weybridge, 9

Weymouth, 8

Whakarewarewa [N. Zealand], 449, 452

wheat, Egyptian, colour of, 395

white marble, 91

white butterflies, swift flight of, 44,58 , $98,534,535$

White Nile, 415-426

whitei, Cameron, Iphiaulax, 199, 212, $214,226,237,239$

Wight, Isle of, 8,14

wild-boars, 119, 167 ।

Wilkinson, S. J., 7, 14

Willcocks, F. C, 400

Willis, Dr. J. C., 343, 376

Wilson, The Ven. J. MI., 11, 12, 13

Wimbledon Common, $9,10,11,14,2.1$

wind and butterflies, $33,545,549,550$, 557,559

WVistaria sp. [Leguminosae], 145

Wollaston, A. F. N., 422

women choristers, 445

women, influenee of Indinn, 107

Wonderboom [Jolınnucsburg], 206, 207 wood befole stone, 92,142

Woodfordia floribunda, Salis. [Lylliraccae], 387

Wood, John, 238, 233, 240

Wood, Rev. J. G., 2

Wood, J. Medley, 594

Wood-Mason, J., 85, 491, 500, 501, 506, $513,514,515$

Woolahra Point [Sydney, N.S.W.], 483 worm, 196

xanthindyma, Boisd., Cosmophila, 120

xantho, Feld., Dircenna, 494

xanthochlora, Koll., Sphaenogona, 315

xanthographa, Fabr., Noctua, 16

xanthographus, Wied., Harpalus, 233, 250

Xantholinus, Dahl., 238

ranthomolas, Walk., Mapeta, 327

zanthomista, Hübn., Polia, 27

Xanthoptera, Guen., 220

Xanthorrhoë, Hübn,, 446

xanthorrhoea, Koll., Porthesia, 58

xanthosoma, Hmpsn., Euproctis, 418, Plate V., Fig. 4

Xanthospilopteryx, Wallgr., 239

Xenica, Brunn., 484,486

Xonitonus, Péring., 211

Xenophanes, Godm. \& S., 307

Xenorrhinus, Faust, 224

Xeroscopa, Meyrk., 469, 477

xiphia, Fabr., Nychitona, $61,71,73,75$, $86,97,101,106,114,338,351,370,373$, 391,536

xuthulus, Brem., Papilio, 134, 137, 141

xuthus, Linn., Papilio, 137

Xylinades, Latr.,:362

Xylocampa, Guen., 172

Xylocopa, Latr., 113, 168, 174, 176, 1S?, $204,214,224,236,257,241,245,249$, $298,316,321,338,340,361,375,382$, $386,396,400,402,411,417,421,428$, 429,435

Xylopertha, Guér., 221

Xylophasia, Steph., 16, 176

Xylorrhiza, Lap., 362

Iylotrupes, Doj., 120

Xynonia, Prout, 468

Xyridacma, Mryrk., 474, 479

Yang-tse-Kiang, 133

Yearsley, MInclcod, 533

jeatiolla, Eabr., Depressaria, 14

yellow butterfly on yellow leat, 194, 253, $369,592-599$

yellow ferer, 323

Yerbury, Col. J. W., 237, 246, 392, 592

yerburyi, Jnc., Lcma, 3S4

Yokohama, 143, 523, 555

Yphthima, Hubn., 51, 60, 65, 71, 72, 75 , $80,83,84,93,98,100,101,109,112,121$, $126,137,141,143,203,201,213,222$, $223,227,228,338,346,364,367,369$, $377,380,383,385,387,390,484,500$, $521,524,527,552,587,588,589,590$ 
ypsilon, Rott. (suffusa, Fabr.), Agrotis, $291,397,402,421,427,428,429,463$, 478,576

\section{Zalissa, Walk., 128}

zalmora, Butl., Neopithecops, 73, 75, $349,367,390$

Zamarada, Mloore, 200

zangis, Fabr., Calisto, 280, 500, 556, 570, 578. Fig. 19

Zaphysema sp. [Mollusca], 302

Zealandicus, Dall., Nysius, 452, 453

Zebra, Burchell's, 209

Zebra undata, Müll. [Mollusca], 302

Zegris, Ramb., 592

Zemeros, Boisd., 79, 80, 82, 83, 127, 548

zenobia, Fabr., ,Erebus, 318

zephus, Butl., Mylon, 316

Zerenopsis, Feld, 195, 236

Zeritis, Boisd., 210, 232

Zethus, Fabr., 317

Zettienia, MIotsch., 138, 143

zeuxis, Lucas, Papilio, 314, 326

Zezius, Hübn., 391, 525

Ziban, 156; Zibans, Route des, 162-164 [Algeria]

Zicca, Am. \& Serv., 327

ziczac, Linn., Notodonta, 22

Zigzag Station, 305, 319, 320
Zinckenolla, Treit., Eticlla, 95, 205, 221, 359,576

Zinckenia, Zell., 48, 58, 68, 293, 319, 340, $359,473,483,576$

Zinnia, sp. [Compositae], 56, 58, 66

Zizera, Moore, 42, 47, 48, 49, 54, 55, 58, $64,65,66,84,87,94,96,106,109,114$, $121,127,130,1133,134,137,143,181$, $186,189,191,197,203,204,215,223$, $225,: 227,229,235,247,307,336,338$, $349,368,373,377,378,380,381,386$, $387,407,419,421,428,441,444,445$, $447,452,454,455,456,458,483,484$, 486, 487, 568

zochalia, Boisd., Belenois, 183, 234, 241

zodia, Butl., Yphthima, 137 141, 143

Zombrus, Mrshll., 238

zonalis, Feld., Precis, 282, 308, 329, 551, 557,579

zonatus, Linn., Podalirius, 361, 375, 377, 392

Zonosoma, Leder, 80

Zophosis,' Latr., 161, 163, 164, 202, 203, $204,214,215,220,232,246,413,431$

Zophosis, waxy excretion of, 163, 232, $431,433,435$

Zophyrion, Godm. \& S., 320

Zwaartkops [S. Africa], 180-2

Zygaena, Fabr., 8, 51, 172

Zygophyllum coccineum, Linn, [Zygophyllaceae], 432

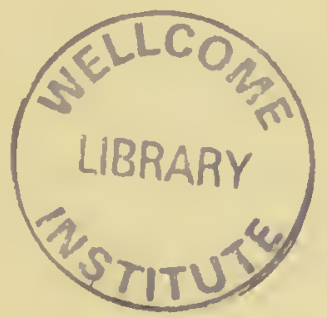








